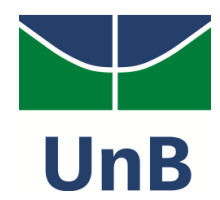

Universidade de Brasília

Faculdade de Arquitetura e Urbanismo

Edificação penal:

um estudo da tecnologia do projeto arquitetônico de estabelecimentos de segurança máxima no Brasil

Augusto Cristiano Prata Esteca 


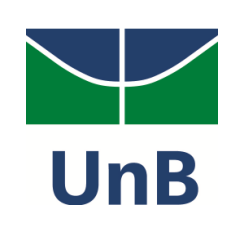

Universidade de Brasília

Faculdade de Arquitetura e Urbanismo

\title{
Edificação penal:
}

um estudo da tecnologia do projeto arquitetônico de estabelecimentos de segurança máxima no Brasil

\author{
Augusto Cristiano Prata Esteca
}




\title{
Augusto Cristiano Prata Esteca
}

\author{
Edificação penal: \\ um estudo da tecnologia do projeto arquitetônico do estabelecimento de segurança \\ máxima no Brasil
}

Trabalho de tese para a obtenção do título de doutor na Faculdade de Arquitetura e Urbanismo da Universidade de Brasília. Área de concentração em Técnicas e Processos de Produção do Ambiente Construído. Orientadora: Prof. Doutora Raquel Naves Blumenschein.

Brasília, 31 de março de 2017.

Banca examinadora:

Profa. Raquel Naves Blumeschein, Doutora (FAU/UnB)

Prof. Márcio Buzar, Doutor (FAU/UnB)

Prof. Hélio Adão Greven, Doutor (UFRGS)

Prof. Benamy Turkienicz, Doutor (UFRGS)

Profa. Débora Diniz Rodrigues, Doutora (FD/UnB) 


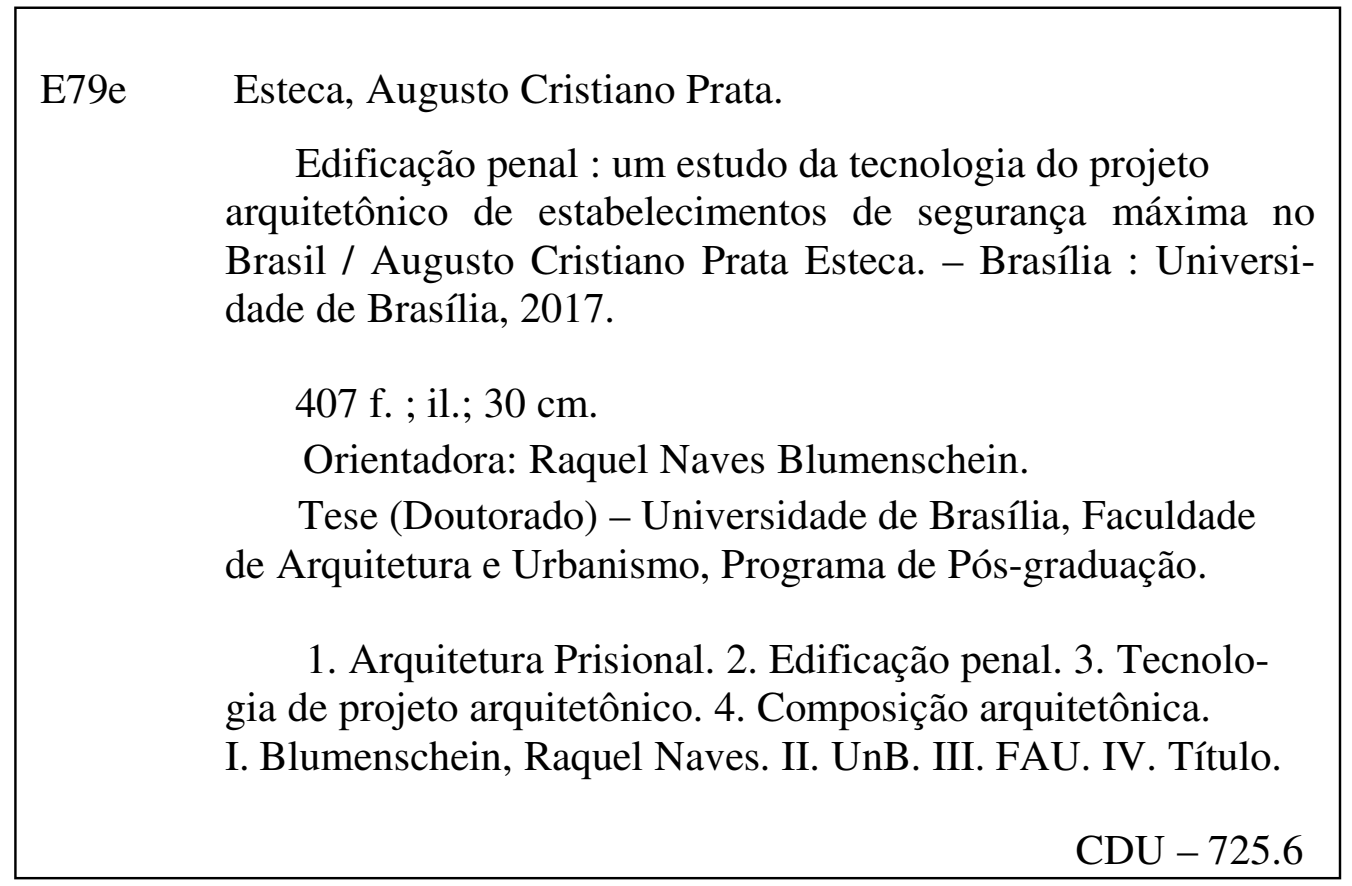

Ficha elaborada pela Bibliotecária Mariana Ferreira dos Anjos - CRB 1976 


\section{Dedicatória}

Dedico este trabalho a todos os interessados, envolvidos e participantes de ações comprometidas com sistema penitenciário, seja no campo jurídico, penal, penitenciário ou nas especializações derivadas, em especial, na arquitetura penal, cujos desafios tornam imprescindível a colaboração, individual ou coletiva, para a melhoria da prisão em nosso país.

Em especial, dedico este trabalho às pessoas que apoiaram a realização desta pesquisa, na universidade, nas empresas, nos governos, nos escritórios e nas prisões.

Em particular, dedico este trabalho à família e aos amigos. 
"Sempre que se impõem mundos, se criam submundos"

GOFFMAN, 2005, p. 246 


\section{Agradecimentos}

Agradeço à minha orientadora, profa. Raquel Blumenschein, pela parceria na busca de uma arquitetura mais adequada ao funcionamento da prisão, em especial, à condição humana das pessoas inseridas no universo prisional.

Estendo este agradecimento:

Ao professor Hélio Adão Greaven cujo coleguismo nos trabalhos realizados no âmbito da arquitetura penal levou a sua participação neste processo.

Ao professor Benamy Turkienicz pela receptividade na UFRGS que se estende até hoje, ao prestigiar o trabalho realizado.

À professora Débora Diniz Rodrigues pela disposição em contribuir com a arquitetura penal anteriormente, mais uma vez neste momento, e com trabalhos futuros.

Ao Sr. Marcos Aurélio Sloniak da Secretaria de Segurança Pública do Distrito Federal pelo auxílio na definição do formato da pesquisa de campo realizada, quando então diretor na Subsecretaria do Sistema Penitenciário do Distrito Federal.

À empresa Verdi Construções S/A que municiou este trabalho dos raros dados sobre a edificação prisional. Em especial, ao diretor Henrique Deboni pela valorização deste trabalho.

Ao Secretário de Estado da Justiça e Cidadania de Santa Catarina, Sr. Leandro Antônio Soares Lima, pela autorização de acesso ao sistema penitenciário catarinense para a realização da pesquisa de campo desta tese.

Ao Diretor da Penitenciária Industrial de Blumenau, Sr. Cleverson Henrique Dreschle, pela mobilização nesta unidade prisional para a realização da pesquisa de campo desta tese.

À Diretora do Comitê de Ética em Pesquisa da Secretaria da Administração Penitenciária do Estado de São Paulo, senhora Fátima França, pela sabedoria na condução da pesquisa de campo desta tese, no sistema penitenciário paulista.

Ao Diretor do Centro de Detenção Provisória II Pinheiros, Sr. Guilherme Silveira Rodrigues pela recepção amistosa nesta unidade prisional para a realização da pesquisa de campo desta tese, além do conhecimento e das histórias compartilhadas.

À Diretora Técnica de Saúde do Centro de Detenção Provisória II Pinheiros, Sra. Eliane de Souza pelo acolhimento para a realização da pesquisa de campo desta tese, e cujo exemplo de dedicação à humanização de pena motivou uma nova parceria.

Aos chefes de segurança, agentes penitenciários e presos entrevistados, cujo material coletado para este trabalho foi inestimável. 
À psicóloga Laís Fernandes Pires pelo suporte técnico na definição do material metodológico para as entrevistas junto aos usuários da edificação penal.

Ao professor Gustavo Sales do Laboratório de Sustentabilidade Aplicado a Arquitetura e ao Urbanismo da Faculdade de Arquitetura e Urbanismo da Universidade de Brasília (LaSUS/FAU/UnB) pela realização de simulações de ventilação dos modelos arquitetônicos desenvolvidos nesta pesquisa.

À arquiteta Francielle Dall'Agnol pelas informações relativa ao LEED da U.S. Green Building Council.

Ao aluno da graduação da Faculdade de Arquitetura e Urbanismo da Universidade de Brasília, Gabriel Lordelo, pela realização de simulações de iluminação dos modelos arquitetônicos desenvolvidos nesta pesquisa

Aos amigos que enviaram conteúdos de toda natureza para ajudar neste trabalho, em especial, às professoras Cecília Maria e Luciana Sabóia da FAU/UnB, pelo apoio e conversas esclarecedoras. 


\section{Resumo}

Este trabalho aborda o projeto arquitetônico de estabelecimentos penais do ponto de vista do processo de projeto, entendido como meio para a obtenção de edificações mais ajustadas ao sistema penal nacional. Na atualidade, o conhecimento específico para a concepção arquitetônica se apresenta incompleto e inconsistente no atendimento das exigências do sistema penal. Este problema compromete o desempenho das edificações que são descritas pela descaracterização e desumanização do espaço arquitetônico. Ao mesmo tempo em que a redução de custo de construção é imposta pela administração penitenciária na ampliação do parque penitenciário. A hipótese levantada nesta pesquisa coloca a viabilidade econômica da qualificação da edificação penal, ao se adequar o conjunto teórico, metodológico e técnico necessário ao projeto de estabelecimentos penais. A composição arquitetônica ajustada minimizaria o ônus na construção inerente ao incremento proposto, enquanto a mesma produziria uma redução do custeio suficiente para abater a diferença gerada. Assim, este trabalho visa uma tecnologia de projeto que sistematiza o conhecimento arquitetônico para o projeto de estabelecimentos penais mais eficientes, em termos da segurança penitenciária, funcionalidade, conforto ambiental e custos de construção e operação. Esta eficiência implica em uma composição arquitetônica mais harmônica entre a segurança penitenciária e o respeito à condição humana no ambiente prisional, moderadas pelas exigências espaciais do nível de segurança máximo. Este reequilíbrio é buscado através da conciliação entre as demandas formais e informais do sistema penal para a arquitetura, emanadas da teoria panóptica e instrumentos técnico-normativos, assim como, da realidade prisional. A conjunção destas demandas caracterizou a modalidade arquitetônica de segurança máxima que prioriza o fechamento e a disciplina espacial da prisão, enquanto agrega elementos para a reinserção social dos presos.

Palavras-chave: edifício penal; arquitetura penal; projeto arquitetônico; composição arquitetônica 


\section{Abstract}

This essay comprehends the architectural design of penal establishments from the point of view of the design process, as being understood as a mean to obtaining buildings that are appropriate for the national criminal system. Currently, the specific knowledge regarding architectural conception is incomplete and inconsistent toentirely fulfill the penal system's requirements. Such problem compromises the buildings' performance which are described by the demischaracterization and dehumanization of the architectural space. Concurrently, the reduction of construction costs is imposed by the penitentiary administration due to the expansion of the penitentiary complex. The hypothesis raised in this research places qualification economic feasibility of the criminal construction, while adjusting the theoretical, methodological and technical sets necessary to designing of penal establishments. Such an architectural composition adjustment would minimize the burdens inherent to the construction for the proposed increments, while it would cause a reduction of sufficient cost sodecreasing the generated balance. Thus, this essay aims to propose a technology project that systematizes architectural knowledge for the design of more efficient penal institutions in terms of prison security, functionality, environmental comfort, and construction and operation costs. This efficiency implies a more harmonious architectural composition between penitentiary security and respect for the human condition inside prison environment, as being moderated by the space requirements of the maximum security level. This rebalancing is obtained through the conciliation between the formal and informal demands of the penal system regarding architecture, which originates from the panoptic theory and the technical normative instruments, as well as prison reality. The combination of such demands characterized the architectural mode for maximum security that

prioritizes the closure and spatial discipline in the prison, while adding elements for the social reintegration of prisoners

Keywords: penal building; criminal architecture; architectural project; architectural composition 


\section{Resumé}

Ce travail traite du project architectural des établissements pénals du point de vue du processus de conception, entendu comme moyen pour obtention des édifications plus ajustées au système pénal national. Dans la actualité, le savoir spécifique pour la conception architeturale se présent incomplèt et incohérent dans la réception des éxigences du système pénale. Ce problème compromet le développement des édifications qui sont décrites pour la perte de caractère et déshumanisation du espace architetural. Au même temps que la réduction de coût de constrution est imposé pour l'administration pénitentiaire dans l'agrandissement du parque penitentiaire. L'hypothèse soulevée dans ce recherche met la viabilité economique de la qualification de l'édification pénale, pour être adepté à l'apport théorique, méthodologique et technique necessaire pour le project des établissements pénals. La composition architectural ajustée minimiserait le fardeau dans la construction inhérent au incrèment proposé, tandis que la même produira une rédution dans la dépense suffisante pour réduire la diference resultante. Ainsi, ce travail vise une technologie du project que systématise le savoir architetural pour le project des établissements pénals plus rentables, en termes de la sécurité pinitentiaire, fonctionnabilité, confort environnementale et coûts de construction et opération. Cet efficité implique dans une composition architectural plus harmonique entre la sécurité penitentiaire et le respect à la condition humaine dans environnement carcéral, moderée pour l'exigences spaciales du niveaux de sécurité maximum. Ce rééquilibrage est cherchée par la concilliation entre les demandes formels et informels du systeme pénal pour la architecture, modifications de la théorie panoptique et instruments techinique-normatifs, ainsi que, de la realité carcérale. La conjuction de cettes demandes a caractérisé le méthode architetural de sécurité maximum qui priorise la fermeture et la discipline spaciale de la prision, tandis que ajoute éléments pour la réinsertion sociale des prisonniers.

Mots-clés: édification pénale; architecture pénale; project architectural; composition architecturale 


\section{Lista de figuras}

$\begin{array}{ll}\text { Figura } 1 \text { - Diagrama do procedimento metodológico } & 17\end{array}$

Figura 2 - Gráficos topológicos de estabelecimentos penais $\quad 22$

$\begin{array}{ll}\text { Figura } 3 \text { - Gravura da Eastern State Penitentiary } & 28\end{array}$

Figura 4 - Fotografia da Penitenciária do Estado de São Paulo 28

Figura 5 - Esquemas dos tipos de vigilância $\quad 30$

Figura 6 - Fotografia do interior do pavilhão da Sing Sing Prison (EUA) 30

Figura 7 - Fotografia da USP Pelican Bay (EUA) 32

Figura 8 - Perspectiva digital do projeto conceitual The 21th Century Prison 33

Figura 9 - Fotografia da Casa de Detenção de São Paulo $\quad 34$

Figura 10- Fotografia da Penitenciária Lemos Brito/BA $\quad 35$

Figura 11 - Esquema da evolução do espaço arquitetônico da prisão 42

Figura 12 - Desenho do Panopticon de Jeremy Bentham 44

Figura 13 - Fotografia do Anexo IV da Penitenciária Lemos Brito/BA 46

Figura 14 - Gravura da cela do Panopticon $\quad 50$

Figura 15 - Fotografia do espaço de vigilância panóptico da Stateville Penitentiary (EUA) 58

Figura 16 - Gráfico da rotina diária ordinária dos presos no sistema penitenciário catarinense 73

Figura 17 - Desenhos do modelo de prisão Category B do Prison Design Briefing System 87

Figura 18 - Fotografia do Presídio Inspetor Martinho Drumond 90

Figura 19 - Perspectiva eletrônica do projeto padrão de cadeia pública do Ministério da Justiça. 92

Figura 20 - Fotografia de cela do CDP de Taubaté com o piso (praia) tomado por colchões 99

Figura 21 - Fotografia da cela da ADX Florence supermax 103

Figura 22 - Fotografia da ocupação cotidiana do espaço prisional na Penitenciária Lemos Brito/BA 106

Figura 23 - Fotografia de cela coletiva de Penitenciária Compacta paulista 107

Figura 24 - Diagrama da representação formal dos princípios panópticos $\quad 128$

Figura 25 - Diagrama da representação formal dos quesitos do programa arquitetônico 129

Figura 26 - Diagrama preliminar da estrutura em árvore para o programa arquitetônico 130

Figura 27 - Representação formal em árvore dos requisitos funcionais $\quad 131$

Figura 28 - Programa arquitetônico para estabelecimentos penais $\quad 132$

Figura 29 - Gráfico do resultado geral da equivalência entre as características formais e informais da edificação penal 133

Figura 30 - Gráfico do resultado geral das melhores soluções para a edificação penal 136

Figura 31 - Gráfico do atendimento dos critérios de análise pelas soluções formais e informais 136

Figura 32 - Gráfico das estruturas física e operacional das diferentes categorias de segurança e porte 141

Figura 33 - Gráfico dos índices físicos e financeiros das capacidades de cela 146

Figura 34 - Desenhos das geometrias dos projetos de referência (sem proporção) 147

Figura 35 - Gráficos de distribuição das áreas das atividades nos projetos de referência $\quad 148$

Figura 36 - Desenhos da setorização dos projetos de referência (sem proporção) 149

Figura 37- Desenhos das circulações dos projetos de referência (sem proporção) 150

Figura 38 - Esquema demonstrativo do tamanho relativo das aberturas de iluminação e ventilação 152

Figura 39 - Desenhos isométricos da vigilância externa dos projetos de referência $\quad 154$

Figura 40 - Desenho isométrico esquemático do desenho-síntese de barreira perimetral desenvolvido para o nível de segurança máximo proposto $\quad 157$

Figura 41 - Desenho esquemático dos raios de visão de um observador externo às edificações da $\begin{array}{lr}\text { prisão } & 158\end{array}$

Figura 42 - Desenhos esquemáticos isométricos do desenho-síntese desenvolvido de cela coletiva de $\begin{array}{lr}\text { oito vagas. } & 159\end{array}$

Figura 43 - Gráfico comparativo do dimensionamento de celas de oito vagas $\quad 161$

Figura 44 - Desenho esquemático isométrico do desenho-síntese desenvolvido de pátio de sol dos presos. 
Figura 45 - Desenhos esquemáticos isométricos do desenho-síntese desenvolvido de posto de controle

Figura 46 - 166

Figura 46 - Desenho de implantação de modelo de unidade prisional (sem escala). 168

Figura 47 - Esquema das alterações promovidas no projeto da Penitenciária do Distrito Federal (sem escala)

172

Figura 48 - Esquema das alterações promovidas ao projeto da Penitenciária Compacta (sem escala).

173

Figura 49 - Esquema das alterações promovidas ao projeto padrão do Ministério da Justiça (sem escala)

175

Figura 50 - Esquema das alterações promovidas no projeto da empresa Verdi Construções S/A (sem escala).

Figura 51 - Gráfico das características gerais dos projetos de referência ajustados 179

Figura 52 - Gráfico dos dados gerais das caracterizações do espaço arquitetônico prisional 182

Figura 53 - Gráfico das diferenças percentuais dos índices da caracterização normativa do espaço arquitetônico e do modelo de unidade prisional desenvolvido

182

Figura 54 - Gráfico das médias gerais das caracterizações normativa e idealizada do espaço arquitetônico prisional, comparadas aos projetos de referência originais e ajustados 184

Figura 55 - Gráfico do resultado da análise do ajustamento implementado nos projetos de referência

185

Figura 56 - Gráfico false color resultante da simulação de iluminação da cela

Figura 57 - Gráfico do resultado da análise do ajustamento implementado nos projetos de referência 195

Figura 58 - Gráfico das faixas latentes entre os projetos de referência revisados e o desenho-síntese $\quad 195$

Figura 59 - Fotografias de satélite com a localização da PDF II $\quad 212$

Figura 60 - Plantas esquemáticas e fotografia da PDF II 213

Figura 61 - Planta esquemática e fotografia da PC de Itatinga 213

Figura 62 - Plantas esquemáticas e imagem da Cadeia Pública do Plano Nacional de Apoio ao Sistema

Penal 214

Figura 63 - Plantas esquemáticas e imagem da penitenciária modelo da empresa Verdi Construções

S/A $\quad 215$

Figura 64 - Planta esquemática e imagem da penitenciária para presos jovens adultos (Pronasci) 215

Figura 65 - Planta esquemática e fotografia de unidade feminina da empresa DM Construtora de

Obras /ES 216

Figura 66 - Planta esquemática e imagem da penitenciária federal do Ministério da Justiça 217

Figura 67 - Planta esquemática e imagem da ADX Florence $\quad 217$

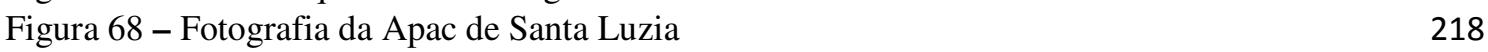

Figura 69 - Perspectiva digital da prisão de Halden Fengsel. 218

Figura 70 - Fotografia da Penitenciária Industrial de Blumenau $\quad 248$

Figura 71 - Fotografia do complexo penitenciário de pinheiros 249

Figura 72 - Representação formal dos vínculos dos requisitos funcionais de ordem externa do programa arquitetônico para estabelecimentos penais 303

Figura 73 - Representação formal dos vínculos dos requisitos funcionais de ordem interna do programa arquitetônico para estabelecimentos penais 304

Figura 74 - Desenhos de cortes do pátio de sol dos presos demonstrativos da visualização do posto de

controle. $\quad 367$

Figura 75 - Desenhos-síntese da cela (planta baixa, corte longitudinal e isométrica). 369

Figura 76 - Desenhos-síntese da cela (cortes transversais e vista externa do corredor de acesso). $\quad 370$

Figura 77 - Desenhos-síntese da cela (detalhes dos nichos). $\quad 371$

Figura 78 - Desenhos-síntese do pátio de sol dos presos (planta baixa e corte A). 372

Figura 79 - Desenhos-síntese do pátio de sol dos presos (cortes B, C e D). 373

Figura 80 - Desenhos-síntese do posto de controle (planta baixa, corte e vista externa). $\quad 374$

Figura 81 - Desenho de implantação de unidade prisional baseado na tecnologia de projeto. $\quad 375$ 


\section{Lista de tabelas}

Tabela 1 - Orçamento estimativo do valor unitário da barreira perimetral 170

Tabela 2 - Ajuste ao custo de construção do projeto da Penitenciária do Distrito Federal 172

Tabela 3 - Ajuste ao custo de construção do projeto da Penitenciária Compacta 174

Tabela 4 - Ajuste ao custo de construção do projeto da Cadeia Pública do Ministério da Justiça 175

Tabela 5 - Ajuste ao custo de construção do projeto modelo da empresa Verdi Construções S/A 177

Tabela 6 - Demonstrativo de área construída acrescida e deduzida nos projetos ajustados $\quad 177$

Tabela 7 - Características gerais originais e revisadas dos projetos de referência 179

Tabela 8 - Quadro Características físico-financeiras dos desenhos-síntese 187

Tabela 9 - Comparativo dos dados físicos gerais da barreira perimetral 188

Tabela 10 - Comparativo dos dados econômicos gerais da barreira perimetral 188

Tabela 11 - Comparativo dos dados gerais físicos das celas 189

Tabela 12 - Comparativo dos dados gerais econômicos das celas 189

Tabela 13 - Comparativo dos dados gerais físicos dos pátios de sol 190

Tabela 14 - Comparativo dos dados gerais econômicos dos pátios de sol 190

Tabela 15 - Comparativo dos dados gerais físicos dos postos de controle $\quad 191$

Tabela 16 - Características econômicas dos projetos de referência 224

Tabela 17 - Custos específicos de construção e operação 224

Tabela 18 - Análise do contexto $\quad 269$

Tabela 19 - Requisitos funcionais e respectivos vínculos 292

Tabela 20 - Análise da equivalência entre as características formal e informal nos projetos de referência 306

Tabela 21 - Avaliação dos componentes da composição arquitetônica

Tabela 22 - Características físico-financeiras dos desenhos-síntese 368

Tabela 23 - Avaliação da tecnologia de projeto 377 


\section{Lista de quadros}

Quadro 1 - Quesitos panópticos relacionados aos princípios, processos e elementos arquitetônicos 48 Quadro 2 - Abordagem dos instrumentos legais e técnico-normativos em relação aos temas da composição arquitetônica da edificação penal

Quadro 3 - Resumo dos conteúdos dos principais temas das Diretrizes Básicas para o projeto arquitetônico

Quadro 4 - Listagem das alterações promovidas nas regras técnicas relativas à modelagem da edificação penal 81

Quadro 5 - Critérios de desempenho da NBR 15575 e da ISO 6241 para o objeto de pesquisa 85

Quadro 6 - Temas da composição arquitetônica comtemplados pelo Technical Guidance of Prision

Planning 88

Quadro 7 - Quesitos de conforto ambiental contemplados pelo caderno BREAAM Prisons 89

Quadro 8 - Quesitos contemplados pelo Certified Prisoner Accomodation 89

Quadro 9 - Quesitos para o programa arquitetônico 127

Quadro 10 - Resumo da análise da equivalência entre as características formais e informais da edificação penal 134

Quadro 11 - Resumo das equivalências entre as características formais e informais por projeto de referência 135

Quadro 12 - Resumo das soluções adotadas para a conformação da tecnologia de projeto 137

Quadro 13 - Resumo dos ajustes às soluções formais e informais 169

Quadro 14 - Comparativo dos dados gerais médios das caracterizações do espaço arquitetônico prisional 181

Quadro 15 - Comparativo dos dados gerais das caracterizações do espaço arquitetônico prisional 183

Quadro 16 - Resumo dos resultados do ajustamento implementado aos projetos de referência 185

Quadro 17 - Características físicas médias dos projetos de referência 219

Quadro 18 - Características físicas médias dos elementos centrais da edificação penal 221

Quadro 19 - Exigências formais dos instrumentos legais e técnico-normativos do Ministério da Justiça

226

Quadro 20 - Características formais da edificação prisional 235

Quadro 21 - Critérios do Technical Guidance for Prison Planning 237

Quadro 22 - Critérios de conforto ambiental de instrumentos técnicos e normativos similares ou correlatos 240

Quadro 23 - Descrição do levantamento realizado no sistema catarinense 247

Quadro 24 - Descrição do levantamento realizado no sistema paulista 248

Quadro 25 - Dados levantados em entrevistas aos usuários da edificação penal 250

Quadro 26 - Tecnologia de projeto 335 


\section{Lista de abreviaturas e siglas}

\section{Abreviaturas}

Art. - Artigo de Lei

Un - Unidade

\section{Siglas}

Anvisa - Agência Nacional da Vigilância Sanitária

CAD - Concreto de Alto Desempenho

CIPP - Comissão Internacional Penal e Penitenciária

CIR - Centro de Internamento e Reeducação

CNPCP - Conselho Nacional de Política Penitenciária

Coena - Coordenação de Engenharia e Arquitetura/Depen

Conama - Conselho Nacional do Meio Ambiente

CPI - Comissão Parlamentar de Inquérito

CR - Centro de Ressocialização

CRIS - Centro de Reabilitação e Integração Social

Depen - Departamento Penitenciário Nacional

EAS - Estabelecimento de Assistência à Saúde

EE.UU. - Estados Unidos da América

Funpen - Fundo Penitenciário Nacional

GDF - Governo do Distrito Federal

GPOE - Gerencia Penitenciária para Operações Especiais

HRW - Human Rights Watch

INCC-FGV - Índice Nacional da Construção Civil da Fundação Getúlio Vargas

Infopen - Sistema Integrado de Informações Penitenciárias

LEP - Lei de Execução Penal

MJ - Ministério da Justiça

ONU - Organização das Nações Unidas

$\mathrm{PC}$ - Penitenciária Compacta

PC-V - Penitenciária Compacta Vertical

PDF - Penitenciária do Distrito Federal

PLB - Penitenciária Lemos Brito

PPP - Parceria Público Privada

PRI - Penal Reform International

Pronasci - Programa Nacional de Segurança Pública com Cidadania

SAP/SP - Secretaria da Administração Penitenciária do Estado de São Paulo

Sesipe - Subsecretaria do Sistema Penitenciário/SSP/DF

SSP/DF - Secretaria de Segurança Pública do Distrito Federal

\section{Símbolos}

$\mathrm{cm}$ - centímetro

$\mathrm{m}$ - metro

$\mathrm{m}^{2}$ - metro quadrado

$\mathrm{m}^{3}$ - metro cúbico

$\mathrm{R} \$$ - Real 


\section{Sumário}

Dedicatória

Agradecimentos

Resumo

Abstract

Resumé

Lista de figuras

Lista de tabelas

Lista de quadros

Lista de abreviaturas e siglas

Sumário

Introdução

vii

ix

$\mathrm{x}$

xi

xii

xiv

XV

$\mathrm{xVi}$

xvii

1. Hipótese

12

2. Objetivos

3. Procedimento metodológico

4. Estrutura da tese

Capítulo 1 - Edificação penal

1.1 Caráter penalógico 20

1.2 Programa arquitetônico

1.3 Mutabilidade do espaço arquitetônico penal

1.4 Espaço arquitetônico penal

1.5 A edificação penal no Brasil

1.6 Conclusão analítica

Capítulo 2 - Panóptico

2.1 Quesitos panópticos para o programa arquitetônico 46

2.2 Composição arquitetônica panóptica $\quad 49$

2.3 Mutabilidade do Panóptico $\quad 58$

2.4 Conclusão analítica 63

$\begin{array}{ll}\text { Capítulo } 3 \text { - Modelo prisional } & 68\end{array}$

$\begin{array}{lll}3.1 & \text { Regras técnicas para a arquitetura } & 74\end{array}$

3.2 Considerações sobre os instrumentos legais e técnico-normativos 77

3.3 Características formais da edificação penal $\quad 82$

3.4 Instrumentos técnico-normativos similares ou correlatos $\quad 84$

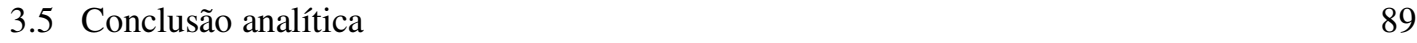

Capítulo 4 - Realidade prisional $\quad 93$

4.1 Política Penitenciária Nacional $\quad 94$

4.2 Sistema Penitenciário Nacional 97

$\begin{array}{lr}4.3 & \text { Paradoxo prisional } \\ 4.3 .1 & 100\end{array}$

$\begin{array}{ll}\text { 4.3.1 Cotidiano prisional } & 101\end{array}$

4.3.2 Cotidiano prisional no Brasil 104

4.4 Características informais da edificação penal 110

4.5 Conclusão analítica $\quad 114$ 
6.1 Programa arquitetônico 123

6.1.1 Quesitos 123

6.2 Representação formal 128

6.3 Estrutura preliminar do programa arquitetônico 130

6.4 Requisitos funcionais 131

6.5 Programa arquitetônico 132

6.6 Análise das características formais e informais da edificação penal 132

6.7 Conclusão Analítica 137

Capítulo 7 - Tecnologia de projeto 139

$\begin{array}{lll}7.1 & \text { Revisão dos quesitos externos } & 139\end{array}$

7.2 Revisão dos quesitos internos 143

7.3 Revisão dos quesitos dos elementos centrais da edificação penal 156

7.5 Conclusão analítica

Capítulo 8 - Avaliação da tecnologia de projeto 170

8.1 Orçamento dos elementos centrais da edificação penal 170

8.2 Aplicação da tecnologia aos projetos de referência 171

8.3 Avaliação da aplicação da tecnologia aos projetos de referência 178

8.4 Conclusão Analítica 194

Conclusão 197

Referências bibliográficas $\quad 201$

Apêndice A - Projetos arquitetônicos de referência 211

Apêndice B - Exigências legais e técnico-normativas

Apêndice C - Estudo de campo 242

Apêndice D - Definição dos requisitos funcionais 268

Apêndice E - Análise das instancias formal e informal $\quad 305$

Apêndice F - Tecnologia de projeto

Apêndice G - Desenhos-síntese dos elementos centrais da edificação penal 364

Apêndice H - Avaliação da aplicação da tecnologia de projeto 376 


\title{
Introducão
}

As edificações prisionais têm apresentado baixa eficiência e eficácia, ao não atenderem as exigências das leis, da segurança, da operacionalidade, da condição humana e do custo.

\begin{abstract}
$\mathrm{Na}$ maioria dos casos, os Estados têm construído as mais esdrúxulas e improvisadas estruturas para abrigar pessoas presas. Constatam-se celas sem nenhuma ventilação, iluminação ou incidência de sol e com pé direito baixo em localidades com médias de temperatura de 30 a 40 graus Celsius. Ou unidades que só tem celas, sem espaço para visitas, atividades educativas ou laborais, administrativas ou alojamento para funcionários. Ou, ainda, unidades hiperequipadas com corredores gradeados, sistemas inteiramente automatizados, várias ante-salas de segurança, grades entre presos e profissionais de saúde, paredes triplas e metros de concreto armado abaixo da construção para abrigar presos acusados de furto, roubo e pequenos traficantes. Não é possível tanto descaso para com as pessoas e para com o dinheiro público (BRASIL, 2011, p. 11).
\end{abstract}

Projetos caros e ruins. Em razão do elevado custo, não atendem à crescente demanda por vagas. Não atendendo à demanda por vagas, rapidamente ficam superlotados e, juntamente com outros fatores desumanizadores do cárcere, contribuem para a brutalização do ser humano preso e, por consequência, acabam por promover mais violência e criminalidade, ou seja, exatamente o oposto daquilo a que originariamente se propõem as prisões (SILVA, 2008).

Estas questões motivaram o trabalho realizado que buscou um conjunto teórico, metodológico e técnico adequado para o projeto de estabelecimentos penais, imbuído em "definir uma nova arquitetura para as prisões que harmonize a necessidade da custódia e da segurança, com o indispensável tratamento penal, voltado para a reintegração das pessoas presas” (BARROS, 2003, p. 4).

A edificação penal surgiu com a Reforma Jurídico-Penal entre os séculos XVIII e XIX com a proposição da humanização do castigo que instaurou a pena privativa de liberdade: o isolamento por um período de tempo, associado ao silêncio, trabalho, educação e orientação religiosa, em ambiente salutar, visando à recuperação do criminoso pela mudança da sua moral e temor de novo castigo, servindo como prevenção dos delitos e mecanismo de inserção social (FOUCAULT, 1987, p. 64 e 76). Com esta nova tecnologia de poder se instaura o duplo objetivo da pena: punir e recuperar. A privação de liberdade previa o encarceramento em um local especializado - a prisão. Assim, surgiu a necessidade de construir edifícios especialmente adaptados ao propósito de manter cativo um número elevado de reclusos, de forma higiênica e segura (ALGARRA, 2007).

A prisão é um estabelecimento social, tanto no sentido amplo da função social que desempenha, como no sentido sociológico: o local onde ocorrem relações sociais (GOFFMAN, 2005). Enquanto estabelecimento social se distingue por ser do tipo Instituição Total.

Uma instituição total pode ser definida como um local de residência e trabalho, onde um grande número de indivíduos com situação semelhante, separados da sociedade mais ampla, por considerável período de tempo, leva uma vida fechada e formalmente administrada (GOFFMAN, 2005, p. 11). 
Segundo Goffman (2005, p. 24), a Instituição Total é definida por processos totais: ações institucionais sistematizadas e relativamente padronizadas que objetivam um reposicionamento do preso, desvinculando o mesmo da sua formação civil, concebida na sociedade. Goffman identifica estes processos como 'mortificações do eu': rebaixamentos, degradações, humilhações e profanações. Os processos totais são: o isolamento social - segregação de um grupo humano em uma instituição com tendências de fechamento em relação ao meio de origem; o integralismo - todos os aspectos da vida são realizados no mesmo local e sob uma única autoridade; o mecanicismo - cada fase diária do preso é realizada em grupo, segundo um plano racional único; e o controle despótico sobre o individual - a vigilância garantidora do atendimento das regras institucionais.

O funcionamento de um estabelecimento prisional é regido pelo modelo prisional (ver capítulo 3) que é conformado pelos princípios de funcionamento da prisão ${ }^{1}$ (ESTECA, 2010, p. 42): o isolamento social e individual dos presos, as atividades dos presos, a vigilância e a administração da pena. Historicamente, estes princípios foram revistos e configurados em diferentes combinações, de acordo com o pensamento penalógico predominante em cada sistema penal. Estas variações originaram as técnicas penitenciárias, tais como, a auburniana e a filadélfica. As técnicas penitenciárias são conjuntos de métodos aplicados à administração das prisões e ao tratamento dos presos, constituídas de regras, procedimentos e rotinas.

Concomitante à implementação da pena moderna, os ideais da prisão foram reformulados com a conformação da sociedade disciplinar, por meio de métodos de dominação social chamados de disciplinas ${ }^{2}$. Em relação à tecnologia de poder reformista, as técnicas penitenciárias caracterizaram outra tecnologia de poder na qual se enfatizou o cumprimento do ritual da pena, de forma otimizada: a economia de recursos e de política para os melhores resultados (FOUCAULT, 1987). Para tanto, a tecnologia de poder disciplinar procedeu a uma despersonificação do preso, o que possibilitou retirar da prática prisional certos padrões de bem-estar considerados ineficientes, em favor de um suposto êxito econômico do modelo prisional - a disciplina-bloco descrita por Foucault ${ }^{3}$.

As críticas à prisão não variaram durante a sua história, sendo direcionadas aos seus aspectos de ordem utilitária: custa caro e não reprime o crime; de ordem moral: como meio de neutralização é puro castigo; e de ordem social: não recupera (OLIVEIRA, 2002, p. 13). A prisão "ao contrário, degrada,

\footnotetext{
${ }^{1}$ No trabalho de Esteca (2010, p. 42), os princípios de funcionamento da prisão foram derivados dos esquemas disciplinares de Foucault.

2 Foucault (1987, p. 118) definiu a sociedade disciplinar como o resultado de um sistema de controle social elaborado pelas classes economicamente dominantes no advento do Estado Liberal na Europa do século XIX. É um sistema que visava "a economia, a eficácia dos movimentos, sua organização interna".

${ }^{3}$ A disciplina-bloco enfatiza o cumprimento da pena, ao focar a vertente punitiva da pena, expressa na concepção negativa da Teoria Preventiva Especial do Direito (ver Capítulo 3): “a instituição fechada, estabelecida à margem, e toda voltada para funções negativas: fazer o mal, romper as comunicações, suspender o tempo" (FOUCAULT, 1987, p.198). Embora a disciplina-bloco enfatize a punição, ela garante o respeito à condição humana dos presos, mantendo a ordem interna e os padrões humanitários mínimos, a despeito dos impactos que esta totalização provoca.
} 
agride, inflige sofrimento desproporcional ao indivíduo e confere natureza estritamente retributiva à pena como castigo legal" (GARBELINI, 2005, p. 158). Conjuntura, em boa parte, aceita pela sociedade como necessária para que seja feita justiça: "é o sentimento de vingança sobrepujando o sentimento de justiça" (BARROS, 2003, p. 04). Assim, "vista sob o ângulo dos interesses das classes dominantes, a prisão cumpre seus objetivos e pode ser classificada como instituição bem sucedida" (CAMARGO, 1989, p. 39).

A atual conjuntura do sistema penal nacional é marcada pela passagem de um período de consolidação legal e administrativa da instituição prisional, entre as décadas de 1970 e 1980, e pelo progressivo reposicionamento penalógico do Estado, fundado no discurso do endurecimento da pena. Nesta conjuntura, a carga de entrada de presos aumentou aceleradamente, sem o proporcional aporte de recursos para a custódia deste grupo. A extrema crise penitenciária traz agravantes para o espaço construído da prisão. Segundo Garbelini (2005, p. 157): "vivemos atualmente um retrocesso arquitetural, prova disto é o resgate do isolamento pensilvânico pelo RDD (Regime Disciplinar Diferenciado), através da solidão e do silêncio do antigo e ineficaz modelo filadélfico".

A questão prisional vem sendo evidenciada no debate da segurança pública e nas políticas de governo para o sistema de justiça criminal. Parte da resposta governamental tem sido a ampliação do parque penitenciário, o que constitui oportunidade do exercício arquitetônico no setor prisional, ao mesmo tempo em que o papel e a importância da edificação no âmbito da execução penal têm sido distorcidos. Credita-se ao espaço construído a melhoria do sistema penitenciário ou mesmo o protagonismo da reforma penitenciária, o que remete ao determinismo arquitetônico ${ }^{4}$. Da mesma maneira, se transfere para a arquitetura questões que, fundamentalmente, não são exclusivas de sua competência e que dependem de uma série de fatores, como uma equipe bem dimensionada e preparada (ESTECA, 2010, p. 110). Estas imposições responsabilizam o edifício pela segurança e a operação do estabelecimento penal, além da economicidade e da condição das pessoas na prisão. No entanto, a arquitetura não figura entre as demandas emergenciais do sistema penitenciário. A CPI do Sistema Carcerário identificou como principais reclamações dos presos a superlotação, a alimentação e os maus tratos, além de violências por parte dos funcionários (BRASIL, 2009).

A realidade prisional traz uma questão fundamental para a pesquisa em arquitetura penal, ao polemizar a viabilidade do aprimoramento do espaço arquitetônico diante das incongruências do sistema penitenciário, especialmente da aglomeração dos presos. Trata-se de um questionamento comum nos

\footnotetext{
${ }^{4}$ o Determinismo Arquitetônico parte da crença de que a arquitetura é geradora dos mais importantes efeitos sobre o comportamento humano, embora qualquer comportamento - espacial, cognitivo ou emocional - dependa dos hábitos e intenções das pessoas e de fatores facilitadores de ordem administrativa, financeira, ou de alguma outra ordem (FLÓSCULO, 2000, p. 4).
} 
trabalhos em arquitetura penal, como no Tomorrow's Prisons (MUIR, 2010), The Creative Prison (RIDEOUT, 2006a) e The 21th Century Prison Model (HENLEY, 2003) que ressaltam a superpopulação no sistema inglês conformada por reincidentes:

\begin{abstract}
Este foco no projeto prisional é contencioso - de fato, muitos da comunidade de reforma penal argumentam que nós deveríamos deixar esta questão de lado. Eles argumentam que a prisão não trabalha em termos da reabilitação e que nós deveríamos focar em desenvolver alternativas para isto. Eles colocam que a menos que nós lidemos com as causas da superpopulação prisional - principalmente com a pressão pública, da mídia e política por sentenças mais duras - não importa quão bem projetadas as prisões são: elas serão simplesmente inundadas por números insustentáveis. Discutir o projeto prisional, estes cépticos argumentam, é desviar das questões mais importantes (MUIR, 2010, p. 7).
\end{abstract}

O relatório Tomorrow's Prisons assume a inviabilidade da 'boa prisão' pelo excedente populacional, associado aos demais problemas do sistema penitenciário. Do ponto de vista das prioridades, posicionamento desta crítica é valido, todavia “a questão permanece importante e inevitável” afirmação defendida pela influencia do projeto arquitetônico no desempenho da instituição (MUIR, 2010, p. 7): embora o regime ou técnica penitenciária aplicada seja mais relevante do que a arquitetura, o projeto pode dificultar ou facilitar a implementação de atividades, assim como, a arquitetura impacta sobre as relações sociais internas e externas, exaltando ou não os antagonismos entre os grupos internos e da instituição com a sociedade. Interessante notar que o documento não cai na falácia idealista, pregando a melhoria da prisão vinculada à humanização da pena. Neste sentido, o mesmo não descarta a necessidade de projetos de maior segurança, independentemente da regularização da população prisional, pois sempre haverá presos mais críticos.

O estudo The Creative Prison aborda diretamente a questão do excedente populacional (RIDEOUT, 2006a, p. 5): "Se reconhece a corrente crise da superpopulação ao mesmo tempo em que se argumenta que esta situação não pode ser utilizada como uma desculpa para não se buscar uma prática melhor". Ao mesmo tempo, este estudo (Idem, 2006a, p. 5 e 6) confirma a necessidade de se ouvir os usuários da edificação, a despeito das inconformidades da realidade prisional. $\mathrm{O}$ mesmo realizou consulta a funcionários e prisioneiros como meio para se alcançar uma eficiência da edificação, através da identificação das questões relacionadas ao espaço construído e as dificuldades de alcançar as respectivas soluções. Segundo o documento (Idem, 2006a), “o pessoal das prisões sabem como o desenho e a organização do espaço ajudam ou dificultam suas tarefas diárias", enquanto "são os prisioneiros que estão melhor localizados, como consumidores e usuários, para comentar estas questões [o perfil, organização e tom dos edifícios prisionais em relação a psicologia dos condenados]". O texto coloca a forma arquitetônica como indicativo do funcionamento da prisão, principalmente em termos das relações sociais, mas também como fator agravante ou atenuante da condição mental das pessoas. Sobre isso Sá (1990, p. 249) ressalta que entre o espaço arquitetônico e a pessoa presa se estabelece uma relação de identificação e de motivação: “entre o homem e o arranjo arquitetural, do qual ele é parte integrante, vai se estabelecer uma simbiose perfeita”. Os efeitos 
recíprocos entre o edifício e o preso são potencializados na prisão pela compulsoriedade e pelo tempo de permanência no estabelecimento. Ao mesmo tempo, o documento aponta como benefício potencial da consulta aos usuários da edificação prisional uma redução de custos relacionada a posteriores adequações arquitetônicas, quando da ocupação do edifício e verificação de falhas operacionais derivadas do espaço arquitetônico.

A conformação de um conjunto tecnológico apropriado para a elaboração de projetos de estabelecimentos penais exigiu a apreensão prévia do que deveria ser gerado em termos teóricos e técnicos. Isto considerando as principais deficiências e as demandas prioritárias para o projeto de edificações penais, ao mesmo tempo em que deveriam ser evitadas as falácias e determinismos da arquitetura na execução da pena. Para tanto, o exame do paradigma tecnológico da edificação penal foi o mecanismo utilizado para conformar o trabalho, tendo apontado os objetivos e as estratégias adotadas nesta pesquisa ${ }^{5}$. Este exame procedeu à identificação dos agentes e dos recursos tecnológicos disponíveis, ao situar a arquitetura penal na Cadeia Produtiva da Indústria da Construção (CPIC) e caracterizar os vetores de influência da inovação responsáveis pela mudança do paradigma tecnológico (BLUMENSCHEIN, 2004).

\section{Paradigma tecnológico da edificação penal}

A definição de paradigma tecnológico da edificação penal sugeriu como ponto de partida para o embasamento desta pesquisa a identificação dos agentes e dos recursos tecnológicos disponíveis no campo da construção de prisões. Para tanto, a arquitetura penal foi situada na Cadeia Produtiva da Indústria da Construção (CPIC) ${ }^{6}$ do setor prisional do país, assim como, os agentes responsáveis pela mudança de paradigma tecnológico da edificação penal foram identificados. Em particular, esta identificação ocorreu segundo os vetores de influência da inovação mais relevantes entre os elencados por Blumenschein (2004) ${ }^{7}$ : o Líder Empreendedor; e o Mercado e Demanda.

O vetor Mercado e Demanda foi caracterizado pelas demandas realísticas do sistema penal que têm exigido soluções espaciais mais criativas para a mitigação dos problemas das prisões. Foi este vetor que definiu o objeto de pesquisa: estabelecimentos de segurança máxima para presos homens.

\footnotetext{
${ }^{5}$ Segundo Dosi (1988, apud BLUMENSCHEIN, 2004, p. 131), o paradigma tecnológico é o padrão ou modelo de princípios derivados de conhecimentos das ciências naturais e da tecnologia existente que define o campo de investigação, os respectivos problemas a serem resolvidos e os procedimentos para resolvê-los.

${ }^{6}$ Entende-se por Cadeia Produtiva da Indústria da Construção (CPIC): “[...] o conjunto de atividades que se articulam progressivamente desde os insumos básicos até o produto final, incluindo distribuição e comercialização, constituindo-se em elos de uma corrente" (MDIC, 2002 apud BLUMENSCHEIN, 2004).

${ }^{7}$ Entre os vetores de influência, se destacam no segmento penal apenas o Mercado e demanda e o Líder Empreendedor. Na Pesquisa e Desenvolvimento (P\&D) o uso da tecnologia é limitado pelas condições operacionais do sistema penal. Na P\&D, o setor privado tem sido o principal agente de inovação, especialmente com a introdução de materiais de alta performance e métodos industriais de construção. No vetor Produção, o projeto normalmente é elaborado pelo Estado, enquanto as obras são terceirizadas na sua totalidade. Quanto ao Sistema Nacional de Inovação (SNI), ao Sistema Nacional de Aprendizado (SNA), aos instrumentos de política ambiental e às Redes não se reconhece um modelo organizado para a inovação no sistema penal.
} 
Enquanto, o Ministério da Justiça configurou como o líder empreendedor, ao ser o principal agente na construção de prisões e vetor de influência da inovação na arquitetura penal, pois é o órgão executivo da política penitenciária nacional, responsável pela assistência técnica na construção de estabelecimentos penais e pela criação de regras para a concepção da edificação penal (LEP, art. 64, 71 e 72; Decreto ${ }^{\circ}$ 6.061/2007, art. 25). Na interrelação entre os vetores de influência da inovação, as razões para inovar do Ministério da Justiça passam para as demandas do sistema penal: a geração de vagas ao menor custo possível.

Com base no Manual do Oslo (OCDE, 1997), se deduz que qualquer melhoria no desempenho do Ministério da Justiça exige mudanças em produtos e processos, ou seja, novos conhecimentos. No campo da arquitetura penal, a reabilitação do setor técnico depende de uma série de ações encadeadas, vinculadas a condições políticas e administrativas favoráveis. No entanto, como o Ministério da Justiça não se habilita como um órgão inovador ${ }^{8}$, não encontra motivos para investir na área técnica, pois desconhece a interface da arquitetura com a penalogia, assim como, o papel e a importância da arquitetura no âmbito penitenciário (MIOTTO, 1992). Em contrapartida, do ponto de vista da inovação, entre os fatores administrativos condicionantes da arquitetura penal, o conhecimento arquitetônico surge como meio para uma melhoria do desempenho das equipes de projeto. Isto porque a implementação deste conhecimento transcende a atuação estatal, permitindo uma contribuição extraordinária, independente das dificuldades de inovação da administração penitenciária⿳9.

A lacuna do conhecimento arquitetônico penal é comprovada pelo material bibliográfico: escasso, disperso, generalista e superficial. Em boa parte, o mesmo tem uma abordagem do ponto de vista da psicologia, sociologia, saúde, direito ou penalogia. A totalidade das referencias encontradas converge para os mesmos textos já consagrados no campo penal, sendo repetidamente citados Erving Goffman, James Webster e Richard Wener, além de Michael Foucault e García Basalo. Ornstein (1989) chama a atenção para a ausência de avaliação das regras técnicas do Ministério da Justiça, embora estas sejam basicamente a única referência sobre este tema no país. Como coloca Rolim (2005), "quando muito, os arquitetos recebem como ‘orientação' algumas normas básicas de segurança a serem observadas”. De uma forma geral, os trabalhos tratam de componentes arquitetônicos em recomendações pontuais e desconexas, enquanto não existe um conteúdo teórico, metodológico e técnico, integrado por

\footnotetext{
8 Ao tratar das razões para inovar do Ministério da Justiça, o conceito de empresa inovadora do Manual de Oslo (OCDE, 1997) foi transposto para o setor público: o órgão inovador - aquele que introduz atividades de inovação que dependem de uma conexão com o Sistema Nacional de Inovação. Apesar do Manual de Oslo colocar a importância da inovação no setor público, não apresenta um modelo de evolução tecnológica específico para o mesmo.

9 Esta possibilidade foi verificada de duas formas. Primeiro, o trabalho de inteligência das universidades consta de forma autônoma da atuação da administração penitenciária na CPIC da edificação penal. Em segundo lugar, a Pesquisa \& Desenvolvimento lista entre os vetores de influência da inovação (BLUMENSCHEIN, 2004), abrangendo a introdução de novas tecnologias na indústria da construção, tal como tecnologias de projeto.
} 
mecanismos projetuais coesos para a elaboração do conjunto construído. Normalmente, o desconhecimento a respeito das expectativas dos usuários é o mais significativo. Não existem informações sistematizadas sobre o funcionamento de um estabelecimento penal, especialmente quanto à relação entre os usuários e o espaço arquitetônico.

A heurística projetual tem sido a reprodução combinada de desenhos clássicos e projetos existentes, às vezes, associada a novas tecnologias em uma pretensa modernização da edificação (ESTECA, 2010). Nela, a deficiência técnica impede esta reprodução de modo criterioso, o que resulta em propostas obsoletas e desajustadas, ao mesmo tempo em que o projetista insiste neste método. Diante disto, a incompletude técnica-científica voltada para a composição arquitetônica da edificação prisional leva o projetista a um círculo vicioso, ao ignorar a inviabilidade da correção arquitetônica sem o domínio do tema (ESTECA, 2010). Neste ponto, o projeto passa a ser sustentado pelas falácias e determinismos que distorcem seu papel e importância. Esta questão se insere no 'achismo' da Ciência Penitenciária descrito por Miotto (1992, p. 46): “questões penitenciárias e de execução penal são tratadas empiricamente - um tipo de 'achologia penitenciária"'.

O exame inicial da CPIC da edificação penal e da inovação arquitetônica no setor prisional apontou que os recursos tecnológicos produzidos pelo Ministério da Justiça e as demandas do sistema penal são críticos para a composição do espaço arquitetônico da prisão. Com base nisto, a atividade, o modelo e a realidade prisionais foram examinados, de modo a se fixar as providências para a reabilitação do conhecimento arquitetônico.

$\mathrm{Na}$ abordagem da atividade prisional foi explorada a disfunção entre a penalogia e a arquitetura, da qual foi evidenciada a incompletude ou a ambiguidade dos instrumentos legais e técnico-normativos, em particular, quanto às propriedades qualificadoras da edificação penal. As regras técnicas do Ministério da Justiça expressam a necessidade de uma qualidade espacial como meta de projeto, embora a definição desta qualidade não seja determinada. A construção de uma base conceitual e descritiva do espaço arquitetônico da prisão gerou um capítulo introdutório nesta pesquisa, acompanhado de apêndice com os projetos de referência utilizados para a caracterização da edificação penal no Brasil.

O modelo prisional revelou a ausência de uma base teórico-metodológica para a composição espacial da edificação prisional. Isto também foi verificado na literatura técnico-científica da arquitetura penal. Esta deficiência implicou em incluir uma base teórico-metodológica nesta pesquisa que foi fundamentada no Panóptico. O Panóptico deriva do trabalho The Inspection House, de 1791, de Jeremy Bentham, redescoberto entre as décadas de 1970 e 1990 em estudos da prisão desenvolvidos 
por Foucault (1975), Ignatieff (1978), Evans (1982), Melossi e Pavarini (1981) e Semple (1993). O estudo do panóptico integrou o segundo capítulo desta tese.

O exame do modelo e da realidade prisional colocou a dissonância das demandas advindas das condicionantes formais e informais da arquitetura penal no centro do problema da arquitetura penal. Esta exame ressaltou que os processos internos da atividade penal, ligados ao funcionamento do estabelecimento, são ignorados nos instrumentos legais e técnico-normativos, que focam a segurança penitenciária. Neste sentido, o modelo e a realidade prisional foram examinados para o levantamento das demandas formais e informais do sistema penal para a arquitetura, através do estudo dos instrumentos legais e técnico-normativos, das políticas penitenciárias e do funcionamento das prisões, complementados pelos projetos arquitetônicos de referência adotados. Estes levantamentos constituíram, respectivamente, os capítulos 3 e 4, desta tese.

Em particular, a abordagem da realidade prisional determinou o levantamento das demandas dos usuários da edificação, principalmente, dos funcionários e presos, com a realização de visitas em unidades prisionais nos estados de São Paulo e Santa Catarina (Apêndice C). Considerar as demandas dos usuários da edificação penal, o que trouxe vantagens em termos de uma particularização da arquitetura nacional, em relação aos trabalhos estrangeiros abarcados, e de um favorecimento da operação penitenciária. Segundo Wener (1993), ao considerar as expectativas das pessoas em relação à edificação e elas reconhecerem nesta uma preocupação com a sua condição, existe redução do estado de violência na prisão, pois as mesmas se sentem mais seguras. O levantamento realizado tratou da perspectiva funcional do edifício, sem constituir avaliação pós-ocupação, pois não objetivou traçar os impactos mútuos entre o ambiente construído e o comportamento das pessoas (ORNSTEIN, 1989).

Com o exame realizado, a solução para o problema da edificação penal foi condicionada à definição das características do espaço arquitetônico de segurança máxima, a partir concordância das demandas formais e informais para o projeto arquitetônico. Esta concordância depende da coordenação sistemática das características de natureza formal e informal encontradas, através de uma estrutura metodológica e critérios definidos pelos conteúdos elaborados, a partir da atividade, do modelo e da realidade prisional. Para esta sistematização foi utilizado o conceito de tecnologia de projeto, entendido como conjunto do conhecimento destinado a apoiar o processo de projeto. Isto porque este conceito consegue agregar as variáveis elencadas, em torno do aprimoramento da edificação penal, principalmente a base teórica, como será tratado mais à diante.

Do exame do paradigma tecnológico realizado ficou objetivada uma tecnologia de projeto da edificação penal, a partir de uma série de providências de natureza teórica, metodológica e técnica para um aprimoramento dos componentes da composição arquitetônica da prisão. Esta proposta foi fundada 
sobre dois eixos centrais: o equilíbrio entre as finalidades punitiva-econômica e humana-social no espaço arquitetônico da prisão e o fortalecimento teórico-metodológico da concepção projetual. Este escopo definiu valores penalógicos, humanos e econômicos a serem alcançados pela edificação que foram condensados nos critérios: segurança penitenciária, funcionalidade, conforto ambiental e custo do estabelecimento penal. Assim como, a participação dos usuários da edificação penal foi estabelecida. Outros temas foram preteridos, tais como a estética, a construção e a sustentabilidade, além da acessibilidade e da materialidade.

Em relação ao equilíbrio almejado, esta pesquisa adotou uma postura moderada, baseada na Teoria Crítica do sociólogo, filósofo e jurista italiano Alessandro Baratta. Para ele, deve-se considerar: “[...] o fato de que a prisão não pode produzir resultados úteis para a ressocialização do sentenciado e que, ao contrário, impõem condições negativas a esse objetivo" (BARATTA, 2002?). A partir desta premissa, o estudioso desenvolveu um discurso conciliatório, no qual a ressocialização do preso é inviável, mas o respeito às condições humanas mínimas é possível. Deste modo, o raciocínio da pesquisa se deu não através do padrão penal existente, mas apesar dele, almejando o possível dentro do cenário existente. Com isto, a pesquisa evitou recair na falácia naturalista da inviabilidade da pena ou na falácia idealista da correção da pena como única solução para a questão prisional. Admitiu-se simplesmente que a execução penal visa à reinserção social, tal como é preconizado no Artigo $1^{\circ}$ da Lei de Execução Penal (LEP), cujo texto não menciona a reeducação ou a ressocialização dos presos.

Como não se pode abrir mão da prisão, conforme nos lembra Michel Foucault, impõe-se uma atitude crítica e realista frente à questão penitenciária, não havendo espaço para aquela ideia, de complexa sustentação na modernidade, de que a prisão ideal seria a não prisão (SILVA, 2008).

Em termos da humanização, a criminologia crítica propõe uma reinterpretação jurídica da reinserção social na qual o tratamento penal, significando a dominação do preso, é revertido em ‘benefício' com uma conotação de oportunidade de reintegração na sociedade. A partir desta proposição, se buscou a definição de padrões de bem-estar arquitetônicos como forma de compensação a situação de carência e privação inerentes à pena de alta segurança, o que permite vislumbrar uma amenização dos efeitos deletérios do espaço e do tempo na prisão. A definição dos padrões de bem-estar considerou as demandas dos usuários da edificação penal, o que trouxe vantagens em termos de uma particularização da arquitetura nacional e da contenção da violência, mediante as relações sociais e de poder na prisão.

\section{Tecnologia de projeto}

Ao buscar uma tecnologia de projeto, esta pesquisa determinou o entendimento deste objeto, inicialmente definido como o conjunto teórico, metodológico e técnico destinado a apoiar o processo de projeto, representativo da organização de um grupo humano, em um dado período de tempo (VERASZTO et al., 2008). 
A definição de tecnologia de projeto buscada estabeleceu algumas ponderações sobre o próprio significado de tecnologia, de modo a particularizá-la mediante confusão com a técnica e a ciência. A palavra técnica vem do termo grego techné, que é saber fazer. O significado original do termo techné tem sua origem em variações do verbo teuchô ou tictein que significa fabricar, produzir, construir, dar à luz ou na palavra teuchos que significa ferramenta, instrumento (TOLMASQUIM, 1989 ; LION, 1997, apud VERASZTO et al., 2008). Técnica é o procedimento ou o conjunto de procedimentos que têm como objetivo obter um determinado resultado. A técnica envolve o como transformar, como modificar. A palavra tecnologia provém de uma junção do termo tecno, do grego techné, e logia, do grego logus, razão. Tecnologia significa a razão do saber fazer (RODRIGUES, 2001 apud VERASZTO et al., 2008). Em outras palavras o estudo da técnica. O estudo da própria atividade do modificar, do transformar, do agir (VERASZTO, 2004; SIMON et al., 2004a). Deste modo, técnica está inserida na noção de tecnologia ${ }^{10}$.

A tecnologia estrutura-se em um campo próprio do conhecimento englobando outros aspectos como o cultural e o organizacional que abrange a economia e as atividades industriais, profissionais, além dos usuários e dos consumidores (GILBERT, 1995; VERASZTO, 2004). Assim, a tecnologia abrange produtos, processos, meios e os recursos técnicos de produção, além das metodologias, competências, capacidades e conhecimentos necessários para realizar as tarefas produtivas, incluindo ainda o próprio uso dos produtos colocados dentro do contexto sócio-cultural (ACEVEDO DÍAZ, 1996, apud VERASZTO et al., 2008). O conhecimento tecnológico é o conhecimento de como fazer, saber fazer e improvisar soluções. A tecnologia exige um profundo conhecimento do porquê e do como seus objetivos são alcançados, se constituindo em um conjunto de atividades humanas associadas a um sistema de símbolos, instrumentos e máquinas, e assim, visa a construção de obras e a fabricação de produtos.

A tecnologia utiliza do conhecimento científico, embora não dependa dele. A mesma tem um caráter pragmático e sintético, enquanto a ciência, teórico e analítico. Neste sentido, a técnica foca as necessidades, idéias e produtos, enquanto a ciência trabalha com o fenômeno natural, o problema, a hipótese e a experimentação. Atualmente, a tecnologia utiliza métodos sistemáticos científicos, porém, além disso, combina teoria com eficiência e eficácia. Os conceitos das distintas áreas das ciências utilizados na tecnologia são reduzidos a conceitos individuais, que recombinados entre si, definem

\footnotetext{
10 Segundo o Manual de Oslo (OECD, 1997), tecnologia é a ciência destinada à aplicação do conhecimento técnico e científico para fins industriais. Veraszto amplia esta definição, na qual a tecnologia não é o instrumento apenas, mas todo o conhecimento que o gerou: "Tecnologia é um conjunto de saberes inerentes ao desenvolvimento e concepção dos instrumentos (artefatos, sistemas, processos e ambientes) para satisfazer as necessidades do homem e requerimentos pessoais e coletivos destinados ou aplicados à transformação de uma dada realidade material". Da mesma forma que técnica e tecnologia se entremeiam, tecnologia e a ciência possuem interconexões. Claramente o Manual se enquadra na concepção da tecnologia como sinônimo de ciência, identificada por Velaszto (2008, p. 68).
} 
novos conceitos individuais para tratar os problemas encontrados nos mesmos contextos ${ }^{11}$ (ACEVEDO DÍAZ, 1998: LAYTON, 1988).

O desenvolvimento da tecnologia ocorre em função de novas demandas e exigências sociais, atrelada às mudanças de padrão cultural e organizacional, assim como, interfere nos valores e costumes, agregando-se à cultura da sociedade. A tecnologia é inerente a sociedade e a cultura, fundida à capacidade dos homens para criar esquemas de ação representacionais e sistemáticos para avaliar as opções e definir a mais apropriada. Esta capacidade de criação se estende ao desenvolvimento de tecnologias simbólicas como a linguagem, a escrita e os mais diferentes sistemas de representação.

O exame da tecnologia indica uma série de convergências com o projeto arquitetônico: a) é voltada para o atendimento das necessidades humanas e para o progresso social e envolvem a modificação do ambiente natural; b) depende de fatores sócio-econômicos para a sua caracterização e o seu desenvolvimento a partir de novas demandas; c) está vinculada tanto à ciência e à técnica, mas também à criatividade humana na avaliação de um contexto e proposição de soluções; d) utiliza de técnicas de representação e de sistematização para a avaliação de um contexto e proposição de soluções; e) tem os seus procedimentos baseados no método da ciência.

Para Sperling, em arquitetura, a tecnologia engloba as ferramentas, os instrumentos e materiais, e processos coordenados para o projeto e a produção do espaço arquitetônico (SPERLING, 2005). Esta definição, no entanto, parece limitada ao instrumental, ignorando o conhecimento e o meio em que está inserido e que são necessários para a acepção de tecnologia. Uma definição mais consistente seria: o conjunto de conhecimentos científicos, metodológicos e pragmáticos subordinados a organização cultural e operacional de um grupo humano em um determinado tempo, destinado a apoiar o processo de projeto, por meio de instrumentos teóricos, processuais e técnicos, compreendidos dentro de uma perspectiva de eficiência e eficácia. Uma possível definição de tecnologia de projeto direcionada para a arquitetura penal determina a correspondência do conhecimento a um padrão jurídico-penal adotado pela sociedade, cujo instrumento teórico-científico seria caracterizado pelo Panóptico. Esta definição garante a vinculação entre a penalogia e a arquitetura, indispensável para o entendimento da problemática penal e da implicação desta na produção arquitetônica e vice-versa ${ }^{12}$.

\footnotetext{
${ }^{11}$ Neste sentido, a definição de tecnologia se assemelha a de inovação, assim como o seu objetivo: a utilidade e eficácia dos inventos e a eficiência no processo de produção (RODRIGUES, 2001). Não se trata apenas de inventos, mas de inovação, envolvendo métodos e objetivos bem definidos.

${ }^{12}$ A tecnologia de projeto varia nos aspectos teóricos e técnicos conforme a especificidade do tema. Assim, devem existir tantas tecnologias quanto forem os problemas de projeto. No entanto, a especialização da edificação penal de segurança máxima pode ser adaptada para outros tipos penais, tendo em vista a base teórica e técnica comum.
} 


\section{Hipótese}

A proposição de uma tecnologia de projeto revisada vislumbrou a possibilidade de melhoria do espaço arquitetônico aliada à viabilidade econômica, o que remeteu à pergunta: é possível qualificar a edificação penal diante das limitações financeiras impostas pelo sistema penal? Acredita-se que o atendimento destas exigências é plausível dentro de uma estratégia mais ampla. Quanto a isto, se partiu do pressuposto que a revisão do conhecimento arquitetônico e o consequente resgate dos princípios da arquitetura penal direcionariam os projetos para soluções mais equilibradas e, portanto, econômicas. Admitiu-se um aumento do custo de construção do estabelecimento penal, porém dentro de uma perspectiva otimista, na qual este acréscimo não inviabilizaria empreendimentos arquitetonicamente aprimorados. Além disto, da adequação arquitetônica proposta era esperada uma redução dos custos operacionais compensatória do eventual incremento orçamentário, em especial, através de uma diminuição dos gastos com pessoal. Assim como, esta economia se reverteria em saldo ao longo do tempo. Para uma conclusão, uma dupla verificação foi realizada com a aplicação da tecnologia de projeto desenvolvida, por meio da relação custo-benefício.

\section{Objetivos}

O objetivo desta pesquisa é contribuir para a adequação da edificação penal, por meio da aplicação do conhecimento arquitetônico necessário à concepção projetual de estabelecimentos penais de segurança máxima mais eficientes e eficazes, nos termos econômicos e humanos da atividade prisional. Para atingir este objetivo foi necessária a revisão teórica, metodológica e técnica na construção de uma tecnologia de projeto, que busca equilibrar a segurança, funcionalidade, conforto ambiental e os custos de construção e operação do empreendimento, dentro de uma posição penalógica moderada.

Para o atingimento do objetivo geral, outros específicos foram cumpridos, tais como:

a) Definir os vetores de modelagem da edificação penal, em termos de conceitos, princípios, diretrizes, modelos e parâmetros arquitetônicos.

b) Construir uma base teórico-metodológica para o projeto de estabelecimentos penais, com destaque para os temas centrais do programa arquitetônico da edificação penal.

c) Levantar as demandas espaciais dos usuários da edificação penal.

d) Elaborar um programa arquitetônico para o projeto de estabelecimentos penais.

e) Verificar a incongruência existente nas características arquitetônicas do espaço projetado.

f) Selecionar as melhores soluções para o aprimoramento do espaço arquitetônico da prisão, integradas por uma base teórica, mecanismos metodológicos e recursos técnicos.

g) Verificar os impactos ambientais e econômicos derivados da aplicação do conjunto tecnológico obtido. 


\section{Procedimento metodológico}

O procedimento metodológico desta pesquisa é descrito por dois momentos (Figura 1). O primeiro momento compõe os estudos preliminares realizados para estabelecer os objetivos e estratégias de pesquisa, através do exame do paradigma tecnológico da edificação penal, apresentado nesta introdução. O segundo momento constitui a fundamentação e os procedimentos analíticos desta tese, conduzidos segundo as definições fixadas nos estudos preliminares realizados.

O exame do paradigma tecnológico da edificação penal efetuado promove o reconhecimento do problema da edificação penal e propõe o desenvolvimento de uma tecnologia de projeto como meio para uma correção da composição arquitetônica da prisão. A tecnologia de projeto concebida sistematiza as melhores soluções arquitetônicas, selecionadas entre as características formais e informais da edificação penal, moderadas por meio de uma base teórico-metodológica. O levantamento destes dados integrou a fundamentação desta pesquisa, por meio da abordagem da edificação penal, do Panóptico, do modelo e da realidade prisional. As características gerais do espaço arquitetônico são inicialmente levantadas na abordagem da edificação penal. Mais à frente, as características formais são levantadas do estudo do modelo prisional, enquanto as características informais advêm da realidade prisional. A base teórico-metodológica para a tecnologia de projeto é alicerçada no estudo Panóptico.

$\mathrm{Na}$ fundamentação, a caracterização da edificação penal é baseada, principalmente, no estudo de projetos de referência nacionais, tais como: a Penitenciária do Distrito Federal (PDF), a Penitenciária Compacta do Estado de São Paulo, o projeto padrão de cadeia pública do Ministério da Justiça e o modelo da empresa Verdi Construções S/A (ver Apêndice A). Estes projetos abrangem sistemas penitenciários, estabelecimentos penais e edificações prisionais relevantes e representativas da conjuntura atual penalógica e da produção arquitetônica do país, com a participação dos principais agentes da inovação da Cadeia Produtiva da Indústria da Construção no setor prisional. Em termos da uniformidade da amostra, todos os exemplares são projetos de unidades penais fechadas de segurança máxima e maior porte. Além dos projetos citados, outros nacionais e estrangeiros são utilizados para desambiguar ou complementar o levantamento realizado, em especial, o modelo super-max norteamericano.

O estudo da edificação penal também fornece conceitos, princípios e tipos do espaço arquitetônico, ao relacionar a penalogia e a arquitetura na perspectiva das necessidades espaciais da atividade prisional. A relação entre a penalogia e a arquitetura abrangeu a evolução do espaço arquitetônico em função das revisões penalógicas ocorridas ao longo da história da prisão, além da abordagem da Teoria Mista do Direito, adotada no ordenamento jurídico brasileiro. Em particular, esta abordagem delineia as 
características mais amplas da modalidade arquitetônica de segurança máxima, ao discutir o balanço entre a punição e a reinserção social previstas na pena privativa de liberdade. As necessidades espaciais da prisão são tratadas através dos processos totais da prisão descritos por Erving Goffman (2005): o isolamento social dos presos, o integralismo e o mecanicismo.

A abordagem do Panóptico se baseia essencialmente no trabalho Vigiar e Punir de Michael Foucault (1987), no qual as disciplinas sociais são relacionadas com o modelo teórico proposto por Jeremy Bentham em 1791, derivando mecanismos para a composição do espaço arquitetônico, reunidos no Panóptico. O Panóptico é adotado por sua correspondência com o espaço arquitetônico da prisão, mediante a perenidade dos princípios da privação de liberdade nos dias de hoje (FOUCAULT, 1987, p. 169). O Panóptico é um modelo organizacional genérico, baseado na disciplina para a maximização dos resultados e processos da atividade abrigada, envolvendo a geometria, funcionalidade, conforto e economia da edificação. O mesmo não deve ser confundido com o edifício Panopticon que se mostrou ineficiente na prática prisional, tão pouco reduzido ao panoptismo que é o princípio de vigilância centralizada concebido por Bentham. A compreensão do Panóptico é complementada por trabalhos mais atuais, como os textos de Jacques-Alain Miller e Michelle Perrot (BENTHAM et al., 2008), Conceição Trigueiros (2011), entre outros.

O modelo prisional caracteriza formalmente a edificação penal, conforme o preconizado nos instrumentos legais e técnico-normativos do sistema penal nacional, tais como: a Constituição Federal (1988), a Lei de Execução Penal (Lei n 7.210, de 11 de julho de 1984, e alterações subseqüentes), as Regras Mínimas para o Tratamento do Preso no Brasil (Resolução CNPCP n 8/1994) e as Diretrizes Básicas para a Arquitetura Penal (Resolução CNPCP n 9/2011) (ver Apêndice B). Este conjunto técnico-normativo configura a execução penal no país, fixando as condições para a reinserção social dos presos, além de conferir recomendações e parâmetros para a composição arquitetônica da prisão. A partir destes instrumentos são feitas considerações quando à evolução do modelo prisional no Brasil e seus reflexos na arquitetura, além da consistência e coerência dos conteúdos técnico-normativos. Outros trabalhos nacionais e estrangeiros são buscados, com destaque para o Technical guidance for prison planning (UNOPS, 2016).

A realidade prisional trata dos temas da política penitenciária nacional e do cotidiano prisional, dos quais emanam as características informais da edificação penal. A política penitenciária federal é integrada pelo Programa Nacional de Apoio ao Sistema Prisional e pelo Plano Nacional de Política Criminal e Penitenciária (CNPCP, 2011b). O cotidiano prisional é explicado por meio do trabalho sociológico de Erving Goffman que apresenta o cotidiano da instituição total sob o enfoque das representações sociais desta em relação à sociedade, assim como entre seus atores internos: os presos e a equipe dirigente (funcionários). Em termos da arquitetura, este trabalho trata de aspectos gerais da 
edificação, especialmente do simbolismo institucional, além da territorialidade interna. A revisão documental da realidade prisional é integralizada por entrevistas de usuários da edificação penal, funcionários e presos, realizadas em visitas a estabelecimentos penais: o Centro de Detenção Provisória de Pinheiros II, no Estado de São Paulo, e a Penitenciária Industrial de Blumenau, no Estado de Santa Catarina (ver Apêndice C).

Após a fundamentação, esta pesquisa se desenvolve com a conformação e a aplicação da tecnologia de projeto vislumbrada nos estudos iniciais, antecedidas pela exposição do detalhamento dos procedimentos analíticos no capítulo 5, desta tese.

A conformação da tecnologia de projeto articula as soluções arquitetônicas mais ajustadas para a composição da edificação penal, com base na análise comparativa das características formais e informais da edificação penal, levantadas previamente na fundamentação. Para tanto, estas instâncias analíticas são organizadas por meio da estrutura de programa arquitetônico. Esta estrutura programática evidencia os temas centrais da composição arquitetônica da prisão, em torno dos quais são definidas as categorias de análise e seus respectivos requisitos (ver Apêndice D).

O procedimento comparativo realizado contabiliza as concordâncias e dissonâncias encontradas entre as duas instâncias analíticas, sendo estabelecidas as compatibilidades e restrições entre os componentes da composição arquitetônica e conclusões para cada item e categoria (ver Apêndice E). A definição das soluções mais aptas ocorre em razão da performance individual de cada item e da consistência do conjunto obtido, segundo os critérios estabelecidos no exame do paradigma tecnológico da edificação penal: a segurança penitenciária, a funcionalidade, o conforto ambiental e os custos de construção e operação do estabelecimento a ser projetado.

O conjunto de soluções definido para a composição da edificação penal é então formatado como uma tecnologia de projeto, onde cada requisito é integrado por informações teóricas, metodológicas e técnicas para a sua aplicação, sendo organizados em um quadro-síntese (ver Apêndice F). Como última providência da conformação da tecnologia de projeto, as soluções dos elementos centrais da edificação penal (barreira perimetral, cela, pátio de sol dos presos e posto de controle) foram graficamente sintetizadas, por meio de desenhos-síntese (ver Apêndice G). Assim como, um desenhosíntese de unidade prisional foi concebido a partir da tecnologia de projeto elaborada.

Em seguida, a tecnologia de projeto obtida é submetida a verificações quanto à sua efetividade, em termos do incremento na relação custo-benefício da edificação penal, vislumbrada pela hipótese de pesquisa. O teste realizado consistiu na aplicação da tecnologia de projeto aos projetos arquitetônicos de referência nesta pesquisa, sendo verificado o aprimoramento do espaço arquitetônico projetado,. Os resultados são avaliados em diferentes abordagens: comparativamente, entre os dados gerais dos 
projetos de referência originais e ajustados; comparativamente, entre os dados gerais dos projetos de referência e as características da edificação penal definidas pelos instrumentos técnico-normativos e pela tecnologia de projeto; individualmente, em cada requisito da tecnologia de projeto, segundo os critérios de segurança penitenciária, funcionalidade, conforto ambiental e custos de construção e operação do estabelecimento a ser projetado; e especificamente, quanto aos elementos centrais da edificação penal.

Em linhas gerais, o procedimento analítico foi baseado em métodos e técnicas de análise, síntese e avaliação que Christopher Alexander (1977a) concebeu para o processo de projeto, em especial, para a estrutura do problema de projeto. Em especial, as publicações Notes on the Syntesis of Form (1977a) e A Pattern Language (1977b) foram utilizadas. Para John Christopher Jones (1976), o método de Alexander configura como uma estratégia para estudar a estrutura do problema de projeto $^{13}$. Por sua vez, Alexander afirma que a Síntese da Forma é apropriada para sistemas complexos, se alinhando com o objeto desta pesquisa. Entre os recursos técnicos constante do trabalho de Alexander, foram utilizados a representação formal e o programa arquitetônico.

Os princípios da Síntese da Forma de Christopher Alexander definiram a sequiência metodológica desta pesquisa: a análise do contexto, a conformação do conjunto forma-contexto e o ajuste do conjunto, respectivos à fundamentação, à conformação da tecnologia de projeto e às adequações implementadas, mediante resultados incongruentes. Nesta pesquisa, o primeiro conjunto de soluções arquitetônicas obtido foi ajustado em termos de uma coerência em torno do nível de segurança máximo. Assim como, a tecnologia de projeto concebida foi pontualmente ajustada diante de resultados desfavoráveis à relação custo-benefício pretendida. Com a elaboração dos desenhos-síntese é atingida a síntese formal do processo de projeto descrito por Alexander.

\footnotetext{
${ }^{13}$ Na lista produzida por Nigel Cross (1984, apud MOREIRA, 2007, p. 23) dos principais expoentes do método de projeto figuram John Christopher Jones, Christopher Alexander, Bruce Archer e John Luckman na abordagem do controle do processo de projeto. Alexander ainda é destacado por Cross na discussão da estrutura dos problemas de projeto.
} 

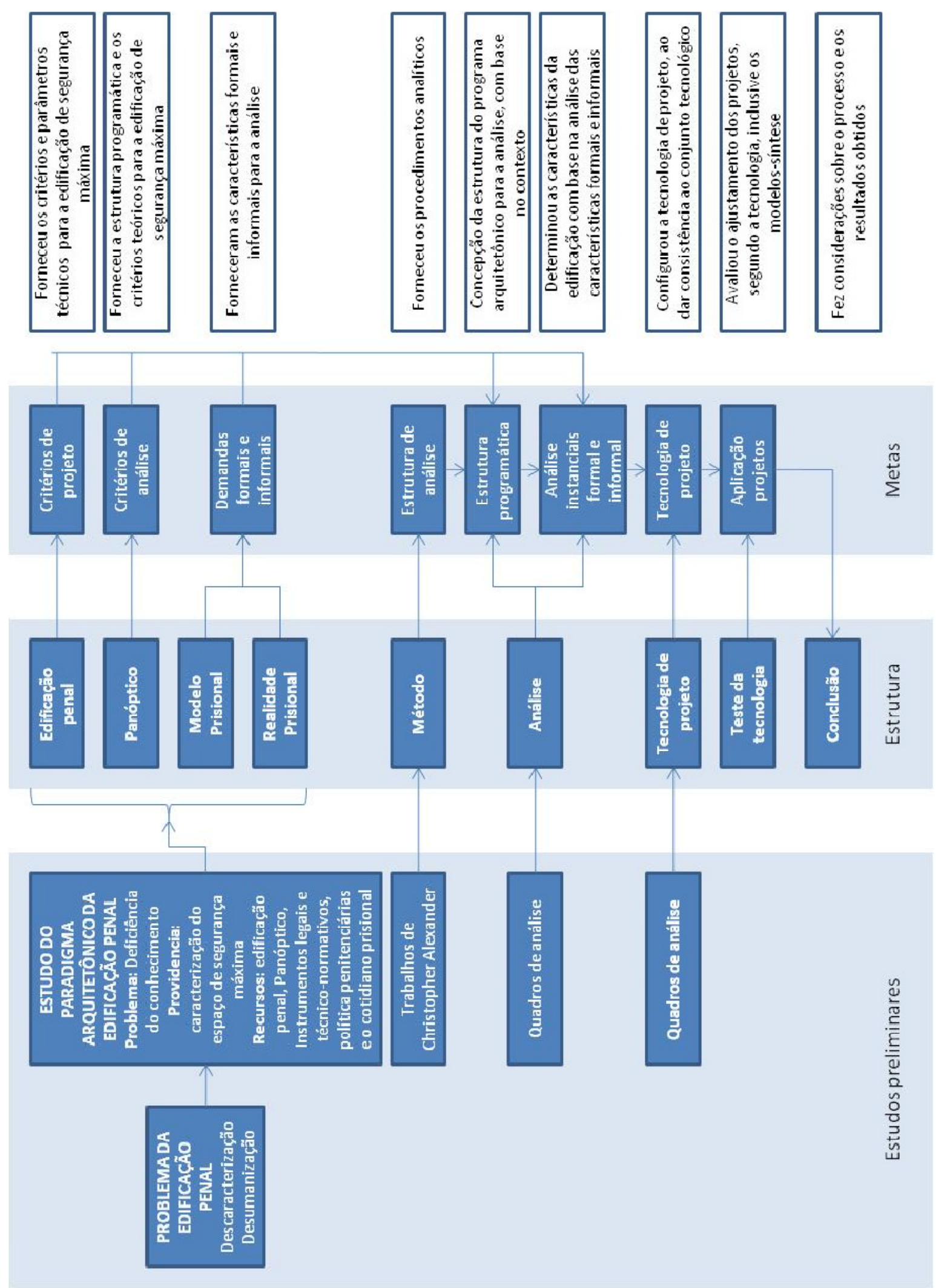

Figura 1 - Diagrama do procedimento metodológico. 


\section{Estrutura da tese}

A tese foi estruturada em oito capítulos. Os quatro capítulos iniciais conformam a fundamentação desta pesquisa, examinando o paradigma tecnológico da edificação penal. Nos quadro capítulos seguintes estão os procedimentos analíticos da concepção e aplicação da tecnologia de projeto, juntamente com a avaliação dos resultados desta.

No capítulo 1, a edificação penal é abordada, sendo levantadas as características do espaço arquitetônico prisional no Brasil, o que evidenciou os processos, componentes e padrões da composição arquitetônica da prisão. Este capítulo é complementado pelo Apêndice A.

No capítulo 2, o exame do Panóptico delineia a base teórico-metodológica para a tecnologia de projeto, em termos da estrutura programática e dos conteúdos para a composição do espaço arquitetônico penal. A conclusão do capítulo discute a atualidade do conteúdo panóptico.

No capítulo 3 são levantadas as características formais para a composição do espaço arquitetônico penal, a partir do exame dos instrumentos legais e técnico-normativos nacionais vigentes, além de instrumentos nacionais correlatos ou estrangeiros. Este capítulo é complementado pelo Apêndice B.

No capítulo 4 são levantadas as características informais para a composição do espaço arquitetônico penal, a partir do exame da política penitenciária nacional e do cotidiano das prisões no sistema brasileiro. A caracterização do espaço informal inclui o estudo de campo realizado em unidades prisionais estaduais. Este capítulo é complementado pelo Apêndice C.

No capítulo 5, os fundamentos metodológicos adotados são apresentados e os procedimentos analíticos realizados são detalhados.

No capítulo 6, a equivalência entre as características formais e informais para a composição arquitetônica da edificação penal é verificada, assim como, as soluções mais aptas para a tecnologia de projeto pretendida são apontadas. Este capítulo é complementado pelos Apêndices D e Apêndice E.

No capítulo 7, a tecnologia de projeto é elaborada, por meio do ajustamento do conjunto obtido na análise realizada, sendo elaborados desenhos-sínteses. A tecnologia de projeto se encontra no Apêndice F e os desenhos técnicos dos desenhos-síntese no Apêndice G, desta tese.

No capítulo 8, a tecnologia de projeto é avaliada. A análise do ajustamento se encontra no Apêndice $\mathrm{H}$, desta tese. 
Na conclusão, considerações sobre o processo e os resultados obtidos são feitas. Assim como, medidas e ações são propostas para a continuidade do aprimoramento da arquitetura penal.

Os capítulos foram acompanhados de apêndices constando os quadros de dados levantados e das análises procedidas:

No apêndice A são apresentados os projetos arquitetônicos dos estabelecimentos penais abordados nesta pesquisa, além da caracterização física e financeira da edificação prisional, em complementação ao capítulo 1 .

No apêndice B são levantadas as características formais para a composição arquitetônica da edificação prisional, após o exame dos instrumentos legais e técnico-normativos da arquitetura penal no Brasil. Este apêndice complementa o capítulo 3, desta tese.

No apêndice $C$, o levantamento conduzido junto aos usuários da edificação prisional em unidades prisionais estaduais é apresentado, em termos do método e dos resultados obtidos. Este apêndice complementa o capítulo 4, desta tese.

No apêndice $\mathrm{D}$, a análise do contexto é apresentada, sendo definidos os requisitos funcionais e os respectivos vínculos levantados na fundamentação e que conformam o programa arquitetônico, definido no capítulo 6, desta tese.

No apêndice E é exposta a análise comparada entre as características formais e informais da edificação penal. Este apêndice complementa o capítulo 6, desta tese.

No apêndice F, a tecnologia de projeto desenvolvida é apresentada. Este apêndice complementa o capítulo 7, desta tese.

No apêndice G são apresentados os desenhos técnicos dos elementos centrais da edificação penal elaborados da tecnologia de projeto elaborada. Este apêndice complementa o capítulo 8, desta tese.

No apêndice $\mathrm{H}$, a análise da tecnologia de projeto aplicada aos projetos de referência é apresentada. Este apêndice complementa o capítulo 8, desta tese. 


\section{Capítulo 1 - Edificacão penal}

Neste capítulo são exibidos os conceitos e as características da edificação penal, ao se abordar a relação da arquitetura com a penalogia. Neste sentido, os condicionamentos penalógicos de ordem teórica, sociológica e pragmática da composição arquitetônica foram examinados. Isto evidenciou os processos, componentes e padrões geradores da composição arquitetônica. Este capítulo é complementado pelo Apêndice A.

Com base na definição de edificação de Edgar Graeff (2006), a edificação penal pode ser entendida como o espaço organizado, por meio da matéria e da forma arquitetônica, para abrigar a atividade prisional. Esta acepção abre campo para a inferência dos vetores da modelagem espacial da prisão, a partir do conceito de espaço e da conjunção entre arquitetura e a atividade prisional.

O conceito de espaço em arquitetura não é consensual, embora as questões da forma e da função sejam recorrentes - a relação entre o interior e o exterior e o invólucro (GRAEFF, 2006, p. 33). Christopher Alexander (1977a) explica a forma como qualquer solução projetada para resolver um determinado problema funcional. Assim, a forma de Alexander equivale ao edifício (MOREIRA, 2007, p. 65). Para Alexander (1977a, p.1), a forma é uma organização física que corresponde conceitualmente ao objeto artificial descrito por Herbert Simon (1981, p. 27). Este artefato artificial é concebido pelo indivíduo como resposta funcional a uma demanda, cuja caracterização pode ocorrer em termos dos objetivos, funções e adaptações a situação em que opera, ao mesmo tempo em que a forma muda constantemente junto com as exigências sociais e as condições de uso. A partir deste entendimento, o espaço arquitetônico pode ser descrito segundo seu objetivo, o modelo como opera e a situação onde funciona (SIMON apud MOREIRA, 2007, p. 59-61). Deste modo, a edificação penal pode ser definida como o espaço construído para abrigar a atividade prisional, constituído em função do padrão penal adotado por um grupo social, em um determinado período de tempo.

A definição formulada apontou três vetores da composição arquitetônica da prisão. Em primeiro lugar, ao abrigar a atividade prisional, a edificação prisional transparece a vertente penalógica predominante, qualificando o espaço como de punição ou de reintegração social. Em segundo lugar, o padrão penal indica as necessidades físicas para o cumprimento da pena, configurando a programação arquitetônica do estabelecimento, conforme o preconizado no modelo prisional. Por último, a variável sóciotemporal evidencia a subordinação da arquitetura à penalogia, cuja mudança produziu modelos espaciais para a prisão. Em suma, a composição arquitetônica da prisão envolve o caráter penalógico, a programação arquitetônica e os padrões arquitetônicos penitenciários, examinados a seguir.

\subsection{Caráter penalógico}

Qualquer abordagem da arquitetura no campo penal deve levar em conta a polarização puniçãoreintegração social da pena privativa de liberdade, cuja equalização implica em uma diversidade de 
estabelecimentos, baseada na correspondência entre a pena e o apenado (UNOPS, 2016, p. 22). Esta equalização é identificada pelo nível de segurança do estabelecimento penal que determina uma escala diretamente proporcional da intensidade punitiva da pena em relação ao perfil dos presos ${ }^{14}$. Para os presos mais perigosos pressupõe-se que a pena é mais rígida, sendo abrigados em estabelecimentos de maior segurança, e vice-versa.

Em termos do espaço arquitetônico, Rolim (2005) afirma que "o projeto arquitetônico de um estabelecimento prisional é o resultado de um conceito de pena privativa de liberdade". Neste sentido, o nível de segurança é a categoria penitenciária que define de forma mais consistente o espaço arquitetônico, configurando as modalidades de espaço arquitetônico (ORLAND, 1978, p.52). As demais categorias resultam apenas em nuanças programáticas. Quanto ao gênero, por exemplo, a unidade feminina difere da masculina apenas na saúde da mulher e no apoio à criança filho de presa, segundo as regras técnicas brasileiras vigentes.

O Technical Guidance for Prison Planning (2016, p.31 e p. 68 - 70) apresenta as características gerais de unidades prisionais de maior segurança: um número maior de barreiras, zonas inacessíveis e obstáculos entre o exterior e as áreas mais internas da unidade prisional, compactação funcional em um edifício único, a separação espacial dos grupos de presos através da minimização do compartilhamento de áreas. Orland (1978, p. 52) especifica alguns dos elementos de maior segurança: a localização isolada, muros altos ou cercas duplas acompanhadas por torres, a população prisional mínima e a incessante vigilância, assistida por dispositivos eletrônicos e holofotes. Nelas, o isolamento celular torna-se preferível e em agrupamentos mínimos de celas. As mesmas não possuem janelas ou estas são diminutas, enquanto as portas são em grade ou com visores, impedindo qualquer privacidade - os banheiros são abertos e monitorados. Os pátios são diminutos e fechados lateralmente, permitindo apenas a visualização superior. Portanto, o espaço arquitetônico de maior segurança tende a ser mais fechado, restritivo, monótono e comprimido para as atividades dos presos.

No outro extremo, as prisões de menor segurança devem ficar próximas às comunidades, a população prisional não deve ser grande, predomina a cerca de arame e poucas ou nenhuma torre de guarda. Nelas existe uma variedade de alojamentos, normalmente coletivos e o controle interno é reduzido. Assim, o espaço arquitetônico de menor segurança tende a ser mais aberto, acessível, criativo e favorável à realização das atividades dos presos. As distinções entre estes espaços são evidenciadas ao se comparar as topologias de uma prisão tradicional e uma contemporânea de princípio recuperativo (Figura 2).

\footnotetext{
${ }^{14}$ De modo informal, este perfil é aferido pela periculosidade do preso. A periculosidade é determinada pelo desvio da conduta do preso em relação ao comportamento regularizado pelas normas de disciplina da prisão (SILVA, J; RODRIGUES, 1989). A periculosidade retrata o potencial ofensivo e o risco que os prisioneiros representam para a instituição prisional (UNOPS, 2016, p. 31).
} 

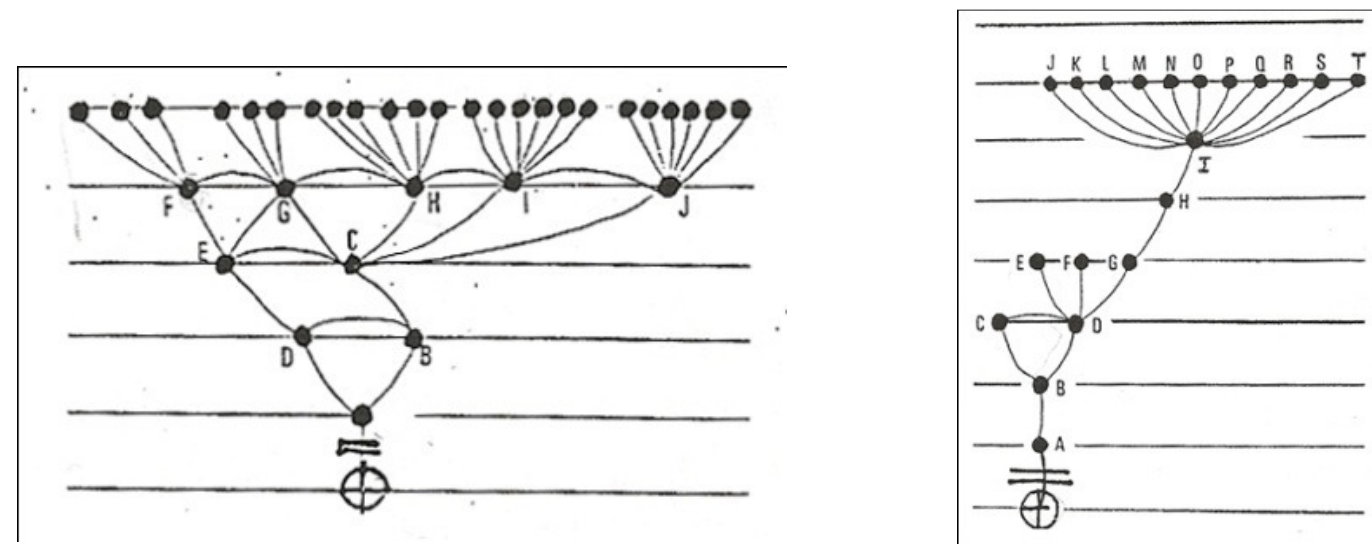

Figura 2 - Gráficos topológicos de estabelecimentos penais ${ }^{15}$

À esquerda, gráfico de uma prisão contemporânea do tipo rede, à direita, gráfico de uma prisão tradicional do tipo árvore. O primeiro apresenta menor profundidade até as celas e profusão de conexões e circuitos, e o programa é amplo. O segundo apresenta maior profundidade devido ao número de controles, poucas conexões e circuitos (poucas alternativas de trajeto), o programa é reduzido.

(Fonte: MARKUS apud SPENS, 1994, p. 17)

$\mathrm{Na}$ atividade prisional, a polarização da pena é materializada pelos instrumentos da segurança penitenciária e do respeito à condição humana, compreendidos como um conjunto sistemático de medidas físicas e operacionais interdependentes, visando à implementação das funções da prisão (ORLAND, 1978). A segurança penitenciária remete à contenção dos presos e ao controle das pessoas, necessária à ordem interna, enquanto a condição humana remete ao bem estar das pessoas. Então, ambas são forças antagônicas e complementares entre si para viabilizar o funcionamento do estabelecimento, ao mesmo tempo em que configuram as modalidades de espaço arquitetônico, associadas ao nível de segurança do estabelecimento penal.

Ao aproximar a funcionalidade da prisão da composição arquitetônica, não se encontrou um termo mais adequado para sintetizar e exprimir as demandas da segurança penitenciária e do respeito à condição humana. Neste sentido, a definição de boa condição penitenciária de Foucault (1987, p. 237238) foi reformulada para esta tese ${ }^{16}$. A concepção original expressava a correta aplicação da pena, significando a prática dos princípios de funcionamento da prisão (ESTECA, 2010, p. 42) à qual foi acrescida a idéia de respeito à condição humana na prisão. Neste exercício, o respeito à condição

\footnotetext{
${ }^{15}$ A representação topológica trata de como os espaços são organizados com respeito de uns aos outros e ao mundo exterior em termos de proximidade - o que cada espaço é em relação ao próximo e ao de onde foi penetrado. Esta é uma questão de topologia, não de geometria. Se todas as interligações são marcadas sobre um plano e depois retificadas em um gráfico de modo que o primeiro espaço (digamos um hall de entrada) se encontra no nível um, tudo mais pode então passar para o nível dois, e assim por diante, uma rede característica aparece. Dois de seus aspectos são a profundidade e o grau em que ele contém anéis e árvores. Profundidade refere-se ao número total de níveis para se alcançar um espaço vindo de outro - quer dizer a partir do exterior para o interior. Um anel indica que se poderá passar de um espaço para os demais e regressar ao ponto de partida por uma via diferente e que, em uma árvore não há escolha senão se mover para trás e para frente ao longo do tronco e galhos. Ambas as propriedades têm demonstrado as interações sociais, encontros, vigilância e controle, em outras palavras, as relações sociais no edifício (MARKUS apud IONA, 1994, p. 15).

${ }^{16}$ Os princípios da boa condição penitenciária foram apresentados por Foucault como "as sete máximas universais da boa 'condição penitenciária”" (1987, p. 237) e são amplamente citadas na literatura jurídico-penal (ver capítulo 2).
} 
humana foi traduzido no conforto ambiental, em atenção à prioridade ditada pelo sistema penal e à conveniência técnica existente, pois o bem-estar é tratado nas regras técnicas vigentes sob esta perspectiva. Com isto, a funcionalidade da prisão corresponde às exigências de natureza utilitária organizadas por Graeff, relativas à eficiência prática (êxito do edifício quando é favorável à atividade humana) e ao conforto físico (êxito do edifício quando é favorável à existência humana). No âmbito legal, estes valores encontram suporte na Lei de Execução Penal (BRASIL, 1984) (ver capítulo 3$)^{17}$. Em suma, o edifício prisional deve atender a duas condições, visando à boa condição penitenciária:

a) A correta aplicação da pena: a composição arquitetônica voltada para as necessidades espaciais institucionais que abordam a prisão como atividade econômica para o cumprimento da pena, prevendo a privação de liberdade, a assistência do Estado e o programa de benefícios aos presos, voltados à reinserção social dos presos.

b) O respeito à condição humana na prisão: a composição arquitetônica voltada para as necessidades espaciais das pessoas que abordam a prisão como atividade humana, voltada para o bem-estar das pessoas, neste caso, com foco no conforto ambiental.

A questão da arquitetura está na moderação entre a segurança penitenciária e o respeito à condição humana, pois o aumento de um resulta no decréscimo do outro. Como afirma Sá (2005), se por um lado a prisão não é corretora do indivíduo, ao tentar perde a sua força de punição. Deste modo, uma edificação equitativamente punitiva e humana é relativamente inviável, pelo menos do ponto de vista econômico, sendo possíveis apenas unidades de maior ou menor segurança (ESTECA, 2010). Da mesma maneira, uma edificação plenamente punitiva ou humana também não é possível. Por um lado, existe o fato básico de a prisão lidar com pessoas e não com objetos (GOFFMAN, 2005). Por outro lado, a natureza da pena implica, por si só, em algum grau de desrespeito à condição humana. Neste sentido, segundo Foucault (1987), a melhor prisão seria a "não-prisão". Portanto, como não é possível falar em 'pena leve', mas em 'pena justa', segundo um cálculo racional (ROLIM, 2005), apenas é possível almejar uma 'arquitetura justa', equalizada entre as concepções negativa e positiva da pena (ESTECA, 2010). Em se tratando de um nível de segurança alto, o incremento da segurança na arquitetura deve ser refreado pela condição humana, não podendo haver prejuízo ao bem-estar das pessoas. Como é posto no Manual Internacional para uma Boa Prática Prisional: "O dever primário de cuidado é o de garantir a segurança das pessoas privadas de liberdade. O dever de cuidado compreende também um dever de garantir o bem-estar da pessoa [...]” (apud ROLIM, 2005). Este raciocínio

\footnotetext{
17 A correta aplicação da pena, segundo os princípios basilares de Foucault (ver seção 2.1, capítulo 2), tem a seguinte relação: a pena reformadora do homem (Art. $10^{\circ}$ ), a classificação dos presos (Art. $5^{\circ}$ ), a progressão de regime (Art. 112), o trabalho (Art. 28), a educação (Art. $n^{\circ} 18$ ), o pessoal das prisões (Art. 77) e a continuidade da assistência do Estado ao preso durante e após o cumprimento da pena (Art. 26-27). O respeito à condição humana é tratada no Art. 3으 desta Lei que afirma ser "assegurado ao preso o respeito à sua individualidade, integridade física e dignidade pessoal", além de outros dispositivos e diplomas abordarem o tema.
} 
encontra paralelo na criminologia crítica de Baratta e na disciplina-bloco de Foucault (1987, p. 173) que assumem a ênfase no cumprimento da pena na prisão.

$\mathrm{Na}$ arquitetura ainda deve ser considerado que a segurança penitenciária depende da operação, então não basta o planejamento do edifício dentro de um esquema de segurança físico, mas associá-lo aos moldes operacionais. Uma maior segurança implica em uma ênfase dos processos totalitários da prisão: "buscas nas celas por armas e contrabandos, o atendimento estrito das regras disciplinares, banhos tomados sob supervisão, prevenção do contato físico com visitantes e vistorias físicas que frequentemente antecedem e prosseguem com as visitas" (ORLAND, 1978, p. 52). Sá (1990, p. 256) demonstra a partir da sua vivência nas prisões, "a relatividade e, até mesmo, a perniciosidade de se confiar excessivamente às medidas arquitetônicas, frias e impessoais, a segurança, à procura de uma segurança máxima”. O mesmo registrou esta questão no depoimento de um agente penitenciário (Idem, 1990, p. 255): "Segurança máxima não existe, porque o preso também é inteligente. Ele tem muito mais tempo do que nós para pensar. O que vai segurar o preso não é a segurança, esses blocos, toda essa parafernália, mas a aceitação, por parte dele de ficar aqui”. Neste sentido, a segurança penitenciária depende da implementação das políticas penitenciárias, do acompanhamento do judiciário, da possibilidade da assistência e do programa de benefícios aos presos e da postura e capacitação dos funcionários (WENER, 1993).

\subsection{Programa arquitetônico}

A atividade prisional transpõe os objetivos da pena para a edificação, percebidos em duas atribuições do espaço arquitetônico: a segregação social do preso e a funcionalidade do estabelecimento penal. Como coloca Markus (apud SPENS, 1994, p. 15), a organização espacial da prisão é representativa das relações de poder internas e em relação ao mundo externo. A primeira atribuição do espaço arquitetônico remete ao conteúdo desenvolvido por Goffman (2005, p. 16-24) sobre o isolamento social das Instituições Totais. Para Goffman (2005, p. 16), estas instituições apresentam diferentes "tendências de fechamento": "seu fechamento ou seu caráter total é simbolizado pela barreira à relação social com o mundo externo e por proibições à saída que muitas vezes estão incluídas no esquema físico. Por exemplo, portas fechadas, paredes altas, arame farpado, fossos, água, florestas ou pântanos". A barreira perimetral é o elemento que garante o cumprimento da justiça e da segurança social, ao mesmo tempo em que rompe a relação social entre aqueles mundos, tornando-se invólucro de uma nova sociedade (ESTECA, 2010, p. 135).

Além da barreira, para Markus, a localização do estabelecimento penal integra o isolamento social (MARKUS apud SPENS, 1994, p. 16): "Claramente, o edifício ou seu sítio requerem limites físicos fortes, ele pode ser localizado em uma locação remota tanto quanto para fazer ambos, a fuga e a 
participação de conspiradores externos, mais difícil". Neste sentido, a distância física entre o mundo interno e o externo é apontada como recurso da segurança penitenciária. Seguindo esta lógica, o isolamento social compreende também os afastamentos extramuros (entre o limite do terreno e a barreira) e intramuros (entre a barreira e as edificações). Estes artifícios do espaço concorrem para apartar o mundo da prisão.

Um aspecto importante do isolamento social é a necessidade de interrupção da comunicação dos presos com o mundo externo - a impermeabilidade, entendida como "o grau em que os padrões sociais mantidos no interior da instituição e na sociedade-ambiente se influenciam mutuamente, e cuja consequência é uma redução das diferenças" (GOFFMAN, 2005, p. 104). A impermeabilidade diz respeito à interação prisão-sociedade que, em termos funcionais, é regrada pelo esquema de segurança penitenciária. Neste sentido, quanto mais elevado o grau de segurança da unidade penal, maior a impermeabilidade, pois o domínio da informação na prisão torna-se essencial para a administração total (GOFFMAN, 2005, p. 19-20).

$\mathrm{Na}$ segunda atribuição do espaço arquitetônico, a funcionalidade do estabelecimento penal é determinada pelo modelo e pela realidade prisionais (ESTECA, 2010). O modelo prisional caracteriza os processos totais na operação penitenciária, por meio da técnica penitenciária aplicada, o que leva a uma reprodução dos diferentes aspectos da vida em liberdade, porem sob um regime totalitário. Neste sentido, o espaço da prisão é comparado a uma pequena cidade sob quarentena para o controle de uma peste (FOUCAULT, 1987, p. 186). A realidade prisional reelabora partes dos processos totais, a partir das relações sociais na prisão, como será visto nos Capítulos 3 e 4 . Assim, os processos totais e as relações sociais na prisão são dois fatores que condicionam a concepção espacial da prisão.

Conforme os ditames do integralismo, do mecanicismo e do controle, a prisão reproduz o conceito de "educação total" de Foucault (1987, p. 222), firmado pelos reformadores do Iluminismo, cujo pensamento seria:

Conceber-se a potência da educação que, não em só dia, mas na sucessão dos dias e mesmo dos anos pode regular para o homem o tempo da vigília e do sono, da atividade e do repouso, o número e a duração das refeições, a qualidade e a ração dos alimentos, a natureza e o produto do trabalho, o tempo da oração, o uso da palavra e, por assim dizer, até do pensamento (Ch. Lucas, 1838, vol II, p. 123-124).

O integralismo determina um programa extenso e multifuncional para a edificação prisional que institui uma autonomia operacional em relação ao mundo externo. O mecanicismo trata da rotina prisional que define uma organização espacial em termos da localização das atividades e dos deslocamentos. O controle permite a administração total, ao estabelecer a supremacia institucional. 
Segundo Goffman (2005), o espaço do edifício prisional é organizado conforme as representações institucionais que definem os diferentes graus de permeabilidade e de liberdade de movimentação, segundo os atores prisionais: visitantes, presos e a equipe dirigente. Com base nesta perspectiva da representação teatral trabalhada por Goffman, o espaço arquitetônico da prisão pode ser observado como um teatro da manipulação das impressões. Esta manipulação objetiva a manutenção da imagem da prisão como "organizações racionais, conscientemente planejadas como máquinas eficientes" (GOFFMAN, 2005, p. 69). Externamente, à sociedade é apresentada a situação institucionalmente definida, o que Goffman denominou de 'fachada'. A entrada do público externo no estabelecimento é permitida até áreas específicas e é condicionada por regras de conduta, de modo a garantir esta representação institucional. Os bastidores são restritos aos presos e funcionários, havendo aí outras representações que não convêm à instituição a apreensão do público. Assim como, a informação externa chega aos presos sob censura da administração, o que favorece o controle destes. Goffman mostra ainda que a estanqueidade entre estes lugares externos e internos, cuja passagem está sob o poder da administração depende da permissividade atribuída aos atores. Esta impermeabilidade garante a aparência produtiva do estabelecimento, mostrada nas áreas mais externas, enquanto são ocultados os problemas da realidade no interior do espaço prisional.

Segundo o esquema teatral de Goffman, a espacialidade da prisão é definida em camadas (setores, blocos e cômodos): a divisão entre o espaço externo da sociedade e o interno da unidade penal se replica pelo corpo do estabelecimento penal de modo fractal, criando lugares relativamente mais externos ou internos. Juntamente com esta percepção, vem uma conotação de lugar mais ou menos próximo da liberdade ou perigoso. Estas significações atribuem valores aos lugares, segundo os interesses de funcionários e presos.

Conforme Goffman (2005), a definição de Instituição Total pressupõe o controle absoluto do espaço arquitetônico pela equipe dirigente, todavia este controle é relativizado na realidade prisional. Para ele, a apropriação de certos espaços pelos presos é inevitável. Com base nesta assertiva, segundo este autor (Idem, 2005, p. 188), o espaço da prisão se classifica em: local vigiado - onde os presos estão submissos à instituição; local livre - onde os presos conseguem certa autonomia e privacidade em relação à instituição; e local proibido - onde a instituição é soberana e a presença de presos é comprometedora. Do ponto de vista do nível de segurança, um grau mais alto significa a predominância de locais proibidos e vigiados, em detrimento dos locais livres. 


\subsection{Mutabilidade do espaço arquitetônico penal}

Para Herbert Simon (1981), o projeto do objeto artificial muda o resultado formal na medida em que os objetivos dos indivíduos também evoluem, em termos das condições de uso, com a adequação das exigências funcionais a serem atendidas. No universo prisional, isto corresponde à afirmação de García Basalo (1959, p. 44): “a evolução da arquitetura penitenciária ocorre juntamente com a transformação das ideias penais e a modificação da legislação punitiva". Esta mutabilidade remete a correlação histórica da arquitetura e da penalogia, na qual a edificação respondeu a cada mudança no status penalógico, originando padrões arquitetônicos penitenciários.

Em um primeiro momento, surgiram os padrões arquitetônicos de inspeção central e de blocos laterais em correspondência a Ciência das Prisões ${ }^{18}$ que tinha como objeto a administração da prisão e o tratamento dos presos (MIOTTO, 1992, p. 32). O padrão arquitetônico de inspeção central contava com três modelos: o panóptico, o circular e o radial, caracterizados pela ênfase na vigilância central. Um ícone deste período foi o edifício Panopticon (capítulo 2), que originou o padrão panóptico, cuja arquitetura "tornou-se, por volta dos anos 1830-1840, o programa arquitetural da maior parte das prisões" (FOUCAULT, 1987, p. 209). Todavia, o edifício era pequeno e de difícil construção, então, caro, além de ser inflexível e falho na visualização interna. Os outros padrões arquitetônicos do período derivaram de técnicas penitenciárias, como o radial e o de blocos laterais. A Eastern State Penitentiary (Figura 3), ocupada em 1829, foi o marco da técnica filadélfica, em substituição ao edifício panóptico ${ }^{19}$, tornando-se "paradigma de cárcere de planta radial” (ALGARRA, 2007). Esta unidade renunciou ao princípio de ver o interior das celas, substituindo-o pela aspiração de "ver desde um ponto central o interior dos pavilhões" (GARCÍA BASALO, 1959, p. 74). O problema era o distanciamento da vigilância, além da inflexibilidade. A Auburn Correctional Facility foi concluída em 1825, disseminando o padrão de blocos laterais por todos os Estados Unidos, sendo primeira a combinar as celas internas com pavilhões retangulares de vários andares. Este modelo foi uma resposta à superlotação, o que implicou em problemas de segurança devido às grandes massas de presos dispostas em grandes áreas. A América Latina produziu uma arquitetura híbrida a partir de técnicas penitenciárias e de modelos arquitetônicos que, segundo García Basalo, "no primeiro caso poderíamos sublinhar um traço ou influência da política penitenciária dos Estados Unidos; no segundo caso uma evidente imitação da arquitetura penitenciária européia" (1959, p. 100).

\footnotetext{
${ }^{18}$ Segundo Miotto (1992, p. 31), a Ciência das Prisões foi resultado imediato da obra dos pensadores precursores da prisão (Beccaria, John Howard e Jeremy Bentham) e foi também referida por autores diversos no período citado, nos Estados Unidos e na França.

19 O padrão radial era apresentado como um modelo aperfeiçoado do Panopticon, no qual a torre de inspeção se tornou a sala octogonal, chamada observatory.
} 


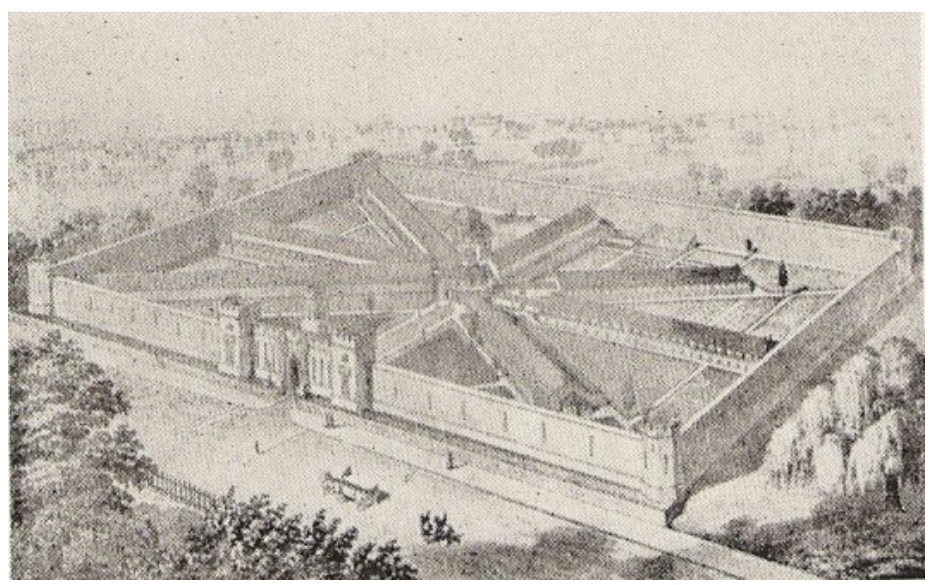

Figura 3 - Gravura da Eastern State Penitentiary

Primeiro exemplo do padrão arquitetônico penitenciário radial. (Fonte: USA, 1949, p. 28)

Em um segundo momento, o padrão arquitetônico paralelo foi elaborado com o advento da Ciência Penitenciária, ainda no século XIX, alavancada pelo movimento da Escola Positiva de Direito Penal que se dedicava à substituição da pena-punição pela pena-tratamento científico. Em 1898, o Centre Pénitentiaire de Fresnes foi construído na França, lançando o modelo que passou a basear a arquitetura penal dos países latino-americanos, quase sem exceções, caracterizado pelo corredor central que interligava os blocos internos, em altura com as atividades no térreo e as celas nos pavimento superiores (GARCÍA BASALO, 1959, p. 102). No Brasil foi inaugurada a Penitenciária do Estado de São Paulo em 1920 (Figura 4). O então chamado Instituto de Regeneração foi considerado uma referência de excelência nas Américas: "[este projeto] foi o marco e grande paradigma importante de projetos penitenciários" (JORGE, 2002, p. 111).

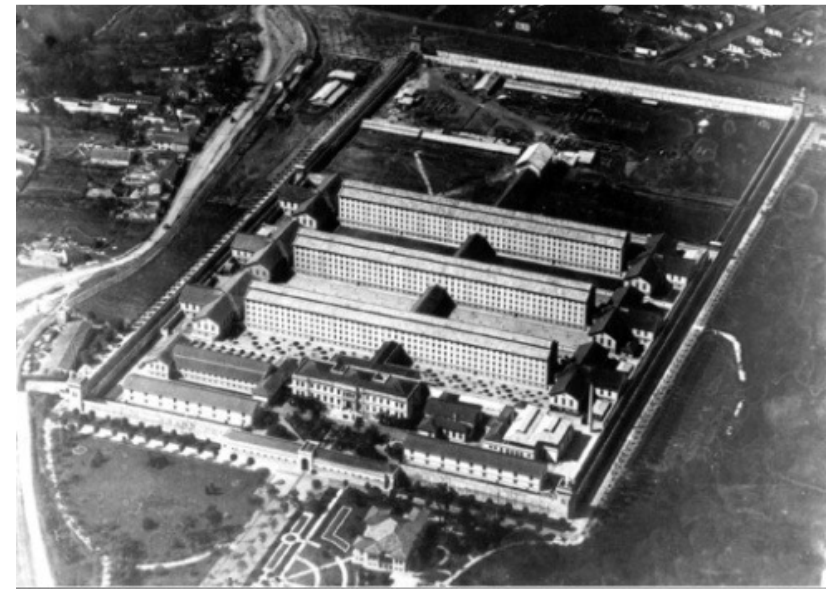

Figura 4 - Fotografia da Penitenciária do Estado de São Paulo Representativado padrão arquitetônico paralelo.

(Disponível em: <http://www.sap.sp.gov.br/common/museu/museu.php>. Acessado em: fev. 2017) 
Por fim, o padrão arquitetônico modular ou pavilhonar é desenvolvido na década de 1960 (figura 7, p. 30), nos Estados Unidos, em decorrência do movimento dos direitos humanos em relação aos presos que culminou com o reconhecimento da modalidade jurídica do Direito Penitenciário, em 1930 (MIOTTO, 1992, p. 40). Nesta nova conjuntura penalógica também surgem instrumentos para a elaboração de edificações penais, com destaque para o Handbook of Correctional Design and Construction, editado em 1949. De uma forma geral, o padrão arquitetônico modular se tornou o paradigma contemporâneo de edificação penal - "as longas linhas de celas e níveis foram substituídos por pequenas unidades de vivência (ou pods) tipicamente contendo 12 a 16 beliches" (WENER, 1993, p. 3). O Prison Design Briefing System (PDBS) (BOURN, 1994) atesta isto, ao formalizar a arquitetura modular como modelo para o Reino Unido nos anos 1980, ao mesmo tempo em que este documento se tornou referência para outros países.

\title{
1.4 Espaço arquitetônico penal
}

A especialização funcional da prisão implicou em uma nova topologia, diferenciada do esquema de um edifício qualquer, no qual as interconexões sociais normalmente configurariam uma "forma de árvore" cuja base é o acesso. Markus (apud SPENS, 1994, p. 15) aponta estas diferenças:

\begin{abstract}
De acordo com estas teorias há um tipo de edificação onde esta estrutura é invertida: visitantes [os presos] estão nos espaços mais profundos e o aumento da profundidade significa diminuição do poder, enquanto os habitantes [funcionários] ocupam o exterior, zonas rasas. Os primeiros estão muitas vezes nas pontas dos galhos de uma estrutura de árvore, os últimos estão no espaço de liberdade de escolha. Esta é a definição espacial de uma instituição como a prisão, o asilo hospital, oficina, na escola ou, em menor grau, a fábrica.
\end{abstract}

Em termos gerais, o espaço arquitetônico penal significa a atomização e caracterização funcional dos espaços, a setorização hierárquica e a vigilância e despersonificação do poder, qualificadas pela tecnologia e detalhamento exaustivo (AGOSTINI, 2002). Estes são temas do Panóptico que ilustram a natureza funcionalista deste espaço, baseada no utilitarismo da pena. Esta essência funcionalista tem a forma como resultado do arranjo racional dos espaços. Como coloca Algarra (2007), "o lema de Louis Sullivan 'a forma segue a função', e a variante de seu discípulo Frank Lloyd Wright 'forma e função são um só', se põem de manifesto claramente na evolução da tipologia carcerária a partir do século XVIII". Assim, o espaço é entendido não só como o espaço cartesiano, mas também o espaço social, o espaço vivenciado pela experiência humana (SÁ, 1990). Deste modo, a resposta formal às demandas funcionais da atividade prisional pode ser verificada por meio da geometria, por exemplo, dos modelos arquitetônicos consagrados. Neste sentido, a edificação penal foi classificada em gerações de estabelecimentos penais, conforme o tipo de vigilância adotada em cada ordenamento penalógico (ORNSTEIN, 1989, p. 12) (Figura 5). 

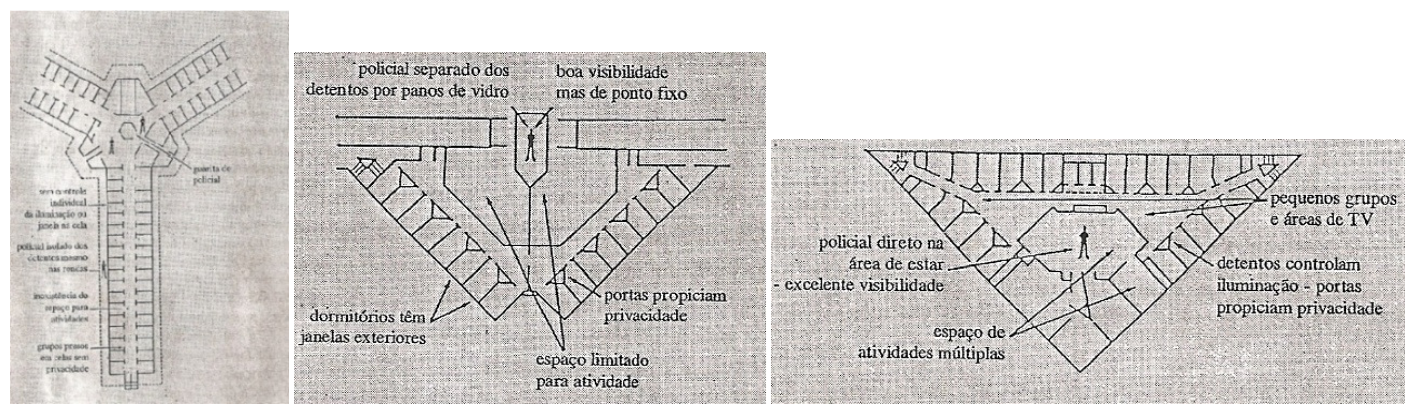

Figura 5 - Esquemas dos tipos de vigilância

A partir da esquerda: a vigilância indireta plena, a vigilância direta e a vigilância direta plena.

(Fonte: ORNSTEIN, 1989, p. 12 e 13)

A primeira geração é denominada de arquitetura linear intermitente, sendo caracterizada pela vigilância indireta plena: o posto de controle ficava fora da área de convívio dos presos, possibilitando o monitoramento dos corredores, esporadicamente patrulhados pelos guardas que conferiam o interior das celas pelas grades (Figura 6) (ORSNTEIN, 1989, p. 12). Esta geração é representada pelos padrões arquitetônicos desenvolvidos até meados do século XX: filadélfico, auburniano e paralelo ${ }^{20}$.

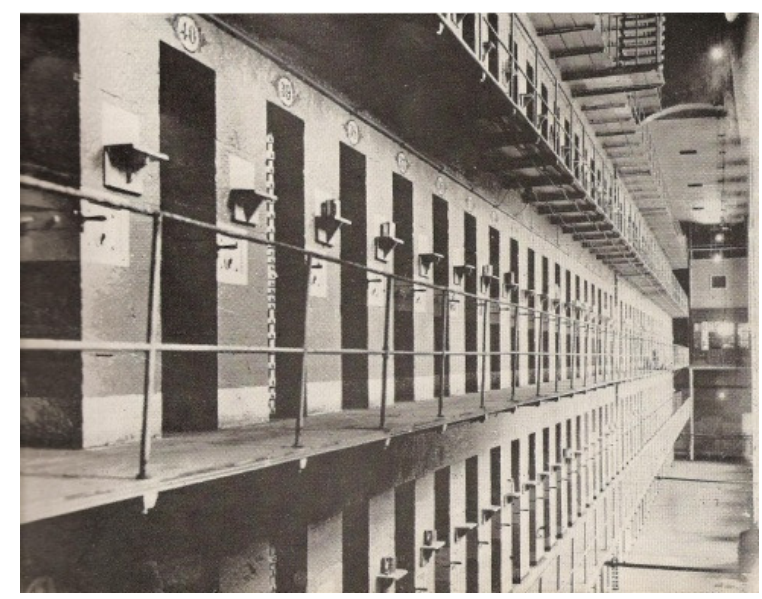

Figura 6 - Fotografia do interior do pavilhão da Sing Sing Prison (EUA) Representativa da arquitetura linear intermitente.

(Fonte: USA, 1949, p. 34)

A segunda geração foi instituída pelo padrão arquitetônico pavilhonar, caracterizada pela vigilância direta, conformada pelo posto de controle inserido na área de convivência dos presos, o que permitia o monitoramento de todo o espaço coletivo (ORNSTEIN, 1989, p. 13). De acordo com Ornstein (1989), o modelo espacial da segunda geração visava a melhorar as condições de habitação e as relações

\footnotetext{
${ }^{20}$ Embora o padrão arquitetônico panóptico seja contemporâneo dos demais padrões da primeira geração, ele apresentava um esquema de vigilância diferente da indireta plena, caracterizado pela ênfase no princípio da vigilância central que pressupunha a visualização total da edificação, inclusive do interior das celas. Este conceito viria a modificar o sistema e a arquitetura penal (PERROT apud BENTHAM et al., 2008, p. 130).
} 
sociais na prisão: "Trata-se de uma nova filosofia de administração e gerenciamento, associada ao arranjo físico, mobiliário e equipamentos adequados, com interações sociais e a possibilidade de privacidade e redução de incidentes com risco de vida" (ORNSTEIN, 1989, p. 13). O Handbook of Correctional Design and Construction e o Prison Design Briefing System (PDBS) são registros da transição da primeira para a segunda geração de estabelecimentos penais.

A terceira geração surgiu na década de 1970 nos Estados Unidos como um aprimoramento do padrão arquitetônico pavilhonar, no sentido de superar os problemas da divisão entre funcionários e presos e a territorialidade na prisão (WENER, 1993, p. 8). A principal inovação foi a vigilância direta plena na qual o controle é centralizado no espaço coletivo e destituído de qualquer separação física (ORNSTEIN, 1989, p.13). Para Fairweather, a terceira geração ainda é pretensiosa e distante do estado da arte, não havendo representatividade diante das inúmeras instituições edificadas no padrão da primeira geração nos Estados Unidos. Ornstein (1989, p. 13 e 14) chama a atenção para o fato de a vigilância direta plena não ser um esquema totalmente aceito, sendo considerada inadequada para unidades de maior segurança. Ao mesmo tempo, o custo operacional é apontado por Fairweather (apud SPENS, 1994, p. 26) como restritivo à terceira geração, principalmente, devido à alta relação entre funcionário e preso e ao custo da mão de obra.

O espaço arquitetônico prisão foi composto em torno de arquétipos que conferem a identidade arquitetônica da edificação penal que permeia o imaginário popular, denominados por Esteca (2010, p. 45) de elementos centrais da edificação penal, sendo eles: a barreira perimetral, a cela, os espaços coletivos para as atividades dos presos e o posto de controle. A origem eclesiástica da arquitetura penal estabelecia que "cada mosteiro dispusesse de locais separados, destinados aos condenados, constituídos por quartos e dependências para trabalho, com possibilidade de aquecimento no inverno, tendo em anexo um pátio" (MIOTTO, 1992, p. 26). Nos antecedentes laicos, os muros foram ressaltados: a arquitetura "sempre com pormenores contra a fuga, que distinguiam aquelas prisões como fortalezas" (MIOTTO, 1992, p. 32). Na instauração da pena moderna, o pensador reformista John Howard discorreu sobre a segurança e a salubridade, ao descrever o muro, a cela e o pátio (ALGARRA, 2007). A Ciência Penitenciária propôs uma variação dos tipos de alojamento, salas de atividades e da barreira em função do perfil dos presos (GARCÍA BASALO, 1957). O Direito Penitenciário arranjou celas e pátios em torno de postos de controle de modo a assistir à população prisional (ORSTEIN, 1989). O Direito Penitenciário reconfigurou o arranjo vislumbrou a disposição com celas e pátios em torno de postos de controle em blocos. Estudos mais recentes, como aqueles realizados por Goffman (2005) e Foucault (1987) associaram processos e princípios da prisão ao espaço prisional, em termos destes elementos (ver capítulo 2). Autores contemporâneos também tratam destes elementos, como Markus (apud SPENS, 1994, p. 16). 
A preponderância do padrão arquitetônico modular determina as características correntes do espaço arquitetônico prisional contemporâneo (Figura 7). Este padrão é descrito pelo conjunto arquitetônico fragmentado em blocos fisicamente separados (ligados por corredores ou pistas), operacionalmente independentes e funcionalmente especializados. A capacidade das unidades penais foi reduzida para 400 ou 500 vagas. Em unidades maiores, a implantação é subdividida com cercas, delimitando os módulos ou grupos de módulos. As funções comuns da unidade são agrupadas em módulos centrais. O bloco carcerário é caracterizado pelo arranjo das celas dispostas em dois níveis, em torno de uma área comum destinada às atividades coletivas, principalmente, refeições e lazer. Esta área é monitorada por um posto de controle centralizado e fechado com vidros blindados. As celas, por sua vez, receberam mobiliário, iluminação e ventilação natural, além de portas fechadas em substituição às grades. Podem existir vários blocos carcerários de forma a dividir a população prisional segundo sua classificação. Com isto, os agentes permanecem isolados dos presos e estes podem ser classificados e separados dentro do próprio estabelecimento (ORNSTEIN, 1989, p. 13).

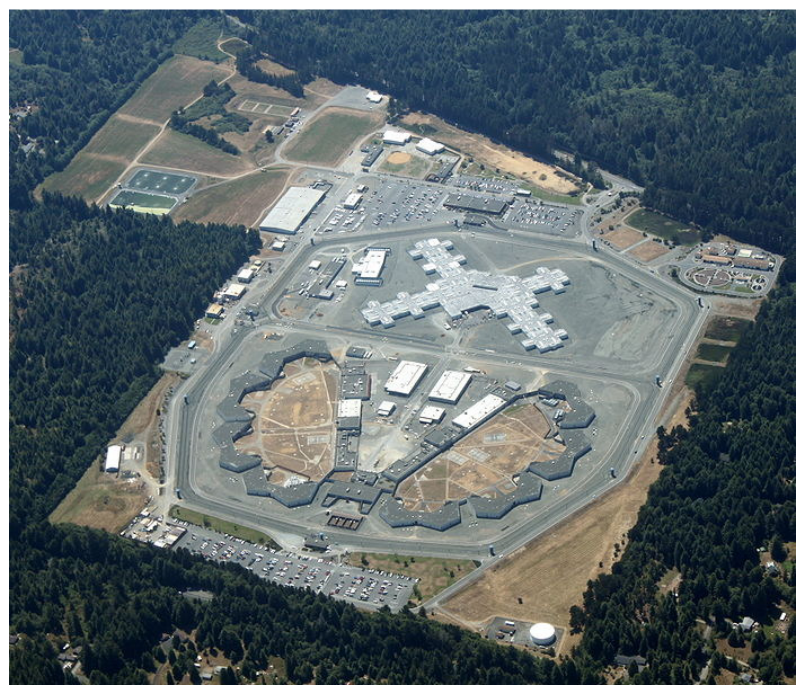

Figura 7 - Fotografia da USP Pelican Bay (EUA)

Representativa do padrão arquitetônico modular. A fotografia mostra a modulação do padrão em pavilhões.

(Disponível em: <https://en.wikipedia.org/wiki/Pelican_Bay_State_Prison>. Acessado em: fev. 2017)

Apesar do movimento de reforma penitenciária ter inserido certos padrões humanitários, a prisão não conseguiu se desvencilhar da concepção penalógica retributiva e de segurança. De um modo geral, no cenário prisional prevaleceu a 'arquitetura de bastilha': o isolamento geográfico e o excesso no tamanho das prisões (entre mil e cinco mil vagas) e da população carcerária, assim como nos procedimentos de segurança (FAIRWEATHER apud SPENS, 1994). O trabalho Tomorrow's Prisons (MUIR, 2010, p. 30) ressalta que o PDBS foca a segurança, em vez de pensar criativamente sobre a reabilitação. Nos Estados Unidos, assim como em outros países, as mudanças na arquitetura da prisão 
ocorreram muito mais pelo ganho econômico ou utilitário que agregavam à atividade prisional do que pela humanização da pena. Na Ciência das Prisões já se procurava "fazê-las menores e menos onerosas" (MIOTTO, 1992, p. 32). Na Ciência Penitenciária, a classificação e a coletivização eram motivadas pelo custo (GARCÍA BASALO, 1959, p. 88). No Direito Penitenciário, o padrão modular foi difundido, em boa parte, pelo controle mais rígido e direto da instituição sobre os presos (ORNSTEIN, 1989, p. 13). O padrão modular é usualmente utilizado para unidades de maior segurança em uma versão espacialmente compacta: as unidades norte-americanas do tipo Administrative Maximum Facility (super-maximun security) são majoritariamente modulares.

Em outra crítica à arquitetura, segundo o trabalho Tomorrow's Prisons se perpetuam soluções arquitetônicas obsoletas e desvinculadas dos objetivos sociais da prisão: "como resultado nós continuamos a construir os mesmos tipos de prisão, mesmo quando sabemos que eles falham em reabilitar os condenados" (MUIR, 2010, p. 4). Em contrapartida, alguns ensaios projetuais investem no trabalho ou na educação dos presos, assim como, em uma maior liberdade de movimentação e convivência. Em comum, os objetivos de incrementar a eficiência da instituição, humanizar o espaço e reduzir a reincidência. Simon Henley (2003) revisitou o Learning Works: The 21th Century Prison, cuja proposta é transferir o tempo e os recursos dos procedimentos de segurança e operação para as atividades de aprendizado. Segundo Simon, este projeto inverteu a topologia da inspeção central, ao configurar uma circulação periférica que interliga os blocos de alojamentos (houses) e as demais funções, arranjadas intercaladamente como em um tabuleiro de xadrez (Figura 8). Já o trabalho The Creative Prison (RIDEOUT, 2006a) vislumbrou um equilíbrio entre os direitos e responsabilidades dos presos, assim como, a boa relação destes com os funcionários. Nele, a prisão é delimitada por um edifício ocupado pelas funções comuns que internamente define um parque com os blocos de alojamentos, associado a um sistema eletrônico de gerenciamento do movimento de pessoas, o que define diferentes níveis de interação social.

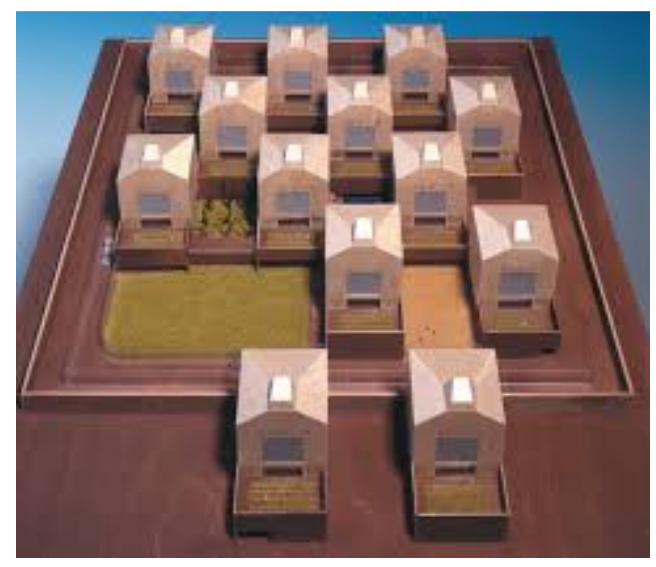

Figura 8 - Perspectiva digital do projeto conceitual The 21th Century Prison (Fonte: HENLEY, 2003, p. 13) 


\subsection{A edificação penal no Brasil}

O sistema penal nacional produziu edificações de relevância mundial, como a Penitenciária do Estado de São Paulo e a Casa de Detenção de São Paulo, sendo citados por García Basalo (1959) (Figura 9). Em especial, a produção arquitetônica das décadas de 1950 e 1960 deixou um legado que indica um amadurecimento da arquitetura penal no Brasil, fortalecido com a publicação de regras técnicas pelo Ministério da Justiça a partir da década de 1970. Para o arquiteto Casimiro de Oliveira (GOMES, 1985), a produção arquitetônica da década de 1960 fundamentou o que ele considerou ser a arquitetura penitenciária brasileira - "Até então, os projetos existentes, copiados de arranjos arquitetônicos alienígenas, obedeciam ao partido tradicional da construção da penitenciária como 'poste telegráfico' [padrão paralelo]" (D’URSO, 1998, p. 17). Com o projeto da Casa de Detenção de São Paulo "começamos a ver no Brasil a construção de pavilhões isolados" (Idem).

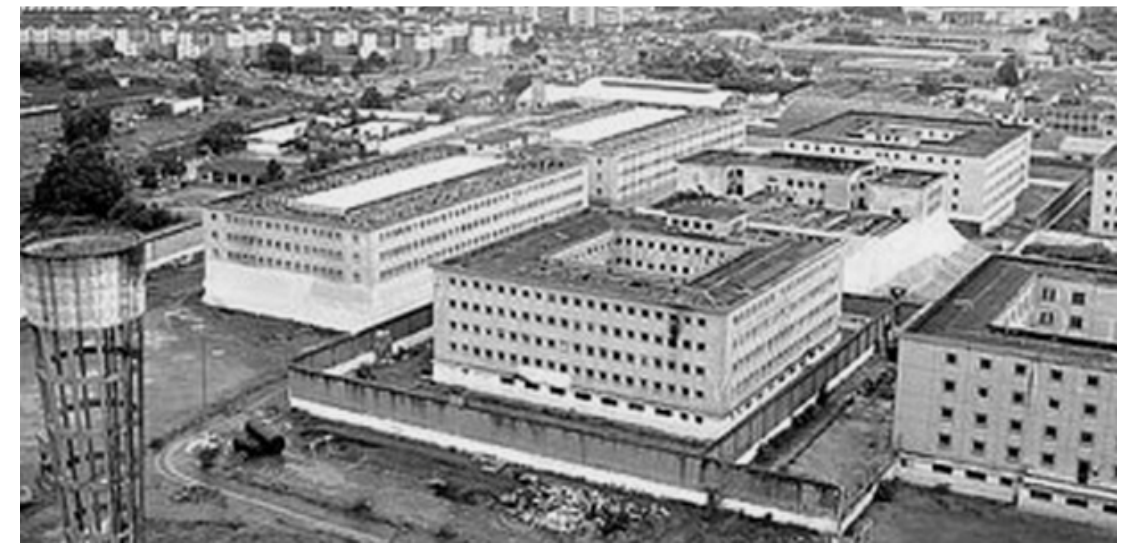

Figura 9 - Fotografia da Casa de Detenção de São Paulo

(Disponível em: <https://www.gutsandgore.co.uk/notorious-prisons/carandiru-prison/>. Acessado em fev. 2017)

Todavia, a despeito da criatividade observada, o portfólio arquitetônico nacional claramente resultou da importação de conceitos dos padrões arquitetônicos penitenciários. Os projetos arquitetônicos e as regras técnicas citadas confirmam isto. Estes projetos reproduzem a geometria geradora dos padrões paralelo e modular, enquanto as Recomendações Básicas para uma Programação Penitenciária explicitaram a preferência pelo padrão arquitetônico modular, rejeitando o padrão de inspeção central, pois aquele possibilitava "não só construções moduladas e de execução progressiva, como também a preservação da segurança sem confinamentos degradantes” (RECOMENDAÇÕES, 1976, p. 199) ${ }^{21}$.

\footnotetext{
${ }^{21}$ A preferência pelo padrão arquitetônico modular das Recomendações foi mantida até 1994, quando as Diretrizes para Elaboração de Projetos e Construção de Unidades Penais no Brasil revisaram o posicionamento nas regras técnicas: "a criatividade deve ser favorecida na elaboração de um projeto para estabelecimento penal" (CNPCP, 1995, p. 76). Todavia, esta revisão não eliminou o conceito modular que implicitamente permeia as recomendações e os programas propostos até a versão atual do documento.
} 
Apesar do reconhecimento do padrão arquitetônico modular como referência oficial para a arquitetura nacional, o mesmo não viria a se tornar uma realidade hegemônica no parque penitenciário. Houve a perpetuação, principalmente do padrão arquitetônico paralelo em diversas unidades federativas como São Paulo, Mato Grosso e Mato Grosso do Sul. Agostini (2002) aponta a conjunção destes padrões nos partidos arquitetônicos penitenciários elaborados no Brasil. Segundo o autor, os pavilhões carcerários onde são alojados os presos, são comumente organizados com as celas e outros espaços coletivos em torno de um pátio descoberto. Arranjo ilustrado pela Penitenciária Lemos Brito, em Salvador/BA (Figura 10).

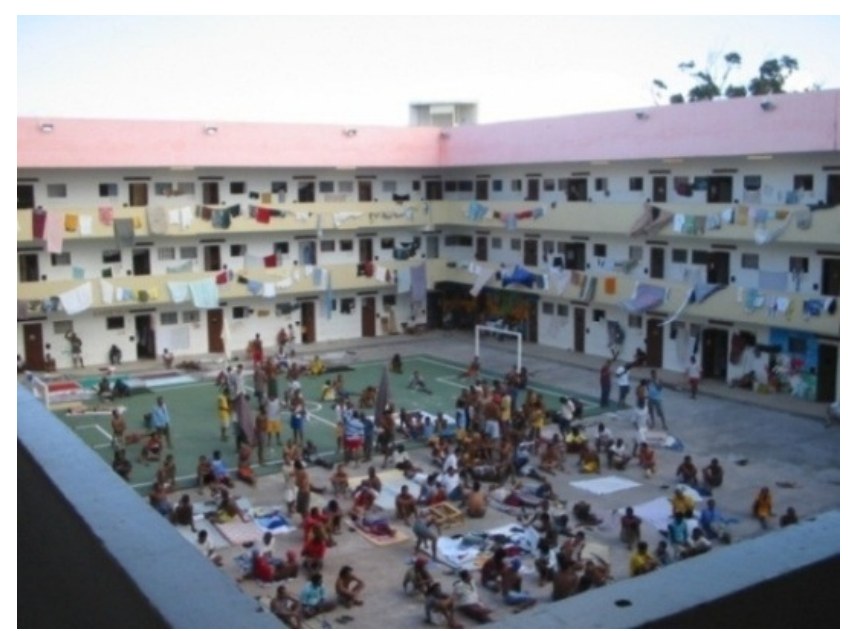

Figura 10- Fotografia da Penitenciária Lemos Brito/BA (Fotografia do autor)

A importação dos padrões arquitetônicos tão pouco significou a reprodução dos desenhos em sua forma pura, mas a apropriação e a releitura de conceitos arquitetônicos, além da combinação de modelos, em um processo de hibridização similar ao observado na América Latina. Por exemplo, a Casa de Detenção de São Paulo foi construída com conceitos divergentes em termos penalógicos e penitenciários do padrão arquitetônico pavilhonar, conformada por edificações em altura com as celas dispostas lateralmente ao longo de um corredor central, descrevendo uma planta quadrada com pátio central. Em outro exemplo, segundo D’Urso (1998, p. 18), a Casa de Detenção de Porto Velho englobou o modelo de "poste telegráfico", adaptando ao centro do projeto um pátio.

A reconfiguração arquitetônica descrita se perpetua em projetos hodiernos, como pode ser verificado nos exemplares de referência desta pesquisa (ver Apêndice A). A Penitenciária do Distrito Federal remete ao padrão modular, mas internaliza e replica uma série de atividades nos módulos de vivência dos presos, ao mesmo tempo em que volta parcialmente ao esquema de vigilância indireta. O projeto padrão do Estado de São Paulo replica o conceito do modelo paralelo, mas compacta a massa construída e elimina a verticalidade. O projeto padrão do Ministério da Justiça remete à circulação 
central do modelo paralelo, porém as edificações são formal e funcionalmente irregulares. O projeto padrão de penitenciária da empresa Verdi Construções S/A mescla o desenho paralelo com o padrão modular, de modo compacto nos blocos de vivência. Chama a atenção nestes projetos o uso da padronização arquitetônica, utilizada como facilitadora da implementação das políticas penitenciárias. Ao mesmo tempo em que se constata uma diversidade arquitetônica, característica da atual produção projetual no sistema penal.

Ainda com base nos projetos de referência é possível avançar na descrição da edificação prisional de segurança máxima no país. Esta segurança maior é atribuída à simplicidade espacial presente nos projetos, associada aos modelos arquitetônicos adotados e aliada a uma subdivisão da população prisional, racionalização da geometria e internalização do programa (as atividades dos presos são localizadas no setor interno). A simplicidade espacial é verificada nas médias superiores de áreas vigiadas e no número otimizado de postos de controle, em particular, no projeto paulista. Como resultado, os projetos apresentam a totalidade dos espaços dominados pela instituição (12\% proibidos e de 60 a 74\% vigiados), enquanto os locais livres se restringem às celas (14\%). Este resultado é justificado pelo monitoramento das celas nos projetos distrital e paulista, mais o uso de circulações exclusivas nos projetos federal e privado. Os projetos de referência giram em torno de um porte médio (530 vagas) e não apresentam previsão de ampliação, embora exista a possibilidade de crescimento inerente aos padrões arquitetônicos, através da replicação ou prolongamento de blocos.

No isolamento social, os projetos de referência tendem ao fechamento máximo com a localização em complexo penitenciário, a especificação de muros ou o encerramento das edificações. Os projetos padronizados têm maior dependência da localização, em particular, o projeto privado que é especificado com cerca. Os projetos de referência não possuem locais para a participação da sociedade no gerenciamento do estabelecimento penal (ver capítulo 2), embora os modelos federal e privado apresentem salas para apoiar organizações sociais. Os projetos distrital e paulista não apresentam locais específicos para a visita social que ocorre nos pátios de sol dos presos. O projeto paulista também não apresenta local para o encontro íntimo que acontece nas celas. Os locais de visita social permitem o contato físico com os presos, enquanto o encontro com o advogado se passa sem este contato. No isolamento individual, os projetos de referência são equipados com celas coletivas uniformes de nove vagas, em média. As celas individuais são especificadas para a aplicação de medida disciplinar ou a separação de presos com problemas de convívio na proporção de $1,5 \%$ da capacidade do estabelecimento, sendo normalmente organizadas em alas ou blocos separados da população prisional.

Os projetos de referência apresentam com uma coordenação hierárquica das atividades satisfatória, porém com complexidades funcionais pontuais (sobreposições de atividades e fluxos). Estes projetos 
tendem a uma disciplina formal, por meio da simplicidade geométrica (fachadas em menor número e quantidade) e, em particular, pelo predomínio da horizontalidade das edificações. Em geral, os mesmos são organizados em três setores: externo, intermediário e interno, com a totalidade do programa no setor interno $(79 \%)$ e, especificamente, com as atividades rotineiras dos presos nos blocos de vivência: o alojamento, o banho de sol e o programa de benefícios aos presos. Neste arranjo, a visita tem grande penetração topológica. A maior exceção é o projeto federal, cuja hierarquia própria de segurança média externaliza estas atividades, o que complica a operação penitenciária pela presença de presos nos locais mais externos. O projeto paulista tende a empoderar os presos, ao unificar as celas e os pátios de sol, o que expõe os funcionários.

A compactação dos padrões arquitetônicos consiste no agrupamento dos blocos funcionais e na generalização funcional com o acúmulo de atividades diversas nestes blocos e, em particular, nos locais de maior aglomeração dos presos. Nos projetos federal e privado, estas condições são moderadas por uma maior especialização funcional dos espaços, em especial, pela previsão de local para a visita social. Outro vetor da compactação é o dimensionamento, cujo impacto é verificado no tamanho das implantações, com uma tendência de redução da área de terreno (35,88 $\left.\mathrm{m}^{2} / \mathrm{vaga}\right)$, com exceção do projeto distrital que se situa em complexo penitenciário $\left(61,68 \mathrm{~m}^{2} / \mathrm{vaga}\right)$. Os projetos de referência reduzem o programa normativo (entre $75 \%$ e $83 \%$ ), principalmente o paulista que se aproxima da minimização espacial $\left(10,93 \mathrm{~m}^{2} / \mathrm{vaga}\right)$, por meio de uma diminuição do programa de reinserção social $\left(1,44 \mathrm{~m}^{2} /\right.$ vaga), associada a uma centralização das atividades laboreducativas dos presos e a um aumento da capacidade do estabelecimento ${ }^{22}$. A penitenciária compacta paulista consuma esta estratégia, pois, o programa, segundo Jorge (2002, p. 112), foi concebido "com redução de espaços e serviços coletivos, no pressuposto de que os presos aí fiquem poucos dias". Os projetos federal e privado apresentam médias superiores $\left(18,70 \mathrm{~m}^{2} / \mathrm{vaga}\right)$ com acréscimos ao programa de benefícios aos presos (de $1,71 \mathrm{~m}^{2} / \mathrm{vaga}$ para $2,16 \mathrm{~m}^{2} / \mathrm{vaga}$ ) e o reforço da segurança (circulações superiores exclusivas - $17 \%$ da área construída). Em contrapartida, os projetos tendem a reduzir as áreas de celas e pátio de sol dos presos. Em média, os projetos possuem quatro blocos de vivência com uma ala carcerária e um pátio de sol cada, o multiplica a área construída, em virtude da internalização de atividades nestes blocos. O projeto distrital apresenta média maior devido à replicação de áreas própria do padrão arquitetônico modular.

Os projetos de referência tendem à sobrecarga dos fluxos devido à internalização das atividades rotineiras dos presos (chegando a cem pontos de sobreposição de fluxos). Porém, os projetos federal e

\footnotetext{
${ }^{22}$ Apesar da imprecisão dos números apresentados pelo Relatório Infopen do ano de 2014 (BRASIL, 2014), as estatísticas são indicativas da incompletude do programa arquitetônico: apenas 37\% dos estabelecimentos têm área para a visita social e 31\% para o encontro íntimo; $62 \%$ têm sala para atendimento social; $42 \%$ não têm sala para atendimento psicológico; $42 \%$ têm sala para apoio jurídico; $63 \%$ não têm área de saúde; $48 \%$ não têm salas de aula; $78 \%$ não têm oficinas de trabalho. Boa parte das áreas existentes tem uso compartilhado.
} 
privado apresentam menos pontos de sobreposição de fluxos (em média 35 pontos de conflito) e estes se concentram beneficamente na circulação central do setor intermediário. Esta redução é atribuída à simplicidade geométrica das circulações, à especialização dos locais de circulação, à previsão de circulações exclusivas para os funcionários no setor interno e acessos exclusivos para o local de visita. Em especial, o projeto privado apresenta distancias mais curtas a serem percorridas pelos presos e visitantes. Nos demais projetos estas distâncias ora são maiores para os presos, ora para os visitantes, conforme a disposição do local de visita (internalizada ou externalizada).

Os projetos de referência apresentam deficiências no dimensionamento das aberturas de iluminação e ventilação, principalmente, nos locais com a presença de presos e, mais fortemente, nas celas dos projetos distrital e paulista. Estes projetos em particular possuem pouca quantidade de fachada para a criação de aberturas de iluminação e ventilação direta $(0,08$ metro linear de fachada por metro quadrado construído), o que associado ao fechamento arquitetônico, direciona as aberturas para pátios e prismas (indireta), principalmente nos setores mais internos do estabelecimento penal. Os projetos federal e privado possuem mais fachadas $(0,18$ metro linear de fachada por metro quadrado construído) e predominam as aberturas diretas. Os projetos paulista e federal apresentam ventilação cruzada nas celas. O projeto paulista é o único que utiliza soluções zenitais nas celas. O projeto privado é o único que prevê controle das aberturas nos locais mais internos, inclusive nas celas.

Em termos do controle, os projetos apresentam a maioria das áreas internas e externas potencialmente vigiadas (62\% e 93\%, respectivamente), inclusive as edificações (100\% de visualização das coberturas), principalmente nos blocos de vivência (68\%). Assim como, os fluxos são relativamente controlados (63\% das circulações são vigiadas). Isto, notoriamente, devido à adoção da vigilância direta e de circulações exclusivas para os funcionários. As exceções são o projeto paulista que adota a vigilância indireta (15\% das circulações) e o projeto federal que possui uma grande complexidade espacial. Com isto, a proteção dos funcionários é relativa, tanto nas áreas externas como internas. Em particular, os projetos paulista e distrital exigem a exposição dos funcionários nos procedimentos ou estes dependem da participação de presos. Os postos de controle tendem a enfatizar o poder institucional, ao serem espacialmente explícitos e elevados em relação ao piso ocupado pelos presos. Porém, os mesmos não incorporam o princípio da inverificabilidade, com exceção do projeto privado que prevê visores com película reflexiva. Os projetos utilizam aparatos de segurança, mas ainda apresentam falhas não corrigidas, tais como: permeabilidade, funcionários sem proteção e pontos fracos na segurança e operação.

Quanto à barreira perimetral, os projetos distrital e privado adotam a cerca, ao privilegiar o custo de construção, enquanto os projetos paulista e federal adotam o muro, ao privilegiar a impermeabilidade e a inexpugnidade. As barreiras apresentam uma geometria simples - retangular, planar e nivelada, além 
de poder ser considerada alta (em média, com $6,45 \mathrm{~m}$ ). Em geral, as mesmas têm proteção relativa para a circulação da guarda externa, sendo mais efetiva na especificação de muro, enquanto a cerca não recebe aparatos para correção do problema. O projeto distrital possui os maiores afastamentos (30m), seguido dos projetos paulista e privado (20 e 15m, respectivamente). O projeto paulista apresenta o maior perímetro de segurança $(13 \mathrm{~m})$, seguido do projeto privado $(5 \mathrm{~m})$. Os projetos distrital e federal não apresentam perímetro de segurança (o projeto distrital está inserido em complexo penitenciário). Os projetos de referência apresentam pista de ronda externa à barreira perimetral, além de linha de tiro interna.

Os projetos de referência configuram celas geometricamente regulares, descritas com uma circulação central que transpassa uma área de dormitório (beliches de duas ou três camas com prateleiras para a guarda de pertences) até o local de higiene pessoal ao fundo (vaso sanitário, lavatório e chuveiro), com dimensões médias de $3,15 \mathrm{~m}$ x $5,70 \mathrm{~m}\left(2 \mathrm{~m}^{2} / \mathrm{vaga}\right)$. A exceção é o projeto distrital que possui acesso descentralizado e banheiro posicionado lateralmente na entrada da cela. Nestas celas, os espaços individuais e coletivos são reduzidos, devassados e destituídos de itens de conforto, impossibilitando a privacidade pessoal. As aberturas de ventilação e iluminação são mínimas (entre 12,28\% e 16,16\% da área do piso), predominando tipos diretos e a ausência de ventilação cruzada. A exceção é o projeto federal que apresenta $24,76 \%$ em aberturas diretas e indiretas, com ventilação cruzada. As aberturas recebem contenções do tipo brises ou grades. As portas são em grade e chapeadas e possuem portinholas. A exceção é o projeto paulista (em grade). A organização por divisórias baixas do espaço das celas dificulta a visualização interna pelos funcionários.

Os projetos de referência constituem pátios de sol coletivos com uma capacidade média de 215 pessoas $\left(1,27 \mathrm{~m}^{2} / \mathrm{vaga}\right)$, eventualmente compartilhados por duas alas carcerárias. Geometricamente, os pátios são regulares, sem divisões internas e são parcialmente cobertos, onde são locados perifericamente os serviços sanitários (cubas e vasos sanitários conformados por divisórias baixas), além de mobiliário (mesas e bancos). Isto permite a visualização da totalidade do local. A cantina foi substituída pela distribuição de alimentos, nos projetos federal e privado. A abertura superior do pátio de sol é fechada por uma grade nos projetos de referência, com exceção do projeto distrital.

Os postos de controle nos projetos de referência têm área média de $15,85 \mathrm{~m}^{2}$ distribuía em uma geometria regular, porém com deficiências em termos dos visores para a visualização (quantidade, posicionamento e especificação), compensada, em parte, pela elevação do piso em relação aos locais vigiados. A planta normalmente é livre o que denota um desamparo para o trabalho dos funcionários, em termos do mobiliário. Já o serviço sanitário é previsto, variando entre dentro ou fora do posto. A segurança do posto é reforçada por grades e vedações nos visores e a funcionalidade do mesmo é incrementada com o uso de mecanismos de abertura remota das portas controladas. 
Comparativamente, a arquitetura nacional atinge índices extremamente econômicos em relação às unidades norte-americanas. As unidades penais brasileiras apresentam uma área construída com cerca de $19 \mathrm{~m}^{2}$ por vaga, ao custo médio de $\mathrm{R} \$ 3.160,00$ por metro quadrado ou $\mathrm{R} \$ 57,6$ mil por vaga (ESTECA, 2010, p. 132). As unidades norte-americanas somam cerca de $100 \mathrm{~m}^{2}$ por vaga (ORLAND, 1978, p. 56), ao custo de US\$ 80 mil por metro quadrado ou US\$ 80 mil por vaga (KESSLER apud FAIRWEATHER E MCCONVILLE, 2003, P. 89). Em média, o custo operacional por preso no Brasil é da ordem de $\mathrm{R} \$ 2.500,00$ reais mensais, a maior parte gasto com a folha de pagamento. No Estado de São Paulo estima-se que a mão de obra corresponda a cerca de $75 \%$ das despesas mensais de operação (BRASIL, 2009). Enquanto os funcionários encarregados da carceragem (agentes de segurança penitenciária) representam em média 68\% dos trabalhadores da prisão (BRASIL, 2014), recebendo, em média, $\mathrm{R} \$ 3.000,00$ - fora encargos trabalhistas que dobram o custo com pessoal.

Em comparação a outros países, a defasagem das soluções arquitetônicas e a negligencia do fator humano são as duas características proeminentes da arquitetura penal brasileira (ESTECA, 2010, p. 201-203). Tomando como exemplo os Estados Unidos, o sistema penal deste país experimenta a terceira geração de estabelecimentos penais, enquanto no Brasil é esboçada uma transição entre a primeira e a segunda geração (ORNSTEIN, 1989, p. 14). Ao mesmo tempo, as adequações e comutações promovidas nos padrões arquitetônicos não são garantia de boas soluções, conforme se observa no desempenho das edificações prisionais. O pátio de sol do projeto da Penitenciária Compacta paulista reproduz a 'rua dez' da Casa de Detenção (VARELLA, 1999), no qual a disposição do espaço inviabiliza a vigilância, propiciando um local para o acerto de contas, brigas mais sérias e mortes. Da mesma maneira, no sistema norte-americano a disciplina é primordial, porém sem prejuízo dos aspectos humanos mínimos: a Standards for Accreditation da American Corrections Association foi aceita pelas Cortes sob o argumento de satisfazer os princípios constitucionais contra a punição cruel e irregular (KESSLER apud SPENS, 1994). No Brasil, as demandas de segurança e financeira forçam o corte de padrões de bem-estar, principalmente dos presos, cujo resultado são projetos voltados apenas para o acondicionamento das pessoas presas - como os cadeiões paulistas (D’URSO, 1995, p. 153). Estes projetos são considerados alternativa viável pelos governos no país para o problema de superlotação no sistema de segurança pública, "para minimizar as mazelas próprias dos cárceres brasileiros" (D’URSO, 1995, p. 153). Pois, segundo Thompson (1976), é melhor a criação de vagas inadequadas, do que a criação de vaga alguma.

\subsection{Conclusão analítica}

A edificação penal é fruto de um processo de dois séculos de evolução do dispositivo jurídico-penal, no qual no movimento de reforma penitenciária imprimiu certos padrões humanitários à arquitetura dos estabelecimentos penais, ao mesmo tempo em que os fatores econômicos condicionaram e 
moldaram o edifício prisional. Por um lado, houve uma preocupação com a melhoria do espaço arquitetônico da prisão: o conforto ambiental e o aparelhamento para as atividades, a diversidade de alojamentos dos presos, a ampliação e especialização do programa e o desenvolvimento da vigilância. Por outro lado, avalia-se que as mudanças positivas na edificação penal ocorreram muito mais pelo ganho econômico ou utilitário do que pela humanização da pena. Neste sentido, a arquitetura foi parcialmente desvinculada de sua justificação penalógica ou morfológica, sendo substancialmente voltada para o controle da população prisional. "Em ponderável parte da opinião pública, e na de alguns doutos também, a ideia de penitenciária é a de um enorme edifício, lúgubre, sinistro, de paredes, grades e muralhas acabrunhadoras, onde estão amontoados mil, dois mil ou mais presos, sempre em número maior do que comportaria a capacidade dele" (MIOTTO, 1992, p. 51).

Em consequência da pressão financeira imposta pela administração penitenciária, o modelo arquitetônico de segurança máxima é constantemente desvirtuado em sua aplicação e conformação, cuja simplificação e compactação do espaço extrapolam os parâmetros da boa condição penitenciária. Como é colocado no Relatório Final da Comissão Parlamentar de Inquérito do Sistema Carcerário: "projetos primários, com erros e falhas básicas, com a preocupação de simplesmente criar mais vagas, sem se importar com o futuro do local e das pessoas" (BRASIL, 2009, p. 432). Para Esteca (2010), isto se manifesta na distorção do papel e da importância da arquitetura no sistema penal. O papel desta é desvirtuado por uma ênfase na função econômica da prisão, em detrimento da humana, o que pode ser observado nas metas políticas do setor. Já a importância é exacerbada ao se apresentar o projeto como se, per si, pudesse resolver a crise penitenciária. No entanto, como coloca Sá (1990, p. 256), "todo sensacionalismo, inclusive o arquitetônico, deve nos colocar em posição de alerta e desconfiança”.

As considerações econômicas que não permitem a construção de edifícios ad hoc é uma questão identificada por López-Rey (apud GARCÍA BASALO, 1959, p. 83) como obstáculo para a adequação da Arquitetura Penitenciária à Penalogia. Ratificando a citação de Lopes-Rey, Miotto (1992) afirma que a atribuição equivocada para o projeto arquitetônico ocorre porque a administração penitenciária desconhece no que consiste a ciência, a técnica e a prática da arquitetura penal.

Ao se avaliar a evolução dos padrões arquitetônicos penitenciários, a centralidade panóptica ou radial cedeu lugar a uma fragmentação da edificação em múltiplos núcleos e a necessária articulação de suas partes (Figura 11). Todavia, esta fragmentação foi revertida na modalidade de segurança máxima, na qual a diretriz de compactação do espaço construído reagrupou os blocos funcionais, como ocorre nos projetos de referência nacionais ou nos projetos norte-americanos do tipo super-max - a ADX Florence e a USP Pelican Bay. Como constantes arquitetônicas, os padrões arquitetônicos tenderam para uma configuração de maior segurança e maior porte, por meio do fechamento das edificações 
(impermeabilidade) e do incremento da capacidade dos estabelecimentos penais, associado à coletivização da cela.

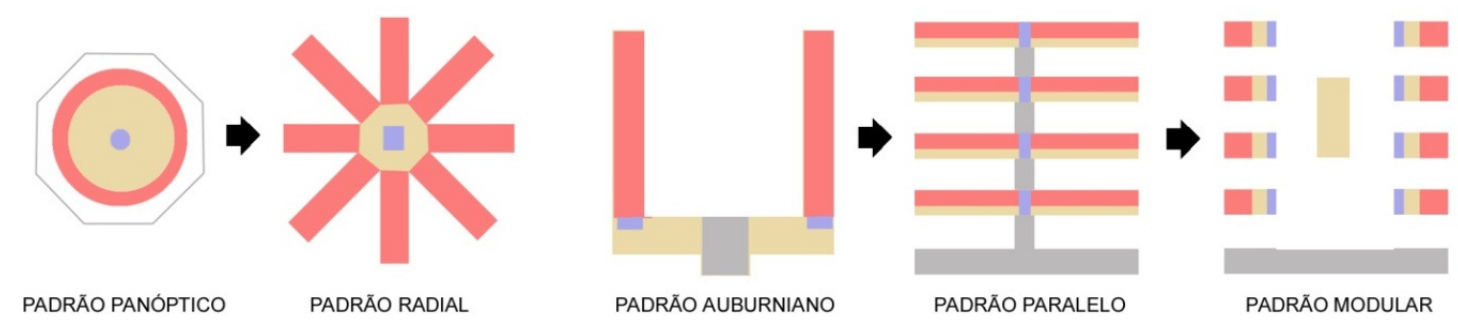

Figura 11 - Esquema da evolução do espaço arquitetônico da prisão

A partir dos padrões arquitetônicos penitenciários e da atual tendência de configuração da edificação penal.

As alterações citadas também se fizeram presentes no espaço arquitetônico da prisão no Brasil, cujo registro está nos edifícios prisionais e nas regras técnicas do Ministério da Justiça. Neste sentido, não apenas a edificação no país replica os modelos estrangeiros, mas soma as releituras e adequações motivadas pelas particularidades do sistema penal nacional. Em geral, esta edificação é caracterizada pela segurança elevada e o porte médio; um desenho misto baseado nos conceitos dos padrões arquitetônicos modular e paralelo, porém térreo e compacto que alia a redução de atividades com a coletivização dos espaços, o aumento das capacidades e a generalização funcional dos locais. Igualmente, as características apontam para um incremento da segurança, por meio da internalização das atividades dos presos, enquanto a vigilância oscila entre a indireta plena e a direta.

Se a edificação prisional no país não configura um padrão arquitetônico próprio, embora existam elementos e características recorrentes, a capacidade de absorção dos padrões estrangeiros e sua reinterpretação demonstram a inovação na arquitetura penal brasileira. Neste sentido, certos conceitos tidos como inovadores pelos estudos ingleses examinados (HENLEY, 2003 e RIDEOUT, 2006) já caracterizam a edificação nacional, como pode ser observado nos projetos de referência (Apêndice A). Outros conceitos são inviáveis em qualquer situação, como salienta Henley (2003, p. 01): "dado que isto é em essência um exercício projetual, enquanto lógico, não pode reivindicar ser absolutamente rigoroso". Enquanto The Creative Prison procura "uma visão alternativa do que a prisão poderia ser" (RIDEOUT, 2006), assumindo o caráter conceitual do projeto, cuja importância está nas ideias e discussões sobre o futuro das prisões. Isto é notório na destinação dos projetos concebidos nestes trabalhos, quando a proposta arquitetônica abrange mais de uma categoria de estabelecimento penal ou é dependente de uma nova conjuntura penalógica. Embora considerações sobre o custo sejam feitas em termos da viabilidade dos projetos, estes trabalhos não avançam neste tópico, sem qualquer estimativa feita. 


\title{
Capítulo 2 - Panóptico
}

Neste capítulo, a base teórico-metodológica para a tecnologia de projeto é delineada, em termos dos quesitos estruturadores do programa arquitetônico, assim como, dos critérios e processos para a composição do espaço arquitetônico penal.

O Panóptico é, conforme Foucault (1987, p. 169), um modelo generalizável de funcionamento que tem por objetivo disciplinar uma atividade, pela intensificação e concentração do poder sobre muitos na mão de poucos, para se obter a economia e a eficácia dos resultados e processos.

\begin{abstract}
Mas o Panóptico não deve ser compreendido como um edifício onírico: é o diagrama de um mecanismo de poder levado à sua forma ideal: seu funcionamento, abstraindo-se de qualquer obstáculo, resistência ou desgaste, pode ser bem representado como um puro sistema arquitetural e óptico: é na realidade uma figura de tecnologia política que se pode e se deve destacar de qualquer uso específico (FOUCAULT, 1987, p. 194).
\end{abstract}

O Panóptico pode ordenar, classificar e analisar a decomposição de qualquer relação produtiva de modo a maximizar os efeitos da coletividade, por meio do controle sobre as individualidades. Conforme Foucault (1987), o Panóptico é uma máquina retificadora dos indivíduos, laboratório de experiências, otimizadora do exercício do poder e democraticamente controlada.

O Panóptico pode ser sintetizado como um aparelho disciplinar cujo objeto e fim são as relações de disciplina $^{23}$, o que Foucault chamou de disciplina-mecanismo e que visa à intensificação e ramificação do poder, por meio de uma ordenação vinculada às relações de custo e benefício de uma atividade. Foucault desenvolve o tema disciplinar citando Baltard, que afirma que as prisões devem ser instituições completas e austeras, ou seja, devem atuar sobre todos os aspectos do individual de forma incessante e despótica - é o "onidisciplinar".

A generalidade do Panóptico permite a sua aplicação diversificada, seja na educação, na terapêutica, na produção ou no castigo. Como coloca Miller (BENTHAM et al., 2008), o Panóptico não é uma prisão. Por outro lado, segundo Foucault (1987, p. 235), “o tema do panóptico - ao mesmo tempo vigilância e observação, segurança e saber, individualização e totalização, isolamento e transparência encontrou na prisão seu local privilegiado de realização".

O Panóptico se desenvolveu na produção intelectual do filósofo inglês Jeremy Bentham (1748-1832). No século XVIII, Bentham propôs uma doutrina moral baseada no Princípio de Utilidade ou Princípio da Maior Felicidade ${ }^{24}$. Este Princípio estabelecia a fórmula: a maior felicidade do maior número de

\footnotetext{
${ }^{23}$ As disciplinas são uma tecnologia de poder, uma modalidade para exercê-lo, que comporta um conjunto de técnicas que visavam a "tornar o exercício do poder o menos custoso possível", com um "máximo de intensidade e estendidos tão longe quanto possível, sem fracasso, nem lacuna" (FOUCAULT, 1987, p.179).

${ }^{24}$ O Princípio de Utilidade consistia na aplicação do método científico ao bom governo das nações (ALGARRA, 2007), visando à maior felicidade para as pessoas como resultante das ações dos governos, por meio de um "cálculo da felicidade" (COLLINSON, 2004, p. 164).
} 
pessoas, e enunciava: a punição é útil somente se estiver voltada para minimizar a dor e maximizar o $\operatorname{prazer}^{25}$ (COLLINSON, 2004, p. 163). Entre os conceitos de utilidade e a felicidade, Miller (BENTHAM et al., 2008, p. 99) aponta a predominância do utilitarismo no pensamento de Bentham para a prisão, instituído como meio ideal de dominação absoluta dos indivíduos e das comunidades.

Segundo ele:

Se a humanidade é serva de dois senhores [prazer e dor], ela será consequentemente serva de quem se fizer senhor de seus senhores. E no Panóptico, como vimos, é como cães que Bentham solta o prazer e a dor em cima dos reclusos.

Em 1791, Bentham publicou A Casa de Inspeção (The Inspection House), apresentando o Panopticon como a utopia do encarceramento perfeito (Figura 12). O Panopticon (lugar de onde tudo se observa) era um projeto de prisão-modelo, dedicado às Casas de Correção. Por isso, embora não fosse arquiteto, há autores que atribuem a Bentham "o primeiro tipo consciente de arquitetura penitenciária" (RODRIGUES apud GARCÍA BASALO, 1959, p. 60). Uma descrição da edificação panóptica:

[...] na periferia uma construção em anel; no centro, uma torre; esta é vazada de largas janelas que se abrem sobre a face interna do anel; a construção periférica é dividida em celas, cada uma atravessando toda a espessura da construção; elas têm duas janelas, uma para o interior, correspondendo às janelas da torre; outra, que dá para o exterior, permite que a luz atravesse a cela de lado a lado. Basta então colocar um vigia na torre central, e em cada cela trancar um louco, um doente, um condenado [...] (FOUCAULT, 1987, p. 165-166).

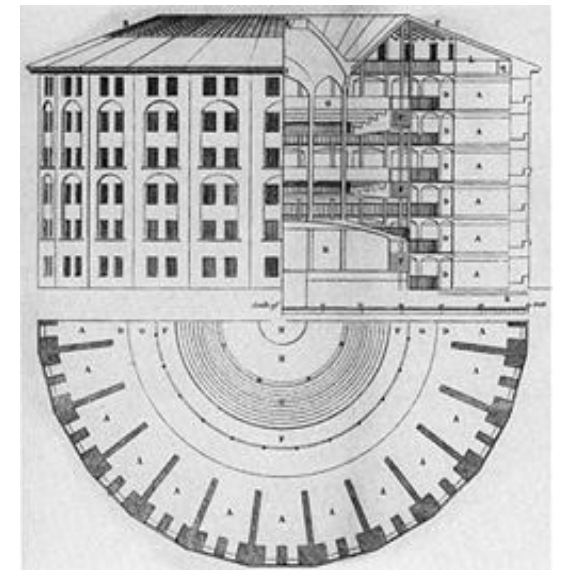

Figura 12 - Desenho do Panopticon de Jeremy Bentham

(Fonte: FOUCAULT, 1987, figura 17)

O projeto Panopticon foi criação do irmão de Jeremy, Samuel Bentham. Samuel elaborou originalmente como uma edificação para a instrução de trabalhadores em uma fazenda em Krichev, na Rússia Branca, no ano de 1786. Em um primeiro momento, o projeto de Samuel se ocupou de um

\footnotetext{
${ }^{25}$ Para Perrot (BENTHAM et al., 2008, p. 114), a publicação An introduction to the principles of morals legislation (1789) define a utilidade como a submissão, científica e calculada, aos dois grandes aspectos que governam toda a conduta dos indivíduos e das sociedades: a evitação da dor e a busca do prazer.
} 
problema pragmático: os abusos dos inspetores ingleses sobre os trabalhadores, remetendo a questão: quem guarda os guardas? Além disso, o projeto incorporou a teatralidade e a dualidade da sociedade russa, materializada na disposição central da casa do inspetor, rodeada pelos camponeses em suas funções. Werret (BENTHAM et al., 2008, p. 168), afirma que "na realidade, a arquitetura do Panóptico apresentava uma forma secularizada dos mecanismos de poder da igreja ortodoxa": a pessoa comum é posicionada orbitando o divino, senhor e intocável. Na conclusão de Werret (Idem, p. 172), a contribuição de Jeremy Bentham foi a descontextualização do projeto do irmão, partindo de uma solução específica para uma genérica, que pudesse ser aplicada "sem exceção, a todos e quaisquer estabelecimentos nos quais (...) se queira manter sob inspeção um certo número de pessoas" (BOWRING apud BENTHAM et al., 2008, p. 40).

O modelo benthaniano foi um reflexo do pensamento penalógico no século XIX, período da Ciência das Prisões: "A surpreendente descoberta que Bentham faz do poder da arquitetura - 'e isso por uma simples idéia de arquitetura', repetia - é adotada por toda a época" (PERROT apud BENTHAM et al., 2008, p. 137). Por outro lado, os problemas do Panopticon levaram os estudiosos do sistema penal a abordar o trabalho de Bentham do ponto de vista filosófico ou idealístico, como sublinha Werret (BENTHAM et al., 2008, p. 154-155) ou, como coloca Perrot, de modo mais indireto do que literal. Ao conceber o Panopticon, Bentham construiu um modelo político para a prisão: um projeto pedagógico que reúne esforços de escolarização e moralização (PERROT apud BENTHAM et al., 2008, p. 136). Particularmente, a tecnologia de Bentham integrou o modelo prisional, a operação e o espaço arquitetônico, por meio de uma argumentação de natureza penalógica e pragmática. Para García Basalo (1959, p. 60), ele "associa intimamente concepção penitenciária e concepção arquitetônica". Por isso, também em arquitetura, o trabalho de Bentham se destaca mais por sua contribuição teórica do que pela morfológica. Algarra (2007) aponta isto na história da prisão:

\begin{abstract}
Vimos como a prisão celular baseada na prisão de Ghent e no Hospício de São Miguel de Roma, se foi impondo como uma solução civilizada. No meio do caminho, a contribuição criativa conceitual de Bentham que, como normalmente acontece com os filósofos, teve mais transcendência como uma ideia do que como modelo real. No outro extremo, nos de resultados práticos, os modelos de prisão radial e corredor dos Estados Unidos se espalharam para o mundo inteiro.
\end{abstract}

Para Basalo (1959, p. 60), o Panóptico é "importante porque as ideias de Bentham exerceram marcada influência na teoria da arquitetura penitenciária e materializando-se em edifícios em cujas linhas gerais é evidente a influência do seu projeto". Assim, o Panóptico se tornou a base teórica da arquitetura penal e o Panopticon seu modelo emblemático. Para Foucault, este edifício é a figura arquitetural do conceito de prisão que persiste até a atualidade: "O fato de ele ter, até nosso tempo, dado lugar a tantas variações projetadas ou realizadas, mostra qual foi durante quase dois séculos sua intensidade imaginária” (1987, p. 194). 
Como prova da força do Panopticon, o desenho foi reproduzido tardiamente e justamente em sua forma mais pura entre os séculos XIX e XX, por exemplo: na Stateville Correctional Center, nos Estados Unidos (1925), e no Presídio Modelo, em Cuba (1928). No Brasil, em Salvador, o Corpo IV da Penitenciária Lemos Brito ainda replicou o modelo com alterações (1950) (Figura 13). Para Trigueiros (2011, p. 19 e 23), "a materialização de Bentham constituiu uma permanência com uma memória coletiva própria que não é dificilmente exorcizável, [...] como conceito arquitetônico, o Panóptico de Bentham influenciou a construção prisional”.

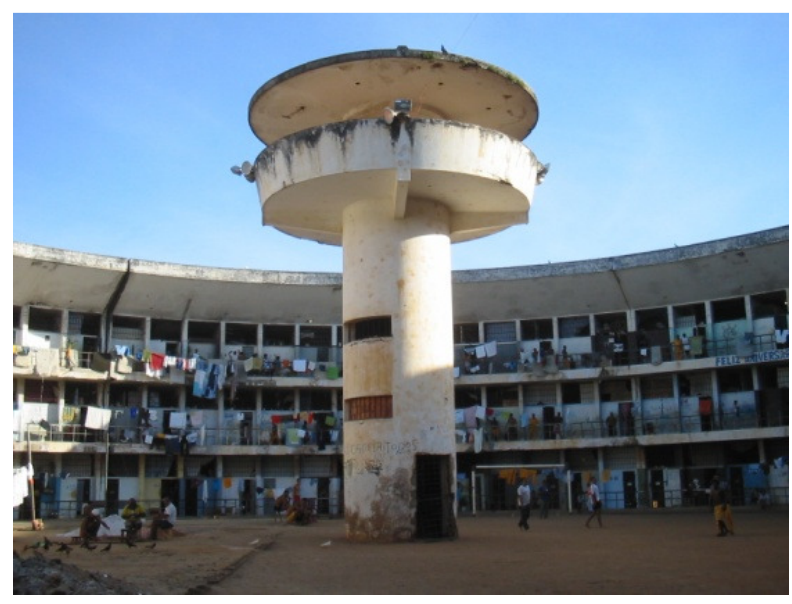

Figura 13 - Fotografia do Anexo IV da Penitenciária Lemos Brito/BA (Fotografia do autor)

\subsection{Quesitos panópticos para o programa arquitetônico}

Os princípios panópticos são um conjunto de pressupostos e regras alicerçados no trabalho teóricoconceitual de Bentham e que regem a concepção do edifício prisional. Eles foram estabelecidos a partir da relação de causa e efeito entre os objetivos da pena e a modelagem espacial da prisão, tendo sido definidos por Esteca (2010), com base no trabalho de Foucault (1987).

Em seu trabalho, Foucault associa a sociedade disciplinar com o Panopticon, relacionando as disciplinas sociais com o modelo proposto por Bentham. Para Foucault (1987, p. 118), as disciplinas sociais foram transpostas para as técnicas penitenciárias, o que intensificou o poder institucional e despersonificou o preso. Segundo o mesmo (Idem, 1987, p. 208), estas disciplinas foram organizadas em três grandes esquemas: o modelo político-moral do isolamento individual e da hierarquia; o modelo econômico da força aplicada a um trabalho obrigatório; o modelo técnico-médico da cura e da normalização - a cela, a oficina, o hospital.

Mais à adiante em seu trabalho, Foucault lista três princípios para a prisão fundados nas disciplinas por ele esquematizadas: o isolamento, o trabalho e a modulação da pena. $\mathrm{O}$ isolamento listado se 
bifurca em duas abordagens: "Isolamento do condenado em relação ao mundo exterior, a tudo que motivou a infração, às cumplicidades que a facilitaram. Isolamento dos detentos em relação uns aos outros [...] pela ruptura de qualquer relação que não seja controlada pelo poder ou ordenada de acordo com a hierarquia" (FOUCAULT, 1987, p. 222 e 226). Assim, o isolamento tem uma dupla intenção: submeter e reformar os presos, aliando os aspectos negativo e positivo da pena. O trabalho dos presos na acepção de Foucault envolve não apenas a oficina, mas todas as atividades destes, racionalmente programadas, que em conjunto fazem parte de uma relação de poder - "um esquema da submissão individual e de seu ajustamento a um aparelho de produção": instrução, refeições, oração, sono em ciclos diários, semanais, mensais, anuais. O isolamento e o trabalho dos presos são vistos como agentes de transformação do indivíduo. Por fim, a modulação da pena trata do ajustamento da punição em razão da recuperação alcançada pelo preso, devendo ser constantemente acompanhada e periodicamente avaliada - o que pode ser exemplificado pelo sistema progressivo de pena, adotado, entre outros países, no Brasil. Para tanto, a prisão é local de punição, mas também de observação dos indivíduos punidos: "as prisões devem ser concebidas como um local de formação para um saber clínico sobre os condenados" (FOUCAULT, 1987, p. 235). A prisão deve vigiar, examinar e registrar.

Do desenvolvimento dos princípios inicialmente elencados, Foucault apresenta os princípios fundamentais da prisão - as sete máximas universais da boa condição penitenciária (1987, p. 237): a correção do indivíduo e a classificação e separação dos tipos de presos; o trabalho como obrigação e como direito do preso, além da educação; e a modulação das penas, gravitando em torno deste os princípios da gestão da pena por pessoal técnico e das instituições anexas que acompanham o preso após sua liberação. Esta lista originou o que Esteca (2010, p. 42) denominou de princípios de funcionamento da prisão (ver capítulo 1): o isolamento social dos presos, o isolamento individual do preso, as atividades dos presos e a vigilância acompanhada da administração da pena.

Em um momento seguinte, ao discutir as diferentes facetas da disciplina prisional, associando os princípios fundamentais da prisão e o espaço arquitetônico panóptico, Foucault abordou indiretamente a composição arquitetônica da edificação penal e apontou subliminarmente os princípios do espaço arquitetônico da prisão ${ }^{26}$. Estes princípios espaciais foram sistematizados por Esteca (2010, p. 46) em quatro: o isolamento social do preso, o isolamento individual do preso, a organização do espaço e o controle. Ambos os isolamentos seguem a abordagem de Foucault, envolvendo a segregação dos presos em relação ao mundo externo e entre si, dentro da prisão. A organização do espaço incluiu não apenas as atividades do preso, mas todas as atividades do estabelecimento necessárias para o funcionamento do mesmo, ou seja, aquelas expressas pelos sistemas de segurança e operacional,

\footnotetext{
${ }^{26}$ O programa multifuncional e a individualização da pena estão baseados no que Foucault denominou de o 'penitenciário', medidas do cumprimento da pena não previstas na sentença jurídica, mas integrantes do funcionamento da prisão.
} 
igualmente submetidas à disciplina espacial panóptica. Por isto, a organização do espaço intercepta de modo sistêmico os demais princípios, que participam com suas particularidades na composição arquitetônica da edificação penal. Esta simbiose ocorre de modo mais visceral com o controle, como foi sublinhado no estudo da edificação penal, no capítulo 1, desta tese. No controle foram enfatizados os procedimentos prisionais ao lado do princípio de inspeção panóptica, baseado na vigilância inverificável. Assim, enquanto a vigilância panóptica pode sugerir um processo estático, esta ênfase também ressalta a dinâmica operacional, constituída do acompanhamento das atividades dos presos.

Os princípios deduzidos do trabalho de Foucault foram associados por Esteca aos processos totais da Instituição Total descritos por Goffman e aos elementos centrais da edificação penal, havendo uma correspondência em ambos os casos (Quadro 1). Destaca-se que a descrição de Goffman das Instituições Totais envolve os mesmos requisitos da prisão panóptica: o controle das necessidades, movimentação e comunicação das pessoas; a centralização do poder na divisão entre um grande grupo controlado e uma pequena equipe dirigente; e a vigilância absoluta e incessante. A convergência observada explicitou o conhecimento da pragmática prisional que Bentham detinha e utilizou no desenvolvimento do Panopticon, assim como, evidenciou a proximidade do trabalho de Foucault em relação à edificação prisional. Neste sentido, o estudo realizado indicou a aplicabilidade teórica do Panóptico para o projeto arquitetônico de estabelecimentos penais, fixando os temas centrais para a composição do espaço arquitetônico deste tipo de edificação, com base na sistemática da atividade prisional do trabalho de Foucault. Estes temas ou quesitos sintetizam os principais aspectos da pena moderna e da edificação prisional, assim como das relações existentes entre ambos, interagindo intimamente com o modelo e a realidade prisionais. Os mesmos preenchidos pelos princípios espaciais panópticos configuram o Panóptico.

Quadro 1 - Quesitos panópticos relacionados aos princípios, processos e elementos arquitetônicos

\begin{tabular}{|c|c|c|c|c|}
\hline Princípios panópticos & $\begin{array}{l}\text { Princípios de } \\
\text { Funcionamento }\end{array}$ & $\begin{array}{l}\text { Processos } \\
\text { Totais }\end{array}$ & $\begin{array}{l}\text { Elementos centrais da } \\
\text { edificação penal }\end{array}$ & Quesitos panópticos \\
\hline Isolamento do preso & $\begin{array}{l}\text { Isolamento social dos } \\
\text { presos }\end{array}$ & $\begin{array}{c}\text { Isolamento } \\
\text { social }\end{array}$ & Barreira Perimetral & $\begin{array}{c}\text { Isolamento social do } \\
\text { preso }\end{array}$ \\
\hline Isolamento do preso & $\begin{array}{c}\text { Isolamento Individual } \\
\text { do preso }\end{array}$ & - & Cela & $\begin{array}{c}\text { Isolamento } \\
\text { individual do preso }\end{array}$ \\
\hline Trabalho & Atividades dos presos & $\begin{array}{l}\text { Integralismo e } \\
\text { Mecanicismo }\end{array}$ & Pátio & $\begin{array}{c}\text { Organização do } \\
\text { espaço }\end{array}$ \\
\hline Controle inverificável & Vigilância & Controle & Salas de Controle & Controle \\
\hline Modulação da pena & Administração da Pena & - & - & \\
\hline
\end{tabular}

(Fonte: adaptado de ESTECA, 2010, p. 192)

\footnotetext{
${ }^{27}$ A administração da pena corresponde ao penitenciário descrito por Foucault (1987, p. 207) e não produz efeitos físicos singulares, mas contribuições aos outros princípios.
} 


\title{
2.2 Composição arquitetônica panóptica
}

A partir dos quesitos panópticos é possível organizar os princípios trabalhados por Bentham, de modo a compilar uma base teórico-metodológica para a composição arquitetônica da prisão.

\subsubsection{Isolamento social da pessoa presa}

O isolamento social do preso trata da segregação social do grupo de pessoas condenadas pela Justiça, atendendo ao caráter retributivo da pena e à função da prisão: a proteção da sociedade. Nas palavras de Garbelini (2005, p. 158): “o principal traço arquitetônico da prisão é impedir a comunicação com o exterior de modo seguro e eficaz". Na perspectiva do princípio panóptico, para Foucault o isolamento social é condição primordial para o exercício da disciplina. $\mathrm{O}$ isolamento cria as condições para o exercício da ciência da punição descrita por Bentham. O utilitarismo determina o cálculo acurado das quantidades de prazer e dor a serem ministradas, de modo a infligir a punição sem inutilizar os corpos. Este cientificismo exige a identificação, o posicionamento, o exame e o registro do processo aplicado a cada preso. Como pretenso ambiente controlado, um laboratório, a prisão parece para Bentham o campo ideal para as suas experimentações (PERROT apud BENTHAM et al., 2008, p. 115). Neste sentido, Agostini (2002, p. 3) enfatiza a complementaridade da disciplina e do isolamento:

\begin{abstract}
Somente com o total afastamento entre os infratores e a vida extra-muros é que se pode conformar um ambiente hierárquico preciso, caracterizado por um cotidiano de submissão do preso ao sistema que lhe é imposto; um espaço com regras próprias e cuja racionalidade disciplinar representa "o sonho de um meio artificial, funcionando como um laboratório ideal".
\end{abstract}

A prisão panóptica trazia uma política de abertura da instituição, na qual qualquer pessoa teria a possibilidade de entrar no estabelecimento e assumir o posto de controle na torre central. A possibilidade de visibilidade ou acessibilidade da instituição panóptica torna "um edifício transparente onde o exercício do poder é controlável pela sociedade inteira” (FOUCAULT, 1987, p. 196). Nas palavras de Foucault, um "controle democrático" da instituição. Para Bentham, este mecanismo era útil, pois promoveria a dissuasão do crime e moralização da população, enquanto esta, atuando como vigilante e fiscal da instituição, reforçaria o controle do estabelecimento, evitando "o risco de que o crescimento de poder devido à máquina panóptica possa degenerar em tirania" (FOULCAULT, 1987, p. 171). Com isto, Bentham insere a prisão na dinâmica social, apresentada como um teatro do castigo, oferecendo aos espectadores "um drama contínuo e continuamente interessante, no qual os personagens nocivos são in specie expostos a uma ignomínia educativa" (MILLER apud BENTHAM et al., 2008, p. 83). É a proposta da Casa de Vidro de Ivan Ângelo (1980), no qual a sociedade participa da rotina do estabelecimento como curiosa ou cientista. Ao mesmo tempo, Bentham reinscreveu a prisão no espaço social, aproximando a sociedade e a prisão. "Daí se deduz a localização das prisões panópticas: elas serão construídas nas proximidades da metrópole, perto das grandes cidades para serem de fácil acesso ao grande número” (MILLER apud BENTHAM et al., 2008, p. 83). 
O controle do perímetro da unidade penal, defendido pela barreira de segurança, adere ao mesmo princípio de vigilância panóptico, no qual todas as áreas (adjacentes à unidade penal, além das áreas internas não edificadas) e construções (a própria barreira e as edificações) devem ser monitoradas. Bentham (2008, p. 23) previa que o "campo de inspeção pode ser dilatado em qualquer medida". Neste sentido, a disposição das torres de vigilância externa e a geometria da barreira devem favorecer esta tarefa - o arranjo próprio das fortalezas: o Panopticon previa muros com geometria pura, quadrada ou hexagonal, em terrenos planos, como era padrão em seu tempo ${ }^{28}$. Além disto, Bentham criou um elaborado sistema de defesas composto por sentinelas, muros, paliçadas e diques, cujo arranjo definia um acesso único à unidade prisional por uma avenida murada, não só para garantir o aprisionamento das pessoas, mas para proteger o estabelecimento de ataques externos (TRIGUEIROS, 2011).

\subsubsection{Isolamento individual da pessoa presa}

Além do poder visível e inverificável, para Basalo (1959) e Agostini (2002), a contribuição mais evidente do Panóptico ao aparelho disciplinar é o princípio do isolamento individualizado. $\mathrm{O}$ isolamento programado no sistema panóptico previa que "não somente a pena deve ser individual, mas também individualizante" (FOUCAULT, 1987, p.199) (Figura 14). Assim, a cela individual foi estabelecida como unidade básica de alojamento para evitar as "más influências recíprocas" e como "garantia da ordem". A partir desta premissa, a cela individual era a célula primordial do projeto benthaniano, onde o preso deveria realizar todas suas atividades e de onde era vigiado.

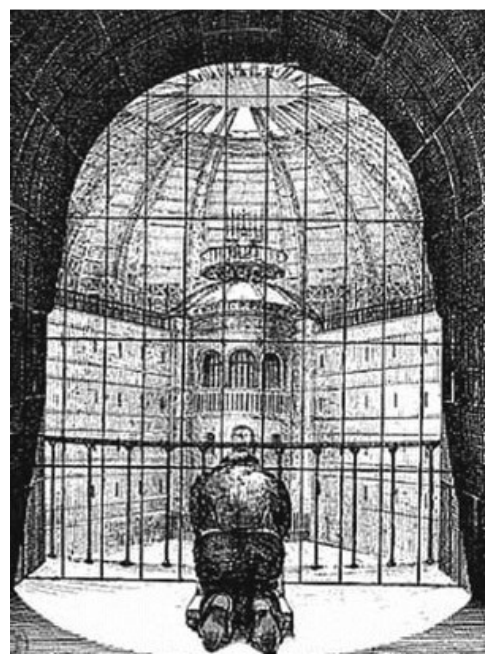

Figura 14 - Gravura da cela do Panopticon (Fonte: FOUCAULT, 1987, figura 21)

\footnotetext{
28 Bentham acreditava na inexpugnidade do edifício circular, não pela resistência de suas paredes, mas pela impossibilidade de um plano de fuga, diante da vigilância perene. Assim, a barreira perimetral não foi um tópico prioritário no trabalho do jurista. O tema surgiu após críticas ao panopticon, sendo desenvolvido nos Postscripts da publicação original (TRIGUEIROS, 2011).
} 
$\mathrm{Na}$ cela, o recluso trabalhava, rezava, dormia e comia. Dentro do utilitarismo de Bentham, isto remetia a policrestia ou maximização do Panóptico que determinava a multiplicidade de usos para cada elemento (MILLER apud BENTHAM et al., 2008, p. 82). A cela possibilitaria a perfeita visualização do seu interior - a transparência almejada por Bentham. A mesma era permeável, transpassada pela luz, já que era fechada internamente com grades e vazada para o exterior da edificação. Foucault (1987, p. 163) se refere à prisão e à cela panópticas: “[...] espaço fechado, recortado, vigiado em todos os seus pontos, onde os indivíduos estão inseridos num lugar fixo, onde os menores movimentos são controlados".

A cela individual se enquadra no esquema disciplinar político-moral de Foucault (1987). Ela submetia o preso a um regime de solidão que era justificado como um mecanismo simultâneo de: regeneração "a solidão deve ser um instrumento positivo de reforma"; disciplina - "que a prisão não forme, a partir dos malfeitores que reúne, uma população homogênea e solidária"; e controle -“a solidão é a condição primeira da submissão total”. As relações eram proibidas e a comunicação ocorria apenas com funcionários. A cela é a síntese da minúcia panóptica na aplicação da tecnologia e no detalhamento exaustivo. Para Perrot (BENTHAM et al., 2008, p. 135), na organização da cela tudo está previsto e amplamente descrito. Miller (BENTHAM et al., 2008, p. 80) ilustra o esmero panóptico citando o sistema de evacuação de excrementos, ao qual Bentham dedica uma longa nota: "resta então, a inventar, a descrever com detalhe, o mecanismo, os materiais que deverão ser empregados".

\subsubsection{Organização do espaço}

Sendo o tema do utilitarismo de Bentham central na abordagem dos princípios propostos, é imperativo explicitar o perfil radical do filósofo nas questões penalógicas. Para Perrot (BENTHAM et al., 2008, p. 113 e 114), Bentham teria a vocação de um Newton de um mundo moral cujo epicentro é o lucro, e resume: "aqui está todo o liberalismo de Bentham: o do dinheiro". Para ele, o mal produzido pelas penas é uma despesa que o Estado faz com vistas a uma vantagem: a eliminação dos crimes. E o mesmo complementa: dizer "uma pena suave" significa associar idéias contraditórias, dizer "uma pena econômica" significa adotar o idioma do cálculo e da razão. Sobre isto, Perrot conclui (Idem, p. 120): "a esse respeito, à humanidade pouco importa a moral; o que importa é a eficácia ao menor custo".

O custo de construção era um fator predominante no projeto de Bentham, no qual eram considerados o valor do terreno que receberia o empreendimento, os materiais especificados, os dimensionamentos da edificação, o programa e os sistemas a serem inseridos, buscando sempre a melhor relação. Por exemplo, para terrenos mais caros sugeria edifícios com mais andares ou as dimensões do edifício eram determinadas pelos tamanhos das peças de madeira para a estrutura (sendo este, segundo Bentham, o material mais barato) (BENTHAM et al., 2008, p. 21-23). Outra preocupação era 
providenciar um número de vagas adequado ao investimento, sempre comparado à capacidade da prisão, tendo em vista um limite máximo para não comprometer a proposta pedagógica. Apesar disto, o Panopticon era uma edificação considerada cara para a época e gerava poucas vagas (entre 96 e 288), em parte devido ao uso da cela individual, em parte porque o filósofo acreditava que uma ampliação da capacidade implicaria na perda das propriedades do edifício. Isto dificultou a aceitação do modelo em um tempo onde um grande número de vagas já era demandado no sistema penitenciário - na ordem dos milhares. Neste sentido, o projeto de Bentham contribuiu mais por meio do panoptismo, o princípio da vigilância centralizada, capaz de reduzir o número de inspetores exigidos e os respectivos gastos com a operação do estabelecimento (BENTHAM et al., 2008, p. 26).

A forma do Panopticon se justifica por sua economia: de política, de pessoal, de deslocamentos, obtidas por meio, principalmente, da centralidade e da invisibilidade da vigilância ${ }^{29}$. O arranjo espacial do edifício condensava e homogeneizava o programa arquitetônico: no centro, a totalidade das atribuições institucionais e, na periferia, a rotina dos presos. A forma é o resultado da função: "a arquitetura propiciará os meios: toda prisão deve exibir sua função, sua aparência deve conformar-se à sua finalidade e mesmo, segundo o axioma utilitarista que já destaquei, exceder a realidade [30], (MILLER apud BENTHAM et al., 2008, p. 88). Neste sentido, Bentham explorou a relação entre espaço e forma derivada do jogo entre o controle real e a liberdade aparente (TRIGUEIROS, 2011).

Agostini (2002, p. 3) aponta os desdobramentos do arranjo formal: "instituir no ambiente prisional um diagrama assimétrico do poder" e a "despersonificação [do poder], pautado sobretudo pela busca do maior distanciamento físico possível entre presos e funcionários". Goffman (2005, p. 18) aborda estas preocupações, ao explicar a divisão básica existente nas Instituições Totais entre um grande grupo controlado e uma pequena equipe de supervisão. Neste sentido, o autor evidencia a grande distancia social que geralmente existe entre estes grupos e é frequentemente prescrita.

O utilitarismo de Bentham ditava que tudo deve ter efeito ou serventia. Além disto, para Miller (BENTHAM et al., 2008, p. 82), a todo sistema benthamiano se pode aplicar a policrestia: um instrumento de múltiplos usos. Todos os elementos devem acumular o máximo de funções, de modo a simplificar o sistema e torná-lo econômico. A cela panóptica exemplifica isto. Segundo Foucault, não se trata de deixar um lugar livre de destinação, mas de determinar as funções que acumulará. Este cuidado ele denomina de localizações funcionais: "lugares determinados se definem para satisfazer

\footnotetext{
${ }^{29}$ Miller (BENTHAM et al., 2008, p. 78) ressalta que "não é essencial que a forma do edifício seja circular [...]”, embora ela seja avaliada como a mais efetiva do ponto de vista da vigilância. A forma do edifício, inicialmente apenas circular, é flexibilizada devido a dificuldades com a comunicação e aproveitamento das áreas internas (PERROT apud BENTHAM et al., 2008, p. 134). Bentham, eventualmente, preconiza o polígono como sendo mais habitável ou se conforma com o semicírculo.

30 Miller ressalta a 'encenação utilitarista' que utiliza simbolismos arquitetônicos para construir uma imagem chocante ou aterrorizante da prisão com a finalidade de inibição do crime futuro e moralização do preso.
} 
não só a necessidade de vigiar, de romper as comunicações perigosas, mas também de criar um espaço útil" (FOUCAULT, 1987, p. 123).

Conforme o utilitarismo, as coisas são úteis mais ou menos umas para as outras em um encadeamento. Esta relatividade preconiza uma hierarquização em relação a um resultado, cujo benefício ou malefício pode ser calculado entre as diferentes soluções, buscando a melhor possível dentro de um balanço. Tudo deve estar baseado no cálculo de perdas e ganhos. Segundo Miller (BENTHAM et al., 2008, p. 80), "o Panóptico é então uma vasta máquina da qual cada elemento é por sua vez máquina, objeto de um cálculo". Isto é possível graças ao isolamento social do estabelecimento que conforma um espaço hermético, operando exclusivamente a partir de seus mecanismos internos, passíveis de uma ordenação lógica (AGOSTINI, 2002, p. 3).

O mecanismo analítico e ordenador do espaço é a disciplina. Mais uma vez, como condição inicial, a disciplina exige a especificação de um local heterogêneo a todos os outros e fechado em si mesmo. A partir disto, ela distribui e divide o espaço de forma rigorosa e calcada em critérios de eficiência e eficácia. Em termos gerais, ela preconiza uma divisão sistemática ou analítica do espaço no qual os indivíduos, as funções e os trânsitos serão distribuídos. Para tanto, a mesma utiliza diversas técnicas que convergem para uma tecnologia de poder denominada por Foucault de 'celular': o fracionamento do espaço e a consequente especialização e hierarquização de suas partes.

Segundo Foucault (1987, p. 137), a disciplina procede em primeiro lugar à distribuição dos indivíduos no espaço. Trata-se de uma tática de "ordenamento espacial dos homens" (FOUCAULT, 1987, p. 127). A partir do indivíduo são identificados os locais de permanência e a movimentação das pessoas.

Importa distribuir os indivíduos num espaço onde se possa isolá-los e localizá-los; mas também articular esta distribuição sobre um aparelho de produção que tem suas exigências próprias. É preciso ligar a distribuição dos corpos, a arrumação espacial do aparelho de produção e as diversas formas de atividade na distribuição dos "postos" (FOUCAULT, 1987, p. 124).

A disciplina organiza o espaço com base em uma classificação funcional. Miller (BENTHAM et al., 2008, p. 90) afirma: o utilitarista classifica. Esta classificação é o que permite a análise, encadeamento e hierarquização dos indivíduos, funções e trânsitos, distribuindo os usos e as pessoas e organizando uma rede de relações. Neste sentido, a classificação geral das pessoas obedece a uma partição global da vida prisional sugerida por Goffman em presos, funcionários e visitantes. Estes três grupos e suas inter-relações são a base da distribuição espacial. Quanto à classificação, Goffman explica que o grupo de presos é heterogêneo e sempre será, apesar de todas as forças exercidas pelos mecanismos de massificação e mortificação da Instituição Total. Por isso, a necessidade de classificação e distribuição das pessoas presas. Em primeiro lugar, para dosar com justiça as penas aos crimes mais ou menos graves. Em segundo lugar, para proporcionar o controle da comunicação interna, abafar motins, 
impedir a formação de cumplicidades, entre outros. Este pressuposto é tratado por Foucault quando expostas as bases do isolamento individual.

A classificação define o lugar que cada coisa ocupa e as relações existentes entre elas. Neste sentido, "deve haver um número certo de pessoas para que o sistema possa funcionar adequadamente, cada um organizadamente exercendo sua função" (BARKER apud CANTER, 1978). Foucault (1987, p. 138) associa este procedimento ao princípio da localização imediata ou quadriculamento:

Cada indivíduo em seu lugar; e em cada lugar, um indivíduo. Evitar as distribuições por grupos; decompor as implantações coletivas; analisar as pluralidades confusas, maciças ou fugidias. O espaço disciplinar tende a se dividir em tantas parcelas quanto corpos ou elementos há a repartir.

O espaço deve exaltar a classificação das pessoas por meio de divisões e subdivisões do edifício, agrupando ou fracionando, aproximando ou afastando (MILLER apud BENTHAM et al., 2008). Isto dentro de uma lógica: se separa para evitar a corrupção moral, para garantir a segurança, a salubridade e os "desejos insatisfazíveis" do sexo; e se junta para reunir famílias, proceder ao exame médico, à educação e à inspeção, assim como permitir o trabalho em comum. O criminoso deve ser contido na prisão, mas dentro dela a massa criminosa deve ser dividida. Neste sentido, a prisão é um espaço de coexistência compulsória da diferenças humanas, onde se administram as classes de pessoas, colocando-as cada uma em seu lugar.

A disciplina, ou o celular descrito por Foucault, tem a preocupação em estabelecer zoneamentos com diferentes níveis de acessibilidade, assim como a fragmentação do estabelecimento conforme as especializações das funções e atividades, além da disposição dos espaços segundo critérios de economia de circulação.

É importante ressaltar que a organização do espaço prisional deve permitir em determinadas situações, a inversão lógica de subdivisão da coletividade, já que esta interessante em alguns momentos pode ser prejudicial em outros. Dessa forma, o espaço prisional mostra-se igualmente eficiente quando é preciso decompor a coletividade ou reagrupá-la em um único local (AGOSTINI, 2002, p. 3).

O quadriculamento cria setores que hierarquizam as funções e atividades, por sua vez, já agrupadas em blocos funcionais especializados. O ordenamento espacial destes setores e blocos obedece à combinação de demandas de fluxo, de aglutinação e de rotina da unidade prisional, reproduzindo o aspecto mecanicista da Instituição Total. Esta decomposição do espaço interno distribui os indivíduos conforme o grupo que integram. Esta distribuição, segundo Goffman (2005), ordena os sucessivos lugares das diferentes representações no estabelecimento social, internas e externas, sobre os quais ocorre a distribuição do programa - a impermeabilidade tratada no capítulo 1.

Somados, ambos atributos - especialização funcional e setorização hierárquica - passam a contribuir decisivamente para a instauração no ambiente prisional de uma rotina planejada em todas as suas instâncias (AGOSTINI, 2002, p. 3). 
A circulação panóptica deve garantir a economia de deslocamento e dos recursos necessários para este procedimento. Esta atua também de modo hierárquico, interligando setores e circuitos locais nos blocos funcionais. A configuração acompanha o quadriculamento do espaço arquitetônico, permitindo o controle da mobilidade e acessibilidade das pessoas, segundo a sua classificação. $\mathrm{O}$ traçado, assim como a geometria geral do edifício, deve ser simples, facilitando a vigilância. A funcionalidade evita cruzamentos ou sobrecargas de fluxos. Para Bentham, a torre central do Panopticon possibilitava fluxos mais eficientes e eficazes, delimitando o contato entre funcionários e presos e marcando dois universos que não se misturavam ${ }^{31}$.

Em cada parte de seu projeto Bentham (2008) apontava cuidados com a iluminação e a ventilação, sempre associados à segurança, ao controle e à economia. A iluminação do espaço central era providenciada pela transparência das celas, cuja janela deveria ser suficientemente larga para iluminar a cela e produzir o efeito luminoso para a vigilância do inspetor na torre central. A cela vazada proporcionava ampla ventilação cruzada. Também era cogitado pelo autor um 'teto solar' na cobertura sobre a torre, que contribuiria com iluminação e ventilação e seria aberto ou fechado conforme a rotina da prisão. Os ambientes seriam aquecidos no inverno e os dutos utilizados para conduzir o calor das fornalhas igualmente atenderiam ao propósito de ventilação, não havendo desperdício de calor ou da corrente de ar. O esforço de Bentham residia na preservação útil dos corpos para o trabalho na prisão, evitando as infecções próprias da vida confinada, o que foi mais bem discutido pelo autor ao descrever a aplicação panóptica ao hospital. Por sua vez, a iluminação artificial noturna prolongava os efeitos de luz e sombra da edificação, preservando a segurança e o controle institucional durante todas as horas do dia. Inclusive a segurança externa, dando visibilidade das áreas adjacentes ao edifício para os guardas que poderiam constatar tentativas de fugas (TRIGUEIROS, 2011). Ao mesmo tempo, os holofotes estendiam a utilidade da pena, quando permitiam a realização das atividades dos presos no turno da noite.

O programa de uma prisão tende a ser completo, remetendo ao processo total do integralismo. Uma das características da Instituição Total (GOFFMAN, 2005). A prisão seria uma repetição da própria sociedade e das suas atividades, porém controlada "por um esquema burocrático, por um grupo de pessoas". Neste sentido, o Panopticon implementava uma maior concentração espacial das funções e atividades. Nele, o preso permanecia confinado em sua cela e nela acontecia a maior parte de suas atividades. Com esta concentração funcional é que Bentham parecia ter resolvido a questão do poder e do quadriculamento: o controle contínuo das pessoas, por meio da centralização da vigilância.

\footnotetext{
${ }^{31}$ O Panopticon apresentou dificuldade em resolver a comunicação interna: "ocorre que entre a torre e o anel periférico, as escadas (flutuantes, depois permanentes) se multiplicam e o espaço de Bentham torna-se o de Piranèse..." (PERROT apud BENTHAM et al., 2008, p. 134). Mais à frente, esta dificuldade se soma a outras questões de ocupação do espaço, reforçando a abertura de Bentham à outras formas geométricas além da circular para a planta panóptica.
} 
Foucault (1987, p. 256) afirma que uma das condições da "boa condição penitenciária" é a existência do trabalho do preso. $\mathrm{O}$ trabalho surgiu nos discursos reformadores como uma suavização com a qual a privação seria totalmente possível - "um remédio certo contra os desvios de sua imaginação (NT imaginação do preso)", referindo-se ao ócio e um meio de dar sentido à propriedade. Para Foucault, o trabalho extrapola esta finalidade para se enquadrar no Panóptico, no qual os "operários são ao mesmo tempo as engrenagens e os produtos”. Para Trigueiros (2011), Bentham transpunha a imagem da máquina para as pessoas, o que em alguma medida privava os presos da sua humanidade. Este é o objetivo do esquema disciplinar do modelo econômico da força aplicada a um trabalho obrigatório, descrito por Foucault. Segundo o Princípio da Utilidade: "toda atividade é analisável como um movimento, todo movimento constitui uma despesa, toda despesa deve ser produtiva” (MILLER apud BENTHAM et al., 2008, p. 81). No panóptico importa o rendimento do trabalho dos presos. Nenhuma subsistência, nenhuma força devia se perder. Era a maximização dos lucros. Como coloca Perrot (BENTHAM et al., 2008, p. 142), "Bentham oferece-nos uma síntese de disciplina e trabalho, de poder e produção, indissoluvelmente vinculados e, de certo modo, consubstanciais".

O espaço panóptico é baseado no axioma de que o indivíduo é produto das circunstâncias (MILLER apud BENTHAM et al., 2008, p. 79). Neste sentido, o controle das circunstâncias implica em um domínio das pessoas. Assim, na prisão todos os aspectos da vida devem ser analisados e prescritos, visando à transformação moral dos presos. Quanto a isto, Bentham compartilha o ideal de Robert Owen, socialista utópico contemporâneo que apontava o indivíduo como mecanismo sujeito ao ambiente, podendo ser treinado pela arquitetura (TRIGUEIROS, 2011). Assim sendo, no espaço arquitetônico, todos os elementos devem ser detalhados e localizados, estabelecendo uma relação causa e efeito entre os atos, gestos e fatos e a arquitetura. Adota-se o princípio do máximo, no qual cada objeto deve ser totalizado em um processo de decomposição, maximização e reconstituição para a sua generalização, o que Bentham denominou methodization. Mais uma vez, a cela panóptica é exemplo disto. Para Agostini (2002, p. 5), "na realidade, é exatamente através destes detalhados aparatos que todo um ideal de controle exaustivo do cotidiano se concretiza e se individualiza".

\subsubsection{Controle}

Para Foucault, a disciplina é o tema central da prisão e ele considera o Panóptico o paradigma de moderna instituição disciplinar. Isto porque o modelo atendia a duas exigências fundamentais: observar e registrar; e garantir a interiorização da individualidade disciplinar. No primeiro caso, tratase de um controle absoluto e detalhado da operação por meio da vigilância e da fiscalização, inclusive da fiscalização do desempenho do órgão pelo próprio órgão e do registro centralizado dos eventos, das pessoas, das coisas. Como sumariza Perrot (BENTHAM et al., 2008, p. 119): “[...] o Panóptico, fundamentado no princípio da inspeção central, da vigilância generalizada e de uma rigorosa 
disposição do espaço". No segundo caso, a vigilância panóptica materializou o princípio da inspeção: a instituição tinha visão absoluta do preso, mas este não era capaz de se certificar se era vigiado ou não. Isto porque esta verificação era impossível, devido ao arranjo espacial que negava a visualização aos presos.

Por isso Bentham colocou o princípio de que o poder deveria ser visível e inverificável. Visível: sem cessar o detento terá diante dos olhos a alta silhueta da torre central de onde é espionado. Inverificável: o detento nunca deve saber se está sendo observado; mas deve ter certeza de que sempre pode sê-lo. Para tornar indecidível a presença ou a ausência do vigia, para que os prisioneiros, de suas celas, não pudessem nem perceber uma sombra ou enxergar uma contraluz, previu Bentham, não só persianas nas janelas da sala central de vigia, mas, por dentro, separações que a cortam em ângulo reto e, para passar de um quarto a outro, não portas, mas biombos: pois a menor batida, uma luz entrevista, uma claridade numa abertura trairiam a presença do guardião (FOUCAULT, 1987, p. 191).

Disto, Foucault sugere o efeito mais importante do Panóptico: o efeito psicológico onde o preso se sente vigiado mesmo que não haja vigilância. A dúvida em cometer um ato reprovável pelo temor da punição correspondente torna o preso um disciplinador de si mesmo, um agente do poder. Assim, a interiorização da individualidade disciplinar é obtida. Com isto, o poder se alivia da necessidade de sua presença oniciente e incessante, pois é multiplicado pela incerteza da vantagem da conduta repreensível. Este princípio significa um aprimoramento, uma otimização do poder, uma economia.

Em suma, os dois princípios fundamentais da construção panóptica são a posição central da vigilância e sua invisibilidade. Com base no esquema panóptico, a prisão é uma casa de controle das rotinas em suas minúcias: "uma vigilância permanente, exaustiva, onipresente, capaz de tornar tudo visível, mas com a condição de se tornar ela mesma invisível" (FOUCAULT, 1987, p. 176).

A sala central de inspeção é o eixo do sistema. Sem o ponto central de inspeção, a vigilância deixa de ser assegurada, contínua e geral; pois é impossível ter inteira confiança na atividade, no zelo e na inteligência do preposto que vigia imediatamente as celas. (...) $\mathrm{O}$ arquiteto deve então colocar toda a sua atenção nesse objeto; há aí ao mesmo tempo uma questão de disciplina e de economia (FOUCAULT, 1987, p. 209).

A disposição espacial da torre de inspeção é uma questão de economia de pessoal, havendo uma exigência mínima de funcionários para vigiar as celas. Estas, por sua vez, favorecem a vigilância por sua uniformidade, garantida pela iluminação e pelo particionamento idênticos. A invisibilidade institucional também é uma questão de economia, pois, o número de funcionários pode ser reduzido na medida em que o efeito óptico se intensifica. Neste sentido, a forma circular se encaixa mais perfeitamente na disposição dos espaços, ou como coloca Trigueiros (2011, p. 39): “da visão nasce a legibilidade dos espaços. Esta exigência - comum a toda concepção arquitetônica - adquire no projeto de Bentham uma importância crucial. É ela que beneficia a qualidade da vigilância e favorece a inspeção".

A vigilância é constante, porém, desigual. O arranjo do Panopticon com a torre central no edifício circular que abriga as celas é a representação das relações de poder instituídas, a divisão básica 
descrita por Goffman. Não importa se a torre está ocupada pelos vigias, pois esta constatação é impossível, a presença da torre é suficiente como representação do poder (Figura 15). O edifício cilíndrico inteiro é o palco das representações institucionais.

O duplo cinturão, a pedra, a guarda, fecham esse espaço e asseguram situação estanque. Mas não é aí que está o mérito original da construção, que inteiramente na tópica interior. Essa tópica tem por função repartir o visível e o invisível (MILLER apud BENTHAM et al., 2008, p. 77).

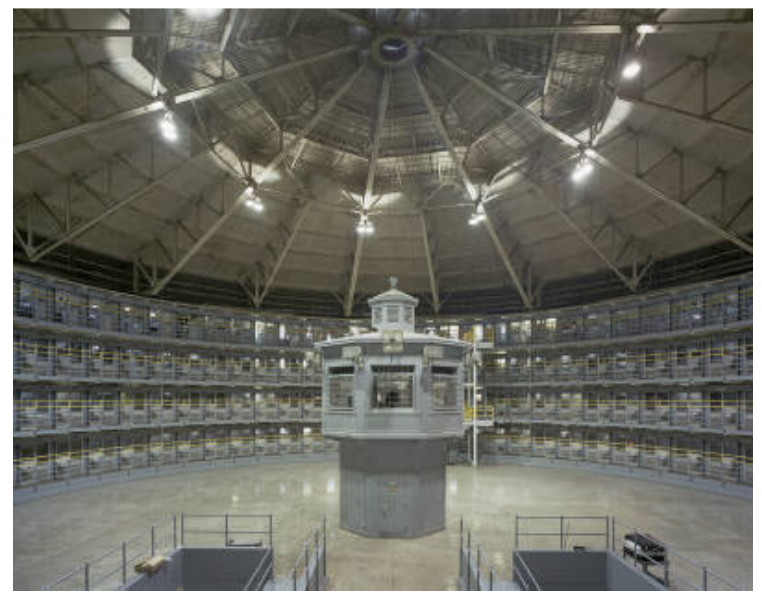

Figura 15 - Fotografia do espaço de vigilância panóptico da Stateville Penitentiary (EUA) (Disponível em: <www.articleslash.net>. Acessado em: fev. 2017)

A vigilância do Panóptico depende da percepção sensorial que o vigilante possui. O Panopticon é o resultado do alcance do raio de visualização e do tipo de informação acessada, sem interferências e condensadas para poucos vigias ${ }^{32}$. Estas informações decorrem da detecção de ruídos, odores e vibrações suspeitas que possam indicar atividades ou ocorrências que exijam a interferência do poder. Portanto, o ambiente destinado ao controle deve garantir a integridade do funcionário, porém sem isolá-lo do ambiente circundante.

\subsection{Mutabilidade do Panóptico}

A evolução do sistema penal impõe uma revisão das demandas projetuais inicialmente colocadas pelo esquema teórico benthaminiano, ao alterar as condições de aplicação do Panóptico. Como coloca Esteca (2010, p. 47), "há de se considerar a aplicabilidade do trabalho de Bentham, elaborado no século XVIII, ante as mudanças ocorridas no modelo jurídico-penal moderno, em especial com a introdução de novas terapias e o respeito à condição humana do preso".

\footnotetext{
32 Apesar do esforço de Bentham, o Panopticon não permitia uma inspeção completa e constante dos presos, assim como, a comunicação entre funcionários e presos não funcionava corretamente. No primeiro caso, a plena visualização dos espaços pelo guarda na torre central não se confirmou na realidade (pontos cegos) (GARCíA BASALO, 1959, p. 94). No segundo caso, Bentham pretendia uma vigilância acústica similar à visual, por meio de dutos de conversação entre a torre central e as celas, porém na prática este mecanismo denunciava os funcionários, cujas conversas podiam ser ouvidas pelos presos em suas celas. Assim, os tubos foram suprimidos do projeto que continuou a ser essencialmente um sistema visual (TRIGUEIROS, 2011).
} 
Houve um tempo em que o panóptico de Jeremy Bentham significava a prisão perfeita, marcada pela utilidade da pena, pelo baixo custo de gerenciamento e pela ideia de controle total sobre o preso. Os tempos agora são outros. O homem mudou (SILVA, 2008).

O plano panóptico subentendia uma condição penalógica que era providenciada pela Ciência das Prisões, mas que se tornou adversa diante da evolução do pensamento penalógico e das técnicas penitenciárias. Em uma perspectiva histórica do modelo prisional e da sua relação com a edificação, as mudanças na aplicação da pena implicaram em revisões dos princípios essenciais do modelo de Bentham: a cela individual e o programa centralizado, condensado e homogeneizado. Duas causas destas revisões podem ser identificadas: a humanização da pena e o ganho econômico ou utilitário associado às mudanças implementadas (ver capítulo 1).

Na história da prisão moderna, o modelo de isolamento individual do Panóptico se mostrou pretensioso. Na transição dos séculos XVIII e XIX, os estabelecimentos norte-americanos já haviam experimentado o solitary confinement e o silent system $^{33}$ e colocado em questão sua viabilidade, pois o "isolamento absoluto foi desde logo apontado como modalidade de punição cruel" (CARVALHO FILHO, 2002, p. 26). Em obras posteriores como The Rationale of Punishment, Bentham abandona a idéia inicial: as celas deveriam alojar três ou quatro presos, porque as relações sociais contribuiriam para a reeducação do preso (ALGARRA, 2007). Goffman também afirma a impossibilidade prática do isolamento panóptico por dois motivos. Primeiro, o objetivo recuperativo da instituição penal determina a assistência aos presos, ou seja, os padrões humanitários que estabelecem o contato entre os agentes da recuperação e os presos. Segundo, o isolamento é burlado por táticas informais que aproximam funcionários e presos, além de outras que montam redes de comunicação e impedem o isolamento absoluto dos presos. Em um exemplo disto, a Penitenciária de São Paulo (1920) sustentou a regra do silêncio sem sucesso. Conforme relatório de dirigentes, os presos se comunicavam por "sinais convencionais" e pelos "tubos dos aparelhos sanitários que têm comunicação com as celas vizinhas" (SALLA, 1999, p. 216). No final do século XIX, a cela individual estaria desacreditada pela crueldade da disciplina, pela corrupção dos vigilantes, pelos elevados custos de construção e manutenção e pela crescente população carcerária, "situação de fato que afetou muitos países" (GARCÍA BASALO, 1959, p. 94). Atualmente, o isolamento solitário se configura muito mais como sansão para as faltas disciplinares, o que demonstra o caráter punitivo do mesmo.

No esquema disciplinar panóptico, o fim da pena individual implica em um aumento do esforço institucional como compensação a uma presumida redução da eficácia e da eficiência do penitenciário descrito por Foucault. A estrutura do poder necessária para manter a ordem se dilata, pois as atividades

\footnotetext{
${ }^{33}$ A técnica da Filadélfia pregava o isolamento absoluto: as únicas operações da correção são a consciência e a arquitetura muda contra a qual ela esbarra (FOUCAULT, 1987, p. 224 e 225). A técnica penitenciária de Auburn prescrevia a cela individual durante a noite e o trabalho e as refeições em comum, mas, sob a regra do silêncio absoluto, os detentos só podendo falar com os guardas, com a permissão destes e em voz baixa.
} 
programadas na cela foram distribuídas pelo edifício penitenciário: oficinas, refeitórios, salas para o culto, além de circulações entre estes locais ${ }^{34}$. Na sua revisão do isolamento individual, Bentham conclui que a coletivização da cela compensaria em alguma medida esta perda de eficiência, por um incremento da autodisciplina dos presos que se fiscalizariam mutuamente dentro da cela (TRIGUEIROS, 2011).

Com a sucessão da Ciência Penitenciária e do Direito Penitenciário ${ }^{35}$, o programa se tornou mais abrangente e complexo, não apenas pela substituição da cela individual, mas devido ao surgimento de novas atividades exigidas pelo assistencialismo aos presos, novamente, criando outros espaços e fluxos. Esta descentralização do programa representou um movimento do espaço estático, individualizante e multifuncional para o espaço dinâmico, coletivo e especializado. Além destes fatores de ordem humanitária, se soma ao programa a reconfiguração de conceitos penalógicos e arquitetônicos imposta pela lógica econômica que remete a uma coletivização com aumento de capacidade da prisão que, por vezes, caracteriza a aglomeração excessiva de presos. Em particular, a conotação produtiva do trabalho foi substituída por ocupação do tempo, sem qualquer propósito de lucro ou formação profissional - a laborterapia. Como coloca Foucault (p. 230), "a utilidade do trabalho penal? Não é o lucro; nem mesmo a formação de uma habilidade útil; mas a constituição de uma relação de poder, de uma forma econômica vazia [...]”. Sobre isto, Goffman (2005, p. 22) aponta uma incompatibilidade do trabalho com a condição do preso.

As revisões na composição espacial da edificação prisional implicaram em reformulações significativas do princípio de vigilância panóptico. Isto já no advento do padrão arquitetônico radial, conforme coloca Perrot (BENTHAM et al., 2008, p. 136):

\begin{abstract}
Mas está bem claro que o próprio desenvolvimento desses planos radiais tornava ilusória a vigilância desmultiplicada, colocando de novo toda a questão do poder e do enquadramento que Bentham havia se proposta a corrigir. Ele já não se reconhecia na enorme máquina de Millbank, com seus pentágonos ramificados em hexágono que abrigava o inspetor, sem que o capelão e os empregados tivessem mais do que um acesso descontínuo aos cinco pátios das celas inferiores.
\end{abstract}

Perrot (BENTHAM et al., 2008, p. 136) avança destacando o padrão paralelo de Fresnes ${ }^{36}$ : "Ruptura completa com o panoptismo [grifo nosso], ele distribui os blocos perpendicularmente a um corredor,

\footnotetext{
34 No modelo panóptico, o trabalho era realizado na cela, enquanto outros sistemas, como o filadélfico e o de auburniano, já previam espaços específicos para o trabalho e as refeições fora das alas carcerárias.

35 Na Ciência Penitenciária, a fundamentação positivista sugeria a diversificação de celas (individuais e coletivas) e introduzia no programa arquitetônico locais específicos para o tratamento penal: classificação de presos, trabalho, educação, recreação, assistência espiritual, médica e psiquiátrica, relações e serviços sociais. Economicamente, a classificação implicava na economia de recursos, pois possibilitava a construção e operação de estabelecimentos penais mais abertos, com menos preocupação com a segurança e, portanto, mais baratos. No Direito Penitenciário, a edificação penal foi encarada como uma organização funcional. O programa foi desmembrado em módulos operacionalmente independentes que permitia um controle mais rígido e direto da instituição sobre os presos: os agentes ficavam protegidos e os presos poderiam ser classificados e separados dentro do estabelecimento.

${ }^{36}$ Neste caso, a autora poderia ter mencionado o padrão de blocos laterais como exemplo desta ruptura, sendo este antecessor ao padrão arquitetônico paralelo francês.
} 
de onde se efetua a vigilância individual das celas" . Neste sentido, de uma forma geral, os padrões arquitetônicos desenvolvidos no século XIX, tais como o radial, o de blocos laterais e o paralelo romperam com o princípio do panoptismo, sendo caracterizados pela vigilância indireta plena.

Em contrapartida à vigilância indireta plena, o padrão arquitetônico modular instituiu a vigilância direta, o que permitiu o monitoramento de todo o espaço coletivo. Este arranjo resgatou, em parte, o princípio da inspeção, especialmente a centralidade, do panoptismo. Por outro lado, concomitantemente à coletivização das celas, observa-se a perda da visibilidade do espaço celular. A grade da cela do Panopticon que permitia a visão do seu interior pelo vigia foi substituída pela porta vedada e pela parede. Em muitos casos este fechamento foi justificado como respeito à privacidade dos presos. Do ponto de vista penalógico, o encerramento da cela representou um retorno à masmorra, com uma ressalva: nesta os presos eram escondidos pela instituição, na cela moderna os presos se escondem da instituição (FOUCAULT, 1987, p. 190).

Com o replanejamento da organização espacial da prisão, o controle central panóptico foi decomposto em diversos postos, de modo a possibilitar o controle de todas as atividades e fluxos instituídos no desenvolvimento penalógico, com efeitos colaterais ao esquema panóptico. O primeiro deles é o potencial enfraquecimento da divisão de poder entre funcionários e presos na medida em que agente institucional se torna não fiscalizado, estando isolado em postos desvinculados da administração do estabelecimento. Daí a autonomia destes funcionários pode representar uma transferência de poder dentro da hierarquia da equipe dirigente. Esta autonomia não fiscalizada juntamente com o convívio prolongado com a população prisional facilita a cumplicidade entre funcionários e presos ou os abusos de autoridade. Outro efeito colateral é a maior demanda de funcionários: uma questão operacional ligada à disposição de recursos e que afeta a proposta de economia do Panóptico. Neste sentido, a criação de postos excessivos pode comprometer a segurança penitenciária de um estabelecimento, ao ocasionar áreas sem vigilância pela ausência do vigilante.

No que seria uma terceira etapa da evolução da vigilância, Perrot aponta a aplicação da tecnologia eletrônica das câmeras, dissociando o poder de controle da forma arquitetural: "o enfraquecimento do poder é consequência de sua diluição cibernética” (BENTHAM et al., 2008, p. 136). A polarização do programa em torno do posto de controle ou mesmo a existência do mesmo passa a ser questionada, sendo substituída pela rede de câmeras de vigilância que reproduzem o efeito panóptico da interiorização da individualidade disciplinar (TRIGUEIROS, 2011). Porém, como coloca Webster (1974, p. 220): "não há engenho eletrônico hoje no mercado que substitua o homem em nenhum tipo de instituição". Afirmação ainda válida, tendo em vista as particularidades da atividade prisional. Por exemplo, o controle não se limita a visualização, mas se estende aos outros sentidos, como ressaltou Bentham. A proximidade do vigia é imprescindível, dada a exigência da sua intervenção imediata 
junto a uma indisciplina qualquer, para que a medida corretiva tenha o devido efeito. Em que pese ainda a capacidade da instituição de manter e modernizar o sistema eletrônico, havendo o risco de perda ou obsolescência da informação gerada.

O isolamento social foi o único quesito panóptico que não sofreu alterações ao longo da história da prisão: "Parece-nos que, ao menos historicamente, uma das grandes primeiras preocupações, nos projetos de edificação carcerária, é a construção de 'barreiras', barreiras grandes e fortes, que, num ato de interposição violenta, separam o interno do meio social de onde veio" (SÁ, 1990, p. 252). Todavia, a transparência pretendida por Bentham nunca se concretizou, seja pelo antagonismo social à prisão ou pela natureza totalitária da instituição. Como coloca Trigueiros (2011, p. 57): "Bentham estava perante o futuro, mas a sua idéia de acesso livre do público ao espetáculo prisional não teria lugar na teoria ou na prática da Penalogia Moderna". O fechamento adotado nos edifícios penais se alinhou com a Instituição Total de Goffman, que defende a impermeabilidade como condição para o funcionamento do estabelecimento penal. Deste modo, o controle democrático da instituição pretendido por Bentham foi subvertido em favor da impermeabilidade do estabelecimento penal, para a qual o modelo panóptico é aplicado para a exclusividade do poder nas mãos da administração. Isto caracteriza a arquitetura fechada e pesada típica dos estabelecimentos penais - a 'arquitetura de fortaleza' citada por Foucault. Para Trigueiros (2011, p. 57): "nos séculos XIX e XX as penitenciárias acabaram por se tornar geralmente eficientes tanto para fechar o inquiridor do lado de fora, como para fechar lá dentro os prisioneiros".

Com base na perspectiva da representação teatral trabalhada por Goffman, o isolamento social é definido pela permeabilidade da prisão. Neste sentido, ao propor a participação da sociedade na vigilância prisional, a democratização da prisão sugerida por Bentham internalizava as representações institucionais: a torre de inspeção era a platéia e as celas o palco. O fechamento da prisão como condição do sistema penitenciário retirou esta encenação das áreas internas da prisão, enfatizando um terceiro elemento nestes locais: os bastidores. Neste novo esquema, a dissolução do posto de vigia central oferece ao visitante um percurso, e não mais uma permanência, já que determina o deslocamento pelas dependências penitenciárias. Como efeito colateral, a visita compromete a segurança interna e a operação com o risco de comprometimento da integridade física dos visitantes e de exposição da rotina interna. Neste sentido, o distanciamento dos bastidores e da platéia é o que possibilita a representação institucional.

A evolução da prisão descrita inicialmente com o Panóptico e em seguida pela sua descaracterização termina por enfatizar a segurança penitenciária. Ao se tentar humanizar a pena e viabilizar economicamente o empreendimento penal, se observa o efeito inverso, na arquitetura "pesada" das prisões. As diretrizes panópticas foram substituídas por uma superposição de mecanismos de 
segurança, um esquema de "caixas dentro de caixas" para se efetivar o controle e a disciplina. $\mathrm{Na}$ rotina dos presos, isto significa a intensificação de alguns processos de mortificação.

\subsection{Conclusão analítica}

Sobre a atualidade do Panóptico, surgem questões referentes à evolução da própria organização social, principalmente quanto ao progresso econômico e tecnológico do último século, em particular com o advento da Tecnologia da Informação. Como sublinha Zimmer (2009, p. 32), "a sociedade que viu nascer o Panóptico e na qual Foucault produziu sua obra não é mais a mesma". Hoje, a sociedade disciplinar coexiste com a sociedade de controle, na qual uma nova tecnologia de poder se instala para o controle social, baseada na desconstrução das instituições totais, substituídas pela sutileza de uma rede de dados (HARDT e NEGRI, 2005, apud ZIMMER, 2009). Este refinamento da disciplina social recai não mais sobre a figura identificada, posicionada e massificada, devidamente observada e examinada de um ponto fixo, mas sobre um indivíduo dinâmico, cujo movimento é constantemente rastreado de qualquer lugar (MUNRO, 2000, apud ZIMMER, 2009). A maior novidade então é a eliminação da territorialidade (BAUMAN, 2001 apud ZIMMER, 2009): a mobilidade espacial das pessoas é substituída por uma mobilidade virtual, viabilizada pelo acesso à informação.

Da evolução do Panóptico emerge o Sinóptico que inverte a lógica da vigilância, na qual muitos passam a observar poucos, o que aponta para o controle horizontal: o monitoramento de um grupo de pessoas por ele mesmo (MATHIESSEN, 1997). Diante desta nova forma de exercer o poder, em um primeiro momento, se proclama o inevitável encerramento do Panóptico e se imputa à prisão a adoção de soluções eletrônicas para o controle: "A tela de vídeo é a torre; a luz, que no esquema original, entrava pelas aberturas ou janelas das celas, é substituída pelos procedimentos de entrada de dados" (ZIMMER, 2009, p. 33). O conceito da The Creative Prison (RIDEOUT, 2006) traz isto ao limite, ao assentar fortemente as soluções de segurança penitenciária na tecnologia eletrônica: câmeras, abertura remota de portas, identificação de pessoas (tags) e sensores de calor. Sobre isto, considerações em dois planos precisam ser feitas.

No plano geral, a organização em rede aceita o convívio com o controle disciplinar: "talvez o que ocorra, ao invés desta passagem de uma forma de sociedade para outra, seja a convivência de recursos disciplinares com outros mecanismos de poder [...]” (ZIMMER, 2009, p. 39). Neste sentido, se verifica esta sobreposição em conceitos como o 'panóptico da informação' e o ‘superpanóptico', nos quais os princípios panópticos recebem ou participam ativamente de mecanismos eletrônicos de observação e exame, muitas vezes, ditando o formato destes (BAUMAN, 2001 apud ZIMMER, 2009).

No plano mais estrito, a transposição da disciplina da informação para o modelo prisional, como ocorreu com a disciplina de controle, parece improvável diante da incompatibilidade entre estes. Em 
primeiro lugar, o Sinóptico carrega consigo o pré-requisito da espontaneidade das pessoas no fornecimento de informações para abastecer os bancos de dados (POSTER, 2004 apud ZIMMER, 2009 , p. 35). Esta estratégia, subliminar no âmbito do controle social, se torna explicita e impositiva na atividade prisional, portanto adere ao jogo de forças entre a instituição e os presos. E nesta disputa sempre existe uma resistência dos presos ao poder (FOUCAULT, p. 105 e 106). Assim, a prisão se mantém antagônica ao Sinóptico. Em segundo lugar, a comunicação horizontal entre os presos é indesejada, particularmente em unidades prisionais de maior segurança. Já o controle no estrato operacional e no sentido vertical pode interessar à instituição, em termos da confirmação da estrutura de poder interna. Para Zuboff (1988 apud ZIMMER, 2009, p. 33), o grupo gerencial tem seu poder aumentado com a Tecnologia da Informação, enquanto o grupo subalterno tem seu poder diminuído.

A contribuição mais expressiva do Sinóptico para a composição arquitetônica da prisão já foi antecipada pelo padrão arquitetônico modular - a desconstrução espacial através da dispersão das pessoas e dos lugares. O impacto do Sinóptico se restringiu ao controle de acesso ou à localização de pessoas na prisão, como o observado nos projetos conceituais ingleses (MUIR, 2010; RIDEOUT, 2006a). Contudo, a implantação de equipamentos ligados a uma intranet ou a identificação digital de pessoas são vistas com reserva pela administração penitenciária no Brasil, mediante as inconformidades do sistema penal (depredações e falta de manutenção). Deste modo, o Sinóptico não representa uma alternativa imediata ao Panóptico, em especial, para a arquitetura nacional.

O panóptico de Bentham constitui, ainda hoje, dois séculos após a revolução industrial, um paradigma do sentido da arquitetura ao serviço da moral, substituindo-se ainda hoje pelas novas tecnologias da vigilância eletrônica, resultante do processo onde o consumo tecnológico impera sem Arquitetura (TRIGUEIROS, 2011, p. 20).

O Panóptico mesmo em outros tempos e sob outras formas (em especial, mediado pela Tecnologia da Informação), continua sendo válido e atual, por sua onipresença mediada pela Tecnologia da Informação, por sua capacidade de vigilância permanente ( 24 horas, sete dias por semana), por ser instrumento de normalização e sanção, permanecendo como elemento central nos estudos sobre vigilância eletrônica (ZIMMER, 2009, resumo).

Em uma segunda abordagem da atualidade do Panóptico, a evolução da penalogia descrita por uma humanização da pena privativa de liberdade oferece um contraponto ao Panóptico, ao ter produzido mudanças no paradigma arquitetônico da prisão (ver capítulo 1). Na essência das transformações ocorridas, o fim do isolamento celular e o incremento da assistência aos presos dispersaram as atividades penitenciárias pelo corpo do edifício, em locais multifuncionais e coletivos. Assim como, o controle central panóptico foi fragmentado em postos setoriais e o princípio da inspeção foi diluído ou suprimido (devido ao fechamento parcial ou total da cela à vigilância). Estas alterações inviabilizaram o Panopticon como modelo arquitetônico de prisão, no qual "cada um em seu lugar, está bem trancado em sua cela de onde é visto de frente pelo vigia" (FOUCAULT, 1987, p.166). A reprodução aproximada do desenho original tornou-se restrita a casos excepcionais, em unidades prisionais de maior segurança. A inviabilidade do desenho de Bentham foi ressaltada pelo arquiteto Rem Koolhaas 
(KOOLHAAS, 1998) no projeto de revitalização da prisão panóptica de Koepel em Arnhem (2001, Holanda). Neste projeto, o arquiteto apontou o uso desvirtuado da torre central, o fim do isolamento celular e o surgimento de um conglomerado caótico em torno do edifício circular (KOOLHAAS, 1998).

Em relação ao conjunto teórico panóptico, as revisões do paradigma arquitetônico implicaram na redução da otimização do poder e da economia dos recursos vislumbrados por Bentham, associada à desconstrução do esquema disciplinar do espaço panóptico. O poder exercido de modo fragmentado exige um esforço maior para a coesão da atuação institucional, em termos da atuação da equipe dirigente e da fiscalização dos funcionários pela administração da prisão. A dispersão das atividades demanda mais áreas em serem construídas e tarefas para a equipe dirigente, tais como, a vigilância e revista dos locais e a condução de presos e visitantes. Por outro lado, a concepção doa edifício penal continua obedecendo aos princípios panópticos (a disciplina, a classificação, o quadriculamento, o celular e o princípio do máximo), dentro da perspectiva de um modelo generalizável de funcionamento disciplinar. Isto porque a organização espacial da prisão continua sendo definida pela disciplina, especialmente pela disposição dos indivíduos no espaço (MARKUS apud SPENS, 1994, p. 15). Em particular, as atribuições panópticas permanecem para o esquema de segurança, consumadas atualmente na vigilância direta da segunda geração de estabelecimentos penais: a separação física entre funcionários e presos, a centralidade setorial dos postos e, em cada posto, o monitoramento máximo e a inverificabilidade do poder institucional.

Conceitualmente, a questão da humanização da pena remete à crítica existente ao mecanicismo do Panóptico. O utilitarismo panóptico é questionado em sua essência ao propor uma máquina artificial absoluta, causal e encadeada, porém considerada insustentável diante da natureza, de característica relativa, casual e fracionada em si: "o paradoxo que corrói o discurso utilitarista é, muito simplesmente, que do relativo por essência - o útil - ele faz seu absoluto" (MILLER apud BENTHAM et al., 2008, p. 97). Nas palavras de Trigueiros (2011, p. 47), "a tecnologia proposta por Bentham não era apenas um auxílio à moralidade - era uma condição prévia necessária à própria moralidade que criava”. Na prisão, a lógica analítica infinita de Bentham esbarra no caráter humano da atividade prisional. A pragmática desabona qualquer intenção panóptica de reforma moral do preso por meio unicamente de artifícios mecânicos, sem uma proximidade entre a instituição e os internos (MARQUET-VASSELOT, 1838, apud PERROT).

Diante das considerações apresentadas, a aplicação teórico-metodológico do Panóptico é condicionada pela inserção de valores humanos nos princípios e no programa arquitetônico, de maneira que o conceito de disciplina-sistema preceda a disciplina-máquina e o respeito à condição humana na prisão permeie a segurança penitenciária, em suma, a boa condição penitenciária. O ajuste do Panóptico 
culmina em uma nova espacialidade, na qual as novas exigências da execução penal são assentadas sobre os princípios originais. Um exemplo disto é o projeto de reforma da Prisão Koepel, sobre o qual Koolhaas lista uma série de providencias para uma revisão do modelo panóptico: a extinção da torre central de vigilância e a absorção do modelo de segurança existente; a adição das instalações adjacentes (ao bloco circular, desvinculadas da forma central); a criação de espaços coletivos (para eliminar as limitações do confinamento solitário); a flexibilização para programas futuros; e a identificação e exploração dos potenciais da prisão.

Agostini analisou o projeto da Prisão Koepel e concluiu que o mesmo é um híbrido entre o antigo e o moderno, congregando em um mesmo espaço tudo o que se relaciona tanto ao positivismo de Benthan quanto ao seu oposto (AGOSTINI, 2001, p. 79). Neste sentido, o projeto plasmou o relaxamento da autoridade central, assim como, a coletivização dos espaços para o convívio entre os presos. O que, segundo Agostini é a maior conquista do mesmo: um novo equilíbrio entre a punição e a recuperação previstas na execução penal. Este reequilíbrio significa uma relativização do utilitarismo absoluto preconizado por Bentham, cuja flexibilização admite o caráter mutável e humano da pena, conciliando, em alguma medida, a máquina artificial panóptica e o caráter natural ou humano da atividade.

Este novo equilíbrio da execução da pena remete à distribuição do poder na prisão, havendo uma redivisão deste poder entre funcionários e presos, assim como, a redefinição dos respectivos domínios territoriais - o que demonstra que a divisão do poder passa a ser o objeto da arquitetura penal. Para estas delimitações, ocorre uma recuperação de recursos panópticos ligados ao sistema de segurança, justamente por compensar a perda de eficiência do esquema de segurança, decorrente da humanização do espaço arquitetônico da prisão. Esta compensação implica em incremento do nível de segurança, por meio de partido arquitetônico compacto e do programa reduzido. Alguns autores ressaltam outras propriedades panópticas apropriadas para um melhor rendimento do aparato penal. Perrot (BENTHAM et al., 2008, p. 135) afirma que, para a maioria dos arquitetos, a preocupação funcional e a minúcia são as duas contribuições essenciais de Bentham. Agostini (2002) destaca a importância do isolamento, setorização hierárquica, atomização e caracterização dos espaços, além da vivência artificial do tempo, tecnologia, detalhamento exaustivo e a vigilância e despersonificação do poder. Basalo (1959) pontua os elementos panópticos que devem ser perpetuados, independentemente do modelo arquitetônico: o princípio da vigilância; o minucioso mecanismo de segurança; a cela coletiva; a visibilidade do interior da cela; e o princípio moral dos presos.

A abordagem dos mecanismos de controle e das demandas penalógicas para a arquitetura aponta para a atualidade do Panóptico, enquanto modelo generalizável de funcionamento disciplinar para a prisão, ao figurar como tecnologia de poder compatível com o modelo prisional vigente, assim como, passível 
de ajuste à exigência de humanização da pena. A aplicabilidade do Panóptico se justifica principalmente em sistemas penais que utilizam mais intensamente a disciplina nos princípios de funcionamento da prisão, o que se identifica no caso brasileiro (ver capítulo 3).

Em um ordenamento mais amplo é possível conjecturar sobre a obsolescência do Panóptico, a partir da sua origem e vinculação com a pena privativa de liberdade. Segundo Werret (BENTHAM et al., 2008, p. 154), para os estudiosos dos temas históricos e políticos, Bentham ajudou na constituição do mecanismo de controle social instaurado com o advento do Estado Moderno Liberal. O controle social disciplinar se refletiu na definição do espaço na escala urbana e nas instituições que materializavam a preocupação da burguesia na organização da sociedade: "todos os lugares onde acontecer a vida cotidiana são organizados e distribuídos 'funcionalmente'” (TRIGUEIROS, 2011, p. 96). Assim como, Bentham fez parte da elaboração do pensamento da Reforma Jurídico-Penal, cujo trabalho na área prisional refletiu os princípios reformistas em termos arquitetônicos - o Panopticon. O Panopticon foi o primeiro exemplo da arquitetura funcional que concordou a forma e a função: o pensamento iluminista representado como edifício, não apenas a representação de idéias. Neste sentido, a vinculação entre a pena moderna e o Panóptico é visceral: o primeiro ditando os princípios de funcionamento da prisão e o segundo atribuindo uma forma arquitetônica. Por sua vez, o paradigma prisional permaneceu inalterado em sua essência desde a Reforma Jurídico-Penal: a prisão continua por definição uma instituição total, o que justifica a consequente manutenção do Panóptico. Da mesma maneira, esta vinculação indica uma superação do Panóptico associada a transformações sociais capazes de rever o modelo punitivo, em particular, o encarceramento.

O Panóptico se mostra atraente ao sistema penitenciário, ao enfatizar a segurança e a economia, inclusive no caso do sistema penitenciário nacional (ver capítulo 4, desta tese). Ao mesmo tempo em que o Panóptico é evidenciado como referência científica, o que remete ao trabalho de Foucault. Como assinala Perrot (BENTHAM et al., 2008, p. 117): "Grandiosa abertura de toda uma literatura totalitária, o Panóptico é um grande texto político, sobre o qual Michel Foucault assinalou a importância: não se poderia fazer melhor”. Para Perrot (BENTHAM et al., 2008, p. 136), o Panóptico é "um dispositivo funcional que deve melhorar o exercício do poder tornando-o mais rápido, mais leve, mais eficaz, um desenho das coerções sutis para uma sociedade que está por vir" (FOUCAULT, 1987, p. 198). A política panóptica define a simplicidade como a sua maior qualidade, abrindo caminho para a economia e a eficácia do modelo: "Bentham se maravilhava de que as instituições panópticas pudessem ser tão leves [...] fim das grades, fim das correntes, fim das fechaduras pesadas: basta que as separações sejam nítidas e as aberturas bem distribuídas” (FOUCAULT, 1987, p. 167). 


\title{
Capítulo 3 - Modelo prisional
}

\begin{abstract}
Neste capítulo são levantadas as características formais para a composição do espaço arquitetônico penal, a partir do exame dos instrumentos legais e técnico-normativos vigentes, apresentados logo no início da seção. Deste levantamento são feitas considerações quanto à aplicabilidade das diretrizes e parâmetros encontrados, assim como, das características morfológicas resultantes. Isto em comparação a outros modelos prisionais e ao Panóptico. Por fim, instrumentos similares ou correlatos foram sondados para garantir a consistência do conteúdo gerado e auxiliar na conformação da tecnologia de projeto. Este capítulo é complementado pelo Apêndice B, desta tese.
\end{abstract}

O ordenamento jurídico brasileiro é adepto da Teoria Mista do Direito que, simultaneamente, adere a Teoria Absoluta (ou retributiva) e a Teoria Relativa (ou preventiva). Para a Teoria Absoluta, a pena é um castigo e uma consequência pelo crime realizado e, por aplicar as sanções previstas na legislação, é considerada uma forma de fazer justiça. Já a Teoria Relativa têm por objetivo a prevenção de novos delitos e subdivide-se em Geral e Especial. A primeira está direcionada aos cidadãos em geral, enquanto a segunda visa apenas o delinquente. A Teoria Especial possui uma vertente positiva, que persegue a reinserção social do delinquente, e outra negativa que busca a segregação do mesmo com o fim de neutralizar uma possível nova ação delitiva.

Em atendimento a natureza dual da Teoria Mista, a prisão acumula duas funções: segregar o condenado e prepará-lo para o retorno social, o que caracteriza a prisão como uma atividade de segurança e social. A segurança exige um aparato para garantir a permanência compulsória e controlada dos presos no estabelecimento, preservando as relações de poder, a imagem institucional e a integridade dos funcionários. Esta função remete a uma interpretação econômica da prisão, suscitando o funcionamento utilitarista de Jeremy Bentham. A função social exige uma estrutura voltada para o assistencialismo do Estado e para o programa de benefícios aos presos, que remete à prisão enquanto atividade humana, cuja matéria prima e produto é a pessoa presa.

O Direito Penitenciário no País têm sido fundamentado nas convenções, nos tratados e nas regras internacionais de que o país é signatário, dentro de um reconhecimento internacional do regime dos direitos humanos que Governo brasileiro tem ratificado. Em 1994, o CNPCP publicou as Regras Mínimas para o Tratamento do Preso no Brasil (Resolução $n^{\circ}$ 8) em atendimento à determinação da Organização das Nações Unidas (Resolução $n^{\circ}$ 2.858/1971) para a adoção da norma internacional homônima de 1955. As Regras Mínimas estabelecem no seu artigo $1^{\circ}$ a obediência à Declaração Universal dos Direitos do Homem, assim como aos instrumentos internacionais. 
A implementação do Direito Penitenciário brasileiro ocorreu com um atraso de cerca de cinquenta anos em relação ao cenário internacional ${ }^{37}$, com o Código Penitenciário sendo promulgado no ano de 1984: a Lei de Execução Penal (LEP- Lei n $7.210 / 1984$ e alterações subsequentes). A LEP encerrou um debate sobre a condição da pessoa presa iniciado nos anos 1970, em fins da ditadura militar. Com ela, o preso deixou de ser visto como objeto na execução penal, sendo reconhecida a humanidade deste, ao estabelecer no artigo $3^{\circ}$ que "é assegurado ao preso o respeito à sua individualidade, integridade física e dignidade pessoal". Este status hoje é inalienável, estando firmado na Constituição Federal que, em 1988, concluía a regulamentação da execução penal com diversos dispositivos para a proteção dos direitos dos presos: os mesmos de qualquer cidadão, exceto os atingidos pela sentença (o direito de ir e vir e de votar). De acordo com o artigo $5^{\circ}$ da Constituição Federal (BRASIL, 1988), "é assegurado aos presos o respeito à integridade física e moral". Segundo Dotti (2000, p. 8), "não há, portanto, lacuna legislativa no panorama dos direitos humanos do preso".

A LEP é a ferramenta jurídica que rege a figura da pessoa presa, os órgãos da execução penal, os estabelecimentos penais e os procedimentos em cada espécie de pena ou medida de segurança - no caso de incidentes de execução. Segundo ela: "a execução penal tem por objetivo efetivar as disposições de sentença e proporcionar condições para a harmônica integração social do condenado e do internado" (BRASIL, 1984, Art. $1^{\circ}$ ). É, portanto, a ferramenta que regula a execução penal no país e resguarda os direitos dos presos, ao definir a técnica penitenciária a ser adotada no sistema penitenciário nacional. Neste sentido, a LEP transparece que a reclusão não se limita à segregação do preso, ela atinge a questão da humanização da pena e os benefícios aos presos por meio da disciplina, do trabalho e da educação. Assim, a mesma materializa os deveres e os direitos dos presos, entre os deveres: a higiene pessoal, o asseio da cela e a conservação dos objetos de uso pessoal e, entre os direitos: a alimentação, vestuário, trabalho, descanso e recreação e atividades laboreducativas.

Por seu caráter genérico quanto à técnica penitenciária, a LEP é complementada pelas resoluções e portarias do Ministério da Justiça, cujas determinações ainda são detalhadas pelos estatutos penitenciários que regem a pragmática penitenciária ${ }^{38}$. Neste sentido, a autonomia administrativa concedida às unidades federativas pela Constituição Federal possibilita a particularização do tratamento do preso entre os sistemas penitenciários estaduais, por meio de uma normatização estadual da pena, desde que respeitada à instância superior.

As regras técnicas federais para a arquitetura penal foram lançadas antes da legislação penitenciária. Em 1976, um grupo de trabalho formado no Ministério da Justiça organizou as Recomendações

\footnotetext{
${ }^{37}$ O Direito Penitenciário foi reconhecido no ano de 1930, no X Congresso Penitenciário Internacional, em Praga.

${ }^{38}$ A pragmática penitenciária é a coleção de regras ou de fórmulas que regulam o cotidiano das prisões para conformá-lo, segundo os objetivos institucionais (MIOTTO, 1992, p. 22).
} 
Básicas para uma Programação Penitenciária: o primeiro documento com padrões técnicos gerais para a arquitetura penal no Brasil. Em atendimento à LEP, que determinava a assistência técnica do Ministério da Justiça aos estados para a implementação da política penitenciária, foram elaboradas em 1987 as Orientações para Elaboração de Projetos e Construções de Estabelecimentos Penais. Estas tratavam do planejamento penitenciário de forma mais detalhada e abrangente, mantendo as diretrizes das Recomendações. As Orientações foram reeditadas em 1994 nas Diretrizes para Elaboração de Projetos e Construção de Unidades Penais no Brasil, já sob a égide do Conselho Nacional de Política Criminal e Penitenciária (Resolução n 16). Estas Diretrizes foram revisadas em 2005, nas Diretrizes Básicas para a Construção, Ampliação e Reforma de Estabelecimentos Penais (Resolução n ${ }^{3}$ ) e em 2011, nas Diretrizes Básicas para a Arquitetura Penal (Resolução nº 9), até então vigente.

A LEP adota o sistema progressivo de cumprimento de pena, onde a Justiça fixa a sentença condenatória e o regime penitenciário apropriado, conforme a pena aplicada ao condenado e a classificação do mesmo. Para o cumprimento da pena foram criados três tipos de regime: o fechado, o semiaberto e o aberto ${ }^{39}$. Na progressão da pena, o preso passa para regimes mais brandos, podendo regredir mediante transgressões. No sentido da classificação dos presos, a Constituição Federal (1988) em seu artigo $5^{\circ}$, inciso XLVIII, ordena a separação em estabelecimentos distintos, apropriados a cada grupo. A legislação "pressupõe naturalmente que a população carcerária não é homogênea" (SILVA, 2008, p. 4). A LEP prevê a disposição dos internos "segundo os seus antecedentes e personalidade, para orientar a individualização da execução penal" (BRASIL, 1984, artigo $5^{\circ}$ ). Para tanto, a mesma constitui diferentes tipos de estabelecimentos penais, além de separações para a mulher e o idoso, assim como, entre o preso provisório e o condenado e entre o preso primário e o reincidente.

A técnica penitenciária varia conforme a pena aplicada e a classificação dos presos. O modelo prisional no país se baseia nas técnicas norte-americanas, mesclando-as: atividades realizadas em grupo durante o dia e recolhimento noturno em cela individual. $\mathrm{O}$ mesmo pode ser caracterizado da seguinte maneira, conforme os princípios de funcionamento da prisão (ESTECA, 2010, p. 42):

a) Isolamento social: A LEP cria dispositivos que permitem a comunicação com o mundo exterior visando à minimização dos impactos da vida na prisão. Ela constitui como direitos do preso (Art. 41), o "contato com o mundo exterior por meio de correspondência escrita, da leitura e de outros meios de informação que não comprometam a moral e os bons costumes"

\footnotetext{
39 regimes penitenciários são caracterizados pelo grau de liberdade permitida ao preso em relação ao seu acesso à sociedade. No regime fechado a saída do preso do estabelecimento em que se encontra é vetada, salvo casos previstos em lei. 0 regime semiaberto possibilita a saída, sem vigilância, mediante decisão do juiz, para a realização de atividades externas: trabalho, estudo e visita à família. O regime aberto permite a saída do preso que deve se recolher para dormir. A LEP ainda prevê o Regime Disciplinar Diferenciado (RDD) no seu texto (Lei $\mathrm{n}^{\circ} 10.792$, de $1^{\circ} / 12 / 2003$ ). O RDD consiste na reclusão do preso em regime de isolamento individual absoluto por períodos de até 360 dias que podem ser prorrogados, somando até $1 / 6$ da pena.
} 
(Alínea XV) e a "visita do cônjuge, da companheira, de parentes e amigos em dias determinados" (Alínea X), em consonância ao previsto no Capítulo XI das Regras Mínimas.

b) Isolamento individual: a LEP (Art. 88) prevê o isolamento celular - "o condenado será alojado em cela individual [...]”. As Regras Mínimas para o Tratamento do Preso no Brasil reforçam esta postura no Artigo $8^{\circ}$ - "Salvo razões especiais, os presos deverão ser alojados individualmente" (CNPCP, 1994, p. 21).

c) Atividades dos presos: de forma a possibilitar a reabilitação, a LEP prevê no Artigo 11 que ao preso deverá ser providenciada assistência material, à saúde, jurídica, educacional, social e religiosa. Assim como, a lei também prevê, mais à frente, no Artigo 41 - dos direitos dos presos, o programa de benefícios aos presos: o exercício das atividades profissionais, intelectuais, artísticas e desportivas compatíveis com a pena, além da visita e da igualdade de tratamento, salvaguardadas as particularidades da pena. Destaque especial no cumprimento da pena é dado ao trabalho, encarado como mecanismo principal para a reinserção social. O trabalho é entendido na LEP como "dever social e condição de dignidade humana", devendo apresentar "finalidade educativa e produtiva" (Art. 28), por isso "o condenado à pena privativa de liberdade está obrigado ao trabalho na medida de suas aptidões e capacidade" (Art. 31), assim como deve proporcionar o aproveitamento das habilidades e das oportunidades do mercado, evitando o "artesanato sem expressão econômica" (Art. 32). Esta perspectiva do trabalho na prisão é prolongada nas Regras Mínimas para o Tratamento do Preso no Brasil (1994) que propõem os afazeres visando à formação profissional dos internos (Art. 56).

d) Vigilância: esta não é tratada na LEP, a não ser pelo que toca aos funcionários que deverão atender critérios de "vocação, formação profissional e antecedentes pessoais" (Art. 77), repetidos nas Regras Mínimas para o Tratamento do Preso no Brasil (Art. 49). Miotto (1986, p. 368) expõe, ao avaliar o pessoal das prisões, que "a vigilância, porém, discreta e velada, mas efetiva, não será contra os presos; será em benefício da ordem interna e da disciplina do estabelecimento, e da segurança de todos que se encontram no estabelecimento [...]".

e) Administração da pena: segundo a LEP, a execução penal é acompanhada pelo Poder Judiciário, por meio do juiz da execução penal (Art. 65). Por outro lado, a mesma confere uma autonomia e poder consideráveis à direção do estabelecimento penitenciário em relação ao Judiciário quanto a certos aspectos do cumprimento da pena. Cabe à administração, por exemplo, instaurar o procedimento disciplinar (Art. 60) no caso de falta disciplinar grave pelo preso. Além do acompanhamento do sistema de sanções (isolamento, suspensão e restrição de direitos) e de recompensas (elogios e concessão de regalias) aos presos (Subseção III, da Seção III, do Capítulo IV). Assim, os procedimentos aplicados pela direção da prisão podem ocorrer com relativa independência do Juiz, o que pode caracterizar o 'penitenciário' descrito por Foucault: a transferência da administração da pena do Judiciário para a direção da prisão. 
Quanto às atividades dos presos, a LEP determina a assistência aos mesmos nos seguintes termos:

a) Assistência material: alimentação, vestuário e instalações higiênicas (Art. 12), assim como "instalações e serviços que atendam aos presos nas suas necessidades pessoais, além de locais destinados à venda de produtos e objetos permitidos e não fornecidos pela Administração" (Art. 13);

b) Assistência à saúde: de caráter preventivo e curativo, compreenderá atendimento médico, farmacêutico e odontológico (Art. 14), com atenção especial à saúde da mulher;

c) Assistência jurídica: pela Defensoria Pública em local apropriado ao atendimento (Art. 16);

d) Assistência à educação: prevê instrução escolar e formação profissional na sua Seção V, na qual o ensino de $1^{\circ}$ grau é obrigatório (Art. 18), assim como a existência de biblioteca;

e) Assistência social: tem por finalidade amparar o preso e o internado e prepará-los para o retorno à liberdade (Art. 22);

f) Assistência religiosa: coloca a liberdade de culto e o acesso dos presos aos serviços realizados no estabelecimento, além de prever local para os cultos.

O cuidado com os aspectos da humanização da pena e do programa de benefícios aos presos não desabilita a preocupação com a disciplina interna do estabelecimento penal. A LEP instrui em seu Artigo 44 que "a disciplina consiste na colaboração com a ordem, na obediência às determinações das autoridades e seus ajudantes e no desempenho do trabalho" (BRASIL, 1984). A disciplina é regulada pelos direitos e deveres dos presos que prevêem em diversos dispositivos prêmios ou sanções, a serem submetidas pela administração, como meios para a obtenção da ordem. Este sistema de recompensas ou castigos integrou o modelo prisional na sua acepção, visto como um mecanismo de incentivo ao preso. Entre os recursos disciplinares, a LEP define, por exemplo, o isolamento em cela individual e o Regime Disciplinar Diferenciado (RDD - Lei n 10.792 , de 1\%12/2003). O RDD consiste na reclusão do preso em regime de isolamento individual absoluto por períodos de até 360 dias que podem ser prorrogados, somando até um sexto da pena. Por outro lado, a LEP e as Regras Mínimas para o Tratamento do Preso no Brasil proíbem práticas disciplinares antigas, como a cela escura- "as sanções não poderão colocar em perigo a integridade física e moral do condenado" (CNPCP, 1994, Art. 45).

O modelo prisional descrito pela LEP é complementado por estatutos proferidos pelas administrações estaduais que regulamentam o cotidiano das prisões $^{40}$. A Instrução Normativa $n^{\circ}$ 001/2010 da

\footnotetext{
40 Segundo o Infopen (BRASIL, 2014), uma minoria dos estabelecimentos penais do país segue algum tipo de regimento interno (70\%). Na totalidade, estes regimentos tratam da generalidade do sistema penitenciário, sem atenção às especificidades de cada tipo penal. No ano de 2011 foi elaborado no Congresso Nacional o Projeto de Lei no 2.230/2011 que propunha instituir o Estatuto Penitenciário Nacional, sendo arquivada no mesmo ano. Este documento reafirmava os princípios da legislação penal, como o contato com o mundo exterior, o respeito ao preso, a separação dos presos em estabelecimentos e a individualização da pena (cela individual), além da assistência do Estado e o programa de benefícios. O mesmo também trazia novidades ao instituir a visita íntima e o índice de desenvolvimento humano do sistema penitenciário (não formatado). Assim como, o mesmo normatizava alguns aspectos da arquitetura penal.
} 
Secretaria de Segurança Pública do Estado de Santa Catarina (SANTA CATARINA, 2010) ilustra o propósito estatutário, ao atribuir responsabilidades aos funcionários, regulamentar as ações e procedimentos a serem seguidos pelos gestores e seus subordinados, além de instituir Manual de Normas e Procedimentos Internos. Este Manual dedica uma seção para os procedimentos de entrada no estabelecimento, detalhando a identificação e a revista. Em outra seção, trata de procedimentos internos, como o recebimento, deslocamento e revista de presos, além de itens da rotina diária, entre eles: o itinerário de banho de sol e refeições, a conferência dos presos e o silêncio noturno (Figura 16).

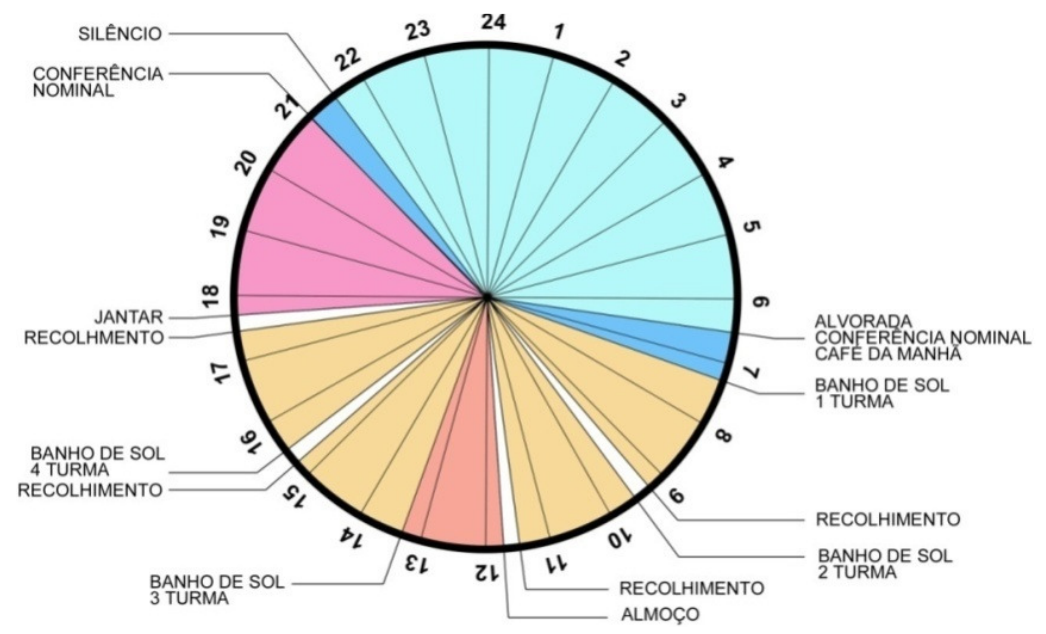

Figura 16 - Gráfico da rotina diária ordinária dos presos no sistema penitenciário catarinense

A regularidade diária é alterada semanalmente pela realização da visita. A ocorrência e o formato da visita também são preconizados nos regimentos prisionais que descrevem os procedimentos de autorização, acesso, contato e permanência das visitas. Em geral, a visitas acessam a unidade pela manhã e saem à tarde. Em destaque, a permissividade de contato físico entre presos e visitantes, inclusive íntimo. A revista física das visitas sociais nas prisões brasileiras é considerada constrangedora e vexatória para o funcionário e, principalmente, para o visitante.

O modelo prisional também conforma o corpo funcional das prisões, em termos das equipes mínimas, além da postura e capacitação dos funcionários. Na Resolução n 9/2011, do CNPCP, a recomendação é de um agente de segurança penitenciário para cada cinco presos. No entanto, este documento não considera as diferenças operacionais inerentes às categorias penitenciárias. O Technical Guidance of Prision Planning da United Nations Office for Project Services (apresentado na seção 3.5) determina a relação de um funcionário para cada cinco presos para unidades de alta segurança e médio porte (o que 
inclui todo o pessoal operacional), e fazem a seguinte consideração ${ }^{41}$ : "Entretanto, esta razão de 1:5 de pessoal para presos pode decair significantemente se os prisioneiros são alojados em celas duplas, ou 25 dormitórios de 20 prisioneiros cada" (UNOPS, 2016, p. 50).

Em relação ao sistema norte-americano, o modelo prisional nacional apresenta particularidades. Nos Estados Unidos, a categorização por nível de segurança ocupa cinco níveis, encabeçados pelo supermax e o maximun security (ou high security no sistema federal). Estas duas categorias são caracterizadas pelo isolamento absoluto dos presos (encarcerados por vinte e três horas diárias), pela ausência de contato físico com outras pessoas (presos, funcionários e visitantes) e pela reduzida oportunização de recompensas por bom comportamento. A ADX Florence permite cinco horas de recreação individual por semana e quatro horas de visita monitorada por mês (EUA, 2017). Nos Estados Unidos, a visita íntima acontece apenas em seis estados, enquanto nos demais, as visitas são admitidas, "mas sem que possam se tocar" (LEAL, 1992, p.51). O número de funcionários alcança a equivalência com o número de presos nas unidades super-max.

\subsection{Regras técnicas para a arquitetura}

Em relação à composição arquitetônica da edificação penal, o modelo prisional se traduz em uma série de recomendações, diretrizes e determinações elencadas nos instrumentos legais e técnico-normativos, com destaque para a LEP, as Regras Mínimas para o Tratamento do Preso no Brasil e as Diretrizes Básicas para a Arquitetura Penal ${ }^{42}$. A Constituição Federal se limita a estabelecer o status jurídico do preso como sujeito de direitos. Estes instrumentos interagem com o tema da seguinte maneira:

a) A LEP não contém parâmetros arquitetônicos diretos, com uma única exceção, ao dispor sobre a cela (Art. 88). Além disso, apenas alguns ambientes obrigatórios são pontuados, como a biblioteca (Art. 21) e a cantina (Art. 13). Indiretamente, a LEP induz a um arcabouço programático, ao preconizar a assistência do Estado e o programa de benefícios aos presos.

b) As Regras Mínimas apresentam "o repertório das normas que constituem a imprescindível disciplina das ações no relacionamento do Estado com o homem preso [...]" (CNPCP, 1994, p. 16). Em comparação à LEP, as Regras Mínimas também são generalistas no âmbito da arquitetura: apenas fazem recomendações quanto ao tipo de alojamento dos presos e o cuidado com as condições de higiene (Art. $8^{\circ}$ e $9^{\circ}$ ).

c) As Diretrizes Básicas é o instrumento que trata mais direta e detalhadamente o conteúdo arquitetônico: "é referência para todas as obras nacionais com fins penais, representando o

\footnotetext{
${ }^{41}$ O Technical Guidance of Prision Planning ressalta que o contingente total deve considerar o shift relief factor que determina quantos funcionários são necessários para ocupar um posto de trabalho, ao se considerar férias, licenças, treinamentos ou para assegurar um operacional mínimo no estabelecimento penal.

${ }^{42}$ Neste trabalho, estas resoluções serão denominadas simplesmente de Regras Mínimas e Diretrizes Básicas, respectivamente.
} 
acúmulo político e social do Estado Democrático de Direito e o conhecimento científico disponível” (CNPCP, 2011a, p.10). As mesmas trazem tipologias e programas arquitetônicos, critérios de mediação e orçamentação, entre outros. O processo de projeto é sucintamente abordado nas Diretrizes Básicas (Idem, p. 27) que recomenda o levantamento de dados e informações que comprovem o tipo e categoria do estabelecimento pretendido.

O exame dos instrumentos listados verificou a correspondência de seus respectivos conteúdos com o escopo desta pesquisa, o que é representado no Quadro $2^{43}$, a seguir. Neste quadro ficou demonstrada a abrangência das Diretrizes Básicas na regulação do espaço arquitetônico da edificação penal. Este mesmo exame também descreveu os conteúdos das Diretrizes Básicas para o projeto arquitetônico da edificação penal, resumidamente exposta no Quadro 3, a seguir.

Quadro 2 - Abordagem dos instrumentos legais e técnico-normativos em relação aos temas da composição arquitetônica da edificação penal

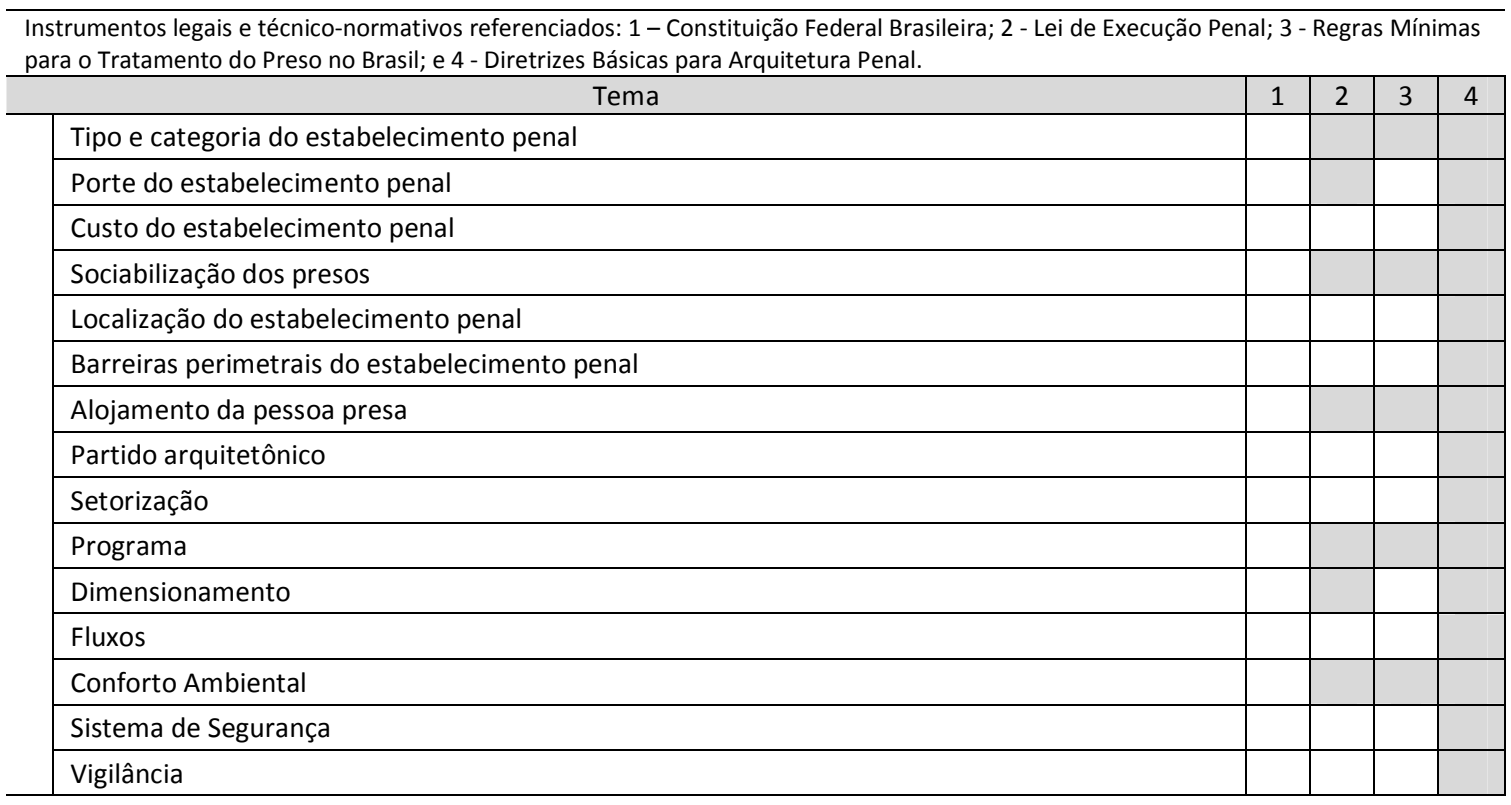

\footnotetext{
${ }^{43}$ Os instrumentos examinados apresentaram temas coincidentes com o programa arquitetônico desenvolvido nesta pesquisa, exposto no Capítulo 6, sendo organizados segundo esta estrutura programática. Estes instrumentos também apresentaram itens transversais ao objeto de pesquisa, tais como: a celebração convênio (cita a licença ambiental); o processo de projetação (refere o levantamento de dados para a tipificação e categorização do estabelecimento penal); recomendações gerais (menciona a padronização de projetos do Ministério da Justiça, o levantamento de dados, a liberdade criativa no partido arquitetônico e a estratégia para a demolição de unidades penais); a operação do estabelecimento penal (tange a administração, a manutenção e o pessoal do estabelecimento penal); a ampliação de unidades penais. Eventualmente, estes itens transversais foram aludidos para embasar ou complementar este trabalho de pesquisa. Assim como, surgiram outros temas que não integram o escopo desta pesquisa surgiram, tais como: a técnica construtiva, a construção sustentável, as instalações, a acessibilidade e os materiais.
} 
Quadro 3 - Resumo dos conteúdos dos principais temas das Diretrizes Básicas para o projeto arquitetônico

\begin{tabular}{|c|c|}
\hline Tema & Abordagem \\
\hline $\begin{array}{l}\text { Tipo e categoria do } \\
\text { estabelecimento penal }\end{array}$ & $\begin{array}{l}\text { Definem a categoria do estabelecimento em função do perfil dos presos, além do } \\
\text { enquadramento no sistema penitenciário, da administração e da proposta metodológica. Esta } \\
\text { categorização determinará as "características técnicas próprias de localização ou mesmo de } \\
\text { tratamento, adequação e dimensionamento de seus espaços físicos" (p. 45). }\end{array}$ \\
\hline $\begin{array}{c}\text { Porte do } \\
\text { estabelecimento penal }\end{array}$ & $\begin{array}{l}\text { Fixam valores para as capacidades máximas de estabelecimentos penais, considerando o } \\
\text { regime penitenciário. }\end{array}$ \\
\hline $\begin{array}{l}\text { Custo do } \\
\text { estabelecimento penal }\end{array}$ & $\begin{array}{l}\text { Colocam que as edificações devem ser econômicas, relativamente à construção, } \\
\text { funcionamento e manutenção, sem prejuízo das condições mínimas de comodidade e } \\
\text { segurança. Enfatizam o custo de construção, atrelando este à escolha do terreno, às } \\
\text { especificações de material e ao funcionamento do estabelecimento. }\end{array}$ \\
\hline $\begin{array}{l}\text { Sociabilização externa } \\
\text { do preso }\end{array}$ & $\begin{array}{l}\text { Prevêem locais para a visita social, inclusive encontro íntimo, além de parlatórios para o } \\
\text { encontro com o advogado. }\end{array}$ \\
\hline $\begin{array}{l}\text { Localização do } \\
\text { estabelecimento penal }\end{array}$ & $\begin{array}{l}\text { Colocam que as unidades penitenciárias devem se localizar fora de zonas urbanas centrais ou } \\
\text { residenciais, respeitados a acessibilidade, comunicação, além de fatores econômicos e sociais. }\end{array}$ \\
\hline Barreira perimetral & $\begin{array}{l}\text { Especificam os tipos de barreira, incluindo as torres de vigilância, além de fixar valores para os } \\
\text { afastamentos e recuos. Fazem considerações sobre o acesso da unidade penal. }\end{array}$ \\
\hline $\begin{array}{l}\text { Alojamento da pessoa } \\
\text { presa }\end{array}$ & $\begin{array}{l}\text { Assumem a cela coletiva como tipo de alojamento para os presos, em que estabelece } \\
\text { capacidades e especifica componentes do local. Determinam } 2 \% \text { da capacidade do } \\
\text { estabelecimento penal em celas individuais. }\end{array}$ \\
\hline Partido arquitetônico & $\begin{array}{l}\text { Permitem a liberdade criativa no partido arquitetônico, sob condições de funcionalidade, } \\
\text { segurança, conforto e impacto ambiental. }\end{array}$ \\
\hline Setorização & $\begin{array}{l}\text { Recomendam a setorização a fim de ordenar os fluxos de pessoas e veículos, em três setores: } \\
\text { externo, intermediário e interno. }\end{array}$ \\
\hline Espacialização & $\begin{array}{l}\text { Prevêem um programa distribuído em áreas funcionais arranjadas em módulos, inclusive } \\
\text { descreve o módulo de vivência, visto como mecanismo de classificação ou divisão do grupo de } \\
\text { presos. Fazem considerações quanto à localização e, em menor grau, quanto ao programa } \\
\text { destes módulos. Recomendam medidas de humanização do espaço relacionadas com o } \\
\text { conforto ambiental, misturadas a cuidados com o controle dos presos (restrição do poder). } \\
\text { Possibilitam o uso de uma área por mais de uma função. }\end{array}$ \\
\hline Dimensionamento & $\begin{array}{l}\text { Fixam áreas mínimas para a totalidade dos cômodos do programa apresentado. Estipulam as } \\
\text { áreas totais construída e de terreno, proporcionalmente à capacidade do estabelecimento } \\
\text { penal. Fixam a capacidade máxima do módulo de vivência, assim como, parâmetros para as } \\
\text { celas coletivas. Ainda trazem parâmetros específicos para os afastamentos e recuos, } \\
\text { circulações, solários, celas de triagem, salas de aula, oficinas, entre outros. }\end{array}$ \\
\hline Fluxos & $\begin{array}{l}\text { Fazem recomendações quanto ao zoneamento dos fluxos, especificamente da sobreposição e } \\
\text { da sobrecarga de fluxos, como meio para a organização das circulações de pessoas e veículos. } \\
\text { Também recomendam verificar o dimensionamento da circulação. Recomendam o uso de alas } \\
\text { celulares nos módulos de vivência, o acesso único à unidade penal e acessos apropriados para } \\
\text { as pessoas. Ressaltam a importância da localização dos módulos para o fluxo de pessoas e a } \\
\text { concentração dos fluxos mais intensos no térreo (no caso de edifícios verticais). }\end{array}$ \\
\hline Conforto ambiental & $\begin{array}{l}\text { Relacionam o conforto ambiental com a segurança e fazem observações sobre as condições } \\
\text { naturais do terreno e do clima da região. Recomendam o uso de áreas verdes (fixam valores } \\
\text { para a permeabilidade do terreno), a previsão passarelas interligando os blocos e evitar } \\
\text { subsolos, além de estratégias de ventilação e iluminação dos ambientes internos, citando a NBR } \\
15220 / 2003 \text {. Ressaltam a necessidade de salubridade das celas, em especial, quanto à } \\
\text { regionalização climática. Fixam valores mínimos para as aberturas de ventilação e iluminação. }\end{array}$ \\
\hline Sistema de Segurança & $\begin{array}{l}\text { Associam os aspectos construtivos e materiais com o nível de segurança. Fazem } \\
\text { recomendações quanto à quantidade, disposição e acesso das torres de vigilância na barreira } \\
\text { perimetral, além da previsão da pista de ronda veicular. Sugerem a divisão dos setores e áreas } \\
\text { internas com cercas, assim como, evitar composições de fachadas ou muros com possíveis } \\
\text { esconderijos ou pontos cegos nas áreas internas da unidade penal. Também sugerem a } \\
\text { monitoria eletrônica para unidades de maior segurança. Estabelecem a particularização da } \\
\text { segurança para diferentes unidades em um conjunto penal. Fazem recomendações quanto à } \\
\text { localização da infraestrutura. Avançam em recomendações de elementos específicos como as } \\
\text { portas de celas e pilares. }\end{array}$ \\
\hline Vigilância & $\begin{array}{l}\text { Determinam a confecção de um estudo de segurança específico de acordo com o tipo e } \\
\text { categoria do estabelecimento penal. Recomendam a obediência ao alinhamento, tanto para as } \\
\text { faces quanto para as empenas dos edifícios. }\end{array}$ \\
\hline
\end{tabular}




\subsection{Considerações sobre os instrumentos legais e técnico-normativos}

O exame dos instrumentos legais e técnico-normativos apontou uma série de incongruências nos mesmos. Neste sentido, a aplicação destes deve ser sujeita à crítica, em especial, a utilização das Diretrizes Básicas (CNCPC, 2011a), pois o conteúdo destas apresenta distorções, incorreções e incompletudes nos conceitos, parâmetros e programas (ESTECA, 2010, p. 129).

Os manuais disponíveis e que orientam a elaboração de projetos chegam a conter erros graves, inclusive quanto à capacidade das celas e alojamentos - onde se admite a construção de penitenciárias com alojamentos coletivos, em clara afronta ao disposto no artigo 88 da Lei de Execução Penal. Disso resulta o previsível: propostas arquitetônicas que não se traduzem em soluções (SILVA, 2008).

Em um ordenamento mais amplo, as Diretrizes Básicas não tratam das teorias da arquitetura penal, especialmente o Panóptico, com exceção de algumas correspondências pontuais. Neste sentido, os requisitos panópticos poderiam fornecer uma estrutura para o documento que atualmente não existe. As Diretrizes Básicas carecem de uma organização lógica que propicie ao projetista uma consulta ágil e objetiva do material. Nos anexos IV e V do documento ${ }^{44}$, os conteúdos são dispostos de maneira confusa, misturando conceitos, recomendações e parâmetros, assim como, os diferentes aspectos da composição arquitetônica.

As Diretrizes Básicas ainda acumulam incorreções e imprecisões, citadas exemplificadas a seguir. Entre as incorreções, as celas individuais são previstas no programa do bloco de vivência coletiva, ao mesmo tempo em que se prevê um bloco específico para elas. De modo similar, o local de visita social é tratado como um módulo especializado, depois como polivalente. O dimensionamento do pátio de sol ora considera seis metros quadrados por preso a serem somados a uma área fixa inicial, ora desconsidera este valor inicial. Um exemplo da imprecisão é o intervalo de doze a sessenta metros quadrados por vaga estipulado para o pré-dimensionamento de qualquer tipo ou categoria de estabelecimento penal, pois esta abrangência não fornece nenhum tipo de orientação ao projetista ${ }^{45}$.

As Diretrizes Básicas são conformadas na sua totalidade por recomendações gerais, embora também sejam entremeadas pela minúcia de alguns elementos ou sistemas, como a porta da cela. Em paralelo ao Handbook of Correctional Design and Construction (USA, 1949), a superficialidade das Diretrizes fica evidente. As regras técnicas norte-americanas estabeleceram critérios e soluções detalhadas para o

\footnotetext{
${ }^{44}$ Apenas os anexos IV e V das Diretrizes Básicas (CNPCP, 2011a) tratam diretamente da composição arquitetônica, os demais se distribuem sobre a celebração de convênios, orçamentação de projeto e medição de obra.

${ }^{45}$ Estes valores foram introduzidos na revisão normativa do ano de 2005, com o objetivo de tornar o projeto padrão da Penitenciária Federal passivo de aprovação segundo as normas ${ }^{45}$. A recomendação anterior era de 12 a 15 metros quadrados de área construída por preso. A Penitenciária Federal era classificada como penitenciária especial (dotada apenas de celas individuais) e sobre a qual não caberiam os parâmetros correntes à época. O mais correto e talvez mais simples fosse inclusão de parâmetros específicos para a penitenciária do tipo especial. Deste modo, estes são parâmetros desprovidos de embasamento e aplicação técnica.
} 
espaço arquitetônico, segundo cada regime penitenciário, nível de segurança e porte de estabelecimento penal.

Observa-se que boa parte das regras e recomendações das Diretrizes Básicas, apesar de serem apresentadas para uma aplicação indistinta entre os diferentes estabelecimentos penais previstos, se refere na sua totalidade, de alguma forma, a penitenciária e a cadeia pública. Isto pode ser verificado pelas soluções de segurança sugeridas, pois potencialmente produzem incongruências quando aplicadas aos tipos penais mais brandos, como a colônia agrícola ou industrial (regime semi-aberto) e a casa do albergado (regime aberto). Deste modo, as Diretrizes Básicas enfatizam segurança física do estabelecimento penal ${ }^{46}$.

A ênfase na segurança penitenciária nas Diretrizes Básicas se limita a poucas recomendações genéricas e desvinculadas da modalidade do estabelecimento penal. As Diretrizes Básicas (CNPCP, 2011a, p. 42, 52 e 53) não criam uma diferenciação nítida entre as arquiteturas de segurança máxima e média - o programa apresentado varia apenas em função do tipo de estabelecimento penal. Neste sentido, o instrumento recomenda: "deverá ser feito um estudo de segurança específico para dotar o estabelecimento, de acordo com sua categoria, tipo e regime, de elementos que auxiliem as guardas interna e externa no controle das pessoas presas, dos visitantes e até mesmo do pessoal administrativo" (CNCPC, 2011a, p. 47). Diante desta indefinição, a ênfase na segurança remete a generalidade do programa apresentado a uma arquitetura de segurança máxima, devido à similaridade deste com as características desta categoria (ver Capítulo 1). Esta imprecisão na caracterização da segurança máxima produz incongruências na categorização dos estabelecimentos nos sistemas penitenciários estaduais. Entre os projetos de referência, por exemplo, a Penitenciária do Distrito Federal é tida como de segurança média pela direção, apesar dos cuidados extremos com a segurança penitenciária.

Da mesma maneira, as Diretrizes Básicas não fornecem parâmetros para uma classificação do estabelecimento penal segundo o porte (pequeno, médio ou grande). As mesmas fornecem apenas os limites máximos para cada tipo de estabelecimento e para as categorias de segurança do tipo penitenciária. Estes limites definem portes diferenciados entre as penitenciárias de segurança máxima e média: a unidade de maior segurança tem uma população prisional reduzida, e vice-versa.

Apesar da importância conferida ao custo na determinação do projeto arquitetônico penitenciário, as Diretrizes Básicas se restringem a duas recomendações, ao citar cuidados com a escolha do terreno (terraplanagem) e dos materiais e sistemas (manutenção e conservação), além de apenas citarem as

\footnotetext{
46 As Diretrizes Básicas (CNPCP, 2011) apresentam itens inteiros dedicados à segurança e tantos outros conexos do ponto de vista do controle, fiscalização, fluxos, entre outros tópicos. No Anexo IV, dois dos sete itens estão inteiramente voltados à segurança (Muros e Alambrados, e Afastamento e Recuos Necessários). No Anexo V, no item Partido, das dez recomendações, quatro citam a segurança e, no item Recomendações Gerais são 13 dos 33 itens.
} 
despesas de funcionamento da unidade penal. Segundo este instrumento (CNCPC, 2011a, p. 42): "As edificações devem ser projetadas de modo a atender aos quesitos necessários quanto ao custo da construção". Em nenhum momento as mesmas adentram no custo de operação.

As Diretrizes Básicas ressaltam a necessidade da proximidade do preso do seu local e comunidade de procedência (CNCPC, 2011a, p. 33): “A origem das pessoas presas é um dos indicadores básicos de localização, de modo a não impedir ou dificultar sua visitação e a preservar seus vínculos para a futura reintegração harmônica à vida em sociedade”. Por outro lado, as Diretrizes Básicas não consideram a localização como um requisito do sistema de segurança, para o qual deveriam ser estabelecidos critérios em função do nível de segurança penitenciária ${ }^{47}$. O instrumento recomenda apenas evitar centros urbanos ou zonas residenciais.

As Diretrizes Básicas não explicitam o objetivo da barreira perimetral: a separação física e sensorial entre os espaços externo e interno da instituição. As mesmas não indicam critérios que classifiquem as barreiras perimetrais, segundo uma categorização dos estabelecimentos penais, o que existia nas versões anteriores das regras técnicas do Ministério da Justiça. As descrições das barreiras neste instrumento, de uma forma geral, se referem à segurança máxima: altas e equipadas com elementos cortantes, além da opção de serem fechadas.

Contrariando a individualização da LEP e as Regras Mínimas, as Diretrizes Básicas (CNCPC, 2011a, p. 25) compreendem a cela coletiva, admitindo uma capacidade de até oito vagas ${ }^{48}$ e estabelecendo parâmetros mínimos de dimensionamento para as mesmas. Esta flexibilização na capacidade da cela atribui um caráter mais pragmático às Diretrizes, que reflete uma demanda da realidade prisional (ver Capítulo 4). As Diretrizes também não explicitam o objetivo da cela. Subentendem-se as funções de dormitório e de higiene pessoal, assim como um uso predominantemente noturno, tendo em vista a especificação dos serviços e do mobiliário. Da mesma forma, as Diretrizes não indicam critérios que classifiquem as celas, segundo uma categorização dos estabelecimentos penais. Nos instrumentos normativos examinados, a discussão da classificação ou a separação dos presos não avança além dos grupos divididos em alas ou módulos de vivência.

A LEP e as Diretrizes Básicas refletem o integralismo da prisão, por meio de um programa arquitetônico completo. Isto vem sendo continuamente reforçado nas revisões das regras técnicas do Ministério da Justiça. Na última revisão, por exemplo, houve a inclusão de áreas específicas para a realização da visita aos presos, assim como, o incremento significativo do programa destinado ao

\footnotetext{
${ }^{47}$ As versões anteriores das regras técnicas vigentes tratavam deste conteúdo.

${ }^{48}$ Segundo as Diretrizes Básicas (CNPCP, 2011a), as capacidades de sete e oito vagas são válidas até 5 de maio de 2015 (cf. Resolução CNPCP no 2/2011).
} 
estabelecimento do tipo cadeia pública. Embora a última revisão das regras técnicas tenha flexibilizado parte do programa arquitetônico proposto, ao vincular a área construída e o número de usuários dos locais, o nível de segurança foi desconsiderado como variável neste ajustamento.

Nas Diretrizes Básicas, o programa arquitetônico é organizado em blocos funcionais, o que remete ao padrão arquitetônico modular, com destaque para a previsão de módulos de vivência para os presos (ver Capítulo 1). Ao mesmo tempo, em algum momento, este instrumento falha na setorização da prisão, quando trata da disposição dos diferentes tipos de pessoas, sem considerar a circulação destas. Em termos da composição espacial, as Diretrizes Básicas interceptam alguns pontos da disciplina espacial panóptica, tais como: as localizações funcionais, o celular, o quadriculamento e o princípio do máximo. Assim como, o programa arquitetônico descrito nas Diretrizes representa, em alguma medida, a extensão e a minúcia da disciplina, além do multipanoptismo ${ }^{49}$ e da policrestia. Todavia, as Diretrizes ainda se mostram acanhadas diante do Panóptico, se limitando a recomendações gerais que podem ser resumidas na seguinte citação:

Deve-se ter consciência da importância que tem a definição de uma linha de projeto que poderá vir a facilitar a administração e a manutenção do edifício proposto e, consequentemente, influir no comportamento das pessoas que dele fazem uso. É fundamental favorecer as instalações com um mínimo de conforto, procurando soluções viáveis que permitam o grau de segurança necessário (CNPCP, 2011a, p.27).

Esta posição das Diretrizes Básicas também se verifica na discussão dos custos da prisão e do isolamento social que são temas centrais do trabalho de Bentham que buscava a melhor relação para o primeiro e a individualização para o segundo. O mesmo ocorre na inflexibilidade do dimensionamento em função do nível de segurança, o que vai de encontro ao Princípio da Utilidade, enquanto na localização do estabelecimento penal os critérios são similares, porém por motivos destoantes, já que Bentham vislumbrava a fiscalização da instituição pela sociedade.

Em diversos momentos, as Diretrizes Básicas abordam o conforto ambiental, compreendendo quase que exclusivamente os quesitos de ventilação e iluminação, para os quais são apresentados critérios, por exemplo, levando em consideração as regiões bioclimáticas. Por outro lado, os parâmetros fixados apresentam incongruências. Em alguns pontos, as Diretrizes mostram uma preocupação em equilibrar o conforto e a segurança no projeto.

Deve-se primar por aspectos de harmonização do ambiente com a vida humana, de forma a favorecer o equilíbrio, a saúde e a tranquilidade, considerando itens como a pintura (cores), acabamento,

\footnotetext{
${ }^{49}$ Perrot (apud BENTHAM et al., 2008, p. 135) apresenta a replicação do edifício panóptico usando o termo multipanoptismo, o que pode ser exemplificado pela Prisão Modelo, em Cuba. "O mesmo teto, tem-se dito, não deve encerrar pessoas que estão em situação tão dessemelhantes [presos provisórios e condenados]. Em uma combinação de casas de inspeção, esta diferenciação deve ser observada, sem qualquer diminuição daquela vigilância que diz respeito a uma custódia segura, a qual, em ambos os casos é igualmente indispensável” (BENTHAM et al., 2008, p. 24).
} 
configuração espacial que minimize a sensação de opressão, respeito ao espaço pessoal, layout dos ambientes obedecendo aos princípios da ergonomia etc. (CNPCP, 2011a, p. 42)

As Diretrizes Básicas são o único instrumento que aborda o controle, porem de modo superficial. De modo direto, as mesmas apenas recomendam "evitar pontos cegos" (CNPCP, 2011a, p. 29). A especificação de postos de controle pelo corpo da edificação prisional nas Diretrizes Básicas remete à segunda geração de estabelecimentos penitenciários, porém as mesmas não discorrem sobre a separação física de funcionários e presos, de acordo com o padrão arquitetônico modular. Esta especificação ilustra a fragmentação da vigilância central panóptica, mas a replicação do panoptismo em cada um destes postos e a previsão do princípio da inverificabilidade panóptica não são tratados. Neste sentido, as Diretrizes Básicas não abordam a questão do poder e do enquadramento que Bentham propôs a corrigir na síntese da vigilância do Panopticon (PERROT apud BENTHAM et al., 2008, p. 136).

A discussão sobre as Diretrizes Básicas alcança a política vigente no sistema penal que objetiva a geração de vagas ao menor custo possível (ver capítulo 4), o que exigiu uma adequação dos parâmetros arquitetônicos pelo aumento das capacidades máximas e pela redução de áreas do estabelecimento penal. Neste sentido, as revisões das regras técnicas reforçaram continuamente a segurança penitenciária, em detrimento da funcionalidade e da humanização da arquitetura. Em especial, a edição das Diretrizes Básicas de 2005 (CNPCP, 2006) retirou diversas recomendações existentes sobre estes temas. As informações pertinentes às mudanças realizadas nas regras técnicas foram resumidamente apresentadas no quadro a seguir:

Quadro 4 - Listagem das alterações promovidas nas regras técnicas relativas à modelagem da edificação penal

\begin{tabular}{|c|c|}
\hline Tópico revisado & Alterações \\
\hline $\begin{array}{l}\text { Tipologia do } \\
\text { estabelecimento penal }\end{array}$ & $\begin{array}{l}\text { Nas Diretrizes Básicas (Resolução 3/2005), a categoria penitenciária especial foi retirada. Ao } \\
\text { mesmo tempo, o Regime Disciplinar Diferenciado foi inserido no texto. }\end{array}$ \\
\hline $\begin{array}{l}\text { Categorização do } \\
\text { estabelecimento penal }\end{array}$ & $\begin{array}{l}\text { Nas Diretrizes Básicas (Resolução } 3 / 2005 \text { ), a tônica dada ao estabelecimento do tipo } \\
\text { penitenciária foi ressaltada, ao excluir considerações que diferenciavam características } \\
\text { específicas dos tipos penais, em termos da localização, definição e dimensionamento dos } \\
\text { alojamentos, especificação das barreiras, entre outros. }\end{array}$ \\
\hline $\begin{array}{l}\text { Capacidade do } \\
\text { estabelecimento penal }\end{array}$ & $\begin{array}{l}\text { As Orientações (1987) estabeleciam um limite de } 400 \text { vagas para a Cadeia Pública, as Diretrizes } \\
\text { (Resolução 3/2005) subiram para } 500 \text { e as Diretrizes Básicas (Resolução 9/2011) para } 800 \text { vagas. }\end{array}$ \\
\hline $\begin{array}{l}\text { Capacidade do bloco } \\
\text { de vivência }\end{array}$ & $\begin{array}{l}\text { A quantidade máxima de presos por módulo ou ala carcerária passou de } 60 \text { nas Diretrizes } \\
\text { (Resolução 3/2005) para } 200 \text { nas Diretrizes Básicas (Resolução 9/2011). }\end{array}$ \\
\hline $\begin{array}{l}\text { Capacidade do } \\
\text { refeitório }\end{array}$ & $\begin{array}{l}\text { Os refeitórios que antes não poderiam servir mais de } 60 \text { presos, nas Diretrizes Básicas (Resolução } \\
\text { 9/2011) são ampliados para até } 100 \text { presos. }\end{array}$ \\
\hline Barreira perimetral & $\begin{array}{l}\text { Nas Diretrizes Básicas (Resolução 9/2011), a altura mínima passou de seis para cinco metros. Os } \\
\text { afastamentos mínimos entre as edificações com permanência prolongada de presos e as } \\
\text { barreiras passaram de vinte para dez metros (para muros) ou quinze metros (no caso de cercas). }\end{array}$ \\
\hline $\begin{array}{l}\text { Perímetro de } \\
\text { segurança }\end{array}$ & $\begin{array}{l}\text { Nas Diretrizes Básicas (Resolução 9/2011), o perímetro de segurança passou de cinco metros para } \\
\text { três metros de afastamento em relação à barreira perimetral. }\end{array}$ \\
\hline Celas individuais & $\begin{array}{l}\text { Nas Diretrizes Básicas (Resolução 9/2011), a quantidade de celas individuais passou de } 5 \% \text { da } \\
\text { capacidade do estabelecimento para } 2 \% \text {. }\end{array}$ \\
\hline $\begin{array}{l}\text { Cela coletiva - } \\
\text { dimensionamento }\end{array}$ & $\begin{array}{l}\text { Nas Diretrizes (Resolução } 3 / 2005 \text { ), os parâmetros mínimos por preso foram reduzidos: no caso de } \\
\text { cela para seis vagas, a área passou de vinte e quatro metros quadrados para quinze metros } \\
\text { quadrados e a cubagem de sessenta metros cúbicos para quarenta e cinco metros cúbicos. Nas } \\
\text { Diretrizes Básicas (Resolução } 9 / 2011 \text { ), a mesma cela passou a ser aceita com dez metros }\end{array}$ \\
\hline
\end{tabular}




\begin{tabular}{|c|c|}
\hline & $\begin{array}{l}\text { quadrados e vinte e cinco metros cúbicos de volume. Nas Diretrizes Básicas (Resolução 9/2011) } \\
\text { são admitidos beliches de três camas e chuveiros em banheiros fora das celas. }\end{array}$ \\
\hline $\begin{array}{l}\text { Cela coletiva - } \\
\text { capacidade }\end{array}$ & $\begin{array}{l}\text { Nas Diretrizes Básicas (Resolução 9/2011), celas com sete e oito vagas passam a ser admitidas em } \\
\text { caráter temporário. }\end{array}$ \\
\hline Partido & $\begin{array}{l}\text { As Recomendações (1976) indicavam o padrão arquitetônico modular, rejeitando o padrão de } \\
\text { inspeção central. As Diretrizes (Resolução 12/1994) passam a permitir a liberdade criativa, } \\
\text { mantida nas revisões seguintes até a versão vigente (Resolução 9/2011). }\end{array}$ \\
\hline Pátio de sol dos presos & $\begin{array}{l}\text { Nas Diretrizes (Resolução 3/2005), os parâmetros mínimos foram reduzidos de oito metros } \\
\text { quadrados por preso para seis metros quadrados. Nas Diretrizes Básicas (Resolução 9/2011), este } \\
\text { parâmetro passou para um metro e meio quadrado por preso. A dimensão mínima de solário foi } \\
\text { proporcionalizada à quantidade de presos e se passou a admitir o rodízio do pátio. }\end{array}$ \\
\hline Espacialização & $\begin{array}{l}\text { Nas Diretrizes Básicas (Resolução 9/2011), diversas recomendações sobre os custos, } \\
\text { funcionalidade, separação dos presos e a humanização foram retiradas. }\end{array}$ \\
\hline Dimensionamento & $\begin{array}{l}\text { Nas Diretrizes Básicas (Resolução 9/2011), o índice de área construída por preso de } 12 \text { a } 15 \\
\text { metros quadrados teve o parâmetro superior modificado para } 65 \text { metros quadrados para } \\
\text { permitir a aprovação do projeto padrão da penitenciária federal. Houve uma descaracterização } \\
\text { dos parâmetros iniciais. }\end{array}$ \\
\hline $\begin{array}{l}\text { Dimensionamento - } \\
\text { cadeia pública }\end{array}$ & $\begin{array}{l}\text { Nas Diretrizes Básicas (Resolução 9/2011), o programa da cadeia pública foi equiparado ao de } \\
\text { penitenciária, com um acréscimo aproximado de } 75 \text { a 105\% de área construída (dependendo da } \\
\text { inclusão de itens opcionais, como quadras de esporte). }\end{array}$ \\
\hline
\end{tabular}

A tendência de continuidade da ênfase na segurança penitenciária e da otimização do espaço arquitetônico da prisão pode ser constatada no Projeto de Lei do Estatuto Penitenciário Nacional (DUTRA, 2011) que elenca uma série de medidas voltadas para a arquitetura, entre as quais são citadas a seguir aquelas previstas entre os artigos 88 e 89 :

a) A capacidade é ampliada para 1.400 a 1.660 vagas, sendo de 120 a 500 vagas em um módulo de vivência e até 250 vagas em uma ala carcerária;

b) Para as celas é previsto apenas o alojamento de oito vagas (a capacidade de seis vagas não é citada);

c) A cela de oito vagas tem dimensões mínimas de três por seis metros, perfazendo dezoito metros quadrados de área mínima (menor que o previsto nas Diretrizes Básicas).

Excepcionalmente, o Relatório Final da Comissão Parlamentar de Inquérito do Sistema Carcerário traz considerações a respeito do custo operacional em relação à arquitetura - "é exatamente neste item que uma arquitetura adequada faz a diferença, proporcionando a redução de custo direto, permitindo que o condenado tenha condições de uma pena digna e seja ressocializado" (BRASIL, 2009, p. 441-444). Este relatório subsidia o Projeto de Lei do Estatuto Penitenciário Nacional, acima tratado.

\subsection{Características formais da edificação penal}

A partir do levantamento das características formais da edificação penal realizada no Apêndice B é possível conduzir um exercício conjectural de descrição do espaço arquitetônico segundo os instrumentos legais e técnico-normativos abordados. Este exercício busca apresentar sinteticamente os dados que compõe a instancia analítica formal no capítulo 6 , desta tese. 
Para uma unidade do tipo penitenciária, os instrumentos examinados definem uma unidade de segurança máxima e de pequeno porte (até 300 vagas). A localização desta unidade é próxima do centro urbano ou de zona residencial, respeitadas a acessibilidade, comunicação, além de fatores econômicos e sociais. O edifício da mesma é dotado de estrutura física para o encontro com a sociedade (sala), o que inclui a visita social (salão) e o encontro íntimo (nove apartamentos), além de parlatórios para locução com o advogado (nove parlatórios).

Quanto ao isolamento dos presos, a unidade prisional idealizada pode apresentar cerca ou muro como barreira perimetral e a cela pode ser individual ou coletiva. Em qualquer caso, a barreira perimetral deve ter uma altura mínima de cinco metros. Ao se admitir a coletivização das celas, em uma unidade penal de 300 vagas são previstas seis celas individuais que podem ficar em um bloco independente para o isolamento de presos ou junto aos blocos de vivência coletiva. As celas prevêem cama e serviço sanitário (pia e vaso) que podem ser acrescidos de prateleira, mesa com bancos e divisórias, além de chuveiro. A cela individual tem minimamente seis metros quadrados. A cela coletiva pode ter até oito vagas $(1,73 \mathrm{~m} 2 /$ vaga). Do mesmo modo que a cela, o pátio pode ser coletivo com tamanho proporcional ao número de usuários.

O modelo preconizado adota os conceitos do padrão arquitetônico modular, prevendo passarelas entre os blocos funcionais. A geometria prevê o alinhamento e a ortogonalidade das fachadas. A verticalização é permitida. Porém, o arranjo das celas voltadas para uma área de convivência interna previsto no padrão modular é descartado nos projetos de referência federais.

O modelo idealizado soma aproximadamente cinco mil metros quadrados de área construída ${ }^{50}$ e ocupa um terreno de 11,7 mil metros quadrados, o que resulta em 16,60 e 38,93 metros quadrados por vaga, respectivamente. Espacialmente, o mesmo é organizado em três setores: externo, intermediário e interno. Estes setores correspondem a $19 \%\left(942,50 \mathrm{~m}^{2}\right), 37 \%\left(1.849,00 \mathrm{~m}^{2}\right)$, e $44 \%\left(2.188,50 \mathrm{~m}^{2}\right)$ da área construída. As atividades laboreducativas dos presos (oficina e sala de aula) ocupam 512 metros quadrados (10\% do total) e as atividades sociais 727 metros quadrados (14\% do total) - equivalente a $1,71 \mathrm{~m}^{2} /$ vaga e $2,43 \mathrm{~m}^{2} / \mathrm{vaga}^{51}$. Estes locais de atividades são localizados no setor intermediário. O setor interno é organizado em dois blocos de vivência coletiva com 144 vagas cada, equipados com pátio de sol, refeitório e ala carcerária que totalizam $2.755,00 \mathrm{~m}^{2}$ ou $32 \%$ da área construída. Em termos do

\footnotetext{
50 Área construída dimensionada para uma unidade de 300 vagas, baseada nas áreas mínimas definidas nas Diretrizes Básicas. As indefinições programáticas foram preenchidas pelo padrão arquitetônico modular e pelo projeto padrão de cadeia pública do Ministério da Justiça. Área de terreno dimensionada para uma unidade de 300 vagas, baseada na área construída estimada (70,60mx70,60m), acrescida dos afastamentos mínimos definidos nas Diretrizes Básicas (105,6x110,6m).

51 Áreas dimensionadas para uma unidade de 300 vagas. A área de trabalho foi estimada em 1,5m2 por preso. A área de sociabilização considera os pátios de sol dos presos e os locais de realização da visita social e íntima, além de local para o encontro reservado com o advogado (parlatório). São informados o percentual da área levantada em relação à área total construída e a relação da mesma com a capacidade do estabelecimento.
} 
domínio territorial, a setorização determina $12 \%$ de locais livres para os presos, $65 \%$ vigiados e $23 \%$ proibidos. A unidade penal tem um acesso único e aproximadamente 820 metros quadrados de circulações $\left(2,73 \mathrm{~m}^{2} /\right.$ vaga). O dimensionamento das aberturas de iluminação e ventilação é regrado pela NBR 15.220/2003 (ABNT, 2003) que determina aberturas de 16\% a $40 \%$ da área de piso, a depender da região bioclimática de implantação da unidade penal. A ventilação cruzada é obrigatória.

O controle nesta unidade fictícia mescla a vigilância indireta e a direta, respectivamente, da primeira e da segunda geração de estabelecimentos penais. Externamente, a unidade penal, passível de receber torres de vigilância, aparatos de segurança e pista de ronda. Internamente, os postos de controle são em número de cinco. A circulação exclusiva para os funcionários é prevista.

\subsection{Instrumentos técnico-normativos similares ou correlatos}

As Diretrizes Básicas elencam outros instrumentos normativos de modo a complementar os seus conteúdos. Todavia, entre estes instrumentos, apenas a NBR 15.220:2003 da Associação Brasileira de Normas Técnicas (ABNT) tange o universo da pesquisa realizada, conexa ao requisito de conforto ambiental (trata das aberturas de ventilação e iluminação) ${ }^{52}$. A ABNT não possui um conjunto normativo específico para a edificação penal. Por outro lado, algumas referências conseguem auxiliar na conformação do espaço arquitetônico penal, indiretamente ou em pontos específicos, tais como: a NBR 15.575:2013 e a ISO 6241:1984 $4^{53}$.

A NBR 15.575:2013 normaliza o desempenho de edificações habitacionais, por isso a sua contribuição para a composição da edificação penal é limitada, se atendo a critérios de segurança e habitabilidade pertencentes à Parte 1 - Requisitos Gerais, deste documento.

Uma edificação com finalidade prisional apresenta certas nuances que a diferenciam das edificações com finalidades de moradia ou de trabalho em muitos fatores, especialmente naqueles relacionados à segurança contra fugas [e resistência contra vandalismos] (UFSC, 2013, p. 11).

A ISO 6241:1984 lista requisitos que tratam do desempenho da edificação em termos da habitabilidade. Esta norma enfrenta as mesmas questões colocadas para a NBR 15.575:2013: as exigências próprias da especialização da edificação penal e a demarcação do objeto desta pesquisa.

\footnotetext{
52 Outros instrumentos citados pelas Diretrizes são: a Resolução do CNPCP n 06, de 09/05/2006 (Padronização Física de Estabelecimento de Assistência à Saúde nas Unidades Penais); a Resolução Anvisa n 50, de 2002; a Lei n 10.098, de 19/12/2000 (Lei de Acessibilidade para Portadores de Necessidades Especiais); a Instrução Normativa $n^{\circ}$ 01/2010 do Ministério do Planejamento, Orçamento e Gestão (trata da sustentabilidade na cadeia produtiva do edifício); os Códigos Ambientais e resoluções do Conselho Nacional do Meio Ambiente (Conama); e as normas de construção municipais e do corpo de bombeiros.

53 International Organization for Standardization (ISO): organização internacional de normalização, com o objetivo de criar normas que facilitem o comércio e promovam boas práticas de gestão e o avanço tecnológico, além de disseminar conhecimentos.
} 
Neste sentido, a mesma contribui nos requisitos de segurança ao uso e conforto higrotérmico, visual e antropodinâmico, além da pureza e qualidade do $\mathrm{ar}^{54}$.

Em suma, a NBR 15.575:2013 e a ISO 6241:1984 têm um caráter genérico, com informações em nível de recomendações para a composição arquitetônica da edificação penal, sendo mais objetivas nos quesitos e parâmetros de conforto ambiental, especialmente quanto ao desempenho térmico e lumínico (Quadro 5).

Quadro 5 - Critérios de desempenho da NBR 15575 e da ISO 6241 para o objeto de pesquisa

\begin{tabular}{|c|c|c|}
\hline NBR 15575 & ISO 6241 & Quesitos estudados \\
\hline $\begin{array}{l}\text { Habitabilidade: } \\
\text { funcionalidade e } \\
\text { acessibilidade }\end{array}$ & $\begin{array}{l}\text { Conforto } \\
\text { antropodinâmico }\end{array}$ & $\begin{array}{l}\text { Aspectos do desenho relativos à resistência humana, agilidade, } \\
\text { maneabilidade e ergonomia; facilidade de movimentos; habilidade } \\
\text { manual na operação de portas, janelas e controle de equipamentos }\end{array}$ \\
\hline $\begin{array}{l}\text { Habitabilidade: } \\
\text { desempenho térmico }\end{array}$ & $\begin{array}{l}\text { Conforto } \\
\text { higrotérmico }\end{array}$ & Controle da temperatura do ar - ventilação \\
\hline $\begin{array}{l}\text { Habitabilidade: } \\
\text { desempenho lumínico }\end{array}$ & Conforto visual & $\begin{array}{l}\text { Provisão ou controle da luz natural; possibilidade de escurecimento; } \\
\text { insolação; iluminação requisitada; contato visual com o mundo } \\
\text { externo e interno }\end{array}$ \\
\hline $\begin{array}{l}\text { Segurança: Segurança no } \\
\text { uso e na operação }\end{array}$ & Segurança ao uso & $\begin{array}{l}\text { Segurança durante movimentos e circulações; segurança contra } \\
\text { intrusões nas áreas comuns }\end{array}$ \\
\hline $\begin{array}{l}\text { Habitabilidade: saúde, } \\
\text { higiene e qualidade do ar }\end{array}$ & $\begin{array}{l}\text { Pureza e } \\
\text { qualidade do ar }\end{array}$ & $\begin{array}{l}\text { Ventilação adequada, controle de odores e cuidados com a pureza do } \\
\text { ar }\end{array}$ \\
\hline
\end{tabular}

Especificamente sobre o espaço arquitetônico prisional foram encontrados cinco trabalhos nacionais voltados exclusivamente para o desempenho da cela prisional, cuja definição de requisitos e critérios de avaliação foi obtida por meio da transposição das normas NBR 15.575:2013 e ISO 6241:1984. De uma forma geral, estes trabalhos ponderam sobre a adequação da NBR 15.575 para a cela, como sublinha o relatório do Núcleo de Pesquisa em Construção (UFSC, 2013, p.18):

Muitos dos critérios especificados na norma NBR 15575 são aplicáveis e necessários nas celas prisionais. Outros não se aplicam. Por outro lado, as celas devem atender a critérios de durabilidade anti-vandalismo e critérios de segurança contra fugas que não são aplicáveis para habitações normais.

Sobre os trabalhos mencionados, algumas considerações podem ser feitas:

a) O relatório Norie (UFRGS, 2006) apresentou o resultado da análise desempenho de celas modulares industrializadas com base na ISO 6241:1984. Como esta norma não fornece parâmetros ou valores a serem alcançados, este trabalho se limitou a comparar o sistema industriado com sistemas construtivos convencionais. Para tanto, foram realizados ensaios de materiais e feitas correlações com sistemas similares.

\footnotetext{
${ }^{54}$ A ISO 6241:1984 lista outros requisitos, tais como: estabilidade, conforto acústico, segurança contra fogo, estanqueidade, higiene e conforto tátil que destoam do objeto de pesquisa. Nesta norma, o conforto térmico citado abrange a umidade, sendo apresentado como conforto higrotérmico.
} 
b) O relatório da Análise do Sistema Construtivo Penitenciário - SISCOPEN (BRASIL, 2007) do ponto de vista das regras técnicas vigentes (CNPCP) e das exigências e demandas da realidade prisional. É o único entre os trabalhos listados que considera os custos de construção e operação de estabelecimentos penais em seu escopo.

c) O relatório NPC (UFSC, 2013) tem a sua contribuição abreviada, pois o mesmo tem outro objetivo: a elaboração de tabela de custos para a construção penal a ser adotada pelo Ministério da Justiça. Neste sentido, este documento se limita a emitir considerações sobre os requisitos de desempenho para a cela, utilizando-se da NBR 15.575, relacionada com outros instrumentos normativos. Este relatório indica as Diretrizes Básicas (CNPCP, 2011a) para parametrizar o requisito de funcionalidade da NBR (Volume I, item 3.9).

d) O relatório Cetac (IPT, 2008) objetivou a "elaboração de diretrizes para a avaliação técnica de sistemas construtivos inovadores, destinados à execução de celas prisionais" com base no modelo de diretriz do Sistema Nacional de Avaliações Técnicas (Sinat). O trabalho define os requisitos e critérios de desempenho que devem ser exigidos para sistemas construtivos de celas, dos quais foram coletadas algumas informações sobre a segurança, funcionalidade e conforto ambiental. Neste sentido, o documento traz referências de fontes normativas, nacionais e internacionais, inclusive das Diretrizes Básicas do CNPCP.

e) Os relatórios Cetac (IPT, 2010a; 2010b) apresentam a avaliação do desempenho de uma cela produzida pela empresa Verdi Sistemas Construtivos S/A, abordando, respectivamente, os requisitos térmico e lumínico, e outros propostos no relatório Cetac/IPT nº 107 898-205 (IPT, 2008). Estes trabalhos demonstram a avaliação de desempenho de um objeto real, implicando em considerações relevantes para esta tese.

O conjunto de relatórios encontrado elenca considerações, princípios, requisitos e critérios, sobre os quais três considerações precisam ser feitas. Em primeiro lugar, o relatório Cetac (IPT, 2208) afirma sua aplicabilidade para "estabelecimentos penais em geral". Todavia este, como os demais trabalhos, remetem à categoria de segurança máxima. Em segundo lugar, os relatórios expõem alguns quesitos e critérios que também são válidos para outros espaços da edificação penal. Sobre isto, o relatório Cetac (IPT, 2008) coloca: “os demais ambientes da penitenciária devem atender os requisitos e critérios de desempenho exigidos para edifícios, salvo exceções que, quando necessárias, são citadas na Diretriz proposta". Em terceiro lugar, a importância destes trabalhos também reside no apanhado e na síntese que os mesmos realizaram de normas de desempenho estrangeiras, em especial, da American Society for Testing and Materials (ASTM) ${ }^{55}$.

\footnotetext{
${ }^{55}$ O material da ASTM remete majoritariamente à resistência dos materiais, listando os ensaios necessários para a validação da edificação penal nos Estados Unidos. Outras normas, como a National Association of Architectural Metal Manufacturers (NAAMM), Facility Planning Criteria for Navy/Marine Corps - Construction Criteria Base - Unified Facilities Criteria (NAVY-UFGS) e National Fluid Power
} 
Em relação aos trabalhos citados, o Manual de Intervenções Ambientais para o Controle da Tuberculose nas Prisões (SANTOS et al., 2012) oferece uma aproximação mais significativa em relação ao tema prisional, ao apresentar recomendações para a ventilação e iluminação natural, acompanhadas de parâmetros e esquemas para o projeto arquitetônico, submetidas a considerações quanto à segurança penitenciária.

Segundo diversos pesquisadores, como Fairweather (2000, p. 24) no cenário mundial dois documentos normativos se destacam. Primeiro, o Handbook of Correctional Design and Construction (HCDC) (USA, 1949), nos Estados Unidos - "influente em todo mundo no melhoramento da qualidade [da arquitetura]". Depois, o Prison Design Briefing System (PDBS), no Reino Unido - "uma esplêndida realização multidisciplinar". Estas normas estabelecem critérios e soluções detalhadas para o espaço arquitetônico, segundo o regime penitenciário, nível de segurança e porte do estabelecimento penal. O PDBS apresenta padrões e especificações para unidades prisionais de seiscentos presos do tipo Category B training prison ${ }^{56}$ (Figura 17).

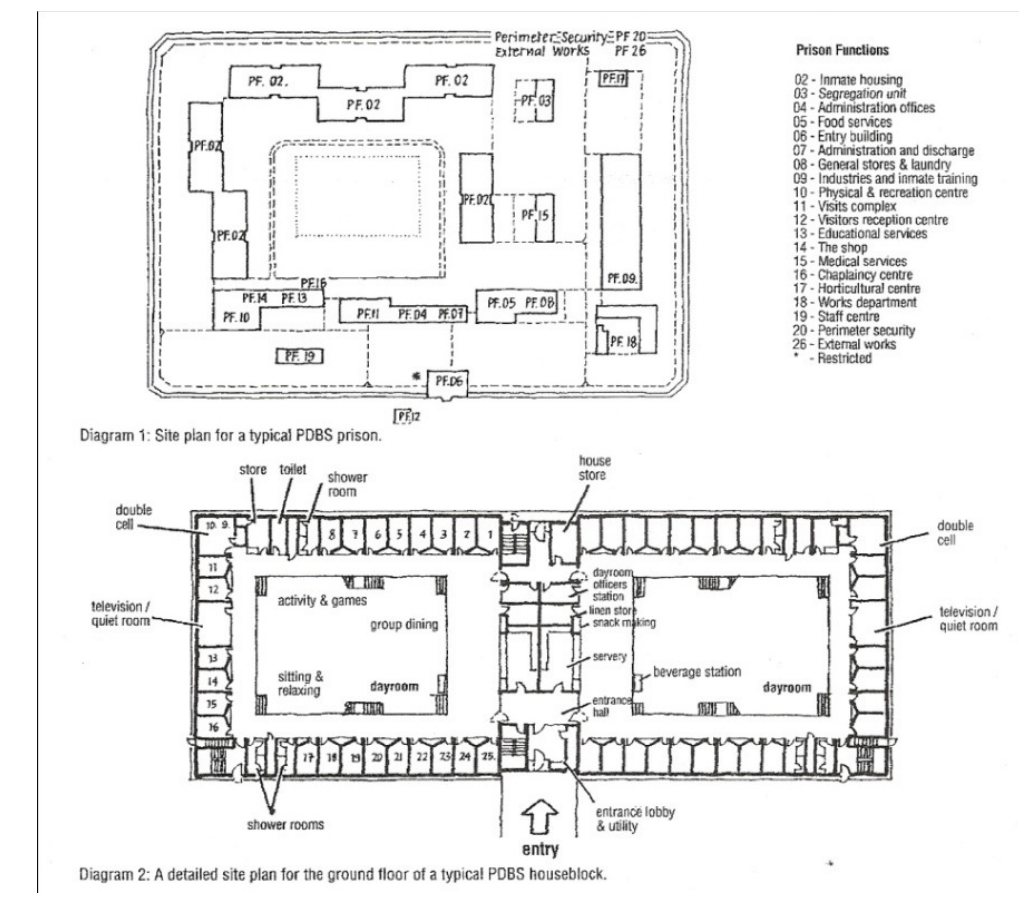

Figura 17 - Desenhos do modelo de prisão Category B do Prison Design Briefing System

Acima, planta de implantação; abaixo, planta do bloco de vivência. Diferente do modelo norte-americano tipicamente descrito por plantas triangulares, o modelo bretão tem planta retangular.

(Fonte: BOURN, 1994, p. 22)

\footnotetext{
Association (NFPA) abordam as exigências de resistência e durabilidade de elementos da edificação penal, como portas, janelas e mobiliário, diante das demandas de combate a fugas e ao vandalismo. Estas normas integram os relatórios Cetac/IPT, por isso, o estudo destes é considerado suficiente nesta tese, já que a materialidade e a resistência de componentes não integra o escopo de pesquisa.

${ }^{56}$ A training prison se destina a unidades regionais. A categoria B se refere à periculosidade dos presos, no caso, àqueles que dispensam o nível mais alto de segurança, mas cuja contenção deve ser reforçada (contra fugas).
} 
Nesta pesquisa, o HCDC não foi aplicado devido à defasagem do conteúdo do mesmo, já que o mesmo trata essencialmente da primeira geração de estabelecimentos penais, não havendo referência à segunda geração predominantemente utilizada nos projetos contemporâneos de maior segurança. Já o PDBS não foi obtido para esta tese, pois o seu uso é reservado ao Governo da Grã-Bretanha (Prison Department/Great Britain). Assim, os conteúdos do PDBS utilizados nesta pesquisa advieram indiretamente de outros trabalhos, tais como, o Control of prison building projects (BOURN, 1994) e o Certified Prisoner Accomodation of Her Majesty's Prison Service (PSI 17/2012).

Em relação ao HCDB e o PDBS, a referência normativa mais atual e abrangente é o Technical Guidance of Prision Planning (UNOPS, 2016), publicado pela Organização das Nações Unidas. Este manual compila as diretrizes arquitetônicas emanadas de acordos internacionais, tendo a Nelson Mandela Rules $^{57}$ como eixo condutor do trabalho (Quadro 6). O mesmo incluiu a última revisão realizada nas Regras Mínimas para o Tratamento de Presos de 1955. De um modo geral, este documento busca ressaltar a humanização do espaço arquitetônico, permeada nos princípios penalógicos e nos parâmetros arquitetônicos apresentados.

Quadro 6 - Temas da composição arquitetônica comtemplados pelo Technical Guidance of Prision Planning

\begin{tabular}{l|l}
\hline Quesito & Technical Guidance of Prision Planning \\
\hline Atividade prisional & $\begin{array}{l}\text { Traz os fundamentos do projeto de prisões, os sistemas prisionais, a questão da } \\
\text { superpopulação, a condição humana na prisão, a reabilitação e a reintegração, as fases do } \\
\text { sistema prisional e a segurança pessoal e prisional. }\end{array}$ \\
\hline Perfil prisional & Aborda os presos, a prisão, a operação, os funcionários e a localização. \\
\hline $\begin{array}{l}\text { Planejamento do } \\
\text { estabelecimento prisional }\end{array}$ & $\begin{array}{l}\text { Aborda o terreno, a implantação, as fases de projeto e construção e o planejamento } \\
\text { considerando a humanização da prisão }\end{array}$ \\
\hline Requisitos espaciais e & $\begin{array}{l}\text { Trata da barreira perimetral, do alojamento dos presos (cela e bloco de vivência) e do } \\
\text { posto de controle, além do pátio de sol dos presos, para os quais estabelece características } \\
\text { gerais e dimensionamentos mínimos. }\end{array}$ \\
\hline
\end{tabular}

Outra fonte técnico-normativa de referência para esta pesquisa foram os métodos e processos de certificação de desempenho sustentável de edificações, tais como, o Building Research Establishment Environmental Assessment Methodology (BREEAM) e o Leadership in Energy and Environmental Design (LEED) (Quadro 7) ${ }^{58}$. Atualmente, o BREEAM é o mais conhecido e mais utilizado método de avaliação do mundo, tendo sido utilizado como base para a formulação de diversos sistemas em outros países $^{59}$ (PEREIRA, 2010). Além disto, a BRE dispõe do caderno BREAAM Prisons (BRE GLOBAL, 2008) que é empregado em sua seção Saúde e Bem-estar (Health and Wellbeing) ${ }^{60}$. O

\footnotetext{
57 As Regras Mínimas para o Tratamento de Presos de publicação da própria ONU foi renomeada de Mandela Rules em homenagem ao legado do ex-presidente da África do Sul, Nelson Mandela.

58 O BREAM foi desenvolvido pela British Regulamentacion Estandartization (BRE) e o LEED pela U.S. Green Building Council (USGBC),

59 O Environmental Assessment Method (BREEAM) é uma certificação voluntária para edifícios verdes, que foi criada no Reino Unido pelo Building Research Establishment (BRE) em 1990.

60 A seção Saúde e Bem Estar lista outros requisitos, tais como: controle do reflexo, iluminação de alta frequência, níveis de iluminação externa e interna, qualidade do ar interno, compostos orgânicos voláteis, conforto térmico, controle térmico, contaminação microbiótica e performance acústica.
} 
LEED estabelece pré-requisitos e requisitos para a ventilação natural e conforto, muitos baseados na norma norte-americana ASHARE.

Quadro 7 - Quesitos de conforto ambiental contemplados pelo caderno BREAAM Prisons

\begin{tabular}{l|l|l}
\hline Quesito & Caderno BREAAM Prisons & LEED \\
\hline Iluminação diurna & $\begin{array}{l}\text { Prevê aos usuários do edifício suficiente luz } \\
\text { diurna }\end{array}$ & Requisito de luz natural \\
\hline Vista externa & Prevê a visão para o exterior do edifício. & Requisito de visibilidade externa \\
\hline Ventilação & Não é abordada. & $\begin{array}{l}\text { Requisitos de qualidade mínima do ar } \\
\text { interno e controlabilidade dos sistemas. }\end{array}$ \\
\hline
\end{tabular}

Um último documento de referência normativa foi o Certified Prisoner Accomodation of Her Majesty's Prison Service, que constitui instruções para o sistema penitenciário (PSI 17/2012), quanto à acomodação dos presos, visando a certificação e a operacionalização dos alojamentos dos presos (Quadro 8) ${ }^{61}$. O documento distingue duas modalidades de cela: 'não-lotadas' e 'lotadas', para as quais define nuanças nos parâmetros para a arquitetura. Para esta pesquisa foram adotados os padrões de lotação (capacidade máxima). Estes parâmetros mínimos abarcam quesitos funcionais e de conforto ambiental, sendo acompanhados de esquemas gráficos com soluções espaciais para a composição da cela (serviço sanitário, mobiliário e espacialização).

Quadro 8 - Quesitos contemplados pelo Certified Prisoner Accomodation

\begin{tabular}{l|l}
\hline Quesito & Caderno BREAAM Prisons \\
\hline Conforto Ambiental & Prevê iluminação, ventilação e aquecimento. \\
\hline Funcionalidade & $\begin{array}{l}\text { Prevê espaço adequado para cada preso e a possibilidade do uso do banheiro com alguma } \\
\text { privacidade em relação aos outros presos }{ }^{62} \text {. O local de cada preso deve providenciar } \\
\text { espaço para o mobiliário e para as atividades realizadas na cela. }\end{array}$ \\
\hline Assistência de emergência & Todos os presos devem ter meios para chamar a assistência quando necessário. \\
\hline
\end{tabular}

\subsection{Conclusão analítica}

A Lei de Execução Penal define que a reclusão não se limita à segregação do preso, ela atinge a questão da humanização da pena por meio da disciplina, do trabalho e da educação. Para tanto, esta Lei determina a classificação dos internos, a individualização da pena, a assistência do Estado e o programa de benefícios aos presos. Este é um princípio penalógico moderno que Bentham adotou na casa de correção - um projeto dedicado aos presos condenados, conformado pela custódia segura, confinamento, solidão, trabalho forçado e instrução (BENTHAM et al., 2008, p. 18). Por outro lado, o recente movimento penalógico tem promulgado medidas para o endurecimento da aplicação da pena

\footnotetext{
${ }^{61}$ o Her Majesty's Prison Service (HM Prison Service) é parte do National Offender Management Service, encarregado do gerenciamento da maioria das prisões da Inglaterra e País de Gales. O PSI 17/2002 substituiu a PSO 1900/2001.

62 A privacidade prevista na cela individual é maior que na coletiva, providenciada por um cubículo ou sanitário anexo que devem ser ventilados separadamente da área de convivência da cela.
} 
impactantes na arquitetura penal (ver capítulo 4). Segundo Garbelini (2005, p. 157): "vivemos atualmente um retrocesso arquitetural, prova disto é o resgate do isolamento pensilvânico pelo RDD (Regime Disciplinar Diferenciado), através da solidão e do silêncio do antigo e ineficaz modelo filadélfico”. Exemplo disto é o Presídio Inspetor Martinho Drumond, em Ribeirão das Neves/MG que suscitou a planta radial e o regime celular (Figura 18). Esta tendência é confirmada de modo mais recente pelo Projeto de Lei do Estatuto Penitenciário Nacional (DUTRA, 2011, p. 28) que, entre outras medidas, previa solários individuais acoplados às celas de isolamento, o que se aproximava do conceito da hipermax norte-americana (USA, 2017): o confinamento solitário constante, sem contato humano algum. Apesar do movimento de endurecimento da execução penal, comparativamente, o modelo prisional brasileiro tende a características mais brandas, sobretudo, ao permitir a coletivização das celas e o contato físico do preso com a visita de modo indiscriminado, no que diz respeito ao nível se segurança.

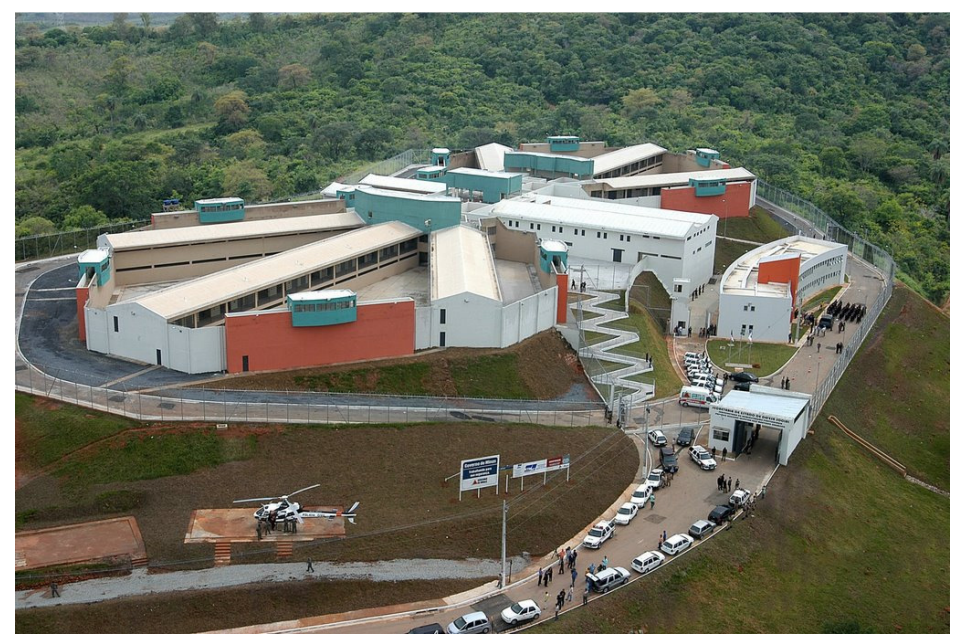

Figura 18 - Fotografia do Presídio Inspetor Martinho Drumond

(Disponível em: <http://hojeemdia.com.br/horizontes/agentes-mant\%C3\%AAm-greve-detentos-deneves-fazem-motim-e-rebeli\%C3\%B5es-podem-se-espalhar-em-minas-1.390680>. Acessado em: fev. 2017)

Em reação ao contexto penalógico atual, os instrumentos técnico-normativos de arquitetura ressaltam a segurança penitenciária e a otimização de recursos financeiros na construção de estabelecimentos penais. Isto foi deduzido tanto da ausência de uma diversificação arquitetônica correlata às categorias de estabelecimentos penais, como do alinhamento dos parâmetros apresentados com as características de maior segurança. Da mesma maneira, a comparação entre as versões das regras técnicas do Ministério da Justiça demonstrou a mudança penalógica em andamento, ao mesmo tempo em que explicitou que as alterações encontradas representam uma adequação à realidade do sistema penitenciário. Nestes casos, algumas das alterações realizadas foram importantes para uma adequação de parâmetros, evitando distorções na edificação penal. De um modo geral, estas revisões 
apresentaram gradualmente parâmetros mais compactos, por meio de um aumento das capacidades e de uma redução de áreas, dimensões e quantitativos, inclusive, ao se reforçar a generalização funcional e o uso alternado de espaços. Esta compactação corresponde ao observado na caracterização da edificação penal do país (ver capítulo 1).

O modelo prisional brasileiro e as respectivas regras técnicas de arquitetura indicam a atualidade do Panóptico enquanto base teórico-metodológica para a arquitetura penal (ver capítulo 2). Neste sentido, as Diretrizes Básicas materializam pontos da disciplina espacial panóptica (setorização das atividades, especialização funcional dos locais, separação doso fluxos por tipo de pessoas). Este indicativo também é verificado nas revisões das regras técnicas, quando ocorre a transição entre a primeira e a segunda geração de estabelecimentos penais. Nestas revisões se encontram traços do processo de humanização da pena que levou à pulverização do esquema espacial panóptico pelo corpo do edifício: a individualização, centralidade e a vigilância concentrada substituídos pela coletivização, modulação dos espaços e pela fragmentação da vigilância. Ao mesmo tempo em que a revisão do espaço arquitetônico da prisão recuperou algumas das características panópticas, por exemplo, ao induzir à vigilância direta, através da previsão de postos de controle.

Os instrumentos técnico-normativos federais estudados não fornecem um método para a organização do espaço prisional, no que diz respeito à articulação dos diversos componentes do programa arquitetônico. A maioria dos documentos não trata da composição espacial da prisão como um todo, mas de partes ou componentes. Isto porque não existe uma tradução dos objetivos e meios da execução penal para a concepção arquitetônica da edificação prisional. De certo modo, ocorre um descolamento entre os processos intermediários da atividade penal e a composição arquitetônica.

Como resultado, o edifício penal é tratado do ponto de vista geométrico, ignorando o funcionamento do estabelecimento penal. Nas Diretrizes Básicas, esta inconsistência é evidente ao embasar o programa arquitetônico no padrão arquitetônico modular, embora a organização espacial proposta não corresponda aos conceitos funcionais do padrão arquitetônico adotado. Atribui-se este desentendimento à questão da capacidade técnica do Ministério da Justiça, identificada nos equívocos cometidos nas revisões das regras técnicas ${ }^{63}$ (ESTECA, 2010).

A realidade ao longo dos séculos demonstra que as ideias, os projetos e as regras sempre estiveram dissociados da realidade carcerária, na medida em que os reclusos sempre foram e continuam sendo excluídos pelo Poder Público e pela própria sociedade a exemplo do Brasil (GARBELINI, 2005, p. 145).

\footnotetext{
${ }^{63}$ A revisão das regras técnicas denota a postura progressivamente descuidada da administração em relação às questões técnicas, verificada em uma redução do debate em torno do espaço construído da prisão (MIOTTO, 1992), associada a uma ingerência política na produção das Diretrizes Básicas (MACAULAY, 2002), quando recomendações foram alteradas para possibilitar a aprovação de projetos em desacordo com as regras técnicas (ESTECA, 2010). Isto ficou claro no objetivo da Resolução $n^{\circ} 03$ do CNPCP, que visava "[adequar] tanto do ponto de vista técnico quanto do ponto de vista político" a relação de parceria entre o DEPEN e os Estados.
} 
Apesar das considerações feitas, os problemas das Diretrizes Básicas não desabilitam o instrumento que estabelece conceitos, critérios e parâmetros importantes. Neste sentido, foi demonstrada a preponderância técnica das Diretrizes Básicas entre os instrumentos legais e técnico-normativos como referência para o projeto arquitetônico penal no país. Pelo contrário, este documento é a referência nacional para o projeto arquitetônico penal, tendo em vista que o Ministério da Justiça é o órgão máximo da administração penitenciária e o responsável pela regulação da arquitetura penal no país ${ }^{64}$. Por isto, o mesmo é adotado pelos órgãos penitenciários para a concepção e análise de projetos e pelos órgãos de controle para a posterior fiscalização de obras. Porem, a aplicação das Diretrizes Básicas deve ocorrer dentro de um reconhecimento de suas limitações. Isto implica na flexibilização de parte de suas exigências na confecção de projetos, tendo em vista que o próprio Ministério da Justiça não consegue projetar estritamente de acordo com as Diretrizes Básicas ${ }^{65}$ (Figura 19).

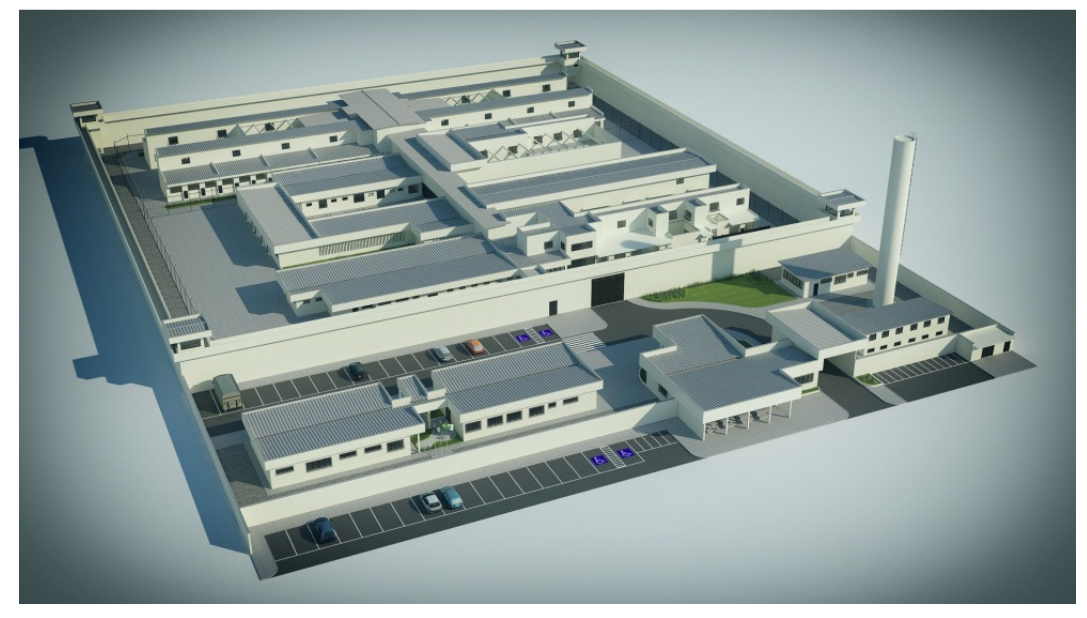

Figura 19 - Perspectiva eletrônica do projeto padrão de cadeia pública do Ministério da Justiça.

(Fonte: Departamento Penitenciário Nacional, 2011)

De modo a mitigar os problemas apresentados pelas Diretrizes Básicas, alguns conteúdos das versões anteriores foram resgatados, após serem alterados ou excluídos nas revisões efetuadas. O exame deste material mostrou a viabilidade do seu aproveitamento, pois este trouxe conteúdos conceituais e paramétricos que ainda encontram ressonância no projeto arquitetônico atual. Neste sentido, estes conteúdos apresentaram, em alguns casos, mais consistência e completude do que a versão vigente. De qualquer modo, as regras anteriores possibilitaram uma argumentação na discussão das questões normativas existentes.

\footnotetext{
64 O Conselho Nacional de Política Criminal e Penitenciária (CNPCP) é um órgão consultivo ao qual cabe a elaboração de normas supletivas à legislação, bem como providências específicas, de acordo com as peculiaridades de cada questão. Ao CNPCP compete "estabelecer regras sobre a arquitetura e construção de estabelecimentos penais e casas de albergados" (Art. $n^{\circ} 64$, inc. VI).

${ }^{65} \mathrm{O}$ projeto padrão do Ministério da Justiça apresenta 21 itens com atendimento parcial e 23 itens dissonantes das Diretrizes Básicas, entre eles podem ser citados: a substituição da cela individual no isolamento do preso por celas duplas (beliche) ou a cela coletiva para dependentes químicos com apenas oito vagas, onde são previstas dez.
} 


\section{Capítulo 4 - Realidade prisional}

Neste capítulo são levantadas as demandas informais para a composição do espaço arquitetônico penal, a partir do exame da política penitenciária nacional e do funcionamento das prisões. Esta abordagem caracterizou o sistema penitenciário e o cotidiano na prisão, particularizando o sistema brasileiro. A caracterização do espaço informal agregou as críticas e exigências levantadas no estudo de campo realizado. Este capítulo é complementado pelo Apêndice $C$.

Segundo Sergio Gárcia Ramírez (apud LEAL, 2009), o sistema penal engloba um "extenso 'equipamento' de delitos, penas, tribunais, prisões, etcétera”. Em outros termos, o sistema penal fornece a aparelhagem necessária para o exercício do direito-poder de punir do Estado que inclui o sistema penitenciário, este significando o conjunto dos estabelecimentos penais, conforme nomenclatura encontrada na Lei de Execução Penal (LEP) (BRASIL, 1984) ${ }^{66}$. Da atuação do sistema penal resulta a realidade prisional: a aplicação das normas, a implementação das políticas, o trabalho da administração e o funcionamento das instituições, considerando os insucessos e os problemas existentes na aplicação da pena.

O sistema penitenciário nacional é conformado pela legislação penitenciária e é conduzido pela política penitenciária (MIOTTO, 1992). Esta conformação implica em uma estrutura organizacional hierárquica das competências administrativas e da distribuição territorial da rede prisional que se conforma em função da modulação da pena (MIOTTO, 1992). Nesta rede prisional, em cada uma das prisões se desenrola o cotidiano prisional, regido pelo modelo prisional para o cumprimento dos objetivos da pena. Neste sentido, o cotidiano prisional pode ser reconhecido por meio das relações sociais e da disputa de poder que se desenrolam no mundo da prisão.

Todavia, a imagem da prisão para a sociedade diverge do "estatuto público de virtude moral, política e social" (MARKUS apud SPENS, 1994, p. 16). Por isto, se compromete a correta aplicação da pena, em especial, a assistência e o programa de benefício aos presos, além do respeito à condição humana, tendo em vista a interpretação de que estes não merecem ter acesso a benefícios. Com isto, são reforçados os processos totalitários de forma a compensar a deficiência dos procedimentos e serviços penitenciários. Segundo Goffman, a prisão não objetiva as mutilações do eu ou a vitória cultural sobre o preso. Trata-se apenas de racionalizações de um sistema que as usa como estratégia para o controle dos homens, criado do esforço para controlar a vida diária de um grande número de pessoas em um espaço restrito e com pouco gasto de recursos (GOFFMAN, 2005, p. 24 e p. 48).

\footnotetext{
${ }^{66}$ O conjunto de estabelecimentos penais recebe diferentes denominações na literatura jurídico-penal, tais como: sistema penal, sistema
} prisional ou sistema carcerário. $O$ termo 'sistema penal' é reservado para o aparato penalógico apontado por Ramírez (apud LEAL, 2009). 


\subsection{Política Penitenciária Nacional}

A atual política penitenciária reflete a conjuntura penalógica conformada no último quadriênio após a redemocratização do país. Entre as décadas de 1950 e 1960, as políticas penitenciárias no Brasil se resumiam à esfera estadual, pois havia um entendimento de que à União cabia apenas ditar regras gerais. De acordo com Miotto (1992, p.142), até a década de 1970, alguns estados apresentavam uma "exagerada ou distorcida noção de autonomia", com normas e práticas próprias, muitas destas fundamentadas em modelos estrangeiros ${ }^{67}$. Segundo esta autora, para estes estados era como se não existissem normas federais. Apenas partir da década de 1970, o Governo Federal passou a protagonizar as ações públicas no setor penitenciário. Neste sentido, uma política penitenciária nacional foi instituída, integrada e consonante com a realidade prisional (MIOTTO, 1992). Assim como, os órgãos penitenciários federais foram criados e foi promulgada a Lei de Execução Penal, além das regras técnicas para a arquitetura terem sido publicadas. Com isto, o sistema penal no âmbito federal estava consolidado em fins dos anos 2000, com seus princípios e finalidades, instrumentos legais e normativos, além de estrutura administrativa (MIOTTO, 1992).

A política elaborada na década de 1970 transpareceu os objetivos da reforma penitenciária. Segundo Pimentel (1978, p. 88), a Lei $n^{\circ} 6.416 / 1977$ revolucionaria o sistema de penas ao induzir a descentralização penitenciária, que previa a construção de unidades de porte menor e de regime semiaberto, territorialmente distribuídas. Segundo Miotto (1992, p.156), esta política colocava o delinquente "como pessoa, sujeito de direitos, de deveres e de responsabilidade" e objetivava "humanizar a pena, humanizar o próprio condenado, sem deixar os delinquentes impunes". Um exemplo disto foi o Centro de Internamento e Reeducação inaugurado em 1979 no Distrito Federal. Esta unidade foi anunciada como uma prisão completa, com vocação para a reinserção social, apresentando avanços como apartamentos para o encontro íntimo e som ambiente (SILVA, 2009).

A partir os anos 1980, a dinâmica do setor prisional foi transformada em função da política prisionalizante instalada no país $^{68}$ que substituiu progressivamente os objetivos da reforma penitenciária. Esta política remete a um endurecimento do sistema de justiça criminal em relação ao crime e ao criminoso, justificada no discurso oficial pela crescente onda de crimes e violência que se apresentou no Brasil e em outros países (MACAULAY, 2002). Citando o caso norte-americano, o sistema se voltou "a uma política criminal de extremo rigor e à imposição de sentenças longas, principalmente para crimes considerados graves como sequestros e homicídios dolosos” (LEAL, 1992,

\footnotetext{
67 Até década de 1960, as unidades prisionais icônicas do sistema penitenciário nacional foram iniciativas estaduais (ver capítulo1).

68 A política prisionalizante se fundamenta no discurso oficial da marginalização da criminalidade. No controle social, a criminologia tradicional infere conclusão que a maioria dos criminosos é pobre, embora a única conclusão válida é de que a pobreza é um traço característico do encarceramento (THOMPSON, 2003, apud SILVA, J.; RODRIGUES, 1989, p. 61).
} 
p. 50). No Brasil, se identifica nas leis a "inflação legislativa” ou 'legislação do pânico' (DOTTI, 2003). A execução da pena recebeu um reforço punitivo, evidenciado pela criação do Regime Disciplinar Diferenciado (RDD) e pela ampliação dos crimes considerados hediondos (FORTE, 2008). Outra decorrência da política prisionalizante foi a ênfase na construção de estabelecimentos de maior segurança (ESTECA, 2010). No ano 2000, a inauguração do Setor C no Complexo Penitenciário da Papuda demonstra a mudança na política penitenciária. $\mathrm{O}$ discurso da pena recuperativa proferido na inauguração do CIR foi substituído pela coerção e controle dos presos:

No Setor $\mathrm{C}$ - apelidado de Cascavel e que fica a dois quilômetros do CIR, a rotina é mais rígida do que no CIR. Os presos não têm tanta liberdade para ir e vir e ficam menos tempo nos pátios e, consequentemente, mais tempo trancafiados. [...]. Ali a vida é mais dura (ARAÚJO JUNIOR, 2005).

A política prisionalizante implicou na aceleração do crescimento da população carcerária e no consequente aumento da superlotação prisional nos países onde foi aplicada, como aponta Leal (1992, p. 53). Os Estados Unidos possuem hoje a maior população presa do mundo, totalizando cerca de dois milhões e meio de encarcerados (USA, 2017). No sistema penitenciário nacional, o contingente de presos no ano de 1995 era de 148.760 presos, segundo o senso carcerário deste ano (CARVALHO FILHO, 2002), enquanto no ano de 2014 superou a marca de 600 mil presos. Isto gerou o aumento exponencial dos gastos com os sistemas penitenciários, uma questão fundamental para os governos, pois sobrecarregaram os orçamentos públicos (MACAULAY, 2002). A conjunção destes fatores, somado ao despreparo das instituições, reforçou a situação de penúria dos sistemas penitenciários, o que agravou a crise penitenciária.

A primeira década do novo governo democrático viu 0 quase total abandono do sistema prisional. No entanto, a década de 1990 presenciou um aumento na atividade penal, resultando em um aumento acentuado nas apreensões e os números de prisioneiros que, por sua vez, em muito intensificou os atuais problemas de superlotação, falta de pessoal e má administração do sistema (MACAULAY, 2002, p. 4).

A aglomeração de presos nas prisões impulsionou a meta de geração de vagas nas políticas penitenciárias. Nos Estados Unidos, "o crescimento nos índices de criminalidade levaram para uma quase insaciável demanda por novas vagas" (FAIRWEATHER apud SPENS, 1992, p. 31). No Brasil, a política penitenciária da década de 1990 passou a ser direcionada a um projeto de renovação do sistema penitenciário, que tinha, entre as metas previstas, a construção de unidades penais. Este projeto de governo foi formalizado em diversos documentos do Conselho Nacional de Política Criminal e Penitenciária (CNPCP), dentre os quais se sobressaíram as Diretrizes Básicas da Política Criminal e Penitenciária (Resolução n 5/1999). O Programa Nacional de Segurança com Cidadania (Pronasci), lançado no ano de 2007, confirmou a continuidade desta posição, prevendo a criação de quarenta mil vagas em penitenciárias de segurança máxima. 
No ano de 2011, a política penitenciária federal passou a ser integrada pelo Programa Nacional de Apoio ao Sistema Prisional e pelo Plano Nacional de Política Criminal e Penitenciária (CNPCP, 2011b). Segundo a sua ementa, o Programa Nacional objetivava a recuperação do sistema penal, tendo como metas eliminar o déficit em estabelecimentos prisionais femininos e reduzir o número de presos em delegacias de polícia. Para tanto, o mesmo previa a criação de 42,5 mil vagas, sendo 27,5 mil com a construção de cadeias públicas, representando o investimento de 1,1 bilhão de reais. Por sua vez, o Plano Nacional de Política Criminal e Penitenciária colocava em suas diretrizes o objetivo de resgatar a cidadania e a responsabilização no sistema penal. O mesmo destinava uma de suas metas à arquitetura, na qual recomendava, principalmente, a compatibilidade espacial com as necessidades das pessoas e o respeito às necessidades humanas. Isto ratificou a afirmação de J. Silva e Rodrigues (1989, p. 64): “O objetivo formal, ideologicamente pregado pela política penitenciária, é a transformação do indivíduo criminoso em não criminoso, ou seja, a tratá-lo para que possa readaptar-se à sociedade e à vida livre".

A geração de vagas e a humanização da pena são apontadas por Thompson (1976, p. 15 e p. 31) como balizares para uma reforma penitenciária, em especial, a resolução da superlotação: "o ponto básico de uma reforma do sistema penitenciário brasileiro seria o de provê-lo de capacidade para absorver a clientela de sua atribuição". Neste sentido, a política federal parecia bem encaminhada. Todavia, os problemas da administração penitenciária desproveram as ações de governo de planejamento, capacidade executiva e recursos financeiros, o que comprometeu os resultados esperados.

Os orçamentos do Ministério da Justiça foram sucessivamente contingenciados pela política econômica do país, esvaziando a ajuda financeira aos sistemas penitenciários estaduais. Segundo o Ministério da Justiça, os recursos financeiros existentes não foram integralmente empenhados entre os anos de 2012 e 2014 - em 2012, por exemplo, não chegou a 70\%. Em setembro de 2015, o Supremo Tribunal Federal determinou o descontingenciamento de, aproximadamente, 2,4 bilhões de reais (Recurso Extraordinário 592.581) (CARVALHO, 2014). Esta escassez de recursos reforçou o foco sobre o custo de construção da política federal, cuja necessidade de redução dos valores das obras foi explicitada no Plano Nacional (CNPCP, 2011b).

O prazo de execução estipulado no Programa Nacional de dois ou três anos resultaria entre 14 e 21 mil vagas por ano, o que significava dobrar ou triplicar a velocidade de ampliação do sistema penitenciário, em comparação com a média anual obtida pelo Pronasci. Além disto, o Plano Nacional apresentava um orçamento seis vezes menor do que o previsto no Pronasci para se gerar uma quantidade de vagas semelhante, sendo dois terços das vagas previstas em unidades novas. Mesmo grosseiramente, se obtém uma estimativa de menos de 26 mil reais por vaga, enquanto no ano de 2007 o custo de construção já era calculado na ordem de 50 mil reais por vaga (BRASIL, 2009). 
Os recursos financeiros federais para as obras penitenciárias estaduais são disponibilizados com a opção preferencial de serem utilizados projetos padronizados elaborados pelo Ministério da Justiça (CNPCP, 2011a, p. 11). A elaboração de projetos padronizados data da década de 1950 com o intuito de minimizar as dificuldades encontradas: prazos emergenciais, deficiências técnicas, carência de recursos para a fase de projeto e processos burocratizados. Todavia, estes projetos apresentaram inconformidades e incorreções que dificultaram seu aproveitamento. Na retrospectiva dos resultados obtidos, nenhum dos projetos da atual conjuntura política foi edificado ${ }^{69}$.

Webster (1974) ressalta a importância da produção arquitetônica (a definição do objeto, o custo e o tempo de projeto e de obra) no planejamento de novas unidades penais. Em contrapartida, como coloca Garbelini (2005, p. 157): "faltam políticas públicas adequadas, que o sistema econômico globalizado e subjugador do terceiro mundo não permite implantar em total menosprezo ao detento". Como resume Jorge (2002, p. 113 e 115), "só se pensa no projeto quando as verbas para edificações aparecem [...] assim, o projeto não é, em geral, suficientemente valorizado pelo setor público, estando o foco de interesse maior concentrado na construção da obra".

\subsection{Sistema Penitenciário Nacional}

O sistema penitenciário nacional é integrado por um sistema federal e pelos sistemas estaduais e do Distrito Federal. Estes sistemas penitenciários variam consideravelmente entre si, principalmente no tamanho da população prisional e em relação ao índice de encarceramento - "os reflexos desta heterogeneidade legal são perceptíveis, na prática, na hierarquia institucional de comando do sistema penal, nos locais de superlotação, custos, salários, cumprimento de normas, etc.” (JORGE, 2002, p. 104). Entre os sistemas penitenciários estaduais destaca-se o paulista, por abrigar mais de um terço da população prisional do Brasil (BRASIL, 2014).

Em atendimento a classificação e a separação das pessoas submetidas à Justiça preconizada na Constituição Federal e na Lei de Execução Penal, os sistemas penitenciários devem contar com diferentes tipos e categorias de estabelecimentos que garantam a individualização da pena. Esta diversidade de classes pressupõe uma heterogeneidade do parque penitenciário. Porém, esta diversidade penalógica foi preterida nas políticas penitenciárias que confirmam a homogeneização histórica em torno de unidades fechadas e de segurança máxima. Na composição do sistema

\footnotetext{
${ }^{69}$ Foram considerados os projetos Déficit Zero (1998), o Centro de Reabilitação e Integração Social (2000) e o projeto para presos jovens adultos do Pronasci (2006).
} 
penitenciário, os tipos penitenciária e cadeia pública correspondem a quase $70 \%$ das 1.421 unidades prisionais existentes, abrigando cerca de $82 \% \operatorname{dos}_{\operatorname{presos}}{ }^{70}$ (BRASIL, 2009).

A geografia penitenciária oscila entre a centralização da política prisionalizante e a descentralização da reforma penitenciária. Por um lado, as grandes unidades prisionais com milhares de vagas localizadas nas capitais foram substituídas por unidades regionais de médio porte, em torno de 442 vagas (BRASIL, 2014). Por outro lado, prisões de grande porte ainda são edificadas, com destaque para o estado de São Paulo, enquanto a dispersão geográfica não alcança o estrato das comarcas.

O Brasil tem uma das maiores populações prisionais do mundo com, aproximadamente, 620 mil presos, que está em franco crescimento, em uma taxa média anual da ordem de 7\% (BRASIL, 2014). Apesar de quase dois terços dos estabelecimentos penais existentes terem sido construídos nos últimos vinte anos, o que representa em torno de 235 mil vagas criadas, o sistema penitenciário acumula um déficit de 230 mil lugares, o que configura a aglomeração de presos nas prisões - a superpopulação, definida por uma taxa de ocupação das unidades prisionais de mais de 160\% (BRASIL, 2014). Como consequência imediata, a classificação e a separação dos presos são relaxadas, principalmente quanto à situação jurídica e ao perfil pessoal, criminal e ofensivo do preso, ocorrendo a massificação da população prisional. "O programa de classificação é usualmente grosseiro, [...] verifica-se que a exigência legal não passa de ficção" (CARVALHO FILHO, 2002, p. 51).

De tal sorte, constroem-se caixas de concreto para onde são levados os presidiários, quaisquer que sejam as razões que tenham determinado a prisão. Misturam-se assaltantes com homicidas, traficantes com estupradores, jovens com veteranos do crime, condenados com presos provisórios (SILVA, H., 2008).

A superpopulação também repercute no esquema de segurança da unidade prisional e na segurança pessoal de funcionários e presos. Em um primeiro momento, ela exigiria o reforço numérico do contingente funcional (UNOPS, 2016, p. 26). Porém, o sistema penitenciário nacional também é caracterizado pela carência de recursos financeiros, humanos e materiais para a sua operação (MACAULAY, 2002). Em particular, a segurança penitenciária apresenta um déficit de cerca de 50 mil agentes penitenciários (BRASIL, 2014). Nas penitenciárias e cadeias públicas, a relação entre o número de agentes e presos ultrapassa um para oito ${ }^{71}$ (BRASIL, 2014). À sobrecarga de trabalho se somam as questões salariais e de condições de trabalho (treinamento, equipamento, serviços de apoio e espaço físico). O salário dos agentes penitenciários varia entre dois mil e setecentos reais no estado de São Paulo e sete mil e quinhentos reais no Distrito Federal, enquanto o funcionário federal recebe

\footnotetext{
70 Segundo dados do Infopen (BRASIL, 2014), a composição do sistema penitenciário nacional, indica aproximadamente 500 mil presos provisórios ou em regime fechado. Os estabelecimentos do tipo cadeia pública somam 725 unidades e penitenciária 260 unidades.

71 Segundo o Relatório Infopen 2014 (p. 79) apenas 38\% das unidades prisionais do país estão dentro da proporção recomendada de um agente para cinco presos (Resolução CNPCP n 9, de 13/11/2009). No Brasil, são 108 mil trabalhadores nas prisões, destes 73 mil agentes de segurança, para cuidar de 607 mil presos.
} 
cerca de cinco mil e quatrocentos reais (BRASIL, 2009). Por sua vez, o risco no interior da unidade penal é mais um desincentivo para a realização das atividades previstas, o que afeta especialmente o grupo de técnicos e profissionais responsáveis pela assistência do Estado e pelo programa de benefícios aos presos. Como afirma Dotti (2000), "Ela [a crise] é determinada, basicamente, pela carência de estruturas humanas e materiais e tem provocado nos últimos anos um novo tipo de vitimidade de massa - guardas, dirigentes, técnicos e familiares".

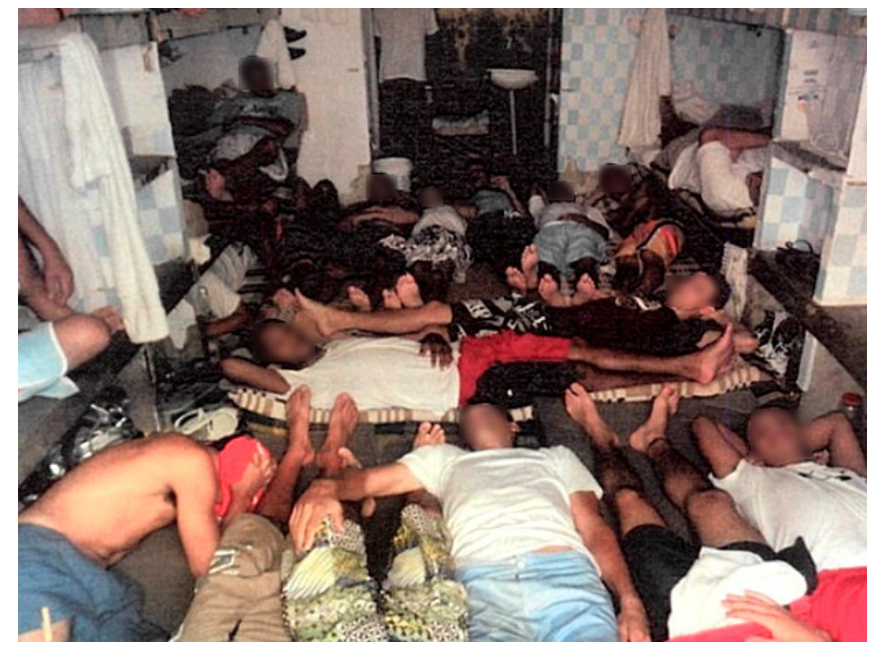

Figura 20 - Fotografia de cela do CDP de Taubaté com o piso (praia) tomado por colchões (Fonte: Disponível em: <http://g1.globo.com/sp/vale-do-paraiba-regiao/noticia/2012/11/imagens-mostramsuperlotacao-e-sujeira-no-cdp-de-taubate.html>. Acessado em fev. 2017)

Se a política penitenciária nacional leva à exigência de geração de vagas ao menor custo de construção, a superpopulação determina a maior geração de vagas possível, enquanto a carência de recursos operacionais, especialmente os humanos, remete à economia no funcionamento das prisões. Isto demanda unidades com grandes capacidades e favoráveis à otimização de pessoal, o que foi verificado nas regras técnicas para a arquitetura do Ministério da Justiça (ver capítulo 3). Especificamente, o Relatório Final da Comissão Parlamentar de Inquérito do Sistema Carcerário (BRASIL, 2009, p. 442) recomendava celas coletivas mais populosas e o uso de postos de controle, prevendo uma redução em até $55 \%$ do número de agentes penitenciários. O Technical Guidance of Prison Planning (UNOPS, 2016, p. 26 e 29) admite a aplicação destas soluções, justificadas pela isonomia na execução da pena, ao se levar em conta o disparate de um projeto de cela dentro dos padrões preconizados, diante da aglomeração de presos. Ao mesmo tempo, este documento sugere a definição de prazos para estas práticas dentro do planejamento prisional, de modo a não se institucionalizar a superpopulação. Esta preocupação existe nas Diretrizes Básicas para a Arquitetura Penal, ao se temporizar o uso da cela de maior capacidade, prevista na última revisão do documento. 
A aglomeração da população prisional e o descumprimento dos serviços penitenciários remetem a uma situação inerente de desrespeito à condição humana (UNOPS, 2016, p. 26). Como coloca Stern (2002, apud ROLIM, 2005), "prisões são muito ruins para a saúde - não apenas para a saúde dos prisioneiros e dos funcionários, mas para a saúde das pessoas que estão fora”. Chama a atenção o descaso com a iluminação, a ventilação e a temperatura, principalmente, nas celas. Doenças de pele e respiratórias são epidêmicas entre os presos. A Human Rights Watch concluiu em seu relatório anual referente a 2008, que "as condições de detenção no país são desumanas" (MARINER, 1998, p. 1).

\subsection{Paradoxo prisional}

Segundo Alvino de Sá (1990), a questão prisional se divide em dois tipos de problemas: um de ordem externa e outro de ordem interna. O problema de ordem externa está relacionado ao sistema penal, historicamente marcado pela incapacidade do Estado na implantação da reforma penitenciária e pela incorreção na aplicação da legislação. $O$ problema de ordem interna está relacionado ao funcionamento da prisão, abordando o choque existente entre o modelo e o cotidiano prisionais. Neste sentido, o mesmo está relacionado ao próprio objetivo oficial da atividade prisional: o isolamento do indivíduo para a sua reconfiguração comportamental segundo uma normalidade definida no pacto social. No entanto, "ninguém aprende a viver em liberdade, sem liberdade" (CASTRO apud SÁ, 1990, p. 10). O paradoxo da pena moderna remete a prisão à ausência de um objetivo claro e aí reside a contradição básica da instituição penal: executar a punição e, ao mesmo tempo, recuperar moralmente o indivíduo preso.

Por um lado, portanto, a pena de prisão traz como consequência o recrudescimento do confronto e do antagonismo entre o preso e a sociedade. Por outro lado, a reintegração social do preso só será viável mediante a participação efetiva, tecnicamente planejada e assistida da comunidade (SÁ, 1990, p. 9).

Para Goffman, o fato de trabalhar com pessoas e não com objetos inanimados cria a contradição do que a prisão deveria fazer e do que realmente faz. $\mathrm{O}$ caráter humanitário da prisão se expressa nos técnicos humanitários ou agentes de recuperação - "exemplo formal da humanização que se contrapõem aos muros como punição do crime" (GOFFMAN, 2005, p. 70). Informalmente, Goffman ainda descreve a "camaradagem dos funcionários" em relação aos problemas dos presos, que transforma estes em seres humanos. Neste sentido, Miotto ressalta na operação de um estabelecimento penal a importância da postura e da capacitação dos funcionários - "as prisões são o que é o seu pessoal, o que são os seus funcionários" (MIOTTO, 1986, p. 406). Como coloca Markus, "claramente o requerimento chefe seriam os recursos adequados de pessoal qualificado" (apud SPENS, 1992, p. $16)$.

Outro aspecto do problema de ordem interna da prisão está na aplicação dos esquemas disciplinares, pois se constata que "nenhum ser humano normal aceita naturalmente um poder totalitário que o 
controla 24 horas por dia” (SÁ, 1990, p. 11). Goffman (2005) e Foucault (1987) apresentam o cotidiano prisional como uma antítese aos modelos teóricos da Reforma Jurídico-Penal. A “inversão do cotidiano" estudada por Certeau e citada por Agostini (2002). Estes autores demonstram que os esquemas disciplinares idealizados para a rotina prisional são distorcidos pela natureza humana da atividade prisional, expressa nas relações sociais no mundo da prisão.

\subsubsection{Cotidiano prisional}

O cotidiano prisional é a antítese do modelo prisional, representando a dissonância entre o que é previsto na legislação e o que é efetivado na prisão. Como coloca Esteca (2010, p. 77):

É verdade que a Técnica Penitenciária absorveu alguns aspectos da Reforma Penitenciária e que alguns países apresentam uma configuração prisional mais próxima dos ideais reformistas. Mas, de uma forma geral, a reforma não alcançou êxito junto aos Sistemas Penitenciários no mundo, nos quais predominam o excedente de presos, a impropriedade dos edifícios, o despotismo desumano contra os internos e as irregularidades na aplicação dos regimentos, em especial no que toca aos direitos dos presos.

O cotidiano prisional é conformado pelas relações sociais entre funcionários, presos e visitantes (GOFFMAN, 2005). A relação entre os funcionários e presos configura o que Goffman (2005, p. 18) definiu como a divisão básica da instituição total: um grande grupo controlado por uma pequena equipe de supervisão. Estes dois grupos formam a sociedade prisional (MIOTTO, 1986, p. 370): "ladrões, estelionatários, traficantes, estupradores, assassinos e o pequeno grupo de funcionários armados que toma conta deles" (VARELLA, 1999, p. 10). Nela, o convívio é antagônico, se estabelecendo uma disputa de forças, na qual cada grupo estabelece estratégias de auto-preservação e dominação. Nesta disputa, cada grupo estabelece territórios e fronteiras: "a 'sociedade intramuros' compõe então grupos informais de poder que controlam setorialmente a Instituição" (ORNSTEIN, 1989).

$\mathrm{Na}$ sociedade prisional, os grupos integrantes apresentam nuanças internas, pois "nem a equipe dirigente, nem o grupo de internados são homogêneos" (GOFFMAN, 2005, p. 102). Os funcionários podem ser classificados segundo a função que desempenham: administrativos, apoio (reparos, manutenção e limpeza), agentes de recuperação (profissionais de assistência e do programa de benefícios), agentes de segurança e guarda externa. Os presos são classificados, por exemplo, em vitimadores, normais e vítimas (ORNSTEIN, 1989, p. 13 e WENER, 1993, p. 8).

As relações sociais nas prisões, formais ou informais, individuais ou coletivas e o "medo de parte a parte" entre presos e funcionários conformam o cotidiano prisional. Da impossibilidade de se implantar corretamente as rotinas elaboradas pela administração, resulta um "pacto latente" entre as partes. "Constitui-se, pois, assim, um ambiente artificial, do qual ninguém gosta, num primeiro momento, mas ao qual todos, com o tempo, acabam aderindo, de uma forma ou outra" (SÁ, 1990, p. 
11). Segundo Goffman (2005, p. 150), "Em outras organizações formais, (como as "muradas") o objetivo oficial pode ter pouca importância, e o problema principal pode ser a conservação ou sobrevivência da própria organização". Logo, importa para o Estado a manutenção da imagem pública institucional da prisão: "organizações racionais, conscientemente planejadas como máquinas eficientes" (GOFFMAN, 2005, p. 69).

A realidade prisional implica na transferência parcial de poder do Estado para os presos, modificando a divisão assimétrica do poder interno na prisão (GOFFMAN, 2005, p. 18). É em torno deste poder adquirido informalmente que se organiza a sociedade dos presos. Como afirma Goffman (2005, p. 246), "sempre que se impõem mundos, se criam submundos". A sociedade dos presos é "um poder informal e uma cultura paralela, definindo regras, costumes, uma ética própria e até mesmo critérios e condições de felicidade e sobrevivência" (SÁ, 1990, p. 11). A justiça entre os presos ilustra esta organização, quando as regras e as punições são definidas pelos mesmos - "os ladrões tornam explícito que seu código penal é implacável quando as vítimas são eles próprios" (VARELLA, 1999, p. 43). A organização dos presos é um movimento de liberdade, onde procuram reaver valores sociais perdidos com a vida na prisão, que foge ao planejamento institucional e à idealização do modelo penitenciário (MIOTTO, 1992).

Nas prisões são encontrados exemplos da 'economia da prisão' (ESTECA, 2010), controlada pelos presos, eventualmente com participação dos funcionários, que se aproveitam do descaso do Estado em favor de interesses extra-institucionais. Segundo a observação de Varella (1999, p. 143), o comércio interno é fundamental para a vitalidade desta economia: "existe custo de vida na cadeia" - "A você que é preso, e não tem dinheiro/ se prepare para anos de sofrer e padecer" (MORAIS apud SILVA, A., 2002, p. 49). Na prisão tudo é negociado: comida, cama, armas, utensílios, drogas, transporte, informação, além de espaço e outros itens. Este comércio é alimentado por uma indústria domestica de serviços e produtos, subsidiada por um conhecimento vivencial concernente à cultura da prisão, além do abastecimento por contrabando, evidenciando a importância de canais com o mundo externo.

O aumento do poder dos presos pode atingir a autogestão, na qual os mesmos passam a definir e controlar rotinas internas do estabelecimento (LEAL, 1992). Neste sentido, os termos negociados no pacto da sociedade prisional são reconfigurados, sendo concedidas aos presos regalias e o acesso a itens restritos ou proibidos.

Para obter-se a tranquilidade no ambiente carcerário, é preciso contar com a colaboração dos sentenciados. [...]. No final da linha, portanto, são os presos que comandam o sistema, pois com eles está a chave da tranquilidade. Se não colaborarem, o sistema balança, e eles conhecem sua força de pressão (PIMENTEL, 1978, p. 84).

No jogo de forças existente, o Estado busca limitar ou reaver o poder transferido aos presos, como salienta Agostini (2002): "Esgotadas as concessões, as possibilidades de negociação e mesmo de 
manipulação da própria delinquência, torna-se necessário voltar a monitorar e condicionar, por um período determinado, todos os movimentos dos presos". O endurecimento do tratamento dos presos é obtido por meio de uma intensificação dos processos totais, o que remete à disciplina-bloco descrita por Foucault (1987, p. 173). O modelo supermax ilustra isto, ao enfatizar o isolamento absoluto e retirar as atividades dos presos, embora o conforto ambiental seja respeitado. Neste regime, as celas são operadas remotamente e, quando fora delas, os presos permanecem nos blocos de vivência (pátios fechados) sob forte contenção e acompanhamento dos funcionários (WENER, 1993) (Figura 21). Eventualmente, os presos são autorizados a comerem juntos.

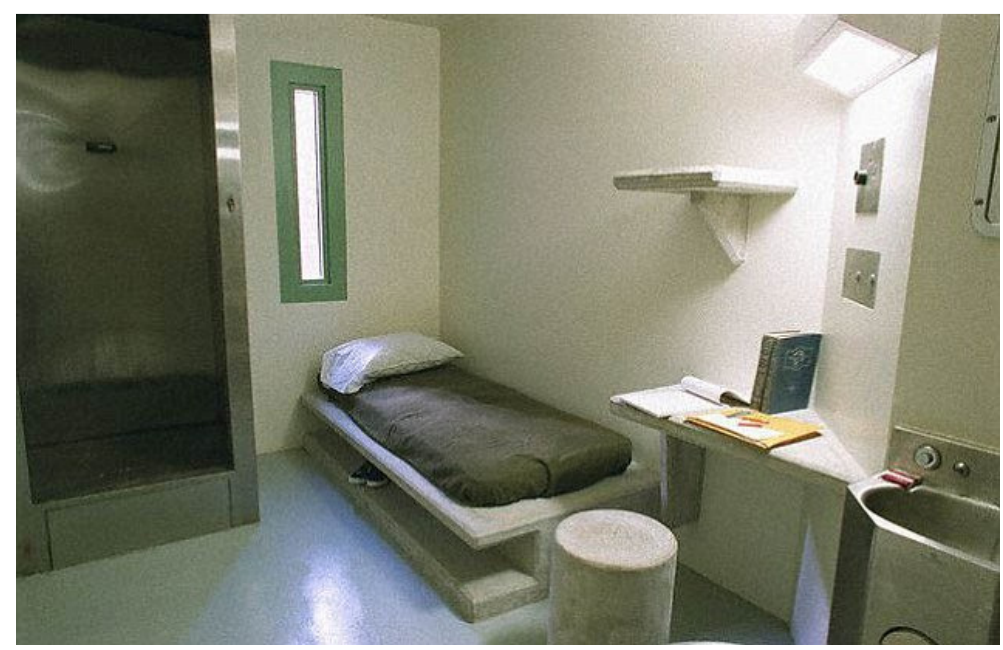

Figura 21 - Fotografia da cela da ADX Florence supermax

(Fonte: Disponível em: <https://www.bostonglobe.com/metro/2015/04/25/the-alcatrazrockies/a0BWrZjRpmQatMsfm8FUOL/story.html>. Acessado em: fev. 2017.)

Do ponto de vista da instituição, um dos métodos habitualmente utilizados para a acomodação do preso no mundo institucional é a mortificação, na qual se extirpam os "agentes contaminantes" (GOFFMAN, 2005, p. 24-40). São esquemas de retirada da identidade (perda do papel social), propriedade (nome, corpo e objetos), imagem (como se apresenta o eu) e sociabilização (contato interpessoal), por meio da massificação (morte civil), mutilação (física) e indignidades (humilhações). Ao mesmo tempo, a instituição reorganiza o eu do preso por meio das regras da casa, baseadas em um sistema de castigos e privilégios que podem incluir a própria liberdade e o trabalho.

A reação dos presos à mortificação ocorre nos ajustamentos secundários, igualmente descritos por Goffman. Eles são entendidos como uma reação a um sentimento de injustiça do preso de que o castigo "ultrapassa o que merece e que é imposto por aqueles que não estão livres de culpa" (GOFFMAN, 2005, p.56). Estes ajustamentos são os códigos, contrabandos, recortes, gozações e confraternizações. Já a adequação dos presos às regras da casa é providenciada por táticas de adequação: o afastamento da situação, a intransigência, a colonização, a conversão e "se virar". Esta 
última é apontada por Goffman como a mais comum, derivada da conjunção de ajustamentos secundários e adequações com o objetivo de tornar a vida na prisão mais suportável, ou seja, menos ariscada.

Destaca-se no processo de adaptação das pessoas à vida prisional o fenômeno da prisionalização: a “adoção em maior ou menor grau dos usos, costumes, hábitos e cultura geral da prisão" (THOMPSON apud SÁ, 1990, p. 10), substituindo a cultura obtida na família e na sociedade (GOFFMAN, 2005, p. 23). Para o preso, a prisionalização carrega a insegurança, o embrutecimento, a solidão, a ociosidade, o abandono da família, o desajuste sexual e as incertezas quanto ao futuro livre (OLIVEIRA, 2002. P. 13). Para os funcionários, representa as "violências inúteis dos guardas" e o "despotismo de uma administração que tem privilégios entre quatro paredes" (FOUCAULT, 1987, p. 208).

A rotina prisional se divide em dois momentos: dias com e sem visita aos presos. Nos dias de visita, a monotonia da rotina prisional é rompida e, de forma relativa, os processos totais são amenizados e o caráter humano na prisão é resgatado. Para os presos é uma oportunidade de sociabilização, de proximidade do mundo exterior e, no caso do encontro íntimo, de maior privacidade. Em decorrência desta experiência se verifica uma redução das tensões da prisão (a violência em geral), oportunamente aproveitada pela administração do estabelecimento penal. Para a instituição, a visita implica em procedimentos operacionais exaustivos para garantir a segurança e a representação institucional (UNOPS, 2016). Isto porque a visita complica o esquema disciplinar da prisão, vista como potencial vítima em motins ou cúmplice em tentativas de fuga e no contrabando. Apesar disto, a visita social é interpretada pela instituição como um ônus necessário, ao reduzir o estresse interno, o que favorece a segurança, e ao facilitar o controle dos presos, quando passa a integrar o sistema de castigos e privilégios. Os procedimentos e representações variam conforme o tipo de visita: social, conjugal, jurídica e oficial (UNOPS, 2016). Nos demais dias sem visita, a rotina da prisão se volta para o cotidiano dos presos, o que significa retornar à atonia dos processos totais.

\subsubsection{Cotidiano prisional no Brasil}

A realidade do sistema penitenciário brasileiro, marcada pela superpopulação e pela carência de recursos particulariza alguns aspectos dos mecanismos sociais e de poder do cotidiano prisional no país. Para Salla (1999, p. 311), "alguns aspectos próprios de nossa formação social, política e administrativa tornaram os cenários do encarceramento mais dramáticos". Em um ordenamento mais amplo, as obrigações do Estado na execução penal são descumpridas, o que implica na falta de compromisso e de adesão dos presos ao pacto social - efeitos descritos por Goffman (2005). Ao mesmo tempo, o lapso na segurança impede a disciplina interna, descrita por um abrandamento dos processos totais e das mortificações: ocorre uma maior liberdade de atividades e de movimentação, 
uma menor vigilância ou afrouxamento em procedimentos e rotinas em alguns setores, além da permissividade de posse ou uso de itens restritos e proibidos. A exceção é o Regime Disciplinar Diferenciado que mantém as características de maior segurança na prática prisional.

No isolamento social dos presos, o rompimento da comunicação dos presos com o mundo externo é relativo nas prisões brasileiras, apesar do caráter indispensável deste para a conformação da disciplina prisional, por meio da perda do papel social e da promulgação dos direitos e deveres ligados a nova situação social (GOFFMAN, 2005, p. 24) (ver capítulos 1 e 2). Informalmente, a transgressão dos presos sobrepuja a barreira perimetral da unidade prisional, por meio visual, verbal ou material, através de faixas escritas, gestos, gritos e bilhetes lançados. O que se prolonga no interior da unidade, por meio do contrabando de bilhetes e aparelhos comunicadores para o interior da prisão. Formalmente, a administração participa da abertura institucional, ao autorizar televisores e rádios, sem qualquer censura sobre a programação disponível (GOFFMAN, 2005). Assim como, a visita social interfere fortemente no isolamento social, ao apresentar o caráter liberal que permite o contato físico e conjugal dos presos. Este modelo é justificado pelos benefícios na prática prisional, ao fortalecer laços familiares e prevenir as violências sexuais na prisão, considerada epidêmica no sistema norteamericano (CARVALHO FILHO, 2002, p. 29).

Quanto ao isolamento individual dos presos, a aglomeração e a massificação dos presos inviabiliza a individualização absoluta legalmente prevista. Atividades tipicamente individualizantes são coletivizadas na realidade prisional, como o alojamento e o banho de sol dos presos, com consequências para a pretendida maximização dos esquemas de mecanização e controle na prisão, além de desdobramentos para a economia de recursos, vislumbrada por meio da administração total - a tendência institucional de transformar as pessoas em objetos inanimados (GOFFMAN, 2005, p. 31). Isto é reforçado pela uniformidade das celas, diferente das celas de diferentes tamanhos recomendadas pela ONU (UNOPS, 2016, p. 88).

Com a massificação e a coletivização, a mortificação dos presos pelo isolamento é substituída por outra modalidade, identificada por Goffman (2005, p. 31 e 35) como contato interpessoal imposto, no qual a vida forçada em grupo contamina o eu de diferentes maneiras: pela violação da reserva de informação do corpo e do espaço; pelo contato com grupos indesejáveis; ou pela exposição das intimidades no uso do banheiro e nos procedimentos de revista, assim como, na exposição da vida familiar na visita. Os presos nunca estão inteiramente sozinhos, perdendo a sua privacidade, o que prejudica a manutenção da sua identidade - "Sabe lá o que é isso, doutor, entra ano e sai ano, nenhum minuto o senhor pode ficar na sua?" (VARELLA, 1999, p. 39). Como lembra Sá (1990, p. 252), "privacidade, identidade - fatores de inestimável importância para a saúde mental e para a readaptação social". 
A cela passa a integrar o que Goffman (2005) denominou de territórios de grupo, nos quais os presos compartilham um local encarado como lar com um grupo limitado de companheiros. Neste espaço, os presos também constroem seu ambiente individual, possibilitando uma manifestação do eu, da autoimagem e do exercício da sua identidade - recriação de um conjunto de identidade (Figura 22 e Figura 23). Mesmo que, no caso da cela coletiva, este espaço individual esteja restrito à cama. Goffman (2005, p. 200) descreve este local como território pessoal, em uma conotação de refúgio "onde o indivíduo cria alguns elementos de conforto, controle e direitos tácitos" - "o cortinório é de lei, devido que senão, tem gente olhando para mim o tempo todo" (VARELLA, 1999, p. 39). O preso o toma como seu: nele estão seus pertences e nele ocorre sua intimidade.

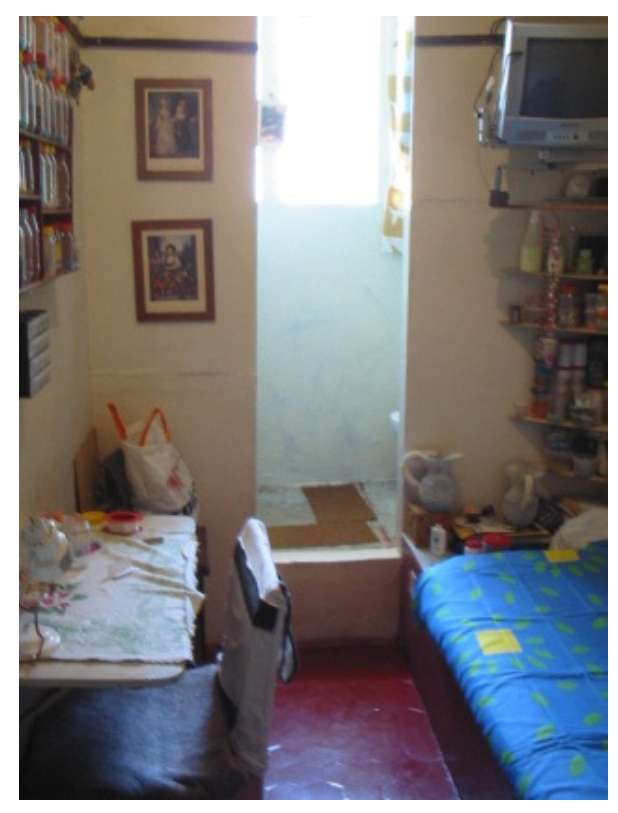

Figura 22 - Fotografia da ocupação cotidiana do espaço prisional na Penitenciária Lemos Brito/BA (Fonte: Fotografia do autor)

Como agravante à perda da privacidade, a carência de pessoal na prisão mantém os presos nas celas por longos períodos de tempo - "O lugar onde a gente vive deveria ser maior. A gente fica 20 horas trancado, como se fosse uma maquininha do capeta" (SÁ, 1990, p. 255). O Technical Guidance of Prison Planning (UNOPS, 2016, p. 80) recomenda pelo menos dez horas por dia fora das celas.

Se o número de guardas, por diminuto, pode manobrar, apenas, uma população prisional de cem presos, basta adotar o expediente de manter os internados trancados nos cubículos dia e noite, privados completamente do sol, para habilitar aquela quantidade de funcionários a custodiar mil e quinhentos (THOMPSON, 1976, p. 21).

Sá (1990, p. 255) levantou que a situação de contato imposto prolongado pode inverter a lógica do isolamento em depoimento de preso: "É preferível a cela individual. A gente tem tempo para pensar, para raciocinar bem". Como coloca este autor: "Aqui a cela já é valorizada como reduto da 
individualidade, como um lugar de solidão construtiva, de encontro consigo mesmo. Valoriza-se a privacidade e o preso sente a invasão dessa privacidade" (SÁ, 1990, p. 255). Sá ainda constatou que os próprios agentes penitenciários reconhecem a importância da individualização do espaço:

Presídio, é com celas individuais. O preso é o dono da cela. Não acontece do mais fraco ter que se submeter. O preso é que vai cuidar de sua cela. Evita a promiscuidade. O indivíduo não é obrigado a dividir seus objetos. Na cela coletiva, a ideia nunca é a mesma (SÁ, 1990, p. 256).

Outra particularidade nacional é o fechamento da cela, o que a caracteriza como o local de maior privacidade dos presos em relação à instituição. O modelo norte-americano, por exemplo, permite a visualização do interior da cela pela vigilância, o que expõe fatos íntimos que normalmente seriam resguardados, sendo os presos observados em circunstâncias humilhantes, por exemplo, no uso do banheiro. Na prática penitenciária, o fechamento da cela encontra uma justificativa além do respeito à intimidade dos presos, pois dificulta a comunicação entre as celas e inibe os ataques dos presos contra os funcionários.

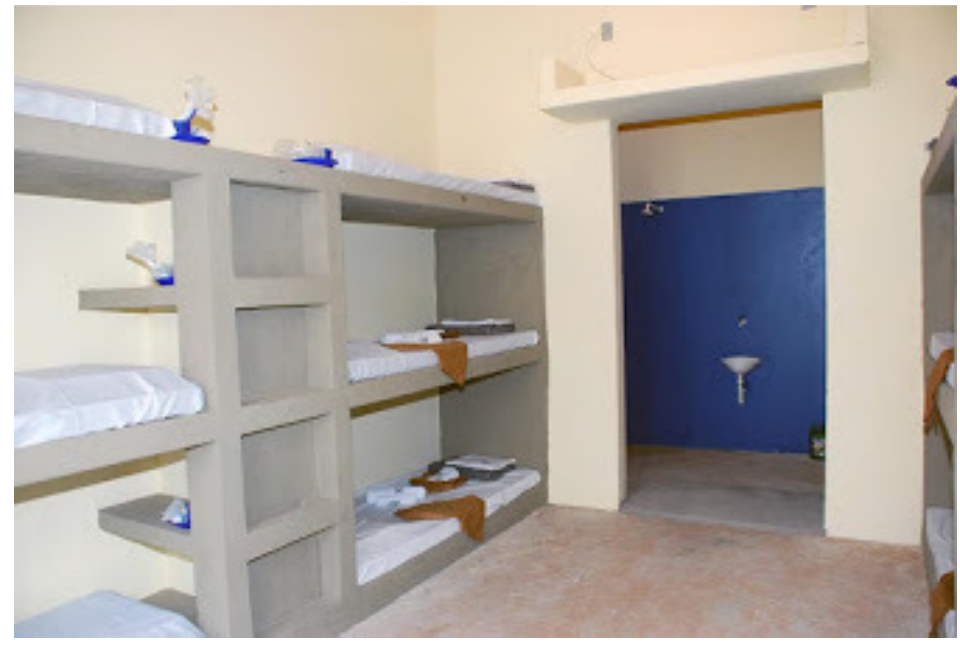

Figura 23 - Fotografia de cela coletiva de Penitenciária Compacta paulista (Fonte: Fotografia do autor)

Se a cela é o local de manifestação da individualidade e de maior privacidade dos presos, o pátio de sol é o lugar de maior aglomeração e sociabilização dos presos, ao juntar os grupos das celas ou alas carcerárias. Além disto, o pátio é o local mais amplo e aberto do edifício prisional, onde os presos podem exercitar mais extensivamente a liberdade cabida. Por isto, configura entre os locais de maior concentração do esquema de segurança do estabelecimento ou recai como território dos presos, algumas vezes sendo inacessível aos funcionários. De qualquer modo, a realidade prisional destaca o pátio de sol entre os espaços das atividades coletivas dos presos. Para a maioria dos presos, o tempo fora das celas é normalmente preenchido pelo banho de sol nos pátios. Em alguns sistemas 
penitenciários, a instituição aproveita a presença dos presos nos pátios de sol para efetivar atividades formais programadas, tais como, a revista estrutural ou funcional nas celas.

No Brasil, as atividades dos presos são inexistentes, insuficientes ou inadequadas (OLIVEIRA, 2002): apenas $11 \%$ da população prisional está envolvida com atividades de educação e $16 \%$ em atividade laboral (BRASIL, 2014). Em geral, "na prisão os internos são submetidos à ociosidade" (GOIFFMAN, 2000): "Como o trabalho é privilégio de poucos, passam o dia encostados, contam mentiras, nas rodinhas do pátio, levantam peso na academia, jogam capoeira no cinema, andam para baixo e para cima, inventam qualquer bobagem para se entreter e, principalmente, arrumam confusão" (VARELLA, 1999, p. 142). Segundo Jorge, "o problema surge mais com a falta de oferta de trabalho e mesmo recreação dentro dos presídios do que com a falta de interesse dos presos em se dedicar a um ofício" (2002, p. 106). Na prisão, qualquer serviço precisa ser aproveitado para a ocupação dos presos. Por isto, parte dos postos de trabalho deixada pela operação penitenciária é preenchida pelos mesmos: "Justiça seja feita, porém: com exceção das atividades ligadas à segurança, as demais tarefas da cadeia são executadas pelos presos" (VARELLA, 1999, p. 142). Neste sentido, o trabalho na prisão perde o valor existente na sociedade, adquirindo uma conotação de ocupar o tempo: "haja muito ou pouco trabalho, o indivíduo que no mundo externo estava orientado para o trabalho tende a tornar-se desmoralizado pelo sistema de trabalho da instituição total". O trabalho dos presos intercepta a questão da educação na prisão: "O nível educacional de grande parte dos presos no Brasil é baixo, reduzindo as possibilidades de trabalho dentro da prisão" (JORGE, 2002, p. 106).

A abreviação da assistência do Estado e do programa de benefícios aos presos na prática prisional conduz ou justifica na composição arquitetônica a retirada ou a minimização dos espaços destinados às atividades dos presos (ver capítulo 3). Conforme o Relatório Infopen (BRASIL, 2014), nas unidades penais levantadas não existem locais para a assistência social em 63\%, assistência jurídica em 25\% e assistência à saúde em $63 \%$. Este relatório também informa a ausência de salas de aula em $48 \%$ das unidades investigadas, além apenas $9 \%$ com sala de informática, 32\% com biblioteca e $18 \%$ com sala de professores. O trabalho do preso é agraciado com espaço de oficina em somente $22 \%$ das unidades.

O dever descumprido do Estado é compensado, em parte, pela economia da prisão. O tempo dos presos é preenchido por iniciativa própria com atividades que têm valor na sua sociedade: produção de armas e ferramentas, criação de esconderijos, planejamento de motins, fugas, distúrbios etc. Os amotinamentos, a depredação do edifício e as ameaças aos funcionários são estratégias para barganhar com a direção da unidade penal e obter regalias, às vezes, distorcendo o sistema de castigos e privilégios. Eventualmente, existe a participação de funcionários nestes atos. As ações dos presos ainda estão relacionadas ao cansaço de estar preso, às vezes, misturado ao tédio (MIOTTO, 1986). 
A escassez de recursos concentra o esquema de segurança nos procedimentos imprescindíveis para a estabilidade institucional e a manutenção de uma rotina interna mínima: a estanqueidade do estabelecimento (combate às fugas ou resgates de presos) e o cumprimento de atividades essenciais (transferência e condução dos presos entre as celas e os pátios de sol). O papel cotidiano da equipe funcional se restringe ao cumprimento da pena do ponto de vista punitivo, com pouca ou nenhuma conotação de orientação ou supervisão das atividades dos internos, o que exclui os cuidados com as atividades de reinserção social. Como coloca Pimentel (1978, p. 83 e 84), os diretores de presídios dão importância muito maior às metas informais da prisão, que são a segurança e a disciplina, do que as metas formais centradas no trabalho de reinserção social do sentenciado.

A administração dos presídios, conforme se constata, orienta-se prioritariamente, para não dizer quase que exclusivamente, no sentido de preservar a segurança, a ordem, a disciplina, de evitar fugas e rebeliões. Um diretor que obtenha êxito nessas frentes é tido como um bom diretor (SÁ, 1990, p. 16).

A reconfiguração do sistema de segurança remete a uma externalização da atuação institucional, ao afastar o corpo funcional das atividades internas da prisão. Neste sentido, o Estado abriu mão de parte do controle do interior das prisões. Conforme Goffman (2005), a lacuna institucional deixada pelo Estado acaba sendo ocupada pelos presos, o que para Macaulay (2002, p. 3) representa uma "perda de controle do Estado dentro das penitenciárias".

Pelo que eu pude constatar nesses últimos anos, a inoperância e a incompetência do estado favoreceram que os presos tomassem um espaço que o Estado não ocupou que, aliás, o Estado desocupou - ele se retirou - e que ficou na mão dos presos (SOUZA apud BRASIL, 2009, p. 50).

Com a externalização institucional, o poder dos presos eventualmente atinge o patamar de autogestão: "Deve ficar claro que o Estado deixou a corrupção e a criminalidade assumirem papel que deveria ser exclusivamente seu: o de impor a ordem, a disciplina e o respeito da integridade das pessoas sob sua responsabilidade" (BANGU I, 2000). Em alguns sistemas estaduais, a sociedade dos presos alcança um nível de organização e potencial ofensivo impositivo sobre o Estado, o que remete ao status de estado dos presos, havendo a presença de facções criminosas ${ }^{72}$ (BRASIL, 2009, p. 48). Exemplo disto é Primeiro Comando da Capital - grupo criminoso criado no sistema penitenciário paulista que conta com estatuto de conduta, estrutura administrativa e recursos operacionais (COUTINHO, 2016). Diante disto, no que diz respeito ao despojamento do $\mathrm{eu}^{73}$, a prisão brasileira apresenta uma amenização das limitações sobre a individualidade do preso. Ao invés da padronização da imagem e da perda da propriedade idealizada pela instituição, é comum encontrar a preservação de símbolos pessoais, o acúmulo de pertences e a apropriação relativa do lugar e da rotina.

\footnotetext{
${ }^{72}$ A faç̧ão criminosa é o "conjunto de atividades ilícitas que operam no mercado, disciplinando-o quando as atividades legais ou o Estado não o fazem" (ZAFFARONI apud BRASIL, 2009, p. 48).

${ }^{73}$ Goffman (2005, p. 29) descreve este processo de mortificação do preso e o define como perda da propriedade, no qual o regime carcerário separa o indivíduo de seus bens - a identidade e os bens materiais.
} 
A reação da instituição ao empoderamento dos presos por vezes degenera em violência - "o fantasma da segurança nas prisões e as ações dos dirigentes, justificadas em seu nome" (GOFFMAN, 2005, p. 77). A Anistia Internacional (1999, p. 3) afirma que "a atmosfera de violência e intimidação, associada às condições de detenção degradantes, afeta também o pessoal carcerário e os policiais, bem como a comunidade circundante". Em relação aos funcionários, Varella (1999) aponta problemas como o alcoolismo e a obesidade. "O comportamento da gente muda. Fica mais esperto. A gente perde a confiança nos outros. Começa a desconfiar dos outros na rua" (depoimento de agente penitenciário, SÁ, 1990, p. 256). Se a prisão é o que são os funcionários, como defende Miotto (1986), esta situação pode ser resumida pela colocação de um agente penitenciário do Distrito Federal, em suposta resposta a um egresso:

Embora você tenha passado por experiências que Ihe marcaram e presenciado a ação de algum policial que não seja correto, a bandidagem de Brasília merece coisa muito pior do que isso que você passou, pois eles matam vidas por nada. Contudo, pessoas de bem, trabalhadores e pais de família, devem ser excluídos desse tratamento desumano (apud SILVA, I., 2009).

De qualquer maneira, nos sistemas onde se acirrou a disputa de poder, a exasperação das relações sociais entre funcionários e presos reforçou o antagonismo e a divisão básica da sociedade prisional descrita por Goffman, ressaltando a violência como forma de demonstração de força. Esta situação remete à necessidade de separação física entre os funcionários e os presos.

\subsection{Características informais da edificação penal}

Com base no levantamento de campo realizado (ver Apêndice C), a caracterização informal do espaço arquitetônico pode ser apresentada sinteticamente como a seguir, sendo ressaltados os dados que compõe a instancia analítica formal no capítulo 6, desta tese.

A caracterização do espaço arquitetônico convergiu para a segurança máxima, com ênfase na impermeabilidade institucional, associada à localização do estabelecimento, embora a particularização desta categoria não esteja clara para os funcionários (as diferenças entre os níveis de segurança).

As equipes dirigentes consideram a melhor capacidade do estabelecimento em 600 presos e o fracionamento destes em quatro grupos de 96 a 160 presos como satisfatório para a classificação e separação da população prisional. Foi explicitado que cada ala carcerária deve ser subdivida em quatro grupos de 24 a 40 indivíduos para o uso alternado dos locais coletivos, como do pátio de sol (evita a aglomeração excessiva). Esta subdivisão favorece a separação de perfis minoritários que devem ser isolados dos demais, com colaborados e trabalhadores - os 'regalias' ou 'regime de observação', além de ofensores sexuais e sexualmente divergentes, entre outros. 
A cela coletiva com uma capacidade entre quatro e oito vagas foi considerada a mais adequada por funcionários e presos, com uma recorrência considerável em torno de seis vagas. A cela individual é considerada insuportável por uma boa parcela dos presos entrevistados, sendo vista pela administração como necessária apenas para o gerenciamento da prisão (isolamento para proteção ou aplicação de medida disciplinar).

A organização funcional é definida pelas atividades dos presos e pela segurança penitenciária, que estabelecem tarefas e procedimentos qualificadores da simplicidade ou complexidade operacional, atreladas ao uso do tempo e aos recursos disponíveis. A princípio, a eficiência deste sistema é buscada por meio da integração da equipe funcional e da fragmentação da população prisional. A interligação entre os componentes do espaço arquitetônico deve disciplinar o fluxo da informação, de modo a integrar as equipes funcionais e isolar os presos entre si e da rotina institucional. As equipes externas e internas devem poder se comunicar mutuamente (visual e verbalmente), conformando um conjunto coeso. Os grupos de presos devem ficar incomunicáveis entre si (celas, alas carcerárias e salas de atividades) e devem ser privados de conhecimento sobre os procedimentos institucionais. Estas demandas implicam no posicionamento e constituição dos locais institucionais e dos locais dos presos, em termos dos ângulos, distancias e aberturas.

A visita social e íntima aos presos é considerada imprescindível pela equipe dirigente e é primada pelos presos, por isto deve contar com local específico e apropriado para disciplinar a atividade e resguardar as visitas do contato com a rotina interna e com presos sem visita. O lugar deve receber brinquedos para as crianças e mobiliário dimensionado para as famílias (mesa com quatro lugares). A visita conjugal deve ser quantificada, em razão do regime, número de encontros conjugais e tempo de permanência (os presos gostariam de duas horas e os funcionários consideram uma hora suficiente).

A condução e a aglomeração dos presos surgiram como situações críticas para a equipe dirigente, em termos da segurança e do tempo dedicado para a revista corporal dos presos e a revista física dos locais (estruturais e funcionais). Na busca por contrabandos, os procedimentos operacionais se desdobram nestas revistas, efetuadas a cada movimentação dos presos ou uso dos espaços, principalmente, nas celas e nos pátios de sol. Em alguns casos, várias vezes por dia. A revista estrutural nestes locais em busca de pontos de fuga é cotidiana, enquanto a revista funcional atrás de objetos proibidos ocorre semanal ou mensalmente. Desta constatação emergiu a importância das contenções nos corredores (grades) ou junto ao posto de controle (gaiolas) para as revistas corporais, embora a revista nestes lugares comprometa a segurança (exposição aos demais presos e interdição da circulação). Neste sentido, os funcionários cogitaram a criação de salas de revista junto à ala carcerária, pátio de sol e salão de visita. As revistas físicas nas celas e pátios de sol dos presos podem incluir represálias de ambos os lados - funcionários e presos, ao envolver a punição por eventuais 
rotas de fuga, contrabandos ou outras indisciplinas encontradas. Por isto, estas revistas físicas devem ser realizadas sem a percepção dos presos, o que exige a especialização funcional dos locais.

Os riscos na condução de presos revelaram a preferência da equipe dirigente pela localização mais interna das áreas de sociabilização (social, conjugal e jurídica), assistência (sala para atendimento imediato) e benefícios aos presos (trabalho, educação, alimentação, culto e banho de sol). Esta localização internalizada foi indicada pelos funcionários nos blocos de vivência. Em particular, para um funcionário, "a visita é mais trabalhosa, mas é mais segura - não oferece risco". A internalização das atividades dos presos concentra os fluxos e as permanências dos presos, o que possibilita otimizar os recursos operacionais.

O trabalho e a educação são considerados essenciais pelos funcionários e presos, vistos como meios benéficos para administrar o tempo, redimir a pena e preparar para o retorno social, por isto oficinas e salas de aula devem ser previstas. A biblioteca é valorizada pelo hábito da leitura na prisão, podendo funcionar no sistema de empréstimos por solicitação dos presos, a partir de uma listagem do acervo disponível nos blocos de vivência.

A segurança penitenciária define aspectos primordiais para a organização funcional, como a previsão de postos para a vigilância e controle, justificados pela separação espacial de funcionários e presos (garantir a integridade). Os funcionários entendem que a disposição dos postos de controle deve ser central, por agrupar o maior número de espaços ao redor, o que reduz o pessoal operacional. Invariavelmente, o pátio de sol é destinatário de um posto de controle, o que reflete a importância funcional deste local. Para os funcionários, o princípio da inverificabilidade é considerado importante no esquema de segurança (os presos são impossibilitados de enxergar o interior dos postos de controle - ver capítulo 2), ao aderir à disciplina da informação e à otimização de recursos. A adoção de postos de controle não desabilita a realização de rondas, principalmente no período noturno, já que a visualização do interior das celas é relativa. A estrutura de apoio aos funcionários deve contar com sanitários próximos aos postos de controle, em quantidade superestimada de modo a evitar a espera.

A barreira perimetral do tipo muro foi apontada pela equipe dirigente como melhor fechamento para o estabelecimento penal, pois garantiria a impermeabilidade institucional e a proteção dos funcionários (contra disparos por arma de fogo). Para a equipe dirigente, as propriedades de estanqueidade e inexpugnidade não são tão relevantes para a escolha do tipo de barreira, pois o muro e a cerca oferecem resistências similares à fuga (salto), enquanto o perfil dos presos reduz a probabilidade de resgate (considerando haver estabelecimentos penais de segurança especial). Da mesma maneira, a definição da altura da barreira perimetral se abrevia é majoritariamente condicionada pela 
impermeabilidade do estabelecimento penal. Com isto, a geometria regular da barreira perimetral e a amplitude dos afastamentos ganham importância no desempenho da barreira perimetral.

A cela e o pátio de sol dos presos sintetizam a coletivização e a generalização funcional do espaço arquitetônico da prisão que trazem demandas em termos das atividades e do conforto ambiental, obviamente, moderadas pela segurança e pela operação penitenciárias. Destas demandas, emerge uma possível complexidade espacial da cela, descrita pelo fracionamento do espaço e incremento do mobiliário, com atenção especial ao banheiro. Em destaque, surge a ideia de uma área de apoio multiuso. A necessidade de melhoria do conforto ambiental ocorre de modo associado à questão privacidade-vigilância. A privacidade se desdobra nos níveis individual (cama), público (banheiro) e coletivo (indefinido), segundo as relações sociais do grupo alojado. Enquanto o controle institucional relativiza a privacidade da cela, ao exigir a exposição da intimidade dos presos.

O pátio de sol reproduz as questões de privacidade, porém o caráter coletivo deste naturalmente minimiza a individualidade e a privacidade dos presos. A natureza gregária e a imposição de um controle ostensivo no pátio de sol mudam a perspectiva de divisão do espaço para o abrigo das atividades extraordinárias, tendendo à especialização funcional acompanhada da criação de espaços específicos adjacentes. Ao pátio se atribuem principalmente o jogo de futebol e a caminhada/corrida exigências majoritárias dos presos. A importância da religião leva a necessidade de local para a prática, podendo ser compartilhado com outras funções (educação), embora os presos prefiram um lugar próprio - em São Paulo, o atendimento ocorre durante todo o dia, em cela do pavilhão. A alimentação dos presos em refeitório é preterida pela administração, devido à vulnerabilidade da segurança - a condução, revista e aglomeração de muitos presos, embora a logística de entrega das marmitas e recolhimento do lixo seria mais simples. O refeitório também é visto negativamente pela maioria dos presos que preferem a privacidade da cela para se alimentarem.

As demandas da segurança penitenciária e das condições de trabalho dos agentes são melhor representadas pelo posto do pátio de sol dos presos, devido ao grau de exigência deste lugar. Como prioridade, a segurança penitenciária exige a capacidade de visualização máxima, associada à necessária otimização da equipe funcional.

Para os funcionários, os postos de controle devem ser inexpugnáveis, de modo a evitar a captura de agentes pelos presos. Neste sentido, o mesmo deve ter uma saída de emergência. $\mathrm{O}$ fechamento do posto condiciona as aberturas de iluminação e ventilação, assim como, para os procedimentos junto aos presos (comunicação e contenção). Segundo os funcionários, as aberturas de iluminação e ventilação devem ser distintas das aberturas para os procedimentos. O serviço sanitário e o mobiliário 
são considerados importantes pelos funcionários para a comodidade na permanência nos postos de controle.

\subsection{Conclusão analítica}

As condicionantes políticas e realísticas do sistema penal para a arquitetura têm implicações para a composição espacial da prisão, em termos da segurança, funcionamento, conforto ambiental e custos, que são verificados no exame dos projetos de referência adotados nesta pesquisa (Capítulo 1). Estas implicações são definidas, principalmente, pela postura prisionalizante do Estado e pela reconfiguração parcial dos princípios de funcionamento da prisão previstos no modelo prisional, mediante a aglomeração dos presos e a carência de recursos para a operação penitenciária.

As condições de superlotação e penúria do sistema penitenciário nacional ressaltam o determinismo arquitetônico na produção projetual, dentro de uma distorção do papel da arquitetura no sistema penal. Para Esteca (2010, p. 110), a administração penitenciária impõe exigências extravagantes e tecnicamente inviáveis ao projetista, quando se atribui a resolução de problemas de segurança e operação unicamente ao espaço físico. Neste sentido, transfere-se para a arquitetura questões que, fundamentalmente, não são exclusivas de sua competência e que dependem de uma série de fatores, como uma equipe funcional bem dimensionada e preparada (UNOPS, 2016, p. 30). A tentativa de conciliação destas questões no espaço arquitetônico dificilmente foge de uma desfiguração dos princípios da composição arquitetônica panóptica, normalmente caracterizada por uma complexidade espacial e funcional da prisão: os altos custos dos presos associados às construções mal feitas, projetos arquitetônicos deformados e reformas paliativas (BRASIL, 2009, p. 352). Na prática prisional, esta complexidade caracteriza um excesso de procedimentos de identificação, contagem, revista, condução e controle de pessoas ou de lugares que desacelera o cumprimento das tarefas e compromete a segurança, ao exaurir as pessoas (funcionários, presos e visitantes) e expor a instituição, seja pela possibilidade de erro humano ou pelos improvisos nos protocolos.

No planejamento da ampliação do parque penitenciário, o discurso de endurecimento da execução penal se mistura às vantagens colaterais do modelo de segurança máxima. As propriedades da arquitetura de maior segurança são exaltadas como modelo de boa arquitetura, pois atingem o objetivo da segregação social (evitam as evasões de presos), além de possibilitarem um gerenciamento relativo da população prisional disforme (disciplina mínima para o funcionamento do estabelecimento penal). Um bom exemplo disto é a indicação pela Comissão Parlamentar de Inquérito do Sistema Carcerário das estruturas modernas encontradas no país: as unidades da Papuda/DF, Presidente Bernardes/SP, Central do Espírito Santo/ES e a Federal de Catanduvas/PR - todas de alto nível de segurança (BRASIL, 2009, p. 462). Deste modo, se encontrou uma justificação para o modelo de maior 
segurança, apesar de seu custo mais elevado em relação a uma unidade de segurança menor (UNOPS, 2016, p. 21).

Ao mesmo tempo, as prioridades operacionais e econômicas da política penitenciária, associadas às indefinições ou incoerências legais e normativas, constantemente deturpam o modelo de segurança máxima. A demanda formulada pela administração penitenciária conforma uma unidade prisional de maior porte, ao menor custo de construção, embora a estrutura física tenda a aumentar, pois acumula as exigências de maximização da segurança e de reinserção social dos presos. A resposta arquitetônica é o aumento da capacidade do estabelecimento penal, o que otimiza a estrutura física e reduz o custo de construção, em termos relativos - o valor da vaga a ser gerada. Neste sentido, a arquitetura penal tem sido atrelada à necessidade emergencial de ampliação do parque penitenciário e à disponibilidade de recursos para as políticas penitenciárias, "o que constitui a verdadeira política habitacional do capitalismo tardio" (GARBELINI, 2005, p. 156). De uma forma geral, para o Estado basta que o setor técnico elabore projetos arquitetônicos de grande porte, com baixo custo de construção e seguros: é considerada uma boa arquitetura aquela que exalta estes aspectos (ESTECA, 2010).

Em particular, a relação conturbada entre a sociedade e a instituição prisional traz repercussões sobre o isolamento social dos presos. A repulsa social define o afastamento geográfico dos núcleos urbanos e o desinteresse por qualquer participação na vida prisional. Por outro lado, a mesma tem levado à escolha por terrenos segundo o critério do 'menos pior': "hoje, dificilmente um município importante aceita novos presídios em seu território" (JORGE, 2002, p. 114). Não raramente são oferecidos terrenos pequenos ou inaproveitáveis. O que é agravado pela falta de uma política fundiária para o sistema penitenciário. Em particular, o dimensionamento da prisão é uma questão conexa ao tamanho dos terrenos a serem ocupados e ambas se somam à maximização da vigilância das áreas externas para definir uma compactação da edificação.

A abordagem da realidade prisional evidencia os motivos pragmáticos que levam às características da edificação penal brasileira (ver capítulo 1), em alguma medida incorporadas às regras técnicas de arquitetura do Ministério da Justiça (ver capítulo 3). Em primeiro lugar, a imposição financeira sobre o projeto arquitetônico significa a concentração dos presos, providenciada pelo aumento da capacidade, associada à redução da área construída observada na edificação penal (ver capítulo 1). Nos projetos de referência estudados, a otimização da área construída é obtida por meio da coletivização no uso dos espaços, generalização funcional dos locais e da minimização ou retirada de itens do programa arquitetônico, especialmente dos espaços voltados para as atividades dos presos.

Em segundo lugar, a postura da administração penitenciária no exercício do poder na prisão define duas estratégias operacionais que resultam em arranjos espaciais distintos, associados à territorialidade 
na prisão: em um arranjo, a instituição busca o domínio da totalidade do espaço prisional, incluindo as áreas mais internas; em outro arranjo, a instituição assume a periferia do espaço prisional, preterindo as áreas mais internas. Para a equipe dirigente, o nível de segurança máximo implica no controle total do espaço da prisão, havendo exceções nas áreas mais internas, tais como, as celas, os apartamentos para o encontro íntimo dos presos e sanitários destinados às visitas.

Em terceiro lugar, a hierarquia espacial das funções descreve duas possibilidades: a localização mais externa ou mais interna (fora ou dentro dos blocos de vivência dos presos) dos lugares de realização das atividades de socialização dos presos com as visitas externas e das atividades dos programas de assistência e benefícios aos presos. Para a equipe dirigente, o nível de segurança máximo determina a internalização destas atividades, justificada pela redução dos percursos realizados pelos presos. $\mathrm{Na}$ rotina prisional, a condução de presos e, em menor grau, de visitas entre as dependências da unidade prisional é apontada como crítica para a instituição, sendo considerado um momento de risco extremo aos funcionários. A externalização das atividades citadas confere deficiências organizacionais ao espaço arquitetônico, identificadas pelos funcionários como complicações para a operação e vulnerabilidade dos funcionários. Neste caso, a externalização é considerada característica de modelos arquitetônicos de menor segurança.

A realidade prisional evidencia as preocupações com a segurança, quando busca assegurar o poder da instituição e a integridade dos funcionários: a maioria das áreas e dos fluxos externos e internos deve ser potencialmente vigiada, assim como, a edificação deve separar fisicamente funcionários e presos. Neste sentido, a especificação da vigilância direta é reforçada pela realidade prisional: postos de controle e circulações exclusivas para os funcionários. Em termos econômicos, a insuficiência de recursos humanos demanda a minimização do número de postos de controle, enquanto a redução de área construída é superada pelas vantagens operacionais das circulações exclusivas para os funcionários.

O levantamento do cotidiano prisional junto aos funcionários e presos detalhou as demandas informais para os elementos centrais da edificação penal. De um modo geral, os funcionários apontaram falhas nestes elementos que foram encontradas nos projetos de referência examinados (capítulo 1), tais como: barreiras perimetrais permeáveis, celas intercomunicantes, pátios de sol disfuncionais e postos de controle vulneráveis. Em particular, os funcionários relataram problemas nos postos de controle para a realização de procedimentos junto aos presos, pois o fechamento destes locais impede a comunicação ou a contenção de crises. Para os presos, as questões de funcionalidade e conforto ambiental sobressaíram, nas quais as atividades realizadas não encontram a estrutura física necessária e os padrões mínimos de bem estar são desrespeitados. A contribuição dos presos alcança as soluções arquitetônicas detalhadas da cela e do pátio de sol. 


\section{Capítulo 5 - Procedimento analítico}

Neste capítulo, o procedimento analítico apresentado resumidamente na introdução desta tese é detalhado, sendo expostos os fundamentos metodológicos adotados e as providências para a elaboração da tecnologia de projeto objetivada neste trabalho e a verificação do impacto desta sobre a composição arquitetônica da edificação penal.

Conforme o exposto na introdução desta tese, o estudo do paradigma tecnológico da edificação penal efetuado vislumbra o aprimoramento do espaço arquitetônico da prisão através de uma tecnologia de projeto ajustada às demandas do sistema penal nacional. Esta tecnologia de projeto sistematiza o conhecimento teórico, metodológico e técnico necessário à composição arquitetônico, ao coordenar as soluções espaciais mais aptas para a modalidade arquitetônica de segurança máxima. Neste sentido, a fundamentação desta pesquisa levanta os conceitos e princípios da arquitetura penal, assim como, as características formais (preconizadas nos modelo prisional) e informais (advindas da realidade prisional) da edificação penal, além da base teórico-metodológica. Enquanto o desenvolvimento da pesquisa concebe e aplica a tecnologia de projeto para a verificação da expectativa de incremento do espaço arquitetônico, por meio da revisão do conhecimento projetual específico. A concepção e a aplicação da tecnologia de projeto constituem as duas etapas analíticas desta tese, sendo explicadas a seguir.

No procedimento analítico foram utilizados conceitos e princípios do trabalho de Christopher Alexander (1974a), conforme o informado na introdução desta tese. Segundo Alexander, o objetivo do projeto é que a forma responda aos problemas colocados pelo contexto, de tal maneira que se obtenha um bom ajuste na relação contexto-forma.

[...] todo problema de projeto tem origem no esforço em se obter o ajuste entre duas entidades: a forma em questão e seu contexto. A forma é a solução para o problema; o contexto define o problema. Em outras palavras, quando falamos de projeto, o centro da discussão não é a forma em si, mas o conjunto que compreende a forma e seu contexto. Um bom ajuste é uma propriedade que se busca neste conjunto, que diz respeito à uma determinada divisão do conjunto em forma e contexto (ALEXANDER, 1977a, p. 15-16).

Esta pesquisa particulariza certos pontos instituídos por Christopher Alexander, de modo fundamentado em uma flexibilidade do processo de projeto vislumbrada pelo próprio autor (ALEXANDER, 1977a, p. 8). Segundo Moreira (2007, p. 55), os princípios descritos por Alexander não pretendem estabelecer um procedimento rigoroso, mas sim uma estrutura onde a concepção possa ser precisa em seus objetivos, além de reduzir a subjetividade do processo. 


\subsection{Concepção da tecnologia de projeto}

A concepção da tecnologia de projeto foi precedida pela definição de uma estrutura analítica, providenciada por meio de programa arquitetônico. Segundo o trabalho de Christopher Alexander, o procedimento metodológico para a estruturação de um programa arquitetônico é composto das etapas de descrição e a análise do contexto para a definição do conjunto de requisitos funcionais ${ }^{74}$, seguida das etapas de vinculação e agrupamento destes requisitos, cuja estrutura permite a organização do programa arquitetônico.

Nesta pesquisa, a descrição do contexto é efetivada na fundamentação, enquanto a análise do contexto é precedida por uma estrutura preliminar do programa arquitetônico ${ }^{75}$. Esta antecipação na disposição metodológica de Alexander se deve ao conhecimento prévio do problema de projeto de estabelecimentos penais, encontrado no trabalho de Esteca (2010). Com esta estrutura preliminar, as etapas previstas para a formulação do programa arquitetônico foram simplificadas, ao se substituir um universo de maior complexidade, formado por um grande número de elementos dispersos, por outro já organizado em categorias analíticas (seções 6.1 a 6.3 do capítulo 6). Esta estrutura preliminar foi definida pelos quesitos de projeto concernentes ao planejamento do sistema penitenciário e à atividade prisional. Estes últimos definidos pelos quesitos panópticos (ver capítulo 2, desta tese).

Com base no padrão de problema adotado, um arcabouço de programa arquitetônico foi elaborado pela aplicação do diagrama de árvore à estrutura preliminar inicialmente obtida, hierarquizando as categorias analíticas (seção 6.3 do capítulo 6) ${ }^{76}$. Neste arcabouço de programa arquitetônico, os requisitos funcionais e os respectivos vínculos são definidos pela análise do contexto (ver Apêndice D). No sentido da nitidez da informação, esta definição priorizou os conteúdos teóricos do Panóptico (capítulo 2) e técnico-normativos do modelo prisional (capítulo 3). Deste modo, poucos requisitos surgiram diretamente da análise da realidade prisional (capítulo 4). Esta medida buscou evitar a transposição de disparidades existentes na realidade prisional para os requisitos funcionais ${ }^{77}$.

\footnotetext{
74 Na representação formal, a análise do contexto deriva um conjunto de requisitos funcionais (ALEXANDER, 1977a, p.1), o que torna o processo de projetação mais objetivo (CARVALHO, p. 60).

${ }^{75}$ A adequação do procedimento original se embasou em considerações do próprio Alexander. No trabalho Community and privacy, Alexander apresenta um estudo de caso de implantação de um grupo de residências em uma cidade para exemplificar o método por ele desenvolvido, no qual admite uma padronização prévia do problema de projeto (CHERMAYEFF; ALEXANDER, 1966, p. 152).

76 Alexander (1977a, p. 74) propõe a decomposição do contexto através de mecanismo de análise denominado 'diagrama de árvore'. Esta decomposição ocorre hierarquicamente do geral para o particular, na qual são representadas apenas as ligações principais e os agrupamentos mais independentes. Isto significa ressaltar os valores de projeto ou as qualidades mais importantes em um edifício (HERSBERGER, 1999, p. 53).

77 A definição dos requisitos funcionais busca atender a recomendação de Christopher Alexander de objetividade na elaboração do programa arquitetônico, transpondo os cuidados do autor, exemplificados com o projeto de uma aldeia na Índia (ALEXANDER, 1977):
}

Para evitar o perigo de ir contra o padrão [estrutural do problema de projeto] vamos observar apenas os aspectos familiares e conhecidos das residências e das suas conexões com a cidade, selecionando apenas os requisitos que são específicos e que não 
Como última providência para a montagem do programa arquitetônico, os vínculos entre os requisitos funcionais são contabilizados e classificados, segundo a natureza destes requisitos: externa (relacionados ao planejamento do sistema penitenciário), interna (intrínsecos à atividade prisional) ou ligados aos elementos centrais da edificação penal. Esta providência revisou o diagrama de árvore preliminarmente obtido na elaboração do arcabouço programático, ao explicitar novas subordinações entre os subgrupos de quesitos (seções 6.4 e 6.5 do capítulo 6).

Com a definição do programa arquitetônico, os procedimentos analíticos se voltam para a definição das soluções integrantes da tecnologia de projeto, através da caracterização formal e informal da arquitetura em cada requisito funcional, seguida da comparação destas instancias em duas abordagens diferentes, explicadas a seguir.

A caracterização formal do espaço arquitetônico refletiu as demandas do modelo prisional, abordado no capítulo 3 (instrumentos legais e técnico-normativos), além de princípios penalógicos sistematizados pelo Panóptico (ver capítulo 2). Esta caracterização também envolveu o padrão arquitetônico modular de segurança máxima, inclusive o modelo supermax norte-americano (ver Apêndice A). A caracterização informal refletiu os projetos de referência adotados nesta pesquisa (ver Apêndice A), em conjunto com as exigências da realidade prisional tratadas no capítulo 4.

Em um primeiro momento, a comparação analítica aborda a equivalência entre as características formal e informal de cada requisito funcional (seção 6.6 do capítulo 6 e Apêndice E), segundo os critérios: convergência plena (equivalência); convergência parcial (maioria de elementos comuns); divergência parcial (maioria de elementos dissonantes); e divergência plena (as características destoam na sua totalidade). Esta equivalência é definida com base nos projetos de referência adotados (ver Apêndice A), sendo estabelecida a partir dos resultados obtidos individualmente em cada um destes projetos. A equivalência encontrada nos requisitos funcionais é então contabilizada em relação ao programa arquitetônico, aos subconjuntos de quesitos e aos projetos de referência. Esta primeira avaliação permite ponderações entre a convergência ou divergência das características formais e informais da edificação penal.

Em um segundo momento, a comparação analítica define as melhores soluções arquitetônicas (seção 6.7 do capítulo 6 e Apêndice E), ao avaliar as características formais e informais no atendimento dos critérios estabelecidos no estudo do paradigma tecnológico da edificação penal (ver introdução). Esta

obscurecidos pelas semânticas mal compreendidas; e que podem ser descritos de modo preciso, que poderão ser reconhecidos como lugares familiares e funcionais em nossas vidas diárias e que não sejam questões de gosto. 
avaliação considera o atendimento de todos os critérios, o atendimento de parte dos critérios ou o não atendimento dos mesmos. Os critérios aplicados são:

a) Segurança ${ }^{78}$ : a graduação e a homogeneidade do sistema de segurança em termos da estanqueidade, impermeabilidade, inexpugnidade, disciplina interna e controle, com a minimização de vulnerabilidades do esquema de segurança; a preservação da integridade dos funcionários (exposição aos riscos); e a manutenção da ordem (disciplina dos presos).

b) Funcionalidade ${ }^{79}$ : a compatibilidade da estrutura física, a qualidade dos espaços disponíveis e as relações entre os espaços. O primeiro ponto verificou a viabilidade das atividades: as características das atividades juntamente com o número de participantes em relação à quantidade de espaço disponível. O segundo ponto trouxe as questões da individualização/coletivização, racionalidade geométrica, compactação e especialização das atividades, tendo como metas a redução de tarefas e a simplificação dos procedimentos ${ }^{80}$. O terceiro ponto considerou a acessibilidade e mobilidade das pessoas e a integração da equipe funcional. Em particular, nos elementos centrais da edificação penal (cela, pátio de sol dos presos e posto de controle) foram considerados outros critérios da sistemática de Graeff (2006), como a compartimentação e o dimensionamento, ou ainda são complementados pela avaliação das aberturas, circulações, equipamentos e mobiliário.

c) Conforto ambiental ${ }^{81}$ : a ventilação e a iluminação naturais (a posição, localização, tipificação e dimensionamento das aberturas, a relevar a padronização e compatibilização das soluções, além do número de pessoas atendidas e áreas internas livres).

d) $\operatorname{Custos}^{82}$ : a compactação espacial e funcional com redução de tarefas e simplificação de procedimentos (diminuição de áreas e de pessoal, além da otimização das estruturas física e

\footnotetext{
${ }^{78}$ A segurança se balizou na descrição da modalidade arquitetônica de segurança máxima, realizada no capítulo 1, sendo exemplificada pelo modelo super-max norte-americano, associada aos requisitos físicos e operacionais do estabelecimento penal encontrados no Panóptico (ver capítulo 2) e no modelo prisional nacional (ver capítulo 3), complementados pela realidade prisional (ver capítulo 4).

79 A funcionalidade diz respeito à eficiência do edifício do ponto de vista das atividades a serem desenvolvidas pelos indivíduos. Compreende a estrutura física necessária para a correta aplicação da pena, em torno do binômio da privação de liberdade/programa de benefícios aos presos, segundo o previsto no modelo prisional e concretizado na realidade prisional. Neste sentido, abordou prioritariamente o cumprimento de pena na perspectiva da prisão como atividade econômica. Além disto, compreendeu a composição arquitetônica na perspectiva das necessidades espaciais associadas aos padrões de bem-estar das pessoas, em particular, no exercício das suas relações sociais e da sua individualidade. $O$ respeito à condição humana na prisão remete à adequação do edifício do ponto da prisão como atividade social. Na pragmática penitenciária, estes itens se traduzem em comodidades para os usuários - funcionários e presos.

${ }^{80}$ A redução de tarefas e simplificação de procedimentos está relacionada ao tempo gasto no cumprimento das rotinas da prisão pelos funcionários e é identificada como velocidade da prisão. Outra abordagem do tempo gasto na rotina prisional é a permanência das pessoas nos locais. Estes parâmetros e a sua mensuração foram fornecidos pelos funcionários nas entrevistas realizadas (ver Apêndice C).

${ }^{81}$ A condição humana é tratada essencialmente nos direitos dos presos, consubstanciados na legislação e nas políticas penitenciárias. No entanto, estes instrumentos não apresentam parâmetros claros ou diretos para o projeto arquitetônico penal, com exceção de cuidados com a higiene ou salubridade. Neste sentido, o respeito à condição humana na prisão na pesquisa focou a característica e o dimensionamento de ambientes e as aberturas de iluminação e ventilação.

82 Os custos envolvem a construção e a operação do edifício prisional. O custo de construção recaiu sobre a superestrutura (edifício). Os custos de operação se limitaram aos operacionais, especialmente no que tange ao contingente de funcionários de segurança estática (postos de controle). Os custos de utilização (manutenção e substituição) não foram abordados. Importante realçar que os custos foram tratados em um nível estimativo (método expedito e paramétrico de orçamento) que oscila a margem de erro entre 10 e 20\% (CARVALHO,
} 
operacional); redução da relação custo por vaga (coletivização e generalização funcional dos espaços com aumento das capacidades).

As soluções arquitetônicas formais ou informais com melhor avaliação (atendimento dos critérios apresentados) são indicadas para compor a tecnologia de projeto. Ao mesmo tempo em que a consistência do conjunto é avaliada em relação às equivalências levantadas na primeira análise e em relação à compatibilidade com o objetivo de aprimoramento do espaço arquitetônico de segurança máxima desta pesquisa (conclusão analítica do capítulo 6). No procedimento realizado, a avaliação do conjunto apontou uma inconsistência que levou a estudos complementares, de forma a diluir qualquer impasse ou incorreção, o que integra o capítulo $7^{83}$.

Após os ajustes do conjunto obtido, a tecnologia de projeto é elaborada como um quadro sintético (ver Apêndice F), baseado no programa arquitetônico concebido. Este quadro apresenta os conteúdos teóricos, metodológicos e técnicos desenvolvidos para cada requisito funcional que justificam, instrumentam e parametrizam as soluções arquitetônicas dispostas nos requisitos funcionais. Os conteúdos teóricos trazem a fundamentação penalógica e arquitetônica, eventualmente complementada por considerações advindas do modelo e da realidade prisional. Os conteúdos metodológicos apontam os objetivos e os processos para a implementação das soluções arquitetônicas definidas. E os conteúdos técnicos exibem as referências normativas relevantes, além de parâmetros de dimensionamento. Os conteúdos apresentam os vínculos existentes entre os requisitos funcionais.

\subsection{Aplicação da tecnologia de projeto}

A segunda parte analítica desta pesquisa visou ao teste da tecnologia de projeto, determinando as relações lógicas para uma conclusão final com base na coerência dos resultados obtidos, no avanço científico e nas aplicações práticas (ver capítulo 8). Este teste objetivou avaliar o impacto da tecnologia de projeto na composição arquitetônica, no sentido do aprimoramento da edificação prisional objetivado na pesquisa proposta (hipótese de pesquisa). Esta experiência evidenciou as convergências e divergências no material tecnológico aplicado, o que ensejou ajustes ou a necessidade de novos testes.

\footnotetext{
2007). As estimativas calculadas na análise de custos realizada utilizaram as médias aritméticas simples dos valores e índices. Os custos foram definidos por itens físicos e operacionais do estabelecimento penal, por isto é um item crítico, ao permear todos os demais critérios. 83 Para Alexander, a organização dos requisitos funcionais e seus agrupamentos no programa arquitetônico define partes interdependentes, assim, quando se altera uma das propriedades do edifício, ela intervém nas demais. Esta representação formal possibilita haver ajustes até a obtenção da opção mais apropriada (contexto-forma). Para Moreira (2007, p. 81 apud PEREIRA, 2010), o programa arquitetônico permite a análise do contexto em partes, de modo a analisá-lo em seus pormenores e entender a estrutura do problema, onde o entendimento das interações é mais importante que o das partes separadas.
} 
No teste realizado, a tecnologia de projeto foi aplicada aos projetos de referência desta pesquisa: a Penitenciária do Distrito Federal, o projeto padrão da penitenciária compacta do Estado de São Paulo, o projeto padrão de cadeia pública do Ministério da Justiça e o modelo de penitenciária da empresa Verdi Construções S/A (ver Apêndice A). A avaliação consistiu em verificar o desempenho dos projetos revistos em comparação aos originais, segundo os critérios de segurança, funcionalidade, conforto ambiental e custo de construção e operação (Apêndice H).

A aplicação da tecnologia de projeto aos projetos de referência foi auxiliada pela confecção de desenhos-síntese de uma unidade prisional e dos elementos centrais da edificação penal (barreira perimetral, cela, pátio de sol dos presos e posto de controle) (seção 8.1 do capítulo 8 e Apêndice G). Estes desenhos-síntese se baseiam no conceito de croqui-síntese de Alexander, tendo sido utilizado para condensar e representar visualmente as soluções da tecnologia de projeto desenvolvida ${ }^{84}$.

A avaliação dos projetos de referência abrangeu quatro abordagens, em termos da comparação entre as características físicas e econômicas dos projetos originais e ajustados: os dados gerais do espaço arquitetônico projetado; estes dados comparados às caracterizações da edificação penal formuladas nos estudos do modelo e da realidade prisional (capítulos 3 e 4), assim como, às características do desenho-síntese de unidade prisional elaborado; individualmente, em cada um dos requisitos funcionais da tecnologia de projeto desenvolvida (Apêndice $\mathrm{F}$ ); e especificamente quanto aos elementos centrais da edificação penal.

A avaliação realizada destacou alguns índices gerais da edificação penal: custo por vaga, custo por área construída, área construída por vaga e número de funcionários por vaga. O índice de custo por vaga estabelece a otimização do programa arquitetônico em função dos recursos disponibilizados para as políticas penitenciárias de ampliação do parque penal. O índice de custo por área construída complementa a avaliação do custo do estabelecimento penal, diluindo eventuais distorções do custo por vaga. $\mathrm{O}$ índice de área construída por vaga indica a proporção de áreas voltadas para o programa de sociabilização e de benefícios aos presos, assim como, para a segurança penitenciária. $\mathrm{O}$ índice do número de funcionários por vaga denota a eficiência operacional do edifício, no sentido de que um contingente menor aponta uma unidade penal arquitetonicamente mais bem resolvida.

\footnotetext{
84 Conforme Duerk (1993, p. 9), na fase de síntese do processo de projeto, cada requisito funcional deriva uma parte da forma e então para uma solução formal geral (proposta arquitetônica). Assim, a elaboração dos desenhos-síntese inicia a síntese arquitetônica prevista no processo de Christopher Alexander. A confecção de croquis-síntese se baseia na constatação de Alexander, da maior capacidade do arquiteto em reter informações visuais.
} 


\section{Capítulo 6 - Análise das características da edificação penal}

Neste capítulo, as análises necessárias para a concepção da tecnologia de projeto são realizadas, por meio da comparação entre as características formais e informais da edificação penal, sendo estabelecida a equivalência entre estas, além das soluções arquitetônicas mais aptas para a composição arquitetônica de segurança máxima. Este capitulo é complementado pelo Apêndice D - requisitos funcionais, e pelo Apêndice Eanálise das instâncias formal e informal, desta tese.

Os procedimentos de análise foram precedidos pela elaboração de um programa arquitetônico necessário à organização das categorias e requisitos analíticos, por meio de uma estrutura hierarquizada e inter-relacionada dos componentes da composição arquitetônica da edificação penal. Com o programa arquitetônico definido, os requisitos funcionais receberam as características formais (preconizadas nos modelo prisional) e informais (advindas da realidade prisional) da edificação penal, levantadas na fundamentação desta pesquisa. Estas instâncias foram comparadas para a definição da equivalência entre as mesmas, além das soluções arquitetônicas mais aptas para a composição arquitetônica de segurança máxima.

\subsection{Programa arquitetônico}

A concepção de um programa arquitetônico para a edificação penal partiu da definição e do ordenamento dos quesitos programáticos que compõe as categorias de análise. A seguir, o levantamento e a vinculação dos requisitos funcionais foram realizados.

\subsubsection{Quesitos}

Os quesitos foram organizados em duas ordens análogas aos tipos de problemas identificados na questão prisional por Alvino de Sá (1990), descritas abaixo com base nas colocações deste autor ${ }^{85}$ :

a) Elementos externos (de planejamento): comunicam as exigências do administrador do sistema penal ao projetista, sendo definidos quando do planejamento de um estabelecimento penal, apontando as características mais amplas da proposta arquitetônica a ser concebida.

b) Elementos internos (específicos da prisão): explicitam as exigências funcionais da prisão ao projetista, segundo os quesitos panópticos do espaço arquitetônico e o modelo prisional vigente (os princípios do funcionamento da prisão), detalhando a proposta arquitetônica a ser concebida.

\footnotetext{
${ }^{85} \mathrm{O}$ problema de ordem externa está relacionado às questões do sistema penal, historicamente marcado pela incapacidade do Estado na implantação da Reforma Penitenciária e pela incorreção na aplicação da legislação. O problema de ordem interna está relacionado à impossibilidade do objetivo oficial da atividade prisional: o isolamento do indivíduo para a sua reconfiguração comportamental segundo uma normalidade definida no pacto social. Estas duas classes distinguem as atuações do promotor e do projetista na Cadeia Produtiva da Indústria da Construção, ressaltando a responsabilidade de cada um no processo de projeto, cabendo ao primeiro a demanda para o trabalho do segundo que deve deter o conhecimento relativo à arquitetura penal concernente aos elementos internos.
} 
Os quesitos externos têm uma natureza mais abrangente, ainda ao nível da relação do projetista com o planejamento penitenciário, na qual estão explícitas as condicionantes da realidade prisional para o projeto arquitetônico de estabelecimentos penais. Neste sentido, os quesitos externos subordinam os internos, por isto foram definidos em primeiro lugar (ESTECA, 2010).

O Handbook of Correctional Institution Design and Construction (USA, 1949, p. 6 a 9) aponta as características da prisão a serem definidas previamente à projetação: o tipo de população prisional destinada ao estabelecimento a ser projetado; o porte do estabelecimento a ser projetado em função do número de vagas para os presos; e o enquadramento do estabelecimento a ser projetado na organização do sistema penitenciário, segundo a situação jurídica dos presos, em conjunto com as estratégias programadas para o sistema penitenciário, que definem a categoria da unidade a ser edificada. Estes tópicos são encontrados no Technical Guidance for Prison Planning (UNOPS, 2017, p. 42 a 45), quando este documento trata dos requerimentos para a definição das características da prisão, tais como: o nível de segurança em função do perfil dos presos, o número de presos a ser acomodado e a separação dos presos em diferentes tipos de estabelecimentos penais, segundo a categoria deste grupo. No âmbito nacional, estes itens são respaldados pelos instrumentos legais e técnico-normativos, em particular, pelas Diretrizes Básicas para a Arquitetura Penal (CNPCP, 2011, p. 25, 27, 29 e p. 45 a 49) (ver Apêndice B).

Conforme o objeto desta pesquisa, o tipo e a categoria do estabelecimento penal a ser projetado são definidos pela penitenciária de segurança máxima para presos, por isto estes requisitos são unificados em um quesito atrelado ao perfil dos presos a serem abrigados. O porte do estabelecimento penal corresponde a um quesito independente, já que está em aberto a capacidade recomendada para unidades prisionais de segurança máxima (discrepante entre os projetos de referência adotados nesta pesquisa e entre os instrumentos normativos e a realidade prisional). $\mathrm{O}$ enquadramento penitenciário do estabelecimento a ser projetado remete à correspondência entre a categorização penitenciária e a modelagem arquitetônica, tratada no capítulo 1, desta tese.

O Handbook (USA, 1949, p. 6 a 9) ainda lista outros aspectos que devem ser considerados no planejamento do empreendimento, tais como: a localização do estabelecimento; o tipo de barreira física e de alojamento para os presos, tendo em vista o programa de reabilitação e a segurança; e o tipo de trabalho que será disponibilizado aos presos, em razão do papel deste no programa de reabilitação. Estes aspectos coincidem com alguns dos quesitos internos, então a sua definição ocorre ao nível do planejamento penitenciário, mas na organização do programa arquitetônico integram os quesitos de ordem interna. Em parte porque a sua correta implementação no projeto depende do conhecimento específico da arquitetura penal, evidente nos quesitos internos. 
Os custos de construção e operação do estabelecimento penal a ser projetado constituem o último quesito de ordem externa, previsto na estratégia de pesquisa definida no estudo do paradigma tecnológico da edificação penal (ver introdução desta pesquisa). Em particular, a relevância do custo de construção foi identificada nas políticas penitenciárias, ao mesmo tempo impactando consideravelmente na definição do espaço arquitetônico da prisão. Enquanto o custo operacional é restrito ao pagamento de pessoal (despesa mais alta da instituição). Deste modo, o custo é duplamente abordado nesta tese, como critério de análise e quesito do programa arquitetônico. Enquanto quesito, o custo observa as características configurativas dos espaços (QUEIROZ, 2000), em termos da influência do orçamento preliminar de construção e operação na geometria do edifício, principalmente, do custeio (PEÑA; PARSHALL; 2001).

O Panóptico descreve os quesitos de natureza interna do programa arquitetônico elaborado (ver capítulo 2): o isolamento social dos presos, o isolamento individual dos presos, a organização do espaço e o controle. $\mathrm{O}$ isolamento social trata da localização ${ }^{86}$ e a barreira física do estabelecimento penal. $\mathrm{O}$ isolamento individual corresponde à tipificação das celas, além de incluir a organização das alas carcerárias. A organização do espaço engloba subgrupos de quesitos (apresentados a seguir), pois abrange uma série de mecanismos de composição espacial da prisão. O controle considera a vigilância externa e interna da unidade prisional.

Os quesitos que integraram a organização do espaço são:

a) Geometria: diz respeito aos espaços externos e internos da edificação, sendo considerado espaço externo as áreas não-edificadas intramuros do estabelecimento penal ${ }^{87}$. A geometria concorda com o que Graeff (2010) denominou de qualidade geométrica da matéria que aborda as linhas, superfícies e volumes. Do trabalho de Graeff foram retirados princípios e procedimentos da coordenação das formas no espaço, em especial, a unidade arquitetônica, providenciada por meios de composição: unidade, harmonia, contraste, proporção e ritmo. Nestes meios de composição foram destacadas algumas propriedades físicas da edificação ressaltadas por Sá (1990): continuidade, alinhamento, centralização e simetria;

b) Funcionalidade: abarca a estrutura interna da edificação (SIMON, 1981, p. 29). Segundo a disciplina espacial panóptica, este quesito trata das localizações funcionais e da classificação funcional - o celular descrito por Michael Foucault (1987) que especializa e hierarquiza os locais (princípio do quadriculamento), distribuindo as pessoas e organizando as relações sociais na prisão. A funcionalidade observa as características configurativas incidentes na

\footnotetext{
${ }^{86}$ A localização é interpretada por Graeff (2010) como um meio para o atendimento das necessidades programáticas, enquanto nesta pesquisa é tomada principalmente do ponto de vista da segurança.

87 Segundo Graeff (2010), o espaço arquitetônico externo é um dos dois elementos constitutivos da forma arquitetônica.
} 
eficiência dos espaços para atividades pragmáticas neles desenvolvidas pelos indivíduos (CAPANEMA, 2010, p. 111). Ela considera o espaço arquitetônico como recipiente físico da ocorrência de práticas utilitárias, usos e usufrutos inerentes às sociedades humanas (KOHLSDORF \& KOHLSDORF, 1999). Entre os aspectos humanos do projeto arquitetônico listados por Hersberger (1999), os tópicos trabalhados correspondem às atividades funcionais, às relações sociais e às características físicas em relação às necessidades dos usuários. $\mathrm{Na}$ estrutura do Problem Seeking (PEÑA; PARSHALL; 2001), estes tópicos promovem considerações sobre a função do edifício (as pessoas, atividades e relações), implicando na definição de requisitos de desempenho importantes para o projeto da edificação prisional. Mediante estas considerações, este quesito foi subdividido ${ }^{88}$ :

i) Atividades: os espaços a serem criados em atendimento às necessidades físicas da atividade prisional, esquematizadas nos sistemas operacional e de segurança, segundo o processo total da integralização descrito por Goffman (a reprodução da vida em liberdade) e o preconizado no modelo prisional, tendo em vista os objetivos punitivos e de humanização da pena;

ii) Espacialização: o arranjo espacial dos espaços e demais elementos arquitetônicos, em atendimento das várias expectativas sociais na prisão, organizadas nas dimensões morfológicas das diversas áreas da arquitetura (CAPANEMA, 2010). O arranjo espacial é definido por meio da disciplina panóptica, segundo o processo total do mecanicismo (o planejamento minucioso da vida na prisão) e as representações sociais, descritos por Goffman (2005);

iii) Dimensionamento: o tamanho da prisão descrito pelas áreas e dimensões dos espaços externos e internos, além das proporcionalidades e relações, informadas por meio de índices e taxas;

iv) Circulação: o trânsito de pessoas, veículos e materiais, em razão do acesso aos lugares mais internos, considerando ainda o traçado e a disposição dos locais de fluxo, segundo o controle na organização, condução e destinação dos transeuntes.

c) Conforto Ambiental: Este quesito remete à Dimensão Bioclimática que observa os fatores configurativos do espaço incidentes no conforto físico dos indivíduos, em termos de temperatura e umidade (Higrotérmico), som (Acústico), luz (Luminoso) e qualidade do ar (KOHLSDORF \& KOHLSDORF, 2004 apud CAPANEMA, 2010). Nesta pesquisa, entre

\footnotetext{
${ }^{88}$ Esta subdivisão foi baseada na sistematização de Edgar Graeff (2010), na estrutura do Problem Seeking (PEÑA; PARSHALL; 2001) e na Teoria Dimensional. A Teoria Dimensional teve origem no grupo de pesquisa Dimensões Morfológicas do Processo de Urbanização (DIMPU), no ano de 1986, na Faculdade de Arquitetura e Urbanismo da Universidade de Brasília - FAU/UnB.
} 
estes fatores, a ventilação e a iluminação naturais são evidenciadas, enquanto os demais são tratados perifericamente, eventualmente abordados no sentido de complementar alguma informação. Entre os aspectos humanos do projeto arquitetônico listados por Hersberger (1999), este quesito corresponde às características fisiológicas e as necessidades dos usuários. $\mathrm{Na}$ visão de Bentham, o conforto contribui para a manutenção do corpo do sentenciado e seu aproveitamento produtivo. Para Graeff (2010), o conforto físico complementa as exigências de natureza utilitária do programa arquitetônico, juntamente com as exigências de natureza funcional, devendo ser favorável à existência das pessoas - o bem estar das pessoas.

d) Aparatos de segurança: envolve os cuidados físicos em suas minúcias para garantir a funcionalidade do estabelecimento penal: portas, grades, anteparos, mecanismos etc., se relacionando estreitamente com o modelo prisional e, em especial, com os protocolos operacionais. Graeff remete a uma preocupação com a solidez da edificação, semelhante ao problem seeking que discrimina a questão como segurança física, enquanto entre os aspectos listados por Hersberger (1999) se destaca a segurança em relação ao criminoso (vandalismo). Na estrutura do Problem Seeking (PEÑA; PARSHALL; 2001), este quesito promove considerações sobre a influência da segurança física na forma do edifício.

Além dos quesitos externo e internos, os elementos centrais da edificação penal (barreira perimetral, cela, pátio de sol dos presos e posto de controle) tiveram seus quesitos particularizados no programa arquitetônico desenvolvido. Esta particularização determina a submissão dos quesitos dos elementos centrais aos quesitos de ordem interna. Neste sentido, os quesitos internos apresentam um caráter generalista, enquanto a discussão pormenorizada da composição arquitetônica se deteve nos elementos centrais. Com estas considerações, os quesitos de análise definidos são:

Quadro 9 - Quesitos para o programa arquitetônico

\begin{tabular}{|c|c|c|}
\hline Subclasse & Grupo de Quesitos & Elemento Central \\
\hline \multirow{3}{*}{$\begin{array}{c}\text { Externos } \\
\text { (Planejamento) }\end{array}$} & Tipo e categoria do estabelecimento penal & - \\
\hline & Porte do estabelecimento penal & - \\
\hline & Custo do estabelecimento penal & - \\
\hline \multirow{10}{*}{ Internos } & Isolamento social dos presos & Barreira física \\
\hline & Isolamento individual dos presos & Cela \\
\hline & Organização do espaço/Geometria & \multirow{7}{*}{$\begin{array}{c}\text { Espaços coletivos } \\
\text { (pátio de sol dos } \\
\text { presos) }\end{array}$} \\
\hline & Organização do espaço/Funcionalidade/Atividades & \\
\hline & Organização do espaço/ Funcionalidade/Espacialização & \\
\hline & Organização do espaço/ Funcionalidade/Dimensionamento & \\
\hline & Organização do espaço/ Funcionalidade/Circulação & \\
\hline & Organização do espaço/Conforto Ambiental & \\
\hline & Organização do espaço/Aparato de Segurança & \\
\hline & Controle & Posto de Controle \\
\hline
\end{tabular}




\subsection{Representação formal}

A vinculação e o agrupamento das variáveis de análise foram iniciados pelos princípios panópticos, sendo progressivamente adicionados os respectivos subconjuntos e, por fim, os elementos externos. No primeiro diagrama, os princípios panópticos são dispostos (Figura 24$)^{89}: 1$ ) isolamento social dos presos; 2) isolamento individual dos presos; 3) organização do espaço; e 4) controle.

Neste conjunto, algumas conexões foram destacadas como principais. Em primeiro lugar, a conexão entre o isolamento individual (2) e a organização do espaço (3), na qual a especificação do tipo de cela e a sua quantidade e arranjo tem grandes consequências para a espacialidade da prisão. A organização espacial (3) com o controle (4) como um reflexo da premissa do controle absoluto no espaço da prisão. A mesma intensidade é verificada na relação entre o controle (4) e o isolamento social (1), visto como um dos objetivos principais da instituição prisional. O controle (4) tem uma ligação de força intermediária com o isolamento individual (2) apesar da importância relativa deste princípio no esquema panóptico. Isto porque o modelo prisional nacional não admite a vigilância interna da cela em nome da privacidade dos presos ou da proteção dos funcionários. As ligações do isolamento social (1) com o isolamento individual (2) e a organização do espaço (3) são tênues, indicando a divisão do sistema de segurança entre o espaço externo e o interno.

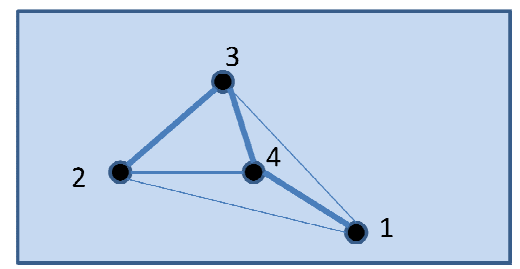

Figura 24 - Diagrama da representação formal dos princípios panópticos

Os pontos correspondem, ao isolamento social dos presos (1); isolamento individual dos presos (2); organização do espaço (3); e controle (4).

No desenvolvimento da representação formal, os elementos externos foram adicionados ao conjunto, sendo estabelecida a ligação entre o planejamento e a teoria arquitetônica da prisão, figurando no diagrama (Figura 25): 1) tipo e categoria; 2) porte; e 3) custo, correspondentes ao subconjunto A. Os conjuntos definidos pelos princípios panópticos permaneceram: 4) isolamento social dos presos; 5) isolamento individual dos presos; 6) organização do espaço; e 7) controle, constituindo o subconjunto B. No novo diagrama montado, a representação inicial foi desmembrada, exibindo os subconjuntos de quesitos subordinados ao esquema panóptico, tais como: 8) geometria; 9) funcionalidade; 10) atividades; 11) espacialização; 12) dimensionamento; 13) circulação; 14) conforto ambiental; e 15)

\footnotetext{
89 Nos diagramas, as vinculações são descritas por traços que interligam os pontos e a intensidade destes vínculos foi evidenciada através da espessura das linhas, linhas mais grossas para um vínculo mais forte, e vice-versa.
} 
aparatos de segurança. Da mesma maneira, os elementos centrais da edificação penal foram introduzidos: 16) barreira perimetral; 17) cela; 18) pátio de sol de presos; e 19) posto de controle, configurando o subconjunto $\mathrm{C}$.

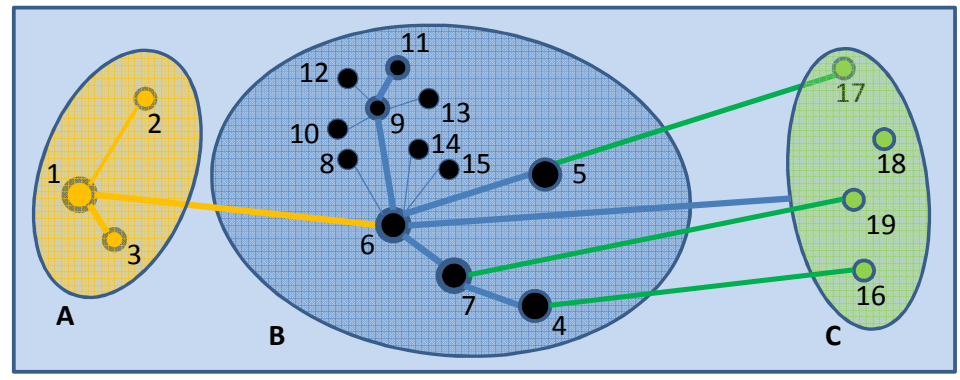

Figura 25 - Diagrama da representação formal dos quesitos do programa arquitetônico

Os pontos correspondem ao tipo e categoria do estabelecimento penal (1); porte do estabelecimento penal (2); custo do estabelecimento penal (3); isolamento social dos presos (4); isolamento individual dos presos (5); organização do espaço (6); controle (7); geometria (8); funcionalidade (9); atividades (10); espacialização (11); dimensionamento (12), circulação (13); conforto ambiental (14), aparatos de segurança (15); barreira perimetral (16); cela (17); pátio de sol dos presos (18); posto de controle (19).

No diagrama final, o subconjunto A (quesitos externos) influencia o subgrupo B (quesitos internos) de um modo geral, mas especialmente o quesito tipo e a categoria do estabelecimento penal, por meio do nível de segurança que interfere fortemente na organização do espaço (6). Por sua vez, o subconjunto B define os elementos centrais da edificação penal (subconjunto C), principalmente através da organização do espaço, além dos temas panópticos definirem diretamente os respectivos componentes arquitetônicos, com exceção do pátio de sol dos presos (18) que deriva da organização do espaço.

Neste mesmo diagrama, no subconjunto A, o quesito tipo e a categoria do estabelecimento penal predomina, juntamente com o custo. No subconjunto $\mathrm{B}$, os quesitos panópticos do isolamento individual (5) e do controle (7) convergem para a organização do espaço (6) que define os princípios espaciais gerais a serem seguidos. Por sua vez estes são emanados mais fortemente da funcionalidade (9) e da espacialização (11). O isolamento social tem maior afinidade com o controle (7), recebendo os influxos da organização do espaço (6) por intermédio deste. Ao se ligar com a organização do espaço, o controle alcança mais intensamente a espacialização (11), além da circulação (13). A espacialização e a circulação concorrem para o arranjo espacial da prisão, definindo a geometria da edificação (8). As atividades (10) e o dimensionamento (12) são resultado das determinantes e condicionantes externas, assim como, o conforto ambiental (14) e os aparatos de segurança (15). De uma maneira geral, estas conexões distinguem o espaço arquitetônico da prisão: a coesão do conjunto em torno da segurança e da racionalidade espacial, na qual não se observa a formação de grupos isolados de elementos. 


\subsection{Estrutura preliminar do programa arquitetônico}

A estrutura do programa arquitetônico foi elaborada pela aplicação do diagrama de árvore à representação formal dos quesitos do programa arquitetônico (Figura 26), levantados na seção anterior (6.2). Neste diagrama, o contexto para o projeto arquitetônico de estabelecimentos penais é explicitado, sendo representada a relação existente entre a penalogia e a arquitetura, a partir dos componentes da composição arquitetônica extraídos dos estudos da edificação penal, do modelo prisional e da realidade prisional, tratados nos capítulos da fundamentação desta tese.

A estrutura do programa arquitetônico elaborada aponta o problema da arquitetura penal, representado pela ligação da realidade prisional aos quesitos de ordem externa (planejamento) que abrangem a tipificação, o porte e os custos do estabelecimento penal. Esta ligação explicita o condicionamento dos custos de construção e operação sobre o modelo de segurança máxima e os sistemas de segurança e operação. Paralelamente, a composição arquitetônica da prisão é definida pelas disciplinas panópticas nos quesitos de ordem interna. Como o planejamento penitenciário determina as demandas para o projeto arquitetônico, a composição arquitetônica da prisão é alterada, em razão do custo do empreendimento, principalmente. Nesta pesquisa, as alterações na composição arquitetônica são verificadas nos elementos centrais da edificação penal (barreira perimetral, cela, pátio de sol dos presos e posto de controle) que são vinculados aos respectivos temas centrais do programa arquitetônico concebido.

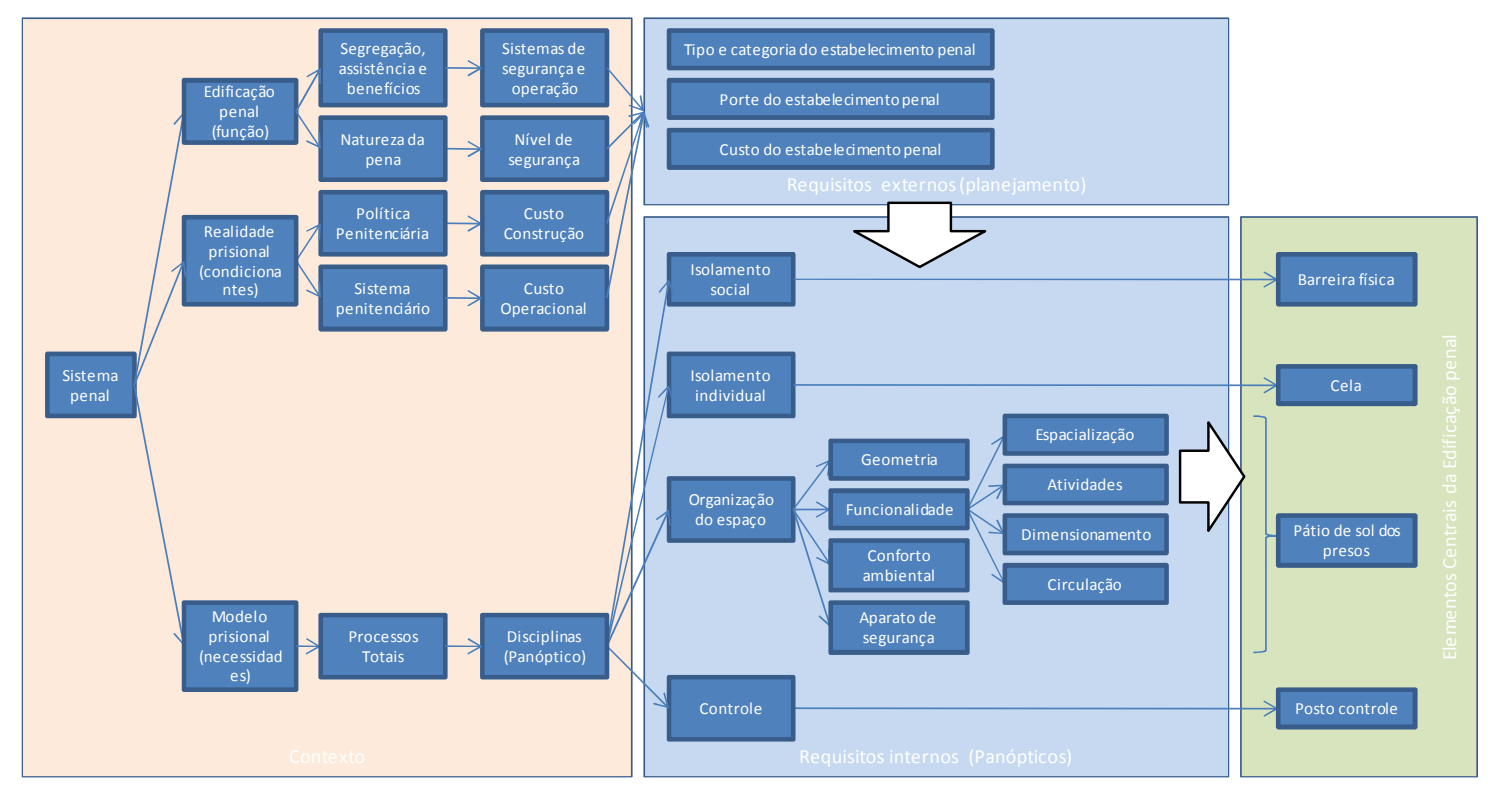

Figura 26 - Diagrama preliminar da estrutura em árvore para o programa arquitetônico 


\subsection{Requisitos funcionais}

A análise do contexto (ver Apêndice D) levantou noventa e dois requisitos funcionais para o programa arquitetônico de estabelecimentos penais, sendo dez requisitos referentes aos quesitos de ordem externa (planejamento) e oitenta e dois aos quesitos de ordem interna (panópticos), dos quais, quarenta são relacionados aos elementos centrais da edificação penal.

Os requisitos funcionais externos condensam as condicionantes e demandas para os quesitos internos, relativas à tipificação e custo do estabelecimento penal a ser projetado. Os requisitos funcionais internos apresentam um caráter genérico na composição do espaço arquitetônico, concernente a edificação penal como um todo. Os requisitos funcionais dos elementos centrais da edificação penal detalham a composição espacial, reproduzindo em sua estrutura alguns temas centrais dos requisitos internos, tais como, a geometria, funcionalidade, conforto ambiental, aparatos de segurança e o controle.

A análise do contexto apontou setecentos e sete vínculos entre os requisitos funcionais levantados. O diagrama de árvore obtido atribuiu peso aos quesitos e definiu as principais ligações do programa arquitetônico, pormenorizando a hierarquia dos quesitos do programa arquitetônico (Figura 27).

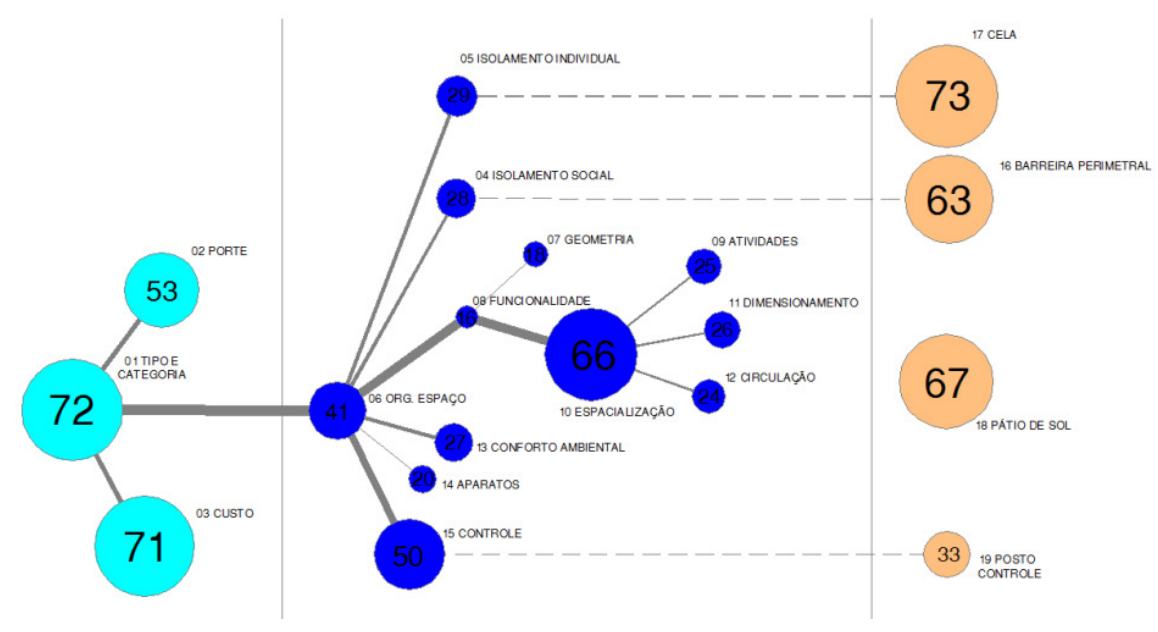

Figura 27 - Representação formal em árvore dos requisitos funcionais

Os valores indicados correspondem à quantidade de ligações de cada grupo de quesitos. A espessura das linhas indica proporcionalmente as principais vinculações entre os quesitos.

A representação formal procedida confirmou a estrutura preliminar de programa arquitetônico definida na seção anterior, 6.3. O diagrama de árvore obtido mostrou os quesitos externos interagindo entre si e com a totalidade dos quesitos programáticos, através do nível de segurança do estabelecimento penal a ser projetado (explicitado na análise do contexto). Entre os quesitos externos, o quesito do tipo e categoria do estabelecimento penal converge os temas do porte e do custo, ao mesmo tempo em que 
conecta o planejamento penitenciário aos quesitos de ordem interna. Esta articulação ocorre com a organização do espaço que contabiliza maior vinculação com o controle. Na organização do espaço, a espacialização possui maior peso, por isto passou a vincular as atividades, o dimensionamento e a circulação.

\subsection{Programa arquitetônico}

O levantamento dos requisitos funcionais e dos seus principais vínculos complementou a estrutura preliminar do programa arquitetônico, definindo o programa arquitetônico para estabelecimentos penais (Figura 28):

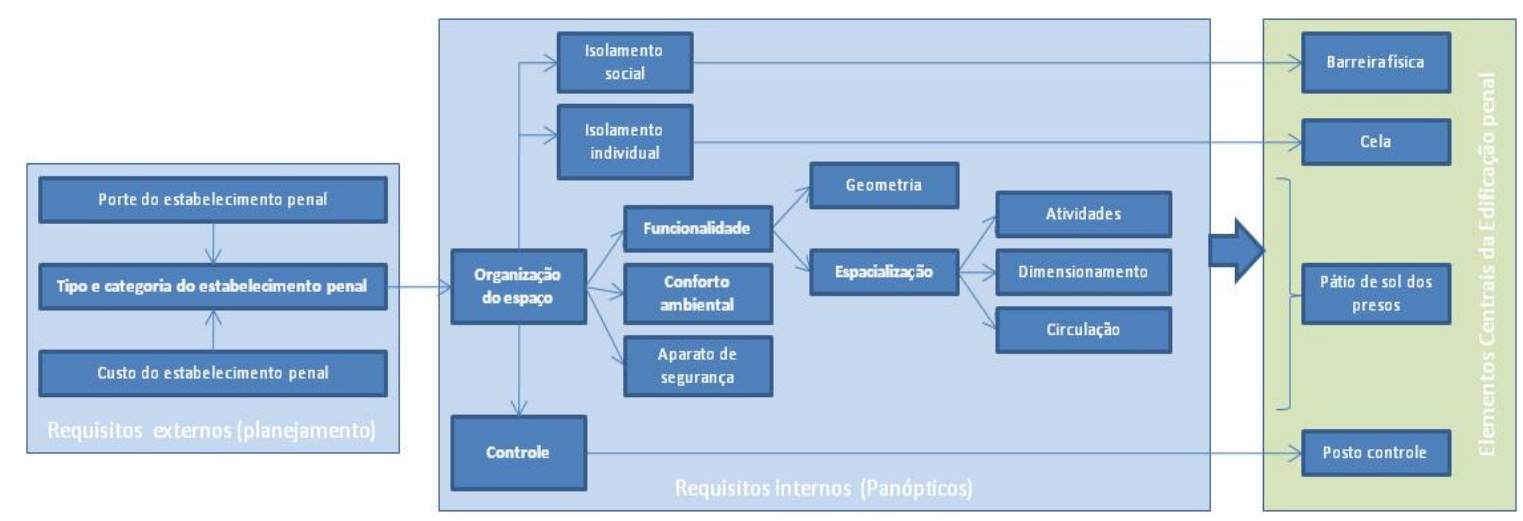

Figura 28 - Programa arquitetônico para estabelecimentos penais

\subsection{Análise das características formais e informais da edificação penal}

Com a definição do programa arquitetônico nas seções iniciais deste capítulo, a estrutura para as análises das características formais (preconizadas nos modelo prisional) e informais (advindas da realidade prisional) da edificação penal foi estabelecida, de modo a se verificar a equivalência entre estas características e selecionar as melhores soluções para a elaboração da tecnologia de projeto (ver Apêndice E).

\subsubsection{Análise da equivalência entre as características da edificação penal}

$\mathrm{Na}$ análise da equivalência entre as características formais e informais da edificação penal (Figura 29), do conjunto total de noventa e dois requisitos funcionais, trinta e cinco itens apresentaram convergência e cinquenta e sete apresentaram divergência entre as características formais e informais da edificação penal (representada pelos projetos arquitetônicos de referência, adotados nesta tese - ver Apêndice A). Entre as convergências, nove foram plenas (C) e vinte e seis foram parciais (CP). Entre as divergências, onze foram plenas (D) e quarenta e seis foram parciais (DP). Deste modo, as avaliações plenas somam vinte itens, enquanto as parciais, setenta e dois. Estes números mostram uma 
divergência nas demandas do sistema penal para a arquitetura, correspondente a $62 \%$ dos requisitos funcionais do programa arquitetônico avaliado. Ao mesmo tempo, se verifica que a maior parte desta dissonância é parcial, cerca de $80 \%$ das divergências identificadas.

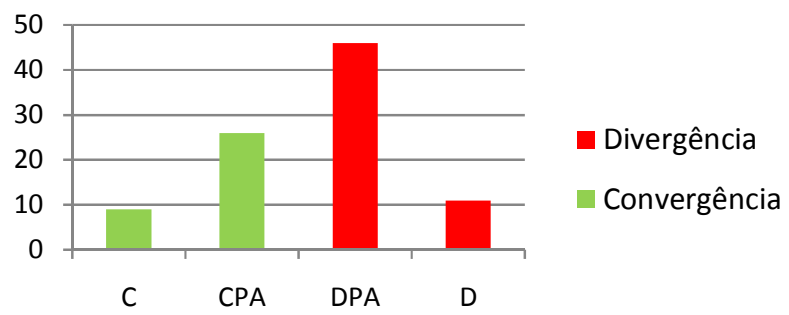

Figura 29 - Gráfico do resultado geral da equivalência entre as características formais e informais da edificação penal

No gráfico são expressos os valores percentuais dos resultados encontrados: convergência (C), divergência (D), convergência parcial (CPA) e divergência parcial (DPA)

O exame dos resultados por grupo de quesitos mostra que, na totalidade, estes são parciais, havendo apenas dois resultados plenos, ambos entre os quesitos de ordem externa: o Porte e o Custo do estabelecimento penal (Quadro 10). Este exame ainda explicita uma maioria dos grupos em divergência - 14 dos 19 grupos. Os grupos convergentes coincidem com temas voltados para a segurança penitenciária, tais como: Aparatos de Segurança, Barreira Perimetral e Posto de Controle. Outros itens diretamente vinculados à segurança, como os Isolamentos Social e Individual e o Controle tiveram resultados divergentes do nível de segurança mais alto. O Isolamento Social perdeu a convergência em razão do modelo de visita, mais brando, enquanto o fechamento da instituição e a contenção dos presos respondem à expectativa social da segregação dos presos. Neste sentido, o Isolamento Social e Barreira Perimetral estão em sintonia. A divergência no Isolamento Individual reflete a coletivização da cela, com reflexos na composição espacial da mesma, embora os cuidados com a manutenção da estanqueidade fiquem evidentes (itens 17.01 e 17.09). O Controle e o Posto de Controle tiveram resultados destoantes entre si. Neste caso, o Controle no arranjo espacial da edificação mostra deficiência na vigilância, enquanto o Posto tem convergência na totalidade dos requisitos. O conforto ambiental apresentou divergência (parcial), tanto nos quesitos internos, como nos itens dos elementos internos (itens 17.08, 18.10 e 19.06).

Na Organização do Espaço, a divergência de seus quesitos componentes é evidenciada: a geometria complexa, a funcionalidade incongruente com a disciplina espacial e o Conforto Ambiental deficiente. Estas características dos projetos de referência concorrem para um prejuízo do desempenho do Controle, principalmente, da Espacialidade e da Circulação na edificação penal. Ainda sobre a Organização do Espaço, as Atividades são o único quesito a apresentar convergência entre os quesitos da Funcionalidade. Esta convergência é justificada pela redução das atividades do programa de 
reinserção social dos presos nos projetos de referência, em especial, nos projetos paulista (Penitenciária Compacta) e privado (empresa Verdi Construções S/A).

Quadro 10 - Resumo da análise da equivalência entre as características formais e informais da edificação penal

\begin{tabular}{|c|c|c|c|c|c|c|c|c|c|c|c|c|c|c|c|c|c|c|c|}
\hline \multirow{4}{*}{ 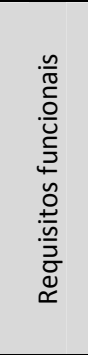 } & \multicolumn{19}{|c|}{ Grupos de quesitos } \\
\hline & \multicolumn{6}{|c|}{$\begin{array}{l}\mathrm{C} \text { - convergência } \\
\text { CPA - convergência parcial }\end{array}$} & \multicolumn{13}{|c|}{$\begin{array}{l}\text { D - divergência } \\
\text { DPA - divergência parcial }\end{array}$} \\
\hline & 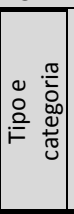 & $\stackrel{\stackrel{\Xi}{t}}{\circ}$ & 总 & 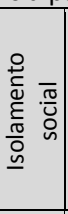 & 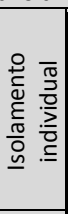 & 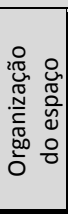 & 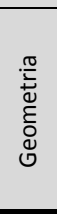 & $\begin{array}{l}\frac{0}{0} \\
\frac{\pi}{0} \\
\frac{0}{\overline{0}} \\
\frac{0}{0} \\
\frac{0}{U} \\
\frac{5}{5} \\
\end{array}$ & $\begin{array}{l}\frac{\tilde{d}}{0} \\
\frac{\pi}{0} \\
\frac{0}{2} \\
\frac{1}{4}\end{array}$ & 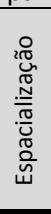 & 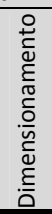 & 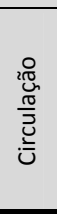 & 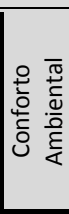 & 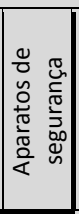 & $\frac{0}{\frac{0}{0}}$ & 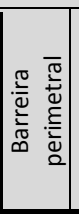 & $\frac{\pi}{0}$ & 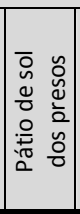 & $\begin{array}{ll}0 & 0 \\
0 & 0 \\
0 & 0 \\
0 & 0 \\
0 & 0 \\
0 & 0 \\
0\end{array}$ \\
\hline & 01 & 02 & 03 & 04 & 05 & 06 & 07 & 08 & 09 & 10 & 11 & 12 & 13 & 14 & 15 & 16 & 17 & 18 & 19 \\
\hline 01 & DP & DP & DP & $\mathrm{CP}$ & $\mathrm{D}$ & $D P$ & $\mathrm{CP}$ & DP & $\mathrm{CP}$ & DP & DP & DP & DP & $\mathrm{CP}$ & $\mathrm{DP}$ & $\mathrm{CP}$ & $C$ & $D$ & $\mathrm{CP}$ \\
\hline 02 & $\mathrm{DP}$ & $\mathrm{D}$ & $\mathrm{D}$ & $\mathrm{CP}$ & $\mathrm{D}$ & $\mathrm{DP}$ & & DP & $\mathrm{CP}$ & DP & $\mathrm{DP}$ & DP & DP & $\mathrm{CP}$ & $\mathrm{DP}$ & DP & DP & $\mathrm{CP}$ & $\mathrm{CP}$ \\
\hline 03 & DP & DP & DP & DP & C & DP & & & & DP & DP & C & & & $\mathrm{CP}$ & DP & C & D & $\mathrm{CP}$ \\
\hline 04 & & & DP & DP & $\bar{D}$ & & & & & $\mathrm{CP}$ & & $\mathrm{DP}$ & & & DP & $\mathrm{CP}$ & $\bar{D}$ & C & $\mathrm{CP}$ \\
\hline 05 & & & & & $\mathrm{CP}$ & & & & & DP & & & & & $\mathrm{CP}$ & $\mathrm{C}$ & DP & $\mathrm{D}$ & $\mathrm{CP}$ \\
\hline 06 & & & & & $\mathrm{DP}$ & & & & & DP & & & & & $\mathrm{CP}$ & C & DP & DP & $D P$ \\
\hline 07 & & & & & & & & & & & & & & & DP & DP & DP & $\mathrm{CP}$ & \\
\hline 08 & & & & & & & & & & & & & & & & $\mathrm{CP}$ & $\mathrm{DP}$ & DP & \\
\hline 09 & & & & & & & & & & & & & & & & $\mathrm{CP}$ & $\mathrm{CP}$ & $\mathrm{DP}$ & \\
\hline 10 & & & & & & & & & & & & & & & & DP & D & DP & \\
\hline 11 & & & & & & & & & & & & & & & & $\mathrm{CP}$ & D & C & \\
\hline 12 & & & & & & & & & & & & & & & & & & $\mathrm{C}$ & \\
\hline \multirow{4}{*}{ Grupo } & DP & $\mathrm{D}$ & $\mathrm{D}$ & DP & DP & DP & $\mathrm{CP}$ & DP & $\mathrm{CP}$ & DP & $\mathrm{DP}$ & DP & DP & $\mathrm{CP}$ & DP & $\mathrm{CP}$ & DP & D & $\mathrm{CP}$ \\
\hline & \multirow{2}{*}{\multicolumn{3}{|c|}{$\begin{array}{l}\text { Externos - } \\
\text { D }\end{array}$}} & & & & & \multicolumn{5}{|c|}{ Funcionalidade - DP } & & & & \multirow{2}{*}{\multicolumn{4}{|c|}{$\begin{array}{c}\text { Elementos Centrais } \\
\text { - DP }\end{array}$}} \\
\hline & & & & & & & & Orga & izaçá & do & spaç & - DP & & & & & & & \\
\hline & \multicolumn{19}{|c|}{ Programa arquitetônico - DP } \\
\hline
\end{tabular}

O apanhado dos elementos centrais da edificação penal refletiu as incongruências entre seus componentes que oscilam entre a convergência e a divergência. Se a Barreira Perimetral e o Posto de Controle espelharam a ênfase na segurança penitenciária do Isolamento Social e do Controle, a Cela e o Pátio de Sol evidenciaram os problemas da organização do espaço concernentes à hibridização das características formais e informais nestes locais. Ao mesmo tempo, esta constatação expõe a questão territorial na prisão, na qual os locais dedicados aos presos são preteridos em benefício dos locais institucionais, conforme o constatado na avaliação dos projetos de referência.

$\mathrm{Na}$ avaliação por projeto de referência (Quadro 11), a maioria apresentou uma divergência parcial, com recorrências entre os grupos de quesitos que ilustram os resultados gerais, derivados da priorização da segurança (segregação dos presos), do relaxamento na disciplina do espaço e da coletivização dos espaços e sobreposição de atividades incompatíveis. A exceção foi o projeto da empresa Verdi Construções S/A (ESTECA, 2014) que obteve uma convergência parcial. Em contrapartida, no Isolamento Social, este projeto tem o pior desempenho do grupo, devido à permeabilidade da barreira perimetral, associada à locação desfavorável dos projetos. Unânimes entre os projetos são os quesitos de Isolamento Individual, Conforto Ambiental e Cela - todos divergentes, 
além dos Aparatos de Segurança (convergente). As celas dos projetos arquitetônicos do Ministério da Justiça e da empresa Verdi Construções S/A apresentam divergências maiores por investirem em itens de conforto que não contabilizam na perspectiva da segurança máxima, ao passo que as celas dos demais projetos vão ao encontro da segurança. Em comum, a cela e o pátio de sol dos presos são deficientes quanto às relações sociais dos presos, pois não apresentam espaços ou aparatos para a individualização ou desenvolvimento das atividades. Já o Posto de Controle possui avaliação positiva ao se enquadrar, em geral, na segunda geração de estabelecimentos penais. A avaliação do Conforto Ambiental em qualquer projeto corrobora a questão da maximização da segurança em detrimento da condição humana na prisão. Na Organização do Espaço, o projeto da empresa Verdi Construções S/A obteve uma convergência, principalmente pela aplicação do princípio de utilidade e do racionalismo disciplinar. Ao unir dois padrões arquitetônicos (paralelo e modular), este projeto conjuga as características positivas de cada um, em atenção às exigências de segurança e operação próprias de cada setor da prisão (intermediário e interno). Nos demais projetos predominam a coletivização dos locais e a generalização funcional, associadas ao aumento de capacidade e ao acúmulo de atividades.

Quadro 11 - Resumo das equivalências entre as características formais e informais por projeto de referência

\begin{tabular}{|c|c|c|c|c|c|}
\hline \multirow{3}{*}{ Grupo de quesitos } & \multicolumn{4}{|c|}{ Projetos } & \multirow{3}{*}{$\begin{array}{l}\text { Resultado por } \\
\text { grupo de } \\
\text { quesito }\end{array}$} \\
\hline & \multicolumn{2}{|c|}{$\begin{array}{l}\text { C - convergência } \\
\text { CPA - convergência parcial }\end{array}$} & \multicolumn{2}{|c|}{$\begin{array}{l}\text { D - divergência } \\
\text { DPA - divergência parcial }\end{array}$} & \\
\hline & $\begin{array}{l}\text { Penitenciária do } \\
\text { Distrito federal }\end{array}$ & $\begin{array}{l}\text { Penitenciária } \\
\text { Compacta (SP) }\end{array}$ & $\begin{array}{l}\text { Projeto padrão } \\
\text { federal (MJ) }\end{array}$ & $\begin{array}{l}\text { Projeto padrão } \\
\text { privado }\end{array}$ & \\
\hline 1. Tipo e Categoria & DP & $\mathrm{CP}$ & D & DP & DP \\
\hline 2. Porte & $\mathrm{D}$ & $\mathrm{D}$ & $\mathrm{D}$ & DP & $\mathbf{D}$ \\
\hline 3. Custo & DP & DP & D & DP & D \\
\hline 4. Isolamento social & $\mathrm{CP}$ & $\mathrm{CP}$ & $\mathrm{CP}$ & DP & DP \\
\hline 5. Isolamento individual & $\mathrm{DP}$ & DP & $\mathrm{D}$ & $\mathrm{D}$ & DP \\
\hline 6. Organização do espaço & $\mathrm{DP}$ & DP & $\mathrm{DP}$ & $\mathrm{CP}$ & DP \\
\hline 7. Geometria & $\mathrm{CP}$ & $\mathrm{CP}$ & DP & $\mathrm{CP}$ & CP \\
\hline 8. Funcionalidade & $\mathrm{CP}$ & $\mathrm{DP}$ & $\mathrm{DP}$ & $\mathrm{CP}$ & DP \\
\hline 9. Atividades & $\mathrm{DP}$ & $\mathrm{CP}$ & $\mathrm{CP}$ & $\mathrm{CP}$ & CP \\
\hline 10. Espacialização & DP & $\mathrm{D}$ & $\mathrm{DP}$ & $\mathrm{CP}$ & DP \\
\hline 11. Dimensionamento & $\mathrm{CP}$ & DP & $\mathrm{DP}$ & $\mathrm{DP}$ & DP \\
\hline 12. Circulação & $\mathrm{DP}$ & $\mathrm{D}$ & DP & $\mathrm{CP}$ & DP \\
\hline 13. Conforto Ambiental & $\mathrm{D}$ & DP & DP & DP & DP \\
\hline 14. Aparatos de segurança & $\mathrm{CP}$ & $\mathrm{CP}$ & $\mathrm{CP}$ & $\mathrm{CP}$ & CP \\
\hline 15. Controle & DP & $\mathrm{D}$ & DP & $\mathrm{CP}$ & DP \\
\hline 16. Barreira perimetral & DP & $\mathrm{CP}$ & $\mathrm{CP}$ & $\mathrm{CP}$ & CP \\
\hline 17. Cela & $\mathrm{DP}$ & DP & $\mathrm{DP}$ & $\mathrm{DP}$ & DP \\
\hline 18. Pátio de sol dos presos & $\mathrm{DP}$ & DP & DP & $\mathrm{CP}$ & D \\
\hline 19. Posto de controle & $\mathrm{CP}$ & $\mathrm{DP}$ & $\mathrm{CP}$ & $\mathrm{CP}$ & CP \\
\hline Resultado por projeto & DPA & DPA & DPA & CPA & - \\
\hline
\end{tabular}

\subsubsection{Análise das características da edificação penal para definição das melhores soluções arquitetônicas para a tecnologia de projeto}

A comparação entre as características formais e informais do espaço arquitetônico apontou as melhores soluções arquitetônicas para a edificação penal, segundo os critérios de segurança, 
funcionalidade, conforto ambiental e custos estipulados, embora, um ou outro destes critérios tenha sido dispensado em alguns requisitos, diante de indiferença concernente à problemática dos conteúdos tratados.

Do conjunto total de noventa e dois requisitos funcionais, setenta e três indicaram soluções formais (F), sete soluções informais (I) e sete soluções equivalentes (as análises formal e informal atingiram a mesma avaliação final, mesmo com ponderações diferentes entre os itens) ou equiparadas (as análises formal e informal apresentaram a mesma avaliação em cada critério) entre o formal e o informal (F/I) (Figura 30). A análise indica o predomínio da formalidade como solução mais adequada para o espaço arquitetônico, ocupando $79 \%$ dos resultados gerados. Ao mesmo tempo, se verifica que a maior parte desta solução foi escolhida tendo atendido a totalidade dos critérios em cada requisito funcional, o que ocorre em cerca de $90 \%$ dos requisitos. Em média, as soluções formais apresentam $86 \%$ de atendimento das demandas, enquanto as soluções informais, 53\% (Figura 31).

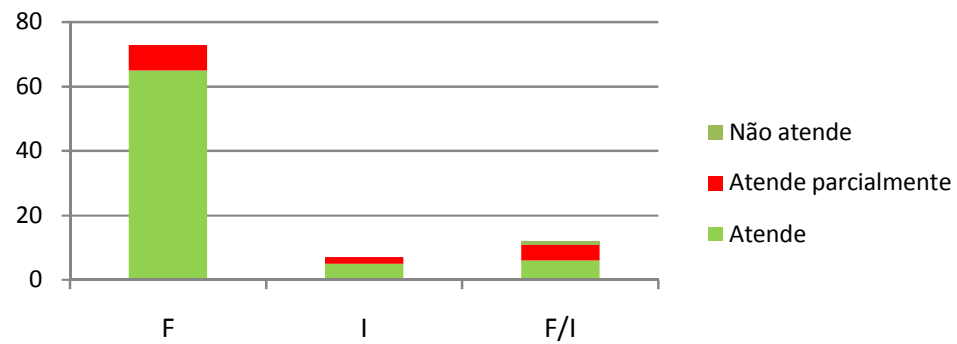

Figura 30 - Gráfico do resultado geral das melhores soluções para a edificação penal

No gráfico são expressos os valores percentuais dos resultados encontrados: soluções formais (F), soluções informais (I) e soluções formais e informais equiparadas (F/I)

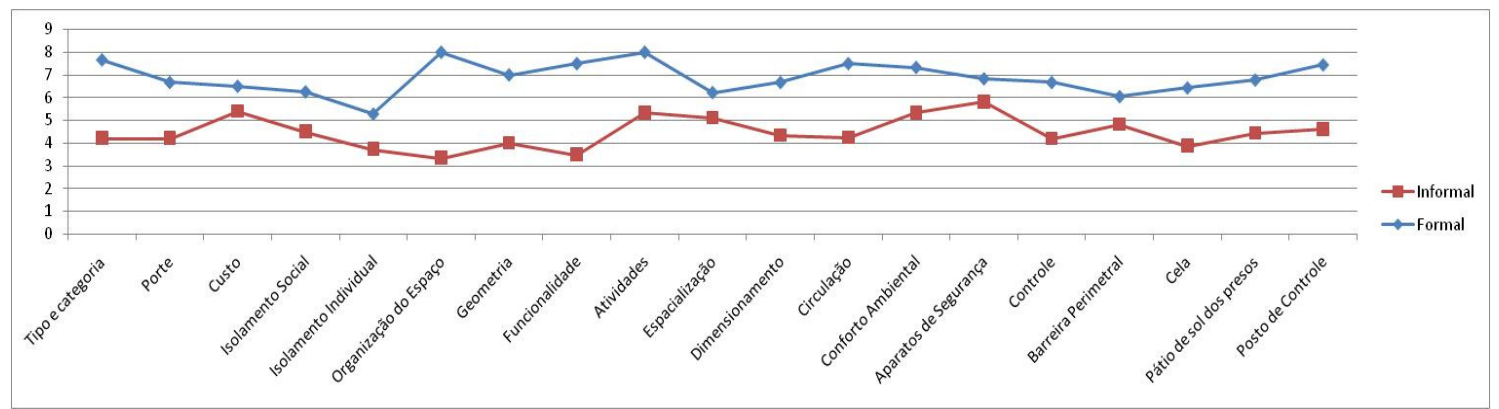

Figura 31 - Gráfico do atendimento dos critérios de análise pelas soluções formais e informais

O exame dos resultados por grupo de quesitos mostra todos os quesitos voltados para soluções formais (Quadro 12), embora ocorram grupos de quesitos com maior heterogeneidade, integrada por soluções informais ou parciais, tais como, o Porte e o Custo do estabelecimento penal a ser projetado. $\mathrm{O}$ Isolamento Social e o Isolamento Individual concentraram os resultados parciais, com desdobramentos na Barreira Perimetral e na Cela. A Cela correspondeu ao único requisito inconsistente (item 17.03), 
cuja solução depende de novas considerações. Os quesitos internos apontaram para soluções formais e completas, com exceção da Espacialização que apresentou resultados mais inconsistentes e próximos das soluções informais.

Quadro 12 - Resumo das soluções adotadas para a conformação da tecnologia de projeto

\begin{tabular}{|c|c|c|c|c|c|c|c|c|c|c|c|c|c|c|c|c|c|c|c|}
\hline \multirow{4}{*}{ 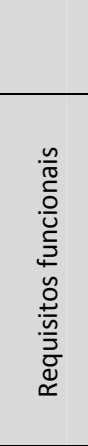 } & \multicolumn{9}{|c|}{$\begin{array}{l}\text { F- caracterização formal } \\
\text { I- caracterização informal } \\
\text { F/I - caracterização formal e informal }\end{array}$} & \multicolumn{10}{|c|}{$\begin{array}{l}\text { Verde - qualificação atende aos critérios } \\
\text { Amarelo - qualificação atende parcialmente aos critérios } \\
\text { Vermelho - qualificação não atende aos critérios }\end{array}$} \\
\hline & \multicolumn{19}{|c|}{ Grupos de quesitos } \\
\hline & 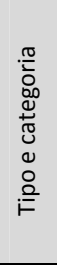 & 䒕 & 苞 & 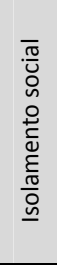 & 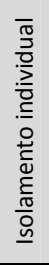 & 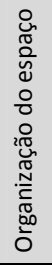 & 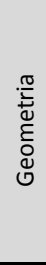 & 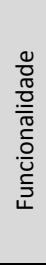 & $\begin{array}{l}\frac{\tilde{0}}{0} \\
\frac{\pi}{0} \\
\frac{0}{2} \\
\dot{X}\end{array}$ & $\begin{array}{l}\frac{0}{2 \pi} \\
\frac{\pi}{\pi} \\
\frac{N}{\pi} \\
\frac{\pi}{\pi} \\
\frac{\pi}{0} \\
\tilde{\omega}\end{array}$ & 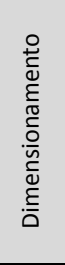 & 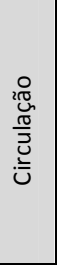 & 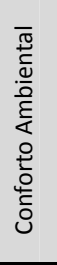 & 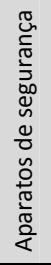 & 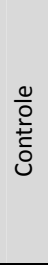 & 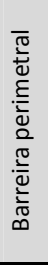 & $\frac{\pi}{0}$ & 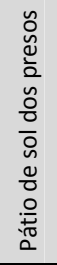 & $\begin{array}{l}\frac{0}{0} \\
\frac{0}{2} \\
0 \\
0 \\
0 \\
0 \\
0 \\
0 \\
0 \\
0\end{array}$ \\
\hline & 01 & 02 & 03 & 04 & 05 & 06 & 07 & 08 & 09 & 10 & 11 & 12 & 13 & 14 & 15 & 16 & 17 & 18 & 19 \\
\hline 01 & $\mathrm{~F}$ & $\mathrm{~F}$ & $\mathrm{~F}$ & 1 & $\mathrm{~F}$ & $\mathrm{~F}$ & $\mathrm{~F}$ & $\mathrm{~F}$ & $\mathrm{~F}$ & $\mathrm{~F}$ & $\mathrm{~F}$ & $\mathrm{~F}$ & $\mathrm{~F}$ & $\mathrm{~F}$ & $\mathrm{~F}$ & 1 & $\mathrm{~F}$ & $\mathrm{~F}$ & $\mathrm{~F}$ \\
\hline 02 & $\mathrm{~F}$ & 1 & 1 & $F / I$ & $\mathrm{~F}$ & $\mathrm{~F}$ & & $\mathrm{~F}$ & $\mathrm{~F}$ & $\mathrm{~F}$ & $\mathrm{~F}$ & $\mathrm{~F}$ & $\mathrm{~F}$ & $\mathrm{~F}$ & $\mathrm{~F}$ & $\mathrm{~F}$ & $\mathrm{~F}$ & $F / I$ & $\mathrm{~F}$ \\
\hline 03 & $\mathrm{~F}$ & $\mathrm{~F}$ & $\mathrm{~F}$ & $\mathrm{~F}$ & $F / I$ & $\mathrm{~F}$ & & & & $\mathrm{~F}$ & $\mathrm{~F} / \mathrm{I}$ & $F / I$ & & & 1 & $\mathrm{~F}$ & $F / I$ & 1 & $\mathrm{~F}$ \\
\hline 04 & & & $\mathrm{~F}$ & $\mathrm{~F}$ & $\mathrm{~F}$ & & & & & 1 & & $\mathrm{~F}$ & & & $\mathrm{~F}$ & $F / I$ & $\mathrm{~F}$ & $\mathrm{~F} / \mathrm{I}$ & $\mathrm{F}$ \\
\hline 05 & & & & & $\mathrm{~F}$ & & & & & $\mathrm{~F}$ & & & & & $\mathrm{~F}$ & $F / I$ & $\mathrm{~F}$ & $\mathrm{~F}$ & $\mathrm{~F}$ \\
\hline 06 & & & & & 1 & & & & & $\mathrm{~F}$ & & & & & $\mathrm{~F}$ & $F / I$ & $\mathrm{~F}$ & $\mathrm{~F}$ & $\mathrm{~F}$ \\
\hline 07 & & & & & & & & & & & & & & & $\mathrm{~F}$ & 1 & $\mathrm{~F}$ & $\mathrm{~F}$ & \\
\hline 08 & & & & & & & & & & & & & & & & $\mathrm{~F}$ & $\mathrm{~F}$ & $\mathrm{~F}$ & \\
\hline 09 & & & & & & & & & & & & & & & & $\mathrm{~F}$ & $\mathrm{~F}$ & $\mathrm{~F}$ & \\
\hline 10 & & & & & & & & & & & & & & & & $\mathrm{~F}$ & $\mathrm{~F}$ & $\mathrm{~F}$ & \\
\hline 11 & & & & & & & & & & & & & & & & $\mathrm{~F}$ & $\mathrm{~F}$ & $\mathrm{~F}$ & \\
\hline 12 & & & & & & & & & & & & & & & & & & $\mathrm{~F}$ & \\
\hline \multirow{4}{*}{ Grupo } & $\mathrm{F}$ & $\mathrm{F}$ & $\mathrm{F}$ & $\mathrm{F}$ & $\mathrm{F}$ & $\mathrm{F}$ & $\mathrm{F}$ & $\mathrm{F}$ & $\mathrm{F}$ & $\mathrm{F}$ & $\mathrm{F}$ & $\mathrm{F}$ & $\mathrm{F}$ & $\mathrm{F}$ & $\mathrm{F}$ & $\mathrm{F}$ & $\mathrm{F}$ & $\mathrm{F}$ & $\mathrm{F}$ \\
\hline & \multirow{2}{*}{\multicolumn{3}{|c|}{$\begin{array}{l}\text { Externos - } \\
\text { F }\end{array}$}} & & & & & \multicolumn{5}{|c|}{ Funcionalidade - $\mathbf{F}$} & & & & \multirow{2}{*}{\multicolumn{4}{|c|}{$\begin{array}{c}\text { Elementos Centrais } \\
-\mathbf{F}\end{array}$}} \\
\hline & & & & & & & & & nizas & io do & espaç & $-F$ & & & & & & & \\
\hline & \multicolumn{19}{|c|}{ Programa arquitetônico - F } \\
\hline
\end{tabular}

\subsection{Conclusão Analítica}

No programa arquitetônico obtido, os quesitos de planejamento (tipo, porte e custo do estabelecimento penal) são basilares para a composição espacial da prisão, delineando um campo penalógico e penitenciário preparatório para os requisitos funcionais de ordem interna. Entre os quesitos de planejamento, o nível de segurança penitenciário é determinante para o espaço arquitetônico da prisão, permeando todos os grupos de quesitos.

A análise das características formais e informais da edificação penal identificou uma divergência nos projetos de referência adotados nesta pesquisa (ver Apêndice A). Esta divergência remete ao caráter totalitário dos instrumentos técnico-normativos de projeto, ao mesmo tempo em que evidencia a adaptação da edificação a certas demandas do sistema penitenciário, tais como, a geração de vagas e a redução de custos de construção. Esta adaptação aponta para a descaracterização da modalidade arquitetônica de segurança máxima (coletivização e generalização dos espaços com aumento das 
capacidades). Por outro lado, a divergência levantada é majoritariamente classificada como parcial, o que sugere a possibilidade de mitigação ou correção mais fácil ou com custos menores.

$\mathrm{Na}$ análise das soluções mais adequadas para a tecnologia de projeto, a maioria dos requisitos funcionais atendeu satisfatoriamente aos critérios aplicados, enquanto uma minoria apresentou soluções parciais e apenas um requisito apresentou resultado negativo (item 17.03). Apesar da consistência deste conjunto, a totalidade dos requisitos recebeu ressalvas advindas da realidade prisional indicativas de possíveis ajustes voltados para soluções arquitetônicas melhores. Estas ressalvas advêm de dois motivos principais, um de ordem interna e outro de ordem externa ao conjunto elaborado. Em primeiro lugar, uma solução considerada melhor em um requisito não significa o atendimento de todos os critérios, podendo ocorrer resultados negativos em alguns critérios (não atendimento). No caso de solução formal, estes resultados negativos decorrem de divergências entre os modelos arquitetônicos, a teoria e os instrumentos técnico-normativos e, no caso de solução informal, entre os projetos de referência adotados nesta pesquisa. Em segundo lugar, os resultados são bem definidos do ponto de vista do problema particularizado em cada requisito funcional, porém o conjunto está subordinado ao atendimento das demandas do sistema penitenciário, prevista no estudo do paradigma tecnológica da edificação penal (ver introdução, desta tese). Entre estas duas considerações de ordem interna e externa, este contraponto mais amplo suscita a estratégia de pesquisa para a revisão do paradigma arquitetônico da prisão, cuja adoção da solução formal para a tecnologia de projeto contraria uma premissa de aprimoramento da edificação penal.

No sentido da melhor composição da tecnologia de projeto, o atendimento das demandas da realidade prisional (ressalvas apensadas às soluções dos requisitos funcionais) se tornou imperativa, o que alterou a perspectiva da composição arquitetônica da edificação penal de segurança máxima. Inicialmente identificada com os modelos supermax ou modular de segurança máxima, a composição arquitetônica tende a absorver os padrões de níveis de segurança mais brandos, encontrados nos projetos de referência adotados. Ao mesmo tempo em que estes padrões não implicam em características do nível de segurança média, definindo uma modalidade penitenciária e arquitetônica intermediária. Esta ponderação entre a segurança máxima e a segurança média determina a maior convergência das soluções arquitetônicas dos projetos de referência adotados com o conjunto tecnológico almejado.

A contradição do conjunto concebido em relação à realidade prisional e a possibilidade de ajustamento por meio das soluções arquitetônicas informais indicaram a necessidade de estudos complementares, de modo a garantir a consistência do conjunto gerado. Deste modo, os resultados obtidos estão inacabados do ponto de vista do método adotado (ver capítulo 5), faltando o ajuste do conjunto elaborado à realidade prisional, o que foi disposto no capítulo 7, desta tese. 


\section{Capítulo 7 - Tecnologia de projeto}

Neste capítulo, os conteúdos para a tecnologia de projeto são elaborados, por meio do ajustamento do conjunto de soluções arquitetônicas obtido na análise realizada no capítulo 6. Em particular, os desenhos-síntese dos elementos centrais da edificação penal e a caracterização do espaço arquitetônico de segurança máxima são apresentados. A tecnologia de projeto desenvolvida se encontra no Apêndice $F$, e o material técnico dos desenhos-síntese se encontra no Apêndice $G$, desta tese.

A análise das características da edificação penal realizada resultou em um conjunto de soluções arquitetônicas de caráter predominantemente formal, voltadas para o modelo prisional e para a maximização da segurança (ver Apêndice E). Ao mesmo tempo, este resultado foi acompanhado de ressalvas para o melhor ajustamento das soluções apontadas, por meio do atendimento das demandas da realidade prisional. $\mathrm{O}$ atendimento da realidade prisional é previsto no estudo do paradigma tecnológico da edificação penal que embasou a lógica analítica desta pesquisa (ver introdução). $\mathrm{O}$ ajustamento do conjunto de soluções arquitetônicas obtido consiste em um reequilíbrio entre o formalismo encontrado e as demandas realísticas, o que implicou em uma revisão dos padrões de segurança inicialmente fixados para a tecnologia de projeto objetivada. A revisão destes padrões remete às soluções espaciais tipicamente mais brandas que a realidade prisional apresenta, conforme o verificado na análise da equivalência das características da edificação penal, procedida no capítulo 6 (seção 6.6.1).

A revisão do conjunto de soluções arquitetônicas obtido adquire uma natureza geral que remete ao ajustamento dos quesitos externos ou de planejamento do programa arquitetônico elaborado. Estes quesitos tratam diretamente do nível de segurança e a adequação dos mesmos tem impacto sobre todo o programa arquitetônico, conforme a hierarquia estabelecida na estrutura do programa arquitetônico. Deste modo, o ajuste do conjunto tratou inicialmente dos quesitos externos para, em seguida, abordar os desdobramentos deste na composição arquitetônica da prisão, pertinente aos quesitos internos e quesitos dos elementos centrais da edificação penal.

\subsection{Revisão dos quesitos externos}

O atendimento da realidade prisional no ajustamento do conjunto de soluções arquitetônicas obtido diz respeito à compatibilidade entre o nível de segurança máximo e o perfil da população prisional a ser abrigada - previsto no primeiro requisito funcional do programa arquitetônico elaborado. Neste sentido, o caráter formal do conjunto obtido corresponde a presos considerados da mais alta periculosidade (UNOPS, 2016, p. 42), ao enfatizar os princípios de isolamento e controle dos presos. No Brasil, este perfil é destinado ao sistema penitenciário federal ou ao Regime Disciplinar Diferenciado (RDD), numericamente inferior a um por cento da população prisional brasileira. Então, trata-se uma excepcionalidade. 
A demanda realística remete a um perfil de grande periculosidade, mas que dispensa a totalização dos processos disciplinares e viabiliza um incremento dos programas de reinserção social dos presos. Segundo dados de Morana (apud AZEVEDO, 2009), cerca de oitenta por cento dos presos brasileiros se enquadram em um perfil de segurança média, o que determina a proporção de vinte por cento da população prisional compatível com a segurança máxima. Esta proporção é encontrada na estatística criminológica do Ministério da Justiça, ao indicar a predominância de crimes menos ofensivos no perfil dos presos (BRASIL, 2014).

Arquitetonicamente, o conjunto de soluções arquitetônicas obtido remete ao modelo espacial norteamericano supermax e ao projeto brasileiro da penitenciária federal, por exemplo, na individualização dos presos (ver Apêndice A). Já a demanda realística é descrita pela hibridização dos projetos de referência adotados nesta pesquisa (idem) que apresentam características de menor segurança, como a valorização das atividades laboreducativas dos presos (ver capítulo 1). Estes projetos de referência representam uma adequação à realidade prisional, em resposta às demandas de geração de vagas e redução dos recursos financeiros na ampliação do sistema penitenciário, porém de modo indistinto entre arquiteturas de segurança máxima e média, o que reflete a indefinição técnico-normativa e a massificação da população prisional, principalmente.

As considerações sobre a correspondência da arquitetura com a realidade prisional apontam para uma lacuna na classificação penitenciária que é preenchida no sistema penitenciário, mas de maneira imprecisa de ponto de vista penitenciário e arquitetônico. Deste modo, o ajustamento do conjunto obtido partiu de uma categorização do nível de segurança máximo e dos respectivos princípios arquitetônicos para a edificação penal. Para tanto, uma classificação penitenciária é proposta para o regime fechado, com as seguintes categorias:

a) Segurança máxima especial: corresponde às características formais levantadas, similares às encontradas nas unidades de RDD. A terminologia 'especial' retrata a peculiaridade da população prisional atendida, equivalente a uma parcela mínima do sistema penitenciário. Este termo foi utilizado nas Diretrizes do CNPCP de 1994 (CNPCP, 1995) para o estabelecimento dotado exclusivamente de celas individuais (esta categoria foi posteriormente abolida nas revisões destas regras técnicas, por isto não consta das Diretrizes Básicas de 2011).

b) Segurança máxima: conforma uma categoria intermediária, na qual a segurança ainda é prioridade, mas agrega características advindas da humanização da pena, como o observado nas mudanças dos princípios panópticos e na arquitetura híbrida dos projetos de referência desta pesquisa. Por sua vez, a segurança máxima especial é mais fiel aos princípios panópticos originais. A categoria proposta corresponde ao nível 2 descrito no Technical Guidance of Prision Planning (UNOPS, 2016, p. 31). 
O acréscimo de um nível de segurança aproxima a classificação nacional da diversidade dos sistemas norte-americano (seis categorias) e inglês (quatro categorias). Em relação ao sistema norte-americano, a segurança máxima especial proposta equivale à administrative prison (ADX), enquanto a segurança máxima adere à hight security, conhecida como United States Penitentiary (USP) (USA, 2017). A USP tem perímetros altamente seguros (muros ou cercas reforçadas), celas individuais e coletivas, alta relação funcionário-preso e grande controle da movimentação dos presos (USA, 2017). Em relação ao sistema inglês, as categorias A e B são análogas às propostas, nesta ordem. A Category B é definida por presos que dispensam o maior nível de segurança, mas para os quais a fuga deve ser muito dificultada (esta categoria está entre uma das quatro tipologias da Training Prison) (RIDEOUT, 2006b).

De imediato, ao incorporar as características informais do espaço arquitetônico, a categoria de segurança máxima proposta reconfigurou os critérios do porte e do custo do estabelecimento penal a ser projetado (Figura 32). O porte se relaciona com a capacidade e a estrutura física do estabelecimento penal, onde um número reduzido de presos favorece tanto a segurança, como a humanização da pena, a depender do objetivo da pena. Com a reconfiguração sugerida, uma gradação foi constituída com a segurança máxima especial assumindo o pequeno porte, a segurança máxima o médio porte, e a segurança média o grande porte. Do ponto de vista da segurança, o pequeno porte é exemplificado pela Penitenciária Federal com 208 vagas, enquanto o grande porte alcança entre oitocentas vagas e mil vagas, segundo as Diretrizes Básicas (CNPCP, 2011a). Do ponto de vista da humanização, uma capacidade de quatrocentas vagas descreve uma unidade de menor segurança, como é verificado nos projetos ingleses Tomorrow's Prison (MUIR, 2010) e The Creative Prison (RIDEOUT, 2006b).

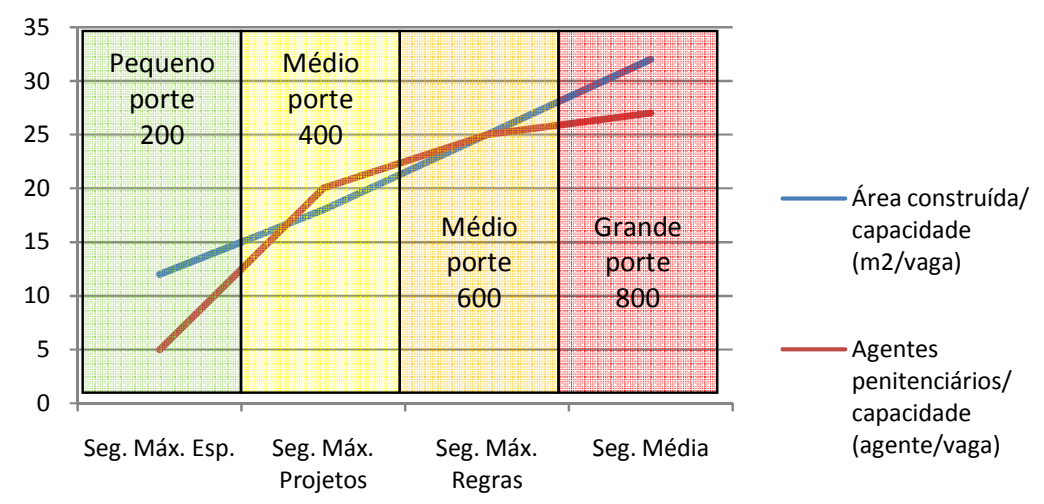

Figura 32 - Gráfico das estruturas física e operacional das diferentes categorias de segurança e porte

O índice da área construída demonstra o incremento do programa, enquanto o índice do pessoal indica uma otimização da mão de obra nos níveis mais brandos de segurança. Dados baseados no projeto da penitenciária federal, nas médias dos projetos de referência e nos parâmetros das Diretrizes Básicas. 
A capacidade adotada para a segurança máxima foi de 500 a 600 vagas, com base nas médias dos projetos de referência (530 vagas) e na manifestação dos funcionários quanto à melhor quantidade de presos (600 vagas) (ver Apêndice C). Corroborada pelos dados de outras referências, como o Prison Design Briefing System (PDBS) que estipula 600 vagas (BOURN, 1994) (Figura 32). A capacidade estimada supera o teto previsto nas Diretrizes Básicas para o estabelecimento de maior segurança (300 vagas), a retomar o parâmetro previsto na versão de 1994 destas regras técnicas (CNPCP, 1994). Para a equipe dirigente, a capacidade do estabelecimento penal pode crescer desde que a população prisional seja fracionada. Esta consideração remete ao padrão arquitetônico modular que oscila entre 400 e 500 vagas. Mesmo nos exemplares de segurança máxima especial a capacidade tende a aumentar com a modulação - o modelo supermax chega a 490 vagas (ADX Florence) (ver Apêndice A). Isto é mais bem tratado à frente, quando a segmentação do grupo de presos é abordada.

As unidades enquadradas na categoria de segurança máxima proposta alcançam valores por vaga menores do que as unidades de segurança máxima especial (28\% a menos) (ver Apêndice A). Isto decorre da maior quantidade de presos, enquanto a estrutura física e operacional não acompanha proporcionalmente o aumento da capacidade ${ }^{90}$. Na estrutura física, se deve levar em consideração que o modelo corrente, representado pelos projetos de referência, apresenta incompletudes. As equipes dirigentes entrevistadas apontaram incompatibilidades pontuais entre o edifício e a operação. A correção deste problema implica em aumento de área construída e de pessoal, com consequente incremento nos custos, interpretada como melhorias dos sistemas de segurança e operação, em particular, em termos da humanização da edificação penal (demandas informais). Na estrutura operacional, se admite a relação de um agente para vinte ou vinte e cinco presos por turno, advinda da realidade prisional, superior ao previsto na Resolução CNPCP n 9/2011, ou no Technical Guidance of Prision Planning (UNOPS, 2016, p. 50), de um agente para cinco presos ${ }^{91}$.

Como estratégia de contenção de gastos, se buscou reduzir a área construída e aumentar as capacidades dos locais (otimização da estrutura física), por meio da hibridização de padrões arquitetônicos, associada à compactação espacial e generalização funcional. Em particular, a limitação dos custos operacionais envolve a redução de tarefas e a simplificação de procedimentos. Sobre isto, as equipes dirigentes destacaram a divisão da população prisional, a distribuição das atividades dos presos e o modelo de vigilância como fatores críticos para o custeio. A melhor definição destas características favorece a economia operacional.

\footnotetext{
90 Existe um programa mínimo explícito em unidades de pequeno porte que aumenta em intervalos mais ou menos coincidentes com os portes, mas cujo aumento advém de incremento que aproveita a estrutura inicial.

910 dimensionamento da equipe funcional se baseou nas informações obtidas junto às equipes dirigentes no estudo de campo realizado, quanto à quantidade ótima de agentes de segurança para a operação penitenciária. Foram considerados os regimes implantados de $12 / 36$ horas (Santa Catarina) e 24/72 horas (São Paulo) e o turno de maior demanda (diurno, em dias de visita). Esta proporção encontra ressonância a média apresentada no Relatório Infopen, de um agente para cada vinte e quatro presos (BRASIL, 2014, p. 79 e 80).
} 


\subsection{Revisão dos quesitos internos}

A proposta de uma categoria de segurança penitenciária, associada às consequentes mudanças no porte e no custo do estabelecimento penal se vincula à totalidade da composição arquitetônica da edificação penal, a produzir adequações para a conformação da edificação. Em particular, estas adequações incorporam as demandas da realidade prisional, em boa parte, advindas das manifestações de funcionários (equipe dirigente) e presos no estudo de campo procedido (ver Apêndice C). Assim como, as características informais da edificação penal são consideradas, tendo sido levantadas dos projetos de referência adotados nesta pesquisa (ver Apêndice A).

\subsubsection{Isolamento social do preso}

A maximização do fechamento da unidade penal prevista nas características formais é mantida na categoria de segurança máxima proposta, pois garante a segregação social do preso e a viabilidade operacional do estabelecimento penal. As equipes dirigentes consideram a impermeabilidade institucional imprescindível para a prisão. A mesma deve ser conseguida por meio da localização do estabelecimento penal, planialtimetria do terreno, configuração da barreira perimetral e fechamento das edificações (sem locais operacionais ou aberturas de iluminação e ventilação expostas para o exterior da unidade prisional). O padrão arquitetônico modular e o modelo supermax ilustram a impermeabilidade pretendida, em particular, com o uso da cerca como barreira perimetral. Neste caso, a permeabilidade da cerca é compensada pelos afastamentos e pela configuração das edificações. Esta composição é atrativa economicamente para o sistema nacional, já que o muro é comparativamente muito mais caro do que a cerca. O muro se justifica ao compensar a eventual inadequação da localização ou dos terrenos (a proximidade de ocupações, ou terrenos pequenos ou irregulares).

O espaço arquitetônico não deve prever estrutura física para a participação da sociedade na administração prisional, tal como o idealizado por Bentham, porém a previsão de sala de encontro com a sociedade nas Diretrizes Básicas pode ser atendida. Isto diante do desinteresse da própria sociedade em relação à prisão e da precedência da instituição pelo monopólio administrativo e pela impermeabilidade e simplificação da estrutura física e operacional, vistos como mandatórios à implementação dos processos totais (maximização da segurança e possível economia de recursos). No modelo supermax e nas unidades brasileiras, a ocasional participação de grupos assistenciais ocorre nas áreas de atividades (pátios de sol, salas de aula ou biblioteca).

Em contraposição à impermeabilidade prevista, a modalidade arquitetônica proposta incorpora o formato da visita ao preso existente no sistema penitenciário, descrito pelo contato físico, inclusive íntimo. Isto em favor da humanização da pena, apesar do comprometimento da segurança, funcionalidade e economia de recursos. Para tanto, o espaço arquitetônico deve prever locais próprios 
para a visitação, dotado de salão e apartamentos de encontro íntimo, o que compensa a permeabilidade e recupera a representação institucional. A criação destes locais é consensual entre a equipe dirigente e os presos, preocupados com a integridade dos visitantes. O contato entre o advogado e o preso permanece proibido.

\subsubsection{Isolamento individual do preso}

O isolamento individual absoluto foi revisado em relação à categoria penitenciária proposta, onde a caracterização formal cedeu à humanização da pena e às imposições do sistema penitenciário. A cela carrega um ideal de individualização voltado à reforma moral do preso que parece superado diante da evolução da penalogia. O próprio Bentham abandonou o isolamento absoluto no desenvolvimento do seu trabalho, no qual concluiu pela superioridade técnica e humana da cela coletiva. Isto foi ratificado em trabalhos recentes, como a reforma da prisão Koopel (KOOLHAAS, 1998). Além disto, funcionários e presos expressaram a preferência pela cela coletiva nas entrevistas realizadas.

Depreende-se que a recorrência da individualização encontrada nos instrumentos legais e normativos levantados nesta pesquisa se vincula a experiências prisionais excepcionais, pois a individualização depende de condições operacionais, econômicas e políticas. A individualização como meio de humanização depende da redução da permanência dos presos na cela (RIDEOUT, 2006b; UNOPS, 2016, p. 88). A individualização deriva modelos dispendiosos, exemplificados pela penitenciária federal brasileira ou a prisão Halden Fengsel. Ou ainda, a cela individual é atrelada à realização de uma reforma penitenciária, como o verificado nos trabalhos do Tomorrow's Prison (MUIR, 2010) e The Creative Prison (RIDEOUT, 2006b).

Segundo o Panóptico, o abandono do isolamento absoluto implicaria na redução da eficácia e eficiência da instituição no seu processo de punição e de reinserção social do preso. Como consequência, o custo econômico, político e social da pena aumentariam (ver capítulo 2). Apesar disto, as questões da realidade prisional se tornaram imperativas. A acomodação celular como padrão é impraticável na conjuntura atual do sistema penal brasileiro: a demanda por novas vagas e a carência de recursos financeiros para as obras penitenciárias, associada ao alto custo da vaga individual. Todos os projetos de referência apresentam celas coletivas, mesmo o modelo do Ministério da Justiça. A cela coletiva gera uma economia de recursos (otimização da estrutura) que compensa, em alguma medida, a perda da eficiência panóptica. Esta lógica é defendida no Technical Guidance of Prision Planning (UNOPS, 2016, p. 50), ao relacionar o dimensionamento da equipe com a coletivização da cela. O alojamento celular se tornou uma particularização destinada à separação de presos com problemas de convívio, sob proteção ou em cumprimento de medida disciplinar, como na Penitenciária Federal. 
Diante do colocado é possível distinguir o tipo de cela em função do nível de segurança penitenciário. A cela individual favorece a segurança, ao materializar o caráter punitivo da pena, por meio da classificação e a separação integral dos encarcerados (controle absoluto da instituição). A cela coletiva traz traços da humanização da pena, ao permitir o agrupamento dos presos, favorável às interações sociais. Ao mesmo tempo, na cela coletiva há uma complicação dos procedimentos e um aumento da exposição dos funcionários. Deste modo, a cela individual é identificada com a segurança especial, já a cela coletiva caracteriza a segurança máxima.

Sobre a viabilidade técnica da cela coletiva, o Manual Internacional para uma Boa Prática Prisional, da Penal Reform Internacional (PRI), admite uma coletivização da cela "desde que o espaço, a ventilação, a mobília e as instalações sanitárias sejam compatíveis" (apud ROLIM, 2005). As Regras Mínimas (CNPCP, 1994, art. 8) aprovam a coletivização do alojamento em caráter de excepcionalidade, desde que observados os cuidados com a higiene, condicionados pelas dimensões e ventilação. O CNPCP emitiu parecer no ano de 2005: "Na hipótese em que as condições e dimensões físicas o permitam, na cela se poderá, resguardando-se sempre a intimidade, alojar mais de uma pessoa, até o limite de seis, desde que não existam razões impeditivas, de ordem médica ou de segurança".

A coletivização do espaço carcerário se prolonga até a organização das celas em alas ou blocos, com a tendência de menos partições e mais celas por partição, o que favorece a funcionalidade e a economia de recursos. Isto será mais bem abordado na Organização do Espaço, devido às implicações adjuntas (item 10.04). Além disto, esta coletivização exige a previsão de ala de celas individuais para a separação de presos, em número equivalente a 1,5\% da capacidade do estabelecimento penal, segundo os projetos de referência (ver Apêndice A). Este percentual é inferior ao disposto nas regras técnicas do Ministério da Justiça e no Technical Guidance of Prision Planning (UNOPS, 2016) (2\%), mas é superior a demanda dos diretores das prisões visitadas (entre $1 \%$ e 1,3\%).

A capacidade da cela coletiva foi estipulada entre quatro e oito vagas (Figura 33). Este intervalo foi apontado pelas equipes dirigentes e pelos presos entrevistados, considerado mais favorável ao controle institucional e à sociabilização dos internos. A cela com seis vagas foi considerada ótima pelos entrevistados. O número de quatro vagas reforça a segurança penitenciária, enquanto oito vagas favorece significativamente os custos. A capacidade proposta é inferior ao encontrado nos projetos de referência que apresentam uma média de nove vagas, com limites individuais entre quatro e doze vagas. A proposta é tecnicamente respaldada nas Diretrizes Básicas e no Technical Guidance of Prision Planning (este prevê um mínimo de quatro pessoas e um máximo de vinte e cinco). 


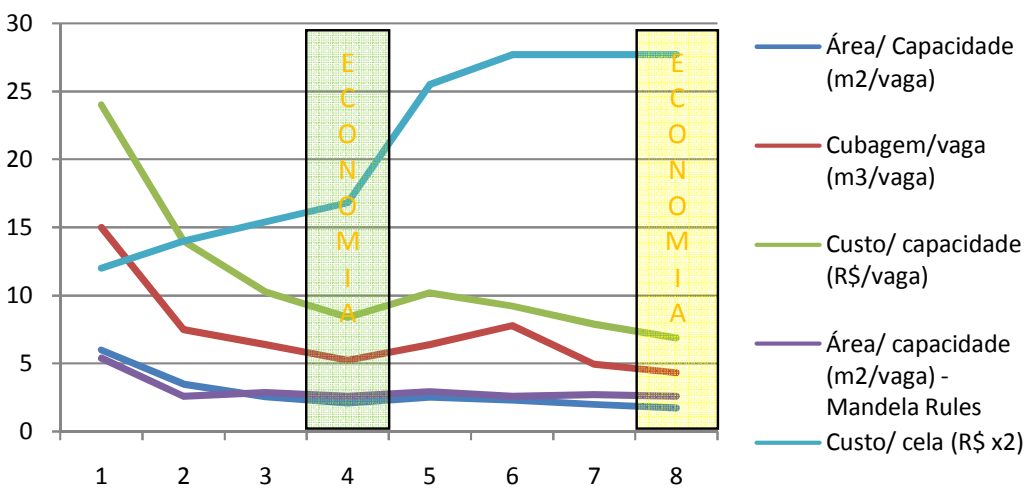

Figura 33 - Gráfico dos índices físicos e financeiros das capacidades de cela

Os índices indicam duas faixas de economia nas celas de quatro e oito vagas. A primeira precede a ampliação do espaço da cela para a quinta cama (menos econômico) que se mantém até oito vagas (beliches). A cela de seis vagas perde economicidade na cubagem. Dados baseados nas Diretrizes Básicas. A Mandela Rules apresenta índices maiores que as regras técnicas nacionais após a cela dupla. Valor de referência médio de quatro mil reais o metro quadrado.

\subsubsection{Organização do espaço}

Segundo o modelo de segurança máxima proposto, a composição do espaço arquitetônico mantém como prioridade a segurança penitenciária (a segregação social e a administração totalitária), porém com a delegação de incorporar a humanização da pena instituída (a sociabilização e os benefícios aos presos). A disciplina-bloco passa a ditar a concepção da unidade de segurança máxima especial, ao preconizar a maximização da segurança limitada pelo respeito à condição humana na prisão. Enquanto a mesma é flexibilizada no modelo de segurança máxima, mediante a complexidade funcional inerente à redefinição de funções e hierarquias que acompanha a modalidade espacial vislumbrada.

A conjunção das demandas de segurança e humanização é obtida por meio do Princípio de Utilidade, através dos processos de integralização e mecanização, além da disciplina espacial. Estes recursos instituem a simplicidade geométrica e funcional como atributos essenciais da edificação prisional. Esta simplicidade é arranjada através da racionalidade geométrica e da síntese funcional (a redução da quantidade de recintos e de circulações). A síntese funcional é obtida por meio do corte de atividades (redução da quantidade de recintos) e da compactação espacial e funcional (redução de áreas). Por sua vez, esta compactação é incrementada pela coletivização com aumento de capacidade e pela generalização funcional dos locais (otimização dos espaços). Estas medidas favorecem a funcionalidade (redução de tarefas e simplificação de procedimentos) e a economia de recursos (minimização das estruturas física e operacional).

Com a simplicidade geométrica, a geometria da edificação deve atender a disciplina espacial, descrita pela regularidade, adensamento, horizontalidade e continuidade das massas construídas, o que tende a 
minimizar a ocupação do terreno e a quantidade de fachadas. Esta simplicidade está presente nos projetos arquitetônicos de referência, tais como, o distrital e paulista. Estas características favorecem a segurança, enquanto a compactação é delimitada pela funcionalidade e pelo conforto ambiental: a utilidade dos locais e a criação das aberturas de iluminação e ventilação. O projeto deve então compatibilizar o desenho racional e a diversidade funcional inata da prisão.

A geometria tende a gerar um volume entrecortado inscrito em um retângulo, no qual o adensamento e a continuidade das massas construídas aumentam progressivamente do setor externo para o setor interno da unidade prisional. Algo intermediário entre os projetos de referência paulista e privado que sintetiza as tipologias campus, cluster e integrated, ao longo dos setores (UNDOC, 2016, p. 47) (Figura 34). Os parâmetros geométricos foram definidos sobre nas médias dos projetos de referência.

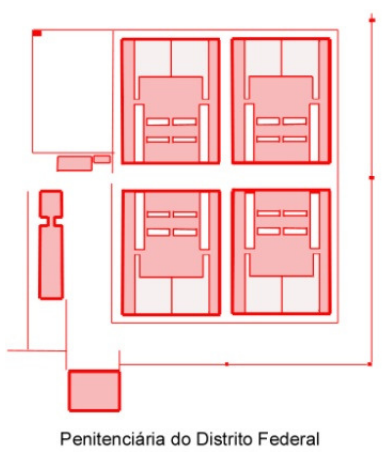

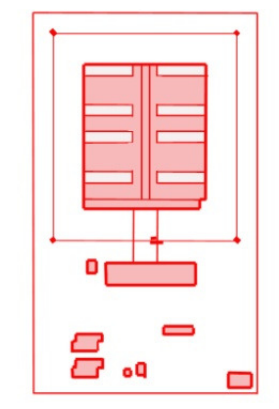

Penitenciária Compacta Paulista

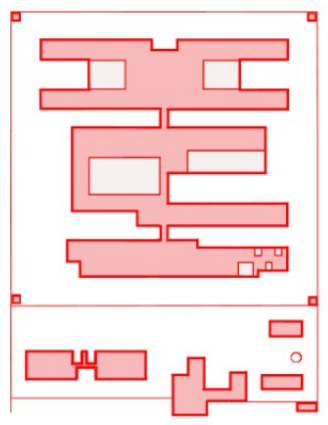

Padrão Ministério da Justiça

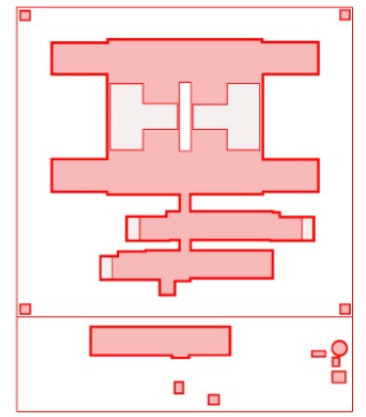

Modelo Empresa Verdi Construçōes

Figura 34 - Desenhos das geometrias dos projetos de referência (sem proporção)

O projeto paulista apresenta a maior compactação (menor relação entre a quantidade de fachadas e a área construída). Os projetos distrital e paulista têm a menor complexidade de fachada, enquanto os demais refletem os conceitos do padrão arquitetônico paralelo. A verticalização é limitada a dois pavimentos.

A humanização da pena redireciona a síntese funcional que formalmente eliminaria ou minimizaria os locais destinados aos programas de sociabilização e de benefícios aos presos (Figura 35). Proporcionalmente, estes programas passam a ser mais valorizados no modelo de segurança máxima, a corresponder a $18 \%$ e $13 \%$ da área construída do estabelecimento penal, ou a $2,06 \mathrm{~m}^{2} / \mathrm{vaga}$ e $1,89 \mathrm{~m}^{2} /$ vaga, respectivamente. A considerar que existe uma flutuação em razão do modelo pedagógico (quantidade de participantes e as atividades a serem realizadas) que pode ser traduzida nos índices de $2,31 \mathrm{~m}^{2} /$ vaga e $2,16 \mathrm{~m}^{2} / \mathrm{vaga}$, respectivamente. Ao mesmo tempo em que os padrões de segurança máxima são mantidos ou ampliados - as circulações exclusivas para os funcionários chegam a 17\% da área construída total. Estes valores foram obtidos das médias dos projetos de referência. 


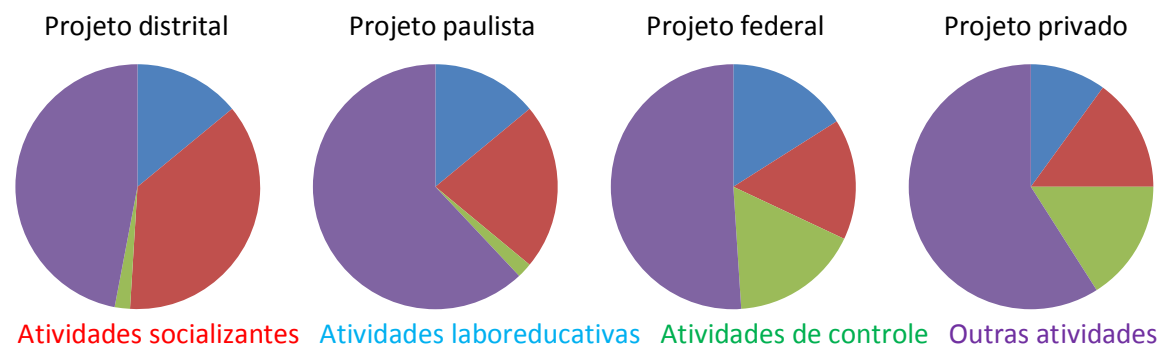

Figura 35 - Gráficos de distribuição das áreas das atividades nos projetos de referência

Os projetos distrital e paulista realizam as atividades socializantes nos pátios de sol dos presos, por isto as grandes áreas. Os projetos federal e distrital apresentam circulações exclusivas para os funcionários, por isto as grandes áreas de controle.

Outra característica da informalidade absorvida é a generalização funcional, em substituição à especialização dos espaços, cuja extrapolação compromete a funcionalidade dos locais (a realização das atividades programadas). No sentido de um reequilíbrio, a generalização funcional deve ser regrada pela policrestia que articula apenas as atividades afins entre si e compatíveis com a estrutura física e operacional planificada. Isto é importante para que a alternância no uso dos espaços por diferentes grupos de presos seja viável na rotina prisional (pessoal suficiente para os procedimentos). Em especial, as grandes áreas coletivas devem ser preparadas para isto.

A espacialização aponta a hibridização, a modulação e a internalização como recursos para a melhor composição arquitetônica, em termos da equalização segurança-humanização da modalidade arquitetônica proposta. Nos projetos de referência, estes recursos mesclam os padrões arquitetônicos penitenciários paralelo e modular, organizados por uma setorização ordinária (setores externo, intermediário e interno) e blocos funcionais relativamente especializados, dispostos ao longo de uma circulação central (Figura 36). A compactação funcional determina a maior concentração de funções em cada bloco funcional, de modo a se abreviar o número de blocos (simplificação funcional com economia de recursos). Em particular, os programas de sociabilização e de benefícios aos presos são dispostos nos blocos de vivência que respondem, em média, a 75\% da área construída do estabelecimento. Isto concentra até $80 \%$ da área construída no setor interno. Esta internalização atende a demanda da equipe dirigente, pois o deslocamento dos presos é considerado um procedimento de alto risco, principalmente diante do contingente reduzido. Com isto, se recupera parte da significação dos padrões arquitetônicos, por meio da adequação destes com a realidade prisional - a concepção topológica vinculada à técnica penitenciária ao invés da pura reprodução formal. Comparativamente, nas Diretrizes Básicas (CNPCP, 2011), os espaços destinados à sociabilização e aos benefícios aos presos são concentrados no setor intermediário, o que se reflete no projeto federal (52\% da área construída estão neste setor). Foram adotadas as médias dos projetos de referência. 


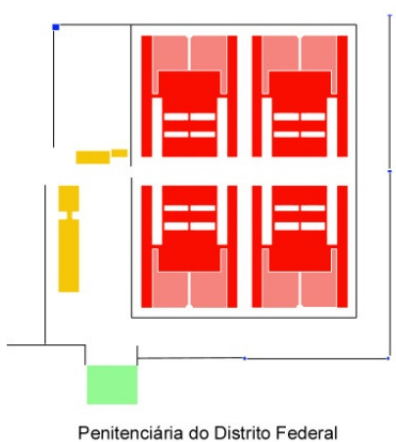

Penitenciária do Distrito Federal

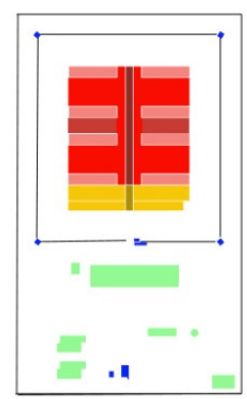

Penitenciária Compacta Paulista

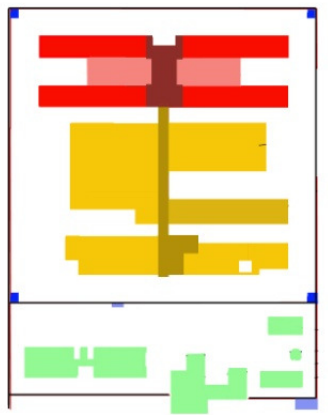

Padrão Ministério da Justiça

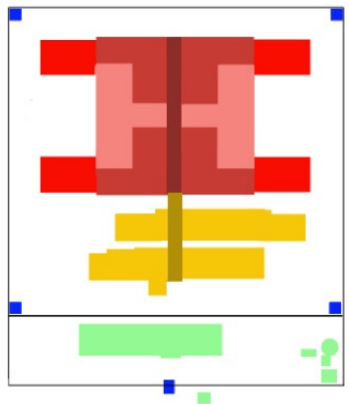

Modelo Empresa Verdi Construçōes

Figura 36 - Desenhos da setorização dos projetos de referência (sem proporção)

O projeto distrital apresenta maior internalização, com $91 \%$ da área construída nos blocos de vivência, enquanto o projeto federal apresenta a maior externalização, com $52 \%$ da área construída no setor intermediário.

A classificação e a separação dos presos em alas carcerárias e o agrupamento destas alas nos blocos de vivência são decisivas para a redução de blocos funcionais. Por um lado, esta modulação beneficia o controle do grupo de presos, por outro lado, repete o programa e fragmenta a equipe de segurança. Em particular, a quantidade de funcionários aumenta com o número de blocos de vivência, especificamente, com o número de pátios de sol dos presos. Segundo os diretores das unidades prisionais visitadas, estas relações determinam a segurança penitenciária com base nos recursos disponíveis. Em termos da segurança, os blocos de vivência preferencialmente devem ter uma ala carcerária cada. A consulta aos funcionários levantou a divisão da população prisional em quatro grupos de 96 a 160 presos, subdivididos em grupos de 24 a 40 indivíduos. Estas subdivisões são importantes para abrigar os perfis minoritários de presos (colaboradores, trabalhadores, ofensores sexuais, sexualmente diversificados e idosos). A modulação média nos projetos de referência é de quatro alas carcerárias de 108 a 144 vagas cada, subdivididas em grupos de 36 presos. As capacidades levantadas estão dentro do limite de até 200 presos previsto nas Diretrizes Básicas (CNPCP, 2011, p. 30). Em relação aos modelos estrangeiros, os valores adotados são altos: as subdivisões das alas carcerárias coincidem com as capacidades dos blocos de vivência do padrão arquitetônico modular (supermax). O PDBS (BOURN, 1994) estima de 50 a 70 presos por ala carcerária; o 21th Century Prison (HENLEY, 2003) por volta de 30 a 40 presos, e The Creative Prison, de 12 ou 13 presos por houseblock (RIDEOUT, 2006b).

A Espacialização interage com a Circulação na distribuição dos conjuntos funcionais, ao compartilhar a simplicidade geométrica (desenho linear, contínuo e com um mínimo de acessos, conversões, entroncamentos, cruzamentos e paralelismos) e a simplicidade funcional (encurtamento das distancias e constituição de espaços de circulação especializados) (Figura 37). Esta configuração é restritiva da acessibilidade e da mobilidade das pessoas. Por isto, a edificação deve ser horizontal e, havendo um segundo piso, este ser destinado exclusivamente aos funcionários. Esta restrição é progressiva no 
sentido dos setores externos para os internos. Para tanto, a circulação deve descrever um gráfico topológico em forma de árvore, com os setores interligados por passagens únicas. Esta concisão topológica evita a sobreposição dos fluxos dos diferentes tipos de pessoas. Além disto, nos projetos de referência, a redução de conflitos de fluxos é atribuída às circulações exclusivas dos funcionários nos blocos de vivência e à locação mais externa do local de visita social. Estas medidas concentram as justaposições na circulação central do setor intermediário, o que favorece a segurança e a funcionalidade.
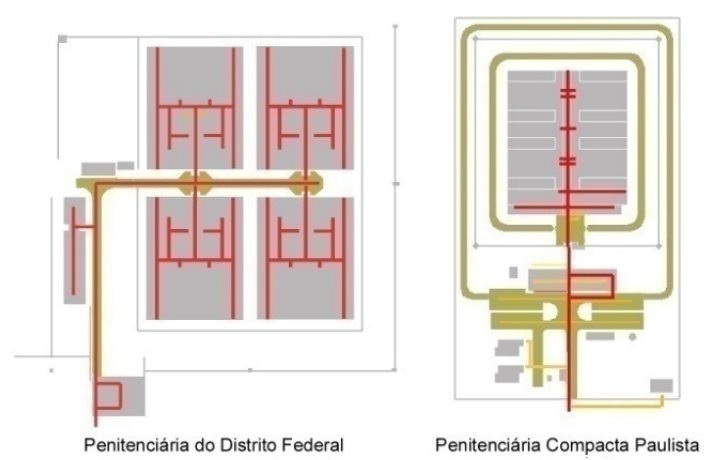

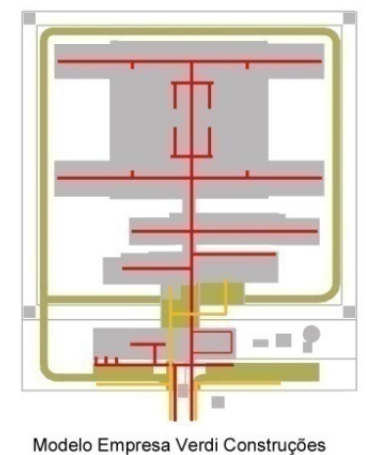

Modelo Empresa Verdi Construçōes

Figura 37- Desenhos das circulações dos projetos de referência (sem proporção)

O projeto paulista apresenta índices mais baixos, todavia, carece de visita e externaliza as atividades dos presos. O projeto privado apresenta uma simplicidade constante, dentro de uma faixa com índices regulares.

O arranjo arquitetônico internalizado produz alterações na territorialidade e na representação institucional, cuja abordagem intercepta os conteúdos do Controle. Espacialmente, o domínio territorial da instituição é adquirido pela redução do grau de liberdade dos presos, para a qual são aplicadas a especialização espacial e a vigilância ostensiva. Este esforço deve incidir mais fortemente nos setores mais internos. Nos blocos de vivência, o trânsito cotidiano dos presos deve acontecer em corredores, principalmente, entre o pátio de sol e as celas. Assim como, são recomendadas as circulações exclusivas para os funcionários e a abertura das celas à vigilância. Os projetos de referência apresentam locais livres, vigiados e proibidos na proporção de 14\%, 74\% e 12\% da área construída. A visualização do interior das celas diminui os locais livres para $8 \%$ e as circulações exclusivas aumentam as áreas proibidas para 30\%. Estas providências limitam a generalização funcional e o contato entre funcionários e presos, o que favorece a segurança e a funcionalidade.

Em relação à representação institucional, a internalização do programa de sociabilização tende a romper com a separação entre os visitantes e as atividades internas da prisão do esquema teatral descrito por Goffman (2005), o que pode ser mitigado pela previsão local específico para a visita, devidamente isolado das rotinas mais internas. Neste sentido, a lógica topológica posiciona os bastidores ao fundo da unidade penal, na maior profundidade (celas), enquanto os locais de visita são 
postos na menor profundidade possível e recebem acessos exclusivos para os visitantes. Isto induz a uma maior profundidade do espaço prisional. Com estes cuidados, a funcionalidade é recuperada.

A simplicidade funcional é reproduzida em cada um dos espaços internos, o que implica em dimensões e equipamentos mínimos, porém adequados a um número certo de usuários e a realização das atividades programadas. Na disciplina, esta síntese funcional é empregada como mecanismo de controle dos presos, por meio da despersonificação do espaço. Na modalidade arquitetônica proposta este controle é amenizado, ao se coletivizar e generalizar os locais, além de se admitir o incremento da humanização do espaço. Esta humanização essencialmente incorpora as demandas realísticas, em respeito à organização social, à realização das atividades e à privacidade dos usuários, o que é percebido principalmente na revisão dos elementos centrais da edificação penal (cela, pátio de sol dos presos e posto de controle), apresentada na seção seguinte.

O Dimensionamento evidencia as particularidades arquitetônicas da modalidade arquitetônica de segurança máxima proposta, ao expressar valores superiores aos esperados para unidades de segurança máxima. Os projetos de referência derivam índices em torno de $18,7 \mathrm{~m}^{2} /$ vaga, variando entre 16,0 e 25,0 $\mathrm{m}^{2} / \mathrm{vaga}$, enquanto as Diretrizes Básicas (p. 28) estimam, no mínimo, 12,0 m²/vaga e, em média, $16,6 \mathrm{~m}^{2} /$ vaga. O incremento do sistema de segurança (circulações exclusivas para os funcionários) e dos programas de sociabilização e benefícios aos presos, replicados nos blocos de vivência, justificam as áreas maiores. A externalização destes programas em blocos intermediários resulta em índices menores - o projeto paulista apresenta $1,44 \mathrm{~m}^{2} / \mathrm{vaga}$ (a sociabilização alcançou $2,16 \mathrm{~m}^{2} / \mathrm{vaga}$ e o programa de benefícios aos presos, 2,50 $\mathrm{m}^{2} / \mathrm{vaga}$, conforme o colocado anteriormente). Para a limitação da área construída, o dimensionamento pode ser feito com base no uso alternado dos lugares (rodízio de presos). Mais radicalmente, o dimensionamento pode utilizar o número de presos efetivamente engajado nas atividades (aqueles que recebem visita, trabalham e estudam). Estas estratégias dependem da rotina prisional: o tamanho dos grupos de presos contemplados e a periodicidade e duração das atividades.

A modalidade arquitetônica de segurança máxima proposta resulta em uma proporcionalidade entre a área de terreno e a capacidade do estabelecimento penal com valores maiores, aproximadamente, $60 \mathrm{~m}^{2} / \mathrm{vaga}$, pertinentes à impermeabilidade e estanqueidade da prisão (afastamentos maiores na barreira perimetral). Este valor se aproxima dos índices do modelo supermax e da Penitenciária Federal, enquanto as recomendações das Diretrizes Básicas estimam uma relação de 38,93m²/vaga e os projetos de referência indicam uma relação de $35,88 \mathrm{~m}^{2} / \mathrm{vaga}$ (com exceção do projeto distrital, com $61,68 \mathrm{~m}^{2} /$ vaga). 
O espaço arquitetônico deve prever aparatos de segurança para mitigar pontos débeis ou fortalecer o esquema de segurança como um todo, em termos da impermeabilidade, disciplina, estanqueidade e inexpugnidade da prisão, especialmente no setor interno da unidade prisional. A aplicação destes recursos integra uma tática de economia de recursos, quando as soluções mais amplas dos sistemas de segurança e operação atingem custos proibitivos e as eventuais vulnerabilidades se tornam pontuais.

O conforto ambiental prioriza as exigências de impermeabilidade, estanqueidade e controle institucional na especificação das aberturas de iluminação e ventilação, em termos da localização, tipificação e configuração destas. A regra geral é a iluminação e ventilação natural de todos os espaços, havendo exceções para os locais sem a permanência prolongada de pessoas (CNPCP, 2011, p. $39-40)$.

Para a modalidade arquitetônica de segurança máxima proposta, as aberturas de iluminação e ventilação têm os parâmetros mínimos definidos pelo Manual de Intervenções Ambientais para o Controle da Tuberculose nas Prisões (SANTOS et al., 2012) (Figura 38). Estes parâmetros são mandatórios para os locais ocupados pelos presos. Os parâmetros máximos são definidos pelas Diretrizes Básicas, sendo aplicáveis a qualquer dependência da unidade prisional. De um modo geral, as aberturas devem ter dimensionamento entre $16 \%$ e $25 \%$ da área do piso, circulação de ar (ventilação cruzada ou em nível) e regulagem das aberturas, esta se realizada pelos funcionários.

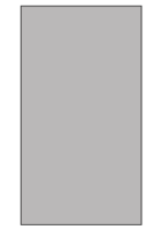

$17.95 m^{2}$

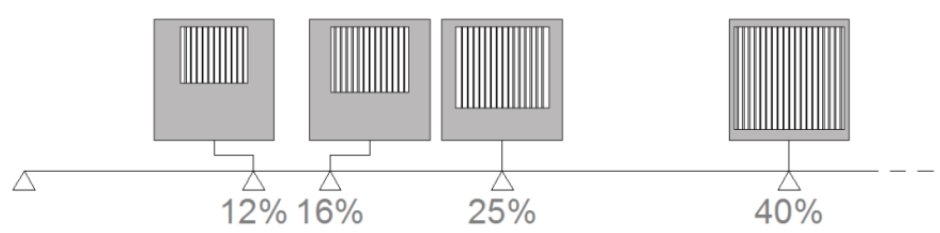

Figura 38 - Esquema demonstrativo do tamanho relativo das aberturas de iluminação e ventilação

Os desenhos representam a parede externa de uma cela, segundo as dimensões médias dos projetos de referência $(3,15 \times 3,15 \mathrm{~m})$. O índice de $16 \%$ foi considerado mais adequado, diante dos condicionamentos de segurança. $\mathrm{O}$ índice de $40 \%$ foi considerado inviável.

\subsubsection{Controle}

A definição espacial do esquema de controle do estabelecimento penal se articula com a Organização do Espaço na definição das características geométricas e funcionais da edificação, ambos condicionados pelo domínio territorial da instituição e pela minimização dos recursos necessários à operação penitenciária. O esquema de controle busca o monitoramento dos espaços e o gerenciamento dos fluxos em sua totalidade, por meio da simplicidade geométrica e funcional (compactação da edificação). Por sua vez, a categoria de segurança máxima proposta agrega demandas realísticas que remetem à questão da privacidade dos presos, em especial, o fechamento da cela. 
O esquema arquitetônico do controle foi assentado sobre conceito da vigilância direta do padrão arquitetônico modular (posto de controle), cuja separação física dos funcionários importa para a segurança penitenciária e para a humanização inerente à categoria penitenciária proposta. Na prática prisional, esta separação protege funcionários e presos simultaneamente, segundo o declarado nas entrevistas realizadas. Por um lado, isto caracteriza o funcionário como um agente de segurança e atesta a divisão do poder interno na prisão. Por outro lado, esta separação não é absoluta. A mesma se concentra em atividades e procedimentos críticos, identificadas pela aglomeração de presos e, especificamente, na condução dos mesmos. Enquanto o contato com os presos é considerado operacionalmente necessário ou inevitável em alguns casos, segundo os funcionários ouvidos, o que é reconhecido na dynamic security (UNOPS, 2016, p. 33). A relação entre funcionários e presos alimenta o trabalho de inteligência da prisão, além de construir um ambiente menos violento, baseado na desconstrução do anonimato, o que previne abusos. Por sua vez, os procedimentos de revista eliminam qualquer retórica de separação total.

No sistema penitenciário nacional, a vigilância externa tem como missão impedir ataques, invasões e fugas. Neste sentido, as torres de vigilância no perímetro da unidade prisional são necessárias, pois apenas a vigilância eletrônica inviabiliza a resposta imediata e proporcional da instituição, através da guarda armada. As torres devem cobrir o entorno da unidade prisional, as faces externas e internas da barreira perimetral e o espaço intramuros, inclusive os edifícios - a totalidade das fachadas e coberturas das edificações, principalmente no setor interno. Preferencialmente, as aberturas de iluminação e ventilação dos locais com a presença de presos devem ser passíveis de observação, segundo demanda da equipe dirigente. O número de quatro torres de vigilância é o que melhor conjuga vigilância efetiva com a minimização da equipe. Nos projetos de referência cobrem $93 \%$ das áreas intramuros e apresentam visualização total das coberturas. Além das torres, as equipes funcionais recomendam postos intermediários entre as torres para eliminar as áreas cegas, a serem ocupados em situações de crise. Deste modo, em unidades de segurança máxima e médio porte, a equipe de vigilância externa no estabelecimento penal soma oito homens - quatro efetivos e quatro de prontidão, que deve ser multiplicada conforme o regime de trabalho. A questão da proteção dos guardas externos a ataques ou invasões com a tomada de reféns é mais bem tratada na seção barreira perimetral.

Para maximizar a vigilância externa, as geometrias da barreira perimetral e das edificações devem ser compatibilizadas, considerando a quantidade e a posição das torres, além da topografia do terreno. A geometria entrecortada ou irregular das edificações tende a constituir áreas cegas. Os projetos de referência apresentam sete áreas cegas, em média (Figura 39). O projeto federal tem pior desempenho (14 áreas cegas) pelo uso de muros internos e pela irregularidade geométrica das edificações. As Diretrizes Básicas recomendam o uso de cercas para a disciplina dos espaços intramuros. O arranjo deve permitir o contato visual entre as torres, inclusive sobre o conjunto construído. 

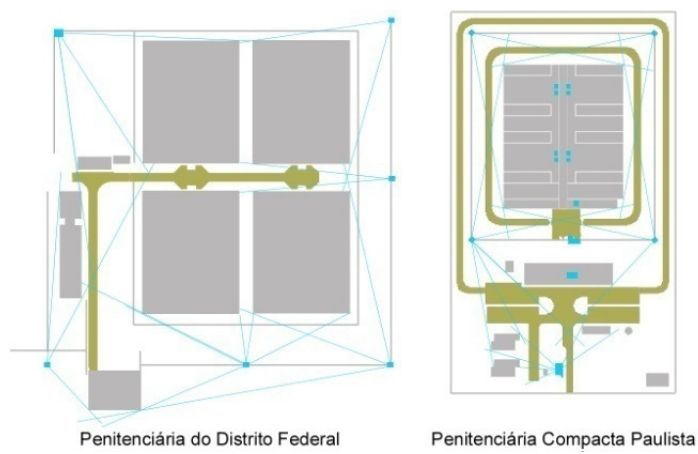

Penitenciária Compacta Paulista

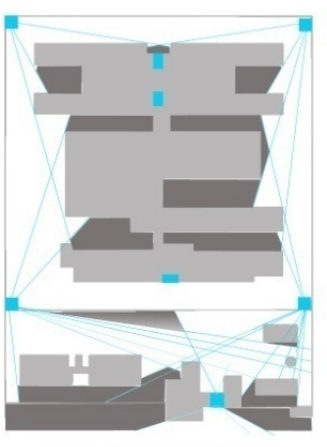

Padrão Ministério da Justiça

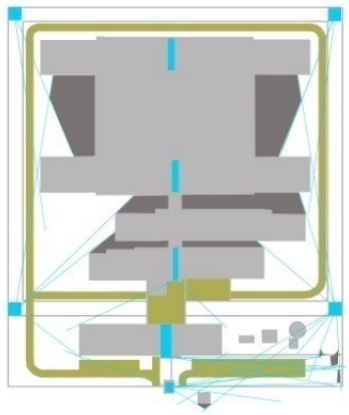

Modelo Empresa Verdi Construçōes

Figura 39 - Desenhos isométricos da vigilância externa dos projetos de referência

As áreas negritadas correspondem aos pontos cegos. Os projetos distrital e paulista apresentam as melhores vigilâncias (93\% e 99\%, respectivamente), reflexo da geometria regular.

Internamente, a vigilância direta concorre para a compactação e reforça a centralidade ao arranjo arquitetônico, onde os recintos são dispostos em torno dos postos de controle, eventualmente assistidos por circulações exclusivas para os funcionários (extensão da vigilância). A vigilância direta deve ser aplicada progressivamente ao longo do edifício, em todos os setores, mas impreterivelmente nos blocos de vivência (pátios de sol dos presos). Os projetos de referência apresentam a maioria das áreas internas potencialmente vigiadas (62\%), principalmente nos blocos de vivência (68\%), notoriamente, pela adoção deste tipo de vigilância. A exceção é o projeto federal, devido à sua complexidade morfológica e funcional, apesar de trazer as soluções citadas $(45 \%$ e $78 \%$, respectivamente), além do projeto paulista que adota a vigilância indireta (28\% e 46\%, respectivamente). Em particular, o monitoramento nos blocos de vivência poderia ser absoluto, já que os presos compõem o objeto de observação, mas é reduzido devido à questão da privacidade das celas, mais bem tratada na seção correspondente. As alas carcerárias são vigiadas por rondas.

O controle dos trânsitos internos corrobora a unificação dos acessos e a convergência dos fluxos na configuração da circulação. Estes pontos são estratégicos para a segurança e a operação, ao serem dotados de postos de controle, pois maximizam o gerenciamento dos transeuntes e a visualização dos corredores, com uma provável redução de pessoal. Nestes pontos, os postos de controle são posicionados centralizadamente, em torno dos quais os fluxos ocorrem e podem ser administrados remotamente. Para a equipe dirigente, os pontos críticos são: a entrada da unidade penal, as ligações entre setores e os acessos dos blocos funcionais, principalmente, no setor interno - blocos de vivência. Neste sentido, importam a minimização das alas carcerárias e a internalização das atividades nos blocos de vivência como fatores positivos ao controle. Este esquema pode ser estendido com a previsão de circulações exclusivas para os funcionários nos locais mais críticos. Estas circulações permitem a maior penetração institucional (domínio territorial) e abrangência dos procedimentos (abertura de portas dos recintos, não apenas das circulações). Os projetos de referência apresentam 
$63 \%$ das circulações vigiadas. A exceção é o projeto paulista que adota a vigilância direta (15\% das circulações).

O controle dos fluxos deve prever contenções nos corredores (aparato de segurança), junto aos postos de controle, que configuram pontos para a identificação, contagem de presos, controle de movimento e ligação de fluxos. Estes pontos são configurados por portas subsequentes, cuja travessia ocorre em sistema de eclusa (a porta seguinte abre apenas após o fechamento da anterior). Da realidade prisional, a revista dos presos emergiu como procedimento pertinente à contenção, porém desprovido de local apropriado (mais reservado e independente da circulação). Estas contenções são sistematizadas no Technical Guidance of Prision Planning (UNOPS, 2016).

O controle institucional obedece à inverificabilidade institucional com vantagens para a proteção dos funcionários e a otimização de recursos. A solução técnica para a inverificabilidade institucional é o arranjo espacial associado ao jogo de luz e sombra: o contraste luminoso entre o interior do posto de controle (escuro) e a área vigiada (claro). De modo simplificado, este efeito é obtido com a colocação de películas reflexivas nos visores ou através do ofuscamento com iluminação direcionada para as áreas monitoradas (funcional no período noturno). A invisibilidade dos funcionários evita que o guarda na torre de vigilância se torne alvo de disparo externo de arma de fogo, assim como, possibilita a redução das equipes nos postos de controle, por meio da internalização da individualidade disciplinar, prevista no Panóptico (ver capítulo 2). Por outro lado, a invisibilidade remete à questão do anonimato que incita os abusos dos guardas. Neste sentido, é interessante que os postos de controle permitam a eventual identificação dos guardas em momentos ou procedimentos específicos que não exijam a invisibilidade (a entrada ou saída dos pátios de sol, por exemplo).

O esquema de controle deve buscar a minimização dos pontos de controle, tanto pela articulação de torres de vigilância e postos de controle no arranjo espacial. Nisto, a modulação da população prisional tem grande repercussão devido à repetição dos postos com os blocos de vivência. Os projetos de referência apresentam poucas torres de vigilância e postos de controle (nove destes, em média). O dimensionamento da equipe funcional considera o número de postos, o número e as características dos locais monitorados, além da coordenação entre os postos. Neste sentido, a integração das equipes dos diversos postos favorece a redução de pessoal (proximidade e contato audiovisual), através da fiscalização e suporte mútuo entre as equipes - as direções das prisões buscam a produtividade máxima de uma equipe reduzida. 


\subsection{Revisão dos quesitos dos elementos centrais da edificação penal}

O ajustamento dos quesitos dos elementos centrais da edificação penal foi condensado em desenhossíntese que agregam as especificidades do conjunto de soluções arquitetônicas de cada um (ver Apêndice G). As especificidades de natureza informal remetem ao estudo de campo realizado, por meio de entrevistas com os usuários da edificação penal (ver Apêndice C).

\subsubsection{Barreira perimetral}

O projeto da barreira perimetral orbita o tipo a ser especificado, muro ou cerca, com base nas exigências de estanqueidade, impermeabilidade e inexpugnidade do nível de segurança máximo (isolamento social dos presos), sendo condicionado por imposições fundiárias (situação e características do terreno) e financeiras da realidade prisional (custo de construção da barreira perimetral). Além disto, a definição da barreira perimetral depende da geometria (horizontalidade) e fechamento das edificações (neste caso, importa a comunicação informal dos presos, escrita ou por sinais), bem como, do esquema de controle da unidade prisional.

A cerca é preferencial pela economia agregada (Figura 40), apesar do seu desempenho adverso por ser vazada, principalmente, no caso de terrenos expostos (próximos a ocupações humanas ou circundados por terras mais altas) ou pequenos (impossibilita o afastamento necessário para compensar a permeabilidade do material aplicado), o que pode ser mitigado por aparatos de segurança. O muro apresenta melhor desenvoltura nas propriedades de fechamento, independentemente do terreno, mas tem custo mais elevado. Os funcionários se sentem mais seguros com o muro, embora também ocorram relatos de uma sensação de aprisionamento.

A geometria da barreira perimetral é subordinada a síntese funcional, devendo apresentar forma simples e dimensões mínimas (conforme cada tipo de barreira). Estas características favorecem a segurança, a funcionalidade e os custos, na medida em que aproximam as torres de vigilância, simplificam os procedimentos e diminuem os quantitativos para a construção. A forma retangular é corrente nos projetos de referência, definindo quatro posições de vigilância. O perímetro médio é de $495 \mathrm{~m}$, com base nos afastamentos propostos mais à frente. 


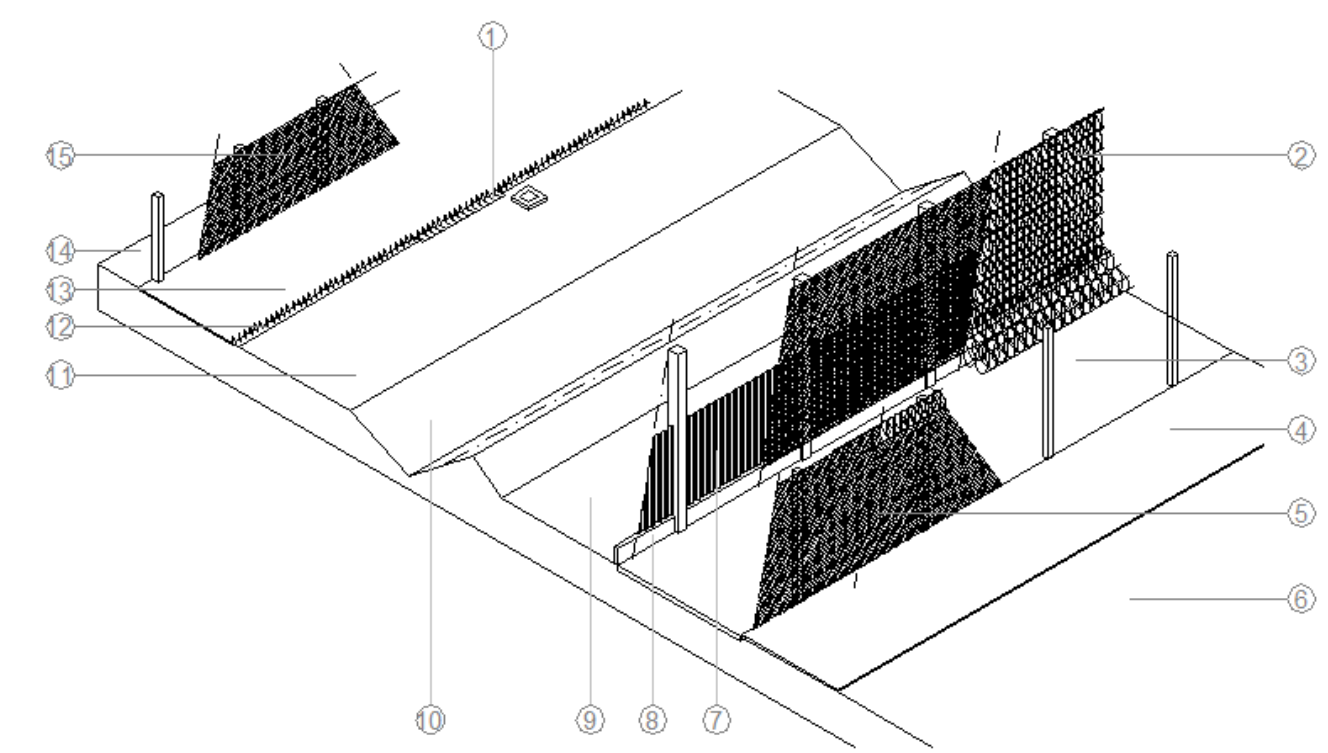

01 - Passagem do dilacerador de pneus para o acesso de veículos.

02 - Bareira perimetral ( $4 \mathrm{~m}$ de altura)

03 - Linha de tiro (5m de largura)

04 - Pista de ronda interna (primária)

05 - Cerca da linha de tiro com $3 \mathrm{~m}$ de altura.

06 - Afastamento Intemo com $30 \mathrm{~m}$ de largura.
07 - Aparato de bloqueio visual e proteção dos funcionários com 2,0m de altura. 08 - Mureta (viga baldrame) com $0,6 \mathrm{~m}$ de altura que atua como proteção contra disparos por arma de fogo.

09 - Distancia no afastamento necessária para a visualização do fundo da trincheira. 10 - Trincheira para obstacularizar a invasão por veículos.

Figura 40 - Desenho isométrico esquemático do desenho-síntese de barreira perimetral desenvolvido para o nível de segurança máximo proposto

Este desenho mostra soluções redundantes para a inexpugnidade da barreira que podem ser combinadas entre si: o dilacerador de pneus, a trincheira e a mureta. Os afastamentos externo e interno foram definidos em trinta metros, cada. A altura da cerca foi definida em quatro metros.

A altura da barreira perimetral é primordial para a representação da instituição: a impressão de força e de segurança que as barreiras altas geram para a sociedade e para a própria instituição: a proteção dos funcionários, além da dissuasão da fuga pelos presos (Figura 41). Os projetos de referência apresentam altura de 6,45m, em média. Por outro lado, o modelo supermax (padrão arquitetônico modular) apresenta cerca com $3,70 \mathrm{~m}$ de altura o que indica uma mudança de paradigma. Neste caso, a redução da altura da cerca está associada a uma localização isolada do estabelecimento penal e a aplicação de aparatos de segurança. Esta redução impacta na construção do estabelecimento e institui a constatação prática de que barreiras mais altas não impedem a fuga - segundo funcionários entrevistados, a altura maior efetiva apenas alguns segundos de retenção até a transposição do obstáculo, enquanto não evita o lançamento de objetos para o interior da unidade. As Diretrizes Básicas prevêem uma altura mínima de cinco metros, menor do que a versão anterior do documento previa, provavelmente já em atendimento a esta economia. Deste modo, a redução da altura da barreira não está vinculada a uma amenização da segregação social, como medida de humanização, sendo justificada apenas por motivos econômicos. 


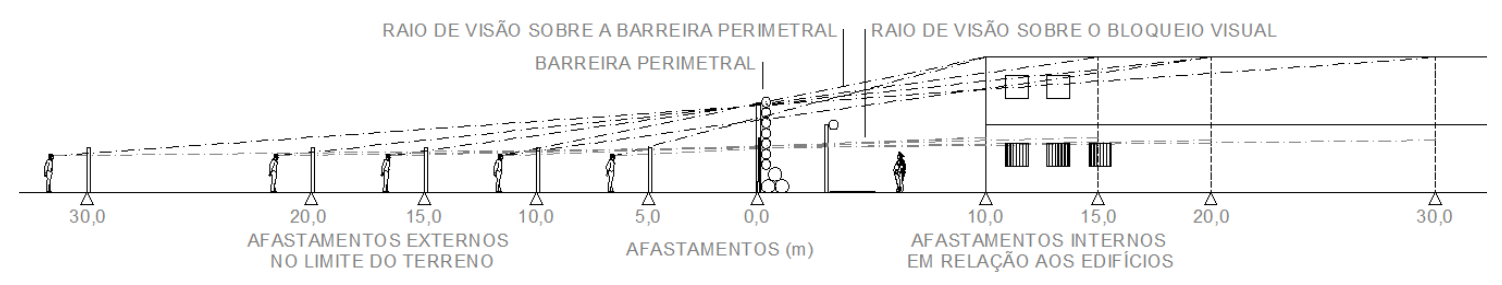

Figura 41 - Desenho esquemático dos raios de visão de um observador externo às edificações da prisão

Estes raios determinam a altura da barreira perimetral (impermeabilidade) com base em diferentes afastamentos para uma edificação térrea (até dois pavimentos).

Em boa parte, a definição da barreira perimetral está atrelada aos afastamentos do perímetro de segurança que podem ser externos e internos à unidade prisional - a sterile area ou prisioner free zone (UNOPS, 2016, p. 184). As Diretrizes Básicas determinam o afastamento externo de cinco metros de largura e afastamento interno entre dez e quinze metros em relação às edificações. Trata-se de uma simplificação de um mecanismo considerado importante pelos funcionários, cuja amplitude favorece a atuação dos guardas nas torres de vigilância. Os projetos de referência apresentam onze e dezenove metros de afastamentos externo e interno, respectivamente. O modelo supermax (padrão arquitetônico modular) apresenta afastamentos de quarenta metros, em média. A equipe dirigente recomenda trinta metros, externa e internamente - tamanhos maiores são considerados contraproducentes, pois as distancias devem permitir a identificação fisionômica.

As propriedades da barreira perimetral devem ser maximizadas por meio de aparatos de segurança, linha de tiro e pista de ronda. Os aparatos de segurança se destinam principalmente a impedir a invasão do estabelecimento e a evasão de presos, além de proteger os funcionários. Entre os tipos de barreira perimetral, a cerca apresenta a maior utilização destes dispositivos, de modo a melhorar seu desempenho em termos do fechamento institucional, ainda com custo inferior ao muro.

\subsubsection{Cela}

A cela na categoria de segurança máxima proposta apresenta uma série de reconfigurações arquitetônicas em relação ao modelo absolutamente punitivo, a partir da implementação das demandas realísticas - a formalização das atividades realizadas cotidianamente (generalização funcional) e das relações sociais advindas da convivência em grupo (coletivização) (Figura 42, ver Apêndice G).

Em termos das atividades previstas na Lei de Execução Penal (LEP) e nas Diretrizes Básicas (CNPCP, 2011a), a cela é programada para o descanso noturno e a higiene pessoal, além de possibilitar a guarda de pertences e a circulação, o que é verificado nos projetos de referência adotados (ver Apêndice A). Para estas atividades são previstos beliches de duas ou três camas, banheiro e prateleiras, além de mesas e bancos. Os beliches se justificam pela compactação espacial. Para a equipe dirigente, o 
beliche de três camas dificulta a revista pelos funcionários, não havendo restrições por parte dos presos. O banheiro apresenta pia, vaso sanitário e chuveiro, o que remete à internalização das atividades diárias dos presos, pois o banho localizado externamente remete ao problema da condução dos internos (falta de pessoal e risco aos funcionários). Do cotidiano prisional, a cela revisada deve absorver as atividades de entretenimento (conversas e jogos), exercício físico, alimentação, lavagem e secagem de roupas, faxina e, em menor grau, o trabalho manual e a leitura (a inclusão de estrutura física para trabalhos e leitura não substitui as oficinas e salas de aula do programa de benefícios aos presos). Para estas atividades, os presos sugerem mesas e bancos, além de uma bancada com tanque. Para os mesmos, a funcionalidade dos espaços individuais e coletivos para a realização das atividades é uma questão de dignidade do grupo.

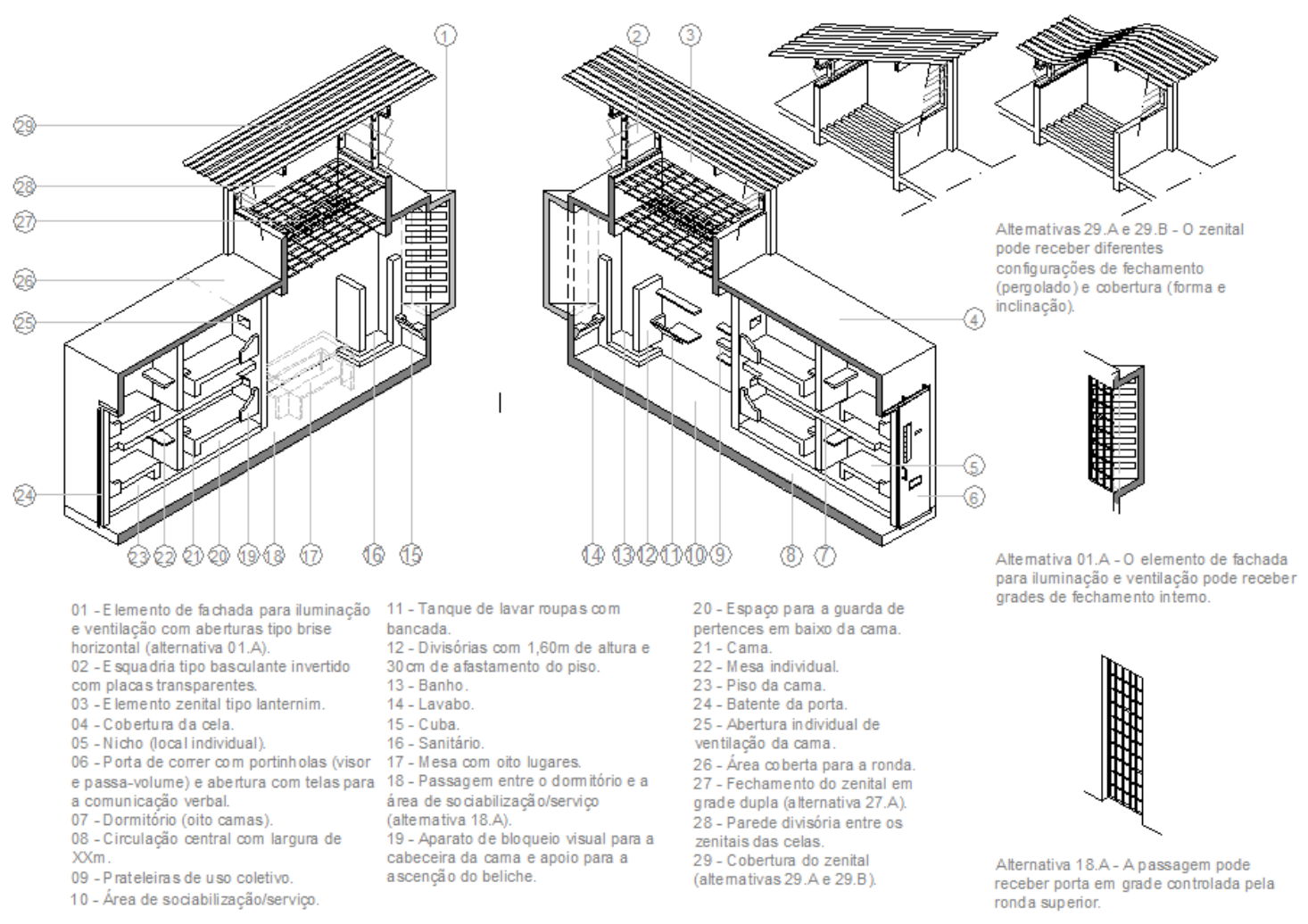

Figura 42 - Desenhos esquemáticos isométricos do desenho-síntese desenvolvido de cela coletiva de oito vagas. Os desenhos mostram alternativas desenvolvidas para componentes da cela

A cela proposta totaliza $25,75 \mathrm{~m}^{2}$ de área construída, sendo $14,40 \mathrm{~m}^{2}$ de dormitório $(61 \%)$, incluídos $5,90 \mathrm{~m}^{2}$ de

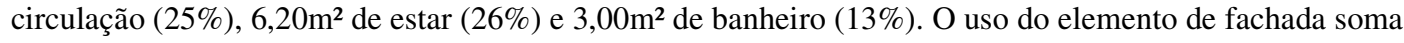
$0,56 \mathrm{~m}^{2}$ à área construída. A largura da cela é de $3,0 \mathrm{~m}$, com uma distancia de $1,60 \mathrm{~m}$ entre os beliches, o que permite o piso individual $(30 \mathrm{~cm})$ e uma circulação de $1,10 \mathrm{~m}$. O pé-direito é de $3,04 \mathrm{~m}$ para criar $1,40 \mathrm{~m}$ de altura entre camas. O pé-direito no zenital é de $5,16 \mathrm{~m}$.

As relações sociais definem lugares individuais e coletivos para a realização das atividades previstas, de acordo com a privacidade e a territorialidade do grupo de presos. Os lugares individuais se restringem às camas (território pessoal), delimitados pela estrutura dos beliches (nichos), o que confere 
certa privacidade na cela. $\mathrm{O}$ restante da cela integra o território de grupo, no qual ocorrem as relações sociais. Em particular, o banheiro tem uso comum e apresenta alguma privacidade, segundo os projetos de referência: localização ao fundo da cela e fechamento com divisória. Para os presos, a privacidade nas camas e no banheiro é fundamental para a dignidade do grupo.

A organização espacial das atividades e das relações sociais induz a uma compartimentação da cela com a criação de locais funcionalmente especializados, dotados de serviços e mobiliário específicos. Este incremento espacial descrito por subdivisões, níveis e de objetos rompe parcialmente com o ambiente integrado, compacto e simples desejado pela segurança penitenciária. Nos projetos de referência, a cela tende a apresentar visualização interna reduzida (58\% da área útil), igualmente atribuída à restrição do ponto de observação se resumir a porta de acesso (grade, portinhola, visor).

A segurança é recuperada por meio da simplicidade geométrica (centralidade, simetria, ortogonalidade e alinhamento), aliada à impessoalidade arquitetônica (espaços minimamente equipados e dimensionados, além de relativamente aberto à vigilância), aplicadas em conjunto a cada um dos espaços e componentes da cela. Esta racionalidade descreve o espaço da cela como uma circulação central que transpassa o dormitório até o banheiro, o que é observado nos projetos de referência adotados (ver Apêndice A). A mesma determina a periferização dos elementos internos (mobiliário e serviços). A posição posterior do banheiro é preferida entre funcionários e presos, ao favorecer a funcionalidade e o conforto do local. A separação do banheiro em relação ao dormitório é prioritária para os presos que majoritariamente reclamam dos odores. Esta configuração é similar ao vislumbrado no Technical Guidance of Prision Planning (UNOPS, 2016, p. 93).

A revisão da cela acarreta um aumento de área da ordem de $43 \%$ a $47 \%$ (ver desenho-síntese, Apêndice G). O aumento de área da cela é perceptível na relação com a capacidade projetada, para a

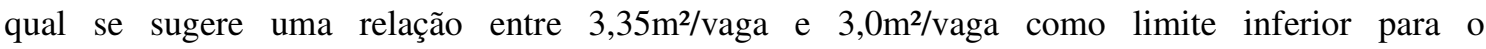
dimensionamento de modelos de quatro a oito vagas, respectivamente (Figura 43). Para celas de quatro vagas, os valores correntes são 2,10 m²/vaga (CNPCP, 2011a) e 2,60 m²/vaga (UNOPS, 2016, p. 94). Para celas de oito vagas, os mesmos são $2,00 \mathrm{~m}^{2} /$ vaga (projetos de referência), $1,73 \mathrm{~m}^{2} /$ vaga (CNPCP, 2011a) e 2,60 m²/vaga (UNOPS, 2016, p. 94). De uma maneira geral, a largura e o pé-direito acompanharam o incremento de área para as celas de quatro e oito vagas: 2,70m e 3,00m de largura e $3,00 \mathrm{~m}$ de pé-direito, embora estes parâmetros sejam menores do que as médias dos projetos de referência (ver Apêndice A). Para celas de quatro vagas, os valores correntes são 2,60m e 2,50m (CNPCP, 2011a) e 2,15m e 2,45m (UNOPS, 2016, p. 94). Para celas de oito vagas, os mesmos são $3,15 \mathrm{~m}$ e $3,17 \mathrm{~m}$ (projetos de referência), 2,85m e 2,50m (CNPCP, 2011a) e 2,15m e 2,45m (UNOPS, 2016, p. 94). 
Além do aumento de área, a revisão da cela implica em uma redistribuição das áreas entre as atividades incluídas no local A cela individual do modelo supermax prevê $20 \%$ da área útil para o dormitório, $17 \%$ em higiene pessoal, $7 \%$ em entretenimento e refeição, 17\% de contenção (exclusiva) e $44 \%$ para a circulação (área livre). De modo conjectural, uma cela de quatro pessoas (dois beliches) duplica área de dormitório da cela individual (40\%), mantém a área de higiene pessoal (15\%) e quadruplica a área de atividades (28\%), reduzindo a área de circulação (16\%). Nos projetos de referência, o programa é distribuído em $44 \%$ da área útil para o descanso noturno dos presos, $12 \%$ para o serviço sanitário e $44 \%$ para a circulação, o que confirma a proporção estimada para celas com capacidades maiores.

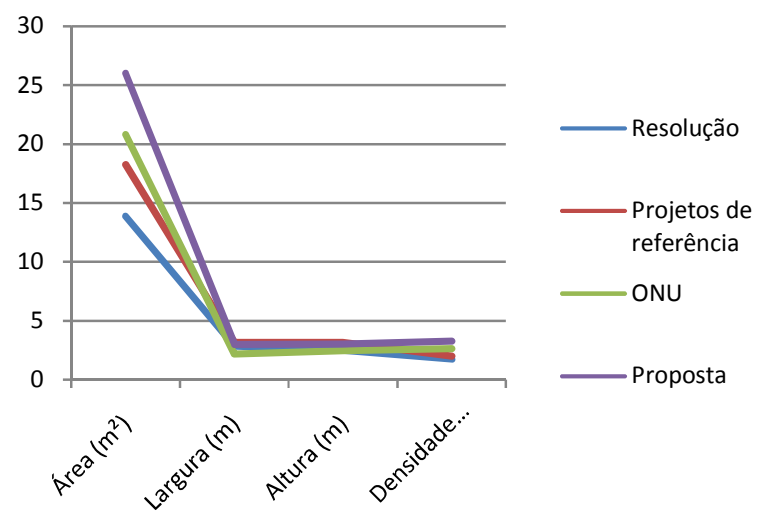

Figura 43 - Gráfico comparativo do dimensionamento de celas de oito vagas

No conforto ambiental da cela, embora a abertura equivalente a $13 \%$ do piso tenha sido considerada boa pelos presos (modelo da empresa Verdi Construções S/A), se recomenda valores entre $16 \%$ e $25 \%$ da área de piso, superiores estabelecidos pelas Diretrizes Básicas (CNPCP, 2001a, p. 38 a 40) e pelo Manual of Environmental Interventions for Tuberculosis Control in Prisons (SANTOS et al., 2012, p. 15). Na categorização do nível de segurança proposta, o valor mínimo de $16 \%$ remete a uma segurança maior, enquanto o teto de $25 \%$ se aproxima da segurança máxima sugerida. Nesta avaliação deve ser considerada a aglomeração de pessoas e de atividades (coletivização e generalização funcional). Já a proporção de 40\% da área do piso (zona climática 8) constante das Diretrizes Básicas (CNPCP, 2011a) é desaconselhada por resultar em aberturas equivalentes a totalidade da parede (ver figura 43).

A demanda de fechamento da cela direciona para a especificação de aberturas indiretas (associadas à geometria simples e compacta da edificação). A visualização do exterior reivindicada pelos presos como fator de bem estar é preterida em favor da segurança, salvaguardados os casos em que o campo visual não compromete a segurança. A ventilação cruzada deve atender a estes critérios de segurança. A equipe dirigente considera a ventilação cruzada crítica, por comunicar os recintos, além de expor a rotina institucional e os funcionários. A regulagem das aberturas é igualmente considerada crítica para 
a segurança pelos funcionários, pois as esquadrias são desmontadas pelos presos para a confecção de utensílios e armas. Por outro lado, a previsão desta regulagem atende a uma reivindicação dos presos para a proteção em temperaturas mais frias, prevista no Technical Guidance of Prision Planning (UNOPS, 2016, p. 89).

O domínio territorial da instituição depende da abertura da cela à vigilância, o que remete à disputa de poder entre a instituição e os presos, em termos do controle da informação. Na categoria de segurança máxima, esta abertura é preferível e deve ser máxima, desde que atendidos alguns critérios. Os funcionários concordam com a abertura da cela desde que preservada a impermeabilidade (aos presos é vetado o conhecimento das rotinas externas) e mantida a proteção contra ataques dos presos. Além disto, os funcionários consideram importante a possibilidade de contenção de crises pelas aberturas de visualização, além da possibilidade de ouvir o interior da cela (conversas e ruídos).

\subsubsection{Pátio de sol dos presos}

Na categoria de segurança máxima proposta, a revisão do pátio de sol dos presos é restrita a soluções pontuais, devido ao potencial empoderamento dos presos advindo da coletivização e do aumento de capacidade dos locais, previstos no ajuste da espacialização da edificação penal. No âmbito da composição arquitetônica da prisão, uma providência para a contenção do potencial ofensivo dos presos é a criação de pátios de sol em número suficiente para a subdivisão deste grupo. Esta subdivisão atende atenção ao princípio de individualização, por meio da classificação e separação dos diferentes perfis de presos. Para os funcionários, o compartilhamento de um pátio por duas alas carcerárias é desaconselhado: é preferível cada ala carcerária contar com pátio próprio. A equipe dirigente considera a capacidade entre vinte e quatro presos e trinta e seis presos um número ótimo, o que determina a ocupação alternada do pátio pelos subgrupos de presos, ao longo do dia. A separação dos presos em diferentes pátios de sol traz impactos relevantes sobre os custos de construção (aumento da área construída) e operação (aumento dos procedimentos).

Especificamente, a ênfase na segurança determinou a manutenção do paradigma arquitetônico do pátio de sol, descrito pela simplicidade geométrica e funcional: um espaço retangular e alto, fechado para o exterior, parcialmente coberto, minimamente equipado e exposto à vigilância. As atividades no pátio de sol revisado se limitam ao banho de sol, sociabilização entre os presos e à prática de esportes e exercícios físicos (caminhada e musculação). Os programas de visitas social, conjugal e jurídica e prática religiosa dos presos devem ser implementados em locais próprios que podem ser topologicamente conexos ao pátio, desde que a estrutura física e operacional permita a condução segura dos presos. A cantina e a distribuição de refeições são desaconselhadas pelos funcionários por estimularem a economia da prisão. 
Na revisão realizada, as intervenções pontuais no espaço arquitetônico do pátio remetem a sugestões dos usuários (Figura 44, ver Apêndice G). Não obstante, estas intervenções pontuais aproximaram o conjunto de soluções das definições do Technical Guidance of Prision Planning (UNOPS, 2016, p. 95 - 99). A geometria pode ser amenizada por chanfros ou arredondamentos dos cantos ou ainda por diferentes alturas ou formas da cobertura. Estes chanfros ou arredondamentos também evitam pontos vulneráveis para a estanqueidade (fuga por escalada) e para a vigilância (os cantos são locais propícios a ações indisciplinares ou criminosas). O pé-direito pode ser reduzido, desde que a abertura superior seja fechada por grade. O piso pode ser concebido em níveis que não configurem pontos cegos para a vigilância, o que cria novas localizações e movimentações para os presos. As diferenças de níveis podem organizar as atividades previstas, já que a especialização funcional e a vigilância descartam tanto a diversidade de funções, como a compartimentação do local. A cobertura é considerada importante fator de humanização, ao proteger contra as intempéries e oportunizar a decisão dos presos em não se expor ao sol.

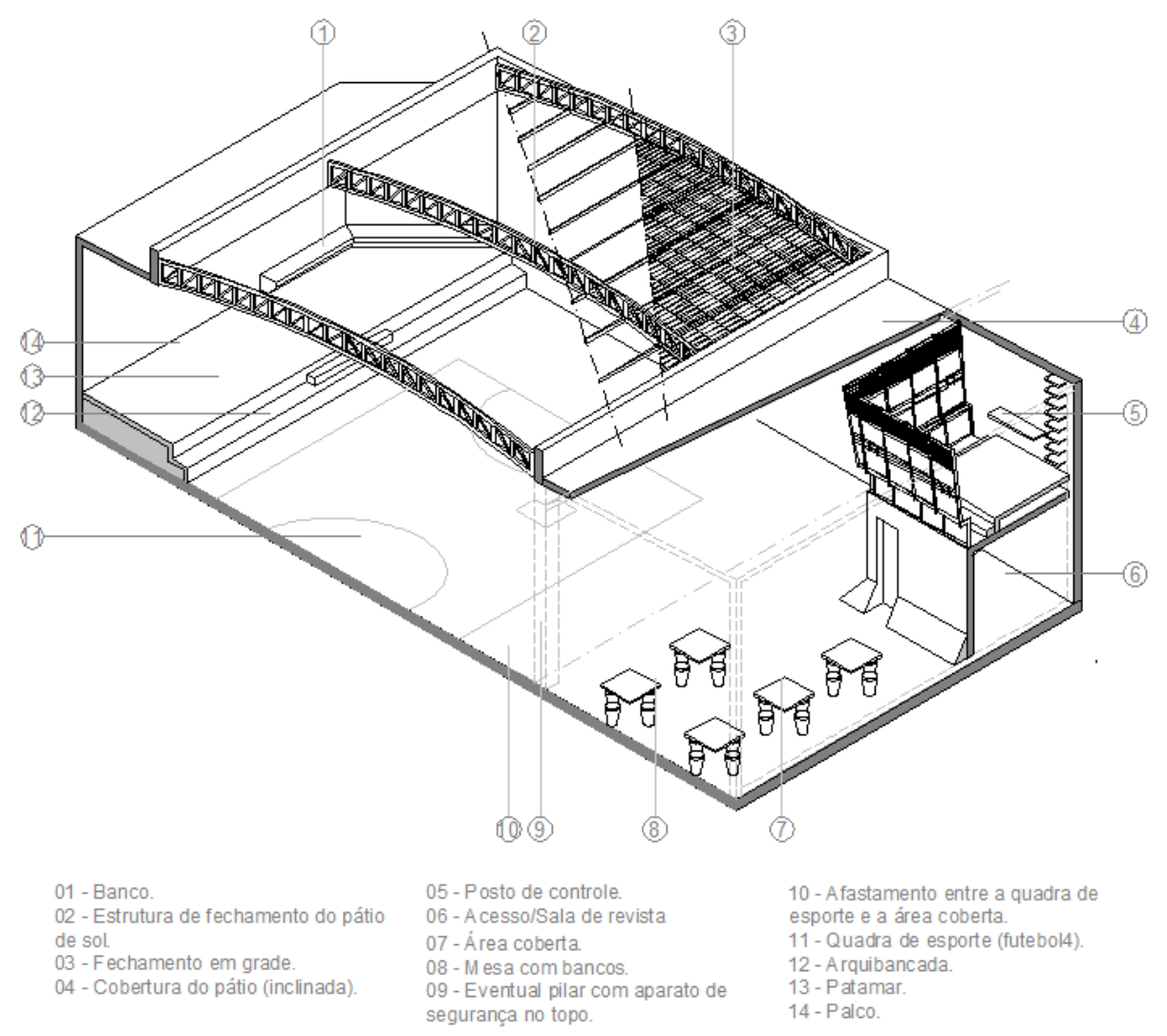

Figura 44 - Desenho esquemático isométrico do desenho-síntese desenvolvido de pátio de sol dos presos. $\mathrm{O}$ desenho mostra metade do pátio (o corte passa ao centro). Notar a sala de revista abaixo do posto de controle

O pátio de sol dos presos foi dimensionado para trinta e seis presos ou um quarto da capacidade de uma ala carcerária (144 presos). Deste modo, quatro grupos de presos utilizam alternadamente o pátio de sol diariamente, cada um por duas horas. O pátio de sol apresenta $302,76 \mathrm{~m}^{2}$, o que resulta em $8,41 \mathrm{~m}^{2} /$ preso. Deste total, $180,0 \mathrm{~m}^{2}$ são descobertos $\left(5,0 \mathrm{~m}^{2} /\right.$ preso) e $122,76 \mathrm{~m}^{2}$ são cobertos $\left(3,41 \mathrm{~m}^{2} /\right.$ preso $)$. 
A diversidade morfológica interna do pátio tende a atuar positivamente sobre os presos, ao estimular a percepção sensorial (mais alto ou mais baixo, mais à frente ou mais ao fundo) e o poder de decisão (ficar ao sol ou à sombra, subir ou descer). Do ponto de vista das relações sociais, os patamares podem ser utilizados na representação da hierarquia entre os presos.

Em termos dos equipamentos e serviços, o pátio deve prever cubas (água potável) e vasos sanitários os chuveiros são opcionais. Mesas e bancos devem ser adicionados para conversas e leitura, além de jogos de cartas e tabuleiro. Quanto a isto, as mesas para seis ou oito pessoas normalmente encontradas (projetos de referência) podem ser intercaladas por mesas menores para quatro pessoas com tabuleiros pintados. O grupo de presos no pátio de sol deve ter a possibilidade de estar sentado, simultaneamente.

O dimensionamento deve comportar o número de presos definido para o banho de sol, além das atividades programadas, considerando a eventual alternância do pátio por diferentes grupos de presos. Para esta situação, os parâmetros fixados pelo UNOPS (2016, p. 99) se aplicam para a área descoberta ( 4,0 a $6,0 \mathrm{~m}^{2}$ por pessoa) e para a área coberta $\left(2,0 \mathrm{~m}^{2}\right.$ a $4,0 \mathrm{~m}^{2}$ por pessoa). Ao mesmo tempo, o pátio deve prever a possibilidade de ocupação pelo total de presos da ala carcerária em situações de crise que exijam a aglomeração dos presos. Para esta outra situação, os valores recomendados pelas Diretrizes Básicas se aplicam (CNPCP, 2011a) para a área descoberta $\left(1,50 \mathrm{~m}^{2}\right.$ por pessoa) e para a área coberta $\left(1,0 \mathrm{~m}^{2}\right.$ por pessoa).

A iluminação e a ventilação ocorrem apenas pela abertura superior do pátio, não havendo qualquer tipo de regulagem no que diz respeito às variações do tempo. Isto reforça a inviabilidade de algumas atividades no pátio devido à chuva, poeira ou insetos, como a realização das refeições. O fechamento do pátio de sol visa a estanqueidade e a impermeabilidade do local. Sobre isto, a demanda de alguns presos de 'ver o lado de fora' é impossibilitada, porém a criação de chanfros ou arredondamentos pode viabilizar a criação de jardins internos (desde que impeçam o acesso dos presos).

O pátio de sol é um ponto vulnerável na estanqueidade da prisão, por isto foi dotado de grade na maioria dos projetos de referência (eventualmente associada a telas para evitar o lançamento de objetos), com exceção do projeto do Distrito Federal que garante a estanqueidade por meio de guarda armado no muro do pátio. A visualização do pátio deve ser privilegiada pelo espaço devassado, o que ocorre nos projetos de referência (em média, $99 \%$ da área do pátio são visualizáveis). A privacidade se resume aos sanitários que ainda tem seu interior parcialmente exposto. Os elementos propostos (mobiliário, patamares e palco) devem ser dispostos a não configurar esconderijos (pontos cegos). 


\subsubsection{Posto de Controle}

A composição arquitetônica do posto de controle reside em dois pontos principais: o monitoramento dos espaços subordinados e a integridade do próprio posto. Destes pontos, emergem condicionamentos associados ao cumprimento das tarefas institucionais de modo seguro e econômico (a vigilância dos locais e o controle dos fluxos), aos quais foi introduzida uma preocupação com a humanização, em termos das relações sociais entre funcionários e presos e das condições de trabalho dos funcionários.

No monitoramento dos espaços, a principal informação a ser obtida é a visual, segundo os funcionários, devido a sua natureza direta e imediata (denuncia o sujeito da ocorrência). Neste sentido, a capacidade de visualização do posto de controle é priorizada, sendo buscada a cobertura absoluta dos ambientes engajados. Para tanto, a vigilância panóptica indica a constituição de um ponto gerador isométrico que concentra a apreensão dos eventos circundantes, conjugadas ao arranjo dos visores. Segundo os funcionários, a existência de múltiplos pontos geradores não compromete a vigilância, já que a mesma normalmente é realizada em equipe. Porém, o número de pontos deve ser mínimo. Estes pontos geradores definem a geometria, a espacialização e o dimensionamento do posto de controle, o que depende da posição do posto e da configuração dos locais vigiados (quantidade, disposição e geometria interna). Os postos de controle do padrão arquitetônico modular apresentam localização centralizada e morfologia contundente: volume mais alto com ângulos agudos, projetado no espaço monitorado (Figura 45, ver Apêndice G). Os funcionários atuam em pisos elevados ou pavimentos superiores. Os visores são inclinados para eliminar pontos cegos e são livres de grades para potencializar a observação. Nos blocos de vivência, estas características se relacionam à representação do poder institucional: a evidência da presença da instituição, simbolizada pelo posto de controle. Nos projetos de referência adotados, por exemplo, o posto de controle dos pátios de sol é normalmente posicionado lateralmente, o que reduz o ângulo do campo a ser visualizado e o número de pontos isométricos geradores.

O fechamento do posto de controle abarca as exigências de impermeabilidade e inexpugnidade que se desdobram na inverificabilidade institucional e na integridade do sistema de segurança. A impermeabilidade do posto de controle diz respeito à comunicação entre os funcionários e os presos, para qual existe um ponto ótimo, segundo o nível de segurança penitenciário. A comunicação trata das relações sociais da sociedade prisional (pode arrefecer as tensões entre funcionários e presos), do trabalho de inteligência no gerenciamento do estabelecimento (fornecer informações estrategicamente úteis para a administração) e da prevenção dos efeitos negativos do anonimato (o abuso de poder). A segurança envolve a interiorização disciplinar que se vincula à economia de recursos humanos (redução da equipe). 
No trabalho The Creative Prison (RIDEOUT, 2006b) foi levantado que as relações sociais entre funcionários e presos se desgastaram devido a decisões inconsistentes, exemplificadas pelo posto de controle no bloco de vivência que inibe a interação, especialmente as consultas dos presos aos funcionários. Este trabalho levantou que não necessariamente os grupos de funcionários e presos guardam ressentimentos entre si, mas ambos se ressentem contra a instituição que eventualmente dificulta as relações verticais desnecessariamente, com perdas para a eficiência social do estabelecimento. Deste modo, o posto de controle deve possibilitar de maneira seletiva a exposição dos funcionários e a interface com os espaços monitorados, por meio da configuração dos visores e do uso de portinholas (aparatos de segurança), associados à iluminação interna.

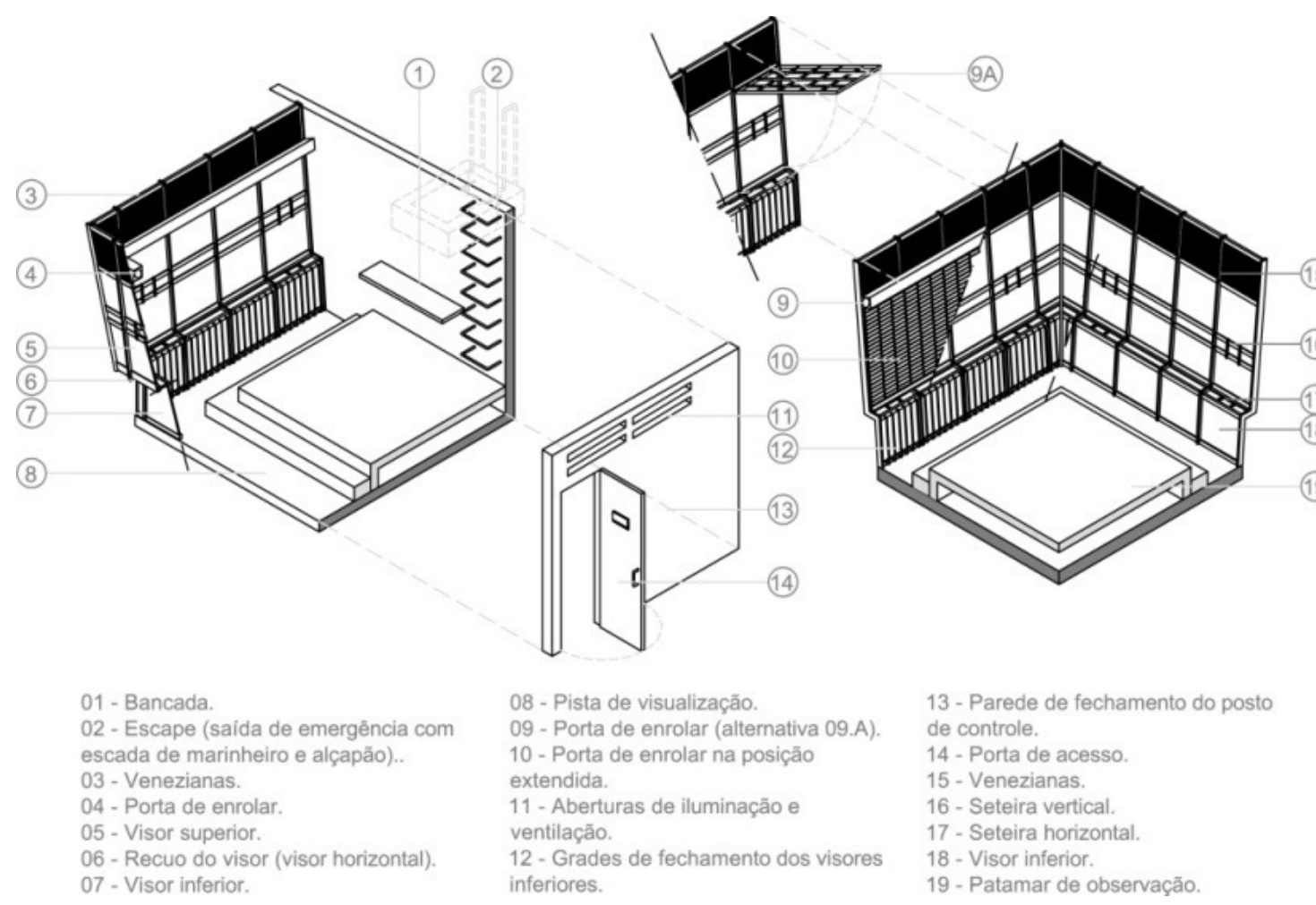

Figura 45 - Desenhos esquemáticos isométricos do desenho-síntese desenvolvido de posto de controle

Este desenho-síntese foi elaborado para o pátio de sol dos presos desenvolvido. O posto de controle foi dimensionado em $16,0 \mathrm{~m}^{2}$, com uma previsão de dois a três agentes alocados. O tamanho de 4,0 x 4,0m permite um distanciamento dos agentes em relação aos visores, o que pode criar um senso de segurança, reforçado pela proporção espacial do local (pé-direito de 3,0m) e pela presença do alçapão de escape no teto.

O sistema de segurança tem como objetivo principal a proteção dos funcionários contra ataques ou captura como refém pelos presos. Além disto, a invasão de um posto pode comprometer uma seção ou a toda a prisão. Por isto, o posto deve resistir a eventuais investidas dos presos, pelo menos até a saída dos funcionários, o que é amplamente atribuído aos aparatos de segurança, especialmente quanto às aberturas (visores e aberturas de iluminação e ventilação). Todavia, este fechamento não deve ser hermético. De acordo com os funcionários, aberturas para a percepção de sons e odores são 
necessárias. Estas aberturas também funcionam para a emissão de comandos, além de procedimentos de repreensão ou contenção de crises (disparos por arma de fogo ou lançamento de bombas). $\mathrm{O}$ fechamento do posto também é refreado pelo bem estar dos funcionários. Sobre isto, os mesmos manifestaram certo desconforto, expresso nas sensações de insegurança e de enclausuramento (em postos de controle pequenos e com vedações em grade).

A simplicidade funcional preconiza espaço suficiente e adequadamente equipado para as funções a serem desempenhadas, em respeito à condição humana dos funcionários. O posto deve ter dimensão suficiente para estabelecer uma distancia segura entre os presos e os funcionários, o que se vincula à localização e altura do posto. Em geral, o mobiliário é resumido a uma bancada e cadeiras. Conforme demanda da equipe dirigente, o sanitário deve ser colocado do lado externo do posto.

O conforto ambiental constitui outra queixa corrente entre os funcionários. As aberturas de iluminação e ventilação são normalmente preteridas nos projetos de referência em prol do fechamento. As aberturas podem ser as mesmas dos visores, desde que estejam voltadas para áreas iluminadas e ventiladas. A ventilação cruzada é admitida, desde que atendidos os critérios de impermeabilidade, estanqueidade e inverificabilidade institucional.

\subsection{Características da unidade prisional de segurança máxima}

A partir dos parâmetros definidos na tecnologia de projeto desenvolvida (ver Apêndice F) é possível caracterizar o estabelecimento penal, por meio de um modelo-síntese (Figura 46, ver Apêndice G). A capacidade deste estabelecimento foi calculada com base na divisão da população prisional em quatro grupos de 144 presos, o que resultou em uma lotação de 576 vagas. As celas de isolamento estão em bloco apartado do setor interno, dotado das atividades rotineiras dos presos e de nove celas individuais, não contabilizadas na capacidade. O pré-dimensionamento buscou a melhor relação entre a capacidade e a área construída, ao adotar o índice ótimo encontrado, de 21,50 $\mathrm{m}^{2} / \mathrm{vaga}$. A área total estimada foi de $11.134,00 \mathrm{~m}^{2}$, distribuídos pelos setores em $10 \%$ ou $1.238,40 \mathrm{~m}^{2}$ (externo), em $20 \%$ ou $2.476,80 \mathrm{~m}^{2}$ (intermediário) e em $70 \%$ ou $8.668,80 \mathrm{~m}^{2}$ (interno). O terreno alcança $61.740,00 \mathrm{~m}^{2}$ ou $107,19 \mathrm{~m}^{2} /$ vaga $(210 \mathrm{x} 294 \mathrm{~m})$ para afastamentos de trinta metros e $43.180,00 \mathrm{~m}^{2}$ ou $74,96 \mathrm{~m}^{2} /$ vaga (170x254m) para afastamentos de vinte metros. A taxa de ocupação variou em $18 \%$ e 25\%, respectivamente.

Os quatro blocos de vivência concebidos internalizam as atividades cotidianas dos presos. Cada ala carcerária conta com 18 celas no desenho-síntese desenvolvido, interligada por um corredor de 2,50m de largura, com uma área de $634,57 \mathrm{~m}^{2}$. Nas áreas de atividades dos presos foram utilizados os índices de $2,16 \mathrm{~m}^{2} /$ vaga e $2,51 \mathrm{~m}^{2} /$ vaga que resultaram em $672,48 \mathrm{~m}^{2}$, por bloco de vivência e $2.690,0 \mathrm{~m}^{2}$ no total. O desenho-síntese dos pátios de sol dos presos apresenta $360,0 \mathrm{~m}^{2}$ ou $10,0 \mathrm{~m}^{2}$ por preso. Os 
blocos são servidos por circulação exclusiva para os funcionários em pavimento superior do setor interno que representa $870 \mathrm{~m}^{2}$ de área construída ou $7 \%$ da área total do estabelecimento.

Os blocos sugerem um alinhamento que inscreve o conjunto em um retângulo com noventa metros de largura. Os blocos atenderam à continuidade das massas construídas sugerida pelos projetos de referência, sendo os blocos externos separados pela barreira perimetral e os blocos intermediários intercalados no padrão arquitetônico paralelo. Os blocos internos formam um volume único. A compactação dos blocos internos é rompida pela criação de áreas para a iluminação e ventilação indireta dos ambientes. $\mathrm{O}$ conjunto é interligado por uma circulação central, coincidente ao eixo de simetria. Sobre esta circulação são colocados postos de controle nos acessos principais - quatro postos no total. Além destes postos, os pátios de sol acrescentam mais quatro à unidade penal. A equipe estimada é de 29 agentes, ou 20 presos/agente para o turno diurno, além de oito guardas externos.

A configuração caracteriza um forte fechamento para as edificações, o que justifica a adoção de cerca para a barreira perimetral. Este fechamento impede o contato visual dos presos com o mundo externo, restrito às áreas internas de ventilação e iluminação. A barreira recebeu quatro torres de vigilância que, em conjunto com os postos de controle, atingem $97 \%$ de visualização das áreas externas.

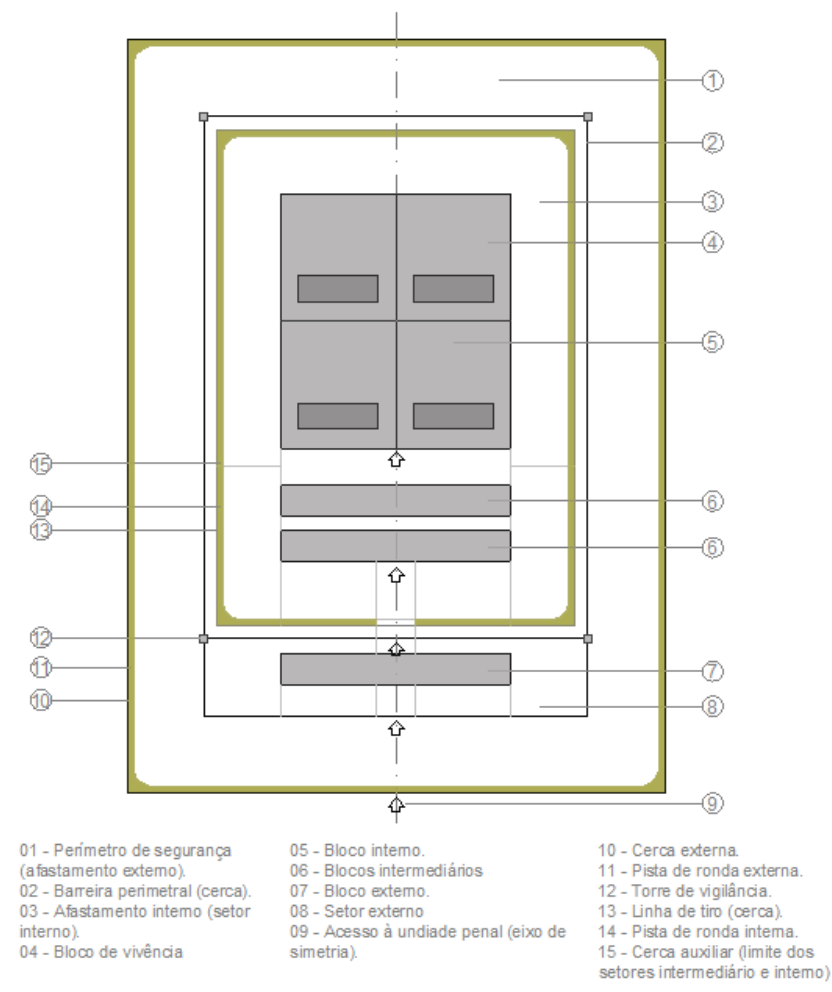

Figura 46 - Desenho de implantação de modelo de unidade prisional (sem escala). 


\subsection{Conclusão analítica}

O ajustamento efetuado ao conjunto obtido na análise das características da edificação penal partiu da proposição de uma modalidade arquitetônica de segurança máxima que interferiu na totalidade da definição dos quesitos (Quadro 13). Doze requisitos funcionais inicialmente definidos por soluções formais passaram a assumir a caracterização informal, dos quais, seis nos quesitos de Isolamento Individual e Cela. Trinta e dois requisitos tiverem as características formais mescladas com as informais. Os quesitos com menos alterações foram os aparatos de segurança, o controle e o posto de controle.

Quadro 13 - Resumo dos ajustes às soluções formais e informais

\begin{tabular}{|c|c|c|c|c|c|c|c|c|c|c|c|c|c|c|c|c|c|c|c|}
\hline \multirow{4}{*}{ 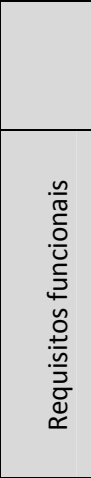 } & \multicolumn{9}{|c|}{$\begin{array}{l}\text { F - caracterização formal } \\
\text { I- caracterização informal } \\
\text { F/I - caracterização formal com adequações informais } \\
\text { I/F - caracterização informal com adequações formais }\end{array}$} & \multicolumn{10}{|c|}{$\begin{array}{l}\text { Verde - sem alteração da análise inicial } \\
\text { Amarelo - sofreu adequações da análise inicial } \\
\text { Vermelho - inverteu a caracterização da análise inicial }\end{array}$} \\
\hline & \multicolumn{19}{|c|}{ Grupos de quesitos } \\
\hline & 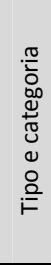 & 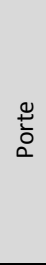 & $\stackrel{0}{\breve{s}}$ & 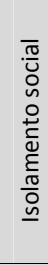 & 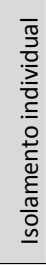 & 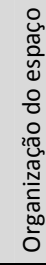 & 胥 & 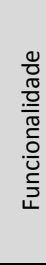 & $\frac{\tilde{D}}{\frac{\pi}{\pi}}$ & 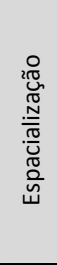 & 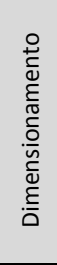 & 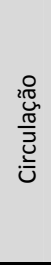 & $\begin{array}{l}\bar{\pi} \\
\stackrel{0}{0} \\
\frac{0}{0} \\
\frac{E}{L} \\
0 \\
0 \\
0 \\
0 \\
0 \\
0\end{array}$ & 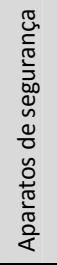 & $\begin{array}{l}\frac{0}{0} \\
\stackrel{2}{0} \\
0\end{array}$ & 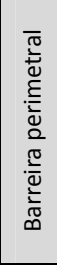 & $\frac{\pi}{0}$ & 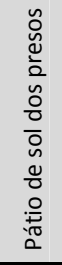 & $\begin{array}{l}0 \\
0 \\
0 \\
0 \\
0 \\
0 \\
0 \\
0 \\
0 \\
0 \\
0\end{array}$ \\
\hline & 01 & 02 & 03 & 04 & 05 & 06 & 07 & 08 & 09 & 10 & 11 & 12 & 13 & 14 & 15 & 16 & 17 & 18 & 19 \\
\hline 01 & 1 & 1 & $\mathrm{~F}$ & $\mathrm{~F}$ & 1 & $\mathrm{~F} / \mathrm{I}$ & $\mathrm{F}$ & $\mathrm{F} / \mathrm{I}$ & $\mathrm{F} / \mathrm{I}$ & $F / I$ & $F / I$ & $\mathrm{~F}$ & $F / I$ & $\mathrm{~F}$ & $\mathrm{~F}$ & $\mathrm{I} / \mathrm{F}$ & $F / I$ & I/F & $\mathrm{F}$ \\
\hline 02 & 1 & 1 & 1 & $\mathrm{~F} / \mathrm{I}$ & 1 & $\mathrm{~F} / \mathrm{I}$ & & $\mathrm{F} / \mathrm{I}$ & $\mathrm{F}$ & $F / I$ & $\mathrm{I} / \mathrm{F}$ & $\mathrm{F} / \mathrm{I}$ & $\mathrm{F} / \mathrm{I}$ & $\mathrm{F}$ & $\mathrm{F}$ & $\mathrm{F} / \mathrm{I}$ & 1 & 1 & $\mathrm{~F}$ \\
\hline 03 & I & $\mathrm{F}$ & $\mathrm{F} / \mathrm{I}$ & 1 & $\mathrm{~F} / \mathrm{I}$ & $\mathrm{F} / \mathrm{I}$ & & & & 1 & $F / I$ & $F / I$ & & & $\mathrm{I} / \mathrm{F}$ & $F / I$ & 1 & $\mathrm{I} / \mathrm{F}$ & $\mathrm{F}$ \\
\hline 04 & & & $F / I$ & $F$ & 1 & & & & & $\mathrm{I} / \mathrm{F}$ & & $\mathrm{F}$ & & & $\mathrm{F}$ & $\mathrm{I} / \mathrm{F}$ & $F / I$ & $F / I$ & $F / I$ \\
\hline 05 & & & & & $\mathrm{~F} / \mathrm{I}$ & & & & & $\mathrm{I} / \mathrm{F}$ & & & & & $\mathrm{F}$ & $\mathrm{F} / \mathrm{I}$ & $\mathrm{I} / \mathrm{F}$ & I/F & $\mathrm{F}$ \\
\hline 06 & & & & & & & & & & $\mathrm{~F}$ & & & & & $\mathrm{~F}$ & $\mathrm{~F} / \mathrm{I}$ & $1 / F$ & $\mathrm{I} / \mathrm{F}$ & $\mathrm{F}$ \\
\hline 07 & & & & & & & & & & & & & & & $\mathrm{~F}$ & $\mathrm{I} / \mathrm{F}$ & $\mathrm{I} / \mathrm{F}$ & $\mathrm{F}$ & \\
\hline 08 & & & & & & & & & & & & & & & & $\mathrm{~F}$ & $F / I$ & $F / I$ & \\
\hline 09 & & & & & & & & & & & & & & & & $\mathrm{~F}$ & $\mathrm{~F}$ & $\mathrm{I} / \mathrm{F}$ & \\
\hline 10 & & & & & & & & & & & & & & & & $\mathrm{~F} / \mathrm{I}$ & $F / I$ & $\mathrm{~F} / \mathrm{I}$ & \\
\hline 11 & & & & & & & & & & & & & & & & $\mathrm{~F}$ & $\mathrm{~F}$ & $\mathrm{~F}$ & \\
\hline 12 & & & & & & & & & & & & & & & & & & $\mathrm{~F}$ & \\
\hline \multirow{4}{*}{ Grupo } & 1 & 1 & $F / I$ & $\mathrm{~F}$ & 1 & $\mathrm{~F} / \mathrm{I}$ & $\mathrm{F}$ & $\mathrm{F} / \mathrm{I}$ & $\mathrm{F}$ & $\mathrm{F}$ & $\mathrm{F}$ & $\mathrm{F}$ & $F / I$ & $\mathrm{~F}$ & $\mathrm{~F}$ & $\mathrm{~F}$ & $\mathrm{~F} / \mathrm{I}$ & $F$ & $\mathrm{~F}$ \\
\hline & \multirow{2}{*}{\multicolumn{3}{|c|}{$\begin{array}{l}\text { Externos - } \\
\text { I }\end{array}$}} & & & & & \multicolumn{5}{|c|}{ Funcionalidade - F } & & & & \multirow{2}{*}{\multicolumn{4}{|c|}{$\begin{array}{c}\text { Elementos Centrais } \\
-\mathbf{F}\end{array}$}} \\
\hline & & & & & & & & & aniza & ão do & espa & $O-F$ & & & & & & & \\
\hline & \multicolumn{19}{|c|}{ Programa arquitetônico - F } \\
\hline
\end{tabular}

A revisão feita incluiu mais sessenta e nove vínculos ao sistema desenvolvido, de modo a atribuir uma maior consistência ao conjunto, em termos da aplicabilidade do mesmo. Majoritariamente, estes vínculos interligam quesitos dentro dos grupos temáticos, sendo a barreira perimetral o grupo com maior acréscimo (vinte e dois vínculos), seguida da cela e do pátio de sol dos presos (cada um com quinze vínculos). 


\section{Capítulo 8 - Avaliação da tecnologia de projeto}

Neste capítulo, a tecnologia de projeto é avaliada do ponto de vista da relação custobenefício, ao se estabelecer o incremento do espaço arquitetônico da edificação penal e os respectivos custos de construção e operação do estabelecimento penal a ser projetado. Para esta avaliação, a tecnologia de projeto é aos projetos de referência adotados nesta pesquisa (ver Apêndice A). A avaliação procedida se encontra no Apêndice $H$, desta tese.

A avaliação realizada integraliza o ajustamento da tecnologia de projeto desenvolvida, ao serem comparadas as características originais dos projetos de referência em relação às características resultantes da aplicação da tecnologia de projeto. Para a avaliação do custo de construção, os orçamentos estimativos dos elementos centrais da edificação penal são inicialmente apresentados para a sua posterior aplicação aos projetos de referência (barreira perimetral, a cela, o pátio de sol e o posto de controle) (ver Apêndice G).

\subsection{Orçamento dos elementos centrais da edificação penal}

A especificação da barreira perimetral do tipo cerca foi baseada em uma estratégia de compensação, na qual a economia obtida em relação ao muro amortizaria um aumento de custo de construção advindo da ampliação dos afastamentos externo e interno (Tabela 1). O custo da barreira perimetral foi estimado em $\mathrm{R} \$ 2.799,08$ por metro linear de barreira. O custo de construção da cela é de $\mathrm{R} \$ 117,78$ mil, com índices de $\mathrm{R} \$ 4.224,32 / \mathrm{m}^{2}$ e $\mathrm{R} \$ 14,72 \mathrm{mil} / \mathrm{vaga}$. O custo de construção unitário do pátio desenvolvido manteve o valor unitário médio dos projetos de referência $\left(\mathrm{R} \$ 4.111,90 / \mathrm{m}^{2}\right.$, enquanto o cálculo chegou a $\left.\mathrm{R} \$ 3.838,00 / \mathrm{m}^{2}\right)^{92}$. O custo do posto de controle é de $\mathrm{R} \$ 126.790,52$.

Tabela 1 - Orçamento estimativo do valor unitário da barreira perimetral

\begin{tabular}{|c|c|c|c|}
\hline \multicolumn{4}{|l|}{ Barreira Perimetral } \\
\hline Alteração & Quantidade & Preço Unitário $(\mathrm{R} \$)^{*}$ & Custo (R\$) \\
\hline Afastamentos (trincheira) & $60,0 \mathrm{~m}$ & $5,55 / \mathrm{m}^{2}$ & 333,00 \\
\hline Cerca externa com pista de ronda externa e dilacerador de pneus & $1 \mathrm{~m}$ & $79,75 / \mathrm{m}$ & 79,75 \\
\hline Barreira perimetral (pista de ronda interna e linha de tiro) & $1 \mathrm{~m}$ & $2.386,33 / \mathrm{m}$ & $2.386,33$ \\
\hline Total & & & $2.799,08$ \\
\hline \multicolumn{4}{|c|}{ Cela (valor acrescido pelo desenho-síntese à média dos projetos de referência) } \\
\hline Alteração & Quantidade & Preço Unitário $(\mathrm{R} \$)^{*}$ & Custo (R\$) \\
\hline Área construída (piso e vedação) & $8,10 \mathrm{~m}^{2}$ & $2.158,00$ & $8.740,00$ \\
\hline Grade fechamento zenital & $16,20 \mathrm{~m}^{2}$ & 804,00 & $13.024,00$ \\
\hline Zenital (alvenaria, estrutura, telhas, esquadria) & Verba & - & $6.470,00$ \\
\hline $\begin{array}{l}\text { Mobiliário (mesa coletiva com bancos, mesa individual, piso dos } \\
\text { nichos e prateleiras) }\end{array}$ & Verba & - & $2.353,00$ \\
\hline Elemento de fachada (brise) & Verba & - & $2.302,66$ \\
\hline Peças hidro-sanitárias & Verba & - & 600,00 \\
\hline Total & & & $126.790,52$ \\
\hline \multicolumn{4}{|l|}{ Pátio de sol dos presos } \\
\hline Alteração & Quantidade & Preço Unitário $(\mathrm{R} \$)^{*}$ & Custo (R\$) \\
\hline
\end{tabular}

\footnotetext{
${ }^{92} \mathrm{O}$ custo considerou a abertura superior com estrutura metálica e grades, o que determina um preço unitário similar à média edificada.
} 


\begin{tabular}{|c|c|c|c|}
\hline Área construída (descontado o vão da abertura superior) & $302,76 m^{2}$ & $4.111,90$ & $893.000,00$ \\
\hline Fechamento da abertura superior (gradil) & $180,0 \mathrm{~m}^{2}$ & $1.360,00$ & $244.800,00$ \\
\hline Arquibancada & $45,0 \mathrm{~m}^{2}$ & 215,28 & $14.530,00$ \\
\hline Mobiliário (mesas com bancos) & Verba & $7.850,00$ & $7.850,00$ \\
\hline Peças hidro-sanitárias & Verba & $1.800,00$ & $1.800,00$ \\
\hline Total & & & $1.161 .980,00$ \\
\hline \multicolumn{4}{|l|}{ Posto de controle } \\
\hline Alteração & Quantidade & Preço Unitário $(\mathrm{R} \$)^{*}$ & Custo (R\$) \\
\hline Área construída & $16,0 \mathrm{~m}^{2}$ & $4.111,90$ & $65.790,00$ \\
\hline Visores (esquadria, vidro $5 \mathrm{~cm}$ com película, portinholas) & $9,16 \mathrm{~m}^{2}$ & Vários & $29.049,00$ \\
\hline Venezianas & $4,20 \mathrm{~m}^{2}$ & 840,30 & $3.529,25$ \\
\hline Bancada & 1 unid. & - & 129,17 \\
\hline Patamar & $7,29 m^{2}$ & 215,28 & $1.569,40$ \\
\hline Porta & 1 unid. & - & $5.248,22$ \\
\hline Alçapão de escape & 1 unid. & - & $1.581,48$ \\
\hline Aparatos de segurança (porta de enrolar, grades) & $\mathrm{Vb}$ & Vários & $20.000,00$ \\
\hline \multicolumn{3}{|l|}{ Total } & $126.790,52$ \\
\hline
\end{tabular}

\subsection{Aplicação da tecnologia aos projetos de referência}

A aplicação da tecnologia de projeto aos projetos de referência selecionados para esta pesquisa (ver Apêndice A) tem os impactos descritos a seguir ${ }^{93}$.

\subsubsection{Penitenciária do Distrito Federal}

A revisão do projeto distrital envolveu uma estratégia mais ampla para o melhor ajustamento da arquitetura, sem comprometer os conceitos espaciais inerentes (Figura 47). Nesta estratégia, o estabelecimento foi interpretado como complexo penitenciário constituído de duas unidades que compartilham a recepção, administração e a infraestrutura. Cada unidade foi integrada por dois blocos de vivência. A revisão reduziu a área construída do bloco de vivência de $6.250,00 \mathrm{~m}^{2}$ para $4.411,00 \mathrm{~m}^{2}$ e a capacidade de 448 vagas para 288 vagas. As vagas individuais foram reduzidas de 120 para 20 ( $1,5 \%$ da capacidade), agrupadas em um bloco funcional destacado no conjunto. O número dos postos de controle foi reduzido em quatro pela retirada da guarita dos pátios de sol, diante do gradeamento da abertura superior dos mesmos. Os demais blocos não sofreram alterações. A área delimitada pela barreira perimetral permaneceu a mesma e um perímetro de segurança foi criado (cercamento externo). Com isto, as torres de vigilância passaram a serem protegidas. A pista de ronda permaneceu fora do perímetro de segurança. Uma torre de vigilância foi retirada pelo reposicionamento do bloco de recepção (o posto de controle deste bloco passa a atuar na vigilância externa).

\footnotetext{
${ }^{93}$ Os cálculos de custo de construção utilizaram os respectivos valores em cada projeto, expostos no Apêndice A. Os cálculos de custo de operação se basearam em duas abordagens para a quantificação dos funcionários: a primeira diz respeito ao número mínimo de agentes para a operação, a segunda remete ao número ótimo de agentes, apontado pelos diretores e chefes de segurança das unidades prisionais visitadas. $\mathrm{O}$ dimensionamento das equipes atendeu às premissas: um posto deve ser ocupado por, pelo menos, dois agentes (um destes pode ser o coordenador que atua em até dois postos); cada recinto vigiado exige, pelo menos, um agente; cada ala carcerária exige, pelo menos, um agente. Estes números tratam do contingente para a situação de maior demanda operacional (visita aos presos).
} 


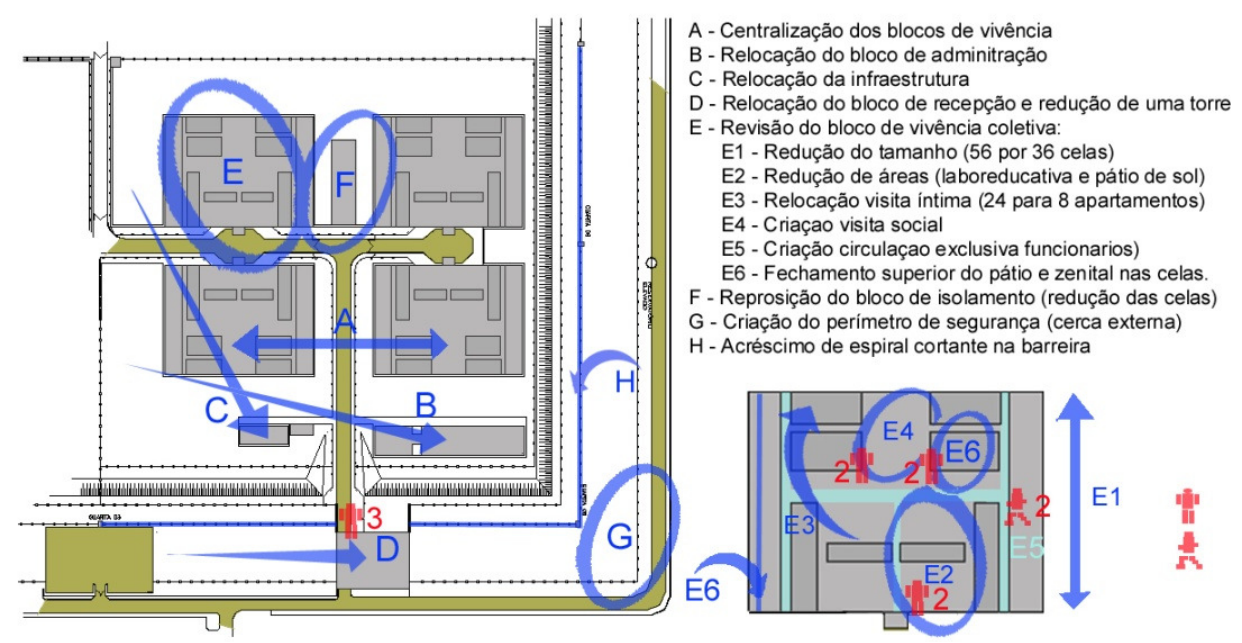

Figura 47 - Esquema das alterações promovidas no projeto da Penitenciária do Distrito Federal (sem escala) A legenda em vermelho indica os postos de controle com as equipes funcionais estimadas.

O complexo revisado resultou em uma área construída de $23.246,00 \mathrm{~m}^{2}$ e uma capacidade de 1.152 vagas, sendo 576 vagas em cada unidade, o que derivou um índice de 20,18 $\mathrm{m}^{2} /$ vaga (Tabela 2). Em comparação ao projeto original, o novo arranjo reduziu a área total em $4.254,00 \mathrm{~m}^{2}$ e a capacidade em 192 vagas, ou seja, houve um aumento na relação da área construída pela capacidade em quase $8 \%$. O terreno com o cercamento externo somou ao complexo quase 76 mil metros quadros ou $66 \mathrm{~m}^{2} / \mathrm{vaga}$, com uma taxa de ocupação de, aproximadamente, $30 \%$.

Tabela 2 - Ajuste ao custo de construção do projeto da Penitenciária do Distrito Federal

\begin{tabular}{|l|c|c|c|}
\hline \multicolumn{1}{|c|}{ Alteração } & Quantidade & Preço Unitário (R\$) & Custo (R\$) \\
\hline $\begin{array}{l}\text { Acréscimo de cerca externa com pista de ronda (perímetro de } \\
\text { segurança) }\end{array}$ & $+500 \mathrm{~m}$ & $800 / \mathrm{m}$ & $+400 \mathrm{mil}$ \\
\hline Acréscimo de elemento cortante na barreira perimetral & $+430 \mathrm{~m}$ & $31,50 / \mathrm{m}$ & $+130 \mathrm{mil}$ \\
\hline Decréscimo de área construída & $-4254,0 \mathrm{~m}^{2}$ & $3.520,23$ & $-14,98 \mathrm{milhões}$ \\
\hline Total & & $-14,45 \mathrm{milhões}$ \\
\hline
\end{tabular}

O custo de construção foi abreviado em mais de quatorze milhões de reais, o que resultou em uma obra de pouco mais de $\mathrm{R} \$ 82$ milhões, com índices de $\mathrm{R} \$ 3.550,00 / \mathrm{m}^{2}$ e $\mathrm{R} \$ 71,66 \mathrm{mil} / \mathrm{vaga}$. O custo operacional foi impactado pela redução de quatro postos de controle (pátios de sol dos presos) e uma torre de vigilância, o que reduziu dezesseis agentes, de 156 para 140 agentes, além de quatro guardas externos do contingente funcional. A economia com esta redução de pessoal é estimada em cerca de $\mathrm{R}$ \$ 1,5 milhão anuais, com tendência a maior de 1,72 milhão de reais (custo de $\mathrm{R} \$$ 7.514,00/agente/mês) (ver Apêndice A).

\subsubsection{Penitenciária Compacta Paulista}

A revisão do projeto paulista implicou em mudanças nos conceitos de compactação e verticalidade originais, justificadas pelo alto custo da barreira perimetral do tipo muro, pela relação de área 
construída por vaga insuficiente e pela presença incompatível de presos no segundo pavimento (Figura 48). Além disto, a unidade prisional teve a capacidade reduzida de 768 vagas para 576 vagas, dentro da estratégia de equiparação dos projetos de referência adotada. Esta redução foi obtida pela eliminação de quatro das oito alas carcerárias e o aumento de capacidade das quatro alas de 96 vagas para 144 vagas (de oito celas com doze vagas, cada, para dezoito celas de oito vagas cada).

Pontualmente, a barreira perimetral tipo muro foi substituída pelo desenho-síntese desenvolvido de cerca, o que ampliou os afastamentos e cresceu o terreno. A quantidade de torres de vigilância foi mantida e foram acrescentados três postos intermediários para ocupação em situações de crise. $\mathrm{O}$ bloco externo teve a área construída reduzida pela metade (horizontalização). O setor intermediário foi arranjado paralelamente e a verticalidade foi eliminada: o bloco de educação original foi substituído por um bloco de assistência à saúde e tratamento penal com programa completo (segundo as Diretrizes Básicas, CNPCP, 2011a). O bloco de isolamento foi transformado térreo e com menos celas individuais (de vinte e quatro para dez celas). O bloco de serviços permaneceu igual.
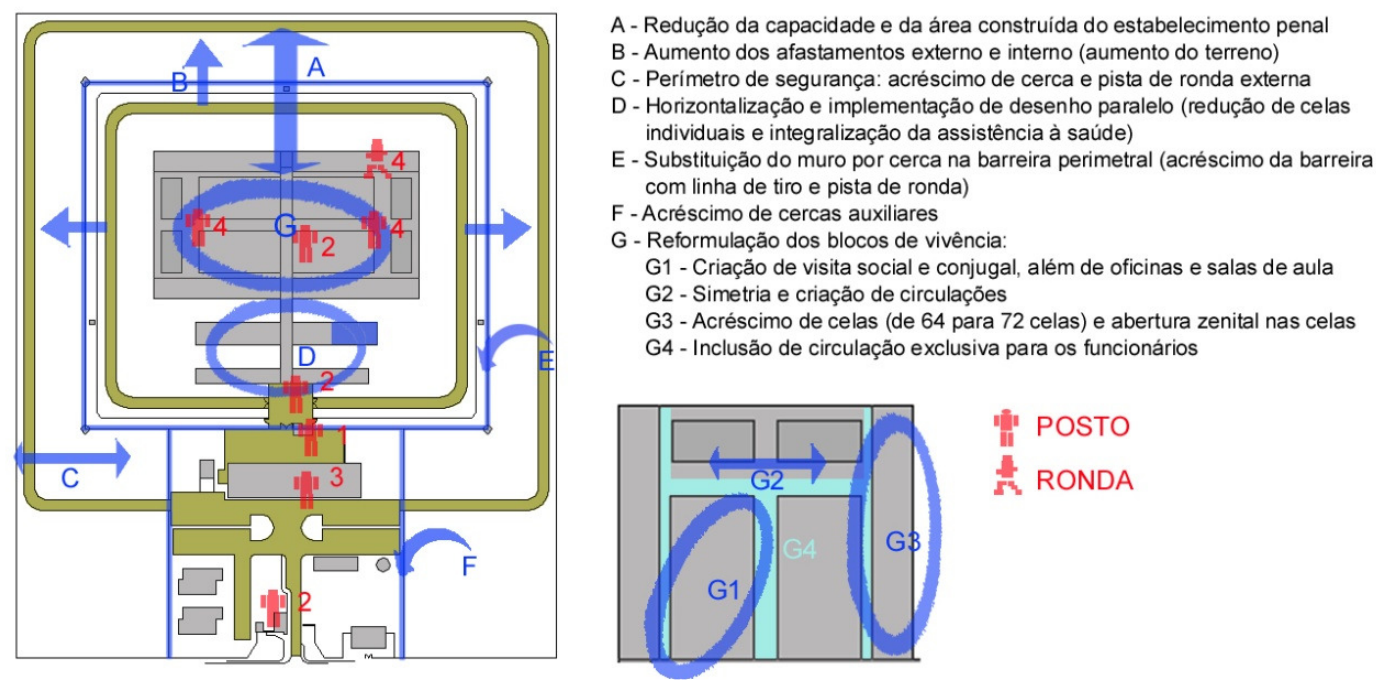

Figura 48 - Esquema das alterações promovidas ao projeto da Penitenciária Compacta (sem escala). A legenda em vermelho indica os postos de controle com as equipes funcionais estimadas.

A compactação dos edifícios foi preservada nos blocos internos. Os blocos de vivência tiveram o controle centralizado e dotado de circulação exclusiva para os funcionários, o que reduziu pela metade o número de postos de controle (de doze para seis postos). Neste arranjo, os locais de trabalho e educação foram internalizados nos blocos de vivência, além de terem sido criados locais de sociabilização (visita social, íntima e encontro com o advogado). Com estas providências, cada grupo de presos conta com estrutura física própria para as atividades rotineiras, enquanto dois grupos são controlados pela mesma estrutura de segurança. 
O projeto ajustado resultou em uma área construída de $10.542,0 \mathrm{~m}^{2}$ e uma capacidade de 576 vagas, o que derivou um índice de $18,97 \mathrm{~m}^{2} /$ vaga. Em comparação ao projeto original, o novo arranjo aumentou a área total em 1.652,0m² e reduziu a capacidade em 192 vagas, ou seja, houve um aumento na relação da área construída pela capacidade de mais de $40 \%$. O terreno com afastamentos de trinta metros ficou em 66 mil m² ou quase 115,0m²/vaga, com uma taxa de ocupação de $16 \%$. Isto representa um aumento de área de terreno superior a $30 \mathrm{mil} \mathrm{m}^{2}$.

O custo de construção foi aumentado em aproximadamente $\mathrm{R} \$ 8,37$ milhões, o que resultou em uma obra de $\mathrm{R} \$ 67,86$ milhões, com índices de $\mathrm{R} \$ 6.437,10 / \mathrm{m}^{2}$ e $\mathrm{R} \$ 117,81 \mathrm{mil} / \mathrm{vaga}$ (Tabela 3). O operacionalmente, o projeto ajustado teve o número de postos diminuído de sete para seis e o número de agentes de 26 para 22, por turno. O impacto no custo operacional foi de dezesseis agentes, o que abate 520 mil reais anuais, com tendência a maior de 974 mil reais por ano (R\$ 2.703,90/agente/mês) (Apêndice A).

Tabela 3 - Ajuste ao custo de construção do projeto da Penitenciária Compacta

\begin{tabular}{|c|c|c|c|}
\hline Alteração & Quantidade & Preço unitário ( $\mathrm{R} \$$ ) & Custo (R\$) \\
\hline Aumento do terreno (pista de ronda externa e trincheira) & $+30.227 \mathrm{~m}^{2}$ & $5,55 / \mathrm{m}^{2}$ & $+168 \mathrm{mil}$ \\
\hline Substituição do muro por cerca & $508 \mathrm{~m}$ & $7.078,00 / \mathrm{m}$ & - 3,60 milhões \\
\hline $\begin{array}{l}\text { Acréscimo de cerca externa com pista de ronda externa e } \\
\text { dilacerador de pneus (perímetro de segurança) }\end{array}$ & $+246 \mathrm{~m}$ & $79,75 / \mathrm{m}$ & $+19,62 \mathrm{mil}$ \\
\hline Acréscimo de barreira (pista de ronda interna e linha de tiro) & $+142 \mathrm{~m}$ & $2.386,33 / \mathrm{m}$ & $+338,86 \mathrm{mil}$ \\
\hline Acréscimo de cercas auxiliares & $+200 \mathrm{~m}$ & $1877,00 / \mathrm{m}$ & $+375,4 \mathrm{mil}$ \\
\hline Acréscimo de área construída & $+1.652 \mathrm{~m}^{2}$ & $6.692,91 / \mathrm{m}^{2}$ & $+11,06$ milhões \\
\hline \multicolumn{3}{|l|}{ Total } & $+8,37$ milhões \\
\hline
\end{tabular}

\subsubsection{Cadeia pública do Ministério da Justiça}

A revisão do projeto federal buscou uma maior compatibilização da capacidade com a demanda realística, o que aumentou a lotação de 374 vagas para 512 vagas, dentro da faixa estipulada para as unidades prisionais de médio porte (Figura 49). Isto acrescentou quatro celas ou trinta e duas vagas a cada ala carcerária que passou a contar com 128 vagas. Estas vagas ditaram os dimensionamentos dos pátios de sol e dos locais dos programas socializante e de benefícios aos presos. Externamente, a barreira perimetral foi trocada de muro para cerca, com a aplicação do desenho-síntese desenvolvido, o que ampliou os afastamentos no projeto revisado. 


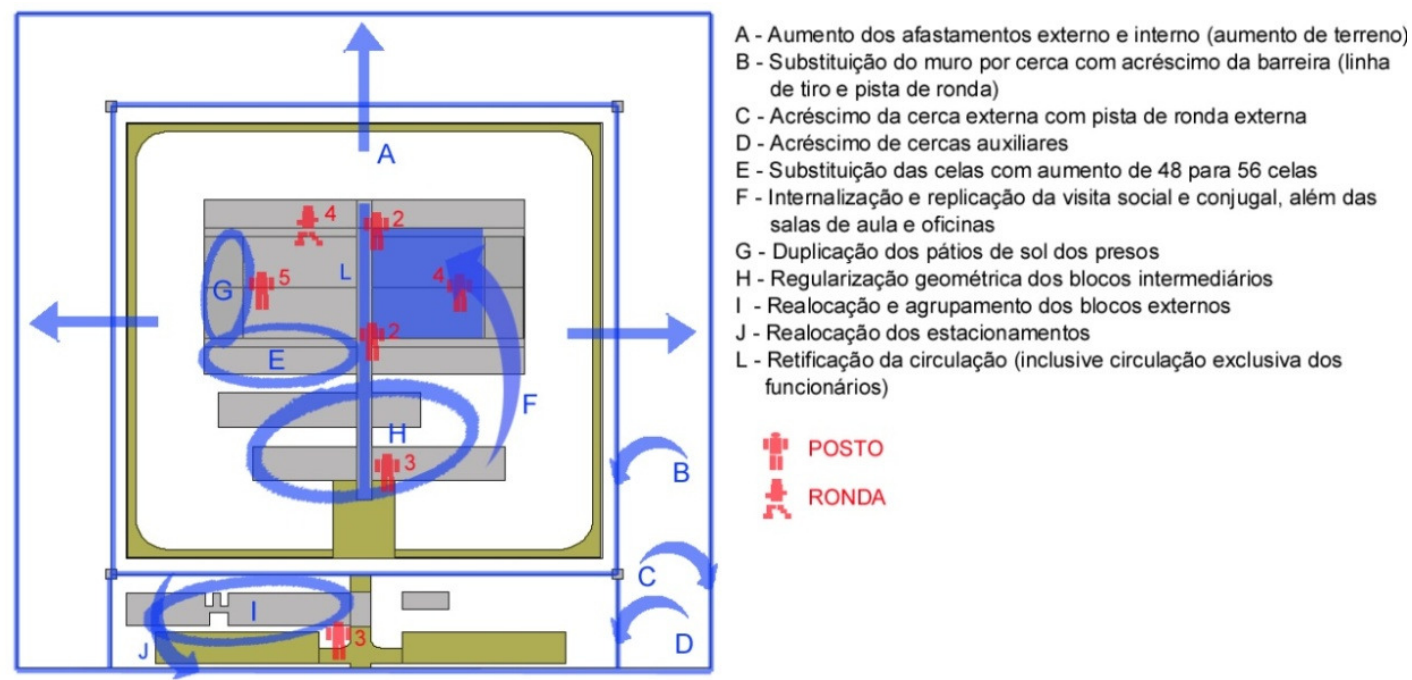

Figura 49 - Esquema das alterações promovidas ao projeto padrão do Ministério da Justiça (sem escala) A legenda em vermelho indica os postos de controle com as equipes funcionais estimadas.

A revisão realizada retificou a geometria das edificações, onde os conceitos de centralidade e simetria foram fortalecidos, ao se alinhar as circulações dos setores externo e internos e se uniformizar as dimensões dos blocos funcionais. Em particular, o setor intermediário ganhou um desenho paralelo. No setor interno, os blocos de vivência receberam os programas de sociabilização e benefícios aos presos (internalização). Ao se objetivar a individualização das atividades dos presos para cada ala carcerária, os locais de sociabilização e laboreducação, juntamente com os pátios de sol dos presos foram duplicados nos blocos de vivência. Este programa foi distribuído em torno dos postos de controle, de modo a otimizar a estrutura operacional. O número dos postos de controle foi reduzido com a retirada do segundo posto na circulação central dos blocos de vivência.

O projeto ajustado resultou em uma área construída de $9.204,00 \mathrm{~m}^{2}$ e uma capacidade de 512 vagas no total, o que derivou um índice de 17,98 $\mathrm{m}^{2} / \mathrm{vaga}$ (Tabela 4). Em comparação ao projeto original, o novo arranjo aumentou a área total em $2.254,00 \mathrm{~m}^{2}$ e a capacidade em 138 vagas, ou seja, houve um aumento na relação da área construída pela capacidade em mais de $32 \%$. O terreno com afastamentos de trinta metros ficou em 46,88 mil metros quadrados ou quase $91,56 \mathrm{~m}^{2} / \mathrm{vaga}$, com uma taxa de ocupação de mais de $17 \%$. Isto representa um aumento de área do terreno superior a $28 \mathrm{mil} \mathrm{m}^{2}$.

Tabela 4 - Ajuste ao custo de construção do projeto da Cadeia Pública do Ministério da Justiça

\begin{tabular}{|c|c|c|c|}
\hline Alteração & Quantidade & Preço Unitário (R\$) & Custo (R\$) \\
\hline Aumento do terreno (pista de ronda externa e trincheira) & $+28.061 \mathrm{~m}^{2}$ & $5,55 / \mathrm{m}^{2}$ & $+156 \mathrm{mil}$ \\
\hline Substituição do muro por cerca & $496 \mathrm{~m}$ & $7.078,0 / \mathrm{m}$ & - 3,51 milhões \\
\hline Acréscimo de cerca externa (com a pista de ronda externa) & $+866 \mathrm{~m}$ & $79,75 / \mathrm{m}$ & $+69,06 \mathrm{mil}$ \\
\hline Acréscimo de barreira perimetral (pista de ronda e linha de tiro) & $+130 \mathrm{~m}$ & $2.386,33 / \mathrm{m}$ & $+310,22 \mathrm{mil}$ \\
\hline Acréscimo de cercas auxiliares & $+110 \mathrm{~m}$ & $1.877,00 / \mathrm{m}$ & $+206,47 \mathrm{mil}$ \\
\hline Acréscimo de área construída & $+2.254 \mathrm{~m}^{2}$ & $2.090,76 / \mathrm{m}^{2}$ & $+4,72$ milhões \\
\hline \multicolumn{3}{|l|}{ Total } & $+1,95$ milhão \\
\hline
\end{tabular}


$O$ custo de construção foi aumentado em aproximadamente $\mathrm{R} \$ 1,95$ milhão, o que resultou em uma obra de $\mathrm{R} \$ 16,45$ milhões, com índices de $\mathrm{R} \$ 1.787,27 / \mathrm{m}^{2}$ e $\mathrm{R} \$ 32.128,00 \mathrm{mil} / \mathrm{vaga}$ (Tabela 4). Operacionalmente, o projeto ajustado teve diminuído o número de postos de sete para seis, mas o número de agentes por turno se manteve em vinte e três (para os parâmetros ideais, até trinta e dois agentes). O impacto no custo operacional foi nulo.

\subsubsection{Penitenciária modelo da empresa Verdi Construções S/A}

A revisão do projeto privado se resume a adequações pontuais nas edificações, em função da aplicação dos desenhos-síntese desenvolvidos e de ajuste das áreas dos locais das atividades laboreducativas (Figura 50). Em especial, o número dos postos de controle foi reduzido em dois. Os blocos de vivência visinhos tiveram os postos de controle individuais substituídos por um único posto central que converge a observação dos pátios de sol e salões de visita destes blocos. Externamente, apenas a ampliação dos afastamentos da barreira perimetral foi implementada.

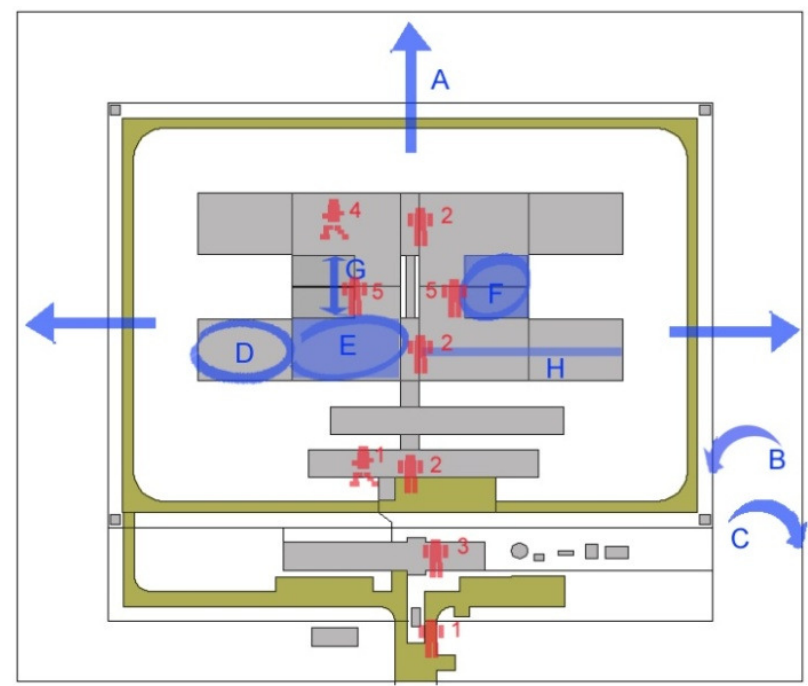

A - Aumento dos afastamentos externo e interno (aumento do terreno)

B - Acréscimo de barreira perimetral com linha de tiro e pista de ronda interna

C - Acréscimo de cerca externa e inclusão da pista de ronda externa

D - Substituição das celas pelo modelo (aumento de área)

E - Aumento das áreas de oficina e sala de aula $\mathrm{F}$ - Aumento das áreas dos pátios de sol

G - Centralizaçăo do controle dos pátios com a

substituição de dois postos por um central

H - Aumento da circulação exclusiva dos funcionários

Ii POSTO

I. RONDA

Figura 50 - Esquema das alterações promovidas no projeto da empresa Verdi Construções S/A (sem escala). A legenda em vermelho indica os postos de controle com as equipes funcionais estimadas.

O projeto ajustado resultou em uma área construída de $11.258,00 \mathrm{~m}^{2}$ com uma capacidade de 576 vagas, o que derivou um índice de 19,54m²/vaga (Tabela 5). Em comparação ao projeto original, o novo arranjo aumentou a área total em $2.228,00 \mathrm{~m}^{2}$, ou seja, houve um aumento na relação da área construída pela capacidade em cerca de $20 \%$. O terreno com afastamentos de trinta metros ficou em 46,88 mil metros quadrados ou quase $81,39 \mathrm{~m}^{2} /$ vaga, com uma taxa de ocupação em cerca de $24 \%$. Isto representam um aumento de área aproximado de 19,3 mil $\mathrm{m}^{2}$. 
Tabela 5 - Ajuste ao custo de construção do projeto modelo da empresa Verdi Construções S/A

\begin{tabular}{|l|c|c|c|}
\hline \multicolumn{1}{|c|}{ Alteração } & Quantidade & Preço Unitário (R\$) & Custo (R\$) \\
\hline $\begin{array}{l}\text { Aumento do terreno (limpeza, drenagem, pista de ronda externa } \\
\text { e trincheira) }\end{array}$ & $+30.355 \mathrm{~m}^{2}$ & $5,55 / \mathrm{m}^{2}$ & $+168,5 \mathrm{mil}$ \\
\hline $\begin{array}{l}\text { Acréscimo de cerca externa (perímetro de segurança com pista de } \\
\text { ronda externa) }\end{array}$ & $+300 \mathrm{~m}$ & $79,75 / \mathrm{m}$ & $+23,93 \mathrm{mil}$ \\
\hline Acréscimo de barreira perimetral (pista de ronda e linha de tiro) & $+136 \mathrm{~m}$ & $2.386,33 / \mathrm{m}$ & $+310,22 \mathrm{mil}$ \\
\hline Acréscimo de cercas auxiliares & $+110 \mathrm{~m}$ & $1877 / \mathrm{m}$ & $+324,54 \mathrm{mil}$ \\
\hline Acréscimo de área construída & $+2.228 \mathrm{~m}^{2}$ & $4.144,49 / \mathrm{m}^{2}$ & $+9,23 \mathrm{milhões}$ \\
\hline Total & & $+10,06$ milhão \\
\hline
\end{tabular}

O custo de construção foi aumentado em aproximadamente $\mathrm{R} \$ 10,06$ milhões, o que resultou em uma obra de $\mathrm{R} \$ 45,06$ milhões, com índices de $\mathrm{R} \$ 4.002,49 / \mathrm{m}^{2}$ e $\mathrm{R} \$ 78,23 \mathrm{mil} / \mathrm{vaga}$ (Tabela 5). O operacionalmente, o projeto revisado teve diminuído o número de postos de nove para sete e o número de agentes por turno se manteve em vinte e dois (para os parâmetros ideais, até trinta agentes). $\mathrm{O}$ impacto no custo operacional foi nulo.

O detalhamento da adequação das áreas construídas dos projetos de referência está na Tabela 6, a seguir:

Tabela 6 - Demonstrativo de área construída acrescida e deduzida nos projetos ajustados

\begin{tabular}{|c|c|c|}
\hline Ajuste & Área $\left(\mathrm{m}^{2}\right)$ & Percentual \\
\hline \multicolumn{3}{|l|}{ Penitenciária do Distrito Federal } \\
\hline $\begin{array}{l}\text { Troca das celas pelo desenho-síntese desenvolvido (redução da quantidade de celas } 56 \text { por } \\
36 \text { celas nos blocos de vivência) }\end{array}$ & $-1.628,0$ & $22 \%$ \\
\hline $\begin{array}{l}\text { Diminuição da área relativa das atividades laboreducativas nos blocos de vivência (de } \\
2,65 \mathrm{~m}^{2} / \text { vaga para } 2,36 \mathrm{~m}^{2} / \text { vaga) }\end{array}$ & $-1.968,0$ & $27 \%$ \\
\hline $\begin{array}{l}\text { Troca dos pátios de sol pelo desenho-síntese desenvolvido, com substituição de área de } \\
\text { pátio pelo salão de visitas e apartamentos de encontro íntimo (de } 24 \text { para } 8 \text { unidades) }\end{array}$ & $-3.708,0$ & $50 \%$ \\
\hline Redução da circulação dos blocos de vivência & $-52,0$ & $1 \%$ \\
\hline Recomposição do bloco de isolamento (redução de celas individuais) & $+326,0$ & $10 \%$ \\
\hline Inclusão de circulação exclusiva para funcionários (13\% da área construída) & $+2.776,0$ & $90 \%$ \\
\hline Troca dos pátios pelo desenho-síntese desenvolvido & 0 & 0 \\
\hline Área total reduzida (percentual em relação à área original) & $-7.356,0$ & $27 \%$ \\
\hline Área total acrescida (percentual em relação à área original) & $+3.102,0$ & $11 \%$ \\
\hline Diferença total entre o reduzido e o acrescido (percentual em relação à área original) & $-4.254,0$ & $16 \%$ \\
\hline \multicolumn{3}{|l|}{ Penitenciária Compacta } \\
\hline Recomposição do bloco de isolamento (horizontalização e redução de celas individuais) & $-198,0$ & $22 \%$ \\
\hline Recomposição do bloco de assistência à saúde (horizontalização e integralização) & $+376,0$ & $15 \%$ \\
\hline Diminuiç̧ão de área da circulação central & $-35,0$ & $4 \%$ \\
\hline $\begin{array}{l}\text { Troca das celas pelo desenho-síntese desenvolvido (aumento da quantidade de celas de } 64 \\
\text { celas para } 72 \text { celas e redução da capacidade do estabelecimento) }\end{array}$ & $+167,0$ & $6 \%$ \\
\hline $\begin{array}{l}\text { Inclusão de local para sociabilização, inclusive apartamentos de encontro íntimo } \\
\left(2,23 \mathrm{~m}^{2} / \text { vaga }\right)\end{array}$ & $+640,0$ & $26 \%$ \\
\hline Adequação da área dos locais de trabalho e educação (de 1,44 para $1,79 \mathrm{~m}^{2} / \mathrm{vaga}$ ) & $+167,0$ & $6 \%$ \\
\hline Troca dos pátios pelo desenho-síntese desenvolvido & $-608,0$ & $69 \%$ \\
\hline Inclusão de corredores para a circulação (2,50m de largura) & $+268,0$ & $10 \%$ \\
\hline Inclusão de circulação exclusiva para funcionários ( $8,7 \%$ da área construída) & $+920,0$ & $37 \%$ \\
\hline Troca dos postos de controle pelo desenho-síntese desenvolvido & 0 & 0 \\
\hline Outros & $-45,0$ & $5 \%$ \\
\hline Área total reduzida (percentual em relação à área original) & $-886,0$ & $10 \%$ \\
\hline Área total acrescida (percentual em relação à área original) & $+2.538,0$ & $30 \%$ \\
\hline Diferença total entre o reduzido e o acrescido (percentual em relação à área original) & $+1.652,0$ & $20 \%$ \\
\hline
\end{tabular}




\begin{tabular}{|c|c|c|}
\hline \multicolumn{3}{|l|}{ Cadeia pública do Ministério da Justiça } \\
\hline $\begin{array}{l}\text { Troca das celas pelo desenho-síntese desenvolvido (aumento da quantidade de celas de } 48 \\
\text { para } 56 \text { celas) }\end{array}$ & $+949,0$ & $35 \%$ \\
\hline $\begin{array}{l}\text { Internalização e adequação da área dos locais de sociabilização (de } 2,91 \text { para } 2,46 \mathrm{~m}^{2} / \text { vaga) } \\
\text { e trabalho e educação (de } 1,56 \text { para } 2,20 \mathrm{~m}^{2} / \text { vaga) }\end{array}$ & $+859,0$ & $31 \%$ \\
\hline Troca dos pátios pelo desenhos-síntese desenvolvido e duplicação dos mesmos & $+917,0$ & $34 \%$ \\
\hline Retificação geométrica da circulação exclusiva para funcionários (10\% da área construída) & $-244,0$ & $8 \%$ \\
\hline Troca dos postos de controle pelo desenho-síntese desenvolvido & 0 & 0 \\
\hline Outros & $-277,0$ & $5 \%$ \\
\hline Área total reduzida (percentual em relação à área original) & $-521,0$ & $7 \%$ \\
\hline Área total acrescida (percentual em relação à área original) & $+2.725,0$ & $39 \%$ \\
\hline Diferença total entre o reduzido e o acrescido (percentual em relação à área original) & $+2.254,0$ & $32 \%$ \\
\hline \multicolumn{3}{|l|}{ Projeto empresa Verdi Construções } \\
\hline Troca das celas pelo desenho-síntese desenvolvido & $+1.104,0$ & $51 \%$ \\
\hline Adequação da área dos locais de trabalho e educação (de $1,57 \mathrm{~m}^{2} /$ vaga para $1,90 \mathrm{~m}^{2} /$ vaga) & $+320,0$ & $14 \%$ \\
\hline Troca dos pátios de sol pelo desenho-síntese desenvolvido & $+556,0$ & $25 \%$ \\
\hline Aumento da circulação exclusiva para funcionários ( $10 \%$ da área construída) & $+102,0$ & $4 \%$ \\
\hline Troca dos postos de controle pelo desenhos-síntese desenvolvido & -44 & $2 \%$ \\
\hline Outros & $+190,0$ & $4 \%$ \\
\hline Área total reduzida (percentual em relação à área original) & - & - \\
\hline Área total acrescida (percentual em relação à área original) & - & - \\
\hline Diferença total entre o reduzido e o acrescido (percentual em relação à área original) & $+2.228,0$ & $26 \%$ \\
\hline
\end{tabular}

\subsection{Avaliação da aplicação da tecnologia aos projetos de referência}

A experimentação realizada foi avaliada em quatro abordagens dos projetos de referência ajustados: as características físicas e econômicas gerais; estas características comparadas às caracterizações normativa e idealizada (capítulos 3 e 4), além da caracterização de unidade prisional baseada na tecnologia de projeto (ver capítulo 7); as características detalhadas, segundo a tecnologia de projeto desenvolvida (Apêndice F); e as características físicas e econômicas dos elementos centrais da edificação penal.

\subsubsection{Análise das características físicas e econômicas gerais da edificação penal}

Na primeira abordagem, a análise inicial dos dados detectou um aumento no custo de construção médio em torno de 3\%, reflexo de um incremento de área construída da ordem de 5\% (Tabela 7). No entanto, a revisão dos projetos de referência resultou em menos 486 vagas no conjunto. Ao mesmo tempo em que a divergência do projeto da Penitenciária do Distrito Federal no conjunto de referência foi evidenciada. O mesmo foi o único a apresentar valores revisados inferiores aos originais - a capacidade reduzida equivale a uma unidade prisional de 432 vagas (quase 30\% da capacidade original).

Em um cenário alternativo, a retirada do projeto da Penitenciária do Distrito Federal da avaliação gerou um aumento do custo de construção médio em torno de 19\%, reflexo de um incremento de área construída da ordem de $18 \%$. Estes percentuais se mostraram mais representativos do conjunto projetual revisado. Isto porque o incremento de área construída é atribuído, em sua maioria (91\%), à 
inclusão da circulação exclusiva para os funcionários (33\%) e do aumento dos locais para as atividades socializantes e laboreducativas dos presos (19\%), além da substituição das celas e pátios de sol originais pelos desenhos-síntese desenvolvidos (39\%). A área construída maior, associada à redução das capacidades, determinou o aumento do índice de área construída por vaga em 29\%, embora o projeto do Ministério da Justiça tenha apresentado redução deste índice. Os projetos revisados apresentaram uma redução do custo de construção por metro quadrado em torno de $5 \%$, atribuído à substituição da especificação barreira perimetral nos projetos da Penitenciária Compacta e do Ministério da Justiça.

Tabela 7 - Características gerais originais e revisadas dos projetos de referência

\begin{tabular}{|c|c|c|c|c|c|c|c|}
\hline Projeto & $\begin{array}{c}\text { Custo } \\
\text { Construção } \\
\text { (R\$ x milhão) }\end{array}$ & $\begin{array}{c}\text { Capacidade } \\
\text { (vagas) }\end{array}$ & $\begin{array}{c}\text { Área } \\
\text { Construída } \\
\left(\mathrm{m}^{2}\right)\end{array}$ & $\begin{array}{c}\text { Custo/ } \\
\text { Área } \\
\left(\mathrm{R} \$ / \mathrm{m}^{2}\right)\end{array}$ & $\begin{array}{c}\text { Custo/ } \\
\text { cap. } \\
(\mathrm{R} \$ / \mathrm{vaga})\end{array}$ & $\begin{array}{c}\text { Área } \\
\text { cons./cap. } \\
\left(\mathrm{m}^{2} / \mathrm{vaga}\right)\end{array}$ & $\begin{array}{c}\text { Agentes/ cap. } \\
\text { (agente/ } \\
\text { vaga) }\end{array}$ \\
\hline Original PDF & 97,00 & 1584 & 27.555 & $3.520,23$ & $61.237,37$ & 17,39 & $1 / 44$ \\
\hline Ajustado PDF & 82,00 & 1152 & 23.246 & $3.550,00$ & $71.660,00$ & 20,18 & $1 / 32$ \\
\hline Original PC & 59,50 & 768 & 8.890 & $6.692,91$ & $77.473,95$ & 11,57 & $1 / 32$ \\
\hline Ajustado PC & 67,86 & 576 & 10.542 & $6.437,10$ & $117.810,00$ & 18,97 & $1 / 28$ \\
\hline Original MJ & 14,50 & 374 & 6.950 & $2.090,76$ & $38.852,40$ & 18,58 & $1 / 23$ \\
\hline Ajustado MJ & 16,45 & 512 & 9.204 & $1.787,27$ & $32.128,00$ & 17,98 & $1 / 23$ \\
\hline Original empresa & 35,00 & 578 & 8.440 & $4.144,49$ & $60.500,00$ & 14,60 & $1 / 25$ \\
\hline Ajustado empresa & 45,06 & 576 & 11.258 & $4.002,49$ & $78.230,00$ & 19,54 & $1 / 25$ \\
\hline Diferença média & $+3 \%$ & $-15 \%$ & $+5 \%$ & $-4 \%$ & $+26 \%$ & $+23 \%$ & $+10 \%$ \\
\hline $\begin{array}{c}\text { Diferença média } \\
\text { sem a PDF }\end{array}$ & $+19 \%$ & $-3 \%$ & $+28 \%$ & $-5 \%$ & $+29 \%$ & $+26 \%$ & $+10 \%$ \\
\hline
\end{tabular}

Individualmente, os projetos ajustados apresentaram resultados heterogêneos, o que ressaltou as peculiaridades espaciais de cada um, em resposta a uniformização arquitetônica do nível de segurança penitenciário (Figura 51).

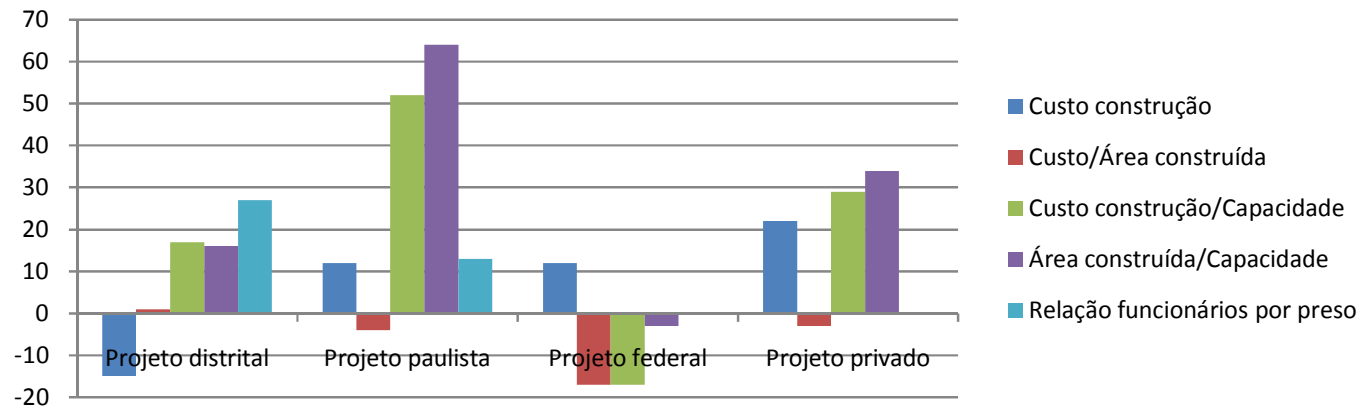

Figura 51 - Gráfico das características gerais dos projetos de referência ajustados

As barras são as diferenças percentuais relativas aos projetos originais. Notar a baixa no custo de construção do projeto da Penitenciária do Distrito Federal e a alta nos custos de construção dos projetos da Penitenciária Compacta e da empresa Verdi Construções; e a queda no custo unitário nos projetos paulista e federal.

Ao retomar a questão da dissonância do projeto da Penitenciária do Distrito Federal, em um raciocínio conjectural, a administração penitenciária do Distrito Federal gastaria cerca de 31 milhões de reais 
para produzir a unidade de 432 vagas subtraída (com base no valor unitário do projeto original de $\mathrm{R} \$$ $3.520,23 / \mathrm{m}^{2}$ ). A economia com pessoal obtida na revisão do projeto original amortizaria este gasto extraordinário em vinte anos ( $\mathrm{R} \$ 1,5$ milhão, anuais). Por outro lado, o aumento dos índices de área construída por vaga (em torno de $16 \%$ ) e do número de agentes por presos (cerca de $30 \%$ ) indicaram uma melhoria do espaço arquitetônico, derivado do aumento do sistema de segurança (mobilidade dos funcionários e separação dos grupos sociais) e da redução da capacidade (individualização da pena).

No projeto da Penitenciária Compacta paulista, o custo da vaga subiu consideravelmente (em torno de $66 \%$ ), devido ao aumento de área construída e à redução de capacidade do estabelecimento penal (18\% e $25 \%$, respectivamente). Este aumento de área é explicado pela compactação inicial deste projeto (maior do grupo) e pelo custo de construção unitário do mesmo (quase o dobro da média do grupo). Com isto, o aumento de áreas foi impactante na revisão, principalmente, em virtude da inclusão de circulação exclusiva para os funcionários (37\% da área acrescida) e de local para a visita aos presos (26\% da área acrescida). De outra perspectiva, o aumento dos índices de área construída por vaga (em torno de $60 \%$ de acréscimo) e do número de agentes por presos (mais de $37 \%$ ) indicou uma melhoria do espaço arquitetônico, em termos da segurança (mobilidade dos funcionários e separação dos grupos sociais) e da reinserção social dos presos (espaços suficientes para a realização das atividades laboreducativas). Como vantagem econômica do ajustamento implementado, o investimento extra de $\mathrm{R} \$ 8,36$ milhões pode ser amortizado pela economia operacional ( $\mathrm{R} \$ 520$ mil anuais), em um período de dezesseis anos de funcionamento do estabelecimento penal.

A revisão do projeto do Ministério da Justiça exemplificou a recategorização espacial de um edifício de segurança média em segurança máxima, ao apresentar aumento no custo, capacidade e área construída, em 13\%, 37\% e 32\%, respectivamente. O aumento de área decorreu da aplicação dos desenhos-síntese de cela e pátio de sol (35\% e 34\% da área acrescida), além da internalização e ajuste das áreas dos locais das atividades socializantes e do programa de benefícios dos presos (31\% da área acrescida). A redução do índice de área construída por vaga refletiu a compactação geométrica e funcional aplicada ao projeto original. Isto é interpretado como otimização do espaço arquitetônico. O projeto federal não teve diminuição da equipe funcional com a revisão efetuada, apesar da redução de postos de controle. Isto é explicado pelo aumento dos recintos vigiados pelos postos de controle (internalização e replicação dos locais de visita, trabalho e educação), já que a equipe aumenta em função do número de locais monitorados. No caso, este número passou de um para quatro recintos observados.

O projeto da empresa Verdi Construções S/A foi essencialmente alterado na área construída, com a adição de $33 \%$ ao total e de $34 \%$ à relação da área construída pela capacidade, sem alterações morfológicas ou funcionais. Isto variou para mais o preço total em $29 \%$ e da vaga em $30 \%$. O aumento 
de área decorreu da aplicação dos desenhos-síntese de cela e pátio de sol dos presos (53\% e 27\% da área acrescida, respectivamente), além da adequação das áreas dos locais das atividades laboreducativas dos presos (15\% da área acrescida). O projeto privado não apresentou redução da equipe funcional, apesar da redução de postos de controle, cuja explicação é a mesma do projeto federal. No projeto privado, a vantagem da redução dos postos de controle foi a maior integração das equipes de vigilância, com a junção dos postos de controle de dois pátios de sol em um posto central.

\subsubsection{Análise comparativa das características gerais da edificação penal}

A segunda abordagem da experimentação realizada traz as caracterizações do espaço arquitetônico elaboradas no exame do modelo prisional (ver capítulo 3) e no ajustamento da tecnologia de projeto (ver capítulo 7), comparadas com os projetos de referência originais e ajustados (Quadro 14).

Quadro 14 - Comparativo dos dados gerais médios das caracterizações do espaço arquitetônico prisional

\begin{tabular}{|c|c|c|c|c|}
\hline \multirow[b]{2}{*}{ Quesitos } & \multicolumn{4}{|c|}{ Médias } \\
\hline & $\begin{array}{l}\text { Projetos de } \\
\text { Referência* }\end{array}$ & Regras técnicas** & $\begin{array}{l}\text { Caracterização da } \\
\text { tecnologia de projeto } \\
\text { (modelo-síntese) }\end{array}$ & $\begin{array}{l}\text { Projetos } \\
\text { Ajustados }\end{array}$ \\
\hline Capacidade (vaga) & 573 & 600 & 576 & 586 \\
\hline Área construída $\left(\mathrm{m}^{2}\right)$ & $8.093,33$ & 7.200 & 11.134 & 10.360 \\
\hline Área construída/cap. (m²/vaga) & 14,92 & 12,00 & 21,50 & 19,41 \\
\hline Área terreno $\left(\mathrm{m}^{2}\right)$ & 37.000 & 17.245 & 61.740 & 56.950 \\
\hline Área terreno/cap. (m²/vaga) & 64,57 & 28,74 & 107,19 & 97,18 \\
\hline Taxa de ocupação (\%) & 38 & 42 & 18 & 18 \\
\hline $\begin{array}{c}\text { Setorização } \\
\text { (\% área construída por setor) }\end{array}$ & $10 / 11 / 79$ & $19 / 37 / 44$ & $10 / 20 / 70$ & $9 / 14 / 77$ \\
\hline Ala carcerária (un) & 6 & 4 & 4 & 4 \\
\hline Composição ala de vivência & 108 vagas ( 15 celas) & 144 vagas (18 celas) & 144 vagas (18 celas) & $\begin{array}{l}140 \text { vagas (18 } \\
\text { celas) }\end{array}$ \\
\hline Bloco de vivência (un) & 4 & 4 & 4 & 4 \\
\hline Área socialização (m²/vaga) & 2,51 & 2,43 & 2,51 & 2,37 \\
\hline Área laboreducativa (m²/vaga) & 2,16 & 1,71 & 2,16 & 2,09 \\
\hline Postos de controle (un) & 9 & 7 & 8 & 8 \\
\hline $\begin{array}{l}\text { Circulação Exclusiva } \\
\text { (\% área construída) }\end{array}$ & 17 & - & 7 & 12 \\
\hline $\begin{array}{l}\text { Relação funcional } \\
\text { (agente/presos) }\end{array}$ & $1 / 31$ & $1 / 5$ & $1 / 20$ & $1 / 27$ \\
\hline Torres de vigilância & 4 & 4 & 4 & 4 \\
\hline
\end{tabular}

Ao expressar graficamente os dados tabulados, o incremento do espaço arquitetônico da prisão foi evidenciado, tanto nos projetos ajustados, como no modelo desenvolvido (Figura 52 e Figura 53). 


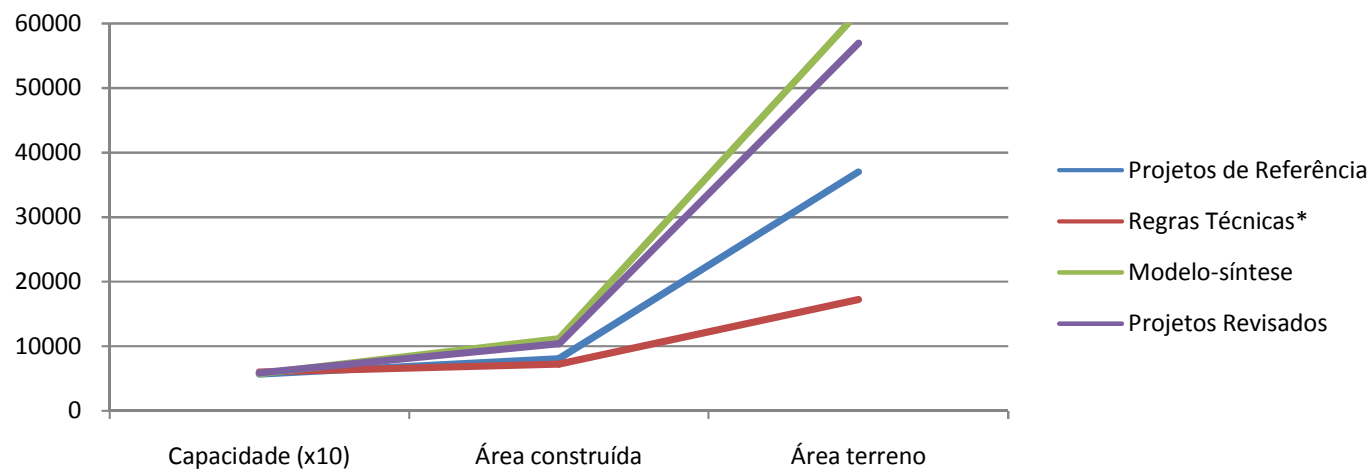

Figura 52 - Gráfico dos dados gerais das caracterizações do espaço arquitetônico prisional Notar o incremento de área construída e de terreno dos projetos de referência revisados e do modelo-síntese.

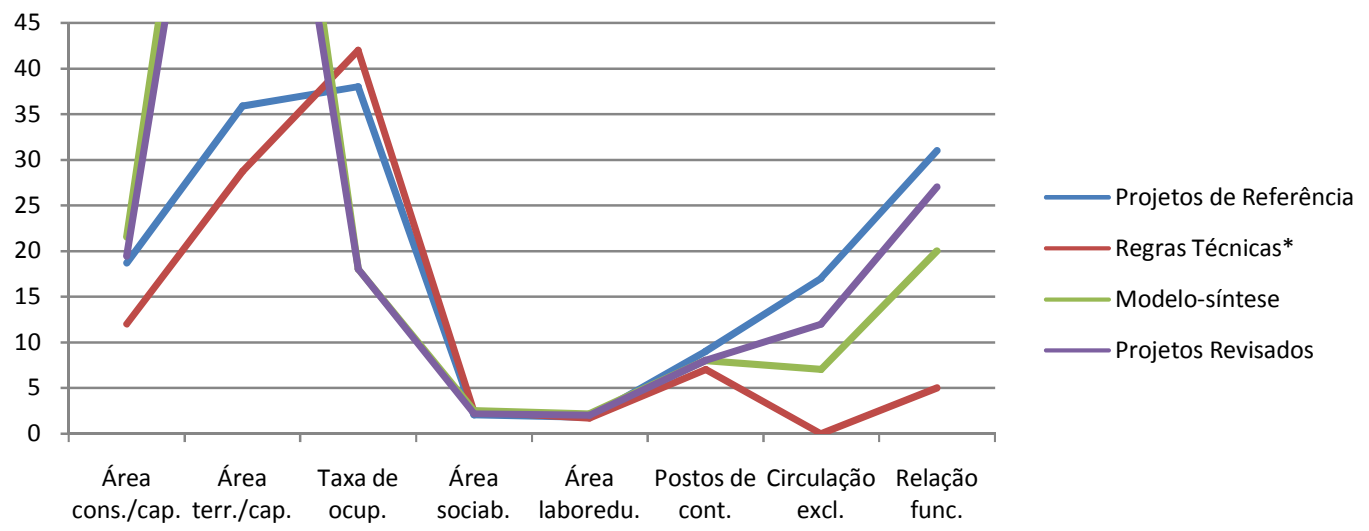

Figura 53 - Gráfico das diferenças percentuais dos índices da caracterização normativa do espaço arquitetônico e do modelo de unidade prisional desenvolvido

Notar a diferença de áreas por capacidade, o que baixa taxa de ocupação e a otimização operacional nos projetos ajustados e no desenho-síntese (postos de controle, circulação exclusiva e relação funcionário/presos).

O comparativo feito permite algumas considerações adicionais. Em primeiro lugar, os projetos ajustados se equiparam ou superam a totalidade das grandezas das regras técnicas, o que de certo modo já era anunciado pelas versões originais destes projetos (os mesmos já apresentavam valores que ultrapassavam os parâmetros normativos). Neste sentido, os projetos de referência ajustados são passíveis de aprovação no âmbito da administração penitenciária federal. Em segundo lugar, os projetos ajustados ficaram aquém do modelo-síntese elaborado, quando os valores obtidos no ajustamento não alcançaram os limites máximos definidos neste modelo, ou seja, os projetos ajustados não atingiram a aplicação plena da tecnologia de projeto desenvolvida. Isto indica uma margem para o aprimoramento da composição arquitetônica da prisão, inerente à tecnologia de projeto desenvolvida. Nos ensaios arquitetônicos realizados, a diferença encontrada é justificada por um princípio de deformação dos projetos existentes, na medida em que os parâmetros evoluíram para os valores máximos elencados na tecnologia de projeto. Esta deformação era caracterizada por massas 
construídas e espaços internos com dimensões desproporcionais, além de desfigurações na modulação e na topologia dos espaços, o que interferia negativamente nos sistemas de segurança e operação previstos nos projetos. Por outro lado, os projetos ajustados ficaram mais econômicos que o modelo de unidade prisional, inclusive operacionalmente (relações agentes por presos de 1/25 e 1/20, respectivamente).

Ao se atribuir preço às caracterizações obtidos no estudo do modelo prisional (ver capítulo 3) e do desenho-síntese (ver capítulo 7) é possível comparar o desempenho econômico dos projetos revisados (Quadro 15).

Quadro 15 - Comparativo dos dados gerais das caracterizações do espaço arquitetônico prisional

\begin{tabular}{|c|c|c|c|c|}
\hline & \multicolumn{4}{|c|}{ Médias } \\
\hline Quesitos & $\begin{array}{l}\text { Projetos de } \\
\text { Referência }\end{array}$ & Regras técnicas* & Modelo-síntese** & Projetos Ajustados \\
\hline Custo construção ( $\mathrm{R} \$$ x milhão) & 51,50 & 29,61 & 43.92 & 52,84 \\
\hline Custo/área $\left(\mathrm{R} \$ / \mathrm{m}^{2}\right)$ & $4.112,10$ & $4.112,10$ & $3.944,22$ & $3.944,22$ \\
\hline Custo/cap. (R\$/vaga) & $59.515,93$ & $49.350,00$ & $79.479,16$ & $90.170,65$ \\
\hline
\end{tabular}

Os projetos ajustados têm o maior custo absoluto e por capacidade do conjunto, seguidos dos projetos de referência e do modelo elaborado, enquanto o custo unitário da área construída ficou menor com a revisão (como já foi dito, relacionado à substituição da barreira perimetral) (Figura 54). Em comparação aos projetos revisados, o modelo de unidade prisional tem custos menores, o que é interpretado como otimização do espaço arquitetônico, por meio da aplicação da tecnologia de projeto desenvolvida. Isto reforça a existência de um potencial latente para o aprimoramento da composição arquitetônica da prisão, também implícito na diferença de custos. Em termos econômicos, grosseiramente, este potencial equivaleria a uma diferença de 15 a $20 \%$ nos custos que ainda poderiam ser revertidos em um maior aprimoramento do espaço arquitetônico.

O comparativo ratificou a natureza compacta do programa arquitetônico das regras técnicas do Ministério da Justiça, primeiramente verificada no exame dos instrumentos técnico-normativos (capítulo3). Diante da estratégia estabelecida para a concepção da tecnologia de projeto, a compactação conformada é mais adequada ao nível de segurança máxima especial proposto, salvaguardadas as particularidades correlatas a conformação desta modalidade arquitetônica. 


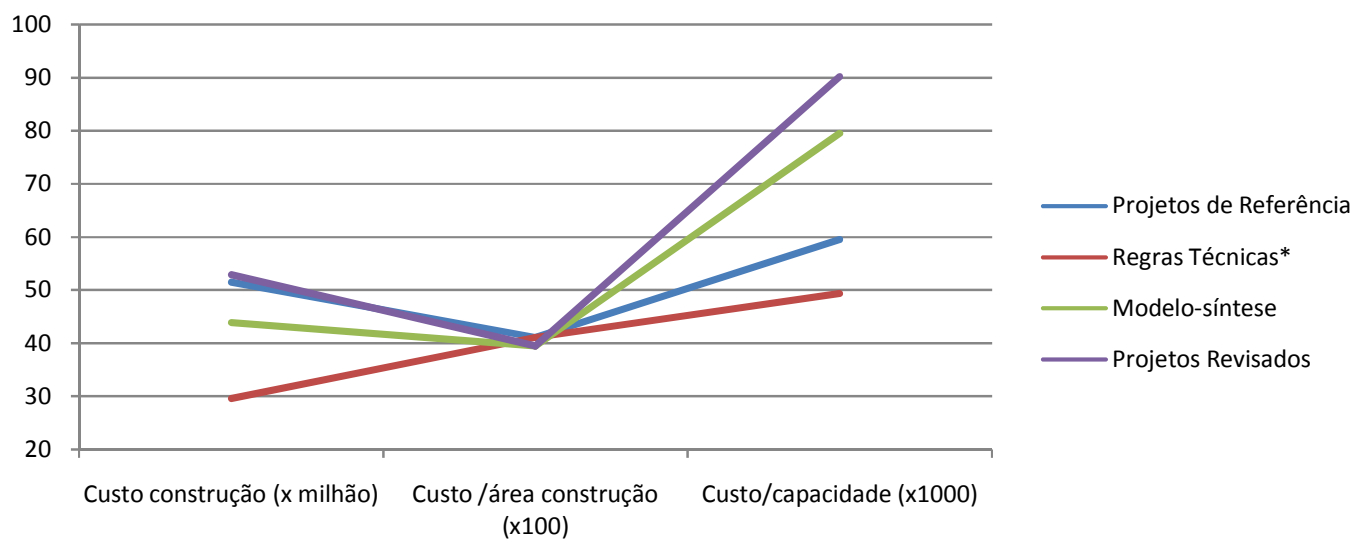

Figura 54 - Gráfico das médias gerais das caracterizações normativa e idealizada do espaço arquitetônico prisional, comparadas aos projetos de referência originais e ajustados

A caracterização normativa consta do capítulo 3, desta tese. Notar que o desenho-síntese indica uma possível melhoria do espaço arquitetônico, ainda contida na tecnologia de projeto desenvolvida.

\subsubsection{Análise das características físicas e econômicas por requisito funcional}

$\mathrm{Na}$ terceira abordagem da experimentação realizada, as características físicas e econômicas específicas dos projetos de referência ajustados foram avaliadas individualmente, em termos do aprimoramento das soluções arquitetônicas originais destes projetos, quanto à segurança, funcionalidade, conforto

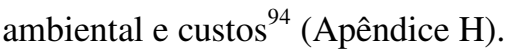

Do conjunto total de noventa e dois requisitos funcionais, setenta e oito itens apresentaram resultados positivos no ajustamento dos projetos de referência e quatorze não tiveram aplicação (S) (Figura 55 e Quadro 16). Não houve resultados negativos. Entre os resultados positivos, cinquenta e nove foram plenos, e nove apresentaram resultados parciais. As aplicações parciais foram dezoito $(\mathrm{P})$ e os itens com impactos nos custos foram cinquenta e três (C). Os números iniciais mostram um ajuste dos projetos de referência, diante dos $74 \%$ de adequação dos componentes da composição arquitetônica. Ao mesmo tempo, se verifica que a maior parte deste ajustamento é pleno, ao figurar em torno de $87 \%$ dos resultados positivos.

\footnotetext{
94 No quadro síntese apresentado, as legendas podem ser explicadas da forma seguinte. Os resultados plenos (em verde) significam um incremento arquitetônico, associado ao atendimento de todos os critérios do requisito disposto na tecnologia de projeto desenvolvida. Os resultados parciais apontam um incremento arquitetônico com o atendimento de parte destes critérios. Os resultados negativos correspondem a uma inadequação arquitetônica. A marcação 'sem aplicação' (S) diz respeito a uma inviabilidade do ajustamento, por dois motivos: primeiro, os itens exigem um grau de detalhamento não alcançado pela revisão dos projetos de referência, devido ao caráter amplo desta revisão (as particularidades se restringiram aos elementos centrais da edificação penal); segundo, os projetos de referência originais já atendiam ao requisito. A marcação 'aplicação parcial' $(P)$ indica o ajustamento quando estes projetos originais atendiam parte dos critérios, sendo complementados pela revisão aplicada. A marcação 'custo agregado' (C) destaca o acréscimo de custo de construção considerado inerente à configuração do modelo de segurança máxima proposto, por isto não constituiu ponto negativo ao requisito.
} 


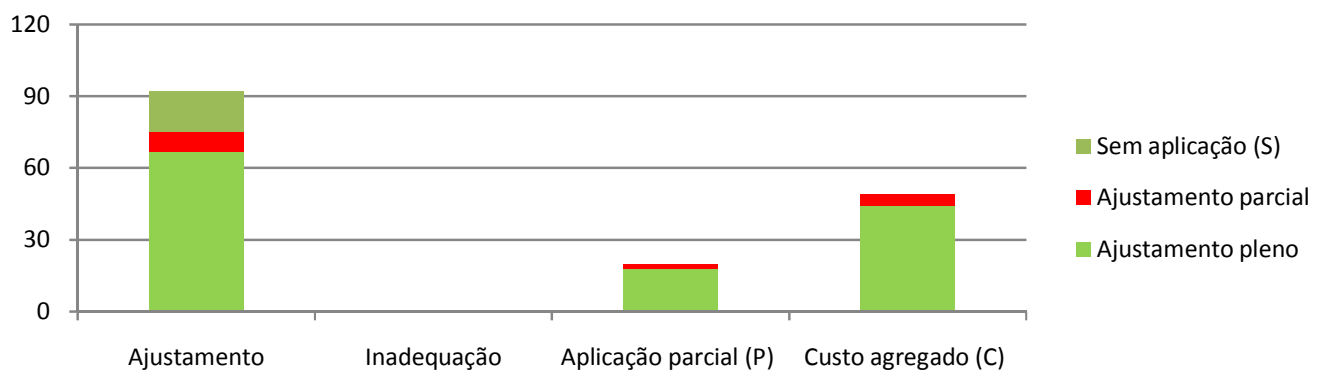

Figura 55 - Gráfico do resultado da análise do ajustamento implementado nos projetos de referência O gráfico mostra as proporções em relação ao número de itens de cada resultado.

Quadro 16 - Resumo dos resultados do ajustamento implementado aos projetos de referência

\begin{tabular}{|c|c|c|c|c|c|c|c|c|c|c|c|c|c|c|c|c|c|c|c|}
\hline \multirow{4}{*}{ 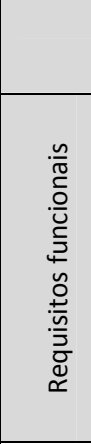 } & \multicolumn{10}{|c|}{$\begin{array}{l}\text { S: sem aplicação } \\
\text { P: aplicação parcial ou em parte dos projetos aplicados } \\
\text { C: custo agregado }\end{array}$} & \multicolumn{9}{|c|}{\begin{tabular}{|l|} 
Verde: resultados positivos plenos \\
Amarelo: resultados positivos parciais \\
Vermelho: resultados negativos
\end{tabular}} \\
\hline & \multicolumn{19}{|c|}{ Grupos de quesitos } \\
\hline & 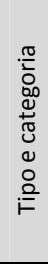 & $\stackrel{\mathscr{t}}{\circ}$ & $\stackrel{9}{3}$ & 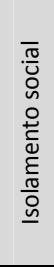 & 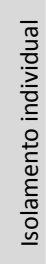 & 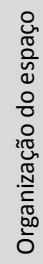 & 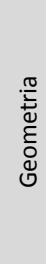 & $\begin{array}{l}\frac{\pi}{0} \\
\frac{\pi}{0} \\
\frac{0}{\overline{0}} \\
.0 \\
\frac{0}{0} \\
5 \\
5\end{array}$ & 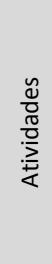 & 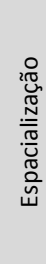 & 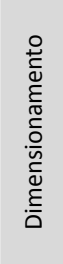 & 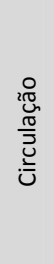 & $\begin{array}{l}\overline{0} \\
\stackrel{0}{0} \\
\frac{0}{0} \\
\frac{E}{c} \\
0 \\
0 \\
\frac{t}{0} \\
\frac{0}{L} \\
0 \\
0\end{array}$ & 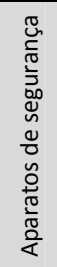 & $\begin{array}{l}\frac{0}{0} \\
\frac{2}{2} \\
\text { ठ }\end{array}$ & 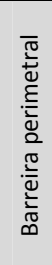 & $\frac{\pi}{0}$ & 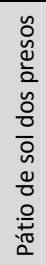 & $\begin{array}{l}0 \\
0 \\
0 \\
0 \\
0 \\
0 \\
0 \\
0 \\
0 \\
0 \\
0\end{array}$ \\
\hline & 01 & 02 & 03 & 04 & 05 & 06 & 07 & 08 & 09 & 10 & 11 & 12 & 13 & 14 & 15 & 16 & 17 & 18 & 19 \\
\hline 01 & C & C & $\mathrm{C}$ & & $\mathrm{S}$ & C & & $P C$ & PC & C & C & $P$ & $\mathrm{~S}$ & $\mathrm{~S}$ & C & $P$ & $\mathrm{~S}$ & C & C \\
\hline 02 & $\mathrm{C}$ & C & $\mathrm{C}$ & $\mathrm{S}$ & & C & & C & $\mathrm{S}$ & C & $\mathrm{S}$ & & C & PC & & $\mathrm{P}$ & PC & C & PC \\
\hline 03 & C & $\mathrm{S}$ & $\mathrm{C}$ & C & $S$ & $\mathrm{C}$ & & & & $\mathrm{C}$ & $\mathrm{C}$ & $S$ & & & & $\mathrm{P}$ & $\mathrm{S}$ & & C \\
\hline 04 & & & C & $S$ & & & & & & & & & & & C & $\mathrm{P}$ & PC & $\mathrm{P}$ & C \\
\hline 05 & & & & & PC & & & & & $\mathrm{C}$ & & & & & & $\mathrm{S}$ & & $\mathrm{C}$ & $\mathrm{C}$ \\
\hline 06 & & & & & & & & & & $\mathrm{C}$ & & & & & & & $\mathrm{PC}$ & PC & $\mathrm{C}$ \\
\hline 07 & & & & & & & & & & & & & & & PC & C & $\mathrm{C}$ & & \\
\hline 08 & & & & & & & & & & & & & & & & $\mathrm{C}$ & PC & C & \\
\hline 09 & & & & & & & & & & & & & & & & $S$ & $\mathrm{C}$ & C & \\
\hline 10 & & & & & & & & & & & & & & & & PC & C & & \\
\hline 11 & & & & & & & & & & & & & & & & $\mathrm{C}$ & C & C & \\
\hline 12 & & & & & & & & & & & & & & & & & & $S$ & \\
\hline \multirow{4}{*}{ Grupo } & $\mathrm{C}$ & $\mathrm{C}$ & $\mathrm{C}$ & C & & C & & C & $\mathrm{C}$ & $\mathrm{C}$ & $\mathrm{C}$ & & C & C & & & $\mathrm{C}$ & $\mathrm{C}$ & C \\
\hline & \multirow{2}{*}{\multicolumn{3}{|c|}{$\begin{array}{l}\text { Externos - } \\
\text { C }\end{array}$}} & & & & & \multicolumn{5}{|c|}{ Funcionalidade - C } & & & & \multirow{2}{*}{\multicolumn{4}{|c|}{$\begin{array}{c}\text { Elementos Centrais } \\
\text { - C }\end{array}$}} \\
\hline & & & & & & & & & niza & âd & espac & $0-\mathrm{C}$ & & & & & & & \\
\hline & \multicolumn{19}{|c|}{ Programa arquitetônico - C } \\
\hline
\end{tabular}

Em um ordenamento mais amplo, dois terços dos itens ajustados foram acompanhados por ressalvas quanto a eventuais incongruências na operação penitenciária, ou por indicação de aumento de custos de construção ou operação. Na sua totalidade, estes apontamentos foram associados ao nível de segurança máxima proposto, indicando as discrepâncias em relação à arquitetura existente que caracterizam a modalidade arquitetônica de segurança máxima vislumbrado: o reequilíbrio entre a segurança e a humanização que regulariza a segurança penitenciária e implementa a humanização do espaço arquitetônico da prisão. Da mesma maneira em que os apontamentos feitos mapeiam o aumento do custo de construção inerente à dita modalidade arquitetônica. Isto demonstra à 
combinação das características formais e informais da edificação penal, determinada na conformação da tecnologia de projeto, em atendimento às demandas da realidade prisional.

No âmbito dos grupos de quesitos, importante notar os resultados positivos plenos nos grupos de quesitos estruturadores do espaço arquitetônico da prisão. Nos quesitos externos, esta positivação consolidou as características da modalidade arquitetônica de segurança máxima proposta, em termos do tipo, porte e custo: para presos de maior potencial ofensivo, a unidade prisional prioriza a segurança, de forma balanceada com a coletivização das atividades, aumento de capacidade e generalização funcional, o que eleva os custos de construção. A consistência desta modalidade é corroborada pela posição intermediária assumida entre o espaço de segurança máxima especial e o espaço de segurança média.

Nos grupos de quesitos internos, o isolamento social apresentou resultado positivo, ao manter as características de segurança máxima do espaço arquitetônico existente, enquanto refletiu no custo de construção a especificação da barreira do tipo cerca (redução de custo) e a valorização dos locais de visita aos presos (aumento de custo). O isolamento individual foi um dos poucos tópicos a não onerar a obra penitenciária, devido à coletivização com aumento de capacidade das alas carcerárias e das celas. Na organização do espaço, a funcionalidade teve resultados positivos plenos, enquanto a geometria, o conforto ambiental e os aparatos de segurança tiveram resultados positivos parciais. A funcionalidade concentrou o maior aumento de custo de construção dentre os quesitos internos, em razão da valorização dos programas de segurança e reinserção social dos presos, no que diz respeito à área construída. A circulação foi outro grupo de quesitos a não onerar a obra, ao compensar eventuais aditivos com subtrações de áreas, através da otimização dos fluxos. O controle foi incrementado sem um aumento de custo de construção expressivo, associado aos postos de controle.

Como foi colocado, alguns grupos funcionais apresentaram resultados parciais ou tiveram ocorrência destes resultados. A geometria (item 07.01) desfavoreceu a segurança nos projetos revisados, devido a um excesso na quantidade média de fachada, além da perda de visualização externa nos projetos da Penitenciária Compacta paulista e da empresa Verdi Construções S/A. Estas incongruências se fizeram sentir no controle, em particular, no item 15.03 que teve resultado parcial e avaliação negativa no projeto paulista quanto à segurança. Todavia, as distorções se resumem a um ponto percentual na perda de visualização e o acréscimo de dois pontos cegos, cuja correção integraria o desenvolvimento do projeto, nos ajustes de localizações e dimensões.

Os resultados parciais do conforto ambiental e dos aparatos de segurança dizem respeito a não aplicação do ajustamento em metade dos requisitos, devido à limitação da revisão dos projetos de referência que não trabalhou as aberturas de iluminação e ventilação ou os aparatos de segurança (itens 
13.01 e 14.01). Ao mesmo tempo em que este exercício foi efetuado nos elementos centrais da edificação penal que apresentaram ajustamento pleno no conforto ambiental e nos aparatos de segurança (itens $17.08,18.10$ e 19.06).

\subsubsection{Análise das características físicas e econômicas dos elementos centrais da edificação penal}

A quarta abordagem da experimentação realizada tratou dos elementos centrais da edificação penal, para os quais as questões analíticas convergiram ao longo das abordagens anteriores, em particular: a estratégia de especificação de barreira do tipo cerca para a redução do custo de construção e o custo da humanização do espaço arquitetônico da prisão (principalmente, a valorização dos programas de reinserção social dos presos e o incremento dos elementos centrais da edificação penal). Além de questões específicas, tais como, a avaliação do conforto ambiental, dos aparatos de segurança e do controle (Tabela 8).

Os elementos centrais da edificação penal reuniram a maioria das indicações de aplicações parciais (12 de 18 recorrências) e metade dos resultados de aumento do custo de construção do conjunto avaliado (25 de 53 recorrências). Isto denota uma tendência para o ajustamento minucioso do espaço arquitetônico da prisão, quando cada localização seria submetida à adequação.

O comparativo de custos se deu entre as médias obtidas dos projetos de referência e dos valores calculados para os desenhos-síntese. Como foi apontado nas avaliações anteriores das características financeiras, os modelos apresentam aumento de custos absolutos, com exceção da barreira perimetral.

Tabela 8 - Quadro Características físico-financeiras dos desenhos-síntese

\begin{tabular}{|c|c|c|c|c|c|c|}
\hline \multirow{2}{*}{$\begin{array}{l}\text { Elemento central da } \\
\text { edificação penal }\end{array}$} & \multicolumn{3}{|c|}{ Projetos de referência* } & \multicolumn{3}{|c|}{ desenho-síntese ${ }^{* *}$} \\
\hline & $\begin{array}{c}\text { Custo } \\
\text { Construção (R\$) }\end{array}$ & $\begin{array}{l}\text { Custo/ Área } \\
\left(\mathrm{R} \$ / \mathrm{m}^{2}\right)\end{array}$ & $\begin{array}{c}\text { Custo/ } \\
\text { Capacidade } \\
\text { (R\$/vaga) }\end{array}$ & $\begin{array}{c}\text { Custo } \\
\text { Construção } \\
(\mathrm{R} \$)\end{array}$ & $\begin{array}{l}\text { Custo/ Área } \\
\left(\mathrm{R} \$ / \mathrm{m}^{2}\right)\end{array}$ & $\begin{array}{c}\text { Custo/ } \\
\text { Capacidade } \\
\text { (R\$/vaga) }\end{array}$ \\
\hline Barreira Perimetral & $4.577,00$ & - & - & $2.340,27$ & - & - \\
\hline Cela & $115.558,41$ & $6.328,50$ & $14.444,80$ & $145.976,23$ & $5.668,98$ & $18.247,03$ \\
\hline Pátio de sol dos presos & $1.122 .600,05$ & $4.112,09$ & $23.885,10$ & $1.244 .976,30$ & $4.112,09$ & $34.582,67$ \\
\hline Posto de controle & - & - & - & $126.896,52$ & $7.931,03$ & - \\
\hline \multicolumn{7}{|c|}{$\begin{array}{l}\text { * O valor da barreira dos projetos de referência é a média do valor médio entre a muralha e a cerca (Apêndice A). Custo unitário médio dos } \\
\text { projetos de referência. Capacidade adotada de } 40 \text { presos ( } 163 \text { da média dos projetos de referência em quatro turnos no uso alternado do } \\
\text { pátio). Não se obteve o custo dos postos de controle. } \\
\text { ** Os valores apresentados são ilustrativos e não compuseram os cálculos da aplicação do desenho-síntese no ajustamento dos projetos de } \\
\text { referência, com exceção dos valores do pátio de sol (Apêndice G). }\end{array}$} \\
\hline
\end{tabular}

A barreira perimetral apresentou aplicação parcial em cinco dos oito requisitos (P), incluindo os quatro primeiros requisitos, onde a parcialidade se deu pela existência prévia de barreira perimetral do tipo cerca nos projetos distrital e privado - não houve troca da barreira do tipo muro por cerca (de 16.01 até 16.04) (Tabela 9). O desempenho de segurança e funcionalidade da barreira em cerca foi garantido pelas cercas externas, afastamentos, pistas de ronda e aparatos de segurança. O quinto requisito com 
aplicação parcial trata dos afastamentos (item 16.10) que estão presentes na totalidade dos projetos de referência originais e foram apenas aumentados. Os afastamentos são críticos para o custo de construção, pois regulam os demais elementos da barreira perimetral, em termos dos quantitativos. Neste sentido, os componentes da barreira perimetral tiveram aumento no custo de construção, com exceção do item 16.06 (altura da barreira). O rebaixo na altura da barreira não teve implicações para a segurança ou funcionalidade, se não para o custo (embora a economia tenha sido mínima). O grupo funcional apresentou dois itens sem aplicação (S) (itens 16.05 e 16.09), pois mantiveram as características originais de geometria e presença de linha de tiro.

Tabela 9 - Comparativo dos dados físicos gerais da barreira perimetral

\begin{tabular}{|c|c|c|c|c|}
\hline $\begin{array}{c}\text { Elemento central da edificação } \\
\text { penal }\end{array}$ & Projetos de Referência & Regras técnicas & desenho-síntese & Diferença (\%)* \\
\cline { 2 - 5 } & 495,0 & & 708,0 & $40 \%$ \\
\hline Barreira perimetral (m) & 766,0 & & 1.022 & $25 \%$ \\
\hline Cerca externa (m) & 6,45 & 5,0 & 4,0 & $-61 \%$ \\
\hline Altura (m) & 19,0 & 15,0 & 30,0 & $37 \%$ \\
\hline Afastamento interno (m) & 11,0 & 3,0 & 30,0 & $63 \%$ \\
\hline Afastamento externo (m) & 4,5 & - & 5,0 & $10 \%$ \\
\hline \multicolumn{2}{|l|}{ Linha de tiro (m) } & \multicolumn{3}{l|}{} \\
\hline * Diferença física entre os projetos de referência originais e revisados.
\end{tabular}

A barreira perimetral apresentou aumento de custo de construção em quatro dos onze requisitos, em virtude da especificação do desenho-síntese desenvolvido (Tabela 10). Sobre isto, as cercas da barreira e da linha de tiro respondem por $85 \%$ do custo unitário estipulado para este modelo, seguidas pelos afastamentos, com quase $6 \%$ do custo de construção. Esta proporcionalidade ratificou a substituição do muro pela cerca nos projetos de referência originais, onde a economia correspondeu a $73 \%$ do montante envolvido. O custo unitário do desenho-síntese é $71 \%$ inferior do que o calculado para o muro do projeto paulista (R\$ 8.116,00/m). O maior aumento do custo de construção médio da barreira veio indiretamente do aumento dos afastamentos (7\%), com os acréscimos das cercas da barreira perimetral (10\%) e do perímetro de segurança (5\%). Com a economia final obtida, o grupo de quesitos da barreira perimetral não gerou aumento no custo de construção dos estabelecimentos penais.

Tabela 10 - Comparativo dos dados econômicos gerais da barreira perimetral

\begin{tabular}{|l|c|c|}
\hline \multicolumn{1}{|c|}{ Quesito } & Custo (R\$) & Diferença (\%)* \\
\hline Mudança de muro para cerca & $-7,11$ milhões & $73 \%$ \\
\hline Aumento dos afastamentos & $+492,5 \mathrm{mil}$ & $10 \%$ \\
\hline Acréscimo de barreira perimetral & $+959,3 \mathrm{mil}$ & $5 \%$ \\
\hline Acréscimo de perímetro de segurança & $+468,39 \mathrm{mil}$ & $2 \%$ \\
\hline Decréscimo de altura & $-216,0 \mathrm{mil}$ & $3 \%$ \\
\hline Outros & $+549,62 \mathrm{mil}$ & \multicolumn{1}{c|}{} \\
\hline * Diferença em relação ao montante total envolvido nas alterações promovidas nos projetos de referência (ajuste). \\
\hline
\end{tabular}

A cela, o pátio de sol dos presos e o posto de controle convergem e sintetizam as diretrizes emanadas da organização do espaço, tendo se saído melhor em relação à geometria e avançado na avaliação do conforto ambiental e nos aparatos de segurança. Em especial, a cela representou fortemente a adequação do espaço convencional da prisão ao modelo de segurança máxima proposto. 
O grupo de quesitos da cela apresentou a totalidade dos requisitos com custo de construção agregado (8/11) e quatro itens marcados como aplicações parciais (P) (Tabela 11). Em geral, a qualificação do espaço arquitetônico da cela justificou estes resultados pela compatibilização do local com as atividades sociais e individuais dos presos. A perda de funcionalidade verificada diz respeito à complicação dos procedimentos na cela (revista física), devido à quantidade de espaços e componentes inseridos no ambiente. Em relação às celas dos projetos de referência originais, o custo de construção do desenho-síntese é majorado principalmente pela área de estar (área construída) e o zenital (elemento mais as grades), seguidos do mobiliário (pisos das camas, mesas e bancos). O grupo funcional apresentou dois itens sem aplicação (S) (itens 17.01 e 17.03), pois mantiveram as características originais de geometria e presença de serviços sanitários.

Tabela 11 - Comparativo dos dados gerais físicos das celas

\begin{tabular}{|c|c|c|c|c|}
\hline \multirow[b]{2}{*}{ Quesitos } & \multicolumn{4}{|c|}{ Médias } \\
\hline & Projetos de Referência & Regras técnicas & $\begin{array}{l}\text { Desenho- } \\
\text { síntese }\end{array}$ & Diferença $(\%)^{*}$ \\
\hline Atividades (\% da área)** & $44 / 44 / 0 / 12$ & & $36 / 25 / 26 / 13$ & - \\
\hline Dimensões $(\mathrm{m})$ & $3,15 \times 5,70 \times 3,17$ & $2,85 \times 4,85 \times 2,50$ & $8,60 \times 3,0 \times 3,04$ & 18 \\
\hline Área $\left(\mathrm{m}^{2}\right)$ & 16,00 & $13,85(18,88)$ & 25,75 & 38 \\
\hline Volume $\left(\mathrm{m}^{3}\right)$ & 40,75 & 34,60 & 78,28 & 48 \\
\hline Área pela capacidade $\left(\mathrm{m}^{2} / \mathrm{vaga}\right)^{* * *}$ & 2,0 & $1,73(2,36)$ & 3,22 & 38 \\
\hline Volume pela capacidade $\left(\mathrm{m}^{3} / \mathrm{vaga}\right)^{* * *}$ & 6,2 & 4,32 & 9,78 & 37 \\
\hline Área das aberturas (\% do piso) & $13,75 \%$ & $16 \%$ & $25 \%$ & 45 \\
\hline Circulação $(\mathrm{m})$ & 1,53 & 1,45 & 1,10 & -39 \\
\hline Visualização do interior (\% da área) & $58 \%$ & - & $79 \%$ & 27 \\
\hline
\end{tabular}

Com a aplicação do desenho-síntese da cela, os projetos de referência apresentaram aprimoramento do espaço arquitetônico, com um aumento de custo de construção, por isto foi o grupo foi classificado como ajustado com custo agregado (o projeto distrital teve redução no número de celas e na área de ala carcerária $-1.628,0 \mathrm{~m}^{2}$, por isto não entrou no comparativo) (Tabela 12).

Tabela 12 - Comparativo dos dados gerais econômicos das celas

\begin{tabular}{|l|c|c|c|}
\hline Projetos de referência & $\begin{array}{c}\text { Custo extra das celas } \\
(\mathrm{R} \$)^{*}\end{array}$ & $\begin{array}{c}\text { Proporção no valor do } \\
\text { ajustamento dos projetos (\%)** }\end{array}$ & $\begin{array}{c}\text { Proporção no valor do projeto } \\
\text { ajustado (\%) }\end{array}$ \\
\hline Projeto paulista & 1,12 milhão & 6 & 1 \\
\hline Projeto federal & 1,70 milhões & 31 & 10 \\
\hline Projeto privado & 4,57 milhões & 45 & 10 \\
\hline $\begin{array}{l}* \\
\text { Valor da substituição das celas originais pelas celas no desenho-síntese. No projeto federal, o acréscimo de celas para o aumento de } \\
\text { capacidade do estabelecimento penal foi subtraído deste cálculo (foi considerado o número de celas do projeto original). } \\
* * \text { Diferença entre o valor extra das celas com o desenho-síntese em relação ao valor acrescido ao projeto original (ajuste). } \\
* * * \text { Diferença entre o valor extra das celas com o desenho-síntese em relação ao valor total do projeto de referência revisado. }\end{array}$
\end{tabular}

O grupo de quesitos do pátio de sol apresentou pouco mais da metade dos requisitos com custo agregado (7/12) e dois itens marcados como aplicações parciais (P) (Tabela 13). O desenho-síntese de pátio desenvolvido apresentou um ajustamento menos destoante nas questões funcionais e econômicas do que o modelo da cela, ao manter as características de segurança dos pátios dos projetos de 
referência originais e apresentar áreas menores do que os pátios dos projetos distrital e paulista originais. Quanto a isto, o único item sem aplicação do grupo de quesitos (S) (item 18.12), resultou da manutenção da vigilância interna do pátio.

Em geral, a qualificação do espaço arquitetônico do pátio justifica os resultados obtidos pela compatibilização do local com as atividades dos presos. Assim como na cela, a eventual perda de funcionalidade diz respeito à complicação dos procedimentos no pátio (revista física), devido à quantidade de espaços e componentes inseridos no ambiente. Diferentemente da cela, o desenhosíntese do pátio não teve aumento no custo unitário em relação aos projetos originais. Isto devido à semelhança nas características físicas e à compensação ocorrida com a redução da área construída que contrabalanceou os benefícios implementados (diversificação espacial e mobiliário). Como já ocorre nos projetos de referência que apresentam a abertura superior fechada em grade (todos estes projetos, com exceção do distrital), o custo unitário da área do pátio se iguala à da área construída das edificações (Apêndice A).

Tabela 13 - Comparativo dos dados gerais físicos dos pátios de sol

\begin{tabular}{|c|c|c|c|c|}
\hline \multirow{2}{*}{ Quesitos } & \multicolumn{4}{c|}{ Médias } \\
\cline { 2 - 5 } & Projetos de Referência & Regras técnicas & Modelo-síntese & Diferença (\%)* \\
\hline Capacidade e Demanda (pessoas) & $215 / 136$ & 144 & $144 / 36$ & -49 \\
\hline Dimensões (m) & $11,30 \times 25,85 \times 6,07$ & $10 \times 36$ & $17 \times 18 \times 4,20$ & -10 \\
\hline Área $\left(\mathrm{m}^{2}\right)$ & 273,0 & 360,0 & 302,76 & 10 \\
\hline Área pela capacidade $\left(\mathrm{m}^{2} / \mathrm{vaga}\right)$ & 1,27 & 1,50 & 8,41 & 662 \\
\hline Área pela demanda $\left(\mathrm{m}^{3} / \mathrm{vaga}\right)$ & 2,39 & 1,50 & 2,09 & -14 \\
\hline Área descoberta pela demanda (m $\left.{ }^{2}\right)$ & 1,07 & 1,00 & 5,00 & 467 \\
\hline Visualização do interior (\% da área) & 99 & - & 99 & 0 \\
\hline * Diferença física entre os projetos de referência originais e revisados. &
\end{tabular}

Com a aplicação do desenho-síntese de pátio de sol, os projetos de referência apresentaram aprimoramento do espaço arquitetônico, com um aumento do custo de construção, por isto o grupo foi classificado como ajustado (os projetos distrital e paulista tiveram redução no número e na área dos pátios de sol em $3.708,0 \mathrm{~m}^{2}$ e $608,0 \mathrm{~m}^{2}$, por isto não entraram no comparativo) (Tabela 14).

Tabela 14 - Comparativo dos dados gerais econômicos dos pátios de sol

\begin{tabular}{|l|c|c|c|}
\hline Projetos de referência & $\begin{array}{c}\text { Custo extra das celas } \\
(\mathrm{R} \$)^{*}\end{array}$ & $\begin{array}{c}\text { Proporção no valor do } \\
\text { ajustamento (\%)** }\end{array}$ & $\begin{array}{c}\text { Proporção no valor do projeto } \\
\text { ajustado (\%)*** }\end{array}$ \\
\hline Projeto federal & 1,92 milhão & 35 & 12 \\
\hline Projeto privado & 2,30 milhões & 19 & 5 \\
\hline $\begin{array}{l}* \\
\text { ** Dalor para a substituição dos pátios originais pelos pátios no desenho-síntese. } \\
* * * \text { Diferença entre o valor extra dos pátios com o desenho-síntese em relação ao valor acrescido ao projeto original (ajuste). }\end{array}$ \\
\hline
\end{tabular}

A complicação nos procedimentos verificada na implantação dos desenhos-síntese de cela e de pátio de sol não implica necessariamente em mais pessoal para a realização das revistas nos locais, mas potencialmente o maior dispêndio de tempo para a consumação das rotinas de segurança, com o mesmo número de funcionários. O único requisito avesso a isto foi o item 18.02 do pátio de sol que 
teve resultado negativo na avaliação do projeto federal, devido à duplicação do número de alas carcerárias e, consequentemente, do número de pátios de sol, o que aumenta a quantidade de pessoal para a vigilância dos pátios. Neste projeto, este aumento de pessoal foi compensado no esquema de controle, com a retirada de outros postos.

O grupo de quesitos do posto de controle obteve dois ajustamentos parciais, relativos às condições de permanência dos funcionários no local e aos visores (itens 19.02 e 19.03), porque a previsão de serviços e a visualização externa são relativamente resolvidas nos projetos de referência originais. No primeiro item, estes projetos apresentam sanitários próximos aos postos de controle. No segundo item, a solução existente é efetiva, se considerada uma equipe corretamente dimensionada. Na situação de apenas um agente ocupando o posto de controle e do monitoramento abranger um ambiente único, o desenho-síntese obteria um resulto pleno em todos os projetos revisados. O grupo de quesitos também apresentou todos os requisitos com custo de construção agregado. Em geral, a qualificação do espaço arquitetônico do posto justificou estes resultados pela compatibilização do local com as atividades dos funcionários (Tabela 15). O posto desenvolvido é $17 \%$ maior que a média dos postos dos projetos de referência originais, tem quase o triplo da superfície de visores e apresenta especificações mais elaboradas, o que levou a um aumento do custo de construção em $48 \%$, em relação aos postos originais.

Tabela 15 - Comparativo dos dados gerais físicos dos postos de controle

\begin{tabular}{|c|c|c|c|c|}
\hline \multirow[b]{2}{*}{ Quesitos } & \multicolumn{4}{|c|}{ Médias } \\
\hline & Projetos de Referência & Regras técnicas & $\begin{array}{l}\text { Desenho- } \\
\text { síntese }\end{array}$ & Diferença $(\%)^{*}$ \\
\hline Área $\left(\mathrm{m}^{2}\right)$ & 13,25 & 6,0 & 16,0 & 17 \\
\hline Área pelos agentes $\left(\mathrm{m}^{2} /\right.$ vaga)** & 6,62 & 3,0 & 18,4 & 278 \\
\hline Visores (\%) & 43 & - & 110,0 & 255 \\
\hline Área das aberturas (\% do piso) & - & $16 \%$ & $26 \%$ & 62 \\
\hline
\end{tabular}

Com a aplicação do desenho-síntese de posto de controle, os projetos de referência apresentaram aprimoramento do espaço arquitetônico, enquanto o aditivo ao custo de construção não se confirmou, por isto o grupo foi classificado como ajustado. Quanto ao custo: os projetos distrital e federal tinham os postos de controle com áreas similares ao desenho-síntese; os projetos distrital, paulista e federal tiveram equivalência entre as áreas totais reduzida e aditada dos postos de controle, em razão da redução do número de postos; e o projeto privado teve uma diferença para menos em $44,0 \mathrm{~m}^{2}$, com a redução do número dos postos de controle.

A avaliação do conforto ambiental (item 13) repassada para os elementos centrais da edificação penal foi abordada nos itens 17.08, 18.10 e 19.06 (cela, pátio de sol e posto de controle, nesta ordem), todos com resultados positivos no ajustamento, relativos ao dimensionamento mínimo das aberturas e às 
normas correlatas levantadas, tratadas mais à frente (Apêndice B). Assim, com a aplicação dos desenhos-síntese, os projetos de referência apresentaram aprimoramento do conforto ambiental por amostragem, com um aumento relativo do custo de construção, por isto o quesito foi reclassificado como ajustado. Os itens concernentes à cela (item 17.08) e ao posto de controle (item 19.06) apresentaram aumento nos custos de construção. O zenital da cela modelo correspondeu a $15 \%$ do valor acrescido ao local, ou $\mathrm{R} \$ 6.470,00$ por cela. As venezianas do posto de controle modelo somaram $2 \%$ do valor acrescido ao local, ou $\mathrm{R} \$ 2.738,00$ por posto.

Os desenhos-síntese atenderam à determinação de iluminação e ventilação natural das regras técnicas do Ministério da Justiça, assim como, da NBR 15.575 (ABNT, 2013) (a considerar as ressalvas feitas mais à frente) e dos relatórios NPC/UFSC (UFSC, 2013); e Cetac/IPT nº 107 898-205 (IPT, 2008)(Apêndice B). Especificamente, a iluminação e a ventilação estão de acordo com os instrumentos correlatos levantados, quanto à ventilação cruzada (NBR 15.575-4, item 11.3), à insolação (ISO 6241:1984) e ao controle das aberturas (PSI 17/2012 [UK, 2012]; NBR 15.575-4 e ISO 6241:1984). Não foram atendidos os itens de vista externa (caderno BREAAM [BRE GLOBAL, 2008], ISO 6241:1984) e proteção das aberturas (NBR 15.575-4), ao se priorizar a segurança penitenciária (fechamento dos locais). Em especial, o Manual de Intervenções Ambientais para o Controle da Tuberculose nas Prisões do Ministério da Justiça (SANTOS et al., 2012) e o Technical Guidance for Prison Planning (UNOPS, 2016) foram plenamente atendidos.

A ventilação e a iluminação nos elementos centrais da edificação penal foram testadas em simulações computadorizadas com resultados favoráveis, pontuados por ressalvas, como é tratado adiante ${ }^{95}$.

\footnotetext{
95 Para as simulações de ventilação natural foram utilizados os programas Solidworks (desenvolvimento dos modelos) e Ansys/CFX (simulação de Dinâmica dos Fluidos Computacional). Os ambientes foram modelados realizando as devidas simplificações tendo em vista as características do projeto e informações disponibilizadas. Após a criação dos modelos foi inserido o domínio - região espacial na qual serão calculadas as equações fundamentais da dinâmica dos fluidos. No domínio, foi criada uma malha de cálculo onde, em cada nó da malha, são calculadas as equações de conservação de massa, momento e energia. De forma geral, foi utilizada uma malha com aproximadamente 611.200 nós e 3.230 .000 elementos (tetraedros) para os modelos simulados. A malha foi refinada no programa Ansys/CFX. Após o refinamento da malha, foram inseridos os dados de entrada (características do fluido) em termos de: velocidade, viscosidade, temperatura, orientação do escoamento, equações de turbulência, entre outros. Como o projeto se apresenta como um estudo inicial, foram utilizados dados default do programa para uma série de aspectos. Importante destacar que foi utilizada uma velocidade de escoamento de $1 \mathrm{~m} / \mathrm{s}$ dado recomendado pelo manual do programa para as situações onde não existe uma informação precisa da velocidade e se objetiva realizar um estudo genérico. Com a obtenção dos valores de velocidade do ar no interior dos ambientes foi possivel calcular o número de renovações de ar por hora - parâmetro importante para a qualidade interna dos recintos. Esta simulação e o descritivo equivalente foram elaborados no âmbito do Lasus/UnB, em fevereiro de 2017.

Para as simulações de iluminação natural foi utilizado o programa ReluxPro para desempenho lumínico - simulação do tipo estática (desenvolvimento dos modelos e simulação do fluxo luminoso por área). O método utilizado foi o procedimento A da NBR 15.575/2013 com algoritmos baseados na NBR 15.215-3, da iluminação natural dos ambientes de permanência prolongada (item 13.2.1 da norma). Foram feitas quatro simulações diferentes para cada ambiente ( 3 cenários em 4 situações: 12 modelos) -23 de abril às $9: 30$ e às 15:30 e dia 23 de outubro às 9:30 e às 15:30. Plano de referência a $75 \mathrm{~cm}$ do piso. Em cada simulação foram avaliados dois gráficos 2D e três modelos 3D. Após a identificação do centro no gráfico de cores falsas, foi identificado o nível de iluminância na tabela de iluminâncias. Caso o centro tenha coincidido entre dois valores, foi feita a média simples destes valores. O mesmo se aplicou para quatro valores. Os ambientes foram avaliados considerando um centro único no banheiro e no estar, enquanto o dormitório recebeu dois centros (um para cada conjunto de quatro nichos). Os centros foram dispostos de acordo com as atividades realizadas (dormitório, banheiro e estar). Os resultados foram gráficos baseados em curvas de luminância (cores falsas) e tabelas de malhas de pontos de medição virtual. Esta simulação e o descritivo equivalente foram elaborados por alunos da graduação da FAU/UnB, em fevereiro de 2017.
} 
Na simulação de ventilação, "na cela, foi identificada uma renovação de 12 RAH (renovações de ar por hora); no pátio 7,5 RAH; e no posto de controle 4,25 RAH. Em todos os casos os valores ficam acima dos 0,5 RAH - valor limite para a saúde humana segundo Wargocki et al. (2002)" (SALES, 2017). Ao tratar da cela, o Relatório Cetac /IPT 107 898-205 (B49) (IPT, 2008) sugere 1,0 RAH e a NBR 15.575-1 (ABNT, 2013) estabelece 5,0 RAH, no mínimo. Se admitida a adoção destes parâmetros para o posto de controle (considerado como escritório, segundo a NBR 15.575-4), o mesmo não atende a ventilação mínima (a ventilação cruzada tem as aberturas voltadas para um corredor). Como medida corretiva, a área de veneziana pode ser aumentada ou o alçapão de escape pode ser adaptado para acumular a função de ventilação (lanternim).

Como resultado da simulação de iluminação:

Todos os ambientes de permanência prolongada das unidades da Área de uso comum e do Pátio de observação apresentaram desempenho satisfatório, atendendo ao requisito de desempenho superior da NBR 15575. A Cela proposta, apesar de parte de seus ambientes avaliados apresentarem desempenho Inferior $(60<$ Lux), pode ser facilmente potencializado por meio da integração com a iluminação artificial e redimensionamento das aberturas nas paredes de concreto dos nichos dos dormitórios (RELATÓRIO, 2017).

Na simulação, os desenhos-síntese de pátio de sol dos presos e posto de controle atenderam ao nível superior de desempenho (maior que 120 lux). Em particular, o posto de controle teve os visores especificados com película fumê, sendo preterida a espelhada, pois a reflexão desta tende a prejudicar o desempenho térmico do pátio de sol. O desenho-síntese de cela apresentou resultados semelhantes no estar e no banheiro, porém no dormitório ficaram abaixo do mínimo definido pela NBR 15.575 (60 lux), devido à profundidade e à obstrução da luz, segundo o relatório produzido. A correção da iluminação da cela ocorreu pela criação de aberturas zenitais no ambiente do dormitório (Figura 56).

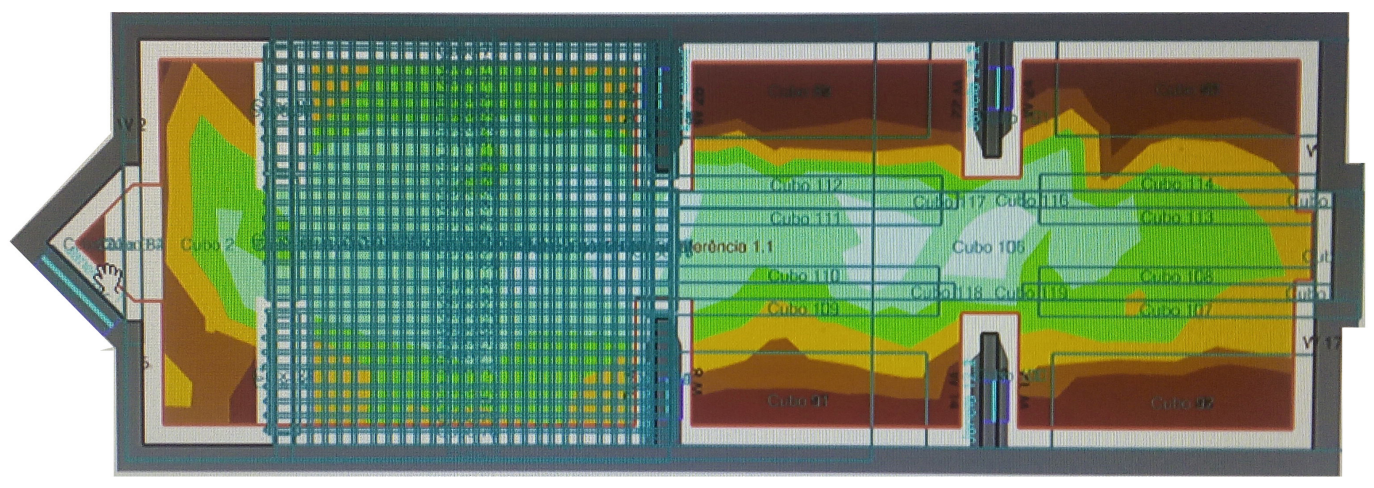

Figura 56 - Gráfico false color resultante da simulação de iluminação da cela Notar a incidência luminosa no dormitório do local. 
Um tópico evidenciado nas simulações realizadas foi a orientação dos desenhos-síntese ${ }^{96}$, o que suscitou a questão da implantação (o item foi considerado sem aplicação na avaliação realizada) e da geometria do estabelecimento penal a ser projetado. Os desenhos-síntese foram testados na melhor condição de vento e insolação. Especificamente, a cela desenvolvida tem melhor desempenho lumínico com o eixo longitudinal no sentido leste-oeste.

Em relação aos aparatos de segurança, a barreira perimetral, a cela, o pátio de sol e o posto de controle abordaram este tema nos itens 16.08, 17.09, 18.11 e 19.05, respectivamente. Em particular, o item 18.11 não teve aplicação (S), pois a maior parte dos pátios dos projetos de referência originais já apresentava cuidados com o fechamento (grade na abertura superior). Os demais itens tiveram avaliação positiva para o ajustamento com aumento nos custos de construção (C). Todavia, estes gastos são minoritários no conjunto orçamentário, embora representem cerca de 42\%, 10\% e 16\% dos respectivos valores unitários dos desenhos-síntese.

\subsection{Conclusão Analítica}

A análise dos projetos de referência revisados determinou o ajustamento do conjunto projetual e a eficiência da tecnologia de projeto desenvolvida, nos termos da melhoria do espaço arquitetônico da prisão, definidos nesta tese (Figura 57). Este ajustamento indica a possibilidade de compatibilização do espaço arquitetônico com as demandas do sistema penal, assim como, o alinhamento das demandas formais e informais entre si. O conjunto projetual revisado respondeu à segurança, funcionalidade, conforto ambiental e ao custo, ao conjugar o atendimento dos instrumentos legais e técniconormativos de arquitetura penal e as expectativas dos usuários da edificação penal. Nas quatro abordagens analíticas realizadas, este ajustamento ocorreu tanto em consideração às caracterizações formais e informais da edificação prisional (projetos de referência, modelo prisional e realidade prisional). Neste sentido, o incremento da estrutura física e operacional da edificação penal foi comprovado no todo e em suas partes, ao ter sido testada a consistência do sistema em suas interdependências - confirmada no exame dos elementos centrais da edificação penal. Para tanto, os projetos revisados foram tratados ao nível das peculiaridades de cada projeto e dos requisitos funcionais, sendo estabelecida a convergência dos grupos de quesitos e dos requisitos funcionais.

\footnotetext{
${ }^{96}$ Para as simulações computadorizadas de ventilação e iluminação realizadas foram consideradas as coordenadas geográficas e o azimute das implantações da Penitenciária do Distrito Federal, Penitenciária Compacta de Mairinque (SP) e da Penitenciária Industrial de Blumenau (SC). A simulação de iluminação utilizou apenas a implantação da unidade prisional de Mairinque que apresenta um azimute de $45^{\circ}$ e cujo resultado apresentou desempenho inferior à melhor orientação (eixo longitudinal da cela no sentido leste-oeste).
} 


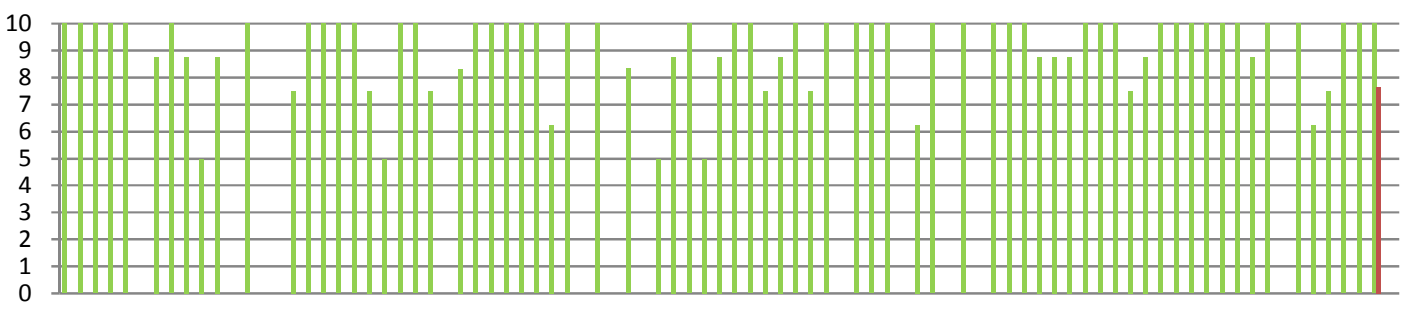

Desempenho dos requisitos funcionais (\%) Média do desempenho (74\%)

Figura 57 - Gráfico do resultado da análise do ajustamento implementado nos projetos de referência.

O gráfico mostra os resultados dos requisitos funcionais. Lacunas referentes aos itens sem aplicação (S).

Apesar do ajustamento obtido, houve o indicativo de que o mesmo não atingiu o potencial inerente à tecnologia de projeto, devido ao surgimento de deformações arquitetônicas, concomitantes à aproximação dos parâmetros máximos estabelecidos na tecnologia. Além de constar como possível saldo para projetos futuros. Os projetos distrital e paulista ilustram esta dificuldade, enquanto a informalidade de ambos confirmou a suposição dos projetos caracteristicamente formais serem mais favoráveis ao ajustamento, formulada na conclusão do capítulo 6. Ao mesmo tempo em que o potencial verificado aponta para a necessidade da elaboração projetual fundamentada em conceitos e parâmetros consistentes e coerentes ou, pelo menos, de modo mais desvinculado das vicissitudes penalógicas e arquitetônicas do sistema penal.

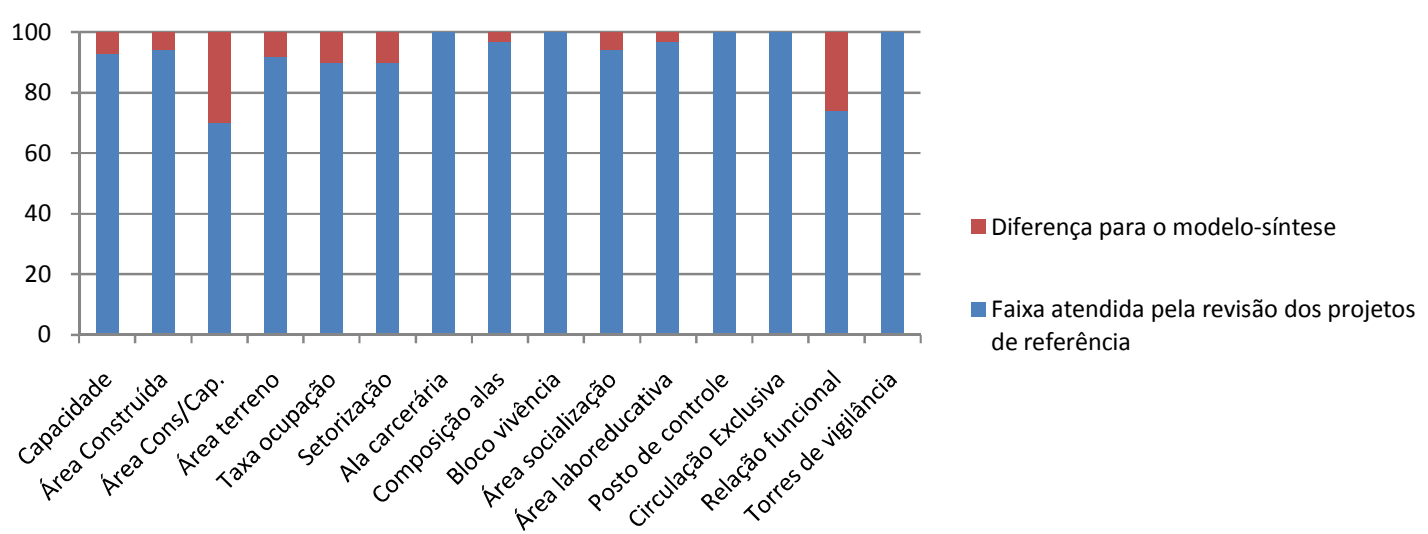

Figura 58 - Gráfico das faixas latentes entre os projetos de referência revisados e o desenho-síntese.

A diferença representa o potencial da tecnologia de projeto não utilizado no ajustamento.

Uma discussão persistente orbita os custos, realimentada pelos resultados obtidos, já que o aditivo de $19 \%$ pode ser considerado elevado na perspectiva da administração pública (ver tabela 12). Diante disto, algumas conjecturas e proposições para a minimização desta diferença podem ser cogitadas, visando à elaboração de projetos arquitetônicos prisionais. De imediato, se cogita uma economia 
advinda do emprego integral e consistente da tecnologia de projeto, a partir da capacidade de otimização do espaço arquitetônico que permaneceu latente no ajustamento realizado.

Em outra proposição de economia, a diferença percentual encontrada pode ser moderada, em termos de uma uniformização das variáveis, ao invés do cálculo da média simples de todos os projetos. Neste sentido, o conjunto projetual tem o aumento de custo de construção inicial atenuado para $14 \%$, ao se focar a avaliação dos projetos que receberam o conjunto completo de desenhos-síntese desenvolvidos, ou seja, os projetos paulista e federal que incluíram a mudança de especificação da barreira perimetral. Da mesma maneira, ao se retirar o projeto distrital deste conjunto, pois foi o único a ter redução do custo de construção, a diferença percentual cai para $18 \%$.

Em outro exercício, os projetos de referência seriam revisados abarcando apenas os desenhos-síntese desenvolvidos de cela, pátio de sol e posto de controle, sem qualquer outra alteração arquitetônica. Neste caso, o número original de celas, pátios de sol e postos de controle foram mantidos. Nesta conjectura, os projetos paulista, federal e privado seriam acrescidos nos valores originais de construção em $\mathrm{R} \$ 1,12$ milhão ou $1 \%$; $\mathrm{R} \$ 1,70$ milhões ou $10 \%$; e $\mathrm{R} \$ 4,57$ milhões ou $10 \%$, respectivamente. Deste modo, um acréscimo médio de pouco mais de $9 \%$ ao valor inicial de obra. Além disto, a substituição da barreira do tipo muro pela cerca anularia este aumento nos projeto paulistas e federal. Neste sentido, a mudança de especificação do muro se confirma como um fator decisivo para a economia na construção dos estabelecimentos penais.

De modo mais específico, a natureza estimativa dos valores trabalhados embute uma margem de erro, ocasionalmente, pendendo para resultados menores. Isto, em parte, porque foram utilizados custos unitários médios na contabilidade procedida e se vislumbra valores abaixo destas médias para algumas situações. Por exemplo, a circulação exclusiva para os funcionários alcançou expressividade nas revisões dos projetos distrital e paulista, cerca de $13 \%$ e $9 \%$ das áreas destes estabelecimentos, com investimento de $\mathrm{R} \$ 8,35$ milhões e $\mathrm{R} \$ 15,19$ milhões, respectivamente. A depender das especificidades destas circulações, o custo unitário das mesmas pode abaixar consideravelmente este investimento.

Das considerações feitas, depreende-se que a concepção arquitetônica principiada no molde da tecnologia de projeto desenvolvida e o posterior desenvolvimento dos projetos conduzido pela mesma podem alcançar resultados mais atrativos do ponto de vista da administração penitenciária. 


\section{Conclusão}

Diante da descaracterização do espaço arquitetônico da prisão, este trabalho objetiva a adequação da edificação penal no atual contexto penitenciário, através da proposição de uma tecnologia de projeto aprimorada para a composição arquitetônica do estabelecimento de segurança máxima. A tecnologia de projeto desenvolvida constitui recurso para a concepção arquitetônica no processo de projeto, cujo aprimoramento consiste em assistir espacialmente a correta aplicação da pena e o respeito à condição humana na prisão, adequadamente ao nível de segurança. A aplicação da pena significa prover a estrutura física necessária à segregação e aos programas de reintegração social dos presos. O respeito à condição humana remete ao bem-estar de presos e funcionários, delimitado nesta pesquisa em torno do conforto ambiental (iluminação e ventilação naturais), envolvendo ainda as interações sociais (territorialidade) e a manifestação da individualidade dos presos (os locais coletivos e individuais). $\mathrm{O}$ nível de segurança balanceia estes fatores, tendo em vista a interdependência existente entre a penalogia e a arquitetura, onde a segurança máxima prioriza o isolamento e o controle no estabelecimento penal.

O problema da arquitetura penal foi abordado no estudo do paradigma tecnológico da edificação penal realizado (ver Introdução, desta tese) que constatou a inconsistência do conhecimento teórico, metodológico e técnico específico para a concepção arquitetônica da prisão e definiu a tecnologia de projeto como mecanismo de recomposição deste conhecimento. O estudo procedido apontou a caracterização do espaço arquitetônico de segurança máxima como linha condutora da elaboração da tecnologia de projeto, por meio da comparação entre as características formais e informais da edificação penal nacional (ver Capítulos 6 e 7). As características formais são definidas pelas demandas do modelo prisional (instrumentos legais e técnico-normativos) e as características informais pelas demandas da realidade prisional (as políticas penitenciárias e o cotidiano prisional).

$\mathrm{Na}$ análise comparativa inicialmente procedida, a descaracterização do espaço arquitetônico da prisão é verificada na divergência encontrada entre as características formais e informais da edificação penal em torno de $62 \%$ do programa arquitetônico. Esta análise ressaltou as demandas da realidade prisional como causa da divergência encontrada, tais como, o aumento da capacidade dos estabelecimentos, a redução de custos de construção e a ênfase na segurança penitenciária.

A divergência encontrada levou à proposta de uma recategorização do nível de segurança penitenciário, baseada no perfil da população prisional e na modulação da pena em regimes penitenciários (ver capítulo 7). Nesta recategorização é proposto o nível de segurança máxima especial, correspondente ao regime penitenciário federal existente, principalmente ao Regime Disciplinar Diferenciado. O nível de segurança máximo é destinado aos presos que dispensam o maior 
nível de segurança, mas para os quais a fuga deve ser muito dificultada - equivalente ao nível 2 descrito no Technical Guidance of Prision Planning (UNOPS, 2016, p. 31). Estas categorias equivalem a modalidades arquitetônicas distintas: a composição espacial de segurança máxima especial absorve as características formais, enquanto a segurança máxima mescla características formais e informais. Com esta combinação, a edificação de segurança máxima apresenta o isolamento e o controle amenizados em relação ao modelo de segurança máxima especial, favorecendo o incremento do bem-estar das pessoas, embora a segurança penitenciária ainda seja prioridade. A prevalência da reinserção social dos presos ocorre no regime semi-aberto, intrinsecamente de segurança média.

Na segunda análise comparativa realizada, a elaboração da tecnologia de projeto sintetiza e sistematiza as características formais e informais do espaço arquitetônico, ao conjugar as soluções arquitetônicas mais aptas, segundo critérios de segurança, funcionalidade, conforto ambiental e custos de construção e operação da prisão (ver Apêndice F). Na formulação da tecnologia de projeto, o conteúdo teóricometodológico é fundamentado no Panóptico que também estrutura os quesitos de projeto. Em particular, as demandas da realidade prisional são integralizadas pelas expectativas dos usuários da edificação penal (ver Apêndice C). Do conjunto tecnológico obtido, desenhos-síntese são gerados para os elementos centrais da edificação penal (barreira perimetral, cela, pátio de sol dos presos e posto de controle) (ver Apêndice G).

A aplicação da tecnologia desenvolvida aos projetos de referência adotados nesta pesquisa (ver Apêndice A) indicou o aprimoramento da composição arquitetônica da amostra, com um atendimento dos critérios fixados em cerca de 74\% dos requisitos de projeto (ver Apêndice H). Este aprimoramento decorreu principalmente do incremento dos espaços destinados às atividades de reinserção social dos presos (socialização com as visitas, trabalho e educação) e do esquema de segurança penitenciária (localização interna das atividades dos presos e generalização da vigilância direta em postos de controle e circulações exclusivas dos funcionários). Estes incrementos implicam em um aumento de área construída da ordem de $28 \%$, enquanto o esquema de segurança aperfeiçoado reduz o contingente de funcionários em torno de 9\% - agentes de segurança penitenciária. Em termos da condição humana na prisão, a aplicação da tecnologia desenvolvida tende a incrementar o bem-estar das pessoas, subentendida no atendimento das demandas dos funcionários e presos nos elementos centrais da edificação penal (desenhos-síntese): a funcionalidade e o conforto ambiental destes locais.

O aumento no custo de construção esperado com o incremento arquitetônico foi confirmado, sendo estimado em torno de $19 \%$ sobre a média dos valores dos projetos de referência. Esta diferença pode diminuir até 9\%, a depender do desenvolvimento do projeto arquitetônico (definição dos espaços e materialidade) e da estratégia de implementação da tecnologia de projeto (uso de partes da 
composição, como apenas os elementos centrais da edificação penal). O custo de operação foi menos impactado, em torno de 7,65\% - nos projetos revisados que apresentaram decréscimo no contingente de pessoal de segurança penitenciária. Os projetos originais que possuíam soluções de controle de caráter formal (postos de controle e circulações exclusivas para os funcionários) não tiveram impacto econômico.

Diante dos resultados apresentados, a pesquisa realizada fortaleceu o processo de projeto e promoveu o aprimoramento da composição arquitetônica da edificação penal, ao propor uma tecnologia de projeto capaz de gerar soluções arquitetônicas mais equilibradas e economicamente viáveis. O ajustamento da composição arquitetônica remete ao 'otimismo responsável' de Leal (2010, p. 379), parafraseado em uma humanização responsável do espaço arquitetônico da prisão. Com isto, esta pesquisa não responde apenas sobre a caracterização da boa prisão, mas qual o preço do aperfeiçoamento do espaço arquitetônico da prisão.

Esta pesquisa representa uma inovação de processo de ordem incremental, tendo avançado em relação aos padrões arquitetônicos convencionais. A tecnologia de projeto consolidou soluções sem paralelo nos projetos de referência estudados, condensadas nos desenhos-síntese dos elementos centrais da edificação penal. O diferencial do conjunto tecnológico desenvolvido ampliou a particularização da edificação penal brasileira em relação aos modelos estrangeiros estudados. Em boa parte, este diferencial é atribuído a incorporação das demandas dos usuários da edificação penal. Isto pode ser interpretado como uma contribuição para a caracterização de uma arquitetura legitimamente nacional. $\mathrm{O}$ avanço desta pesquisa fica evidente em comparação à totalidade dos trabalhos de arquitetura penal que tratam o projeto como produto, em torno de uma generalidade do que deve ser feito, e focando uma maioria de soluções incompatíveis com a conjuntura vigente - dependentes de uma reforma penitenciária.

A tecnologia de projeto desenvolvida tem desdobramentos na reinserção social dos presos. Ao valorizar a pessoa inserida no meio prisional, a mesma tratou a arquitetura como vetor de melhoria da aplicação da pena, buscando minimizar os efeitos deletérios da vida na prisão e beneficiando o regresso do preso à sociedade. Mais além, os desdobramentos deste trabalho alcançam os custos da atuação criminal e do sistema de justiça criminal, além dos danos sociais e humanos. Diante disto, um aspecto relevante desta pesquisa é a sua implicação sócio-humana. Destas proposições, se depreende que o investimento no aperfeiçoamento da edificação penal integra o desenvolvimento do próprio país. Isto remete a afirmação de Nelson Mandela (UNODC, 2016): "comenta-se que ninguém de fato conhece uma nação até que se veja numa de suas prisões. Uma nação não deveria ser julgada pela forma que trata seus mais ilustres cidadãos, mas como trata os seus mais simplórios". 
Alguns comentários e sugestões são pertinentes, mediante os percalços ocorridos ao longo desta pesquisa e dos caminhos abertos para a continuidade do aprimoramento da arquitetura penal:

a) A aplicação da tecnologia de projeto desenvolvida se restringe ao plano de trabalho ou estudo de viabilidade do projeto arquitetônico, além do lançamento do partido arquitetônico do estabelecimento penal a ser projetado. A aplicação em etapas mais avançadas do processo de projeto depende da aquisição e processamento de dados mais completos, detalhados e atuais, em especial, quanto ao custeio.

b) A caracterização da modalidade arquitetônica de segurança máxima incita o estudo e definição do projeto arquitetônico das categorias de segurança máxima especial e segurança média. A tecnologia de projeto desenvolvida pode embasar a composição destes conjuntos tecnológicos, sendo feitas adequações quanto às especificidades de cada nível de segurança.

c) O levantamento de dados da realidade prisional ficou desfalcado da Penitenciária do Distrito Federal, cujo estudo de campo não foi realizado, embora o mesmo tenha sido autorizado pela Vara de Execução Penal do Distrito Federal e Territórios. Isto devido a uma série de imprevistos, finalizados por uma greve dos agentes penitenciários em dezembro de 2016 (AGENTES, 2016). Este estudo permanece relevante, principalmente no que diz respeito ao sistema de segurança, para o aperfeiçoamento dos resultados desta tese.

d) Durante o levantamento de dados na unidade prisional paulista, um retorno para apresentação dos modelos-síntese foi programada, porém não foi realizada. Este retorno configura a continuidade desta pesquisa junto aos usuários da edificação penal, tanto para a revisão dos resultados, como para o desenvolvimento de métodos para a avaliação pós-ocupação em prisões - campo de pesquisa inédito, identificado por Ornstein (1989).

e) Um provável desenvolvimento dos modelos-síntese aborda a sociologia, a psicologia e a saúde das pessoas, tratando de dimensões arquitetônicas ausentes no objeto desta pesquisa, tais como, a estética, sustentabilidade, ergonomia, instalações prediais, sistemas construtivos, materialidade e paisagismo.

f) Dentro de uma estratégia de aplicação da tecnologia de projeto desenvolvida, a apresentação do trabalho para os gestores públicos deve integrar metas próximas. Neste sentido, a mesma é relevante para os órgãos da administração penitenciária para a elaboração de regras técnicas, suporte às políticas e elaboração de projetos arquitetônicos. Além de fundamentar indicadores de desempenho para classificação e certificação das edificações.

g) Os estudos e providências listadas devem ser implementados por intermédio do Núcleo de Estudo e Pesquisa da Edificação Penal do Laboratório do Ambiente Construído, Inclusão Social e Sustentabilidade da Universidade de Brasília (Nuesp/Lacis/UnB). 


\section{Referências bibliográficas}

ACEVEDO DÍAZ, J. A. Cambiando la práctica docente em la enseñanza de las ciências a través de CTS. Biblioteca Digital da OEI (Organização de Estados Iberoamericanos para a Educação, a Ciência e a Cultura, 1996. Disponível: <http://www.oei.es/historico/salactsi/acevedo2.htm >. Acesso: 27 fev. 2017.

AGENTES penitenciários suspendem atos e paralisações no DF até 2017. G1 DF,Brasília, 21 de nov. 2016, Seção Distrito Federal. Disponível em: <http://g1.globo.com/distritofederal/noticia/2016/11/agentes-penitenciarios-suspendem-atos-e-paralisacoes-no-df-ate-2017.html>. Acesso em: 28 fev. 2017.

AGOSTINI, Flávio Mourão. O Edifício Inimigo: a arquitetura de estabelecimentos penais no Brasil. 2002. 155 f. Dissertação (Mestrado em Arquitetura e Urbanismo) - Escola de Arquitetura da UFMG, Belo Horizonte, 2002. Disponível em: < http://m3arquitetura.com.br/textos/AGOSTINI,\%20Flavio.\%200\%20Edificio\%20Inimigo.pdf >. Acesso em: 25 fev. 2017.

AGOSTINI, Flávio Mourão. Ampliação de uma prisão panóptica. Caderno de Arquitetura e Urbanismo, Belo Horizonte, v. 8, n. 8, p. 70-80, fev. 2001.

ALEXANDER, C. Notes on the synthesis of form. 9 th. Print. Cambridge: Harvard University Press, 1977a. 216 p.

ALEXANDER, C.; ISHIKAWA, S.; SILVERSTEIN, M. A pattern language: towns, buildings, contruction. New York: Oxford University Press, 1977b. 1216 p.

ALGARRA, Javier García. La Reforma Carcerária em el pensamiento ilustrado y sus modelos arquitectónicos. Espanha: Universidad Nacional de Educación a Distancia, UNED, 2007. Disponível em: <http://maytediez.blogia.com/temas/historia-del-arte>. Acesso em: 25 fev. 2017.

ÂNGELO, Ivan. A casa de vidro. São Paulo: Cultura, 1980. 258 p.

ANISTIA INTERNACIONAL. Brasil: aqui ninguém dorme sossegado: violações dos direitos humanos contra detentos. Porto Alegre: Anistia Internacional, 1999.

ARAÚJO JUNIOR, Marcondes de Souza. O discurso da imprensa sobre o Complexo Penitenciário da Papuda em Brasília, de 1979 aos nossos tempos. 2005. 55 f. Monografia (Graduação em História)-Centro Universitário de Brasília-UniCeub, Brasília, 2005. Disponível em: $<$ http://www.monografias.brasilescola.com>. Acesso em: $27 \mathrm{fev} .2017$.

ASSOCIAÇÃO BRASILEIRA DE NORMAS TÉCNICAS. NBR 15220: Desempenho Térmico de Edificações. Rio de Janeiro, 2003.

ASSOCIAÇÃO BRASILEIRA DE NORMAS TÉCNICAS. NBR 15575: Edificações habitacionais Norma de Desempenho. Rio de Janeiro, 2013.

AZEVEDO, Solange. A Ciência e os assassinos. Época, São Paulo, SP, n. 591, p. 82, 11 set. 2009.

BARATTA, Alessandro. Ressocialização ou controle social: uma abordagem crítica da "reintegração social" do sentenciado. Alemanha: Universidade de Saarland. [2002?]. Disponível em: <http://www.eap.sp.gov.br/pdf >. Acesso em: 25 fev. 2017. 
BARroS, Ângelo Roncali de Ramos. A Execução Penal e o Sistema Penitenciário - Política Penitenciária Nacional. In: Congresso Nacional de Execução Penal, Rio de Janeiro, 3 e 5 de set. 2003. Disponível em: < http://www.memorycmj.com.br/cnep/palestras/angelo_roncalli.pdf >. Acesso em: 25 fev. 2017.

BAXTER, M. Projeto de produto: guia prático para o design de novos produtos. São Paulo: Blucher, 2000. $261 \mathrm{p}$.

BENTHAM, Jeremy [et al.] O Panóptico. Organização de Tomaz Tadeu. Traduções de Guacira Lopes Louro, M. d. Magno, Tomaz Tadeu. 2 ed. Belo Horizonte: Autêntica Editora, 2008. 202 p.

BLUMENSCHEIN, Raquel Naves. A sustentabilidade na cadeia produtiva da indústria da construção. 2004. 263 f. Tese (Doutorado em Sustentabilidade). Centro de Desenvolvimento Sustentável-CDS. CDS, Universidade de Brasília, Brasília, 2004.

BOURN, John. Control of prison building projets. [Report by the comptrollerand auditor general]. London: National Audit Office, 14 july 1994. 51 p.

BRASIL. [Lei de Execução Penal (1984)]. Lei de execução penal: lei n. 7.210, de 1984, que institui a Lei de Execução Penal-LEP, e legislação correlata. Brasília: Câmara dos Deputados, Coordenação de edições Câmara, 2010. 111 p.

BRASIL. Congresso Nacional. Câmara dos Deputados. Comissão Parlamentar de Inquérito do Sistema Carcerário. CPI sistema carcerário. Brasília: Câmara dos Deputados, Edições Câmara, 2009. 620 p. (Série ação parlamentar ; n. 384).

BRASIL. Constituição (1988). Constituição da República Federativa do Brasil. Brasília, DF: Senado Federal: Centro Gráfico, 1988. 292 p.

BRASIL. Lei n. 10.792, de $1^{\circ}$ de dezembro de 2003. Altera a Lei no 7.210, de 11 de junho de 1984 Lei de Execução Penal e o Decreto-Lei no 3.689, de 3 de outubro de 1941 - Código de Processo Penal e dá outras providências. Disponível em: <http://www.planalto.gov.br/ccivil_03/leis/2003/L10.792.htm>. Acesso em: 27 fev. 2017.

BRASIL. Ministério da Justiça. Conselho Nacional de Política Criminal e Penitenciária. Plano Nacional de Politica Criminal e Penitenciaria. Brasília: MJ, 2011.

BRASIL. Ministério da Justiça. Departamento Penitenciário Nacional. Relatório de Análise do Sistema Construtivo Penitenciário-Siscopen: avaliação técnica e da relação custo e benefício. Brasília: Ministério da Justiça/DEPEN, 2007.

BRASIL. Ministério da Justiça. Departamento Penitenciário Nacional. Levantamento Nacional de informações penitenciárias-Infopen. Brasília: Ministério da Justiça/DEPEN, jun. 2014. 148 p.

BRASIL. Ministério da Justiça. Departamento Penitenciário Nacional. Memorial Descritivo dos Projetos Modulares de Médio e Grande Porte. Brasília: Ministério da Justiça, 2006.

BRITISH REGULAMENTACION ESTANDARTIZATION (BRE GLOBAL). BreeamPrisons 2008. [Hertfordshire]: 2008. $321 \mathrm{p}$.

CAMARGO, Maria Soares de. A Prisão na Sociedade Industrial. Revista da Escola do Serviço Penitenciário do Rio Grande do Sul, Porto Alegre. v. 1, n. 1, p. 33-41, out./dez. 1989. 
CANTER, David. Action and Place: The Existential Dialetic. In: 8th International Conferenceon Enviroment and Human Action, Berlin, p. 16-26, jul. 2084.

CAPANEMA, Bruno Pereira. Inserção de critérios de sustentabilidade à fase de concepção de projetos arquitetônicos: subsídios para uma ferramenta. 2010. 205 f. Dissertação (Mestrado em Arquitetura e Urbanismo) - Faculdade de Arquitetura e Urbanismo de Brasília, Brasília, 2010.

CARVAlHO FILHO, Luís Francisco. A Prisão. São Paulo: Publifolhas, 2002. 88 p. (Folha Explica).

CARVALHO, Jailton de. Apesar do déficit de mais de 200 mil vagas, Fundo Penitenciário tem R\$ 1 bi em caixa: dinheiro não é o problema principal em crise do sistema penitenciário. O Globo.Com. 16 jan. 2014. Disponível em: <http://oglobo.globo.com/brasil/apesar-do-deficit-de-mais-de-200-milvagas-fundo-penitenciario-tem-1-bi-em-caixa-11312506 >. Acesso em: 27 fev. 2017.

CARVALHO, Kelly. Construtoras têm ferramentas próprias para estimar de forma rápida a viabilidade dos empreendimentos. Construção mercado, negócios de incorporações e construção. Seção Construção Mercado n. 72, jul. 2007. Disponível em: <construcaomercado.pini.com.br/negocios-incorporacao-construcao/72/artigo281507-1.aspx>.

Acessado em: fev. 2017.

CEOTTO, Luiz H. A sustentabilidade como valor estratégico para a TishmanSpeyer. In: Encontro Internacional de Sustentabilidade na Construção, org CTE (Centro de Tecnologia de Edificações). São Paulo. Anais...São Paulo: CTE, 2008.

CHERMAYEFF, S. : ALEXANDER, C. Community and Privacy: Toward a New Arquitecture of Humanism. Harmandsworth, UK: Penguin Books, 1966. 255 p.

COLLINSON, Diané. 50 Grandes Filósofos: da Grécia Antiga ao Século XX. Tradução de Maria Waldman e Bia Costa. São Paulo: Contexto, 2004. 288 p. il.

CONSELHO NACIONAL DE POLÍTICA CRIMINAL E PENITENCIÁRIA (CNPCP)(Brasil). Resolução n. 09, 2011. Diretrizes Básicas para Arquitetura Penal. Brasília: Ministério da Justiça / CNPCP, 2011a. 111 p. Disponível em: < http://www.criminal.mppr.mp.br/arquivos/File/ExecucaoPenal/CNPCP/2011Diretrizes_Arqui teturaPenal_resolucao_09_11_CNPCP.pdf >. Acesso em: 25 fev. 2017.

CONSELHO NACIONAL DE POLÍTICA CRIMINAL E PENITENCIÁRIA (CNPCP) (Brasil). Resolução n. 16, de 12 de dez. 1994. Estabelece as Diretrizes para Elaboração de Projetos e Construção de Unidades Penais no Brasil. Brasília: Ministério da Justiça /CNPCP,1995.

CONSELHO NACIONAL DE POLÍTICA CRIMINAL E PENITENCIÁRIA (CNPCP) (Brasil). Resolução n.05, 19 de jul. 1999. Institui as Diretrizes Básicas da Política Criminal e Penitenciária. Brasília: Ministério da Justiça /CNPCP,1999.

CONSELHO NACIONAL DE POLÍTICA CRIMINAL E PENITENCIÁRIA (CNPCP)(Brasil). Resolução n. 03, de 23 set. 2005. Diretrizes Básicas para Construção, Ampliação e Reforma de Estabelecimentos Penais. Brasília: Ministério da Justiça / CNPCP, 2006. 104 p.

CONSELHO NACIONAL DE POLÍTICA CRIMINAL E PENITENCIÁRIA (CNPCP) (Brasil). Resolução n. 08, de 12 jul. 1994. Resolve fixar as Regras Mínimas para o Tratamento do Preso no Brasil. Brasília: Ministério da Justiça / CNPCP, 1994. 9 p. Disponível em: $<$ http://www.justica.gov.br/seus-direitos/politica-penal/cnpcp-1/resolucoes/resolucoes- 
arquivos-pdf-de-1980-a-2015/resolucao-no-08-de-12-de-julho-de-1994.pdf>. Acesso em: 27 fev. 2017.

CONSELHO NACIONAL DE POLÍTICA CRIMINAL E PENITENCIÁRIA (CNPCP) (Brasil). Plano nacional de política criminal e penitenciária. Brasília: Ministério da Justiça /CNPCP, 2011b.

COUTINHO, Leonardo. O cartel. Veja, São Paulo, edição 2498, ano 49, 2016. p. 88-97. Disponível em: <http://vejasp.abril.com.br/edicoes/2498/>. Acesso em: 27 fev. 2017.

CREATIVE ARTS FOR REHABILITATION (RIDEOUT). The CreativePrison: InsidetheArchitecture: The role ofconsultation. London: Rideout, 2006b. Disponível em: <www.rideout.org.uk/creative_prison.aspx>. Acesso em: 25 fev. 2017.

DUARTE, J; BARROS, A. Entrevista em profundidade. Paper. Disponível em: < http://xa.yimg.com/kq/groups/21729374/795258217/name/Entrevista+em+profundidade.doc>.

Acessado em: 27 fev. 2017.

D’URSO, Luiz Flávio Borges. Linhas Mestras para Construção, Arquitetura e Localização de Estabelecimentos Penais. Arquivos do Ministério da Justiça, Brasília, v. 48, n. 185, p. 131-154, jan./jun. 1995.

DOSI, G. et al. Technical change and economic theory. GreatBritain: Pinter Publishers, 1988. 641 p.

DOTTI, René Ariel. A Crise do sistema penal. In: Anais da XVII Conferência Nacional da Ordem dos Advogados do Brasil, 17.: justiça: realidade e utopia, Brasília: OAB, Conselho Federal, 2000. p. 491510 .

DUERK, D. P. Architectural Programming: information management for design. New York: John Wileyand Sons, 1993. 258 p.

DUTRA, Domingos. Projeto de Lei n. 2230 de Emenda Parlamentar para Instituir o Estatuto Penitenciário Nacional, 05 set. de 2011. Disponível em: $<$ http://www.camara.gov.br/proposicoesWeb/fichadetramitacao?idProposicao=518923>. Acesso em: 27 fev. 2017.

ESTECA, Augusto Cristiano Prata. Arquitetura Penitenciária no Brasil: análise das relações entre a arquitetura e o sistema jurídico-penal. 2010. 224 f. Dissertação (Mestrado em Arquitetura). Faculdade de Arquitetura e Urbanismo, Universidade de Brasília, Brasília, 2010.

ESTECA, Augusto Cristiano Prata. Sistema arquitetônico penal: descrição de uma ferramenta arquitetônica para o projeto de estabelecimentos penais Siscopen. 2. ed. Brasília: Ler, 2014.124 p.

FAIRWEATHER, Leslie ; MCCONVILLE, Seán. Prison Architecture: policy, Design and Experience.Oxford: Architectural Press, 2000.

FLÓSCULO, Frederico (tradutor). Questões Emergentes em Arquitetura. Brasília: Universidade de Brasília/Faculdade de Arquitetura e Urbanismo. Cadernos Eletrônicos da Pós, v. 2, 2000. Disponível em: <http://vsites.unb.br/fau/pos_graduacao/paranoa/edicao2000/edicao2000.htm>. Acesso em : 25 fev. 2017. 
FORTE, Francisco Alexandre de Paiva. Análise sobre o programa nacional e segurança pública com cidadania - Pronasci - instituído pela lei 1.530/07 e MP 416/08. Estudos, Goiânia, v. 35, n. 4, p. 575587, jul./ago. 2008.

FOUCAULT, Michel. Vigiar e punir: nascimento da prisão. Tradução de R. Ramalhete. Petrópolis: Vozes, 1987.

GARBELINI, Sandra Mara. Arquitetura prisional: a construção de penitenciárias e a devida execução penal, Revista do Conselho Nacional de Política Criminal e Penitenciária, Brasília, v. 1, n. 18, p. 145-159, jan./jun. 2005.

GARCÍA BASALO, J. Carlos. Introducción a La Arquitectura Penitenciária. Revista Penal y Penitenciária, Buenos Aires, n. 91/94, tomo XXII, p. 41-132, ene./dic. 1959.

GILBERT, J. K. Educación Tecnológica: uma nueva Asignatura em todo el mundo Ensenãnza de las Ciencias, 1995, Vol. 13, No. 1, p. 15-24.

GOFFMAN, Erving. Manicômios, prisões e conventos. Tradução de D. M. Leite. São Paulo: Debates, 2005.

GOIFMAN, Kiko. A morte do tempo na prisão. Boletim Ibccrim, São Paulo, v. 8, n. 95, p. 2, out. 2000.

GOMES, Luiz Flávio. Crime organizado: o que se entende por isso depois da lei 10.217, de 11.04.2002? Apontamentos sobre a perda de eficácia de grande parte da Lei 9.034/95. Revista dos Tribunais, v. 91, n.795, São Paulo, jan. 2002.

GRAEFF, Edgar Albuquerque. Uma sistemática para o estudo da teoria da arquitetura. Goiânia: Trilhas Urbanas, 2006. 120 p.

HENLEY, Simon. The 21st century model prison. London: Proceeding4tInternational Space Syntax Symposium, 2003. Disponível em: <http://www.spacesyntax.net/symposiaarchive/SSS4/fullpapers/03Henleypaper.pdf>. Acesso em: 25 fev. 2017.

HERSBERGER, R. G. Architectural Programming and Predesign Manager. New York: McGrawHill, 1999. 506 p.

INSTITUTO DE PESQUISAS TECNOLÓGICAS (IPT). Centro Tecnológico do Ambiente Construído. Laboratório de Componentes e Sistemas Construtivos. Elaboração de Diretrizes para a avaliação técnica de sistemas construtivos destinados a celas prisionais. Relatório técnico n. 107 898-205/dez.2008. São Paulo: IPT, 2008. 2 volumes.

INSTITUTO DE PESQUISAS TECNOLÓGICAS (IPT). Centro Tecnológico do Ambiente Construído. Laboratório de Conforto Ambiental e Sustentabilidade dos Edifícios. Avaliação do desempenho térmico e lumínico de cela prisional composta por sistema construtivo em concreto. Relatório técnico n. 116 846-205/abr.2010. São Paulo: IPT, 2010a. 17 p.

INSTITUTO DE PESQUISAS TECNOLÓGICAS (IPT). Centro Tecnológico do Ambiente Construído. Laboratório de Componentes e Sistemas Construtivos. Avaliação Técnica de Sistema Construtivo Integrado por Painéis pré-moldados de Concreto destinados a Celas Prisionais em Edificações Térreas. Relatório técnico n. 116 048-205/ago.2010.São Paulo: IPT, 2010b. 6 volumes. 
INTERNATIONAL ORGANIZATION FOR STANDARDIZATION. ISO 6241:1984. Performance standards in building -- Principles for theirpreparationandfactorstobeconsidered. Disponível em: $<$ https://www.iso.org/contact-iso.html>. Acesso em: 27 fev; 2017.

SPENS, Iona. Architecture of incarceration. Estados Unidos: AcademyEditions/Academy Group Ltda, 1994.

JONES, Christopher. Design Methods: Seeds of Human Futures. Nova Iorque: John Wiley\& Sons Ltd., 1970; p. 3-10.

JORGE, Wilson Edson. Projetos Prisionais no estado de São Paulo. Revista do Programa de PósGraduação da Faculdade de Arquitetura e Urbanismo da Universidade de São Paulo, São Paulo, n. 12, p. 100-117, dez. 2002.

KOHLSDORF, G. ; KOHLSDORF, M. E. A avaliação de desempenho morfológico no ensino de Arquitetura e Urbanismo. Brasília: UnB, 1999.

KOOLHAAS, Rem. Study for the renovation of a panopticon prison. Arnhem, Netherlands. 197981. p. 235-251. In: KOOLHAAS, Rem; MAU, Bruce; Sigler, Jennifer. S,M,L,XL. OMA. [S.1.]: Office for Metropolitan Architecture Monacelli Press, 1998. 1344 p.

LAYTON, D. Revaluingthe T in STS. International Journal of Science Education, v. 10, n. 4, p. 367-378, 1988.

LEAL, César Barros. Execução penal na América Latina à luz dos direitos humanos: viagem pelos caminhos da dor. Curitiba: Juruá, 2010. 482 p.

LEAL, César Barros. O crime e a pena nos Estados Unidos. Nomos: revista do curso de mestrado em direito da Universidade Federal do Ceará, Fortaleza, v. 11/12, n. 1/2: p. 47-58, jan./dez. 1992.

LUTZ, Jim. Mobility of Ground Vehicles: US Military View, a overview primer and reference source guide vintage 2003. Apresentação slides. Quest Systems Inc. EUA, Jun. 1993. Disponível em: $<$ https://www.slideshare.net/QuestSystems/a-primer-on-military-vehicle-mobility-vintage-2003presentation>. Acessado em: 28 fev. 2017.

MACAULAY, Fiona. Political and institutional challenges of reforming the Brazilian prison system. 2002. 27 f. Paper Series $n^{\circ}$ CBS-31-02. 2002. University of Oxford Centre for Brazilian Studies. Disponível em: < http://www.cibera.de/fulltext/2/2117/workingpapers/Macaulay31.pdf>. Acesso em: 25 fev. 2017.

MARINER, Joanne. O Brasil atrás das grades. Rio de Janeiro: HumanRightsWatch, 1998.

MIOTTO, Armida Bergamini. O pessoal das prisões e os presos. Revista de Informação Legislativa, Brasília, v. 23, n. 90, p. 361-372, abr./jun. 1986. Disponível em: < http://www2.senado.gov.br/bdsf/item/id/181705 >. Acesso em: 27 fev. 2017.

MIOTTO, Armida Bergamini. Temas Penitenciários. São Paulo: Revista dos Tribunais, 1992. 227 p.

MOREIRA, Daniel de Carvalho. Os princípios da síntese da forma e a análise de projetos arquitetônicos. 2007. 351 f. Tese (Doutorado em Engenharia Civil). Faculdade de Engenharia Civil, Universidade de Estadual de Campinas, Campinas, 2007. 
MUIR, Rick; LOADER, Ian. Tomorrow's prisons: designingthe future prisonestate. London: Institute for PublicPolicyReserch, 2010. 34 p.

OLIVEIRA, Edmundo. Consensualismo Penitenciário. Boletim Ibccrim, São Paulo, v. 10, n. 113, abr. 2002.

Organização para Cooperação e Desenvolvimento Econômico (OCDE). Manual de Oslo: diretrizes para coleta e interpretação de dados sobre inovação. 3. ed. Oslo: OCDE, 1997. 184 p.

ORLAND, Leonard. Prisons, Houses of Darkness. New York: The Free Press, 1978.

ORNSTEIN, Sheila. Arquitetura e responsabilidade social: algumas considerações sobre a avaliação pós-ocupação (APO) de estabelecimentos penais urbanos. Sinopses, São Paulo, v. 15, p.10-16, jun. 1989.

PEÑA, W. M. ; PHARSHALL, S. A. ProblemSeeking: na ArchtectualProgramming Primer, 4th. ed., New York: John Wileyand Sons, 2001. 224 p.

PERROT, Michelle. O inspetor Bentham. In: O Panóptico. 2. ed. Belo Horizonte: Autêntica, 2008. $199 \mathrm{p}$.

PIMENTEL, Pedro Manoel. Prisões Fechadas, Prisões Abertas. São Paulo: Cortez \& Moraes, 1978.

PROGRAMA NACIONAL DE SEGURANÇA PÚBLICA COM CIDADANIA (PRONASCI) (Brasil). Pronasci. Brasília: Ministério da Justiça / Pronasci, 2007. 31 p.: il., color.

PROPOSTA de orientações para elaboração de projetos de construção de estabelecimentos penais. In: ENCONTRO NACIONAL SOBRE ARQUITETURA PENAL, 1., 1987, Brasília. Anais... Brasília: Coleção Folheto, DEPEN, 1987.

QUEIROZ, José Jandson. Ensaio sobre procedimentos de projetação urbanística. 2000. Dissertação (mestrado em Urbanismo) - Universidade de Brasília, Brasília, 2000.

RECOMENDAÇÕES Básicas para uma Programação Penitenciária. Arquivos do Ministério da Justiça, Rio de Janeiro, v.33, n.138, p.199-207, abr./jun., 1976.

RELATÓRIO final de consultoria: avaliação do desempenho lumínico segundo NBR 15.575 para projeto penitenciário em Mairinque-SP. Brasília: [s.n], 2017. 89 p.

RIDEOUT (CreativeArts for Rehabilitation). The CreativePrison: CreativeThinkingwithinthePrisonEstate. London: Rideout, 2006a. Disponível em: <www.rideout.org.uk/creative_prison.aspx>. Acesso em: 25 fev. 2017.

ROLIM, Marcos. Sobre os projetos arquitetônicos dos novos presídios federais e estaduais. Parecer técnico de cooperação entre UNESCO e Ministério da Justiça. Porto Alegre, abr. 2005. Disponível em: <http://www.rolim.com.br/2002/_pdfs/projarq.pdf>. Acesso em: 25 fev. 2017.

SÁ, Alvino Augusto de. Arquitetura Carcerária e Tratamento Penal. Revista dos Tribunais, São Paulo, v. 79, n. 651, p. 247-257, jan.1990.

SÁ, Alvino Augusto de. Sugestão para um esboço das bases conceituais para o Sistema Penitenciário Federal. São Paulo: Imprensa Oficial do Estado de São Paulo, Secretaria de Administração Penitenciária, Departamento de Reintegração Social, Manual de reintegração Social, 
2005, p. 13. Disponível em: $<$ http://www.sap.sp.gov.br/download_files/reint_social/apresentacao/sugestao_esboco.doc>. Acesso em: 25 fev. 2017.

SALES, Gustavo. Laboratório do Ambiente Construído em Sustentabilidade - LASUS. Relatório de simulação computadorizada de ventilação natural dos elementos centrais da edificação penal. Brasília: UnB, 2017.

SALLA, Fernando. As prisões em São Paulo: 1822-1940. São Paulo: Annablume, 1999.

SANTA CATARINA. Secretaria de Segurança Pública e Defesa do Cidadão. Secretaria Executiva de Justiça e Cidadania. Departamento de Administração Prisional. Instrução Normativa n. 01 de 2010.Dispõe sobre normas e procedimentos operacionais de segurança a serem adotadas pelas Unidades Prisionais do Estado de Santa Catarina. Santa Catarina: DEP, 2010. Disponível em: $<$ http://www.deap.sc.gov.br/index.php/downloads/normativas-e-portarias/39-12042012-instrucaonormativa-0012010-deap-1/file>. Acesso em: 27 fev. 2017.

SANTOS, Flávio Anthero Vianna dos. MD3E: uma proposta de método aberto para uso no design industrial. 2005. 168 f. Tese (Doutorado em Engenharia de Produção) - Universidade Federal de Santa Catarina, Florianópolis, 2005.

SANTOS, Mauro et al. Manual of Environmental Interventions for Turberculosis Control in Prisons = Manual de intervenções ambientais para o controle da tuberculose nas prisões. [Rio de Janeiro]: Fundo Global Tuberculose Brasil, 2012. 65 p.

SERRA, Geraldo G. Pesquisa em arquitetura e urbanismo: guia prático para pesquisadores em trabalho de pós-graduação. São Paulo: Edusp, 2006.

SILVA, A.et al. Força de Expressão: poesia expressão de paz e amor e alegria. Organização de Ana Cristina A. de Alencar, Esther Simão Bentes, Márcia Portugal da Costa. Belém: Imprensa Oficial do Estado do Pará, 2002.

SILVA, Haroldo Caetano da. Arquitetura Penitenciária: a simplicidade como solução. Boletim Ibccrim, São Paulo, v. 16, n. 191, p. 4-5, out. 2008.

SILVA, Israel Moreira da. Detento sem crime. Brasília: 2009. Disponível em: $<\mathrm{http} / / / \mathrm{www}$.israelmoreiradasilva.blogspot.com>. Acesso em: 27 fev. 2017.

SILVA, Jenifer K. Leal da; RODRIGUES, Suzana Santa Maria. Um estudo sobre a formação do estigma do presidiário considerado de alta periculosidade. Revista da Escola do Serviço Penitenciário do Rio Grande do Sul, Porto Alegre. v. 1, n. 1, p. 54-105, out./dez. 1989.

SIMON, Fernanda de Oliveira. Habilidades e competências de engenheiros sob a ótica dos alunos dos cursos de engenharia. In: Congresso Brasileiro de Ensino de Engenharia, 12.,2004, Brasília, Anais... Brasília: Cobenge, 2004. p. 1-7.

SIMON, H. A. As ciências do artificial. Coimbra: Arménio Amado, 1981. 351 p.

SPERLING, David Moreno.

THOMPSON, Augusto F. G. A Questão Penitenciária. Petrópolis: Vozes, 1976. 
TOMÁSQUIM, A. T. Instrumentalização e Simulação como Paradigmas da Ciência Moderna: 83-87. In: D’ Ambrosio, U. (org.). Anais do Congresso Latino-Americano de História da Ciência e da Tecnologia, 2. São Paulo: Nova Stella, 1989.

TRIGUEIROS, Conceição. Panóptico: as ordens da vigilância: uma arquitectura moralista. Portugal: Caleidoscópio, 2011.97 p.

U.S.GREEN BUILDING COUNCIL (USGBC). Leadership in Energy and Environmental DesignLEED. Green Building Design and Construction. Washington: LEED, 2009. 674 p.

UK. MINISTRY OF JUSTICE. NATIONAL OFFENDER MANAGEMENT SERVICE. Certifiedprisoneraccomodation. PSI 17/2012. London: MJ, 2012.

UNITED NATIONS OFFICE FOR PROJECT SERVICES (UNOPS). Technical guidance for prison planning: technical and operational considerations based on the standard minimum rules for the Treatment of Prisoners (The Nelson Mandela Rules). Copenhagen: Unosps, 2016. 256 p. Disponível em:<https://www.unops.org/SiteCollectionDocuments/Publications/TechnicalGuidance_PrisonPlannin g.pdf>. Acesso em: 27 fev. 2017.

UNITED NATIONS OFFICE ON DRUGS AND CRIME (UNODC). UNODC calls for humane prison conditions on Nelson Mandela International Day. 18 july 2016. Disponível em: \&lt; https://www.google.com/url?hl=ptBR\&amp;q=http://www.unodc.org/unodc/en/frontpage/2016/July/u nodc-calls- for-humane- prison-conditions-on- nelson-mandela- internationalday.html\&amp;source=gmail\&amp;ust=1488414854445000\&amp;usg=AFQjCNH3W3fgYrXffPMN 1qvg71H3iAPTJg\&gt;. Acesso em: 28 fev. 2017.

UNIVERSIDADE FEDERAL DE SANTA CATARINA (UFSC). Centro Tecnológico da Universidade Federal de Santa Catarina. Núcleo em Pesquisa em Construção (NPC). Cooperação para elaboração da tabela de referência SINAPI: Departamento Penitenciário Nacional. Relatório III. Florianópolis: UFSC, 2013. 4 volumes.

UNIVERSIDADE FEDERAL DO RIO GRANDE DO SUL (UFRGS). Faculdade de Engenharia Civel. Programa de Pós-Graduação. Núcleo Orientado para a Inovação da Edificação. Análise de desempenho técnico da Penitenciária Modulada Pré-fabricada em GRC + CAD. 2006. Relatório técnico. Porto Alegre: UFRGS, 2006.

USA. FEDERAL BUREAU OF PRISONS. General visiting information. Disponível em: $<$ https://www.bop.gov/inmates/visiting.jsp>. Acesso em: 27 fev. 2017.

USA. United States Bureau of Prisons. Handbook of Correctional Institution Design and Construction.United States: Bureau of Prisons, 1949.

USA. UNITED STATES GOVERNAMENT. Guide to Active Vehicle Barrier (AVB): Specification e Selection Resources. Department of Homeland Security, 2014. 69 p. Disponível em: $<$ https://www.dhs.gov/sites/default/files/publications/Guide-to-Active-Vehicle-Barrier-2014-508.pdf>. Acessado em: 28 fev. 2014.

VARELLA, Drauzio. Estação Carandiru. São Paulo: Companhia das Letras, 1999.

VERASZTO, et al. Tecnologia: buscando uma definição para o conceito. Prisma.Com, n. 7, 2008. 85 p. ISSN 1646-3153. 
WENER, Richard. The environmental psychology of jails: an explanatory model of violent behavior. Sinopse, São Paulo, n. 19, p. 5-12, jun. 1993.

ZIMMER, Marco Vinício. O panóptico está superado Estudo etnográfico sobre a vigilância eletrônica. 2009. 138 f. Tese (Doutorado em Administração). Faculdade de Administração, Universidade Federal do Rio Grande do Sul, 2009. 


\section{Apêndice A - Projetos arquitetônicos de referência}

Neste apêndice são apresentados os projetos arquitetônicos dos estabelecimentos penais abordados nesta pesquisa, além dos dados físicos e econômicos da edificação prisional, em complementação ao Capítulo $1^{97}$.

Os exemplares elencados buscaram sintetizar a produção arquitetônica penitenciária nacional, segundo critérios de uniformidade, relevância, representatividade e disponibilidade de dados. Quatro projetos foram selecionados para compor o grupo de referência nesta pesquisa:

a) Penitenciária do Distrito Federal II (PDF II): este estabelecimento foi listado em terceiro lugar entre os melhores do país (BRASIL, 2009, p. 472). Além disto, esta arquitetura foi modelo para sistemas penitenciários estaduais e na elaboração do Estatuto Penitenciário Nacional ${ }^{98}$.

b) Penitenciária Compacta do Estado de São Paulo (PC): este projeto tem importância quantitativa no sistema penitenciário nacional, tanto em termos dos estabelecimentos em operação, como do futuro cenário da construção penitenciária, com o crescimento do sistema penitenciário paulista ${ }^{99}$. Além disto, este projeto foi modelo para outros sistemas estaduais.

c) Cadeia Pública do Plano Nacional de Apoio ao Sistema Penal: este projeto integra a política penitenciária federal de ampliação do sistema penitenciário nacional. Este projeto se destaca por sua abrangência, podendo ser executado por qualquer unidade federativa.

d) Modelo de penitenciária desenvolvido pela empresa Verdi Construções S/A: entre as empresas especializadas, este projeto tem notoriedade pela industrialização construtiva e racionalidade operacional (BRASIL, 2007). Além disto, este modelo contabiliza dezenas de unidades distribuídas pelo território nacional.

Todos os projetos são similares quanto à modalidade arquitetônica e ao contexto penitenciário, em alinhamento com o objeto desta pesquisa. Os mesmos guardam semelhança conceitual e espacial: foram em boa parte determinados pela economicidade, tanto na construção como na operação, e apresentam uma composição que oscila entre a primeira e a segunda geração de estabelecimentos penitenciários. Os projetos escolhidos coincidem com a inovação dos agentes público e privado relevantes na Cadeia Produtiva da Indústria da Construção da edificação penal. Aqueles elaborados no âmbito público testemunham a capacidade técnica da administração penitenciária. Em especial, o projeto federal incorpora as prerrogativas técnico-normativas do Ministério da Justiça.

\footnotetext{
97 A divulgação de informações está sujeita à censura por motivo de segurança. Por isto, os desenhos, imagens e dados não informam sobre a edificação como um todo ou detalhes estratégicos. Os desenhos advêm de fontes abertas e são esquemáticos e sem escala.

${ }^{98}$ O projeto foi replicado, por exemplo, no Complexo Penitenciário Dr. Manoel Carvalho Neto (Copemcan), em Aracajú/SE. O Estatuto Penitenciário Nacional instituía parâmetros espaciais baseados na PDF na seção destinada à arquitetura penal (DUTRA, 2011) subsidiado pelo Relatório Final da Comissão Parlamentar de Inquérito do Sistema Carcerário (BRASIL, 2009).

99 O Sistema Penitenciário paulista abriga cerca de $40 \%$ da população prisional no Brasil - dado do Sistema Integrado de Informações Penitenciárias (Infopen) (BRASIL, 2014).
} 
Um grupo de projetos assistiu a amostra principal diante de eventuais ambiguidades ou incompletudes, além de ter permitido uma contraprova das características arquitetônicas encontradas. Entre estes projetos se destacam: a Penitenciária para presos jovens adultos e a Penitenciária Federal do Ministério da Justiça; e o Modelo de penitenciária desenvolvido pela empresa DM Construtora de Obras. Alguns projetos de menor segurança foram selecionados para exemplificar a humanização do espaço arquitetônico, ao mesmo tempo em que demonstraram as diferenças arquitetônicas entre níveis de segurança: o Centro de Ressocialização do Estado de São Paulo (CR) e a APAC de Santa Luzia/MG. Projetos estrangeiros também foram buscados com o objetivo de ilustrar o padrão arquitetônico modular, assim como, a para demonstrar o limite da maximização da segurança ou a humanização do espaço arquitetônico prisional em uma unidade de segurança máxima, respectivamente: a Adminitrative Maximun Facility (ADX Florence), e a Halden Fengsel.

\section{A) Penitenciária do Distrito Federal II - PDF II (denominado projeto distrital)}

O projeto arquitetônico foi desenvolvido pela Secretaria de Segurança Pública do Distrito Federal no ano 2000, como modelo para quatro unidades penais que constituiriam o Setor C, no Complexo Penitenciário da Papuda (CPP). É o projeto que representa melhor o padrão arquitetônico modular, enquanto apresenta uma série de particularidades devido ao modelo de gestão local: a saúde é providenciada pelo sistema público e a alimentação é terceirizada. A penitenciária é classificada como de segurança média, mas apresenta características de segurança máxima ${ }^{100}$.

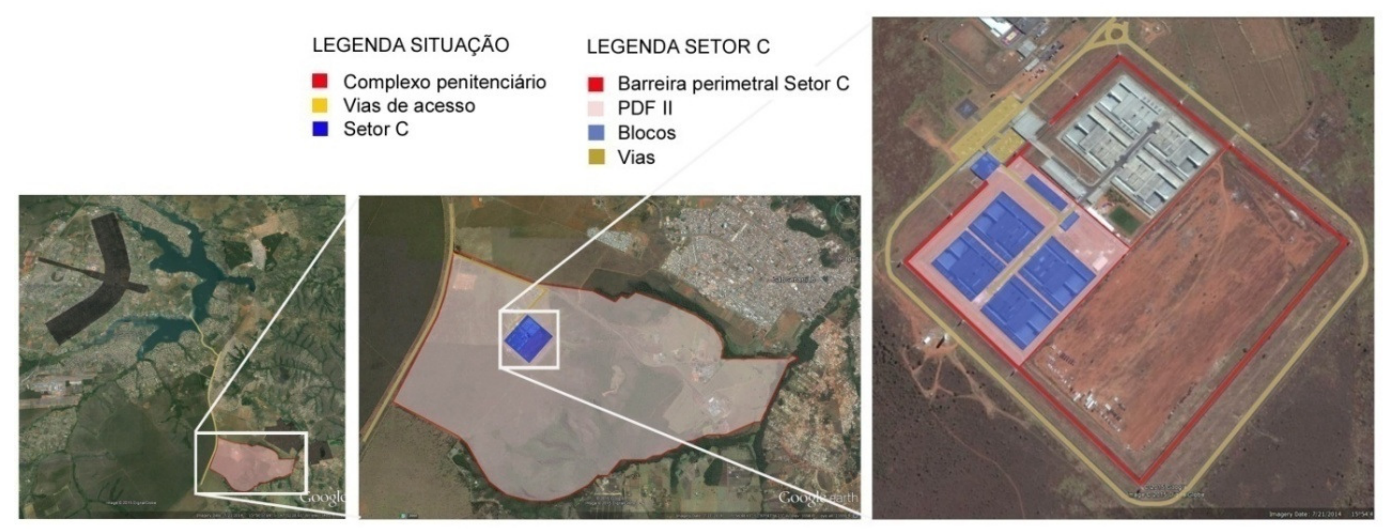

Figura 59 - Fotografias de satélite com a localização da PDF II

Da esquerda para a direita: o CPP em relação ao Plano Piloto de Brasília, a locação do Setor C no CPP e a implantação da PDF II no Setor C.

(Fonte: Imagens geradas a partir do Google Earth. Acesso em: Fev. 2017)

\footnotetext{
100 O estabelecimento penal é apresentado pelo órgão local como de segurança média. Apenas o bloco de vivência individual (celas individuais) é considerando de segurança máxima. No entanto, o conjunto arquitetônico tem características de geometria, programa, fluxos, segurança e controle de alta segurança.
} 


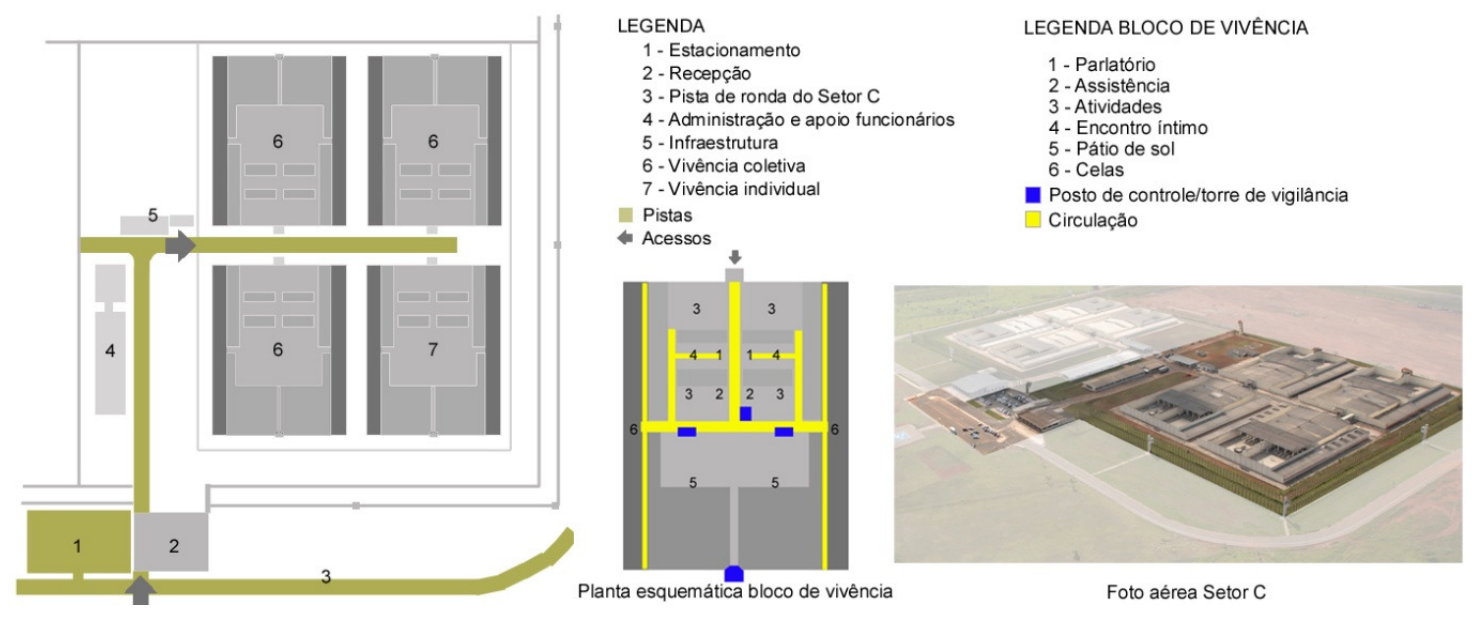

Figura 60 - Plantas esquemáticas e fotografia da PDF II (Fonte da fotografia: Secretaria de Segurança Pública/DF)

B) Penitenciária Compacta do Estado de São Paulo (PC) (denominado projeto paulista)

O projeto arquitetônico foi desenvolvido pela Secretaria da Administração Penitenciária nos anos 2000 como padrão para a construção de estabelecimentos penais nesta unidade federativa. É o projeto que representa melhor o padrão arquitetônico paralelo, assim como, a compactação espacial da prisão. Existe uma versão vertical para unidades construídas próximas ou dentro do perímetro urbano (PC-V).
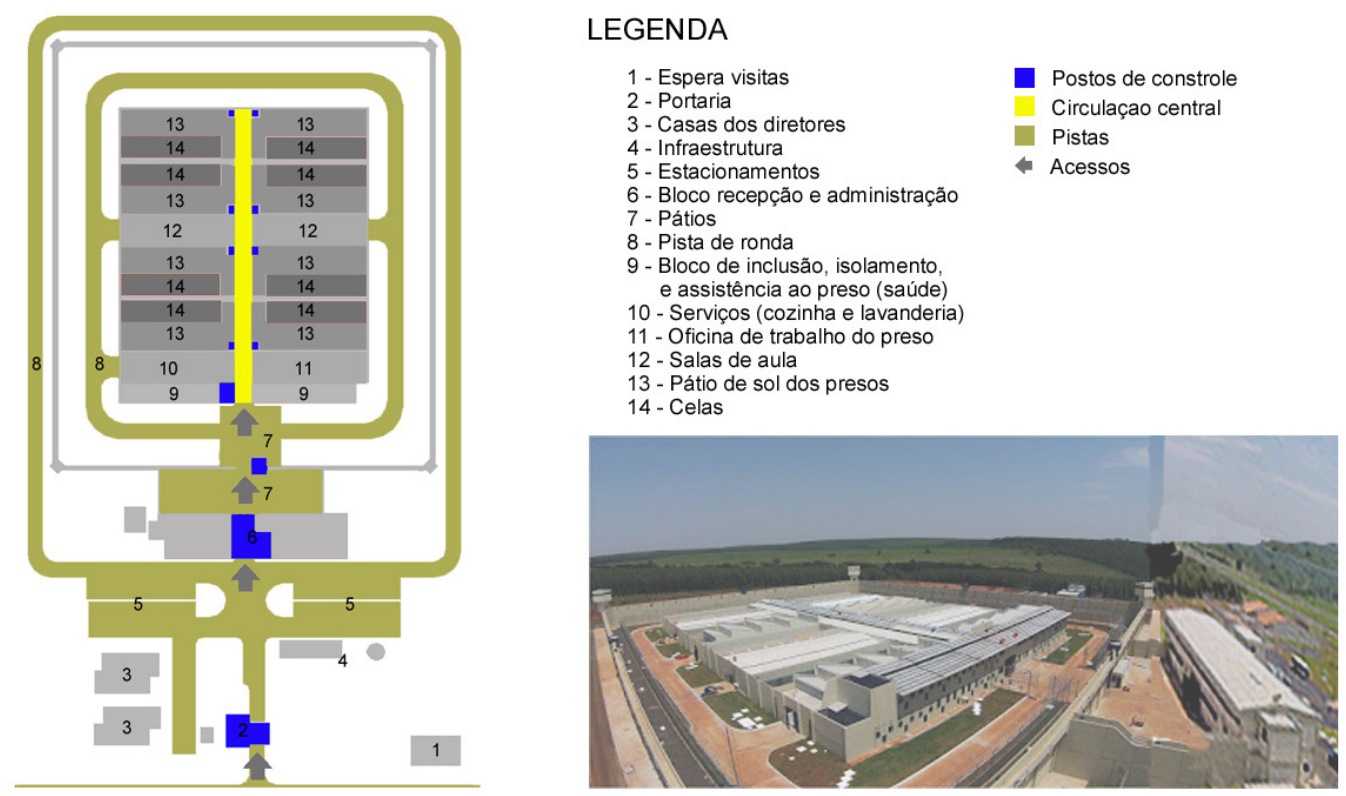

Figura 61 - Planta esquemática e fotografia da PC de Itatinga

(Fonte da fotografia: disponível em: <iptecdpitatinga/blogspot.com.br/2016_03_27_archive.html>. Acesso em: ago. 2016) 
C) Cadeia Pública do Plano Nacional de Apoio ao Sistema Penal (denominado projeto federal)

O projeto arquitetônico foi desenvolvido pelo Depen e lançado no ano de 2013 (ainda sem ocupação) ${ }^{101}$. Este projeto demonstra o melhor atendimento das regras técnicas do Ministério da Justiça. A cadeia pública é classificada como de segurança máxima, mas apresenta características de segurança média.
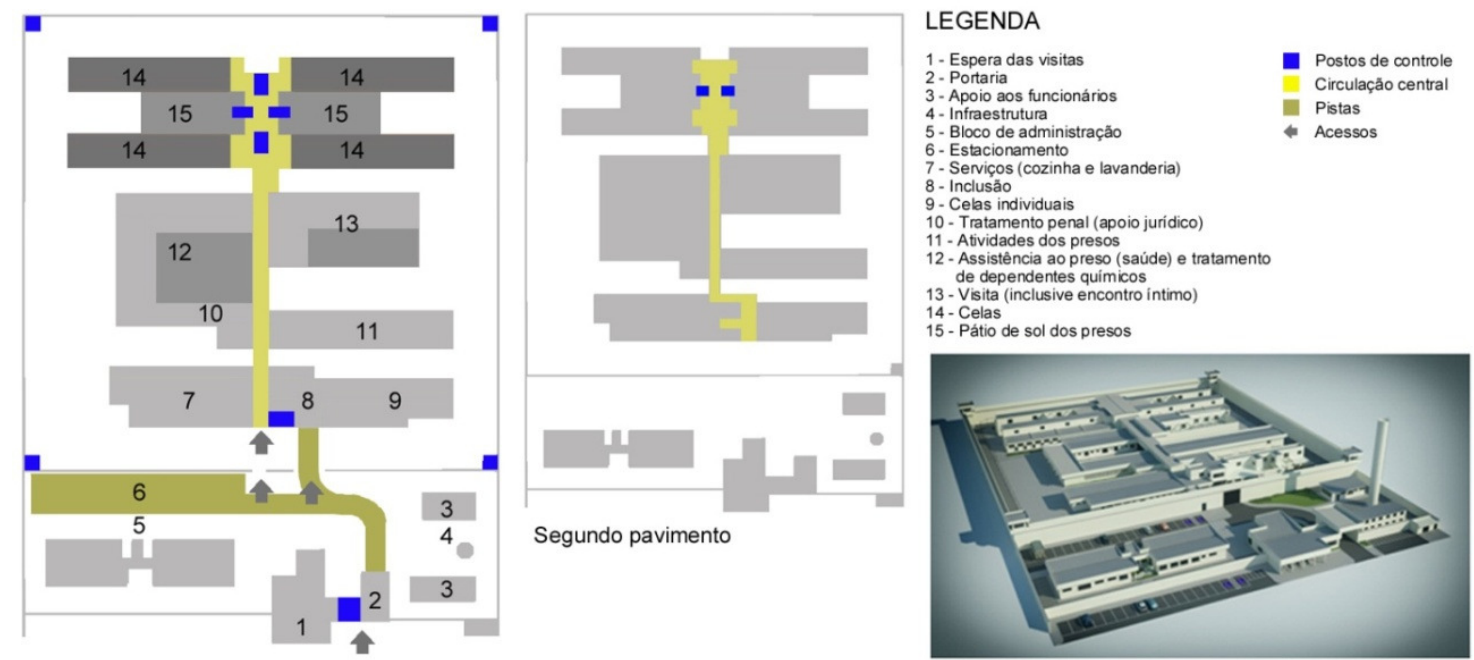

Figura 62 - Plantas esquemáticas e imagem da Cadeia Pública do Plano Nacional de Apoio ao Sistema Penal (Fonte da imagem: Depen/Ministério da Justiça, em 2016)

D) Penitenciária modelo desenvolvida pela empresa Verdi Construções S/A (projeto privado)

O projeto arquitetônico foi elaborado no ano de $2008^{102}$. Este projeto ilustra melhor a hibridização de padrões arquitetônicos penitenciários e a inovação da edificação penal, em especial com o uso de circulações exclusivas para os funcionários.

\footnotetext{
101 O projeto integra um conjunto de projetos padronizados de estabelecimentos penais de diversos tipos e categorias. Para esta tese foi selecionado o projeto denominado G3. O projeto se encontra em construção em alguns estados no ano de 2016. O projeto é caracterizado como cadeia pública porque não dispõe de área de trabalho para os presos. O projeto pode ser de pequeno ou médio porte, entre $292 \mathrm{e}$ 380 vagas, em função da capacidade das celas coletivas: seis ou oito vagas. Para esta tese foi selecionada a versão de cela com oito vagas para aproximar a proposta dos índices médios dos projetos estudados.

102 O projeto arquitetônico integra um sistema arquitetônico de estabelecimentos penais de diversos tipos e categorias. Para esta tese foi selecionado o projeto médio deste sistema. 0 mesmo foi executado com alterações pontuais na arquitetura prevista, por isto não existe um exemplar edificado fidedigno ao elaborado. O projeto selecionado adota oito vagas por cela que é o tipo aplicado nas obras mais recentes da empresa.
} 


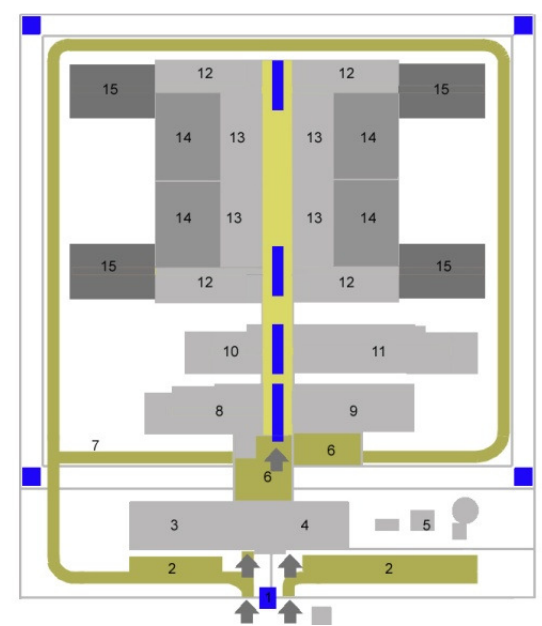

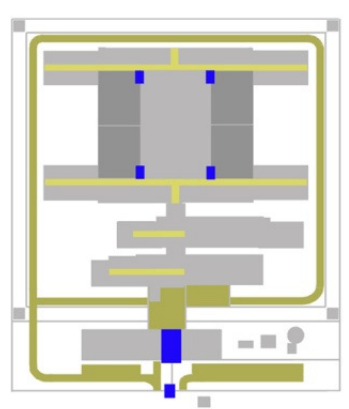

Segundo pavimento

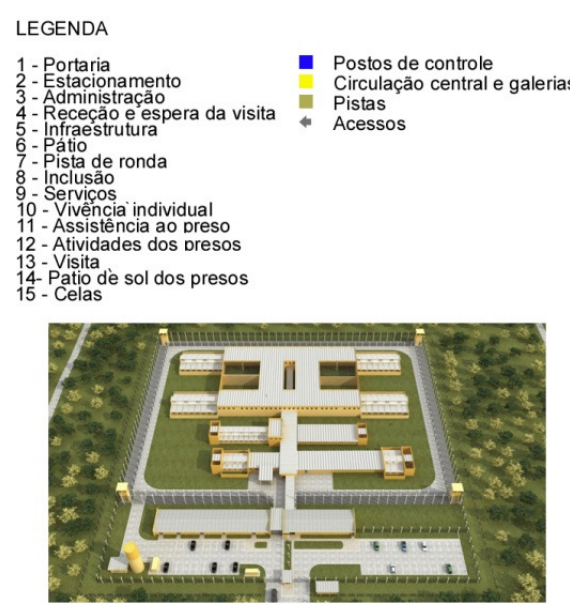

Figura 63 - Plantas esquemáticas e imagem da penitenciária modelo da empresa Verdi Construções S/A

(Fonte da imagem: ESTECA, 2014)

E) Grupo de projetos complementar

O projeto arquitetônico da Penitenciária para presos jovens adultos do Pronasci foi desenvolvido pelo Depen (2006) ${ }^{103}$. O projeto concorre com o projeto distrital, ao apresentar desenho baseado no padrão arquitetônico modular, além de se alinhar ao projeto federal, ao aplicar a totalidade das regras técnicas do Ministério da Justiça. O projeto traz características relevantes como a internalização de atividades nos blocos de vivência, a visita social e circulações exclusivas para os funcionários.
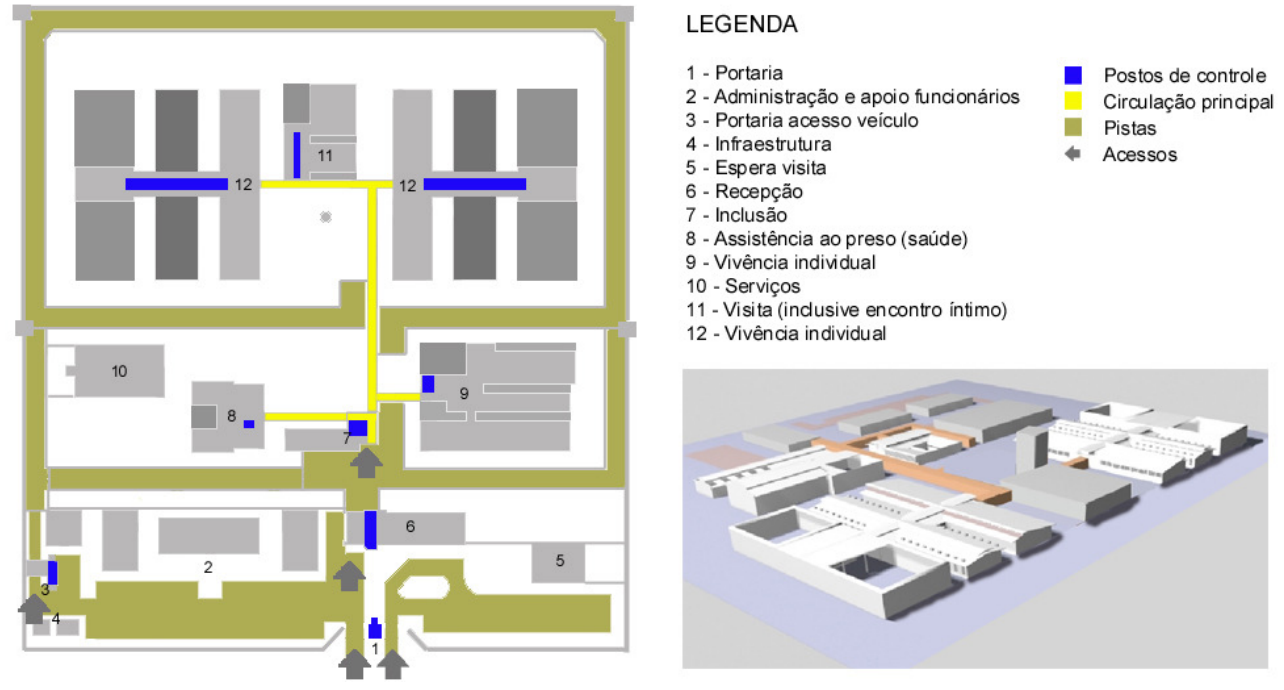

Figura 64 - Planta esquemática e imagem da penitenciária para presos jovens adultos (Pronasci) (Fonte da imagem: BRASIL, 2006)

\footnotetext{
103 O projeto integra um conjunto de projetos padronizados de estabelecimentos penais de diversos tipos e categorias. Para esta tese foi abordado o modelo escolhido pela administração penitenciária para compor o Pronasci.
} 
O projeto arquitetônico da Penitenciária modelo desenvolvido pela empresa DM Construtora de Obras foi revisado na década de 2000 , sendo abordada esta última versão. O projeto emparelha com o projeto privado, ao apresentar novidades da importação de modelo norte-americano, tais como: a ausência de torres de vigilância, celas com capacidade menor.
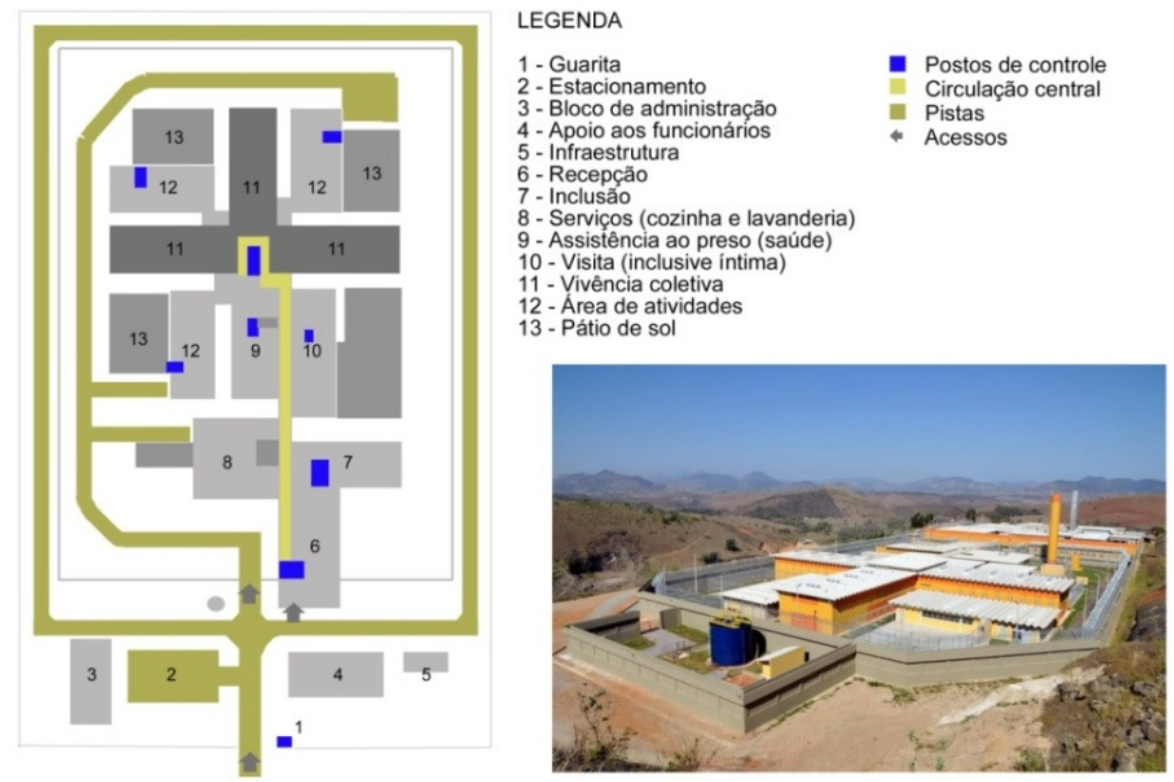

Figura 65 - Planta esquemática e fotografia de unidade feminina da empresa DM Construtora de Obras /ES (Fonte da fotografia: Disponível em: <http://www.folhavitoria.com.br/policia/noticia/2011/01/presos-fogem-depresidio-de-seguranca-maxima-de-cachoeiro.html>. Acesso em: ago. 2016)

O projeto arquitetônico da penitenciária federal foi concluído pelo Depen no ano de 2005, com o objetivo de instituir o sistema penitenciário federal, voltado para a contenção dos presos de maior potencial ofensivo do sistema nacional, sendo corriqueiramente utilizado para a aplicação do Regime Disciplinar Diferenciado ${ }^{104}$. O projeto foi trazido como exemplo de isolamento absoluto do preso, por ser dotado de celas individuais. Além disto, o projeto demonstra a relação entre o grau de segurança e a capacidade do estabelecimento penal, sendo o único da amostra classificado como de pequeno porte.

\footnotetext{
104 O projeto arquitetônico foi replicado na construção de cinco unidades: Mato Grosso do Sul, Paraná, Rondônia, Rio Grande do Norte e Distrito federal (obra em execução no ano de 2016).
} 

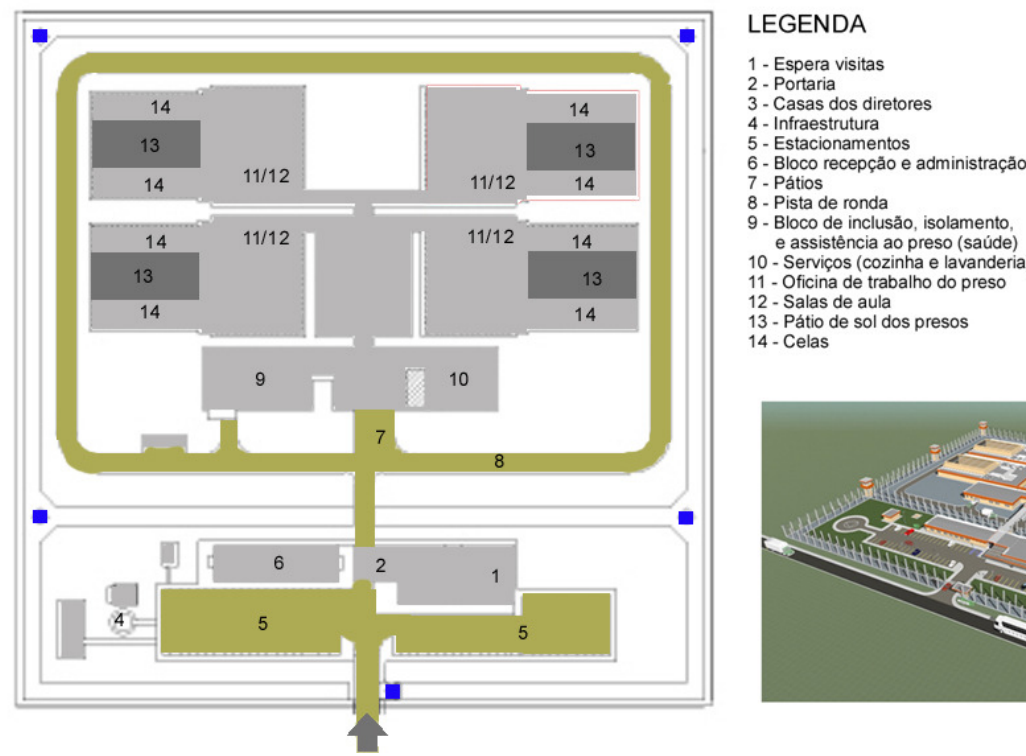

Figura 66 - Planta esquemática e imagem da penitenciária federal do Ministério da Justiça (Fonte da imagem: Depen, Ministério da Justiça)

A ADX Florence é uma unidade federal norte-americana classificada como supermax aberta no ano de $1994^{105}$. A edificação guarda uma série de particularidades: a barreira perimetral baixa; a compactação do padrão arquitetônico modular; os módulos de vivência interligados subterraneamente por corredores; e inviabilidade da orientação das pessoas nos edifícios.
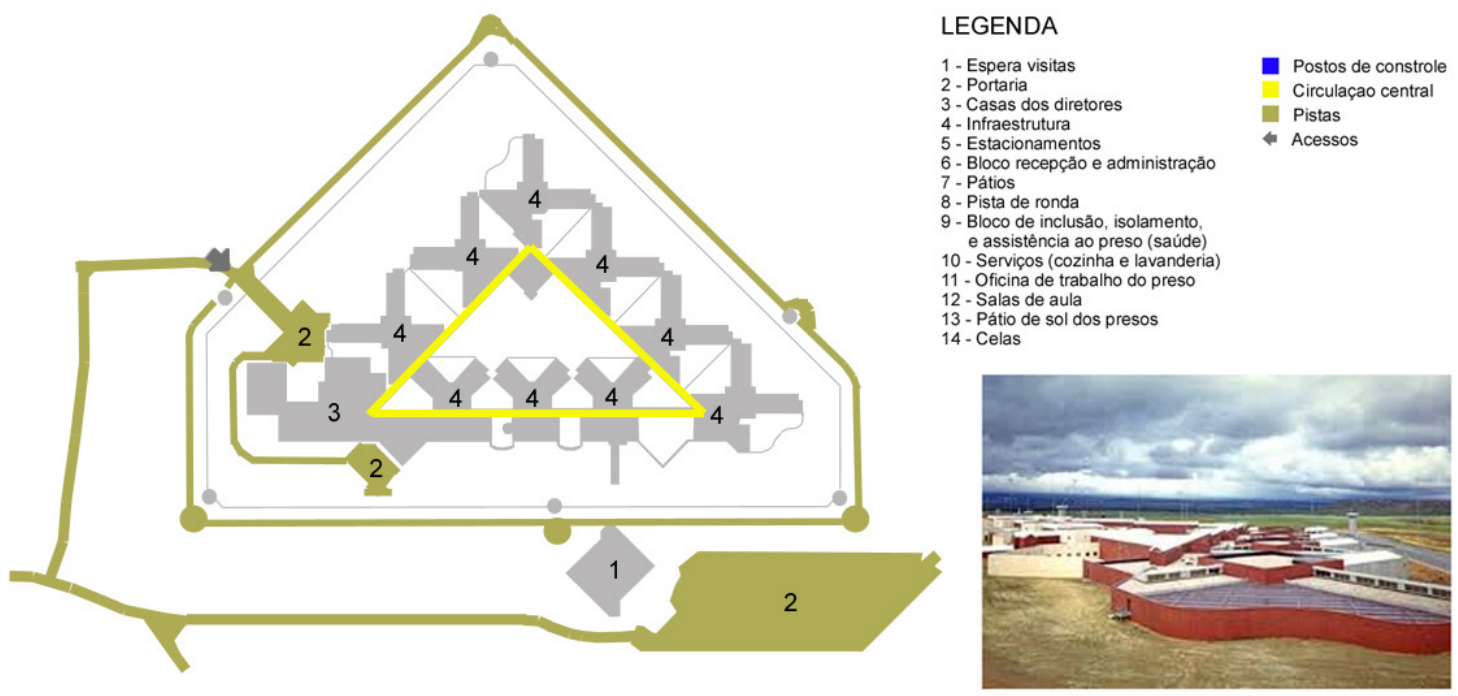

Figura 67 - Planta esquemática e imagem da ADX Florence (Fonte: USA, 2017)

\footnotetext{
105

No sistema penitenciário norte-americano, as unidades penais são classificadas segundo a segurança em seis níveis, tendo a super-max como limite superior. A penitenciária supermax é "uma altamente restritiva, unidade habitacional de custódia dentro de uma instalação de segurança, ou uma instalação de segurança inteira que isola o preso da população prisional geral e um do outro" (MORRIS apud FAIRWEATHER ; MCCONVILLE, 2000, p. 98).
} 
Os próximos projetos representam a humanização do espaço da pena. O projeto da Apac de Santa Luzia/MG ${ }^{106}$ (2006) foi concebido por um grupo de trabalho formado por membros da Congregação dos Irmãos Maristas, PUC Minas e da Arquidiocese de Belo Horizonte. O Centro de Ressocialização (CR) é um modelo do Estado de São Paulo criado nos anos 2000, que opera em parceria com organizações não governamentais com uma proposta de proximidade do preso de seu local de origem.

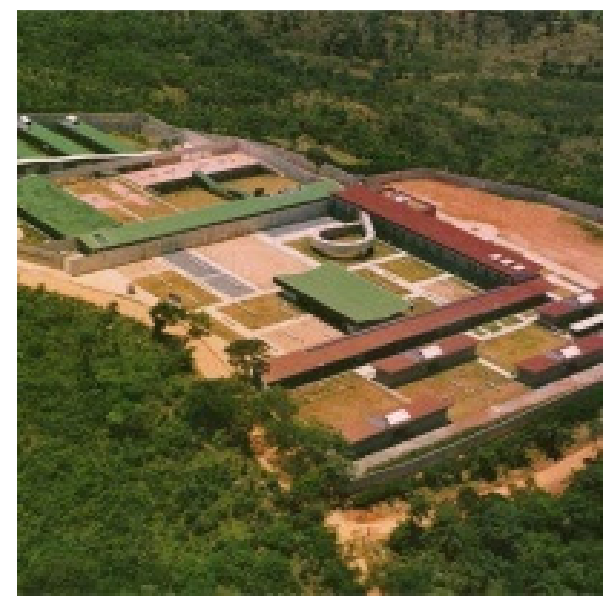

Figura 68 - Fotografia da Apac de Santa Luzia

(Fontes: Disponível em: http://noticias.r7.com/minas-gerais/presos-armados-rendem-segurancas-e-fogem-daapac-de-santa-luzia-07022017. Acessado em: fev. 2017)

O projeto arquitetônico da Halden Fengsel ilustra a maximização da humanização em uma unidade de segurança máxima. A prisão norueguesa foi inaugurada no ano de 2000 e apresenta características relevantes, tais como: celas individuais e arquitetura que simula o espaço de uma vila, com espaços diferenciados segundo as atividades.

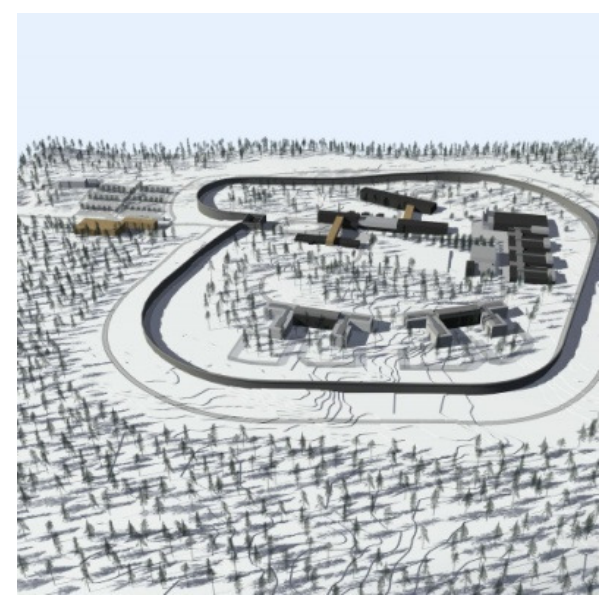

Figura 69 - Perspectiva digital da prisão de Halden Fengsel.

(Fonte: Disponível em: <http://incolors.club/collectionhdwn-halden-prison-plan.htm>. Acessado em: fev. 2017)

\footnotetext{
${ }^{106}$ A Associação de Proteção e Assistência aos Condenados (Apac) é uma entidade civil de Direito Privado dedicada à recuperação e reintegração social dos presos, por meio de um método de valorização humana, vinculada à evangelização.
} 


\section{Características físicas médias levantadas dos projetos de referência}

As médias simples dos projetos do grupo principal eventualmente eram distorcidas por amostras dissonantes que foram excluídas para resultados coerentes do ponto de vista da configuração de parâmetros de referência para a elaboração projetual. O exame realizado apontou que as distorções em alguns tópicos derivaram, na totalidade, das peculiaridades arquitetônicas da PDF II $^{107}$. Além da PDF II, houveram itens condicionados pelo projeto arquitetônico da PC, tais como o volume da cela e a proporção de área do pátio pela quantidade de vagas atendidas. As médias substituídas e os respectivos projetos excluídos do calculo foram indicados, assim como, a utilização dos projetos complementares para confirmar ou retificar a informação.

Quadro 17 - Características físicas médias dos projetos de referência

\begin{tabular}{|c|c|}
\hline \multicolumn{2}{|c|}{ Capacidade do estabelecimento penal e sociabilização dos presos } \\
\hline Item & Médias \\
\hline \multirow[t]{2}{*}{ Capacidade da unidade penal (porte) } & $\begin{array}{l}530 \text { vagas (inicial } 796 \text { vagas; } 581 \text { vagas sem a PDF; utilizou os } \\
\text { projetos complementares) }\end{array}$ \\
\hline & $\begin{array}{l}\text { A capacidade da unidade penal soma as vagas em celas coletivas e } \\
\text { individuais. O porte médio varia entre } 351 \text { e } 600 \text { vagas (ESTECA, 2010). }\end{array}$ \\
\hline Local para a participação da sociedade & Não prevê \\
\hline $\begin{array}{l}\text { Local para a visita social (nível de contato físico } \\
\text { preso e visita) }\end{array}$ & Possui salão de visita com contato físico \\
\hline $\begin{array}{l}\text { Local para a visita íntima (relação com a } \\
\text { capacidade da unidade penal) }\end{array}$ & $\begin{array}{l}10 \text { apartamentos ( } 53 \text { vagas/apart.) (inicial } 29 \text { apart.; em a PDF; } \\
\text { utilizou os projetos complementares) }\end{array}$ \\
\hline $\begin{array}{l}\text { Local para o encontro com o advogado } \\
\text { (quantidade de parlatórios e relação com a } \\
\text { capacidade da unidade penal) }\end{array}$ & Nove parlatórios, sem contato físico (110 vagas/parlatório) \\
\hline Localização do estabelecimento penal & Isolada \\
\hline \multicolumn{2}{|l|}{ Alojamento dos presos } \\
\hline Item & Médias \\
\hline Tipo de alojamento (quantidade na unidade penal) & Coletiva \\
\hline Capacidade & Nove vagas \\
\hline \multirow[t]{2}{*}{ Diversidade espacial } & Não \\
\hline & $\begin{array}{l}\text { A diversidade espacial trata de diferenças arquitetônicas entre celas de um } \\
\text { mesmo estabelecimento. }\end{array}$ \\
\hline \multirow[t]{2}{*}{$\begin{array}{l}\text { Celas de isolamento (proporção em relação à } \\
\text { capacidade da unidade penal) }\end{array}$} & $\begin{array}{l}1,50 \% \text { (inicial } 3,06 \% ; 1,35 \% \text { sem a PDF; utilizou os projetos } \\
\text { complementares) }\end{array}$ \\
\hline & $\begin{array}{l}\text { As celas de isolamento são individuais e destinadas à aplicação de medida } \\
\text { disciplinar e separação de presos com problemas de convívio. }\end{array}$ \\
\hline Localização/disposição da ala de isolamento & Bloco funcional específico \\
\hline \multicolumn{2}{|l|}{ Composição espacial do estabelecimento penal } \\
\hline Item & Médias \\
\hline \multirow[t]{2}{*}{ Partido arquitetônico } & $\begin{array}{l}\text { Partido misto baseado nos conceitos dos padrões modular e } \\
\text { paralelo, porém térreos e compactos }\end{array}$ \\
\hline & $\begin{array}{l}\text { O partido observou a aplicação dos padrões arquitetônicos penitenciários, } \\
\text { nas suas formas puras, modificadas ou combinadas, para descrever a } \\
\text { morfologia predominante. }\end{array}$ \\
\hline Geometria (número de faces do perímetro total & 104 faces, variando entre 81 e 126 faces ( 45 no bloco interno) \\
\hline
\end{tabular}

107 Estas características são atribuídas: às particularidades do modelo prisional local que utiliza serviços externos, como alimentação e assistência à saúde; à implantação em complexo penitenciário que muda a lógica do acesso e da vigilância externa da unidade penal; à especificação do padrão arquitetônico modular que exige grandes áreas de implantação e aumenta a área construída ao replicar o programa nos módulos; e ao grande porte da unidade penal que incrementa o programa arquitetônico de certas funções e procedimentos operacionais. 


\begin{tabular}{|c|c|}
\hline edificado) & $\begin{array}{l}\text { A contabilização considerou uma face qualquer planificação maior que } \\
\text { sessenta centímetros. Foram contabilizadas as diferenças entre pavimentos e } \\
\text { a interrupção das fachadas configurou diferentes faces (interrupção por } \\
\text { muro, passarela ou cobertura que corte o campo de visão). }\end{array}$ \\
\hline \multirow[t]{2}{*}{ Verticalização (ocupação) } & Dois pavimentos (Circulação exclusiva para os funcionários) \\
\hline & A verticalização não considerou as torres de vigilância na barreira perimetral. \\
\hline Centralidade e simetria & Predominam no setor interno \\
\hline \multirow[t]{2}{*}{ Continuidade } & Predomina nos setores internos \\
\hline & A continuidade considerou as interrupções entre as massas construídas. \\
\hline \multirow[t]{2}{*}{ Atividades (percentuais do programa atendido) } & $\begin{array}{l}\text { Programa relativamente completo: } 78 \% \text { (inicial } 64 \% ; 72 \% \text { sem a } \\
\text { PDF; utilizou os projetos complementares) }\end{array}$ \\
\hline & $\begin{array}{l}\text { Os percentuais dizem respeito às recomendações gerais, além do programa } \\
\text { arquitetônico e do programa discriminado nas Diretrizes Básicas. }\end{array}$ \\
\hline \multirow[t]{2}{*}{$\begin{array}{l}\text { Atividades laboreducativas dos presos (área } \\
\text { construída e proporção da mesma em relação à } \\
\text { área construída e à capacidade da unidade penal) }\end{array}$} & $\begin{array}{l}1,89 \mathrm{~m}^{2} / \text { vaga, variando entre } 1,56 \mathrm{~m}^{2} / \text { vaga e } 2,16 \mathrm{~m}^{2} / \text { vaga (inicial } \\
3,60 \mathrm{~m}^{2} / \text { vaga; } 1,89 \% \text { sem a PDF; } 2,16 \mathrm{~m}^{2} / \text { vaga com os projetos } \\
\text { complementares) }\end{array}$ \\
\hline & Considera as oficinas e salas de aula. \\
\hline \multirow{2}{*}{$\begin{array}{l}\text { Atividades socializantes (área construída e } \\
\text { proporção da mesma em relação à área construída } \\
\text { e à capacidade da unidade penal) }\end{array}$} & $\begin{array}{l}2,31 \mathrm{~m}^{2} / \text { vaga, variando entre } 2,06 \mathrm{~m}^{2} / \text { vaga até } 2,51 \mathrm{~m}^{2} / \text { vaga (inicial } \\
3,63 \mathrm{~m}^{2} / \text { vaga; } 2,51 \% \text { sem a PDF) }\end{array}$ \\
\hline & $\begin{array}{l}\text { Considera os locais de realização da visita social e íntima (se for o caso, } \\
\text { considera os pátios de sol dos presos), além do local para o encontro } \\
\text { reservado com o advogado (parlatório). }\end{array}$ \\
\hline Setorização & Setor externo, mais intermediário e interno conjugados \\
\hline $\begin{array}{l}\text { Setorização - proporção da área construída em } \\
\text { relação à área construída da unidade penal }\end{array}$ & $\begin{array}{l}\text { Externo: } 10 \% \text {; Intermediário: } 10 \% \text { a } 20 \% \text {; Interno: } 70 \% \text { a } 80 \% \text { (inicial } \\
8 \%, 22 \% \text { e } 70 \% \text { com a PDF) }\end{array}$ \\
\hline \multirow{2}{*}{$\begin{array}{l}\text { Territorialidade - proporção da área construída } \\
\text { dos territórios em relação à área construída da } \\
\text { unidade penal }\end{array}$} & Livre: $8 \%$ a $14 \%$; Vigiado: $60 \%$ a $74 \%$; Proibido: $12 \%$ a $30 \%$ \\
\hline & $\begin{array}{l}\text { Considera locais livres aqueles sem possibilidade de vigilância } \\
\text { (eventualmente, pelo risco aos funcionários), locais vigiados aqueles com } \\
\text { postos ou pontos de vigilância (presença de funcionários) e proibidos aqueles } \\
\text { sem a presença de presos (incluindo postos de controle). }\end{array}$ \\
\hline $\begin{array}{l}\text { Localização das atividades laboreducativas dos } \\
\text { presos }\end{array}$ & Tende a ser Internalizada \\
\hline Localização da visita social & Setor \\
\hline Localização do encontro com o advogado & Setor interno \\
\hline \multirow{2}{*}{$\begin{array}{l}\text { Camadas topológicas (quantidade total de } \\
\text { camadas/apenas nos setores internos) }\end{array}$} & 18 camadas, variando entre 16 e 20 ( 12 camadas no setor interno) \\
\hline & $\begin{array}{l}\text { O número de camadas topológicas no percurso a pé entre a camada mais } \\
\text { externa (acesso da unidade penal) e a camada mais interna dos projetos. }\end{array}$ \\
\hline Última camada topológica & Cela coletiva \\
\hline $\begin{array}{l}\text { Bloco de vivência (quantidade, capacidade e } \\
\text { proporção ente as áreas construídas do bloco e da } \\
\text { unidade penal) }\end{array}$ & $\begin{array}{l}\text { Quatro blocos, variando até seis blocos ( } 75 \%)-140 \text { a } 144 \text { vagas } \\
\text { (inicial } 215 \text { vagas; } 140 \text { sem a PDF; utilizou os complementares) }\end{array}$ \\
\hline $\begin{array}{l}\text { Distribuição dos presos (alas por bloco de } \\
\text { vivência) }\end{array}$ & Uma ala por bloco, variando até duas alas \\
\hline Capacidade ala carcerária & 108 vagas \\
\hline \multirow[t]{2}{*}{ Área do terreno } & $\begin{array}{l}27,40 \text { mil m², variando até } 39,50 \mathrm{mil} \mathrm{m}^{2} \text { (inicial } 37 \mathrm{mil} \mathrm{m}^{2} ; 16,83 \mathrm{mil} \\
\mathrm{m}^{2} \text { sem a PDF; utilizou os complementares) }\end{array}$ \\
\hline & A área considera o perímetro de segurança (afastamento externo). \\
\hline Dimensões do terreno (frente e fundo) & $143 \times 191 \mathrm{~m}$, variando até $182 \times 212 \mathrm{~m}$ \\
\hline Área construída da unidade penal & $\begin{array}{l}8,42 \mathrm{mil} \mathrm{m}{ }^{2} \text {, variando até } 12,87 \mathrm{~m}^{2} / \text { vaga (inicial } 12,87 \mathrm{mil} \mathrm{m}^{2} ; 8 \mathrm{mil} \\
\mathrm{m}^{2} \text { sem a PDF; utilizou os complementares) }\end{array}$ \\
\hline $\begin{array}{l}\text { Índice da área de terreno pela capacidade da } \\
\text { unidade penal }\end{array}$ & $\begin{array}{l}35,88 \mathrm{~m}^{2} / \text { vaga, variando até } 49,09 \mathrm{~m}^{2} / \text { vaga (inicial } 42,33 \mathrm{~m}^{2} / \text { vaga; } \\
35,88 \mathrm{~m}^{2} / \text { vaga sem a PDF; utilizou os complementares) }\end{array}$ \\
\hline $\begin{array}{l}\text { Índice da área construída total pela capacidade da } \\
\text { unidade penal }\end{array}$ & $\begin{array}{l}18,70 \mathrm{~m}^{2} / \text { vaga, variando até } 16,20 \mathrm{~m}^{2} / \text { vaga (inicial } 16,20 \mathrm{~m}^{2} / \text { vaga; } \\
18,70 \mathrm{~m}^{2} / \text { vaga sem a PDF) }\end{array}$ \\
\hline Taxa ocupação & $38 \%$, variando até $31 \%$ \\
\hline \multirow[t]{2}{*}{$\begin{array}{l}\text { Distancias entre as celas e o pátio de sol dos } \\
\text { presos/ a atividades dos presos/ a visita social }\end{array}$} & $\begin{array}{l}\text { Pátio de sol: entre } 31 \text { e } 42 \mathrm{~m} \text {; atividades dos presos: entre } 42 \text { e } 93 \mathrm{~m} \text {; } \\
\text { visita social: entre } 63 \text { e } 89 \mathrm{~m}\end{array}$ \\
\hline & $\begin{array}{l}\text { As distancias entre os locais dizem respeito ao percurso realizado pelas } \\
\text { pessoas nas circulações do estabelecimento penal de porta a porta, } \\
\text { considerando a situação mais crítica: por exemplo, a cela mais ao fundo. }\end{array}$ \\
\hline $\begin{array}{l}\text { Distancias entre o acesso da unidade penal e o } \\
\text { encontro com o advogado/ a visita social }\end{array}$ & Encontro com o advogado: $89 \mathrm{~m}$; visita social: $160 \mathrm{~m}$ \\
\hline
\end{tabular}




\begin{tabular}{|c|c|}
\hline capacidade da unidade penal (proporção em & 1,24 sem o projeto federal) \\
\hline relação ao setor interno) & $\begin{array}{l}\text { Considerou-se a circulação principal do estabelecimento penal que interliga } \\
\text { os setores e blocos funcionais e define os fluxos nos mesmos. }\end{array}$ \\
\hline $\begin{array}{l}\text { Área de circulação (proporção em relação à área } \\
\text { construída total) }\end{array}$ & $15 \%$, variando entre $11 \%$ e $19 \%$ \\
\hline Largura da circulação central & $4,60 \mathrm{~m}$ \\
\hline Geometria da circulação principal (característica e & Linear e ortogonal; 15 pontos de derivação, variando até 30 pontos \\
\hline pontos de derivação) & $\begin{array}{l}\text { A circulação principal diz respeito à via que atravessa e interliga os setores } \\
\text { intermediário e interno do estabelecimento penal até a última camada } \\
\text { topológica, considerando ainda os fluxos nos blocos funcionais. Os pontos } \\
\text { somam as ocorrências. A circulação exclusiva para os funcionários foi } \\
\text { contabilizada. }\end{array}$ \\
\hline Anéis topológicos & Três anéis \\
\hline Circulações verticais (usuários) & Três escadas (funcionários) \\
\hline Fechamento da circulação & Pista no setor externo e pátio mais corredor nos setores internos \\
\hline Conflitos entre os fluxos & 35 pontos, variando até 75 pontos \\
\hline Acesso a unidade penal & Acesso único \\
\hline Rota de escape & Não \\
\hline Perímetro total das edificações (proporção em & $1.398 \mathrm{~m}$, variando entre $1.300 \mathrm{~m}$ e $1.500 \mathrm{~m}$ (76\% no setor interno) \\
\hline relação aos setores internos) & $\begin{array}{l}\text { O perímetro das edificações considera os principais blocos, o que exclui a } \\
\text { infraestrutura, portarias, guaritas, torres e construções incomuns, como as } \\
\text { casas dos diretores no projeto paulista. }\end{array}$ \\
\hline $\begin{array}{l}\text { Índices de fachada pela capacidade e pela área } \\
\text { construída da unidade penal }\end{array}$ & $2,13 \mathrm{~m} /$ vaga e $0,13 \mathrm{~m} / \mathrm{m}^{2}$, variando até $1,17 \mathrm{~m} /$ vaga e $0,08 \mathrm{~m} / \mathrm{m}^{2}$ \\
\hline Aberturas de iluminação e ventilação & $\begin{array}{l}\text { Subdimensionadas, direta, sem zenital, ventilação cruzada nos } \\
\text { blocos externos, sem controle de abertura nas celas }\end{array}$ \\
\hline Aparatos de segurança & $\begin{array}{l}\text { Abertura remota de portas, aberturas com grades, portas com } \\
\text { portinholas, contenções em grades, controles com visores em grade, } \\
\text { pátios com tela }\end{array}$ \\
\hline Cercas divisórias internas & Predominam nas passagens entre setores \\
\hline Controle & \\
\hline Item & Médias \\
\hline Tipo vigilância & Vigilância indireta e direta \\
\hline Áreas internas controladas & $\begin{array}{l}62 \% \text { ( } 68 \% \text { no setor interno), variando até } 70 \% \text { (inicial 53\%; } 62 \% \text { sem } \\
\text { o projeto paulista; utilizou os complementares) }\end{array}$ \\
\hline & $\begin{array}{l}\text { O percentual considera a área dos ambientes monitorados nos blocos de } \\
\text { vivência em relação à área total destes blocos. }\end{array}$ \\
\hline Áreas externas controladas e pontos cegos & $93 \%$ e sete pontos cegos \\
\hline & $\begin{array}{l}\text { O percentual considera a área externa os espaços não edificados intramuros. } \\
\text { O percentual é calculado com base na isovista das áreas externas com } \\
\text { pontos de geração nas torres de vigilância e, eventualmente, pelos postos de } \\
\text { controle que tem visibilidade destas áreas. }\end{array}$ \\
\hline Vigilância das coberturas & $100 \%$ \\
\hline Torres vigilância e postos de controle & $\begin{array}{l}\text { Quatro torres; nove postos ( } 67 \text { vagas/posto) (inicial } 11 \text { postos; } 8 \\
\text { postos sem a PDF; utilizou os complementares) }\end{array}$ \\
\hline $\begin{array}{l}\text { Circulação exclusiva (área e percentual área } \\
\text { construída) }\end{array}$ & $\begin{array}{l}\text { Circulação exclusiva nos locais com presos. } \\
17 \% \text {, variando até } 8 \%\end{array}$ \\
\hline Circulação vigiada & $63 \%$, variando até $82 \%$ (inicial 51\%; 63\% sem a PDF) \\
\hline
\end{tabular}

Quadro 18 - Características físicas médias dos elementos centrais da edificação penal

\begin{tabular}{|l|l|}
\hline \multicolumn{1}{|c|}{ Barreira perimetral Item } & \multicolumn{1}{c|}{ Médias } \\
\hline Tipo & Cerca em tela, estrutura tubular metálica com viga baldrame \\
\hline Geometria & Retangular, plana \\
\hline Perímetro & $495,00 \mathrm{~m}$ (inicial 633,73m; 495m sem a PDF) \\
\cline { 2 - 2 } & $\begin{array}{l}\text { O perímetro considera a barreira de segurança correspondente ao setor } \\
\text { interno. }\end{array}$ \\
\hline Altura & $6,45 \mathrm{~m}$ \\
\hline Proteção circulação guarda externa & Proteção variável e acesso exclusivo \\
\hline Aparatos de segurança & Possui aparatos de segurança \\
\hline Linha de tiro & Possui linha de tiro (3m de altura, afastada em 5m) \\
\hline Afastamento & $19 \mathrm{~m}$ (utilizou os complementares) \\
\hline
\end{tabular}




\begin{tabular}{|c|c|}
\hline & $\begin{array}{l}\text { O afastamento considera as distancias entre os blocos de vivência e a } \\
\text { barreira perimetral. }\end{array}$ \\
\hline \multirow[t]{2}{*}{ Perímetro de segurança } & $11 \mathrm{~m}$ (inicial 6m sem a PDF; $11 \mathrm{~m}$ com os complementares) \\
\hline & $\begin{array}{l}\text { O perímetro de segurança considera as distancias entre a barreira perimetral } \\
\text { e a cerca limítrofe do terreno. }\end{array}$ \\
\hline \multirow[t]{2}{*}{ Pista de ronda } & Possui pista externa \\
\hline & $\begin{array}{l}\text { O item considera a localização da pista de ronda em relação à barreira } \\
\text { perimetral. }\end{array}$ \\
\hline \multicolumn{2}{|r|}{ 1 } \\
\hline Item & Médias \\
\hline Geometria & Prisma reto de base retangular \\
\hline Atividades & Dormitório, higiene pessoal \\
\hline Serviços de higiene pessoal & Cuba, chuveiro e vaso. \\
\hline Mobiliário & Quatro beliches, prateleiras e divisórias baixas \\
\hline Descrição do espaço & $\begin{array}{l}\text { Acesso e circulação centrais com beliches laterais junto às paredes e } \\
\text { banheiro ao fundo. }\end{array}$ \\
\hline Atividades (proporção da área útil) & Dormitório 44\%; Circulação 44\%; Banheiro 12\% \\
\hline Dimensões & $3,15 \mathrm{~m} \times 5,70 \mathrm{~m} \times 3,17 \mathrm{~m}$ \\
\hline Área útil & $18,26 \mathrm{~m}^{2}$ \\
\hline Volume & $\begin{array}{l}40,75 \mathrm{~m}^{3} \text { (inicial } 58,16 \mathrm{~m}^{3} ; 43,49 \mathrm{~m}^{3} \text { sem a PDF; } 40,75 \mathrm{~m}^{3} \text { com os } \\
\text { complementares) }\end{array}$ \\
\hline \multirow[t]{2}{*}{ Índice da área útil pela capacidade da cela } & $2,00 \mathrm{~m}^{2} /$ vaga \\
\hline & O índice calcula a proporção de área da cela pela capacidade da mesma. \\
\hline \multirow[t]{2}{*}{ Índice do volume pela capacidade da cela } & $6,2 \mathrm{~m}^{3} /$ vaga \\
\hline & O índice calcula a proporção de área da cela pela capacidade da mesma. \\
\hline Aberturas de iluminação e ventilação & $\begin{array}{l}\text { Abertura direta, do tipo brise, sem controle e sem ventilação } \\
\text { cruzada (utilizou os complementares) }\end{array}$ \\
\hline \multirow[t]{2}{*}{ Área das aberturas de iluminação e ventilação } & $2,73 \mathrm{~m}^{2}(13,65 \%)$ (inicial $16,42 \% ; 13,65 \%$ sem o projeto federal) \\
\hline & $\begin{array}{l}\text { Informa a relação entre a área das aberturas de iluminação e ventilação e a } \\
\text { área da cela. }\end{array}$ \\
\hline Porta de acesso & Porta de correr \\
\hline Largura da circulação & $1,53 \mathrm{~m}$ \\
\hline $\begin{array}{l}\text { Aparatos de segurança nas aberturas de } \\
\text { iluminação e ventilação }\end{array}$ & Variável \\
\hline Fechamento da cela para a instituição & Abertura parcial. Visualização pela porta. \\
\hline \multirow{2}{*}{ Visualização do interior da cela } & $58 \%$ \\
\hline & $\begin{array}{l}\text { O percentual é calculado com base na isovista do interior da cela, em relação } \\
\text { à área, com ponto de geração nas aberturas voltadas para o local de acesso } \\
\text { da mesma (brises, porta e visores). }\end{array}$ \\
\hline \multicolumn{2}{|r|}{ 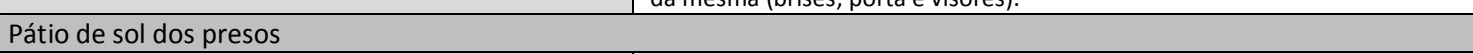 } \\
\hline Item & Médias \\
\hline Atividades & Banho de sol, esportes, lazer, refeições e cultos \\
\hline Separação dos grupos de presos & Um pátio por ala carcerária \\
\hline \multirow[t]{2}{*}{ Capacidade e demanda } & 215 presos; 136 vagas (inicial 372 presos e 214 vagas; sem a PDF) \\
\hline & $\begin{array}{l}\text { A capacidade diz respeito ao número máximo de presos suportado pelo } \\
\text { espaço do pátio, contabilizando as áreas coberta e descoberta, com base nas } \\
\text { Diretrizes Básicas. A demanda corresponde à capacidade das alas carcerárias } \\
\text { atendidas pelo pátio, sem considerar revezamento no uso do local. }\end{array}$ \\
\hline Geometria & Retangular, plana. \\
\hline Composição espacial & Pátios descoberto e coberto contíguos \\
\hline Serviços e facilidades & 04 sanitários; 03 cubas; mesas e bancos \\
\hline Cantina & Possui distribuição \\
\hline $\begin{array}{l}\text { Dimensões e áreas úteis do pátio (coberta + } \\
\text { descoberta) }\end{array}$ & $\begin{array}{l}11,30 \times 25,85 \mathrm{~m} \times 6,07 \mathrm{~m} ; 273 \mathrm{~m}^{2} \text { (inicial } 15,07 \times 30,07 \mathrm{~m} \text { e } 477 \mathrm{~m}^{2} ; \mathrm{sem} \\
\text { a PDF) }\end{array}$ \\
\hline \multirow[t]{2}{*}{ Área útil pela capacidade e pela demanda } & $1,27 \mathrm{~m}^{2} /$ vaga; $2,39 \mathrm{~m}^{2} /$ vaga \\
\hline & $\begin{array}{l}\text { A capacidade projetada foi calculada com base na área mínina exigida pelas } \\
\text { Diretrizes Básicas. A capacidade demandada corresponde à capacidade das } \\
\text { alas carcerárias atendidas pelo local. }\end{array}$ \\
\hline Área descoberta & $163,80 \mathrm{~m}^{2}$ (inicial $303,42 \mathrm{~m}^{2} ;$ sem a PDF) \\
\hline \multirow[t]{2}{*}{ Capacidade e demanda da área descoberta } & $\begin{array}{l}163 \text { presos; } 1,07 \mathrm{~m}^{2} / \text { vaga (inicial } 198 \text { presos e } 1,50 \mathrm{~m}^{2} / \text { vaga; sem a } \\
\text { PDF e a PC). }\end{array}$ \\
\hline & $\begin{array}{l}\text { A capacidade projetada foi calculada com base na área mínina exigida pelas } \\
\text { Diretrizes Básicas. A capacidade demandada corresponde à capacidade das }\end{array}$ \\
\hline
\end{tabular}




\begin{tabular}{|c|c|}
\hline & alas carcerárias atendidas pelo local. \\
\hline Área coberta & $109,43 \mathrm{~m}^{2}$ (inicial $173,57 \mathrm{~m}^{2}$; sem a PDF) \\
\hline \multirow[t]{2}{*}{ Capacidade da área coberta/demanda } & $\begin{array}{l}109 \text { presos; } 0,71 \mathrm{~m}^{2} / \text { vaga (inicial } 173 \text { presos e } 0,89 \mathrm{~m}^{2} / \text { vaga; sem a } \\
\text { PDF e a PC) }\end{array}$ \\
\hline & $\begin{array}{l}\text { A capacidade projetada foi calculada com base na área mínina exigida pelas } \\
\text { Diretrizes Básicas. A capacidade demandada corresponde à capacidade das } \\
\text { alas carcerárias atendidas pelo local. }\end{array}$ \\
\hline Aberturas de iluminação e ventilação & Apenas a abertura superior do pátio \\
\hline Aparatos de segurança & Grade na abertura superior do pátio \\
\hline \multirow[t]{2}{*}{ Visualização do interior do pátio } & 99\% (possui posto de controle) \\
\hline & $\begin{array}{l}\text { O percentual é calculado com base na isovista do interior do pátio, com } \\
\text { ponto de geração nos postos de controle (quando o mesmo existir). }\end{array}$ \\
\hline \multicolumn{2}{|l|}{ Posto de controle ${ }^{108}$} \\
\hline Item & Médias \\
\hline Geometria e localização & Retangular, variável \\
\hline Visualização & Visores com grade vertical, piso elevado ou pavimento superior \\
\hline Área dos visores (relação com a área de piso) & 7,0 a $9,0 m^{2}-50 \%$ a $70 \%$ \\
\hline Inverificabilidade & Variável \\
\hline Circulação exclusiva & Predominante nos setores internos \\
\hline Composição & Planta livre \\
\hline Sanitários & Sim \\
\hline Mobiliário & Não \\
\hline Área e diâmetro mínimo & Entre $13,25 \mathrm{~m}^{2}$ e $15,85 \mathrm{~m}^{2} ; 2,45 \mathrm{~m}$ \\
\hline Aberturas de iluminação e ventilação & Variável \\
\hline Controle remoto de portas & Predomina o controle remoto mecânico \\
\hline Aparatos de segurança & Grades e fechamentos nos visores \\
\hline
\end{tabular}

\section{Dados econômicos dos projetos de referência}

A exposição dos dados financeiros abrange os custos de construção e operação de estabelecimentos penais representativos dos projetos arquitetônicos de referência. De uma forma geral, as informações financeiras tratam da área construída, capacidade e custo de construção de estabelecimentos penais. O cruzamento destas informações gerou indexações, como o custo de construção do metro quadrado e da vaga. Os custos de construção do grupo de referência principal foram definidos com base nos orçamentos de obra iniciais, a partir de fontes diversas ${ }^{109}$. Os custos operacionais das unidades prisionais não foram obtidos, sendo conseguidos dados quanto ao contingente de agentes de segurança e os salários médios pagos pelas unidades federativas ${ }^{110}$.

\footnotetext{
108

${ }^{108}$ A descrição abordou os postos dos setores internos, submetidos ao contato com os presos, principalmente nos pátios de sol dos presos.

109 O custo obtidos: PDF (ESTECA, 2010). Os valores da PC e da cadeia pública federal foram fornecidos pelos órgãos penitenciários do estado de São Paulo (licitações do ano de 2014) e do Ministério da Justiça (estimativa do órgão). A empresa Verdi Construções S/A proveu dados de obras recentes, em particular da Penitenciária Industrial de Blumenau (SC). Penitenciária para presos jovens adultos e da penitenciária federal (ESTECA, 2010 ; BRASIL, 2007). Os valores dos projetos do centro de ressocialização e da Apac foram encontrados nos endereços eletrônicos. Os valores das obras da ADX Florence e da Halden Fengsel foram retirados da Wikipédia (disponíveis em: <https://en.wikipedia.org/wiki/ADX_Florence> e <https://en.wikipedia.org/wiki/Halden_Prison>. Acessados em fev. 2017). Todos os valores foram atualizados pelo INCC para março de 2016 (valores aproximados): custo da Penitenciária do Distrito Federal no ano de 2010 era de R\$ 65 milhões; custo da Penitenciária Compacta no ano de 2014 era de R\$ 53,5 milhões; custo da Cadeia Pública no ano de 2012 era de R\$11,2 milhões; custo da Penitenciária para Jovens Adultos do Pronasci no ano de 2009 era de R\$ 27,5 milhões; custo da Penitenciária modelo da empresa DM Construtora de Obras no ano de 2007 era de $R \$ 18,6$ milhões. As médias não consideram as variações em itens relevantes para a construção penal (aço, concreto). O custo de construção não contabiliza o valor do terreno. Os índices de custo por vaga e custo por área são resultado de médias aritméticas simples.

${ }^{110} \mathrm{O}$ número de agentes de segurança dos projetos paulista e privado foram levantados nas visitas realizadas às unidades de Pinheiros 2 SP e Penitenciária Industrial de Blumenau - SC (Apêndice C, desta tese). Para o projeto distrital, estes dados foram levantados em reuniões
} 
Tabela 16 - Características econômicas dos projetos de referência

\begin{tabular}{|c|c|c|c|c|c|c|c|}
\hline \multicolumn{8}{|c|}{ Grupo principal } \\
\hline Projeto & $\begin{array}{c}\text { Custo } \\
\text { Construção } \\
\text { (R\$ x milhões) }\end{array}$ & $\begin{array}{l}\text { Capacidade } \\
\text { (vagas) }\end{array}$ & $\begin{array}{c}\text { Área } \\
\text { Construída } \\
\left(\mathrm{m}^{2}\right)\end{array}$ & $\begin{array}{c}\text { Custo/ } \\
\text { Área } \\
\left(\mathrm{R} \$ \mathrm{~m}^{2}\right)\end{array}$ & $\begin{array}{c}\text { Custo/ } \\
\text { Capacidade } \\
\text { (R\$̦/vaga) }\end{array}$ & $\begin{array}{c}\text { Área } \\
\text { construída/ } \\
\text { capacidade } \\
\left(\mathrm{m}^{2} / \text { vaga) }\right.\end{array}$ & $\begin{array}{l}\text { Agentes/ } \\
\text { capacidade } \\
\text { (agente/ } \\
\text { vaga) }\end{array}$ \\
\hline PDF & 97,0 & 1584 & 27.555 & $3.520,23$ & $61.237,37$ & 17,39 & $1 / 44$ \\
\hline PC & 59,5 & 768 & 8.890 & $6.692,91$ & $77.473,95$ & 11,57 & $1 / 32$ \\
\hline Padrão MJ & 14,5 & 374 & 6.950 & $2.090,76$ & $38.852,40$ & 18,58 & $1 / 23$ \\
\hline $\begin{array}{l}\text { Modelo } \\
\text { empresa }\end{array}$ & 35,0 & 578 & 8.440 & $4.144,49$ & $60.500,00$ & 14,60 & $1 / 25$ \\
\hline Média & 51,5 & 826 & $12.958,75$ & $4.112,09$ & $59.515,93$ & 15,54 & $1 / 31$ \\
\hline \multicolumn{8}{|c|}{ Grupo complementar } \\
\hline Jovens Adultos & 43,7 milhões & 421 & $9.248,66$ & $4.725,00$ & $103.800,47$ & 21,97 & - \\
\hline Modelo DM & 34,8 milhões & 432 & $8.718,00$ & $3.991,74$ & $80.555,55$ & 20,18 & - \\
\hline \multicolumn{8}{|c|}{ Grupo complementar - projetos comparativos } \\
\hline $\begin{array}{c}\text { Penitenciária } \\
\text { Federal }\end{array}$ & 35,9 milhões & 208 & 12.760 & $2.813,48$ & $172.596,15$ & 61,35 & - \\
\hline $\mathrm{CR}$ & 11,5 & 210 & 2.970 & $3.872,05$ & $54.761,90$ & 14,14 & - \\
\hline Apac & 26,7 & 200 & 6.700 & $3.985,07$ & $133.500,00$ & 33,50 & - \\
\hline ADX Florence & 60,0 (US\$) & 408 & 22.500 & $2.666,66$ & $64.724,91$ & 24,27 & $1 / 1$ \\
\hline Halden Fengsel & 252,0 (US\$) & 252 & 26.000 & - & - & 103,17 & - \\
\hline
\end{tabular}

Alguns custos específicos foram calculados para embasar os procedimentos realizados, tais como, das barreiras perimetrais do tipo muro e cerca, além da cela. Para o pátio de sol dos presos se verificou a aplicação de valores idênticos aos das edificações da prisão, especificamente no projeto privado, por isto se adotou o valor médio calculado. Não foi possível deduzir o custo dos postos de controle nos orçamentos obtidos. Para a composição dos custos específicos, os custos unitários foram retirados de planilha genérica da empresa Verdi Construções S/A (data base no ano de 2016) e de planilha padrão de obra de penitenciária compacta paulista, integrante do Relatório de Análise do Sistema Construtivo Penitenciário, cujos valores foram ajustados para março de 2016 (BRASIL, 2007). Os sistemas penitenciários contatados nesta pesquisa não forneceram informações sobre o custeio das unidades prisionais. Foram obtidos os salários dos funcionários.

Tabela 17 - Custos específicos de construção e operação

\begin{tabular}{|c|c|c|c|c|c|c|c|c|c|}
\hline \multirow{2}{*}{ Projeto } & \multicolumn{2}{|c|}{ Barreira Perimetral } & \multicolumn{3}{c|}{ Cela } & \multicolumn{2}{c|}{ Pessoal } & \multicolumn{2}{c|}{ Custo } \\
\cline { 2 - 10 } & $\begin{array}{c}\text { Custo } \\
(\mathrm{R} \$ \mathrm{~m})\end{array}$ & $\%$ & $\begin{array}{c}\text { Custo } \\
\left(\mathrm{R} \$ / \mathrm{m}^{2}\right)\end{array}$ & $\begin{array}{c}\text { Custo } \\
(\mathrm{R} \$ / \mathrm{vaga})\end{array}$ & $\%$ & Equipe & Efetivo & $\begin{array}{c}\text { Preso } \\
(\mathrm{R} \$ / \mathrm{mês})\end{array}$ & $\begin{array}{c}\text { Salário } \\
(\mathrm{R} \$)\end{array}$ \\
\hline PDF & - & - & - & - & - & - & - & - & $7.514,00$ \\
\hline PC & $8.116,00$ & 6,6 & $4.657,00$ & $9.703,00$ & 6,7 & 90 & 30 & $1.400,00$ & $2.703,90$ \\
\hline $\begin{array}{c}\text { Modelo } \\
\text { empresa }\end{array}$ & $1.038,00$ & 2,3 & $8.000,00$ & $15.000,00$ & 50 & 100 & 30 & - & $3.340,48$ \\
\hline $\begin{array}{c}\text { Penitenciária } \\
\text { federal }\end{array}$ & - & - & - & - & - & - & - & $3.472,22$ & $5.403,95$ \\
\hline $\begin{array}{c}\text { Centro } \\
\text { Ressocialização }\end{array}$ & - & - & - & - & - & - & - & 900,00 & $2.703,90$ \\
\hline
\end{tabular}

prévias. O projeto padrão do Ministério da Justiça não conta com plano de ocupação ou funcionamento e não possui uma unidade concluída, por isto não integrou o levantamento. 


\section{Apêndice B - Exigências legais e técnico-normativas}

Neste apêndice são levantados os parâmetros das exigências formais para a composição arquitetônica da edificação prisional, após o exame dos principais instrumentos legais e técnico-normativos da arquitetura penal no Brasil, além de referências estrangeiras. Este apêndice complementa o Capítulo 3, desta tese.

As exigências dos instrumentos legais e técnico-normativos no âmbito nacional foram organizadas no Quadro 19, que destacou as emanações advindas das Diretrizes Básicas para a Arquitetura Penal (CNPCP, 2011a), devido à preponderância da mesma na composição da edificação prisional ${ }^{111}$. Sempre que necessário, cada item elencado recebeu considerações a respeito de sua consistência e aplicação, segundo os objetivos desta pesquisa, além de apontamentos quanto à interrelação com outros itens ou correspondência entre os instrumentos examinados.

As exigências levantadas foram condensadas, em um exercício conjectural, que caracterizou o espaço arquitetônico preconizado pelos instrumentos legais e técnico-normativos examinados, exposto no Quadro 20.

As exigências advindas de outros instrumentos similares ou correlatos foram sintetizadas em dois outros quadros (Quadro 21 e Quadro 22). O primeiro trata do Technical Guidance for Prison Planning (UNOPS, 2016). O segundo promove uma compilação das normas e relatórios técnicos brasileiros encontrados sobre o conforto ambiental, juntamente com o caderno BREAAM Prison (BRE GLOBAL, 2008) e os trabalhos ingleses de certificação da edificação prisional (UK, 2012 ; USGBC, 2009).

\footnotetext{
111 Além das regras técnicas do Ministério da Justiça (Resolução n 9, de 18/11/2011, do CNPCP), a Constituição Federal, a Lei de Execução Penal (LEP - Lei $n^{\circ} 7.210 / 1984$ e alterações subsequentes) e as Regras Mínimas para o Tratamento dos Presos no Brasil (Resolução no 11 ou 14, de 11/11/1994, do CNPCP) foram consideradas.
} 
Quadro 19 - Exigências formais dos instrumentos legais e técnico-normativos do Ministério da Justiça

\begin{tabular}{|c|c|}
\hline Diretrizes Básicas para a Arquitetura Penal & Considerações \\
\hline $\begin{array}{l}\text { No Partido Arquitetônico (Anexo IV, item 2, p. 27): Qualquer nível de segurança de construção pode ser usado em } \\
\text { qualquer estabelecimento penitenciário, dependendo da destinação e da proposta metodológica da unidade. }\end{array}$ & Os demais instrumentos não tratam do tema. \\
\hline $\begin{array}{l}\text { No Programa para Estabelecimentos Penais (Anexo V, p. } 45 \text { - 49): "Deve ser observada a separação entre as pessoas } \\
\text { presas, conforme o sexo e a faixa etária, [...]". E prossegue: "A diferença essencial entre os vários tipos de } \\
\text { estabelecimentos penais está na categoria das pessoas presas que os ocuparão". "Essa diferença de categoria } \\
\text { provocará, na elaboração dos projetos, a particularização para cada tipo de estabelecimento, de características } \\
\text { técnicas próprias de localização ou mesmo de tratamento, adequação e dimensionamento de seus espaços físicos". }\end{array}$ & $\begin{array}{l}\text { A Constituição Federal (Art. } 5^{\circ} \text {, inciso XLVIII), ordena a separação dos } \\
\text { presos em estabelecimentos distintos, apropriados a cada grupo. } \\
\text { A LEP determina a classificação e separação dos presos - "segundo os } \\
\text { seus antecedentes e personalidade, para orientar a individualização da } \\
\text { execução penal" (Art. 5o). } \\
\text { As Regras Mínimas preconizam que "presos pertencentes a categorias } \\
\text { diversas devem ser alojados em diferentes estabelecimentos prisionais } \\
\text { e suas seções, observadas características pessoais [...." (Art.7). } \\
\text { As Diretrizes Básicas não estipulam distinções no edifício, por exemplo, } \\
\text { quanto ao nível de segurança ou ao regime penitenciário. As mesmas } \\
\text { tendem a caracterizar unidades de segurança máxima. }\end{array}$ \\
\hline $\begin{array}{l}\text { Nas Recomendações Gerais (Anexo IV, subitem 3.1, p. 29): Ao tratar da categorização: "[...] há que se avaliar } \\
\text { paralelamente as características administrativas e de tratamento do sistema penitenciário da Unidade da Federação, } \\
\text { bem como o tipo ou regime, a categoria e a segurança". }\end{array}$ & $\begin{array}{l}\text { Os demais instrumentos não tratam do tema. } \\
\text { Nas Diretrizes Básicas, esta recomendação está misturada à questão } \\
\text { do porte (capacidade). }\end{array}$ \\
\hline $\begin{array}{l}\text { Na Classificação e Conceituação de Estabelecimentos Penais (Anexo II, alíneas c e d, p. 25): As penitenciárias são } \\
\text { dotadas de celas coletivas e individuais. }\end{array}$ & $\begin{array}{l}\text { Os demais instrumentos não tratam do tema. } \\
\text { Este é o único parâmetro das Diretrizes Básicas que particulariza o } \\
\text { programa de penitenciária. O mesmo não ocorre para a cadeia pública. }\end{array}$ \\
\hline \multicolumn{2}{|l|}{ 02. Porte do estabelecimento penal } \\
\hline $\begin{array}{l}\text { No Partido Arquitetônico (Anexo IV, item 2, alínea a, p. 28): "o planejamento prévio de possíveis ampliações para o } \\
\text { correto dimensionamento de dependências destinadas a assistir a pessoa presa de acordo com a capacidade total a } \\
\text { ser atingida". Nas Recomendações Gerais (Anexo IV, subitem 3.1, p. } 29 \text { e 30): ao se definir uma capacidade deve-se } \\
\text { levar em conta futuras ampliações. }\end{array}$ & $\begin{array}{l}\text { Os demais instrumentos não tratam do tema. } \\
\text { Nas Diretrizes Básicas, este item pressupõe a existência de um plano } \\
\text { diretor para o sistema penitenciário. }\end{array}$ \\
\hline $\begin{array}{l}\text { Ao tratar das capacidades máximas (tabela 01), para as penitenciárias de segurança máxima e média, as } \\
\text { capacidades máximas são de } 300 \text { e } 800 \text { vagas, respectivamente. Para cadeias públicas, o máximo é de } 800 \text { vagas. Em } \\
\text { casos justificados estes limites podem variar para mais ou menos. }\end{array}$ & $\begin{array}{l}\text { Segundo a LEP, Art. } \mathrm{n}^{\circ} \text { 85: "o estabelecimento deverá ter lotação } \\
\text { compatível com a sua estrutura e finalidade". }\end{array}$ \\
\hline \multicolumn{2}{|l|}{ 03. Custo do estabelecimento penal } \\
\hline $\begin{array}{l}\text { Nas Recomendações Técnicas (Anexo IV, subitem 3.13, p. 42): "As edificações devem ser projetadas de modo a } \\
\text { atender aos quesitos necessários quanto ao custo da construção", isto considerando o material e despesas de } \\
\text { manutenção e funcionamento, sem, contudo, acarretar prejuízo das condições mínimas de comodidade } \\
\text { "indispensáveis para a segurança e a preservação dos direitos fundamentais da pessoa humana". }\end{array}$ & Os demais instrumentos não tratam do tema. \\
\hline
\end{tabular}




\begin{tabular}{|c|c|}
\hline $\begin{array}{l}\text { Na Localização (Anexo IV, subitem 3.3, p. 33): "Os estabelecimentos devem ser edificados em terreno que favoreça } \\
\text { sua implantação [...], tendo em vista o alto custo gerado por movimentos de terra e por fundações especiais". }\end{array}$ & Os demais instrumentos não tratam do tema. \\
\hline \multicolumn{2}{|l|}{ 04. Sociabilização do preso } \\
\hline $\begin{array}{l}\text { No Programa para Estabelecimentos Penais (Anexo V, p. 45): as normas prevêem locais de visitação (salão), } \\
\text { inclusive encontro íntimo ( } 3 \% \text { da capacidade do estabelecimento penal) e parlatórios ( } 3 \% \text { da capacidade do } \\
\text { estabelecimento penal). As mesmas ainda prevêem sala de encontro com a sociedade (p. } 67 \text { ). }\end{array}$ & $\begin{array}{l}\text { A LEP constitui (Art. 41, Alíneas XV e X), o "contato com o mundo } \\
\text { exterior", inclusive a "visita do cônjuge, da companheira, de parentes e } \\
\text { amigos em dias determinados". A visita íntima não é prevista. } \\
\text { As Regras Mínimas prevêem a visita social (Art. 33) e a locução com } \\
\text { advogado (Art. 43). }\end{array}$ \\
\hline \multicolumn{2}{|l|}{ 05. Localização do estabelecimento penal } \\
\hline $\begin{array}{l}\text { Na Localização (Anexo IV, subitem } 3.3, \text { p. } 32 \text { e } 33 \text { ): as unidades penitenciárias devem se localizar fora de zonas } \\
\text { centrais urbanas ou residenciais, desde que respeitados a facilidade de acesso e a presteza das comunicações, tendo } \\
\text { em vista a proximidade do preso de seu local de origem - critério básico, assim como, a conveniência } \\
\text { socioeconômica e as peculiaridades do entorno. }\end{array}$ & $\begin{array}{l}\text { Os demais instrumentos não tratam do tema. } \\
\text { Nas Diretrizes Básicas, a localização enfatiza a proximidade do preso } \\
\text { com a sua comunidade de origem, visando também à acessibilidade } \\
\text { dos familiares. }\end{array}$ \\
\hline \multicolumn{2}{|l|}{ 06. Barreiras Perimetrais } \\
\hline $\begin{array}{l}\text { Nos Muros ou Alambrados (Anexo IV, subitem 3.4, p. } 33 \text { e } 34 \text { ): a barreira pode ser muro ou alambrado e pode ter no } \\
\text { mínimo } 5 \mathrm{~m} \text { de altura (p. } 34 \text { ). A mesma pode ter guaritas, posicionadas estrategicamente e com distância que não } \\
\text { comprometa a segurança do estabelecimento penal. A quantidade, a disposição e a intercomunicação das guaritas } \\
\text { dependem do regime e do tipo de segurança do estabelecimento proposto (Anexo V, p. 47). Recomenda-se que as } \\
\text { guaritas possuam mictórios e lavatórios e acesso vertical individual, de preferência dentro do perímetro de } \\
\text { segurança da unidade. }\end{array}$ & Os demais instrumentos não tratam do tema. \\
\hline $\begin{array}{l}\text { No Programa para Estabelecimentos Penais (Anexo V, p. 47): "O acesso [à barreira externa] não permitirá o contato } \\
\text { entre a guarda e as pessoas presas". }\end{array}$ & Os demais instrumentos não tratam do tema. \\
\hline $\begin{array}{l}\text { Nos Afastamentos e Recuos Necessários (Anexo IV, subitem } 3.5, \text { p. 34): são previstos afastamentos mínimos para os } \\
\text { edifícios e recomenda-se que a barreira permita a ronda veicular. }\end{array}$ & Os demais instrumentos não tratam do tema. \\
\hline \multicolumn{2}{|l|}{ 07. Alojamento da pessoa presa } \\
\hline Diretrizes Básicas para a Arquitetura Penal & Considerações \\
\hline $\begin{array}{l}\text { Na Classificação e Conceituação de Estabelecimentos Penais (Anexo II, alíneas 'c' e 'd', p. 25): As penitenciárias são } \\
\text { dotadas de celas coletivas e individuais. }\end{array}$ & $\begin{array}{l}\text { As Diretrizes Básicas assumem a cela coletiva em contraposição à LEP } \\
\text { (ver item 07.02). }\end{array}$ \\
\hline $\begin{array}{l}\text { Nos Parâmetros Arquitetônicos para a Acomodação de Pessoas Presas (Anexo IV, subitem 3.2, p. 31): são previstos } \\
\text { dois tipos de celas: a individual e coletiva. A cela individual segue os parâmetros da LEP. Para a cela coletiva, as } \\
\text { capacidades previstas variam de duas até oito vagas (celas de } 07 \text { e } 08 \text { vagas permitidas até 2015). Além da cama e } \\
\text { do sanitário, a cela pode ter chuveiro. Pode haver outros mobiliários além das camas que podem ser justapostas até } \\
\text { o número de três (Anexo IV, subitem 3.13, p. 41). }\end{array}$ & $\begin{array}{l}\text { Segundo a LEP, Art. 88, "O condenado será alojado em cela individual } \\
\text { que conterá dormitório, aparelho sanitário e lavatório". } \\
\text { Segundo as Regras Mínimas, Art. 8, "Salvo razões especiais, os presos } \\
\text { deverão ser alojados individualmente". }\end{array}$ \\
\hline $\begin{array}{l}\text { Nas Recomendações Gerais (Anexo IV, subitem 3.1, p. 30): "uma unidade penitenciária conformada por celas } \\
\text { coletivas deverá apresentar uma proporcionalidade mínima em torno de } 2 \% \text { da capacidade total em celas } \\
\text { individuais". As celas individuais se aplicam para presos com problemas convívio e colaboradores. Pelo menos uma } \\
\text { cela para PNE, citando a NBR 9050/2004. }\end{array}$ & $\begin{array}{l}\text { A LEP trata somente da cela individual (Art. 88) (ver item 07.02). As } \\
\text { celas individuais contam para a capacidade do estabelecimento penal. }\end{array}$ \\
\hline
\end{tabular}




\begin{tabular}{|c|c|}
\hline \multicolumn{2}{|l|}{ 08. Partido arquitetônico } \\
\hline $\begin{array}{l}\text { No Partido Arquitetônico (Anexo IV, item 2, p. 27): É permitida a liberdade criativa no Partido, porém "[...] terão que } \\
\text { ser comprovadas medidas que prevejam funcionalidade, segurança, conforto e impacto ambientais." }\end{array}$ & $\begin{array}{l}\text { Os demais instrumentos não tratam do tema. } \\
\text { Apesar da liberdade criativa colocada, as Recomendações e o } \\
\text { Programa das Diretrizes Básicas são baseados no padrão arquitetônico } \\
\text { modular. }\end{array}$ \\
\hline $\begin{array}{l}\text { No Partido Arquitetônico (Anexo IV, item 2, p. 27): se recomenda: “Deve-se ter consciência da importância que tem } \\
\text { a definição de uma linha de projeto que poderá vir a facilitar a administração e a manutenção do edifício proposto } \\
\text { (...)". }\end{array}$ & $\begin{array}{l}\text { Os demais instrumentos não tratam do tema. } \\
\text { As Diretrizes Básicas ressaltam uma preocupação com a funcionalidade } \\
\text { do estabelecimento penal. }\end{array}$ \\
\hline \multicolumn{2}{|l|}{ 09. Programa arquitetônico } \\
\hline $\begin{array}{l}\text { No Programa para Estabelecimentos Penais (Anexo V, p. 45, 46, } 47 \text { e 49): Os projetos para estabelecimentos penais } \\
\text { deverão prever, conforme tipo de estabelecimento, seguintes áreas funcionais: assistência religiosa e culto; ensino } \\
\text { e biblioteca; assistência jurídica; assistência social; assistência psicológica; oficinas de trabalho; enfermaria e } \\
\text { assistência médica e odontológica; solário; de convivência; prática de esporte e lazer e apartamentos de visitas } \\
\text { íntimas. } \\
\text { E ainda acrescenta áreas de administração, visitas, refeitório, cozinha, lavanderia, panificação, manutenção, } \\
\text { parlatório (de comunicação reservada entre a pessoa presa e seu advogado) e estágio para estudantes } \\
\text { universitários. Além de prever subestação de energia, central de gás, reservatórios superior e inferior de água, } \\
\text { estacionamentos e pistas de ronda veicular. } \\
\text { Não são listados, mas estão no Anexo: módulos de triagem e inclusão de presos, recepção e revista, alojamento para } \\
\text { agentes e guarda externa e almoxarifado. }\end{array}$ & $\begin{array}{l}\text { Segundo a LEP, art. } n^{\circ} 83 \text {, o estabelecimento, dependendo de sua } \\
\text { natureza, deverá contar "com áreas e serviços destinados a dar } \\
\text { assistência, educação, trabalho, recreação e prática desportiva". A } \\
\text { assistência prevê locais para a assistência social, jurídica, saúde } \\
\text { (médica, farmacêutica e odontológica) e educação (biblioteca - Art. } n^{\circ} \\
\text { 21). São determinados alguns locais específicos para o estagio de } \\
\text { estudantes universitários, os cultos religiosos (Art. } n^{\circ} 24 \text { ), a cantina } \\
\text { (Art. } n^{\circ} 13 \text { ) e a cela individual para medida disciplinar (art. } n^{\circ} 52 \text { e } 53 \text { ). } \\
\text { As Regras Mínimas determinam a criação de locais para a assistência } \\
\text { jurídica, religiosa, saúde (enfermaria e observação), biblioteca (Art. } n^{\circ} \\
41 \text { ), visitas de advogado, estagio de estudantes universitários, guarda } \\
\text { pertences dos presos e exercícios físicos adequados ou banho de sol } \\
\text { (Art. } n^{\circ} 14 \text { ). } \\
\text { As Diretrizes Básicas são o instrumento que apresenta o programa } \\
\text { mais completo. }\end{array}$ \\
\hline \multicolumn{2}{|l|}{ 10. Setorização } \\
\hline Diretrizes Básicas para a Arquitetura Penal & Considerações \\
\hline $\begin{array}{l}\text { No Programa para Estabelecimentos Penais (Anexo V, item 1, p. 49): O programa de necessidades do projeto deve } \\
\text { ser elaborado de forma a caracterizar, através do uso, os setores que devem estar zoneados a fim de promover um } \\
\text { fluxo ordenado de pessoas e de veículos. No Programa para Estabelecimentos Penais (Anexo V, item 1, p. 49): } \\
\text { Definem-se a seguir os setores, de uma forma geral: a) setor externo, cujo fluxo componha-se de pessoas estranhas } \\
\text { ao estabelecimento (visitas), guarda externa e pessoal administrativo; b) setor intermediário, onde possam vir a } \\
\text { circular pessoas dos setores externo e interno; e c) setor interno, onde o uso é exclusivamente de pessoas presas e } \\
\text { de funcionários. }\end{array}$ & $\begin{array}{l}\text { Os demais instrumentos não tratam do tema. } \\
\text { As Diretrizes Básicas não enfatizam de modo conexo a espacialização } \\
\text { em função do uso associado à localização e movimentação das pessoas } \\
\text { (ver item 09.02). Este item se relaciona com a Circulação e o Aparato } \\
\text { de Segurança (itens } 12.02 \text { e } 14.03 \text {, respectivamente). Na } \\
\text { caracterização dos setores, as Diretrizes Básicas utilizam como } \\
\text { parâmetro os tipos de pessoas que os ocuparão. }\end{array}$ \\
\hline $\begin{array}{l}\text { No Programa para Estabelecimentos Penais (Anexo V, p. } 46 \text { e 47): "É possível a destinação da mesma dependência } \\
\text { para mais de uma finalidade ou uso". }\end{array}$ & Os demais instrumentos não tratam do tema. \\
\hline $\begin{array}{l}\text { No Programa para Estabelecimentos Penais (Anexo V, p. } 45 \text { p. } 45,46,47 \text { e } 49 \text { ): os projetos para estabelecimentos } \\
\text { penais deverão prever, conforme o tipo de estabelecimento, os módulos conforme o programa de necessidades, } \\
\text { atendendo atividades. }\end{array}$ & $\begin{array}{l}\text { Os demais instrumentos não tratam do tema. } \\
\text { A recomendação é baseada no padrão arquitetônico modular. }\end{array}$ \\
\hline
\end{tabular}


Nas Recomendações (Anexo IV, item 2, alínea e, p. 29): considerar como unidade de vivência as alas celulares, que contam com as celas, áreas para lazer diário, refeitório e pátio, o que permite uma melhor seleção de pessoas presas segundo sua categoria (As normas repetem no Programa para Estabelecimentos Penais - Anexo V, p. 47).

Nas Recomendações Técnicas (Anexo IV, subitem 3.13, p. 42): "Deve-se primar por aspectos de harmonização do ambiente com a vida humana, de forma a favorecer o equilíbrio, a saúde e a tranquilidade, considerando itens como a pintura (cores), acabamento, configuração espacial que minimize a sensação de opressão, respeito ao espaço pessoal, layout dos ambientes obedecendo aos princípios da ergonomia etc. Tais cuidados são necessários para minimizar os efeitos da prisionalização, nocivos à saúde mental, não só dos presos, mas também dos funcionários que vivenciam os espaços prisionais". Assim como, "Sugere-se, também, que a configuração espacial não favoreça o empoderamento de grupos" (p. 44).

No Programa para Estabelecimentos Penais (Anexo V, p. 47): Os locais para visitas deverão constituir módulo próprio e isolado (visitas íntimas, pátios cobertos e descobertos, sanitários, revista, controle do agente, entre outros), com via de acesso exclusivo.

No Programa para Estabelecimentos Penais (Anexo V, p. 47): Cada módulo de celas individuais ou coletivas deverá ser dotado de áreas reservadas para: refeição e lazer, assim como pátios cercados para banho de sol (A norma se repete nas Recomendações do Partido - Anexo IV, item 2, alínea e, p. 29).

\section{Dimensionamento} são fixadas as áreas mínimas.

Nas Recomendações do Partido (Anexo IV, item 2, alínea c, p. 28): a área total construída do estabelecimento deverá estar entre 12 a $60 \mathrm{~m}^{2}$ por vaga. A área total do terreno deverá estar entre 16 a $100 \mathrm{~m}^{2}$ por vaga.

Nas Recomendações Gerais (Anexo IV, subitem 3.1, p. 30): o módulo de vivência não deverá ultrapassar 200 presos de capacidade.

Nos Parâmetros Arquitetônicos para a Acomodação de Pessoas Presas (Anexo IV, subitem 3.2, p. 31): são estabelecidas áreas, diâmetros e cubagens mínimas para as diferentes capacidades das celas (tabela 2). São feitas duas ressalvas para celas coletivas: para beliches de três camas, pé-direito mínimo de 3,5m; e o chuveiro fora da cela, pode subtrair $0,96 \mathrm{~m}^{2}$ da área mínima prevista. No módulo de vivência coletiva, a área do chuveiro externo é dimensionada em $0,63 \mathrm{~m}^{2}$ chuveiro e quantificada "de acordo com a capacidade do modulo" (ver item 11.13). Um
Os demais instrumentos não tratam do tema.

No Programa para Estabelecimentos Penais (Anexo V, p. 47), a recomendação baseada no padrão arquitetônico modular é repetida (ver item 10.09).

A LEP (Art. $n^{\circ} 3$ ) determina: "Ao condenado e ao internado serão assegurados todos os direitos não atingidos ela sentença ou pela lei". As Regras Mínimas obedecem à Declaração Universal dos Direitos do Homem e outros instrumentos de que o Brasil é signatário.

Os demais instrumentos não tratam do tema.

Nas Diretrizes Básicas, este item entra em conflito com a previsão da área de visita compartilhando seu espaço com outras atividades (item 10.15).

Os demais instrumentos não tratam do tema.

Nas Recomendações do Partido (Anexo IV, item 2, alínea e, p. 29), a recomendação baseada no padrão arquitetônico modular é repetida (ver item 10.04). No Programa para Estabelecimentos Penais (Anexo V, subitem 2.3, tópico e, p. 68): as celas individuais são mencionadas no módulo de vivência coletiva, enquanto tópico $f$, as celas individuais estão repetidas no Módulo de Vivência Individual.

Os demais instrumentos não tratam do tem

Os demais instrumentos não tratam do tema.

As Diretrizes Básicas apresentam intervalos muito amplos para estes índices de dimensionamento, sem uma discriminação por tipo ou categoria de estabelecimento (item 01.04).

Os demais instrumentos não tratam do tema.

Nas Diretrizes Básicas, a recomendação está misturada à questão do porte - capacidade (ver item 02.01).

A LEP, Art. $\mathrm{n}^{\circ} 88$, trata apenas da área da cela individual que deve ter, no mínimo, $6 \mathrm{~m}^{2}$.

Nas Diretrizes Básicas, enquanto na cela coletiva é previsto um desconto de $0,96 \mathrm{~m}^{2}$ no caso de retirada do chuveiro, a área deste no banho coletivo é de $0,63 \mathrm{~m}^{2}$ 


\begin{tabular}{|c|c|}
\hline uveiro para PNE. & \\
\hline $\begin{array}{l}\text { Nas Recomendações Gerais (Anexo IV, subitem 3.1, p. 30): "uma unidade penitenciária conformada por celas } \\
\text { coletivas deverá apresentar uma proporcionalidade mínima em torno de } 2 \% \text { da capacidade total em celas } \\
\text { individuais". }\end{array}$ & Os demais instrumentos não tratam do tema. \\
\hline $\begin{array}{l}\text { Nos Afastamentos e Recuos Necessários (Anexo IV, subitem } 3.5, \text { p. 34): os afastamentos e recuos mínimos são } \\
\text { condicionados pelas características da barreira, presença de presos e verticalidade da edificação (tabela 3). A } \\
\text { distância é de } 10 \mathrm{~m} \text { no caso de muro e de } 15 \mathrm{~m} \text { no caso de cerca. É previsto um perímetro externo de } 3 \text { ou } 5 \mathrm{~m} \text { no uso } \\
\text { de itens cortantes no topo ou na base da cerca, respectivamente (Errata CNPCP). }\end{array}$ & Os demais instrumentos não tratam do tema. \\
\hline $\begin{array}{l}\text { Nos Acessos e Circulações (Anexo IV, subitem } 3.7, p .36 \text { ): nas circulações no módulo de celas a largura mínima de } \\
2,00 \mathrm{~m} \text { (celas em uma lateral) e de } 2,50 \mathrm{~m} \text { (celas nas duas laterais). Nas passagens cobertas que interligam os } \\
\text { módulos, a largura mínima deve ser de } 2,50 \mathrm{~m} \text {. }\end{array}$ & Os demais instrumentos não tratam do tema. \\
\hline $\begin{array}{l}\text { No Conforto Ambiental (Anexo IV, item } 3.10, \text { p. 38): preconiza o cálculo de dimensões mínimas de aberturas e o } \\
\text { atendimento da NBR } 15220 / 2003 \text {. As aberturas devem ter no mínimo de } 16 \% \text { à } 25 \% \text { ou mais de } 40 \% \text { da área do piso, } \\
\text { dependendo da zona bioclimática (com exceção de circulações com menos de } 10 \mathrm{~m}^{2} \text { ). Esta norma também vale para } \\
\text { zenitais. A ventilação cruzada é definida pela relação de no mínimo } 50 \% \text { entre aberturas de entrada e de saída para } \\
\text { a circulação de ar (Errata CNPCP, p. 39). }\end{array}$ & Os demais instrumentos não tratam do tema. \\
\hline $\begin{array}{l}\text { No Programa para Estabelecimentos Penais (Anexo V, p. } 47 \text { ): o solário deverá ter no mínimo, } 6,00 \mathrm{~m}^{2} \text { ou, em caso de } \\
\text { pátio de sol coletivo, respeitada a proporção de } 1,50 \mathrm{~m}^{2} \text { por indivíduo. O solário poderá ser utilizado em forma de } \\
\text { rodízio. O diâmetro mínimo varia de acordo com o número de usuários (tabela } 7 \text { ). } \\
\text { No subitem } 2.3 \text {, tópico e, p. } 69 \text { : no módulo de vivência coletiva, a área coberta é dimensionada em } 1 \mathrm{~m}^{2} \text { por preso, } \\
\text { com possibilidade de revezamento. O pátio de sol é dimensionado em } 1,5 \mathrm{~m}^{2} \text { por preso, com revezamento. } \\
\text { No subitem } 2.3 \text {, tópico f, p. } 69 \text { : no módulo de vivência individual, a área coberta é dimensionada em } 0,5 \mathrm{~m}^{2} \text { por } \\
\text { preso. O pátio de sol é dimensionado em } 1,5 \mathrm{~m}^{2} \text { por preso. O item não cita revezamento. }\end{array}$ & $\begin{array}{l}\text { Os demais instrumentos não tratam do tema. } \\
\text { Nas Diretrizes Básicas, este item apresenta uma divergência no cálculo } \\
\text { da área mínima do pátio de sol coletivo. }\end{array}$ \\
\hline $\begin{array}{l}\text { No Programa para Estabelecimentos Penais (Anexo V, subitem } 2.3 \text {, tópico c, p. } 66 \text { ): no módulo de ensino, as salas de } \\
\text { aula são para, no máximo, } 30 \text { vagas, devendo atender a todos os presos em até } 3 \text { turnos. A sala é dimensionada em } \\
1,5 \mathrm{~m}^{2} \text { por preso. A sala de informática é dimensionada para atender a } 3 \% \text { dos presos. }\end{array}$ & Os demais instrumentos não tratam do tema. \\
\hline No Programa para Estabelecimentos Penais (Anexo V, subitem 2.3, tópico d, p. 67): no módulo de oficinas, a área de & Os demais instrumentos não tratam do tema. \\
\hline
\end{tabular}




\begin{tabular}{|c|c|}
\hline \multicolumn{2}{|l|}{ trabalho é dimensionada para atender $100 \%$ dos presos em dois turnos, de acordo com o uso do espaço. } \\
\hline $\begin{array}{l}\text { As Diretrizes Básicas trazem dimensionamentos específicos de elementos, ambientes e blocos funcionais }{ }^{112} \text { : } \\
\text { a) Dimensionamento de estacionamentos, camas das celas, alojamentos e vestiários de funcionários, guarda } \\
\text { pertences, almoxarifado, sala de atendimento jurídico, cozinha, área de chuveiro, módulos polivalente, } \\
\text { tratamento de dependentes químicos e esportes; e } \\
\text { b) Quantificação de chuveiros para os presos, boxes de revista de visitas, celas de enfermaria, apartamentos de } \\
\text { encontro íntimo. } \\
\text { c) Além de tratar de taxas de permeabilidade. }\end{array}$ & $\begin{array}{l}\text { Os demais instrumentos não tratam do tema. } \\
\text { Eventualmente, estes itens são abordados na pesquisa } \\
\text { complementando as análises, mas não integram diretamente o objeto } \\
\text { de pesquisa. } \\
\text { Destaca-se que no Programa para Estabelecimentos Penais (Anexo V, } \\
\text { subitem } 2.1 \text {, tópico a, p. } 50 \text { ): a Resolução № } 9 \text { de } 2009 \text {, do CNPCP, } \\
\text { determina que o número de agentes do estabelecimento penal deve } \\
\text { respeitar a proporção de um agente penitenciário para cada cinco } \\
\text { presos, por turno. }\end{array}$ \\
\hline \multicolumn{2}{|l|}{ 12. Fluxos } \\
\hline Diretrizes Básicas para a Arquitetura Penal & Considerações \\
\hline $\begin{array}{l}\text { Nas Recomendações do Partido (Anexo IV, item 2, alínea f, p. 29): evitar a sobreposição e a sobrecarga de fluxos nas } \\
\text { escadas e circulações onde transitem presos. }\end{array}$ & Os demais instrumentos não tratam do tema. \\
\hline $\begin{array}{l}\text { Nas Recomendações do Partido (Anexo IV, item 2, alínea h, p. 29): ao tratar do zoneamento, caracterizar um } \\
\text { zoneamento geral intencional que permita a organização de cada fluxo de circulação em particular. }\end{array}$ & Os demais instrumentos não tratam do tema. \\
\hline $\begin{array}{l}\text { Nas Recomendações do Partido (Anexo IV, item 2, alínea e, p. 29): ao tratar do módulo de vivência, afirma que o } \\
\text { uso de "alas celulares" visa "organizar melhor os fluxos internos no estabelecimento". }\end{array}$ & Os demais instrumentos não tratam do tema. \\
\hline $\begin{array}{l}\text { Nos Acessos e Circulações (Anexo IV, subitem 3.7, p. 36): verificar a área necessária para circulação e parada de } \\
\text { veículos, bem como a circulação de pedestres por acessos apropriados. }\end{array}$ & Os demais instrumentos não tratam do tema. \\
\hline $\begin{array}{l}\text { Nos Acessos e Circulações (Anexo IV, subitem 3.7, p. 36): a localização deve ser levada em conta para possibilitar um } \\
\text { bom fluxo de pessoas presas e de funcionários. }\end{array}$ & Os demais instrumentos não tratam do tema. \\
\hline $\begin{array}{l}\text { No Programa para Estabelecimentos Penais (Anexo V, p. 47): Nas edificações com mais de um pavimento, as } \\
\text { dependências de maior fluxo e atividade, deverão, preferencialmente, ser situadas no pavimento térreo. }\end{array}$ & Os demais instrumentos não tratam do tema. \\
\hline $\begin{array}{l}\text { Nos Acessos e Circulações (Anexo IV, subitem 3.7, p. 36): O acesso de pedestres e de veículos deve ser único, através } \\
\text { de portal específico e mediante vistoria. }\end{array}$ & Os demais instrumentos não tratam do tema. \\
\hline
\end{tabular}

112 Os itens elencados nas Diretrizes Básicas são: a) Nos Muros ou alambrados (Anexo IV, subitem 3.4, p. 34): a barreira perimetral deve ter altura mínima de $5 \mathrm{~m}$ (ver item 06.01). Os próximos itens se encontram na seção Programa para Estabelecimentos Penais (Anexo V): d) (p. 47): “A quantidade, a disposição e a intercomunicação das guaritas deverão ser estudadas em consonância com o regime e o tipo de segurança do estabelecimento proposto" (ver item 06.01); e) (p. 47): o compartimento para banho dos presos terá um chuveiro a cada cinco pessoas, até o máximo de 12 pontos, e tantos outros compartimentos para o que exceder este máximo; f) (subitem 2.1, tópico a, p. 49): o número de leitos da guarda externa deve ser na razão de 2/3 do número de guardas (ver item 10.07); g) (subitem 2.1, tópicos a, b e c, p. 50): os vestiários podem abranger instalações sanitárias, na proporção de um vaso sanitário para cada vinte homens ou dez mulheres e um lavatório para cada quinze pessoas (ver item 10.07); o) (subitem 2.3, tópico a, p. 65): no módulo polivalente (ver item 10.15), a área coberta é dimensionada para 50\% das vagas, na proporção de $1 \mathrm{~m}^{2}$ por preso. A área descoberta já adota um índice de $3 \mathrm{~m}^{2}$ por pessoa; $p$ ) (subitem 2.3, tópico b, p. 66): no módulo de encontro íntimo, os apartamentos são quantificados na proporção de 1 para cada 50 vagas, sendo um para PNE (ver item 10.08); r) (subitem 2.3, tópico j, p. 73): o módulo de esportes prevê uma quadra poliesportiva de $20 \times 40 \mathrm{~m}$ com recuos de $2 \mathrm{~m}$. Na Taxa de Permeabilidade (Anexo IV, item 3.6, p. 35): estabelece taxas de permeabilidade correspondentes às faixas de áreas dos empreendimentos. 


As Diretrizes Básicas trazem fluxos específicos de elementos, ambientes e blocos funcionais, tais como: saúde,
cozinha e lavanderia.
cozinha e lavanderia.

\section{Conforto ambiental}

Diretrizes Básicas para a Arquitetura Penal

No Partido Arquitetônico (Anexo IV, item 2, p. 27): “É fundamental favorecer as instalações com um mínimo de conforto, procurando soluções viáveis que permitam o grau de segurança necessário." Além de serem feitas observações sobre topografia, insolação, aeração, ventilação e iluminação, segundo as condições climáticas regionais.

No Partido Arquitetônico (Anexo IV, item 2, alínea b): "planejar as construções de novos estabelecimentos penais de maneira a atender às demandas por novas vagas, sem prescindir de critérios que favoreçam a saúde mental e o conforto ambiental daqueles que usam este espaço".

No Partido Arquitetônico (Anexo IV, item 2, alínea d, p. 28): fazer uso de áreas verdes, visando a humanizar sem deixar de lado as particularidades de segurança.

No Partido Arquitetônico (Anexo IV, item 2, alínea g, p. 29): devem ser evitados subsolos. Caso existam, destinar a eles os serviços, devidamente iluminados, ventilados e com saídas de emergência.

No Partido Arquitetônico (Anexo IV, item 2, alínea i, p. 29): interligar blocos isolados, por passarelas cobertas (quando o projeto assim se caracterizar).

Na Taxa de Permeabilidade (Anexo IV, item 3.6, p. 35): "São permeáveis as áreas sem pavimentação e sem edificação subterrânea, dotadas de solo natural ou vegetação, ou com pavimento drenante, que contribua para o equilíbrio climático e favoreçam a drenagem de águas pluviais".

No Conforto Ambiental (Anexo IV, item 3.10, p. 38): "deverão ser adotadas estratégias para aproveitamento de ventilação e de iluminação naturais", em termos do material, ventilação e proteção para cada região. Os ambientes deverão possuir ventilação cruzada (p. 39). A localização das aberturas deve estar na altura do usuário, a fim de se obter o resfriamento fisiológico. Em caso de temperatura baixa, as aberturas deverão ser passíveis de fechamento. Em caso de calmaria, é obrigatória a instalação de sistemas mecânicos de exaustão. A orientação solar deverá permitir a insolação ou sombreamento dependendo da região e época do ano (p. 40). O condicionamento térmico passivo (sombreamento e dimensionamento das aberturas) deve obedecer a NBR 15220/2003 - Zonas Bioclimáticas.

Nas Recomendações Técnicas (Anexo IV, subitem 3.13, p. 43): “As questões de salubridade das celas devem ser analisadas em caráter regional, tomando-se as precauções necessárias quanto aos materiais aplicados, sua disposição, ou as necessárias adaptações".
Os demais instrumentos não tratam do tema.

Eventualmente, estes itens são abordados na pesquisa complementando as análises, mas não integram diretamente o objeto de pesquisa.

Considerações

A LEP trata somente da cela no Art. $\mathrm{n}^{\circ} 88$ (ver item 13.06): "salubridade do ambiente pela concorrência dos fatores de aeração, insolação e condicionamento térmico adequado à permanência humana".

As Regras Mínimas colocam: "Os locais destinados aos presos deverão satisfazer as exigências de higiene, de acordo com o clima, particularmente no que se refere à superfície mínima, volume de ar, calefação e ventilação" (Art. n9). Os lugares de atividades dos presos deverão apresentar janelas amplas para a ventilação e iluminação naturais (Art. $n^{\circ} 10$ ).

Os demais instrumentos não tratam do tema.

Os demais instrumentos não tratam do tema.

Os demais instrumentos não tratam do tema.

Os demais instrumentos não tratam do tema.

Os demais instrumentos não tratam do tema.

A LEP preconiza para a cela a "salubridade do ambiente pela concorrência dos fatores de aeração, insolação e condicionamento térmico adequado à permanência humana" (Art. $n^{\circ} 88$ ).

\section{Sistema de Segurança}




\begin{tabular}{|c|c|}
\hline $\begin{array}{l}\text { Na Classificação e Conceituação de Estabelecimentos Penais (Anexo II, alíneas c e d, p. 25): as construções deverão } \\
\text { obedecer à ordem de segurança nos aspectos construtivos e nos materiais empregados. O material depende do } \\
\text { setor e da segurança. Ainda recomenda para os "módulos de vivência coletiva" especificações de materiais, segundo } \\
\text { níveis de segurança. }\end{array}$ & $\begin{array}{l}\text { Os demais instrumentos não tratam do tema. } \\
\text { As Diretrizes Básicas estabelecem três níveis de segurança, } \\
\text { caracterizados apenas pelos materiais aplicados. A materialidade não } \\
\text { integra o objeto de pesquisa. A norma não distingue o espaço } \\
\text { arquitetônico quanto ao nível de segurança ou regime. }\end{array}$ \\
\hline $\begin{array}{l}\text { No Programa para Estabelecimentos Penais (Anexo V, p. 47): "A quantidade, a disposição e a intercomunicação das } \\
\text { guaritas deverão ser estudadas em consonância com o regime e o tipo de segurança do estabelecimento proposto". } \\
\text { Nos Muros ou Alambrados (Anexo IV, subitem 3.4, p. 34): "guaritas [...] de preferência dentro do perímetro de } \\
\text { segurança da unidade". } \\
\text { Nos Muros ou Alambrados (Anexo IV, subitem 3.4, p. 34): "É recomendável que os muros externos que limitam os } \\
\text { estabelecimentos penais sejam implantados de forma a permitir a circulação de viaturas em todo seu perímetro } \\
{[\ldots] \text { ".. }}\end{array}$ & Os demais instrumentos não tratam do tema. \\
\hline $\begin{array}{l}\text { Nos Muros ou Alambrados (Anexo IV, subitem 3.4, p. 34): "sugere-se que sejam utilizados alambrados para cercar } \\
\text { ou setorizar áreas internas, o que minimiza a dificuldade por parte dos agentes ou guarda externa na fiscalização } \\
\text { das pessoas presas". }\end{array}$ & Os demais instrumentos não tratam do tema. \\
\hline $\begin{array}{l}\text { No Partido Arquitetônico (Anexo IV, item 2, alínea j, p. 29): evitar elementos de composição e de fachada que } \\
\text { possam ser utilizados como esconderijos para pessoas ou objetos. }\end{array}$ & Os demais instrumentos não tratam do tema. \\
\hline $\begin{array}{l}\text { No Partido Arquitetônico (Anexo IV, item 2, alínea k, p. 29): evitar barreiras visuais que possam criar pontos cegos } \\
\text { em áreas de segurança. }\end{array}$ & Os demais instrumentos não tratam do tema. \\
\hline $\begin{array}{l}\text { Nos Muros ou Alambrados (Anexo IV, subitem 3.4, p. 34): "O muro não poderá, em hipótese alguma, possuir } \\
\text { saliências ou reentrâncias em sua face interna". }\end{array}$ & Os demais instrumentos não tratam do tema. \\
\hline Nos Acessos e Circulações (Anexo IV, subitem 3.7, p. 36): o acesso de pedestres e de veículos deve ser único. & Os demais instrumentos não tratam do tema. \\
\hline $\begin{array}{l}\text { Nas Esquadrias (Anexo IV, subitem } 3.11 \text {, p. } 40 \text { ): As portas das celas, quando não forem de grade, deverão possuir } \\
\text { visor, sempre que necessário, complementado na parede contígua à porta. As mesmas, quando fechadas, não } \\
\text { deverão possuir folgas de nenhuma espécie (p. 40). As mesmas deverão sempre abrir para fora e todas em um só } \\
\text { sentido. Estas também poderão ser corrediças. }\end{array}$ & Os demais instrumentos não tratam do tema. \\
\hline $\begin{array}{l}\text { Nas Recomendações Técnicas (Anexo IV, subitem 3.13, p. 42): Os pilares devem, de preferência, ser embutidos na } \\
\text { alvenaria. }\end{array}$ & Os demais instrumentos não tratam do tema. \\
\hline $\begin{array}{l}\text { No Programa para Estabelecimentos Penais (Anexo V, p. 47): Nos conjuntos penais ou em seções específicas, cada } \\
\text { estabelecimento ou módulo deverá ter suas próprias precauções de segurança, conforme, a categoria, o tipo ou o } \\
\text { regime e a espécie. } \\
\text { No Programa para Estabelecimentos Penais (Anexo V, p. 47): Mesmo que haja uma administração geral ou a } \\
\text { centralização de serviços para o conjunto penal, cada estabelecimento deverá ser fisicamente autônomo, com } \\
\text { características e precauções de segurança próprias. }\end{array}$ & Os demais instrumentos não tratam do tema. \\
\hline $\begin{array}{l}\text { No Programa para Estabelecimentos Penais (Anexo } \mathrm{V} \text {, subitem 2.1, tópico a, p. 49): ao tratar da infraestrutura: a } \\
\text { subestação de energia elétrica, a central de gás, o castelo d'água, a cisterna e o lixo deverão ser implantados } \\
\text { próximos ao módulo da guarda. Este módulo deve ser anexo ao módulo de administração com acesso individual. }\end{array}$ & Os demais instrumentos não tratam do tema. \\
\hline
\end{tabular}




\begin{tabular}{|c|c|}
\hline $\begin{array}{l}\text { No Partido Arquitetônico (Anexo IV, item 2, p. 27): Nos níveis de segurança I e II é sugerida a monitoria eletrônica } \\
\text { (circuito fechado de televisão). }\end{array}$ & Os demais instrumentos não tratam do tema. \\
\hline \multicolumn{2}{|l|}{ 15. Vigilância } \\
\hline Diretrizes Básicas para a Arquitetura Penal & Considerações \\
\hline $\begin{array}{l}\text { No Programa para Estabelecimentos Penais (Anexo V, p. 49): deverá ser feito um estudo de segurança específico } \\
\text { para dotar o estabelecimento, de acordo com sua categoria, tipo e regime, de elementos que auxiliem as guardas } \\
\text { interna e externa no controle das pessoas presas, dos visitantes e até mesmo do pessoal administrativo. }\end{array}$ & Os demais instrumentos não tratam do tema. \\
\hline $\begin{array}{l}\text { No Programa para Estabelecimentos Penais (Anexo V, p. 49): recomenda-se, também, a obediência ao alinhamento, } \\
\text { tanto para as faces quanto para as empenas dos edifícios, de forma a facilitar a vigilância. }\end{array}$ & Os demais instrumentos não tratam do tema. \\
\hline
\end{tabular}

tanto para as faces quanto para as empenas dos edifícios, de forma a facilitar a vigilância. 
Quadro 20 - Características formais da edificação prisional

\begin{tabular}{|c|c|}
\hline \multicolumn{2}{|c|}{ Capacidade do estabelecimento penal e sociabilização dos presos } \\
\hline Item & Características Médias \\
\hline \multirow[t]{2}{*}{$\begin{array}{l}\text { Capacidade da unidade } \\
\text { penal }\end{array}$} & $\begin{array}{l}\text { Até } 300 \text { vagas (pequeno porte) para penitenciárias de segurança máxima e até } 800 \text { vagas } \\
\text { (grande porte) para cadeias públicas. }\end{array}$ \\
\hline & $\begin{array}{l}\text { Capacidade da unidade penal é soma das vagas geradas em celas coletivas e individuais. O porte foi } \\
\text { definido com base nos seguintes intervalos: pequeno até } 350 \text { vagas, médio entre } 351 \text { e } 600 \text { vagas, } \\
\text { grande } 601 \text { até } 800 \text { vagas (ESTECA, 2010). }\end{array}$ \\
\hline $\begin{array}{l}\text { Local para a participação da } \\
\text { sociedade }\end{array}$ & Prevê sala de encontro com a sociedade. \\
\hline $\begin{array}{l}\text { Local para a visita } \\
\text { social/contato físico }\end{array}$ & Prevê salão de visita e o contato físico é permitido. \\
\hline Local visita íntima & Prevê nove apartamentos de encontro íntimo (3\% da capacidade do estabelecimento). \\
\hline \multirow{2}{*}{$\begin{array}{l}\text { Local de encontro com o } \\
\text { advogado (quantidade e } \\
\text { relação com a capacidade) }\end{array}$} & Prevê nove parlatórios - 33 vagas/parlatório (3\% da capacidade do estabelecimento). \\
\hline & Quantidade dimensionada para uma unidade de 300 vagas. \\
\hline $\begin{array}{ll}\text { Localização } & \text { do } \\
\text { estabelecimento penal }\end{array}$ & Fora do centro urbano ou zona residencial. \\
\hline \multicolumn{2}{|l|}{ Alojamento dos presos } \\
\hline Item & Características Médias \\
\hline $\begin{array}{l}\text { Tipo de cela para pena ou } \\
\text { reclusão }\end{array}$ & $\begin{array}{l}\text { A definição é ambígua: a LEP determina a cela individual e as Diretrizes Básicas admite a } \\
\text { cela coletiva. }\end{array}$ \\
\hline \multirow[t]{2}{*}{ Diversidade espacial } & Não se sugere a diversidade. \\
\hline & A diversidade espacial trata de diferenças arquitetônicas entre celas de um mesmo estabelecimento. \\
\hline \multirow{2}{*}{$\begin{array}{l}\text { Celas de isolamento } \\
\text { (quantidade) }\end{array}$} & Admitindo-se o uso de celas coletivas, prevê seis celas individuais (2\%). \\
\hline & Quantidade dimensionada para uma unidade de 300 vagas. \\
\hline Local da ala de isolamento & Bloco funcional específico \\
\hline \multicolumn{2}{|l|}{ Composição espacial } \\
\hline Item & Características Médias \\
\hline Partido & Adota o conceito modular com blocos térreos e com o programa internalizado. \\
\hline \multirow{4}{*}{$\begin{array}{l}\text { Geometria } \\
\text { Verticalização } \\
\text { Atividades laboreducativas } \\
\text { dos presos (área construída } \\
\text { e área por vaga) }\end{array}$} & Recomenda o alinhamento dos edifícios. Não trata da centralidade ou simetria. \\
\hline & Admite pavimentos. \\
\hline & Oficina e sala de aula: $512 \mathrm{~m}^{2}\left(10 \%-1,71 \mathrm{~m}^{2} /\right.$ vaga $)$ \\
\hline & $\begin{array}{l}\text { A área de trabalho foi estimada em } 1,5 \mathrm{~m} 2 \text { por preso. Quantidade dimensionada para uma unidade de } \\
300 \text { vagas. }\end{array}$ \\
\hline \multirow{2}{*}{$\begin{array}{l}\text { Atividades sociais dos presos } \\
\text { (área construída e área por } \\
\text { vaga) }\end{array}$} & $727 m^{2}\left(14 \%-2,43 m^{2} /\right.$ vaga $)$ \\
\hline & $\begin{array}{l}\text { Considera os pátios de sol dos presos e locais de realização da visita social e íntima (quando } \\
\text { existirem), além de local para o encontro reservado com o advogado (parlatório). São informados o } \\
\text { percentual da área levantada em relação à área total construída e a relação da mesma com a } \\
\text { capacidade do estabelecimento. Estimativa para uma unidade de } 300 \text { vagas. }\end{array}$ \\
\hline Setorização & Setores externo, intermediário e interno \\
\hline $\begin{array}{l}\text { Setorização (áreas } \\
\text { construídas e proporção) }\end{array}$ & Externo: 942,50m²-19\%; Intermediário: $1.849,00 \mathrm{~m}^{2}-37 \%$; Interno: $2.188,50 \mathrm{~m}^{2}-44 \%$ \\
\hline \multirow{2}{*}{$\begin{array}{l}\text { Territorialidade } \\
\text { Localização da visita social }\end{array}$} & Livre: 12\%; Vigiado: 65\%; Proibido: $23 \%$ \\
\hline & Setor intermediário \\
\hline \multirow{2}{*}{$\begin{array}{l}\text { Bloco vivência (área } \\
\text { construída) }\end{array}$} & Dois blocos $\left(2.755,00 \mathrm{~m}^{2}-32 \%\right)$ \\
\hline & $\begin{array}{l}\text { Diz respeito à proporção da área construída dos blocos de vivência em relação à área total do } \\
\text { estabelecimento. Quantidade dimensionada para uma unidade de } 300 \text { vagas. }\end{array}$ \\
\hline Capacidade do bloco de viv. & 144 vagas \\
\hline \multirow{3}{*}{$\begin{array}{l}\text { Composição das alas carcer. } \\
\text { Capacidade da ala carcerária }\end{array}$} & 18 celas, uma ala por bloco, dois blocos de vivência \\
\hline & 144 vagas \\
\hline & Estimativa para uma unidade de 300 vagas. \\
\hline \multirow[t]{2}{*}{ Área terreno } & $11.679,36 \mathrm{~m}^{2}$ \\
\hline & $\begin{array}{l}\text { Quantidade dimensionada para uma unidade de } 300 \text { vagas, baseada na área construída estimada } \\
(70,60 \times 70,60 \mathrm{~m}), \text { acrescida dos afastamentos mínimos definidos nas Diretrizes Básicas } \\
(105,6 \times 110,6 \mathrm{~m}) \text {. }\end{array}$ \\
\hline Índice $A_{T} / C$ & $38,93 \mathrm{~m}^{2} /$ vaga \\
\hline
\end{tabular}




\begin{tabular}{|c|c|}
\hline & $\begin{array}{l}\text { Quantidade dimensionada para uma unidade de } 300 \text { vagas. As Diretrizes Básicas definem um } \\
\text { intervalo entre } 16 \text { e } 100 \mathrm{~m}^{2} / \mathrm{vaga} \text {, do qual se assume o limite inferior para unidade de segurança } \\
\text { máxima, o que resulta em } 4.800 \mathrm{~m}^{2} \text { de área de terreno. }\end{array}$ \\
\hline \multirow[t]{2}{*}{ Área construída } & $4.980,00 \mathrm{~m}^{2}$ \\
\hline & $\begin{array}{l}\text { Quantidade dimensionada para uma unidade de } 300 \text { vagas. As indefinições programáticas foram } \\
\text { preenchidas pelo padrão arquitetônico modular e pelo projeto padrão do Ministério da Justiça. }\end{array}$ \\
\hline \multirow[t]{2}{*}{ Índice $A_{c} / C$} & $16,60 \mathrm{~m}^{2} /$ vaga \\
\hline & $\begin{array}{l}\text { O índice calcula a proporção de área construída pela capacidade da unidade penal. Quantidade } \\
\text { dimensionada para uma unidade de } 300 \text { vagas. As Diretrizes Básicas definem um intervalo entre } 12 \text { e } \\
60 \mathrm{~m}^{2} / \text { vaga, do qual se assume o limite inferior para unidade de segurança máxima, o que resulta em } \\
3.600 \mathrm{~m}^{2} \text { de área construída. }\end{array}$ \\
\hline \multirow[t]{2}{*}{ Taxa ocupação } & $75 \%$ \\
\hline & Proporção dimensionada para uma unidade de 300 vagas. \\
\hline \multirow{2}{*}{$\begin{array}{l}\text { Circulação - relação com a } \\
\text { capacidade }\end{array}$} & $820 m-2,73 m / v a g a$ \\
\hline & $\begin{array}{l}\text { Considerou-se a circulação principal do estabelecimento penal que interliga os setores e blocos } \\
\text { funcionais e define os fluxos nos mesmos. Quantidade dimensionada para uma unidade de } 300 \text { vagas. }\end{array}$ \\
\hline Acesso a unidade penal & Acesso único \\
\hline Rota de escape & Não prevê \\
\hline $\begin{array}{l}\text { Aberturas de iluminação e } \\
\text { ventilação }\end{array}$ & $\begin{array}{l}\text { Subdimensionada, indireta, sem zenital, ventilação cruzada nos blocos externos, controle } \\
\text { abertura blocos externos }\end{array}$ \\
\hline Aparatos de segurança & Prevê \\
\hline Cercas divisórias internas & Sim. Entre setores e nas circulações. \\
\hline \multicolumn{2}{|l|}{ Controle } \\
\hline Item & Características Médias \\
\hline Tipo vigilância & Vigilância indireta e direta \\
\hline \multirow{2}{*}{$\begin{array}{l}\text { Torres vigilância e postos de } \\
\text { controle }\end{array}$} & Cinco ou seis torres; 22 postos (66 vagas/posto)* \\
\hline & Quantidade dimensionada para uma unidade de 300 vagas. \\
\hline Circulação exclusiva & Não prevê \\
\hline \multicolumn{2}{|l|}{ Barreira perimetral } \\
\hline Item & Características Médias \\
\hline Tipo & $\begin{array}{l}\text { Cerca ou muro com passadiço. Não trata da geometria, perímetro, proteção da guarda } \\
\text { externa e linha de tiro. }\end{array}$ \\
\hline Altura & Cinco metros, no mínimo. \\
\hline Aparatos de segurança & Não distingue em função do nível de segurança \\
\hline Afastamento & Entre 10 e $15 \mathrm{~m}$ (horizontal) \\
\hline Pista de ronda & Prevê \\
\hline \multicolumn{2}{|l|}{ Cela coletiva } \\
\hline Item & Características Médias \\
\hline Composição espacial & Prevê dormitório e higiene pessoal. Não trata da geometria ou espacialização. \\
\hline Serviços de higiene pessoal & Pia com torneira, vaso sanitário e chuveiro (opcional). \\
\hline Mobiliário & Camas ou beliches, mesa com banco, prateleiras e divisórias. \\
\hline Atividades & Dormitório, guarda de pertences e higiene pessoal \\
\hline Índice A/C & Cela individual: $6,0 \mathrm{~m}^{2} /$ vaga e cela coletiva: $2,36 \mathrm{~m}^{2} /$ vaga (média) \\
\hline Índice V/C & Cela individual: $15,0 \mathrm{~m}^{3} /$ vaga e cela coletiva: $5,80 \mathrm{~m}^{3} /$ vaga (média) \\
\hline \multirow{2}{*}{$\begin{array}{l}\text { Aberturas de iluminação e } \\
\text { ventilação (controle da } \\
\text { abertura) }\end{array}$} & Cela individual: $0,96 \mathrm{~m}^{2}$ e cela coletiva: $2,22 \mathrm{~m}^{2}$ (seis vagas). Prevê controle das aberturas. \\
\hline & $\begin{array}{l}\text { Considerou a predominância do parâmetro de } 16 \text { a } 25 \% \text { da área de piso entre as zonas bioclimáticas } \\
(1 \text { a } 7) \text {. }\end{array}$ \\
\hline Porta acesso & Em grade ou fechada com visor, de abrir ou correr. \\
\hline Visualização do interior & Deve permitir a visualização máxima. \\
\hline \multicolumn{2}{|l|}{ Pátio de sol dos presos } \\
\hline Item & Características Médias \\
\hline $\begin{array}{l}\text { Separação dos grupos de } \\
\text { presos }\end{array}$ & $\begin{array}{l}\text { Um pátio por ala carcerária. Dois pátios na unidade prisional, considerando } 300 \text { vagas. } \\
\text { Não trata da geometria e composição espacial. }\end{array}$ \\
\hline Capacidade & 144 pessoas \\
\hline Serviços e facilidades & 08 vasos sanitários e 08 pias (uma de cada peça para cada vinte usuários). \\
\hline Cantina & Distribuição \\
\hline Dimensões e área do pátio & Pátio coberto: $144 \mathrm{~m}^{2}\left(1,0 \mathrm{~m}^{2} /\right.$ vaga $)$ \\
\hline
\end{tabular}




\begin{tabular}{|l|l|}
\hline (coberta + descoberta) & Pátio descoberto: $10,0 \times 21,6 \mathrm{~m}$ e $216 \mathrm{~m}^{2}\left(1,5 \mathrm{~m}^{2} /\right.$ vaga) \\
\hline Aberturas de ilum. e vent. & Apenas a abertura superior do pátio \\
\hline Aparatos de segurança & Proteção dos beirais \\
\hline Posto de controle \\
\hline \multicolumn{1}{|c|}{ Item } & \\
\hline Sanitários Características Médias \\
\hline Área & Prevê \\
\hline
\end{tabular}

Quadro 21 - Critérios do Technical Guidance for Prison Planning

\begin{tabular}{|c|c|}
\hline \multicolumn{2}{|c|}{ 01. Tipo e categoria do estabelecimento penal } \\
\hline Quesito & Critério \\
\hline $\begin{array}{l}\text { Categoria de } \\
\text { segurança } \\
\text { penitenciária }\end{array}$ & $\begin{array}{l}\text { Estabelece quatro níveis de segurança, sendo o nível } 1 \text { o mais seguro, voltado para os presos que } \\
\text { oferecem mais risco (p. 31). As prisões de nível } 2 \text { se caracterizam pela ausência da zona central } \\
\text { livre de presos, mas ainda tem perímetros de segurança internos para prevenir a chegada de } \\
\text { presos à barreira perimetral. }\end{array}$ \\
\hline \multicolumn{2}{|c|}{ 02. Porte do estabelecimento penal } \\
\hline Capacidade & $\begin{array}{l}\text { Estabelece três capacidades: } 200,500 \text { e } 1.000 \text { vagas e o critério de segurança: capacidades } \\
\text { maiores estão associadas a níveis de segurança menores e vice-versa. O documento informa } \\
\text { sobre a recomendação do Mandela Rules n. } 83 \text { que recomenda uma capacidade de até } 500 \text { vagas } \\
\text { para unidades de regime fechado. }\end{array}$ \\
\hline \multicolumn{2}{|c|}{ 03. Custo do estabelecimento penal } \\
\hline $\begin{array}{l}\text { Custo de construção } \\
\text { (segurança) }\end{array}$ & $\begin{array}{l}\text { Estabelece a relação entre o sistema de segurança e o custo do estabelecimento, por isto a } \\
\text { definição do nível de segurança deve ser acurada para não configurar o desperdício de recursos } \\
\text { em segurança com presos de perfil brando. Por exemplo, na especificação da barreira perimetral } \\
\text { (p. 184). }\end{array}$ \\
\hline $\begin{array}{l}\text { Custo operacional } \\
\text { (tamanho da equipe) }\end{array}$ & $\begin{array}{l}\text { Estabelece a relação de um funcionário para cada cinco presos e faz considerações a respeito da } \\
\text { coletivização das celas como meio para uma provável redução do contingente funcional, porém } \\
\text { com uma possível dificuldade de gerenciamento da prisão e risco de incidentes (p. 50). }\end{array}$ \\
\hline \multicolumn{2}{|c|}{ 04. Sociabilização do preso } \\
\hline Sociabilização & $\begin{array}{l}\text { Estabelece quatro categorias de visita (p. 125): com contato físico (social), sem contato físico } \\
\text { (parlatório), oficial (funcionários do sistema de justiça criminal, entre outros) e conjugal. }\end{array}$ \\
\hline \multicolumn{2}{|c|}{ 05. Localização do estabelecimento penal } \\
\hline Nível de segurança & Estabelece que localizações isoladas estão associadas a níveis de segurança maiores e vice-versa. \\
\hline \multicolumn{2}{|c|}{ 06. Barreiras Perimetrais } \\
\hline Tipo & Estipula barreira em muro ou cerca. \\
\hline Arranjo & $\begin{array}{l}\text { Estabelece diferentes arranjos de barreira para os níveis de segurança (p. 184). O nível } 1 \\
\text { configura um perímetro externo, com torres de vigilância, mais um perímetro interno e entre eles } \\
\text { uma faixa de contenção (sterile area), além de cercas nos edifícios com maior risco. O nível } 2 \text { não } \\
\text { prevê este perímetro interno. }\end{array}$ \\
\hline $\begin{array}{l}\text { Torre de vigilância } \\
\text { externa (watchtower) }\end{array}$ & $\begin{array}{l}\text { Prevê torres de vigilância externa nos cantos da barreira perimetral e, eventualmente, torres } \\
\text { intermediária, a depender do tamanho da barreira. }\end{array}$ \\
\hline \multicolumn{2}{|c|}{ 07. Alojamento da pessoa presa } \\
\hline Quesito & Critérios \\
\hline Capacidade & $\begin{array}{l}\text { É preferível a cela individual ou, no máximo, com duas pessoas (p. 92). É admissível a cela coletiva } \\
\text { entre quatro e vinte e cinco pessoas, considerada de fácil gerenciamento (p. 93). }\end{array}$ \\
\hline Espacialização & Exemplifica o espaço da cela por duas linhas de beliches (seis de cada lado) (p. 93). \\
\hline Serviços & $\begin{array}{l}\text { Prevê um vaso sanitário dentro da cela (p. 91) até a capacidade de vinte e cinco vagas (p. 93). } \\
\text { Prevê um chuveiro com ou sem divisórias para minimamente, um banho por preso por semana. }\end{array}$ \\
\hline Diversidade das celas & Estabelece que deve haver tamanhos diferentes de celas (p. 88 e p. 235). \\
\hline Ventilação & $\begin{array}{l}\text { Estipula que um dormitório com doze beliches em duas linhas de seis beliches cada, para vinte e } \\
\text { quatro camas no total, a ventilação será suficiente se dois conjuntos de janelas forem } \\
\text { providenciados (p. 93). }\end{array}$ \\
\hline
\end{tabular}




\begin{tabular}{|c|c|}
\hline Tipologia & $\begin{array}{l}\text { O nível de segurança estabelece a tipologia arquitetônica, sendo listados três tipos (p. 46): prisão } \\
\text { integrada (integrated prison), sistema agrupado (cluster system) e sistema de campus (campus } \\
\text { system). O nível } 2 \text { de segurança aceita os tipos prisão integrada e sistema agrupado (p. 70). }\end{array}$ \\
\hline Planejamento geral & $\begin{array}{l}\text { Estabelece os espaços internos (ventilação), iluminação natural, ruído, visualização da paisagem } \\
\text { externa e uso de espaços externos como quesitos para a humanização do espaço prisional (p. 75). }\end{array}$ \\
\hline \multicolumn{2}{|l|}{ 09. Atividades } \\
\hline $\begin{array}{l}\text { Blocos de celas (cell } \\
\text { block) }\end{array}$ & $\begin{array}{l}\text { Estabelece que o preso deve permanecer pelo menos dez horas diárias fora da cela (p. 88). } \\
\text { Estabelece que o preso deve ter pelo menos uma hora de sol diário (p. 95). } \\
\text { Prevê barbearia, treino físico e recreacional (p. 95). }\end{array}$ \\
\hline $\begin{array}{l}\text { Espaço externo } \\
\text { (outdoor space) }\end{array}$ & $\begin{array}{l}\text { Estabelece o uso de área externa por, pelo menos, uma hora diária (p. 95). } \\
\text { O uso deve separar os diferentes grupos de presos (p. 95). } \\
\text { Prevê área coberta e instalações sanitárias (pia e vaso sanitário) (p. 95). } \\
\text { Prevê área para se sentar, jogar jogos e praticar esportes (p. 95). } \\
\text { Prevê a possibilidade do contato com vegetação (presenciar a mudanças das estações) (p. 95). } \\
\text { Prevê um vaso para com vinte e cinco presos e um chuveiro para cada cinquenta presos (p. 95). }\end{array}$ \\
\hline Pátio (yard) & $\begin{array}{l}\text { Estabelece a prática de exercícios físicos por, pelo menos, uma hora diária (p. 99). } \\
\text { O uso deve separar os diferentes grupos de presos (p. 99). } \\
\text { Prevê área coberta (pátio coberto) (p. 99). }\end{array}$ \\
\hline $\begin{array}{l}\text { Posto de controle } \\
\text { (staff office) }\end{array}$ & $\begin{array}{l}\text { Estipula um posto de controle em cada pavimento (p. 104). } \\
\text { O posto de controle deve ser seguro e resistente (contra a invasão) (p. 104). }\end{array}$ \\
\hline $\begin{array}{l}\text { Cela de isolamento } \\
\text { (solitary } \\
\text { confinament) }\end{array}$ & $\begin{array}{l}\text { Estipula uma quantidade de celas de isolamento de } 2 \% \text { da capacidade da unidade prisional, } \\
\text { porém estas celas não contabilizam nesta capacidade (p. 109). } \\
\text { Estabelece o fechamento da cela com parede e porta vedada com visor, além de mobiliário fixo e } \\
\text { pé-direito mais alto ( } p .109) \text {. } \\
\text { Prevê um vaso sem privacidade (p. 109). } \\
\text { Admite cela dupla. }\end{array}$ \\
\hline Visita (visits) & $\begin{array}{l}\text { Estabelece que a questão primária é a privacidade do preso, moderada pela vigilância e } \\
\text { segurança (p. 125). } \\
\text { Estabelece que a revista corporal é proibida (p. 125). } \\
\text { Prevê local para apresentações (palco) para a visita social (p. 125). }\end{array}$ \\
\hline $\begin{array}{l}\text { Torre de vigilância } \\
\text { externa (watchtower) }\end{array}$ & Prevê sanitário (p. 184). \\
\hline \multicolumn{2}{|l|}{ 10. Setorização } \\
\hline Quesito & Critérios \\
\hline $\begin{array}{l}\text { Bloco de celas (cell } \\
\text { block) }\end{array}$ & $\begin{array}{l}\text { Estabelece a composição do bloco de celas abrangendo o pátio (yard) e o salão de convivência } \\
\text { (dayroom) (p. 99). }\end{array}$ \\
\hline $\begin{array}{l}\text { Bloco de celas (cell } \\
\text { block) }\end{array}$ & $\begin{array}{l}\text { Estabelece no diagrama do bloco de celas (p. 106) a verticalização em dois pavimentos com as } \\
\text { celas em torno de um salão de convivência central (mezanino), seguindo o padrão arquitetônico } \\
\text { modular. O salão de convivência dá acesso à sala multiuso, sala de televisão e sala de } \\
\text { musculação. }\end{array}$ \\
\hline $\begin{array}{l}\text { Posto de controle } \\
\text { (staff office) }\end{array}$ & Estabelece que deve ser localizado perto do acesso dos locais vigiados (p. 104). \\
\hline $\begin{array}{l}\text { Cela de isolamento } \\
\text { (solitary } \\
\text { confinament) }\end{array}$ & Estabelece um bloco autônomo próprio com todas as atividades cotidianas dos presos (p. 109). \\
\hline $\begin{array}{l}\text { Torres de vigilância } \\
\text { (watchtowers) }\end{array}$ & $\begin{array}{l}\text { Estabelece a localização das torres de vigilância dentro de uma faixa inacessível aos presos } \\
\text { (prisioner-free zone), dentro do perímetro de segurança da unidade prisional (p. 184). }\end{array}$ \\
\hline
\end{tabular}




\begin{tabular}{|c|c|}
\hline Cela & $\begin{array}{l}\text { Estipula dimensionamentos para cela (quadro na página } 94 \text { ). } \\
\text { A cela individual deve ter área mínima de } 5,4 \mathrm{~m}^{2} \text {. } \\
\text { A cela dupla deve ter área mínima de } 6,8 \mathrm{~m}^{2}, \text { no caso da especificação de camas simples (p. } 91 \text { ). } \\
\text { A cela coletiva deve ter área mínima de } 3,4 \mathrm{~m}^{2} / \text { vaga, no caso da especificação de camas simples. } \\
\text { A cela coletiva deve ter área mínima de } 2,6 \mathrm{~m}^{2} / \text { vaga, no caso da especificação de beliches de duas } \\
\text { camas. } \\
\text { A cela coletiva deve ter área mínima de } 2,3 \mathrm{~m}^{2} / \text { vaga, no caso da especificação de beliches de três } \\
\text { camas. } \\
\text { O pé-direito mínimo é de } 2,45 \mathrm{~m} \text { (p. } 91 \text { ), devendo ser recalculado no caso de beliches de três } \\
\text { camas (p. } 93 \text { ). O espaço mínimo vertical entre camas do beliche é de } 1,2 \mathrm{~m} \text { (p. } 93 \text { ). } \\
\text { O diâmetro mínimo é de } 2,15 \mathrm{~m} \text { (p. } 91 \text { ). } \\
\text { A cama/beliche ocupa uma área de } 1,6 \mathrm{~m}^{2} \text { (p. } 93 \text { ). }\end{array}$ \\
\hline Espaço externo & Estipula uma área mínima de $4,0 \mathrm{~m}^{2} /$ preso (p. 95). \\
\hline Pátio (yard) & $\begin{array}{l}\text { Estipula uma área mínima de } 4,0 \mathrm{~m}^{2} / \text { preso em locais de clima frio e de } 6,0 \mathrm{~m}^{2} / \text { preso em locais de } \\
\text { clima quente (p. 99). }\end{array}$ \\
\hline $\begin{array}{l}\text { Salão de convivência } \\
\text { (dayroom) }\end{array}$ & $\begin{array}{l}\text { Estipula uma área mínima de } 4,0 \mathrm{~m}^{2} / \text { preso em locais de clima frio e de } 2,0 \mathrm{~m}^{2} / \text { preso em locais de } \\
\text { clima quente (p. 99). }\end{array}$ \\
\hline $\begin{array}{l}\text { Posto de controle } \\
\text { (staff office) }\end{array}$ & $\begin{array}{l}\text { Estabelece que deve ser grande o bastante para receber mesa, armário e depósito com os } \\
\text { prontuários dos presos (p. 104). }\end{array}$ \\
\hline $\begin{array}{l}\text { Cela de isolamento } \\
\text { (solitary } \\
\text { confinament) }\end{array}$ & $\begin{array}{l}\text { A cela individual deve ter área mínima de } 5,4 \mathrm{~m}^{2} \text { (p. 109). } \\
\text { A cela dupla deve ter área mínima de } 3,4 \mathrm{~m}^{2} / \text { vaga (p. 109). } \\
\text { O diâmetro mínimo é de } 2,15 \mathrm{~m} \text { (p. 109). } \\
\text { O pé-direito mínimo é de } 2,45 \mathrm{~m} \text { (p. 109). }\end{array}$ \\
\hline Visita (visits) & $\begin{array}{l}\text { Estabelece que os dimensionamento das áreas de visita deve considerar o tipo, a quantidade e a } \\
\text { frequência de visitantes, apontando quatro categorias (p. 125): com contato físico (social), sem } \\
\text { contato físico (parlatório), oficial (funcionários do sistema de justiça criminal, entre outros) e } \\
\text { conjugal. }\end{array}$ \\
\hline \multicolumn{2}{|r|}{ ( } \\
\hline Quesitos & Critérios \\
\hline Contenção & $\begin{array}{l}\text { Estabelece cinco tipos de contenção segundo a função nos procedimentos de acesso e condução } \\
\text { das pessoas (p. 33): revista corporal, controle de movimento, contagem de presos, interligação e } \\
\text { identificação. Aplicar as contenções segundo a funcionalidade atribuída à circulação de pessoas } \\
\text { no esquema especial da prisão. }\end{array}$ \\
\hline Funcionalidade & Estabelece um desenho facilitador da transferência de presos (p. 102). \\
\hline Controle & $\begin{array}{l}\text { Estabelece que o controle de movimento das pessoas foca a transição entre pavimentos, o acesso } \\
\text { de espaços coletivos e as contenções (p. 102). }\end{array}$ \\
\hline Integração & $\begin{array}{l}\text { Estipula que os fluxos devem aderir à segurança dinâmica (dynamic security), por meio da criação } \\
\text { de espaços onde os funcionários podem interagir regularmente com os presos (p. 102). }\end{array}$ \\
\hline \multicolumn{2}{|c|}{ 13. Conforto ambiental } \\
\hline Ventilação & $\begin{array}{l}\text { Estabelece que a área das aberturas de ventilação deve ser de, no mínimo, } 4 \% \text { área de piso, com } \\
\text { uma troca de ar interno de } 0,1 \text { a } 1,4 \mathrm{~m}^{3} / \text { minuto/pessoa (p. } 89 \text { ). Caso não seja viável este } \\
\text { dimensionamento, aplicar } 0,1 \mathrm{~m}^{2} / \text { pessoa. } \\
\text { Especificar pé-direito alto, principalmente em locais de clima quente (p. 89). } \\
\text { Prever controle das aberturas, manuseado preferencialmente pelos presos (p. 89). }\end{array}$ \\
\hline Iluminação & $\begin{array}{l}\text { Estabelece que a área das aberturas de iluminação deve ser de, no mínimo, } 8 \% \text { área de piso (p. } \\
\text { 90). Caso não seja viável este dimensionamento, aplicar } 0,1 \mathrm{~m}^{2} / \text { pessoa. } \\
\text { A profundidade dos cômodos não deve exceder a duas vezes a distancia do piso até o topo das } \\
\text { aberturas. }\end{array}$ \\
\hline $\begin{array}{l}\text { Visualização do } \\
\text { exterior }\end{array}$ & $\begin{array}{l}\text { É preferível que as aberturas de iluminação e ventilação possibilitem a visualização externa (p. } \\
\text { 91). }\end{array}$ \\
\hline $\begin{array}{l}\text { Torres de vigilância } \\
\text { externa (watchtower) }\end{array}$ & Estabelece o conforto dos guardas nas torres (sobreamento). \\
\hline \multicolumn{2}{|c|}{ 14. Sistema de Segurança } \\
\hline Tipos de segurança & $\begin{array}{l}\text { Estabelece a coexistência de três tipos de segurança no esquema de uma unidade prisional: } \\
\text { estática, procedimentos e dinâmica. Na segurança dinâmica (dynamic security), o funcionário tem } \\
\text { contato com os presos (p. 33), de modo a antecipar problemas (inteligência). Proporcionar a } \\
\text { comunicação cotidiana entre funcionários e presos. }\end{array}$ \\
\hline
\end{tabular}




\begin{tabular}{|l|l|}
\hline Espaços externos & $\begin{array}{l}\text { Especifica o uso de cercas duplas para dividir os grupos de presos no uso dos espaços externos (p. } \\
95) .\end{array}$ \\
\hline Contenções & Estabelece que as contenções devem ser configuradas por portas duplas (p. 104). \\
\hline Barreira perimetral & $\begin{array}{l}\text { Prevê aparatos de segurança (p. 184): consertina na base e no topo da cerca para evitar a } \\
\text { transposição, placas metálicas ou cercas com duas camadas de alambrado na base para evitar o } \\
\text { corte, elementos abaulados ou projetados no topo para evitar a transposição e muro enterrado } \\
\text { para evitar túneis. Nos muros, prevê o passadiço. } \\
\text { Prevê eventual proteção balística (p. 184). }\end{array}$ \\
\hline 15. Vigilância & A área de banho na cela deve ser visualizável pelos funcionários (p. 95). \\
\hline Cela & Estabelece a importância da visibilidade dos espaços externo de uso dos presos (p. 95). \\
\hline Espaço externo & Estabelece que deve ter boa visibilidade (p. 103). \\
\hline $\begin{array}{l}\text { Posto de controle } \\
\text { (staff office) }\end{array}$ & $\begin{array}{l}\text { Estabelece que a função da torre de vigilância é monitorar os presos, prevenir fugas ou ataques } \\
\text { externos e resgates de presos, além de contrabandos (p. 186). }\end{array}$ \\
\hline $\begin{array}{l}\text { Torre de vigilância } \\
\text { externa (watchtower) }\end{array}$
\end{tabular}

Quadro 22 - Critérios de conforto ambiental de instrumentos técnicos e normativos similares ou correlatos

\begin{tabular}{|c|c|c|}
\hline Quesito & Norma/Relatório & Critério \\
\hline \multirow[t]{2}{*}{ Conforto visual } & $\begin{array}{l}\text { NBR 15.575-1 } \\
\text { Habitabilidade: desempenho } \\
\text { lumínico } \\
\text { Relatório Cetac/IPT no } 107 \text { 898- } \\
205 \\
\text { Desempenho lumínico } \\
\text { Relatório NPC/UFSC Desempenho } \\
\text { lumínico } \\
\text { ISO 6241:1984 } \\
\text { Conforto visual }\end{array}$ & $\begin{array}{l}\text { Conforme o item } 13.2 \text { da NBR 15.575-1 (2013): iluminação } \\
\text { natural. } \\
\text { O relatório Cetac/IPT no } 107 \text { 898-205 (IPT, 2010) adequa o texto } \\
\text { normativo para uma generalidade: durante o dia, as } \\
\text { dependências do conjunto prisional devem receber conveniente } \\
\text { iluminação seja ela oriunda diretamente do exterior ou } \\
\text { indiretamente através de recintos adjacentes. } \\
\text { Os relatórios NPC/UFSC (UFSC, 2013) e Cetac/IPT no } 107898- \\
205 \text { (IPT, 2010) adéquam o texto normativo para as celas: a } \\
\text { edificação deve propiciar condições de iluminação natural em } \\
\text { todas as celas prisionais durante o dia. O relatório NPC/UFSC } \\
\text { sugere um nível de iluminamento maior que } 60 \text { lux, equiparado } \\
\text { às dependências de dormitório, banheiro, área de trabalho e } \\
\text { leitura, oficina e biblioteca. O relatório Cetac/IPT no } 107898-205 \\
\text { (IPT, } 2010 \text { ) sugere o Fator de Luz Diurna (FLD) no centro da cela } \\
\text { de, no mínimo, 0,9\%. } \\
\text { O caderno BREAAM (BRE GLOBAL, 2008) determina, } \\
\text { minimamente, } 80 \% \text { da área de piso de cada dos cômodos com } \\
\text { ocupação prolongada adequadamente iluminado com um FLD, } \\
\text { médio, de } 2 \% \text { (para celas este fator é de 1,5\%). } \\
\text { A ISO 6241:1984 determina a provisão ou controle da luz } \\
\text { natural; possibilidade de escurecimento; insolação; contato } \\
\text { visual com o mundo externo e interno, entre outros requisitos. }\end{array}$ \\
\hline & $\begin{array}{l}\text { Caderno BREEAM Prison } \\
\text { Daylighting e Viewout }\end{array}$ & $\begin{array}{l}\text { O caderno BREAAM (BRE GLOBAL, 2008) estipula que a vista } \\
\text { externa se configura por uma distancia máxima de sete metros } \\
\text { da parede com a abertura (profundidade do cômodo) e que esta } \\
\text { abertura tenha uma área igual ou maior que } 20 \% \text { da área } \\
\text { interna desta parede. } \\
\text { Para a cela ter vista externa, elementos de bloqueio visual } \\
\text { externo devem estar a uma distancia igual ou maior que } 10 \mathrm{~m} \\
\text { das aberturas de visualização da cela. }\end{array}$ \\
\hline $\begin{array}{l}\text { Conforto } \\
\text { antropodinâmico }\end{array}$ & $\begin{array}{l}\text { NBR 15.575-1 } \\
\text { Segurança: } \\
\text { segurança no uso e na operação } \\
\text { NBR } 15.575-1 \\
\text { Habitabilidade: }\end{array}$ & $\begin{array}{l}\text { Conforme o item } 9.3 \text { da NBR 15.575-1 (2013) - Segurança na } \\
\text { circulação de pisos internos: os pisos devem ser projetados de } \\
\text { maneira a prevenir lesões em seus usuários, provocadas por } \\
\text { quedas decorrentes de irregularidades localizadas, tais como } \\
\text { desníveis abruptos (maiores que } 5 \mathrm{~mm} \text { ) e frestas (maiores que } \\
4 \mathrm{~mm} \text { ). }\end{array}$ \\
\hline
\end{tabular}




\begin{tabular}{|c|c|c|}
\hline & $\begin{array}{l}\text { funcionalidade e acessibilidade } \\
\text { ISO } 6241: 1984 \\
\text { Segurança ao uso } \\
\text { PSI 12/2012 } \\
\text { Cela }\end{array}$ & $\begin{array}{l}\text { Conforme o item } 14.2 .3 \text { da NBR } 15.575-1 \text { (2013): a edificação } \\
\text { deve apresentar adequada organização dos cômodos e } \\
\text { dimensões compatíveis com as necessidades humanas. O pé- } \\
\text { direito mínimo é de } 2,50 \mathrm{~m} \text {. } \\
\text { A ISO } 6241: 1984 \text { determina aspectos do desenho relativos à } \\
\text { resistência humana, agilidade, maneabilidade e ergonomia; } \\
\text { facilidade de movimentos; habilidade manual na operação de } \\
\text { portas, janelas e controle de equipamentos. } \\
\text { O PSI 12/2012 (UK, 2012) prevê as atividades de dormir, se } \\
\text { vestir e despir, refeições, higiene pessoal, guarda de pertences e } \\
\text { circulação, além de individualizações. O mesmo prevê } \\
\text { mobiliário: cama ou beliche, armário (compacto), guarda roupa, } \\
\text { mesa e cadeira, além banheiro. A privacidade do banheiro é } \\
\text { definida pelo abrigo relativo a alguns pontos da cela (mesa, } \\
\text { cama). O instrumento prevê um estudo ergonômico (croquis) } \\
\text { anexo. }\end{array}$ \\
\hline Conforto térmico & $\begin{array}{l}\text { NBR 15.575-1 } \\
\text { Habitabilidade: } \\
\text { desempenho térmico } \\
\text { Relatório NPC/UFSC } \\
\text { Desempenho térmico } \\
\text { ISO } 6241: 1984 \\
\text { Conforto higrotérmico } \\
\text { PSI 12/2012 }\end{array}$ & $\begin{array}{l}\text { Conforme o item } 11.3 \text { da NBR 15.575-4 (2013): aberturas para } \\
\text { ventilação, sendo os parâmetros mínimos: para as zonas } \\
\text { bioclimáticas de } 1 \text { a } 6 \text {, A igual ou maior que } 8 \% \text {; para a zona } 7, A \\
\text { maior ou igual a } 5 \% \text {; e para a zona } 8 \text {, A maior ou igual } 15 \% \text { da } \\
\text { área de piso. Para o projeto arquitetônico (item } 11.3 .1 .1 \text { ): } \\
\text { A=100x(Aa/Ap)\%, sendo Aa - área abertura e Ap - área do piso. } \\
\text { Constam como recursos: ventilação cruzada, ventilação ( } 5 \text { ren/h) } \\
\text { e proteção das aberturas (sombreamento). } \\
\text { O relatório NPC/UFSC (UFSC, 2013) adéqua o texto normativo } \\
\text { para as celas: a edificação deve obrigatoriamente proporcionar a } \\
\text { ventilação interna dos ambientes de longa permanência (celas). } \\
\text { A ISO } 6241: 1984 \text { determina o controle da temperatura do ar. } \\
\text { O PSI 12/2012 (UK, 2012) dispensa a ventilação do banheiro em } \\
\text { celas de 'capacidade máxima'. } \\
\text { O PSI 12/2012 (UK, 2012) prevê controle das aberturas. }\end{array}$ \\
\hline $\begin{array}{l}\text { Saúde, higiene e } \\
\text { qualidade do ar }\end{array}$ & $\begin{array}{l}\text { NBR 15.575-1 } \\
\text { Habitabilidade: } \\
\text { Saúde, higiene e qualidade do ar } \\
\text { Caderno BREEAM Prison }\end{array}$ & - \\
\hline
\end{tabular}




\section{Apêndice C - Estudo de campo}

Neste apêndice, o levantamento conduzido junto aos usuários da edificação prisional em unidades prisionais estaduais é apresentado, em termos do método e da técnica aplicados, bem como, do procedimento efetuado e dos resultados obtidos. Este apêndice complementa o Capítulo 4.

No estudo de campo, os funcionários e presos forneceram informações diferenciadas a respeito da atividade e do espaço prisional (Quadro 25). Os funcionários contribuíram em temas mais gerais da segurança e da operação, além de elementos específicos da segurança penitenciária, como a barreira perimetral e o posto de controle. Os presos se manifestaram pontualmente nestes temas, enquanto colaboraram expressivamente em temas correlatos a sua rotina, tais como, a visita, o trabalho, a cela e o pátio de sol. Estas informações atingiram o patamar das minúcias panópticas, atreladas às pequenas ações cotidianas definidoras da rotina prisional e qualificadoras do uso do tempo na prisão.

Os funcionários e os presos inicialmente se manifestavam com foco nos problemas, o que era progressivamente substituído durante os colóquios por soluções limitadas pela realidade prisional e soluções desejáveis para a realidade prisional. Os funcionários atrelaram seus comentários aos recursos operacionais disponíveis, alicerçados na avaliação das unidades prisionais em que trabalham, enquanto os presos se contiveram pela institucionalização e pela condição limítrofe vivenciada. Os presos exibiram uma preocupação com a melhor solução para a instituição, às vezes, acompanhada de autopunição: errou e não pode exigir muito por isto - "ninguém mandou, agora aguenta". As respostas eram associadas às distorções do sistema penitenciário, em particular à superlotação: para quem vive em uma cela com cinquenta pessoas, se houverem apenas vinte está ótimo (mesmo que ainda superlotada). Com alguns presos, não se atingiu um estado propício para a imaginação de um espaço melhor: "aqui não tem como ser bom, eu estou preso".

\section{Considerações iniciais}

O conjunto dos projetos de referência adotados nesta pesquisa (Apêndice A) indicou a amostra para o estudo de campo que inicialmente incluiu três dos principais sistemas penitenciários do país: Distrito Federal, São Paulo e Santa Catarina ${ }^{113}$. Todavia, a incursão na unidade do Distrito Federal não se concretizou. De qualquer modo, além de garantir uma representatividade do universo penitenciário

\footnotetext{
113 O projeto padrão de penitenciária do Ministério da Justiça não foi edificado, por isto, não integrou o levantamento realizado.
} 
nacional, a incursão em diferentes unidades federativas foi importante para homogeneizar a informação, ao nivelar as particularidades inerentes aos sistemas estaduais, abaixo resumidas (BRASIL, 2014):

a) O sistema catarinense conta com, aproximadamente, vinte mil presos, quatorze mil vagas e quase cinquenta estabelecimentos, o que configura uma superlotação de 132\%. Este sistema é descrito pela disciplina mais rígida, sem a formação de autogoverno dos presos ou a imposição das facções criminosas, onde houve um investimento do governo para a estabilização das prisões.

b) O sistema paulista conta com, aproximadamente, duzentos e vinte mil presos, mais de cento e trinta mil vagas e cento e sessenta estabelecimentos, o que configura uma superlotação de $170 \%$. Este sistema é o maior do país e explicita problemas críticos da prisão, tais como: a superlotação e a disputa de poder com a atuação de facções criminosas, notoriamente, o Primeiro Comando da Capital.

O estudo de campo exigiu uma série de tratativas com as administrações penitenciárias para a anuência e preparação do trabalho, pois qualquer permissão é vista com cautela, especialmente quando envolve os presos. Em parte, para proteger a instituição de uma exposição pública ou da atuação de inteligência de grupos criminosos. Em outra parte, para preservar a integridade física e moral das pessoas inseridas no ambiente prisional. Além disto, se deve considerar a situação de recursos escassos e tensão constante do sistema penitenciário. Por isto, o estudo foi delineado por algumas restrições quanto ao número de participantes e o tipo de informação a ser divulgada, o que definiu o método a ser aplicado.

\section{Método}

Um modelo de pesquisa qualitativo ficou estabelecido para esta pesquisa, fundado na técnica de representação social e na entrevista em profundidade do tipo semi-estruturada. A opção por este tipo de método derivou da natureza do problema investigado, do problema de pesquisa e da forma de abordagem junto aos entrevistados, pontualmente condicionados pelo número de presos previsto para este trabalho e pela relativa incapacidade dos mesmos em responder questionários escritos ${ }^{114}$.

\footnotetext{
114 A natureza do problema remete à complexidade da arquitetura penal que envolve um conhecimento de caráter intersubjetivo e compreensivo, cuja construção permite uma multiplicidade analítica alinhada com os vários fenômenos e perspectivas envolvidas no contexto analisado, ao invés de apenas dados objetivos e explicativos. Neste sentido, os mecanismos quantitativos podem obstar muitos dos problemas e fenômenos envolvidos nas relações sociais, quando estas são expressas em números e estatísticas. O problema de pesquisa se classifica como complexo, ao mesmo tempo em que contou com uma base teórica e organizacional, providenciadas pelo Panóptico e pelo programa arquitetônico concebido nesta tese que definiram categorias analíticas e anteciparam possíveis situações para o levantamento de campo. A abordagem por meio de entrevista alcança melhor a confiabilidade dos dados obtidos, diante das condições do meio prisional, em termos da essência totalitária da atividade prisional e dos antagonismos da sociedade prisional que podem distorcer as intenções dos participantes. Nas consultas preliminares, o então diretor adjunto da Penitenciária do Distrito Federal, Marcos Soliak, colocou a dificuldade dos presos de
} 
A abordagem da pesquisa qualitativa permitiu uma multiplicidade analítica alinhada com os vários fenômenos e perspectivas envolvidas no contexto analisado, admitindo a manifestação espontânea dos entrevistados, o que potencialmente enriqueceu a compreensão do fenômeno social aplicado da prisão. Enquanto a entrevista se apresentou como técnica de coleta de dados mais favorável para a compreensão do intercâmbio entre os fenômenos sociais e a arquitetura, sendo recomendada para temas pouco conhecidos ou para o detalhamento de pontos específicos que exigem pontos de vista individuais. Outro aspecto positivo da entrevista é a privacidade do participante, devido à natureza delicada do temacontexto. Por isto, as entrevistas foram individuais.

Para garantir dados confiáveis, duas estratégias foram implementadas na pesquisa realizada. Na primeira, a abordagem paradigmática na obtenção dos dados foi cunhada sobre uma posição emocionalista, sendo buscados junto aos entrevistados dados a partir de sua experiência em termos do uso do espaço arquitetônico prisional. Na segunda estratégia, um modelo de entrevista neutro foi adotado, fazendo do entrevistador um transmissor de estímulos positivos, buscando maior impessoalidade e equilíbrio na entrevista. Assim, o entrevistado fica liberado para construir suas respostas de modo propositivo, o que permite o surgimento de novas informações, eventualmente inesperadas, por meio da interação entrevistado-entrevistador.

A abordagem dos participantes procurou o estabelecimento de rapport entre entrevistador e entrevistado, o que exigiu certas condições garantidoras da veracidade e fidedignidade da informação obtida ${ }^{115}$. Estes cuidados permeiam a representação social de Goffman, na qual o entrevistador passa a integrar o esquema teatral da prisão (POUPARD, 2008). Segundo Goffman, cada encontro é situacional e seu controle relativo depende de um ambiente e contexto favoráveis. Em particular, a abordagem dos participantes se desenvolveu sobre o conceito do appreciative inquiry, apresentado no livro Prisons and Their Moral Performance de Alison Liebling (2004). Este conceito de entrevista consiste na identificação da 'melhor experiência' dos usuários da edificação, buscando as experiências ou ideias positivas, ao invés dos problemas e queixas ou das falhas existentes.

\footnotetext{
comunicação por linguagem escrita, pois a totalidade destes é considerada analfabeta funcional, o que implicou na necessidade de um interlocutor para garantir a informação objetivada. Esta unidade penal inicialmente disponibilizaria em terno de dez presos para esta pesquisa.

115 Para isto, o manejo da coleta de dados deve favorecer um ambiente não-coercitivo. Neste sentido, a realização das entrevistas foi prevista nos dias sem visitação e nos horários em que os presos estão fora das celas e sem atividades previstas, assim como, a realização do encontro se daria em local ordinário, sem divisórias, constando de mesa e cadeiras. Da mesma maneira, seriam usadas roupas neutras que não remetessem a uniformes oficiais. Ao início da coleta de dados foi apontado o objetivo da pesquisa, explicitada a importância do trabalho realizado e elucidado cada item do Termo de Consentimento Livre e Esclarecido (TCLE). Quanto ao TCLE, o participante seria informado sobre todas as condições, especialmente: a) a garantia da participação de caráter voluntário, mediante consentimento livre e esclarecido; b) a garantia do anonimato, salvo interesse manifesto do participante; e c) a garantia de acesso aos resultados da pesquisa, caso desejem a instituição penal e os envolvidos. Aliado a estes pontos, ainda foi ressaltado que o material coletado seria utilizado exclusivamente para esta pesquisa e de modo correto, sem edições ou descontextualizações. Feitas as considerações iniciais, estando o TCLE devidamente assinado, a entrevista seria iniciada com base no roteiro de perguntas.
} 
No tipo de entrevista em profundidade semiaberta ou semipadronizada, a interlocução é conduzida por um guia de entrevista que consiste de questões-chave, com a inserção de perguntas complementares, pois algumas informações objetivadas se aproximam de especificidades que podem exigir um conhecimento supostamente inexistente dos entrevistados. Na estratégia de interlocução, se parte de questões mais amplas para as mais específicas, neste caso, eventualmente preenchidas por questões do tipo fechada, cujas respostas são objetivas. Nesta providencia, a realização das perguntas ocorre individualmente e, apenas quando um tema for esgotado, se passa para a pergunta seguinte.

Quanto à coleta de dados, foram utilizados dois instrumentos de registro das respostas: anotação e gravação. No rapport, o uso do gravador seria explicado e seu uso dependeria de permissão - caso o participante fizesse oposição, a entrevista prosseguiria exclusivamente através de anotações no Protocolo Experimental. Quanto à compilação dos dados, as respostas foram acomodadas em fichas que expressam as informações redundantes e estáveis emanadas das entrevistas, eventualmente apontando variações ou anomalias relevantes surgidas nos depoimentos. A descrição e análise dos resultados foram estruturadas pelas categorias definidas no programa arquitetônico elaborado nesta pesquisa e consolidadas no roteiro de perguntas semi-estruturadas. Para Duarte (2005, p. 4), "a triangulação de dados com o acréscimo de fontes diversificadas de evidências, como documentos, observação e literatura e seu encadeamento consistente na etapa de análise, ajuda a garantir a validade dos resultados suportados por entrevistas em profundidade".

\section{Guia de entrevista}

O questionário foi baseado os temas centrais definidos no programa arquitetônico concebido nesta tese. Consequentemente, o levantamento realizado recaiu sobre as exigências funcionais das pessoas inseridas na prisão e não sobre as soluções físicas das edificações visitadas. Para Christopher Alexander (1977a), identificar os problemas de projeto em termos funcionais torna o processo de projetação mais objetivo. Além disto, esta objetividade foi reforçada por uma delimitação em torno dos elementos centrais da edificação penal. Deste modo, os funcionários e os presos foram confrontados com questões mais pragmáticas de seus respectivos universos, com maior isenção das especificidades ou polêmicas teóricas e técnicas da arquitetura penal. Neste sentido, os presos responderam sobre as relações sociais, em especial, na cela e no pátio de sol, enquanto os funcionários foram arguidos sobre a segurança e a funcionalidade, com foco na barreira perimetral e no posto de controle dos funcionários. Estas demarcações favoreceram os trabalhos, ao abreviar o tempo de realização das entrevistas. 
A elaboração do guia de entrevista se fundamentou em dois trabalhos: uma APO de unidades prisionais procedida no sistema norte-americano em década de 1980, com a participação de Richard Wener ${ }^{116}$ (apud ORNSTEIN, 1989), e a etapa de consulta realizada no desenvolvimento do trabalho The Creative PrisonInside the arquitecture: the hole of consultation (RIDEOUT, 2017). Dentre os mecanismos metodológicos utilizados no primeiro trabalho foram apropriados aqueles destinados a coleta de dados referentes ao ambiente físico, se atendo ao exame do projeto arquitetônico no conjunto de aspectos avaliados. A avaliação comportamental que tratava da rotina interna e das relações sociais, visando medir os níveis de satisfação das pessoas, não integrou o escopo desta pesquisa. Do segundo trabalho foram apreendidas as abordagens e o tipo de informação a ser gerada, principalmente, quanto à funcionalidade (uso, acesso e espaço) e conforto ambiental, além das técnicas mais favoráveis para a coleta de dados. Em relação aos procedimentos adotados nos trabalhos citados, o método construído apresentou as seguintes adequações: a entrevista informal com a direção da unidade prisional foi substituída pela aplicação do guia de entrevista; a aplicação de questionários aos presos foi substituída pela entrevista; e as entrevistas com os presos e os funcionários prevista na APO foram individualizadas (a APO misturava presos e funcionários em grupos de cinco a dez pessoas).

\section{Amostra}

Sobre os informantes, para cada unidade prisional foram solicitados de dez a vinte presos e de quatro a oito funcionários (a APO da Jay Farbstein \& Associates, Inc [apud ORNSTEIN, 1989] abrangeu um universo de cento e cinquenta presos e setenta e cinco funcionários). Nos métodos qualitativos é preferível poucas fontes, mas representativas, que, adequadamente escolhidas, podem fazer um relato bastante consistente sobre o tema. Neste caso, a diversidade dos entrevistados é relevante, o que sugeriu a abordagem de atores em posições distintas na sociedade prisional: funcionários e presos, dos mais 'novatos' aos mais 'veteranos' - a depender do tempo no sistema penitenciário. A conformação dos entrevistados classificou a amostra como não probabilística, tendo sido inicialmente delineada pelo pesquisador em torno de informantes-chave, como o diretor e o chefe de segurança - considerados indispensáveis para a pesquisa. Já os demais funcionários e os presos foram apontados pelas direções dos estabelecimentos penais, o que a classificou a amostra como acidental ou por conveniência - quando as fontes são selecionadas por disponibilidade.

\footnotetext{
${ }^{116}$ O trabalho foi executado pelo escritório Jay Farbstein \& Associates, Inc., tendo sido contratado pelo United States Departamento of Justice, por intermédio do National Institute of Corrections - Prision Division. O mesmo avaliou, principalmente, os custos, o impacto ambiental nos funcionários, o projeto arquitetônico e a superlotação (ORNSTEIN, 1989, p. 14). Entre os espaços da edificação prisional, este trabalho focou a cela, na qual foram realizadas medições e observações quanto às funções realizadas e configurações físicas, entre outros apontamentos.
} 
Entre os funcionários não havia necessidade de distinção de gênero, todavia foi recomendado serem todos da equipe de segurança e possuírem tempo de serviço suficiente para o conhecimento e vivência do funcionamento da prisão. Entre os funcionários, foi solicitado, pelo menos, um guarda externo. Entre os presos, julgou-se essencial a participação de usuários do pátio de sol e, no mínimo, dois internos que fizessem uso de visitas íntimas. Isto porque era esperado que fossem designados colaboradores da administração que, eventualmente, não integram plenamente a rotina prisional.

\section{Relatório do procedimento}

Os trabalhos transcorreram de modo tranquilo, sem ocorrências extraordinárias, tendo sido cumpridas as recomendações de segurança. No total foram entrevistadas 51 pessoas, 26 funcionários, sendo 2 diretores, 2 chefes de segurança e 18 agentes penitenciários ( 2 agentes de segurança externa), além de 29 presos. A cada novo entrevistado era feita uma breve apresentação do objetivo do trabalho, o Termo de Consentimento Livre e Esclarecido (TCLE) era assinado e, ao final, era feito um agradecimento verbal. O TCLE não ficou com os presos, em atenção ao protocolo das unidades visitadas (em Santa Catarina foi anexado ao prontuário). As entrevistas foram registradas por meio de anotações e gravação (apenas um funcionário refutou a gravação). Foi produzido apenas um desenho (croqui), por preso.

\begin{tabular}{l}
\hline Quadro 23 - Descrição do levantamento realizado no sistema catarinense \\
\hline Unidade prisional: \\
Penitenciária Industrial de Blumenau (PIB) \\
\hline Dados Gerais: \\
As entrevistas foram realizadas entre os dias 31 de agosto e 3 de setembro de 2016 . A unidade prisional se localiza \\
na Rua Silvano Cândido de Silva Sênior, 957 , Bairro Ponta Aguda, Blumenau. A mesma tinha seis meses de operação \\
(inaugurada em janeiro de 2016). \\
\hline Descrição da unidade prisional: \\
A unidade conta com 600 presos para 576 vagas, configurando uma superlotação da ordem de $1 \%$ (Erro! Fonte de \\
referência não encontrada.). A unidade opera com 90 agentes de segurança, estes trabalhando no regime de \\
$24 / 72$ horas, o que mantém cerca de 20 agentes operacionais na unidade, atuando de modo revezado nos blocos \\
de vivência. Existe a previsão de $50 \%$ a $60 \%$ de presos com visita que ocorrerá em quatro dias na semana, com a \\
duração de duas horas, em média. A unidade é uma versão reduzida do modelo arquitetônico da empresa Verdi \\
Construções S/A, sem blocos específicos de isolamento dos presos e assistência à saúde (estas funções estão \\
acumuladas no bloco de inclusão e serviços, respectivamente), assim como, o programa administrativo e de apoio \\
aos funcionários e aos visitantes está incompleto. Esta versão tem muro no lugar de cerca como barreira \\
perimetral. \\
Entrevistados: \\
Foram ouvidas 25 pessoas, entre 17 funcionários, incluindo o diretor da unidade, além de 12 presos. Os \\
funcionários integram a equipe de segurança da unidade penal. Um destes funcionários atua na segurança externa. \\
O chefe de segurança não foi entrevistado por indisponibilidade de tempo. O perfil dos presos é variável, com \\
penas entre cinco e cem anos, advindos, na totalidade, da comarca. Cinco destes presos atuavam nos trabalhos \\
internos do estabelecimento, sendo reconhecidos pela administração como 'regalias'. Estes presos não utilizam o \\
pátio de sol e permanecem de oito a dez horas diárias fora da cela. Os demais presos estavam em um regime diário \\
de 22 horas nas celas, duas nos pátios de sol.
\end{tabular}


Entrevistas:

Todas as entrevistas foram individuais e privadas, sem escolta (no caso dos presos) e com todos sentados. As interlocuções variaram entre 25 e 50 minutos (uma funcionária refutou a gravação). As entrevistas com os funcionários ocorreram em diversas dependências da unidade penal: sala de reunião na administração, sala do chefe de segurança no controle intermediário e posto de controle da recepção. As entrevistas com os presos colaboradores ocorreram em sala da administração, enquanto os demais presos foram ouvidos em parlatórios nos blocos de vivência, por meio de interfone (estes presos permaneceram algemados durante a entrevista).

Peculiaridades:

A unidade não apresentava superlotação massiva (1\%). Pela ocupação recente (seis meses), diversos funcionários eram recém contratados pelo estado e as atividades de trabalho e educação ainda estavam sendo implantadas (havia educação para poucos presos). Além disto, a unidade estava saindo de uma medida disciplinar com restrição de pátio de sol e suspensão da visita social. Por estas condições, os funcionários e presos ainda não haviam experimentado plenamente a rotina própria da unidade: a operação é diferenciada pelo uso de postos de controle e da circulação exclusiva para os funcionários.

Considerações:

Por se tratar da primeira incursão no sistema prisional, as entrevistas nesta unidade prisional foram acompanhadas de psicóloga que procedeu a um treinamento para os levantamentos nos demais sistemas prisionais. As peculiaridades encontradas limitaram algumas informações recebidas, principalmente quando à realização da visita e ao uso do pátio de sol dos presos.

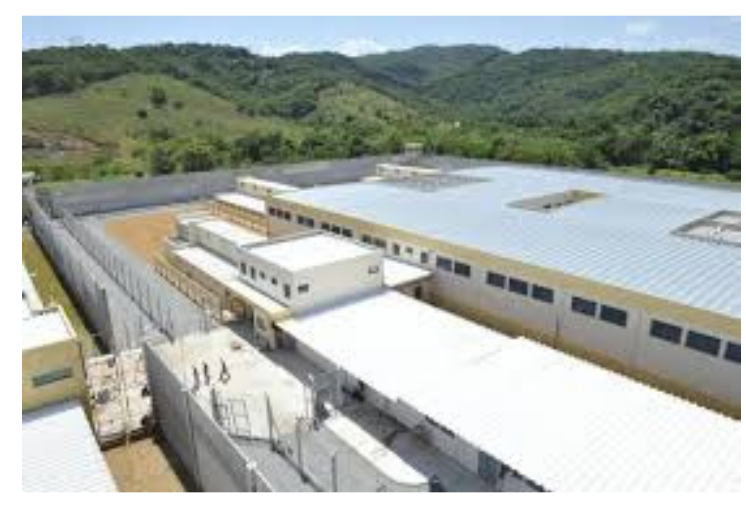

Figura 70 - Fotografia da Penitenciária Industrial de Blumenau

(Fonte: Disponível em: <http://jornaldesantacatarina.clicrbs.com.br/sc/geral/noticia/2016/03/pancho-transferenciade-presos-para-penitenciaria-industrial-de-blumenau-ocorrera-ate-inicio-de-abril-5110683.html>. Acessado em: 27 fev. 2017)

\begin{tabular}{|l|}
\hline Quadro 24 - Descrição do levantamento realizado no sistema paulista \\
\hline Unidade prisional: \\
Centro de Detenção Provisório Pinheiros 2 (CDP2 Pinheiros) \\
\hline Dados Gerais: \\
As entrevistas foram realizadas entre os dias 24 e 26 de outubro de 2016 . A unidade prisional se localiza na Avenida \\
das Nações Unidas, 1.230, Bairro Vila Leopoldina, São Paulo. A unidade foi inaugurada no ano de 2004 , após \\
reforma de antiga instalação da polícia civil (Dacar-2)(Erro! Fonte de referência não encontrada.). \\
\hline Descrição da unidade prisional: \\
A unidade prisional conta com aproximadamente 1.500 presos para 517 vagas, configurando uma superlotação da \\
ordem de $200 \%$. A unidade e opera com 110 agentes de segurança, estes trabalhando no regime de $12 / 36$ horas, o \\
que mantém cerca de $25 / 30$ agentes operacionais na unidade, atuando de modo revezado no bloco de vivência \\
(pavilhões). A unidade recebe cerca de 150 visitantes por dia, com duração de $4 \mathrm{~h}$, em média. O modelo Dacar \\
difere do padrão paralelo da Penitenciária Compacta, sendo descrito por um posto de controle central a quatro \\
\hline
\end{tabular}


pavilhões. Cada pavilhão possui um pátio ladeado por dois pavimentos de celas coletivas.

Entrevistados:

Foram ouvidas 26 pessoas, entre 9 funcionários, incluindo o diretor da unidade prisional, o chefe da segurança e o chefe do plantão, além de 17 presos. Os funcionários integram a equipe de segurança da unidade penal, em média, com 11 anos de serviço. Dois destes funcionários atuavam na segurança externa, sendo um destes o chefe da segurança externa. O perfil dos presos é variável, com penas entre quatro meses e 23 anos, advindos, na totalidade, da comarca. Dez destes presos atuavam nos trabalhos internos do estabelecimento, sendo reconhecidos pela administração como 'regime de observação'. Os demais presos ocupavam posições de confiança da administração no gerenciamento dos pavilhões.

Entrevistas:

Todas as entrevistas foram individuais e privadas, sem escolta (no caso dos presos) e com todos sentados em uma mesa. As interlocuções variaram entre 25 minutos e uma hora. As entrevistas com os funcionários e os presos ocorreram em sala da assistência social, no bloco de assistência à saúde, fora dos pavilhões. Os presos de confiança permaneceram algemados durante a entrevista.

Peculiaridades:

A unidade visitada é reconhecida no sistema penitenciário paulista por seu trabalho social junto aos presos, o que possibilitou o contato com boas iniciativas e ações no campo prisional. 0 edifício retrata mais fidedignamente o esquema panóptico, com um posto de controle central ('bolha'). O posto central é complementado por dois corredores ('radiais'), nos quais permanecem as equipes para os procedimentos de entrada/saída do bloco. Nestas radiais ficam quatro celas coletivas dos presos trabalhadores. A unidade estava passando por uma reforma nos pavilhões, ao substituir os beliches de duas camas das celas por beliches triplos, para o aumento de capacidade do estabelecimento. Com isto, os presos de um pavilhão estavam alocados nos demais.

\section{Considerações:}

A pesquisa de campo solicitou acesso a uma unidade do tipo penitenciária compacta (PC), sendo disponibilizada a unidade visitada, por decisão da administração prisional do estado. As peculiaridades encontradas exigiram um esforço para a obtenção de alguns dados, em virtude dos padrões vivenciados pelos funcionários e presos, além de tentar se aproveitar a experiência de alguns presos que estiveram em unidades do tipo penitenciária compacta.

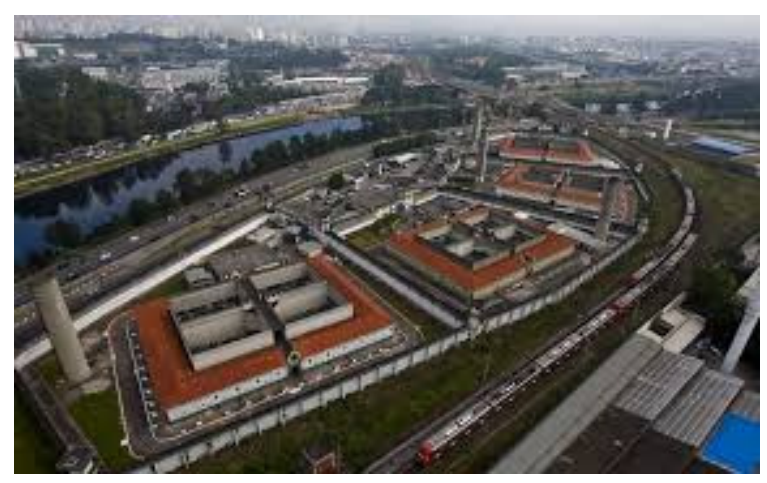

Figura 71 - Fotografia do complexo penitenciário de pinheiros

(Fonte: < http://fotografia.folha.uol.com.br/galerias/16587-cdp-de-pinheiros-superlotado>. Acessado em: 27 fev. 2017)

\section{Resumo dos dados levantados}

Segue resumo dos dados levantados. 
Quadro 25 - Dados levantados em entrevistas aos usuários da edificação penal

\begin{tabular}{|c|c|}
\hline \multicolumn{2}{|l|}{ Tipo e categoria do estabelecimento penal } \\
\hline Demandas & Considerações \\
\hline $\begin{array}{l}\text { As equipes dirigentes têm uma noção de segurança máxima própria de unidades de RDD (capacidade reduzida, contato externo } \\
\text { restrito, alojamento individual, programa reduzido e controle elevado). Os funcionários oscilam em classificar as unidades visitadas, } \\
\text { de todo modo, consideradas de segurança inferior ao máximo. Os mesmos relatam a sensação de aprisionamento, embora se sintam } \\
\text { seguros na unidade prisional. Os presos relataram a sensação de serem constantemente vigiados - "claro!". Um preso destacou a } \\
\text { coerção institucional, mas o grupo afirmou não sentir medo (a sensação de risco à integridade pessoal). }\end{array}$ & $\begin{array}{l}\text { A unidade prisional de Santa Catarina apresenta } \\
\text { características de uma unidade de segurança } \\
\text { máxima. A unidade prisional de São Paulo se } \\
\text { aproxima de uma segurança máxima, mas } \\
\text { apresenta aspectos de uma segurança menor (a } \\
\text { exposição dos funcionários). }\end{array}$ \\
\hline \multicolumn{2}{|l|}{ Porte do estabelecimento penal } \\
\hline $\begin{array}{l}\text { As equipes dirigentes consideram a melhor capacidade do estabelecimento em torno de } 600 \text { presos, mediante o potencial ofensivo } \\
\text { da população prisional e os recursos disponíveis. Os presos não souberam responder. Em Santa Catarina, a equipe de } 90 \text { agentes é } \\
\text { considerada pequena (relação de 1/7), segundo funcionários (inclusive o diretor) deveria ter de } 30 \% \text { a } 40 \% \text { a mais (relação de } 1 / 5 \text { ). } \\
\text { Com menos funcionários, a operação fica lenta: "uma lista de tarefas que se acumulam". Para a direção, a escala de } 12 / 36 \mathrm{~h} \text { é } \\
\text { considerada mais produtiva, ao poupar os funcionários (menos estressante). Em São Paulo, a equipe de } 100 \text { agentes é considerada } \\
\text { pequena (relação de 1/7), segundo funcionários (inclusive o diretor) deveria ser de } 200 \text { agentes (relação de 1/5). }\end{array}$ & $\begin{array}{l}\text { Em Santa Catarina, a escala é de } 24 / 72 \mathrm{~h} \text { : em um } \\
\text { turno são aproximadamente } 20 \text { agentes } \\
\text { penitenciários. Em São Paulo, a escala é de } 12 / 36 \mathrm{~h} \text { : } \\
\text { em um turno são aproximadamente } 30 \text { agentes } \\
\text { penitenciários de dia e } 15 \text { agentes à noite. São } \\
\text { Paulo trabalha com um 'núcleo de segurança' de } \\
25 \text { agentes. }\end{array}$ \\
\hline $\begin{array}{l}\text { A equipe dirigente catarinense considera a estrutura física da unidade compatível com a capacidade, com exceção da área de } \\
\text { trabalho dos presos (diminuta), do isolamento dos presos (agrupado com a inclusão) e do apoio aos funcionários (insuficiente). A } \\
\text { equipe dirigente paulista considera a estrutura física da unidade incompatível com a capacidade - "trata-se de uma adaptação do } \\
\text { edifício, quando a cadeia não exigia a estrutura de hoje". }\end{array}$ & $\begin{array}{l}\text { A unidade catarinense é um projeto reduzido da } \\
\text { empresa. A unidade paulista foi configurada como } \\
\text { cadeia pública nos moldes anteriores à revisão } \\
\text { normativa. }\end{array}$ \\
\hline \multicolumn{2}{|l|}{ Custo do estabelecimento penal } \\
\hline $\begin{array}{l}\text { A equipe dirigente considera o custo operacional da unidade prisional dentro dos limites encontrados. Os funcionários paulistas } \\
\text { consideram seus salários baixos - "podia melhorar". }\end{array}$ & $\begin{array}{l}\text { Os salários são de } \mathrm{R} \$ 2.703,90 \text { e } \mathrm{R} \$ 3.340,48 \text { para a } \\
\text { unidade paulista e catarinense. }\end{array}$ \\
\hline $\begin{array}{l}\text { As equipes dirigentes destacaram o condicionamento do custo operacional à divisão da população prisional, distribuição das } \\
\text { atividades dos presos e ao modelo de vigilância adotado. A demanda de funcionários para a vigilância e os procedimentos aumenta } \\
\text { proporcionalmente ao número de blocos de vivência e pátios de sol e à dispersão das atividades. Segundo os diretores, esta relação } \\
\text { determina a segurança penitenciária com base nos recursos disponíveis. }\end{array}$ & $\begin{array}{l}\text { A unidade catarinense replica as atividades em } \\
\text { blocos funcionais que definem quatro equipes } \\
\text { locais e uma equipe geral. A unidade paulista } \\
\text { centraliza o controle, o que configura três equipes, } \\
\text { porém não oferece as atividades dos presos. }\end{array}$ \\
\hline \multicolumn{2}{|l|}{ Isolamento social dos presos } \\
\hline $\begin{array}{l}\text { As equipes dirigentes consideram a estanqueidade uma obviedade no funcionamento da prisão. As unidades prisionais não tiveram } \\
\text { fugas recentes. Os diretores apresentaram um contraponto ao determinismo arquitetônico: a operação resolvendo falhas ou } \\
\text { deficiências de segurança do edifício. Os funcionários em Santa Catarina apontaram vulnerabilidades do edifício e ponderaram sobre } \\
\text { o desconhecimento do funcionamento projetado para a unidade - "falta um manual", "agente faz como acha que foi pensado para } \\
\text { ser". Foram apontados problemas na abertura de portas, realização de procedimentos e circulação de pessoas, além de fragilidades } \\
\text { favoráveis às ações subversivas dos presos, tais como as grades nas janelas das celas e a cobertura acessível - a cobertura é o ponto } \\
\text { de fuga mais visado atualmente. Em São Paulo, a edificação antiga apresenta uma série de problemas, advinda principalmente da } \\
\text { incompatibilidade com o atual perfil do sistema penitenciário e dos presos. }\end{array}$ & As unidades têm muro de $6 \mathrm{~m}$ de altura. \\
\hline $\begin{array}{l}\text { As equipes dirigentes consideram a impermeabilidade como imprescindível ao funcionamento do estabelecimento, havendo uma } \\
\text { preocupação com o entorno da unidade prisional (residências próximas), a permeabilidade da barreira perimetral (cerca) e a abertura }\end{array}$ & $\begin{array}{l}\text { A unidade catarinense tem entorno com morros } \\
\text { altos e casas vizinhas, barreira perimetral do tipo }\end{array}$ \\
\hline
\end{tabular}


dos edifícios (pátios e aberturas de iluminação e ventilação). Em boa medida, os funcionários se preocupam com a impermeabilidade do edifício, ao criticar ou sugerir o fechamento da arquitetura. O muro é tratado como solução óbvia para os eventuais problemas de impermeabilidade com o entorno e a edificação.

As equipes dirigentes consideram a visita social do preso imprescindível para a manutenção das suas funções sociais - a identificação com o mundo externo e a manutenção dos laços familiares. Como foi observado em Santa Catarina, a visita ao preso integra o sistema de recompensas e castigos. Os presos primam pela visita, embora a maioria não seja visitada. Na unidade catarinense se estima que 30 a $40 \%$ dos presos terão visita. Na unidade paulista são $35 \%$ dos presos com visita. Os presos demonstram uma preocupação com o bem estar da visita maior do que por eles próprios. Segundo preso, "os amigos são importantes, mas a família é mais". Neste sentido, é importante que a unidade prisional tenha local específico para a visita social para a comodidade das pessoas. Para os funcionários, este local é visto como meio para disciplinar a atividade. O chefe de segurança paulista critica fortemente a ausência do local de visita. Para os presos (6), o local de visita é visto como meio para poupar as visitas do contato com a vida na prisão e com presos sem visita - a "visita não deve ter acesso ao interior da prisão", "o pátio é para quem não tem visita". Os presos sugeriram brinquedos para as crianças e mobiliário constituído de mesas para quatro pessoas (grupo familiar).

As equipes dirigentes consideram a visita íntima do preso importante para a manutenção da intimidade e para evitar promiscuidades entre a população prisional. Os presos consideram a visita íntima como saudável, além de garantir o matrimônio, já que "a mulher tem as necessidades dela". Em São Paulo, o encontro íntimo na cela é tido como constrangedor pelos presos devido ao barulho (outros casais ou 'moradores') - a questão da privacidade na prisão. Este constrangimento preocupa os presos quanto ao abandono da mulher. $O$ rádio (música) é usado para disfarçar o ambiente. Neste sentido, para os presos, um local específico para o encontro conjugal é visto como meio de respeito à intimidade do casal e de manutenção da visita (4), o que é evidenciado em São Paulo - "é melhor". Para os funcionários, um local de visita íntima é visto como meio para disciplinar a atividade. Não foi apontada uma quantidade melhor de apartamentos que depende do regime de visita. Os funcionários consideram uma hora de permanência como suficiente. Os presos apontam duas horas.

As equipes dirigentes consideram a localização do estabelecimento penal essencial para o esquema de segurança, destacando a constituição geográfica do entorno, construções vizinhas e o acesso, como fatores críticos, em termos de um ataque externo e da impermeabilidade de prisão.

Isolamento individual dos presos

As equipes dirigentes (diretor e chefe de segurança) consideram a melhor divisão da população prisional em quatro grupos para a classificação e separação na unidade prisional (foi cogitada uma quinta ala destinada aos presos por crimes sexuais), tendo em vista os perfis mais significantes (a existência de facções criminosas se sobrepõe à classificação criminológica ou penalógica) e os recursos operacionais disponíveis. Cada ala é considerada bem dimensionada com 8 a 10 celas (1), máximo de 12 celas. A divisão dos presos se prolonga nas alas carcerária, fracionadas em outros quatro grupos cada (SC). 0 melhor tamanho de um grupo de presos é de 24 a 40 indivíduos, o que define de 96 a 160 presos por ala carcerária ou bloco de vivência, com uma recorrência maior em torno de 100 presos. Existem subgrupos envolvidos em atividades colaborativas com a instituição e que são separados nas próprias alas: faxinas (cuidam da limpeza, distribuição de refeições, ordem interna, atividades e trabalhos de pátio de sol), serviços (cozinha e lavanderia) e externos (manutenção, limpeza, retirada de lixo, transporte).

A equipe dirigente (diretor e chefe de segurança) considera necessárias as celas individuais para o gerenciamento da prisão, em uma proporção de $1 \%$ em relação à capacidade do estabelecimento. A direção de Santa Catarina sugeriu a relação de 10 celas coletivas (oito vagas) por cela individual. A necessidade de separação física deste conjunto de celas em relação aos blocos de vivência é muro e edificações com janelas nas celas. A unidade paulista tem locação urbana, barreira do tipo muro e bloco de vivência fechado.

A unidade catarinense possui local específico para a visita social dos presos. A unidade paulista não possui espaço específico, a visita ocorre no pátio de sol dos presos (como ocorre no modelo da PC). Em Santa Catarina, a visita ocorre em quatro dias, com cerca de 30/40 visitantes por dia, sendo metade da uma ala pela manhã e a outra à tarde. A visita tem duração de duas horas. Em São Paulo, a visita ocorre em dois dias, com cerca de 150 visitantes por dia, com duração de $8 \mathrm{~h}$.

A unidade catarinense apresenta 12 apartamentos de encontro íntimo (12/vaga/dia). A unidade paulista não possui encontro íntimo que ocorre nas celas, durante a visita social (como ocorre no modelo da PC). Em Santa Catarina, a visita íntima ocorre uma vez por mês, com duração de duas horas ou mais.

O projeto catarinense é locado em área de relevo acidentado, com casas circundantes e um acesso desprotegido. A unidade paulista tem locação urbana, ao lado de avenida e edifícios altos.

\section{Considerações}

As unidades visitadas apresentam uma separação espacial em quatro blocos ou pavilhões. Os presos sexuais em Santa Catarina são 120.

A unidade catarinense possui 15 celas individuais que atendem ao isolamento e à triagem. A unidade paulista não possui celas de isolamento (existem 


\begin{tabular}{|c|c|}
\hline unânime para preservar os presos isolados em caso de tomada da prisão (rebelião), o que exige uma & quatro celas coletivas impróprias para o uso). \\
\hline $\begin{array}{l}\text { As equipes dirigentes e os presos consideram a cela coletiva o melhor tipo, tendo em vista a superlotação e os recursos operacionais } \\
\text { disponíveis, com vantagens e desvantagens, além de nuanças. Para os funcionários, a cela coletiva é vista como meio para a redução } \\
\text { das tarefas e simplificação de procedimentos, além de empoderar os presos. Para os presos, a mesma é vista como meio de } \\
\text { sociabilização e coesão do grupo, embora exija um exercício constante de dialogo e negociação para uma convivência pacífica. A } \\
\text { interpretação do grupo social na cela pelos presos varia entre uma família (irmãos) e "pessoas que não são minhas amigas". Um preso } \\
\text { relatou não ter problemas com a vida coletiva. Alguns presos rejeitaram a cela individual, porque não suportariam ficar sozinhos - } \\
\text { "depressão, solidão" (7) e "falta de carinho". Outros presos optaram pela cela individual (3) pela exaustão da vida coletiva - "ter um } \\
\text { canto para a reflexão". }\end{array}$ & $\begin{array}{l}\text { As unidades prisionais adotam celas coletivas. A } \\
\text { superlotação em São Paulo agrava a vida em grupo } \\
\text { (conflitos, inimizades) o que estimula a preferência } \\
\text { de alguns presos pela cela individual. }\end{array}$ \\
\hline $\begin{array}{l}\text { As equipes dirigentes e os presos consideram valores similares para a melhor capacidade da cela coletiva, tendo em vista a } \\
\text { superlotação, as relações sociais e os recursos operacionais disponíveis. Estes valores estão entre quatro (8) e oito pessoas (11), com } \\
\text { uma manifestação significativa por seis ocupantes (7). Para os funcionários, este intervalo é visto como favorável ao controle com } \\
\text { redução da exposição dos funcionários, sendo quatro presos melhor (procedimentos são realizados mais rapidamente) e oito diante } \\
\text { da demanda de vagas (um agente considerou excessivo). Para os presos, com menos de quatro pessoas a convivência é entediante } \\
\text { (não tem assunto para as conversas), mas ocorrem "menos brigas"; entre quatro e oito é melhor (privacidade, convivência e higiene); } \\
\text { e mais de oito complica a convivência (administrar as diferenças). Resultados minoritários tenderam a capacidades inferiores em } \\
\text { Santa Catarina: um (1), dois (3), três (2) ou cinco presos (4). Em São Paulo tenderam para mais, chegando a } 11 \text { (2), } 12 \text { (3), } 15 \text { (1), 18 (1) } \\
\text { ou } 20 \text { presos (1). }\end{array}$ & $\begin{array}{l}\text { As unidades prisionais adotam celas de oito vagas. } \\
\text { A superlotação em São Paulo distorce o padrão do } \\
\text { que seria uma capacidade melhor, tendo sido } \\
\text { inicialmente citados números de } 20 \text { ou } 25 \text { presos } \\
\text { em uma cela. A superlotação chega a mais de } \\
\text { cinquenta presos em algumas celas (dois presos } \\
\text { por cama, camas no chão e redes amarradas em } \\
\text { furos nas camas e grades). }\end{array}$ \\
\hline \multicolumn{2}{|l|}{ Organização do espaço } \\
\hline $\begin{array}{l}\text { A equipe dirigente (SC) considera como estrutura física para a visita aos presos uma recepção com espaço para as crianças, armários } \\
\text { para guarda de volumes e um salão com sanitários, mesas e cadeiras. Na recepção dois boxes para a revista corporal é considerado } \\
\text { suficiente, considerando o número de visitantes e os recursos disponíveis. Um funcionário citou a inclusão de pátio descoberto. Os } \\
\text { presos reclamam um espaço para as crianças na área de visita (2). A revista corporal das visitas incomoda profundamente os presos, } \\
\text { devido ao constrangimento imposto. Diversos presos pararam de receber visitas ou pediram para as mesmas não retornarem (SC). }\end{array}$ & $\begin{array}{l}\text { Em Santa Catarina, a revista das visitas é física. Em } \\
\text { São Paulo, a mesma é eletrônica, por meio de } \\
\text { escâner corporal. }\end{array}$ \\
\hline $\begin{array}{l}\text { A revista corporal dos presos representa parte significativa das tarefas dos funcionários. As revistas são realizadas nos corredores das } \\
\text { alas carcerárias (SC) e no quadrante dos pavilhões - a 'viúva' (SP). A vantagem destes locais é a proteção de uma parte da equipe } \\
\text { pelas contenções. As desvantagens são a paralisia da circulação (lentidão no funcionamento) e a apreensão por outros presos } \\
\text { (aquisição de informação). Foi sugerida a criação de salas de revista com visores ou grades, próximas às celas e aos acessos das } \\
\text { atividades dos presos (especialmente, do pátio de sol e da visita social). O uso do corredor não foi descartado por alguns funcionários. } \\
\text { Uma equipe de dois ou três agentes é considerada suficiente para os procedimentos de retirada/retorno dos presos das celas que } \\
\text { envolvem a revista corporal (menos presos é melhor por agilizar os procedimentos). Segundo presos, a revista física não representa } \\
\text { um incômodo - "faz parte". }\end{array}$ & $\begin{array}{l}\text { Nenhuma das unidades possui espaços de revista } \\
\text { corporal. }\end{array}$ \\
\hline $\begin{array}{l}\text { A equipe dirigente (diretor e chefe de segurança - SC) considera necessária uma sala multiuso junto aos blocos de vivência para a } \\
\text { imediata assistência médica, social ou jurídica. A mesma é vista pela direção como meio de reduzir o transito interno de presos para } \\
\text { os blocos de assistência. }\end{array}$ & $\begin{array}{l}\text { A unidade catarinense conta com uma sala de } \\
\text { apoio em cada bloco de vivência. A unidade } \\
\text { paulista não dispõe deste espaço. }\end{array}$ \\
\hline $\begin{array}{l}\text { As equipes dirigentes (diretores e chefes de segurança) e os presos consideram o trabalho essencial (mais do que o simples } \\
\text { cumprimento legal), enquanto os espaços não são adequados (tamanho ou localização). Os presos reclamam sobre a falta de trabalho } \\
\text { (8), visto como meio para a vida na prisão ser suportável (a questão do tempo). Em Santa Catarina, o trabalho ainda ia ser } \\
\text { disponibilizado. Em São Paulo, o trabalho ofertado é mínimo (sessenta presos) (a reforma atual representa parte do trabalho } \\
\text { ofertado). Alguns presos trabalhadores relataram o cansaço no final do dia e o consequente sono na cela - "não dá tempo de ficar }\end{array}$ & $\begin{array}{l}\text { A unidade catarinense possui oficinas que foram } \\
\text { consideradas pequenas e serão reformadas. Esta } \\
\text { unidade ainda conta com salas de aula. A unidade } \\
\text { paulista possui estruturas periféricas que foram } \\
\text { acrescidas pela administração atual e incluem }\end{array}$ \\
\hline
\end{tabular}


pensando ou conversando e o tempo passa melhor". Para os presos, o trabalho também redime tempo de pena (1/3) e ajuda no retorno à sociedade (aprender um ofício). Igualmente, a educação integra a reclamação dos presos em intensidade menor (5) - um preso cobrou cursos profissionalizantes. Em Santa Catarina, havia aula nas quartas-feiras, pela manhã. Em São Paulo, existe aula de informática. O hábito da leitura destaca a importância da biblioteca.

A equipe dirigente considera a estrutura física para os funcionários deficiente, o que compromete em parte as condições de trabalho: falta de sanitários, devidamente quantificados nos blocos de vivência, além de sala de reunião de trabalho (2), dormitório com chuveiros, sala de estar (3) e academia de ginástica (3) - "os presos passam o dia malhando e os guardas engordando". A quantidade de sanitários deve ser superestimada para evitar a espera do funcionário, o que favorece a otimização do pessoal.

As equipes dirigentes e os presos consideram a religião parte importante da assistência. Para os funcionários, a prática é vista como meio para se reduzir as tensões, o que favorece a segurança e a operação. Para presos, a prática é essencial para suportar a vida na prisão. A maioria dos presos declarou religião e se considera praticante: a leitura de textos e a comunhão nas celas e no pátio de sol. A maioria dos presos se declarou evangélico ou católico, com uma minoria de espíritas. Em São Paulo, o atendimento ocorre durante todo o dia no pátio de sol e os cultos nos finais de semana ocorrem com a presença de membros das igrejas (visitantes). A ausência de local específico leva os presos catarinenses a comungar através das janelas das celas e os paulistas a destinarem uma cela nos pavilhões para atividades religiosas (os presos trabalhadores utilizam a biblioteca). Um preso paulista sugeriu o dimensionamento do local de culto com base na relação de uma cadeira para cada cinco presos.

As equipes dirigentes (diretor e chefe de segurança) consideram o refeitório dos presos complicado para a segurança e a operação, devido à aglomeração de pessoas e às tarefas e procedimentos envolvidos, considerando os recursos disponíveis. Embora a disciplina de um local próprio pudesse favorecer a entrega das marmitas e o recolhimento do lixo com vantagens para a segurança: evitaria o alumínio na mão dos presos - "vira qualquer coisa". As refeições são servidas nas celas pelos presos de confiança (faxinas): café da manhã, almoço e jantar, havendo liberação para as atividades entre as refeições. Para o almoço, os presos são recolhidos nas celas. Alguns presos se manifestaram a favor do refeitório - fica mais organizado e limpo (2), mas a maioria prefere a cela para o almoço, pois tem privacidade e liberdade em relação à instituição - retemperar a marmita e comer no seu ritmo.

Em termos da organização da prisão, as direções buscam a produtividade máxima de uma equipe reduzida, por meio da operação integrada, o que permite a fiscalização e o suporte mútuo entre as equipes, no cumprimento das respectivas responsabilidades. Para os funcionários, esta integração é vista na comunicabilidade entre as equipes - os guardas nas torres de vigilância e os agentes em suas posições devem se visualizar e trocar informação. Ao mesmo tempo, a população prisional deve ser alijada de informação, sendo constrita ao seu universo na prisão. Isto concerne à impermeabilidade e à representação institucional na sociedade prisional: os presos não recebem informação a respeito dos funcionários e os grupos de presos não se comunicam entre si. Os locais dos funcionários são impermeáveis aos presos, mas não o contrário, o que configura uma unilateralidade. Os locais dos presos são impermeáveis entre si (3): os diferentes espaços (celas, pátios e salas de atividades), as alas carcerárias, blocos de vivência e os espaços de um grupo de presos.

As equipes dirigentes (diretor e chefe de segurança) consideram necessário o distanciamento dos presos em relação às áreas mais externas da prisão. Para os funcionários, as atividades rotineiras dos presos (principalmente as coletivas) realizadas mais ao fundo do estabelecimento são vistas como favoráveis à segurança e operação: é mais fácil para a instituição manejar e revistar os presos, ao mesmo tempo em que se concentram os fluxos e permanências dos mesmos, o que diminui as tarefas e simplifica os procedimentos (otimiza a estrutura operacional). Esta internalização inclui a visita, então o visitante adentra mais no espaço da prisão - "a visita é mais trabalhosa, mas é mais segura - não oferece risco".

A vistoria das celas ocorre em termos estruturais - a "bateção" (testa a solidariedade da construção, em termos da perfuração,

oficina, sala de aula e biblioteca.

A unidade catarinense tem um sanitário para cada dois blocos de vivência e não previa alojamento (improvisado em um depósito), sala de reunião, sala de estar e academia de ginástica. A unidade paulista repete este cenário, sem o sanitário.

As unidades não possuem local específico para o culto religioso.

As unidades não contam com refeitório. A unidade catarinense tem mesas e bancos no pátio coberto, mas a quantidade de lugares exigiria o uso alternado para a alimentação (inviável no tempo de almoço, diante da necessidade de revistas dos grupos).

$\mathrm{Na}$ unidade catarinense, existe uma série de 'vazamentos': entre a área de visita e o pátio de sol dos presos (distribuição de refeições), entre as celas (janelas), entre as alas carcerárias (gritos) e entre as celas e os corredores (funcionários). $\mathrm{Na}$ unidade paulista, as celas de uma ala conformam um conjunto carcerário único, enquanto a área dos funcionários é isolada dos locais dos presos.

$\mathrm{Na}$ unidade catarinense, as atividades dos presos estão locadas nos blocos de vivência, inclusive a visita. Na unidade paulista, as atividades dos presos são mínimas e externas ao bloco de vivência, enquanto a visita ocorre no pátio de sol.

$\mathrm{Na}$ unidade catarinense, as alas carcerárias e os 
quebra ou corte dos elementos para a fuga) e funcionais (busca esconderijos de contrabandos e manufaturados nos acabamentos, instalações, colchões, pertences dos presos). Em Santa Catarina, as revistas estruturais são realizadas diariamente nas celas (com a saída dos presos para o pátio de sol) e nos pátios de sol (a cada novo grupo de presos). Em São Paulo, as revistas estruturais são feitas diariamente e as funcionais mensalmente (com os presos no pátio de sol). Em São Paulo, a revista de uma cela demora entre 10 e 15 minutos - "muita coisa acumulada". Em ambos estados, uma vistoria esporádica pode ser realizada mediante denuncia. Para este procedimento, os presos não podem estar próximos para evitar o estresse e as pressões bilaterais entre os mesmos e os funcionários (sinais e códigos denunciando ocorrências ou recomendando ignorá-las). Da mesma maneira, a entrada dos funcionários nas celas depende da certeza que a mesma está vazia.

A equipe dirigente considera melhor o encontro íntimo ficar acoplado à visita social e o seu acesso e os dos apartamentos serem controlados pelos agentes. Cuidado especial deve ser tomado com o barulho proveniente do encontro íntimo em relação aos cômodos adjacentes para evitar o constrangimento das pessoas - "às vezes, alguém está passando e faz uma piada" (SC).

A equipe dirigente (SC) considera a localização interna do alojamento dos funcionários mais apropriada (no bloco de vivência), por uma questão operacional (o tempo de resposta diante de uma crise). Por outro lado, a posição no setor externo é considerada mais conveniente para o descanso, para amenizar a sensação de "preso junto com os presos" (3). Em São Paulo, o funcionário "não dorme em serviço".

Conforto ambiental

\section{Demandas}

As equipes dirigentes consideram as aberturas de iluminação e ventilação necessárias para o conforto das pessoas, porém com ressalvas prioritárias aplicadas, principalmente, aos locais ocupados pelos presos, eventualmente incluindo os visitantes. Para os funcionários, estas aberturas fragilizam a segurança, ao possibilitar a percepção da rotina institucional, a comunicação informal e o tráfico interno (questão da impermeabilidade), além de constituírem rotas de fuga evidentes (questão da estanqueidade). As considerações dos funcionários descrevem aberturas mínimas, indiretas e isoladas. As aberturas voltadas para locais operacionalmente críticos são vetadas pelos funcionários: acessos, circulações, revistas, postos de controle ou quaisquer pontos estratégicos para a segurança penitenciária. As equipes dirigentes e os presos reclamaram da temperatura nas unidades prisionais calor no verão e frio no inverno: "o calor é pior" (devido às roupas e equipamentos dos agentes ou à aglomeração de presos). As áreas mais internas da prisão são mais críticas (aberturas insuficientes e sem regulagem).

Sistema de Segurança

\begin{tabular}{|c|c|}
\hline Demandas & Considerações \\
\hline $\begin{array}{l}\text { As equipes dirigentes relataram a necessidade de seteiras nas torres de vigilância e nos postos de controle externos para a reação } \\
\text { armada dos funcionários no caso de ataques externos. Em Santa Catarina e em São Paulo, as unidades sofrem disparos por arma de } \\
\text { fogo, enquanto o fechamento dos postos impossibilita uma retaliação, a não ser que o guarda se exponha, ao abrir janelas ou sair } \\
\text { para um terraço. }\end{array}$ & $\begin{array}{l}\text { Nas unidades, as torres de vigilância e os postos de } \\
\text { controle não possuem seteiras. }\end{array}$ \\
\hline $\begin{array}{l}\text { As equipes dirigentes consideram necessária colocação de aparatos nas aberturas de iluminação e ventilação para o bloqueio visual } \\
\text { dos presos entre as celas e alas carcerárias (questão da impermeabilidade). Segundo os funcionários, estes aparatos não podem } \\
\text { comprometer a visualização externa das aberturas pela torres de vigilância. Em Santa Catarina, os presos ocupam as aberturas das } \\
\text { celas se sentando, encostando ou pendurando coisas de modo a disfarçar o corte das grades (um agente descreveu a rota de fuga } \\
\text { pela fachada). Para os presos, estes aparatos são prejudiciais, pois reduzem a ventilação e iluminação na cela ou restringem a } \\
\text { visualização do mundo externo. Em São Paulo, os aparatos colocados têm este efeito - "agente fica torcendo por um vento bater na } \\
\text { parede subindo (a única forma do ar entrar pela abertura da fachada)". }\end{array}$ & $\begin{array}{l}\text { A unidade catarinense tem painéis em frente às } \\
\text { janelas das celas. A unidade paulista tem aparatos } \\
\text { do tipo caixa metálica (com chapas e tela moeda) } \\
\text { nas aberturas dos banheiros das celas. }\end{array}$ \\
\hline
\end{tabular}

pátios de sol dos presos são independentes. $\mathrm{Na}$ unidade paulista, as celas e os pátios de sol são contíguos - os presos são acomodados em um trecho do pátio, rendidos pelos agentes com cachorros para a realização das revistas.

$\mathrm{Na}$ unidade catarinense, o encontro íntimo pertence à área de visita, porém os presos controlam as portas dos apartamentos. $\mathrm{Na}$ unidade paulista não existe encontro íntimo.

Na unidade catarinense, o alojamento está nos blocos de vivência (improvisado). Na unidade paulista, o alojamento fica externo, junto à administração.

\section{Considerações}

As unidades prisionais apresentam ambientes sem aberturas de ventilação natural ou aberturas insuficientes ou destituídas de regulagem. parede subindo (a única forma do ar entrar pela abertura da fachada)". 
A equipe dirigente $(\mathrm{SC})$ considera imprescindível a subdivisão ou delimitação dos espaços por meio de contenções (em geral, grades com portas). Para os funcionários, estas contenções são vistas como meio para a segurança e disciplina das tarefas de condução e revista dos presos. A complicação dos procedimentos é considerada secundária (lentidão do funcionamento). Em São Paulo, a abertura das contenções exigia uma espera. Na edificação, estas contenções marcam os acessos e as passagens de salas com atividades coletivas, blocos funcionais e setores. Estas contenções são configuradas por duas portas em sequência - uma só abre após o fechamento da anterior (ambas nunca estão abertas simultaneamente). Nas alas carcerárias, estas contenções configuram os espaços de revista dos presos e segmentam a circulação, o que dificulta a tomada do bloco pelos presos e favorece o escape dos funcionários.

As equipes dirigentes consideram necessário o fechamento de aberturas de ventilação e iluminação entre espaços de diferentes blocos ou setores ou que sejam utilizados simultaneamente pelos presos, por meio de aparatos que impeçam a passagem de objetos ou a comunicação entre as pessoas, tais como, telas ou venezianas.

As equipes dirigentes consideram a contagem dos presos um procedimento importante para a estanqueidade da prisão. A contagem dos presos ocorre duas vezes ao dia (manhã e tarde). Em Santa Catarina, este procedimento é realizado nas contenções dos corredores ou na cela pela portinhola da porta ou pelas janelas. Em São Paulo, o mesmo é realizado pela grade das celas. Em São Paulo, a contagem de um pavilhão demora cerca de 30 minutos. A opção da contagem nas contenções não desobriga a verificação da cela estar vazia antes da entrada de funcionários (revista da cela). A contagem via portinhola ou janela cria uma exposição dos funcionários (ataque dos presos). Isto exige um distanciamento do funcionário. Foi sugerido um visor na porta com portinhola. Controle Demandas

A equipe dirigente $(\mathrm{SC})$ considera estratégico para o esquema de segurança um posto de controle junto ao acesso do terreno da unidade prisional (pista de acesso), longe da portaria de acesso, para evitar a aproximação de pessoas estranhas e configurar uma primeira linha de defesa contra ataques externos. Neste posto avançado seria feita a triagem das pessoas e veículos (identificação).

As equipes dirigentes consideram a vigilância externa essencial para a segurança penitenciária, em termos de ataques externos e da vigilância interna. Para os funcionários, o número de torres recomendado é de quatro, uma em cada canto da barreira perimetral, de modo a cobrir a maior área possível, considerando os recursos disponíveis. Para situações de crise devem ser previstas torres intermediárias para cobrir eventuais pontos cegos, a serem ocupadas pelo pessoal de prontidão. Em Santa Catarina apenas duas torres estavam em operação por falta de pessoal. Em São Paulo, a guarda é quantificada pelo dobro do número de torres - metade dos guardas fica em vigilância e metade em prontidão, com alternância a cada 3 h. A questão é manter os guardas alertas (evitar o efeito 'olho de vidro' ou mantê-los acordados), por isto, é previsto um homem fazendo ronda entre as torres.

Os funcionários (guarda externa) consideram a independência da torre de vigilância no esquema de segurança e operacional, ao sintetizar medidas de segurança e o guarda trabalhar isolado no posto. A visualização é considerada a propriedade mais relevante das torres. A altura das torres deve permitir a observação das coberturas das edificações - atual rota de fuga e ocupação, no caso de rebeliões. Os elementos da torre devem concebidos de modo a não interferir no campo visual (pilares): o perímetro da área de vigilância deve ser livre. Em São Paulo, foi sugerido um pilar central para sustentar a cobertura. Para a operação segura, a equipe recomenda visores fixos blindados (pelo menos nas faces voltadas para o exterior da unidade prisional). Segundo o chefe de segurança externa paulista, as torres não devem ter trancas, pois os guardas aproveitam para dormir. A torre deve ser equipada com mictório e pia (o vaso sanitário não foi recomendado, pois justifica a ausência do guarda na vigilância). O mobiliário se resume a um banco alto (sem conforto). As aberturas de ventilação e iluminação devem ser altas, de modo a proteger o guarda de disparo por arma de fogo. As torres foram criticadas pela temperatura - calor ou frio, mediante a roupa e o equipamento (colete), o que torna o
A unidade catarinense apresenta as contenções nas circulações (acessos e passagens), inclusive nas alas carcerárias. A unidade paulista apresenta contenções na recepção e na circulação central do bloco de vivência, na distribuição para os pavilhões ('viúva').

Na unidade catarinense, as áreas de visita comunicam com outros espaços (o estacionamento ou o pátio de sol dos presos).

$\mathrm{Na}$ unidade catarinense, as portas contam com portinholas. Na unidade paulista, as celas são fechadas com grades.

Na unidade catarinense o limite do terreno está distante da portaria de acesso e não possui portaria. Na unidade paulista, a portaria está no limite do terreno, junta à pista de acesso.

As unidades prisionais apresentam quatro torres de vigilância nos cantos da barreira perimetral. A unidade paulista compartilha uma das torres com uma unidade vizinha. A mesma apresenta postos intermediários.

As unidades prisionais apresentam torres altas, o campo de visão é interrompido por pilares e não existe mobiliário. $\mathrm{Na}$ unidade catarinense, os visores não são blindados, o banheiro fica fora da área de vigilância (pavimento intermediário) e as torres são trancadas por dentro. As aberturas em ambas são esquadrias que abrem (visores). 


\begin{tabular}{|c|c|}
\hline $\begin{array}{l}\text { As equipes dirigentes consideram a separação física entre funcionários e presos a melhor solução para a operação (postos de } \\
\text { controle e circulação exclusiva para os funcionários) - "dois leões, os funcionários e os presos". Para os funcionários, a separação dos } \\
\text { presos è vista como proteção, pois evita ataques e rendições. Em Santa Catarina, a condução de presos é avaliada como um } \\
\text { procedimento de alto risco para os funcionários, devido ao pequeno número de agentes. Nesta unidade, o atendimento de cela, pátio } \\
\text { e oficina é realizado por circulação superior exclusiva para os funcionários. Em São Paulo, a liberação/tranca dos presos nas celas foi } \\
\text { apontada como procedimento de alto risco, devido à exposição do agente. Nesta unidade, este procedimento é realizado por um } \\
\text { funcionário que entra sozinho no pátio para soltar os presos de confiança que depois acompanham o funcionário. Um funcionário } \\
\text { paulista sugeriu um muro entre as celas e o pátio de sol. Para os presos, a separação dos funcionários também é vista como proteção, } \\
\text { pois evita impropriedades destes (cutucos, empurrões, intimidações). Por outro lado, a separação física não deve inviabilizar a } \\
\text { comunicação entre funcionários e presos. O chefe de segurança de São Paulo enfatizou este aspecto, se declarando favorável ao } \\
\text { contato para a criação de confiança mútua - "os funcionários e os presos tem que se conhecer para se respeitar". Para os } \\
\text { funcionários, esta comunicação é vista como meio para o trabalho de inteligência: a coleta de informações sobre o estado dos presos } \\
\text { e possíveis ações subversivas. Para os presos, a mesma é vista como meio para serem feitos pedidos, reclamações e denúncias. Em } \\
\text { Santa Catarina, os presos gritam para os funcionários. Em São Paulo, o canal é atribuído a presos e funcionários selecionados } \\
\text { (normalmente ocorre na 'viúva'). }\end{array}$ & $\begin{array}{l}\text { A unidade catarinense apresenta postos de } \\
\text { controle e circulação exclusiva para os } \\
\text { funcionários. A unidade paulista tem o posto de } \\
\text { controle central ('bolha'). A relação } \\
\text { funcionário/preso recomendada para escolta é de } \\
1 / 1 \text {, na prática um funcionários conduz até seis } \\
\text { presos, ou mais. }\end{array}$ \\
\hline $\begin{array}{l}\text { Os funcionários da unidade catarinense consideram a circulação exclusiva para os funcionários com vantagens e desvantagens, } \\
\text { conforme o tipo adotado: a lateral é melhor para acompanhar as revistas nos presos, mas é considerada vulnerável a ataques destes, } \\
\text { enquanto a circulação superior é considerada mais segura, porém menos eficiente pela visualização limitada pelo piso. O piso tem } \\
\text { que ser parcialmente fechado ou pode ser bloqueado pelos presos, ao incendiar colchões abaixo da passarela, sendo citado o projeto } \\
\text { da PC por funcionário. Para uma funcionária, a circulação por cima reforça o sentimento de superioridade de alguns funcionários, } \\
\text { enquanto os presos não manifestaram um descontentamento sobre o funcionário trabalhar em posição elevada. }\end{array}$ & $\begin{array}{l}\text { A unidade catarinense apresenta circulação } \\
\text { exclusiva para os funcionários do tipo superior. A } \\
\text { unidade paulista não tem circulação exclusiva para } \\
\text { os funcionários. }\end{array}$ \\
\hline $\begin{array}{l}\text { As equipes dirigentes consideram a centralidade do posto de controle como fator para a redução do contingente funcional. Neste } \\
\text { sentido, a especificação de postos, por si só, não garante esta redução. Isto porque o posto nunca é ocupado por um funcionário } \\
\text { apenas, sendo a equipe mínima de dois agentes. Em Santa Catarina, os blocos de vivência são operados por três agentes em cada } \\
\text { bloco ( } 140 \text { vagas, aproximadamente), para operar o posto de controle e a circulação exclusiva (pátio de sol), mais dois agentes de } \\
\text { ronda e um chefe de turno. No plantão, um agente em cada ala, dois agentes de ronda e um chefe, mais } 14 \text { em descanso se } \\
\text { revezando a cada duas horas ( } 2 / 3 \text { ). A equipe catarinense recomenda três postos de controle em um bloco de vivência: no acesso, na } \\
\text { circulação principal e pátio de sol dos presos. Em São Paulo, o posto central ('bolha') demanda uma equipe de quatro homens no } \\
\text { período de uso dos pátios de sol (um por pavilhão), mais um chefe ( } 600 \text { vagas, aproximadamente). Além de seis agentes em cada } \\
\text { 'radial' para realizar procedimentos no bloco de vivência (corredores de acesso). }\end{array}$ & $\begin{array}{l}\text { A unidade catarinense apresenta um posto de } \\
\text { controle em cada bloco de vivência e outro posto } \\
\text { para cada dois blocos de vivência (acessos e } \\
\text { circulações), mais a circulação exclusiva. A unidade } \\
\text { paulista apresenta um posto de controle central } \\
\text { aos pavilhões, mais dois espaços laterais para } \\
\text { procedimentos (radiais). }\end{array}$ \\
\hline $\begin{array}{l}\text { As equipes dirigentes consideram a inverificabilidade institucional importante para a segurança e a operação penitenciária, ao } \\
\text { impedir o vazamento de informação sobre a rotina e a equipe funcional para estranhos e presos (horários e procedimentos, } \\
\text { quantidade e identificação dos agentes). A inverificabilidade não pode dificultar ou impedir o contato visual dos funcionários nas } \\
\text { torres de vigilância ou nos postos de controle (a questão da integração das equipes de segurança). Em São Paulo foi citada a } \\
\text { impossibilidade de verificação se uma torre foi tomada pelo uso de películas muito escuras. Um cuidado ressaltado na especificação } \\
\text { da película é a inversão da invisibilidade, associada à inversão da luminosidade à noite. Em Santa Catarina, o uso de películas nos } \\
\text { postos de controle internos dificulta a visualização das áreas vigiadas. Em São Paulo, a iluminação artificial no posto de controle } \\
\text { central é pontual e direcionada para manter o efeito óptico. Em Santa Catarina, as circulações exclusivas para os funcionários buscam } \\
\text { a inverificabilidade noturna a partir da iluminação, por meio do ofuscamento dos presos (considerada pouco efetiva, pois também } \\
\text { ofusca os funcionários). }\end{array}$ & $\begin{array}{l}\text { As unidades utilizam películas reflexivas nos } \\
\text { visores das torres de vigilância e dos postos de } \\
\text { controle. A unidade catarinense apresenta um } \\
\text { esquema de ofuscamento dos presos por meio da } \\
\text { iluminação artificial. }\end{array}$ \\
\hline
\end{tabular}


As equipes dirigentes consideram a realização de rondas importante para a segurança penitenciária. Neste sentido, a especificação de postos de controle não desabilita esta medida. Estas rondas visam flagrar indisciplinas dos presos no período noturno (escavação, rompimento e corte de elementos), em especial, por meio da detecção de ruídos e odores. Em Santa Catarina, a ronda ocorre tanto pela circulação exclusiva para os funcionários, como pela área externa, junto às aberturas de iluminação e ventilação das celas. A ronda realizada pela circulação exclusiva possibilita o trabalho do agente sem a necessária detecção pelos presos - "se caminha com passos leves e sem fazer barulho", mas não proporciona a informação visual das celas. Em São Paulo, a ronda acontece ao redor do bloco de vivência e dentro do pátio de sol, porém a percepção do agente pelos presos é mais fácil. Barreira perimetral

Os funcionários consideram o muro mais eficiente que a cerca, devido às propriedades de fechamento vinculadas à impermeabilidade e à inexpugnidade - rompe melhor a comunicação dos presos com o mundo externo, além de resguardar a instituição da observação e de ataques externos. Pelo perfil do preso, a unidade paulista não é visada para invasões, mas sofre disparos por arma de fogo. Os funcionários relataram a sensação de segurança advinda do muro. A especificação da cerca foi condicionada a locações rurais afastamentos maiores. Quanto à estanqueidade, não houve uma preferência do muro ou da cerca, pois os presos transpõem ambos igualmente. Todavia, a unidade catarinense tem um trecho em cerca, considerado o ponto fraco para a fuga de presos.

O corpo da guarda considera melhor uma geometria regular para a barreira perimetral, o que favorece a vigilância completa do perímetro da unidade prisional com poucas torres de vigilância. A posição entreposta das torres de vigilância foi considerada adequada para a visualização (com vista dos lados externos e interno).

O corpo da guarda considera os afastamentos importantes para o fechamento da prisão, ao distanciar as pessoas estranhas e aumentar a possibilidade de identificação de uma ocorrência (ataques externos, comunicação informal ou fugas). Para os funcionários, os afastamentos inibem mais o lançamento de contrabando para dentro da prisão, do que a altura da barreira perimetral. Para os mesmos, os afastamentos das unidades prisionais visitadas são curtos. Os critérios para os afastamentos são viabilidade de monitoramento de grandes áreas (manutenção das áreas, quantidade de torres e a efetividade da vigilância em distâncias longas), além da vigilância cautelosa dos edifícios internos, com possibilidade de discriminar as ações suspeitas (perceber o corte de grades das janelas, por exemplo) e de identificação fisionômica. Foi sugerido afastamento externo entre 30 e $100 \mathrm{~m}$ (perímetro de segurança) e interno em torno de $30 \mathrm{~m}$ (entre a barreira e os edifícios). As barreiras do limite do terreno e da linha de tiro devem ser do tipo cerca para não bloquear a visão.

As equipes dirigentes consideram a altura da barreira perimetral mais importante para a impermeabilidade da instituição, do que para a estanqueidade ou inexpugnidade. Para o chefe da segurança da unidade paulista, a barreira poderia ter $2,1 \mathrm{~m}$ de altura, sem segurança, porque o edifício é o responsável pela estanqueidade. A altura da barreira se relaciona com a sensação de segurança dos funcionários.

O corpo da guarda considera a proteção da circulação dos funcionários na barreira perimetral importante, tendo em vista disparos de arma de fogo. Em Santa Catarina, os guardas se consideram protegidos dentro dos muros, em particular, porque não são vistos. Em São Paulo, o chefe da segurança externa relatou que o trânsito no passadiço é vulnerável pela vedação em alvenaria - disparos com fuzil facilmente atravessam os tijolos.

$\mathrm{O}$ corpo da guarda considera os aparatos de segurança importantes para a estanqueidade do estabelecimento (fugas). Em Santa Catarina, o chefe da segurança relatou a fuga de preso com a escalada dos elementos cortantes - "passa da mesma forma". O chefe de segurança da unidade paulista citou a substituição do túnel por buracos na cobertura como método de evasão, devido à introdução da 'caixa de areia' (um bolsão abaixo do muro, com três metros de profundidade, utilizado para colapsar os túneis). Foram sugeridos obstáculos físicos na barreira perimetral, como projeções e abaulamentos.
As unidades permitem a ronda externa, mas apenas a unidade catarinense permite a ronda interna inverificável, porém sem a informação visual.

Considerações

As unidades possuem barreiras perimetrais do tipo muro.

As unidades possuem geometria regular, retangular ou próximo disso.

A unidade catarinense tem o afastamento externo de $20 \mathrm{~m}$ e interno de $15 \mathrm{~m}$. A unidade paulista não tem o perímetro de segurança e o afastamento interno é de $15 \mathrm{~m}$.

As unidades têm barreiras perimetrais com altura média de seis metros.

A unidade catarinense providencia proteção aos funcionários através da circulação junto ao muro. A unidade paulista providencia a proteção aos funcionários por meio de passadiço sobre o muro. A unidade catarinense apresenta espirais cortantes na linha de tiro e no topo do muro. A unidade paulista não tem aparatos de segurança na barreira perimetral, além da 'caixa de areia'. 
O corpo da guarda considera a linha de tiro necessária para explicitar a atuação dos guardas e disciplinar os fluxos internos (afastar as pessoas da barreira perimetral para garantir a integridade do fechamento). O chefe de segurança da unidade paulista ressaltou a improbabilidade da efetivação de disparo contra preso em fuga, conforme o determinado na Portaria Interministerial 4.226/2010. A distância de cinco metros até a barreira perimetral é tida como suficiente.

O corpo da guarda considera a pista de ronda complementar a barreira perimetral, ao facilitar o trânsito dos guardas até as torres (neste deslocamento ocorre a averiguação da barreira). Neste sentido, a pista de ronda fica dentro da linha de tiro (caso não exista passadiço). Foi cogitada a pista de ronda mais interna para providências junto às edificações (vistoria, apoio tático, obras civis e incêndios). Também se conjeturou sobre uma pista de ronda exterior, no caso do afastamento externo maior (perímetro de segurança), sendo esta a melhor situação (similar ao modelo PC). Cela

\section{Demandas}

As equipes dirigentes consideram a permanência prolongada dos presos nas celas necessária, tendo em vista a superlotação e os recursos disponíveis. Para os funcionários, a concentração de atividades nas celas é vista como meio para reduzir tarefas e simplificar procedimentos. Para os presos, a mesma é vista como um castigo extra - não ter nada para fazer, no mesmo lugar, todos os dias. Além de dormir e da higiene pessoal, os presos elencaram como atividades realizadas nas celas (em ordem de recorrência): ler (10), fazer exercícios físicos (7), redação de cartas (7), assistir televisão (7), conversar (6), fazer artesanato (6), jogar (5) e lavar e secar roupa (4), além de olhar fotografias (3), ouvir rádio (3), estudar (3) e ficar pensando (3). As conversas tratam de dívidas e planos para o futuro. $\mathrm{O}$ artesanato envolve trabalhos em palito de picolé ou crochê. $\mathrm{O}$ jogo pode ser baralho, dominó, xadrez, dama. Em Santa Catarina, as roupas lavadas e secadas são apenas as íntimas. A refeição foi pouco citada, mas todos comem na cela. A prática religiosa em grupo foi citada por dois presos. Para um preso, a cela deveria ser só para dormir.

As equipes dirigentes e os presos consideram a melhor localização do chuveiro dentro das celas, com exceção de um agente. Para os funcionários, a localização interna é vista como mais segura (evita a aglomeração de presos em banhos coletivos e reduz a exposição dos agentes), além de ser um meio para reduzir as tarefas (principalmente, no caso de banhos individuais). Para os presos, esta localização propicia segurança pessoal (evita as violências típicas dos banhos coletivos), além de privacidade (em relação à instituição) e comodidade - "já toma banho e dorme" (reduz a disputa pelo chuveiro devido à quantidade de pessoas). Na unidade paulista, os presos citaram o 'duchão' - banho coletivo que existia na unidade - "onde acontece as ocorrências". Dois presos consideram melhor o banho externo, por uma questão de saúde (umidade).

As equipes dirigentes e os presos consideram a melhor localização do banheiro ao fundo da cela, principalmente pela proximidade das aberturas de ventilação. Para os funcionários, a localização ao fundo favorece a visualização interna e a entrada forçada (o banheiro não constitui obstáculo à invasão do local). Na unidade catarinense, um funcionário citou o constrangimento de agentes e presos pela mostra do banheiro pelas janelas, a partir da torre de vigilância ou da ronda.

As equipes dirigentes consideram suficiente o serviço sanitário constituído de pia, vaso sanitário e chuveiro. O banheiro da unidade catarinense foi considerado 'bom' pelos presos. Os presos paulistas consideram o banheiro ruim (8), tendo em vista a superlotação e as atividades realizadas na cela. Sobre as atividades extras, nos dois casos, existe a limpeza da cela (panos de chão). Na unidade paulista, ainda se acumula a lavagem de louças (pratos, talheres e copos plásticos) e roupas (inclusive de cama). Nesta unidade, a pia é reservada para lavar louça, os dentes são escovados no vaso sanitário e as roupas e panos de chão são lavados no chuveiro. Os presos sugeriram mais uma pia e um tanque de lavar roupas. Foi citado, como exemplo positivo, o banheiro da PC que tem quatro
As unidades possuem linha de tiro.

A unidade catarinense possui pista de ronda intramuros. A unidade paulista possui pista de ronda interna.

\section{Considerações}

Na unidade catarinense, os presos estão 22 horas dentro das celas. Na unidade paulista, as celas são abertas entre 7:00h e 8:00h e fechadas por volta das 17:00h. Na unidade catarinense, a televisão não havia sido liberada. A mesma conta com lavanderia industrial. A realização de exercícios físicos nas celas é predominante em Santa Catarina. A televisão é solicitação majoritária dos presos, seguida do rádio (questão da conexão com o mundo - "mundo que existe").

As unidades apresentam os chuveiros nas celas. A unidade paulista tinha banheiros coletivos no pátio de sol que foram incluídos nas celas após reforma. Na unidade catarinense, o banho em Santa é de uma hora $-5 / 6$ minutos por pessoa. Na unidade paulista, o banho é intermitente (problemas na instalação de água). Em ambas, os presos organizam o banho (fila e tempo).

As unidades o banheiro ao fundo das celas. A unidade catarinense tem aberturas do tipo janela nas celas. A unidade paulista não dá visualização do banheiro pelo lado de fora da edificação (mesmo padrão da PC).

As unidades prisionais um conjunto de pia, vaso sanitário e chuveiro, em cada cela. A unidade catarinense conta com lavanderia industrial e os presos comem em marmitas (não tem louça). $\mathrm{Na}$ unidade paulista, os presos têm mais pertences. 


\begin{tabular}{|c|c|}
\hline torneiras, dois vasos sanitários e dois chuveiros nas celas. & \\
\hline $\begin{array}{l}\text { As equipes dirigentes e os presos consideram o beliche a melhor solução para o dormitório. Para os funcionários, o beliche é visto } \\
\text { como meio de gerar mais vagas (superpopulação) e reduzir tarefas (menos celas). Para os presos, o beliche é visto como 'normal', não } \\
\text { havendo dificuldade em subir na cama de cima, ao mesmo tempo em que cria uma diversidade na cela. A distribuição das camas é } \\
\text { feita pelos presos, segundo critérios de ordem de inclusão na cela e do bom senso do grupo. Neste sentido, as camas de baixo são } \\
\text { mais acessíveis, sendo destinadas a pessoas de mais idade ou com limitações físicas. A cama de cima é considerada mais bem } \\
\text { iluminada e privativa, embora mais quente. Este gerenciamento foi rechaçado por um preso que prefere a decisão da instituição - } \\
\text { para evitar as discussões e disputas. Sobre o beliche de três camas, os funcionários apontaram a criação de pontos cegos e a maior } \\
\text { dificuldade da revista das camas superiores, enquanto os presos consideram estas camas mais privadas. Na unidade paulista, ele é } \\
\text { visto com reserva, pois exige o uso de equipamento de segurança pessoal, segundo a legislação paulista. O que para o chefe de } \\
\text { segurança "não dá, porque o aparato operacional atrapalha". Os beliches de três camas em construção nesta unidade têm o } \\
\text { espaçamento entre as camas reduzido. }\end{array}$ & $\begin{array}{l}\text { As unidades apresentam beliches de duas camas } \\
\text { nas celas. Na unidade paulista, estes beliches estão } \\
\text { sendo substituídos por modelos de três camas } \\
\text { (mesmo padrão da PC). }\end{array}$ \\
\hline 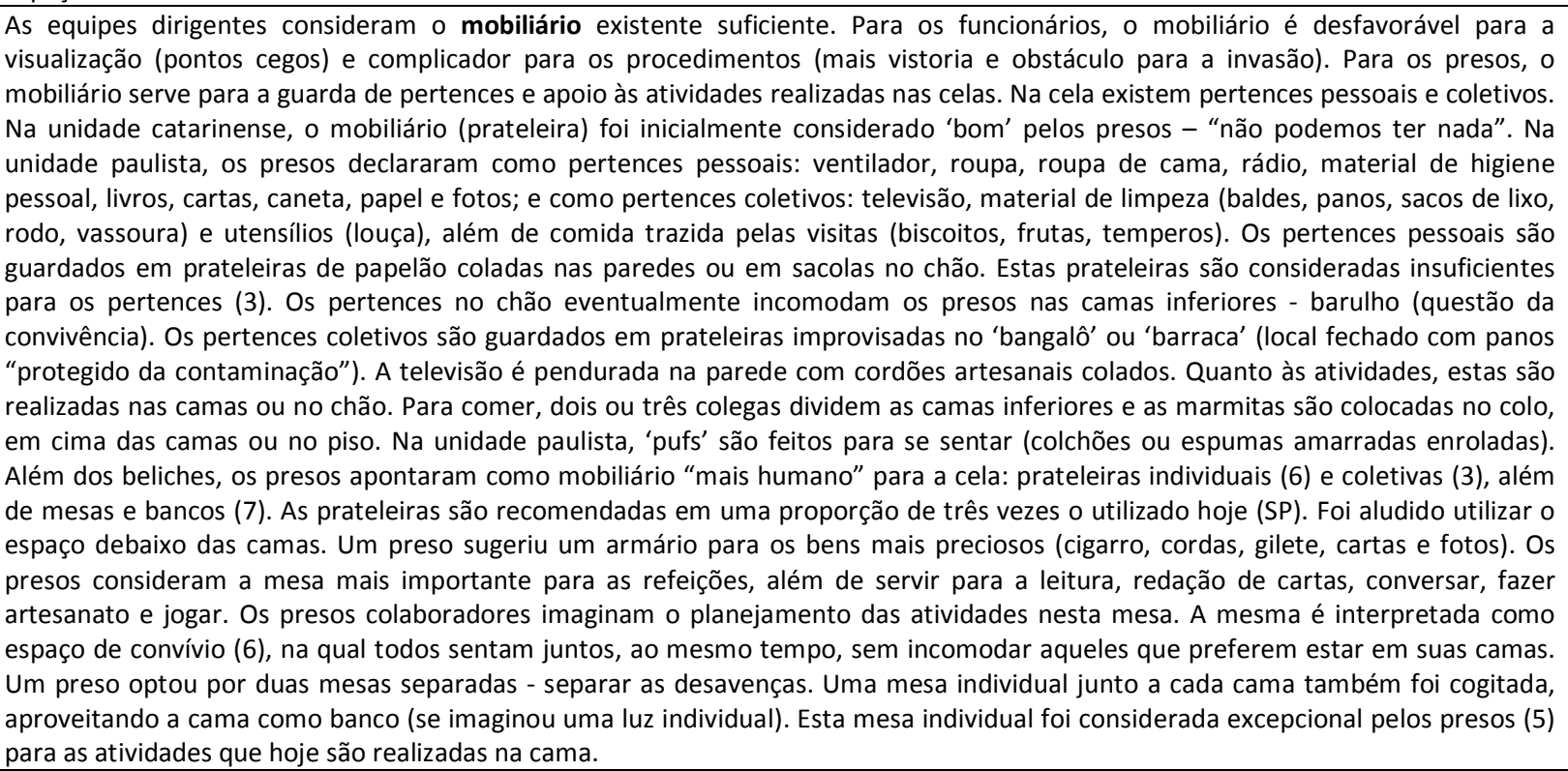 & $\begin{array}{l}\text { A unidade catarinense prateleira individuais em } \\
\text { cada cama das celas. A unidade paulista não tem } \\
\text { outro mobiliário, além dos beliches. A } \\
\text { Penitenciária Compacta tem um suporte para a } \\
\text { televisão coletiva. A iluminação das celas é } \\
\text { apagada às 22:00h. }\end{array}$ \\
\hline $\begin{array}{l}\text { As equipes dirigentes consideram a melhor espacialidade da cela a descrita pela singularidade, integração e continuidade - os } \\
\text { arranjos das celas das unidades prisionais são tidos como adequados (acesso e circulação centrais, beliches laterais contíguos e } \\
\text { banheiro conjugado ao fundo). Para os funcionários, esta composição é favorável à segurança (visualização e invasão do local) e } \\
\text { simplifica os procedimentos (agiliza as revistas). Na unidade catarinense, o espaço da cela foi inicialmente considerado 'bom' pelos } \\
\text { presos, com ressalvas ao banheiro. Na unidade paulista foi dito que faltam espaços e o banheiro é problemático (questão da } \\
\text { coletivização e da generalização funcional). Ler, escrever, olhar fotos e ouvir rádio ocorrem individualmente nas camas. As refeições e } \\
\text { assistir televisão (SP) são atividades coletivas realizadas com os presos nas camas. O exercício físico (SC) e o jogo são feitos no chão do }\end{array}$ & $\begin{array}{l}\text { As unidades apresentam celas conformadas por } \\
\text { um espaço único, ocupado perifericamente pelos } \\
\text { beliches com o banheiro ao fundo (mesmo padrão } \\
\text { da PC). A cela catarinense é retangular com uma } \\
\text { circulação central. A cela paulista é mais quadrada, } \\
\text { com uma grande área livre central (a 'praia') e o } \\
\text { banheiro em uma posição mais lateral (em um dos }\end{array}$ \\
\hline
\end{tabular}


corredor, enquanto a conversa ocupa todo o espaço. O uso do banheiro é individual, segundo as regras de convivência da cela. Porém, o uso compartilhado não é incomum, mediante necessidades inadiáveis e a permissão do 'preso da vez'. Os presos sugeriram a subdivisão do espaço da cela em três partes: dormitório, serviços e banheiro (3). A parte de serviço teria um uso alternado pelas diferentes atividades. A separação do banheiro do restante da cela foi recorrente. Assim como, a compartimentação do banheiro em espaços para a pia, o vaso sanitário e o chuveiro (4) (questão da privacidade), por meio de divisórias baixas.

As equipes dirigentes consideram a privacidade na cela um aspecto secundário na prisão. Para os funcionários, a exposição dos presos constitui espaços abertos, favoráveis à segurança (evita o preso escondido para render um funcionário) e à simplificação dos procedimentos (reduz as revistas). Para os presos, a privacidade na cela é vista como exercício das vontades individuais e respeito da dignidade pessoal. Um comentário geral entre os presos foi a ausência de privacidade na cela (8), tanto do espaço individual, como no uso do banheiro. O espaço individual é a cama, incrementado pelo 'quieto' (pano que fecha este espaço), considerado muito importante pelos presos - "meu canto" (10). O cansaço da convivência e as desavenças levam a um desejo majoritário de estar só em alguns momentos, porque "fica neurótico" (7). Apenas um preso foi contra o quieto: a sociabilização é mais importante e não cada um no seu canto, citando a imagem do espaço da cela demarcado pelos 'quietos', sem que se veja ninguém. Para outro preso, "tendo o espaço individual, não importa quantos em uma cela" (questão da capacidade da cela). A intimidade da cama é utilizada para ler, escrever cartas, olhar fotos, ouvir rádio, pensar na vida e chorar. Como as refeições são realizadas nas camas então, por uma questão de higiene, a masturbação é considerada conveniente apenas no banho. Havendo o quieto, o barulho de colegas de cela (presos mal educados ou 'surtados') foi apontado como maior incômodo (conversas, gritos e televisão em volume alto)(2). A composição do banheiro fere a dignidade das pessoas em dois níveis: em relação à cela e no uso simultâneo dos serviços. A devassidão do banheiro é eventualmente mitigada pela colocação de cortinas improvisadas. A premissa do uso alternado do banheiro é desvirtuada pela aglomeração de presos que leva ao uso compartilhado - "agente está no vaso com o pênis do outro na cara [este no banho]". Às vezes, o uso é coletivo - "se juntam quatro, cinco, seis pessoas debaixo do chuveiro e ninguém toma banho direito" (coletividade agravada pelo racionamento de água na unidade paulista). Foi sugerida a separação do banheiro do restante da cela, por meio de porta baixa. Também foi sugerida a compartimentação dos serviços do banheiro por meio de divisórias baixas (3). Esta compartimentação otimizaria o banheiro que poderia ser utilizado simultaneamente por mais de uma pessoa, o que reduziria o tempo de espera para a higiene pessoal ou outras atividades- lavagem de louças, panos, roupas.

Os presos reclamaram em maioria do odor do banheiro (6) - "a cela inteira é um banheiro". Alguns presos afirmaram não adiantar lavar o banheiro. Na unidade paulista foi relatada a formação de um 'gel de fungos e bactérias' nas paredes. Foi sugerido colocar o banheiro fora da cela (1) ou isolar o banheiro com porta ou por meio de ventilação (2)(aberturas baixas e altas para retirar o ar contaminado). Um preso afirmou não se sentir incomodado pelo cheiro. Os presos também reclamaram da umidade, embora a proximidade com as aberturas de ventilação e iluminação seja considerada conveniente. Neste sentido, além do banho, as diversas atividades de limpeza e secagem contribuem para a umidade na cela. Na unidade catarinense, as roupas lavadas são penduradas nas grades das janelas. Na unidade paulista, varais são feitos para secar as roupas lavadas nas celas.

Um efeito colateral da realização das refeições na cela que é destacado pelos presos é o lixo (recipientes e restos de comida). O lixo é retirado uma vez por dia, pela manhã. Assim, o lixo diário permanece na cela até o dia seguinte em sacos plásticos ou lixeiras domésticas. Para os funcionários, a retirada diária reduz as tarefas (o lixo é descartado por um preso colaborador, escoltado até a parte de fora da unidade). Para os presos, o lixo atrai ratos e insetos, mas é preferível a coleta matutina porque durante a noite podem cuidar das celas. Restos de comida são regularmente lançados no estogo, via vaso sanitário.

As equipes dirigentes e os presos consideram o dimensionamento das celas suficiente (4), desde que a quantidade de pessoas e camas seja equivalente, com exceção dos banheiros - "poderia ser maior" (1). Na unidade paulista, um preso citou o teto baixo (questão do conforto ambiental). cantos, ao fundo). $\mathrm{Na}$ unidade catarinense, os presos ainda não tinham acesso à televisão e ficavam mais tempo na cela. Na unidade paulista, os presos viviam em maior aglomeração.

As unidades apresentam camas abertas e banheiros fechados por divisórias baixas, sem porta. Os banheiros são constituídos por um espaço único que agrupa as peças hidrossanitárias. Mesmos padrões da PC. O uso individual das camas ainda é vivenciado na unidade catarinense e nas celas para os presos colaboradores da unidade paulista (estas celas com oito camas têm de oito a doze pessoas - os extras dormem em colchões no chão).

As unidades apresentam banheiros ao fundo das celas. A unidade catarinense tem janelas ao fundo da cela. A unidade paulista tem uma ventana com aparato de fechamento.

A unidade catarinense apresenta quase dois metros quadrados por vaga na cela. A unidade paulista apresenta $1,85 \mathrm{~m}^{2} /$ vaga 
As equipes dirigentes consideram as aberturas de iluminação e ventilação críticas nas celas, em termos da impermeabilidade e da estanqueidade. Para os funcionários, estas aberturas devem ser mínimas e contidas, de modo a limitar o contato com os espaços adjacentes (áreas externas e corredor ou pátio de acesso) e entre os grupos de presos (celas). Para os presos, as aberturas de iluminação e ventilação estão associadas ao seu bem estar. Um comentário geral entre os presos foi sobre a temperatura alta. Na unidade catarinense, a ventilação foi considerada 'boa' pelos presos - "a janela é mais arejada", mas com a observação: "vamos ver no verão". Na unidade paulista, a cela foi considerada muito quente - precisa de "mais ar", com exceção de um preso que considerou a cela arejada (gradeada na parte frontal). A maioria considerou a abertura insuficiente. Um preso relacionou o calor na cela com o muro e o pátio de sol fechado - "impedem a ventilação". Foi sugerida a criação de uma circulação de ar, por meio de aberturas baixas e altas, a 2 ou $3 \mathrm{~m}$ de altura. Quase sempre foi pedido o ventilador (5), utilizado nos 'quietos' (questão da privacidade/individualidade). Um preso fez ponderações sobre a ambientação nos 'quietos': se o ventilador é colocado dentro, apenas circula o ar quente - "eu coloco passando o quieto, virado para fora e deixo entrar ar novo" (exaustão). Na unidade catarinense, apenas dois presos reclamaram da iluminação natural. Na unidade paulista, a iluminação natural foi considerada péssima por um preso, principalmente para os mais velhos. Para os presos, as aberturas ainda remetem à interação com o mundo externo. Houve a manifestação do desejo de se olhar para fora da cela (5) - "ver um passarinho", "ver o céu". Um preso relatou estar a quatro anos sem ver o céu noturno - "estrela no céu é mentira".

As equipes dirigentes consideram a regulagem das aberturas inviável, tendo em vista a segurança. Para os presos, esta regulagem é vislumbrada para os dias de frio (8), embora não possa ser totalmente fechada - "muita gente junta". Na unidade catarinense, foi relatado que o mecanismo de fechamento das janelas vira arma (2). Na unidade paulista, alguns presos admitiram a possibilidade de desmonte deste mecanismo para a produção de armas ou ferramentas (3). A regulagem é improvisada com cortinas (pano ou plástico) ou com pedaços de espuma. Foi cogitado o manuseio das regulagens pelos funcionários, sendo considerada viável, mas contrária à redução das tarefas. Em paralelo, foi registrado o problema para se dormir à noite com os mosquitos, o que também justifica o 'quieto' e o ventilador (2).

As equipes dirigentes consideram melhor o tipo de abertura brise, em comparação à grade, que exige uma maior atenção da segurança. Para os funcionários, o brise aumenta a segurança (estanqueidade) e minimiza a percepção do espaço externo (impermeabilidade). O brise é considerado mais resistente ao corte, além de dificultar esta ação, ao gerar resíduos e barulho e exigir maior dissimulação (os presos maquiam as quebras com materiais caseiros). O brise pode direcionar o ângulo de visão dos presos, limitando a visualização do exterior. Em contrapartida, as aberturas do tipo janela com grades permitem o monitoramento do espaço interno das celas pela instituição, além de auxiliar na contenção de crises (incêndios, motins). Na unidade catarinense, um funcionário sugeriu a criação de uma 'caixa' com muro e grade contígua à cela para bloquear as janelas. Na unidade paulista, funcionários e presos concordam que a caixa metálica que protege a abertura da cela impede a função ambiental da mesma.

As equipes dirigentes consideram melhor a porta do tipo corrediça, em relação à porta dobradiça. Para os funcionários, a porta de correr é vista como mais segura, funcional e prática, pela resistência ao arrancamento, manuseio simples e espaço ocupado reduzido. Em particular, a porta de correr evita que os presos empurrem o agente durante a abertura da cela. Os funcionários teceram comentários sobre os elementos da porta. A tranca deve ser inacessível aos presos. Na unidade paulista, a porta em grade exigiu a colocação de chapas para evitar o acesso aos cadeados. A portinhola deve permitir a comunicação com os presos, a passagem de alimentação (marmita) e a visualização do interior da cela, além da entrega de remédios e algemar os presos. A portinhola aberta deve permanecer na posição horizontal para a passagem dos materiais. A mesma deve ser lavável (eventualmente, cai comida ou bebida). Foi sugerido um visor associado à portinhola, pois esta tem a desvantagem da exposição dos agentes (ataques e odor). Para os presos, a porta é vista como um elemento institucional, não houve manifestações relevantes sobre a mesma. Na unidade catarinense, a porta foi considerada 'boa'.

As equipes dirigentes consideram a visualização do interior da cela importante, em termos da segurança (verificação de ações
A unidade catarinense apresenta duas janelas em cada cela. A unidade paulista apresenta grades na frente das celas ('tampa') e uma abertura ao fundo, junto ao banheiro (semelhante ao padrão da PC que apresenta 'ventana' na cobertura para o banheiro). A unidade catarinense ainda não experimentou as temperaturas de verão.

A unidade catarinense apresenta um fechamento do tipo guilhotina nas janelas das celas, por meio de uma placa de policarbonato que corre em trilhos laterais, sendo regulada em diferentes aberturas por um fecho. A unidade paulista não possui regulagem (mesmo padrão da $\mathrm{PC}$ ).

A unidade catarinense apresenta amplas janelas com grades nas celas. A unidade paulista apresenta a frente toda em grade ('tampa') e uma abertura ao fundo das celas, dotada de uma caixa metálica com tela moeda (semelhante ao padrão da PC que prevê grades na 'ventana' da cobertura).

A unidade catarinense apresenta porta de correr, chapeada, com portinhola nas celas. A unidade paulista apresenta porta dobradiça em grade, com chapas para impedir que os presos alcancem os cadeados (semelhante padrão da PC que prevê os ferrolhos embutidos nas paredes). 
subversivas) e da operação (evitar ataques aos funcionários), desde que não haja a visualização dos funcionários pelos presos. Para os funcionários da unidade catarinense, o fechamento da cela é considerado melhor, visto como solução definitiva para quaisquer subterfúgios dos presos. Na unidade catarinense, a porta incorporou abas para impedir a visualização através das frestas, o que eliminou o fluxo de ar cruzado na cela (questão do conforto ambiental). Os presos admitem o uso das aberturas para a observação dos funcionários e para a comunicação entre as celas. A visualização das celas no caso catarinense é feita através das janelas, por meio de rondas. Para os funcionários da unidade paulista, a visualização dos presos dentro das celas é mais importante, devido ao modelo de vigilância adotado. Apesar disto, os presos reclamam menos da exposição à instituição do que entre si (questão da privacidade). Na prisão, os presos assumem a necessidade óbvia da sua exposição e se sentem constantemente vigiados, menos na cama ('burra').

As equipes dirigentes consideram a visualização máxima do interior da cela importante para a operação. Para os funcionários, a visualização do interior da cela exige o espaço único e as subdivisões são vistas como desfavoráveis à segurança (os presos podem se esconder). Para alguns funcionários da unidade paulista, a possibilidade do preso se esconder é vaga, tendo em vista o procedimento de contagem anterior à entrada de funcionários na cela (revista da cela). Os funcionários apontam os beliches e o sanitário (divisória) como pontos cegos, principalmente as camas ao fundo e em baixo.

\section{Pátio de sol dos presos}

\section{Demandas}

As equipes dirigentes e os presos consideram valores similares para a melhor capacidade do pátio de sol, tendo em vista a superlotação, as relações sociais e os recursos operacionais disponíveis. Estes valores estão entre 40 (4) e 80 pessoas (3), com uma recorrência intermediária entre 70 (2) e 100 ocupantes. Resultados minoritários tenderam para um máximo entre 120 e 150 presos. Para os funcionários, este intervalo é visto como favorável ao controle, com uma redução da exposição dos funcionários, sendo 40 presos melhor (procedimentos são realizados mais rapidamente) e 80 diante da demanda de vagas (um agente considerou excessivo). Para os presos, entre 70 e 80 pessoas é aceitável (administrar as diferenças), mas 40 é melhor (privacidade, convivência e higiene), podendo chegar até 45 ou 50 pessoas. Na unidade catarinense, este número equivale a um quarto da ala carcerária. Na unidade paulista, o mesmo equivale a um terça das vagas de um pavilhão.

As equipes dirigentes (diretores e chefes de segurança) consideram a relação de um pátio de sol por ala carcerária como melhor, de modo a preservar a divisão da população prisional, considerando os perfis mais significantes e os recursos operacionais disponíveis. $\mathrm{Na}$ unidade catarinense, o uso do pátio de sol é alternado pelos quatro grupos de presos de uma ala carcerária, a cada duas horas. A alternância também ocorre na ordem de uso do pátio, fechando um ciclo a cada quatro dias. Eventualmente, existem horários especiais para os condenados por crise sexual (não podem ser misturados aos demais). Para os presos envolvidos em atividades colaborativas, se pressupõe que o trabalho supre a necessidade de sol diária, o que de fato não se verifica com os colaboradores 'faxinas' e dos serviços (realizam trabalhos dentro dos edifícios).

As equipes dirigentes consideram a permanência dos presos nos pátios de sol suficiente, tendo em vista a superlotação e os recursos operacionais disponíveis. Para os funcionários, a concentração de atividades nos pátios é vista como meio para reduzir tarefas e simplificar procedimentos. Para os presos, a mesma é vista como um castigo extra - fazer as mesmas coisas, no mesmo lugar, todos os dias. Além do banho de sol, os presos elencaram como atividades realizadas nos pátios (em ordem de recorrência): futebol, correr e caminhar (majoritários), exercícios físicos (6), a prática religiosa (2) e jogos de mesa (2). Na unidade paulista, também se joga vôlei (3). Os presos interpretam o pátio como um local de sociabilização - encontrar os "amigos" e ter conversas com pessoas diferentes enquanto se caminha (2) (os mesmos fazem amizades em diferentes celas). Além das atividades realizadas, os presos pontuaram outras como desejadas: música, capoeira, filmes e dança, além do basquete (5)(o aro é um problema reconhecido pelos presos pode ser utilizado com arma ou ferramenta). Individualmente, foi cobrado um local para pequenos trabalhos, principalmente no caso interior pelas janelas das celas. A unidade paulista tem visualização pela frente das celas que é toda em grade ('tampa').

A unidade catarinense possui como pontos cegos as camas. A unidade paulista tem como ponto cego o sanitário.

Considerações

A unidade catarinense opera atualmente com cerca de 50 presos no pátio de sol, com duas horas de banho de sol, em regime de rodízio. A unidade paulista opera com mais de 500 presos em um pátio, com aproximadamente seis horas de banho de sol.

A unidade catarinense tem um pátio de sol por ala carcerária que é ocupado alternadamente por quatro grupos de presos, com a permanência de duas horas cada. A unidade paulista tem um pátio de sol por pavilhão que é ocupado simultaneamente pelos respectivos presos.

As unidades apresentam pátios de sol sem espaços ou estrutura física para a realização das atividades elencadas pelos presos. $\mathrm{Na}$ unidade paulista, durante a realização do banho de sol, uma cela é destinada ao culto, uma cela ao trabalho e uma cela ao esporte. Embora não tenha sido apontado, um dos pátios de sol tinha roupas secando em varais e nas estruturas, cobrindo todo o espaço interno. Da mesma forma, o serviço de barbearia 
de presos sem visita. Um preso sugeriu a refeição no pátio.

As equipes dirigentes e os presos consideram uma cobertura no pátio de sol importante para a comodidade dos presos (proteger do

sol e da chuva) - segundo preso, "dia de visita é horrível, sol para quem não tem visita" (para liberar o uso das celas). Um preso sugeriu uma cobertura retrátil, para regular a área ensolarada e aumentar a proteção das intempéries.

As equipes dirigentes consideram o mobiliário existente suficiente, embora o melhor fosse não tê-lo. Para os funcionários, o mobiliário é visto como complicador para a visualização e procedimentos (pontos cegos, esconderijos e retirada de peças e partes para a confecção de objetos, aumento da vistoria e obstáculo para a entrada forçada dos funcionários). Segundo agente, as mesas e bancos devem ser previstos em refeitório. Para os presos, o mobiliário serve para o apoio às atividades realizadas - para não precisar se sentar no chão ou no chinelo (não sujar a roupa). Na unidade catarinense, o mobiliário foi inicialmente considerado 'bom' pelos presos. Um preso prefere sem mobiliário - tira o espaço para as atividades. Na unidade paulista, os presos apontaram a necessidade de mobiliário, como mesas e bancos (6). Nela, o mobiliário é improvisado com colchões e espumas amarradas enroladas - o 'puff'. Foi cogitado mesas e bancos para jogos (xadrez, dama). Um preso argumentou a necessidade pela presença de idosos. Além do mobiliário, foram sugeridos uma arquibancada e um palco.

As equipes dirigentes e os presos consideram os sanitários no pátio importantes para a comodidade das pessoas. Para os funcionários, os sanitários são vistos como desfavoráveis para a segurança (compromete a visualização), além de complicar procedimentos (aumenta as revistas). Para os presos, os sanitários propiciam a permanência no pátio de sol. Na unidade catarinense, a quantidade de sanitários foi considerada suficiente pelos presos. Na unidade paulista, os presos citaram o 'duchão' - banheiro coletivo do pátio - descrito como insalubre: se urina no chão (se utiliza os banheiros das celas). Foi sugerido chuveiros para os dias de calor intenso.

As equipes dirigentes consideram a melhor espacialidade do pátio a descrita pela singularidade, integração e continuidade - os arranjos dos pátios das unidades prisionais são considerados adequados (espaços abertos, contíguos os eventuais componentes periféricos). Para os funcionários, esta espacialização é vista como favorável à segurança (visualização do interior e invasão do local) e como meio para simplificar procedimentos (agiliza as revistas). A subdivisão do pátio de sol para outras atividades eventualmente realizadas, como o culto religioso, lavanderia e barbearia, além daquelas desejadas pelos presos como a música, capoeira, filmes e dança não é viável, segundo os funcionários - muita gente, fazendo muita coisa diferente e em muitos lugares. Neste sentido, alguns funcionários colocaram que o melhor seria estas atividades ocorrerem em salas separadas. Na unidade catarinense, a espacialização foi inicialmente considerada 'boa' pelos presos. Os esportes, a caminhada e a corrida ocorrem na área descoberta, enquanto as demais atividades ocorrem na área coberta que abriga o mobiliário e o sanitário. Na unidade paulista, os presos colocaram que faltam espaços. Foi sugerida uma quadra circundada por uma pista de corrida/caminhada, delimitadas por um degrau para evitar a bolada nos transeuntes (foi citada a unidade de Franco da Rocha - um degrau em frente às celas). Este degrau poderia ser utilizado para sentar e escrever (1). Outros presos sugeriram a divisão do pátio, por meio de redes, ou simplesmente criar dois pátios: uma para a quadra (ginásio) e outro para correr/caminhar (divide os presos)(3). Um preso sugeriu a realização dos exercícios físicos na área coberta.

A equipe dirigente e os presos da unidade prisional catarinense consideram as dimensões do pátio de sol e da área coberta grandes para a quantidade de usuários (6), tendo em vista o rodízio do local por grupos menores de presos. Na unidade paulista, os presos consideram o pátio pequeno (excesso de pessoas e de atividades). Como a dimensão não comporta o futebol e a corrida/caminhada (risco de bolada nos transeuntes), estas atividades são alternadas: o futebol é suspenso em determinado momento. Um preso transferido de unidade do modelo compacto (PC) considera o tamanho do pátio desta "o pior" (1). Sobre a altura do pátio (muros e cobertura), os funcionários a consideram ineficaz como meio de estanqueidade - é rapidamente vencida pelos presos (escalada, pirâmide humana, cabos de vassoura emendados, cordas - 'terezas'). A altura é mais relevante para a impermeabilidade do local -

\section{foi identificado.}

A unidade catarinense tem área coberta no pátio de sol. A unidade paulista não tem área coberta no pátio de sol (se usam as celas).

A unidade catarinense tem mesas e bancos com dez ou doze lugares, cada conjunto. A unidade paulista não tem mobiliário no pátio de sol.

A unidade catarinense tem três sanitários e uma cuba com torneira. A paulista tem sanitários coletivos, mas são utilizados os das celas.

A unidade catarinense tem o pátio de sol configurado por um espaço único, cuja área descoberta é antecedida por uma área coberta contígua, que protege o acesso, o mobiliário e os sanitários. A unidade paulista tem o pátio de sol configurado por um espaço vazio totalmente descoberto e sanitários coletivos ('duchão'), integrados às alas carcerárias.

A unidade catarinense tem $10 \times 15 \mathrm{~m}$ metros e seis metros de altura. A unidade paulista apresenta $15 \times 20 \mathrm{~m}$ e $7 \mathrm{~m}$ de altura. 
impedir a comunicação dos presos no pátio com outros grupos. Para os presos, o pátio pode se tornar muito constrito. Um preso da unidade paulista considera que "o muro é muito alto". Outros presos colocaram a necessidade de altura para os jogos de futebol ou vôlei.

As equipes dirigentes e os presos consideram a cantina inapropriada devido ao comércio informal - "o dinheiro complica", além aumentar os procedimentos de revista e exigir maior controle. Os presos reclamaram da eventualidade de esquemas (dívidas impagáveis e preços abusivos) e da marginalização daqueles que não recebem dinheiro para o consumo. Estas condições passam a integrar as disputas de poder internas.

As equipes dirigentes consideram a privacidade no pátio um aspecto irrelevante, tendo em vista a natureza estritamente coletiva do local. Para os funcionários, os espaços e elementos do pátio devem ser abertos ao máximo, de modo a favorecer a segurança (visualização) e a simplificação dos procedimentos (reduz as revistas). Os funcionários da unidade catarinense criticaram as portas dos sanitários - não deveria haver. Para os presos, a privacidade no pátio se resume ao uso dos sanitários que devem preservar minimamente a intimidade em relação ao próprio grupo, principalmente para defecar. Segundo presos, o pátio de sol é o local em que se sentem mais vigiados.

As equipes dirigentes consideram a abertura do pátio de sol suficiente para o banho de sol dos presos, em termos do tamanho do grupo de presos e das atividades realizadas. Para os funcionários, esta abertura deve ser mínima, de modo a limitar o contato com os espaços adjacentes (áreas externas e outros cômodos), principalmente entre os grupos de presos (diferentes pátios de sol). 0 pátio de sol da unidade catarinense é criticado pela disposição parelha dos pátios (divididos por uma parede) e pela existência de aberturas de iluminação e ventilação de outros cômodos para o pátio. Um funcionário sugeriu o distanciamento dos pátios por intermédio de uma área vazia (os pátios poderiam ser fechados com cercas). Na unidade catarinense, a ventilação foi considerada 'boa' pelos presos. Porém, os funcionários relataram que uma parte dos presos prefere ficar nas celas em dias muito frios ou de chuva. Na unidade paulista, o pátio foi considerado quente - muito concreto e muito alto. Segundo um preso, o ar não circula o que é agravado pelo muro da unidade - "impedem a ventilação" (convecção). Foi sugerida a criação de aberturas laterais. Neste sentido, foi colocado o desejo de ver o exterior - vegetação, "verde" (2). Um preso sugeriu uma cobertura retrátil, para regular a área ensolarada e o grau de insolação. Não houve comentários sobre a iluminação.

As equipes dirigentes consideram o pátio de sol crítico para a segurança, em termos da impermeabilidade, da estanqueidade e da disciplina interna, mediante a abertura de sol e a aglomeração dos presos, associada ao maior grau de liberdade destes. Para os funcionários, o pátio de sol configura entre as tarefas de maior esforço do esquema de segurança do estabelecimento, ao exigir mais da vigilância e das vistorias - muita gente, muita coisa acontecendo, em muito espaço. Para os presos, o pátio é o local mais amplo, aberto e coletivo da edificação, onde o grupo de presos consegue maior expressividade, o que representa oportunidades de fuga ou motim. Sobre o espaço físico, os funcionários e os presos citam pontos cegos, rotas de fuga, esconderijos e retiradas partes para a confecção de objetos. Na unidade catarinense, foram apontados alguns pontos cegos no pátio (questão da visualização). Ainda foram relatadas tentativas de fuga por meio de escalada (quinas das paredes e elementos construtivos - pilares, divisórias, janelas, grades), pirâmide humana (recurso para a escalada), cabos de vassoura emendados e cordas - 'terezas'. A cobertura do pátio é um ponto visado para a fuga ou rebelião. Foram narrados casos de presos escondidos na estrutura da cobertura e outros de esconderijos de facas usadas em brigas. O mobiliário e as portas metálicas dos sanitários foram criticados como prováveis alvos da retirada de material e da criação de esconderijos. Os presos deixam claro que não são todos que concordam ou participam destas ações. Como contramedidas, na unidade catarinense, os funcionários aconselham a colocação de espelhos para cobrir os pontos cegos (devidamente protegidos de boladas do futebol). Os mesmos consideram adequado o fechamento superior da abertura de sol por grades para dificultar a fuga, mas recomendam o fechamento também por telas para impedir a passagem de objetos. Isto também se aplica às janelas de iluminação e ventilação que existem no pátio. As peças estruturais e as vedações devem receber obstáculos projetados e escorregadiços (evitar pontos de pega ou ancoragem) e elementos cortantes (evitar a aproximação, passagem ou

A unidade catarinense possui uma distribuição de refeições no lugar da cantina e cogita transformála em revista dos presos. A unidade paulista não possui cantina ou distribuição.

A unidade catarinense tem sanitários com divisórias baixas e portas. A unidade paulista tem sanitários coletivos, mas são utilizados os das celas.

A unidade catarinense apresenta pátios com área descoberta, mais janelas para o salão polivalente (iluminação e ventilação indireta). A unidade catarinense ainda não experimentou as temperaturas de verão. A unidade paulista apresenta pátios descobertos com as celas conjugadas.

A unidade catarinense tem grade na parte superior do pátio de sol e nas aberturas de iluminação e ventilação. A unidade paulista tem elementos cortantes no topo das vedações dos pátios. 
permanência). Os componentes arquitetônicos (mobiliário e sanitário) devem ser solidários, maciços e fixos, sem articulações ou peças metálicas, assim como, devem permitir a maior visualização possível, não constituindo impedimentos visuais (esconderijos). Para os presos, o pátio tende a ficar excessivamente constrito, embora, segundo eles, a grade superior impeça a bola de futebol de sair do pátio durante o jogo.

A equipe dirigente $(\mathrm{SC})$ considera melhor a porta do tipo corrediça, em relação à porta dobradiça. Para os funcionários, a porta de correr é vista como mais segura, funcional e prática, pela resistência ao arrancamento, manuseio simples e espaço ocupado reduzido. Em particular, a porta de correr evita que os presos empurrem o agente durante a abertura da cela. Os funcionários teceram comentários sobre os elementos da porta. A tranca deve ser inacessível aos presos. A função de comunicação e visualização da portinhola é secundária no esquema do pátio, complementar ou auxiliar ao posto de controle. A mesma deve permitir a comunicação com os presos e a visualização do interior imediato do pátio, além de algemar os presos. Para os presos, a porta é vista como um elemento institucional, não houve manifestações relevantes sobre a mesma. Na unidade paulista, a contenção na saída do pátio de sol é considerada indispensável pelos funcionários (questão dos aparatos de segurança).

As equipes dirigentes consideram a melhor a visualização absoluta do interior do pátio de sol, efetuada por um posto de controle corretamente posicionado e configurado, associado a um espaço devidamente conformado. Para os funcionários, a visualização do interior do pátio exige o espaço único e as subdivisões são vistas como desfavoráveis à segurança (os presos podem se esconder). Os funcionários apontam os sanitários (divisória) e o mobiliário como empecilhos visuais. Os sanitários não devem ter portas ou anteparos para a privacidade. Os sanitários são locais de acerto de contas entre os presos, com mortes, cuja retirada de corpo não deve ser dificultada por anteparos. O fechamento deve ser providenciado por cortina. Para os presos, a privacidade é minimizada, embora reconheçam que a vigilância propicia segurança pessoal (evita as violências típicas nos sanitários). Na unidade paulista, os presos citaram o 'duchão' - banho coletivo que existia na unidade - "onde acontecem as ocorrências". Na unidade catarinense, preso relatou quatro pontos cegos no pátio onde ocorrem as indisciplinas e crimes. Os funcionários cotaram um ou três pontos cegos. Na unidade paulista, a reforma em andamento está relocando a escada de acesso ao pavimento superior, pois esta configurava um ponto cego. Nesta unidade, a vigilância no pátio também foi interpretada como segurança para os próprios presos (2) - "o procedimento protege os presos".

Posto de controle

Demandas
peculiaridades espaciais. De um modo geral, os postos devem ser isolados: a comunicação com os transeuntes deve ser intermediada por aparatos físicos e eletrônicos (comunicadores e passa volumes) e as portas, portões e cancelas devem ser manuseados remotamente. $\mathrm{O}$ controle de acesso do estabelecimento penal deve possuir guichês para a identificação das pessoas e estrutura para a revista eletrônica e física, pessoal e veicular. As pessoas devem passar por detector de metais e os pertences em aparelho de raiosX. Os veículos devem passar por vistoria dos compartimentos. No caso de visita, as pessoas passam por revista corporal e os volumes trazidos são fiscalizados. Na unidade paulista, a revista corporal foi eliminada com a instalação de aparelho escâner (raios-X). O local de vistoria dos volumes deve ter uma pia e bancada central. Segundo o chefe de segurança de São Paulo, neste posto deveria haver guardas armados. Para liberar a passagem das pessoas e veículos, os postos devem ter visualização de ambos os lados das portas/portões de acesso, com o pleno conhecimento das condições dos espaços de fora e de dentro. Internamente, existem postos dedicados a monitoria de locais específicos, como os pátios de sol. Estes postos recebem elementos para a comunicação pública e para procedimentos de disciplina e contenção de crises. Os mesmos são preparados para a evasão dos funcionários. Na unidade catarinense, o esquema de acesso é criticado, ao permitir a entrada de pessoas e veículos até a administração/apoio de funcionários sem a revista. Na unidade paulista, a recepção e a revista de pessoas e veículos compartilham o mesmo espaço de acesso à

A unidade catarinense apresenta porta de correr, chapeada, com portinhola nas celas. A unidade paulista apresenta porta dobradiça em grade, seguida de porta chapeada, configurando uma contenção na saída do pátio.

As unidades catarinense e paulista têm postos de controle e pontos cegos nos pátios. O sanitário da unidade catarinense tem um espaço mais reservado que dificulta o ângulo de visão do vigia. $\mathrm{Na} \mathrm{PC}$, os sanitários possuem portas, todavia a manutenção destas é justificada pelo uso restrito dos sanitários apenas nos dias de visita para dar conforto aos visitantes (acordado entre os presos). Os presos normalmente usam os sanitários das celas nesta unidade.

Considerações

A unidade catarinense possui um posto de acesso, um posto de recepção, um posto de acesso intermediário (setores internos), postos de acesso aos blocos de vivência e postos nos pátios de sol, além de circulações exclusivas para os funcionários. Todos os postos são fechados e possuem aparatos de segurança. A unidade paulista possui um posto de recepção, um posto de acesso interno e um posto no bloco de vivência (este é o único que tem a configuração própria de um posto de controle). 


\begin{tabular}{|c|c|}
\hline administração/apoio aos funcionários. & \\
\hline $\begin{array}{l}\text { As equipes dirigentes consideram a visualização a propriedade mais relevante do posto de controle, associada à elevação, formato, } \\
\text { posicionamento e configuração (invólucro e interior). Para os funcionários, a altura dos postos auxilia na visualização, ao aumentar o } \\
\text { ângulo de visão, além de superar o eventual bloqueio visual no nível monitorado - os presos criam agrupamentos em setores do local } \\
\text { monitorado em favor de ações subversivas. O formato e o posicionamento dos postos devem criar pontos de observação suficientes } \\
\text { para cobrir toda a área monitorada (questão da centralidade no espaço monitorado). Sobre isto, os funcionários consideram melhor } \\
\text { ter alguns pontos de observação do que um ponto central. Isto porque o posto é normalmente ocupado por uma equipe, ao mesmo } \\
\text { tempo em que uma posição estática pode ser demasiadamente cansativa - a movimentação renova a atenção. Uma questão } \\
\text { operacional é manter o agente alerta (acordado). Ao mesmo tempo, a quantidade pontos de observação deve considerar os recursos } \\
\text { disponíveis (pessoal). Na unidade paulista, o posto de controle do bloco de vivência ('bolha') é descrito por quatro pontos de } \\
\text { observação (quatro pavilhões), coordenados por um agente. Segundo funcionários, este é o número ideal de agentes para este posto, } \\
\text { considerando a quantidade de locais monitorados. Na unidade catarinense, o posto de controle do pátio de sol dos presos é descrito } \\
\text { por dois pontos de observação e é ocupado por dois agentes, havendo mais um coordenador dos blocos de vivência. Na prática, a } \\
\text { carência de pessoal implica em equipes reduzidas. Na unidade paulista, o posto central é eventualmente operado por três pessoas. } \\
\text { Na unidade catarinense, eventualmente permanece apenas um funcionário. Os visores dos postos devem propiciar o maior campo de } \\
\text { visão possível, horizontal e vertical (ângulo de visão). Os visores devem ser posicionados e dimensionados livres de interferência } \\
\text { (pilares, instalações, esquadrias, grades). Nas unidades catarinense e paulista, os funcionários reclamaram dos visores, insuficientes } \\
\text { na primeira e com pontos cegos na segunda. }\end{array}$ & $\begin{array}{l}\text { A unidade catarinense apresenta posto de controle } \\
\text { no pátio de sol dos presos, posicionado no andar } \\
\text { superior e em um canto do pátio, que avança no } \\
\text { espaço do mesmo e recebe dois visores pontuais. } \\
\text { A unidade paulista apresenta posto de controle } \\
\text { central aos pátios de sol dos presos, elevado em } \\
\text { relação ao piso destes pátios, avançado nos } \\
\text { espaços dos mesmos e possui amplos visores em } \\
\text { todo ser perímetro. }\end{array}$ \\
\hline $\begin{array}{l}\text { Além da visualização, os funcionários consideram outros sentidos importantes para o monitoramento, através de odores e ruídos } \\
\text { para perceber o uso de drogas, incêndios, brigas, demolições ou vandalismos, entre outros. Segundo os funcionários, esta percepção } \\
\text { depende de aberturas não muito grandes nos postos de controle, voltadas para as áreas monitoradas. }\end{array}$ & $\begin{array}{l}\text { O posto da unidade catarinense apresenta visores } \\
\text { com aberturas para o pátio de sol. O posto da } \\
\text { unidade paulista apresenta aberturas (ventanas) } \\
\text { para os pátios de sol. }\end{array}$ \\
\hline $\begin{array}{l}\text { As equipes dirigentes consideram os serviços sanitários importantes para os postos de controle, em termos da segurança e condições } \\
\text { de trabalho, com a previsão de um banheiro próximo a cada posto. Para os funcionários, o sanitário é cômodo e garante a efetividade } \\
\text { da vigilância, por meio do protocolo de funcionamento - o vigia deve ser substituído para ir ao banheiro. Os funcionários (chefes de } \\
\text { segurança) relatam a falha na vigilância justificada pelo vigia com a ida ao banheiro. Na unidade catarinense, os funcionários } \\
\text { reclamam da quantidade de sanitários, considerada insuficiente, o que cria um tempo de espera. A vigilância dos pátios é } \\
\text { interrompida a cada duas horas (troca do grupo de presos). Na unidade paulista, os funcionários têm que sair do bloco de vivência } \\
\text { para usar o banheiro que está no setor intermediário (bloco de assistência). O tempo de permanência no controle central é de oito } \\
\text { horas. }\end{array}$ & $\begin{array}{l}\text { A unidade catarinense possui um sanitário comum } \\
\text { a dois blocos de vivência. A unidade paulista possui } \\
\text { sanitário externo (fora do bloco de vivência). }\end{array}$ \\
\hline $\begin{array}{l}\text { As equipes dirigentes consideram o mobiliário importante para os postos de controle, em termos da visualização e tarefas a serem } \\
\text { desempenhadas. Para os chefes de segurança, o mobiliário se resume a bancos altos (sem conforto) e uma mesa para apoio (trabalho } \\
\text { burocrático, equipamentos, garrafa de água). A bancada não é recomendada para o agente não ter uma superfície para dormir, além } \\
\text { de não obstruir a aproximação dos visores - o perímetro de vigilância deve ser desimpedido (os funcionários devem chegar até os } \\
\text { visores para obter melhor ângulo de visão ou estabelecer melhor comunicação com os presos). Na unidade paulista, os funcionários } \\
\text { listaram as seguintes atividades no posto de controle: relatório dos procedimentos, registro das pessoas e anotação de ocorrências, } \\
\text { além do rádio comunicador, central de alarme e interfone. }\end{array}$ & $\begin{array}{l}\text { A unidade catarinense não possui mobiliário nos } \\
\text { postos de controle internos, apenas bancada no } \\
\text { posto do acesso e da recepção. A unidade paulista } \\
\text { possui bancada nos postos de controle, inclusive } \\
\text { no posto central do bloco de vivência. }\end{array}$ \\
\hline $\begin{array}{l}\text { As equipes dirigentes consideram as dimensões dos postos 'boas', suficientes para o mobiliário e para a mobilidade dos agentes. Em } \\
\text { termos da distancia dos presos, os funcionários se sentem seguros nos postos de controle, sem o receito de ataques inesperados. }\end{array}$ & $\begin{array}{l}\text { Na unidade catarinense, a segurança advém da } \\
\text { elevação do posto. Na unidade paulista, a } \\
\text { segurança advém da contenção anterior ao posto }\end{array}$ \\
\hline
\end{tabular}


As equipes dirigentes consideram as aberturas de iluminação e ventilação importantes nos postos de controle, em termos da inexpugnidade. Para os funcionários, estas aberturas devem ser suficientes, porém protegidas e contidas, de modo a evitar ataques ou o vazamento de informação para os mesmos. Neste sentido, as aberturas diretas para o exterior da edificação ou voltadas para áreas sem a permanência de presos foram cogitadas como melhor situação. Para os funcionários, as aberturas de iluminação e ventilação estão associadas ao seu bem estar. A reclamação geral dos funcionários é a temperatura: muito calor - "estufa", o que torna o trabalho muito cansativo, principalmente ao se considerar o equipamento (colete). No inverno, o frio também é incômodo. Nas unidades catarinense e paulista, as aberturas de ventilação foram consideradas insuficientes. Em São Paulo, a ventilação voltada para o pátio gera certo desconforto pelo "cheiro do cigarro dos presos". Outro problema relatado são os mosquitos. Por estes motivos, as aberturas deveriam ter regulagem e telas. Não houveram comentários quanto à iluminação dos postos de controle.

As equipes dirigentes consideram melhor a porta do tipo dobradiça, em relação à porta corrediça, vista como mais prática no caso de evasão do posto. A tranca da porta deve ser apenas interna e inacessível pelo lado de fora. No caso de porta com chapa, uma portinhola deve permitir a comunicação e a visualização com o lado de fora do posto. Foi sugerido um visor associado à portinhola, pois esta tem a desvantagem da exposição dos agentes (ataques). Na unidade catarinense, a porta foi considerada 'boa'.

As equipes dirigentes consideram os aparatos de segurança importantes para a inexpugnidade e a operação segura do posto de controle, principalmente, em termos dos visores e dispositivos para os procedimentos. Na unidade catarinense, os funcionários recomendam fechamentos balísticos nos postos externos. Na unidade paulista, os funcionários recomendam visores fixos e resistentes, em especial, em locais de grande aglomeração ou acessibilidade dos presos. Os visores que podem ser abertos (esquadrias) mostram o interior do posto (expor os funcionários) e são visados para a invasão pelos presos - "se eu abrir a janela, os presos vão ficar de olho". Os visores devem resistir às investidas dos presos em motins ou rebeliões, por meio de fechamento balístico ou grades - "o policarbonato derrete com o fogo". Na unidade paulista, os vidros dos visores do posto de controle central ('bolha') apresentam trincas do impacto de assaltos dos presos. Entre os dispositivos para os procedimentos, estão aberturas para a comunicação ou contenção de crises (disparo por arma de fogo e lançamento de spray ou bombas). Em Santa Catarina, foi relatada a impossibilidade de contramedidas dos agentes nos postos, pois faltam estas aberturas. Em São Paulo foram sugeridas portinholas nas aberturas para os procedimentos. Outros dispositivos relevantes se destinam a manipulação remota de portas. Os funcionários elogiam principalmente o uso de sistemas mecânicos (alavancas, puxadores e ferrolhos estendidos). Na unidade paulista, estes mecanismos foram concebidos por preso com materiais reciclados. Os postos de controle dos acessos externo e intermediários da unidade prisional devem contar com passa-volume (gaveta ou tambor giratório). Os postos de controle devem possuir escotilhas para a evasão dos funcionários em caso de crise com tomada do acesso do posto.

As equipes dirigentes consideram a inexpugnidade dos postos de controle estratégica para o esquema de segurança e para a integridade dos funcionários (segurança pessoal). Para os funcionários, o posto de controle deve apresentar uma resistência temporal mínima à investida dos presos (invasão), vinculada à sua posição e constituição, além da possibilidade de escape diante do tomada do acesso do posto. Na unidade paulista, um funcionário definiu que o posto não pode ser invadido em menos de cinco minutos - tempo necessário para a saída dos funcionários pelo ponto de fuga. A possibilidade de evasão representa uma tranquilidade para os funcionários (qualidade nas condições de trabalho). Segundo o funcionário, a rota de escape é melhor pela fachada para o agente não ser confundido com preso em fuga na cobertura (fogo amigo das torres de vigilância).

\section{('viúva').}

A unidade catarinense apresenta postos fechados que ventilam e iluminam para os espaços adjacentes (continuidade espacial). $O$ posto de controle do pátio ventila para o pátio de sol e para os corredores internos. A unidade paulista tem aberturas no posto de controle central para os pátios de sol. Os demais postos interam espaços comuns dos edifícios.

A unidade catarinense apresenta fechamentos em placas de policarbonato (não balístico) e grades. Os postos dos pátios de sol têm visores apenas com grades, projetados no pátio para permitir a visualização da parede do posto. A unidade paulista tem fechamentos em vidro laminado e grades. Os visores são esquadrias passíveis de serem abertas. Embora não tenha sido citado, o distanciamento dos presos em relação aos visores é um item de segurança para o posto de controle.

A unidade catarinense possui saídas de pânico nas circulações exclusivas dos funcionários. A unidade prisional de São Paulo não tem saída. 


\section{Apêndice D - Definição dos requisitos funcionais}

Neste apêndice são apresentados os requisitos funcionais levantados na análise do contexto e que integralizam o programa arquitetônico no Capítulo 6, desta tese. Na segunda parte deste apêndice, os vínculos entre estes requisitos funcionais são computados. Esta informação complementa a representação formal exposta no mesmo Capítulo 6.

A parir da análise do contexto procedida (Tabela 18), os requisitos funcionais foram organizados na Tabela 19, segundo a estrutura do programa arquitetônico definido, com os respectivos vínculos obtidos na análise do contexto. Os itens foram numerados de modo a permitir o endereçamento entre eles. Esta numeração é fixa e acompanha os requisitos nas análises procedidas nos capítulos 7 e 8 .

Para a avaliação dos vínculos encontrados, os mesmos foram classificados hierarquicamente quanto à natureza do requisito e à origem da vinculação, o que explicitou as subordinações no programa arquitetônico. Assim sendo, os requisitos externos apresentaram vínculos gerais e específicos que corresponderam a conexões dos grupos de quesitos e de requisitos individuais deste grupo, respectivamente. Nos requisitos internos, os itens referentes aos elementos centrais foram particularizados e os vínculos seguiram a classificação instituída entre gerais e específicos. A representação formal dos vínculos se encontra nas Figuras 72 e 73 (p. 303 e 304). 
Tabela 18 - Análise do contexto

\section{Tipo e categoria do estabelecimento penal}

Análise do Contexto/Vínculos específicos

01.01 Os instrumentos técnico-normativos determinam que os presos devem ser classificados e separados, segundo o seu perfil pessoal, criminal e jurídico. Segundo as Diretrizes Básicas, (p. 49) "a diferença essencial entre os vários tipos de estabelecimentos penais está na categoria das pessoas presas que os ocuparão". E o documento prossegue: "Essa diferença de categoria provocará, na elaboração dos projetos, a particularização para cada tipo de estabelecimento, de características técnicas próprias de localização ou mesmo de tratamento, adequação e dimensionamento de seus espaços físicos". Assim, a categoria dos presos define a composição arquitetônica do estabelecimento penal a ser projetado (ver item 01.02). No sistema penitenciário, a classificação e a separação dos presos são precárias, normalmente, estes se encontram massificados e aglomerados nas prisões.

01.02 O padrão penal brasileiro é baseado na Teoria Mista do Direito: prevê simultaneamente a reintegração social e a punição dos presos. A segurança penitenciária sintetiza este objetivo, por meio de um balanço entre a segurança e a humanização, medidas pelo nível de segurança que necessariamente enfatiza as necessidades físicas e operacionais de um ou outro. Neste sentido, o nível de segurança é a principal categoria dos estabelecimentos penais do ponto de vista da composição arquitetônica (ver item 01.01), ligando o conceito de pena a ser aplicada a uma modalidade de espaço arquitetônico. Os instrumentos legais e técnico-normativos não distinguem explicitamente o modelo arquitetônico em razão do nível de segurança. Segundo as Diretrizes Básicas (p. 27): "Qualquer nível de segurança de construção pode ser usado em qualquer estabelecimento penitenciário, dependendo da destinação e da proposta metodológica da unidade". No sistema penitenciário, a massificação dos presos deforma o critério da periculosidade deste grupo de pessoas: o nível de segurança máxima é amplamente adotado. Ao mesmo tempo, a indefinição legal e técnico-normativa determina indiscriminadamente a assistência e o programa de benefícios aos presos, independentemente da categoria penitenciária, o que choca com o padrão de segurança máxima (ver itens 09.01 e 11.01).

01.03 Além do perfil do preso, outros fatores podem ser considerados para a definição da categoria de um estabelecimento penal. As Diretrizes Básicas colocam (p. 29): "[...] há que se avaliar paralelamente as características administrativas e de tratamento do sistema penitenciário da Unidade da Federação, bem como o tipo ou regime, a categoria e a segurança". Além destes fatores, outros de ordem financeira e organizacional devem ser considerados (ver itens 02.02 e 03.02). No planejamento do sistema penitenciário, estas questões são regularmente menosprezadas em favor da solução de segurança máxima (ver item 01.02).

\section{Porte do estabelecimento penal}

Análise do Contexto/Vínculos específicos

02.01 Segundo a LEP (Art. 85): “o estabelecimento deverá ter lotação compatível com a sua estrutura e finalidade”. Neste sentido, o porte está vinculado às necessidades físicas e operacionais que se conjugam nos sistemas de segurança e operação do estabelecimento penal e cuja caracterização depende do tipo e categoria penitenciária (ver item 01.02). No sistema penitenciário, em geral, a capacidade dos estabelecimentos penais é superada pela população prisional, o que determina a demanda superlativa de vagas para as ações de ampliação do parque penitenciário. Na prática prisional, esta superpopulação inviabiliza parcialmente a implementação do modelo prisional, comprometendo o desempenho da estrutura física da prisão.

02.02 Para o Panóptico, "o número máximo de pessoas que pode ser acomodado em um único edifício desse tipo deve ser consistente com os propósitos de cada uma das diversas instituições [...]" (BENTHAM apud SILVA, 2000, p. 23). Neste sentido, o porte de um estabelecimento penal é condicionado pelo nível de segurança penitenciário estipulado (ver item 01.02). As Diretrizes Básicas estabelecem uma proporcionalidade entre a capacidade e o tipo de estabelecimento penal, mas não explicitam esta relação em termos do nível de segurança penitenciário. No sistema penitenciário, a política de prisionalização e a demanda superlativa por
Requisito funcional/Vinculação geral

Conceber o espaço arquitetônico da prisão de modo consonante ao perfil da população prisional prevista para o estabelecimento penal a ser projetado.

Este item baseia o programa arquitetônico como um todo.

Viabilizar os sistemas de segurança e operação penitenciária em função do nível de segurança definido para o estabelecimento a ser projetado.

Este item baseia o programa arquitetônico como um todo.

Considerar

características

administrativas e do modelo prisional na definição do espaço arquitetônico do estabelecimento penal a ser projetado.

Este item baseia o programa arquitetônico como um todo.

Requisito funcional/Vinculação geral

Compatibilizar a capacidade do estabelecimento penal a ser projetado com as estruturas físicas necessárias para o funcionamento do local.

Este item baseia o programa arquitetônico como um todo.

Especificar o porte do estabelecimento penal a ser projetado segundo o nível de segurança estipulado para o mesmo.

Este item baseia o programa arquitetônico como um todo, principalmente $o$ 


\begin{tabular}{|c|c|c|}
\hline & vagas, condensadas na centralização penitenciária impõe unidades de maior porte (ver itens 05.01, 08.01, 09.01 e 11.01). & $\begin{array}{l}\text { Isolamento Individual, as Atividades e o } \\
\text { Dimensionamento. }\end{array}$ \\
\hline 02.03 & $\begin{array}{l}\text { Segundo as Diretrizes Básicas ( } \text { p. 29), ao se definir uma capacidade: "há que se ter em mente a necessidade imediata de } \\
\text { acomodação e as ampliações que forem projetadas (plano diretor de ocupação da área)". Este documento recomenda (p.30): "o } \\
\text { planejamento prévio de possíveis ampliações para o correto dimensionamento de dependências destinadas a assistir a pessoa presa } \\
\text { de acordo com a capacidade total a ser atingida". No sistema penitenciário, uma série de condicionantes, como o planejamento } \\
\text { deficiente e o imediatismo nas decisões administrativas, além do tamanho dos terrenos (ver item 04.04) e da indisponibilidade de } \\
\text { recursos financeiros para as obras penitenciárias, dificultam a previsão de ampliações nos projetos arquitetônicos elaborados. }\end{array}$ & $\begin{array}{l}\text { Considerar futuras ampliações para o } \\
\text { estabelecimento penal a ser projetado. } \\
\text { Este item se relaciona com a Organização } \\
\text { do Espaço, especialmente com a } \\
\text { Geometria, as Atividades e } \quad \text { o } \\
\text { Dimensionamento. }\end{array}$ \\
\hline \multicolumn{3}{|c|}{ 03. Custo do estabelecimento penal } \\
\hline \multicolumn{2}{|c|}{ Análise do Contexto/Vínculos específicos } & \multirow[b]{2}{*}{$\begin{array}{l}\text { Requisito funcional/Vinculação geral } \\
\text { Conceber o edifício prisional de modo a } \\
\text { favorecer a economia de recursos de toda } \\
\text { ordem, tanto na construção como na } \\
\text { operação do estabelecimento penal a ser } \\
\text { projetado. } \\
\text { Este item baseia o programa arquitetônico } \\
\text { como um todo. }\end{array}$} \\
\hline 03.01 & $\begin{array}{l}\text { Para Bentham, a arquitetura era baseada em um cálculo de perdas e ganhos, em uma economia de recursos de toda ordem. } 0 \\
\text { edifício como um todo, e cada elemento deste, era avaliado do ponto de vista financeiro, buscando a economia de recursos e } \\
\text { política. Nas Diretrizes Básicas (p. 42) recomenda-se: "as edificações devem ser projetadas de modo a atender aos quesitos } \\
\text { necessários quanto ao custo da construção", isto considerando o material e despesas de manutenção e funcionamento. No sistema } \\
\text { penal, as políticas penitenciárias exaltam a minoração do custo de construção, sendo eleito um bom projeto aquele que atende a } \\
\text { esta exigência: o valor da vaga a ser gerada predomina na avaliação de um projeto arquitetônico. Por outro lado, a eficiência e a } \\
\text { eficácia na operação são pouco reconhecidas, não sendo discutidos indicadores para este item. No sistema penitenciário, a política } \\
\text { prisionalizante e a carência de recursos operacionais concentram os investimentos no sistema de segurança, em detrimento do } \\
\text { operacional, em especial, aquele relacionado à assistência do Estado e ao programa de benefícios aos presos (ver item 09.01). }\end{array}$ & \\
\hline 03.02 & $\begin{array}{l}\text { O custo de construção e operação de um estabelecimento penal pode ser associado à categoria do mesmo (ver item 01.02). As } \\
\text { categorias de maior segurança e de pequeno porte tendem a serem mais dispendiosas, em termos da construção e operação. Isto } \\
\text { ocorria no projeto de Bentham que justificava o custo pela alta segurança e eficiência operacional. A diferença dos custos de } \\
\text { construção e operação entre unidades de segurança máxima e média é considerável: cerca de três ou quatro vezes. No sistema } \\
\text { penitenciário, as unidades construídas são majoritariamente de segurança máxima e de maior porte (ver itens } 01.02 \text { e } 02.02 \text { ). Diante } \\
\text { da insuficiência de recursos financeiros para a construção de novos estabelecimentos, o maior investimento na construção } \\
\text { associado à maior segurança é compensado pelo aumento da capacidade, na busca de uma redução do valor da vaga. Em } \\
\text { contrapartida, o sistema operacional é otimizado, inclusive o esquema de segurança (ver item 15.06). }\end{array}$ & $\begin{array}{l}\text { Considerar os custos de construção e } \\
\text { operação relativos à categoria } \\
\text { penitenciária do estabelecimento a ser } \\
\text { projetado. } \\
\text { Este item baseia o programa arquitetônico } \\
\text { como um todo, principalmente as } \\
\text { Atividades e o Dimensionamento. }\end{array}$ \\
\hline 03.03 & $\begin{array}{l}\text { Os objetivos econômico e social da atividade prisional devem estar equilibrados (ver item 01.05). No panopticon, o custo não era } \\
\text { impeditivo de soluções de conforto, como o correto dimensionamento dos ambientes e a apropriada ventilação e iluminação do } \\
\text { edifício. Segundo as Diretrizes Básicas (p. 42): o custo de construção deve ser reduzido, "sem, contudo, acarretar o prejuízo das } \\
\text { condições mínimas de comodidade" (ver item 13.01). No sistema penitenciário, a imposição de redução de custos de construção } \\
\text { sobre o projeto arquitetônico de estabelecimentos penais tem levado a uma exacerbação da otimização do espaço arquitetônico da } \\
\text { prisão, inclusive com desrespeito à condição humana das pessoas na prisão (ver itens } 09.01 \text { e 10.05). }\end{array}$ & $\begin{array}{l}\text { Limitar a economia de recursos } \\
\text { financeiros na concepção do espaço } \\
\text { arquitetônico diante do respeito à } \\
\text { condição humana na prisão. } \\
\text { Este item baseia o programa arquitetônico } \\
\text { como um todo e se relaciona } \\
\text { especialmente com o Conforto Ambiental. }\end{array}$ \\
\hline 03.04 & $\begin{array}{l}\text { A forma do Panopticon se justificava por sua economia: de política, de pessoal, de deslocamentos, obtidas por meio, principalmente, } \\
\text { da centralidade e da invisibilidade da vigilância. A geometria e o dimensionamento da edificação penal são atreladas aos custos de } \\
\text { operação (ver itens } 07.01 \text { e 11.01). Neste sentido, por exemplo, a utilização do padrão arquitetônico modular sugerida pelas } \\
\text { Diretrizes Básicas deve considerar as propriedades deste modelo que determinam a necessidade de grandes terrenos ou de uma } \\
\text { equipe de funcionários que pode ser maior do que a de modelos compactos, devido ao programa repetitivo e espacialmente } \\
\text { fracionado. }\end{array}$ & $\begin{array}{l}\text { A questão do custo operacional deve ser } \\
\text { considerada no aproveitamento de } \\
\text { padrões arquitetônicos no projeto de } \\
\text { estabelecimentos penais. } \\
\text { Este item se relaciona com a Organização } \\
\text { do Espaço, especialmente com a }\end{array}$ \\
\hline
\end{tabular}




\begin{tabular}{|c|c|}
\hline \multicolumn{2}{|c|}{ 04. Isolamento social do preso } \\
\hline Análise & o Contexto/Vínculos específicos \\
\hline 04.01 & $\begin{array}{l}\text { Segundo a representação teatral de Goffman, uma condição fundamental para o funcionamento da prisão é a impermeabilidade: a } \\
\text { capacidade de romper a livre comunicação informal entre as pessoas de dentro e de fora da prisão. É a constituição da'fachada' que } \\
\text { possibilita a representação institucional - a manutenção da imagem oficial de organismo racional e austero. A impermeabilidade } \\
\text { está associada ao fechamento da prisão ao mundo externo: o distanciamento entre a rotina prisional e a sociedade. A } \\
\text { impermeabilidade é diretamente proporcional ao nível de segurança do estabelecimento penal (ver item 14.01). Os instrumentos } \\
\text { legais e técnico-normativos não tratam da impermeabilidade da prisão. Formalmente, esta impermeabilidade é rompida em alguma } \\
\text { medida pela visita aos presos (ver item 10.03). No sistema penitenciário, a impermeabilidade é constantemente burlada pela } \\
\text { comunicação informal dos presos com o exterior da unidade penal, por exemplo, com o uso de cartazes e bilhetes lançados sobre a } \\
\text { barreira. }\end{array}$ \\
\hline
\end{tabular}

04.02 Do ponto de vista da reinserção social, a participação da comunidade nas atividades prisionais é interpretada como necessária para a manutenção da saúde mental e dos vínculos sociais dos presos, de modo a facilitar o retorno do mesmo à sociedade. Por isto, a LEP (Art. 90) determina a proximidade do estabelecimento penal do local de origem do preso. A interação entre a sociedade e a prisão é mediada pelo nível de segurança penitenciário. No sistema penitenciário, a rejeição da sociedade tende a distancia geograficamente a prisão, ao mesmo tempo em que a maximização da segurança e os problemas operacionais restringem a participação popular (ver item 04.04). A prisão é incompatível com a abertura institucional à sociedade, ao mesmo tempo em que a instituição tem dificuldades viabilizar ou em garantir a integridade dos visitantes. As unidades penais que trabalham conjuntamente com a sociedade são excepcionais, normalmente concernentes à política de descentralização penitenciária, como é o caso da Apac.

04.03 A LEP e as Regras Mínimas prevêem a comunicação do preso com o mundo exterior, por meio da visita e do encontro reservado com o advogado constituído. Este contato é preconizado como direito dos presos à sociabilização e assistência jurídica. Para os presos, a visita significa um momento de aproximação com o mundo externo e mudança da rotina diária. Para a instituição, a mesma é vista como meio de atenuar as tensões e controlar os presos, integrando o sistema de castigos e recompensas. Embora a visita represente um rompimento da impermeabilidade e um dificultador para os sistemas de segurança e operação penitenciária. Neste sentido, a acessibilidade e o contato com os presos dependem do tipo de visita (visita social ou advogado). A LEP não vislumbra a visita íntima. As Diretrizes Básicas (p. 45) prevêem locais de visitação - pátios, salas, parlatórios e apartamento de encontro íntimo (ver itens 09.01 e 10.03). No sistema penitenciário, a visita ao preso é regular e com contato físico que pode ocorrer nos pátios de sol dos presos ou nas celas. A visita do advogado ocorre sempre no parlatório. O encontro íntimo é corrente nos estabelecimentos penais, com exceção do RDD.

04.04 No isolamento social, a localização interfere fortemente na definição do tipo de barreira perimetral (ver item 16.04) e dos afastamentos (ver item 16.10), associada às questões de impermeabilidade (ver item 16.02) e fechamento (ver item 16.01). As Diretrizes Básicas não tratam a localização do estabelecimento penal como um requisito do sistema de segurança, emitindo apenas algumas recomendações gerais. Segundo as Diretrizes Básicas (p. 32 e 33): as unidades penais devem se localizar fora de zonas centrais urbanas ou residenciais, desde que respeitados a facilidade de acesso e a presteza das comunicações, assim como, a conveniência socioeconômica e as peculiaridades do entorno. A localização é condicionada ao nível de segurança penitenciária (ver tem 01.01). No sistema penitenciário, mais do que um critério de segurança ou de manutenção dos vínculos sociais dos presos, a localização dos estabelecimentos penais tem sido definida inicialmente pela sociedade: vigora o maior isolamento geográfico possível. Na prática, se constrói onde se consegue um terreno, independentemente do critério de segurança.
Geometria e o Dimensionamento.

Requisito funcional/Vinculação geral

Configurar a impermeabilidade institucional do estabelecimento penal a ser projetado, segundo o nível de segurança estipulado para o mesmo.

Este item baseia os demais itens do Isolamento Social, principalmente, a localização e a Barreira Perimetral, e se relaciona com a Organização do Espaço, especialmente com os Aparatos de Segurança.

Cogitar a participação da sociedade na atividade prisional em função do nível de segurança definido para o estabelecimento a ser projetado.

Este item se relaciona com as Atividades.

Permitir a comunicação dos presos com o mundo exterior, por meio do encontro entre estes e os visitantes, cujo formato é em função do nível de segurança definido para o estabelecimento a ser projetado. Este item se relaciona com as Atividades.

Considerar a localização do estabelecimento penal a ser projetado como componente do isolamento social do preso, em função do nível de segurança definido para estabelecimento a ser projetado.

Este item se relaciona com a Barreira Perimetral. 


\begin{tabular}{|c|c|c|}
\hline \multicolumn{3}{|c|}{ 05. Isolamento individual do preso } \\
\hline \multicolumn{2}{|c|}{ Análise do Contexto/Vínculos específicos } & Requisito funcional/Vinculação geral \\
\hline 05.01 & $\begin{array}{l}\text { O isolamento individual do preso reflete as concepções positiva e negativa da pena, por meio do tipo do alojamento dos presos: a } \\
\text { cela individual possui uma conotação punitiva maior e a cela coletiva uma conotação humana maior (ver itens } 05.04 \text { e } 17.05 \text { ). Na } \\
\text { montagem do sistema penal moderno, a cela individual foi considerada desumana, tendo a cela coletiva como alternativa, pois } \\
\text { possibilitava o contato interpessoal necessário à sanidade mental dos presos. O próprio Bentham abandonou o isolamento absoluto } \\
\text { no desenvolvimento do seu trabalho, no qual concluiu pela superioridade técnica e humana da cela coletiva. De qualquer maneira, } \\
\text { com as técnicas penitenciárias, o isolamento individual ou em pequenos grupos foi considerado uma técnica de submissão do grupo } \\
\text { de presos. A LEP (Art. 88) determina o cumprimento de pena em cela individual. As Regras Mínimas (Art. 8) admitem o uso de cela } \\
\text { coletiva em casos excepcionais. As Diretrizes Básicas prevêem ambas as possibilidades (p. 25): "As penitenciárias são dotadas de } \\
\text { celas coletivas e individuais", o que é estendido para o estabelecimento penal tipo cadeia pública. No sistema penitenciário, com a } \\
\text { demanda por vagas e redução de custo de construção, as celas coletivas são especificadas para a generalidade das prisões (ver item } \\
05.02 \text { ), sendo as celas individuais utilizadas em casos particulares (ver item 05.05). }\end{array}$ & $\begin{array}{l}\text { Especificar o tipo de alojamento dos } \\
\text { presos de modo coerente com os } \\
\text { objetivos penalógicos inerentes ao tipo do } \\
\text { estabelecimento penal a ser projetado. } \\
\text { Este item baseia o programa arquitetônico } \\
\text { da cela como um todo (ver item 01.02). }\end{array}$ \\
\hline 05.02 & $\begin{array}{l}\text { A proposta de classificação e separação de Bentham atinge exaustivamente a individualização do preso. O Panopticon fracionava o } \\
\text { grupo ao nível dos indivíduos, dispostos em celas estanques, sem contato entre eles. Do ponto de vista da reinserção social, a } \\
\text { individualização dos presos vislumbra a correção na aplicação da pena pelo emprego do tratamento mais adequado a cada preso. } \\
\text { Do ponto de vista da prisão como atividade econômica, esta individualização possibilita o controle total da instituição sobre cada } \\
\text { pessoa encarcerada. A LEP (Art. 88) determina o uso da cela individual, adequada à individualização, enquanto as Diretrizes Básicas } \\
\text { prevêem celas coletivas, avessas a este princípio (ver item } 05.01 \text { ). No sistema penitenciário, a superpopulação e a aglomeração dos } \\
\text { presos, associadas à predominância da cela coletiva, inviabilizam a individualização pretendida. Dentro do possível, os presos com } \\
\text { perfis semelhantes são agrupados na mesma cela ou em conjuntos de celas - alas carcerárias (ver item 10.04). A individualização dos } \\
\text { presos se manifesta essencialmente nos casos particulares em que se aplica a cela individual. }\end{array}$ & $\begin{array}{l}\text { Permitir a classificação e a separação dos } \\
\text { presos de acordo com a individualização } \\
\text { pretendida no estabelecimento penal a } \\
\text { ser projetado. } \\
\text { Este item se relaciona diretamente com o } \\
\text { tipo de cela. }\end{array}$ \\
\hline 05.03 & $\begin{array}{l}\text { A classificação e a separação dos presos em um estabelecimento penal remetem à discussão em torno da diversificação espacial das } \\
\text { celas (ver item } 10.04 \text { e 17.05). Bentham colocava que as celas seriam "[...] mais espaçosas ou menos espaçosas, de acordo com o } \\
\text { uso que se planeja fazer delas" (SILVA, 2000, p. 21). A variação das configurações internas e das áreas das celas é uma proposta } \\
\text { penalógica associada ao sistema de castigos e recompensas e à progressão de pena, que visa combater a massificação e a perda da } \\
\text { identidade na prisão. Os instrumentos legais e técnico-normativos não prevêem diferenças entre as celas de um mesmo regime } \\
\text { penitenciário. Neste sentido, o princípio de isonomia na aplicação da pena também deve ser considerado. No sistema penitenciário, } \\
\text { as celas homogêneas favorecem a segurança e a operação ao mecanizar os procedimentos (manuseio de portas, incursões às celas, } \\
\text { vigilância). Pelo contrário, a diversidade espacial pode motivar o comércio de privilégios entre os presos e alimentar a economia } \\
\text { informal da prisão. }\end{array}$ & $\begin{array}{l}\text { Considerar diferentes tipos de cela em } \\
\text { termos do espaço interno, em função de } \\
\text { uma provável diversidade do perfil da } \\
\text { população prisional no estabelecimento } \\
\text { penal a ser projetado. } \\
\text { Este item se relaciona diretamente com o } \\
\text { tipo de cela. }\end{array}$ \\
\hline 05.04 & $\begin{array}{l}\text { A segurança penitenciária (ver item 01.01) alcança o papel e a importância da cela junto aos sistemas de segurança e operação do } \\
\text { estabelecimento penal, relacionando diretamente o nível de segurança com o tipo de cela. Os instrumentos legais e técnico- } \\
\text { normativos não classificam as celas segundo o nível de segurança penitenciário. Neste sentido, do ponto de vista do padrão de } \\
\text { segurança máxima é melhor a cela individual (ORLAND, 1978, p.52). Deste modo, a LEP tende para o padrão de segurança máxima, } \\
\text { enquanto as Diretrizes misturam os modelos de segurança, criando um conflito no espaço penitenciário de segurança máxima } \\
\text { dotado de celas coletivas. No sistema penitenciário, as celas coletivas são especificadas para a generalidade dos estabelecimentos, } \\
\text { sendo as celas individuais utilizadas em casos particulares (ver item 05.05). }\end{array}$ & $\begin{array}{l}\text { Especificar o tipo de cela de modo } \\
\text { consonante ao nível de segurança } \\
\text { penitenciária determinado para o } \\
\text { estabelecimento a ser projetado. } \\
\text { Este item baseia os demais itens do } \\
\text { isolamento individual do preso. }\end{array}$ \\
\hline
\end{tabular}


05.05 A LEP (Art. 88) prevê a cela individual para a aplicação de sanção disciplinar. Além disto, as Diretrizes Básicas (p. 31) prevêem a cela individual para a separação de presos com problema de convívio ou colaboradores sob proteção da instituição (Portaria Ministério da Justiça/DEPEN no 01, de 27/01/2004). As Diretrizes Básicas (p. 30) estipulam uma quantidade mínima de celas individuais voltadas para o cumprimento de medida disciplinar: "uma unidade penitenciária conformada por celas coletivas deverá apresentar uma proporcionalidade mínima em torno de $2 \%$ da capacidade total em celas individuais". Estes instrumentos não especificam ou quantificam a cela individual segundo o nível de segurança penitenciária. No sistema penitenciário, as celas individuais são estratégicas para a administração prisional na manutenção da ordem interna, embora, devido à superpopulação, algumas prisões apresentam celas individuais ocupadas coletivamente. Por sua vez, alguns presos são isolados por terem sua integridade física ameaçada, inclusive com risco de morte. Na ocorrência de rebeliões ou motins, estes presos são vitimados se alcançados pelos algozes. Um terceiro tipo de preso em isolamento goza da individualização por fazer valer a LEP e cumpre pena em cela individual.

05.06 As Diretrizes Básicas (p. 31) descrevem capacidades diferenciadas para as celas coletivas (até oito vagas), porém não classificam estas capacidades de acordo com o nível de segurança penitenciário. Do ponto de vista da reinserção social e da segurança penitenciária, um número menor de vagas em uma cela é mais favorável (ver item 05.04). No sistema penitenciário, a grande demanda por novas vagas e a carência de recursos financeiros para as obras penitenciárias, impõe a maximização da capacidade da cela coletiva (ver item 17.07). Isto porque este quesito traz implicações no porte do estabelecimento penal (ver item 02.02) e no custo do empreendimento (ver item 03.01) que justificam o aumento do número de vagas por cela.

06. Organização do espaço

Análise do Contexto/Vínculos específicos

06.01 Abrigar a atividade prisional consiste na coordenação sinérgica de um conjunto de funções, organizadas racionalmente para um melhor desempenho da instituição, e subordinadas a um esquema de segurança que permita a administração totalitária do estabelecimento. Isto se baseia no Princípio da Utilidade que transforma a prisão em uma máquina racional e sistemática, cuja meta é a economia de recursos de toda ordem, medida constantemente, em suas partes e no todo, pela relação custo e benefício, segundo um cálculo matemático (ver itens 03.01 e 03.02). O benefício almejado é o cumprimento da pena de modo humano (a boa condição penitenciária) (ver item 01.02). No sistema penal, a prevalência da concepção negativa da pena atrela o desempenho da prisão ao índice de custos do estabelecimento penal, considerado elevado pela administração penitenciária.

06.02 O Princípio de Utilidade tem como ferramenta a disciplina. Ela é o mecanismo analítico e ordenador do espaço arquitetônico prisional. A disciplina concebe um espaço arquitetônico racional, distribuindo e dividindo o mesmo de forma rigorosa e calcada em critérios de eficiência e eficácia: "as disciplinas, organizando as 'celas', os 'lugares' e as 'fileiras' criam espaços complexos: ao mesmo tempo arquiteturais, funcionais e hierárquicos" (FOUCAULT, 2013, p. 142). Em termos gerais, ela preconiza a distribuição sistemática dos indivíduos, das funções e dos trânsitos. O Panóptico define duas premissas básicas para o espaço arquitetônico: o foco nas pessoas e a disciplina espacial. Os instrumentos legais e técnico-normativos refletem aspectos da disciplina espacial na prisão, embora não a explicitem de modo estruturado. No cotidiano prisional, a subversão de parte da técnica penitenciária impossibilita o esquema de distribuição disciplinar, devido à redefinição de papeis dos grupos de pessoas, aos improvisos e inviabilidades funcionais e aos fluxos superpostos e excessivos.

06.03 A intensificação da disciplina remete às características físicas e operacionais do estabelecimento penal de segurança máxima (ve item 01.02). Neste sentido, o espaço arquitetônico estende os cuidados com a segurança até o limite permitido pela condição humana na prisão, configurando um patamar da boa condição penitenciária concernente a disciplina-bloco. A disciplina-bloco implica no domínio da totalidade do espaço arquitetônico prisional, inclusive das áreas mais internas, o que significa o controle sobre o trânsito e a vigilância das atividades de modo absoluto e com o menor risco possível para os funcionários. No sistema penal, a unidade de segurança máxima é amplamente utilizada (ver item 01.01), ao mesmo tempo em que são agregados componentes
Separar os presos submetidos à medida disciplinar ou sob proteção da população prisional em geral.

Compatibilizar a capacidade da cela coletiva com o nível de segurança do estabelecimento penal a ser projetado.

Este item se relaciona com o porte (item 3)

e o custo (item 4) do estabelecimento penal, além do dimensionamento da cela.

Requisito funcional/Vinculação geral

Organizar o espaço arquitetônico do estabelecimento a ser projetado com base no Princípio de Utilidade.

Este item baseia o programa arquitetônico como um todo, especialmente a espacialização.

Organizar o espaço arquitetônico do estabelecimento a ser projetado por meio da aplicação da disciplina.

Este item baseia o programa arquitetônico como um todo, especialmente a espacialização.

Aplicar a disciplina espacial em intensidade equivalente ao nível de segurança estipulado para

estabelecimento penal a ser projetado.

Este item baseia o programa arquitetônico como um todo, especialmente a 


\begin{tabular}{|c|c|c|}
\hline & $\begin{array}{l}\text { típicos de uma unidade de segurança média e os limites mínimos definidos pela condição humana são ultrapassados (ver itens } 10.05 \\
\text { e 13.01). No cotidiano prisional, as disputas pelo poder nas prisões redefinem os domínios territoriais, impondo uma lógica } \\
\text { divergente da disciplinar na operação prisional, com ocorrências do autogoverno dos presos (ver item 10.02). }\end{array}$ & espacialização e o controle. \\
\hline \multicolumn{3}{|c|}{ 07. Geometria } \\
\hline \multicolumn{2}{|c|}{ Análise do Contexto/Vínculos específicos } & Requisito funcional/Vinculação geral \\
\hline 07.01 & $\begin{array}{l}\text { A edificação prisional reflete o utilitarismo na concepção espacial e é essencialmente funcionalista, tendo a forma como resultado } \\
\text { do arranjo racional dos espaços (ver item 10.01). A geometria da edificação prisional é resultado da função. A mesma atende aos } \\
\text { princípios da disciplina espacial, buscando favorecer o funcionamento (ver item 08.01) e o controle dos espaços externos e internos } \\
\text { (ver itens } 15.01 \text { e 15.03) de modo econômico (ver item 15.06). Neste sentido, a geometria reflete o modelo prisional vigente, } \\
\text { representado pelos padrões arquitetônicos penitenciários (ver item 03.04). Os instrumentos técnico-normativos não discriminam a } \\
\text { geometria segundo o nível de segurança penitenciária. As Diretrizes Básicas se restringem a recomendar: "Deve-se ter consciência } \\
\text { da importância que tem a definição de uma linha de projeto que poderá vir a facilitar a administração e a manutenção do edifício } \\
\text { proposto (...)". Além de perfazer outras recomendações pontuais, todas visando à vigilância externa. As Diretrizes Básicas induzem } \\
\text { ao uso do padrão arquitetônico modular, embora de maneira descolada dos princípios penalógicos correspondentes. }\end{array}$ & $\begin{array}{l}\text { Conciliar a geometria com a } \\
\text { espacialização de modo a garantir o } \\
\text { desempenho dos espaços externos e } \\
\text { internos, além da performance do } \\
\text { invólucro da edificação, do ponto de vista } \\
\text { da segurança e da operação, em função } \\
\text { do nível de segurança definido para o } \\
\text { estabelecimento a ser projetado. } \\
\text { Este item se relaciona a barreira } \\
\text { perimetral, a espacialização, o conforto e } \\
\text { ocontrole. }\end{array}$ \\
\hline \multicolumn{3}{|c|}{ 08. Funcionalidade } \\
\hline \multicolumn{2}{|r|}{ Análise do Contexto/Vínculos específicos } & Requisito funcional/Vinculação geral \\
\hline 08.01 & $\begin{array}{l}\text { A funcionalidade diz respeito ao espaço arquitetônico interno da prisão: a estrutura interior que dá forma ao edifício e é resultado } \\
\text { da resolução dos problemas funcionais (ver item 07.01), em um processo de desenvolvimento de um sistema, no qual as atividades } \\
\text { a serem desempenhadas são coordenadas entre si. O modelo prisional determina o integralismo e o mecanicismo na operação } \\
\text { penitenciária: a reprodução planejada dos aspectos da vida em liberdade sob um regime totalitário (Goffman, 2005) - "Antes de ser } \\
\text { liberal, apercebemo-nos disto, o utilitarista é despótico" (MILLER apud SILVA, 2000, p. 90). As Diretrizes Básicas (p. 45) apenas citam } \\
\text { a funcionalidade. No sistema penitenciário, a carência de recursos para a operação penitenciária reduz as atividades (ver item } \\
\text { 09.01), especialmente dos presos, inclusive o deslocamento entre os locais de realização destas (ver item 12.02). Da mesma } \\
\text { maneira, o mecanismo sofre adequações para a simplificação das tarefas, havendo a retirada de rotinas e a transferência de certos } \\
\text { procedimentos para os presos, até mesmo de segurança, como a abertura e o fechamento de portas (ver itens 09.02 e 10.01). }\end{array}$ & $\begin{array}{l}\text { Reproduzir as atividades cotidianas da } \\
\text { vida em liberdade de modo planejado, } \\
\text { segundo um regime totalitário. } \\
\text { Este item baseia o programa arquitetônico } \\
\text { como um todo, especialmente as } \\
\text { atividades, a espacialização e o controle. }\end{array}$ \\
\hline 08.02 & $\begin{array}{l}\text { A funcionalidade permeia a composição arquitetônica da edificação prisional, o que remete à minúcia panóptica, ao ressaltar a } \\
\text { vertente econômica da atividade prisional prisão no espaço arquitetônico, cujo contraponto é a humanização (ver item 10.05). O } \\
\text { Panopticon articulava as capacidades e as dimensões dos espaços com os aparelhos e serviços necessários para a realização das } \\
\text { tarefas, dentro da lógica utilitarista de disciplina e economia de recursos. O padrão arquitetônico modular significou o cumprimento } \\
\text { de padrões mínimos de bem estar com a introdução de serviços (comunicação, lazer e entretenimento) e mobiliário para os presos. } \\
\text { As Diretrizes Básicas (p. 42) colocam que se deve primar por aspectos de harmonização do ambiente com a vida humana, por meio } \\
\text { de uma "configuração espacial que minimize a sensação de opressão, respeito ao espaço pessoal, layout dos ambientes obedecendo } \\
\text { aos princípios da ergonomia etc". Neste sentido, este instrumento aborda melhor a cela e do pátio de sol dos presos, ao fazer } \\
\text { recomendações quando à capacidade, dimensionamento e mobiliário (ver itens 17.03, 17.04, 17.07, } 18.03 \text { e 18.06). No sistema } \\
\text { penitenciário, a aglomeração de presos e o acúmulo de atividades nos espaços comprometem a estrutura física disponibilizada, } \\
\text { tornando-a incoerente com a demanda. Além disto, a exigência de incremento da segurança, associada à carência de recursos para } \\
\text { as obras penitenciárias cortam excessivamente os padrões de bem estar, especialmente dos presos, tornando a estrutura física } \\
\text { insuficiente. }\end{array}$ & $\begin{array}{l}\text { Propiciar a realização das atividades } \\
\text { rotineiras da prisão, respeitados os } \\
\text { padrões mínimos de bem estar em } \\
\text { relação à segurança penitenciária. } \\
\text { Este item se relaciona com a Capacidade, } \\
\text { Atividades, Espacialização e o o } \\
\text { Dimensionamento, especialmente da cela } \\
\text { e do pátio de sol dos presos. }\end{array}$ \\
\hline
\end{tabular}


09.01 Os instrumentos legais e técnico-normativos refletem o integralismo descrito por Goffman (ver item 08.01), por meio de um programa arquitetônico completo. As atividades e espaços previstos nestes instrumentos cobrem as necessidades físicas para a penalização e a reintegração social do preso, listando itens voltados para o encarceramento, a assistência do Estado e o programa de benefícios aos presos (ver item 01.02). A reintegração social é tratada especialmente na LEP. No artigo $\mathrm{n}^{\circ} 83$ desta Lei, o estabelecimento deverá contar "com áreas e serviços destinados a dar assistência, educação, trabalho, recreação e prática desportiva". Os instrumentos técnico-normativos não discriminam as atividades segundo o nível de segurança penitenciária. A segurança penitenciária implica em uma maior ênfase nas atividades voltadas para a segurança ou para a reinserção social (ver item 01.01). No sistema penal, a carência de recursos financeiros para as obras penitenciárias, impõe a redução do programa arquitetônico, incidindo mais fortemente sobre as atividades relacionadas à reintegração dos presos (ver itens 03.01 e 11.01). Estas medidas se alinham com a política prisionalizante vigente, configurando a edificação prisional de segurança máxima, voltada para a contenção e coerção dos presos, embora deficiente diante das demandas operacionais, o que fragiliza o esquema de segurança.

09.02 A atividade prisional é suportada por funções adjacentes e complementares que possibilitam o funcionamento do estabelecimento penal, constituindo os sistemas de segurança e operação do mesmo (ver item 01.02). Os instrumentos legais e técnico-normativos especificam estas funções. Em termos do sistema de segurança, as Diretrizes Básicas prevêem as barreiras, portaria, torres de vigilância e pista de ronda (ver item 16). Em termos do sistema operacional, as mesmas prevêem administração, apoio aos funcionários, acesso à unidade penal, serviços, guarda e manutenção de materiais e inclusão e triagem de presos e celas de isolamento individual. Ainda são previstos itens de infraestrutura. Alguns espaços específicos são pontuados: local para o estagio de estudantes universitários, biblioteca, guarda pertences dos presos, entre outros. No sistema penal, a carência de recursos financeiros para as obras penitenciárias impõe a redução do programa arquitetônico que, eventualmente, desrespeita as exigências e recomendações legais e técnico-normativas (ver itens 03.01 e 09.01). Isto pode comprometer o atendido das demandas operacionais e fragilizar o esquema de segurança.

\section{Espacialização}

Análise do Contexto/Vínculos específicos

10.01 A edificação prisional resulta da decomposição da atividade prisional em suas partes, acompanhada da definição dos espaços necessários e da organização destes para o funcionamento otimizado do estabelecimento penal (os sistemas de segurança operação), por meio da aplicação do utilitarismo e da disciplina (ver itens 06.01 e 06.02). Neste sentido, a edificação prisional materializa o mecanicismo da prisão descrito nas rotinas e procedimentos preconizados pelo modelo prisional (ver item 08.01). As Diretrizes Básicas interceptam alguns pontos da disciplina espacial panóptica: as localizações funcionais, o celular, o quadriculamento e o princípio do máximo. As mesmas (p. 49) descrevem uma espacialização em setores e módulos (ver item 07.01): "o programa de necessidades do projeto deve ser elaborado de forma a caracterizar, através do uso, os setores que devem estar zoneados a fim de promover um fluxo ordenado de pessoas e de veículos". Este instrumento distingue os setores com base nos tipos de pessoas que os ocuparão. Os módulos são aparentemente distribuídos segundo sua função, atendendo a algumas recomendações pontuais. Os instrumentos técnico-normativos não discriminam a espacialização da prisão segundo o nível de segurança penitenciária (ver item 06.03). No sistema penitenciário, a carência de recursos para a operação penitenciária impõe dificuldade a certos procedimentos, o que leva a improvisos funcionais, inclusive com a transferência de atribuições aos presos que permeiam o espaço prisional de modo inconsistente com a disciplina.

10.02 A espacialização da edificação prisional é definida pelas relações sociais na prisão, especialmente entre os funcionários e presos, da qual se destaca a questão da territorialidade, definindo locais próprios para cada grupo. Goffman classifica estes locais segundo o

Requisito funcional/Vinculação geral

Propiciar as atividades necessárias para a segregação e a reintegração social dos presos, em função do nível de segurança definido para o estabelecimento a ser projetado.

Este item se relaciona com a espacialização, especialmente

dimensionamento e o controle.

Complementar os sistemas de segurança e operação do estabelecimento penal com as atividades de apoio e infraestrutura. Este item se relaciona com a espacialização.

Requisito funcional/Vinculação geral

Propiciar o funcionamento otimizado para os sistemas de segurança e operação, conforme o modelo prisional e o nível de segurança definido para estabelecimento a ser projetado.

Este item baseia o programa arquitetônico como um todo.

Considerar as relações sociais na definição do espaço arquitetônico da prisão, 
grau de liberdade dos presos: livres, vigiados ou proibidos. No Panopticon, esta territorialidade era evidente: no centro, o espaço institucional e, na periferia, o espaço dos presos. Com o incremento e a dispersão do programa arquitetônico, este esquema se espalhou e se reproduziu pelo corpo da edificação. $O$ contato entre os funcionários e presos e a distribuição territorial dos espaços são regrados pelo nível de segurança penitenciário (ver itens 01.01 e 15.04). As Diretrizes Básicas se limitam a uma recomendação: configurar o espaço arquitetônico da prisão de modo combativo ao empoderamento dos presos. No sistema penitenciário, a postura da administração penitenciária diante da disputa de poder na prisão produz duas situações (ver item 15.05): primeiro, a política de caráter prisionalizante, implementada por meio da disciplina-bloco, busca o controle sobre a totalidade da edificação prisional inclusive dos locais mais internos da prisão; segundo, há uma retirada do Estado destes lugares mais internos, onde ocorre o autogoverno dos presos, com a instituição se concentrando nas áreas externas (ver item 06.03).

10.03 O espaço arquitetônico da prisão concorre para a conformação da imagem institucional oficial, juntamente com a geometria da edificação (ver item 07.01), por meio da obtenção da impermeabilidade necessária, o que ocorre com a distribuição do programa em camadas (ver item 06.02). Estas camadas se desenvolvem das áreas mais externas para as mais internas, correspondendo ao esquema teatral de Goffman das representações institucionais que prevê o palco, a platéia e os bastidores. Estas camadas representam os diferentes graus de permeabilidade e de liberdade de movimentação no espaço, condicionados ao tipo de pessoa (funcionário, visitante e preso) (ver item 12.01). Topologicamente, a estratificação do espaço arquitetônico prisional imprime uma noção de mais ou menos profundo, assim como, uma significação penalógica aos espaços: a distância da liberdade para os presos e a periculosidade para os funcionários. No sistema penitenciário, se destaca a inexistência de locais de visita que remete esta atividade às áreas mais internas (por exemplo, nos pátios de sol dos presos ou nas celas) (ver item 04.03), o que expõe mutuamente a rotina prisional e os visitantes (ver item 12.02). A visita social ocorre com contato físico e de modo coletivo, independentemente do grau de segurança do estabelecimento penal (com exceção do RDD). $\mathrm{O}$ advogado é mais contido em termos da sua acessibilidade e do contato com o preso.

10.04 A individualização da aplicação da pena alcança a classificação e a separação dos presos no estabelecimento penal. As Regras Mínimas preconizam que "presos pertencentes a categorias diversas devem ser alojados em diferentes estabelecimentos prisionais e suas seções, observadas características pessoais [...]" (Art. $\mathrm{n}^{\circ}$ 7). As Diretrizes Básicas (p. 29) recomendam a acomodação dos presos em módulos de vivência, o que pode minimizar os efeitos da superpopulação massificada e do empoderamento dos presos (ver item 05.02). No sistema penitenciário, a superpopulação caracteriza a aglomeração dos presos, na qual indivíduos com diferentes perfis são absorvidos em um mesmo estabelecimento penal, no qual a classificação e separação dos presos ficam a encargo da administração da unidade. A carência de recursos financeiros para as obras penitenciárias impõe o aumento da capacidade do módulo de vivência (ver itens 02.01 e 02.02) que raramente é acompanhada do respectivo incremento das atividades no módulo (ver itens 09.01 e 18.02).

10.05 As Diretrizes Básicas recomendam no partido arquitetônico (p. 27): "É fundamental favorecer as instalações com um mínimo de conforto, procurando soluções viáveis que permitam o grau de segurança necessário". Este instrumento não distingue configurações espaciais segundo o nível de segurança penitenciário. No sistema penitenciário, a política de prisionalização associada à condição penitenciária (massificação dos presos e carência de recursos) enfatiza a segurança, remetendo a generalização da categoria de segurança máxima. Na prática, os cuidados com a segurança, associados às questões do déficit do conhecimento e da redução de custos, eventualmente, ocorrem em detrimento da condição humana na prisão (ver item 03.03). Estes cuidados implicam na retirada de padrões de bem estar, em parte, relacionados ao indivíduo (ver item 06.01) e à funcionalidade (ver item 08.01). Por exemplo, é mais relevante para a instituição na disputa de poder com os presos impedir a comunicação destes com o mundo externo, coletivizar as atividades, simplificar os procedimentos e aumentar a vigilância do que o cumprimento do programa de reinserção social ou a boa condição penitenciária (ver item 09.01).

segundo o nível de segurança
penitenciário.

Este item se relaciona principalmente com o Controle.

Propiciar a representação institucional no estabelecimento a ser projetado.

Este item se relaciona com o Isolamento social, as Atividades e a Circulação.

Permitir a classificação e a separação dos grupos de presos com perfil semelhante no estabelecimento penal a ser projetado. Este item se relaciona diretamente com o Isolamento Individual, especificamente com o tipo de cela (ver item 05.01), além do Dimensionamento e Circulação.

Equilibrar os aspectos de segurança e humanização na configuração espacial, segundo o nível de segurança estipulado para o estabelecimento a ser projetado. Este item se relaciona diretamente com o Conforto Ambiental. 
10.06 O racionalismo espacial da prisão (ver itens 06.01 e 06.02) exige a especialização dos espaços ou a sua utilização por atividades bem definidas e compatíveis entre si, o que remete à policrestia. Esta definição é regrada pelo nível de segurança penitenciário. As Diretrizes Básicas (p. 46) recomendam que "é possível a destinação da mesma dependência para mais de uma finalidade ou uso". Ao mesmo tempo, as Diretrizes listam um extenso programa, eventualmente incompatível com a capacidade operacional das prisõe (ver item 09.01). No sistema penitenciário, a carência de recursos para a operação segura ou para a disponibilização dos serviços penitenciários leva à improvisos na utilização dos espaços com a aglomeração de funções em alguns locais (ver itens 17.02 e 18.01) e a ociosidade de outros. Estes locais ociosos podem ser indevidamente ocupados com atividades informais dos presos, o que fragiliza o esquema de segurança do estabelecimento.

11. Dimensionamento

Análise do Contexto/Vínculos específicos

11.01 A área construída de um estabelecimento penal é proporcional a capacidade do mesmo, sendo estimada pelo índice de área construída por vaga. As Diretrizes Básicas (p. 28) estipulam uma faixa entre 12 e 60 metros quadrados por vaga, sem qualquer distinção de tipo ou categoria penitenciária. O intervalo fixado nas Diretrizes é muito amplo, limitando a aplicação técnica do índice proposto. Anteriormente, as regras técnicas estipulavam um índice de 12 a 15 metros quadrados por vaga, aparentemente mais conveniente para a especificação de unidades de segurança máxima e para a redução de custos de construção buscada na política penitenciária atual (ver item 09.01). Isto deve ser avaliado diante das mudanças programáticas ocorridas na versão corrente do instrumento: a flexibilização do dimensionamento de áreas e a inclusão de áreas específicas para algumas atividades, como o incremento do sistema de segurança com a criação de postos e circulações exclusivas. No sistema penitenciário, a carência de recursos financeiros para as obras penitenciárias, impõe a redução de áreas do programa arquitetônico (ver item 11.02), incidindo mais fortemente sobre as atividades relacionadas à reintegração dos presos (ver item 03.01). Esta medida se alinha com a política prisionalizante vigente, configurando a edificação prisional de segurança máxima, voltada para a contenção e coerção dos presos, embora deficiente no atendido das demandas operacionais, o que fragiliza o esquema de segurança. Por outro lado, o aumento de outras áreas construídas pode prejudicar o desempenho da instituição, tendo em vista as questões operacionais (ver item 10.06).

11.02 As Diretrizes Básicas fixam os ambientes e as respectivas áreas mínimas para a totalidade das atividades da prisão. Este programa è estipulado sem distinção de categoria penitenciária (ver item 09.01). Por um lado, as Diretrizes definem parâmetros superlativos para locais como: a oficinas de trabalho, as celas de saúde etc. Por outro lado, as mesmas incorporam a compactação espacial, por meio da adoção de parâmetros atrelados ao número de usuários (cela coletiva) e da alternância do uso de espaços por diferentes grupos de presos (pátio de sol, refeitório, sala de aula e oficina de trabalho). No sistema penitenciário, as áreas maiores podem implicar em locais subutilizados e maior exigência sobre os sistemas de segurança e operação, enquanto a compactação converge com a realidade prisional (ver item 10.06). Neste sentido, a política de redução de custos impõe a minimização dos espaços.

11.03 A área de terreno de um estabelecimento penal é proporcional a capacidade do mesmo, sendo estimada pelo índice de área de terreno por vaga. As Diretrizes Básicas (p. 28) estipulam uma faixa entre 16 e 100 metros quadrados por vaga, sem qualquer distinção de tipo ou categoria penitenciária . O intervalo fixado nas Diretrizes é muito amplo, limitando a aplicação técnica do índice proposto. Anteriormente, as regras técnicas estipulavam um índice de 12 a 15 metros quadrados por vaga, aparentemente mais conveniente para a redução de custos de construção buscada na política penitenciária atual (ver item 09.01). Neste sentido, as Diretrizes ressaltam que (p. 33): "os estabelecimentos devem ser edificados em terreno que favoreça sua implantação [...], tendo em vista o alto custo gerado por movimentos de terra e por fundações especiais". Isto deve ser avaliado diante das mudanças programáticas ocorridas na versão corrente do instrumento (ver item 11.01). No sistema penitenciário, a questão da localização determina terrenos desfavoráveis à construção penitenciária, muitas vezes com tamanhos reduzidos ou altimetria irregular (ver itens 04.04 e 16.10), implicando em um maior investimento para a sua adequação.
Um espaço pode ser utilizado por mais de uma atividade, condicionada pelo nível de segurança estipulado para o estabelecimento a ser projetado. Este item se relaciona com as Atividades.

\section{Requisito funcional/Vinculação geral}

Adotar o parâmetro de área por vaga para o dimensionamento do estabelecimento a ser projetado, cujo valor corresponde ao nível de segurança estipulado para o mesmo.

Este item se relaciona com as Atividades $e$ a Espacialização.

Dimensionar os espaços do
estabelecimento penal a ser projetado considerando o nível de segurança penitenciário estipulado para o mesmo.

Este item se relaciona com as Atividades e a Espacialização.

Adotar o parâmetro de área por vaga para o dimensionamento do terreno do estabelecimento a ser projetado, tomando valores segundo o nível de segurança estipulado para o mesmo. Este item se relaciona com o Isolamento Social e a Barreira Perimetral. 
12. Circulação

Análise do Contexto/Vínculos específicos

12.01 A circulação trabalha em conjunto com a espacialização na definição do conjunto arquitetônico da prisão, atuando ao mesmo tempo como uma atividade e como um agente do arranjo espacial, em termos da funcionalidade (agregando o fator operacional à composição arquitetônica na conexão entre os espaços) (ver item 10.01). Por isto, as circulações correspondem ao modelo prisional, atuando à disciplina interna e à economicidade da atividade prisional. Neste sentido, a circulação exige um espaço especializado que integra o esquema topológico do espaço prisional (ver item 10.03), enquanto ambos definem os níveis de acessibilidade e mobilidade na unidade penal. Para tanto, a circulação é definida com base nos diferentes tipos de fluxos (veículos, pessoas e materiais), em especial, nos tipos de pessoas (funcionários, presos e visitantes). No Panóptico, a edificação definia e separava explicitamente os locais de circulação e os tipos fluxos na torre central, nos anéis e nos pavimentos, interligados por escadas e passarelas exaustivamente pensados. As Diretrizes Básicas relacionam a espacialidade com a circulação: "Um dos primeiros aspectos a ser considerado é o que diz respeito à localização das diversas unidades, sua interligação e aglutinação, que deve ser levada em conta para possibilitar um bom fluxo de pessoas presas e de funcionários". Neste sentido, a indução ao padrão arquitetônico modular (p. 29), inerente à recomendação de alas celulares (ver item 10.04), também visa "organizar melhor os fluxos internos no estabelecimento", de modo a evitar a sobreposição e a sobrecarga de fluxos, especialmente onde transitem presos. As Diretrizes não avançam na descrição da circulação e na sua relação com a espacialidade ou fazem distinção segundo a categoria penitenciária. As mesmas deixam implícito no programa apresentado a acessibilidade de visitantes e presos até o setor intermediário, onde ocorrem a sociabilização e as atividades de reinserção social (ver item 10.02). No sistema penitenciário, o sistema de segurança atua fortemente no controle dos locais de acesso e circulação (ver item 15.01), ao mesmo tempo em que o procedimento de condução de presos representa um alto risco para os funcionários (ver item 15.04). Por isto, a demanda de segurança internaliza a visita, aumentando a profundidade topológica da circulação dos visitantes (ver item 15.05).

12.02 A circulação participa da modelagem geométrica da edificação (ver item 07.01), principalmente por meio da sua associação com a impermeabilidade institucional e o controle interno. A circulação tem como parâmetros de desempenho o fechamento, as distâncias a serem percorridas e o desenho dos locais de trânsito, em termos de cruzamentos e derivações, o que depende da geometria e da espacialização da edificação, remetendo a escolha do padrão arquitetônico penitenciário (ver itens 07.01 e 10.01). As Diretrizes Básicas não abordam diretamente este tópico, então, não distinguem distancias ou configurações de circulação segundo o nível de segurança penitenciário. Indiretamente, este instrumento (p. 47) tende a reduzir os deslocamentos dos presos, ao internalizar os espaços dedicados às atividades cotidianas nos módulos de vivência - o que leva a um aumento do percurso realizado pelas visitas (com exceção do advogado que permanece nos locais mais externos) (ver item 10.02). No sistema penitenciário, o excedente prisional, associado à carência de recursos humanos exige distancias menores a serem vencidas nos diversos trânsitos no interior da unidade e uma configuração mais simples, aliviando a carga sobre os sistemas de segurança e operacional. Da mesma maneira, a política de redução de custos de construção exige uma minimização das áreas de circulação (ver item 11.01). Por sua vez, a demanda de impermeabilidade e controle das pessoas impõe circulações fechadas, configuradas por corredores.

12.03 A circulação interage com a acessibilidade do estabelecimento penal, tanto no acesso à unidade penal, como de suas partes: setores e blocos funcionais. As Diretrizes Básicas (p. 29) recomendam que o acesso ao estabelecimento penal deva ser único. As mesmas não abordam os acessos entre setores ou dos blocos funcionais ou fazem distinção quanto o nível de segurança penitenciário (ver item 10.03). No sistema penitenciário, a carência de recursos humanos exige a convergência dos fluxos nos acessos e passagens entre setores e aos blocos funcionais (ver item 15.05). Ao mesmo tempo e em alguma medida, os fluxos cotidianos podem ser resolvidos operacionalmente, assim, outros acessos são possíveis, desde que submetidos ao controle, levando em consideração as limitações operacionais existentes.

Requisito funcional/Vinculação geral

Considerar a circulação como elemento e agente da espacialização, integrando a definição da composição do espaço arquitetônico da prisão.

Este item se relaciona com a Geometria, a Espacialização e o Controle.

Configurar as circulações de acordo com o nível de segurança penitenciário do estabelecimento penal a ser projetado.

Este item se relaciona com a Geometria, a Espacialização e o Controle.

Definir o acesso ao estabelecimento penal e aos setores e blocos funcionais considerando o nível de segurança do estabelecimento penal a ser projetado. Este item se relaciona com a Espacialização e o Controle. 
12.04 O esquema de segurança da unidade penal deve garantir a integridade física e metal dos funcionários, o que implica na possibilidade de evacuação em situações de crise, especialmente com a finalidade de evitar a sua tomada como refém (ver item 15.04). Nas áreas internas da unidade penal, a circulação descrita por acessos únicos pode comprometer a evasão dos funcionários, caso os presos dominem estes pontos. Neste sentido, a criação de saídas de emergência para os funcionários é recomendada, especialmente no setor interno da unidade penal e em unidades de maior segurança. As Diretrizes Básicas não abordam este tópico.

13. Conforto Ambiental

Análise do Contexto/Vínculos específicos

13.01 O conforto ambiental permeia os diversos quesitos da composição arquitetônica da edificação prisional, representando um dos aspectos da humanização da pena e do espaço arquitetônico da prisão, cujo contraponto é a segurança penitenciária (ver item 10.05). O conforto ambiental na prisão converge para dois requisitos: o conforto lumínico e térmico, sintetizados nos cuidados com as aberturas para a iluminação e ventilação dos ambientes internos. Ao tratar da cela (ver item 17.08), a LEP prevê (Art. 88): "salubridade do ambiente pela concorrência dos fatores de aeração, insolação e condicionamento térmico adequado à permanência humana". As Regras Mínimas colocam: "Os locais destinados aos presos deverão satisfazer as exigências de higiene, de acordo com o clima, particularmente no que se refere à superfície mínima, volume de ar, calefação e ventilação" (Art. n9). Este instrumento prossegue: os lugares de atividades dos presos deverão apresentar janelas amplas para a ventilação e iluminação naturais (Art. $\mathrm{n}^{\circ}$ 10). As Diretrizes Básicas fazem recomendações pontuais quanto o conforto ambiental, sempre ressaltando a importância das questões de segurança e operação da unidade penal na definição do mesmo (ver item 10.05). As mesmas recomendam (p. 27): "É fundamental favorecer as instalações com um mínimo de conforto, procurando soluções viáveis que permitam o grau de segurança necessário". No partido arquitetônico, este instrumento recomenda: "planejar as construções de novos estabelecimentos penais de maneira a atender às demandas por novas vagas, sem prescindir de critérios que favoreçam a saúde mental e o conforto ambiental daqueles que usam este espaço" (ver item 03.03). As Diretrizes não fazem distinção dos critérios de conforto ambiental segundo o nível de segurança penitenciário. As Diretrizes ( $p .38$ a 40) tratam essencialmente da iluminação e ventilação quando definem parâmetros mínimos para o cálculo das dimensões das aberturas. Neste cálculo, as Diretrizes apresentam uma falha, pois alguns dos índices adotados resultam em áreas de aberturas inviáveis, equivalentes, por exemplo, a área total da parede de fachada de uma cela, limitando a aplicação técnica dos índices propostos. O instrumento (p. 39) também recomenda a ventilação cruzada e o controle das aberturas de modo generalizado. As Diretrizes Básicas não abordam o conforto ambiental de espaços em particular. No sistema penitenciário, o conforto ambiental conflita com a segurança e a operação penitenciária, especialmente no caso das aberturas de iluminação e ventilação (ver item 14.01). Nos setores mais internos, os presos utilizam estas aberturas para romper a impermeabilidade e a estanqueidade da prisão, estabelecer a comunicação entre os grupos internos e vigiar a instituição. Os elementos de controle das aberturas (esquadrias) e outros componentes (vidros) são desmontados para a confecção de utensílios e armas. O mesmo ocorre com aparelhos de ventilação e exaustão.

13.02 A geometria da edificação penal está atrelada ao conforto ambiental no que diz respeito à relação entre espaços livres adjacentes à edificação e a quantidade de fachadas (ver item 07.01). A definição de um partido com entrecortes e mais fachadas pode favorecer a criação de aberturas para a iluminação e a ventilação do interior do edifício. Ao mesmo tempo, a geometria pode beneficiar a segurança, em termos da impermeabilidade institucional, resguardando as aberturas por meio da própria configuração. As Diretrizes Básicas não abordam a geometria do ponto de vista do conforto ambiental. Este instrumento apenas recomenda (p. 28) fazer uso de áreas verdes, visando a humanizar sem deixar de lado as particularidades de segurança (ver item 16.10). No sistema penitenciário, a dificuldade de obter terrenos para a construção penal remete a uma geometria mais compacta e a uma taxa de ocupação maior na implantação, reduzindo as áreas livres (ver item 04.04).
Permitir a evacuação dos funcionários em casos de crise.

Este item se relaciona com o Controle.

\section{Requisito funcional/Vinculação geral}

Considerar o conforto ambiental em todos os espaços internos da edificação, priorizando a iluminação e a ventilação, por meio de aberturas configuradas segundo o nível de segurança do estabelecimento penal a ser projetado.

Este item se relaciona com a Espacialização e os Aparatos de Segurança, especialmente da cela e do pátio de sol dos presos.

Considerar a geometria da edificação penal na definição do conforto ambiental. Este item se relaciona com a Localização, a Geometria e os afastamentos e recuos da Barreira Perimetral. 
14. Aparatos de segurança

Análise do Contexto/Vínculos específicos

14.01 O cumprimento da pena exige um sistema de segurança que suporte a operação do estabelecimento em termos da impermeabilidade (ver itens 04.01 e 16.02), estanqueidade (ver item 16.01), inexpugnidade (ver item 16.03) e da disciplina interna no cumprimento das rotinas prisionais (ver item 06.03), além de garantir a integridade dos funcionários (ver item 15.04). Neste sentido, o sistema de segurança atua inicialmente sobre as providências gerais para o funcionamento da prisão. Em um segundo momento, o mesmo avança na direção dos pormenores, contemplando elementos e subsistemas, de modo a atingir a segurança necessária por todo o corpo da prisão, mas que se evidencia nos locais mais críticos. Estes pormenores são reforços pontuais, cujas soluções dentro do esquema de segurança mais amplo provavelmente implicariam em custos desproporcionais. Ao mesmo tempo, o sistema de segurança é definido pelo seu componente mais débil, neste sentido, estas medidas são necessárias para nivelar o sistema de segurança. Isto remete a minúcia panóptica (2006, p. 38): "a disciplina é uma anatomia política do detalhe" (FOUCAULT, 1987 , p. 141). Por sua natureza, os aparatos de segurança correspondem à concepção punitiva da pena, cujo contraponto é a humanização, portanto seu limite é o respeito à condição humana na prisão. As Diretrizes Básicas enfatizam a segurança penitenciária em recomendações de caráter genérico, mas que, por vezes, atingem a minúcia, por exemplo, ao sugerir o uso de espirais cortantes ou detalhar a porta da cela (p. 40). As Diretrizes não fazem distinção dos aparatos de segurança segundo a categoria penitenciária. No sistema penitenciário, a carência de recursos para a construção penitenciária impõe a substituição de sistemas pesados e caros por outros mais leves e baratos, por exemplo, na especificação da barreira perimetral. Esta substituição, eventualmente, necessita de reforços para uma equivalência (ver itens 16.04 e 16.08). A carência de recursos para as atividades de reinserção social e para a operação penitenciária agrava o quadro de fugas e indisciplinas, principalmente nas celas e pátios de sol dos presos (ver itens 17.09 e 18.11). Isto impõe a adequação constante do sistema de segurança no combate aos mecanismos implementados pelos presos. Esta mitigação imediatamente torna outros itens mais frágeis e alvo de investida dos presos, criando um ciclo permanente de reforço da segurança, formada por uma estratificação de dispositivos que protegem outros dispositivos.

14.02 A espacialização da prisão em setores e blocos funcionais exige um complemento disciplinar do espaço externo da prisão, de modo a demarcar os locais em termos da acessibilidade e da mobilidade dos diferentes tipos de pessoas (ver item 10.03). As Diretrizes Básicas (p. 34) sugerem "que sejam utilizados alambrados para cercar ou setorizar áreas internas, o que minimiza a dificuldade por parte dos agentes ou guarda externa na fiscalização das pessoas presas". Isto é relevante principalmente no caso de prisões com mais áreas livres intramuros. No sistema penitenciário, a proximidade de pessoas externas junto à barreira perimetral é utilizada para o lançamento de objetos para as áreas abertas da unidade (ver item 16.10), assim como, presos colaboradores podem transitar em torno das edificações transportando objetos ou bilhetes entre os blocos de vivência.

15.01 Para Foucault (1987, p. 176), o controle utiliza a observação e o registro como ferramentas disciplinares (ver item 06.02), implementadas por meio de uma vigilância permanente, exaustiva, onipresente, capaz de tornar tudo visível. Neste sentido, as pessoas na prisão são constantemente e intimamente observadas, assim como, qualquer ação está subordinada à instituição, restando pouca autonomia aos presos e visitantes. O panopticon garantia a vigilância essencialmente pelo arranjo arquitetônico centralizado e pela concentração das atividades nas celas. $O$ padrão arquitetônico modular enfatizou estas características nos blocos de vivência dos presos ao instituir postos de controle (segunda geração de estabelecimentos penais). As Diretrizes Básicas (p. 49) recomendam apenas "[...] ser feito um estudo de segurança específico para dotar o estabelecimento, de acordo com sua categoria, tipo e regime, de elementos que auxiliem as guardas interna e externa no controle das pessoas presas, dos visitantes e até mesmo do pessoal administrativo". As Diretrizes não fazem distinção da vigilância segundo a categoria penitenciária. O nível de segurança

Requisito funcional/Vinculação geral

Equalizar o sistema de segurança do estabelecimento penal a ser projetado em suas minúcias, segundo o nível de segurança penitenciário estipulado para o mesmo.

Este item se relaciona com o programa arquitetônico como um todo, especialmente com os elementos centrais da edificação penal.

Disciplinar a acessibilidade e a mobilidade das pessoas nos espaços abertos do estabelecimento penal a ser projetado. Este item se relaciona com a Espacialização.

Requisito funcional/Vinculação geral

Vigiar as pessoas nos espaços internos do estabelecimento penal a ser projetado, segundo o nível de segurança penitenciário estipulado para o mesmo. Este item baseia o programa arquitetônico como um todo, especialmente com a Espacialização. 
determina a intensidade da vigilância, equivalente ao perfil dos presos. No sistema penitenciário, a carência de recursos para a operação penitenciária inviabiliza a vigilância ostensiva de todas as áreas da prisão, havendo um aproveitamento do pessoa disponível nos locais e tarefas mais críticas, onde são realizadas atividades coletivas ou com uma maior aglomeração de presos. Esta dificuldade também está associada às questões do empoderamento dos presos e das indisciplinas internas que impedem, em alguma medida, a vigilância de locais dominados pelos presos, em especial das celas (ver item 10.02).

15.02 A vigilância prisional se baseia no princípio da inspeção panóptica, por sua vez, alicerçado na inverificabilidade: a impossibilidade de constatação se há o monitoramento. Diante desta incerteza, o preso evita a conduta repreensível, o que caracteriza a internalização da disciplina em cada indivíduo. A inverificabilidade na vigilância prevê uma economia de recursos, pois alivia a rotina da instituição no controle das pessoas. Como coloca Foucault (1987), "Este princípio significa um aprimoramento, uma otimização do poder, uma economia". Neste sentido, a interiorização pode atingir tanto presos como os funcionários, o que remete a questão de quem controla os vigias, amplamente trabalhada por Bentham. As Diretrizes Básicas não abordam o princípio da inverificabilidade nos postos de controle. A inverificabilidade é ditada pelo nível de segurança penitenciário, equivalente ao perfil dos presos. No sistema penitenciário, a transferência de poder aos presos envolve a inversão na vigilância, na qual os presos eventualmente passam a observar e a registrar a rotina funcional - o que justifica, em parte, o fechamento da cela (ver item 17.10). Neste sentido, a inverificabilidade é transferida para todos os locais onde os presos podem ter a percepção do trabalho dos funcionários, como nos corredores e áreas externas, preservando os bastidores e a representação institucional (ver item 10.03).

15.03 A vigilância externa do estabelecimento penal atua como mecanismo garantidor do cumprimento da pena, ao conformar o isolamento social da prisão, em termos da estanqueidade e da inexpugnidade, por meio do monitoramento do perímetro de segurança (ver itens 16.01 e 16.03). A vigilância externa é normalmente providenciada pelas torres da barreira perimetral, eventualmente associadas a outros postos, como as portarias de acesso da unidade penal. Esta vigilância também abrange as áreas e edificações intramuros da unidade penal. A mesma atende aos preceitos de eficiência da disciplina, aderindo ao princípio de vigilância panóptico (ver item 15.02): a quantidade, a posição e o distanciamento entre as torres atuam em conjunto com a geometria da barreira perimetral e da edificação, além da planialtimetria do terreno, de modo a maximizar a área sob monitoramento e minimizar os recursos necessários para esta tarefa (ver item 16.05). As Diretrizes Básicas (p. 47 e 49 ) se restringem a poucas recomendações de caráter pontual que se resumem a "evitar pontos cegos" ou o alinhamento das empenas dos edifícios. As mesmas não distinguem a vigilância externa em razão do nível de segurança penitenciário. No sistema penitenciário, a postura da administração penitenciária e as deficiências operacionais impõem a concentração da estanqueidade e da inexpugnidade no perímetro de segurança, atribuída à vigilância externa.

15.04 O controle naturalmente expõe os funcionários, tanto na defesa do estabelecimento penal contra ataques externos, como no convívio com os presos (ver itens 12.01 e 15.05). As Diretrizes Básicas não abordam a proteção dos funcionários, embora preconizem a adoção de torres de vigilância e postos de controle. Estes elementos têm como objetivo a atuação segura dos mesmos na operação penitenciária na vigilância e controle de pessoas, por meio da separação física dos funcionários. No sistema penitenciário, os postos externos podem sofrer disparos por arma de fogo ou serem invadidos. Internamente, o excedente de presos e a carência de recursos humanos potencializam os ataques físicos aos funcionários pelos presos, seja pela coerção e intimidação verbais ou pela violência física na conformação de reféns em ocorrências de motins e rebeliões (ver item 19.05).

15.05 A disciplina espacial ressalta a interdependência da espacialização da edificação penal com o controle, segundo a qual locais de fiscalização devem ser dispostos estrategicamente sobre o arranjo arquitetônico para a coordenação dos fluxos (ver item 12.01). Em boa parte, os padrões arquitetônicos penitenciários são resultado do arranjo arquitetônico em torno do tema da vigilância, o que derivou os tipos de vigilância e as gerações de estabelecimento penais. O padrão arquitetônico radial enfatizava esta característica, concentrando os fluxos internos da prisão em torno do posto de controle central. Neste sentido, a caracterização, o posicionamento

Interiorizar a individualidade disciplinar segundo o nível de segurança penitenciário estipulado para o estabelecimento penal a ser projetado. Este item baseia o programa arquitetônico como um todo, especialmente o Posto de Controle.

Monitorar as áreas e elementos externos do estabelecimento penal a ser projetado segundo o nível de segurança penitenciário estipulado para o mesmo. Este item se relaciona com a Barreira Externa e a Geometria.

Garantir a integridade dos funcionários encarregados da vigilância externa e interna.

Este item se relaciona com o Posto de Controle.

Controlar os fluxos no estabelecimento penal a ser projetado.

Este item se relaciona com a geometria, a Espacialização e a Circulação. 
e o acesso das atividades apontam para os pontos críticos na perspectiva da segurança e da operação. As Diretrizes Básicas prevêem postos de controle nos acessos de parte dos blocos funcionais. Isto pode comprometer o esquema de segurança e operação, tendendo a surgir áreas sem fiscalização ou com a necessidade de um contingente excessivo de funcionários. No sistema penitenciário, a carência de recursos para a operação penitenciária inviabiliza o controle da toda a circulação da prisão, havendo um aproveitamento do pessoal disponível nos locais mais problemáticos (ver item 15.01). Em termos da circulação, devido à situação prisional, o procedimento mais perigoso para os funcionários reside no trânsito diário entre as celas e o pátio de sol. De uma maneira geral, os presos são conduzidos escoltados, com exceção de presos colaboradores.

15.06 A quantidade de postos de controle e a sua disposição atende a eficiência da disciplina, especialmente na economia de recursos com pessoal no funcionamento da unidade penal. O padrão arquitetônico pavilhonar instituiu a 'vigilância direta', na qual um posto de controle fechado é inserido centralizadamente na área de convivência dos presos, o que permite a vigilância de todo o espaço coletivo por poucos funcionários. Este arranjo resgatou, em parte, a centralidade do panoptismo, na qual o programa orbita o posto de controle, definindo certos aspectos da espacialidade. As Diretrizes Básicas não sugerem ou recomendam o posicionamento dos postos de controle, previstos em número de sete no programa sugerido, assim como, não discriminam este quantitativo segundo o nível de segurança penitenciário. No sistema penitenciário, a postura penalógica da administração penitenciária (ver item 10.02) determina o arranjo das atividades em relação aos postos de controle. Enquanto as deficiências operacionais, associadas ao antagonismo entre funcionários e presos exigem a extensão destes espaços pelo corpo do edifício, principalmente nas áreas mais internas. Ao mesmo tempo, a carência de recursos humanos pode resultar em postos subutilizados, prejudicando a operação e a segurança penitenciária.

15.07 O controle afeta a disputa do domínio territorial entre a instituição e o grupo de presos. O arranjo do Panopticon com a torre central no edifício circular é a representação das relações de poder instituídas, a divisão básica descrita por Goffman. Não importa se a torre está ocupada pelos vigias, a presença da torre é suficiente como representação do poder. Estes atores são substituídos pela torre de vigilância incansável, inflexível e insondável que, por si só, inibe as indisciplinas dos presos. O edifício cilíndrico inteiro é o palco das representações institucionais. As Diretrizes Básicas não abordam a representação do poder incutida nos postos de controle. Esta representação é definida pelo nível de segurança penitenciário. No sistema penitenciário, a postura penalógica da administração penitenciária (ver item 10.02) determina a inclusão de postos de controle em áreas internas, em uma afirmação da força institucional em locais eventualmente dominados pelos presos, ou a inversão na vigilância, na qual os presos eventualmente passam a observar e a registrar a rotina funcional (ver item 17.10). Além disto, pode ocorrer o enfraquecimento da divisão de poder entre funcionários e presos na medida em que agente institucional se torna não fiscalizado, estando distante da administração do estabelecimento. Daí a autonomia destes funcionários pode representar uma transferência de poder dentro da hierarquia da equipe dirigente. Esta autonomia não fiscalizada juntamente com o convívio prolongado com a população prisional facilita a cumplicidade entre funcionários e presos ou os abusos de autoridade. Segundo Goffman (2005), "situação que exige uma inspeção da direção sobre o funcionário". As Diretrizes Básicas não abordam este tópico.

\section{Barreira perimetral}

\section{Análise do Contexto}

16.01 Do ponto de vista da prisão como atividade econômica, a barreira perimetral tem como atribuição garantir a segregação social do preso para o cumprimento da pena ou para o andamento do processo penal (ver item 04.01). As Diretrizes Básicas não explicitam este objetivo da barreira perimetral. No sistema penitenciário, o antagonismo entre a sociedade e a prisão, assim como a prevalência da concepção negativa da pena ressaltam o caráter retributivo da penalidade. $O$ índice de fugas passa a ser um critério de qualidade dos estabelecimentos penais. A carência de recursos para a operação concentra o esquema de segurança na contenção dos presos (ver itens 10.02 e 15.03). Em geral, estes efetuam fugas pelo perímetro de segurança escalando a barreira ou

Quantificar o número de postos de controle do estabelecimento penal a ser projetado de acordo com a capacidade operacional e o nível de segurança penitenciário estipulados para o mesmo. Este item se relaciona com a Espacialização e a Circulação.

Considerar a estrutura social e as relações de poder na configuração do controle, segundo $o$ nível de segurança penitenciário estipulado estabelecimento penal a ser projetado.

Este item se relaciona com Espacialização e a Circulação.

Requisito funcional

Impedir a evasão de presos da prisão: garantir a estanqueidad estabelecimento penal a ser projetado. Este item se relaciona com o Isolamento Social e o Controle. 
por túneis.

16.02 A prisão consiste em um espaço objetivamente delimitado, cuja separação do mundo externo é necessária para a implementação de um regime totalitário e o controle da população prisional. $\mathrm{O}$ isolamento é condição primordial para o exercício da disciplina: a identificação, o posicionamento, o exame e o registro do processo aplicado a cada preso. Neste sentido, a barreira perimetral tem como atribuição a impermeabilidade da unidade penal (ver itens 04.01). As Diretrizes Básicas não explicitam este objetivo da barreira perimetral. No sistema penitenciário, o contato entre os presos e o meio externo ocorre, em parte, através da barreira perimetral, o que é potencializado pela localização ou implantação desfavorável de alguns estabelecimentos (ver itens 04.04 e 11.03).

16.03 A barreira perimetral combate tanto a evasão como a invasão do estabelecimento penal (ver item 16.01). As Diretrizes Básicas não explicitam este objetivo da barreira perimetral: defender a unidade penal contra ataques externos. No sistema penitenciário, existem ocorrências de invasão pela derrubada de parte da barreira perimetral para o resgate de presos, seja pela utilização de dispositivo explosivo ou de veículo pesado.

16.04 O tipo de barreira a ser especificado depende das características de estanqueidade (ver item 16.01), impermeabilidade (ver item 16.02) e inexpugnidade (ver item 16.03) associadas ao nível de segurança penitenciário. Segundo as Diretrizes Básicas (p. 33 e 34 ), a barreira perimetral pode ser do tipo muro ou cerca. As mesmas não classificam estes tipos de acordo com o nível de segurança penitenciário. As recomendações neste instrumento, de uma forma geral, se referem a características de segurança máxima. No sistema penitenciário, as questões da locação (ver item 04.04) e do tamanho do terreno (ver item 11.03) remetem a especificação de barreiras de caráter fechado. Enquanto a exigência de redução do custo de construção aponta para barreiras mais leves (ver item 03.01).

16.05 A geometria da barreira perimetral atende aos princípios da disciplina espacial, trabalhando em conjunto com a forma arquitetônica da edificação, buscando dotar este elemento de uma racionalidade e economia que favoreça a funcionalidade (ver item 08.01) e o controle dos espaços externos e internos (ver item 15.03). Os instrumentos técnico-normativos não discriminam a geometria da barreira segundo o nível de segurança penitenciária. No sistema penitenciário, as questões da locação (ver item 04.04) e do terreno (ver item 11.03) interferem na geometria da barreira. A carência de pessoal exige desenhos mais simples e regulares, pois diminuem a quantidade de torres de vigilância e de pessoal para operá-las (ver item 15.06).

16.06 As Diretrizes Básicas estipulam uma altura mínima de cinco metros para a barreira perimetral. O instrumento não discrimina outras alturas ou discrimina esta dimensão da barreira segundo o nível de segurança penitenciário. A altura da barreira está relacionada à imagem institucional de força, atendendo ao caráter retributivo da penalidade e à função da prisão: a proteção da sociedade (ver item 04.04). Neste sentido, barreiras altas promovem uma sensação de segurança no corpo social. No sistema penitenciário, as barreiras altas são igualmente transpostas pelos presos em fuga, implicando apenas em uma resistência temporal extra até o salto. A exigência de redução do custo de construção aponta para barreiras mais baixas (ver item 03.01).

16.07 A barreira perimetral está associada à circulação da guarda externa da unidade penal. As Diretrizes Básicas recomendam apenas ( $p$. 47): "O acesso [à barreira externa] não permitirá o contato entre a guarda e as pessoas presas". Este instrumento não discrimina a circulação na barreira segundo o nível de segurança penitenciária. Para a barreira tipo muro, este instrumento prevê o passadiço. No sistema penitenciário, a circulação da guarda externa na barreira perimetral exige proteção contra ataques externos, principalmente, de disparo por arma de fogo ou para render o guarda (ver item 16.11). Neste sentido, os acessos às torres de vigilância também integram esta proteção, na qual as mesmas se vigiam reciprocamente (ver item 16.05).
Romper com a comunicação informal entre os presos e o mundo externo à prisão: garantir a impermeabilidade do estabelecimento penal a ser projetado. Este item se relaciona com o Isolamento Social e o Dimensionamento.

Proteger a prisão contra ataques externos: garantir a inexpugnidade do estabelecimento penal a ser projetado. Este item se relaciona com o Isolamento Social.

Especificar a barreira perimetral do estabelecimento penal a ser projetado segundo o nível de segurança estipulado. Este item se relaciona com o Custo, o Isolamento Social e o Dimensionamento.

Conceber a geometria da barreira perimetral de modo econômico, funcional e eficiente do ponto de vista do controle (vigilância).

Este item se relaciona com a Geometria e o Controle.

Dimensionar a altura da barreira perimetral do estabelecimento penal a ser projetado segundo o nível de segurança estipulado para o mesmo.

Este item se relaciona com o Custo, o Isolamento Social e o Dimensionamento. Promover a circulação protegida da guarda eterna.

Este item se relaciona com a Geometria e o Controle. 
16.08 A barreira perimetral pode ser revestida de aparatos de segurança para incrementar a sua performance em termos da estanqueidade, impermeabilidade e inexpugnidade, segundo o nível de segurança penitenciário (ver itens 16.02 e 16.03). As Diretrizes Básicas não tratam deste assunto. No sistema penitenciário, a barreira perimetral recebe recursos especialmente para obstacularizar a fuga de presos. A utilização destes recursos é viável do ponto de vista econômico, pois são soluções leves relativamente eficientes. Torna-se preferível para a administração penitenciária reduzir o investimento da barreira principal e revesti-la com estes aparatos. A inframuralha ou inframuro está em desuso (combate a fuga por túnel). A eletrificação de elementos é proibida.

16.09 Os instrumentos legais e técnico-normativos não prevêem a linha de tiro junto à barreira perimetral (faixa onde presumidamente o disparo de arma de fogo contra presos fugitivos é permitido). No sistema penitenciário, a linha de tiro foi instituída informalmente a partir da atuação da guarda armada nas torres de vigilância, reprimindo as tentativas de fuga pelo temor do preso em ser alvejado. Assim, a linha de tiro integra as medidas de reforço da barreira perimetral voltadas para evitar a fuga de presos.

16.10 Os afastamentos entre a barreira perimetral e as edificações da prisão integram o isolamento social dos presos ao colaborarem principalmente, na estanqueidade (ver item 16.01) e na impermeabilidade (ver item 16.02) do conjunto: distanciando os presos do mundo externo à prisão, o que dificulta a comunicação informal, além de criar um obstáculo horizontal a ser ultrapassado em uma fuga (pela superfície ou túnel). As Diretrizes Básicas (p. 34) prevêem afastamentos mínimos diferenciados para barreiras do tipo muro (medida menores) e cerca (medidas maiores). Embora não atribuía discrimine os afastamentos segundo uma categorização penitenciária, as associações entre os afastamentos e os tipos de barreira estão consonantes com o nível de segurança penitenciaria. No sistema penitenciário, a questão do dimensionamento do terreno (ver item 11.03) e da redução de custo de construção impõe uma minimização dos afastamentos que interferem na criação de áreas livres no interior da prisão (ver item 13.02).

16.11 As Diretrizes Básicas (p. 34) prevêem pista de ronda veicular junto à barreira perimetral. Este instrumento não explicita o objetivo da mesma, assim como não especifica a sua localização (dentro ou fora do perímetro de segurança) ou a sua aplicação de acordo com as categorias penitenciárias ou tipos de barreira. No sistema penitenciário, a pista de ronda integra as medidas de reforço d barreira perimetral voltadas para evitar a fuga de presos, no caso pela fiscalização da integridade da barreira de perimetral. Além disto, a pista de ronda pode descrever a circulação dos guardas (ver item 16.07) e facilitar o acesso de veículos para intervenções em situações de crise (motins, incêndio, acidente).

Análise do Contexto

17.01 No projeto Panopticon, a forma da cela era essencial para a vigilância do inspetor na torre central, reproduzindo a racionalidade utilitária da prisão: a eficiência e a economia de recursos (ver item 06.01). Os instrumentos legais e técnico-normativos não tratam objetivamente da geometria da cela, subtendendo-se a prerrogativa de desenhos retangulares a partir dos parâmetros fixados nas Diretrizes Básicas (p. 31). A forma das celas é condicionada pelo nível de segurança penitenciário. No sistema penitenciário, a simplicidade geométrica favorece a visualização e os procedimentos de segurança no interior da cela (ver itens 17.10 e 17.11).

17.02 A cela panóptica abrigava várias atividades do cotidiano do preso (dormir, estudar, rezar, comer) que foram distribuídas pelo corpo da prisão. Neste processo, a cela alcançou uma singularidade funcional, dedicada ao recolhimento noturno para o descanso dos presos. Os instrumentos legais e técnico-normativos ratificam este uso. Segundo a LEP (Art. 88) e Diretrizes Básicas (p. 33), a cela é composta de dormitório, área de higiene pessoal e circulação, assim como, o único mobiliário obrigatório é a cama (ver itens 17.03, 17.04 e 17.05). Da mesma maneira, a técnica penitenciária indica o uso predominantemente noturno da cela: descreve o
Reforçar a barreira perimetral do estabelecimento penal a ser projetado por meio de aparatos de segurança, segundo - nível de segurança estipulado para o mesmo.

Este item se relaciona com o Custo.

Considerar a linha de tiro para o estabelecimento penal a ser projetado, segundo o nível de segurança estipulado.

Este item se relaciona com o Controle (ver item 15.03).

Reforçar a estanqueidade da barreira perimetral do estabelecimento penal a ser projetado por meio dos afastamentos entre a mesma e as edificações, segundo o nível de segurança estipulado.

Este item se relaciona com a Localização, o Dimensionamento, o Conforto e o Controle.

Considerar a pista de ronda para o estabelecimento penal a ser projetado, segundo o nível de segurança estipulado. Este item se relaciona com o Controle.

\section{Requisito funcional}

Favorecer o monitoramento do interior da cela por meio da geometria, segundo o nível de segurança do estabelecimento penal a ser projetado.

Este item se relaciona com a Geometria e com o Controle.

Alojar os presos para o descanso diário.

Este item se relaciona com as Atividades. 
procedimento de tranca dos presos ao final de um dia e abertura no dia seguinte, além de prever as atividades dos presos fora da cela durante o dia. Estes instrumentos não especificam o uso da cela segundo o nível de segurança penitenciária. No sistema penitenciário, a falta de recursos para a realização dos procedimentos e atividades programadas prolonga a estadia dos presos nas celas. A administração prisional busca compensar fazendo concessões. Com isto, em alguma medida, atividades não programadas ocorrem nas celas, tais como: o lazer, a alimentação, a preparação de alimentos, a realização de pequenos trabalhos, a lavagem e secagem de roupas e utensílios. A realização de atividades extraordinárias nas celas muda a perspectiva funcional deste espaço que sofre adequações por parte dos presos: criação de prateleiras, ganchos, varais, divisórias, entre outros.

17.03 Os instrumentos legais e técnico-normativos definem como aparelhos mínimos para a higiene pessoal nas celas um vaso sanitário e um lavatório (LEP, Art. 88). Segundo as Diretrizes Básicas (p. 31), o chuveiro é opcional, podendo ser localizado dentro ou fora da cela. Estes instrumentos não discriminam estes itens segundo o nível de segurança penitenciário. No sistema penitenciário, a falta de recursos para a realização dos procedimentos de segurança dificulta o banho coletivo, tendo em vista a condução de presos e a sua aglomeração que podem oferecer riscos. Em contrapartida, a retirada do chuveiro da cela é defendida pela diminuição da umidade no ambiente - uma questão de salubridade relacionada à saúde dos presos (ver itens 08.02 e 17.08).

17.04 A LEP (Art. 88) determina a obrigatoriedade da cama na cela. As Diretrizes Básicas (p. 41) cogitam a inclusão de mesa com banco, prateleiras, divisórias, entre outros elementos. Estes instrumentos não discriminam o mobiliário segundo o nível de segurança penitenciária, mas definem critérios de conformação da mobília em termos da fixação das peças nos pisos e paredes e materiais aplicados (ver item 17.02). No sistema penitenciário, a permanência prolongada dos presos nas celas, a inclusão de atividades extraordinárias e a posse de mais bens materiais podem implicar em maiores exigências em termos do mobiliário. Estas exigências definem itens para a realização de refeições e trabalhos, além da guarda de pertences pessoais. Ao mesmo tempo, as exigências de segurança e redução de custos de construção determinam a simplificação e minimização do mobiliário (ver item 17.11).

17.05 A espacialidade da cela reproduz o mecanismo disciplinar do espaço: a eficiência e a economia de recursos (ver item 06.02) - a cela panóptica era conformada por um espaço único e devassado. Esta espacialização inclui a organização em camadas topológicas das atividades realizadas. Os instrumentos legais e técnico-normativos não tratam objetivamente da composição espacial das celas, havendo algumas recomendações nas Diretrizes Básicas que, em sua maioria, caracterizam um nível de segurança alto (ver item 05.03). A espacialidade das celas é condicionada pelo nível de segurança penitenciário. No sistema penitenciário, o arranjo interno das celas deve a favorecer a visualização e os procedimentos de segurança no local (ver item 17.11). Os presos utilizam os obstáculos visuais e a dificuldade de acesso como esconderijos para pessoas e objetos. Neste sentido, o acúmulo desordenado de atividades e a conseqüente adequação do espaço da cela por meio de divisórias prejudicam a segurança (ver item 17.02). As exigências de segurança e operação, associadas à demanda de redução de custos de construção impõe a simplicidade espacial da cela.

17.06 A natureza totalitária da prisão define a cela como um território de domínio institucional (ver item 10.02). O Panopticon explicitava isto, ao devassar as celas para a vigilância. Isto é incrementado por meio da disciplina prisional que tende a despersonificar os presos através do processo de mortificação da perda da propriedade (identidade e bens materiais), segundo o qual a manifestação do eu fica restringida, inclusive aquela relacionada com a apropriação do espaço físico das celas. $O$ estatuto prisional ratifica isto, por exemplo, censurando adereços ao local (colagens, pinturas, penduricalhos) ou prevendo a mudança periódica dos presos entre as celas. Os instrumentos legais e técnico-normativos não tratam objetivamente da relação entre o espaço arquitetônico da cela e o preso. Esta relação é condicionada pelo nível de segurança penitenciária. No sistema penitenciário, as celas são demarcadas como de domínio dos presos, o que é potencializado pela privacidade destes locais em relação à instituição (ver item 17.11). No entendimento de Goffman, a cela possui um caráter de local livre para o preso que é esquadrinhado em territórios de grupo (circulação, banheiro) e territórios pessoais (quase sempre configurados pela cama). O acúmulo de atividades nas celas torna o

Proporcionar a higiene pessoal dos presos nas celas.

Este item se relaciona com o Conforto Ambiental.

Providenciar mobiliário para apoiar as atividades realizadas na cela, segundo o nível de segurança do estabelecimento penal a ser projetado.

Este item se relaciona com o Custo.

Compor o espaço arquitetônico da cela em função da disciplina espacial, segundo o nível de segurança do estabelecimento penal a ser projetado.

Este item se relaciona com a Espacialização e o Controle.

Considerar as relações de poder e sociais, assim como a manifestação individual no espaço arquitetônico da cela, segundo o nível de segurança do estabelecimento penal a ser projetado.

Este item se relaciona com a Espacialização. 
território de grupo diminuto, assim como a aglomeração inviabiliza os territórios pessoais. Em parte, atividades que poderiam ser realizadas em grupo (como assistir televisão ou as refeições) acontecem individualmente nas camas.

17.07 A LEP (Art. 88) determina a área mínima da cela individual. As Diretrizes Básicas (p. 31) fixam áreas, dimensões e volumes mínimos para as celas coletivas. As Diretrizes (p. 41) ainda fornecem dimensões mínimas para a cama e para o pé-direito, no caso do uso de beliche de três camas. A partir dos parâmetros fixados é possível calcular a largura mínima da circulação e do banheiro. As dimensões mínimas nas Diretrizes induzem à composição espacial predominante nas prisões (ver item 17.05), relacionada a um nível de segurança mais alto (ver item 10.05). As mesmas não discriminam o dimensionamento segundo o nível de segurança penitenciária (ver item 08.02). No sistema penitenciário, a exigência de redução de custo de construção impõe uma minimização das áreas das celas (ver item 11.02).

17.08 A LEP determina condições para a salubridade do alojamento do preso (cela individual). As Diretrizes Básicas (p. 38) fazem recomendações quanto ao conforto ambiental em geral que se aplicam às celas - por exemplo, a ênfase na ventilação e iluminação (ver item 13.01). Estes instrumentos não discriminam os parâmetros de conforto ambiental segundo o nível de segurança penitenciária. O conforto ambiental envolve as questões da previsão do banheiro e chuveiro na cela em termos da qualidade do ar, tendo em vista a contaminação advinda do uso do vaso sanitário e à umidade do banho (ver item 17.03). No sistema penitenciário, a inversão da vigilância, a comunicação informal dos presos e as fugas em boa parte se dão pelas aberturas das celas (ver item 17.09). Os elementos de controle das aberturas são desmontados para a fabricação de objetos. A ocupação e o uso indevido das celas (ver itens 17.02 e 17.05) dificultam a circulação do ar e a distribuição da luz.

17.09 A cela condensa o esforço de segurança e operação da unidade penal que se multiplica em cada um dos seus elementos arquitetônicos. Dos instrumentos legais e técnico-normativos, apenas as Diretrizes Básicas (p. 41) fazem recomendações quanto ao aparato de segurança, em especial a conformação das aberturas de iluminação e ventilação e do mobiliário (ver itens 17.04 e 17.08) que remetem à segurança máxima. Estes instrumentos não distinguem soluções segundo o nível de segurança penitenciária. No sistema penitenciário, os componentes da cela são utilizados para a fuga, confecção de objetos ou produção de esconderijos. As medidas de segurança podem afetar o conforto e a funcionalidade da cela em alguma medida, por exemplo, impedindo a iluminação e a ventilação do interior da mesma. Isto remete ao limite da maximização da segurança na concepção do espaço arquitetônico da cela diante do respeito à condição humana dos presos (ver item 10.05).

17.10 O controle panóptico dependia da visibilidade do interior da cela para a observação integral das atividades da prisão e a conseqüente economia de recursos, assim a mesma era não apenas aberta para o vigia, mas seu espaço era exposto pelo jogo de luz que a atravessava (ver item 15.01). Esta configuração determinava a relação de poder na prisão, caracterizando a cela como território institucional (ver item 17.06). Os instrumentos legais e técnico-normativos não tratam objetivamente do fechamento da cela em relação à instituição. As Diretrizes Básicas (p. 41) fazem apenas algumas recomendações que permitem a visualização esporádica do interior da cela, como o uso de portinhola ou visores presentes na porta ou nas paredes. Oficialmente, o fechamento da cela ocorre em nome de uma privacidade dos presos. A visualização da cela é condicionada pelo nível de segurança penitenciário. Neste sentido, as Diretrizes remetem a um nível de segurança mais brando. No sistema penitenciário, o fechamento das celas se justifica pela contenção dos presos, evitando o controle dos corredores e pátios adjacentes (ver item 15.01), além do ataque a funcionários pelos mesmos. Em contrapartida, as celas adquirem a conotação de masmorra, na qual os presos se escondem da instituição.

Dimensionar a cela de acordo com a capacidade estipulada e segundo o nível de segurança do estabelecimento penal a ser projetado.

Este item se relaciona com o Custo.

Condicionar ambientalmente a cela, principalmente em termos da ventilação e iluminação, segundo o nível de segurança do estabelecimento penal a ser projetado. Este item se relaciona com o Conforto Ambiental.

Reforçar as propriedades de segurança da cela por meio de aparatos, segundo o nível de segurança estipulado para estabelecimento penal a ser projetado. Este item se relaciona com a Funcionalidade e o Conforto Ambiental.

Definir a abertura ou fechamento da cela de acordo com a visualização do interior pretendida, segundo o nível de segurança estipulado para estabelecimento penal a ser projetado.

Este item se relaciona com o Controle. 
17.11 Diante da improbabilidade do arranjo arquitetônico panóptico e do fechamento da cela emerge a necessidade da melhor visualização possível do interior da cela desde pontos de observação o que abrange a geometria, a especificação dos elementos e a configuração do espaço interno (ver itens 17.01, 17.04 e 17.05). Os instrumentos legais e técnico-normativos não discriminam soluções para a visualização interna das celas segundo o nível de segurança penitenciário (ver item 17.10). No sistema penitenciário, a necessidade de observação do interior da cela pelo funcionário, mesmo que a partir de uma portinhola ou visor, exige a apreensão do ambiente, evitando pontos cegos onde presos possam se esconder ou proceder à ocultação de objetos. A privacidade dos presos exige pelo menos a reserva no uso do banheiro, enquanto o incremento da segurança penitenciária visa à exposição do banheiro.

\section{Análise do Contexto}

18.01 O banho de sol dos presos surgiu com a pena moderna relacionado a uma questão de saúde, inserido no conjunto de espaço destinados às atividades coletivas dos presos, em complemento ao isolamento celular. Para Bentham, a saúde dos presos era uma questão de economia: a utilidade dos corpos para as tarefas produtivas na prisão. Além do banho de sol, os pátios previam as atividades de trabalho, educação, refeição e recreação. Do ponto de vista da disciplina, o pátio pode receber atividades afins limitadas em razão da operação segura do estabelecimento penal. A LEP não prevê o banho de sol entre os direitos dos presos: o tema é tratado na descrição do RDD (Art. 52), ao preconizar duas horas diárias de banho de sol. As Regras Mínimas (Art. 14) determinam local para a realização de exercícios físicos ou banho de sol. As Diretrizes Básicas prevêem objetivamente o pátio para banho de sol nos módulos de vivência. As mesmas ainda prevêem uma área coberta que pode ser junto ao pátio, o que permite a realização de outras atividades. No sistema penitenciário, o banho de sol é diário, obedecendo a um tempo médio de duas horas, em alguns sistemas se estendendo durante todo o período diurno. A falta de recursos para a realização dos procedimentos de segurança e operação, assim como, das atividades programadas define o pátio como local de permanência mais prolongada para a maioria dos presos, depois da cela (ver item 17.02). No cotidiano prisional, o pátio é o lugar de maior aglomeração dos presos na prisão, onde ocorre a convivência mais ampla deste grupo social. Também devido à falta de recursos, no pátio se desenvolvem atividades formais e informais, sendo transferidas para os pátios atividades extras, tais como: o lazer, a prática desportiva, a alimentação, o culto, a realização de pequenos trabalhos, a lavagem e secagem de roupas, entre outras que normalmente seriam realizadas em locais específicos (ver item 09.01). Em alguns sistemas penitenciários, a visita social aos presos também ocorre no pátio (ver item 10.03). Na rotina prisional, estas atividades eventualmente ocorrem simultaneamente no pátio, o que pode levar a uma utilização tumultuada, com conflitos entre as atividades (ruído, espaço) e difícil de ser monitorada.

18.02 A determinação de classificação e separação dos presos no estabelecimento penal atinge a concepção dos pátios de sol dos presos (ver item 10.04). Neste sentido, os diferentes grupos de presos não poderiam ocupar ao mesmo tempo um pátio. As Diretrizes Básicas ressaltam isto ao prever um pátio em cada módulo de vivência dos presos ou ao permitir o revezamento de uso do pátio por grupos diferentes de presos em horários distintos. No sistema penitenciário, esta medida contribui para a disciplina interna, além de evitar violências entre grupos de presos rivais ou a coerção de grupos mais vulneráveis. A política de redução de custos de construção pode impor a previsão de pátios compartilhados por grupos diferentes de presos, seguindo um esquema de alternância no local.
Permitir a visualização do interior da cela, segundo o nível de segurança estipulado para estabelecimento penal a ser projetado.

Este item se relaciona com a Espacialização e o Controle.

\section{Requisito funcional}

Propiciar o banho de sol dos presos, segundo o nível de segurança estipulado para estabelecimento penal a ser projetado.

Este item se relaciona com as Atividades.

Separar os diferentes perfis de presos para o banho de sol.

Este item se relaciona com o Custo e a Espacialização. 
18.03 Os instrumentos legais e técnico-normativos prevêem pátios individuais e coletivos, de acordo com a situação do preso, sendo destinado o individual para presos em medida disciplinar ou RDD, e o coletivo para a população prisional em geral. As Diretrizes Básicas (p. 47) não abordam a capacidade do pátio em relação ao nível de segurança penitenciário. As mesmas prevêem o rodízio de grupos de presos na utilização do pátio. No sistema penitenciário, os pátios são utilizados por grupos completos de presos, pois as deficiências do programa de benefícios aos presos que oportunizam poucas vagas para as atividades de trabalho e educação levam ao pátio presos que poderiam estar nestas atividades. Ao mesmo tempo, a falta de recursos para a realização dos procedimentos de segurança e operação impede a alternância de presos no pátio. A estes fatores deve ser somado o aumento da capacidade de celas e alas carcerárias (ver itens 05.06 e 10.04), cujo resultado é a exigência de pátios com capacidades maiores (ver item 18.09).

18.04 A geometria dos pátios de sol dos presos reproduz a racionalidade utilitária da prisão: a eficiência e a economia de recursos (ver item 06.01). Os instrumentos legais e técnico-normativos não tratam diretamente da geometria do pátio, subtendendo-se a prerrogativa de desenhos retangulares a partir das recomendações e dos parâmetros fixados nas Diretrizes Básicas (p. 47 e 69). A forma dos pátios é condicionada pelo nível de segurança penitenciário. No sistema penitenciário, a utilização intensa do pátio exige cuidados com a visualização e os procedimentos de segurança (ver item 18.12).

18.05 A espacialidade do pátio de sol do preso reproduz o mecanismo utilitarista e disciplinar do espaço: a eficiência e a economia de recursos (ver item 06.02). Os instrumentos legais e técnico-normativos não tratam objetivamente da composição espacial dos pátios, havendo algumas recomendações nas Diretrizes Básicas que, em sua maioria, caracterizam um nível de segurança alto. As Diretrizes Básicas prevêem uma área coberta que pode ser adjacente ao pátio. A espacialidade dos pátios é condicionada pelo níve de segurança penitenciário. No sistema penitenciário, o arranjo interno dos pátios deve a favorecer a visualização e os procedimentos de segurança no local (ver item 18.12). Os presos aproveitam a configuração do espaço e de seus componentes como os obstáculos visuais à vigilância e dificuldade de acesso à vistoria, utilizando-os para escalar, ocultar objetos, se esconder ou praticar indisciplinas ou crimes. Neste sentido, o acúmulo desordenado de atividades e a conseqüente adequação do espaço do pátio são complicadores (ver item 18.01).

18.06 A permanência dos presos no pátio de sol demanda itens de conforto e serviços, tais como: área coberta, mobiliário, sanitários e água potável. As Diretrizes Básicas vislumbram a área coberta e os sanitários, porém este instrumento não discrimina estes elementos segundo o nível de segurança penitenciário. No sistema penitenciário, os presos aproveitam destes componentes para escalar, ocultar ou esconder, além de depredá-los para a retirada de peças ou para desestabilizar a administração da prisão. As atividades extraordinárias no pátio (ver item 18.01) podem implicar em maiores exigências em termos do mobiliário. Ao mesmo tempo, as exigências de segurança e redução de custos de construção determinam a minimização dos itens de conforto (ver item 18.10).

18.07 A LEP (Art. 13) determina que a unidade penal possua cantina para a disponibilização aos presos de artigos não ofertados pelo estabelecimento penal. Na prisão, a cantina normalmente é anexada ao pátio, configurando uma atividade correlata (ver item 18.01). No sistema penitenciário, a cantina eventualmente integra esquemas de contrabando e controle do comércio na prisão, por isto sendo eventualmente preterida pela administração penitenciária. O espaço é revertido, em algumas unidades, em distribuição das refeições dos presos, quando estas são realizadas no pátio. Neste sentido, a cantina vai de encontro ao preceito de segurança.

Compatibilizar a capacidade do pátio de sol com o nível de segurança do estabelecimento penal a ser projetado.

Este item se relaciona com o Porte e o Custo do estabelecimento penal, assim como, com o Dimensionamento.

Favorecer a disciplina e o monitoramento do pátio de sol por meio da geometria, segundo o nível de segurança do estabelecimento penal a ser projetado. Este item se relaciona com a Geometria e com o Controle.

Compor o espaço interno do pátio de sol em função da disciplina espacial, segundo o nível de segurança do estabelecimento penal a ser projetado.

Este item se relaciona com Espacialização e o Controle.

Proporcionar condições de permanência dos presos no pátio do ponto de vista do conforto e serviços.

Este item se relaciona com a Espacialização, os Aparatos de Segurança e o Controle.

Considerar cantina ou área conexa ao pátio para a distribuição de refeições, segundo o nível de segurança do estabelecimento penal a ser projetado. Este item se relaciona com as Atividades. 
18.08 A natureza totalitária da prisão define o pátio como um território de domínio institucional que, no entendimento de Goffman, possui um caráter de local vigiado (ver item 10.02). Os instrumentos legais e técnico-normativos não tratam objetivamente da relação entre o espaço arquitetônico pátio e o preso. Esta relação é condicionada pelo nível de segurança penitenciário. 0 domínio institucional é implementado através da massificação. No sistema penitenciário, os pátios são demarcados como de domínio dos presos, dependendo da postura da administração penitenciária. Em alguns casos, o acesso dos funcionários ao pátio é proibido. Em contrapartida, os presos se submetem a rotina de entrada e saída nos horários agendados. $O$ espaço do pátio é esquadrinhado em territórios de grupo, conforme a divisão e a hierarquia da sociedade prisional e os interesses na realização de atividades coletivas: praticar esportes, orar, negociar, entre outras.

18.09 As Diretrizes Básicas (p. 47 e 69) fixam áreas e dimensões mínimas para o pátio de sol dos presos, todavia não trata da altura do mesmo. O dimensionamento do pátio é condicionado pelo nível de segurança penitenciário (ver item 08.02). As Diretrizes prevêem rodízio de grupos de presos na utilização do pátio. Este rodízio permitiria uma redução do grupo de presos, o que beneficiaria os procedimentos de condução e vigilância. Assim como, o mesmo possibilitaria absorver o aumento do grupo de presos nas alas carcerárias, sem um acréscimo da área do pátio. No sistema penitenciário, a falta de recursos para a realização dos procedimentos de segurança e operação e as deficiências do programa de benefícios aos presos, associadas à política de redução de custos de construção levam a um aumento do número de usuários do pátio, enquanto o acréscimo do espaço é dificultado (ver itens 11.02 e 18.03). Isto a despeito da utilização massiva do local, o que leva a aglomeração de pessoas nos pátios.

18.10 As Diretrizes Básicas fazem recomendações quanto ao conforto ambiental da edificação penal em geral que se aplicam ao pátio de sol dos presos (ver item 13.01). Este instrumento não distingue os parâmetros de conforto ambiental segundo o nível de segurança penitenciário (ver item 10.05). O conforto ambiental envolve questões de salubridade advindas da previsão de banheiro no pátio em termos da qualidade do ar, tendo em vista a contaminação advinda do uso do vaso sanitário. No sistema penitenciário, a comunicação informal dos presos e as fugas em boa parte se dão pelo pátio descoberto. Em contrapartida, o incremento da segurança penitenciária, associada à política de redução de custos de construção impõe providências de estanqueidade e despojamento do pátio que pode comprometer a iluminação e ventilação, em especial, pode aquecer exageradamente o lugar. A ocupação e o uso indevido do pátio podem dificultar a circulação do ar e a distribuição da luz (ver item 18.01).

18.11 O esforço de segurança e operação da unidade penal se replica em cada um dos elementos arquitetônicos do pátio. Os instrumentos legais e técnico-normativos não especificam ou distinguem estes elementos segundo o nível de segurança penitenciária (ver item 14.01). Apenas as Diretrizes Básicas fazem algumas recomendações, tal como: a proteção dos beirais para evitar o acesso dos presos à cobertura. No sistema penitenciário, os componentes do pátio são utilizados para a fuga, confecção de objetos ou produção de esconderijos (ver item 18.06). Em contrapartida, as medidas de segurança podem afetar o conforto e a funcionalidade do pátio em alguma medida. Isto remete ao limite da maximização da segurança na concepção do espaço arquitetônico do pátio diante do respeito à condição humana dos presos (ver item 10.05).

18.12 O controle do pátio envolve a vigilância integral do local, a interiorização da individualidade disciplinar e a garantia da integridade física dos funcionários (ver itens 15.01, 15.02 e 15.04). Os instrumentos legais e técnico-normativos não tratam do controle do pátio que é condicionado pelo nível de segurança penitenciário. No sistema penitenciário, o domínio territorial, a aglomeração dos presos e a utilização intensa do pátio tornam o local crítico para o sistema de segurança e operação do estabelecimento (ver itens 18.01 18.05 e 18.08). Neste sentido, o controle do pátio pela instituição exige a presença impositiva da instituição e a separação física entre funcionários e presos, permitindo a vigilância do local e a preservação dos funcionários. A vigilância tende para a adoção de postos de controle nos moldes da segunda geração de estabelecimentos penais, envolvendo a configuração espacial do local e de seus componentes (ver itens 18.04 e 18.05).
Considerar as relações de poder e sociais entre a instituição e os presos, segundo o nível de segurança do estabelecimento penal a ser projetado.

Este item se relaciona com Espacialização.

Dimensionar o pátio de acordo com a capacidade e segundo o nível de segurança do estabelecimento penal a ser projetado.

Este item se relaciona com o Custo.

Condicionar ambientalmente o pátio, principalmente em termos da ventilação e iluminação, segundo o nível de segurança do estabelecimento penal a ser projetado. Este item se relaciona com o Conforto Ambiental.

Reforçar as propriedades de segurança do pátio por meio de aparatos, segundo o nível de segurança estipulado para estabelecimento penal a ser projetado. Este item se relaciona com a Funcionalidade e o Conforto Ambiental.

Permitir a visualização do interior do pátio, segundo o nível de segurança estipulado para estabelecimento penal a ser projetado.

Este item se relaciona com a Espacialização e o Controle. 


\begin{tabular}{|c|c|c|}
\hline \multicolumn{2}{|r|}{ Análise do Contexto } & \multirow[b]{2}{*}{$\begin{array}{l}\text { Requisito funcional } \\
\text { Permitir a apreensão dos eventos nos } \\
\text { ambientes monitorados, utilizando a } \\
\text { menor equipe possível, segundo o nível de } \\
\text { segurança estipulado para } \\
\text { estabelecimento penal a ser projetado. } \\
\text { Este item se relaciona com a Geometria e } \\
\text { Espacialização. }\end{array}$} \\
\hline 19.01 & $\begin{array}{l}\text { A vigilância do Panóptico dependia da percepção sensorial que o vigilante possuía. O Panopticon é o resultado do alcance do raio de } \\
\text { visualização e do tipo de informação acessada, sem interferências e condensadas para poucos vigias (ver item 15.06). Estas } \\
\text { informações decorrem da detecção de ruídos, odores e vibrações suspeitas que possam indicar atividades ou ocorrências que exijam } \\
\text { a interferência do poder. Neste sentido, o posto de controle tem sua eficiência atrelada a capacidade de apreensão dos eventos a } \\
\text { sua volta pelo funcionário, além da sua posição e da constituição dos espaços monitorados. Assim como, o controle só é efetivo se } \\
\text { permitir uma resposta imediata do agente penitenciário a uma situação verificada. A centralidade da torre panóptica com visores } \\
\text { em todo seu perímetro, permitindo a visualização de todo o anel periférico simbolizava este esquema. Deste modo, o posto de } \\
\text { controle é definido pela interação entre os lugares interno e o externo - institucional e vigiado, que depende de uma coordenação } \\
\text { de geometrias e visores (ver item 15.01). As Diretrizes Básicas não abordam estes cuidados e não distinguem soluções segundo o } \\
\text { nível de segurança penitenciário. No sistema penitenciário, os presos aproveitam os pontos cegos ou vulneráveis da vigilância do } \\
\text { espaço para ocultar ou esconder suas açães. Assim como, os presos usam artifícios para limitar a capacidade de observação do } \\
\text { vigilante, de modo a oportunizar os ajustamentos secundários, por meio da criação de barreiras visuais (aglomeração de pessoas ou } \\
\text { colocação de objetos - varais para secagem de roupa) ou barulhos para criar uma distração. }\end{array}$ & \\
\hline 19.02 & $\begin{array}{l}\text { A permanência dos funcionários no posto de controle demanda itens de conforto e serviços, tais como: mobiliário e sanitário. As } \\
\text { Diretrizes Básicas vislumbram o sanitário, porém este instrumento não discrimina estes elementos segundo o nível de segurança } \\
\text { penitenciário. No sistema penitenciário, a permanência dos funcionários no posto de controle pode ser prolongada devido ao } \\
\text { número reduzido de pessoal, o que exige o suporte de serviços sanitários próximos. No uso do banheiro externo, o funcionário } \\
\text { precisa ser substituído no posto, o que pode complicar a operação e fragilizar a segurança. Por outro lado, o uso do banheiro interno } \\
\text { pelo vigia (no de ser apenas um) pode implicar em um lapso operacional do posto, o que é utilizado pelos funcionários para justificar } \\
\text { atos dos presos não notados. O funcionário também pode desempenhar atividades que exijam uma bancada, tais como: o registro } \\
\text { em livro de ocorrência, a monitoria eletrônica, o apoio de aparelhos (rádio) ou o controle remoto de portas. }\end{array}$ & $\begin{array}{l}\text { Proporcionar condições de permanência } \\
\text { dos funcionários no posto de controle, do } \\
\text { ponto de vista do conforto e serviços, } \\
\text { segundo o nível de segurança do } \\
\text { estabelecimento penal a ser projetado. } \\
\text { Este item se relaciona com a } \\
\text { Funcionalidade. }\end{array}$ \\
\hline 19.03 & $\begin{array}{l}\text { O posto de controle pode contar com elementos de apoio aos funcionários, tais como: mobiliário, escadas e sanitários (ver item } \\
\text { 19.02) que não podem interferir na vigilância, constituindo fechamentos ou obstáculos que configurem a perda de visibilidade ou } \\
\text { dificuldade de acesso aos visores (ver item 19.01). As Diretrizes Básicas não abordam a espacialização dos postos de controle. A } \\
\text { espacialização do posto é condicionada pelo nível de segurança penitenciário. No sistema penitenciário, a exigência de redução de } \\
\text { custos de construção, evidenciada na redução do programa e das áreas, pode complicara distribuição ou acomodação dos } \\
\text { componentes espaciais, o que remete ao desempenho do controle e a boa condição de trabalho dos funcionários. }\end{array}$ & $\begin{array}{l}\text { Distribuir os componentes do posto de } \\
\text { controle de modo a evitar interferências e } \\
\text { conflitos na vigilância. } \\
\text { Este item se relaciona com a } \\
\text { Espacialização. }\end{array}$ \\
\hline 19.04 & $\begin{array}{l}\text { As dimensões do posto de controle devem ser compatíveis com o programa definido, além de permitir a melhor percepção dos } \\
\text { locais monitorados (ver itens } 19.02 \text { e 19.03). Neste sentido, o tamanho do posto depende dos componentes necessários para a } \\
\text { respectiva operação, assim como, do ponto focal que concentra recepção da informação e permite a economia com recursos } \\
\text { humanos (ver item 19.01). As Diretrizes Básicas fixam uma área para o posto de controle, independentemente dos espaços } \\
\text { monitorados ou do nível de segurança penitenciário. As mesmas não tratam da capacidade de visualização em função das } \\
\text { dimensões do posto. No sistema penitenciário, o dimensionamento também se relaciona com o conforto dos funcionários. Nos } \\
\text { postos gradeados, existe uma distancia em relação aos visores (presos) que proporciona uma sensação de segurança. Por outro } \\
\text { lado, os agentes podem experienciar certo desconforto devido ao enclausuramento inerente ao posto de controle (ver itens } 08.02 \text { e } \\
\text { 15.04). O que pode ser agravado nos postos ocupados por equipes de dois ou três funcionários e que recebem instalações e } \\
\text { equipamentos, por exemplo, para a monitoria eletrônica (ver item 19.03). }\end{array}$ & $\begin{array}{l}\text { Conciliar, no dimensionamento do posto } \\
\text { de controle, a visualização otimizada das } \\
\text { áreas monitoradas, em função do nível de } \\
\text { segurança do estabelecimento penal a ser } \\
\text { projetado. } \\
\text { Este item se relaciona com a } \\
\text { Espacialização. }\end{array}$ \\
\hline
\end{tabular}


19.05 O posto de controle é um elemento estratégico do sistema de segurança, especialmente nas áreas mais internas do estabelecimento penal, por isto a sua estanqueidade contra invasões é imprescindível para a instituição prisional. A situação é mais crítica quando os postos de controle são conectados, por exemplo, por circulação exclusiva para os funcionários. Neste caso, a tomada de um dos postos pelos presos poderia comprometer todo o sistema que estivesse interligado. Segundo Goffman (2005), o posto de controle e caracterizado como local proibido aos presos. Ao mesmo tempo, o controle e a vigilância normalmente são relativos, buscando sempre a melhor situação operacional, mas eventualmente trazendo falhas, como pontos cegos (ver item 19.01). Diante destas questões, aparatos de segurança podem incrementar a proteção e a funcionalidade do posto de controle, ao instrumentá-lo com dispositivos complementares aos visores e mecanismos para manuseio remoto de portas (ver item 14.01). As Diretrizes Básicas não tratam do posto de controle de modo integrado no sistema de segurança, particularmente em função do nível de segurança penitenciário. As mesmas também não tratam do posto de controle do ponto de vista dos aparatos de segurança. No sistema penitenciário, a integração das equipes é favorável para a coordenação da operação e reação no caso de crises (motins, rebeliões). Nestas situações, os presos podem tentar uma invasão dos postos de controle, especialmente pelas aberturas de visualização e pelo acesso para o domínio de setores do estabelecimento penal ou para a conformação de reféns (ver item 15.04). Isto exige uma resistência mínima à investida dos presos por um tempo suficiente para o escape dos funcionários (ver item 12.04). No cotidiano prisional, a utilização de acessórios para corrigir falhas na segurança, como espelhos convexos, é relativa. Isto porque a indisciplina interna permite que os presos destruam o que estiver ao seu alcance, principalmente a depredação favorecer os ajustamentos secundários. Isto pode implicar em proteção destes mecanismos. Estes aparatos e o controle remoto de portas estão sujeitos à carência de recursos para a operação penitenciária. No caso de manutenção, reparo ou troca de peças, soluções mais caras podem ser abandonadas ou substituídas por outras mais acessíveis. Isto pode levar a improvisos que comprometem a segurança e a operação penitenciária.

19.06 As Diretrizes Básicas (p. 38) fazem recomendações quanto ao conforto ambiental da edificação penal em geral que se aplicam aos postos de controle - por exemplo, a ênfase na ventilação e iluminação (ver item 13.01). Os postos de controle podem apresenta um dificultador para a iluminação e ventilação do seu espaço devido ao posicionamento centralizado. As Diretrizes não distinguem os critérios de conforto ambiental segundo o nível de segurança penitenciária. No sistema penitenciário, o conforto ambiental do posto de controle conflita com a segurança penitenciária, especialmente no caso das aberturas de iluminação e ventilação.

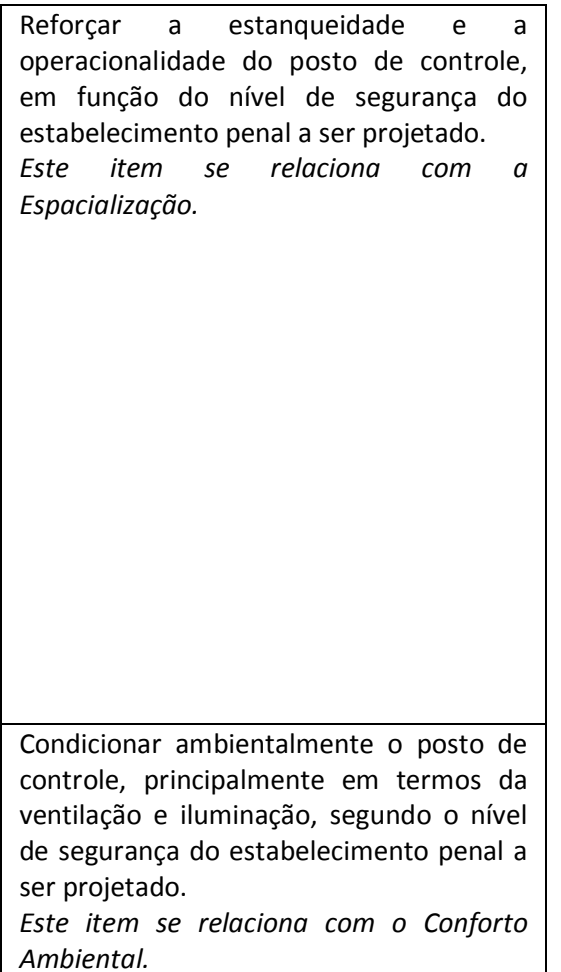


Tabela 19 - Requisitos funcionais e respectivos vínculos

Tipos de vínculo: 01 - Requisitos externos de natureza geral; 02 - Requisitos externos específicos; 03 - Requisitos internos; 04 - Requisitos internos dos elementos centrais da edificação penal de natureza geral; 05 - Requisitos internos dos elementos centrais da edificação penal específicos

\section{Requisitos Funcionais}

01. Tipo e categoria do estabelecimento penal

Conceber o espaço arquitetônico da prisão de modo

01.01 consonante ao perfil da população prisional prevista para o estabelecimento penal a ser projetado

01.02 Viabilizar os sistemas de segurança e operação definido para o estabelecimento a ser projetado

Considerar as características administrativas e do

01.03 modelo prisional na definição do espaço arquitetônico do estabelecimento a ser projetado

\section{Total}

02. Porte do estabelecimento penal

\begin{tabular}{|c|c|c|c|c|c|c|c|c|c|}
\hline \multirow{2}{*}{\multicolumn{2}{|c|}{\begin{tabular}{|c|c|}
02.01 & $\begin{array}{c}\text { Compatibilizar a capacidade e a estrutura física } \\
\text { necessária para o funcionamento do } \\
\text { estabelecimento penal a ser projetado }\end{array}$ \\
\end{tabular}}} & \\
\hline & & 18 & 1 & 2 & 0 & 0 & 21 & $\begin{array}{l}\text { Baseia o programa } \\
\text { arquitetônico }\end{array}$ & $\begin{array}{l}\text { O porte e os sistemas de segurança e operação e a caracterização } \\
\text { do tipo e categoria penitenciária (item 01.02). }\end{array}$ \\
\hline 02.02 & $\begin{array}{l}\text { Especificar o porte do estabelecimento penal a ser } \\
\text { projetado segundo o nível de segurança estipulado } \\
\text { para o mesmo }\end{array}$ & 18 & 7 & 2 & 0 & 0 & 27 & \begin{tabular}{|c|} 
Baseia o programa \\
arquitetônico \\
(Isolamento Individual, \\
Atividades e \\
Dimensionamento) \\
\end{tabular} & $\begin{array}{l}\text { O porte e o nível de segurança do estabelecimento (item 01.02). } \\
\text { A política e a demanda por vagas e o porte do estabelecimento } \\
\text { (itens 05.01, 08.01, 09.01 e 11.01). }\end{array}$ \\
\hline 02.03 & $\begin{array}{l}\text { Considerar futuras ampliações para o } \\
\text { estabelecimento penal a ser projetado }\end{array}$ & 0 & 5 & 0 & 0 & 0 & 5 & \begin{tabular}{|c|} 
Organização do \\
Espaço (Geometria, \\
Atividades e \\
Dimensionamento) \\
\end{tabular} & $\begin{array}{l}\text { O tamanho dos terrenos e a ampliação de unidades prisionais } \\
\text { (item 04.04). }\end{array}$ \\
\hline \multicolumn{2}{|l|}{ Total } & 36 & 13 & 4 & 0 & 0 & 53 & & \\
\hline \multicolumn{2}{|c|}{ 03. Custo do estabelecimento penal } & \multicolumn{8}{|c|}{$\begin{array}{l}\text { Relaciona-se de forma mais direta com o nível de segurança e o Porte do estabelecimento, assim como das Atividades e } \\
\text { Dimensionamento, além da Barreira Perimetral e o Controle, principalmente, em virtude de condicionantes operacionais. }\end{array}$} \\
\hline 03.01 & $\begin{array}{l}\text { Conceber o edifício prisional de modo a favorecer a } \\
\text { economia de recursos de toda ordem, tanto na } \\
\text { construção como na operação do estabelecimento } \\
\text { penal a ser projetado }\end{array}$ & 16 & 1 & 4 & 0 & 0 & 21 & $\begin{array}{c}\text { Baseia o programa } \\
\text { arquitetônico }\end{array}$ & $\begin{array}{l}\text { A política e a carência de recursos operacionais e a assistência do } \\
\text { Estado e o programa de benefícios aos presos (item 09.01). }\end{array}$ \\
\hline 03.02 & Considerar os custos de construção e operação & 16 & 6 & 0 & 1 & 0 & 23 & Baseia o programa & O custo e a categoria penitenciária (itens 01.02 e 02.02). 0 \\
\hline
\end{tabular}

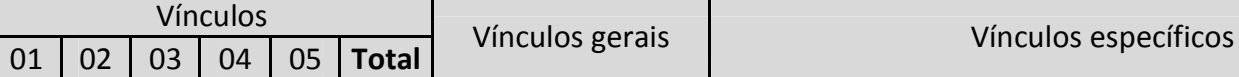

A principal categoria é o nível de segurança penitenciário que define a configuração do espaço arquitetônico como um todo, condicionando os demais quesitos.

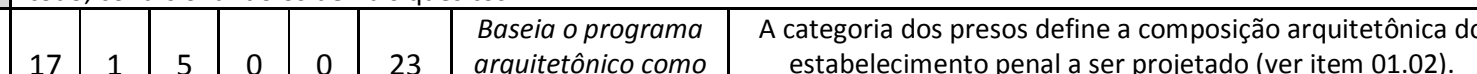

um todo

Baseia o programa $\quad$ O nível de segurança é a principal categoria (ver item 01.01). A arquitetônico como assistência e o programa de benefícios aos presos e a segurança um todo

\begin{tabular}{l|l} 
Baseia o programa & Fatores de ordem financeira e organizacional (itens $02.02 \mathrm{e}$
\end{tabular} $\begin{array}{ll}\text { arquitetônico como } & \text { 03.02). O planejamento penitenciário e a solução de segurança }\end{array}$ um todo máxima (item 01.02).

\begin{tabular}{l|l|l|l|l|l|l|}
51 & 11 & 9 & 1 & 0 & $\mathbf{7 2}$
\end{tabular}

Relaciona-se de forma mais direta com o Custo, além da Geometria e da Organização do Espaço, especialmente com as

categoria dos presos define a composição arquitetônica do

\begin{tabular}{l|l|l|l|l|l|l}
17 & 7 & 4 & 1 & 0 & 29
\end{tabular}




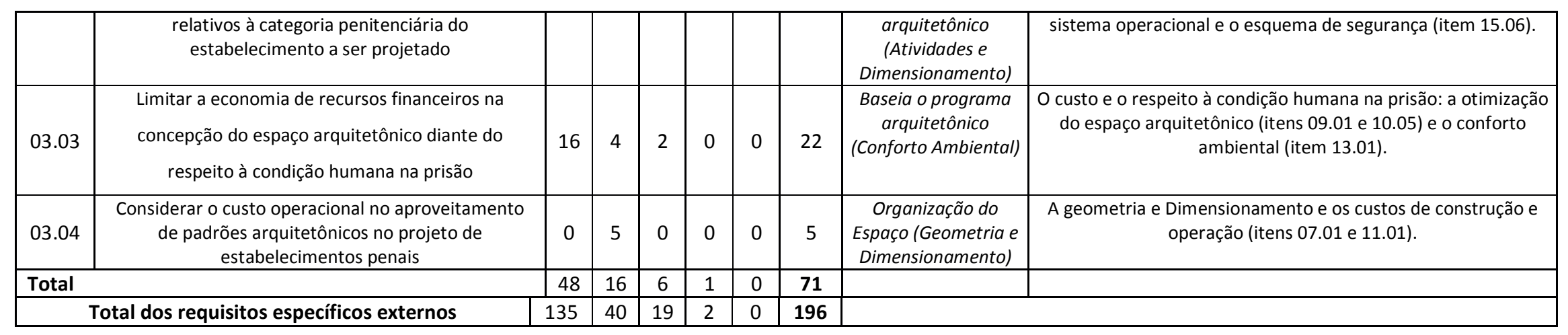

Tipos de vínculo: 01 - Requisitos externos de natureza geral; 02 - Requisitos externos específicos; 03 - Requisitos internos; 04 - Requisitos internos dos elementos centrais da edificação penal de natureza geral; 05 - Requisitos internos dos elementos centrais da edificação penal específicos

\begin{tabular}{|c|c|c|c|c|c|c|c|c|c|}
\hline \multirow{2}{*}{\multicolumn{2}{|c|}{ Requisitos Funcionais }} & \multicolumn{6}{|c|}{ Vínculos } & \multirow{2}{*}{ Vínculos gerais } & \multirow{2}{*}{ Vínculos específicos } \\
\hline & & 01 & 02 & 03 & 04 & 05 & Total & & \\
\hline 04.01 & $\begin{array}{l}\text { Configurar a impermeabilidade institucional do } \\
\text { estabelecimento penal a ser projetado, segundo o } \\
\text { nível de segurança estipulado para o mesmo }\end{array}$ & 0 & 0 & 7 & 2 & 0 & 9 & \begin{tabular}{|c|} 
Baseia o Isolamento Social, \\
(localização), além da \\
Barreira Perimetral e \\
Aparatos de Segurança \\
\end{tabular} & $\begin{array}{l}\text { A proporcionalidade entre a impermeabilidade e o nível de } \\
\text { segurança (item 14.01). O rompimento da } \\
\text { impermeabilidade pela visita aos presos (item 10.03). }\end{array}$ \\
\hline 04.02 & $\begin{array}{c}\text { Cogitar a participação da sociedade na atividade } \\
\text { prisional em função do nível de segurança definido } \\
\text { para o estabelecimento a ser projetado }\end{array}$ & 0 & 0 & 3 & 0 & 0 & 3 & Atividades & A localização e a participação popular (item 04.04) \\
\hline 04.04 & $\begin{array}{l}\text { Maximizar o isolamento social do preso por meio do } \\
\text { distanciamento do estabelecimento penal a ser } \\
\text { projetado em relação às ocupações humanas }\end{array}$ & 0 & 1 & 10 & 2 & 0 & 13 & Barreira Perimetral & $\begin{array}{l}\text { A localização e o nível de segurança (01.01). A localização } \\
\text { associada à impermeabilidade (item 16.02) e ao } \\
\text { fechamento (item 16.01). A localização e a Barreira } \\
\text { Perimetral (item 16.04), inclusive os afastamentos (item } \\
\text { 16.10). }\end{array}$ \\
\hline
\end{tabular}




\begin{tabular}{|c|c|c|c|c|c|c|c|c|c|}
\hline & $\begin{array}{l}\text { acordo com os objetivos penalógicos inerentes ao } \\
\text { tipo do estabelecimento penal a ser projetado }\end{array}$ & & & & & & & $\begin{array}{c}\text { arquitetônico da cela (item } \\
\text { 01.02) }\end{array}$ & (itens 05.04 e 17.05). \\
\hline 05.02 & $\begin{array}{l}\text { Permitir a classificação e a separação dos presos de } \\
\text { acordo com a individualização pretendida no } \\
\text { estabelecimento penal a ser projetado }\end{array}$ & 0 & 0 & 2 & 0 & 0 & 2 & Tipo de cela. & $\begin{array}{l}\text { O isolamento individual e o tipo de cela (item 05.01) e o } \\
\text { perfil dos presos (item 10.04). }\end{array}$ \\
\hline 05.03 & $\begin{array}{l}\text { Considerar diferentes tipos de cela em termos do } \\
\text { espaço interno, em função de uma provável } \\
\text { diversidade do perfil da população prisional no } \\
\text { estabelecimento penal a ser projetado } \\
\end{array}$ & 0 & 0 & 2 & 0 & 0 & 2 & Tipo de cela. & $\begin{array}{l}\text { A classificação e separação dos presos e a diversidade } \\
\text { especial das celas (item } 10.04 \text { e 17.05). }\end{array}$ \\
\hline 05.04 & $\begin{array}{c}\text { Especificar o tipo de cela consonante ao nível de } \\
\text { segurança penitenciária determinado para o } \\
\text { estabelecimento a ser projetado }\end{array}$ & 0 & 0 & 4 & 0 & 0 & 4 & $\begin{array}{l}\text { Baseia os demais itens do } \\
\text { Isolamento Individual dos } \\
\text { presos. }\end{array}$ & $\begin{array}{l}\text { A segurança penitenciária (item 01.01) e o tipo de cela. A } \\
\text { particularização das celas individuais (item 05.05). }\end{array}$ \\
\hline 05.05 & $\begin{array}{l}\text { Separar os presos submetidos à medida disciplinar } \\
\text { ou sob proteção da população prisional em geral }\end{array}$ & 0 & 0 & 4 & 0 & 0 & 4 & - & - \\
\hline 05.06 & $\begin{array}{l}\text { Compatibilizar a capacidade da cela coletiva com o } \\
\text { nível de segurança do estabelecimento penal a ser } \\
\text { projetado }\end{array}$ & 0 & 0 & 6 & 1 & 0 & 7 & $\begin{array}{l}\text { Porte e o Custo, além do } \\
\text { dimensionamento da cela. }\end{array}$ & $\begin{array}{l}\text { A segurança penitenciária e a reinserção social em relação } \\
\text { à capacidade da cela (item 05.04). A demanda por vagas } \\
\text { (item 02.02) e a carência de recursos (item 03.01) em } \\
\text { relação à maximização da capacidade da cela (item 17.07). }\end{array}$ \\
\hline \multicolumn{2}{|l|}{ Total } & 3 & 1 & 24 & 1 & 0 & 29 & & \\
\hline \multicolumn{2}{|c|}{ 06. Organização do espaço } & 14 & 2 & 0 & 0 & 0 & 16 & \multicolumn{2}{|c|}{$\begin{array}{l}\text { Relaciona-se de forma mais direta com a Espacialização, conjugando o Isolamento dos } \\
\text { presos e o Controle. }\end{array}$} \\
\hline 06.01 & $\begin{array}{c}\text { Organizar o espaço arquitetônico do } \\
\text { estabelecimento a ser projetado com base no } \\
\text { Princípio de Utilidade }\end{array}$ & 0 & 0 & 7 & 2 & 0 & 9 & \begin{tabular}{|c|} 
Baseia o programa \\
arquitetônico \\
(Espacialização)
\end{tabular} & \begin{tabular}{|c|} 
A economia de recursos (itens 03.01 e 03.02 ) e o \\
cumprimento da pena de modo humano (a boa condição \\
penitenciária) (item 01.02)
\end{tabular} \\
\hline 06.02 & $\begin{array}{l}\text { Organizar o espaço arquitetônico do } \\
\text { estabelecimento a ser projetado por meio da } \\
\text { disciplina }\end{array}$ & 0 & 0 & 5 & 2 & 0 & 7 & $\begin{array}{l}\text { Baseia o programa } \\
\text { arquitetônico } \\
\text { (Espacialização) }\end{array}$ & - \\
\hline 06.03 & $\begin{array}{l}\text { Aplicar a disciplina espacial em intensidade } \\
\text { equivalente ao nível de segurança estipulado para o } \\
\text { estabelecimento penal a ser projetado }\end{array}$ & 0 & 0 & 9 & 0 & 0 & 9 & $\begin{array}{c}\text { Baseia o programa } \\
\text { arquitetônico } \\
\text { (Espacialização e Controle) }\end{array}$ & $\begin{array}{c}\text { As características físicas e operacionais de segurança } \\
\text { máxima - a disciplina-bloco (itens 01.01 e 01.02). A } \\
\text { descaracterização e a desumanização do espaço (itens } \\
10.05 \text { e 13.01). A territorialidade com o poder dos presos } \\
\text { (item 10.02). }\end{array}$ \\
\hline \multicolumn{2}{|l|}{ Total } & 14 & 2 & 22 & 4 & 0 & 41 & & \\
\hline \multicolumn{2}{|c|}{ 7. Geometria } & 2 & 2 & 0 & 0 & 0 & 4 & \multicolumn{2}{|c|}{$\begin{array}{l}\text { Relaciona-se com o Custo e o Porte, além da Espacialização, Circulação e Conforto } \\
\text { Ambiental e, em menor intensidade, com a Funcionalidade. }\end{array}$} \\
\hline 07.01 & $\begin{array}{c}\text { Formatar a edificação de modo a garantir a } \\
\text { segurança e a operação em função do nível de } \\
\text { segurança definido para o estabelecimento a ser } \\
\text { projetado }\end{array}$ & 1 & 0 & 13 & 0 & 0 & 14 & $\begin{array}{l}\text { Barreira Perimetral, } \\
\text { Espacialização, Conforto } \\
\text { Ambiental e Controle. }\end{array}$ & \begin{tabular}{|c|} 
A forma e o arranjo dos espaços (item 10.01), buscando \\
favorecer o funcionamento (item 08.01) e o controle (itens \\
15.01 e 15.03), de modo econômico (ver item 15.06). A \\
Geometria e os padrões arquitetônicos penitenciários (item \\
03.04).
\end{tabular} \\
\hline
\end{tabular}




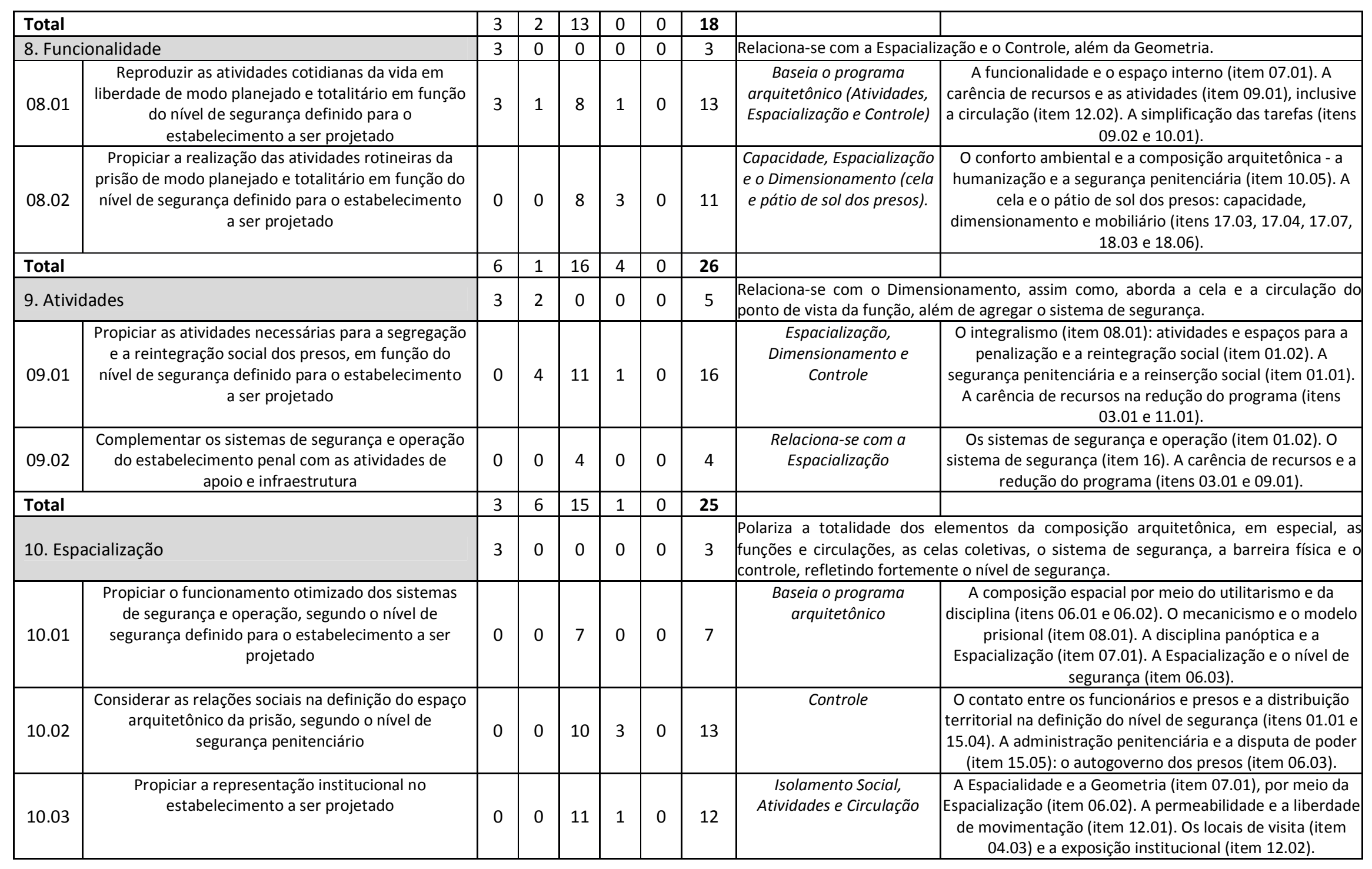




\begin{tabular}{|c|c|c|c|c|c|c|c|c|c|}
\hline 10.04 & $\begin{array}{l}\text { Permitir a classificação e a separação dos grupos de } \\
\text { presos com perfil semelhante no estabelecimento } \\
\text { penal a ser projetado }\end{array}$ & 0 & 0 & 10 & 1 & 0 & 11 & $\begin{array}{c}\text { Isolamento Individual (o tipo } \\
\text { de cela - ver item 05.01), } \\
\text { Dimensionamento e } \\
\text { Circulação }\end{array}$ & $\begin{array}{c}\text { A individualização da pena e os módulos de vivência (item } \\
\text { 05.02). A carência de recursos e a capacidade do módulo } \\
\text { de vivência (itens } 02.01 \text { e 02.02) na definição das atividades } \\
\text { do módulo (itens } 09.01 \text { e 18.02). }\end{array}$ \\
\hline 10.05 & $\begin{array}{c}\text { Equilibrar os aspectos de segurança e humanização } \\
\text { na configuração espacial, segundo o nível de } \\
\text { segurança estipulado para o estabelecimento a ser } \\
\text { projetado } \\
\end{array}$ & 0 & 1 & 7 & 4 & 0 & 12 & Conforto Ambiental & \begin{tabular}{|c|} 
A segurança e a condição humana (item 03.03) - os \\
padrões de bem estar (item 06.01) na definição da \\
Funcionalidade (item 08.01) - a redução do programa (item \\
09.01). \\
\end{tabular} \\
\hline 10.06 & $\begin{array}{c}\text { Compartilhar o espaço por mais de uma atividade, } \\
\text { condicionada pelo nível de segurança estipulado } \\
\text { para o estabelecimento a ser projetado }\end{array}$ & 0 & 0 & 8 & 0 & 0 & 8 & Atividades & $\begin{array}{c}\text { O racionalismo espacial (itens } 06.01 \text { e 06.02) e a policrestia. } \\
\text { O nível de segurança e o programa na definição da } \\
\text { capacidade operacional (item 09.01). A carência de } \\
\text { recursos e a aglomeração de funções (itens } 17.02 \text { e 18.01) } \\
\text { na ociosidade de espaços. }\end{array}$ \\
\hline \multicolumn{2}{|l|}{ Total } & 3 & 1 & 53 & 9 & 0 & 66 & & \\
\hline \multicolumn{2}{|c|}{ 11. Dimensionamento } & 3 & 3 & 0 & 0 & 0 & 6 & \multicolumn{2}{|c|}{$\begin{array}{l}\text { Relaciona-se com as funções para o dimensionamento dos espaços, incluindo a } \\
\text { circulação. }\end{array}$} \\
\hline 11.01 & $\begin{array}{l}\text { Adotar o parâmetro de área por vaga para o } \\
\text { dimensionamento do estabelecimento a ser } \\
\text { projetado, cujo valor corresponde ao nível de } \\
\text { segurança estipulado para o mesmo }\end{array}$ & 0 & 3 & 6 & 0 & 0 & 9 & \begin{tabular}{l|} 
Atividades e a \\
Espacialização
\end{tabular} & $\begin{array}{c}\text { A área construída e a capacidade em relação à categoria } \\
\text { penitenciária (item 09.01). A carência de recursos e a } \\
\text { reintegração dos presos na redução de áreas (itens } 11.02 \text { e } \\
\text { 03.01). O aumento de áreas e as questões operacionais } \\
\text { (item 10.06). }\end{array}$ \\
\hline 11.02 & $\begin{array}{l}\text { Dimensionar os espaços do estabelecimento penal a } \\
\text { ser projetado considerando o nível de segurança } \\
\text { penitenciário estipulado para o mesmo }\end{array}$ & 0 & 0 & 2 & 0 & 0 & 2 & $\begin{array}{l}\text { Atividades e a } \\
\text { Espacialização }\end{array}$ & $\begin{array}{c}\text { As áreas mínimas e o programa segundo a categoria } \\
\text { penitenciária (item 09.01). O dimensionamento e a } \\
\text { segurança em relação à operação e à economia de recursos } \\
\text { (item 10.06). }\end{array}$ \\
\hline 11.03 & $\begin{array}{c}\text { Adotar o parâmetro de área por vaga para o } \\
\text { dimensionamento do terreno do estabelecimento a } \\
\text { ser projetado, tomando valores segundo o nível de } \\
\text { segurança estipulado para o mesmo }\end{array}$ & 0 & 0 & 6 & 3 & 0 & 9 & $\begin{array}{l}\text { Isolamento Social e a } \\
\text { Barreira Perimetral }\end{array}$ & $\begin{array}{c}\text { O terreno e a capacidade em relação à redução de custos } \\
\text { (itens } 09.01 \text { e 11.01). A questão da localização (itens } 04.04 \\
\text { e 16.10). }\end{array}$ \\
\hline \multicolumn{2}{|l|}{ Total } & 3 & 6 & 14 & 3 & 0 & 26 & & \\
\hline \multicolumn{2}{|c|}{ 12. Circulação } & 2 & 0 & 0 & 0 & 0 & 2 & \multicolumn{2}{|c|}{$\begin{array}{l}\text { Relaciona-se com as funções e o controle interno, assim como, com o sistema de } \\
\text { segurança e o dimensionamento. }\end{array}$} \\
\hline 12.01 & $\begin{array}{l}\text { Considerar a circulação como elemento e agente da } \\
\text { espacialização, integrando a definição da } \\
\text { composição do espaço arquitetônico da prisão }\end{array}$ & 0 & 0 & 11 & 0 & 0 & 11 & $\begin{array}{l}\text { Geometria, Espacialização e } \\
\text { Controle }\end{array}$ & \begin{tabular}{|c|} 
A circulação e a Espacialização, em termos da \\
Funcionalidade (item 10.01), da Geometria (item 07.01) e \\
do esquema topológico (item 10.03). O padrão \\
arquitetônico modular (ver item 10.04) e a acessibilidade \\
no setor intermediário (item 10.02). O sistema de \\
segurança (item 15.01) e o procedimento de condução de \\
presos (item 15.04) na internalização de atividades (item \\
15.05).
\end{tabular} \\
\hline
\end{tabular}




\begin{tabular}{|c|c|c|c|c|c|c|c|c|c|}
\hline 12.02 & $\begin{array}{c}\text { Configurar as circulações de acordo com o nível de } \\
\text { segurança penitenciário do estabelecimento penal a } \\
\text { ser projetado }\end{array}$ & 0 & 0 & 6 & 0 & 0 & 6 & \begin{tabular}{|c|}
$\begin{array}{c}\text { Geometria, Espacialização e } \\
\text { Controle }\end{array}$ \\
\end{tabular} & \begin{tabular}{|c} 
A circulação (distâncias) na disposição dos locais - o padrão \\
arquitetônico penitenciário (itens 07.01 e 10.01). O \\
$\begin{array}{c}\text { aumento do percurso das visitas (item 10.02). A redução de } \\
\text { custos e a minimização das áreas de circulação (item } \\
11.01 \text { ). }\end{array}$ \\
\end{tabular} \\
\hline 12.04 & $\begin{array}{l}\text { Permitir a evacuação dos funcionários em casos de } \\
\text { crise }\end{array}$ & 0 & 0 & 2 & 0 & 0 & 2 & Controle & $\begin{array}{l}\text { Integridade dos funcionários e a evacuação em situações } \\
\text { de crise (item 15.04). }\end{array}$ \\
\hline 13.01 & $\begin{array}{l}\text { Considerar o conforto ambiental em todos os } \\
\text { espaços internos da edificação, priorizando a } \\
\text { iluminação e a ventilação, por meio de aberturas } \\
\text { configuradas segundo o nível de segurança do } \\
\text { estabelecimento penal a ser projetado }\end{array}$ & 0 & 1 & 7 & 3 & 0 & 11 & \begin{tabular}{c|}
$\begin{array}{c}\text { Espacialização e Aparatos } \\
\text { de Segurança }\end{array}$ \\
\end{tabular} & \begin{tabular}{|c|} 
O Conforto Ambiental e a Cela (item 17.08) e as questões \\
de segurança e operaçãa (ver item 10.05) - as aberturas de \\
iluminação e ventilação (item 14.01). O partido \\
arquitetônico e o nível de segurança (item 03.03).
\end{tabular} \\
\hline 13.02 & $\begin{array}{l}\text { Considerar a geometria da edificação penal na } \\
\text { definição do conforto ambiental }\end{array}$ & 0 & 0 & 5 & 0 & 0 & 5 & \begin{tabular}{|c|} 
Localização, a Geometria e \\
os afastamentos e recuos da \\
Barreira Perimetral. \\
\end{tabular} & \begin{tabular}{|c|} 
A Geometria e o Conforto Ambiental - espaços livres \\
adjacentes e fachadas (item 07.01). As áreas verdes e a \\
segurança (item 16.10). O terreno e a Geometria - taxa de \\
ocupação (ver item 04.04).
\end{tabular} \\
\hline 14.01 & $\begin{array}{c}\text { Equalizar o sistema de segurança do } \\
\text { estabelecimento penal a ser projetado, segundo o } \\
\text { nível de segurança penitenciário estipulado para o } \\
\text { mesmo }\end{array}$ & 0 & 0 & 13 & 2 & 0 & 15 & \begin{tabular}{|c|} 
Programa arquitetônico, \\
especialmente com os \\
elementos centrais
\end{tabular} & \begin{tabular}{|l} 
O sistema de segurança e a impermeabilidade (itens 04.01 \\
e 16.02), a estanqueidade (item 16.01), a inexpugnidade \\
(item 16.03) e a disciplina interna (item 06.03). A \\
integridade dos funcionários (item 15.04). A carência de \\
recursos e a especificação de aparatos (itens 16.04 e 16.08) \\
- celas e pátios de sol dos presos (itens 17.09 e 18.11).
\end{tabular} \\
\hline 14.02 & $\begin{array}{c}\text { Disciplinar a acessibilidade e a mobilidade das } \\
\text { pessoas nos espaços abertos do estabelecimento } \\
\text { penal a ser projetado }\end{array}$ & 0 & 0 & 3 & 0 & 0 & 3 & Espacialização & $\begin{array}{c}\text { A Espacialização e a demarcação dos locais (item 10.03). As } \\
\text { áreas abertas (item 16.10) e os contrabandos e } \\
\text { comunicação dos presos. }\end{array}$ \\
\hline \multicolumn{2}{|l|}{ Total } & 2 & 0 & 16 & 2 & 0 & 20 & & \\
\hline 15. Cont & role & 3 & 0 & 0 & 0 & 0 & 3 & \multicolumn{2}{|c|}{$\begin{array}{l}\text { É definido pelo nível de segurança e relaciona-se diretamente com a Organização do } \\
\text { Espaço. O controle externo e o interno se interrelacionam. O controle externo relaciona- } \\
\text { se fortemente com a Barreira Perimetral, o Aparato de Segurança e a Geometria. O } \\
\text { controle interno relaciona-se com a Organização do Espaço e o Aparato de Segurança. }\end{array}$} \\
\hline
\end{tabular}




\begin{tabular}{|c|c|c|c|c|c|c|c|c|c|}
\hline 15.01 & $\begin{array}{c}\text { Vigiar as pessoas nos espaços internos do } \\
\text { estabelecimento penal a ser projetado, segundo o } \\
\text { nível de segurança penitenciário estipulado para o } \\
\text { mesmo }\end{array}$ & 0 & 0 & 7 & 3 & 0 & 10 & $\begin{array}{l}\text { Baseia o programa } \\
\text { arquitetônico } \\
\text { (Espacialização) }\end{array}$ & $\begin{array}{l}\text { O controle e a disciplina (06.02), por meio da vigiância. O } \\
\text { empoderamento dos presos e as indisciplinas internas } \\
\text { (item 10.02). }\end{array}$ \\
\hline 15.02 & $\begin{array}{l}\text { Interiorizar a individualidade disciplinar segundo o } \\
\text { nível de segurança penitenciário estipulado para o } \\
\text { estabelecimento penal a ser projetado }\end{array}$ & 0 & 0 & 4 & 1 & 0 & 5 & $\begin{array}{c}\text { Baseia o programa } \\
\text { arquitetônico (Posto de } \\
\text { Controle) }\end{array}$ & $\begin{array}{l}\text { A inversão na vigilância (ver item 17.10) e a } \\
\text { inverificabilidade do trabalho dos funcionários (item 10.03) }\end{array}$ \\
\hline 15.03 & $\begin{array}{c}\text { Monitorar as áreas e elementos externos do } \\
\text { estabelecimento penal a ser projetado segundo o } \\
\text { nível de segurança penitenciário estipulado para o } \\
\text { mesmo }\end{array}$ & 0 & 0 & 7 & 1 & 1 & 9 & $\begin{array}{l}\text { Barreira Perimetral e a } \\
\quad \text { Geometria }\end{array}$ & $\begin{array}{l}\text { A vigilância externa e o isolamento social (itens } 16.01 \text { e } \\
\text { 16.03). A vigilância externa e o princípio de vigilância } \\
\text { panóptico (item 15.02). A maximização do monitoramento } \\
\text { e a economia dos recursos (item 16.05). }\end{array}$ \\
\hline 15.04 & $\begin{array}{c}\text { Garantir a integridade dos funcionários } \\
\text { encarregados da vigilância externa e interna }\end{array}$ & 0 & 0 & 5 & 2 & 0 & 7 & Posto de Controle & $\begin{array}{c}\text { O risco dos funcionários (ver itens } 12.01 \text { e } 15.05) \text {. O } \\
\text { excedente de presos e a carência de recursos humanos (ver } \\
\text { item 19.05). }\end{array}$ \\
\hline 15.05 & $\begin{array}{c}\begin{array}{c}\text { Controlar os fluxos no estabelecimento penal a ser } \\
\text { projetado }\end{array} \\
\end{array}$ & 0 & 0 & 5 & 0 & 0 & 5 & $\begin{array}{c}\text { Geometria, Espacialização e } \\
\text { Circulaçẫo }\end{array}$ & $\begin{array}{l}\text { A espacialização e o controle (item 12.01). A carência de } \\
\text { recursos para a operação (item 15.01). }\end{array}$ \\
\hline 15.06 & $\begin{array}{c}\text { Quantificar o número de postos de controle do } \\
\text { estabelecimento penal a ser projetado de acordo } \\
\text { com a capacidade operacional e o nível de segurança } \\
\text { penitenciário estipulados para o mesmo }\end{array}$ & 0 & 1 & 4 & 2 & 0 & 7 & Espacialização e Circulação & $\begin{array}{l}\text { A postura penalógica da administração (item 10.02) e o } \\
\text { arranjo das atividades em relação aos postos de controle. }\end{array}$ \\
\hline 15.07 & $\begin{array}{l}\text { Considerar a estrutura social e as relações de poder } \\
\text { na configuração do controle, segundo o nível de } \\
\text { segurança penitenciário estipulado no } \\
\text { estabelecimento penal a ser projetado }\end{array}$ & 0 & 0 & 4 & 0 & 0 & 4 & Espacialização e Circulação & $\begin{array}{l}\text { A postura penalógica da administração (item 10.02) } \\
\text { determina a inclusão de postos em áreas internas. A } \\
\text { inversão na vigilância (ver item 17.10). }\end{array}$ \\
\hline \multicolumn{2}{|l|}{ Total } & 3 & 1 & 36 & 9 & 1 & 50 & & \\
\hline \multicolumn{2}{|c|}{ Total dos requisitos específicos internos } & 33 & 22 & 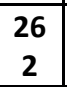 & 41 & 1 & 359 & & \\
\hline \multicolumn{10}{|c|}{$\begin{array}{l}\text { Tipos de vínculo: } 01 \text { - Requisitos externos de natureza geral; } 02 \text { - Requisitos externos específicos; } 03 \text { - Requisitos internos; } 04 \text { - Requisitos internos dos elementos centrais } \\
\text { da edificação penal de natureza geral; } 05 \text { - Requisitos internos dos elementos centrais da edificação penal específicos }\end{array}$} \\
\hline \multirow{2}{*}{\multicolumn{2}{|c|}{ Requisitos Funcionais }} & \multicolumn{5}{|c|}{ Vínculos } & & Vínculos gera & Vínculos específicos \\
\hline & & 01 & 02 & 03 & 04 & 05 & Iotal & & \\
\hline \multicolumn{2}{|c|}{ 16. Barreira perimetral } & 3 & 0 & 0 & 0 & 0 & 3 & \multicolumn{2}{|c|}{$\begin{array}{l}\text { É definida essencialmente pelo nível de segurança, repercutindo no custo de construção } \\
\text { e interage diretamente com o Controle e o Aparato de Segurança. }\end{array}$} \\
\hline 16.01 & $\begin{array}{c}\text { Impedir a evasão de presos da prisão: garantir a } \\
\text { estanqueidade do estabelecimento penal a ser } \\
\text { projetado }\end{array}$ & 0 & 0 & 3 & 6 & 2 & 11 & \begin{tabular}{|c|} 
Isolamento Social e o \\
Controle
\end{tabular} & $\begin{array}{l}\text { A barreira perimetral e a segregação social do preso (item } \\
\text { 04.01). A carência de recursos para a operação e a } \\
\text { contenção dos presos (itens } 10.02 \text { e 15.03). }\end{array}$ \\
\hline 16.02 & $\begin{array}{l}\text { Romper com a comunicação informal entre os } \\
\text { presos e o mundo externo à prisão: garantir a } \\
\text { impermeabilidade do estabelecimento penal a ser }\end{array}$ & 0 & 0 & 2 & 4 & 1 & 7 & $\begin{array}{l}\text { Isolamento Social e o } \\
\text { Dimensionamento }\end{array}$ & $\begin{array}{l}\text { O isolamento e a disciplina: a impermeabilidade (itens } \\
04.01 \text { ). A questão da localização ou da implantação (itens } \\
04.04 \text { e } 11.03 \text { ). }\end{array}$ \\
\hline
\end{tabular}




\begin{tabular}{|c|c|c|c|c|c|c|c|c|c|}
\hline & projetado & & & & & & & & \\
\hline 16.03 & $\begin{array}{c}\text { Proteger a prisão contra ataques externos: garantir a } \\
\text { inexpugnidade do estabelecimento penal a ser } \\
\text { projetado }\end{array}$ & 0 & 0 & 2 & 3 & 2 & 7 & Isolamento Social & $\begin{array}{l}\text { A barreira perimetral e a invasão do estabelecimento (item } \\
\text { 16.01). }\end{array}$ \\
\hline 16.04 & $\begin{array}{c}\text { Especificar a barreira perimetral do estabelecimento } \\
\text { penal a ser projetado segundo o nível de segurança } \\
\text { estipulado }\end{array}$ & 0 & 0 & 2 & 2 & 2 & 6 & $\begin{array}{l}\text { Custo, Isolamento Social e } \\
\text { Dimensionamento }\end{array}$ & \begin{tabular}{|c|} 
O tipo de barreira e as características de estanqueidade \\
(item 16.01), impermeabilidade (item 16.02) e \\
inexpugnidade (item 16.03), associadas ao nível de \\
segurança. A locação (item 04.04) e o terreno (item 11.03) \\
em relação ao custo (item 03.01). \\
\end{tabular} \\
\hline 16.05 & $\begin{array}{l}\text { Conceber a geometria da barreira perimetral de } \\
\text { modo econômico, funcional e eficiente do ponto de } \\
\text { vista do controle (vigilância) }\end{array}$ & 0 & 0 & 1 & 4 & 2 & 7 & Geometria e Controle & $\begin{array}{c}\text { A geometria da barreira e a disciplina espacial, a } \\
\text { funcionalidade (item 08.01) e o controle (item 15.03). A } \\
\text { locação (item 04.04) e o terreno (item 11.03). A carência } \\
\text { de pessoal (item 15.06). }\end{array}$ \\
\hline 16.06 & $\begin{array}{l}\text { Dimensionar a altura da barreira perimetral do } \\
\text { estabelecimento penal a ser projetado segundo o } \\
\text { nível de segurança estipulado para o mesmo }\end{array}$ & 0 & 0 & 0 & 2 & 3 & 5 & $\begin{array}{l}\text { Custo, Isolamento Social e } \\
\text { Dimensionamento }\end{array}$ & $\begin{array}{l}\text { A altura da barreira e o nível de segurança - a imagem } \\
\text { institucional (item 04.04). O custo de construção (item } \\
\text { 03.01). }\end{array}$ \\
\hline 16.07 & Promover a circulação protegida da guarda externa & 0 & 0 & 0 & 1 & 0 & 1 & Geometria e Controle & $\begin{array}{c}\text { A circulação da guarda externa (item 16.11). Os acessos às } \\
\text { torres de vigilância (item 16.05). }\end{array}$ \\
\hline 16.08 & $\begin{array}{c}\text { Reforçar a barreira perimetral do estabelecimento } \\
\text { penal a ser projetado por meio de aparatos de } \\
\text { segurança, segundo o nível de segurança estipulado } \\
\text { para o mesmo }\end{array}$ & 0 & 0 & 1 & 2 & 1 & 4 & Custo & $\begin{array}{l}\text { A barreira perimetral e os aparatos de segurança (itens } \\
16.02 \text { e 16.03). }\end{array}$ \\
\hline 16.09 & $\begin{array}{c}\text { Considerar a linha de tiro para o estabelecimento } \\
\text { penal a ser projetado, segundo o nível de segurança } \\
\text { estipulado para o mesmo }\end{array}$ & 0 & 0 & 0 & 0 & 1 & 1 & Controle (item 15.03) & - \\
\hline 16.10 & $\begin{array}{l}\text { Reforçar a estanqueidade da barreira perimetral do } \\
\text { estabelecimento penal a ser projetado por meio dos } \\
\text { afastamentos entre a mesma e as edificações, } \\
\text { segundo o nível de segurança estipulado } \\
\end{array}$ & 0 & 0 & 4 & 3 & 2 & 9 & \begin{tabular}{|c|} 
Localização, \\
Dimensionamento, Conforto \\
Ambiental e Controle.
\end{tabular} & \begin{tabular}{|c|} 
Os afastamentos e a estanqueidade (item 16.01) e a \\
impermeabilidade (item 16.02). O terreno (item 11.03) e o \\
custo de construção (item 13.03).
\end{tabular} \\
\hline 16.11 & $\begin{array}{c}\text { Considerar a pista de ronda para o estabelecimento } \\
\text { penal a ser projetado, segundo o nível de segurança } \\
\text { estipulado }\end{array}$ & 0 & 0 & 0 & 1 & 1 & 2 & Controle & A pista de ronda e a circulação dos guardas (item 16.07). \\
\hline \multicolumn{2}{|l|}{ Total } & 3 & 0 & 15 & 28 & 17 & 63 & & \\
\hline \multirow{2}{*}{\multicolumn{2}{|c|}{ Requisitos funcionais }} & \multicolumn{5}{|c|}{ Vínculos } & Totais & \multirow{2}{*}{ Vínculos gerais } & \multirow{2}{*}{ Vínculos específicos } \\
\hline & & 01 & 02 & 03 & 04 & 05 & & & \\
\hline \multicolumn{2}{|c|}{ 17. Cela } & 3 & 0 & 0 & 0 & 0 & 3 & \multicolumn{2}{|c|}{$\begin{array}{l}\text { É definida essencialmente pelo nível de segurança. Relaciona-se com o Porte e o Custo } \\
\text { do estabelecimento. Reproduz os quesitos da Organização do Espaço. }\end{array}$} \\
\hline 17.01 & $\begin{array}{l}\text { Favorecer o monitoramento do interior da cela por } \\
\text { meio da geometria, segundo o nível de segurança do } \\
\text { estabelecimento penal a ser projetado }\end{array}$ & 0 & 0 & 2 & 3 & 2 & 7 & Geometria e Controle & $\begin{array}{c}\text { A forma da cela e a eficiência e a economia de recursos } \\
\text { (item 06.01). A Geometria e a visualização e os } \\
\text { procedimentos de segurança (itens } 17.10 \text { e 17.11). }\end{array}$ \\
\hline
\end{tabular}




\begin{tabular}{|c|c|c|c|c|c|c|c|c|c|}
\hline 17.02 & Alojar os presos para o descanso diário & 0 & 0 & 1 & 5 & 1 & 7 & Atividades & A composição da cela (itens $17.03,17.04$ e 17.05). \\
\hline 17.03 & Proporcionar a higiene pessoal dos presos & 0 & 0 & 1 & 2 & 1 & 4 & Conforto Ambiental & O chuveiro na cela e a salubridade (itens 13.02 e 17.08 ). \\
\hline 17.07 & $\begin{array}{c}\text { Dimensionar a cela de acordo com a capacidade } \\
\text { estipulada e segundo o nível de segurança do } \\
\text { estabelecimento penal a ser projetado. }\end{array}$ & 0 & 0 & 3 & 4 & 1 & 8 & Custo & $\begin{array}{l}\text { A área mínima da cela (ver item 17.05) e o nível de } \\
\text { segurança (item 10.05 e 13.02). O custo de construção e as } \\
\text { áreas das celas (item 11.02). } \\
\end{array}$ \\
\hline 17.08 & $\begin{array}{c}\text { Condicionar ambientalmente a cela, principalmente } \\
\text { em termos da ventilação e iluminação, segundo o } \\
\text { nível de segurança do estabelecimento penal a ser } \\
\text { projetado. }\end{array}$ & 0 & 0 & 1 & 5 & 1 & 7 & Conforto Ambiental & $\begin{array}{l}\text { A salubridade e a ventilação e iluminação (item 13.01). A } \\
\text { qualidade do ar e o uso do vaso sanitário e do banho (item } \\
\text { 17.03). As aberturas de iluminação e ventilação das celas } \\
\text { (item } 17.09,17.02 \text { e 17.05). }\end{array}$ \\
\hline 17.10 & $\begin{array}{c}\text { Definir a abertura ou fechamento da cela de acordo } \\
\text { com a visualização do interior pretendida, segundo o } \\
\text { nível de segurança estipulado para estabelecimento } \\
\text { penal a ser projetado }\end{array}$ & 0 & 0 & 2 & 4 & 1 & 7 & Controle & $\begin{array}{l}\text { A visibilidade do interior da cela (item 15.01) e a relação de } \\
\text { poder (item 17.06). O fechamento da cela (item 15.01). }\end{array}$ \\
\hline 17.11 & $\begin{array}{l}\text { Permitir a visualização do interior da cela, segundo o } \\
\text { nível de segurança estipulado para estabelecimento } \\
\text { penal a ser projetado }\end{array}$ & 0 & 0 & 0 & 5 & 2 & 7 & Espacialização e o Controle & $\begin{array}{c}\text { A visualização do interior da cela em relação à geometria, à } \\
\text { especificação dos elementos e a configuração do espaço } \\
\text { interno (itens 17.01, 17.04 e 17.05). A visualização e o nível } \\
\text { de segurança (item 17.10). }\end{array}$ \\
\hline \multicolumn{2}{|l|}{ Total } & 3 & 0 & 14 & 41 & 15 & 73 & & \\
\hline \multirow{2}{*}{\multicolumn{2}{|c|}{ Requisitos funcionais }} & \multicolumn{5}{|c|}{ Vínculos } & Total & \multirow{2}{*}{ Vínculos gerais } & \multirow{2}{*}{ Vínculos específicos } \\
\hline & & 01 & 02 & 03 & 04 & 05 & Total & & \\
\hline \multicolumn{2}{|c|}{ 18. Pátio de sol dos presos } & 3 & 0 & 0 & 0 & 0 & 3 & \multirow{2}{*}{\multicolumn{2}{|c|}{$\begin{array}{l}\text { É definido essencialmente pelo nível de segurança. Relaciona-se com o Porte e o Custo } \\
\text { do estabelecimento. Reproduz os quesitos da Organização do Espaço. }\end{array}$}} \\
\hline 18.01 & Propiciar o banho de sol dos presos, segundo o nível & 0 & 0 & 1 & 7 & 1 & 9 & \begin{tabular}{|l|} 
Atividades \\
\end{tabular} & \\
\hline
\end{tabular}




\begin{tabular}{|c|c|c|c|c|c|c|c|c|c|}
\hline & $\begin{array}{l}\text { de segurança estipulado para estabelecimento penal } \\
\text { a ser projetado }\end{array}$ & & & & & & & & $\begin{array}{l}\text { 17.02). As atividades formais e informais (item 09.01). A } \\
\text { visita social aos presos e o pátio de sol (item 10.03). }\end{array}$ \\
\hline 18.02 & $\begin{array}{c}\text { Separar os diferentes perfis de presos para o banho } \\
\text { de sol }\end{array}$ & 0 & 0 & 1 & 1 & 4 & 6 & Custo e a Espacialização & $\begin{array}{l}\text { A classificação e a separação dos presos em relação aos } \\
\text { pátios de sol dos presos (ver item 10.04). }\end{array}$ \\
\hline 18.03 & $\begin{array}{l}\text { Compatibilizar a capacidade do pátio de sol com o } \\
\text { nível de segurança do estabelecimento penal a ser } \\
\text { projetado }\end{array}$ & 0 & 0 & 1 & 3 & 3 & 7 & $\begin{array}{c}\text { Porte, Custo e } \\
\text { Dimensionamento }\end{array}$ & $\begin{array}{l}\text { A capacidade de celas e alas carcerárias em relação à } \\
\text { capacidade dos pátios de sol (itens } 05.06,10.04 \text { e 18.09). }\end{array}$ \\
\hline 18.04 & $\begin{array}{l}\text { Favorecer a disciplina e o monitoramento do pátio } \\
\text { de sol por meio da geometria, segundo o nível de } \\
\text { segurança do estabelecimento penal a ser projetado }\end{array}$ & 0 & 0 & 0 & 2 & 0 & 2 & Geometria e Controle & $\begin{array}{l}\text { A geometria dos pátios de sol e a eficiência e a economia } \\
\text { de recursos (item 06.01). A forma dos pátios e o nível de } \\
\text { segurança penitenciário - a visualização e os } \\
\text { procedimentos de segurança (item 18.12). }\end{array}$ \\
\hline 18.06 & $\begin{array}{l}\text { Proporcionar condições de permanência dos presos } \\
\text { no pátio do ponto de vista do conforto e serviços }\end{array}$ & 0 & 0 & 1 & 3 & 3 & 7 & \begin{tabular}{|l|} 
Espacialização, Aparatos de \\
Segurança e Controle
\end{tabular} & $\begin{array}{c}\text { As atividades extraordinárias no pátio e o mobiliário (ver } \\
\text { item 18.01A segurança e a redução de custos de } \\
\text { construção em relação ao conforto (ver item 18.10). }\end{array}$ \\
\hline 18.07 & $\begin{array}{l}\text { Considerar cantina ou área conexa ao pátio para a } \\
\text { distribuição de refeições, segundo o nível de } \\
\text { segurança do estabelecimento penal a ser projetado }\end{array}$ & 0 & 0 & 0 & 1 & 1 & 2 & Atividades & A cantina e o pátio de sol dos presos (ver item 18.01). \\
\hline 18.09 & $\begin{array}{c}\text { Dimensionar o pátio de acordo com a capacidade e } \\
\text { segundo o nível de segurança do estabelecimento } \\
\text { penal a ser projetado }\end{array}$ & 0 & 0 & 0 & 4 & 1 & 5 & Custo & $\begin{array}{l}\text { O dimensionamento do pátio de sol e o nível de segurança } \\
\text { penitenciário (item 13.02). A capacidade do pátio (itens } \\
11.02 \mathrm{e} 18.03 \text { ). }\end{array}$ \\
\hline 18.10 & $\begin{array}{c}\text { Condicionar ambientalmente o pátio, principalmente } \\
\text { em termos da ventilação e iluminação, segundo o } \\
\text { nível de segurança do estabelecimento penal a ser } \\
\text { projetado }\end{array}$ & 0 & 0 & 0 & 2 & 1 & 3 & Conforto Ambiental & $\begin{array}{l}\text { O Conforto Ambiental (item 13.01) e o nível de segurança } \\
\text { penitenciário (item 10.05). O uso do espaço e a circulação } \\
\text { do ar e a distribuição da luz (item 18.01). }\end{array}$ \\
\hline 18.11 & $\begin{array}{l}\text { Reforçar as propriedades de segurança do pátio por } \\
\text { meio de aparatos, segundo o nível de segurança } \\
\text { estipulado para estabelecimento penal a ser } \\
\text { projetado }\end{array}$ & 0 & 0 & 1 & 3 & 2 & 6 & $\begin{array}{c}\text { Funcionalidade e o Conforto } \\
\text { Ambiental }\end{array}$ & $\begin{array}{l}\text { Os elementos arquitetônicos do pátio do sol e o nível de } \\
\text { segurança (item } 14.01 \text { e item 18.06). A segurança e o } \\
\text { conforto e a funcionalidade do pátio (item 10.05). }\end{array}$ \\
\hline 18.12 & $\begin{array}{l}\text { Permitir a visualização do interior do pátio, segundo } \\
\text { o nível de segurança estipulado para } \\
\text { estabelecimento penal a ser projetado }\end{array}$ & 0 & 0 & 0 & 7 & 2 & 9 & Espacialização e o Controle & $\begin{array}{l}\text { O controle e a vigilância, a interiorização da individualidade } \\
\text { disciplinar e a garantia da integridade física dos } \\
\text { funcionários (itens } 15.01,15.02 \text { e } 15.04) \text {. O domínio } \\
\text { territorial, a capacidade e as atividades em relação à }\end{array}$ \\
\hline
\end{tabular}




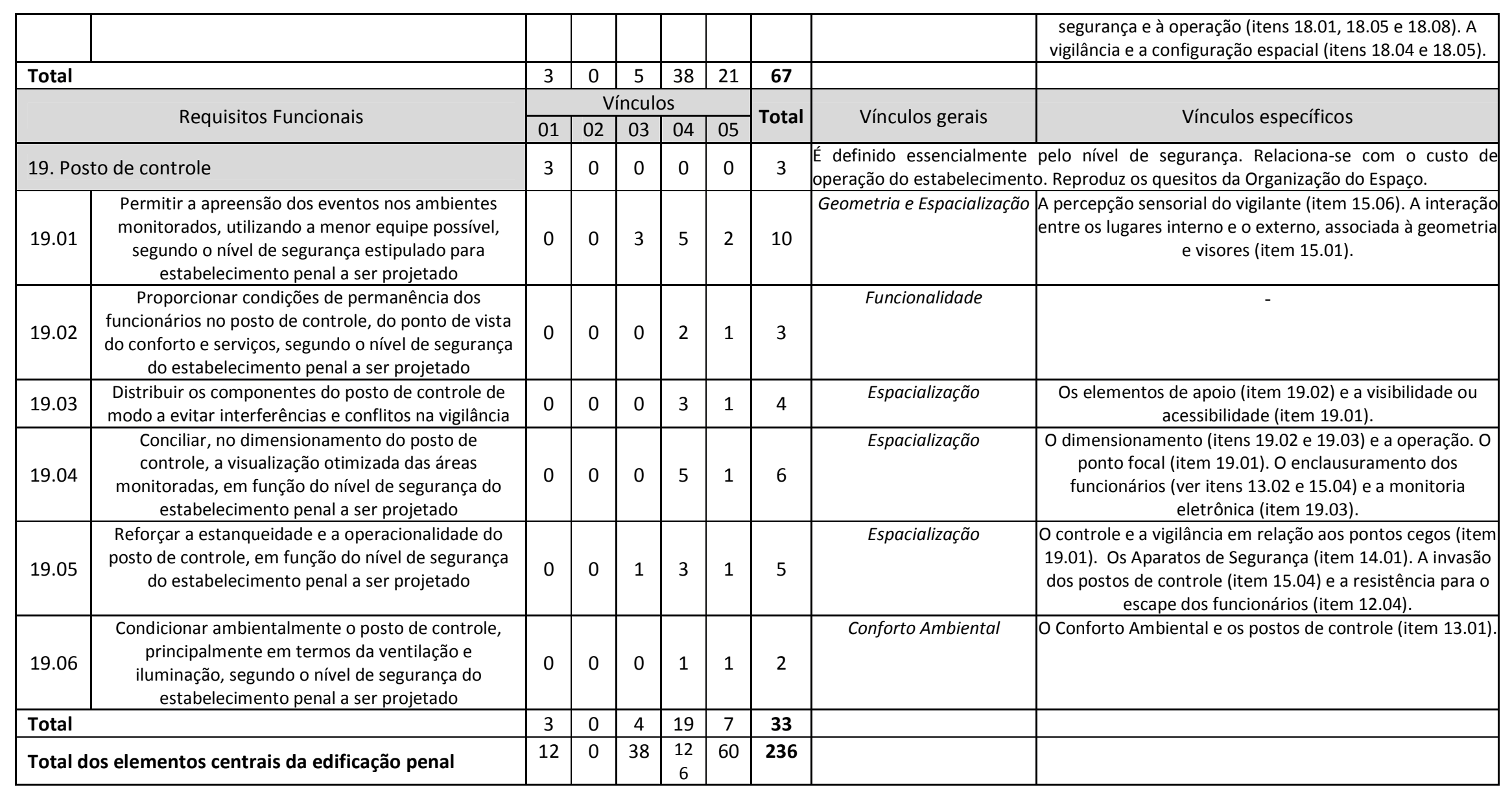




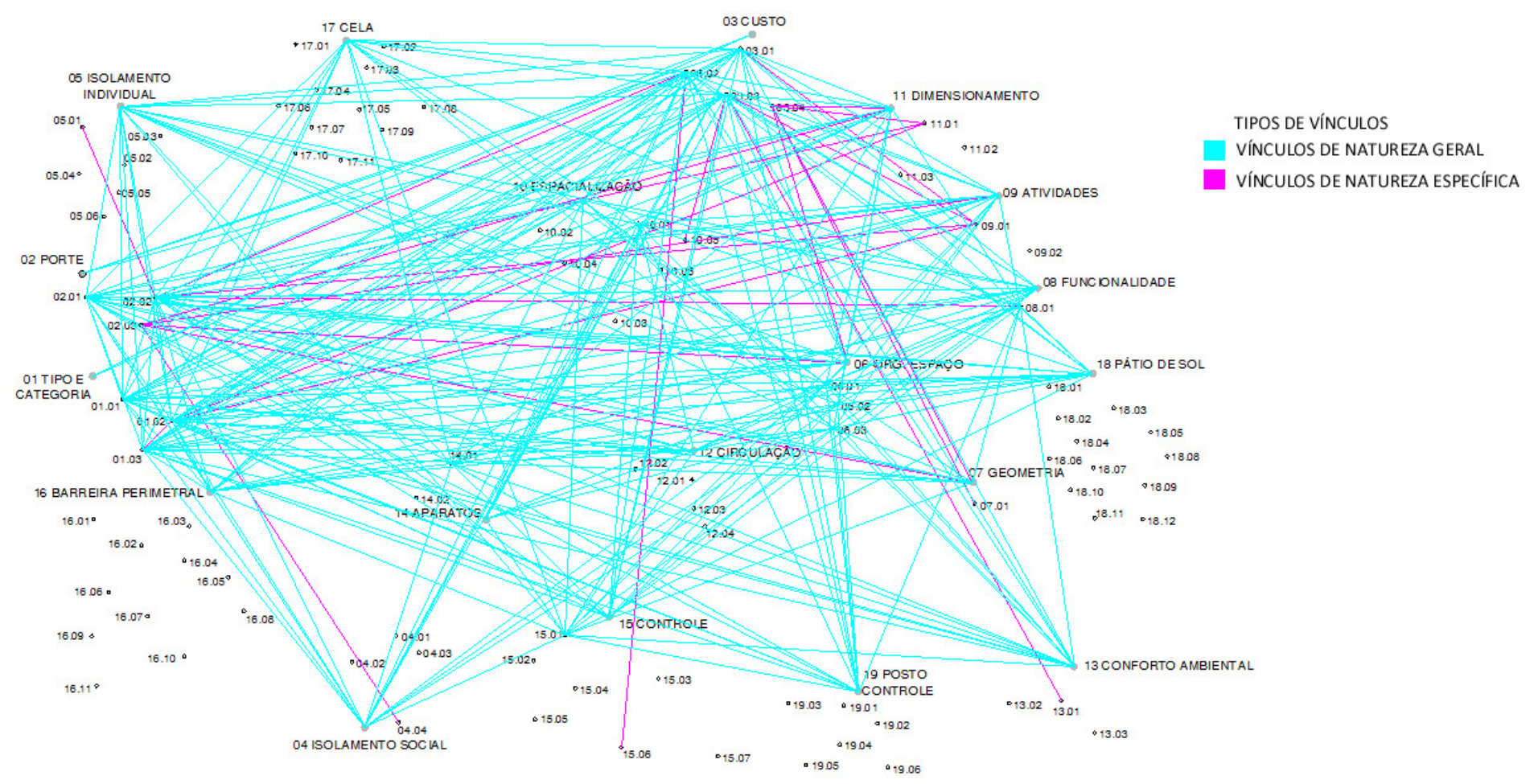

Figura 72 - Representação formal dos vínculos dos requisitos funcionais de ordem externa do programa arquitetônico para estabelecimentos penais 


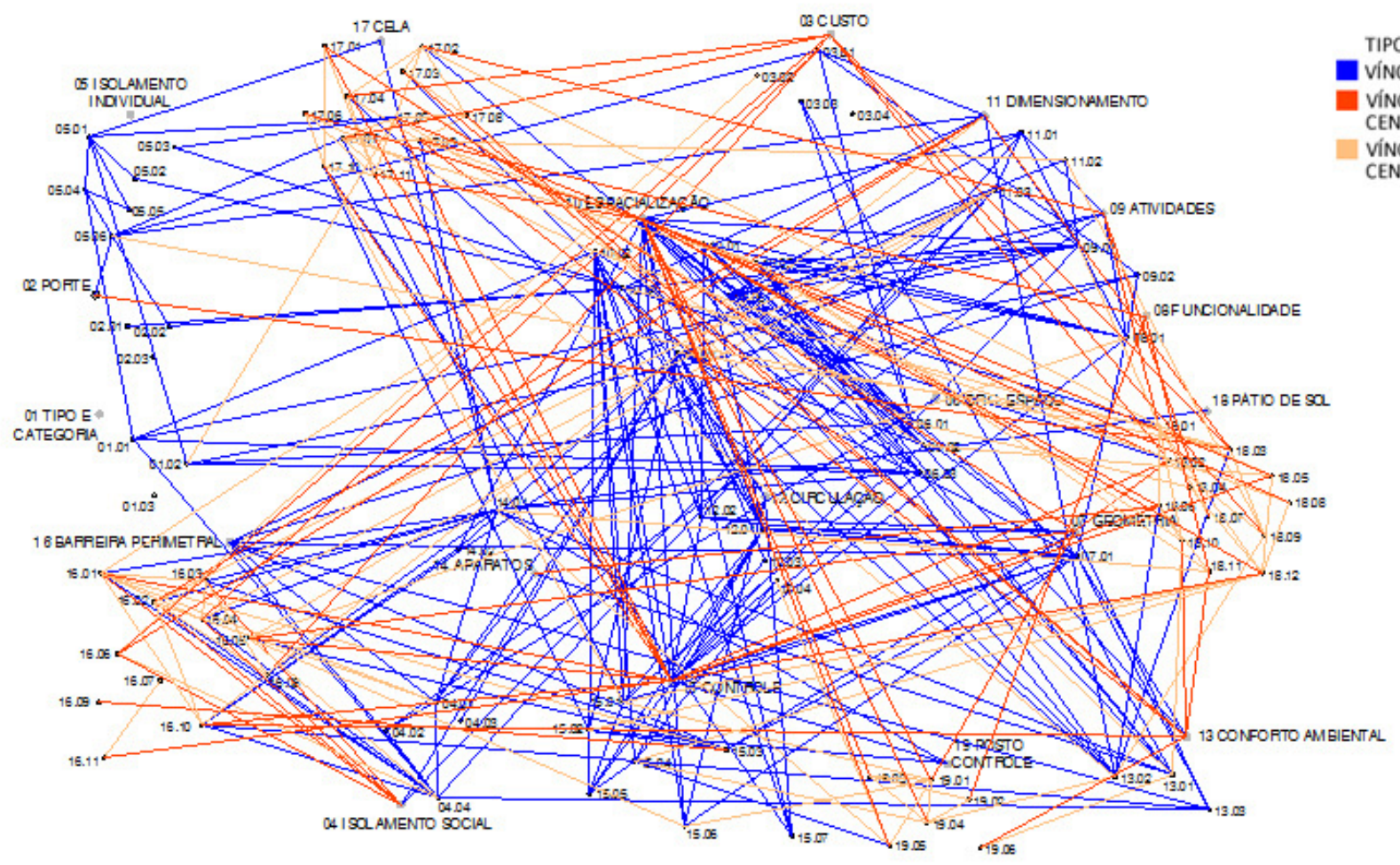

IPOS DE VINCULO:

VÍNCULOS REQUISTIOS INIERNOS

VINCULOS REQUISTIOS ELEMENTOS

CENTRAIS DE NATUREZA ESPECIFICA

Figura 73 - Representação formal dos vínculos dos requisitos funcionais de ordem interna do programa arquitetônico para estabelecimentos penais 


\section{Apêndice E - Análise das instancias formal e informal}

Neste apêndice é exposta a análise comparada entre as características formais e informais da edificação penal, segundo os requisitos funcionais levantados no Capítulo 6. Esta análise trouxe a avaliação da convergência entre as características comparadas e das características mais ajustadas para compor a tecnologia de projeto.

A primeira análise visou estabelecer a correspondência entre as características formais e informais (Tabela 20). Esta correspondência se deu em dois níveis: ao nível de cada requisito funcional e ao nível dos grupos de quesitos. A correlação entre as instancias analíticas foi consubstanciada por meio da seguinte classificação:

- Convergência plena (CP): as características se equivalem.

- Convergência parcial (CPA): as características apresentam uma maioria de elementos comuns.

- Divergência parcial (DPA): as características apresentam uma maioria de elementos dissonantes.

- Divergência plena (DP): as características destoam na sua totalidade.

A análise comparativa lançou mão dos projetos de referência desta pesquisa (Apêndice A) para caracterizar a edificação penal e, por meio dela, determinar a correlação do espaço arquitetônico existente com as demandas formais (Tabela 21). Para cada projeto de referência, os requisitos funcionais foram examinados para determinar esta correspondência. De modo a distinguir as convergências e divergências foi adotado um padrão de cores: as convergências são verdes e as divergências são vermelhas.

$\mathrm{Na}$ segunda análise, a indicação de um componente formal ou informal para a composição arquitetônica foi determinada pelo melhor desempenho em cada critério. Cada requisito funcional recebeu uma classificação. A classificação dos itens ocorreu atribuindo a eles um dos três possíveis resultados, conforme seu desempenho:

- Atende (A): o item beneficia o projeto arquitetônico.

- Atende parcialmente (AP): cabem considerações à sua aplicação no projeto arquitetônico.

- Não atende (NA): o item pode trazer prejuízos ao projeto arquitetônico.

$\mathrm{Na}$ análise foram geradas conclusões mais amplas, extraídas das conclusões individuais dos componentes ou dos grupos de quesitos. Isto possibilitou a comparação dos componentes ou grupos, visando garantir a coerência da informação, por meio da eliminação de conclusões contraditórias. 
Tabela 20 - Análise da equivalência entre as características formal e informal nos projetos de referência

Projetos:

1 - Penitenciária do Distrito federal; 2 - Penitenciária Compacta do estado de São Paulo; 3 - Projeto padrão do Ministério da Justiça para o Plano Nacional de Apoio ao Sistema Prisional; 4 - Projeto padrão da empresa Verdi Construções S/A

\begin{tabular}{|c|c|c|c|c|c|c|c|}
\hline \multicolumn{3}{|c|}{ Projeto } & Parci & Avaliação dos projetos & Final \\
\hline 1 & 2 & 3 & 4 & al
\end{tabular}

01. Tipo e Categoria do estabelecimento penal

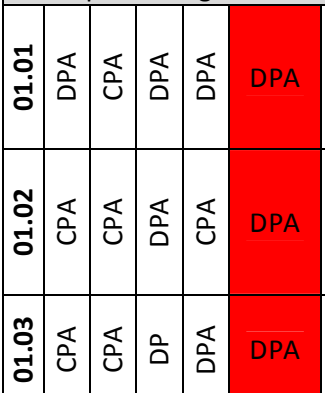

O projeto paulista se aproxima da simplicidade espacial associada ao modelo arquitetônico adotado, enquanto os demais projetos apresentam uma complexidade maior. Esta simplicidade é verificada nas médias superiores de áreas vigiadas e no número regular de postos de controle.

Os projetos se alinham com uma segurança maior, ao subdividir a população prisional, racionalizar a geometria e internalizar o programa. A exceção é o projeto federal que apresenta características de segurança média. 0 projeto paulista ainda reduz o dimensionamento, embora externalize o programa.

Os projetos estaduais tendem a absorver as demandas locais, enquanto a padronização dos demais projetos impede esta particularização, por sua abrangência nacional.

02. Porte do estabelecimento penal

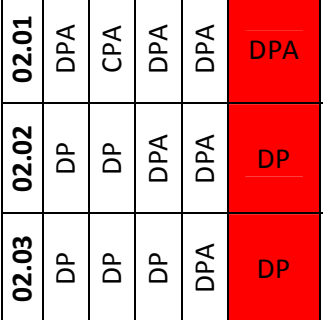

O projeto paulista se aproxima da minimização espacial $\left(10,93 \mathrm{~m}^{2} / \mathrm{vaga}\right)$, enquanto os demais $\left(18,70 \mathrm{~m}^{2} /\right.$ vaga) refletem o reforço da segurança (circulações superiores e postos de controle) ou o padrão arquitetônico modular (replicação de áreas).

A capacidade média (530 vagas) supera o normatizado (300 vagas), em particular nos projetos distrital e paulista.

Os projetos não apresentam previsão de ampliação. Os projetos extrapolam a capacidade máxima para a penitenciária. Arquitetonicamente, existe a possibilidade de crescimento, por meio da replicação ou prolongamento de blocos, inerente aos padrões arquitetônicos. 03. Custo do estabelecimento penal

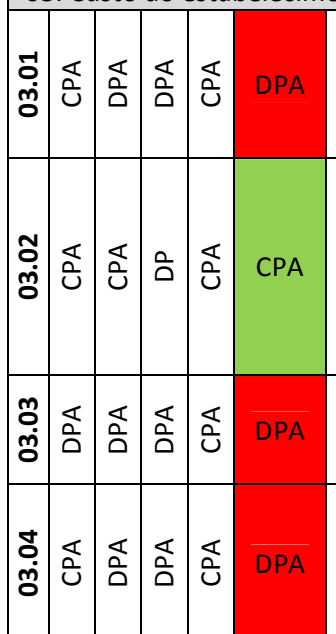

Os projetos buscam a economia geral de recursos através da racionalidade construtiva e espacial (geometria e modulação). A exceção são projetos paulista e federal, parcialmente desvinculados da economia operacional (complexidade geométrica e número de postos de controle).

Os projetos equiparam as características de segurança e operação em relação à economia de recursos, ao privilegiar a segurança e reduzir o programa de assistência e benefícios aos presos, especialmente os projetos paulista e privado (dimensionamento). A exceção é o projeto federal que apresenta características de segurança média, assim como, os demais projetos divergem do nível de segurança mais alto, ao aumentar a capacidade do estabelecimento em prol do custo da vaga.

Nos projetos, a economia de recursos normalmente implica em desrespeito aos parâmetros mínimos de dimensionamento e conforto ambiental (ventilação e iluminação), em favor da segurança. Em especial, em relação aos espaços dos presos.

Os projetos adéquam e mesclam conceitos dos padrões arquitetônicos, ao buscar soluções mais econômicas na construção (geometria e dimensionamento) e operação (simplificação dos procedimentos e redução das equipes de segurança). O número de torres de vigilância e a relação dos postos de controle com a capacidade equiparam os projetos.

04. Isolamento social dos presos

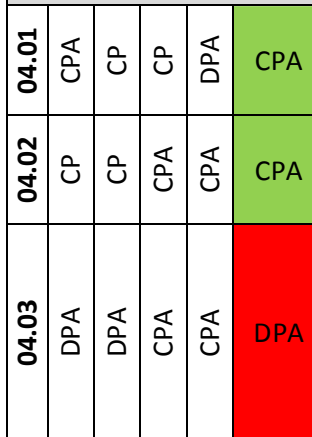

Os projetos buscam o fechamento institucional. O projeto distrital se localiza em complexo penitenciário. Os projetos paulista e federal utilizam muros como barreiras. A exceção é o projeto privado que tem implantação genérica, terreno mínimo e cerca.

Os projetos não apresentam locais para a participação da sociedade. Os projetos federal e privado apresentam salas para apoiar organizações com ações de reintegração social (profissionalização, cursos, práticas físicas).

Os projetos distrital e paulista não apresentam locais para a visita social que ocorre nos pátios de sol dos presos. O projeto paulista também não apresenta o encontro íntimo, enquanto o projeto distrital prevê apartamentos. Os projetos federal e privado especificam locais para a visita social e íntima. Nos projetos, os locais de visita social permitem o contato físico com os presos. Os projetos apresentam local para o encontro com o advogado, sem contato físico com os presos. 


\begin{tabular}{|c|c|c|c|c|c|c|c|}
\hline $\begin{array}{l}\dot{O} \\
\dot{0}\end{array}$ & O & 呑 & 呑 & 号 & DPA & $\begin{array}{l}\text { Os projetos padronizados têm maior dependência da localização para o isolamento social, } \\
\text { em especial, o projeto privado que é especificado com cerca. A exceção é o projeto distrital } \\
\text { que é locado em complexo penitenciário. }\end{array}$ & \\
\hline \multicolumn{8}{|c|}{ 05. Isolamento individual dos presos } \\
\hline $\begin{array}{l}-1 \\
\text { ถ் }\end{array}$ & 吕 & ㅇ & ดे & 号 & DP & $\begin{array}{l}\text { Os projetos apresentam celas coletivas. As celas individuais são especificadas para a } \\
\text { aplicação de medida disciplinar ou a separação de presos com problemas de convívio. A } \\
\text { exceção é o projeto distrital que possui celas individuais que podem ser ocupadas para o } \\
\text { cumprimento da pena. }\end{array}$ & \\
\hline $\begin{array}{l}\text { ㅇ. } \\
\text { ถ் }\end{array}$ & 吕 & 으 & 号 & ธิ & DP & $\begin{array}{l}\text { Os projetos apresentam celas coletivas. A exceção é o projeto distrital que possui celas } \\
\text { individuais que podem ser ocupadas para o cumprimento da pena. }\end{array}$ & \\
\hline $\begin{array}{l}\text { mo } \\
\text { ம் }\end{array}$ & U & ப & ভ & பे & $\mathrm{CP}$ & $\begin{array}{l}\text { Os projetos apresentam as celas uniformizadas. As celas diferenciadas resultam mais de } \\
\text { uma retificação da geometria do edifício ou do aproveitamento de áreas residuais, além da } \\
\text { conformação. }\end{array}$ & \\
\hline $\begin{array}{l}\text { ठ் } \\
\text { ஜ் }\end{array}$ & 豆 & 号 & จ & ธิ & DP & $\begin{array}{l}\text { Os projetos apresentam celas coletivas. A exceção é o projeto distrital que possui celas } \\
\text { individuais que podem ser ocupadas para o cumprimento da pena. Neste projeto, o bloco } \\
\text { de celas individuais é considerado de segurança máxima. }\end{array}$ & DPA \\
\hline 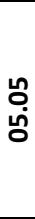 & ป̊ & ப & ¿ & ป̊ & CPA & $\begin{array}{l}\text { Os projetos prevêem a cela individual para o castigo ou proteção de presos na proporção } \\
\text { de } 1,5 \% \text { da capacidade do estabelecimento penal. A exceção é o projeto distrital que } \\
\text { apresenta mais de } 8 \% \text { (ou } 4 \% \text { se fracionado entre a PDF I e a PDF II). Nos projetos, as celas } \\
\text { individuais são organizadas em alas ou blocos separados da população prisional. Em } \\
\text { particular, o projeto federal agrupa celas individuais de diferentes funções (isolamento, } \\
\text { inclusão, saúde, tratamento de dependentes químicos). }\end{array}$ & \\
\hline $\begin{array}{l}\text { ஜே } \\
\text { ஸे }\end{array}$ & ถิ & ด & 号 & ธิ & DP & $\begin{array}{l}\text { Os projetos distrital, federal e privado apresentam oito vagas por cela. O projeto paulista } \\
\text { apresenta doze vagas por cela. A média é de nove vagas por cela. }\end{array}$ & \\
\hline \multicolumn{8}{|c|}{ 06. Organização do espaço } \\
\hline $\begin{array}{l}-1 \\
\dot{8} \\
\dot{8}\end{array}$ & 咅 & 吕 & 叴 & 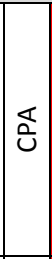 & DPA & $\begin{array}{l}\text { Os projetos revelam deficiências utilitárias em algum grau. Os mesmos apresentam uma } \\
\text { coordenação hierárquica das atividades satisfatória, porém com sobreposições funcionais. } \\
\text { A maior exceção é o projeto federal que apresenta uma hierarquia com características de } \\
\text { segurança média. Os projetos também favorecem a administração totalitária e a } \\
\text { mecanização dos processos. As exceções são os projetos paulista (empodera os presos) e } \\
\text { federal (complica a operação). O projeto distrital em particular desfavorece a relação custo- } \\
\text { benefício, principalmente devido à desumanização de espaços (em especial, dos presos). }\end{array}$ & \\
\hline $\begin{array}{l}\text { Tे } \\
\stackrel{0}{0}\end{array}$ & ৫্口 & 叴 & 叴 & 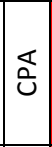 & DPA & $\begin{array}{l}\text { Os projetos revelam deficiências disciplinares no espaço em algum grau. Os mesmos } \\
\text { apresentam uma coordenação disciplinar focada nas funços, em detrimento da disciplina } \\
\text { espacial segundo os diferentes tipos de indivíduos. Este desequilíbrio leva à sobreposição } \\
\text { de atividades e fluxos, além do prolongamento dos percursos e exposição dos funcionários. }\end{array}$ & DPA \\
\hline $\begin{array}{l}\text { ô } \\
\dot{\phi} \\
\dot{8}\end{array}$ & 遌 & 呑 & 品 & 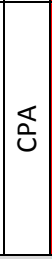 & DPA & $\begin{array}{l}\text { Os projetos apresentam a totalidade dos espaços dominados pela instituição (12\% } \\
\text { proibidos e de } 60 \text { a } 74 \% \text { vigiados). Os espaços livres se restringem às celas (14\%). Os } \\
\text { projetos distrital e paulista tendem a ampliar a territorialidade dos presos, ao expor os } \\
\text { funcionários nos procedimentos de transferência e condução de presos. Assim como, } \\
\text { nestes projetos a acessibilidade dos funcionários apresenta alguma dependência da } \\
\text { colaboração dos presos. O projeto federal apresenta os sistemas de segurança e operação } \\
\text { mais complexos o que dificulta a imposição institucional. }\end{array}$ & \\
\hline \multicolumn{8}{|c|}{ 07. Geometria } \\
\hline & $\overleftarrow{\Xi}$ & 【 & 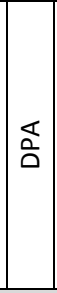 & ป̊ & CPA & $\begin{array}{l}\text { Os projetos apresentam uma disciplina formal, por meio de uma racionalidade e } \\
\text { simplicidade geométrica (fachadas em menor número e quantidade: } 104 \text { faces, sendo } 45 \text { no } \\
\text { bloco interno, e índices de fachada por preso de } 2,13 \mathrm{~m} / \text { vaga e por área construída de } \\
0,13 \mathrm{~m} / \mathrm{m}^{2} \text {, o que facilita a maior ocupação do terreno - } 38 \% \text { ). Esta conformação é } \\
\text { percebida nas médias superiores de áreas vigiadas com um número regular de postos ( } 93 \% \\
\text { da área vigiada e sete pontos cegos). A exceção é o projeto federal que apresenta uma } \\
\text { complexidade plástica (maior número de planos de fachada, com } 86 \% \text { da área vigiada e } 14 \\
\text { pontos cegos). }\end{array}$ & CPA \\
\hline
\end{tabular}




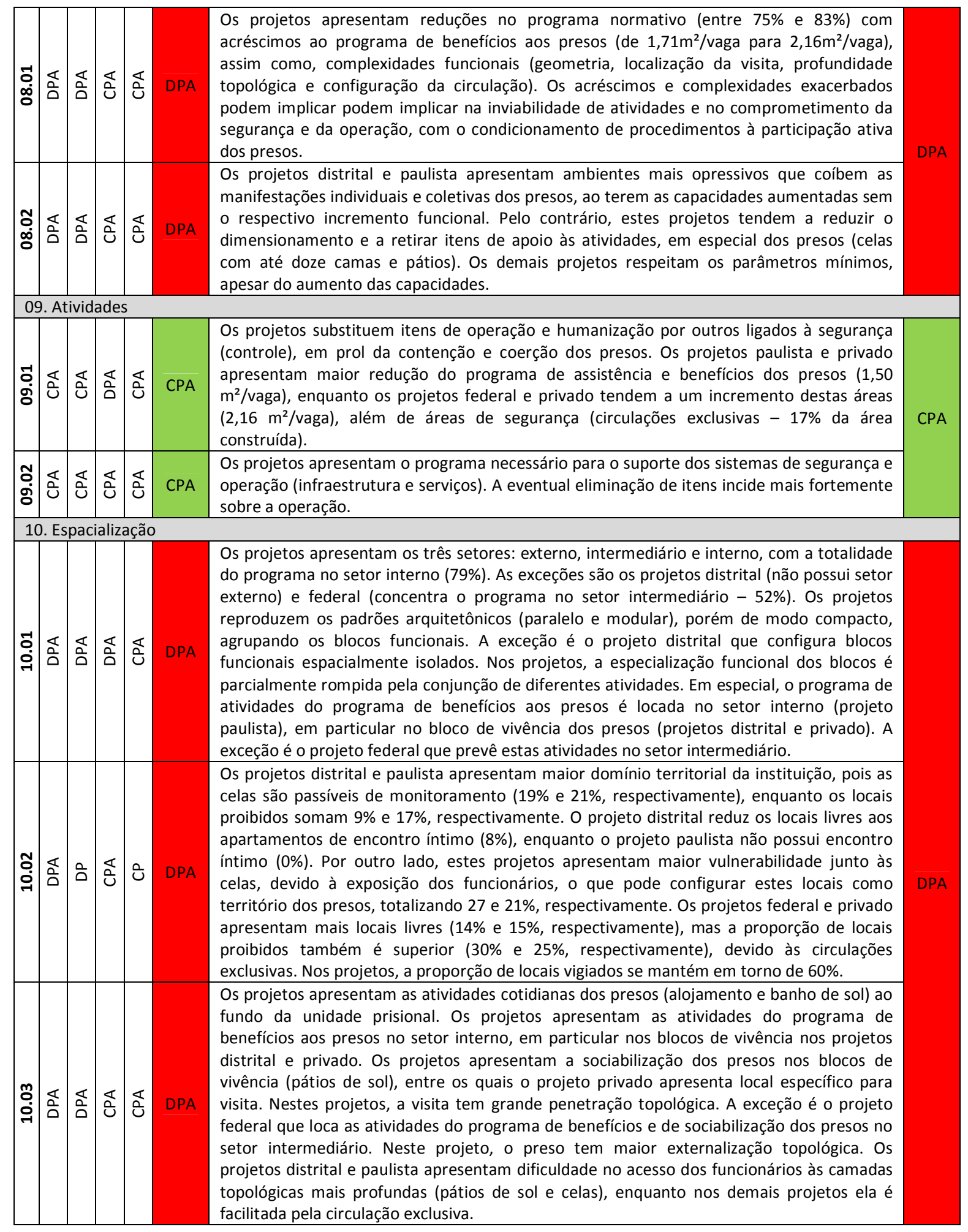




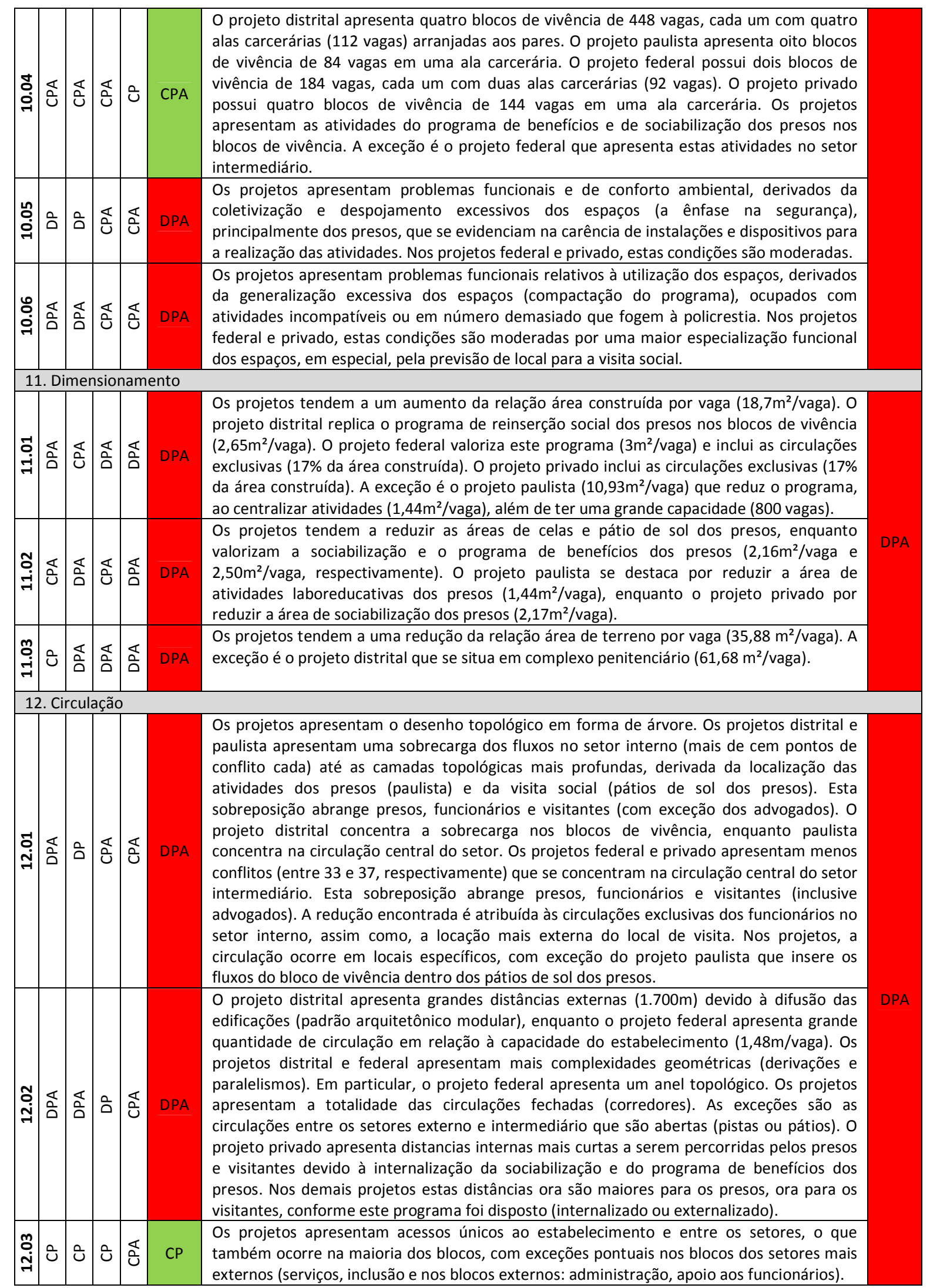




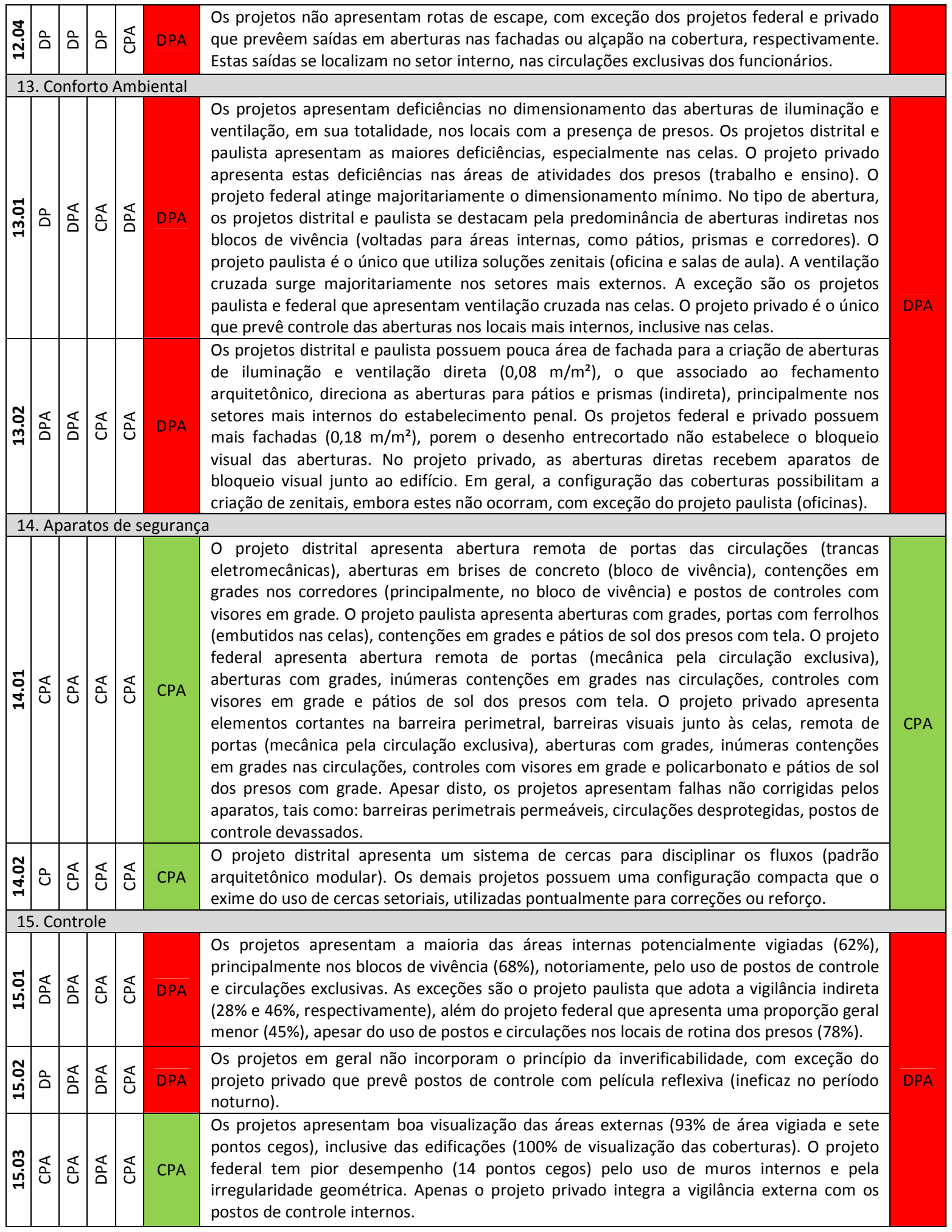




\begin{tabular}{|c|c|c|c|c|c|c|c|}
\hline $\begin{array}{l}\text { ه̊ } \\
\text { nُ }\end{array}$ & ப̊ & 음 & $\begin{array}{l}\varangle \\
\text { ¿ }\end{array}$ & ப̊ & $\overline{D P A}$ & $\begin{array}{l}\text { Os projetos apresentam os acessos às torres de vigilância externa protegidos. O projeto } \\
\text { distrital está inserido no complexo penitenciário. O projeto paulista adota o passadiço } \\
\text { sobre a muralha. O projeto federal coloca os acessos dentro do muro do setor interno. O } \\
\text { projeto privado coloca os acessos na linha de tiro. Os projetos apresentam uma separação } \\
\text { física entre presos e funcionários relativa. No setor interno ela é maior pela adoção da } \\
\text { vigilância direta, inclusive com circulações exclusivas. A exceção é o projeto paulista exige a } \\
\text { exposição dos funcionários nos procedimento. Assim como, os projetos distrital e federal } \\
\text { apresentam pontos vulneráveis. No projeto distrital, os procedimentos nas alas carcerárias } \\
\text { dependem da participação de presos. O projeto federal apresenta áreas que expõe os } \\
\text { funcionários no setor intermediário, em especial, no isolamento dos presos. }\end{array}$ & \\
\hline $\begin{array}{l}\text { ำ } \\
\text { กิ }\end{array}$ & ভ̊ & 文 & 志 & ¿ & CPA & $\begin{array}{l}\text { Os projetos apresentam fluxos relativamente controlados, ao condensarem e centralizarem } \\
\text { os mesmos em poucas circulações, facilitando o esquema de postos de controle (63\% das } \\
\text { circulações vigiadas). A exceção é o projeto paulista que adota a vigilância direta (15\%). }\end{array}$ & \\
\hline 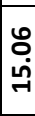 & Ù & ㅇ & ৩ & 杀 & CPA & $\begin{array}{l}\text { Os projetos apresentam um esquema de vigilância externa otimizado (quatro torres). Os } \\
\text { projetos também apresentam um número reduzido de postos internos (nove postos). A } \\
\text { exceção é o projeto distrital (17 postos). }\end{array}$ & \\
\hline 오 & 宭 & $\begin{array}{l}\mathbb{a} \\
0 \\
0\end{array}$ & ป & ป̊ & DPA & $\begin{array}{l}\text { Os projetos apresentam postos de controle que enfatizam o poder institucional na } \\
\text { materialização da divisão social da prisão, ao serem espacialmente explícitos (geometria } \\
\text { contundente) e elevados em relação ao piso ocupado pelos presos. Porém, a implantação } \\
\text { da vigilância direta no edifício e da inverificabilidade nestes postos não é predominante. Os } \\
\text { projetos federal e privado ressaltam o poder institucional ao preverem circulações } \\
\text { exclusivas em pavimento superior. Enquanto os projetos distrital e paulista falham ao expor } \\
\text { os funcionários e os procedimentos internos aos presos. Em menor grau isto também } \\
\text { ocorre nas áreas externas dos demais projetos. }\end{array}$ & \\
\hline \multicolumn{8}{|c|}{$\begin{array}{l}\text { Projetos: } \\
01 \text { - Penitenciária do Distrito federal; } 02 \text { - Penitenciária Compacta do estado de São Paulo; } 03 \text { - Projeto padrão do Ministério } \\
\text { da Justiça para o Plano Nacional de Apoio ao Sistema Prisional; } 04 \text { - Projeto padrão da empresa Verdi Construções S/A }\end{array}$} \\
\hline & & Proj & jeto & & & \multirow{2}{*}{ Avaliação dos projetos } & \\
\hline & 1 & 2 & 3 & 4 & & & \\
\hline \multicolumn{8}{|c|}{ 16. Barreira perimetral } \\
\hline ơ & 造 & ৩ & ป & 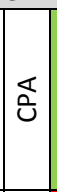 & CPA & $\begin{array}{l}\text { Os projetos apresentam barreiras de difícil transposição (muros com passadiços e cercas } \\
\text { com elementos cortantes). A exceção é o projeto distrital que possui cerca vedada com } \\
\text { alambrado trançado, sem elementos cortantes. Nos projetos, a atuação das torres de } \\
\text { vigilância reforça a estanqueidade, enquanto o fechamento das edificações alivia esta } \\
\text { responsabilidade sobre a barreira perimetral. }\end{array}$ & \\
\hline ํ. & 宭 & ৩ & บ & 各 & DPA & $\begin{array}{l}\text { Os projetos distrital e privado adotam barreiras permeáveis (cerca) o que compromete a } \\
\text { impermeabilidade institucional. Os projetos paulista e federal adotam barreiras } \\
\text { impermeáveis (muro) o que favorece a impermeabilidade institucional. }\end{array}$ & \\
\hline $\begin{array}{l}m \\
\dot{0} \\
\dot{\sigma}\end{array}$ & 造 & ৩ & ப & 号 & DPA & $\begin{array}{l}\text { Os projetos distrital e privado adotam barreiras leves (cerca) o que compromete a } \\
\text { inexpugnidade do estabelecimento. Isto é mitigado pela locação em complexo } \\
\text { penitenciário do projeto distrital. Os projetos paulista e federal adotam barreiras pesadas } \\
\text { (muro) o que favorece a inexpugnidade institucional. }\end{array}$ & \\
\hline $\begin{array}{l}\text { ठ্ } \\
\dot{\sigma}\end{array}$ & 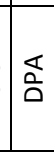 & ৩ & ป & ป̊ & CPA & $\begin{array}{l}\text { Os projetos distrital e privado adotam a cerca, ao privilegiar o custo de construção, } \\
\text { enquanto os projetos paulista e federal adotam o muro, ao privilegiar a impermeabilidade e } \\
\text { a inexpugnidade, principalmente por serem projetos padronizados e o muro permitir uma } \\
\text { independência do estabelecimento em relação ao entorno. }\end{array}$ & CPA \\
\hline $\begin{array}{l}\text { مٌ } \\
\dot{\varphi}\end{array}$ & U & ப & บ & ¿ & $\mathrm{CP}$ & $\begin{array}{l}\text { Os projetos apresentam uma geometria simples - retangular, planar e nivelada. As } \\
\text { exceções podem acontecer excepcionalmente devido a replicação dos projetos } \\
\text { (padronização) em terrenos eventualmente irregulares: o projeto distrital apresenta } \\
\text { desníveis com taludes (até } 7 \mathrm{~m} \text { ). }\end{array}$ & \\
\hline 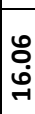 & บ & ப & ¿ & ¿ & $\mathrm{CP}$ & $\begin{array}{l}\text { Os projetos apresentam barreiras perimetrais que podem ser consideradas altas (em } \\
\text { média, com } 6,45 \mathrm{~m} \text { ). }\end{array}$ & \\
\hline S. & 爻 & ปิ & ৩ & 卆 & $\overline{D P A}$ & $\begin{array}{l}\text { O projeto distrital não apresenta proteção para a circulação da guarda externa, embora } \\
\text { deva ser considerada a locação do estabelecimento em complexo penitenciário. Os projetos } \\
\text { paulista e federal apresentam passadiço sobre o muro. O projeto privado apresenta a } \\
\text { circulação da guarda externa dentro da linha de tiro que não protege contra disparos de } \\
\text { arma de fogo. }\end{array}$ & \\
\hline
\end{tabular}




\begin{tabular}{|c|c|c|c|c|c|c|}
\hline 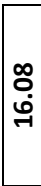 & $\mid \varangle$ & 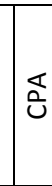 & 适 & نे & CPA & $\begin{array}{l}\text { O projeto distrital não apresenta aparatos de segurança que poderiam corrigir a fragilidade } \\
\text { contra fugas dos presos. Os projetos paulista e federal descartam a necessidade de } \\
\text { aparatos de segurança pelo uso do muro. O projeto privado apresenta elementos cortantes } \\
\text { que mitigam a fragilidade contra fugas dos presos, além de elementos de bloqueio visual } \\
\text { junto às aberturas dos edifícios ocupados pelos presos que minimizam a permeabilidade. }\end{array}$ \\
\hline ڤ̊ & $\mid \overleftarrow{\Delta}$ & ด & : & 음 & DP & $\begin{array}{l}\text { Os projetos apresentam linha de tiro definida por cerca paralela à barreira perimetral (em } \\
\text { média com } 3 \mathrm{~m} \text { de altura). A exceção é o projeto distrital cuja barreira (cerca dupla) já } \\
\text { constitui a linha de tiro. }\end{array}$ \\
\hline $\begin{array}{l}0 \\
7 \\
6 \\
6\end{array}$ & U⿺ & 遌 & : & 呑 & DPA & $\begin{array}{l}\text { O projeto distrital apresenta os maiores afastamentos }(30 \mathrm{~m}) \text {, seguido dos projetos paulista } \\
\text { e privado }(20 \text { e } 15 \mathrm{~m} \text {, respectivamente). O projeto federal apresenta os afastamentos mais } \\
\text { curtos }(10 \mathrm{~m}) \text {. O projeto paulista apresenta o maior perímetro de segurança (13m), seguido } \\
\text { do projeto privado }(5 \mathrm{~m}) \text {. Os projetos distrital e federal não apresentam perímetro de } \\
\text { segurança (o projeto distrital está inserido em complexo penitenciário). }\end{array}$ \\
\hline $\begin{array}{l}-1 \\
\stackrel{1}{6} \\
\stackrel{-1}{-1}\end{array}$ & 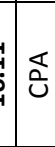 & 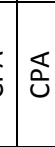 & i & ப & CPA & $\begin{array}{l}\text { Os projetos apresentam pista de ronda externa à barreira perimetral. No projeto distrital } \\
\text { está dentro do complexo penitenciário. No projeto paulista está dentro do perímetro de } \\
\text { segurança. No projeto privado é interna. A exceção é o projeto federal que não apresenta } \\
\text { pista de ronda. }\end{array}$ \\
\hline \multicolumn{7}{|r|}{ I } \\
\hline - & : & ৩ & i & ৩ & $\mathrm{CP}$ & $\begin{array}{l}\text { Os projetos apresentam celas com plantas retangulares e paredes prismáticas. Os projetos } \\
\text { distrital e federal apresentam teto horizontal plano. Os projetos paulista e privado } \\
\text { apresentam teto inclinado. O projeto paulista apresenta ressalto no teto. }\end{array}$ \\
\hline đั & ? & : & 造 & 造 & DPA & $\begin{array}{l}\text { Os projetos apresentam celas com áreas de dormitório e de higiene pessoal (inclusive o } \\
\text { banho), além de possibilitar a guarda de pertences (com exceção do projeto distrital). O } \\
\text { projeto paulista enfatiza o entretenimento televisivo. }\end{array}$ \\
\hline m̊ & ن & O & i & ป & $C P$ & $\begin{array}{l}\text { Os projetos apresentam celas dotadas do serviço de higiene pessoal completo: vaso } \\
\text { sanitário, lavatório e chuveiro. }\end{array}$ \\
\hline 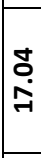 & 은 & 음 & 5 & 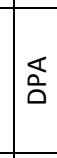 & DP & $\begin{array}{l}\text { Os projetos apresentam celas com mobiliário reduzido: camas configuradas como beliches } \\
\text { e prateleiras para os pertences dos presos. As exceções são o projeto distrital que não tem } \\
\text { prateleiras e o projeto paulista que apresenta beliche de três camas com escada, além de } \\
\text { base para televisão coletiva. Os projetos não apresentam mesa com bancos. }\end{array}$ \\
\hline$\stackrel{\leftrightarrow}{\leftrightarrow}$ & 䓃 & 造 & $\frac{8}{a}$ & 各 & DPA & $\begin{array}{l}\text { Os projetos apresentam celas com acesso central continuado por uma circulação que } \\
\text { transpassa o dormitório até o banheiro que fica ao fundo. O dormitório é configurado por } \\
\text { beliches laterais, longitudinalmente acoplados às paredes. Os beliches e a divisão entre o } \\
\text { dormitório e o banheiro são descritos por divisórias baixas. A exceção é o projeto distrital } \\
\text { que possui acesso descentralizado e banheiro posicionado lateralmente à entrada da cela. }\end{array}$ \\
\hline 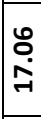 & Oे & 志 & j) & 呑 & DPA & $\begin{array}{l}\text { Os projetos apresentam celas que inibem a manifestação individual e a apropriação do } \\
\text { espaço pelos presos. Os espaços individual e coletivo são mínimos, devassados e } \\
\text { destituídos de itens de conforto, impossibilitando a privacidade pessoal ou do grupo. }\end{array}$ \\
\hline 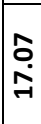 & 䓃 & 造 & 5 & 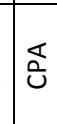 & DPA & $\begin{array}{l}\text { Os projetos apresentam celas com dimensões mínimas }\left(3,15 \mathrm{~m} \times 5,70 \mathrm{~m}-2 \mathrm{~m}^{2} / \mathrm{vaga}\right) \text {, } \\
\text { suficientes para os beliches, circulação e banheiro. Os projetos distrital e paulista } \\
\text { apresentam médias maiores, enquanto os demais projetos médias menores. }\end{array}$ \\
\hline 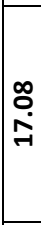 & : & $\frac{\pi}{0}$ & \begin{tabular}{l|l}
$\frac{\pi}{2}$ \\
5
\end{tabular} & $\overleftrightarrow{\Xi}$ & DPA & $\begin{array}{l}\text { O projeto distrital apresenta } 12,5 \% \text { de aberturas indiretas (corredor), sem ventilação } \\
\text { cruzada. O projeto paulista apresenta } 16,16 \% \text { de aberturas diretas (zenital) e indiretas } \\
\text { (pátio de sol), com ventilação cruzada. O projeto federal apresenta } 24,76 \% \text { de aberturas } \\
\text { diretas (janela) e indiretas (corredor), com ventilação cruzada. O projeto privado apresenta } \\
12,28 \% \text { de aberturas diretas (janela), sem ventilação cruzada. Este é o único projeto que } \\
\text { apresenta controle das aberturas. }\end{array}$ \\
\hline$\stackrel{8}{\stackrel{2}{9}}$ & ?̦ & ป̊ & $\frac{\pi}{2}$ & 过 & CPA & $\begin{array}{l}\text { Os projetos apresentam celas com contenções nas aberturas de iluminação e ventilação } \\
\text { (brises ou grades). As portas das celas dos projetos são em grade e chapeadas. A exceção é } \\
\text { o projeto paulista (em grade). As portas dos projetos federal e privado possuem } \\
\text { portinholas. }\end{array}$ \\
\hline$\stackrel{\circ}{\rightarrow}$ & ta & $\frac{\square}{\Delta}$ & $\frac{1}{5}$ & 음 & DP & \\
\hline F. & : & jo & $\frac{1}{5}$ & 음 & DP & $\begin{array}{l}\text { O espaço único da cela recebe obstáculos visuais (divisórias baixas) nas camas e na área de } \\
\text { higiene pessoal. }\end{array}$ \\
\hline
\end{tabular}


Tabela 21 - Avaliação dos componentes da composição arquitetônica

\begin{tabular}{|c|c|c|c|c|c|c|c|}
\hline \multicolumn{8}{|c|}{ 01. Tipo e categoria do estabelecimento $p$} \\
\hline \multirow[t]{7}{*}{01.01} & \multicolumn{6}{|c|}{ Equivalência Demandas } & \multirow{7}{*}{$\begin{array}{l}\text { O espaço arquitetônico formal é ajustado ao perfil do preso, o que corresponde a uma modalidade arquitetônica, descrito pelo nível de } \\
\text { segurança penitenciário (simplicidade espacial e funcional). Isto favorece a segurança (homogeneização do sistema de segurança), a } \\
\text { funcionalidade (redução das tarefas e simplificação dos procedimentos), o conforto ambiental (compatibilização das soluções) e os custos } \\
\text { (redução de áreas e otimização da estrutura física e operacional). O espaço informal tende a uma descaracterização do modelo de } \\
\text { segurança máxima, ao conjugar características espaciais concernentes a diferentes perfis de presos (níveis de segurança), o que reflete a } \\
\text { imprecisão normativa. Isto compromete o ajustamento. As demandas são parcialmente divergentes (DP). A solução formal prevalece, } \\
\text { porém identifica-se uma possível modalidade arquitetônica (perfil intermediário de preso), não contemplada nos instrumentos técnicos. }\end{array}$} \\
\hline & Projeto & DF & SP & MJ & EV & & \\
\hline & Paridade & $D P$ & $C P$ & $D P$ & $D P$ & DP & \\
\hline & \multicolumn{6}{|c|}{ Avaliação Ajustamento } & \\
\hline & Critério & $\mathrm{S}$ & $\mathrm{F}$ & CA & $\mathrm{C}$ & & \\
\hline & Formal & $A$ & $A$ & $A$ & $A$ & $A$ & \\
\hline & Informal & $A P$ & $A P$ & $A P$ & $A P$ & $A P$ & \\
\hline \multirow[t]{7}{*}{01.02} & \multicolumn{6}{|c|}{ Equivalência Demandas } & \multirow{7}{*}{$\begin{array}{l}\text { A demanda formal maximiza a segurança e minimiza a humanização (programas de sociabilização e de benefícios aos presos, além dos } \\
\text { padrões de bem estar), o que descreve um modelo bem definido pela disciplina-bloco (individualização, racionalidade geométrica, } \\
\text { redução das atividades e síntese funcional). Isto favorece o ajustamento, com exceção dos custos (aumento de áreas). A demanda } \\
\text { informal tende a desvirtuar o modelo de segurança máxima, ao agregar características de níveis de segurança mais brandos (porte maior, } \\
\text { coletivização e generalização funcional dos locais e valorização dos programas) e desrespeitar os padrões mínimos de bem-estar. Este } \\
\text { modelo híbrido compromete o ajustamento, o que reflete a imprecisão normativa. As demandas são parcialmente divergentes (DP). A } \\
\text { solução formal prevalece, porém com a ressalva de responder à geração de vagas, aliada à economia de recursos. }\end{array}$} \\
\hline & Projeto & $\mathrm{DF}$ & SP & MJ & EV & & \\
\hline & Paridade & $C P$ & $C P$ & $D P$ & $C P$ & DP & \\
\hline & \multicolumn{6}{|c|}{ Avaliação Ajustamento } & \\
\hline & Critério & $\mathrm{S}$ & $\mathrm{F}$ & CA & $\mathrm{C}$ & & \\
\hline & Formal & $A$ & $A$ & $A$ & $A P$ & $A$ & \\
\hline & Informal & $A P$ & $A P$ & NA & $A P$ & $A P$ & \\
\hline \multirow[t]{7}{*}{01.03} & \multicolumn{6}{|c|}{ Equivalência Demandas } & \multirow{7}{*}{$\begin{array}{l}\text { O espaço arquitetônico formal de segurança máxima apresenta características próprias, relativas ao enquadramento no sistema } \\
\text { penitenciário. Predomina o padrão arquitetônico modular (compactado). Isto favorece a segurança (homogeneização do sistema de } \\
\text { segurança), a funcionalidade (redução das tarefas e simplificação dos procedimentos) e os custos (redução de áreas e otimização da } \\
\text { estrutura física e operacional). A demanda informal tende a combinar os padrões modular e paralelo (compactados e horizontalizados). } \\
\text { Em comparação ao modelo modular, o padrão paralelo concentra fluxos e atividades (simplicidade espacial e funcional). Isto favorece a } \\
\text { funcionalidade (simplificação dos procedimentos) e os custos operacionais (redução de pessoal). As demandas são parcialmente } \\
\text { divergentes (DP). A solução formal prevalece, porém com a ressalva de equiparar a simplicidade do padrão paralelo. }\end{array}$} \\
\hline & Projeto & DF & SP & MJ & EV & & \\
\hline & Paridade & $C P$ & $C P$ & $D$ & $D P$ & $D P$ & \\
\hline & \multicolumn{6}{|c|}{ Avaliação Ajustamento } & \\
\hline & Critério & $\mathrm{S}$ & $\mathrm{F}$ & $\mathrm{CA}$ & $\mathrm{C}$ & & \\
\hline & Formal & $A$ & $A$ & 1 & $A$ & $A$ & \\
\hline & Informal & $A P$ & $A$ & I & $A$ & $A$ & \\
\hline Grupo & $\begin{array}{l}\text { As exigêr } \\
\text { generaliz } \\
\text { dos instr } \\
\text { econômi }\end{array}$ & & & & & & \\
\hline \multicolumn{8}{|c|}{ 02. Porte do estabelecimento penal } \\
\hline \multirow[t]{7}{*}{02.01} & \multicolumn{6}{|c|}{ Equivalência Demandas } & \multirow{7}{*}{$\begin{array}{l}\text { A demanda formal minimiza a estrutura física em relação à quantidade de usuários, principalmente, os programas de sociabilização e de } \\
\text { benefícios aos presos (complexidade espacial). Isto favorece o ajustamento (redução das tarefas e simplificação dos procedimentos, além } \\
\text { da redução de áreas). A demanda informal tende a desvirtuar o modelo de segurança máxima, ao aumentar a relação estrutura por vaga, } \\
\text { através do incremento do sistema de segurança (circulações exclusivas para os funcionários) e dos programas citados, o que reflete a } \\
\text { imprecisão normativa existente. Isto favorece a segurança (separação física dos funcionários), enquanto compromete a funcionalidade } \\
\text { (aumento das tarefas) e os custos (aumento de áreas e de pessoal). As demandas são parcialmente divergentes (DP). A solução formal } \\
\text { prevalece, porém com a demanda de responder ao modelo prisional, aliado à economia de recursos. }\end{array}$} \\
\hline & Projeto & DF & SP & MJ & EV & & \\
\hline & Paridade & $D P$ & $C P$ & $D P$ & $D P$ & DP & \\
\hline & \multicolumn{6}{|c|}{ Avaliação Ajustamento } & \\
\hline & Critério & $\mathrm{S}$ & $\mathrm{F}$ & $\mathrm{CA}$ & $\mathrm{C}$ & & \\
\hline & Formal & $A$ & $A$ & & $A$ & & \\
\hline & Informal & $A$ & $A P$ & & & & \\
\hline \multirow[t]{3}{*}{02.02} & \multicolumn{6}{|c|}{ Equivalência Demandas } & \multirow{3}{*}{$\begin{array}{l}\text { O espaço arquitetônico formal possui menor capacidade (até } 300 \text { vagas). Isto favorece a segurança (submissão dos presos) e a } \\
\text { funcionalidade (redução das tarefas), enquanto desfavorece os custos (aumenta a relação custo por vaga). O espaço informal tende a } \\
\text { capacidades maiores ( } 530 \text { vagas, com uma tendência para mais) (coletivização com aumento de capacidade). O modelo supermax chega a }\end{array}$} \\
\hline & Projeto & DF & SP & MJ & EV & & \\
\hline & & & & & & & \\
\hline
\end{tabular}


Avaliação Ajustamento

\begin{tabular}{|c|c|c|c|c|c|}
\hline Critério & $\mathrm{S}$ & $\mathrm{F}$ & $\mathrm{CA}$ & $\mathrm{C}$ & \\
\hline Formal & $A$ & $A$ & $I$ & NA & $A P$ \\
\hline Informal & $A P$ & $A P$ & $I$ & $A$ & $\boldsymbol{A}$ \\
\hline \multicolumn{6}{|c|}{ Equivalência Demandas } \\
\hline
\end{tabular}

02.03

Equivalência Demandas

\begin{tabular}{|l|l|l|l|l|}
\hline Projeto & DF & SP & MJ & EV \\
\hline
\end{tabular}

Paridade

Avaliação Ajustamento

\begin{tabular}{|c|c|c|c|c|} 
Critério & S & F & CA & C \\
\hline Formal & A & A & A & A \\
\hline
\end{tabular}

\begin{tabular}{|c|c|c|c|c|c|}
\hline Formal & A & A & A & A & A \\
\hline
\end{tabular}

\begin{tabular}{l|c|c|c|} 
Informal & AP & AP & AP \\
\hline
\end{tabular} exigida. Sobressaem as questões penitenciárias da demanda por vagas, da generalização da categoria de segurança máxima e da redução de custos de construção, assim como, as questões do planejamento penitenciário (política fundiária), além da indefinição dos instrumentos técnicos de projeto.

03. Custo do estabelecimento penal

\begin{tabular}{|c|c|c|c|c|c|c|}
\hline \multirow[t]{7}{*}{03.01} & \multicolumn{6}{|c|}{ Equivalência Demandas } \\
\hline & Projeto & DF & $S P$ & MJ & EV & \\
\hline & Paridade & $D P$ & $C P$ & $D P$ & $D P$ & $D P$ \\
\hline & \multicolumn{6}{|c|}{ Avaliação Ajustamento } \\
\hline & Critério & $\mathrm{S}$ & $\mathrm{F}$ & CA & C & \\
\hline & Formal & $A$ & $A$ & 1 & $A P$ & $A$ \\
\hline & Informal & $A P$ & $A P$ & 1 & $A P$ & $A P$ \\
\hline
\end{tabular}

03.02

Equivalência Demandas

\begin{tabular}{|l|c|c|c|c|c|}
\hline Projeto & DF & SP & MJ & EV & \\
\hline Paridade & $D$ & $D$ & DP & DP & D \\
\hline
\end{tabular}

Avaliação Ajustamento

\begin{tabular}{|c|c|c|c|c|c|}
\hline Critério & S & F & CA & C & \\
\hline Formal & $A$ & $A$ & $I$ & $N A$ & $A P$ \\
\hline
\end{tabular}

\begin{tabular}{c|c|c|c|c|c|}
\hline Informal & $A P$ & $A P$ & $I$ & $A$ & $A$
\end{tabular}

03.03

Equivalência Demandas

\begin{tabular}{|c|c|c|c|c|c|}
\hline Projeto & DF & SP & MJ & EV & \\
\hline Paridade & - & - & $D$ & $C P$ & $D$ \\
\hline
\end{tabular}

Avaliação Ajustamento

\begin{tabular}{|c|c|c|c|c|c|}
\hline Critério & S & F & CA & C & \\
\hline
\end{tabular}

\begin{tabular}{c|c|c|c|c|c|}
\hline Formal & $A$ & $A$ & $A$ & $A P$ & $\boldsymbol{A P}$ \\
\hline
\end{tabular}

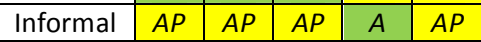

03.04 Equivalência Demandas

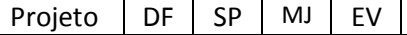

\begin{tabular}{l|l|l|l|l|l|}
\hline Paridade & $C P$ & $C$ & $D$ & $C P$ & $D F$
\end{tabular}
490 vagas, enquanto as Diretrizes Básicas estipulam até 800 vagas para a cadeia pública. As unidades de menor porte são identificadas com o RDD, por exemplo, a Penitenciária Federal. Isto compromete a segurança (empoderamento dos presos) e a funcionalidade (aumento das tarefas), enquanto favorece os custos (otimização da estrutura física e operacional). As demandas são plenamente divergentes (D). A solução informal prevalece, porém com a demanda de responder à segurança e à funcionalidade.

O espaço arquitetônico formal permite a ampliação da unidade prisional, dentro dos limites do modelo de segurança máxima. Isto favorece o ajustamento (compatibilização da estrutura física e operacional à capacidade), em especial quanto à economia de recursos (redução da relação custo por vaga). O espaço informal não prevê ampliações (normalmente, já prevê as capacidades máximas normatizadas). Isto compromete o ajustamento (excessos, redundâncias ou carências na estrutura física e operacional em relação à capacidade - improvisações), enquanto desfavorece os custos (aumento de obras e de pessoal). As demandas são parcialmente divergentes (DP). A solução formal prevalece, de modo dependente do planejamento penitenciário (política fundiária).
A demanda formal maximiza a economia na construção e no funcionamento da prisão, aliada a máxima eficiência dos sistemas de segurança e operação. Isto favorece o ajustamento, com exceção da economia de recursos (se admite que o nível de segurança máximo aumenta o custo da vaga). As equipes dirigentes destacaram a divisão da população prisional, a distribuição das atividades dos presos e o modelo de vigilância como fatores relevantes para o custeio, principalmente, diante dos recursos disponíveis. A demanda informal busca a economia na construção, negligenciando a operação, o que afeta o desempenho dos sistemas de segurança e operação. Isto compromete o ajustamento (aumento das vulnerabilidades, complicação dos procedimentos e aumento de pessoal). As demandas são parcialmente divergentes (DP). A solução formal prevalece, porém com a demanda de reduzir os custos de construção e operação.

O espaço arquitetônico formal materializa a segurança máxima, ao apresentar um porte menor, individualização dos presos, compactação espacial, redução das atividades e vigilância direta. Isto favorece a segurança (submissão dos presos e separação física dos funcionários) e a funcionalidade (redução das tarefas e simplificação dos procedimentos), enquanto desfavorece a economia de recursos (aumento da relação custo por vaga). O espaço informal apresenta uma coletivização com aumento de capacidade e generalização funcional, seguida do programa de benefícios aos presos valorizado, além de eventual vigilância indireta. Isto compromete a segurança (empoderamento dos presos) e a funcionalidade, enquanto favorece os custos (redução de áreas e de pessoal). As instâncias são plenamente divergentes (D). A solução informal prevalece, porém com a demanda de responder à segurança e à funcionalidade, aliada à economia de recursos.

A demanda formal concentra os recursos no sistema de segurança físico e operacional, porém sem prejuízo dos padrões de bem-estar mínimos. Isto favorece a segurança (maximização do sistema de segurança), a funcionalidade (redução das tarefas) e o conforto ambiental (padrões mínimos), enquanto compromete os custos (incremento da estrutura física e operacional). A demanda informal tende a enfatizar apenas a segurança física (a segurança operacional é preterida) e desrespeitar os padrões mínimos de bem-estar. Isto desfavorece o ajustamento (exposição dos funcionários), enquanto favorece os custos (otimização da estrutura física e operacional). As demandas são parcialmente divergentes (DP). A solução formal prevalece, porém dependente das questões do planejamento (política fundiária).

O espaço arquitetônico formal reproduz o padrão arquitetônico modular, com a capacidade aumentada e espacialmente compactado. 0 modelo supermax apresenta capacidade de 400 a 500 vagas e os módulos de vivência são agrupados. Isto favorece a segurança (maximização do sistema de segurança), a funcionalidade (redução de tarefas e simplificação dos procedimentos) e o conforto ambiental 
(padrões mínimos), enquanto a quantidade de blocos de vivência compromete os custos (aumento de áreas e de pessoal). 0 espaço informal tende a reproduzir conceitos dos padrões arquitetônicos paralelo e modular, com capacidades maiores, fracionamento menor e compactados. Isto compromete o ajustamento, enquanto favorece os custos (redução de áreas e otimização da estrutura). As demandas

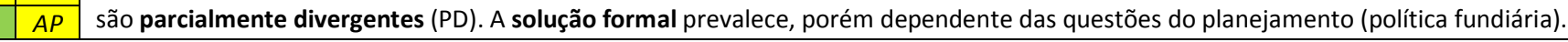

Grupo As exigências formais e informais são parcialmente divergentes, ao apresentar programas mais completos, o que tende a aumentar os custos, ao mesmo tempo em que apresenta grandes capacidades e áreas construídas compactas, o que tende a diminuir custo por vaga. Isto compromete a redução dos custos (custo por vaga).

\begin{tabular}{|c|c|c|c|c|c|c|c|}
\hline \multicolumn{8}{|c|}{ 04. Isolamento Social } \\
\hline \multirow[t]{7}{*}{04.01} & \multicolumn{6}{|c|}{ Equivalência Demandas } & \multirow{7}{*}{$\begin{array}{l}\text { O espaço arquitetônico formal tem uma maior impermeabilidade, por meio das características do terreno, especificação da barreira } \\
\text { perimetral e fechamento das edificações. Isto favorece a segurança (rompe a comunicação informal), a funcionalidade (simplificação dos } \\
\text { procedimentos) e o conforto ambiental (respeito aos padrões mínimos), com exceção dos custos (aumento de áreas e do custo dos } \\
\text { componentes). A equipe dirigente considera imprescindível a impermeabilidade. O espaço informal eventualmente apresenta terrenos } \\
\text { inadequados (pequenos ou irregulares), barreiras perimetrais vazadas (cercas destituídas de dispositivos de bloqueio visual) e arquitetura } \\
\text { aberta (pátios e aberturas nas fachadas). Isto compromete o ajustamento (redução da impermeabilidade). As demandas são parcialmente } \\
\text { convergentes (CP). A solução formal prevalece, porém com a demanda de responder a economia na construção. }\end{array}$} \\
\hline & Projeto & DF & SP & MJ & EV & & \\
\hline & Paridade & $C P$ & $C$ & $C$ & $D P$ & CP & \\
\hline & \multicolumn{6}{|c|}{ Avaliação Ajustamento } & \\
\hline & Critério & $\mathrm{S}$ & $\mathrm{F}$ & $\mathrm{CA}$ & $\mathrm{C}$ & & \\
\hline & Formal & & $A$ & & & & \\
\hline & Informal & $A P$ & $A P$ & $A P$ & $A P$ & & \\
\hline \multirow[t]{7}{*}{04.02} & \multicolumn{6}{|c|}{ Equivalência Demandas } & \multirow{7}{*}{$\begin{array}{l}\text { O espaço arquitetônico formal e informal não prevê a atuação administrativa da sociedade na atividade prisional, o que determina a } \\
\text { impermeabilidade institucional e a centralização administrativa (vista como necessária à totalização dos processos prisionais). Na prática, } \\
\text { a atuação de grupos assistenciais é casual (organizações de igrejas e da sociedade civil). No modelo supermax e nos projetos de } \\
\text { referência, a interação com estes grupos ocorre nas áreas de atividades dos presos. As Diretrizes Básicas prevêem sala de encontro com a } \\
\text { sociedade. Isto favorece o ajustamento (impermeabilidade institucional, redução das tarefas, redução de áreas e de pessoal). As } \\
\text { demandas são parcialmente convergentes (CP). As soluções formal e informal se equivalem: desconsiderar a participação da sociedade - } \\
\text { prevalece o fechamento institucional. }\end{array}$} \\
\hline & Projeto & DF & SP & MJ & EV & & \\
\hline & Paridade & C & $C$ & $C P$ & $C P$ & $C P$ & \\
\hline & \multicolumn{6}{|c|}{ Avaliação Ajustamento } & \\
\hline & & $\mathrm{S}$ & $\mathrm{F}$ & CA & $\mathrm{C}$ & & \\
\hline & al & $A$ & $A$ & & $A$ & $A$ & \\
\hline & formal & $A$ & $A$ & 1 & $A$ & $A$ & \\
\hline \multirow[t]{7}{*}{04.03} & \multicolumn{6}{|c|}{ Equivalência Demandas } & \multirow{7}{*}{$\begin{array}{l}\text { A demanda formal restringe o contato dos presos com os visitantes e exige uma estrutura física específica (salão de visitas sociais e } \\
\text { parlatórios), o que compensa a permeabilidade do visitante e permite a representação social. Isto favorece o ajustamento (redução de } \\
\text { vulnerabilidades, simplificação dos procedimentos e redução de áreas e de pessoal). A equipe dirigente e os presos consideram } \\
\text { imprescindível o isolamento das visitas em relação ao meio carcerário e a presos sem visita. O espaço informal tende a apresentar locais } \\
\text { para a visita social, conjugal e jurídica, nos quais ocorre o contato físico com os presos (exceção da visita jurídica). Isto compromete o } \\
\text { ajustamento. As demandas são parcialmente divergentes (DP). A solução formal prevalece, porém com a demanda de responder ao } \\
\text { modelo prisional, aliada aos custos. }\end{array}$} \\
\hline & & DF & SP & MJ & EV & & \\
\hline & idade & $D P$ & $D P$ & $C P$ & $C P$ & $D P$ & \\
\hline & \multicolumn{6}{|c|}{ Avaliação Ajustamento } & \\
\hline & Critérios & $\mathrm{S}$ & $\mathrm{F}$ & $\mathrm{CA}$ & $\mathrm{C}$ & & \\
\hline & Formal & $A$ & $A$ & & & & \\
\hline & formal & $A P$ & $A P$ & & $A P$ & & \\
\hline \multirow[t]{7}{*}{04.04} & \multicolumn{6}{|c|}{ Equivalência Demandas } & \multirow{7}{*}{$\begin{array}{l}\text { O espaço arquitetônico formal é geograficamente isolado, o que exige estrutura de apoio (funcionários e visitantes). Isto favorece a } \\
\text { segurança (aumento da impermeabilidade e estanqueidade) e o conforto ambiental (áreas livres), enquanto compromete a } \\
\text { funcionalidade (aumenta as tarefas) e desfavorece os custos (aumento de áreas e de pessoal). A equipe dirigente considera o isolamento } \\
\text { essencial (romper a comunicação informal e defender contra ataques externos). O espaço informal tende a uma localização isolada, com } \\
\text { eventuais locações inseridas ou próximas a ocupações urbanas. Isto desfavorece ou compromete o ajustamento (maior dependência do } \\
\text { terreno, do tipo de barreira perimetral e do fechamento das edificações). As demandas são parcialmente divergentes (DP). A solução } \\
\text { formal prevalece, porém com a demanda de atender a acessibilidade e o suporte aos usuários, aliada os custos. }\end{array}$} \\
\hline & ojeto & DF & SP & MJ & EV & & \\
\hline & ridade & & $D P$ & $D P$ & & $D P$ & \\
\hline & \multicolumn{6}{|c|}{ Avaliação Ajustamento } & \\
\hline & Critérios & $\mathrm{s}$ & & $\mathrm{CA}$ & $\mathrm{C}$ & & \\
\hline & Formal & $A$ & $A P$ & $A$ & $\overline{N A}$ & $A P$ & \\
\hline & Informal & & & & & & \\
\hline
\end{tabular}


social e na localização dos estabelecimentos, por isto dissonante da segurança exigida. Isto apesar da convergência parcial da impermeabilidade institucional (04.01 e 04.02). Sobressaem as questões penais do modelo prisional e do planejamento penitenciário (política fundiária), além da questão penitenciária da redução de custos de construção.

\begin{tabular}{|c|c|c|c|c|c|c|c|}
\hline \multicolumn{8}{|c|}{ 05. Isolamento Individual } \\
\hline \multirow[t]{7}{*}{05.01} & \multicolumn{6}{|c|}{ Equivalência Demandas } & \multirow{7}{*}{$\begin{array}{l}\text { O espaço arquitetônico formal concorre para a individualização absoluta (caráter punitivo da pena). Isto favorece a segurança (submissão } \\
\text { dos presos) e o conforto ambiental (aumenta a relação abertura/vaga), enquanto o aumento da quantidade de alas carcerárias prejudica a } \\
\text { funcionalidade (aumento das tarefas) e desfavorece os custos (aumento de áreas e de pessoal). O espaço informal é dotado de celas } \\
\text { coletivas. A equipe dirigente e os presos preferem a cela coletiva (otimização da estrutura física e operacional e valorização das relações } \\
\text { sociais). Isto desfavorece ou compromete o ajustamento, com exceção dos custos (redução de áreas e de pessoal). As demandas são } \\
\text { plenamente divergentes } \\
\text { custo de A solução formal prevalece, porém com a demanda de responder à pressão por vagas, aliada à redução do } \\
\text { custo deano. }\end{array}$} \\
\hline & Projeto & DF & SP & MJ & EV & & \\
\hline & Paridade & $D P$ & $D$ & $D$ & $D$ & D & \\
\hline & \multicolumn{6}{|c|}{ Avaliação Ajustamento } & \\
\hline & Critérios & $\mathrm{S}$ & $\mathrm{F}$ & $\mathrm{CA}$ & $\mathrm{C}$ & & \\
\hline & Formal & $A$ & $A P$ & $A$ & $N A$ & $A P$ & \\
\hline & Informal & NA & $A P$ & $A P$ & $A$ & $A P$ & \\
\hline \multirow[t]{7}{*}{05.02} & \multicolumn{6}{|c|}{ Equivalência Demandas } & \multirow{7}{*}{$\begin{array}{l}\text { O espaço arquitetônico formal concorre para a classificação e a separação individualizada dos encarcerados. O modelo supermax (padrão } \\
\text { arquitetônico modular) cria entre oito e nove grupos de } 24 \text { a } 48 \text { pessoas cada. Isto favorece a segurança (submissão dos presos), } \\
\text { enquanto a quantidade de alas carcerárias compromete a funcionalidade (aumento das tarefas) e desfavorece os custos (aumento de } \\
\text { áreas e de pessoal). O espaço informal é dotado de quatro blocos de vivência com } 96 \text { a } 144 \text { presos, em média, o que constitui uma } \\
\text { massificação dos presos. Isto desfavorece a segurança (empoderamento dos presos) e a funcionalidade (complicação dos procedimentos), } \\
\text { enquanto favorece os custos (redução de áreas e otimização da estrutura com redução de pessoal). As demandas são plenamente } \\
\text { divergentes (D). A solução formal prevalece, porém com a demanda de responder à funcionalidade e à economia de recursos. }\end{array}$} \\
\hline & Projeto & $\mathrm{DF}$ & SP & MJ & EV & & \\
\hline & Paridade & $D P$ & $D$ & $D$ & $D$ & D & \\
\hline & \multicolumn{6}{|c|}{ Avaliação Ajustamento } & \\
\hline & Critérios & $\mathrm{S}$ & $\mathrm{F}$ & $\mathrm{CA}$ & $\mathrm{C}$ & & \\
\hline & Formal & $A$ & $A P$ & 1 & NA & $A P$ & \\
\hline & Informal & NA & NA & 1 & $A$ & $N A$ & \\
\hline \multirow[t]{7}{*}{05.03} & \multicolumn{6}{|c|}{ Equivalência Demandas } & \multirow{7}{*}{$\begin{array}{l}\text { O espaço arquitetônico formal e informal concorre para a isonomia na aplicação da pena, ao apresentar celas uniformes, com a exceção } \\
\text { de celas acessíveis (PNE). Isto favorece o ajustamento (homogeneização do sistema de segurança, simplificação dos procedimentos, } \\
\text { compatibilização e padronização das aberturas e racionalidade construtiva). As demandas são plenamente convergentes (C). As soluções } \\
\text { formal e informal se equivalem: uniformizar o espaço arquitetônico da cela. }\end{array}$} \\
\hline & Projeto & DF & SP & MJ & EV & & \\
\hline & Paridade & $C$ & $C$ & $C$ & $C$ & $C$ & \\
\hline & \multicolumn{6}{|c|}{ Avaliação Ajustamento } & \\
\hline & Critérios & $\mathrm{S}$ & $\mathrm{F}$ & CA & $\mathrm{C}$ & & \\
\hline & Formal & $A$ & $A$ & $A$ & $A$ & $A$ & \\
\hline & Informal & $A$ & $A$ & $A$ & $A$ & $A$ & \\
\hline \multirow[t]{7}{*}{05.04} & \multicolumn{6}{|c|}{ Equivalência Demandas } & \multirow{7}{*}{$\begin{array}{l}\text { O espaço arquitetônico formal é dotado de celas individuais, ao buscar atender ao grau de segurança máximo (caráter punitivo da pena). } \\
\text { Isto favorece a segurança (submissão dos presos), enquanto o aumento da quantidade de alas carcerárias compromete a funcionalidade } \\
\text { (aumento das tarefas) e desfavorece os custos (aumento de áreas e de pessoal). O espaço informal é dotado de celas coletivas, o que } \\
\text { reflete a imprecisão normativa (tipo de alojamento tipicamente de segurança média). Isto desfavorece a segurança (empoderamento dos } \\
\text { presos) e a funcionalidade (aumento das tarefas e complicação dos procedimentos), enquanto favorece os custos (redução de áreas e } \\
\text { otimização da estrutura física e operacional). As demandas são plenamente divergentes (D). A solução formal prevalece, porém com a } \\
\text { demanda de responder à pressão por vagas, aliada à economia de recursos. }\end{array}$} \\
\hline & Projeto & $\mathrm{DF}$ & SP & MJ & EV & & \\
\hline & Paridade & $D P$ & $D$ & $D$ & $D$ & D & \\
\hline & \multicolumn{6}{|c|}{ Avaliação Ajustamento } & \\
\hline & Critérios & $\mathrm{S}$ & $\mathrm{F}$ & $\mathrm{CA}$ & $\mathrm{C}$ & & \\
\hline & Formal & $A$ & $A P$ & 1 & $N A$ & $A P$ & \\
\hline & Informal & NA & NA & 1 & $\bar{A}$ & NA & \\
\hline \multirow[t]{7}{*}{05.05} & \multicolumn{6}{|c|}{ Equivalência Demandas } & \multirow{7}{*}{$\begin{array}{l}\text { O espaço arquitetônico formal é dotado de celas individuais para a separação de presos, em número de } 2 \% \text { da capacidade e localizadas } \\
\text { isoladamente da população prisional. Isto favorece a segurança (maximização da disciplina interna) e a funcionalidade (especialização das } \\
\text { funções), enquanto compromete os custos (aumento de áreas e de pessoal). O espaço informal tende a apresentar uma ala de isolamento } \\
\text { na proporção de } 1,5 \% \text { da capacidade. Eventualmente, a ala de celas individuais é comum a outras funções ou apresenta celas duplas. A } \\
\text { equipe dirigente considera necessária a individualidade e o isolamento destas celas, sendo suficiente a proporção de } 1 \% \text { da capacidade. } \\
\text { Isto compromete o ajustamento, enquanto favorece os custos (redução de áreas e otimização da estrutura física e operacional). As } \\
\text { demandas são parcialmente convergentes (DP). A solução formal prevalece, porém com a demanda de responder à pragmática prisional }\end{array}$} \\
\hline & Projeto & DF & SP & MJ & EV & & \\
\hline & Paridade & $C P$ & & $C P$ & $C P$ & $C P$ & \\
\hline & \multicolumn{6}{|c|}{ Avaliação Ajustamento } & \\
\hline & Critérios & $\mathrm{S}$ & $\mathrm{F}$ & CA & C & & \\
\hline & Formal & $A$ & $A$ & 1 & $A P$ & & \\
\hline & Informal & $A P$ & $A P$ & I & & & \\
\hline
\end{tabular}




\begin{tabular}{|c|c|c|c|c|c|c|c|}
\hline & & & & & & & \\
\hline \multirow[t]{7}{*}{05.06} & \multicolumn{6}{|c|}{ Equivalência Demandas } & \multirow{7}{*}{$\begin{array}{l}\text { A demanda formal prevê a menor capacidade para as celas coletivas. Isto favorece a segurança (submissão dos presos) e o conforto } \\
\text { ambiental (aumento da relação abertura por vaga), enquanto o aumento da quantidade de alas carcerárias prejudica a funcionalidade } \\
\text { (aumento das tarefas) e desfavorece os custos (aumento de áreas e de pessoal). O espaço informal tende a uma capacidade ampliada } \\
\text { (média de nove vagas, variando entre de quatro e doze vagas). Isto favorece a funcionalidade (redução das tarefas) e os custos (redução } \\
\text { de áreas e otimização da estrutura física e operacional), enquanto compromete a segurança (empoderamento dos presos) e o conforto } \\
\text { ambiental (aglomeração dos presos). A equipe dirigente e os presos optam por celas entre quatro e oito pessoas. As demandas são } \\
\text { parcialmente divergentes (DP). A soluçãa informal prevalece, porém com a demanda de responder à segurança e ao conforto ambiental. }\end{array}$} \\
\hline & Projeto & $\mathrm{DF}$ & SP & MJ & EV & & \\
\hline & & & & & & $D P$ & \\
\hline & \multicolumn{6}{|c|}{ Avaliação Ajustamento } & \\
\hline & itérios & $s$ & $\mathrm{~F}$ & & $\mathrm{C}$ & & \\
\hline & & $A$ & & & & & \\
\hline & rmal & $A P$ & $A$ & $A P$ & A & $A P$ & \\
\hline Grupo & \multicolumn{7}{|c|}{$\begin{array}{l}\text { As exigências formais e informais são plenamente divergentes, ao se gerar uma edificação adversa no isolamento individual dos presos (coletivização da cela), por isto dissonante } \\
\text { dos objetivos penalógicos e da segurança exigida. Isto apesar da convergência plena ou parcial na uniformização e na separação de presos (05.03 e 05.05). Sobressaem as questões } \\
\text { penitenciárias (demanda superlativa por vagas) e de redução do custo de construção (custo da vaga). A solução formal prevalece, porém as soluções informais fornecem critérios } \\
\text { para a necessária adequação da edificação em termos da pragmática prisional, além de aspectos funcionais e econômicos, conforme a realidade prisional. }\end{array}$} \\
\hline \multicolumn{8}{|c|}{ do espaço } \\
\hline \multirow[t]{7}{*}{06.01} & \multicolumn{6}{|c|}{ Equivalência Demandas } & \multirow{7}{*}{$\begin{array}{l}\text { O espaço arquitetônico formal tem as funções coordenadas racionalmente, de modo a atingir a segurança máxima com o mínimo de } \\
\text { recursos, dentro do objetivo de cumprimento da pena: a simplicidade geométrica e funcional. Isto favorece o ajustamento (submissão dos } \\
\text { presos, simplificação dos procedimentos, respeito aos padrões mínimos de bem-estar, redução de áreas e de pessoal). O espaço informal } \\
\text { apresenta inconsistências organizacionais, ao conjugar características espaciais de modalidades distintas de arquitetura. Isto compromete } \\
\text { o ajustamento (empoderamento dos presos, aumento das tarefas, desrespeito aos padrões mínimos), enquanto desfavorece os custos. As } \\
\text { demandas são parcialmente divergentes (DP). A solução formal prevalece, porém com a demanda de responder ao modelo prisional: o } \\
\text { atendimento da reinserçãa social, aliada à economia de recursos. }\end{array}$} \\
\hline & & & & & & & \\
\hline & & & & & $C P$ & & \\
\hline & \multicolumn{6}{|c|}{ Avaliação Ajustamento } & \\
\hline & & & & & & & \\
\hline & & $A$ & & & & & \\
\hline & & & & & & & \\
\hline \multirow[t]{7}{*}{06.02} & \multicolumn{6}{|c|}{ Equivalência Demandas } & \multirow{7}{*}{$\begin{array}{l}\text { O espaço arquitetônico formal é organizado em função da disciplina, que arranja os diferentes tipos de pessoas (presos, funcionários e } \\
\text { visitantes), funções (segurança e operação) e fluxos (pessoas, veículos e materiais), tendo em vista a maximização da segurança e a } \\
\text { minimização do consumo de recursos. Isto favorece o ajustamento (aumento do controle institucional, redução das tarefas, respeito aos } \\
\text { padrões mínimos de bem-estar e redução de áreas e de pessoal). O espaço informal apresenta uma racionalidade inerente aos padrões } \\
\text { arquitetônicos penitenciários (paralelo e modular), porém desvinculada dos conceitos penalógicos, ao focar as funçães em detrimento das } \\
\text { pessoas e dos fluxos (modelo prisional). Isto compromete o ajustamento. As demandas são parcialmente divergentes (DP). A soluçãã } \\
\text { formal prevalece, porém com a demanda de responder à pressão por vagas, aliada à economia de recursos. }\end{array}$} \\
\hline & & DF & 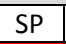 & & & & \\
\hline & & & $D P$ & $D P$ & & & \\
\hline & \multicolumn{6}{|c|}{ Avaliação Ajustamento } & \\
\hline & & $\mathrm{s}$ & & CA & $\mathrm{C}$ & & \\
\hline & & $A$ & $A$ & $A$ & & $A$ & \\
\hline & & $A P$ & & & & & \\
\hline \multirow[t]{7}{*}{06.03} & \multicolumn{6}{|c|}{ Equivalência Demandas } & \multirow{7}{*}{$\begin{array}{l}\text { A demanda formal aplica a disciplina-bloco: a maximização da segurança limitada pelo respeito à condição humana na prisão, obtida pelo } \\
\text { domínio total da instituiçãao das atividades e fluxos (especialização espacial das funções e circulações), com o menor risco aos funcionários } \\
\text { (separação física). Isto favorece o ajustamento. A demanda informal tende a implementar a disciplina-bloco, porém conjuga } \\
\text { características espaciais de modalidades distintas de arquitetura (coletivização, complexidade geométrica, aumento das atividades, } \\
\text { externalização funcional e vigilância indireta). Isto compromete o ajustamento (empoderamento dos presos, aumento de tarefas, } \\
\text { exposiçăo dos funcionários e aumento de áreas e de pessoal). As demandas são parcialmente divergentes (DP). A solução formal } \\
\text { prevalece, porém com a demanda de responder ao modelo prisional: o atendimento da reinserção social, aliada à economia de recursos. }\end{array}$} \\
\hline & & DF & SP & MJ & & & \\
\hline & & & & & & & \\
\hline & \multicolumn{6}{|c|}{ Avaliação Ajustamento } & \\
\hline & & & & CA & & & \\
\hline & & & & & & & \\
\hline & & & & & & & \\
\hline & & & & & & & \\
\hline
\end{tabular}


projetista. A solução formal prevalece, porém as soluções informais fornecem critérios para a necessária adequação da edificação em termos da condição do sistema penitenciário e da pragmática prisional, conforme a realidade prisional.

07. Geometria

$07.01 \quad$ Equivalência Demandas

\begin{tabular}{|c|c|c|c|c|c|c|}
\hline Projeto & DF & SP & MJ & EV & \\
\hline Paridade & $C P$ & $C P$ & $D P$ & $C P$ & $C P$ \\
\hline \multicolumn{7}{|c|}{ Avaliação Ajustamento } \\
\hline Critérios & $S$ & $F$ & $C A$ & $C$ & \\
\hline Formal & $A P$ & $A$ & $A$ & $A$ & $A$ \\
\hline Informal & $A P$ & $A P$ & $A P$ & $A P$ & $A P$ \\
\hline
\end{tabular}

O espaço arquitetônico formal apresenta simplicidade geométrica (formas puras, regulares e lineares, além de horizontais), coordenadas por meio da centralidade, simetria, ortogonalidade e alinhamentos (adensamento) (disciplina-bloco). O modelo supermax tende a uma complexidade geométrica, ao mesmo tempo em que agrupa os módulos (compactação). Isto desfavorece a segurança (aumento das vulnerabilidades), enquanto favorece a funcionalidade (simplificação dos procedimentos), o conforto ambiental (respeito aos padrões mínimos de bem-estar) e os custos (otimização da estrutura física e operacional). O espaço informal tende a apresentar uma simplicidade geométrica, baseada nos padrões paralelo e modular (compactados e horizontalizados). Eventualmente ou pontualmente, ocorrem complexidades (irregularidades formais, dissimetrias e descontinuidades). Isto compromete o ajustamento. As demandas são parcialmente convergentes (CP). A solução formal prevalece, porém com a demanda da simplicidade espacial, aliada à segurança.

Grupo As características formais e informais são parcialmente convergentes, ao se gerar uma edificação que atende à disciplina formal e dos conceitos dos padrões arquitetônicos penitenciários, mas que eventualmente apresenta uma complexidade geométrica que se alinha ao padrão modular, por isto destoante da exigência de segurança máxima. Sobressai a questão da indefinição nos instrumentos técnicos de projeto e a deficiência do projetista em articular a geometria com a funcionalidade. A solução formal prevalece, porém com a ressalva de atender aos pressupostos conceituais, enquanto solução informal corrobora a necessária adequação da edificação em termos da compactação espacial.

08. Funcionalidade

$08.01 \quad$ Equivalência Demandas

\begin{tabular}{|c|c|c|c|c|c|c|c|}
\hline Projeto & DF & SP & MJ & EV & \\
\hline Paridade & DP & DP & $C P$ & $C P$ & $D P$ \\
\hline \multicolumn{7}{|c|}{ Avaliação Ajustamento } \\
\hline Critérios & S & F & CA & C & \\
\hline Formal & $A$ & $A$ & $I$ & $A$ & $A$ \\
\hline Informal & $A P$ & $A P$ & $I$ & $A P$ & $A P$ \\
\hline
\end{tabular}

$08.02 \quad$ Equivalência Demandas

\begin{tabular}{|l|l|l|l|l|l|}
\hline Projeto & DF & SP & MJ & EV & \\
\hline Paridade & $D P$ & $D P$ & $C P$ & $C P$ & $D P$ \\
\hline
\end{tabular}

O espaço arquitetônico formal apresenta simplicidade funcional, ao enfatizar o objetivo punitivo nos processos totais do integralismo e mecanicismo (disciplina-bloco): redução da quantidade de recintos (redução e sobreposição das atividades) e minimização dos deslocamentos - a síntese funcional. Isto favorece o ajustamento (aumento do controle institucional, redução de tarefas, simplificação dos procedimentos e redução de áreas e de pessoal). A demanda informal relaxa os processos totais, ao conjugar modalidades distintas de arquitetura, o que caracteriza a coletivização com aumento de capacidades, a generalização funcional dos locais e a valorização dos programas de sociabilização e de benefícios aos presos. Isto compromete o ajustamento (empoderamento dos presos, aumento das tarefas e aumento de áreas e de pessoal). As demandas são parcialmente divergentes (DP). A solução formal prevalece, porém com a demanda de responder ao modelo prisional: o atendimento da reinserção social, aliada à economia de recursos.

O espaço arquitetônico formal reproduz a simplicidade funcional em cada um dos recintos - o dimensionamento e aparelhamento mínimos, dentro dos padrões de bem-estar mínimos. Isto favorece o ajustamento (redução de vulnerabilidades e simplificação dos procedimentos), com exceção dos custos (aumento de áreas e incremento do aparelhamento). A demanda informal tende a prejudicar a realização das atividades (coletivização com aumento de capacidade e generalização funcional). A equipe dirigente aponta a deficiência dos locais. Isto compromete a segurança e o conforto ambiental, enquanto desfavorece a funcionalidade (redução da utilidade dos Avaliação Ajustamento

\begin{tabular}{l|c|c|c|c|c|c|c|} 
Criterios & S & F & CA & C & \\
\hline Formal & A & A & A & AP & A \\
\hline
\end{tabular}

\begin{tabular}{c|c|c|c|c|c|} 
Informal & $A P$ & $A$ & $A$ & $A P$ & $A$ \\
& $A P$ & $A P$ & $A$ & $A P$
\end{tabular}
espaços) e favorece os custos (redução de áreas e otimização da estrutura física e operacional). As demandas são parcialmente divergentes (DP). A solução formal prevalece, porém com a demanda de responder à pressão por vagas e ao modelo prisional: 0 atendimento da reinserção social, aliadas à economia de recursos.

Grupo As características formais e informais são parcialmente divergentes, ao se gerar uma edificação adversa da simplicidade funcional descrita pelos processos totais, por isto parcialmente dissonante da segurança exigida. Sobressaem as questões penitenciárias do incremento da segurança e da demanda superlativa por vagas, além da redução do custo de construção, aliadas à indefinição nos instrumentos técnicos de projeto e à deficiência do projetista. A solução formal prevalece, porém as soluções informais fornecem critérios para a necessária adequação da edificação em termos da condição do sistema penitenciário e da pragmática prisional, conforme a realidade prisional.

09. Atividades

\begin{tabular}{|l|c|c|c|c|c|c|}
\hline 09.01 & \multicolumn{5}{|c|}{ Equivalência Demandas } \\
\cline { 2 - 7 } & Projeto & DF & SP & MJ & EV & \\
\cline { 2 - 7 } & Paridade & $C P$ & $C P$ & $D P$ & $C P$ & CP \\
\hline
\end{tabular}

O espaço arquitetônico formal implica em uma redução dos programas de sociabilização e de benefícios aos presos (2,0m²/vaga). Isto favorece a segurança (redução de vulnerabilidades), a funcionalidade (redução de tarefas) e os custos (redução de áreas e otimização da estrutura física e operacional). A demanda informal tende a valorizar os programas de sociabilização e de benefícios aos presos 
Avaliação Ajustamento

\begin{tabular}{|c|c|c|c|c|c|}
\hline Critérios & $\mathrm{S}$ & $\mathrm{F}$ & $\mathrm{CA}$ & $\mathrm{C}$ & \\
\hline Formal & $A$ & $A$ & $I$ & $A$ & $A$ \\
\hline Informal & $A P$ & $A P$ & $I$ & $A P$ & $A P$ \\
\multicolumn{6}{|c|}{ Equivalência Demandas } \\
\hline
\end{tabular}

09.02 Equivalência Demandas

\begin{tabular}{|l|l|l|l|l|l|}
\hline Projeto & $\mathrm{DF}$ & $\mathrm{SP}$ & $\mathrm{MJ}$ & $\mathrm{EV}$ & \\
\hline Paridade & $\mathrm{CP}$ & $\mathrm{CP}$ & $\mathrm{CP}$ & $\mathrm{CP}$ & $\mathbf{C P}$ \\
\hline
\end{tabular}
Avaliação Ajustamento

\begin{tabular}{|c|c|c|c|c|c|}
\hline Critérios & $\mathrm{S}$ & $\mathrm{F}$ & $\mathrm{CA}$ & $\mathrm{C}$ & \\
\hline
\end{tabular}

\begin{tabular}{c|c|c|c|c|c|}
\hline Formal & $A$ & $A$ & $I$ & $A$ & $\boldsymbol{A}$ \\
\hline Informal & $A P$ & $A P$ & $I$ & $A$ & $A P$ \\
\hline
\end{tabular}

(2,33 $\left.\mathrm{m}^{2} / \mathrm{vaga}\right)$ (mescla características de segurança máxima e média) e, eventualmente, o sistema de segurança (circulações exclusivas para os funcionários chegam a $17 \%$ da área construída). Isto compromete o ajustamento, em especial, quando não ocorre o investimento na segurança. As demandas são parcialmente convergentes (CP). A solução formal prevalece, porém com a demanda de responder ao modelo prisional: o atendimento da segurança e da reinserção social, aliadas à economia de recursos.

A demanda formal garante o funcionamento seguro do estabelecimento penal, ao contemplar as atividades de apoio e os serviços de infraestrutura necessários aos sistemas de segurança e operação. Isto favorece a segurança e a funcionalidade, a despeito dos custos (o investimento é impreterível). A demanda informal tende a reduzir ou subtrair atividades de apoio necessárias tanto à segurança (postos de controle, portarias ou torres de vigilância), como à operação (almoxarifado, apoio aos funcionários, serviços gerais, entre outros), o que abrange $22 \%$ dos itens discriminados nas Diretrizes Básicas. Isto compromete a segurança e a funcionalidade, enquanto favorece os custos (redução de áreas e de componentes). As demandas são parcialmente convergentes (CP). A solução formal prevalece, porém com a demanda de responder à economia de recursos.

Grupo As exigências formais e informais são parcialmente convergentes, ao se gerar uma edificação provida da totalidade da estrutura física necessária para os sistemas de segurança e operação, por isto parcialmente dissonante da segurança exigida. Isto apesar da inclusão de itens característicos do nível de segurança média e da exclusão de outros itens necessários ao funcionamento da prisão. Sobressaem as questões penitenciárias do incremento da segurança e de redução do custo de construção, aliadas à indefinição programática nos instrumentos técnicos de projeto. A solução formal prevalece, porém as soluções informais fornecem critérios para a necessária adequação da edificação em termos da pragmática prisional, conforme a realidade prisional.

\begin{tabular}{|c|c|c|c|c|c|c|c|}
\hline \multicolumn{7}{|c|}{ 10. Espacialização } & \\
\hline \multirow[t]{7}{*}{10.01} & \multicolumn{6}{|c|}{ Equivalência Demandas } & \\
\hline & Projeto & DF & SP & MJ & EV & & \\
\hline & Paridade & $D P$ & $D P$ & $D P$ & $C P$ & DP & \\
\hline & \multicolumn{6}{|c|}{ Avaliação Ajustamento } & \\
\hline & Critérios & $\mathrm{S}$ & $\mathrm{F}$ & CA & $\mathrm{C}$ & & \\
\hline & Formal & A & $A$ & 1 & $A P$ & A & \\
\hline & Informal & $A P$ & $A P$ & 1 & $A P$ & $A P$ & \\
\hline \multirow[t]{7}{*}{10.02} & \multicolumn{6}{|c|}{ Equivalência Demandas } & \\
\hline & Projeto & DF & SP & MJ & EV & & \\
\hline & Paridade & $D P$ & $D$ & $C P$ & $C$ & $D P$ & \\
\hline & \multicolumn{6}{|c|}{ Avaliação Ajustamento } & \\
\hline & Critérios & $\mathrm{S}$ & $\mathrm{F}$ & CA & C & & \\
\hline & Formal & $A$ & $A$ & 1 & $A P$ & A & \\
\hline & Informal & $A P$ & $A P$ & l & $A$ & $A P$ & \\
\hline \multirow[t]{6}{*}{10.03} & \multicolumn{6}{|c|}{ Equivalência Demandas } & \\
\hline & Projeto & DF & SP & MJ & EV & & \\
\hline & Paridade & $D P$ & $D P$ & $C P$ & $D P$ & $D P$ & \\
\hline & \multicolumn{6}{|c|}{ Avaliação Ajustamento } & \\
\hline & Critérios & $\mathrm{S}$ & $\mathrm{F}$ & CA & C & & \\
\hline & Formal & $A$ & $A P$ & 1 & A & A & \\
\hline
\end{tabular}

A demanda formal enfatiza a síntese funcional, o que implica na setorização e especialização funcional. 0 modelo supermax concentra a área construída no setor interno (87\%), ao replicar atividades nos blocos de vivência. Isto favorece a segurança (aumento do controle institucional) e a funcionalidade (redução de tarefas), enquanto compromete os custos (aumento de áreas e de pessoal). O espaço informal tende a uma complexidade funcional, ao conjugar os padrões arquitetônicos paralelo e modular conceitualmente desvirtuados e desvinculados do modelo prisional (desordenamento hierárquico e generalização funcional) embora apresente uma compactação geométrica e internalização dos programas citados ( $79 \%$ da área construída no setor interno). Isto compromete o ajustamento. As demandas são parcialmente divergentes (DP). A solução formal prevalece, porém com a demanda de responder à economia de recursos.

O espaço arquitetônico formal estabelece o domínio territorial da instituição ( $88 \%$ da área construída) através da especialização funcional e do controle extensivo, além da separação física dos grupos de funcionários e presos (vigilância direta). Isto favorece a segurança (maximização do controle institucional) e a funcionalidade (redução das tarefas e simplificação dos procedimentos), enquanto compromete os custos (aumento de áreas). O espaço informal tende a permitir um domínio maior dos presos (de $24 \%$ a $32 \%$ de locais livres), derivado da generalização funcional (principalmente, pela contiguidade entre recintos coletivos de uso dos presos - ausência da intermediação de circulações) e pelo contato físico de funcionários e presos. Isto compromete a segurança (empoderamento dos presos e exposição dos funcionários) e a funcionalidade (complicação dos procedimentos), enquanto favorece os custos (redução de áreas e otimização da estrutura física e operacional). As demandas são parcialmente divergentes (DP). A solução formal prevalece, porém com a demanda de responder à economia de recursos.

A demanda formal conforma a representação institucional, ao limitar a entrada da visita ao setor intermediário (palco) e isolar os presos ao fundo da unidade penal (bastidores). O modelo supermax (padrão arquitetônico modular) concentra a visita no setor intermediário. Isto favorece a segurança (redução de vulnerabilidades) e os custos (redução de áreas e otimização da estrutura), enquanto complica a funcionalidade (aumento das tarefas). A demanda informal tende a prejudicar a representação institucional, ao internalizar o programa de sociabilização dos presos, principalmente na ausência de local próprio de visita (não se configura o palco). Mitigado pela menor profundidade topológica dos locais de visita. A equipe dirigente considera importante o local das visitas e crítico o deslocamento de 


\begin{tabular}{|c|c|c|c|c|c|c|c|}
\hline & Informal & $A$ & $A P$ & 1 & $A P$ & $A P$ & $\begin{array}{l}\text { resos. Isto favorece a segurança (redução do deslocamento dos presos), enquanto o aumento da quantidade de alas carcerárias } \\
\text { ompromete a funcionalidade (aumento das tarefas) e os custos (aumento de áreas e de pessoal). As demandas são parcialmente } \\
\text { ivergentes (DP). A solução formal prevalece, porém com a demanda de responder à internalização do palco e à economia de recursos. }\end{array}$ \\
\hline \multirow[t]{7}{*}{10.04} & \multicolumn{6}{|c|}{ Equivalência Demandas } & \multirow{7}{*}{$\begin{array}{l}\text { O espaço arquitetônico formal fraciona a população prisional em pequenos grupos (entre oito e nove grupos de } 24 \text { a } 48 \text { pessoas cada), } \\
\text { abrigados em blocos de vivência, enquanto centraliza e externaliza o programa de benefícios (padrão arquitetônico modular). Isto } \\
\text { favorece a segurança (submissão dos presos), enquanto a quantidade de alas carcerárias complica a funcionalidade (aumento das tarefas) } \\
\text { e desfavorece os custos (aumento de áreas e de pessoal). O espaço informal tende a frações maiores (quatro grupos de } 108 \text { a } 140 \\
\text { indivíduos cada) e os blocos de vivência recebem os programas de sociabilização e de benefícios aos presos (internalização). Isto } \\
\text { compromete a segurança (empoderamento dos presos), enquanto favorece a funcionalidade (redução tarefas) e os custos (redução de } \\
\text { áreas e otimização da estrutura física e operacional). As demandas são parcialmente convergentes (CP). A solução informal prevalece, } \\
\text { porém com a demanda de responder à segurança (tamanho dos grupos de presos). }\end{array}$} \\
\hline & Projeto & $\mathrm{DF}$ & $\mathrm{SP}$ & MJ & EV & & \\
\hline & Paridade & $C P$ & $C P$ & $C P$ & C & $C P$ & \\
\hline & \multicolumn{6}{|c|}{ Avaliação Ajustamento } & \\
\hline & Critérios & $S$ & $\mathrm{~F}$ & $\mathrm{CA}$ & $\mathrm{C}$ & & \\
\hline & Formal & $A$ & $A P$ & 1 & $N A$ & $A P$ & \\
\hline & Informal & $A P$ & $A$ & 1 & $A$ & $\boldsymbol{A}$ & \\
\hline \multirow[t]{7}{*}{10.05} & \multicolumn{6}{|c|}{ Equivalência Demandas } & \multirow{7}{*}{$\begin{array}{l}\text { A demanda formal enfatiza a individualização e a disciplina-bloco em cada um dos espaços internos para a imposição da impessoalidade } \\
\text { (não-apropriação do espaço), dentro dos padrões mínimos de bem-estar. No modelo supermax, o espaço pessoal é a cela e não existe } \\
\text { privacidade em relação à instituição. Isto favorece a segurança (submissão dos presos) e a funcionalidade (simplifica procedimentos), } \\
\text { enquanto compromete os custos (aumento de áreas e de pessoal). O espaço informal tende a desabilitar a impessoalidade como } \\
\text { mecanismo de controle (coletivização com aumento de capacidade e fechamento da cela). O espaço pessoal é a cama e a privacidade } \\
\text { entre os presos inexiste, mas ocorre uma apropriação dos locais. Isto compromete a segurança (aumento da vulnerabilidade) e a } \\
\text { funcionalidade (complicação dos procedimentos), enquanto favorece os custos (redução de áreas e otimização da estrutura física e } \\
\text { operacional). As demandas são parcialmente divergentes (DP). A solução formal prevalece, porém com a demanda de responder à } \\
\text { pressão por vagas e o modelo prisional, aliados à economia de recursos. }\end{array}$} \\
\hline & Projeto & $\mathrm{DF}$ & $\mathrm{SP}$ & MJ & $\mathrm{EV}$ & & \\
\hline & Paridade & $D$ & $D$ & $C P$ & $C P$ & $D P$ & \\
\hline & \multicolumn{6}{|c|}{ Avaliação Ajustamento } & \\
\hline & Critérios & $\mathrm{S}$ & $\mathrm{F}$ & CA & $\mathrm{C}$ & & \\
\hline & rmal & $A$ & $A$ & 1 & $A$ & $A$ & \\
\hline & ormal & $A P$ & $A P$ & 1 & $A$ & $A P$ & \\
\hline \multirow[t]{7}{*}{10.06} & \multicolumn{6}{|c|}{ Equivalência Demandas } & \multirow{7}{*}{$\begin{array}{l}\text { O espaço arquitetônico formal é policresto, ao concentrar atividades afins. Em geral, as grandes áreas coletivas exemplificam isto. No } \\
\text { modelo supermax, as visitas e atividades dos presos ocorrem no mesmo local. Isto favorece o ajustamento (homogeneização do sistema } \\
\text { de segurança, redução de tarefas, redução de áreas e otimização da estrutura física e operacional). A demanda informal tende a } \\
\text { generalizar a utilização dos locais com atividades nem sempre compatíveis (generalização funcional), enquanto o revezamento das } \\
\text { atividades nem sempre é possível devido ao contingente funcional reduzido. Isto compromete a segurança (redução da disciplina interna) } \\
\text { e a funcionalidade (inviabilização de atividades), enquanto favorece os custos (redução de áreas e otimização da estrutura). As demandas } \\
\text { são parcialmente divergentes (DP). A solução formal prevalece, porém com a demanda de responder à economia de recursos. }\end{array}$} \\
\hline & Projeto & $\mathrm{DF}$ & SP & MJ & $\mathrm{EV}$ & & \\
\hline & & $D P$ & $D P$ & $C P$ & $C P$ & $D P$ & \\
\hline & \multicolumn{6}{|c|}{ Avaliação Ajustamento } & \\
\hline & itérios & $\mathrm{S}$ & $\mathrm{F}$ & CA & $\mathrm{C}$ & & \\
\hline & & $A$ & $A$ & 1 & $A$ & $A$ & \\
\hline & ormal & $A P$ & $A P$ & l & $A$ & $A P$ & \\
\hline Grupo & & & & & & & $\begin{array}{l}\text { cialmente divergentes, ao se gerar uma edificação espacialmente adversa do modelo prisional (realização das atividades previstas, de } \\
\text { to tempo em que descumpre os padrões de bem estar mínimos, por isto dissonante da segurança exigida. Isto embora permita a } \\
\text { em as questões penitenciárias da disputa de poder nas prisões, do incremento da segurança, da demanda por vagas e da massificação } \\
\text { construção, assim como, a deficiência do projetista. A solução formal prevalece, porém as soluções informais fornecem critérios para a } \\
\text { rmos da pragmática prisional, conforme a realidade prisional. }\end{array}$ \\
\hline \multicolumn{8}{|c|}{ 11. Dimensionamento } \\
\hline \multirow[t]{7}{*}{11.01} & \multicolumn{6}{|c|}{ Equivalêr } & \multirow{7}{*}{$\begin{array}{l}\text { O espaço arquitetônico formal tende a compactação espacial, ao minimizar o índice de área construída por vaga (a partir de } 12 \mathrm{~m}^{2} / \mathrm{vaga} \text { e } \\
\text { em média } 16,6 \mathrm{~m}^{2} / \text { vaga). O modelo supermax (padrão arquitetônico modular) apresenta uma relação maior } 46,94 \mathrm{~m}^{2} / \mathrm{vaga} \text { (em parte, pela } \\
\text { repetição de atividades nos blocos de vivência). Isto favorece o ajustamento (simplicidade funcional), com exceção dos custos (aumento } \\
\text { de áreas e de pessoal). O espaço informal tende a desvirtuar o modelo de segurança máxima, ao apresentar valores maiores } \\
\left(18,7 \mathrm{~m}^{2} / \text { vaga), apesar do aumento da capacidade. Isto compromete o ajustamento (aumento das tarefas, das áreas e de pessoal), }\right. \\
\text { enquanto favorece o conforto ambiental. As demandas são parcialmente divergentes (DP). A solução formal prevalece, porém com a } \\
\text { demanda de responder ao modelo prisional: o atendimento da reinserção social, aliada à economia de recursos. }\end{array}$} \\
\hline & & DF & SP & MJ & $\mathrm{EV}$ & & \\
\hline & Paridade & & & & $D P$ & DP & \\
\hline & \multicolumn{6}{|c|}{ Avaliação Ajustamento } & \\
\hline & térios & $\mathrm{S}$ & $\mathrm{F}$ & CA & C & & \\
\hline & Formal & $A$ & $A$ & $A$ & $N A$ & $\boldsymbol{A}$ & \\
\hline & Informal & $A P$ & $A P$ & $A$ & $A P$ & & \\
\hline
\end{tabular}




\begin{tabular}{|c|c|c|c|c|c|c|c|}
\hline \multirow[t]{7}{*}{11.02} & \multicolumn{6}{|c|}{ Equivalência Demandas } & \multirow{7}{*}{$\begin{array}{l}\text { A demanda formal prioriza os espaços destinados aos sistemas de segurança e operação e minimiza as áreas dos programas de } \\
\text { sociabilização }\left(2,43 \mathrm{~m}^{2} / \text { vaga) e de benefícios aos presos }\left(1,71 \mathrm{~m}^{2} / \mathrm{vaga}\right) \text {, pela concentração destas atividades. Isto favorece o ajustamento, }\right. \\
\text { em especial os custos (redução de áreas e de pessoal). A demanda informal tende a desvirtuar o modelo de segurança máxima, ao } \\
\text { aumentar as áreas dos programas de sociabilização }\left(2,51 \mathrm{~m}^{2} / \mathrm{vaga}\right) \text { e de benefícios aos presos }\left(2,16 \mathrm{~m}^{2} / \text { vaga) (em parte, pela replicação }\right. \\
\text { destes programas nos blocos de vivência). Eventualmente, a segurança também é incrementada (circulações exclusivas para os } \\
\text { funcionários - até } 17 \% \text { da área construída). Isto compromete o ajustamento (aumento de vulnerabilidades, tarefas, áreas e pessoal). As } \\
\text { demandas são parcialmente divergentes (DP). A solução formal prevalece, porém com a demanda de responder ao modelo prisional: o } \\
\text { atendimento da segurança e da reinserção social, aliada à economia de recursos. }\end{array}$} \\
\hline & Projeto & DF & SP & MJ & $\mathrm{EV}$ & & \\
\hline & Paridade & $C P$ & $D P$ & $C P$ & $D P$ & $D P$ & \\
\hline & \multicolumn{6}{|c|}{ Avaliação Ajustamento } & \\
\hline & Critérios & $\mathrm{S}$ & $\mathrm{F}$ & CA & $\mathrm{C}$ & & \\
\hline & Formal & $A$ & $A$ & $I$ & $A$ & $\boldsymbol{A}$ & \\
\hline & Informal & $A P$ & $A P$ & 1 & $A P$ & $A P$ & \\
\hline \multirow[t]{7}{*}{11.03} & \multicolumn{6}{|c|}{ Equivalência Demandas } & \multirow{7}{*}{$\begin{array}{l}\left.\text { A demanda formal tende a aumentar o tamanho do terreno, ao maximizar o índice de área de terreno por vaga (a partir de } 16 \mathrm{~m}^{2} / \mathrm{vaga}\right) .0 \\
\text { modelo supermax (padrão arquitetônico modular) soma mais de } 300 \mathrm{~m}^{2} / \text { vaga. As Diretrizes Básicas estimam uma relação de } \\
38,93 \mathrm{~m}^{2} / \text { vaga. Isto favorece a segurança (aumento da impermeabilidade e da estanqueidade) e o conforto ambiental (áreas livres } \\
\text { internas), enquanto compromete a funcionalidade (aumento das tarefas) e desfavorece os custos (aumento de áreas). A demanda } \\
\text { informal tende a desvirtuar o modelo de segurança máxima, ao apresentar índices menores ( } 35,88 \mathrm{~m}^{2} / \text { vaga). Isto favorece a a } \\
\text { funcionalidade (redução das tarefas) e os custos (redução de áreas e de pessoal), enquanto desfavorece a segurança e compromete o } \\
\text { conforto ambiental. As demandas são parcialmente divergentes (DP). As soluções formal e informal se equiparam com vantagens e } \\
\text { desvantagens próprias, prevalece a demanda de responder ao modelo de segurança máxima. }\end{array}$} \\
\hline & Projeto & DF & SP & MJ & EV & & \\
\hline & Paridade & $C$ & $D P$ & $D P$ & $D P$ & $D P$ & \\
\hline & \multicolumn{6}{|c|}{ Avaliação Ajustamento } & \\
\hline & Critérios & $\mathrm{S}$ & $\mathrm{F}$ & CA & $\mathrm{C}$ & & \\
\hline & Formal & $A$ & $A P$ & $A$ & NA & $A P$ & \\
\hline & Informal & NA & $A$ & $A P$ & $A$ & $A P$ & \\
\hline Grupo & $\begin{array}{l}\text { As exigên } \\
\text { segurança } \\
\text { A solução } \\
\text { a realidad }\end{array}$ & & & & & & \\
\hline \multicolumn{8}{|c|}{ 12. Circulação } \\
\hline \multirow[t]{7}{*}{12.01} & \multicolumn{6}{|c|}{ Equivalência Demandas } & \multirow{7}{*}{$\begin{array}{l}\text { A demanda formal restringe a acessibilidade e a mobilidade no interior da prisão (síntese funcional), ao isolar os tipos de fluxos e criar } \\
\text { espaços especializados de circulação, organizados em um gráfico topológico em forma de árvore. A compactação do modelo supermax } \\
\text { evidencia esta restrição. Isto favorece a segurança (aumento do controle institucional) e a funcionalidade (redução de tarefas), enquanto } \\
\text { compromete os custos (aumento de áreas). O espaço informal sobrepõe os tipos de fluxos e a circulação com outras funções } \\
\text { (generalização funcional), assim como, apresenta circuitos topológicos (complexidade funcional). Eventualmente, mitigados pelas } \\
\text { circulações exclusivas para os funcionários e pela menor profundidade topológica do local de visita. Isto compromete o ajustamento } \\
\text { (aumento das vulnerabilidades e exposição dos funcionários, além do aumento das tarefas), com exceção dos custos (redução de áreas e } \\
\text { otimização da estrutura física e operacional). As demandas são parcialmente divergentes (DP). A solução formal prevalece, porém com a } \\
\text { demanda de responder ao modelo prisional: a reinserção social dos presos, aliada à economia de recursos. }\end{array}$} \\
\hline & Projeto & DF & SP & MJ & EV & & \\
\hline & Paridade & $D P$ & $D$ & $C P$ & $C P$ & $D P$ & \\
\hline & \multicolumn{6}{|c|}{ Avaliação Ajustamento } & \\
\hline & Critérios & $\mathrm{S}$ & $\mathrm{F}$ & CA & $\mathrm{C}$ & & \\
\hline & Formal & $A$ & $A$ & 1 & & $A$ & \\
\hline & Informal & $A P$ & $A P$ & I & $A$ & $A P$ & \\
\hline \multirow[t]{7}{*}{12.02} & \multicolumn{6}{|c|}{ Equivalência Demandas } & \multirow{7}{*}{$\begin{array}{l}\text { A demanda formal acondiciona os fluxos (fechamento), minimiza as distâncias (compactação) e regulariza a geometria das circulações } \\
\text { (simplicidade espacial). O modelo supermax evidencia estas características. Isto favorece a segurança (impermeabilidade, vigilância e } \\
\text { controle) e a funcionalidade (simplificação dos procedimentos), enquanto compromete o custo de construção (aumento de áreas). O } \\
\text { espaço informal tende a fechar as circulações e a complicar a geometria, enquanto as distancias oscilam, ao encurtar ou alongar os } \\
\text { deslocamentos dos presos (internalização ou externalização dos programas de socialização e de benefícios aos presos) - a equipe } \\
\text { dirigente considera a condução de presos crítica para a segurança. Isto compromete o ajustamento (permeabilidade, complicação } \\
\text { funcional e aumento das tarefas e de pessoal). As demandas são parcialmente divergentes (DP). A solução formal prevalece, porém com } \\
\text { a demanda de responder ao modelo prisional: a reinserção social dos presos, aliada à economia de recursos. }\end{array}$} \\
\hline & ojeto & DF & $\mathrm{SP}$ & MJ & $\mathrm{EV}$ & & \\
\hline & ridade & $D P$ & $D P$ & $D$ & $C P$ & $D P$ & \\
\hline & \multicolumn{6}{|c|}{ Avaliação Ajustamento } & \\
\hline & Critérios & $S$ & $\mathrm{~F}$ & CA & $\mathrm{C}$ & & \\
\hline & Formal & $A$ & $A$ & $A$ & $A P$ & & \\
\hline & Informal & $A P$ & $A P$ & $A P$ & $A P$ & $A P$ & \\
\hline
\end{tabular}




\begin{tabular}{|c|c|c|c|c|c|c|c|}
\hline \multirow[t]{7}{*}{12.03} & \multicolumn{6}{|c|}{ Equivalência Demandas } & \multirow{7}{*}{$\begin{array}{l}\text { As demandas formais e informais prevêem um acesso único para o estabelecimento e concentram os acessos intersetoriais e dos blocos } \\
\text { funcionais. Eventualmente, existe mais de um acesso em alguns blocos intermediários, especialmente para a recepção de presos e a } \\
\text { carga/descarga de materiais e produtos. Excepcionalmente, é previsto um acesso alternativo na barreira perimetral para veículos de } \\
\text { emergência ou manutenção. Isto favorece a segurança (aumento da estanqueidade), a funcionalidade (simplificação dos procedimentos) } \\
\text { e os custos (redução de áreas e otimização da estrutura física e operacional com redução de pessoal). As demandas são plenamente } \\
\text { convergentes (DP). As soluções formal e informal se equivalem: unificar e condensar os acessos. }\end{array}$} \\
\hline & Projeto & DF & SP & MJ & EV & & \\
\hline & Paridade & C & C & $C$ & $C P$ & C & \\
\hline & \multicolumn{6}{|c|}{ Avaliação Ajustamento } & \\
\hline & Critérios & $\mathrm{S}$ & $\mathrm{F}$ & CA & $\mathrm{C}$ & & \\
\hline & Formal & $A$ & $A$ & 1 & $A$ & $A$ & \\
\hline & Informal & $A$ & $A$ & 1 & $A$ & $A$ & \\
\hline \multirow[t]{7}{*}{12.04} & \multicolumn{6}{|c|}{ Equivalência Demandas } & \multirow{7}{*}{$\begin{array}{l}\text { O espaço arquitetônico formal apresenta rota para a evacuação dos funcionários. Isto favorece a segurança (integridade dos } \\
\text { funcionários). O espaço informal não prevê a rota de evacuação, o que desfavorece a segurança (risco de tomada de funcionários como } \\
\text { reféns). As demandas são parcialmente divergentes (DP). A solução formal prevalece: prever a rota de evasão dos funcionários. }\end{array}$} \\
\hline & Projeto & DF & SP & MJ & EV & & \\
\hline & Paridade & $D$ & $D$ & $D$ & $C P$ & $D P$ & \\
\hline & \multicolumn{6}{|c|}{ Avaliação Ajustamento } & \\
\hline & Critérios & $\mathrm{S}$ & $\mathrm{F}$ & CA & $\mathrm{C}$ & & \\
\hline & Formal & $A$ & 1 & 1 & 1 & $A$ & \\
\hline & Informal & $N A$ & 1 & 1 & 1 & $N A$ & \\
\hline Grupo & $\begin{array}{l}\text { As exigên } \\
\text { isto disso } \\
\text { incremen } \\
\text { a necessá }\end{array}$ & & & & & & $\begin{array}{l}\text { arcialmente divergentes, ao se gerar uma edificação operacionalmente complexa (sobrecargas nos fluxos e deslocamentos dilatados), por } \\
\text { ida e do nível de segurança buscado. Isto, embora sejam previstos poucos pontos de acesso. Sobressaem as questões penitenciárias do } \\
\text { do custo de construção, além da deficiência do projetista. A solução formal prevalece, porém as soluções informais fornecem critérios para } \\
\text { m termos do modelo e da pragmática prisional, conforme a realidade prisional. }\end{array}$ \\
\hline \multicolumn{8}{|c|}{ 13. Conforto Ambiental } \\
\hline \multirow[t]{7}{*}{13.01} & \multicolumn{6}{|c|}{ Equivalência $\mathrm{D}$} & \multirow{7}{*}{$\begin{array}{l}\text { O espaço arquitetônico formal apresenta aberturas indiretas, minimamente dimensionadas e destituídas de regulagem, principalmente } \\
\text { nos setores internos, dentro dos padrões de bem-estar (disciplina-bloco). Isto favorece a segurança (aumento da impermeabilidade e } \\
\text { estanqueidade), a funcionalidade (redução das tarefas), o conforto ambiental (respeitos dos padrões mínimos) e os custos (redução de } \\
\text { componentes e de pessoal). O espaço informal oscila entre aberturas diretas e a indiretas, normalmente minimamente dimensionadas } \\
\text { (locais dos presos) e sem regulagem ou ventilação cruzada. Isto compromete o ajustamento, com exceção dos custos (padronização das } \\
\text { soluções). As demandas são parcialmente divergentes (DP). A solução formal prevalece: aberturas indiretas, mínimas e fixas, porém com } \\
\text { a demanda de incorporar a ventilação cruzada e regulagem. }\end{array}$} \\
\hline & Projeto & $\mathrm{DF}$ & SP & MJ & EV & & \\
\hline & Paridade & $D$ & $D P$ & $C P$ & $D P$ & $D P$ & \\
\hline & \multicolumn{6}{|c|}{ Avaliação Ajustamento } & \\
\hline & Critérios & $\mathrm{S}$ & $\mathrm{F}$ & CA & $\mathrm{C}$ & & \\
\hline & Formal & $A$ & $A$ & $A$ & $A$ & $A$ & \\
\hline & Informal & $A P$ & $A P$ & $A P$ & $A$ & $A P$ & \\
\hline \multirow[t]{7}{*}{13.02} & \multicolumn{6}{|c|}{ Equivalência Demandas } & \multirow{7}{*}{$\begin{array}{l}\text { O espaço arquitetônico formal propicia fachadas e coberturas suficientes e adequadas para as aberturas de iluminação e ventilação } \\
\text { (quantidade e localização protegida). O modelo supermax apresenta um índice de quantidade linear de fachada pela capacidade do } \\
\text { estabelecimento de } 2,49 \mathrm{~m} / \text { vaga (chega até } 3,5 \mathrm{~m} / \text { vaga). Isto favorece a segurança (aumento da impermeabilidade) e o conforto ambiental } \\
\text { (respeito aos padrões mínimos de bem-estar), enquanto compromete os custos (aumento de fachadas). A demanda informal tende a } \\
\text { reduzir a quantidade de fachada ( } 2,13 \mathrm{~m} / \mathrm{vaga} \text { ) (simplicidade geométrica), o que direciona para aberturas indiretas. Em uma segunda } \\
\text { tendência, ocorrem geometrias entrecortadas nas quais predominam aberturas diretas. Isto favorece os custos, enquanto compromete o } \\
\text { conforto ambiental (quantidade e adequação das aberturas). As demandas são parcialmente divergentes (DP). A solução formal } \\
\text { prevalece, porém com a demanda de responder à economia de recursos. }\end{array}$} \\
\hline & Projeto & $\mathrm{DF}$ & SP & MJ & EV & & \\
\hline & Paridade & $D P$ & $D P$ & $C P$ & $C P$ & $D P$ & \\
\hline & \multicolumn{6}{|c|}{ Avaliação Ajustamento } & \\
\hline & Critérios & $\mathrm{S}$ & $\mathrm{F}$ & CA & $\mathrm{C}$ & & \\
\hline & Formal & $A$ & 1 & $A$ & $A P$ & $A$ & \\
\hline & Informal & $A$ & I & $A P$ & $A$ & $A$ & \\
\hline Grupo & $\begin{array}{l}\text { As exigên } \\
\text { buscado. } \\
\text { formal pr } \\
\text { realidade }\end{array}$ & & & & & & $\begin{array}{l}\text { jarcialmente divergentes, o que resulta em edificações adversas do conforto ambiental exigido, por isto dissonante do nível de segurança } \\
\text { istema penitenciário (incremento do nível de segurança e de redução do custo de construção), além da deficiência do projetista. A solução } \\
\text { informais fornecem critérios para a necessária adequação da edificação em termos do modelo e da pragmática prisional, conforme a }\end{array}$ \\
\hline & & & & & & & \\
\hline
\end{tabular}




\begin{tabular}{|c|c|c|c|c|c|c|c|}
\hline \multirow[t]{7}{*}{14.01} & \multicolumn{6}{|c|}{ Equivalência Demandas } & \multirow{7}{*}{$\begin{array}{l}\text { O espaço arquitetônico formal recebe aparatos de segurança para mitigar pontos fracos da impermeabilidade, estanqueidade e } \\
\text { inexpugnidade da prisão. Isto favorece o ajustamento (maximização do sistema de segurança), com exceção dos custos (aumento de } \\
\text { componentes). O espaço informal tende a subutilizar ou especificar equivocadamente os aparatos de segurança (perpetua as falhas da } \\
\text { segurança). Isto compromete o ajustamento (aumento das vulnerabilidades e procedimentos, além do desrespeito dos padrões mínimos } \\
\text { de bem-estar), enquanto favorece os custos (redução de componentes). As demandas são parcialmente convergentes (CP). A solução } \\
\text { formal prevalece, porém com a demanda de responder à economia de recursos. }\end{array}$} \\
\hline & Projeto & DF & SP & MJ & EV & & \\
\hline & Paridade & $C P$ & $C P$ & $C P$ & $C P$ & $C P$ & \\
\hline & \multicolumn{6}{|c|}{ Avaliação Ajustamento } & \\
\hline & Critérios & $\mathrm{S}$ & $\mathrm{F}$ & CA & $\mathrm{C}$ & & \\
\hline & Formal & $A$ & $A$ & $A$ & $A P$ & $A$ & \\
\hline & Informal & $A P$ & $A P$ & $A P$ & $A$ & $A P$ & \\
\hline \multirow[t]{7}{*}{14.02} & \multicolumn{6}{|c|}{ Equivalência Demandas } & \multirow{7}{*}{$\begin{array}{l}\text { O espaço arquitetônico formal tem cercamento setorial nas áreas exteriores, o que evidencia e prolonga as divisões funcionais internas } \\
\text { Este cercamento também disciplina os fluxos entre setores e blocos funcionais (padrão arquitetônico modular). Isto favorece a segurança } \\
\text { (aumento do controle institucional), enquanto compromete os custos (aumento de componentes). A demanda informal tende a minimizar } \\
\text { ou dispensar o cercamento setorial devido ao fechamento das edificações e aos terrenos pequenos (o mesmo se torna inócuo). Isto } \\
\text { favorece a segurança (simplicidade) e os custos (redução de componentes). As demandas são parcialmente convergentes (CP). A solução } \\
\text { formal prevalece, porém com a demanda de responder à economia de recursos. }\end{array}$} \\
\hline & Projeto & $\mathrm{DF}$ & SP & MJ & EV & & \\
\hline & Paridade & $C$ & $C P$ & $C P$ & $C P$ & $C P$ & \\
\hline & \multicolumn{6}{|c|}{ Avaliação Ajustamento } & \\
\hline & Critérios & $\mathrm{S}$ & $\mathrm{F}$ & CA & $\mathrm{C}$ & & \\
\hline & Formal & $A$ & 1 & 1 & $A P$ & $A$ & \\
\hline & Informal & $A$ & $I$ & 1 & $A$ & $A$ & \\
\hline Grupo & $\begin{array}{l}\text { As exigên } \\
\text { mas que } \\
\text { Sobressa } \\
\text { informais }\end{array}$ & & & & & & $\begin{array}{l}\text { arcialmente convergentes, ao gerar uma edificação que atende a totalidade da maximização e homogeneização do sistema de segurança, } \\
\text { has passíveis de resolução e não evidencia a setorização interna da prisão, por isto discorda em parte do nível de segurança exigido. } \\
\text { custo de construção e da deficiência do projetista na resolução do sistema de segurança. A solução formal prevalece, porém as soluções } \\
\text { essária adequação da edificação em termos do modelo e da pragmática prisional, conforme a realidade prisional. }\end{array}$ \\
\hline
\end{tabular}

\begin{tabular}{|c|c|c|c|c|c|c|c|}
\hline \multicolumn{8}{|c|}{ 15. Controle } \\
\hline \multirow[t]{7}{*}{15.01} & \multicolumn{6}{|c|}{ Equivalência Demandas } & \multirow{7}{*}{$\begin{array}{l}\text { O espaço arquitetônico formal possibilita o monitoramento interno absoluto (inclusive das celas) (disciplina-bloco), por meio da vigilância } \\
\text { direta que conjuga a localização centralizada e as características do posto de controle. Isto favorece a segurança (aumento do controle } \\
\text { institucional) e a funcionalidade (redução das tarefas), enquanto compromete os custos (aumento de componentes). O espaço informal } \\
\text { tende a apresentar a maioria das áreas internas potencialmente vigiadas ( } 62 \% \text { da área construída), ao configurar a vigilância direta (os } \\
\text { postos predominam nos setores internos). Em uma segunda tendência, a vigilância indireta é aplicada e as celas são relativamente } \\
\text { fechadas à vigilância (rondas). Isto compromete o ajustamento (expõe funcionários, aumento das tarefas e de pessoal). As demandas são } \\
\text { parcialmente divergentes (DP). A solução formal prevalece, porém com a demanda de responder à economia de recursos. }\end{array}$} \\
\hline & Projeto & DF & SP & MJ & EV & & \\
\hline & Paridade & $D P$ & $D P$ & $C P$ & $C P$ & DP & \\
\hline & \multicolumn{6}{|c|}{ Avaliação Ajustamento } & \\
\hline & Critérios & $\mathrm{S}$ & $\mathrm{F}$ & CA & $\mathrm{C}$ & & \\
\hline & Formal & $A$ & $A$ & 1 & $A P$ & $A$ & \\
\hline & Informal & $A P$ & $A P$ & 1 & $A P$ & $A P$ & \\
\hline \multirow[t]{7}{*}{15.02} & \multicolumn{6}{|c|}{ Equivalência Demandas } & \multirow{7}{*}{$\begin{array}{l}\text { O espaço arquitetônico formal propicia a internalização disciplinar, por meio da inverificabilidade institucional (vigilância direta associada } \\
\text { à invisibilidade dos funcionários), o que inclui as circulações exclusivas para os funcionários. Isto favorece a segurança (aumenta a } \\
\text { disciplina interna) e a funcionalidade (redução de tarefas), enquanto compromete os custos (aumenta os componentes, embora otimize a } \\
\text { estrutura física e operacional). A equipe dirigente considera importante a inverificabilidade. A demanda informal tende a ignorar a } \\
\text { internalização disciplinar, ao eventualmente aderir à vigilância indireta ou apresentar postos abertos (grades). Isto desfavorece a } \\
\text { segurança e a funcionalidade (exposição institucional), enquanto compromete os custos (aumento de pessoal). As demandas são } \\
\text { parcialmente divergentes (DP). A solução formal prevalece, porém com a demanda de responder à economia de recursos. }\end{array}$} \\
\hline & Projeto & DF & SP & MJ & EV & & \\
\hline & Paridade & $D$ & $D P$ & $D P$ & $C P$ & DP & \\
\hline & \multicolumn{6}{|c|}{ Avaliação Ajustamento } & \\
\hline & Critérios & S & $\mathrm{F}$ & CA & $\mathrm{C}$ & & \\
\hline & Formal & $A$ & $A$ & 1 & $A P$ & $A$ & \\
\hline & Informal & $N A$ & $\overline{N A}$ & 1 & $A P$ & $\overline{N A}$ & \\
\hline \multirow[t]{3}{*}{15.03} & \multicolumn{6}{|c|}{ Equivalência Demandas } & \multirow{3}{*}{$\begin{array}{l}\text { O espaço arquitetônico formal possibilita a vigilância externa absoluta (barreira perimetral e adjacências). O modelo supermax utiliza } \\
\text { torres de vigilância perimetrais contra ataques e invasões que utilizam o princípio da inverificabilidade. Isto favorece a segurança } \\
\text { (aumenta a inexpugnidade), enquanto compromete a funcionalidade (aumento das tarefas) e os custos (aumento de áreas e de pessoal). }\end{array}$} \\
\hline & Projeto & DF & SP & MJ & EV & & \\
\hline & Paridade & $C P$ & $C P$ & $D P$ & $C P$ & & \\
\hline
\end{tabular}


Avaliação Ajustamento

\begin{tabular}{|c|c|c|c|c|c|}
\hline Critérios & $\mathrm{S}$ & $\mathrm{F}$ & $\mathrm{CA}$ & $\mathrm{C}$ & \\
\hline Formal & $A$ & $A P$ & $I$ & $A P$ & $A P$ \\
\hline Informal & $A P$ & $A$ & $I$ & $A$ & $A$ \\
\hline \multicolumn{7}{|c|}{} \\
\hline
\end{tabular}

15.04 Equivalência Demandas

\begin{tabular}{|l|l|c|c|c|c|}
\hline Projeto & DF & SP & MJ & EV & \\
\hline Paridade & $C P$ & $D$ & $D P$ & $C P$ & $D P$ \\
\hline
\end{tabular}

Avaliação Ajustamento

\begin{tabular}{|c|c|c|c|c|c|}
\hline Critérios & S & F & CA & C & \\
\hline
\end{tabular}

\begin{tabular}{|c|c|c|c|c|c|c|}
\hline Formal & $A$ & $A$ & $I$ & $A P$ & $\boldsymbol{A}$ \\
\hline Informal & $A P$ & $A P$ & $I$ & $A P$ & $A P$ \\
\hline
\end{tabular}

15.05

Equivalência Demandas \begin{tabular}{|c|c|c|c|c|c|}
\hline Projeto & $\mathrm{DF}$ & $\mathrm{SP}$ & $\mathrm{MJ}$ & $\mathrm{EV}$ & \\
\hline Paridade & $\mathrm{CP}$ & $\mathrm{DP}$ & $\mathrm{CP}$ & $\mathrm{C}$ & $\mathbf{C P}$ \\
\hline
\end{tabular} Avaliação Ajustamento

\begin{tabular}{|c|c|c|c|c|c|}
\hline Critérios & $\mathrm{S}$ & $\mathrm{F}$ & $\mathrm{CA}$ & $\mathrm{C}$ & \\
\hline Formal & $A$ & $A$ & $I$ & $A P$ & $\boldsymbol{A}$ \\
\hline Informal & $A P$ & $A P$ & $I$ & $A P$ & $A P$ \\
\hline \multicolumn{7}{|c|}{ Equivalência Demandas } \\
\hline
\end{tabular}

15.06

\begin{tabular}{|c|c|c|c|c|c|}
\hline Projeto & DF & SP & MJ & EV \\
\hline Paridade & CP & D & CP & CP \\
\hline
\end{tabular}

\begin{tabular}{|c|c|c|c|c|c|}
\hline Projeto & DF & SP & MJ & EV & \\
\hline Paridade & $C P$ & $D$ & $C$ & $C P$ & $C P$ \\
\hline
\end{tabular}

Avaliação Ajustamento

\begin{tabular}{|c|c|c|c|c|c|} 
Critérios & S & F & CA & C & \\
\hline
\end{tabular}

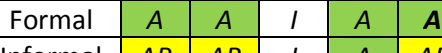

15.07 Equivalência Demandas

\begin{tabular}{l|l|l|l|l|} 
Projeto & DF & SP & MJ & EV \\
\hline
\end{tabular}

\begin{tabular}{|l|l|l|l|l|l|}
\hline Paridade & $D P$ & $D P$ & $C P$ & $C P$ & $D$ \\
\hline
\end{tabular}

Avaliação Ajustamento

\begin{tabular}{|c|c|c|c|c|c|}
\hline Critérios & S & F & CA & C & \\
\hline Formal & $A$ & $A$ & $I$ & $A P$ & $A$ \\
\hline
\end{tabular}

A demanda informal incorpora as áreas intramuros na vigilância externa, além das construções. As torres em geral reproduzem o princípio da inverificabilidade. Isto compromete a segurança (aumento de vulnerabilidades), enquanto favorece a funcionalidade (divisão das tarefas com os postos de controle) e os custos (otimização da estrutura física e operacional). As demandas são parcialmente convergentes (CP). A solução informal prevalece, porém com a demanda de responder à segurança necessária.

O espaço arquitetônico formal protege o acesso das torres de vigilância e providencia a separação física entre funcionários e presos no interior da unidade penal. O modelo supermax (padrão arquitetônico modular) tende a separar funcionários e presos por meio de postos de controle e de circulações exclusivas para os funcionários (vigilância direta). A equipe dirigente e os presos consideram a separação física entre estes grupos importante. Isto favorece a segurança (resguarda os funcionários) e a funcionalidade (aumento da acessibilidade e mobilidade dos funcionários), enquanto compromete os custos (aumento de áreas). O espaço informal loca as torres dentro do perímetro de segurança e prevê a separação de funcionários e presos (ênfase nos setores mais internos). Em uma segunda tendência, a vigilância indireta predomina. Isto compromete o ajustamento. As demandas são parcialmente divergentes (DP). A solução formal prevalece, porém com a demanda de responder à economia de recursos.

O espaço arquitetônico formal possibilita o controle dos fluxos na prisão, através de postos de controle nos pontos de convergência das circulações (disciplina-bloco e vigilância direta). Isto favorece a segurança (aumento do controle institucional e separação dos funcionários) e a funcionalidade (redução de tarefas), enquanto a quantidade de alas carcerárias pode comprometer os custos (aumento de áreas). $O$ espaço informal tende a um maior controle dos fluxos (vigilância direta), em especial com as atividades internalizadas nos blocos de vivência e com a utilização de circulação exclusiva para os funcionários. Em uma segunda tendência, ocorre um controle menor devido à adoção da vigilância indireta, associada à generalização funcional. Isto compromete o ajustamento. As demandas são parcialmente convergentes (CP). A solução formal prevalece, porém com a demanda de responder à economia de recursos.

A demanda formal minimiza a quantidade de torres de vigilância e postos de controle (disciplina-bloco). Isto favorece a segurança (redução de vulnerabilidades), a funcionalidade (integração da equipe) e os custos (redução de áreas e de pessoal). O modelo supermax prevê seis torres de vigilância. As Diretrizes Básicas estimam 22 postos de controle (66 vagas/posto). 0 espaço informal tende a ter poucas torres de vigilância (quatro, em média) e postos de controle (nove em média). Eventualmente, a complexidade geométrica e a externalização dos programas de sociabilização e de benefícios aos presos implica em uma quantidade maior de postos de controle (setor intermediário). Isto pode comprometer a segurança e a funcionalidade, enquanto favorece os custos (redução de áreas). As demandas são parcialmente convergentes (CP). A solução formal prevalece.

A demanda formal evidencia os postos de controle na representação do poder institucional (ressalta a posição dos funcionários em relação aos presos). O modelo supermax (padrão arquitetônico modular) apresenta postos de controle com geometria contundente, níveis elevados e visores ressaltados. O que está associado ao princípio da inverificabilidade. Isto favorece a segurança (submissão dos presos) e a funcionalidade (redução de tarefas), enquanto compromete os custos (complicação dos componentes). O espaço informal tende a salientar os postos de controle, porém de modo atenuado e, eventualmente, sem a inverificabilidade. Isto compromete a segurança e a funcionalidade, enquanto favorece os custos. As demandas são parcialmente divergentes (DP). A solução formal prevalece, com a demanda de responder ao custo de construção.

Grupo As exigências formais e informais são parcialmente divergentes, ao se gerar edificações adversas da vigilância absoluta, capaz da inverificabilidade institucional, da interiorização da individualidade disciplinar, da proteção dos funcionários e da imposição do poder institucional exigidas, por isto dissonante da segurança buscada. Embora as edificações atendam às exigências da vigilância da totalidade dos espaços externos e do controle dos fluxos de modo econômico. Sobressaem as questões penais (a disputa de poder nas prisões) e penitenciárias da redução do custo de construção, além das deficiências operacionais, que inviabilizam a criação de espaços exclusivos para os funcionários, assim como a deficiência do projetista. A solução formal prevalece, porém com a ressalva de atender à economia de recursos. Pontualmente, as soluções informais fornecem critérios para a necessária adequação da edificação em termos da pragmática prisional, conforme a realidade prisional. 


\begin{tabular}{|c|c|c|c|c|c|c|c|}
\hline \multicolumn{8}{|c|}{ 16. Barreira Perimetral } \\
\hline \multirow[t]{7}{*}{16.01} & \multicolumn{6}{|c|}{ Equivalência Demandas } & \multirow{7}{*}{$\begin{array}{l}\text { Formalmente, a barreira perimetral é estanque, ao dificultar ao máximo a transposição (superfície e seção de difícil escalada). Isto } \\
\text { favorece a segurança (aumento da contenção de fugas), enquanto compromete os custos (aumento dos componentes e do custo dos } \\
\text { materiais). Informalmente, a barreira tende a ser especificada em tela (cerca)(passível de escalada). O modelo supermax utiliza cerca em } \\
\text { tela. Isto compromete a segurança, enquanto favorece os custos. Em uma segunda tendência, a barreira do tipo muro é adotada. A } \\
\text { mesma tem desempenho equivalente à descrição formal. A equipe dirigente considera a estanqueidade óbvia e ambas as soluções } \\
\text { passíveis de transposição. As demandas são parcialmente convergentes (CP). A solução informal prevalece, porém com a demanda de } \\
\text { responder à estanqueidade: maximizar a estanqueidade da barreira perimetral. }\end{array}$} \\
\hline & Projeto & $\mathrm{DF}$ & SP & MJ & EV & & \\
\hline & Paridade & $D P$ & C & $C P$ & $C P$ & $C P$ & \\
\hline & \multicolumn{6}{|c|}{ Avaliação Ajustamento } & \\
\hline & Critérios & $\mathrm{S}$ & $\mathrm{F}$ & CA & $\mathrm{C}$ & & \\
\hline & Formal & $A$ & I & 1 & $A P$ & $A$ & \\
\hline & Informal & $A P$ & 1 & 1 & $A$ & $A$ & \\
\hline \multirow[t]{7}{*}{16.02} & \multicolumn{6}{|c|}{ Equivalência Demandas } & \multirow{7}{*}{$\begin{array}{l}\text { Formalmente, a barreira perimetral é impermeável, ao romper ao máximo com comunicação informal (vedações fechadas). Isto favorece } \\
\text { a segurança (aumento do controle de informação) e a funcionalidade (redução de tarefas), enquanto compromete os custos (aumentc } \\
\text { dos componentes e do custo dos materiais). Informalmente, a barreira tende a ser especificada em tela (cerca) (permeável). O modelc } \\
\text { supermax utiliza cerca em tela. Isto compromete a segurança, enquanto favorece os custos. Em uma segunda tendência, a barreira tipc } \\
\text { muro é adotada. A mesma tem desempenho equivalente à descrição formal. A equipe dirigente considera a impermeabilidade important } \\
\text { e o muro mais eficiente. As demandas são parcialmente divergentes (DP). A solução formal prevalece, porém com a demanda de } \\
\text { responder à economia de recursos. }\end{array}$} \\
\hline & Projeto & $\mathrm{DF}$ & SP & MJ & EV & & \\
\hline & ridade & $D P$ & $C$ & $C$ & $D P$ & DP & \\
\hline & \multicolumn{6}{|c|}{ Avaliação Ajustamento } & \\
\hline & Critérios & $\mathrm{S}$ & $\mathrm{F}$ & CA & $\mathrm{C}$ & & \\
\hline & Formal & $A$ & $A$ & I & $A P$ & $A$ & \\
\hline & Informal & $A P$ & $A P$ & & A & $A P$ & \\
\hline \multirow[t]{7}{*}{16.03} & \multicolumn{6}{|c|}{ Equivalência Demandas } & \multirow{7}{*}{$\begin{array}{l}\text { Formalmente, a barreira perimetral é inexpugnável, ao resistir ao máximo a ataques externos (estruturas e vedações resistentes ao } \\
\text { choque ou explosões). Isto favorece a segurança (aumento da contenção de invasões), enquanto compromete os custos (aumento dos } \\
\text { componentes e do custo dos materiais). Informalmente, a barreira tende a ser especificada em tela (cerca)(mecanicamente frágil). O } \\
\text { modelo supermax utiliza cerca em tela. Isto compromete a segurança, enquanto favorece os custos. Em uma segunda tendência, a } \\
\text { barreira tipo muro é adotada. A mesma tem desempenho equivalente à descrição formal. A equipe dirigente considera a invasão um risco } \\
\text { secundário. As demandas são parcialmente divergentes (DP). A solução formal prevalece, porém com a demanda de responder à } \\
\text { economia de recursos. }\end{array}$} \\
\hline & Projeto & DF & SP & $\mathrm{MJ}$ & EV & & \\
\hline & ridade & $D P$ & $C$ & $C$ & $D$ & $D P$ & \\
\hline & \multicolumn{6}{|c|}{ Avaliação Ajustamento } & \\
\hline & Crit & $\mathrm{S}$ & $\mathrm{F}$ & CA & $\mathrm{C}$ & & \\
\hline & & $A$ & 1 & 1 & $A P$ & $A$ & \\
\hline & & $A P$ & 1 & 1 & $A$ & & \\
\hline \multirow[t]{7}{*}{16.04} & \multicolumn{6}{|c|}{ Equivalência Demandas } & \multirow{7}{*}{$\begin{array}{l}\text { Formalmente, a barreira perimetral do tipo muro apresenta melhor estanqueidade, impermeabilidade e inexpugnidade. O muro favorece } \\
\text { a segurança e a funcionalidade, enquanto vai de encontro ao custo de construção (componentes e materiais). Informalmente, a barreira } \\
\text { tende a ser do tipo cerca. O modelo supermax utiliza cerca em tela. Isto compromete o ajustamento, com exceção dos custos (aumento } \\
\text { de componentes e do custo dos materiais). Em uma segunda tendência, a barreira perimetral é do tipo muro. A equipe dirigente } \\
\text { considera o muro mais eficiente. As demandas são parcialmente convergentes (CP). As soluções formal e informal se equiparam, mas a } \\
\text { solução informal é preferencial, porém com a demanda de responder à estanqueidade, impermeabilidade e inexpugnidade necessárias } \\
\text { para o nível de segurança penitenciário. }\end{array}$} \\
\hline & & $\mathrm{DF}$ & SP & & EV & & \\
\hline & & $D P$ & $C$ & $C P$ & $C P$ & $C P$ & \\
\hline & \multicolumn{6}{|c|}{ Avaliação Ajustamento } & \\
\hline & Critérios & $\mathrm{S}$ & $\mathrm{F}$ & CA & $\mathrm{C}$ & & \\
\hline & Formal & $A$ & $A$ & 1 & $N A$ & & \\
\hline & Informal & $A P$ & $A P$ & & & $A P$ & \\
\hline \multirow[t]{7}{*}{16.05} & \multicolumn{6}{|c|}{ Equivalência Demandas } & \multirow{7}{*}{$\begin{array}{l}\text { Formal e informalmente, a barreira perimetral apresenta simplicidade geométrica (formas regulares e sem desníveis) e compactação } \\
\text { dimensional. O modelo supermax (padrão arquitetônico modular) apresenta um desenho mais complexo (de cinco a oito faces com } \\
\text { diferentes ângulos e } 870 \mathrm{~m} \text { de perímetro), porém linear e nivelado. Os projetos de referência apresentam um perímetro retangular e } \\
\text { compacto de } 495 \mathrm{~m} \text {, em média, além de terreno nivelado ou com um caimento insignificante do ponto de vista do controle. Isto favorece a } \\
\text { segurança (maximização da vigilância), a funcionalidade (simplificação dos procedimentos) e os custos (redução do quantitativo e de } \\
\text { pessoal). As demandas são plenamente convergentes (C). As soluções formal e informal se equivalem: simplificar a geometria da barreira } \\
\text { perimetral. }\end{array}$} \\
\hline & & DF & SP & MJ & EV & & \\
\hline & Paridade & $C$ & $C$ & C & & C & \\
\hline & \multicolumn{6}{|c|}{ Avaliação Ajustamento } & \\
\hline & Crité & $\mathrm{S}$ & $\mathrm{F}$ & CA & $\mathrm{C}$ & & \\
\hline & Formal & $A$ & $A$ & 1 & $A$ & & \\
\hline & formal & $A$ & $A$ & 1 & & $\boldsymbol{A}$ & \\
\hline \multirow[t]{3}{*}{16.06} & \multicolumn{6}{|c|}{ Equivalência Demandas } & \multirow{3}{*}{$\begin{array}{l}\text { Formal e informalmente, a barreira perimetral tem a estanqueidade e impermeabilidade reforçadas, ao ter a altura maximizada. As } \\
\text { Diretrizes Básicas prevêem uma altura mínima de cinco metros. Os projetos de referência apresentam uma altura entre seis e sete } \\
\text { metros. Isto favorece a segurança (aumento da contenção de fugas e do controle de informação), enquanto desfavorece os custos }\end{array}$} \\
\hline & Projeto & $\mathrm{DF}$ & SP & MJ & EV & & \\
\hline & Paridade & C & C & & & & \\
\hline
\end{tabular}




\begin{tabular}{|c|c|c|c|c|c|c|c|}
\hline & \multicolumn{6}{|c|}{ Avaliação Ajustamento } & \multirow{4}{*}{$\begin{array}{l}\text { aumento do quantitativo). A equipe dirigente considera a altura maior pouco significante para a estanqueidade e impermeabilidade. } 0 \\
\text { hodelo supermax (padrão arquitetônico modular) tem } 3,7 \mathrm{~m} \text { de altura. Isto favorece os custos (redução do quantitativo). As demandas } \\
\text { áo plenamente convergentes } \\
\text { (C). As soluções formal e informal se equivalem, porém com a demanda de responder à economia de } \\
\text { ecursos. }\end{array}$} \\
\hline & ritérios & $\mathrm{S}$ & $\mathrm{F}$ & $\mathrm{CA}$ & $\mathrm{C}$ & & \\
\hline & & $A$ & 1 & & & & \\
\hline & Informal & $A$ & 1 & 1 & NA & & \\
\hline \multirow[t]{7}{*}{16.07} & \multicolumn{6}{|c|}{ Equivalência Demandas } & \multirow{7}{*}{$\begin{array}{l}\text { Formalmente, a barreira perimetral apresenta proteção contra disparo por arma de fogo ou rendição dos guardas externos. Isto favorece } \\
\text { a segurança (redução de vulnerabilidades) e a funcionalidade (simplificação de procedimentos), enquanto desfavorece os custos } \\
\text { (aumento de componentes). O modelo supermax não apresenta proteção física. Informalmente, a barreira tende a ser do tipo cerca que } \\
\text { protege de abordagens, mas não de disparo de arma de fogo. Isto compromete a segurança e a funcionalidade, enquanto favorece os } \\
\text { custos (redução do custo dos materiais). Em uma segunda tendência, a barreira do tipo muro é adotada. A mesma tem desempenho } \\
\text { equivalente ao formal. Os funcionários relataram se sentirem mais seguros com o muro. As demandas são parcialmente divergentes (DP). } \\
\text { A solução informal prevalece, porém com a demanda de responder à proteção da guarda externa. }\end{array}$} \\
\hline & ojeto & DF & & & EV & & \\
\hline & ridade & & $C P$ & C & $D P$ & DP & \\
\hline & \multicolumn{6}{|c|}{ Avaliação Ajustamento } & \\
\hline & itérios & $\mathrm{S}$ & $\mathrm{F}$ & & $\mathrm{C}$ & & \\
\hline & & $\bar{A}$ & $\bar{A}$ & & $N A$ & & \\
\hline & ormal & & & 1 & $A$ & $A P$ & \\
\hline \multirow[t]{7}{*}{16.08} & \multicolumn{6}{|c|}{ Equivalência Demandas } & \multirow{7}{*}{$\begin{array}{l}\text { Formalmente, a barreira perimetral recebe aparatos de segurança para mitigar pontos fracos da impermeabilidade, estanqueidade e } \\
\text { inexpugnidade. Isto favorece o ajustamento (maximização do sistema de segurança), com exceção dos custos (aumento de componentes). } \\
\text { O modelo supermax utiliza elementos cortantes em profusão (cerca). Informalmente, a barreira tende a ser do tipo cerca e a receber } \\
\text { aparatos de segurança, principalmente, o espiral cortante. Normalmente não são prescritos elementos de bloqueio visual ou de proteção } \\
\text { mecânica ou balística contra ataques externos. Isto compromete a segurança (redução do controle da informação e da contenção de } \\
\text { invasões) e a funcionalidade (aumento das tarefas), enquanto favorece os custos. As demandas são parcialmente convergentes (CP). A } \\
\text { solução formal é preferencial, porém com a demanda de responder à economia de recursos. }\end{array}$} \\
\hline & Projeto & & & & EV & & \\
\hline & de & & & $C P$ & C & CP & \\
\hline & \multicolumn{6}{|c|}{ Avaliação Ajustamento } & \\
\hline & itérios & $\mathrm{S}$ & $\mathrm{F}$ & & $\mathrm{C}$ & & \\
\hline & 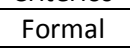 & & & & & $A$ & \\
\hline & formal & $A P$ & & 1 & $A$ & A & \\
\hline \multirow[t]{7}{*}{16.09} & \multicolumn{6}{|c|}{ Equivalência Demandas } & \multirow{7}{*}{$\begin{array}{l}\text { Formalmente, a barreira perimetral tem a estanqueidade reforçada, ao apresentar a linha de tiro. O modelo supermax adota a linha de } \\
\text { tiro (cerca com três metros de altura, afastamento de seis metros e elemento cortante no topo). Isto favorece a segurança (aumento da } \\
\text { contenção de fugas) e a funcionalidade (redução de tarefas), enquanto compromete os custos. Informalmente, a barreira tende a } \\
\text { apresentar a linha de tiro. Os instrumentos legais e técnico-normativos não prevêem a linha de tiro. As demandas são parcialmente } \\
\text { convergentes (CP). A solução formal prevalece, porém com a demanda de responder à economia de recursos. }\end{array}$} \\
\hline & to & & & & EV & & \\
\hline & ridade & & $C$ & $C$ & $C$ & & \\
\hline & \multicolumn{6}{|c|}{ Avaliação Ajustamento } & \\
\hline & & & $\mathrm{F}$ & & $\mathrm{C}$ & & \\
\hline & & & & & & 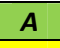 & \\
\hline & ormal & & & 1 & $A P$ & & \\
\hline \multirow[t]{7}{*}{16.10} & \multicolumn{6}{|c|}{ Equivalência Demandas } & \multirow{7}{*}{$\begin{array}{l}\text { Formalmente, a barreira perimetral tem as propriedades de fechamento reforçadas (estanqueidade e impermeabilidade), ao serem } \\
\text { maximizados os afastamentos internos (entre a barreira perimetral e os edifícios) e externos (perímetro de segurança). O modelo } \\
\text { supermax (padrão arquitetônico modular) apresenta afastamentos de } 40 \mathrm{~m} \text {, em média. Isto favorece a segurança (aumento da contenção } \\
\text { de fugas e do controle de informação) e o conforto ambiental (áreas livres), enquanto compromete a funcionalidade (aumento de tarefas) } \\
\text { e os custos (aumento de área de terreno, de quantitativo e de pessoal). Informalmente, a barreira tende a apresentar afastamentos } \\
\text { minimizados, ao apresentar distâncias de } 19 \mathrm{~m} \text {, em média, e perímetro de segurança de } 11 \mathrm{~m} \text {, em média. As Diretrizes Básicas definem } \\
\text { afastamentos mínimos entre dez e quinze metros e perímetro de segurança de cinco metros, no mínimo. Isto prejudica o ajustamento, } \\
\text { com exceção dos custos (redução de área de terreno, de quantitativo e de pessoal). As demandas são parcialmente divergentes (DP). A } \\
\text { solução formal prevalece, porém com a demanda de responder à economia de recursos. }\end{array}$} \\
\hline & & & & & $\mathrm{EV}$ & & \\
\hline & & $C P$ & $D P$ & $D P$ & $D P$ & DP & \\
\hline & \multicolumn{6}{|c|}{ Avaliação Ajustamento } & \\
\hline & térios & & & & $\mathrm{C}$ & & \\
\hline & rmal & & & & $A P$ & & \\
\hline & formal & $A P$ & $A P$ & $A P$ & $A$ & $A P$ & \\
\hline \multirow[t]{5}{*}{16.11} & \multicolumn{6}{|c|}{ Equivalência Demandas } & \multirow{5}{*}{$\begin{array}{l}\text { Formalmente, a barreira perimetral tem as propriedades de fechamento reforçadas (estanqueidade), ao prever a pista de ronda. } 0 \\
\text { modelo supermax apresenta a pista de ronda veicular na parte externa da barreira perimetral. Isto favorece a segurança (aumento da } \\
\text { vigilância e da fiscalização da integridade da barreira) e a funcionalidade (simplificação dos procedimentos), enquanto desfavorece os } \\
\text { custos. Informalmente, a barreira tende a apresentar a pista de ronda externa à barreira perimetral. As demandas são parcialmente } \\
\text { convergentes (CP). A solução formal prevalece, porém com a demanda de responder à economia de recursos. }\end{array}$} \\
\hline & to & & & $\mathrm{MJ}$ & EV & & \\
\hline & & & $C P$ & & & & \\
\hline & & & & & & & \\
\hline & itérios & & & & $\mathrm{C}$ & & \\
\hline
\end{tabular}


\begin{tabular}{c|c|c|c|c|c|} 
Formal & $A$ & $A$ & $I$ & $A P$ & $A$ \\
\hline Informal & $A P$ & $A P$ & $I$ & $A$ & $A$ \\
\hline
\end{tabular}

Grupo As exigências formais e informais são parcialmente divergentes, ao se gerar barreiras perimetrais adversas da impermeabilidade e inexpugnidade, além de expor a guarda externa e reduzir os afastamentos, por isto dissonante da segurança buscada. Embora as barreiras perimetrais atendam às exigências da estanqueidade e simplicidade geométrica, o que aproxima o grupo de uma convergência parcial. Sobressaem as questões penais da política fundiária e penitenciárias da redução do custo de construção, além das deficiências operacionais e do projetista. A solução formal prevalece, havendo uma similaridade significativa com soluções informais, porém com a ressalva de atender à economia de recursos. Pontualmente, as soluções informais fornecem critérios para a necessária adequação da edificação, segundo a realidade prisional.

\begin{tabular}{|c|c|c|c|c|c|c|c|}
\hline \multicolumn{8}{|c|}{ 17. Cela } \\
\hline \multirow[t]{7}{*}{17.01} & \multicolumn{6}{|c|}{ Equivalência Demandas } & \multirow{7}{*}{$\begin{array}{l}\text { Formal e informalmente, a cela apresenta simplicidade geométrica (formas prismáticas retas, sem reentrâncias, saliências ou desníveis). } \\
\text { Isto favorece a segurança (aumento de visualização e simplificação de procedimentos), a funcionalidade (aumento da utilidade do } \\
\text { espaço), o conforto ambiental (homogeneização da ventilação e iluminação) e os custos (simplificação construtiva e otimização da } \\
\text { estrutura física e operacional). O modelo supermax (padrão arquitetônico modular) apresenta um desenho mais complexo (saliência do } \\
\text { shaft). Informalmente, a cela é geometricamente simples. Isto favorece o ajustamento, enquanto compromete o conforto ambiental } \\
\text { (formas alongadas determinam profundidades excessivas em relação às aberturas). As demandas são plenamente convergentes (C). A } \\
\text { solução formal prevalece, porém com a demanda da pragmática prisional, aliada ao conforto ambiental. }\end{array}$} \\
\hline & Projeto & DF & SP & MJ & $\mathrm{EV}$ & & \\
\hline & Paridade & C & C & C & $C$ & C & \\
\hline & \multicolumn{6}{|c|}{ Avaliação Ajustamento } & \\
\hline & Critérios & $\mathrm{S}$ & $\mathrm{F}$ & CA & $\mathrm{C}$ & & \\
\hline & Formal & $A$ & $A$ & $A$ & $A$ & $A$ & \\
\hline & Informal & $A$ & $A$ & $A P$ & $A$ & $A$ & \\
\hline \multirow[t]{7}{*}{17.02} & \multicolumn{6}{|c|}{ Equivalência Demandas } & \multirow{7}{*}{$\begin{array}{l}\text { Formalmente, a cela reproduz a especialização funcional (disciplina-bloco), ao alojar os presos para o descanso noturno. Isto favorece a } \\
\text { segurança (redução de vulnerabilidades), a funcionalidade (simplificação de procedimentos), o conforto ambiental (redução dos } \\
\text { obstáculos) e os custos (redução de componentes e otimização da estrutura). O modelo supermax prevê área de descanso, higiene } \\
\text { pessoal, entretenimento e refeição, além de contenção e circulação. Informalmente, a cela recebe atividades extras e não programadas } \\
\text { (generalização funcional). Isto desfavorece a segurança (redução da vigilância e aumento de procedimentos), a funcionalidade (conflito } \\
\text { entre as atividades) e o conforto ambiental (incompatibilização das soluções), enquanto favorece os custos (redução de áreas e } \\
\text { otimização da estrutura física e operacional). As demandas são parcialmente divergentes (DP). A solução formal prevalece, porém com as } \\
\text { demandas da pressão por vagas e da pragmática prisional, aliadas à economia de recursos. }\end{array}$} \\
\hline & Projeto & DF & SP & MJ & EV & & \\
\hline & Paridade & $D P$ & $D$ & $D P$ & $D P$ & $D P$ & \\
\hline & \multicolumn{6}{|c|}{ Avaliação Ajustamento } & \\
\hline & Critérios & $\mathrm{S}$ & $\mathrm{F}$ & CA & $\mathrm{C}$ & & \\
\hline & Formal & $A$ & $A$ & $A$ & $A$ & $A$ & \\
\hline & Informal & $N A$ & NA & NA & $A$ & NA & \\
\hline \multirow[t]{7}{*}{17.03} & \multicolumn{6}{|c|}{ Equivalência Demandas } & \multirow{7}{*}{$\begin{array}{l}\text { Formal e informalmente, a cela proporciona a higiene pessoal dos presos (cuba ou pia e vaso sanitário, além de chuveiro). O modelo } \\
\text { supermax prevê conjugado de cuba e vaso sanitário, além de box com chuveiro. Raramente o banho é locado fora da cela. Isto } \\
\text { compromete a segurança (aumento das vulnerabilidades e aumento dos procedimentos), a funcionalidade (conflito entre as atividades) e } \\
\text { os custos (aumento de componentes), enquanto desfavorece o conforto ambiental (desrespeito à higiene e à saúde). A equipe dirigente e } \\
\text { os presos consideram melhor o banheiro na cela (redução de tarefas e aumento da privacidade). As demandas são plenamente } \\
\text { convergentes (C). As soluções formal e informal se equivalem, ambas com a demanda do modelo prisional, aliada à segurança, } \\
\text { funcionalidade, conforto ambiental e economia de recursos. }\end{array}$} \\
\hline & Projeto & DF & SP & MJ & EV & & \\
\hline & Paridade & C & $C$ & $C$ & $C$ & $C$ & \\
\hline & \multicolumn{6}{|c|}{ Avaliação Ajustamento } & \\
\hline & Critérios & $\mathrm{S}$ & $\mathrm{F}$ & CA & $\mathrm{C}$ & & \\
\hline & Formal & $A P$ & $A P$ & NA & $A P$ & NA & \\
\hline & Informal & $A P$ & $A P$ & $\overline{N A}$ & $A P$ & & \\
\hline \multirow[t]{7}{*}{17.04} & \multicolumn{6}{|c|}{ Equivalência Demandas } & \multirow{7}{*}{$\begin{array}{l}\text { Formalmente, a cela reproduz a minimização dos padrões de bem estar (disciplina-bloco), ao apresentar mobiliário reduzido e simples. O } \\
\text { modelo supermax (padrão arquitetônico modular) prevê cama, mesa com banco e prateleira (no caso de beliche, a escada não é prevista). } \\
\text { O mobiliário é maciço, fixo e solidário. Isto favorece a segurança (redução de vulnerabilidades e simplificação de procedimentos), a } \\
\text { funcionalidade (viabilização das atividades), o conforto ambiental (desobstrui o espaço) e os custos (redução de componentes e } \\
\text { otimização da estrutura). Informalmente, a cela tende a apresentar mobiliário excessivamente reduzido e simples (camas/beliches sem } \\
\text { escada e prateleiras). Os presos consideram o mobiliário insuficiente. Isto favorece o ajustamento, com exceção da funcionalidade } \\
\text { (inviabilização das atividades). As demandas são plenamente divergentes (D). A solução formal prevalece, porém com a demanda da } \\
\text { pragmática prisional, aliada à funcionalidade. }\end{array}$} \\
\hline & Projeto & DF & SP & MJ & EV & & \\
\hline & Paridade & $D$ & $D$ & $D P$ & $D P$ & & \\
\hline & \multicolumn{6}{|c|}{ Avaliação Ajustamento } & \\
\hline & Critérios & $\mathrm{S}$ & $\mathrm{F}$ & CA & $\mathrm{C}$ & & \\
\hline & Formal & $A$ & $A$ & $A$ & $A$ & $A$ & \\
\hline & Informal & $A$ & $A P$ & $A$ & $A$ & $A$ & \\
\hline
\end{tabular}




\begin{tabular}{|c|c|c|c|c|c|c|c|}
\hline \multirow[t]{7}{*}{17.05} & \multicolumn{6}{|c|}{ Equivalência Demandas } & \multirow{7}{*}{$\begin{array}{l}\text { ormalmente, a cela reproduz a síntese funcional (disciplina-bloco). O padrão arquitetônico modular prevê um ambiente integrado, no } \\
\text { qual a cama e o banheiro são expostos. O modelo supermax apresenta um espaço bipartido e lateralmente assimétrico. Isto favorece a } \\
\text { egurança (redução de vulnerabilidades, simplificação dos procedimentos e aumento da visualização) e os custos (redução de áreas e de } \\
\text { pessoal), enquanto compromete a funcionalidade (conflito entre atividades) e desfavorece o conforto ambiental (desrespeito à higiene e } \\
\text { saúde). Informalmente, a cela tende à compactação espacial, porém integra a coletivização com aumento de capacidade e a } \\
\text { jeneralização funcional (camas, níveis e divisórias). Isto compromete a segurança (redução da visualização) e os custos (aumento de área } \\
\text { de pessoal), enquanto desfavorece a funcionalidade (inviabilização das atividades) e o conforto ambiental (relação aberturas por vaga). } \\
\text { As demandas são parcialmente divergentes (DP). A solução formal prevalece, porém com a demanda da pragmática prisional. }\end{array}$} \\
\hline & Projeto & DF & SP & MJ & EV & & \\
\hline & & & & $D P$ & $D P$ & $D P$ & \\
\hline & \multicolumn{6}{|c|}{ Avaliação Ajustamento } & \\
\hline & Critérios & $\mathrm{S}$ & $\mathrm{F}$ & CA & $\mathrm{C}$ & & \\
\hline & & & & & & & \\
\hline & & $A P$ & NA & NA & $A P$ & NA & \\
\hline \multirow[t]{7}{*}{17.06} & \multicolumn{6}{|c|}{ Equivalência Demandas } & \multirow{7}{*}{$\begin{array}{l}\text { Formalmente, a cela define a maior impessoalidade possível (disciplina-bloco), por meio da individualização absoluta, da síntese funciona } \\
\text { e da exposição da intimidade. O modelo supermax apresenta poucas atividades, dimensionamento mínimo e espaço devassado (não } \\
\text { existe privacidade em relação à instituição). Isto favorece a segurança (submissão dos presos e simplificação dos procedimentos), a } \\
\text { funcionalidade (simplificação de procedimentos) e os custos (redução de componentes e otimização de pessoal). Informalmente, a cela } \\
\text { constitui o território dos presos pela privacidade (fechamento), coletivização (empoderamento) e generalização funcional (complexidade } \\
\text { funcional), enquanto restringe as manifestações coletivas e individuais (aglomeração de presos). Isto desfavorece a segurança } \\
\text { (complicação de procedimentos), enquanto compromete a funcionalidade (realização das atividades) e os custos (redução de áreas). As } \\
\text { demandas são parcialmente divergentes (DP). A solução formal prevalece, porém com a demanda do modelo prisional. }\end{array}$} \\
\hline & & DF & SP & MJ & EV & & \\
\hline & & $c$ & $C P$ & $D P$ & & $D P$ & \\
\hline & \multicolumn{6}{|c|}{ Avaliação Ajustamento } & \\
\hline & ios & & $\mathrm{F}$ & CA & $\mathrm{C}$ & & \\
\hline & & & $A$ & & & $\boldsymbol{A}$ & \\
\hline & & & $A P$ & I & $A$ & $A P$ & \\
\hline \multirow[t]{7}{*}{17.07} & \multicolumn{6}{|c|}{ quivalência Demandas } & \multirow{7}{*}{$\begin{array}{l}\text { Formalmente, a cela tem as dimensões minimizadas, ao reproduzir a síntese funcional, dentro dos padrões mínimos de bem-estar } \\
\text { (disciplina-bloco). O modelo supermax apresenta áreas úteis entre } 7,0 \text { e } 7,2 \mathrm{~m}^{2} \text {. Isto favorece a segurança (simplificação dos } \\
\text { procedimentos), a funcionalidade (realização das atividades), o conforto ambiental (aumento da relação aberturas por vaga) e os custos } \\
\text { (redução de áreas). Informalmente, a cela tende a ser minimamente dimensionada ( } 6,0 \mathrm{~m}^{2} / \mathrm{vaga} \text { ). A cela coletiva extrapola isto, devido ao } \\
\text { aumento de capacidade e ao adensamento obtido com a utilização de beliches }\left(2,0 \mathrm{~m}^{2} / \mathrm{vaga}\right) \text {. Isto compromete a segurança (complicação } \\
\text { dos procedimentos) e o conforto ambiental (redução da relação aberturas por vaga), enquanto desfavorece a funcionalidade } \\
\text { (inviabilização das atividades) e favorece os custos (redução de áreas e otimização da estrutura). As demandas são parcialmente } \\
\text { divergentes (DP). A solução formal prevalece, porém com a demanda do modelo prisional. }\end{array}$} \\
\hline & & & $\mathrm{SP}$ & & $\mathrm{EV}$ & & \\
\hline & & $D P$ & $D P$ & $C P$ & $C P$ & & \\
\hline & \multicolumn{6}{|c|}{ Avaliação Ajustamento } & \\
\hline & os & & $\mathrm{F}$ & & $\mathrm{C}$ & & \\
\hline & & & & & & & \\
\hline & & $A P$ & NA & $A P$ & $A$ & $A P$ & \\
\hline \multirow[t]{7}{*}{17.08} & \multicolumn{6}{|c|}{ Equivalência Demandas } & \multirow{7}{*}{$\begin{array}{l}\text { Formalmente, a cela tem as aberturas de iluminação e ventilação minimizadas, dentro dos padrões de bem estar (disciplina-bloco). As } \\
\text { Diretrizes Básicas determinam um dimensionamento de } 12,5 \% \text { da área de piso. O modelo supermax apresenta } 0,2 \% \text {. As aberturas são } \\
\text { desprovidas de controle e não existe ventilação cruzada. Isto favorece a segurança (contenção de fugas e rompimento da comunicação } \\
\text { informal), o conforto (respeito às aberturas mínimas) e os custos (redução dos componentes). Informalmente, a cela tende apresentar a } \\
\text { as aberturas minimizadas ( } 13,65 \% \text { da área de piso), enquanto adere à coletivização com aumento de capacidade. As aberturas são } \\
\text { desprovidas de controle (com exceções). A ventilação cruzada é evitada. Isto favorece a segurança, enquanto compromete o conforto } \\
\text { ambiental (relação aberturas por vaga) e os custos (aumento e complicação dos componentes). As demandas são parcialmente } \\
\text { divergentes (DP). A solução formal prevalece, porém com a demanda do modelo e da pragmática prisional. }\end{array}$} \\
\hline & & & SP & & & & \\
\hline & & & $D P$ & $D P$ & & & \\
\hline & \multicolumn{6}{|c|}{ Avaliação Ajustamento } & \\
\hline & & & $\mathrm{F}$ & & & & \\
\hline & & & 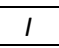 & & & & \\
\hline & & $A$ & I & & & $A$ & \\
\hline \multirow[t]{7}{*}{17.09} & \multicolumn{6}{|c|}{ Equivalência Demandas } & \multirow{7}{*}{$\begin{array}{l}\text { Formal e informalmente, a cela recebe dispositivos para a estanqueidade e impermeabilidade do local, assim como, para garantir a } \\
\text { integridade espacial de seus elementos constituintes (disciplina-bloco). Isto favorece a segurança (contenção de fugas e rompimento da } \\
\text { comunicação informal), a funcionalidade (simplificação de procedimentos) e o conforto ambiental (respeito aos padrões mínimos de bem- } \\
\text { estar), enquanto compromete os custos (aumento dos componentes). Informalmente, a cela apresenta aparatos de segurança (brises e } \\
\text { grades nas aberturas de iluminação e ventilação, portas com portinholas e dispositivos de bloqueio visual), eventualmente incompletos ou } \\
\text { inconsistentes. Isto favorece a segurança, enquanto compromete a funcionalidade (complicação de procedimentos), o conforto ambiental } \\
\text { (descaracterização das aberturas) e os custos. As demandas são parcialmente convergentes (CP). A solução formal prevalece, porém com } \\
\text { a demanda de responder à economia de recursos. }\end{array}$} \\
\hline & & & & & & & \\
\hline & & $C P$ & & $C P$ & & & \\
\hline & \multicolumn{6}{|c|}{ Avaliação Ajustamento } & \\
\hline & & & & & & & \\
\hline & & & & & & & \\
\hline & & $A$ & $A P$ & & & & \\
\hline
\end{tabular}




\begin{tabular}{|c|c|c|c|c|c|c|c|}
\hline \multirow[t]{7}{*}{17.10} & \multicolumn{6}{|c|}{ Equivalência Demandas } & \multirow{7}{*}{$\begin{array}{l}\text { Formalmente, a cela é aberta para a vigilância institucional - a exposição dos presos ao controle. O padrão arquitetônico modular } \\
\text { apresenta portas em grade ou chapa perfurada. Isto favorece a segurança (submissão dos presos e proteção dos funcionários) e o } \\
\text { conforto ambiental (ventilação cruzada), enquanto compromete o custo de construção (especificação das vedações). Informalmente, a } \\
\text { cela tende a ser fechada à vigilância institucional, tendo como ponto de observação uma portinhola. O modelo supermax apresenta a cela } \\
\text { fechada, com o monitoramento viabilizado por visores. Eventualmente, a cela tende a ser parcialmente aberta (brise ou porta em grade). } \\
\text { Isto compromete a segurança (exposição dos funcionários) e o conforto ambiental, enquanto favorece o custo de construção. As } \\
\text { demandas são plenamente divergentes (DP). A solução formal prevalece, porém com a demanda de responder à economia de recursos. }\end{array}$} \\
\hline & Projeto & $\mathrm{DF}$ & SP & MJ & $\mathrm{EV}$ & & \\
\hline & Paridade & $D P$ & $D P$ & $D$ & $D$ & D & \\
\hline & \multicolumn{6}{|c|}{ Avaliação Ajustamento } & \\
\hline & Critérios & $\mathrm{S}$ & $\mathrm{F}$ & CA & $\mathrm{C}$ & & \\
\hline & Formal & $A$ & 1 & $A$ & $A P$ & $A$ & \\
\hline & Informal & $A P$ & 1 & $A P$ & $A$ & $A P$ & \\
\hline \multirow[t]{7}{*}{17.11} & \multicolumn{6}{|c|}{ Equivalência Demandas } & \multirow{7}{*}{$\begin{array}{l}\text { Formalmente, a cela possibilita a vigilância interna absoluta e veta a percepção do espaço externo (disciplina-bloco). O padrão } \\
\text { arquitetônico modular apresenta a porta em grade, o que permite a visualização mútua. O modelo supermax fecha a cela, periferiza os } \\
\text { elementos internos e prevê visores ( } 100 \% \text { de apreensão do espaço interno). Isto favorece a segurança (aumento da visualização e } \\
\text { simplificação dos procedimentos) e compromete o custo de construção (complicação dos componentes). Informalmente, a cela tende a } \\
\text { ser fechada e a apresentar visualização interna reduzida ( } 58 \% \text { da área útil), devido à complexidade espacial associada à restrição do ponto } \\
\text { de observação. Assim como, expõe a rotina institucional aos presos (inversão da vigilância). Isto compromete a segurança (redução da } \\
\text { visualização) e favorece os custos (simplificação dos componentes). As demandas são plenamente divergentes (D). A solução formal } \\
\text { prevalece, porém com a demanda de responder à economia de recursos. }\end{array}$} \\
\hline & Projeto & $\mathrm{DF}$ & SP & MJ & EV & & \\
\hline & & $C P$ & $D P$ & $D$ & $D$ & $D$ & \\
\hline & \multicolumn{6}{|c|}{ Avaliação Ajustamento } & \\
\hline & Critérios & $\mathrm{S}$ & $\mathrm{F}$ & CA & $\mathrm{C}$ & & \\
\hline & Formal & $A$ & 1 & 1 & $A P$ & $A$ & \\
\hline & Informal & $A$ & 1 & 1 & $A P$ & $A$ & \\
\hline Grupo & & & & & & & \\
\hline \multicolumn{8}{|c|}{ 18. Pátio de sol dos presos } \\
\hline \multirow[t]{7}{*}{18.01} & \multicolumn{6}{|c|}{ Equivalência [} & \multirow{7}{*}{$\begin{array}{l}\text { Formalmente, o pátio de sol é destinado ao banho de sol, ao reproduzir a especialização funcional (disciplina-bloco). O modelo supermax } \\
\text { prevê apenas o pátio descoberto. Isto favorece a segurança (aumento da vigilância e do controle), a funcionalidade (simplificação dos } \\
\text { procedimentos), o conforto ambiental (compatibilização das soluções) e os custos (redução de áreas e de pessoal). Informalmente, o pátio } \\
\text { de sol recebe atividades extras, algumas não programadas (higiene pessoal, esportes, lazer, refeições, cultos e visita) (generalização } \\
\text { funcional). As Diretrizes Básicas prevêem outras atividades, tais como lazer e práticas desportivas. Isto desfavorece o ajustamento, com } \\
\text { exceção dos custos (otimização da estrutura). As demandas são plenamente divergentes (D). A solução formal prevalece, porém com as } \\
\text { demandas da pressão por vagas e da pragmática prisional, aliadas à economia de recursos. }\end{array}$} \\
\hline & Projeto & DF & SP & MJ & EV & & \\
\hline & & $D$ & $D$ & $D P$ & $D P$ & D & \\
\hline & \multicolumn{6}{|c|}{ Avaliação Ajustamento } & \\
\hline & Critérios & $\mathrm{S}$ & $\mathrm{F}$ & & $\mathrm{C}$ & & \\
\hline & Formal & $A$ & $A$ & $A$ & $A$ & $A$ & \\
\hline & Informal & $N A$ & $N A$ & NA & & $N A$ & \\
\hline \multirow[t]{7}{*}{18.02} & \multicolumn{6}{|c|}{ Equivalência Demandas } & \multirow{7}{*}{$\begin{array}{l}\text { O espaço arquitetônico formal concorre para a classificação e a separação integral dos presos (individualização e controle absoluto), ao } \\
\text { maximizar a fragmentação deste grupo. O modelo supermax é dotado de pátios de sol individuais. Isto favorece a segurança (submissão } \\
\text { dos presos), enquanto o aumento da quantidade de alas carcerárias compromete a funcionalidade (aumento das tarefas) e desfavorece os } \\
\text { custos (aumento de áreas e de pessoal). O espaço informal concorre para a classificação e a separação em grupos (coletivização). O } \\
\text { padrão arquitetônico modular prevê pátios de sol coletivos. Um pátio pode atender a dois grupos de presos (uso alternado do local). Os } \\
\text { pátios individuais são especificados para casos particulares (cela individual). Isto compromete o ajustamento (empoderamento dos presos } \\
\text { e complicação funcional). As demandas são parcialmente convergentes (CP). As soluções formal e informal se equiparam, prevalece a } \\
\text { solução formal com a demanda da pragmática prisional, aliada à economia de recursos. }\end{array}$} \\
\hline & Projeto & DF & SP & MJ & EV & & \\
\hline & Paridade & $C P$ & $C$ & $C P$ & $C$ & $C P$ & \\
\hline & \multicolumn{6}{|c|}{ Avaliação Ajustamento } & \\
\hline & Critérios & $\mathrm{S}$ & $\mathrm{F}$ & CA & $\mathrm{C}$ & & \\
\hline & Formal & $A$ & $A P$ & 1 & $\overline{N A}$ & $A P$ & \\
\hline & Informal & $A P$ & $A P$ & 1 & $A P$ & $A P$ & \\
\hline \multirow[t]{3}{*}{18.03} & \multicolumn{6}{|c|}{ Equivalência Demandas } & \multirow{3}{*}{$\begin{array}{l}\text { A demanda formal determina a menor capacidade para os pátios de sol coletivos, de modo a se aproximar da individualização da pena e } \\
\text { do grau de segurança exigido. Isto favorece a segurança (submissão dos presos), enquanto o aumento da quantidade de alas carcerárias } \\
\text { compromete a funcionalidade (aumento das tarefas), além de desfavorecer os custos (aumento de áreas e de pessoal). O espaço informal }\end{array}$} \\
\hline & & $\mathrm{DF}$ & SP & MJ & EV & & \\
\hline & & $D$ & & & & & \\
\hline
\end{tabular}




\begin{tabular}{|c|c|c|c|c|c|c|c|}
\hline & \multicolumn{6}{|c|}{ Avaliação Ajustamento } & \multirow{4}{*}{$\begin{array}{l}\text { ende a apresentar uma área dimensionada para uma capacidade maior (entre } 215 \text { e } 372 \text { presos). Isto compromete a segurança } \\
\text { empoderamento dos presos), enquanto favorece a funcionalidade (redução das tarefas) e os custos (otimiza a estrutura). Os grupos de } \\
\text { resos podem ser fragmentados por meio da alternância na utilização do local (em torno de } 40 \text { presos), o que é ressaltado pela equipe } \\
\text { irigente. As demandas são plenamente divergentes (D). A solução informal prevalece, porém com a demanda da segurança. }\end{array}$} \\
\hline & ritérios & $\mathrm{S}$ & $\mathrm{F}$ & CA & $\mathrm{C}$ & & \\
\hline & & $A$ & & & & & \\
\hline & nformal & $A P$ & $A$ & 1 & $A$ & & \\
\hline \multirow[t]{7}{*}{18.04} & \multicolumn{6}{|c|}{ Equivalência Demandas } & \multirow{7}{*}{$\begin{array}{l}\text { Formal e informalmente, o pátio de sol apresenta simplicidade geométrica (formas prismáticas retas, sem reentrâncias, saliências ou } \\
\text { desníveis). O modelo supermax (padrão arquitetônico modular) apresenta um desenho mais complexo (angular ou ondulado), porém } \\
\text { linear e nivelado. Os projetos de referência apresentam pátios retangulares. Isto favorece a segurança (aumento da visualização e do } \\
\text { controle), a funcionalidade (aumento da utilidade do espaço) e os custos (simplificação dos procedimentos). As demandas são } \\
\text { plenamente convergentes (C). As soluções formal e informal se equivalem, porém com a demanda da pragmática prisional. }\end{array}$} \\
\hline & Projeto & DF & & & EV & & \\
\hline & & C & & C & $C$ & C & \\
\hline & \multicolumn{6}{|c|}{ Avaliação Ajustamento } & \\
\hline & itérios & $S$ & $\mathrm{~F}$ & & $\mathrm{C}$ & & \\
\hline & & & & & $A$ & & \\
\hline & ormal & $A$ & & 1 & $A$ & & \\
\hline \multirow[t]{7}{*}{18.05} & \multicolumn{6}{|c|}{ Equivalência Demandas } & \multirow{7}{*}{$\begin{array}{l}\text { ormalmente, o pátio de sol reproduz a síntese funcional (disciplina-bloco). O modelo supermax (padrão arquitetônico modular) prevê um } \\
\text { mbiente único. Isto favorece a segurança (redução de vulnerabilidades e aumento da visualização), a funcionalidade (simplificação de } \\
\text { ocedimentos e realização das atividades) e os custos (redução de áreas e de pessoal). Informalmente, o pátio de sol tende a apresentar } \\
\text { ma simplicidade espacial (ambiente único que articula área coberta e descoberta contíguas), porém com serviços locados } \\
\text { erifericamente. Os presos consideram o pátio insuficiente para as atividades realizadas. Isto compromete a segurança (aumento de } \\
\text { lnerabilidades e redução da visualização), enquanto desfavorece a funcionalidade (conflitos de atividades) e favorece os custos. As } \\
\text { emandas são plenamente divergentes (D). A solução formal prevalece, porém com a demanda da pragmática prisional. }\end{array}$} \\
\hline & & & & & EV & & \\
\hline & & & $D$ & $D P$ & $D P$ & $D$ & \\
\hline & \multicolumn{6}{|c|}{ Avaliação Ajustamento } & \\
\hline & itérios & $\mathrm{S}$ & $\mathrm{F}$ & & & & \\
\hline & al & & & & $A$ & $\boldsymbol{A}$ & \\
\hline & & & & 1 & $A$ & $A$ & \\
\hline \multirow[t]{7}{*}{18.06} & \multicolumn{6}{|c|}{ Equivalência Demandas } & \multirow{7}{*}{$\begin{array}{l}\text { Formalmente, o pátio de sol reproduz a minimização dos padrões de bem estar (disciplina-bloco), ao apresentar serviços e equipamentos } \\
\text { reduzidos (mobiliário e aparelhos sanitários), dentro dos padrões mínimos de bem-estar. O padrão arquitetônico modular prevê } \\
\text { conjuntos de mesas e bancos metálicos. O modelo supermax não prevê serviço higiênico. Isto favorece a segurança (redução de } \\
\text { vulnerabilidades e aumento da vigilância) e os custos (redução de componentes e de pessoal), enquanto compromete a funcionalidade } \\
\text { (realização das atividades). Informalmente, o pátio de sol tende apresentar área coberta com serviço hidrossanitário e mobiliário. Os } \\
\text { presos consideram estes itens insuficientes (aglomeração de presos). Isto desfavorece a segurança, enquanto compromete a } \\
\text { funcionalidade (complicação dos procedimentos) e os custos (aumento dos componentes e de pessoal). As demandas são parcialmente } \\
\text { divergentes (DP). A solução formal prevalece, porém com a demanda da pragmática prisional, aliada à economia de recursos. }\end{array}$} \\
\hline & & & & & EV & & \\
\hline & & & $D P$ & $D P$ & $C P$ & DP & \\
\hline & \multicolumn{6}{|c|}{ Avaliação Ajustamento } & \\
\hline & itérios & & & & $\mathrm{C}$ & & \\
\hline & & & & & $A$ & $\boldsymbol{A}$ & \\
\hline & & & $A P$ & I & $A P$ & $A P$ & \\
\hline \multirow[t]{7}{*}{18.07} & \multicolumn{6}{|c|}{ Equivalência Demandas } & \multirow{7}{*}{$\begin{array}{l}\text { Formalmente, o pátio de sol reproduz a especialização funcional (disciplina-bloco), ao desconsiderar a cantina e a distribuição de } \\
\text { refeições. O modelo supermax (padrão arquitetônico modular) não prevê estes itens. Isto favorece a segurança (redução de } \\
\text { vulnerabilidades), a funcionalidade (redução de tarefas e simplificação de procedimentos) e os custos (redução de áreas e de pessoal). Os } \\
\text { instrumentos legais e técnicos recomendam estes espaços junto ao pátio independentemente do nível de segurança. Informalmente, o } \\
\text { pátio de sol tende a apresentar a distribuição de refeições, em especial, quando a área coberta do pátio é prevista como refeitório. O } \\
\text { pátio de sol dificilmente apresenta a cantina. Na prática, as refeições não são realizadas no pátio de sol. Isto compromete o ajustamento. } \\
\text { As demandas são parcialmente convergentes (CP). A solução formal prevalece, porém com a demanda da pragmática penitenciária. }\end{array}$} \\
\hline & Projeto & & & & EV & & \\
\hline & & & & & $\overline{C P}$ & & \\
\hline & & & & & & & \\
\hline & térios & & & & $\mathrm{C}$ & & \\
\hline & rmal & & & & & & \\
\hline & & & $A P$ & & $A P$ & & \\
\hline \multirow[t]{6}{*}{18.08} & \multicolumn{6}{|c|}{ Equivalência Demandas } & \multirow{6}{*}{$\begin{array}{l}\text { Formalmente, o pátio de sol apresenta uma maximização da impessoalidade, ao reproduzir a individualização absoluta, a síntese funcional } \\
\text { e a exposição dos presos (disciplina-bloco). No modelo supermax se configura a especialização funcional, a inexistência de equipamentos, } \\
\text { o dimensionamento mínimo e o espaço devassado (não existe privacidade em relação à instituição). Isto favorece a segurança (submissão } \\
\text { dos presos), a funcionalidade (simplificação dos procedimentos) e os custos (redução de componentes e de pessoal). Informalmente, o } \\
\text { pátio de sol tende a constituir o território dos presos pela coletivização (empoderamento) e generalização funcional (complexidade } \\
\text { funcional), enquanto restringe as manifestações coletivas pela simplicidade espacial (redução dos padrões de bem estar, dimensões }\end{array}$} \\
\hline & 0 & & & & EV & & \\
\hline & & & & $D P$ & $C P$ & & \\
\hline & \multicolumn{6}{|c|}{ Avaliação Ajustamento } & \\
\hline & & $\mathrm{S}$ & & CA & C & & \\
\hline & & & & & & & \\
\hline
\end{tabular}




\begin{tabular}{|c|c|c|c|c|c|c|c|}
\hline & formal & $A P$ & $A P$ & I & $A$ & $A P$ & $\begin{array}{l}\text { duzidas e exposição dos presos à instituição). Isto compromete a segurança (complicação dos procedimentos) e a funcionalidade } \\
\text { ealização das atividades), enquanto favorece os custos (redução de área e otimização da estrutura). As demandas são parcialmente } \\
\text { vergentes (DP). A solução formal prevalece, porém com a demanda do modelo e da pragmática prisional. }\end{array}$ \\
\hline \multirow[t]{7}{*}{18.09} & \multicolumn{6}{|c|}{ Equivalência Demandas } & \multirow{7}{*}{$\begin{array}{l}\text { Formalmente, o pátio de sol apresenta uma minimização das dimensões, ao reproduzir a síntese funcional (disciplina-bloco), enquanto a } \\
\text { altura ou pé-direito são maximizados para garantir a segurança (seis metros). As Diretrizes Básicas estimam } 1,5 \mathrm{~m}^{2} / \text { vaga. Isto favorece a } \\
\text { segurança (submissão dos presos), a funcionalidade (simplificação de procedimentos) e os custos (redução de áreas e otimização da } \\
\text { estrutura). Informalmente, o pátio de sol tende a ter dimensões maiores }\left(2,39 \mathrm{~m}^{2} / \mathrm{vaga} \text { ) (possibilita a ocupação pelo grupo completo de }\right. \\
\text { uma ala carcerária ou bloco de vivência), enquanto a altura ou pé-direito tende a ser maximizada. O padrão arquitetônico modular } \\
\text { apresenta uma área útil de } 16 \mathrm{~m}^{2} / v a g a \text {. Isto compromete a segurança (empoderamento dos presos) e os custos (aumento de áreas), } \\
\text { enquanto favorece a funcionalidade (realização das atividades). Os presos consideram as dimensões insuficientes. As demandas são } \\
\text { parcialmente divergentes (DP). A solução formal prevalece, porém com a demanda da pragmática prisional. }\end{array}$} \\
\hline & Projeto & DF & $\mathrm{SP}$ & $\mathrm{MJ}$ & EV & & \\
\hline & & $D P$ & $D P$ & $C P$ & & $D P$ & \\
\hline & \multicolumn{6}{|c|}{ Avaliação Ajustamento } & \\
\hline & Critérios & $S$ & $\mathrm{~F}$ & CA & $\mathrm{C}$ & & \\
\hline & Formal & $A$ & $A$ & & & $\boldsymbol{A}$ & \\
\hline & & $A P$ & $A P$ & I & $A P$ & $A P$ & \\
\hline \multirow[t]{7}{*}{18.10} & \multicolumn{6}{|c|}{ Equivalência Demandas } & \multirow{7}{*}{$\begin{array}{l}\text { Formalmente, o pátio de sol apresenta uma restrição das aberturas de iluminação e ventilação, dentro dos padrões de bem estar } \\
\text { (disciplina-bloco). O padrão arquitetônico modular apresenta pátios fechados com cerca. O modelo supermax apresenta pátios fechados } \\
\text { com paredes altas (seis metros). Isto favorece a segurança (contenção de fugas e rompimento da comunicação informal) e o conforto } \\
\text { ambiental (cerca), enquanto compromete o custo de construção (aumento dos componentes). Informalmente, o pátio de sol apresenta } \\
\text { uma maximização do fechamento (inviabiliza a ventilação cruzada e a regulagem da abertura). Os presos consideram os pátios quentes } \\
\text { (proporções do lugar, incidência solar e coletivização). Isto favorece a segurança, enquanto compromete o conforto ambiental e os custos. } \\
\text { As demandas são parcialmente divergentes (DP). A solução formal prevalece, porém com a demanda da pragmática prisional. }\end{array}$} \\
\hline & & DF & SP & & $\mathrm{EV}$ & & \\
\hline & & $D$ & $D P$ & $C P$ & $c$ & $D P$ & \\
\hline & \multicolumn{6}{|c|}{ Avaliação Ajustamento } & \\
\hline & & $\mathrm{S}$ & $\mathrm{F}$ & & $\mathrm{C}$ & & \\
\hline & & $A$ & $I$ & & & $A$ & \\
\hline & & $A$ & 1 & $A P$ & $A P$ & $A$ & \\
\hline \multirow[t]{7}{*}{18.11} & \multicolumn{6}{|c|}{ Equivalência Demandas } & \multirow{7}{*}{$\begin{array}{l}\text { Formal e informalmente, o pátio de sol apresenta uma maximização da segurança, ao receber dispositivos para reforçar a estanqueidade } \\
\text { e impermeabilidade do local (disciplina-bloco). O modelo supermax apresenta fechamento em tela estruturada na parte superior do pátio } \\
\text { de sol. Isto favorece a segurança (contenção de fugas e rompimento da comunicação informal) e a funcionalidade (redução de tarefas), } \\
\text { enquanto compromete os custos (aumento dos componentes). Informalmente, o pátio de sol apresenta aparatos de segurança (telas, } \\
\text { grades e elementos cortantes), eventualmente incompletos ou inconsistentes. Isto favorece a segurança (embora apresente } \\
\text { vulnerabilidades), enquanto compromete a funcionalidade (complicação de procedimentos) e os custos. As demandas são plenamente } \\
\text { convergentes (C). A solução formal prevalece, porém com a demanda de responder à economia de recursos. }\end{array}$} \\
\hline & & & $\mathrm{SP}$ & & & & \\
\hline & & $C P$ & $C$ & $C$ & $C$ & $\bar{C}$ & \\
\hline & \multicolumn{6}{|c|}{ valiação Ajustamento } & \\
\hline & & $\mathrm{S}$ & $\mathrm{F}$ & & C & & \\
\hline & & $A$ & $A$ & & & $\boldsymbol{A}$ & \\
\hline & & $A$ & $A P$ & 1 & $A P$ & $A$ & \\
\hline \multirow[t]{7}{*}{18.12} & \multicolumn{6}{|c|}{ Equivalência Demandas } & \multirow{7}{*}{$\begin{array}{l}\text { Formalmente, o pátio de sol proporciona a vigilância interna absoluta (disciplina-bloco). O padrão arquitetônico modular angula a } \\
\text { geometria do pátio para configurar um ponto focal propício ao posto de controle. O modelo supermax dispensa qualquer elemento } \\
\text { interior (sanitário, mobiliário, equipamentos). Isto favorece a segurança (aumento da visualização) e a funcionalidade (simplificação dos } \\
\text { procedimentos), enquanto compromete o custo de construção (complicação construtiva). Informalmente, o pátio de sol tende a } \\
\text { visualização interna absoluta ( } 99 \% \text { da área útil) (continuidade espacial, à disposição lateral dos sanitários e ao mobiliário baixo). Os } \\
\text { funcionários consideram os sanitários e o mobiliário como pontos cegos. Isto compromete a segurança e a funcionalidade, enquanto } \\
\text { favorece os custos (otimização da estrutura). As demandas são plenamente convergentes (C). A solução formal prevalece, porém com a } \\
\text { demanda de responder à economia de recursos. }\end{array}$} \\
\hline & & DF & $\mathrm{SP}$ & & & & \\
\hline & ridade & $C$ & $C$ & $C P$ & $C$ & 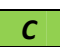 & \\
\hline & \multicolumn{6}{|c|}{ Avaliação Ajustamento } & \\
\hline & & $\mathrm{S}$ & $\mathrm{F}$ & & $\mathrm{C}$ & & \\
\hline & & & $A$ & 1 & & & \\
\hline & ormal & & $A P$ & 1 & $A$ & $A$ & \\
\hline upo & & & & & & & $\begin{array}{l}\text { parcialmente divergentes, ao se gerar pátios de sol adversos da funcionalidade, tipificação, espacialização, poder institucional, } \\
\text { al, por isto dissonante da segurança buscada. Embora os pátios atendam às exigências da classificação e separação dos presos, da } \\
\text { dos padrões de bem estar, previsão de distribuição de refeições, reforço da estanqueidade e visualização do interior. Sobressaem as } \\
\text { custo de construção, além das deficiências operacionais e do projetista. A solução formal prevalece, porém com a ressalva de atender à }\end{array}$ \\
\hline
\end{tabular}




\begin{tabular}{|c|c|c|c|c|c|c|c|}
\hline \multicolumn{8}{|c|}{ 19. Posto de Controle } \\
\hline \multirow[t]{7}{*}{19.01} & \multicolumn{6}{|c|}{ Equivalência Demandas } & \multirow{7}{*}{$\begin{array}{l}\text { Formalmente, o posto de controle propicia a vigilância absoluta (disciplina-bloco), ao constituir um ponto gerador isométrico que } \\
\text { concentra a apreensão dos eventos dos recintos monitorados. O padrão arquitetônico modular apresenta postos de controle com } \\
\text { geometria contundente (ângulos agudos, chanfros, avanços). Isto favorece a segurança (aumento do campo de visão), a funcionalidade } \\
\text { (simplificação de procedimentos) e os custos (otimizaça da estrutura e redução de pessoal). Informalmente, o posto de controle } \\
\text { apresenta uma dispersão do ponto focal (configura dois ou três pontos geradores geométricos) pela posição, forma e projeção reduzidas } \\
\text { (embora apresente piso elevado). Isto compromete a segurança, a funcionalidade e os custos (aumento de áreas e equipes). As demandas } \\
\text { são parcialmente convergentes (CP). A solução formal prevalece, porém com a demanda do conforto ambiental. }\end{array}$} \\
\hline & Projeto & $\mathrm{DF}$ & SP & MJ & EV & & \\
\hline & Paridade & $C P$ & $D P$ & $C P$ & $C P$ & $C P$ & \\
\hline & \multicolumn{6}{|c|}{ Avaliação Ajustamento } & \\
\hline & Critérios & $\mathrm{S}$ & $\mathrm{F}$ & CA & $\mathrm{C}$ & & \\
\hline & Formal & $A$ & $A$ & 1 & $A$ & & \\
\hline & Informal & $A P$ & $A P$ & 1 & $A P$ & & \\
\hline \multirow[t]{7}{*}{19.02} & \multicolumn{6}{|c|}{ Equivalência Demandas } & \multirow{7}{*}{$\begin{array}{l}\text { Formalmente, o posto de controle propicia condições de trabalho, ao apresentar serviço sanitário e mobiliário adequado para o } \\
\text { cumprimento das tarefas. O padrão arquitetônico modular (supermax) prevê conjuntos de mesas e cadeiras. Os serviços sanitários são } \\
\text { localizados fora do posto de controle. Isto favorece a segurança (garante a efetividade da equipe) e a funcionalidade (garante o } \\
\text { cumprimento dos procedimentos), enquanto compromete o custo de construção (aumento de componentes). Informalmente, o posto de } \\
\text { controle tende a ser destituído de mobiliário, enquanto tende a apresentar os serviços sanitários (previsto junto ou perto do posto de } \\
\text { controle). Os funcionários consideram a quantidade de sanitários insuficiente. Isto compromete o ajustamento. As demandas são } \\
\text { parcialmente convergentes (CP). A solução formal prevalece, porém com a demanda dos custos. }\end{array}$} \\
\hline & Projeto & DF & SP & MJ & EV & & \\
\hline & Paridade & $C P$ & $C P$ & $C P$ & $C P$ & $C P$ & \\
\hline & \multicolumn{6}{|c|}{ Avaliação Ajustamento } & \\
\hline & Critérios & $\mathrm{S}$ & $\mathrm{F}$ & CA & $\mathrm{C}$ & & \\
\hline & al & $A$ & $A$ & I & & & \\
\hline & Informal & $A P$ & $A P$ & & $A P$ & & \\
\hline \multirow[t]{7}{*}{19.03} & \multicolumn{6}{|c|}{ Equivalência Demandas } & \multirow{7}{*}{$\begin{array}{l}\text { Formalmente, o posto de controle apresenta uma maximização da visualização dos ambientes engajados (isometria), pela disposição, } \\
\text { quantidade, dimensionamento e desenho dos visores (perímetro suficiente e livre de obstáculos). O padrão arquitetônico modular } \\
\text { configura um perímetro desimpedido e visores inclinados (ângulo de visão), de acordo com o ponto gerador isométrico do posto de } \\
\text { controle. Isto favorece a segurança (aumento do campo de visão) e a funcionalidade (redução de tarefas). Informalmente, o posto de } \\
\text { controle apresenta interferências (elementos estruturais, instalações ou escadas) ou inconsistências (desconsidera o ângulo de visão), } \\
\text { embora constitua um espaço livre interno. Isto compromete a segurança, enquanto favorece a funcionalidade (suporte aos } \\
\text { procedimentos). As demandas são parcialmente convergentes (CP). A solução formal prevalece. }\end{array}$} \\
\hline & Projeto & DF & SP & MJ & EV & & \\
\hline & Paridade & $C P$ & C & $C P$ & $C P$ & & \\
\hline & \multicolumn{6}{|c|}{ Avaliação Ajustamento } & \\
\hline & Crité & $\mathrm{S}$ & $\mathrm{F}$ & CA & $\mathrm{C}$ & & \\
\hline & & $A$ & $A$ & & & & \\
\hline & ormal & $A P$ & $A$ & 1 & 1 & & \\
\hline \multirow[t]{7}{*}{19.04} & \multicolumn{6}{|c|}{ Equivalência Demandas } & \multirow{7}{*}{$\begin{array}{l}\text { Formalmente, o posto de controle tem as dimensões equilibradas (síntese funcional), ao se concentrar a informação advinda dos locais } \\
\text { vigiados (ponto gerador isométrico), dentro dos padrões mínimos de bem-estar (disciplina-bloco). O padrão arquitetônico modular } \\
\text { apresenta áreas entre } 25,0 \text { e } 36,0 \mathrm{~m}^{2} \text {. As Diretrizes Básicas estipulam uma área de } 6,0 \mathrm{~m}^{2} \text {. Isto favorece a segurança (aumento do campo de } \\
\text { visão), a funcionalidade (simplificação dos procedimentos), o conforto ambiental (proporção das aberturas) e os custos (redução de área). } \\
\text { Informalmente, o posto de controle tende a ser minimamente dimensionado (área de } 15,83 \mathrm{~m}^{2} \text {, em média), porém de modo desvinculado } \\
\text { do princípio de vigilância, por isto esta redução nem sempre favorece a visualização pelos funcionários. Isto compromete o ajustamento, } \\
\text { enquanto favorece os custos (redução de áreas). As demandas são parcialmente convergentes (CP). A solução formal prevalece. }\end{array}$} \\
\hline & Proje & DF & SP & & EV & & \\
\hline & Parid & C & $D P$ & $C P$ & $C P$ & & \\
\hline & \multicolumn{6}{|c|}{ Avaliação Ajustamento } & \\
\hline & Critérios & $\mathrm{S}$ & $\mathrm{F}$ & & $\mathrm{C}$ & & \\
\hline & Formal & $A$ & $A$ & & & & \\
\hline & formal & $A P$ & $A P$ & $A P$ & & & \\
\hline \multirow[t]{7}{*}{19.05} & \multicolumn{6}{|c|}{ Equivalência Demandas } & \multirow{7}{*}{$\begin{array}{l}\text { Formalmente, o posto de controle tem a inexpugnidade e a operacionalidade maximizada, ao receber aparatos de segurança para o } \\
\text { bloqueio das aberturas, manuseio remoto de portas e evasão dos funcionários (a operação segura e a integridade dos funcionários). O } \\
\text { padrão arquitetônico modular apresenta visores, portas manuseadas remotamente e portinholas nas portas. Isto favorece a segurança } \\
\text { (separação física dos funcionários), a funcionalidade (simplificação dos procedimentos) e o conforto ambiental (viabilização das } \\
\text { aberturas), enquanto compromete o custo de construção (aumento de componentes). Informalmente, o posto de controle tende a } \\
\text { apresentar aparatos de segurança, porém incompletos ou inconsistentes. Isto compromete o ajustamento, enquanto favorece os custos. } \\
\text { As demandas são parcialmente convergentes (CP). A solução formal prevalece, porém com a demanda dos custos. }\end{array}$} \\
\hline & Projeto & & SP & & EV & & \\
\hline & Paridade & $C P$ & $D P$ & $C P$ & C & & \\
\hline & \multicolumn{6}{|c|}{ Avaliação Ajustamento } & \\
\hline & Crité & $\mathrm{S}$ & $\mathrm{F}$ & CA & $\mathrm{C}$ & & \\
\hline & Formal & $A$ & $A$ & $A$ & $A P$ & & \\
\hline & formal & $A P$ & $A P$ & $A P$ & & & \\
\hline \multirow[t]{3}{*}{19.06} & \multicolumn{6}{|c|}{ Equivalência Demandas } & \multirow{3}{*}{$\begin{array}{l}\text { Formalmente, o posto de controle tem o conforto ambiental minimizado (aberturas de iluminação e ventilação), em favor do fechamento } \\
\text { (inexpugnidade), dentro dos padrões mínimos de bem-estar. O posto de controle do padrão arquitetônico modular (supermax) é fechado, } \\
\text { artificialmente iluminado e climatizado. As Diretrizes Básicas determinavam um dimensionamento de } 12,5 \% \text { da área de piso. Isto favorece }\end{array}$} \\
\hline & & DF & SP & & EV & & \\
\hline & Paridade & $C P$ & & & & & \\
\hline
\end{tabular}


Avaliação Ajustamento

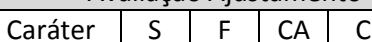

Formal $A$ A 1 A

\begin{tabular}{l|l|l|l|l|l} 
Informal & $A$ & $I$ & NA & $A P$ & $A P$
\end{tabular}

Grupo

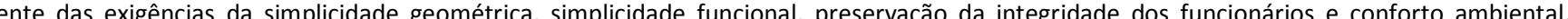
Sobressaem as questões penitenciárias da redução do custo de construção, além das deficiências operacionais e do projetista. A solução formal prevalece, porém com a ressalva de atender à economia de recursos e o conforto ambiental.

a segurança (redução de vulnerabilidades), o conforto ambiental (proporção das aberturas) e os custos (redução dos componentes). Informalmente, o posto de controle tende a ser iluminado e ventilado indiretamente através dos visores (grade) ou pelos corredores de acesso ou locais circundantes. As aberturas são desprovidas de regulagem. Os funcionários consideram o posto de controle desconfortável (temperatura). Isto favorece a segurança, enquanto desfavorece o conforto ambiental e compromete os custos. As demandas são parcialmente divergentes (DP). A solução formal prevalece. 


\section{Apêndice F - Tecnologia de projeto}

Neste apêndice, a tecnologia de projeto desenvolvida é apresentada como resultado dos ajustamentos entre as soluções formais e informais, complementados pelo teste da tecnologia, realizados nos capítulos 7 e 8 desta tese, respectivamente.

$\mathrm{Na}$ tecnologia de projeto, cada um dos requisitos funcionais é acompanhado da fundamentação teórica, do procedimento metodológico e dos recursos técnicos pertinentes. A fundamentação teórica eventualmente acumulou informações da realidade prisional, sempre que o requisito interagisse com o sistema penitenciário ou a prática prisional (Quadro 26). O procedimento metodológico trouxe os processos gerais para a implantação das soluções demandadas, associados aos princípios geradores dos esquemas propostos. Os recursos técnicos exibem as referências técnico-normativas mais relevantes e os respectivos parâmetros para a concepção arquitetônica. Estas referências se encontram indicadas entre colchetes, através da seguinte legenda:

- PR - Projetos de referência adotados nesta pesquisa;

- $\mathrm{CF}$ - Constituição Federal;

- LEP - Lei de Execução Penal (Lei

- RM - Regras Mínimas para o Tratamento de Presos (Resolução

- DB - Diretrizes Básicas para a Arquitetura Penal (Resolução CNPCP n ${ }^{\circ}$ 9, de 13/11/2009);

- $\mathrm{RP}-$ Realidade prisional

Outras referências aparecem ao longo da tecnologia de projeto, sendo citadas diretamente.

Os vínculos constantes do Apêndice D foram alocados ao longo do corpo da tecnologia. Cada grupo temático é introduzido pelos vínculos condensados do grupo de quesitos. Os vínculos gerais de cada requisito funcional estão em itálico, ao final da informação teórica. Os vínculos específicos estão entre parêntesis, permeando os conteúdos dos requisitos, indicando consulta a itens conexos. Os vínculos específicos acrescidos após os ajustamentos realizados nos capítulos 7 e 8 estão em itálico, entre parêntesis. Esta separação visou distinguir as ligações advindas do estudo realizado, daquelas inseridas em termos da aplicabilidade do documento. 
Quadro 26 - Tecnologia de projeto

\begin{tabular}{|c|c|c|c|}
\hline \multicolumn{4}{|c|}{ 01. Tipo e categoria do estabelecimento penal } \\
\hline \multicolumn{4}{|c|}{ A principal categoria é o nível de segurança penitenciário que define a configuração do espaço arquitetônico como um todo, condicionando os demais quesitos. } \\
\hline Requisito & Fundamentação Teórica & Procedimento Metodológico & Recursos Técnicos \\
\hline $\begin{array}{l}\text { 01.01 } \\
\text { Conceber o espaço } \\
\text { arquitetônico da prisão de } \\
\text { modo consonante ao perfil } \\
\text { da população prisional } \\
\text { prevista para o o } \\
\text { estabelecimento penal a } \\
\text { ser projetado }\end{array}$ & $\begin{array}{l}\text { O perfil do preso corresponde a uma modalidade } \\
\text { de arquitetura particular, atrelada a um modelo de } \\
\text { execução da pena, indicado pelo nível de } \\
\text { segurança penitenciário [CF, art. } 5^{\circ} ; \text { LEP, art. } 5^{\circ} ; \\
\text { RM, art. 7; DB, p. 45-49] (ver item 01.02). O nível } \\
\text { de segurança máxima é destinado aos presos que } \\
\text { dispensam o maior nível de segurança, mas para os } \\
\text { quais a fuga deve ser muito dificultada e o controle } \\
\text { incrementado. Baseia o programa arquitetônico. }\end{array}$ & $\begin{array}{l}\text { Importa compreender as relações sociais a serem } \\
\text { desenvolvidas (representações institucionais e } \\
\text { territorialidade), por meio da definição dos } \\
\text { processos totais e dos princípios de funcionamento } \\
\text { da prisão, particularizados pela realidade prisional } \\
\text { (ver item 06.03). O caráter punitivo da pena é } \\
\text { priorizado, o que enfatiza os processos totais } \\
\text { (isolamento social e controle). }\end{array}$ & $\begin{array}{l}\text { Prever o contato social supervisionado; a } \\
\text { coletivização do alojamento dos presos; a } \\
\text { ampliação das atividades de reinserção social; a } \\
\text { maximização da vigilância e a administração } \\
\text { totalitária. } \\
\text { Evidenciar o domínio territorial da instituição e a } \\
\text { divisão social (ver item 10.02). }\end{array}$ \\
\hline $\begin{array}{l}\mathbf{0 1 . 0 2} \\
\text { Viabilizar os sistemas de } \\
\text { segurança e operação } \\
\text { penitenciária em função do } \\
\text { nível de segurança definido } \\
\text { para o estabelecimento a } \\
\text { ser projetado }\end{array}$ & $\begin{array}{l}\text { A Teoria Mista do Direito prevê simultaneamente a } \\
\text { punição e a reintegração social dos presos, por } \\
\text { meio de um balanço medido pelo nível de } \\
\text { segurança penitenciário (ver item 01.01). O nível } \\
\text { de segurança máxima enfatiza a segurança física e } \\
\text { operacional. As atividades assistenciais, } \\
\text { socializantes e laboreducativas dos presos são } \\
\text { relativizadas (ver itens } 09.01 \text { e 11.01). Baseia o } \\
\text { programa arquitetônico. }\end{array}$ & $\begin{array}{l}\text { O espaço arquitetônico deve maximizar o } \\
\text { fechamento institucional e a disciplina interna, por } \\
\text { meio da atuação ostensiva dos funcionários } \\
\text { (acessibilidade, mobilidade e permanência) e } \\
\text { proteção dos mesmos (redução dos riscos). A } \\
\text { assistência deve ser disponibilizada para todos os } \\
\text { presos. As atividades de reinserção social são } \\
\text { previstas de modo parcelado (grupos de presos ou } \\
\text { turnos). }\end{array}$ & $\begin{array}{l}\text { Reforçar a localização e a configuração da } \\
\text { barreira perimetral, das edificações e dos postos } \\
\text { de controle. } \\
\text { Prever locais para as atividades assistenciais, } \\
\text { socializantes e laboreducativas, quantificados e } \\
\text { dimensionados para o uso alternado por grupos } \\
\text { de presos [DB, p. } 66 \text { e 67; RP]. }\end{array}$ \\
\hline 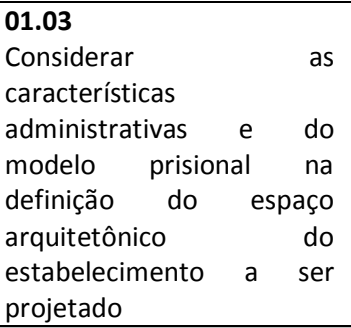 & $\begin{array}{l}\text { O Federalismo Brasileiro centraliza a normatização } \\
\text { da execução penal, embora delegue a aplicação da } \\
\text { pena aos estados, produzindo nuanças entre os } \\
\text { sistemas penitenciários que se manifestam na } \\
\text { arquitetura. Baseia o programa arquitetônico. }\end{array}$ & $\begin{array}{l}\text { Os fatores administrativos, políticos, } \\
\text { organizacionais e pragmáticos de um sistema } \\
\text { penitenciário devem ser considerados, em especial } \\
\text { aqueles de ordem financeira e realística (ver itens } \\
01.02,02.02 \text { e 03.02). Estes fatores determinam } \\
\text { particularidades arquitetônicas, subordinadas ao } \\
\text { modelo de segurança máxima. }\end{array}$ & $\begin{array}{l}\text { Levantar a posição penalógica da administração } \\
\text { penitenciária (ênfase na punição ou reinserção), } \\
\text { as normas e as políticas penitenciárias vigentes e } \\
\text { vislumbradas, a estrutura e a composição do } \\
\text { sistema penitenciário (população prisional e } \\
\text { parque penitenciário) e o modelo prisional (os } \\
\text { regimentos de funcionamento das unidades } \\
\text { prisionais) [DB, p. } 27 \text { e 29]. }\end{array}$ \\
\hline \multicolumn{4}{|c|}{ 02. Porte do estabelecimento penal } \\
\hline \multicolumn{4}{|c|}{ Relaciona-se de forma mais direta com o Custo, além da Geometria e da Organização do Espaço, especialmente com as Atividades e o Dimensionamento. } \\
\hline Requisito & Fundamentação Teórica & Procedimento Metodológico & Recursos Técnicos \\
\hline $\begin{array}{lr}02.01 & \\
\text { Compatibilizar } & \text { a } \\
\text { capacidade e a } & \text { estrutura } \\
\text { física necessária } & \text { para } 0 \\
\text { funcionamento } & \text { do }\end{array}$ & $\begin{array}{l}\text { O porte está vinculado às necessidades físicas dos } \\
\text { sistemas de segurança e operação, havendo uma } \\
\text { quantidade de área ideal para cada nível de } \\
\text { segurança, em razão dos programas de segurança } \\
\text { e de reinserção social dos presos [LEP, art. 85] (ver }\end{array}$ & $\begin{array}{l}\text { A estrutura física é proporcional à capacidade, } \\
\text { dentro de parâmetros concernentes ao nível de } \\
\text { segurança, em uma razão inversa: os espaços } \\
\text { tendem à otimização com o aumento da } \\
\text { capacidade. Isto corresponde ao princípio da }\end{array}$ & $\begin{array}{l}\text { Considerar a especificação de circulações } \\
\text { exclusivas para os funcionários e a proposta } \\
\text { pedagógica para os presos. } \\
\text { Considerar a replicação de áreas do padrão } \\
\text { arquitetônico penitenciário (padrão modular). }\end{array}$ \\
\hline
\end{tabular}




\begin{tabular}{|c|c|c|c|}
\hline $\begin{array}{l}\text { estabelecimento penal a } \\
\text { ser projetado }\end{array}$ & item 01.02). Baseia o programa arquitetônico. & $\begin{array}{l}\text { maximização, com a utilização rotativa de espaços } \\
\text { (ver item 06.01). }\end{array}$ & $\begin{array}{l}\text { Considerar o pré-dimensionamento com base na } \\
\text { capacidade (ver item 11.01) [PR e DB, p. 28]. }\end{array}$ \\
\hline $\begin{array}{l}\mathbf{0 2 . 0 2} \\
\text { Especificar o porte do } \\
\text { estabelecimento penal a } \\
\text { ser projetado segundo o } \\
\text { nível de segurança } \\
\text { estipulado para o mesmo }\end{array}$ & $\begin{array}{l}\text { Para o Panóptico, o número máximo de pessoas } \\
\text { deve ser consistente com os propósitos de cada } \\
\text { uma das diversas instituições (BENTHAM et al., } \\
2000, \text { p. 23). A segurança penitenciária determina } \\
\text { um número menor de presos (pequeno porte)(ver } \\
\text { item 01.02). Vínculos: Isolamento Individual, } \\
\text { Atividades e Dimensionamento. }\end{array}$ & $\begin{array}{l}\text { A segurança máxima admite um aumento da } \\
\text { população prisional em relação à segurança } \\
\text { máxima especial (unidades de maior porte), desde } \\
\text { que haja um fracionamento da população prisional } \\
\text { em grupos e subgrupos (ver itens 05.01, 08.01, } \\
\text { 09.01 e 11.01). }\end{array}$ & $\begin{array}{l}\text { Dimensionar a capacidade da unidade prisional } \\
\text { entre } 500 \text { e } 600 \text { vagas (médio porte), a } \\
\text { considerar uma média ótima entre } 530 \text { e vagas } \\
\text { com uma tendência para mais (soma das vagas } \\
\text { em celas coletivas) [PR; RP]. } \\
\text { [DB, tabela1]. }\end{array}$ \\
\hline $\begin{array}{lll}02.03 & & \\
\text { Considerar } & \text { futuras } \\
\text { ampliações para } & \text { o } \\
\text { estabelecimento penal } & \text { a } \\
\text { ser projetado } & & \end{array}$ & $\begin{array}{l}\text { O Panóptico prevê o multipanoptismo: a repetição } \\
\text { do núcleo de encarceramento, aumentando a } \\
\text { capacidade do estabelecimento penal, com o } \\
\text { aproveitamento das funções comuns (otimização) } \\
\text { (administração, serviços, infraestrutura). Vínculos: } \\
\text { Geometria, Atividades e Dimensionamento. }\end{array}$ & $\begin{array}{l}\text { As Diretrizes Básicas (p. } 28-30) \text { sugerem a } \\
\text { previsão das ampliações na concepção projetual } \\
\text { (ver item 04.04). Ampliações não previstas devem } \\
\text { considerar o incremento proporcional dos } \\
\text { programas de sociabilização, assistência e } \\
\text { benefícios aos presos. }\end{array}$ & $\begin{array}{l}\text { Aplicar o conceito do padrão arquitetônico } \\
\text { modular (modular o programa arquitetônico de } \\
\text { modo que a replicação dos blocos de vivência } \\
\text { aproveite a estrutura comum do } \\
\text { estabelecimento penal). }\end{array}$ \\
\hline \multicolumn{4}{|c|}{ 03. Custo do estabelecimento penal } \\
\hline \multicolumn{4}{|c|}{$\begin{array}{l}\text { Relaciona-se de modo mais direto com o nível de segurança e o Porte do estabelecimento, assim como das Atividades e Dimensionamento, além da Barreira Perimetral e o Controle, } \\
\text { principalmente, em virtude de condicionantes operacionais. }\end{array}$} \\
\hline Requisito & Fundamentação Teórica & Procedimento Metodológico & Recursos Técnicos \\
\hline $\begin{array}{l}03.01 \\
\text { Conceber o edifício } \\
\text { prisional de modo a } \\
\text { favorecer a economia de } \\
\text { recursos de toda ordem, } \\
\text { tanto na construção como } \\
\text { na operação do } \\
\text { estabelecimento penal a } \\
\text { ser projetado }\end{array}$ & $\begin{array}{l}\text { O Panóptico busca a economia de recursos de toda } \\
\text { ordem, segundo um calculo de custo-benefício que } \\
\text { pondera o investimento na construção e na } \\
\text { operação em relação ao número de vagas geradas. } \\
\text { Existe uma estrutura mínima para cada porte de } \\
\text { estabelecimento penal que é irredutível e } \\
\text { necessita de uma quantidade mínima de presos } \\
\text { para amparar o investimento. A otimização desta } \\
\text { estrutura é limitada pelo comprometimento da } \\
\text { proposta pedagógica pelo aumento da capacidade } \\
\text { (ver item 09.01). Baseia o programa arquitetônico. }\end{array}$ & $\begin{array}{l}\text { A economia de recursos deve ser buscada pela } \\
\text { redução da estrutura física e operacional e pelo } \\
\text { aumento da capacidade. A estrutura mínima deve } \\
\text { ser estabelecida, por exemplo, se dimensionando } \\
\text { uma unidade de pequeno porte, a partir da qual os } \\
\text { acréscimos estruturais são proporcionalmente } \\
\text { menores em relação ao aumento da capacidade. } \\
\text { Este processo segue até o início da inviabilidade da } \\
\text { assistência e dos benefícios aos presos, quando a } \\
\text { estrutura passa a atender novos parâmetros. }\end{array}$ & $\begin{array}{l}\text { Subdividir a população prisional para atingir } \\
\text { capacidades maiores (otimização da estrutura } \\
\text { física e operacional). } \\
\text { Adensar a prisão por meio da compactação } \\
\text { geométrica e funcional (redução de área). } \\
\text { Otimizar a equipe operacional por meio da } \\
\text { vigilância direta (redução de pessoal). } \\
\text { Proporcionalizar os serviços (cozinha e } \\
\text { lavanderia) e a assistência (saúde) em relação à } \\
\text { capacidade (otimização da estrutura física). } \\
\text { [DB, p. 42] }\end{array}$ \\
\hline 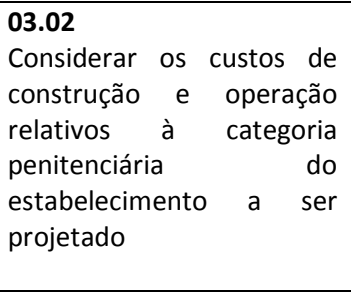 & $\begin{array}{l}\text { Os custos de construção e operação por vaga do } \\
\text { nível de segurança máxima especial são } \\
\text { explicitamente maiores do que os da segurança } \\
\text { máxima devido à proporção entre a estrutura física } \\
\text { e operacional em relação à quantidade de presos - } \\
\text { esta estrutura tende a se manter constante para } \\
\text { ambas as categorias (ver itens } 01.02,02.02 \text { e } \\
\text { 15.06). Vínculos: Atividades e Dimensionamento. }\end{array}$ & $\begin{array}{l}\text { Os índices dos custos de construção e de operação } \\
\text { por vaga são indicadores da especificação de } \\
\text { elementos, da quantidade de área construída e do } \\
\text { arranjo espacial (atividades, localizações funcionais } \\
\text { e tipo de vigilância). O custo de operação tem } \\
\text { como principal peso o tamanho da equipe de } \\
\text { segurança penitenciária, associado aos salários, } \\
\text { encargos e acordos trabalhistas. }\end{array}$ & $\begin{array}{l}\text { Considerar o custo de construção no pré- } \\
\text { dimensionamento [PR; MD]. } \\
\text { Considerar o custo de operação no pré- } \\
\text { dimensionamento [DB], a adotar a relação entre } \\
\text { agentes de segurança e presos de } 1 / 20 \text { a } 1 / 25 \text {, } \\
\text { por turno (escala de } 12 / 36 h \text { ) [RP]. }\end{array}$ \\
\hline
\end{tabular}




\begin{tabular}{|c|c|c|c|}
\hline $\begin{array}{l}03.03 \\
\text { Limitar a economia de } \\
\text { recursos financeiros na } \\
\text { concepção do espaço } \\
\text { arquitetônico diante do } \\
\text { respeito à condição } \\
\text { humana na prisão }\end{array}$ & $\begin{array}{l}\text { A economia de recursos financeiros implica em } \\
\text { uma redução proporcional dos padrões de bem- } \\
\text { estar até o limite do respeito à condição humana } \\
\text { na prisão (ver item } 09.01,10.05 \text { e } 13.01 \text { ). O nível } \\
\text { de segurança máximo tende a amenizar os cortes } \\
\text { previstos pela disciplina-bloco. As reduções } \\
\text { tendem a se distanciar do mínimo, garantindo a } \\
\text { condição humana. Baseia o programa } \\
\text { arquitetônico (Conforto Ambiental). }\end{array}$ & $\begin{array}{l}\text { A redução de padrões de bem-estar voltados para } \\
\text { os funcionários é desnecessária (não produz efeito } \\
\text { significante). A redução de padrões de bem-estar } \\
\text { deve se concentrar nas áreas destinadas aos } \\
\text { presos, onde a segurança penitenciária estabelece } \\
\text { os parâmetros arquitetônicos mais claramente. }\end{array}$ & $\begin{array}{l}\text { Conceber os espaços com o mobiliário, serviços, } \\
\text { dimensões e conforto ambiental adequados à } \\
\text { realização das atividades de modo cômodo. } \\
\text { Considerar as questões de manifestação pessoal } \\
\text { e de grupo (apropriação do espaço) e } \\
\text { privacidade (individual e entre presos e } \\
\text { funcionários). } \\
\text { [DB, p. 42] }\end{array}$ \\
\hline $\begin{array}{lr}03.04 & \\
\text { Considerar o custo } \\
\text { operacional no } \\
\text { aproveitamento } & \text { de } \\
\text { padrões arquitetônicos no } \\
\text { projetor de } \\
\text { estabelecimentos penais }\end{array}$ & $\begin{array}{l}\text { As formas dos padrões arquitetônicos } \\
\text { penitenciários sintetizam soluções econômicas } \\
\text { para o funcionamento da prisão (ver itens } 07.01 \text { e } \\
\text { 11.01). O padrão paralelo concentra os fluxos do } \\
\text { estabelecimento sobre um eixo central. O padrão } \\
\text { modular concentra as funções locais em torno de } \\
\text { postos de controle. Vínculo: Organização do } \\
\text { Espaço (Geometria e Dimensionamento). }\end{array}$ & $\begin{array}{l}\text { A forma se justifica por sua economia: de política, } \\
\text { de pessoal, de deslocamentos, obtidas por meio, } \\
\text { principalmente, da centralidade que afeta } \\
\text { diretamente a geometria e o dimensionamento. A } \\
\text { aplicação do padrão modular deve considerar a } \\
\text { multiplicação das funções e dos postos nos blocos } \\
\text { de vivência. }\end{array}$ & $\begin{array}{l}\text { Conjugar os conceitos arquitetônicos dos } \\
\text { padrões paralelo e modular (ver item 06.03). } \\
\text { Considerar a compactação geométrica e } \\
\text { funcional dos conceitos arquitetônicos dos } \\
\text { padrões paralelo e modular (ver item 08.01). } \\
\text { [DB, p. 33] }\end{array}$ \\
\hline \multicolumn{4}{|c|}{ 04. Isolamento social dos presos } \\
\hline \multicolumn{4}{|c|}{ É definido essencialmente pelo nível de segurança e interfere na Barreira Perimetral. } \\
\hline Requisito & Fundamentação Teórica & Procedimento Metodológico & Recursos Técnicos \\
\hline $\begin{array}{l}04.01 \\
\text { Configurar a } \\
\text { impermeabilidade } \\
\text { institucional do } \\
\text { estabelecimento penal a } \\
\text { ser projetado, segundo o } \\
\text { nível de segurança } \\
\text { estipulado para o mesmo }\end{array}$ & $\begin{array}{l}\text { O isolamento social é condição primordial para o } \\
\text { exercício da disciplina e para a representação } \\
\text { teatral, por meio da impermeabilidade: a } \\
\text { capacidade de romper a comunicação informal dos } \\
\text { presos com o mundo externo (ver item 14.01). } \\
\text { Formalmente, a impermeabilidade é rompida pela } \\
\text { visita aos presos (ver item 10.03). Vínculos: } \\
\text { Isolamento Social (localização), Barreira Perimetral } \\
\text { e Organização do Espaço (Aparatos de Segurança). }\end{array}$ & $\begin{array}{l}\text { A impermeabilidade deve ser obtida pela } \\
\text { conjunção das características do terreno, do tipo } \\
\text { de barreira perimetral e do fechamento das } \\
\text { edificações, sendo estas variáveis } \\
\text { interdependentes. As mesmas devem ser ajustadas } \\
\text { ao custo de construção. }\end{array}$ & $\begin{array}{l}\text { Optar por terrenos nivelados ou elevados em } \\
\text { relação ao entorno, amplos, planos e regulares } \\
\text { (ver item 11.03). } \\
\text { Especificar barreira perimetral com propriedades } \\
\text { de fechamento. } \\
\text { Conceber edificações sem a exposição ao público } \\
\text { de áreas operacionais ou ocupadas pelos presos. } \\
\text { [DB, p. 33] }\end{array}$ \\
\hline $\begin{array}{l}\mathbf{0 4 . 0 2} \\
\text { Cogitar a participação da } \\
\text { sociedade na atividade } \\
\text { prisional em função do } \\
\text { nível de segurança definido } \\
\text { para o estabelecimento a } \\
\text { ser projetado }\end{array}$ & $\begin{array}{l}\text { A atividade prisional reflete a necessidade de uma } \\
\text { administração centralizada para a totalização dos } \\
\text { processos prisionais, o que restringe a participação } \\
\text { da sociedade (ver item 04.04). Admite-se apenas } \\
\text { uma participação na assistência aos presos } \\
\text { (terapias, cursos, práticas físicas). Vínculo: } \\
\text { Atividades. }\end{array}$ & $\begin{array}{l}\text { A adequação do espaço arquitetônico para a } \\
\text { participação gerencial ou fiscalizadora da } \\
\text { sociedade é dispensada. A eventual participação } \\
\text { ocorre nas áreas de atividades dos presos ou em } \\
\text { sala de encontro com a sociedade no setor } \\
\text { intermediário (bloco de tratamento penal). }\end{array}$ & $\begin{array}{l}\text { Prever sala para apoiar a assistência aos presos } \\
\text { [DB, p. 67]. }\end{array}$ \\
\hline $\begin{array}{l}\mathbf{0 4 . 0 3} \\
\text { Permitir a comunicação } \\
\text { dos presos com o mundo } \\
\text { exterior, por meio do }\end{array}$ & $\begin{array}{l}\text { A comunicação do preso com o mundo externo } \\
\text { integra o direito à sociabilização e à assistência } \\
\text { jurídica, por meio da visita social e do encontro } \\
\text { reservado com o advogado (ver itens } 09.01 \text { e }\end{array}$ & $\begin{array}{l}\text { O espaço arquitetônico da prisão deve contar com } \\
\text { locais espećficos para a visita, configurados } \\
\text { segundo o tipo de visitante (social, conjugal e } \\
\text { jurídico), em função do contato físico com os }\end{array}$ & $\begin{array}{l}\text { Prever salão de visita social com sanitário. } \\
\text { Prever apartamentos de encontro íntimo na } \\
\text { proporção de } 2 \% \text { da capacidade do } \\
\text { estabelecimento ou um apartamento para } 50\end{array}$ \\
\hline
\end{tabular}




\begin{tabular}{|c|c|c|c|}
\hline 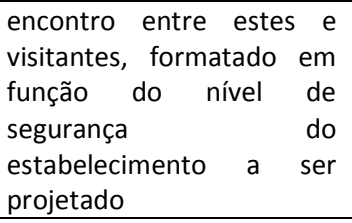 & $\begin{array}{l}\text { 10.03). A visita social tem contato físico com o } \\
\text { preso, inclusive encontro íntimo. O advogado não } \\
\text { tem contato físico com os presos. O perfil da visita } \\
\text { varia entre os sistemas penitenciários. Vínculo: } \\
\text { Atividades. }\end{array}$ & $\begin{array}{l}\text { presos. Os locais de visita são definidos pela } \\
\text { frequência, alternância, duração e quantidade de } \\
\text { visitantes, em termos da quantidade, configuração } \\
\text { e dimensionamento dos espaços. O apartamento } \\
\text { de encontro íntimo deve ter cama de casal e } \\
\text { banheiro. }\end{array}$ & $\begin{array}{l}\text { presos (uma hora de permanência) [PR]. } \\
\text { Prever parlatórios que separem o preso e o } \\
\text { advogado (visores e interfones) na proporção de } \\
2 \% \text { da capacidade do estabelecimento ou em } \\
\text { torno de um parlatório para } 50 \text { presos [PR]. } \\
\text { [LEP, art. } 41 ; \mathrm{RM} \text {, art. } 33 \text { e } 43 ; \mathrm{DB}, \mathrm{p} .45]\end{array}$ \\
\hline $\begin{array}{l}\text { O4.04 } \\
\text { Maximizar o isolamento } \\
\text { social do preso por meio } \\
\text { do distanciamento do } \\
\text { estabelecimento penal a } \\
\text { ser projetado em relação } \\
\text { às ocupações humanas }\end{array}$ & $\begin{array}{l}\text { A localização da prisão é um componente do } \\
\text { isolamento social, a integrar a segurança } \\
\text { penitenciária (ver item 01.01), onde a distância em } \\
\text { relação a ocupações reforça a impermeabilidade } \\
\text { (ver item 16.02) e a estanqueidade da unidade } \\
\text { prisional (ver item 16.01). Vínculo: Barreira } \\
\text { Perimetral. }\end{array}$ & $\begin{array}{l}\text { A prisão deve ser territorialmente isolada, desde } \\
\text { que respeitados a facilidade de acesso e a presteza } \\
\text { das comunicações, além da conveniência } \\
\text { socioeconômica e as peculiaridades do entorno. A } \\
\text { localização interfere no tipo e configuração da } \\
\text { barreira perimetral, principalmente, nos } \\
\text { afastamentos (ver itens } 16.04 \text { e 16.10). }\end{array}$ & $\begin{array}{l}\text { Optar por terrenos fora de zonas centrais } \\
\text { urbanas ou residenciais, mas servidos de } \\
\text { infraestrutura e serviços públicos [PR; DB, p. } 32 \mathrm{e} \\
\text { 33]. }\end{array}$ \\
\hline \multicolumn{4}{|c|}{ 05. Isolamento individual dos presos } \\
\hline \multicolumn{4}{|c|}{ É definido essencialmente pelo nível de segurança e interfere na cela. } \\
\hline Requisito & Fundamentação Teórica & Procedimento Metodológico & Recursos Técnicos \\
\hline $\begin{array}{l}05.01 \\
\text { Especificar o tipo de } \\
\text { alojamento dos presos de } \\
\text { acordo com os objetivos } \\
\text { penalógicos inerentes ao } \\
\text { nível de segurança } \\
\text { penitenciária determinado } \\
\text { para o estabelecimento a } \\
\text { ser projetado }\end{array}$ & $\begin{array}{l}\text { O perfil do preso corresponde a uma modalidade } \\
\text { de cela, evidenciado pelo nível de segurança } \\
\text { penitenciário (ver item 01.02). A cela individual } \\
\text { tem uma conotação punitiva maior (submissão e } \\
\text { solidão), enquanto a cela coletiva favorece a } \\
\text { humanização (sociabilização), portanto, mais } \\
\text { próxima do nível de segurança máximo. Baseia os } \\
\text { demais itens do Isolamento Individual dos presos e } \\
\text { o programa arquitetônico da cela. }\end{array}$ & $\begin{array}{l}\text { A cela coletiva deve ser especificada para o nível } \\
\text { de segurança máximo (ver itens } 05.02,05.04 \text { e } \\
\text { 17.05). A cela individual é indicada para o nível de } \\
\text { segurança máxima especial (RDD) ou para casos } \\
\text { particulares (ver item 05.05): separação de presos } \\
\text { com problemas de convívio, sob proteção ou em } \\
\text { cumprimento de medida disciplinar. }\end{array}$ & $\begin{array}{l}\text { Especificar a cela coletiva com base nos } \\
\text { instrumentos legais e técnico-normativos (ver } \\
\text { item 17.03). } \\
\text { [LEP, art. 88; RM, art. 8; DB, p. 25, } 31 \text { e 41]. }\end{array}$ \\
\hline $\begin{array}{l}05.02 \\
\text { Permitir a classificação e a } \\
\text { separação dos presos de } \\
\text { acordo com a } \\
\text { individualização pretendida } \\
\text { no estabelecimento penal } \\
\text { a ser projetado }\end{array}$ & $\begin{array}{l}\text { A classificação e a separação dos encarcerados } \\
\text { concerne ao tratamento penal e ao controle da } \\
\text { instituição. Com a coletivização da cela (ver item } \\
\text { 05.01), os presos são agrupados em perfis e grupos } \\
\text { sociais semelhantes. A individualização passa a } \\
\text { implicar em grupos menores de presos. As } \\
\text { questões do porte e do custo remetem a grupos } \\
\text { maiores de presos do que os modelos empregam. } \\
\text { Relaciona-se com o tipo de cela. }\end{array}$ & $\begin{array}{l}\text { A população prisional deve ser fracionada em alas } \\
\text { carcerárias (ver item 10.04). A ala carcerária deve } \\
\text { conjugar o menor número de celas possível com } \\
\text { uma capacidade tendendo a maior. As alas } \\
\text { carcerárias devem ser subdivididas em conjuntos } \\
\text { de celas. O número de presos destas repetições } \\
\text { deve favorecer o manuseio da população prisional, } \\
\text { de modo seguro para os funcionários. As alas } \\
\text { carcerárias podem ter capacidades diferenciadas. }\end{array}$ & $\begin{array}{l}\text { Organizar os presos em alas carcerárias, a } \\
\text { considerar uma média ótima de quatro alas } \\
\text { (tendência para cinco alas) [DB, p. 29; PR; RP]. } \\
\text { Estimar capacidades de } 96 \text { a } 160 \text { vagas para as } \\
\text { alas carcerárias, a considerar uma média ótima } \\
\text { de } 128 \text { a } 144 \text { vagas [PR; RP; DB, p. } 30] \text {. } \\
\text { Subdividir as alas carcerárias em grupos de } 24 \text { a } \\
40 \text { presos, a considerar uma média ótima de } 36 \\
\text { vagas (ver item 14.01) [PR; RP]. }\end{array}$ \\
\hline $\begin{array}{l}05.03 \\
\text { Considerar diferentes } \\
\text { configurações de cela, em } \\
\text { função de uma provável } \\
\text { diversidade do perfil da } \\
\text { população prisional no }\end{array}$ & $\begin{array}{l}\text { A diversidade espacial das celas é uma proposta } \\
\text { penalógica associada à progressão de pena que } \\
\text { combate a massificação dos presos (ver item } \\
\text { 10.04). A ênfase na segurança penitenciária não } \\
\text { comporta esta diversidade. A homogeneidade } \\
\text { favorece a isonomia na aplicação da pena e a }\end{array}$ & $\begin{array}{l}\text { As celas devem ser padronizadas, a atender às } \\
\text { demandas da instituição e dos presos (ver item } \\
\text { 17.05). Esta padronização se aplica a cada tipo de } \\
\text { cela - cela de triagem, cela de isolamento e cela de } \\
\text { alojamento. No alojamento coletivo da população } \\
\text { prisional, a exceção são as celas adaptadas para }\end{array}$ & $\begin{array}{l}\text { Considerar os tipos de cela em termos da função } \\
\text { - triagem, isolamento e alojamento. } \\
\text { Padronizar cada tipo de cela. } \\
\text { Prever celas adaptadas para portadores de } \\
\text { necessidades espaciais, conforme a NBR } \\
9050 / 2004 \text { (prever uma cela adaptada por ala }\end{array}$ \\
\hline
\end{tabular}




\begin{tabular}{|c|c|c|c|}
\hline $\begin{array}{l}\text { estabelecimento penal a } \\
\text { ser projetado }\end{array}$ & $\begin{array}{l}\text { simplificação dos procedimentos penitenciários. A } \\
\text { variedade pode incentivar o comércio de } \\
\text { privilégios. Relaciona-se com o tipo de cela. }\end{array}$ & portadores de necessidades espaciais. & carcerária). \\
\hline $\begin{array}{l}05.04 \\
\text { Separar os } r \text { presos } \\
\text { submetidos à medida } \\
\text { disciplinar ou sob proteção } \\
\text { da população prisional em } \\
\text { geral }\end{array}$ & $\begin{array}{l}\text { As celas individuais são estratégicas para a } \\
\text { administração prisional na manutenção da ordem } \\
\text { interna da prisão. As mesmas são utilizadas para o } \\
\text { castigo, para a separação de presos com problema } \\
\text { de convívio ou para colaboradores sob proteção da } \\
\text { instituição. Estes presos podem ser atacados pela } \\
\text { população prisional em motins ou rebeliões - o } \\
\text { procedimento de evasão é imprescindível. }\end{array}$ & $\begin{array}{l}\text { O espaço arquitetônico da prisão deve ser dotado } \\
\text { de celas individuais, agrupadas em alas carcerárias } \\
\text { ou blocos de vivência apartados da população } \\
\text { prisional. A localização da ala ou bloco deve } \\
\text { favorecer a evasão deste grupo em caso de crise - } \\
\text { locação mais externa ou próxima à saída. A } \\
\text { coletivização de celas de isolamento é vetada. }\end{array}$ & $\begin{array}{l}\text { Estimar a quantidade de celas de isolamento em } \\
1,5 \% \text { da capacidade do estabelecimento penal } \\
\text { [RP] (as celas de isolamento não são } \\
\text { contabilizadas na capacidade do } \\
\text { estabelecimento penal [UNOPS, 2016]). } \\
\text { Especificar a cela de isolamento segundo a LEP, } \\
\text { art. } 52,53 \text { e } 88 \text { [RM; DB, p. } 31] \text {. }\end{array}$ \\
\hline $\begin{array}{l}05.05 \\
\text { Compatibilizar a } \\
\text { capacidade da cela coletiva } \\
\text { com o nível de segurança } \\
\text { do estabelecimento penal } \\
\text { a ser projetado }\end{array}$ & $\begin{array}{l}\text { Com a cela coletiva, a individualização associada } \\
\text { ao caráter punitivo da pena aponta para uma } \\
\text { capacidade menor do alojamento (ver item 05.04). } \\
\text { As técnicas penitenciárias consideram o } \\
\text { isolamento em pequenos grupos uma técnica de } \\
\text { submissão dos presos. Os presos consideram que } \\
\text { um grupo menor melhora o convívio. As questões } \\
\text { do porte e do custo remetem a capacidades } \\
\text { maiores (ver itens } 02.02,03.01 \text { e 17.07). }\end{array}$ & $\begin{array}{l}\text { A cela coletiva deve ter a capacidade minimizada. } \\
\text { Esta minimização favorece a segurança, a } \\
\text { funcionalidade e o conforto ambiental. } \\
\text { Capacidades maiores favorecem a economia nos } \\
\text { custos de construção e operação. }\end{array}$ & $\begin{array}{l}\text { Estimar a capacidade da cela coletiva entre } \\
\text { quatro e oito vagas, a considerar seis vagas como } \\
\text { a capacidade ótima [RP]. }\end{array}$ \\
\hline \multicolumn{4}{|c|}{ 06. Organização do espaço } \\
\hline \multicolumn{4}{|c|}{ Relaciona-se de forma mais direta com a Espacialização, conjugando o Isolamento dos presos e o Controle. } \\
\hline Requisito & Fundamentação Teórica & Procedimento Metodológico & Recursos Técnicos \\
\hline 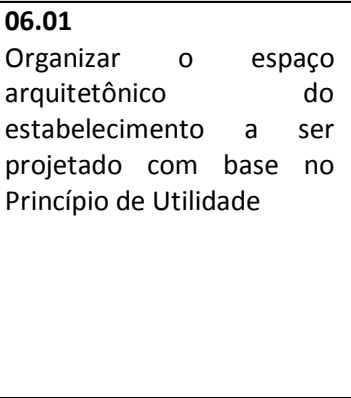 & $\begin{array}{l}\text { O Princípio de Utilidade objetiva transformar a } \\
\text { prisão em uma máquina racional e sistemática, } \\
\text { cujas metas são o bem-estar das pessoas } \\
\text { (felicidade) e a economia de recursos no } \\
\text { cumprimento da pena. O mesmo consiste na } \\
\text { coordenação sinérgica das funções, organizadas } \\
\text { para um melhor desempenho da instituição, de } \\
\text { modo a conjugar as demandas de segurança } \\
\text { (administração totalitária) e de reinserção social } \\
\text { (humanização da pena). Baseia o programa } \\
\text { arquitetônico (Espacialização). }\end{array}$ & $\begin{array}{l}\text { A aplicação do Princípio de Utilidade envolve os } \\
\text { processos de integralização e mecanização, além } \\
\text { da disciplina espacial: a definição da forma e das } \\
\text { funções, permeadas pelo conforto ambiental e } \\
\text { pelo controle. Na elaboração de projeto, estes } \\
\text { processos são constantemente avaliados, em suas } \\
\text { partes e no todo, pela relação custo-benefício - o } \\
\text { cálculo da felicidade utilitarista (ver itens } 04.01 \text { e } \\
\text { 04.02). Nesta conta, o benefício é o cumprimento } \\
\text { da pena de modo humano (a boa condição } \\
\text { penitenciária) (ver itens } 01.02 \text { e 01.01). }\end{array}$ & $\begin{array}{l}\text { Definir as atividades a serem realizadas, segundo } \\
\text { o modelo prisional (ver item 08.01). } \\
\text { Definir as rotinas a serem realizadas, em termos } \\
\text { das atividades e dos fluxos (ver item 12.01), } \\
\text { segundo o modelo prisional. } \\
\text { Pormenorizar as tarefas e os procedimentos (ver } \\
\text { grupo } 09 \text { - Atividades). } \\
\text { Aplicar a Disciplina para a organização do espaço } \\
\text { (ver item 06.02). } \\
\text { Adotar a segurança, funcionalidade, conforto } \\
\text { ambiental e o custo como critérios [DB, p. 27). }\end{array}$ \\
\hline $\begin{array}{lrr}06.02 & & \\
\text { Organizar o } & \text { espaço } \\
\text { arquitetônico } & \text { do } \\
\text { estabelecimento } & \text { a } & \text { ser } \\
\text { projetado por } & \text { meio } & \text { da } \\
\text { Disciplina } & & \\
\end{array}$ & $\begin{array}{l}\text { O Princípio de Utilidade tem como ferramenta de } \\
\text { implementação a Disciplina. Ela é o mecanismo } \\
\text { analítico e ordenador do espaço arquitetônico, } \\
\text { atribuindo racionalidade ao processo de criação, } \\
\text { ao dividir e articular o espaço de forma rigorosa e } \\
\text { calcada em critérios de eficiência e eficácia. Baseia }\end{array}$ & $\begin{array}{l}\text { O espaço arquitetônico da prisão deve distribuir } \\
\text { sistematicamente os indivíduos, as funções e os } \\
\text { trânsitos. O espaço deve ser fracionado para a } \\
\text { especialização e hierarquização de suas partes. A } \\
\text { reunião destas partes segue as afinidades entre as } \\
\text { pessoas e as funções, além da acessibilidade, em }\end{array}$ & $\begin{array}{l}\text { Aplicar a tecnologia de poder denominada por } \\
\text { Foucault de 'celular' (ver item 10.01). } \\
\text { Utilizar como referência os conceitos dos } \\
\text { padrões arquitetônicos modular e paralelo, } \\
\text { puros ou combinados, sobretudo na } \\
\text { concentração espacial e no tipo de vigilância. }\end{array}$ \\
\hline
\end{tabular}




\begin{tabular}{|c|c|c|c|}
\hline & o programa arquitetônico (Espacialização). & razão da economia na circulação. & \\
\hline $\begin{array}{l}06.03 \\
\text { Aplicar a disciplina espacial } \\
\text { em intensidade } \\
\text { equivalente ao nível de } \\
\text { segurança estipulado para } \\
\text { o estabelecimento penal a } \\
\text { ser projetado }\end{array}$ & $\begin{array}{l}\text { A disciplina-bloco preconiza a maximização da } \\
\text { segurança limitada pelo respeito à condição } \\
\text { humana na prisão. O modelo de segurança máxima } \\
\text { flexibiliza a disciplina-bloco, ao incrementar o } \\
\text { programa voltado à reinserção social e elevar os } \\
\text { padrões de bem-estar. Isto implica em uma } \\
\text { complexidade inerente à redefinição de funções e } \\
\text { hierarquias que acompanha esta modalidade (ver } \\
\text { itens } 01.01 \text { e 01.02). Baseia o programa } \\
\text { arquitetônico (Espacialização e Controle). }\end{array}$ & $\begin{array}{l}\text { O espaço arquitetônico da prisão deve priorizar a } \\
\text { segurança penitenciária com o dispêndio mínimo } \\
\text { de recursos, por meio da compactação espacial e } \\
\text { do adensamento populacional (redução ou } \\
\text { otimização da estrutura física e operacional) (ver } \\
\text { itens } 10.02,10.05 \text { e 13.01). A compactação e o } \\
\text { adensamento são moderados pelo incremento dos } \\
\text { serviços penitenciários e dos padrões de bem-estar } \\
\text { (programas de sociabilização e de benefícios aos } \\
\text { presos). }\end{array}$ & $\begin{array}{l}\text { Aplicar a coletivização com aumento de } \\
\text { capacidade e a generalização funcional dos } \\
\text { locais. } \\
\text { Utilizar como referência os conceitos dos } \\
\text { padrões arquitetônicos modular e paralelo, } \\
\text { puros ou combinados, sobretudo na geometria e } \\
\text { na funcionalidade (ver itens } 07.01 \text { e 08.01). }\end{array}$ \\
\hline \multicolumn{4}{|c|}{ 07. Geometria } \\
\hline \multicolumn{4}{|c|}{ Relaciona-se fortemente com o Custo e o Porte, além da Espacialização, Circulação e Conforto Ambiental e, em menor intensidade, com a Funcionalidade. } \\
\hline Requisito & Fundamentação Teórica & Procedimento Metodológico & Recursos Técnicos \\
\hline $\begin{array}{l}07.01 \\
\text { Formatar a edificação de } \\
\text { modo a garantir a } \\
\text { segurança e a operação em } \\
\text { função do nível de } \\
\text { segurança definido para o } \\
\text { estabelecimento a ser } \\
\text { projetado }\end{array}$ & $\begin{array}{l}\text { A edificação reflete o utilitarismo e os princípios da } \\
\text { Disciplina, flexibilizados pelo modelo de segurança } \\
\text { máxima (ver item 03.04). A geometria resulta da } \\
\text { retificação do arranjo dos espaços internos (ver } \\
\text { item 10.01), buscando favorecer o funcionamento } \\
\text { (ver item 08.01) e o controle externo, de modo } \\
\text { econômico (ver itens 15.01, } 15.03 \text { e 15.06). A } \\
\text { compactação é delimitada pela funcionalidade e } \\
\text { conforto ambiental. Vínculos: Barreira Perimetral, } \\
\text { Espacialização, Conforto Ambiental e Controle. }\end{array}$ & $\begin{array}{l}\text { O espaço arquitetônico da prisão deve apresentar } \\
\text { a maior simplicidade geométrica possível, através } \\
\text { do uso de formas regulares, coordenadas por meio } \\
\text { da centralidade, simetria, ortogonalidade e } \\
\text { alinhamentos. A compactação do conjunto é } \\
\text { moderada pela necessidade de entrecortes para a } \\
\text { iluminação e ventilação interior. A compactação se } \\
\text { acentua no sentido dos setores mais internos. A } \\
\text { verticalização é desaconselhada para pavimentos } \\
\text { com presos ou mais de dois pavimentos. O padrão } \\
\text { arquitetônico paralelo tende a aumentar a } \\
\text { fragmentação das fachadas. }\end{array}$ & $\begin{array}{l}\text { Utilizar como referência os padrões } \\
\text { arquitetônicos paralelo e modular, puros ou } \\
\text { combinados, sobretudo os conceitos de } \\
\text { continuidade e compactação [PR; DB, p. 27]. } \\
\text { Estimar o perímetro edificado entre } 1.300,00 \mathrm{~m} \text { e } \\
1.500,00 \text {, a considerar uma média ótima de } \\
1.400,00 \mathrm{~m}^{117} \text {. Ou } 2,13 \mathrm{~m} / \mathrm{vaga} \text { ou } 0,13 \mathrm{~m} / \mathrm{m}^{2} \text {, com } \\
\text { uma tendência a menor de } 1,17 \mathrm{~m} / \mathrm{vaga} \text { e } 0,08 \\
\mathrm{~m} / \mathrm{m}^{2} \text {, respectivamente [PR]. } \\
\text { Limitar a complexidade das fachadas entre } 80 \text { e } \\
125 \text { faces, a considerar uma média ótima de } 105 \\
\text { faces (30\% nos blocos internos) }{ }^{118} \text { [PR]. } \\
\text { Limitar a verticalização em dois pavimentos [PR]. }\end{array}$ \\
\hline \multicolumn{4}{|l|}{ 08. Funcionalidade } \\
\hline \multicolumn{4}{|c|}{ Relaciona-se fortemente com a Espacialização e o Controle, além da Geometria. } \\
\hline $\begin{array}{l}08.01 \\
\text { Reproduzir as atividades } \\
\text { cotidianas da vida em }\end{array}$ & $\begin{array}{l}\text { A funcionalidade diz respeito ao espaço } \\
\text { arquitetônico interno: a estrutura interior gerada } \\
\text { da resolução dos problemas funcionais (ver item }\end{array}$ & $\begin{array}{l}\text { O espaço arquitetônico da prisão deve apresentar } \\
\text { a maior simplicidade funcional possível, se } \\
\text { assumindo as particularidades do modelo de }\end{array}$ & $\begin{array}{l}\text { A LEP (art. 83) determina a assistência, } \\
\text { educação, trabalho, recreação e prática } \\
\text { desportiva, além de atividades específicas (art. }\end{array}$ \\
\hline
\end{tabular}

117 O perímetro das edificações considera os principais blocos, excluindo a infraestrutura, portarias, guaritas, torres e construções incomuns, como as casas dos diretores no projeto paulista. O perímetro considera os pátios e prismas de iluminação e ventilação.

${ }^{118}$ A geometria diz respeito à complexidade da edificação, medida pelo número de faces do perímetro externo. Foi considerada uma face qualquer plano maior que sessenta centímetros, dimensão suficiente para uma pessoa se esconder. Considerou-se que a interrupção de uma fachada por qualquer elemento (por exemplo, muro, passarela, cobertura) divide a mesma em duas faces. A contabilidade considera as diferenças planares entre pavimentos, quando estas ocorrem nos projetos. 


\begin{tabular}{|c|c|c|c|}
\hline $\begin{array}{l}\text { liberdade de modo } \\
\text { planejado e totalitário em } \\
\text { função do nível de } \\
\text { segurança definido para o } \\
\text { estabelecimento a ser } \\
\text { projetado }\end{array}$ & $\begin{array}{l}\text { 07.01). O espaço arquitetônico da prisão é } \\
\text { integralista e mecanicista (ver itens } 09.02 \text { e 10.01). } \\
\text { No modelo de segurança máxima, o integralismo } \\
\text { especifica programas de sociabilização e de } \\
\text { reinserção social (ver item 09.01) que aumentam } \\
\text { os procedimentos no mecanicismo (revista e } \\
\text { condução dos presos) (ver item 12.02). Baseia o } \\
\text { programa arquitetônico (Atividades, Espacialização } \\
\text { e Controle). }\end{array}$ & $\begin{array}{l}\text { segurança, através do abatimento da quantidade } \\
\text { de recintos (redução e sobreposição de atividades) } \\
\text { e do encurtamento de deslocamentos. Isto por } \\
\text { meio da coletivização (aumento da capacidade), da } \\
\text { generalização funcional (redução dos recintos) e } \\
\text { da racionalização das circulações (localização das } \\
\text { atividades). Ao mesmo tempo em que a segurança } \\
\text { deve ser privilegiada, por meio da criação ou } \\
\text { incremento de espaços de controle. }\end{array}$ & $\begin{array}{l}\text { 13, 21, 24, } 52 \text { e } 53 \text { ). } \\
\text { As Regras Mínimas determinam a assistência } \\
\text { jurídica, religiosa e à saúde, além de exercícios } \\
\text { físicos e banho de sol (art. 14) e de atividades } \\
\text { específicas (art. } 41 \text { ). } \\
\text { As Diretrizes Básicas (Anexo V) condensam e } \\
\text { complementam os instrumentos citados. Até } \\
22 \% \text { deste programa pode ser relativizado, com } \\
\text { exceção dos itens mandatórios [PR]. }\end{array}$ \\
\hline $\begin{array}{l}\mathbf{0 8 . 0 2} \\
\text { Propiciar a realização das } \\
\text { atividades rotineiras da } \\
\text { prisão em função do nível } \\
\text { de segurança definido para } \\
\text { o estabelecimento a ser } \\
\text { projetado }\end{array}$ & $\begin{array}{l}\text { A funcionalidade permeia a composição } \\
\text { arquitetônica da edificação prisional, o que remete } \\
\text { à minúcia panóptica. O espaço arquitetônico } \\
\text { reproduz a simplicidade funcional em cada um dos } \\
\text { recintos, o que significa garantir a utilidade dos } \\
\text { locais do ponto de vista econômico da prisão, ao } \\
\text { mesmo tempo em que se incorporam aspectos da } \\
\text { humanização da pena (ver item 10.05). Vínculos: } \\
\text { Capacidade, Espacialização e o Dimensionamento } \\
\text { (cela, pátio de sol dos presos e posto de controle). }\end{array}$ & $\begin{array}{l}\text { O espaço arquitetônico da prisão deve minimizar } \\
\text { as dimensões e o aparelhamento em cada um dos } \\
\text { espaços, dentro da lógica utilitarista, de modo } \\
\text { proporcional aos padrões de bem-estar definidos } \\
\text { (ver itens } 17.03,17.04,17.07,18.03 \text { e } 18.06 \text { ). Esta } \\
\text { minimização não deve comprometer a realização } \\
\text { das atividades programadas ou a comodidade das } \\
\text { pessoas. Da mesma maneira, a coletivização e a } \\
\text { generalização funcional dos espaços devem ser } \\
\text { limitadas pela funcionalidade. }\end{array}$ & $\begin{array}{l}\text { A LEP e as Regras Mínimas determinam áreas, } \\
\text { locais e serviços para as atividades previstas. } \\
\text { Aplicar dimensionamentos mínimos aos espaços, } \\
\text { a considerar a quantidade de usuários e as } \\
\text { atividades a serem realizadas. } \\
\text { Prever serviços e mobiliário para apoiar as } \\
\text { atividades a serem realizadas, a considerar a } \\
\text { quantidade de usuários. }\end{array}$ \\
\hline \multicolumn{4}{|l|}{ 09. Atividades } \\
\hline \multicolumn{4}{|c|}{ Relaciona-se fortemente com o Dimensionamento, assim como, aborda a cela e a circulação do ponto de vista da função, além de agregar o sistema de segurança. } \\
\hline & & & \\
\hline $\begin{array}{l}09.01 \\
\text { Propiciar as atividades } \\
\text { necessárias para a } \\
\text { segregação social e a } \\
\text { reintegração social dos } \\
\text { presos, em função do nível } \\
\text { de segurança definido para } \\
\text { o estabelecimento a ser } \\
\text { projetado }\end{array}$ & $\begin{array}{l}\text { O programa arquitetônico reflete o integralismo } \\
\text { inerente aos instrumentos legais e técnico- } \\
\text { normativos (ver item 08.01). As atividades de } \\
\text { segurança são priorizadas (isolamento dos presos e } \\
\text { controle) em relação às atividades de } \\
\text { sociabilização e benefícios aos presos, em prol da } \\
\text { economia de recursos (ver itens } 01.01 \text { e } 01.02 \text { ). A } \\
\text { quantidade de atividades interfere na } \\
\text { funcionalidade (quantidade de tarefas e } \\
\text { complexidade dos procedimentos). Na prática, } \\
\text { estas atividades estão fortemente associadas a } \\
\text { procedimentos de revista corporal e estrutural dos } \\
\text { locais. Vínculos: Espacialização, Dimensionamento }\end{array}$ & $\begin{array}{l}\text { O espaço arquitetônico da prisão deve programar } \\
\text { as atividades necessárias para o funcionamento da } \\
\text { prisão de modo a minimizar a quantidade de } \\
\text { recintos. A segurança deve ser privilegiada e a } \\
\text { assistência aos presos deve ser mantida. Os } \\
\text { programas de sociabilização e de benefícios aos } \\
\text { presos podem ser minorados em razão do uso } \\
\text { definido pelo modelo prisional e pelo sistema } \\
\text { penitenciário (visita, trabalho e educação) (ver } \\
\text { itens } 03.01 \text { e 11.01). Neste sentido, o modelo } \\
\text { pedagógico, a quantidade de participantes e as } \\
\text { atividades a serem realizadas devem ser } \\
\text { consideradas. As atividades programadas devem }\end{array}$ & $\begin{array}{l}\text { Prever locais de controle e circulação exclusiva } \\
\text { para os funcionários (ver item } 11.01 \text { ) [PR]. } \\
\text { Considerar o atendimento de, pelo menos, } 78 \% \\
\text { do programa discriminado nas DB, sem exceção } \\
\text { dos itens majoritários }{ }^{119} \text {. } \\
\text { Prever locais de visita (social, jurídica e conjugal) } \\
\text { entre } 2,06 \text { e } 2,51 \mathrm{~m}^{2} / \text { vaga, a considerar a média } \\
\text { ótima de } 2,31 \mathrm{~m}^{2} / \text { vaga [PR]. } \\
\text { Prever locais de ensino e trabalho (salas de aula } \\
\text { e oficinas) entre } 1,76 \text { e } 2,16 \mathrm{~m}^{2} / \text { vaga, a } \\
\text { considerar a média ótima de } 1,91 \mathrm{~m}^{2} / \text { vaga [PR]. } \\
\text { Prever locais para a revista corporal dos presos } \\
\text { nos acessos das alas carcerárias ou dos locais das }\end{array}$ \\
\hline
\end{tabular}

119 O percentual diz respeito à proporção dos itens atendidos em relação às recomendações gerais (20 itens), considerações ao programa arquitetônico (9 itens) e ao programa (126 itens) discriminado nas Diretrizes Básicas do Ministério da Justiça. 


\begin{tabular}{|c|c|c|c|}
\hline & e Controle. & ser acompanhadas de revistas. & atividades programadas [UNOPS, 2016, p. 33]. \\
\hline $\begin{array}{l}09.02 \\
\text { Complementar os sistemas } \\
\text { de segurança e operação } \\
\text { do estabelecimento penal } \\
\text { com as atividades de apoio } \\
\text { e infraestrutura }\end{array}$ & $\begin{array}{l}\text { A atividade prisional é suportada por funções } \\
\text { complementares e serviços de infraestrutura (ver } \\
\text { item 01.02) que constituem os sistemas de } \\
\text { segurança e operação (ver itens } 03.01,09.01 \text { e } 16 \text { ). } \\
\text { A retirada de itens pode comprometer o esquema } \\
\text { de segurança e fragilizar a operação. Vínculos: } \\
\text { Espacialização. }\end{array}$ & $\begin{array}{l}\text { O espaço arquitetônico da prisão deve contemplar } \\
\text { as atividades de apoio e serviços de infraestrutura } \\
\text { de modo a garantir o perfeito funcionamento do } \\
\text { estabelecimento, evitando improvisos ou } \\
\text { adaptações ocupacionais na edificação penal. }\end{array}$ & $\begin{array}{l}\text { As Diretrizes Básicas (Anexo V) determinam } \\
\text { itens de apoio e infraestrutura. }\end{array}$ \\
\hline \multicolumn{4}{|l|}{ 10. Espacialização } \\
\hline \multicolumn{4}{|c|}{$\begin{array}{l}\text { Polariza a totalidade dos elementos da composição arquitetônica, em especial, as funções e circulações, as celas coletivas, o sistema de segurança, a barreira física e o controle, refletindo } \\
\text { fortemente o nível de segurança. }\end{array}$} \\
\hline $\begin{array}{l}10.01 \\
\text { Propiciar o funcionamento } \\
\text { otimizado dos sistemas de } \\
\text { segurança e operação, } \\
\text { segundo o nível de } \\
\text { segurança definido para o } \\
\text { estabelecimento a ser } \\
\text { projetado }\end{array}$ & $\begin{array}{l}\text { A edificação prisional resulta da decomposição da } \\
\text { atividade prisional em suas partes, acompanhada } \\
\text { da definição e organização dos espaços } \\
\text { necessários para o funcionamento otimizado do } \\
\text { estabelecimento penal, por meio dos recursos } \\
\text { técnicos do Panóptico (ver itens } 06.01 \text { e 06.02). O } \\
\text { Panóptico define duas premissas básicas para o } \\
\text { espaço arquitetônico: o foco nas pessoas e a } \\
\text { disciplina espacial. A disciplina alterna espaços } \\
\text { individuais e coletivos, topologicamente } \\
\text { interligados, de modo a maximizar a utilização dos } \\
\text { locais e potencializar o controle institucional (ver } \\
\text { item 07.01). Assim, a edificação prisional } \\
\text { materializa o mecanicismo da prisão descrito nas } \\
\text { rotinas preconizadas no modelo prisional, } \\
\text { transpostas por meio da lógica topológica para a } \\
\text { edificação (ver item 08.01). Baseia o programa } \\
\text { arquitetônico. }\end{array}$ & $\begin{array}{l}\text { O espaço arquitetônico deve atender a três } \\
\text { processos: fracionamento, especificação e } \\
\text { hierarquização, que constituem o celular. Em } \\
\text { primeiro lugar, a classificação funcional relaciona } \\
\text { as atividades a serem realizadas e os diferentes } \\
\text { tipos de pessoas, em termos da localização e } \\
\text { movimentação. Estas relações são organizadas } \\
\text { hierarquicamente em setores e blocos funcionais, } \\
\text { por meio do quadriculamento que procede a } \\
\text { agrupamentos e posicionamentos em razão da } \\
\text { especialização das funções e da economia das } \\
\text { circulações. As localizações funcionais definem } \\
\text { esta hierarquia, por meio da maior utilidade das } \\
\text { correlações feitas (tipos de pessoas e de } \\
\text { atividades), baseada nas aglutinações, fluxos e na } \\
\text { rotina prisional (compatibilidades e divergências). } \\
\text { Neste sentido, o princípio do máximo deve ser } \\
\text { enfatizado para restringir a sobreposição de } \\
\text { atividades - especialização (ver item 10.06). }\end{array}$ & $\begin{array}{l}\text { Considerar três tipos de pessoas (funcionários, } \\
\text { presos e visitantes) e as respectivas categorias. } \\
\text { Considerar três setores em função dos tipos de } \\
\text { pessoas (em relação à área construída) [DB, p. } \\
\text { 49]: externo (10\%), intermediário ( } 10 \% \text { a } 20 \% \text { ) e } \\
\text { interno ( } 70 \% \text { a } 80 \%) \text {, respectivamente [PR]. } \\
\text { Considerar a topologia em forma de árvore e a } \\
\text { profundidade entre } 16 \text { e } 20 \text { camadas, a } \\
\text { considerar a média ótima de } 18 \text { camadas (12 } \\
\text { camadas no setor interno) }{ }^{120} \text { [PR]. } \\
\text { Considerar a compactação funcional } \\
\text { (coletivização com o aumento de capacidades e } \\
\text { generalização funcional) e a internalização das } \\
\text { atividades rotineiras dos presos na conformação } \\
\text { dos blocos funcionais (ver item 06.03) [PR; DB, } \\
\text { Anexo V, p. 45-49]. } \\
\text { Considerar a conformação de blocos de vivência } \\
\text { (ver item 10.04) [PR; DB, p. } 29 \text { e 47]. }\end{array}$ \\
\hline $\begin{array}{l}10.02 \\
\text { Considerar as relações } \\
\text { sociais na definição do } \\
\text { espaço arquitetônico da } \\
\text { prisão, segundo o nível de } \\
\text { segurança penitenciário }\end{array}$ & $\begin{array}{l}\text { A espacialização é definida pela relação entre } \\
\text { funcionários e presos - o grau de contato físico } \\
\text { entre ambos, da qual se destaca a questão da } \\
\text { territorialidade (ver item } 15.05 \text { ) que define locais } \\
\text { livres, vigiados ou proibidos. O nível de segurança } \\
\text { mais alto determina a separação física entre estes }\end{array}$ & $\begin{array}{l}\text { O espaço arquitetônico deve distinguir os espaços } \\
\text { de funcionários e de presos e deve qualificar a } \\
\text { totalidade dos locais como vigiados, minimizando } \\
\text { os locais livres. Isto, principalmente, no setor } \\
\text { interno. Para tanto, a disciplina espacial deve atuar } \\
\text { homogeneamente em todos os locais, prevendo a }\end{array}$ & $\begin{array}{l}\text { Adotar a vigilância direta (postos de controle). } \\
\text { Estimar os locais livres, vigiados e proibidos (em } \\
\text { relação à área construída): entre } 8 \% \text { e } 14 \% \text {, } \\
\text { entre } 60 \% \text { e } 74 \% \text { e entre } 12 \% \text { e } 30 \% \text {, } \\
\text { respectivamente (a vigilância das celas e as } \\
\text { circulações exclusivas definem os valores de } 8 \% \text {, }\end{array}$ \\
\hline
\end{tabular}

${ }^{120}$ O número de camadas topológicas se refere ao percurso a pé entre a camada mais externa (acesso da unidade penal) e a camada mais interna do projeto (cela) realizada por um funcionário. 


\begin{tabular}{|c|c|c|c|}
\hline & $\begin{array}{l}\text { grupos, além do controle institucional sobre a } \\
\text { totalidade dos espaços, inclusive nos locais mais } \\
\text { internos (ver itens } 01.01 \text { e } 06.03 \text { ). A separação } \\
\text { física dos grupos sociais e vigilância absoluta são } \\
\text { contrapostas pela comunicabilidade necessária e a } \\
\text { privacidade dos presos (ver item 15.04). Vínculo: } \\
\text { Controle. }\end{array}$ & $\begin{array}{l}\text { utilidade de todos os espaços e o monitoramento } \\
\text { nos pontos mais críticos (ver item 15.05). A } \\
\text { especialização funcional é substituída pela } \\
\text { generalização que deve ser contida pela } \\
\text { policrestia. A visualização do interior das celas } \\
\text { diminui os locais livres para } 8 \% \text { e as circulações } \\
\text { exclusivas aumentam as áreas proibidas para } 30 \% \text {. }\end{array}$ & $\begin{array}{l}60 \% \text { e } 30 \% \text { - maior segurança) [PR]. } \\
\text { Prever circulações exclusivas para os } \\
\text { funcionários (setor interno) (ver item 11.01) [PR]. } \\
\text { Aplicar a Policrestia (ver item 10.06) [DB, p. 46]. }\end{array}$ \\
\hline 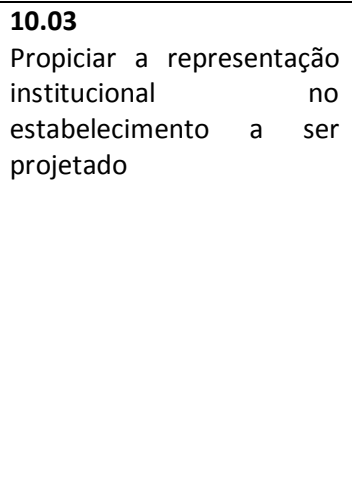 & $\begin{array}{l}\text { A espacialização concorre para a imagem } \\
\text { institucional juntamente com a geometria (ver } \\
\text { item 07.01), por meio da impermeabilidade e da } \\
\text { representação institucional que pressupõe um } \\
\text { esquema teatral: o palco, a platéia e os bastidores. } \\
\text { Neste esquema, a sociedade prisional } \\
\text { (funcionários e presos) encena para os visitantes. } \\
\text { Esta interpretação depende da reserva do mundo } \\
\text { prisional aos visitantes, associada ao transito e } \\
\text { permanência dos estranhos nas dependências } \\
\text { prisionais. Os funcionários de segurança devem ter } \\
\text { acessar todos os locais da prisão. Vínculos: } \\
\text { Isolamento Social, Atividades e Circulação. }\end{array}$ & $\begin{array}{l}\text { O espaço arquitetônico deve ser interpretado em } \\
\text { camadas topológicas e em uma profundidade } \\
\text { maior (ver item 06.02). Estas camadas } \\
\text { representam os diferentes graus de } \\
\text { permeabilidade e de liberdade de movimentação, } \\
\text { segundo o tipo de pessoa (ver item 12.01). A } \\
\text { representação social permeia estas camadas até o } \\
\text { local de configuração do palco com a configuração } \\
\text { do espaço para a visitação, devidamente isolado } \\
\text { da rotina carcerária (ver itens 04.03 e } 12.02 \text { ). O } \\
\text { palco é localizado no setor interno, de modo a } \\
\text { favorecer a operação. Os presos são mantidos ao } \\
\text { fundo da unidade penal (bastidores) - a cela ocupa } \\
\text { a última camada topológica. }\end{array}$ & $\begin{array}{l}\text { Considerar três tipos de pessoas (funcionários, } \\
\text { presos e visitantes) e as respectivas categorias. } \\
\text { Estimar a profundidade topológica entre } 16 \text { e } 20 \\
\text { camadas, a considerar uma média ótima de } 18 \\
\text { camadas (12 no setor interno) [PR]. } \\
\text { Aumentar a profundidade por meio de } \\
\text { contenções nas circulações. } \\
\text { Situar os locais de visita no setor interno-blocos } \\
\text { de vivência [PR]. } \\
\text { Criar circulações ou acessos exclusivos que } \\
\text { impeçam a exposição mútua entre os visitantes e } \\
\text { a rotina prisional (ver item 12.01). }\end{array}$ \\
\hline $\begin{array}{l}\mathbf{1 0 . 0 4} \\
\text { Permitir a classificação e a } \\
\text { separação dos grupos de } \\
\text { presos com perfil } \\
\text { semelhanter no } \\
\text { estabelecimento penal a } \\
\text { ser projetado }\end{array}$ & $\begin{array}{l}\text { A classificação e a separação dos presos na } \\
\text { unidade penal são estratégicas para a } \\
\text { administração prisional na manutenção da ordem } \\
\text { interna da prisão. Com a coletivização e o aumento } \\
\text { de capacidade (ver itens } 02.01 \text { e 02.02), a } \\
\text { individualização objetiva a divisão em grupos de } \\
\text { perfil semelhante (ver item 05.02). A separação } \\
\text { dos presos implica na impermeabilidade } \\
\text { (incomunicabilidade) entre os grupos. Vínculos: } \\
\text { Isolamento Individual (ver item 05.01), } \\
\text { Dimensionamento e Circulação. }\end{array}$ & $\begin{array}{l}\text { O espaço arquitetônico deve fracionar a população } \\
\text { prisional em blocos de vivência com as atividades } \\
\text { rotineiras dos presos (internalização), de modo } \\
\text { que os diferentes grupos não se encontrem pelo } \\
\text { compartilhamento dos locais (ver itens } 09.01 \text { e } \\
\text { 18.02). Estas atividades incluem a ala carcerária, o } \\
\text { pátio de sol dos presos e os programas de } \\
\text { sociabilização e benefícios aos presos, além da } \\
\text { assistência imediata (penal e saúde). A disposição } \\
\text { e a configuração dos blocos de vivência devem } \\
\text { impedir a comunicação entre os grupos de presos. }\end{array}$ & $\begin{array}{l}\text { Fracionar a população prisional entre quatro ou } \\
\text { seis blocos de vivência, a considerar a média } \\
\text { ótima de quatro blocos (ver item 10.01) [PR]. } \\
\text { Preferir uma ala por bloco de vivência [PR]. } \\
\text { Locar em cada bloco de vivência as atividades } \\
\text { rotineiras dos presos (programas de socialização } \\
\text { e de benefícios aos presos) [PR; DB, p. } 29 \text { e } 47] \text {. } \\
\text { Estimar a área dos blocos de vivência em } 75 \% \text { da } \\
\text { área construída do estabelecimento penal [PR]. } \\
\text { Estimar a equipe funcional em três agentes em } \\
\text { postos fixos por bloco, mais dois para a ronda e } \\
\text { um chefe de turno [RP]. }\end{array}$ \\
\hline $\begin{array}{l}\mathbf{1 0 . 0 5} \\
\text { Equilibrar os aspectos de } \\
\text { segurança e humanização } \\
\text { na configuração espacial, } \\
\text { segundo o nível de } \\
\text { segurança estipulado para } \\
\text { o estabelecimento a ser }\end{array}$ & $\begin{array}{l}\text { O espaço arquitetônico utiliza a despersonificação } \\
\text { do espaço como mecanismo de controle, ao } \\
\text { regular as manifestações individuais e sociais das } \\
\text { pessoas. Esta estratégia prioriza a segurança } \\
\text { penitenciária por meio da simplicidade funcional } \\
\text { (redução de tarefas e simplificação de } \\
\text { procedimentos - otimização de pessoal), sem }\end{array}$ & $\begin{array}{l}\text { O espaço arquitetônico deve minimizar dimensões, } \\
\text { além de equipamentos e serviços (mobiliário, } \\
\text { sanitários)(ver item 06.01), em especial, nos locais } \\
\text { ocupados pelos presos (ver itens } 08.01 \text { e 09.01). } \\
\text { Esta minimização deve permear a coletivização e a } \\
\text { generalização funcional, de modo a conter o } \\
\text { aumento de elementos (mobília, peças, }\end{array}$ & $\begin{array}{l}\text { Minimizar as dimensões dos ambientes, dentro } \\
\text { dos limites da condição humana (funcionalidade) } \\
\text { [DB, p. 42]. } \\
\text { Minimizar os itens de conforto (bebedouros, } \\
\text { sanitários, mobiliário). } \\
\text { Simplificar a geometria e a funcionalidade dos } \\
\text { elementos espaciais (formas regulares, }\end{array}$ \\
\hline
\end{tabular}




\begin{tabular}{|c|c|c|c|}
\hline projetado & $\begin{array}{l}\text { comprometer a funcionalidade dos locais, em } \\
\text { termos das atividades previstas, observados ainda } \\
\text { os padrões de bem estar (ver item 03.03). Vínculo: } \\
\text { Conforto Ambiental. }\end{array}$ & $\begin{array}{l}\text { dispositivos), dentro das necessidades para a } \\
\text { realização das atividades e para a comodidade das } \\
\text { pessoas. A simplicidade deve caracterizar cada um } \\
\text { dos elementos constituintes. }\end{array}$ & $\begin{array}{l}\text { coordenadas por meio da centralidade, simetria, } \\
\text { ortogonalidade e alinhamentos). }\end{array}$ \\
\hline $\begin{array}{l}10.06 \\
\text { Compartilhar o espaço por } \\
\text { mais de uma atividade, } \\
\text { segundo o nível de } \\
\text { segurança estipulado para } \\
\text { o estabelecimento a ser } \\
\text { projetado }\end{array}$ & $\begin{array}{l}\text { O racionalismo espacial da prisão exige a } \\
\text { especialização dos espaços ou a sua utilização por } \\
\text { atividades bem definidas e compatíveis entre si } \\
\text { (ver itens } 06.01 \text { e 06.02). Neste último caso, o que } \\
\text { remete à policrestia (ver itens } 09.01,17.02 \text { e } \\
\text { 18.01). A policrestia se vincula conceitualmente ao } \\
\text { princípio do máximo e às localizações funcionais. A } \\
\text { polivalência associada não significa uma } \\
\text { indefinição funcional. Vínculo: Atividades }\end{array}$ & $\begin{array}{l}\text { O espaço arquitetônico deve destinar atividades } \\
\text { concernentes entre si a um mesmo local, } \\
\text { atendendo aos critérios de compatibilidade e de } \\
\text { viabilidade operacional (a possibilidade de } \\
\text { revezamento de um espaço diante dos recursos } \\
\text { operacionais - pessoal). As grandes áreas coletivas } \\
\text { devem ser preparadas para isto, tendo em vista a } \\
\text { generalização funcional. A especialização funcional } \\
\text { é preferível ao acúmulo de atividades } \\
\text { incompatíveis. }\end{array}$ & $\begin{array}{l}\text { Prever a policrestia como critério para a } \\
\text { generalização funcional [DB, p. } 46] \text {. }\end{array}$ \\
\hline \multicolumn{4}{|l|}{ 11. Dimensionamento } \\
\hline \multicolumn{4}{|c|}{ Relaciona-se fortemente com as funções para o dimensionamento dos espaços, incluindo a circulação. } \\
\hline Requisito & Fundamentação Teórica & Procedimento Metodológico & Recursos Técnicos \\
\hline $\begin{array}{l}11.01 \\
\text { Adotar o parâmetro de } \\
\text { área por vaga para o } \\
\text { dimensionamento } \quad \text { do } \\
\text { estabelecimento a ser } \\
\text { projetado, tomando } \\
\text { valores segundo o nível de } \\
\text { segurança estipulado para } \\
\text { o mesmo }\end{array}$ & $\begin{array}{l}\text { O espaço arquitetônico da prisão apresenta uma } \\
\text { proporcionalidade entre a área construída e a } \\
\text { capacidade do estabelecimento que varia em razão } \\
\text { do nível de segurança penitenciário (ver itens } \\
09.01,11.02 \text { e 03.01). Esta proporcionalidade } \\
\text { oscila em razão das atividades especificadas e da } \\
\text { espacialização - o tipo de vigilância adotado. O } \\
\text { nível de segurança máximo prioriza a segurança } \\
\text { penitenciária, enfatiza a reinserção social e adota a } \\
\text { vigilância direta. O índice de área construída por } \\
\text { vaga pode ser considerado um indicador da } \\
\text { humanização do espaço arquitetônico, em } \\
\text { contrapartida ao custo por vaga. Vínculos: } \\
\text { Atividades e Espacialização. }\end{array}$ & $\begin{array}{l}\text { O espaço arquitetônico deve ser dimensionado } \\
\text { com base no índice de área construída por vaga. A } \\
\text { composição deste índice deve considerar a } \\
\text { especificação de circulações exclusivas para os } \\
\text { funcionários e a valorização dos programas de } \\
\text { sociabilização e de benefícios aos presos, bem } \\
\text { como, a modulação da população prisional e a } \\
\text { internalização das atividades rotineiras dos presos } \\
\text { nos blocos de vivência. Nestes casos, o } \\
\text { crescimento do índice deve ser limitado pela } \\
\text { coletivização dos com aumento de capacidade e } \\
\text { pela generalização funcional, associadas a medidas } \\
\text { operacionais (o uso alternado dos locais) (ver item } \\
\text { 10.06). }\end{array}$ & $\begin{array}{l}\text { Estimar a área construída total entre } 18,0 \\
\mathrm{~m}^{2} / \text { vaga e } 25,0 \mathrm{~m}^{2} / \text { vaga, a considerar uma média } \\
\text { ótima de } 21,5 \mathrm{~m}^{2} / \text { vaga [PR]. } \\
\text { Estimar as circulações entre } 11 \% \text { e } 19 \% \text { da área } \\
\text { construída total, a considerar uma média ótima } \\
\text { de } 15 \% \text { [PR]. } \\
\text { Estimar as circulações exclusivas entre } 8 \% \text { e } 17 \% \\
\text { da área construída total, a considerar uma média } \\
\text { ótima de } 11 \% \text { [PR]. } \\
\text { Adotar a relação de duas vezes a altura da } \\
\text { edificação mais alta para a distância entre } \\
\text { blocos. }\end{array}$ \\
\hline $\begin{array}{l}\mathbf{1 1 . 0 2} \\
\text { Dimensionar os espaços do } \\
\text { estabelecimento penal a } \\
\text { ser projetado, } \\
\text { considerando o nível de } \\
\text { segurança estipulado para } \\
\text { o mesmo }\end{array}$ & $\begin{array}{l}\text { O Princípio de Utilidade determina o } \\
\text { dimensionamento exato dos espaços, segundo o } \\
\text { número de usuários e as atividades a serem } \\
\text { abrigadas (ver item 09.01). O nível de segurança } \\
\text { máximo valoriza tanto os espaços dos sistemas de } \\
\text { segurança e operação, como os espaços dos } \\
\text { programas de sociabilização e benefícios aos } \\
\text { presos (ver item 10.06). Isto é limitado pelos } \\
\text { recursos disponíveis. Vínculos: Atividades e a }\end{array}$ & $\begin{array}{l}\text { O espaço arquitetônico deve minimizar os espaços } \\
\text { dos programas de sociabilização e de benefícios } \\
\text { aos presos, considerando o contingente funcional } \\
\text { reduzido e o grupo de presos efetivamente } \\
\text { atendido pelos serviços penitenciários. O } \\
\text { dimensionamento dos espaços destinados aos } \\
\text { presos deve considerar o uso alternado dos locais } \\
\text { por grupos menores de usuários. O } \\
\text { dimensionamento deve atender a parâmetros }\end{array}$ & $\begin{array}{l}\text { Estimar o dimensionamento dos espaços } \\
\text { segundo as Diretrizes Básicas (Anexo V), } \\
\text { confrontadas com as demandas da realidade } \\
\text { prisional. } \\
\text { Estimar o dimensionamento dos elementos } \\
\text { centrais da edificação penal conforme o } \\
\text { apresentado (ver quesitos } 16,17,18 \text { e } 19 \text { ). }\end{array}$ \\
\hline
\end{tabular}




\begin{tabular}{|c|c|c|c|}
\hline & Espacialização. & $\begin{array}{l}\text { mínimos para não comprometer as atividades } \\
\text { previstas ou o bem-estar das pessoas. }\end{array}$ & \\
\hline $\begin{array}{l}11.03 \\
\text { Adotar o parâmetro de } \\
\text { área por vaga para o } \\
\text { dimensionamento } \text { do } \\
\text { terreno } \\
\text { estabelecimento a ser } \\
\text { projetado, to } \\
\text { valores segundo o nível de } \\
\text { segurança estipulado para } \\
\text { o mesmo }\end{array}$ & $\begin{array}{l}\text { O espaço arquitetônico da prisão apresenta uma } \\
\text { proporcionalidade entre a área de terreno e a } \\
\text { capacidade do estabelecimento que varia em razão } \\
\text { do nível de segurança penitenciário. Esta } \\
\text { proporcionalidade oscila em razão da localização, } \\
\text { dos afastamentos e das atividades programadas } \\
\text { (ver itens 04.04, 16.10, e 09.01). O nível de } \\
\text { segurança máximo isola a unidade penal, } \\
\text { incrementa os afastamentos e aumenta as } \\
\text { atividades. O índice de área de terreno por vaga } \\
\text { interage com as propriedades de } \\
\text { impermeabilidade e estanqueidade do } \\
\text { estabelecimento penal (ver item 11.01). Vínculos: } \\
\text { Isolamento Social e a Barreira Perimetral. }\end{array}$ & $\begin{array}{l}\text { O espaço arquitetônico deve ser dimensionado } \\
\text { com base no índice de área de terreno por vaga. A } \\
\text { composição deste índice deve considerar o tipo de } \\
\text { barreira perimetral e afastamentos. Além disto, a } \\
\text { mesma deve considerar a área construída, em } \\
\text { particular, no que diz respeito às definições da } \\
\text { modulação da população prisional, da } \\
\text { internalização das atividades, dos programas de } \\
\text { sociabilização e de benefícios aos presos, bem } \\
\text { como, a especificação de circulações exclusivas } \\
\text { para os funcionários. É importante ainda } \\
\text { considerar o conforto ambiental, em termos das } \\
\text { áreas livres adjacentes às edificações } \\
\text { (afastamentos internos). }\end{array}$ & $\begin{array}{l}\text { Estimar a área de terreno total entre } \\
70,0 \mathrm{~m}^{2} / \text { vaga e } 110,0 \mathrm{~m}^{2} / \mathrm{vaga}[\mathrm{MD}] \text {, a considerar } \\
\text { uma média ótima de } 95,0 \mathrm{~m}^{2} / \mathrm{vaga} \text { (terreno de } \\
210 \times 300 \mathrm{~m} \text { ) }[\mathrm{MD}] \text { (para afastamentos de } 30 \mathrm{~m} \text { ). } \\
\text { Estimar a área de terreno total entre } \\
60,0 \mathrm{~m}^{2} / \text { vaga e } 80,0 \mathrm{~m}^{2} / \text { vaga, a considerar uma } \\
\text { média ótima de } 70,0 \mathrm{~m}^{2} / \text { vaga (terreno de } \\
170 \times 255 \mathrm{~m} \text { ) }[\mathrm{MD}] \text { (para afastamentos de } 20 \mathrm{~m} \text { ). } \\
\text { Estimar a taxa de ocupação em } 31 \% \text {, a } \\
\text { considerar uma tendência a maior até } 38 \%[\mathrm{PR}] \text {. }\end{array}$ \\
\hline \multicolumn{4}{|l|}{ 12. Circulação } \\
\hline \multicolumn{4}{|c|}{ Relaciona-se fortemente com as funções e o controle interno, assim como, com o sistema de segurança e o dimensionamento. } \\
\hline Requisito & Fundamentação Teórica & Procedimento Metodológico & \\
\hline $\begin{array}{l}12.01 \\
\text { Considerar a circulação } \\
\text { como elemento e agente } \\
\text { da espacialização, } \\
\text { integrando a composição } \\
\text { do espaço arquitetônico da } \\
\text { prisão }\end{array}$ & $\begin{array}{l}\text { No modelo de segurança máxima, as pessoas têm } \\
\text { a acessibilidade e a mobilidade constantemente } \\
\text { verificadas e monitoradas. A circulação interage } \\
\text { diretamente com a espacialização, atuando } \\
\text { simultaneamente como sujeito e objeto de } \\
\text { definição do arranjo espacial - a circulação atende } \\
\text { à simplicidade funcional (ver item 10.01). A } \\
\text { circulação agrega as partes do conjunto } \\
\text { arquitetônico, ao materializar a operação, segundo } \\
\text { o modelo e a realidade prisional. Ao mesmo tempo } \\
\text { em que integra o esquema topológico do espaço } \\
\text { arquitetônico prisional (ver item 10.03). Deste } \\
\text { modo, a circulação evita a sobreposição e a } \\
\text { sobrecarga de fluxos (ver item 10.04). Assim, a } \\
\text { circulação responde à simplicidade funcional, } \\
\text { contribuindo com a disciplina interna e a economia } \\
\text { de recursos (ver itens } 10.04 \text { e 10.02). Vínculos: } \\
\text { Geometria, Espacialização e Controle. }\end{array}$ & $\begin{array}{l}\text { O espaço arquitetônico deve criar espaços } \\
\text { especializados de circulação, isolar os fluxos dos } \\
\text { diferentes tipos de pessoas e descrever um gráfico } \\
\text { topológico em forma de árvore. Os fluxos devem } \\
\text { ser acondicionados em locais próprios de } \\
\text { circulação (ver item 10.03). Em especial, entre as } \\
\text { celas e os pátios de sol dos presos. Os diferentes } \\
\text { fluxos definem os níveis de acessibilidade e } \\
\text { mobilidade na unidade penal, por meio do } \\
\text { quadriculamento (ver itens } 15.01 \text { e } 15.04 \text { ). O } \\
\text { arranjo topológico deve ser serial, centralizado, } \\
\text { com poucas alternativas de trajeto (anéis } \\
\text { topológicos). Estas propriedades são } \\
\text { progressivamente ressaltadas no sentido do setor } \\
\text { interno. As sobreposições de fluxos no setor } \\
\text { interno (funcionários e visitantes) podem ser } \\
\text { evitadas com circulações exclusivas para os } \\
\text { funcionários e com a locação mais externa do local } \\
\text { de visita (ver item 15.05). }\end{array}$ & $\begin{array}{l}\text { Considerar três tipos de fluxos (funcionários, } \\
\text { presos e visitantes) e as respectivas categorias } \\
\text { [DB, p. 29]. } \\
\text { Estimar a área da circulação entre } 11 \% \text { e } 19 \% \text { da } \\
\text { área construída total, a considerar a média ótima } \\
\text { de } 15 \% \text { [PR]. } \\
\text { Estimar a profundidade topológica entre } 16 \text { e } 20 \\
\text { camadas, a considerar uma média ótima de } 18 \\
\text { camadas (12 no setor interno) [PR]. } \\
\text { Limitar os conflitos dos fluxos em } 35 \text { pontos, a } \\
\text { considerar uma tendência a maior até } 75 \text { pontos, } \\
\text { e concentrá-los na circulação do setor } \\
\text { intermediário [PR]. } \\
\text { Limitar os anéis topológicos em três e concentrá- } \\
\text { los junto aos acessos do setor intermediário } \\
\text { (inclusão, serviços) [PR]. } \\
\text { Evitar a contiguidade entre as celas e o } \\
\text { respectivo pátio de sol dos presos [PR; RP]. }\end{array}$ \\
\hline $\begin{array}{l}\mathbf{1 2 . 0 2} \\
\text { Configurar as circulações }\end{array}$ & $\begin{array}{l}\text { A circulação interage diretamente com a } \\
\text { geometria, atuando simultaneamente como }\end{array}$ & $\begin{array}{l}\text { O espaço arquitetônico deve acondicionar os } \\
\text { fluxos, minimizar as distâncias percorridas e }\end{array}$ & $\begin{array}{l}\text { Considerar o padrão paralelo como modelo. } \\
\text { Dimensionar a largura da circulação central em }\end{array}$ \\
\hline
\end{tabular}




\begin{tabular}{|c|c|c|c|}
\hline $\begin{array}{lll}\begin{array}{l}\text { segundo o nível } \\
\text { segurança }\end{array} & & \text { de } \\
\text { estabelecimento } & \text { penal a } \\
\text { ser projetado } & & \end{array}$ & $\begin{array}{l}\text { sujeito e objeto de definição da forma espacial - a } \\
\text { circulação atende à simplicidade geométrica (ver } \\
\text { item 07.01). A circulação participa da } \\
\text { impermeabilidade, da funcionalidade e do controle } \\
\text { do estabelecimento penal (fluxos e vigilância) (ver } \\
\text { item 15.01). Em especial, na funcionalidade, o } \\
\text { procedimento de condução de presos representa } \\
\text { um alto risco para os funcionários, assim como, o } \\
\text { fluxo vertical de presos (ver item 15.04). Assim a } \\
\text { circulação responde à simplicidade funcional, } \\
\text { contribuindo com a disciplina interna e economia } \\
\text { de recursos (ver itens 10.04 e 10.02). Vínculos: } \\
\text { Geometria, Espacialização e Controle. }\end{array}$ & $\begin{array}{l}\text { regularizar a geometria das circulações. A } \\
\text { circulação deve ser configurada por corredores } \\
\text { (fechamento). As distâncias devem refletir a } \\
\text { internalização - a aproximação entre as atividades } \\
\text { dos presos (compactação) (ver itens } 10.02,11.01 \text { e } \\
\text { 15.05). Os blocos de vivência devem estabelecer } \\
\text { uma continuidade volumétrica. Isto reduz a } \\
\text { exposição dos funcionários. O desenho da } \\
\text { circulação deve ser linear, ortogonal, horizontal, } \\
\text { com um mínimo de conversões e cruzamentos (ver } \\
\text { item 10.01). Estas características são ressaltadas } \\
\text { no sentido do setor interno. As escadas são } \\
\text { destinadas ao uso dos funcionários [RP]. }\end{array}$ & $\begin{array}{l}\text { torno de } 4,60 \mathrm{~m} \text { [PR] e das demais circulações em } \\
2,50 \mathrm{~m} \text { [DB, p. } 36] \text {. } \\
\text { Estimar a quantidade linear da circulação em } \\
1,24 \mathrm{~m} / \text { vaga, a considerar uma tendência a maior } \\
\text { de } 1,80 \mathrm{~m} / \text { vaga ( } 70 \% \text { nos setores internos) } \\
\text { [PR]. } \\
\text { Estimar a descrição geométrica da circulação em } \\
15 \text { pontos de derivação, a considerar uma } \\
\text { tendência a maior até } 30 \text { pontos }{ }^{122} \text { [PR]. } \\
\text { Estimar as distâncias: cela/pátio de sol - de } 30 \text { a } \\
42 \mathrm{~m} \text {; cela/atividades laboreducativas - de } 42 \text { a } \\
93 \mathrm{~m} \text {; cela/visita - de } 63 \text { a } 89 \mathrm{~m} \text {; e acesso da } \\
\text { unidade/visita - entre } 90 \text { (advogado) e } 160 \mathrm{~m} \\
\text { (social) [PR]. }\end{array}$ \\
\hline $\begin{array}{l}12.03 \\
\text { Definir o acesso ao } \\
\text { estabelecimento penal, } \\
\text { setores e blocos funcionais } \\
\text { segundo o nível de } \\
\text { segurança do } \\
\text { estabelecimento penal a } \\
\text { ser projetado }\end{array}$ & $\begin{array}{l}\text { A circulação interage diretamente com o controle, } \\
\text { atuando simultaneamente como sujeito e objeto } \\
\text { de definição do sistema de segurança. O espaço } \\
\text { arquitetônico é restritivo na acessibilidade e } \\
\text { mobilidade na unidade penal (ver item 10.03). A } \\
\text { entrada do estabelecimento penal e as passagens } \\
\text { entre os setores são críticas para o controle (ver } \\
\text { item 15.05). Vínculos: Espacialização e Controle. }\end{array}$ & $\begin{array}{l}\text { O espaço arquitetônico deve constituir acessos } \\
\text { únicos para o estabelecimento penal, os setores e } \\
\text { os blocos funcionais, por meio de um gráfico } \\
\text { topológico com pontos de convergência dos fluxos. } \\
\text { Um acesso alternativo para a unidade penal pode } \\
\text { ser previsto (veículos de emergência ou } \\
\text { manutenção). O setor intermediário e seus blocos } \\
\text { admitem mais de um acesso (inclusão e serviços), } \\
\text { desde que devidamente controlados. }\end{array}$ & $\begin{array}{l}\text { Prever um acesso único para o estabelecimento } \\
\text { penal [DB, p. 36]. } \\
\text { Estabelecer acessos únicos no interior da } \\
\text { unidade prisional entre as passagens dos setores } \\
\text { externo, intermediário e interno. } \\
\text { Vetar portas nas cercas de segurança para } \\
\text { retirada ou passagem de lixo, abastecimento da } \\
\text { infraestrutra e manutenção [RP]. }\end{array}$ \\
\hline $\begin{array}{l}12.04 \\
\text { Permitir a evacuação dos } \\
\text { funcionários em casos de } \\
\text { crise }\end{array}$ & $\begin{array}{l}\text { O sistema de segurança da unidade penal deve } \\
\text { garantir a integridade dos funcionários, o que } \\
\text { implica na possibilidade de evacuação em } \\
\text { situações de crise, especialmente com a finalidade } \\
\text { de evitar a conformação de reféns (ver item } \\
\text { 15.04). Nas áreas internas da unidade penal, a } \\
\text { circulação descrita por acessos únicos pode } \\
\text { comprometer a evasão dos funcionários, caso os } \\
\text { presos dominem estes pontos. Vínculo: Controle. }\end{array}$ & $\begin{array}{l}\text { O espaço arquitetônico deve ter rota de evacuação } \\
\text { dos funcionários nos locais onde a tomada de } \\
\text { parte da unidade penal pelos presos pode implicar } \\
\text { na ocorrência de reféns, especialmente no setor } \\
\text { interno da unidade penal. A rota de fuga é } \\
\text { providenciada por alçapões ou portinholas, } \\
\text { protegidas nos postos de controle ou nas } \\
\text { circulações exclusivas para os funcionários, com } \\
\text { saída para as fachadas da edificação. }\end{array}$ & $\begin{array}{l}\text { Prever escapes nos postos de controle e nas } \\
\text { extremidades das circulações exclusivas para os } \\
\text { funcionários [RP]. } \\
\text { Prever escadas ou outros elementos externos } \\
\text { para a descida dos funcionários, no caso de } \\
\text { saídas em altura [RP]. }\end{array}$ \\
\hline
\end{tabular}

${ }^{121}$ As distancias entre os espaços (cela, pátio, visita e acesso) dizem respeito ao percurso realizado pelas pessoas nas circulações do estabelecimento penal de porta a porta, considerando a situação mais crítica: a cela mais ao fundo.

${ }^{22}$ A circulação principal diz respeito à via que atravessa e interliga os setores intermediário e interno do estabelecimento penal até a última camada topológica, considerando ainda os acessos para os blocos funcionais. Os pontos somam as ocorrências. A circulação exclusiva é contabilizada. 


\begin{tabular}{|c|c|c|c|}
\hline \multicolumn{4}{|l|}{ 13. Conforto Ambiental } \\
\hline \multicolumn{4}{|c|}{ Relaciona-se fortemente com o Isolamento Individual e a Espacialidade, assim como, com a Barreira Perimetral e a Geometria. } \\
\hline Requisito & Fundamentação Teórica & Procedimento Metodológico & Recursos Técnicos \\
\hline $\begin{array}{l}13.01 \\
\text { Considerar o conforto } \\
\text { ambiental em todos os } \\
\text { espaços internos da } \\
\text { edificação, priorizando a } \\
\text { iluminação e a ventilação, } \\
\text { por meio de aberturas } \\
\text { conformadas segundo o } \\
\text { nível de segurança do } \\
\text { estabelecimento penal a } \\
\text { ser projetado }\end{array}$ & $\begin{array}{l}\text { O conforto ambiental permeia a composição } \\
\text { arquitetônica, associada ao respeito à condição } \\
\text { humana na prisão, cujo contraponto é a segurança } \\
\text { penitenciária (ver item 10.05). O conforto } \\
\text { ambiental prioriza os aspectos lumínico e térmico, } \\
\text { sintetizados nos cuidados com as aberturas de } \\
\text { iluminação e ventilação. Estas aberturas devem } \\
\text { respeitar a impermeabilidade, a estanqueidade e o } \\
\text { controle institucional, principalmente nos setores } \\
\text { mais internos da unidade penal (locais com a } \\
\text { presença de presos). Na prática, as aberturas } \\
\text { exigidas para os presos são mínimas, indiretas e } \\
\text { isoladas. O conforto ambiental também envolve a } \\
\text { salubridade em termos da qualidade do ar. O } \\
\text { conforto ambiental varia em função da localização } \\
\text { (ver item 04.04) e do terreno (ver item 11.03), de } \\
\text { modo a favorecer a posição das aberturas, em } \\
\text { termos da insolação e ventos dominantes. } \\
\text { Vínculos: Espacialização e Aparatos de Segurança. }\end{array}$ & $\begin{array}{l}\text { O espaço arquitetônico deve providenciar a } \\
\text { iluminação e ventilação de modo equilibrado com } \\
\text { a segurança penitenciária, por meio da localização, } \\
\text { tipologia, quantidade e configuração das } \\
\text { aberturas. As aberturas devem ser resguardadas, } \\
\text { de modo a bloquear a percepção das atividades } \\
\text { institucionais e a impedir a comunicação entre os } \\
\text { grupos de presos (geometria da edificação, } \\
\text { configuração das aberturas ou aparatos de } \\
\text { segurança). A ventilação cruzada ou em nível é } \\
\text { recomendada, desde que atenda a estes critérios. } \\
\text { Assim como, a visualização dos espaços externos } \\
\text { fica condicionada por estes critérios. Nos locais } \\
\text { com a presença de presos, as aberturas devem ser } \\
\text { mínimas e a regulagem é restrita (deve ser } \\
\text { realizada pelos funcionários). O dimensionamento } \\
\text { das aberturas deve considerar a zona bioclimática, } \\
\text { além da quantidade de pessoas e atividades } \\
\text { previstas. }\end{array}$ & 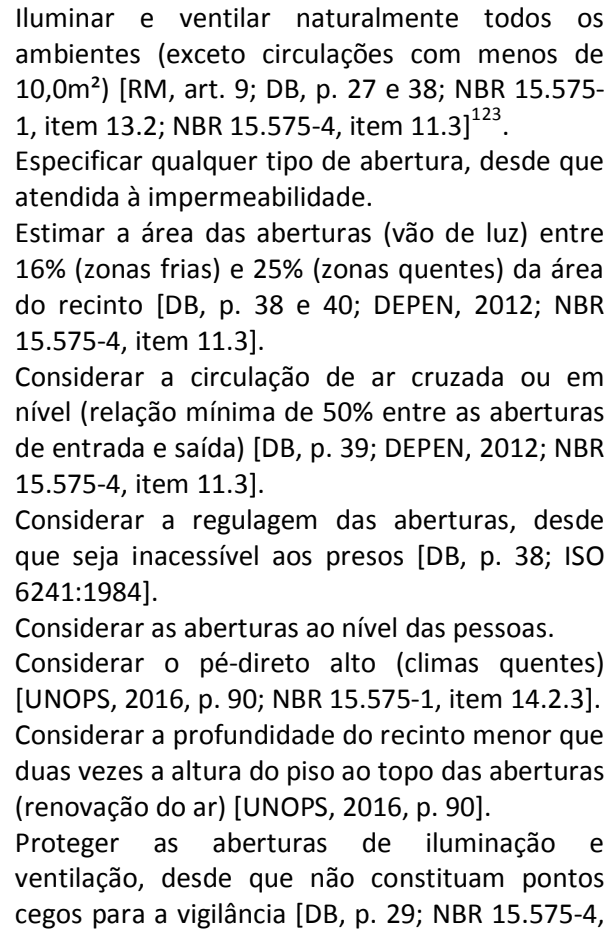 \\
\hline
\end{tabular}

123 Os relatórios NPC/UFSC (2013) e Cetac/IPT no 107 898-205 (2008) adéquam o texto normativo para as celas: a edificação deve propiciar condições de iluminação natural em todas as celas prisionais durante o dia. O relatório NPC/UFSC sugere um nível de iluminamento maior que 60 lux, equiparado às dependências de dormitório, banheiro, área de trabalho e leitura, oficina e biblioteca. O relatório Cetac/IPT no $107898-205$ sugere o Fator de Luz Diurna (FLD) no centro da cela de, no mínimo, 0,9\%. O caderno BREAAM determina, minimamente, $80 \%$ da área de piso de cada um dos cômodos com ocupação prolongada adequadamente iluminado com um FLD, médio, de 2\% (para celas este fator é de 1,5\%). No item 11.3 da NBR 15.575-4 (2013) - aberturas para ventilação, consta entre os recursos: ventilação (5ren/h). 


\begin{tabular}{|c|c|c|c|}
\hline & & & $\begin{array}{l}\text { item 11.3; ISO 6241:1984; PSI 12/2012]. } \\
\text { Cogitar a visualização do exterior [ISO } \\
6241: 1984 ; \text {; Caderno BREEAM] }\end{array}$ \\
\hline $\begin{array}{l}13.02 \\
\text { Considerar a geometria da } \\
\text { edificação penal na } \\
\text { definição do } \text { conforto } \\
\text { ambiental }\end{array}$ & $\begin{array}{l}\text { A geometria interage com o conforto ambiental no } \\
\text { que diz respeito ao espaço livre adjacente à } \\
\text { edificação penal e à quantidade de fachada para a } \\
\text { criação de aberturas de ventilação e iluminação } \\
\text { (ver item 07.01). Ao mesmo tempo, a geometria } \\
\text { interage com a impermeabilidade, ao resguardar } \\
\text { as aberturas por meio da forma construída. } \\
\text { Vínculos: Localização, Geometria e afastamentos } \\
\text { da Barreira Perimetral. }\end{array}$ & $\begin{array}{l}\text { O espaço arquitetônico deve apresentar } \\
\text { espaçamentos adjacentes e entrecortes que } \\
\text { resguardem as aberturas e propiciem a quantidade } \\
\text { de fachada necessária para a criação das aberturas } \\
\text { de iluminação e ventilação. Ao mesmo tempo, a } \\
\text { geometria deve permitir o monitoramento das } \\
\text { aberturas pela vigilância externa. As coberturas } \\
\text { devem favorecer a especificação da iluminação e } \\
\text { ventilação zenitais. }\end{array}$ & $\begin{array}{l}\text { Prever áreas livres [DB, p. 28], por meio dos } \\
\text { afastamentos internos (ver item 16.10), a } \\
\text { considerar a taxa de ocupação em torno de } 38 \% \\
\text { [PR]. } \\
\text { Estimar o perímetro edificado e a área de } \\
\text { fachadas de acordo com a geometria (ver item } \\
\text { 07.01). } \\
\text { Limitar a verticalização a dois pavimentos. }\end{array}$ \\
\hline \multicolumn{4}{|l|}{ 14. Aparatos de Segurança } \\
\hline \multicolumn{4}{|c|}{$\begin{array}{l}\text { Permeia a totalidade dos elementos da composição arquitetônica, em especial, os quesitos da funcionalidade, as celas coletivas, a barreira física e o controle, refletindo fortemente o nível } \\
\text { de segurança. }\end{array}$} \\
\hline Requisito & Fundamentação Teórica & Procedimento Metodológico & Recursos Técnicos \\
\hline $\begin{array}{l}14.01 \\
\text { Homogeneizar o sistema } \\
\text { de segurança do } \\
\text { estabelecimento penal a } \\
\text { ser projetado, segundo o } \\
\text { nível de segurança } \\
\text { penitenciário estipulado } \\
\text { para o mesmo }\end{array}$ & $\begin{array}{l}\text { A segurança penitenciária exige a consistência do } \\
\text { fechamento e do controle da unidade prisional, } \\
\text { definida pelo componente mais débil. Os aparatos } \\
\text { de segurança se destinam a impermeabilidade, } \\
\text { estanqueidade, inexpugnidade e disciplina interna } \\
\text { (ver itens } 04.01 \text { e } 06.03 \text { ), além da proteção dos } \\
\text { funcionários (ver item 15.04). Estes aparatos } \\
\text { tratam dos pormenores do sistema de segurança, } \\
\text { ao contemplar subsistemas e elementos (ver itens } \\
16.08,17.09,18.11 \text { e } 19.05 \text { ). Os mesmos mitigam } \\
\text { as vulnerabilidades deixadas pelo esquema de } \\
\text { segurança, quando as soluções gerais não } \\
\text { alcançam certas especificidades porque estas se } \\
\text { tornam excessivamente complexas ou custosas. Os } \\
\text { aparatos de segurança são limitados pelos padrões } \\
\text { de bem-estar. Permeia o programa arquitetônico, } \\
\text { especialmente os elementos centrais. }\end{array}$ & $\begin{array}{l}\text { O espaço arquitetônico deve complementar e } \\
\text { homogeneizar o sistema de segurança, organizado } \\
\text { em níveis de fechamento equivalentes aos riscos } \\
\text { externos e internos, inerentes à presença dos } \\
\text { presos e às atividades institucionais. Para cada } \\
\text { nível, uma combinação de soluções deve ser } \\
\text { estabelecida e o conjunto destas deve compor um } \\
\text { sistema coeso. A aplicação de aparatos tende a } \\
\text { intensificação nos setores mais internos, em } \\
\text { especial, nos locais com a presença de presos. Os } \\
\text { aparatos de segurança conferem funcionalidade à } \\
\text { operação, por meio de dispositivos passivos ou } \\
\text { remotos para o fechamento institucional, redução } \\
\text { de tarefas, simplificação de procedimentos e } \\
\text { controle das atividades e dos fluxos. Em particular, } \\
\text { os aparatos devem garantir a proteção dos } \\
\text { funcionários. }\end{array}$ & $\begin{array}{l}\text { Especificar, conforme a necessidade [DB, p. 47]: } \\
\text { redutores de velocidade e cancelas nas pistas } \\
\text { veiculares; elementos perfurantes ou cortantes } \\
\text { contra a escalada; obstáculos para o bloqueio } \\
\text { visual; anteparos nas aberturas de ventilação e } \\
\text { iluminação (caixas, telas, grades, brises ou } \\
\text { pergolados); portinholas, visores e conjuntos de } \\
\text { trancas nas portas; dispositivos contra a escalada } \\
\text { de pilares, paredes ou muros (ressaltos e gradis); } \\
\text { contenções nas circulações para a disciplina dos } \\
\text { fluxos (uma porta simples ou duas portas } \\
\text { sucessivas com abertura assíncrona); passadores } \\
\text { de volumes, visores e mecanismos de manuseio } \\
\text { remoto de portas. } \\
\text { Especificar dispositivos de baixa tecnologia } \\
\text { (passivos e mecânicos). }\end{array}$ \\
\hline
\end{tabular}

124 O caderno BREAAM (BRE GLOBAL, 2008) estipula que a vista externa se configura por uma distancia máxima de sete metros da parede com a abertura (profundidade do cômodo) e que esta abertura tenha uma área igual ou maior que $20 \%$ da área interna desta parede. Para a cela ter vista externa, elementos de bloqueio visual externo devem estar a uma distancia igual ou maior que $10 \mathrm{~m}$ das aberturas de visualização da cela. 


\begin{tabular}{|c|c|c|c|}
\hline $\begin{array}{l}14.02 \\
\text { Disciplinar a acessibilidade } \\
\text { e a mobilidade das pessoas } \\
\text { nos espaços abertos do } \\
\text { estabelecimento penal a } \\
\text { ser projetado }\end{array}$ & $\begin{array}{l}\text { O fluxo de pessoas pelas áreas externas intramuros } \\
\text { compromete a impermeabilidade e a disciplina } \\
\text { interna, ao acessar os blocos funcionais com } \\
\text { contato entre diferentes grupos de presos e } \\
\text { atividades (ver item 10.03). Vínculo: } \\
\text { Espacialização. }\end{array}$ & $\begin{array}{l}\text { O espaço arquitetônico deve setorizar as áreas } \\
\text { externas intramuros, ao prolongar as divisões } \\
\text { setoriais e funcionais internas, de modo a delimitar } \\
\text { a acessibilidade e da mobilidade dos diferentes } \\
\text { tipos de pessoas. Os elementos divisórios não } \\
\text { devem dificultar a visualização dos espaços. }\end{array}$ & $\begin{array}{l}\text { Especificar cercas em torno dos edifícios } \\
\text { ocupados pelos presos e nos pátios de } \\
\text { interligação ou recepção (inclusão, serviços) [DB, } \\
\text { p. } 29 \text { e 34; UNOPS, 2016, p. 32]. } \\
\text { Dimensionar as cercas com uma altura mínima } \\
\text { de } 3 m \text { [PR]. }\end{array}$ \\
\hline \multicolumn{4}{|l|}{ 15. Controle } \\
\hline \multicolumn{4}{|c|}{$\begin{array}{l}\text { É definido pelo nível de segurança e relaciona-se diretamente com a Organização do Espaço. O controle externo e o interno se interrelacionam. O controle externo relaciona-se fortemente } \\
\text { com a Barreira Perimetral, o Aparato de Segurança e a Geometria. O controle interno relaciona-se fortemente com a Organização do Espaço e o Aparato de Segurança. }\end{array}$} \\
\hline Requisito & Fundamentação Teórica & Procedimento Metodológico & Recursos Técnicos \\
\hline $\begin{array}{l}15.01 \\
\text { Vigiar os aspectos da } \\
\text { operação penitenciária, em } \\
\text { termos dos espaços } \\
\text { internos do } \\
\text { estabelecimento penal a } \\
\text { ser projetado, segundo o } \\
\text { nível de segurança } \\
\text { estipulado para o mesmo }\end{array}$ & $\begin{array}{l}\text { O controle utiliza a observação e o registro como } \\
\text { ferramentas disciplinares (ver item 06.02), } \\
\text { implementadas por meio da vigilância. As pessoas } \\
\text { são constante e intensamente acompanhadas e } \\
\text { qualquer ação está subordinada à instituição, } \\
\text { restando pouca autonomia aos presos e visitantes. } \\
\text { Isto remete à disciplina espacial, segundo a qual a } \\
\text { espacialidade e o controle concorrem para o } \\
\text { domínio territorial da instituição: a totalidade dos } \\
\text { espaços deve ser passível de monitoramento. A } \\
\text { vigiância é moderada pela privacidade mínima das } \\
\text { pessoas (sanitários, encontro íntimo, instalações } \\
\text { funcionais), em especial, o alojamento dos presos. } \\
\text { Baseia o programa arquitetônico (Espacialização). }\end{array}$ & $\begin{array}{l}\text { O espaço arquitetônico deve possibilitar a } \\
\text { vigilância máxima dos locais da prisão, } \\
\text { principalmente no setor interno (ver item 10.02). } \\
\text { Isto é obtido pela centralização e concentração das } \\
\text { atividades: o arranjo arquitetônico dos recintos em } \\
\text { torno dos postos de controle (vigilância direta), } \\
\text { assistidos por circulações exclusivas para os } \\
\text { funcionários (vigilância nas rondas). A prioridade } \\
\text { na vigilância são os pátios de sol dos presos, } \\
\text { seguido dos acessos e circulações, além das salas } \\
\text { de atividades e locais de visitação. As alas } \\
\text { carcerárias são monitoradas por rondas, já que as } \\
\text { celas são relativamente fechadas para a instituição } \\
\text { (ver itens } 10.02 \text { e 17.12). }\end{array}$ & $\begin{array}{l}\text { Considerar o padrão arquitetônico modular } \\
\text { como modelo (vigilância direta) para a } \\
\text { espacialização dos blocos de vivência (postos de } \\
\text { controle) [PR]. } \\
\text { Estimar a vigilância interna em torno de } 62 \% \text { da } \\
\text { área construída, sendo em torno de } 78 \% \text { no } \\
\text { setor interno (blocos de vivência) [PR]. } \\
\text { Prever aberturas nas circulações exclusivas nos } \\
\text { blocos de vivência para a vigilância durante as } \\
\text { rondas [PR]. } \\
\text { Prever postos de controle nos pavimentos com a } \\
\text { presença de presos (edificações verticais) (ver } \\
\text { item 07.01) [UNOPS, 2016, p. 102]. }\end{array}$ \\
\hline $\begin{array}{llr}15.02 & \\
\text { Interiorizar } & \text { a } \\
\text { individualidade disciplinar } \\
\text { segundo o nível de } \\
\text { segurança penitenciário } \\
\text { estipulado para o } \\
\text { estabelecimento penal a } \\
\text { ser projetado }\end{array}$ & $\begin{array}{l}\text { A vigilância prisional se baseia no princípio da } \\
\text { inspeção que se alicerça na inverificabilidade } \\
\text { institucional e produz o efeito da internalização da } \\
\text { disciplina em cada indivíduo (funcionários e } \\
\text { presos). A 'inversão na vigilância' prolonga a } \\
\text { inverificabilidade para os locais de vulnerabilidade } \\
\text { institucional (ver item 10.03). Isto justifica o } \\
\text { fechamento da cela (ver item 17.10). Na prática, a } \\
\text { inverificabilidade auxilia na proteção e na } \\
\text { otimização da equipe de funcionários. Baseia o } \\
\text { programa arquitetônico (Posto de Controle). }\end{array}$ & $\begin{array}{l}\text { As torres de vigilância e os postos de controle } \\
\text { devem adotar a inverificabilidade institucional, } \\
\text { estendida para as circulações exclusivas dos } \\
\text { funcionários e para os casos particulares de } \\
\text { monitoramento (visores nas salas de atividades } \\
\text { dos presos e celas). Isto é obtido por meio da } \\
\text { posição e geometria dos pontos de vigilância, além } \\
\text { de recursos luminotécnicos e da especificação dos } \\
\text { visores. Os pontos de controle devem ter a } \\
\text { faculdade de inabilitar a inverificabilidade para o } \\
\text { eventual contato externo (ver itens } 15.04 \text { e 15.07). }\end{array}$ & $\begin{array}{l}\text { Prever o arranjo espacial associado ao jogo de } \\
\text { luz e sombra: o contraste entre o local de } \\
\text { vigilância (escuro) e a área vigiada (claro). Isto } \\
\text { por meio das aberturas de iluminação destes } \\
\text { espaços (localização e dimensionamento), além } \\
\text { da previsão de aparatos (brises, persianas), da } \\
\text { colocação de películas reflexivas nos visores ou } \\
\text { do ofuscamento através de luz direcionada para } \\
\text { as áreas monitoradas (natural ou artificial) [RP]. }\end{array}$ \\
\hline $\begin{array}{l}15.03 \\
\text { Monitorar as áreas e } \\
\text { elementos externos do } \\
\text { estabelecimento penal a } \\
\text { ser projetado, segundo o }\end{array}$ & $\begin{array}{l}\text { A vigilância externa garante o cumprimento da } \\
\text { pena, ao conformar o isolamento social, em } \\
\text { termos da estanqueidade e da inexpugnidade, por } \\
\text { meio do monitoramento do perímetro de } \\
\text { segurança e das áreas e edificações intramuros da }\end{array}$ & $\begin{array}{l}\text { O espaço arquitetônico deve maximizar a vigilância } \\
\text { externa, ao mesmo tempo em que deve minimizar } \\
\text { os recursos necessários para esta tarefa. A } \\
\text { vigilância deve considerar a quantidade, a posição } \\
\text { e a altura das torres. As torres devem ser locadas }\end{array}$ & $\begin{array}{l}\text { Prever torres de vigilância nos cantos da barreira } \\
\text { perimetral (quatro torres) [PR; DB, p. 47; UNOPS, } \\
\text { 2016, p. 184]. } \\
\text { Estimar a visualização das áreas externas em } \\
93 \% \text { da área [PR]. }\end{array}$ \\
\hline
\end{tabular}




\begin{tabular}{|c|c|c|c|}
\hline $\begin{array}{ll}\text { nível de } & \text { segurança } \\
\text { penitenciário } & \text { estipulado } \\
\text { para o mesmo } & \end{array}$ & $\begin{array}{l}\text { unidade penal (ver itens } 16.01 \text { e 16.03). A } \\
\text { vigilância atende aos preceitos de eficiência da } \\
\text { disciplina, inclusive econômica (ver item 16.05), ao } \\
\text { aderir ao princípio de vigilância (ver item 15.02). A } \\
\text { mesma atua em conjunto com a geometria da } \\
\text { barreira perimetral e da edificação, além da } \\
\text { planialtimetria do terreno (áreas cegas). A } \\
\text { vigilância externa deve unificar a equipe de } \\
\text { guarda. Vínculos: Barreira Perimetral e Geometria. }\end{array}$ & $\begin{array}{l}\text { intermediamente sobre a linha da barreira } \\
\text { perimetral. As torres devem prever a visualização } \\
\text { da totalidade das fachadas e coberturas das } \\
\text { edificações. As mesmas devem permitir o contato } \\
\text { visual entre os guardas nas torres, inclusive sobre } \\
\text { as edificações. O monitoramento das torres de } \\
\text { vigilância deve ser integrado e articulado com os } \\
\text { postos de controle nas edificações. As torres } \\
\text { devem reproduzir a inverificabilidade institucional. }\end{array}$ & $\begin{array}{l}\text { Limitar os pontos cegos derivados da geometria } \\
\text { das edificações em sete [PR] e prever torres } \\
\text { intermediárias para a cobertura destes pontos } \\
\text { durante crises (fugas, rebeliões) [RP]. } \\
\text { Prever a visualização das fachadas das alas } \\
\text { carcerárias (aberturas de iluminação e } \\
\text { ventilação) e das coberturas [RP]. } \\
\text { Prever a linha de visão dos guardas nas torres } \\
\text { mais alta do que a cumeeira dos edifícios [RP]. } \\
\text { Estimar a guarda pelo dobro do número de } \\
\text { torres (metade em prontidão) [RP]. }\end{array}$ \\
\hline $\begin{array}{l}15.04 \\
\text { Garantir a integridade dos } \\
\text { funcionários encarregados } \\
\text { da vigilância e controle } \\
\text { externo e interno }\end{array}$ & $\begin{array}{l}\text { As atividades de vigilância e controle naturalmente } \\
\text { expõem os funcionários, tanto na defesa do } \\
\text { estabelecimento (disparos por arma de fogo ou } \\
\text { invasões), como nas atividades internas (ataques } \\
\text { verbais e físicos ou captura de reféns) (ver itens } \\
12.01 \text { e 15.05). Para a atuação segura dos } \\
\text { funcionários nestas funções é necessária a } \\
\text { separação física destes em relação aos estranhos, } \\
\text { presos e visitantes. Esta separação é relativa: aos } \\
\text { funcionários deve ser possibilitada a realização de } \\
\text { procedimentos e a comunicação com as pessoas } \\
\text { (ver item 19.05). Na prática, a mesma é solicitada } \\
\text { pelos funcionários e presos para a proteção de } \\
\text { ambos os grupos. Os postos não desabilitam a } \\
\text { realização de rondas. Vínculo: Posto de Controle. }\end{array}$ & $\begin{array}{l}\text { O espaço arquitetônico deve adotar torres de } \\
\text { vigilância e postos de controle, além de circulações } \\
\text { exclusivas para os funcionários (vigilância direta). } \\
\text { O acesso às torres de vigilância deve ser único, } \\
\text { exclusivo e controlado (junto ao bloco da guarda } \\
\text { externa). Os mesmos devem ser cuidados pela } \\
\text { vigilância externa. Os acessos dos postos de } \\
\text { controle devem ser protegidos por contenções. A } \\
\text { separação física dos funcionários é constante ao } \\
\text { longo do corpo da edificação prisional, se } \\
\text { intensificando nos locais de aglomeração ou } \\
\text { condução de presos (setores internos). As } \\
\text { circulações exclusivas devem auxiliar as rondas. } \\
\text { Circulações exclusivas que liguem postos devem } \\
\text { conter a propagação de eventuais invasões. }\end{array}$ & $\begin{array}{l}\text { Prever torres de vigilância e postos de controle } \\
\text { inexpugnáveis [DB, Anexo V]. } \\
\text { Articular as torres e os postos de controle com } \\
\text { os esquemas de vigilância externa e interna [DB, } \\
\text { p. } 47 \text { e 49]. } \\
\text { Locar os postos de controle próximos aos } \\
\text { acessos dos locais monitorados [UNOPS, 2016, p. } \\
102 \text { ]. } \\
\text { Prever circulações exclusivas para os } \\
\text { funcionários nas alas carcerárias [PR; RP]. } \\
\text { Prever contenções nas circulações exclusivas dos } \\
\text { funcionários que interliguem postos [PR]. } \\
\text { Prever mecanismos para a resposta dos } \\
\text { funcionários aos eventos externos } \\
\text { (procedimentos e comunicação) (ver item 19.05). }\end{array}$ \\
\hline $\begin{array}{l}\text { Controlar os fluxos do } \\
\text { estabelecimento penal a } \\
\text { ser projetado }\end{array}$ & $\begin{array}{l}\text { A disciplina espacial ressalta a interdependência da } \\
\text { espacialização e do controle na administração dos } \\
\text { fluxos (circulação). A eficiência funcional e } \\
\text { econômica do controle dos fluxos depende da } \\
\text { simplicidade geométrica da circulação e da } \\
\text { internalização das atividades (ver itens } 12.01 \text { e } \\
\text { 15.01). A quantidade de alas carcerárias interfere } \\
\text { na economicidade do controle dos fluxos, } \\
\text { enquanto o esquema espacial da vigilância direta } \\
\text { favorece a eficiência. Vínculos: Geometria, } \\
\text { Espacialização e Circulação. }\end{array}$ & $\begin{array}{l}\text { O espaço arquitetônico deve dispor } \\
\text { estrategicamente os postos de controle sobre o } \\
\text { arranjo arquitetônico, cobrindo os principais } \\
\text { acessos, passagens e interseções de fluxos (pontos } \\
\text { de convergência topológica), especialmente nos } \\
\text { locais com a presença de presos. Os postos devem } \\
\text { ser posicionados de modo centralizado, em torno } \\
\text { dos quais os fluxos podem ser coordenados com a } \\
\text { menor equipe funcional possível. A circulação } \\
\text { exclusiva para os funcionários favorece o controle, } \\
\text { ao estender a atuação segura dos funcionários. }\end{array}$ & $\begin{array}{l}\text { Considerar o padrão arquitetônico modular } \\
\text { como modelo (vigilância direta), em termos da } \\
\text { espacialização dos postos de controle [PR]. } \\
\text { Estimar o controle dos fluxos em torno de } 63 \% \\
\text { da área de circulação, a considerar um valor } \\
\text { ótimo de } 82 \% \text { [PR]. } \\
\text { Condicionar a abertura das portas à visualização } \\
\text { de ambos os lados da mesma (entrada e saída) } \\
\text { pelo ponto de controle. }\end{array}$ \\
\hline Otimizar o número de & $\begin{array}{l}\text { A quantidade de pontos de controle atende à } \\
\text { disciplina, em particular, quanto à economia de } \\
\text { recursos (contingente funcional). Os postos de }\end{array}$ & $\begin{array}{l}\text { O espaço arquitetônico deve maximizar o controle } \\
\text { do estabelecimento de modo econômico: a maior } \\
\text { cobertura com o menor número de postos de }\end{array}$ & $\begin{array}{l}\text { Estimar o número de postos de controle em } \\
\text { torno de nove ou segundo a relação entre } \\
\text { capacidade e quantidade de postos de } 65\end{array}$ \\
\hline
\end{tabular}




\begin{tabular}{|c|c|c|c|}
\hline $\begin{array}{l}\text { postos de controle do } \\
\text { estabelecimento penal a } \\
\text { ser projetado }\end{array}$ & $\begin{array}{l}\text { controle focam os pontos mais críticos da } \\
\text { segurança penitenciária, tais como, os principais } \\
\text { acessos e as atividades cotidianas dos presos, } \\
\text { especialmente o pátio de sol. A quantificação dos } \\
\text { postos de controle depende fortemente da } \\
\text { internalização das atividades e da quantidade de } \\
\text { alas carcerárias (ver item 10.02). Na prática, a } \\
\text { operação integrada das equipes configura } \\
\text { estratégia para redução dos postos. O excedente } \\
\text { ou a insuficiência de postos de controle pode } \\
\text { comprometer o esquema de segurança e operação } \\
\text { (áreas sem fiscalização ou desprotegidas). } \\
\text { Vínculos: Espacialização e Circulação. }\end{array}$ & $\begin{array}{l}\text { controle. Isto determina a disposição destes } \\
\text { pontos, definindo certos aspectos da espacialidade } \\
\text { (ver itens } 15.01 \text { e 15.05). Os mesmos são } \\
\text { posicionados centralizadamente, o que permite a } \\
\text { vigilância dos espaços adjacentes por poucos } \\
\text { funcionários. Assim como, os postos devem } \\
\text { permitir a visualização e a comunicação entre as } \\
\text { equipes. Neste sentido, a caracterização, o } \\
\text { posicionamento e o acesso das atividades apontam } \\
\text { para os pontos críticos na perspectiva da } \\
\text { segurança e da operação. A quantificação da } \\
\text { equipe de funcionários depende da conjunção } \\
\text { destas variáveis. }\end{array}$ & $\begin{array}{l}\text { vagas/posto a } 75 \text { vagas/posto [PR]. } \\
\text { Considerar o controle do acesso, do corredor e } \\
\text { do pátio de sol do bloco de vivência [RP]. } \\
\text { Integrar os postos de controle visualmente } \\
\text { através de visores especializados, sem prejuízo } \\
\text { da inverificabilidade institucional [RP]. } \\
\text { Estimar a equipe média de funcionários em três } \\
\text { agentes por posto (vigia, atendente e } \\
\text { coordenador). Um vigia é somado a cada novo } \\
\text { recinto monitorado (um vigia por recinto). No } \\
\text { esquema de segurança, a integração de postos } \\
\text { (fisicamente próximos) implica no } \\
\text { compartilhamento do coordenador [RP]. }\end{array}$ \\
\hline $\begin{array}{l}15.07 \\
\text { Considerar a estrutura } \\
\text { social e as relações de } \\
\text { poder segundo o nível de } \\
\text { segurança penitenciário } \\
\text { estipulado no } \\
\text { estabelecimento penal a } \\
\text { ser projetado }\end{array}$ & $\begin{array}{l}\text { O controle participa da disputa de força entre a } \\
\text { instituição e o grupo de presos, na qual o posto de } \\
\text { controle é o objeto da representação das relações } \\
\text { de poder instituídas. Neste sentido, o posto de } \\
\text { controle deve evidenciar a força institucional, } \\
\text { ressaltando a subornação dos presos à autoridade } \\
\text { do Estado. Isto adere à mecanização dos } \\
\text { procedimentos: a despersonificação da instituição, } \\
\text { na qual a atuação de seus representantes é } \\
\text { desprovida de humanidade (impessoalidade com } \\
\text { os presos). Vínculos: Espacialização e Circulação. }\end{array}$ & $\begin{array}{l}\text { O espaço arquitetônico deve evidenciar a divisão } \\
\text { social da prisão e enfatizar a representação } \\
\text { totalitária da instituição, por meio da presença } \\
\text { física explícita e despersonificada dos postos de } \\
\text { controle, obtida pela localização, forma e } \\
\text { configuração destes, o que inclui a } \\
\text { inverificabilidade institucional (ver itens } 10.02 \text { e } \\
\text { 17.10). O espaço institucional deve ser situado em } \\
\text { um nível mais alto. As circulações exclusivas para } \\
\text { os funcionários devem reproduzir estas } \\
\text { características. }\end{array}$ & $\begin{array}{l}\text { Evidenciar visualmente os postos de controle nos } \\
\text { locais monitorados: elaborar formas } \\
\text { contundentes, agudas e projetadas sobre os } \\
\text { espaços monitorados [PR]. } \\
\text { Elevar o piso dos postos de controle ou locar os } \\
\text { postos em pavimentos superiores [PR]. }\end{array}$ \\
\hline \multicolumn{4}{|c|}{ 16. Barreira perimetral } \\
\hline \multicolumn{4}{|c|}{ É definida essencialmente pelo nível de segurança, repercutindo fortemente no custo de construção e interage diretamente com o Controle e o Aparato de Segurança. } \\
\hline Requisito & Fundamentação Teórica & Procedimento Metodológico & Recursos Técnicos \\
\hline $\begin{array}{l}16.01 \\
\text { Impedir a evasão de presos } \\
\text { da prisão: garantir a } \\
\text { estanqueidade } \quad \text { do } \\
\text { estabelecimento penal a } \\
\text { ser projetado }\end{array}$ & $\begin{array}{l}\text { Do ponto de vista da prisão como atividade } \\
\text { econômica, a barreira perimetral tem como } \\
\text { atribuição garantir a segregação social do preso } \\
\text { para o cumprimento da pena (ver item 04.01). Esta } \\
\text { segregação é ressaltada pelo antagonismo da } \\
\text { sociedade (ver itens } 10.02 \text { e 15.03). Vínculos: } \\
\text { lsolamento Social e o Controle. }\end{array}$ & $\begin{array}{l}\text { A barreira perimetral deve constituir superfície e seção } \\
\text { de difícil escalada, sem reentrâncias ou saliências e em } \\
\text { altura suficiente (ver item 16.06). O esquema de } \\
\text { vigilância (torres) e o fechamento das edificações } \\
\text { (aberturas de iluminação e ventilação) podem } \\
\text { absorver parte da estanqueidade exigida, o que } \\
\text { favorece soluções mais leves e econômicas. }\end{array}$ & $\begin{array}{l}\text { Definir vedações verticais, planas e contínuas } \\
\text { [DB, p. 34]. } \\
\text { Especificar aparatos de segurança } \\
\text { (obstáculos) (ver item 16.08) [PR]. } \\
\text { Concentrar a estanqueidade nos setores } \\
\text { internos, amenizados no setor externo. }\end{array}$ \\
\hline
\end{tabular}




\begin{tabular}{|c|c|c|c|}
\hline $\begin{array}{l}16.02 \\
\text { Romper com a } \\
\text { comunicação informal } \\
\text { entre os presos e o mundo } \\
\text { externo à prisão: garantir a } \\
\text { impermeabilidade do } \\
\text { estabelecimento penal a } \\
\text { ser projetado }\end{array}$ & $\begin{array}{l}\text { A prisão consiste em um espaço objetivamente } \\
\text { delimitado, cuja separação do mundo externo é } \\
\text { necessária para a implementação de um regime } \\
\text { totalitário e o controle da população prisional. O } \\
\text { isolamento é condição primordial para o exercício } \\
\text { da disciplina. Neste sentido, a barreira perimetral } \\
\text { tem como atribuição o rompimento da } \\
\text { comunicação informal dos presos com o mundo } \\
\text { externo (ver itens 04.01). Vínculos: Isolamento } \\
\text { Social e o Dimensionamento. }\end{array}$ & $\begin{array}{l}\text { A barreira perimetral deve apresentar vedações } \\
\text { fechadas e em altura suficiente (ver item 16.06). A } \\
\text { planialtimetria (entorno e terreno), os afastamentos } \\
\text { (ver itens 04.04 e 11.03) e o fechamento das } \\
\text { edificações (aberturas de iluminação e ventilação) } \\
\text { podem absorver parte da impermeabilidade exigida, o } \\
\text { que favorece soluções mais leves e econômicas. Em } \\
\text { qualquer caso, a verticalização de edificações vizinhas } \\
\text { ou da prisão condiciona a impermeabilidade. }\end{array}$ & $\begin{array}{l}\text { Especificar vedações fechadas (opacas - } \\
\text { translúcidas não são recomendadas). } \\
\text { Especificar aparatos de segurança (bloqueio } \\
\text { visual), em especial, no caso de barreira do } \\
\text { tipo cerca (ver item 16.08) [MD]. } \\
\text { Concentrar a impermeabilidade nos setores } \\
\text { internos, amenizados no setor externo. }\end{array}$ \\
\hline $\begin{array}{l}16.03 \\
\text { Proteger a prisão contra } \\
\text { ataques externos: garantir } \\
\text { a inexpugnidade do } \\
\text { estabelecimento penal a } \\
\text { ser projetado }\end{array}$ & $\begin{array}{l}\text { A barreira perimetral combate tanto a evasão de } \\
\text { presos, como defende a unidade penal contra } \\
\text { ataques externos - a invasão do estabelecimento } \\
\text { penal para o resgate de presos, seja pela utilização } \\
\text { de dispositivo explosivo ou de veículo pesado (ver } \\
\text { item 16.01). Vínculo: Isolamento Social. }\end{array}$ & $\begin{array}{l}\text { A barreira perimetral deve apresentar resistência } \\
\text { mecânica a ataques externos (materiais e sistemas). A } \\
\text { localização do estabelecimento (proximidade de vias } \\
\text { automotivas) e os afastamentos (ver itens } 04.04 \text { e } \\
\text { 11.03) podem absorver parte da resistência exigida, o } \\
\text { que favorece soluções mais leves. }\end{array}$ & $\begin{array}{l}\text { Especificar elementos resistentes a ataques } \\
\text { (explosivos ou veículos pesados). } \\
\text { Especificar aparatos de segurança } \\
\text { (obstáculos) (ver item 16.08) [MD]. } \\
\text { Concentrar a inexpugnidade nos setores } \\
\text { internos, amenizados no setor externo. }\end{array}$ \\
\hline 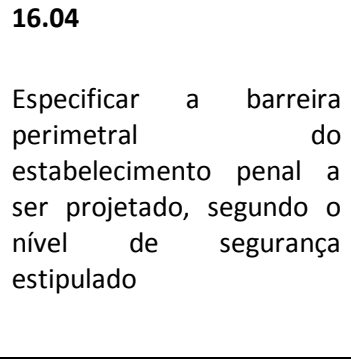 & $\begin{array}{l}\text { O tipo de barreira a ser especificado depende das } \\
\text { características de estanqueidade, } \\
\text { impermeabilidade e inexpugnidade (ver itens } \\
\text { 16.01, } 16.02 \text { e 16.03), condicionado pelo custo de } \\
\text { construção (ver item 03.01), além da localização } \\
\text { (ver item 04.04) e do tamanho do terreno (ver } \\
\text { item 11.03). Vínculos: Custo, Isolamento Social e } \\
\text { Dimensionamento. }\end{array}$ & $\begin{array}{l}\text { A barreira perimetral do tipo muro apresenta melhor } \\
\text { desenvoltura, enquanto o custo de construção } \\
\text { restringe sua aplicação. A barreira do tipo cerca é } \\
\text { preferível, desde que as propriedades de fechamento } \\
\text { e proteção sejam atendidas. Este atendimento deve } \\
\text { considerar a planialtimetria, afastamentos, vigilância } \\
\text { externa e fechamento das edificações. Caso contrário, } \\
\text { o muro se justifica. A barreira deve receber Aparatos } \\
\text { de Segurança, em especial a cerca (ver item 16.08). }\end{array}$ & $\begin{array}{l}\text { A barreira pode ser cerca ou muro [DB, p. 33; } \\
\text { UNOPS, 2016, p. 184]. } \\
\text { Para a barreira do tipo cerca, especificar } \\
\text { vedação em tela com estrutura em concreto } \\
\text { a cada três metros (mourões) e viga } \\
\text { baldrame com quarenta centímetros de } \\
\text { altura. A estrutura é posicionada na face } \\
\text { externa da cerca [DB, p. } 33 \text { e } 34 ; \text { PR]. } \\
\text { Para a barreira do tipo muro, especificar } \\
\text { vedação em concreto armado [PR]. }\end{array}$ \\
\hline $\begin{array}{l}\text { Conceber a geometria da } \\
\text { barreira perimetral de } \\
\text { modo econômico, } \\
\text { funcional e eficiente do } \\
\text { ponto de vista do controle }\end{array}$ & $\begin{array}{l}\text { A geometria da barreira perimetral atende à } \\
\text { disciplina espacial, em conjunto com a forma das } \\
\text { edificações, buscando a racionalidade do } \\
\text { utilitarismo em prol da funcionalidade (ver item } \\
08.01 \text { ) e do controle dos espaços (ver item 15.03). } \\
\text { A geometria da barreira varia em função da } \\
\text { localização (ver item 04.04) e do terreno (ver item } \\
\text { 11.03) e interfere na quantidade de torres de } \\
\text { vigilância (ver item 15.06). Vínculos: Geometria e } \\
\text { Controle. }\end{array}$ & $\begin{array}{l}\text { A barreira perimetral deve apresentar a maior } \\
\text { simplicidade geométrica possível, por meio de formas } \\
\text { puras, regulares e lineares (ver item 07.01). As } \\
\text { dimensões devem ser minimizadas - considerar os } \\
\text { afastamentos (ver item 16.10). Preferencialmente, a } \\
\text { barreira deve evitar desníveis ou patamares ou pode } \\
\text { ser considerado um caimento insignificante do ponto } \\
\text { de vista da vigilância (não constitui pontos cegos, ao se } \\
\text { considerar uma pessoa deitada). }\end{array}$ & $\begin{array}{l}\text { Adotar uma forma retangular, nivelada (ver } \\
\text { item 15.03) [PR]. } \\
\text { Conferir eventuais desníveis pela isovista das } \\
\text { torres de vigilância. } \\
\text { Considerar a distancia entre as torres de } \\
\text { vigilância [DB, p. 47]. } \\
\text { Estimar um perímetro entre } 500 \mathrm{~m} \text { e } 630 \mathrm{~m} \text {, a } \\
\text { considerar um valor ótimo de } 500 \mathrm{~m} \text { [PR]. }\end{array}$ \\
\hline 16.06 & $\begin{array}{l}\text { A altura da barreira integra a representação } \\
\text { institucional, ao atender ao caráter retributivo da } \\
\text { penalidade e à função de segregação da prisão (ver }\end{array}$ & $\begin{array}{l}\text { A altura da barreira perimetral deve garantir a } \\
\text { estanqueidade e a impermeabilidade, mas independe } \\
\text { da inexpugnidade. A planialtimetria do entorno e do }\end{array}$ & $\begin{array}{l}\text { Estimar uma altura de quatro metros } \\
\text { unidades consideradas isoladas, vigiadas, } \\
\text { horizontais (até dois pavimentos) e fechadas }\end{array}$ \\
\hline
\end{tabular}




\begin{tabular}{|c|c|c|c|}
\hline $\begin{array}{l}\text { Dimensionar a altura da } \\
\text { barreira perimetral do } \\
\text { estabelecimento penal a } \\
\text { ser projetado segundo o } \\
\text { nível de segurança } \\
\text { estipulado para o mesmo }\end{array}$ & $\begin{array}{l}\text { item 04.04). Barreiras altas promovem uma } \\
\text { sensação de segurança para a sociedade e para os } \\
\text { funcionários, além de coibirem os presos. A } \\
\text { exigência de redução do custo de construção } \\
\text { aponta para barreiras mais baixas (ver item 03.01). } \\
\mathrm{Na} \mathrm{prática,} \mathrm{a} \mathrm{altura} \mathrm{não} \mathrm{interfere} \mathrm{na} \\
\text { estanqueidade, pois o tempo de fuga é similar para } \\
\text { diferentes alturas. A altura da barreira varia em } \\
\text { função da localização e do terreno. Vínculos: Custo, } \\
\text { Isolamento Social e Dimensionamento. }\end{array}$ & $\begin{array}{l}\text { terreno, os afastamentos, o esquema de vigilância } \\
\text { (torres) e o fechamento das edificações (aberturas de } \\
\text { iluminação e ventilação) podem absorver parte da } \\
\text { estanqueidade e da impermeabilidade exigidas, o que } \\
\text { favorece alturas menores. Esta redução depende da } \\
\text { localização isolada (sem edificações em pavimentos } \\
\text { vizinhas) e da horizontalidade das edificações do } \\
\text { estabelecimento. Caso contrário, a altura deve ser } \\
\text { maximizada. No caso de barreira do tipo cerca, a } \\
\text { impermeabilidade pode ditar alturas menores apenas } \\
\text { para o aparato de bloqueio visual (ver item 16.08). }\end{array}$ & $\begin{array}{l}\text { [DB, p. 34; MD]. } \\
\text { Estimar uma altura entre cinco e sete } \\
\text { metros, a considerar um valor ótimo de } \\
6,50 \mathrm{~m} \text {, para unidades consideradas } \\
\text { vulneráveis [PR; MD]. } \\
\text { Calcular a altura do bloqueio visual pelo raio } \\
\text { de visão do observador externo à unidade } \\
\text { prisional (ver item 16.08) [MD]. } \\
\text { Primariamente, o ponto observado é o mais } \\
\text { alto com a possibilidade de contato com os } \\
\text { presos ou de exposição da rotina prisional. }\end{array}$ \\
\hline $\begin{array}{llr}16.07 & & \\
& & \\
\begin{array}{l}\text { Promover } \\
\text { protegida }\end{array} & \text { da } & \text { gurculação } \\
\text { externa } & & \end{array}$ & $\begin{array}{l}\text { A circulação da guarda externa da unidade penal } \\
\text { exige proteção contra ataques externos, } \\
\text { principalmente, de disparo por arma de fogo e } \\
\text { abordagem para rendição do guarda (ver item } \\
\text { 16.11). As torres devem vigiar seus acessos } \\
\text { reciprocamente (ver item 16.05). Vínculos: } \\
\text { Geometria e Controle. }\end{array}$ & $\begin{array}{l}\text { A barreira perimetral deve apresentar a circulação dos } \\
\text { guardas abrigada e inacessível, o que remete ao } \\
\text { fechamento da barreira. Os afastamentos podem } \\
\text { absorver parte do fechamento exigido, o que favorece } \\
\text { soluções mais leves e econômicas (ver item 16.04), } \\
\text { associadas a Aparatos de Segurança (ver item 16.08). } \\
\text { Caso contrário, o fechamento pode necessitar de } \\
\text { proteção balística ou o muro se justifica. }\end{array}$ & $\begin{array}{l}\text { Inserir a circulação dos guardas na barreira } \\
\text { perimetral (ver item 16.11) [DB, p. 34; PR]. } \\
\text { Prever Aparatos de Segurança no caso de } \\
\text { barreira do tipo cerca (ver item 16.08). } \\
\text { Calcular a altura da proteção balística pelo } \\
\text { raio de visão do observador (ver item 16.06) } \\
\text { [MD]. }\end{array}$ \\
\hline 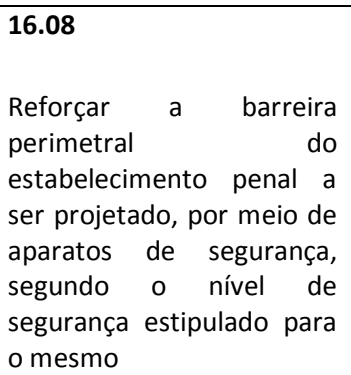 & $\begin{array}{l}\text { Os aparatos de segurança contribuem para a } \\
\text { estanqueidade, impermeabilidade e } \\
\text { inexpugnidade da barreira perimetral (ver itens } \\
16.02 \text { e 16.03), além da proteção dos funcionários } \\
\text { (ver item 14.01). A integralização destas } \\
\text { propriedades por meio do tipo ou geometria da } \\
\text { barreira implica em custos comparativamente } \\
\text { elevados aos aparatos de segurança. Os aparatos } \\
\text { variam principalmente em função da localização e } \\
\text { do terreno. Vínculo: Custo. }\end{array}$ & $\begin{array}{l}\text { As propriedades da barreira perimetral devem ser } \\
\text { maximizadas e homogeneizadas: o reforço do conjunto } \\
\text { e a correção dos componentes mais débeis. A } \\
\text { definição das vulnerabilidades deve considerar a } \\
\text { localização, o terreno, os afastamentos, o fechamento } \\
\text { das edificações, além do tipo de barreira (ver item } \\
\text { 14.04). Os afastamentos podem absorver parte das } \\
\text { soluções, de modo mais eficiente ou econômico. }\end{array}$ & $\begin{array}{l}\text { Podem ser revistos [PR]: espirais cortantes } \\
\text { na base, na altura e no topo; elementos } \\
\text { contra a escalada (projeções e } \\
\text { abaulamentos); alambrado duplo; obstáculos } \\
\text { visuais em altura suficiente para romper a } \\
\text { comunicação informal e proteger os } \\
\text { funcionários (ver item 16.06); proteções } \\
\text { mecânicas contra impactos; dilaceradores de } \\
\text { pneus de veículos; trincheiras ou banquizas; } \\
\text { colchões de areia ou brita. }\end{array}$ \\
\hline $\begin{array}{l}16.09 \\
\text { Considerar a linha de tiro } \\
\text { para o estabelecimento } \\
\text { penal a ser projetado, } \\
\text { segundo o nível de } \\
\text { segurança estipulado }\end{array}$ & $\begin{array}{l}\text { A linha de tiro integra as medidas de reforço da } \\
\text { barreira perimetral voltadas para evitar a fuga de } \\
\text { presos, a partir da atuação da guarda armada nas } \\
\text { torres de vigilância. No sistema penitenciário, a } \\
\text { mesma foi instituída informalmente. Na prática, o } \\
\text { disparo pelo guarda é improvável, porém a linha } \\
\text { de tiro é exigida. Vínculo: Controle (item 15.03). }\end{array}$ & $\begin{array}{l}\text { A barreira perimetral deve prever a linha de tiro em } \\
\text { toda a sua extensão. A definição da linha de tiro deve } \\
\text { considerar a planialtimetria do terreno e o esquema } \\
\text { de vigilância. As torres de vigilância devem ter a } \\
\text { visualização de toda a linha de tiro, enquanto a mesma } \\
\text { não pode impedir a visualização das áreas adjacentes } \\
\text { (pontos cegos). }\end{array}$ & $\begin{array}{l}\text { Prever cerca com três metros de altura, } \\
\text { interna e paralelamente disposta à barreira } \\
\text { perimetral em cinco metros (ver item 16.04) } \\
{[P R] \text {. }} \\
\text { [Portaria Interministerial } 4.226 / 2010]\end{array}$ \\
\hline 16.10 & $\begin{array}{l}\text { Os afastamentos integram o isolamento social dos } \\
\text { presos ao colaborarem com as propriedades de } \\
\text { fechamento da barreira (ver item 16.01, } 16.02 \text { e }\end{array}$ & $\begin{array}{l}\text { O espaço arquitetônico deve apresentar afastamentos } \\
\text { externos (perímetro de segurança) e internos } \\
\text { (distanciamento das edificações), em especial, no setor }\end{array}$ & $\begin{array}{l}\text { Estimar afastamentos mínimos de vinte } \\
\text { metros para unidades consideradas isoladas } \\
\text { e fechadas [DB, p. 34; PR]. }\end{array}$ \\
\hline
\end{tabular}




\begin{tabular}{|c|c|c|c|}
\hline $\begin{array}{l}\text { perimetral do } \\
\text { estabelecimento penal a } \\
\text { ser projetado por meio de } \\
\text { afastamentos externo e } \\
\text { interno, segundo o nível de } \\
\text { segurança estipulado }\end{array}$ & $\begin{array}{l}\text { 16.03), inclusive com a proteção dos funcionários e } \\
\text { com a vigilância externa. No sistema penitenciário, } \\
\text { as questões do dimensionamento do terreno (ver } \\
\text { item 11.03) e da redução de custo de construção } \\
\text { impõem uma minimização dos afastamentos que } \\
\text { interfere na criação de áreas livres intramuros (ver } \\
\text { item 13.02). Os afastamentos variam em função da } \\
\text { localização e do terreno, enquanto os mesmos } \\
\text { condicionam os quesitos da barreira perimetral. } \\
\text { Vínculos: Localização, Dimensionamento, Conforto } \\
\text { Ambiental e Controle. }\end{array}$ & $\begin{array}{l}\text { interno. Em particular, os afastamentos equacionam a } \\
\text { altura da barreira (ver item 16.06) e viabilizam } \\
\text { aparatos de segurança (ver item 16.08). O tipo de } \\
\text { barreira e a característica das edificações } \\
\text { (horizontalidade e o fechamento) podem absorver } \\
\text { parte do fechamento exigido, o que favorece } \\
\text { dimensões menores. Caso contrário, as distâncias } \\
\text { tendem a maximização, limitada pela segurança } \\
\text { (distancia entre as torres), funcionalidade (tamanho } \\
\text { dos percursos) e custo (quantitativos). }\end{array}$ & $\begin{array}{l}\text { Estimar afastamentos mínimos da ordem de } \\
\text { trinta metros para unidades consideradas } \\
\text { vulneráveis [DB, p. 34; PR]. } \\
\text { Limitar a maximização dos afastamentos em } \\
\text { trinta metros. } \\
\text { Fechar os afastamentos externos, no limite } \\
\text { da área de segurança, por meio de cerca com } \\
\text { dois metros de altura em mourões de } \\
\text { concreto e tela (sem elementos cortantes ou } \\
\text { perfurantes) [DB, p. 34; PR]. }\end{array}$ \\
\hline $\begin{array}{l}16.11 \\
\text { Considerar a pista de ronda } \\
\text { para o estabelecimento } \\
\text { penal a ser projetado, } \\
\text { segundo o nível de } \\
\text { segurança estipulado }\end{array}$ & $\begin{array}{l}\text { A pista de ronda integra as medidas de reforço da } \\
\text { barreira perimetral voltadas para evitar a fuga de } \\
\text { presos, no caso pela fiscalização da integridade da } \\
\text { barreira de perimetral. A pista de ronda pode } \\
\text { descrever a circulação dos guardas (ver item 16.07) } \\
\text { e facilitar o acesso de veículos para intervenções } \\
\text { em situações excepcionais (atendimento médico, } \\
\text { combate a incêndio, obras civis, entre outros). } \\
\text { Vínculos: Controle. }\end{array}$ & $\begin{array}{l}\text { A barreira perimetral deve prever a pista de ronda } \\
\text { veicular. A pista de ronda pode ser acessada pela } \\
\text { vistoria veicular ou por acesso exclusivo e restrito a } \\
\text { situações excepcionais. A mesma deve circundar o } \\
\text { perímetro da barreira perimetral ou cul de sac. No } \\
\text { caso de afastamentos externos amplos, pode ser } \\
\text { prevista uma pista de ronda secundária para inspeção } \\
\text { do perímetro externo. }\end{array}$ & $\begin{array}{l}\text { Prever pista de ronda veicular com largura } \\
\text { mínima de } 2,5 \mathrm{~m} \text { e raio mínimo de } 10 \mathrm{~m} \text {, } \\
\text { inserida no perímetro da barreira perimetral } \\
\text { (fora da linha de tiro) [DB, p. } 34 ; \mathrm{PR}] \text {. }\end{array}$ \\
\hline \multicolumn{4}{|l|}{ 17. Cela } \\
\hline \multicolumn{4}{|c|}{ É definida essencialmente pelo nível de segurança. Relaciona-se fortemente com o Porte e o Custo do estabelecimento. Reproduz os quesitos da Organização do Espaço. } \\
\hline Requisito & Fundamentação Teórica & Procedimento Metodológico & Recursos Técnicos \\
\hline $\begin{array}{l}\text { Favorecer a disciplina e o } \\
\text { monitoramento do interior } \\
\text { da cela por meio da } \\
\text { geometria, segundo o nível } \\
\text { de segurança do } \\
\text { estabelecimento penal a } \\
\text { ser projetado }\end{array}$ & $\begin{array}{l}\text { A cela adere à simplicidade geométrica, em favor } \\
\text { da visualização e dos procedimentos de segurança, } \\
\text { ao reproduzir a racionalidade do utilitarismo em } \\
\text { prol do controle (ver itens } 06.01,17.10 \text { e } 17.11 \text { ). A } \\
\text { apreensão do local é completa e direta, sem } \\
\text { pontos cegos ou esconderijos, o que simplifica e } \\
\text { agiliza as revistas. Vínculos: Geometria e Controle. }\end{array}$ & $\begin{array}{l}\text { A cela deve apresentar a maior simplicidade } \\
\text { geométrica possível com o uso de formas puras, } \\
\text { regulares e lineares, coordenadas por meio da } \\
\text { centralidade, simetria, ortogonalidade e alinhamentos. } \\
\text { A simplicidade geométrica tende a compactar a ala } \\
\text { carcerária e aumentar o aproveitamento do espaço } \\
\text { interno (maior utilidade). }\end{array}$ & $\begin{array}{l}\text { Conceber plantas retangulares e paredes } \\
\text { prismáticas retas, sem reentrâncias ou } \\
\text { saliências, além de pisos sem desníveis [PR]. } \\
\text { Os tetos podem ser inclinados [PR]. }\end{array}$ \\
\hline $\begin{array}{l}\text { Alojar os presos para o } \\
\text { descanso diário }\end{array}$ & $\begin{array}{l}\text { A cela recupera a multifuncionalidade do esquema } \\
\text { panóptico, evidenciando o integralismo no espaço } \\
\text { do alojamento, ao abrigar atividades do cotidiano } \\
\text { do preso (ver itens } 17.03,17.04 \text { e 17.05), tanto } \\
\text { formais (o descanso noturno, a guarda de } \\
\text { pertences pessoais, a higiene pessoal e o serviço } \\
\text { sanitário), como informais (entretenimento, } \\
\text { alimentação, exercícios físicos, faxina, trabalhos }\end{array}$ & $\begin{array}{l}\text { A cela deve comportar a diversidade funcional } \\
\text { existente, de modo a atender as necessidades } \\
\text { espaciais exigidas pelo cotidiano prisional e evitar } \\
\text { improvisos por parte dos presos ou funcionários. A } \\
\text { definição das atividades deve considerar a segurança, } \\
\text { a funcionalidade e o conforto (ver item 14.04), em } \\
\text { termos da espacialização e dimensionamento (ver item } \\
\text { 17.07). No caso de não atendimento, a atividade deve }\end{array}$ & $\begin{array}{l}\text { Considerar um acréscimo de } 40 \text { a } 50 \% \text { de } \\
\text { área em relação aos modelos correntes [DB, } \\
\text { p. 31; PSI 12/2012; MD]. } \\
\text { Estimar a distribuição das atividades em } \\
\text { (percentual da área útil) (PR): dormitório } \\
\text { (40\%), banheiro (15\%), entretenimento e } \\
\text { refeição (15\%), serviços (15\%) e área interna } \\
\text { livre/circulação (15\%) [PR; MD]. }\end{array}$ \\
\hline
\end{tabular}




\begin{tabular}{|c|c|c|c|}
\hline & $\begin{array}{l}\text { lanuais, lavagem e secagem de roupas). Vínculo: } \\
\text { tividades. }\end{array}$ & ser redirecionada para outro local. & $\begin{array}{l}\text { Prever tanque de lavar no caso de lavagem } \\
\text { de panos de faxina ou de roupa [RP]. }\end{array}$ \\
\hline 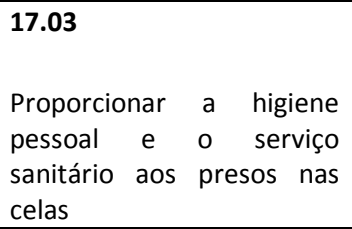 & $\begin{array}{l}\text { A permanência dos presos nas celas exige a higiene } \\
\text { pessoal e o serviço sanitário. A inclusão do banho } \\
\text { favorece a simplicidade funcional, ao reduzir os } \\
\text { procedimentos para o banho externo à cela (ver } \\
\text { itens } 08.02 \text { e 17.08). Vínculo: Conforto Ambiental. }\end{array}$ & $\begin{array}{l}\text { A cela deve prever pia ou cuba para lavar as mãos, } \\
\text { escovar os dentes e barbear, além de vaso sanitário } \\
\text { para satisfazer as necessidades fisiológicas e chuveiro } \\
\text { para tomar o banho. }\end{array}$ & $\begin{array}{l}\text { Prever uma pia ou cuba, um vaso sanitário e } \\
\text { um chuveiro para celas até oito vagas [LEP, } \\
\text { art. 88; RM, art. 9; DB, p. } 31 \text { e 41; PR; } \\
\text { UNOPS, 2016, p. 93]. }\end{array}$ \\
\hline $\begin{array}{l}17.04 \\
\text { Providenciar mobiliário } \\
\text { para apoiar as atividades } \\
\text { realizadas na cela, } \\
\text { configurado segundo o } \\
\text { nível de segurança do } \\
\text { estabelecimento penal a } \\
\text { ser projetado }\end{array}$ & $\begin{array}{l}\text { A permanência dos presos na cela exige mobiliário } \\
\text { para a funcionalidade do local, o que remete à } \\
\text { minúcia panóptica. As exigências de segurança e } \\
\text { economia preconizam a simplificação e a } \\
\text { minimização do mobiliário, de modo a facilitar o } \\
\text { procedimento de revista na cela (ver itens } 17.02 \text { e } \\
\text { 17.11). Ao mesmo tempo o mobiliário incorpora a } \\
\text { demanda de otimização do espaço (aumento da } \\
\text { capacidade). Vínculo: Custo. }\end{array}$ & $\begin{array}{l}\text { A cela deve prever mobiliário para as atividades } \\
\text { realizadas na cela (ver item 17.01), tais como, camas, } \\
\text { prateleiras, bancadas e mesas com bancos (ver item } \\
\text { 17.06). O mobiliário deve evitar o esconderijo de } \\
\text { objetos e resistir ao vandalismo. A otimização do } \\
\text { espaço é obtida com a especificação de beliches } \\
\text { (beliches de três camas são desaconselhados por } \\
\text { complicar a revista e arriscar a segurança do } \\
\text { funcionário). A escada é facultativa. Cada cama deve } \\
\text { ter prateleira individual e podem ser previstas } \\
\text { prateleiras de uso comum. A mesa é de uso coletivo. } \\
\text { Mesas individuais são opcionais. }\end{array}$ & $\begin{array}{l}\text { Considerar as dimensões mínimas da cama } \\
\text { em } 70 \times 190 \mathrm{~cm} \text { [DB]. } \\
\text { Considerar a distância vertical entre as } \\
\text { camas em } 1,20 \mathrm{~m} \text { [UNOPS, 2016, p. } 94] \text {. } \\
\text { Considerar o pé-direito mínimo de } 3,50 \mathrm{~m} \\
\text { para beliches de três camas [DB, p. 31]. } \\
\text { Estimar a área das prateleiras individuais em, } \\
\text { pelo menos, } 0,5 \mathrm{~m}^{2} \text { [PR]. } \\
\text { Vetar peças fechadas (armário ou gavetas) } \\
\text { ou articuladas (retráteis ou dobráveis) [RP]. } \\
\text { O mobiliário deve maciço (sem reentrâncias } \\
\text { ou vazios), fixo (piso e paredes) e solidário. }\end{array}$ \\
\hline $\begin{array}{l}17.05 \\
\text { Compor o espaço } \\
\text { arquitetônico da cela em } \\
\text { função da disciplina } \\
\text { espacial, segundo o nível } \\
\text { de segurança do } \\
\text { estabelecimento penal a } \\
\text { ser projetado }\end{array}$ & $\begin{array}{l}\text { A cela adere à simplicidade funcional (ver item } \\
06.02 \text { ), ao reproduzir a racionalidade do } \\
\text { utilitarismo em prol da funcionalidade e do } \\
\text { controle (procedimentos de segurança e } \\
\text { visualização) (ver item 17.11), em favor da } \\
\text { utilidade do local do ponto de vista econômico da } \\
\text { prisão (ver item 05.03). No sistema penitenciário, } \\
\text { os presos demandam certa privacidade, em } \\
\text { especial, do banheiro (humanização da pena). } \\
\text { Vínculos: Espacialização e o Controle. }\end{array}$ & $\begin{array}{l}\text { A cela deve configurar um ambiente único e compacto, } \\
\text { no qual os lugares são integrados de modo serial, por } \\
\text { uma circulação central (não existem espaços fechados } \\
\text { - portas são vetadas). Os lugares são funcionalmente } \\
\text { especializados, ao abrigar atividades afins, o que limita } \\
\text { a compartimentação (ver itens } 17.02 \text { e 17.03). O } \\
\text { arranjo estabelece uma privacidade progressiva na } \\
\text { profundidade topológica. Em qualquer caso, o } \\
\text { banheiro deve ser locado ao fundo da cela. }\end{array}$ & $\begin{array}{l}\text { Aplicar a simplicidade geométrica e a } \\
\text { impessoalidade como mecanismos de } \\
\text { ajustamento da complexidade inerente a } \\
\text { multifuncionalidade e a subdivisão do espaço } \\
\text { da cela (ver itens } 17.01 \text { e 17.06). } \\
\text { Demarcar o espaço por meio de divisórias } \\
\text { estreitas e baixas (ambientes e camas). }\end{array}$ \\
\hline 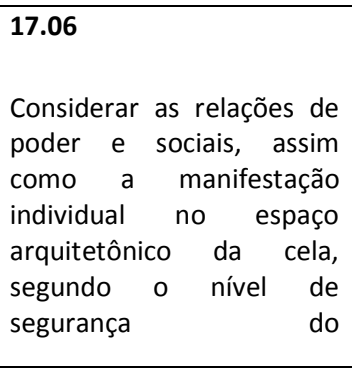 & $\begin{array}{l}\text { A natureza totalitária da prisão define a cela como } \\
\text { um território institucional (ver item 10.02), cujo } \\
\text { domínio é instituído por meio da disciplina que } \\
\text { restringe a apropriação do espaço físico. Este } \\
\text { processo é refreado pela privacidade em relação à } \\
\text { instituição (ver item 17.11) e pelas relações sociais } \\
\text { dos presos que esquadrinham a cela em territórios } \\
\text { de grupo e pessoais. Na prática, surgem demandas } \\
\text { realísticas: as atividades realizadas na cela, a } \\
\text { privacidade do banheiro e o espaço individual }\end{array}$ & $\begin{array}{l}\text { A cela deve definir a maior impessoalidade espacial } \\
\text { possível, por meio da simplicidade funcional (espaços } \\
\text { minimamente equipados e dimensionados) e da } \\
\text { exposição das pessoas (espaços devassados). Em } \\
\text { contrapartida, a cela deve configurar locais coletivos e } \\
\text { individuais para a realização das atividades, de acordo } \\
\text { com as manifestações sociais e pessoais dos presos. Os } \\
\text { locais coletivos envolvem o grupo completo de presos. } \\
\text { O local individual se limita ao nicho do beliche, } \\
\text { restringida pelo aumento da capacidade da cela. O }\end{array}$ & $\begin{array}{l}\text { Especializar e distinguir os locais coletivos, } \\
\text { individuais e comuns (privacidade) [RP]. } \\
\text { Conceber mesa e bancos para o grupo } \\
\text { completo de presos [RP] (ver item 17.04). } \\
\text { Valorizar os locais individuais, através de } \\
\text { mobiliário e aparatos de fechamento [RP]. } \\
\text { Subdividir os serviços sanitários e de higiene } \\
\text { pessoal do banheiro por meio de divisórias } \\
\text { baixas (lavabo, vaso sanitário e banho), sem } \\
\text { portas [RP]. }\end{array}$ \\
\hline
\end{tabular}




\begin{tabular}{|c|c|c|c|}
\hline $\begin{array}{l}\text { estabelecimento penal a } \\
\text { ser projetado }\end{array}$ & (humanização da pena). Vínculo: Espacialização. & $\begin{array}{l}\text { banheiro é o local comum da cela, no qual se } \\
\text { concentra a privacidade pessoal (localização e } \\
\text { configuração) que se reproduz em suas partes. }\end{array}$ & \\
\hline $\begin{array}{l}17.07 \\
\text { Dimensionar a cela de } \\
\text { acordo com a capacidade } \\
\text { estipulada e segundo o } \\
\text { nível de segurança do } \\
\text { estabelecimento penal a } \\
\text { ser projetado }\end{array}$ & $\begin{array}{l}\text { O Princípio de Utilidade (ver item 08.02) determina } \\
\text { o dimensionamento da cela segundo o número de } \\
\text { usuários e as atividades a serem abrigadas (ver } \\
\text { item 17.05), condicionado pela segurança } \\
\text { penitenciária (ver item 10.05) e pelo custo de } \\
\text { construção (ver item 11.02). A estas } \\
\text { condicionantes se somam as exigências realísticas: } \\
\text { as atividades realizadas no pátio e a consequente } \\
\text { variação espacial (humanização da pena) (ver item } \\
\text { 17.05) Vínculo: Custo. }\end{array}$ & $\begin{array}{l}\text { A cela deve ter as dimensões minimizadas, cujo limite } \\
\text { é a funcionalidade que deve articular o aumento de } \\
\text { capacidade, o adensamento (beliches) e as múltiplas } \\
\text { atividades realizadas nas celas, além das relações de } \\
\text { poder e sociais (ver itens } 17.02 \text { e } 17.06 \text { ). Isto tende a } \\
\text { um aumento da área para a acomodação dos locais } \\
\text { funcionalmente especializados, inclusive do mobiliário. }\end{array}$ & $\begin{array}{l}\text { Para celas de quatro e oito vagas, estimar as } \\
\text { dimensões mínimas (respectivamente): área } \\
\text { de } 3,0 \mathrm{~m}^{2} / \text { vaga e } 3,35 \mathrm{~m}^{2} / \text { vaga; cubagem de } \\
9 \mathrm{~m}^{3} / \text { vaga e } 10,05 \mathrm{~m}^{3} / \text { vaga; largura de } 2,70 \mathrm{~m} \\
\text { e } 3,00 \mathrm{~m} \text {. } \\
\text { Estimar o pé-direito em, pelo menos, } 2,45 \mathrm{~m} \text {. } \\
\text { Estimar a largura da circulação em, pelo } \\
\text { menos, } 1,50 \mathrm{~m} \text {. } \\
\text { [DB, p. } 31 ; \mathrm{PR} ; \mathrm{MD} \text {; UNOPS, } 2016, \text { p. } 93 \text { e } 94] \text {. }\end{array}$ \\
\hline 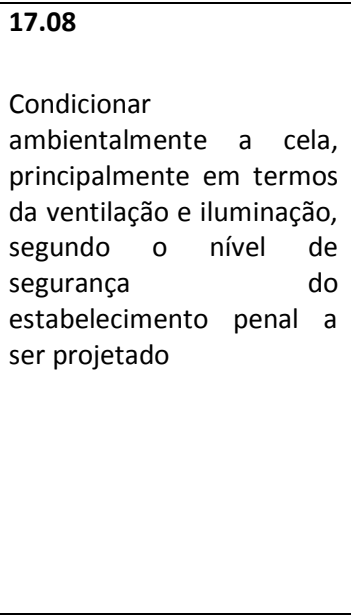 & $\begin{array}{l}\text { O conforto ambiental permeia a composição } \\
\text { arquitetônica da cela (ver itens } 17.02 \text { e 17.05), } \\
\text { associada ao respeito à condição humana na } \\
\text { prisão, cujo contraponto e a segurança } \\
\text { penitenciária (ver item 10.05). O conforto } \\
\text { ambiental prioriza os aspectos lumínico e térmico, } \\
\text { materializados nas aberturas de iluminação e } \\
\text { ventilação (ver item 13.01) que devem respeitar a } \\
\text { impermeabilidade, a estanqueidade e o controle } \\
\text { institucional (ver item 17.09). A solução de } \\
\text { conforto varia em função da posição solar e dos } \\
\text { ventos dominantes. O conforto ambiental também } \\
\text { envolve o banheiro da cela em termos da } \\
\text { qualidade do ar (ver item 17.03). Na prática, os } \\
\text { presos demandam a regulagem da ventilação e o } \\
\text { isolamento do banheiro (humanização da pena). } \\
\text { Vínculo: Conforto Ambiental. }\end{array}$ & $\begin{array}{l}\text { A cela deve estender as providências de segurança até } \\
\text { o limite mínimo do conforto ambiental. A segurança } \\
\text { exigida prioriza aberturas indiretas ou zenitais, } \\
\text { enquanto restringe a ventilação cruzada (vetada } \\
\text { quando aberta para áreas ocupadas por outros presos } \\
\text { ou funcionários). Assim como, a visualização do } \\
\text { exterior é dispensável. O limite mínimo deve } \\
\text { considerar a quantidade de pessoas e as atividades } \\
\text { realizadas. A regulagem das aberturas de ventilação é } \\
\text { facultativa. Na especificação da mesma, esta deve ser } \\
\text { inacessível aos presos e exclusivamente manuseada } \\
\text { pelos funcionários. O banheiro deve ser isolado do } \\
\text { dormitório por meio da localização e configuração das } \\
\text { aberturas (retirada do ar contaminado advindo do } \\
\text { vaso sanitário). Os locais individuais devem ser } \\
\text { ambientados por pequenas aberturas nas divisórias } \\
\text { (renovação do ar). }\end{array}$ & $\begin{array}{l}\text { Considerar os critérios e parâmetros gerais } \\
\text { de conforto ambiental (ver item 13.01), } \\
\text { apoiados pelas recomendações específicas } \\
\text { para a cela [LEP, art. 88; RM, art. 9]. } \\
\text { Prever a regulagem das aberturas por meio } \\
\text { de dispositivos mecânicos simples [RP]. } \\
\text { Considerar a tela mosquiteira nas aberturas } \\
\text { [RP]. } \\
\text { Especificar ventilação com diferença de nível } \\
\text { ou com zenital para o isolamento do } \\
\text { banheiro (convecção, sucção ou canalização) } \\
\text { [DEPEN, 2012]. } \\
\text { Locar as aberturas nas divisórias das camas a } \\
30 \mathrm{~cm} \text { acima do colchão [DEPEN, 2012]. } \\
\text { Dimensionar o pé-direito mínimo de celas } \\
\text { com camas, pelo menos, 2,50m (ver item } \\
\text { 17.07) [NBR 15.575-1]. }\end{array}$ \\
\hline $\begin{array}{l}17.09 \\
\text { Reforçar as propriedades } \\
\text { disciplinares da cela por } \\
\text { meio de aparatos de } \\
\text { segurança, segundo o nível } \\
\text { de segurança estipulado } \\
\text { para estabelecimento } \\
\text { penal a ser projetado }\end{array}$ & $\begin{array}{l}\text { Os aparatos de segurança contribuem para a } \\
\text { estanqueidade e impermeabilidade da cela (ver } \\
\text { itens } 16.02 \text { e 16.03), além da disciplina e da } \\
\text { preservação dos funcionários. A integralização das } \\
\text { propriedades da cela por meio da geometria ou } \\
\text { configuração implica em custos comparativamente } \\
\text { elevados à aplicação destes aparatos. As } \\
\text { providências de segurança se estendem até a } \\
\text { condição humana dos presos (funcionalidade e } \\
\text { conforto ambiental) (ver itens 10.05, 17.04 e }\end{array}$ & $\begin{array}{l}\text { As propriedades da cela devem ser maximizadas e } \\
\text { homogeneizadas: o reforço do conjunto e a correção } \\
\text { dos componentes mais débeis. A definição das } \\
\text { vulnerabilidades deve considerar a quantidade de } \\
\text { presos e as atividades previstas, assim como, os } \\
\text { procedimentos institucionais (contagem dos presos, } \\
\text { revista da cela, contenção de crises). Os pontos } \\
\text { conhecidamente críticos são a porta de acesso e as } \\
\text { aberturas de iluminação e ventilação. A visibilidade } \\
\text { das fachadas e coberturas deve ser observada (pontos }\end{array}$ & $\begin{array}{l}\text { Especificar preferencialmente brises ou } \\
\text { pergolados para as aberturas de iluminação e } \\
\text { ventilação. A alternativa são grades duplas } \\
\text { [PR]. } \\
\text { Prever dispositivos de bloqueio visual junto } \\
\text { das aberturas de iluminação e ventilação } \\
\text { [PR]. } \\
\text { Especificar porta de correr, dotada de } \\
\text { mecanismos de travamento, operação e } \\
\text { visualização (portinholas) [DB, p. 40]. }\end{array}$ \\
\hline
\end{tabular}




\begin{tabular}{|c|c|c|c|}
\hline & $\begin{array}{l}\text { 17.08). Vínculos: Funcionalidade e Conforto } \\
\text { Ambiental. }\end{array}$ & $\begin{array}{l}\text { cegos)(ver item 15.03), assim como, os afastamentos } \\
\text { podem absorver parte do fechamento exigido. }\end{array}$ & $\begin{array}{l}\text { Prever portinholas nas paredes para garantir } \\
\text { a visualização interna. }\end{array}$ \\
\hline $\begin{array}{l}\text { Definir a abertura ou } \\
\text { fechamento da cela de } \\
\text { acordo com a visualização } \\
\text { do interior pretendida, } \\
\text { segundo o nível de } \\
\text { segurança estipulado para } \\
\text { estabelecimento penal a } \\
\text { ser projetado }\end{array}$ & $\begin{array}{l}\text { O controle panóptico depende da visibilidade do } \\
\text { interior da cela para firmá-la como território } \\
\text { institucional (ver item 15.01). Colateralmente, esta } \\
\text { abertura permite a inversão da vigilância e a } \\
\text { comunicação informal, o que leva ao fechamento } \\
\text { da cela e o domínio territorial local dos presos (ver } \\
\text { item 17.06). Na prática, os presos demandam a } \\
\text { privacidade (humanização da pena), enquanto os } \\
\text { funcionários demandam a proteção contra ataques } \\
\text { e a ampliação do monitoramento (para os } \\
\text { funcionários, a audição e o olfato também são } \\
\text { relevantes). Vínculo: Controle. }\end{array}$ & $\begin{array}{l}\text { O fechamento da cela deve ser relativizado quanto à } \\
\text { unilateralidade e extensão da informação. O } \\
\text { funcionário tem a percepção do interior da cela (visual, } \\
\text { auditiva e olfativa), dentro dos critérios de } \\
\text { privacidade, mas o inverso é vetado aos presos. Neste } \\
\text { sentido, a inverificabilidade institucional deve ser } \\
\text { aplicada às aberturas de visualização, a serem } \\
\text { utilizadas no esquema de ronda (aberturas de } \\
\text { iluminação e ventilação podem ser utilizadas). Estas } \\
\text { aberturas devem impedir o ataque aos funcionários, } \\
\text { por meio das distancias e aparatos de segurança. As } \\
\text { mesmas também devem viabilizar a intervenção para a } \\
\text { contenção de amotinamentos ou brigas. }\end{array}$ & $\begin{array}{l}\text { Aplicar o princípio da inspeção (ver item } \\
\text { 15.02). } \\
\text { Prever portinhola e visor na porta (pode ser } \\
\text { o mesmo componente) [DB, p. 40]. } \\
\text { Prever aberturas nas paredes ou tetos que } \\
\text { podem ser dotadas de visores ou } \\
\text { portinholas. }\end{array}$ \\
\hline 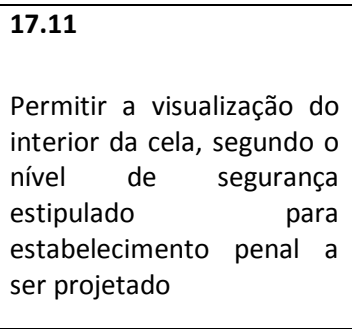 & $\begin{array}{l}\text { O controle define a melhor visualização possível do } \\
\text { interior da cela desde pontos de observação (ver } \\
\text { item 17.10), o que abrange a geometria e a } \\
\text { configuração do espaço interno (ver itens } 17.01 \text {, } \\
17.04 \text { e 17.05). A apreensão do local é completa e } \\
\text { imediata, sem pontos cegos ou esconderijos, o que } \\
\text { também simplifica as revistas. A privacidade dos } \\
\text { presos exige minimamente a reserva no uso do } \\
\text { banheiro. Vínculos: Espacialização e o Controle. }\end{array}$ & $\begin{array}{l}\text { A cela deve permitir a visualização máxima de seu } \\
\text { interior pelo funcionário, o que determina uma rápida } \\
\text { apreensão do ambiente. Para tanto, o espaço deve } \\
\text { retificado pela aplicação da simplicidade funcional. O } \\
\text { mobiliário deve ser periférico (junto às paredes) (ver } \\
\text { item 17.04). A mesma deve prever mais de um ponto } \\
\text { de observação de modo a evitar pontos cegos onde } \\
\text { presos possam se esconder (pontos geradores } \\
\text { isométricos). }\end{array}$ & $\begin{array}{l}\text { Aplicar a simplicidade funcional (ver item } \\
\text { 17.04). } \\
\text { Prever portinholas e visores que permitam a } \\
\text { visualização da maior parte da cela. } \\
\text { Estimar a visualização entre } 47 \% \text { e } 67 \% \text { da } \\
\text { área da cela, a considerar um valor ótimo de } \\
58 \% \text { (isovista) [PR]. }\end{array}$ \\
\hline \multicolumn{4}{|l|}{ 18. Pátio de sol dos presos } \\
\hline \multicolumn{4}{|c|}{ É definido essencialmente pelo nível de segurança. Relaciona-se fortemente com o Porte e o Custo do estabelecimento. Reproduz os quesitos da Organização do Espaço. } \\
\hline & & & \\
\hline $\begin{array}{l}\text { Propiciar o banho de sol } \\
\text { dos presos, segundo o nível } \\
\text { de segurança estipulado } \\
\text { para estabelecimento } \\
\text { penal a ser projetado }\end{array}$ & $\begin{array}{l}\text { O banho de sol dos presos constitui uma questão } \\
\text { de saúde e economia, inserido no conjunto de } \\
\text { atividades coletivas, complementares ao } \\
\text { isolamento individual (ver item 17.02). Estima-se o } \\
\text { banho de sol diário de, pelo menos, duas horas. Do } \\
\text { ponto de vista da disciplina, o pátio pode receber } \\
\text { atividades afins, limitadas em razão da segurança e } \\
\text { da funcionalidade (ver item 10.03). Vínculo: } \\
\text { Atividades. }\end{array}$ & $\begin{array}{l}\text { O espaço arquitetônico deve prever local descoberto, } \\
\text { primariamente destinado ao banho de sol dos presos, } \\
\text { podendo receber atividades afins, como esportes e } \\
\text { exercícios físicos. Atividades de sociabilização e } \\
\text { entretenimento podem ocupar local conexo ao pátio. } \\
\text { Outras atividades devem ser destinadas a locais } \\
\text { específicos (refeições, culto religioso, lavagem de } \\
\text { roupas) (ver item 09.01). }\end{array}$ & $\begin{array}{l}\text { Prever espaço descoberto [LEP, art. 83; RM, } \\
\text { art. 14; DB, p. } 47 \text {; UNOPS, 2016, p. 95]. } \\
\text { Prever quadra de futebol } 4(6 \times 12 \mathrm{~m}) \text { ou } 5 \\
(10 \times 18 \mathrm{~m}) \text { (pintura no piso) [idem]. } \\
\text { Prever espaço para caminhada [RP]. } \\
\text { Cogitar bancos ou degraus para a prática de } \\
\text { exercícios físicos (ver item 18.06) [RP; } \\
\text { UNOPS, 2016, p. 95]. }\end{array}$ \\
\hline $\begin{array}{l}\text { Separar os diferentes perfis } \\
\text { de presos para o banho de }\end{array}$ & $\begin{array}{l}\text { A classificação e a separação dos presos na prisão } \\
\text { atingem a definição dos pátios de sol que } \\
\text { reproduzem o fracionamento da população } \\
\text { prisional (ver item 10.04). O isolamento dos presos }\end{array}$ & $\begin{array}{l}\text { O espaço arquitetônico deve apresentar um pátio para } \\
\text { cada ala carcerária ou bloco de vivência. Um pátio } \\
\text { pode ser utilizado por dois grupos de presos em } \\
\text { regime de revezamento, desde que a estrutura física e }\end{array}$ & $\begin{array}{l}\text { Prever, preferencialmente, quatro pátios de } \\
\text { sol, ou dois pátios de sol para cada duas alas } \\
\text { carcerárias (uso alternado pelos grupos de } \\
\text { presos) [DB, p. } 29 \text { e } 47 ; \text { PR]. }\end{array}$ \\
\hline
\end{tabular}




\begin{tabular}{|c|c|c|c|}
\hline sol & $\begin{array}{l}\text { de diferentes das alas carcerárias deve ser } \\
\text { absoluto durante o banho de sol, em termos da } \\
\text { comunicação entre estes grupos e da percepção } \\
\text { dos espaços adjacentes (impermeabilidade). } \\
\text { Vínculos: Custo e a Espacialização. }\end{array}$ & $\begin{array}{l}\text { operacional permita o translado dos presos. Os pátios } \\
\text { devem ser configurados e arranjados de modo a serem } \\
\text { impermeáveis, por meio do fechamento e altura das } \\
\text { vedações e das coberturas. }\end{array}$ & Coincidir as coberturas de pátios vizinhos. \\
\hline $\begin{array}{l}18.03 \\
\text { Compatibilizar } \\
\text { capacidade do pátio de sol } \\
\text { com o nível de segurança } \\
\text { do estabelecimento penal } \\
\text { a ser projetado }\end{array}$ & $\begin{array}{l}\text { O pátio segue a lógica do isolamento individual, } \\
\text { segundo a qual a individualização absoluta é } \\
\text { substituída pela coletivização, porém regrada pelo } \\
\text { menor número de presos possível (ver itens } 05.06 \\
\text { e } 10.04 \text { ). O pátio de sol individual é destinado às } \\
\text { celas individuais. Na prática, o pátio de sol pode } \\
\text { ser utilizado para a aglomeração dos presos nos } \\
\text { casos de revistas gerais ou contenção de crises. } \\
\text { Vínculos: Porte, Custo e Dimensionamento. }\end{array}$ & $\begin{array}{l}\text { O espaço arquitetônico deve ser dotado de pátios } \\
\text { coletivos, a destinar os pátios individuais para os } \\
\text { presos isolados. A menor capacidade é obtida pelo } \\
\text { fracionamento da ala carcerária e pela alternância na } \\
\text { utilização do local, a considerar o tempo mínimo de } \\
\text { banho de sol (ver item 18.09). A menor capacidade } \\
\text { deve gerar um espaço suficiente para abrigar o grupo } \\
\text { da ala carcerária, }\end{array}$ & $\begin{array}{l}\text { Considerar a capacidade cotidiana entre } 36 \text { e } \\
50 \text { presos, a considerar um valor ótimo de } 36 \\
\text { presos (fração da ala carcerária) e eventual } \\
\text { entre } 120 \text { e } 150 \text { presos, a considerar um } \\
\text { valor ótimo de } 144 \text { presos (ala carcerária } \\
\text { completa) [DB, p. } 30 ; \text { RP]. } \\
\text { Considerar o tempo de pátio em duas horas } \\
\text { (quatro turnos por dia) e os procedimentos } \\
\text { de revezamento em quinze minutos [LEP; } \\
\text { RM; UNOPS, 2016, p. 95; RP]. }\end{array}$ \\
\hline $\begin{array}{l}18.04 \\
\text { Favorecer a disciplina e o } \\
\text { monitoramento do interior } \\
\text { do pátio de sol por meio da } \\
\text { geometria, segundo o nível } \\
\text { de segurança do } \\
\text { estabelecimento penal a } \\
\text { ser projetado }\end{array}$ & $\begin{array}{l}\text { O pátio adere à simplicidade geométrica, em favor } \\
\text { da visualização e dos procedimentos de segurança } \\
\text { no interior da local, reproduzindo a racionalidade } \\
\text { do utilitarismo em prol do controle (ver itens } 06.01 \\
\text { e 18.12). A apreensão do local é completa e direta, } \\
\text { sem pontos cegos ou esconderijos, o que simplifica } \\
\text { e agiliza as revistas. Vínculos: Geometria e } \\
\text { Controle. }\end{array}$ & $\begin{array}{l}\text { O pátio deve apresentar a maior simplicidade } \\
\text { geométrica possível com o uso de formas puras, } \\
\text { regulares e lineares, coordenadas por meio da } \\
\text { centralidade, simetria, ortogonalidade e alinhamentos. } \\
\text { A simplicidade geométrica tende a compactar o bloco } \\
\text { de vivência e aumentar o aproveitamento do espaço } \\
\text { interno (maior utilidade). Em termos da funcionalidade } \\
\text { e da humanização do espaço, o recorte do desenho } \\
\text { pode ser implementado (chanfros, arredondamentos, } \\
\text { níveis, alturas, inclinações), em função da visualização. }\end{array}$ & $\begin{array}{l}\text { Conceber plantas retangulares e paredes } \\
\text { prismáticas retas, sem reentrâncias ou } \\
\text { saliências [PR]. } \\
\text { Evitar elementos estruturais ou } \\
\text { arquitetônicos que facilitem a escalada [PR]. } \\
\text { Condicionar eventuais recortes aos ângulos } \\
\text { de visualização dos pontos de controle } \\
\text { (isovista). } \\
\text { Prever a cobertura em altura equivalente aos } \\
\text { fechamentos do pátio. }\end{array}$ \\
\hline $\begin{array}{l}18.05 \\
\text { Compor o espaço interno } \\
\text { do pátio de sol em função } \\
\text { da disciplina espacial, } \\
\text { segundo o nível de } \\
\text { segurança } \\
\text { estabelecimento penal a } \\
\text { ser projetado }\end{array}$ & $\begin{array}{l}\text { O pátio adere à simplicidade funcional (ver item } \\
\text { 06.02), reproduzindo a racionalidade do } \\
\text { utilitarismo em prol da funcionalidade e do } \\
\text { controle (ver item 18.12), em favor da utilidade do } \\
\text { local do ponto de vista econômico da prisão, assim } \\
\text { como da visualização e dos procedimentos de } \\
\text { segurança no interior do local. A privacidade e a } \\
\text { apropriação do espaço ocorrem pontualmente } \\
\text { devido a coletivizaça da atividade. Vínculos: } \\
\text { Espacialização e Controle. }\end{array}$ & $\begin{array}{l}\text { O pátio deve configurar um ambiente único e } \\
\text { compacto (não existem espaços fechados - portas são } \\
\text { vetadas). A previsão de área coberta implica na } \\
\text { contiguidade dos espaços, sem separação física. Os } \\
\text { sanitários e outros serviços devem ser cobertos e } \\
\text { dispostos perifericamente no espaço. O acesso ao } \\
\text { pátio e o mobiliário devem estar na área coberta. O } \\
\text { acesso e o espaço interno devem ser desimpedidos } \\
\text { para os procedimentos de saída dos presos e invasão } \\
\text { para a contenção de crises. }\end{array}$ & $\begin{array}{l}\text { Aplicar a simplicidade geométrica. } \\
\text { Estabelecer uma área livre junto ao acesso } \\
\text { do pátio [RP]. } \\
\text { Arrumar o mobiliário de modo a facilitar o } \\
\text { acesso e o trânsito interno [RP]. } \\
\text { Utilizar divisórias baixas e destacadas do piso } \\
\text { nos sanitários (portas são vetadas) [RP]. }\end{array}$ \\
\hline $\begin{array}{l}\text { Proporcionar condições de } \\
\text { permanência dos presos no } \\
\text { pátio, segundo o nível de }\end{array}$ & $\begin{array}{l}\text { A permanência dos presos no pátio exige } \\
\text { elementos para a funcionalidade e a comodidade } \\
\text { do local, em termos da realização das atividades e } \\
\text { do bem estar dos presos, o que remete à minúcia } \\
\text { panóptica (ver item 18.01). As exigências de }\end{array}$ & $\begin{array}{l}\text { O pátio deve ter uma área protegida das intempéries e } \\
\text { ser dotado de cuba, bebedouro e serviço sanitário, } \\
\text { além de mobiliário e apetrechos esportivos (ver item } \\
\text { 18.08). O banho é opcional. O mobiliário é composto } \\
\text { por mesas com diferentes capacidades para atividades }\end{array}$ & $\begin{array}{l}\text { Prever cobertura conexa ao pátio [DB, p. } 47 \text { e } \\
69 ; \text { PR; UNOPS, 2016, p. } 95 \text { e 99]. } \\
\text { Prever, pelo menos, uma torneira e um } \\
\text { bebedouro (água potável) para cada } 50 \\
\text { presos (opcionalmente, um chuveiro) }\end{array}$ \\
\hline
\end{tabular}




\begin{tabular}{|c|c|c|c|}
\hline $\begin{array}{l}\text { segurança } \\
\text { estabelecimento penal a } \\
\text { ser projetado }\end{array}$ & $\begin{array}{l}\text { segurança e economia preconizam a simplificação } \\
\text { e a minimização destes aparatos, para facilitar a } \\
\text { vigilância e o procedimento de revista no pátio (ver } \\
\text { item 18.10). Vínculos: Espacialização, Aparatos de } \\
\text { Segurança e Controle. }\end{array}$ & $\begin{array}{l}\text { variadas (quatro e oito bancos). Todos os presos } \\
\text { devem ter lugar para sentar. O mobiliário deve maciço } \\
\text { (sem reentrâncias ou vazios), fixo (piso e paredes) e } \\
\text { solidário. Os apetrechos para musculação são } \\
\text { facultativos, podendo ser pranchas retas ou inclinadas. } \\
\text { Os elementos devem ser mínimos e simples para evitar } \\
\text { o esconderijo de objetos e resistir ao vandalismo. }\end{array}$ & $\begin{array}{l}\text { [UNOPS, 2016, p. 95]. } \\
\text { Prever um vaso sanitário para cada } 25 \text { presos } \\
\text { [UNOPS, 2016, p. 95]. } \\
\text { Prever quadra de futebol pintada no piso da } \\
\text { área descoberta (ver item 18.01). } \\
\text { Prever mobiliário (bancos para a capacidade } \\
\text { projetada). }\end{array}$ \\
\hline $\begin{array}{l}18.07 \\
\text { Considerar a cantina ou } \\
\text { área conexa ao pátio para } \\
\text { a distribuição de refeições } \\
\text { segundo o nível de } \\
\text { segurança } \quad \text { do } \\
\begin{array}{ll}\text { estabelecimento penal a } \\
\text { ser projetado }\end{array}\end{array}$ & $\begin{array}{l}\text { A simplicidade funcional ditada pela especialização } \\
\text { dos locais (ver item 18.01) vai de encontro à } \\
\text { previsão de cantina ou distribuição no pátio de sol. } \\
\text { Na prática, a cantina desfavorece a segurança e a } \\
\text { funcionalidade, além de contribuir para a } \\
\text { economia da prisão. A distribuição torna-se inútil } \\
\text { com a realização das refeições nas celas. Vínculo: } \\
\text { Atividades. }\end{array}$ & $\begin{array}{l}\text { O pátio de sol deve ser especializado e a previsão de } \\
\text { cantina ou distribuição de refeições é desaconselhada. } \\
\text { A distribuição está atrelada ao refeitório que deve } \\
\text { constituir um local próprio, se houver previsão do } \\
\text { mesmo. }\end{array}$ & [LEP, art. 13; DB; PR] \\
\hline $\begin{array}{l}18.08 \\
\text { Considerar as relações de } \\
\text { poder e sociais, segundo o } \\
\text { nível de segurança do } \\
\text { estabelecimento penal a } \\
\text { ser projetado }\end{array}$ & $\begin{array}{l}\text { A natureza totalitária da prisão define o pátio } \\
\text { como um território institucional (ver item 10.02), } \\
\text { cujo domínio é consolidado por meio da disciplina } \\
\text { que restringe a apropriação do espaço físico, } \\
\text { através da vigilância absoluta (minimização da } \\
\text { privacidade). A síntese funcional abrevia a divisão } \\
\text { territorial entre os grupos de presos e define a } \\
\text { maior impessoalidade possível. A natureza coletiva } \\
\text { do local inviabiliza os locais pessoais. Estes } \\
\text { processos são refreados pelas relações sociais dos } \\
\text { presos que segmentam o pátio conforme os } \\
\text { interesses e a hierarquia da sua sociedade. Na } \\
\text { prática, surgem demandas realísticas: as atividades } \\
\text { realizadas no pátio e a privacidade do banheiro } \\
\text { (humanização da pena). Vínculo: Espacialização. }\end{array}$ & $\begin{array}{l}\text { O pátio deve definir a maior impessoalidade espacial } \\
\text { possível, por meio da simplicidade funcional (espaço } \\
\text { minimamente equipado e dimensionado) e da } \\
\text { exposição das pessoas (espaço devassado). Em } \\
\text { contrapartida, o pátio deve configurar locais para a } \\
\text { realização das atividades previstas, de acordo com as } \\
\text { manifestações dos presos (ver item 18.06): a } \\
\text { sociabilização envolve o grupo completo de presos } \\
\text { sentados (conversas e jogos), o esporte é a atividade } \\
\text { preferida (futebol) e os exercícios focam a caminhada } \\
\text { (com conversas). As relações sociais podem } \\
\text { estabelecer nuanças espaciais compatíveis com a } \\
\text { homogeneidade espacial (ver item 18.05): níveis ou } \\
\text { patamares, chanfros ou arredondamentos, a } \\
\text { disposição do mobiliário e diferentes alturas ou } \\
\text { desenhos dos tetos. A privacidade no pátio recai sobre } \\
\text { o uso do sanitário (localização e configuração). }\end{array}$ & $\begin{array}{l}\text { Dimensionar as mesas e os bancos para o } \\
\text { grupo completo de presos [RP]. } \\
\text { Prever quadra de futebol pintada no piso da } \\
\text { área descoberta (ver item 18.01). } \\
\text { Proteger as áreas para sociabilização e } \\
\text { caminhada de boladas do jogo de futebol } \\
\text { (ver item 18.05). } \\
\text { Considerar os chanfros ou arredondamentos } \\
\text { de cantos como fator de segurança (dificulta } \\
\text { a escalada) [RP]. } \\
\text { Estabelecer os desníveis ou elementos em } \\
\text { nível por meio da isovista dos pontos de } \\
\text { vigilância (ver item 18.04). } \\
\text { Utilizar divisórias baixas e destacadas do piso } \\
\text { nos sanitários (portas são vetadas) [RP]. }\end{array}$ \\
\hline $\begin{array}{l}\text { Dimensionar o pátio de } \\
\text { acordo com a capacidade e } \\
\text { segundo o nivel } \\
\text { segurança }\end{array}$ & $\begin{array}{l}\text { O Princípio de Utilidade (ver item 08.02) determina } \\
\text { o dimensionamento do pátio segundo o número } \\
\text { de usuários e as atividades a serem abrigadas (ver } \\
\text { item 18.03), condicionado pela segurança } \\
\text { penitenciária (ver item 10.05) e pelo custo de } \\
\text { construção (ver item 11.02). A estas } \\
\text { condicionantes se somam as exigências realísticas: }\end{array}$ & $\begin{array}{l}\text { O pátio deve ter dimensões mínimas, limitadas pela } \\
\text { funcionalidade que deve considerar as atividades } \\
\text { realizadas, além das relações de poder e sociais. O } \\
\text { dimensionamento deve atender igualmente, o uso } \\
\text { alternado do local por grupos menores de presos } \\
\text { (capacidade) e a ocupação pelo grupo completo de } \\
\text { presos (demanda). Estes cuidados tendem a aumentar }\end{array}$ & $\begin{array}{l}\text { Estimar a área do pátio de sol por pessoa } \\
\text { (capacidade) entre } 4,0 \text { e } 6,0 \mathrm{~m}^{2} \text { (a variar para } \\
\text { climas frios ou quentes, respectivamente). } \\
\text { Estimar a área do pátio de sol entre } 1,25 \text { e } \\
1,50 \mathrm{~m}^{2} \text { por pessoa (demanda). } \\
\text { Estimar a área coberta por pessoa } \\
\text { (capacidade) entre } 2,0 \text { e } 4,0 \mathrm{~m}^{2} \text { (a variar para }\end{array}$ \\
\hline
\end{tabular}




\begin{tabular}{|c|c|c|c|}
\hline $\begin{array}{l}\text { estabelecimento penal a } \\
\text { ser projetado }\end{array}$ & $\begin{array}{l}\text { as atividades realizadas no pátio e a consequente } \\
\text { variação espacial (humanização da pena) (ver item } \\
\text { 18.08). Na prática, o pátio é ocupado por grupos } \\
\text { menores de presos, segundo um rodízio no uso do } \\
\text { local (capacidade). Eventualmente, o pátio é } \\
\text { ocupado pelo grupo completo de presos (ala } \\
\text { carcerária) (demanda). Vínculo: Custo. }\end{array}$ & $\begin{array}{l}\text { a área. A minimização da altura ou do pé-direito deve } \\
\text { garantir a estanqueidade e impermeabilidade do local, } \\
\text { auxiliada por aparatos de segurança (ver item 18.11). } \\
\text { A altura ou pé-direito deve superar a altura de dois } \\
\text { homens sobrepostos. }\end{array}$ & $\begin{array}{l}\text { climas frios ou quentes, respectivamente). } \\
\text { Estimar a área coberta por pessoa entre } 0,85 \\
\text { e } 1,0 \mathrm{~m}^{2} \text { (demanda). } \\
\text { [DB, p. } 47 \text { e } 69 ; \mathrm{PR} \text {; UNOPS, 2016, p. } 95 \text { e 99] } \\
\text { Considerar o diâmetro mínimo do pátio de } \\
\text { sol em } 10 \mathrm{~m} \text { [DB, p. 47]. } \\
\text { Considerar a altura ou o pé-direto mínimo } \\
\text { em 4,20m [RP]. }\end{array}$ \\
\hline $\begin{array}{l}18.10 \\
\text { Condicionar } \\
\text { ambientalmente o pátio, } \\
\text { principalmente em termos } \\
\text { da ventilação e iluminação, } \\
\text { segundo o nível de } \\
\text { segurança } \\
\text { estabelecimento penal a } \\
\text { ser projetado }\end{array}$ & $\begin{array}{l}\text { O conforto ambiental permeia a composição } \\
\text { arquitetônica do pátio (ver item 18.05), associada } \\
\text { ao respeito à condição humana na prisão, cujo } \\
\text { contraponto é a segurança penitenciária (ver item } \\
\text { 10.05). O conforto ambiental prioriza os aspectos } \\
\text { lumínico e térmico, materializados nas aberturas } \\
\text { de iluminação e ventilação (ver item 13.01) que } \\
\text { devem respeitar a impermeabilidade, a } \\
\text { estanqueidade e o controle institucional (ver item } \\
\text { 18.01). A solução de conforto varia em função da } \\
\text { posição solar e dos ventos dominantes. O conforto } \\
\text { ambiental também envolve o banheiro da cela em } \\
\text { termos da qualidade do ar. Vínculo: Conforto } \\
\text { Ambiental. }\end{array}$ & $\begin{array}{l}\text { O pátio deve ser ventilado e iluminado pela abertura } \\
\text { superior (conveç̧ão) que deve garantir a insolação } \\
\text { necessária durante todo o período do ano, } \\
\text { especialmente no inverno. A área e altura do pátio } \\
\text { devem ser coordenadas para isto. Aberturas nas } \\
\text { fachadas (indiretas) podem ser previstas em casos } \\
\text { especiais para garantir o conforto ambiental } \\
\text { (ventilação cruzada). As mesmas devem ser pontuais e } \\
\text { mínimas, de modo a atender a impermeabilidade e a } \\
\text { estanqueidade. A visualização do exterior pelos presos } \\
\text { é dispensável. O banheiro deve ser isolado por meio } \\
\text { da localização e proximidade das aberturas. A } \\
\text { geometria do pátio deve limitar a profundidade do } \\
\text { espaço coberto, enquanto o pé-direito mais alto } \\
\text { favorece a ventilação e a iluminação (ver item 18.07). }\end{array}$ & $\begin{array}{l}\text { Considerar os critérios e parâmetros gerais } \\
\text { de conforto ambiental (ver item 13.01). } \\
\text { Dimensionar a abertura superior (capacidade } \\
\text { cotidiana) em } 4,0 \mathrm{~m}^{2} \text { por pessoa (climas frios) } \\
\text { ou } 6,0 \mathrm{~m}^{2} \text { por pessoa (climas quentes) [DB, p. } \\
47 \text { e 69; PR; UNOPS, 2016, p. } 95 \text { e 99]. } \\
\text { Dimensionar a abertura superior (capacidade } \\
\text { eventual) em 1,50m² por pessoa [idem]. } \\
\text { Vetar a ventilação cruzada quando aberta } \\
\text { para áreas ocupadas por funcionários ou } \\
\text { outros presos. } \\
\text { Limitar a profundidade da área coberta em } \\
\text { até duas vezes a distancia do piso até o topo } \\
\text { da abertura. }\end{array}$ \\
\hline $\begin{array}{l}18.11 \\
\text { Reforçar as propriedades } \\
\text { disciplinares do pátio por } \\
\text { meio de aparatos de } \\
\text { segurança, segundo o nível } \\
\text { de segurança estipulado } \\
\text { para estabelecimento } \\
\text { penal a ser projetado }\end{array}$ & $\begin{array}{l}\text { Os aparatos de segurança contribuem para a } \\
\text { estanqueidade e a impermeabilidade do pátio (ver } \\
\text { item 10.05), além da disciplina e da preservação } \\
\text { dos funcionários. Ao mesmo tempo em que } \\
\text { favorecem a economia na construção do } \\
\text { estabelecimento (ver item 14.01). A integralização } \\
\text { das propriedades do pátio por meio da geometria } \\
\text { ou configuração implica em custos } \\
\text { comparativamente elevados à aplicação de } \\
\text { aparatos de segurança (ver item 18.04). As } \\
\text { providências de segurança se estendem até a } \\
\text { condição humana dos presos (ver item 10.05). } \\
\text { Vínculos: Funcionalidade e Conforto Ambiental. }\end{array}$ & $\begin{array}{l}\text { As propriedades do esquema de segurança do pátio } \\
\text { devem ser maximizadas e homogeneizadas: o reforço } \\
\text { do conjunto e a correção dos componentes mais } \\
\text { débeis. A definição das vulnerabilidades deve } \\
\text { considerar a quantidade de presos e as atividades } \\
\text { previstas, assim como, os procedimentos previstos } \\
\text { (revista do pátio, contenção de crises). Os pontos } \\
\text { conhecidamente críticos são a porta de acesso e a } \\
\text { abertura superior. Os elementos suscetíveis à } \\
\text { escalada, como pilares, vigas, grades e beirais da } \\
\text { cobertura devem ser protegidos. Além disto, o pátio } \\
\text { deve receber dispositivos de proteção das peças de } \\
\text { apoio aos procedimentos. A visibilidade das coberturas } \\
\text { deve ser observada (pontos cegos) (ver item 15.03). }\end{array}$ & $\begin{array}{l}\text { Prever grades e telas para a abertura } \\
\text { superior do pátio [PR]. } \\
\text { Prever espirais cortantes nos elementos } \\
\text { estruturais e de cobertura. } \\
\text { Prever eclusa para disciplinar o fluxo de } \\
\text { presos na porta de acesso ao pátio. } \\
\text { Especificar porta de correr no acesso do } \\
\text { pátio, dotada de mecanismos de travamento, } \\
\text { operação e visualização (portinholas). } \\
\text { Prever portinholas e espelhos nas paredes } \\
\text { para garantir a visualização interna. } \\
\text { Prever dispositivos de bloqueio visual junto } \\
\text { de eventuais aberturas de iluminação e } \\
\text { ventilação nas fachadas. }\end{array}$ \\
\hline 18.12 & $\begin{array}{l}\text { O controle define a melhor visualização possível do } \\
\text { interior do pátio desde pontos de observação, o } \\
\text { que abrange a geometria e a configuração do }\end{array}$ & $\begin{array}{l}\text { O pátio deve ter o espaço retificado pela aplicação da } \\
\text { simplicidade funcional, o que determina uma rápida } \\
\text { apreensão do ambiente. Elementos estruturais em }\end{array}$ & $\begin{array}{l}\text { Aplicar a simplicidade funcional (ver item } \\
\text { 18.05). } \\
\text { Prever portinholas e visores que permitam a }\end{array}$ \\
\hline
\end{tabular}




\begin{tabular}{|c|c|c|c|}
\hline $\begin{array}{l}\text { interior do pátio, segundo } \\
\text { o nível de segurança } \\
\text { estipulado } r \text { para } \\
\text { estabelecimento penal a } \\
\text { ser projetado }\end{array}$ & $\begin{array}{l}\text { espaço interno (ver itens } 18.04 \text { e 18.05). A } \\
\text { apreensão do local é completa e imediata, sem } \\
\text { pontos cegos ou esconderijos, o que também } \\
\text { simplifica as revistas. A privacidade dos presos } \\
\text { exige minimamente a reserva no uso do banheiro. } \\
\text { Vínculos: Espacialização e o Controle. }\end{array}$ & $\begin{array}{l}\text { meio ao espaço devem ser evitados. Os sanitários } \\
\text { devem ser periféricos (junto às paredes) (ver item } \\
\text { 17.04) e relativamente abertos. O pátio deve prever } \\
\text { mais de um ponto de observação de modo a evitar } \\
\text { pontos cegos ou vulneráveis, onde presos possam se } \\
\text { esconder ou cometer indisciplinas. }\end{array}$ & $\begin{array}{l}\text { visualização da maior parte do pátio. } \\
\text { Visualizar pelo menos } 99 \% \text { da área do pátio } \\
\text { (isovista) [PR]. } \\
\text { Utilizar divisórias baixas e destacadas do piso } \\
\text { nos sanitários (portas são vetadas). }\end{array}$ \\
\hline \multicolumn{4}{|l|}{ 19. Posto de controle } \\
\hline \multicolumn{4}{|c|}{ É definido essencialmente pelo nível de segurança. Relaciona-se fortemente com o custo do de operação do estabelecimento. Reproduz os quesitos da Organização do Espaço. } \\
\hline Requisito & Fundamentação Teórica & \begin{tabular}{|l|l} 
Procedimento Metodológico & \\
\end{tabular} & Recursos Técnicos \\
\hline $\begin{array}{l}19.01 \\
\text { Permitir a apreensão dos } \\
\text { eventos nos ambientes } \\
\text { monitorados, utilizando a } \\
\text { menor equipe possível, } \\
\text { segundo o nível de } \\
\text { segurança estipulado para } \\
\text { estabelecimento penal a } \\
\text { ser projetado }\end{array}$ & $\begin{array}{l}\text { O posto de controle é definido pela capacidade de } \\
\text { apreensão dos eventos, a partir da interação entre } \\
\text { o espaço interno (posto) e externo (vigiado). Esta } \\
\text { apreensão depende da percepção sensorial do } \\
\text { agente, definida pelo tipo de informação acessada } \\
\text { (visual, auditiva ou olfativa). A informação mais } \\
\text { relevante é a visual, condensada para poucos } \\
\text { vigias (ver item 15.06). A visualização é definida } \\
\text { pela coordenação da geometria e dos visores (ver } \\
\text { item 15.01) e depende da posição do posto e da } \\
\text { quantidade e configuração dos locais monitorados. } \\
\text { Vínculos: Geometria e Espacialização. }\end{array}$ & $\begin{array}{l}\text { O posto de controle deve privilegiar a visualização } \\
\text { dos espaços, ao constituir pontos geradores } \\
\text { isométricos em quantidade mínima e de modo } \\
\text { concentrado. A isovista define a posição, a } \\
\text { geometria, os níveis e os visores do posto de } \\
\text { controle, de acordo com o raio de visão dos pontos } \\
\text { geradores isométricos. O fechamento do posto de } \\
\text { controle deve ser relativo, havendo aberturas que } \\
\text { permitam a percepção de sons e odores, (ver item } \\
\text { 19.05). Neste sentido, as aberturas de ventilação do } \\
\text { posto podem ser utilizadas (ver item 19.06). }\end{array}$ & $\begin{array}{l}\text { Conceber plantas angulares (entre } 90^{\circ} \text { e } 180^{\circ} \text { ) } \\
\text { locadas no canto do recinto monitorado [MD]. } \\
\text { Prever piso elevado, em altura suficiente para } \\
\text { a visão sobre as pessoas [PR]. } \\
\text { Configurar os visores (dimensões, ângulos e } \\
\text { projeções) de modo a corresponder ao campo } \\
\text { de visão definido pelas isovistas. } \\
\text { Estimar os visores com área de } 50 \text { a } 70 \% \text { da } \\
\text { área do piso [PR] } \\
\text { Prever aberturas para a percepção de sons e } \\
\text { odores, além da comunicação e da realização } \\
\text { de procedimentos [RP]. }\end{array}$ \\
\hline $\begin{array}{l}19.02 \\
\text { Proporcionar condições de } \\
\text { permanência dos } \\
\text { funcionários no posto de } \\
\text { controle, do ponto de vista } \\
\text { funcional, segundo o nível } \\
\text { de segurança do } \\
\text { estabelecimento penal a } \\
\text { ser projetado }\end{array}$ & $\begin{array}{l}\text { A permanência dos funcionários no posto de } \\
\text { controle demanda itens de conforto e serviços, tais } \\
\text { como: mobiliário e sanitário, em especial, em } \\
\text { condições de permanência prolongada. O } \\
\text { mobiliário apóia o registro, a monitoria eletrônica, } \\
\text { a radiocomunicação ou o controle remoto de } \\
\text { portas. Na operação, é preferível formalizar a } \\
\text { substituição do vigia para o uso do sanitário, o que } \\
\text { garante a efetividade da vigilância. Vínculo: } \\
\text { Funcionalidade. }\end{array}$ & $\begin{array}{l}\text { O posto de controle deve oferecer o apoio de } \\
\text { mobiliário para os funcionários que se resume a uma } \\
\text { bancada e cadeiras. As cadeiras podem incluir } \\
\text { bancos altos para favorecer o ângulo de visão. O } \\
\text { serviço sanitário deve estar localizado fora do posto } \\
\text { de controle, próximo ao mesmo. O mesmo deve } \\
\text { contar com pia e vaso sanitário. O compartilhamento } \\
\text { de sanitário por mais de um posto deve evitar a } \\
\text { espera dos funcionários para o uso. }\end{array}$ & $\begin{array}{l}\text { Prever bancada [RP]. } \\
\text { Prever um vaso sanitário para cada posto de } \\
\text { controle [PR; RP]. No caso de } \\
\text { compartilhamento, o sanitário conformará } \\
\text { boxes com os sanitários. Considerar a divisão } \\
\text { por gênero nos locais de atuação de } \\
\text { funcionárias (setores mais externos) [RP]. }\end{array}$ \\
\hline $\begin{array}{l}19.03 \\
\text { Distribuir os componentes } \\
\text { do posto de controle de } \\
\text { modo a evitar } \\
\text { interferências e conflitos } \\
\text { na vigilância }\end{array}$ & $\begin{array}{l}\text { Os elementos constituintes do posto de controle } \\
\text { (mobiliário, sanitários, escadas, equipamentos e } \\
\text { instalações) (ver item 19.02) não podem interferir } \\
\text { na vigilância, ao constituir fechamentos ou } \\
\text { obstáculos que reduzam a visibilidade ou a } \\
\text { dificultem o acesso aos visores (ver item 19.01). } \\
\text { Vínculo: Espacialização. }\end{array}$ & $\begin{array}{l}\text { O posto de controle deve constituir um perímetro } \\
\text { livre para o acesso e posicionamento dos visores. O } \\
\text { mobiliário deve ser conformado para não atrapalhar } \\
\text { a aproximação aos visores - pode ser previsto em } \\
\text { uma posição central ou oposta aos visores no posto. }\end{array}$ & $\begin{array}{l}\text { Conceber espaço do posto de controle como } \\
\text { uma planta livre [DB, p. 29; PR; RP]. }\end{array}$ \\
\hline
\end{tabular}




\begin{tabular}{|c|c|c|c|}
\hline $\begin{array}{lr}\text { Conciliar a visualização } \\
\text { otimizada das áreas } \\
\text { monitoradas com o } \\
\text { dimensionamento } & \text { do } \\
\text { posto de controle, em } \\
\text { função do nível de } \\
\text { segurança } \\
\text { estabelecimento penal a } \\
\text { ser projetado }\end{array}$ & $\begin{array}{l}\text { As dimensões do posto de controle compatibilizam } \\
\text { a melhor vigilância possível (ponto focal) (ver itens } \\
19.01,19.02 \text { e 19.03), as atividades de apoio } \\
\text { (mobiliário e serviços) e as condições de trabalho } \\
\text { dos funcionários. Estas condições tratam } \\
\text { especificamente das sensações de segurança ou } \\
\text { enclausuramento (ver itens } 08.02 \text { e 15.04). A } \\
\text { sensação de segurança diz respeito ao ataque aos } \\
\text { visores (rompimento por golpes), mas } \\
\text { principalmente ao ataque físico (estocadas ou } \\
\text { agarramentos). O dimensionamento adere à } \\
\text { síntese funcional, com vistas os custos (área } \\
\text { construída e quantidade de visores). Vínculo: } \\
\text { Espacialização. }\end{array}$ & $\begin{array}{l}\text { O posto de controle deve ter as dimensões } \\
\text { minimizadas, ao reproduzir a síntese funcional, de } \\
\text { modo a favorecer a concentração da informação } \\
\text { advinda dos locais vigiados (ponto gerador } \\
\text { isométrico). Esta minimização deve ser limitada pela } \\
\text { área necessária para as tarefas e para criação de um } \\
\text { raio de segurança que depende do tipo de proteção } \\
\text { das aberturas. Deve haver uma distancia entre os } \\
\text { funcionários (ponto de observação) e os presos } \\
\text { superior ao alcance de ataque pessoal (visores em } \\
\text { grade) ou por golpes (visores em vidro ou similar). A } \\
\text { diferença de nível do posto favorece estes } \\
\text { distanciamentos. }\end{array}$ & $\begin{array}{l}\text { Adotar uma área média de } 14,0 \mathrm{~m}^{2} \text {, com uma } \\
\text { tendência para maior até } 20,0 \mathrm{~m}^{2}[\mathrm{PR}] \text {. } \\
\text { Adotar uma largura mínima de } 3 \mathrm{~m}[\mathrm{PR}] \text {. } \\
\text { Considerar uma distancia mínima entre os } \\
\text { visores e os pontos de observação de } 80 \mathrm{~cm} \\
\text { [RP]. } \\
\text { Considerar uma altura dos visores em relação } \\
\text { ao nível do local monitorado de, pelo menos, } \\
2,40 \mathrm{~m}[\mathrm{MD}] \text {. } \\
\text { Adotar um pé-direito mínimo de } 2,70 \mathrm{~m}[\mathrm{MD}] \text {. }\end{array}$ \\
\hline $\begin{array}{l}19.05 \\
\text { Reforçar o fechamento e a } \\
\text { operacionalidade do posto } \\
\text { de controle, em função do } \\
\text { nível de segurança do } \\
\text { estabelecimento penal a } \\
\text { ser projetado }\end{array}$ & $\begin{array}{l}\text { O posto de controle é um elemento estratégico do } \\
\text { sistema de segurança, especialmente nas áreas } \\
\text { mais internas do estabelecimento penal, por isto a } \\
\text { inexpugnidade e funcionalidade do local são } \\
\text { imprescindíveis para a instituição (ver item 15.04). } \\
\text { Neste sentido, estas propriedades devem ser } \\
\text { maximizadas, em termos da proteção dos } \\
\text { funcionários (ver item 12.04) e da vigilância e } \\
\text { gerenciamento: a recepção de todos os tipos de } \\
\text { informação sensorial (ver item 19.01), o manuseio } \\
\text { remoto de portas (ver item 14.01), a resposta } \\
\text { imediata em situações de crise e a comunicação } \\
\text { com as pessoas (presos, visitante e outro } \\
\text { funcionários). Ao mesmo tempo em que } \\
\text { favorecem a economia na construção do } \\
\text { estabelecimento. A integralização das } \\
\text { propriedades do pátio por meio da geometria ou } \\
\text { configuração implica em custos comparativamente } \\
\text { elevados à aplicação de aparatos de segurança (ver } \\
\text { item 18.04). As providências de segurança se } \\
\text { estendem até o bem estar dos funcionários (ver } \\
\text { item 10.05). Vínculo: Espacialização. }\end{array}$ & $\begin{array}{l}\text { As propriedades de inexpugnidade e de } \\
\text { operacionalidade do posto de controle devem ser } \\
\text { maximizadas e homogeneizadas: o reforço do } \\
\text { conjunto e a correção dos componentes mais débeis. } \\
\text { A definição das vulnerabilidades deve considerar a } \\
\text { quantidade de indivíduos e as atividades } \\
\text { monitoradas, assim como, os procedimentos } \\
\text { previstos. Os pontos conhecidamente críticos são a } \\
\text { porta de acesso e as aberturas de visualização. A } \\
\text { inexpugnidade exige aparatos de fechamento e com } \\
\text { uma resistência mínima à investida dos presos por } \\
\text { um tempo suficiente para o escape dos funcionários. } \\
\text { A operacionalidade exige visores associados a } \\
\text { aberturas para o som e cheiros, elementos para } \\
\text { melhorar o campo de visão, eliminar pontos cegos e } \\
\text { otimizar a equipe; mecanismos para a abertura } \\
\text { remota das portas; e soluções para a comunicação } \\
\text { (inclusive com a passagem de objetos) e contenções } \\
\text { (disparos por armas de fogo e lançamento de } \\
\text { bombas). As aberturas de iluminação e ventilação } \\
\text { devem ser protegidas e bloqueadas para favorecer a } \\
\text { inverificabilidade institucional. Os dispositivos mais } \\
\text { simples são preferidos (passivos ou mecânicos). }\end{array}$ & $\begin{array}{l}\text { Prever espelhos convexos nos pontos cegos e, } \\
\text { eventualmente, a proteção destes por grades. } \\
\text { Prever visores (eventualmente, balísticos) e } \\
\text { grades (eventualmente, telas) nas aberturas de } \\
\text { visualização. } \\
\text { Especificar porta dobradiça com mola no } \\
\text { acesso do posto, dotada de mecanismos de } \\
\text { travamento, operação e visualização } \\
\text { (portinholas). } \\
\text { Cogitar descidas rápidas nos postos elevados, } \\
\text { como tubos de escorregar. } \\
\text { Especificar mecanismos para a operação } \\
\text { remota das portas das circulações controladas, } \\
\text { como ferrolhos com molas e alavancas } \\
\text { estendidas. } \\
\text { Prever portinholas nas aberturas e seteiras } \\
\text { para os procedimentos de comunicação e } \\
\text { contenção. Cogitar o passa-volume. } \\
\text { Prever grades ou outros fechamentos nas } \\
\text { aberturas de iluminação e ventilação. } \\
\text { Prever dispositivos de bloqueio da luz nas } \\
\text { aberturas de iluminação e ventilação além da } \\
\text { porta (ver item 19.06). }\end{array}$ \\
\hline 19.06 & $\begin{array}{l}\text { O conforto ambiental permeia a composição } \\
\text { arquitetônica do posto de controle, associada ao } \\
\text { respeito à condição humana na prisão, cujo }\end{array}$ & $\begin{array}{l}\text { O posto de controle deve apresentar aberturas de } \\
\text { iluminação e ventilação pontuais e mínimas, porém } \\
\text { suficientes para a quantidade de pessoas e as }\end{array}$ & $\begin{array}{l}\text { Considerar os critérios e parâmetros gerais de } \\
\text { conforto ambiental (ver item 13.01). } \\
\text { Cogitar o uso de zenitais. }\end{array}$ \\
\hline
\end{tabular}




\begin{tabular}{|c|c|c|c|}
\hline 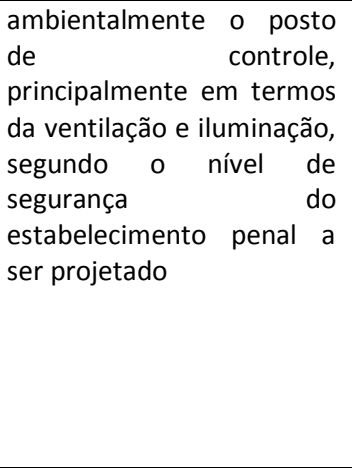 & $\begin{array}{l}\text { contraponto é a segurança penitenciária (ver item } \\
\text { 10.05). O conforto ambiental prioriza os aspectos } \\
\text { lumínico e térmico, materializados nas aberturas } \\
\text { de iluminação e ventilação (ver item 13.01) que } \\
\text { devem respeitar a impermeabilidade, a } \\
\text { inexpugnidade e o controle institucional (a } \\
\text { inverificabilidade institucional), condicionados pelo } \\
\text { posicionamento do posto. Ao mesmo tempo em } \\
\text { que se incorpora a demanda realística: a } \\
\text { regulagem da ventilação (humanização). Vínculo: } \\
\text { Conforto Ambiental. }\end{array}$ & $\begin{array}{l}\text { atividades previstas. A localização e a configuração } \\
\text { destas aberturas devem impedir a percepção do } \\
\text { interior do posto pelos presos (efeito de luz e } \\
\text { sombra). Esta percepção é facultada aos } \\
\text { funcionários através da regulagem da luminosidade. } \\
\text { A ventilação cruzada é desejada dentro destas } \\
\text { condições. O posto de controle majoritariamente } \\
\text { apresenta uma localização internalizada, por isto o } \\
\text { uso de zenitais é admissível. A regulagem das } \\
\text { aberturas e a tela mosquiteira devem ser } \\
\text { incorporadas como itens de humanização. O pé- } \\
\text { direito deve favorecer a ventilação e a iluminação } \\
\text { (ver item 19.04). }\end{array}$ & $\begin{array}{l}\text { Vetar a ventilação cruzada quando aberta para } \\
\text { áreas ocupadas por presos. } \\
\text { Dimensionar as aberturas entre } 16 \% \text { e } 25 \% \text { da } \\
\text { área de piso, segundo a zona bioclimática. } \\
\text { Prever a regulagem das aberturas, por meio de } \\
\text { mecanismos controlados pelos funcionários. } \\
\text { Considerar a tela mosquiteira nas aberturas. } \\
\text { Limitar a profundidade em até duas vezes a } \\
\text { distancia do piso até o topo da abertura. }\end{array}$ \\
\hline
\end{tabular}




\section{Apêndice G - Desenhos-síntese dos elementos centrais da edificação penal}

Neste apêndice são apresentados os projetos arquitetônicos dos desenhos-síntese desenvolvidos nesta pesquisa e aplicados na avaliação da tecnologia de projeto elaborada, no Capítulo 8, desta pesquisa.

\section{Barreira Perimetral}

A proposta concebida convergiu com o nível 2 de segurança do Technical Guidance of Prision Planning (UNOPS, 2016, p. 89). Este arranjo alivia a dependência da localização do estabelecimento penal para o isolamento social dos presos. A cerca recebeu aparatos de segurança para garantir as propriedades de fechamento ${ }^{125}$. A estanqueidade foi reforçada por meio de elementos cortantes em toda a altura da barreira e de colchão de brita na linha de tiro. Os afastamentos mais largos dispensaram dispositivos de combate a túneis, tais como, a caixa de areia. A impermeabilidade foi providenciada por meio de telhas metálicas com uma altura de dois metros. A inexpugnidade foi arranjada por meio de três linhas de defesa: dilacerador de pneus, trincheira e mureta na cerca. Estes elementos também fornecem a proteção dos guardas: impedem a pontaria de arma de fogo (telhas) e criam abrigo balístico (trincheira e mureta). O custo linear da barreira perimetral completa foi de $\mathrm{R} \$$ $2.340,27 / \mathrm{m}$, sendo $\mathrm{R} \$ 1.476,50 / \mathrm{m}$ a cerca com consertina e $\mathrm{R} \$ 803,00$ a linha de tiro (cerca e faixa estéril ${ }^{126}$. O valor unitário dos afastamentos foi de $\mathrm{R} \$ 1,71 / \mathrm{m}^{2}$, incluindo cercas, pistas e aparatos de segurança.

\section{Cela}

$\mathrm{Na}$ cela proposta, as atividades foram agrupadas em recintos, delimitados por divisórias estreitas, baixas e sem portas: dormitório (dormir e ler), estar (sociabilização, refeitório, trabalho, lavanderia, exercícios físicos, entretenimento e guarda de material de uso comum) e banheiro (higiene pessoal e serviços sanitários) (Erro! Fonte de referência não encontrada.) ${ }^{127}$. O dormitório tem natureza mais reservada, enquanto o estar tem um caráter gregário e absorve a maior parte das atividades. A opção pelos beliches contribuiu para a otimização do espaço (compactação). O banheiro é equipado com duas cubas e tem as divisórias destacadas do piso. A ordem destas funções foi definida pela simplicidade funcional, associada à segurança e ao conforto ambiental. Ao internalizar os locais

\footnotetext{
125 O detalhamento da barreira perimetral pode lançar mão dos parâmetros contidos no Guide to Active Vehicle Barrier (USA, 2014), no A Primer on Military Mobility Vintage (LUTZ, 2003) e nas normas NATO Reference Mobility Model (NRMM), na seção Standard Obstacles.

${ }^{126}$ O custo calculado considerou as cercas externa, da barreira e da linha de tiro, afastamentos externo e interno, pistas de ronda externa e interna, dilacerador de pneus, trincheira, mureta, bloqueio visual, consertina e colchão de brita. Foram adotados os custos unitários de obras penitenciárias do estado de São Paulo, com atualização para a data base de março de 2016, pelo INCC. Os valores apresentados são ilustrativos e não compuseram os cálculos da aplicação do modelo-síntese no ajustamento dos projetos de referência (capítulo 8). Este cálculo se prestou para determinar as proporções e grandezas econômicas na composição arquitetônica.

127 O detalhamento da cela pode lançar mão dos parâmetros contido na NBR 15.757 (2013) e no PSI 12/2012 (UK, 2012).
} 
coletivos, a cela inverteu a sequência da residência, suscitada Ornstein (1989) e outros trabalhos técnicos que fazem analogia entre a cela e a residência (IPT, 2008 ; IPT, 2010). A espacialização proposta estabeleceu graus de individualização. Em um primeiro plano, ao oferecer a opção de permanência no estar ou no dormitório. Depois, ao valorizar o nicho como território pessoal (cama), ao ser claramente delimitado e equipado, inclusive com piso e mesa próprios (a cama faz a função de banco para otimizar o espaço).

Diante da necessidade de impermeabilidade entre as celas e destas em relação aos demais espaços internos e externos da prisão, a iluminação e ventilação zenital foi considerada mais adequada (Erro! Fonte de referência não encontrada.). As aberturas nas fachadas foram tratadas como alternativa na proposta, cuja especificação depende de outras condições (barreira perimetral, geometria da edificação e aparatos de segurança). Estas aberturas foram especificadas como brises horizontais em ângulos de $45^{\circ}$ para limitar a visualização do exterior. Como vantagem, as mesmas implementam a ventilação cruzada na cela.

O zenital especificado corresponde ao estar da cela, devido às atividades previstas no local e às atribuições assumidas no conjunto, em termos da funcionalidade (separa o dormitório do banheiro) e do conforto ambiental (distribuição da iluminação e ventilação). Em relação à alimentação no estar, o conflito com o banheiro deverá ser atenuado com o regramento no uso do sanitário. O zenital foi dimensionado em $25 \%$ da área de piso e permite a regulagem das aberturas pelos funcionários (a área do zenital foi definida pelo tamanho da mesa coletiva no estar da cela).

O elemento zenital foi associado às questões da visualização do interior da cela e da privacidade dos presos, quando se propôs a atuação dos funcionários pela cobertura da ala carcerária. A visualização foi privilegiada com a especificação de grades duplas, ao invés do pergolado em concreto que é mais seguro em termos da estanqueidade. Segundo os funcionários, a visualização é mais importante, assim como a realização de procedimentos, como o verificado na unidade catarinense. Para os funcionários paulistas, o procedimento de contagem elimina parte da vulnerabilidade das grades. A privacidade do dormitório e do banheiro foi minimamente respeitada. Considerando o visor da porta, $79 \%$ da área da cela são expostas, havendo pontos cegos nas mesas individuais dos nichos.

O acréscimo estimado é $\mathrm{R} \$ 42,7$ mil por cela $\left(58,6 \%\right.$ de adição), ou $\mathrm{R} \$ 1.158 / \mathrm{m}^{2}$, totalizando $\mathrm{R} \$$ $5.269,90 / \mathrm{m}^{2}$ (valores referentes à área média das celas, de $18,26 \mathrm{~m}^{2}$, e o valor unitário médio da área dos projetos de referência, de $\mathrm{R} \$ 4.112,09)^{128}$.

\footnotetext{
128 O custo calculado considerou a área construída acrescida em relação à área média das celas dos projetos de referência, o elemento
} zenital (alvenaria, estrutura metálica da cobertura, telhas e basculante em policarbonato sem caixilho), a grade de fechamento do zenital, o 


\section{Pátio de sol dos presos}

O pátio manteve as características de fechamento vigentes em prol da segurança (estanqueidade e impermeabilidade): um espaço confinado, aberto apenas na parte superior (Erro! Fonte de referência não encontrada. e Erro! Fonte de referência não encontrada.). Em termos da humanização, algumas alternativas pontuais foram implementadas na geometria e na espacialidade do pátio, em parte, derivadas das atividades admitidas no local. Neste sentido, chanfros foram previstos nos cantos opostos ao posto de controle e o pé-direito foi progressivamente rebaixado até o limite de $4,20 \mathrm{~m}$. Este rebaixo foi possibilitado pelo gradeamento da abertura superior do pátio.

O pátio foi organizado em três partes, nesta sequência: salão de socialização coberto, quadra de esportes descoberta e um patamar mais alto, também coberto. Então, a quadra de esportes distinguiu as duas áreas cobertas, enquanto a diferença de nível evidenciou a divisão funcional do pátio. O local de sociabilização recebeu o acesso ao pátio, o posto de controle e os serviços higiênicos e sanitários, além de mesas e cadeiras com lugar para todos os presos. O patamar foi constituído por uma arquibancada que proporciona assento para se assistir ao jogo, conversar e fazer exercícios físicos. No patamar, as pessoas podem caminhar e fazer exercícios físicos. O mesmo ainda funciona um como palco.

A privacidade dos presos no pátio se restringe aos sanitários, e de modo mínimo - as divisórias tapam apenas as partes íntimas do corpo. Indiretamente, o patamar ao fundo do pátio pode estabelecer um senso de privacidade nos presos, ao estabelecer um distanciamento do posto de controle. Todavia, a elevação do patamar aumenta a exposição e favorece a vigilância. Neste sentido, a vigilância do pátio regrou a espacialização concebida, não havendo perda de visualização ou criação de pontos cegos. $\mathrm{O}$ conjunto pátio de sol e posto de controle desenvolvido permite a apreensão de $99 \%$ da área, além dos tetos e da grade superior (Erro! Fonte de referência não encontrada.). No pátio de sol proposto, os vãos estruturais dispensaram pilares dentro do espaço, de modo a evitar obstáculos visuais. No caso de um pilar imprescindível, o mesmo seria encabeçado por aparato de segurança contra escalada.

$\mathrm{Na}$ concepção do desenho-síntese do pátio, algumas alternativas foram descartadas. O fechamento do pátio remete à abstinência visual dos presos em relação à natureza (vegetação). Como solução, jardins poderiam ser criados junto ao pátio, por exemplo, nos cantos residuais dos chanfros criados. Estes

mobiliário (mesa coletiva com bancos, mesa individual, piso dos nichos e prateleiras), elementos de fachada e hidrosanitários (tanque e cuba com bancadas). Foram adotados os custos unitários de obras penitenciárias do estado de São Paulo, com atualização para a data base de março de 2016, pelo INCC. Os valores apresentados são ilustrativos e não compuseram os cálculos da aplicação do modelo-síntese no ajustamento dos projetos de referência (capítulo 8). Este cálculo se prestou para determinar as proporções e grandezas econômicas na composição arquitetônica. 
jardins seriam enclausurados, abertos para o pátio por meio de grades ou brises. Outra alternativa seria a regulagem da abertura superior através de coberturas móveis para períodos de frio ou chuva intensa.

O valor unitário adotado para o pátio de sol foi de $\mathrm{R} \$ 4.112,09 / \mathrm{m}^{2}{ }^{129}$.

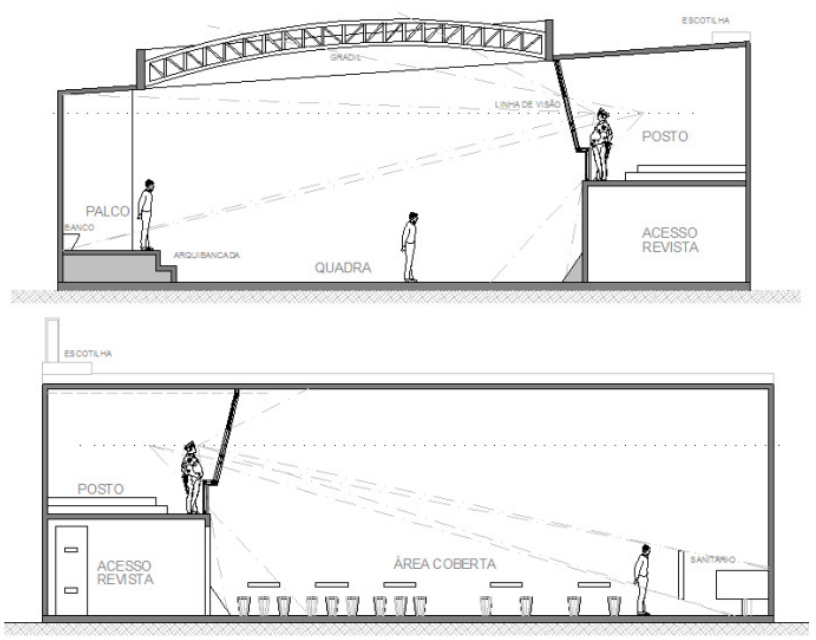

Figura 74 - Desenhos de cortes do pátio de sol dos presos demonstrativos da visualização do posto de controle.

\section{Posto de controle}

A quantidade e a configuração dos locais monitorados são as variáveis primordiais da composição do posto de controle (Erro! Fonte de referência não encontrada.). Neste sentido, o desenho-síntese foi elaborado para o pátio de sol dos presos desenvolvido. O monitoramento de mais locais implica na ampliação do posto ou na criação de outros postos, com consequente aumento de área.

O posto de controle proposto privilegiou a visualização por meio da posição no local vigiado, aliada à geometria, espacialização e dimensionamento, além da configuração dos visores. A posição lateral adotada apresenta vantagens quando comparada a posição central. Em um canto do espaço engajado na vigilância, o ângulo necessário para a observação de todo o local é reduzido, o que concentra a informação recebida (poucos pontos geradores isométricos). A espacialização interna do posto buscou a planta livre, porém em dois níveis, ao ser previsto um patamar que delimitou uma faixa para movimentação junto aos visores. Este patamar recebeu uma bancada para o trabalho burocrático, ao mesmo tempo em que permite a monitoria pelo agente, sentado. $\mathrm{O}$ dimensionamento descreve uma área de $16,0 \mathrm{~m}^{2}$, com uma previsão de dois a três agentes atuando. O tamanho de 4,0 x 4,0m permite

\footnotetext{
${ }^{129}$ O custo adotado considerou a área construída e os elementos constituintes do local: as coberturas, o fechamento da abertura superior em grade, o mobiliário e as peças hidrosanitárias. O valor apresentado compôs os cálculos da aplicação do modelo-síntese no ajustamento dos projetos de referência (capítulo 8).
} 
um distanciamento dos agentes em relação aos visores, o que pode criar um senso de segurança, reforçado pela proporção espacial do local (pé-direito de 3,0m) e pelo alçapão de escape.

Os visores ocupam todo o perímetro livre e a totalidade do pé-direito do posto de controle. A seção destes visores é parcialmente inclinada e avançada na parte superior. Estes cuidados permitem a visualização máxima. Em particular, os visores horizontais permitem a observação da base do posto de controle. Para a inexpugnidade do posto, os visores são fechados por placas de vidro laminado de cinco centímetros de espessura, complementadas por grades nas peças inferiores e dispositivos móveis nas peças superiores (porta de enrolar ou dobradiça, em grade). Estes dispositivos têm acionamento de emergência, por meio de mecanismos de pânico, e travamento automático. Este esquema é incrementado pela distancia entre o piso vigiado e as aberturas de vigilância, reforçada por meio da inclinação da parede abaixo do posto. A operacionalidade do posto foi providenciada por portinholas nos visores que podem ser abertas mediante a necessidade de comunicação ou intervenção por força.

A ventilação e a iluminação são providenciadas por aberturas acima dos visores, fechadas por venezianas, além de aberturas ao fundo do posto para a circulação de ar, dotadas de anteparos para o controle da luz. O conjunto de venezianas e anteparos previsto reduz a luminosidade interna para o efeito da invisibilidade institucional, primariamente obtido por películas reflexivas nos visores. Neste sentido, a abertura da porta pode contar com anteparo funcionalmente similar, como uma cortina ou externo ao posto, de modo que não dificulte a passagem dos funcionários. $\mathrm{O}$ interior do posto pode ser revelado durante procedimentos de admissão e liberação dos presos, através da iluminação artificial interna.

$\mathrm{O}$ custo do posto de controle é de, aproximadamente, $\mathrm{R} \$ 126,89 \mathrm{mil}$, ou $\mathrm{R} \$ 7.931,00 / \mathrm{m}^{2}{ }^{130}$. O item orçamentário de maior peso são os visores (16\%), depois da estrutura e vedações.

Tabela 22 - Características físico-financeiras dos desenhos-síntese

\begin{tabular}{|c|c|c|c|c|c|c|}
\hline Desenho-síntese & $\begin{array}{c}\text { Custo } \\
\text { Construção } \\
(\mathrm{R} \$)^{*}\end{array}$ & $\begin{array}{c}\text { Capacidade } \\
\text { (vagas) }\end{array}$ & $\begin{array}{c}\text { Área } \\
\text { Construída } \\
\left(\mathrm{m}^{2}\right)\end{array}$ & $\begin{array}{c}\text { Custo/ } \\
\text { Área } \\
\left(\mathrm{R} \$ \mathrm{~m}^{2}\right)^{*}\end{array}$ & $\begin{array}{c}\text { Custo/ } \\
\text { Capacidade } \\
\text { (R\$/vaga) }\end{array}$ & $\begin{array}{c}\text { Área construída/ } \\
\text { capacidade } \\
\left(\mathrm{m}^{2} / \mathrm{vaga}\right)\end{array}$ \\
\hline Barreira Perimetral & $2.340,27$ & - & - & - & - & - \\
\hline Cela & $145.976,23$ & 8 & 25,75 & $5.668,98$ & $18.247,03$ & 3,22 \\
\hline Pátio de sol dos presos & $1.244 .976,30$ & $36 / 144$ & 302,76 & $4.112,09$ & $34.582,67$ & 8,41 \\
\hline Posto de controle & $126.896,52$ & - & 16 & $7.931,03$ & - & - \\
\hline
\end{tabular}

\footnotetext{
130 O custo calculado considerou a área construída, o patamar, os visores (caixilhos, vidro, portinholas, película), as venezianas, a bancada, a porta e o alçapão. Foram adotados os custos unitários de obras penitenciárias do estado de São Paulo, com atualização para a data base de março de 2016, pelo INCC. Os valores apresentados são ilustrativos e não compuseram os cálculos da aplicação do modelo-síntese no ajustamento dos projetos de referência (capítulo 8). Este cálculo se prestou para determinar as proporções e grandezas econômicas na composição arquitetônica.
} 


\section{Desenhos}

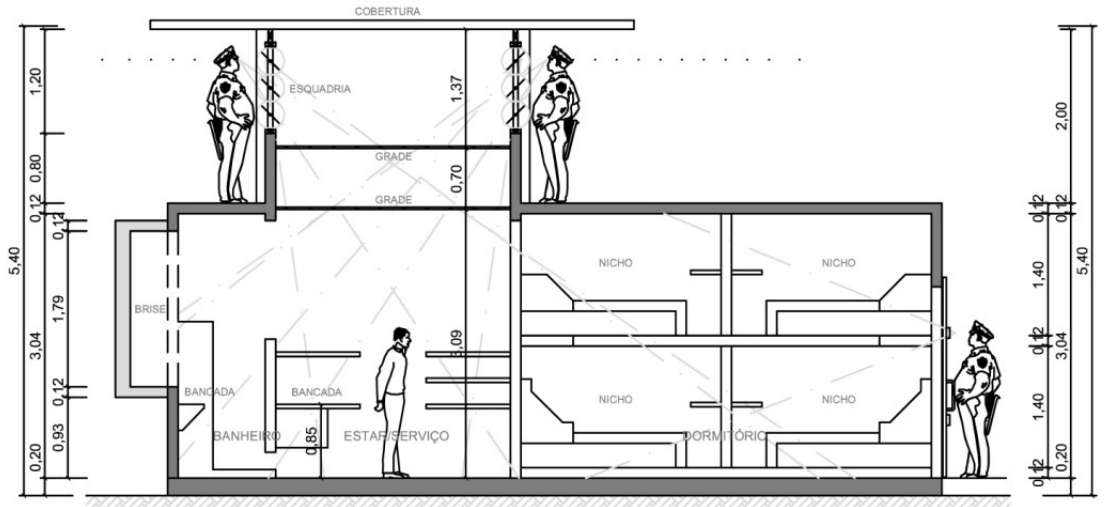

CORTE LONGITUDINAL
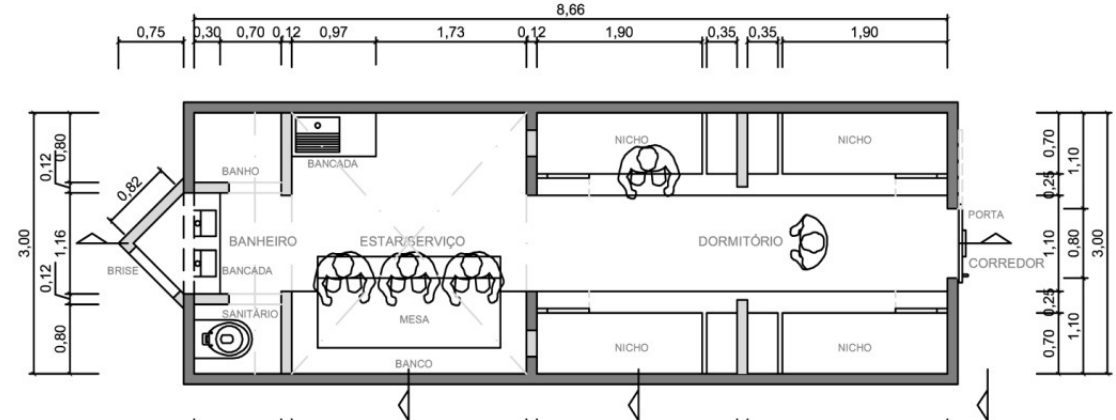

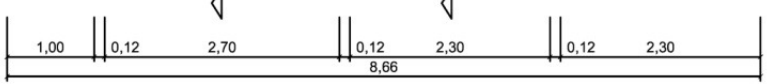

PLANTA BAIXA

PISO EM CONCRETO

PAREDES EM CONCRETO (12cm)

MOBUARIO EM CONCRETO

PORTADE CORRER EM GRADE

REVESTIDA DE CHAPA METÁLICA

FECHAMENTO DO ZENITAL EM GRADE

ESQUADRIA COM ESTRUTURA

METALICA EASCULANTES EM

POLLCARBONATO
COBERTURA DO ZENITAL EM TELHAS

COBERTURA DO
TRANSLUUCIDAS

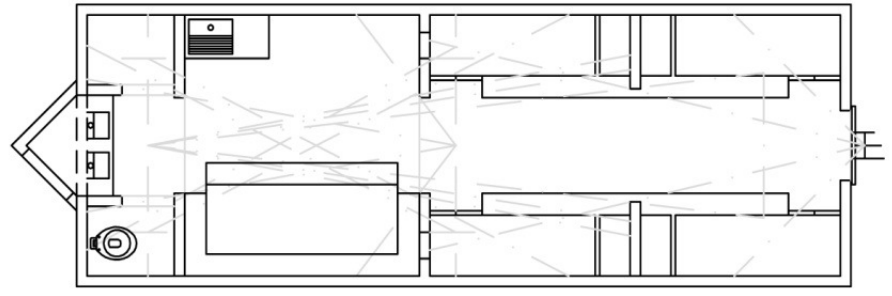

ISOMÉTRICA

Figura 75 - Desenhos-síntese da cela (planta baixa, corte longitudinal e isométrica). 

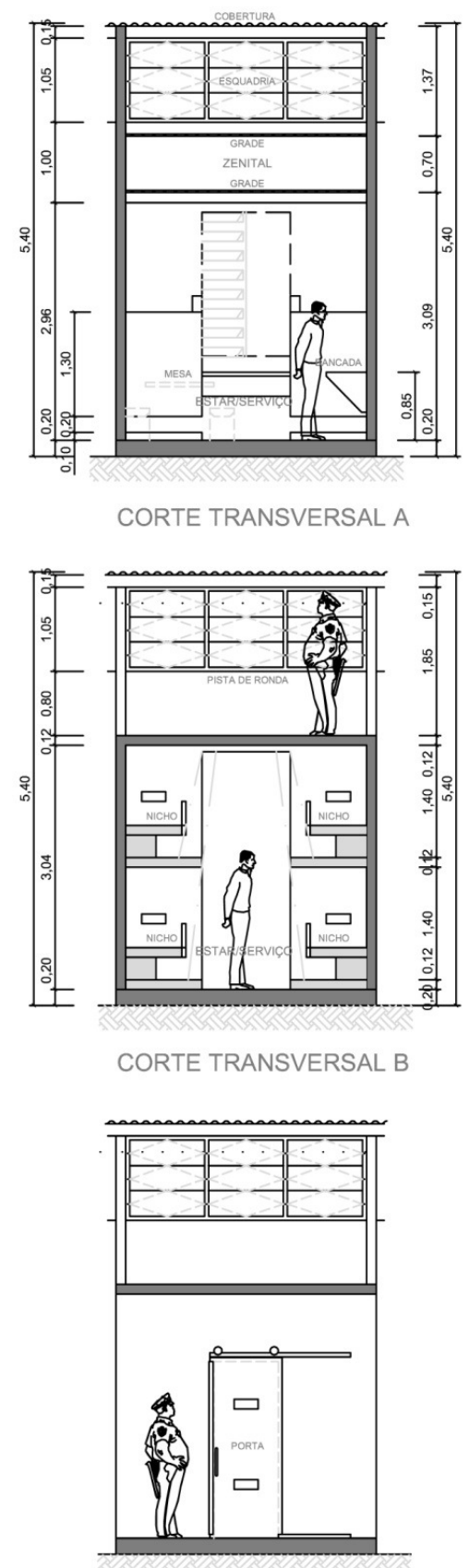

CORTE TRANVERSAL C

Figura 76 - Desenhos-síntese da cela (cortes transversais e vista externa do corredor de acesso). 

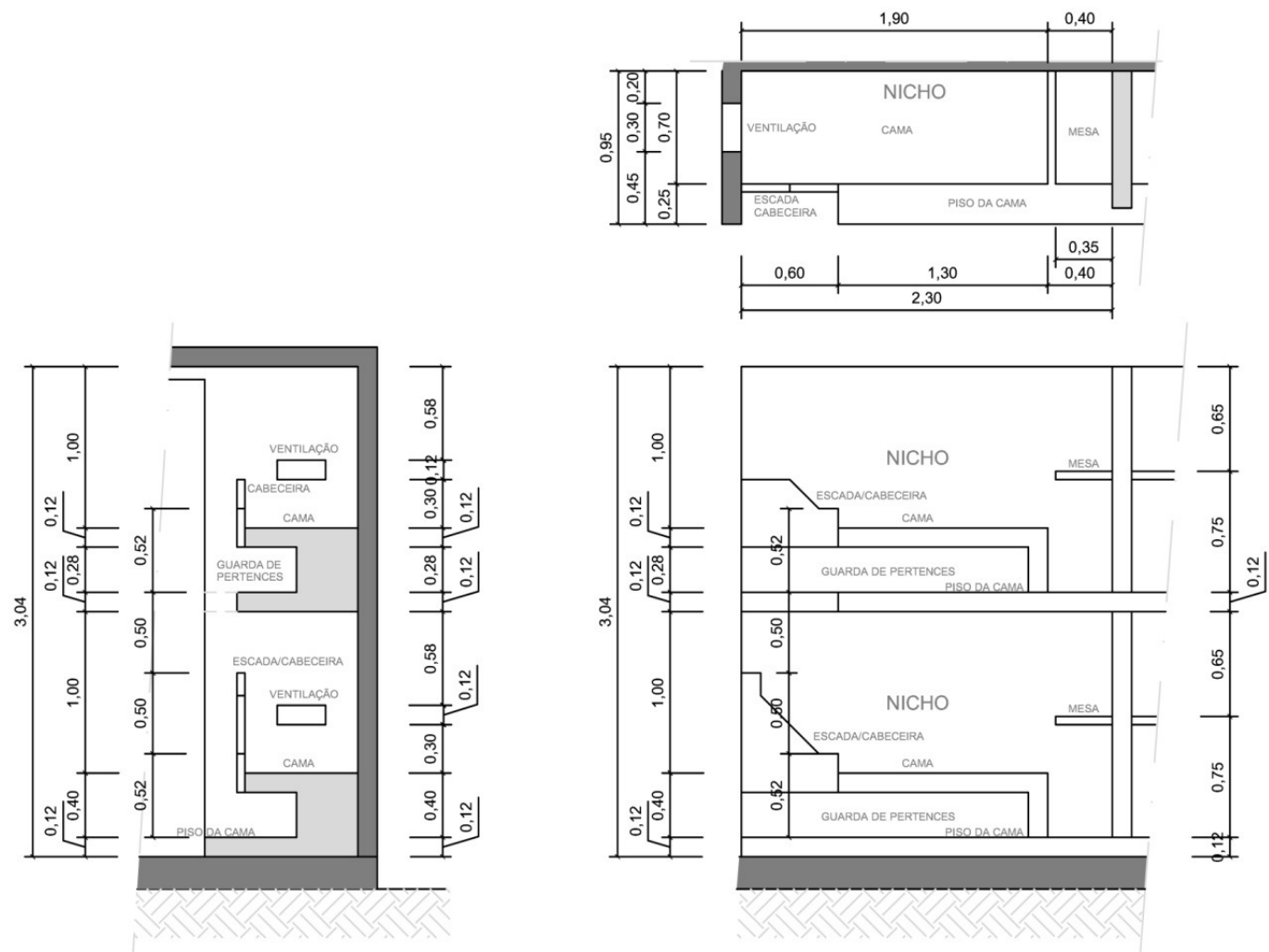

DETALHE DOS NICHOS

Figura 77 - Desenhos-síntese da cela (detalhes dos nichos). 


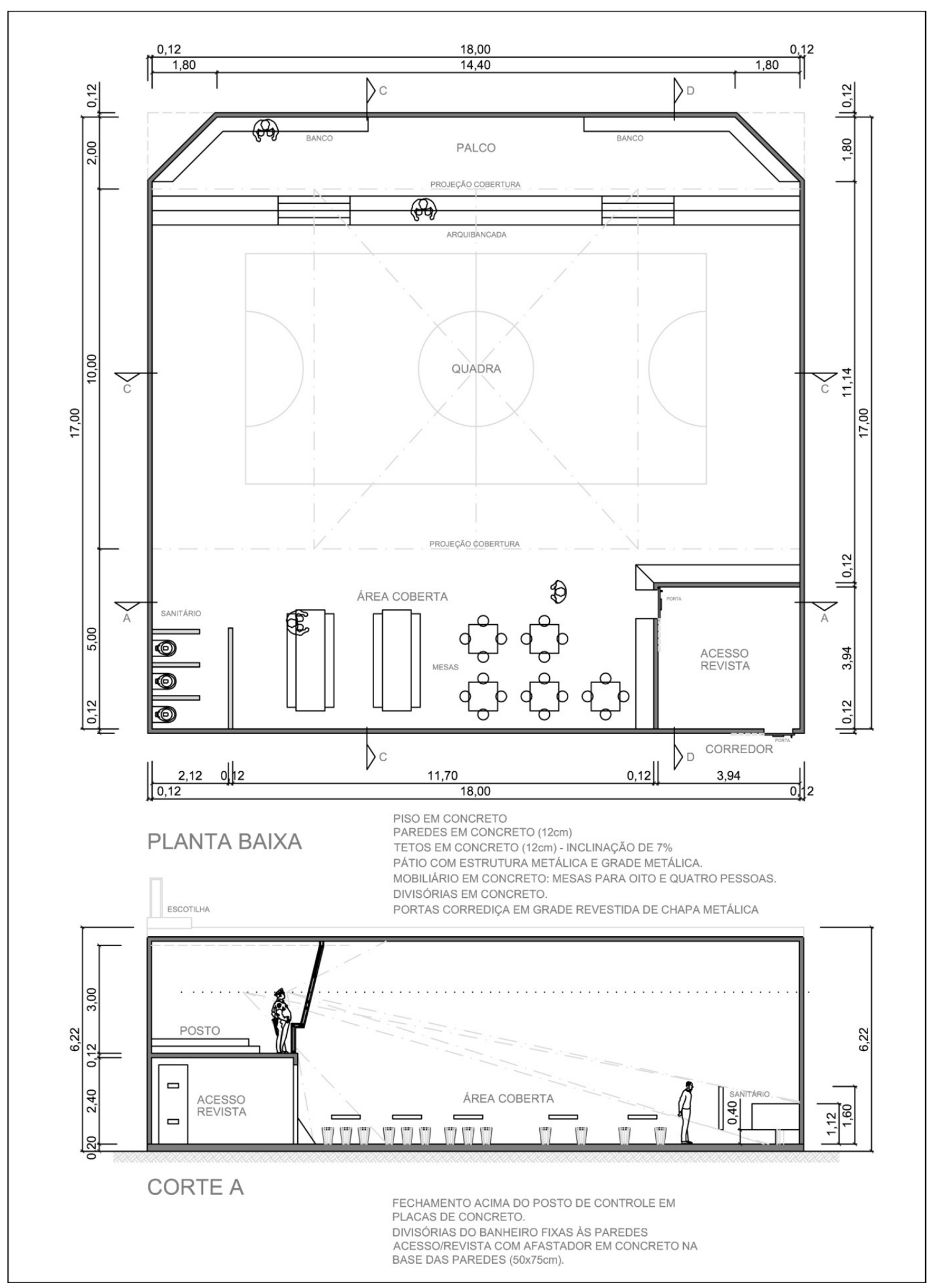

Figura 78 - Desenhos-síntese do pátio de sol dos presos (planta baixa e corte A). 


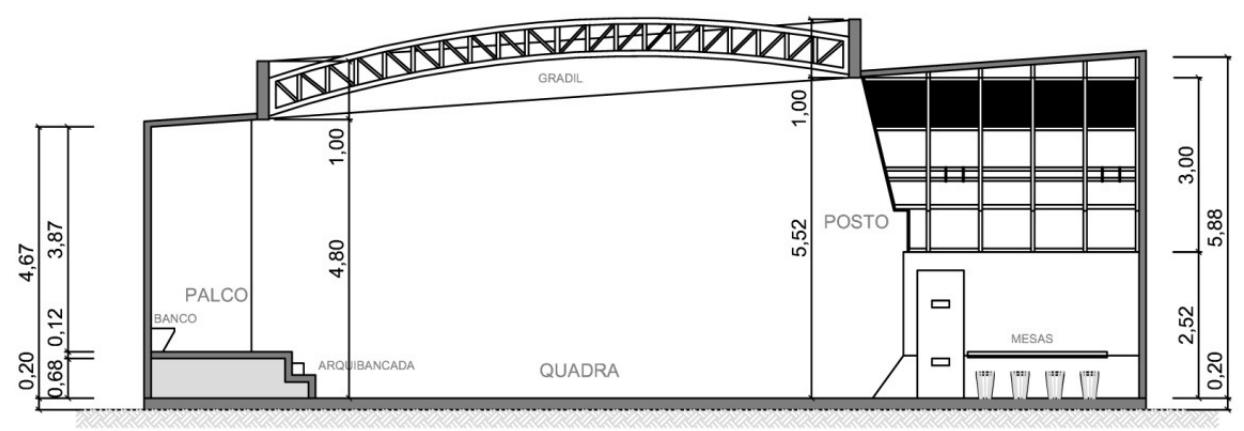

CORTE B
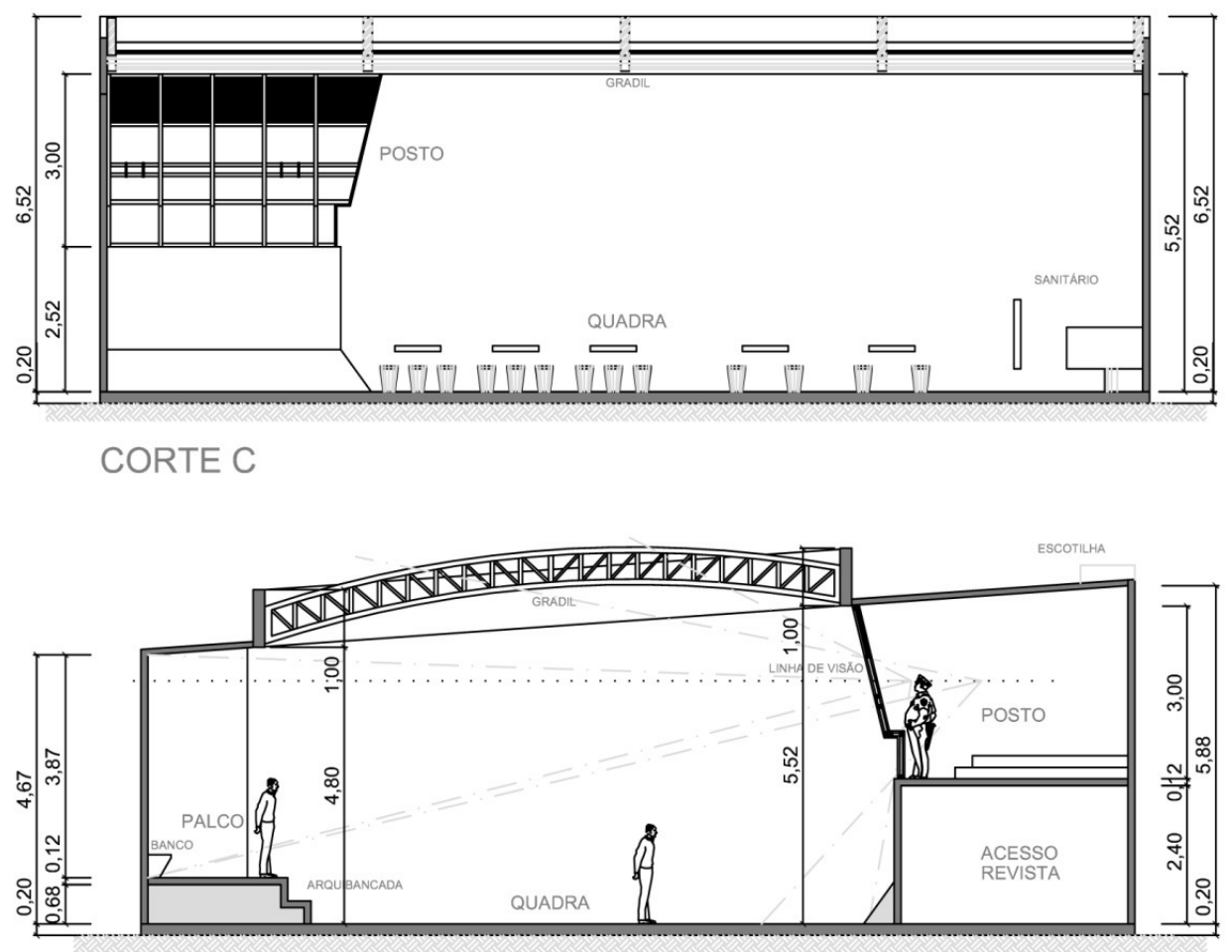

CORTE D

PISO EM CONCRETO

PAREDES EM CONCRETO $(12 \mathrm{~cm})$

TETOS EM CONCRETO (12cm) - INCLINAÇÃO DE 7\%

PÁTIO COM ESTRUTURA METÁLICA E GRADE METÁLICA.

MOBILIÁRIO EM CONCRETO: MESAS PARA OITO E QUATRO

PESSOAS.

DIVISORIAS EM CONCRETO
FECHAMENTO ACIMA DO POSTO DE CONTROLE EM PLACAS DE CONCRETO.

DIVISORIAS DO BANHEIRO FIXAS ȦS PAREDES ACESSO/REVISTA COM AFASTADOR EM CONCRETO NA BASE DAS PAREDES $(50 \times 75 \mathrm{~cm})$.

ARQUIBANCADA EM CONCRETO - ALTURA $80,0 \mathrm{~m}(2 \times 40,0 \mathrm{~cm})$

Figura 79 - Desenhos-síntese do pátio de sol dos presos (cortes B, C e D). 


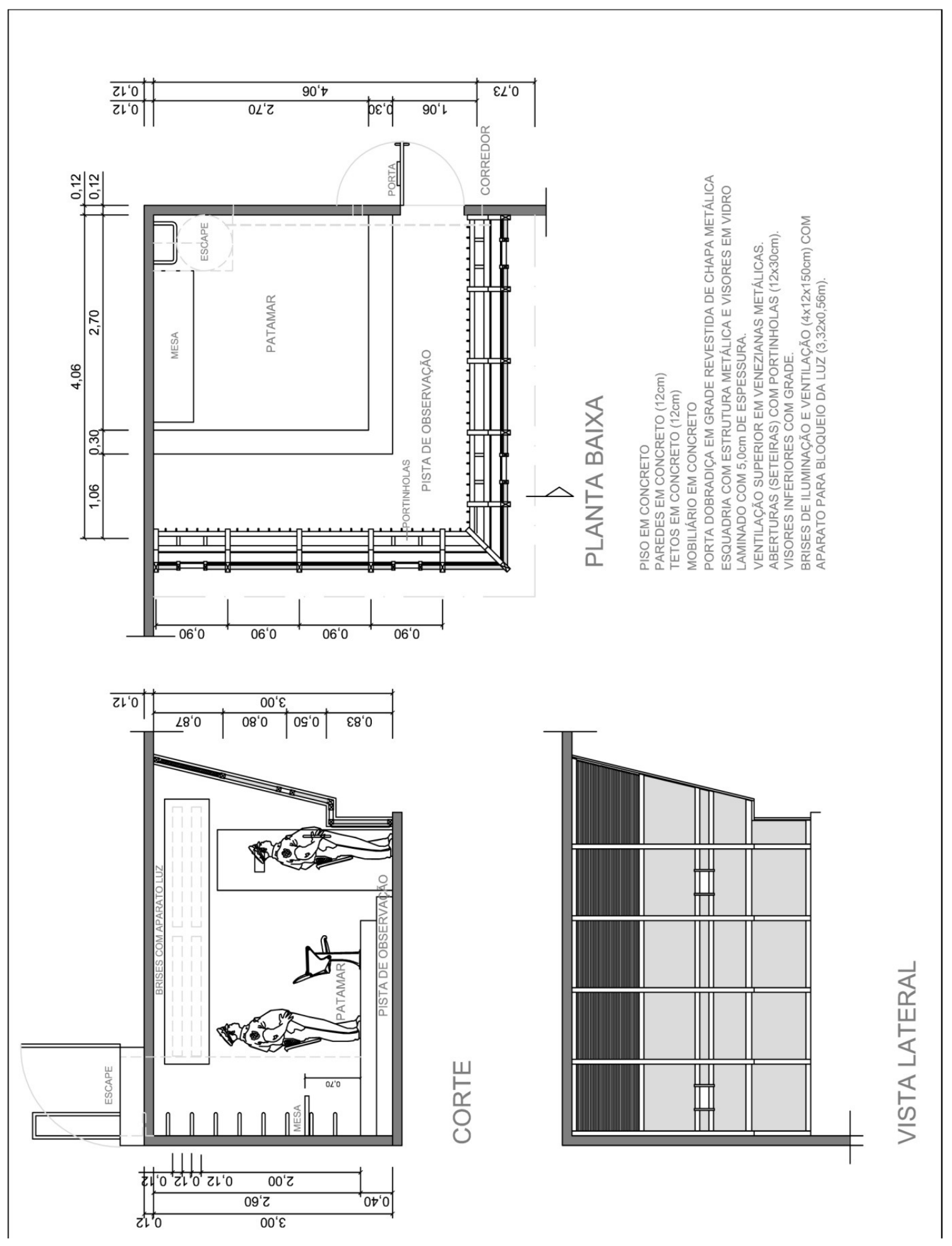

Figura 80 - Desenhos-síntese do posto de controle (planta baixa, corte e vista externa). 


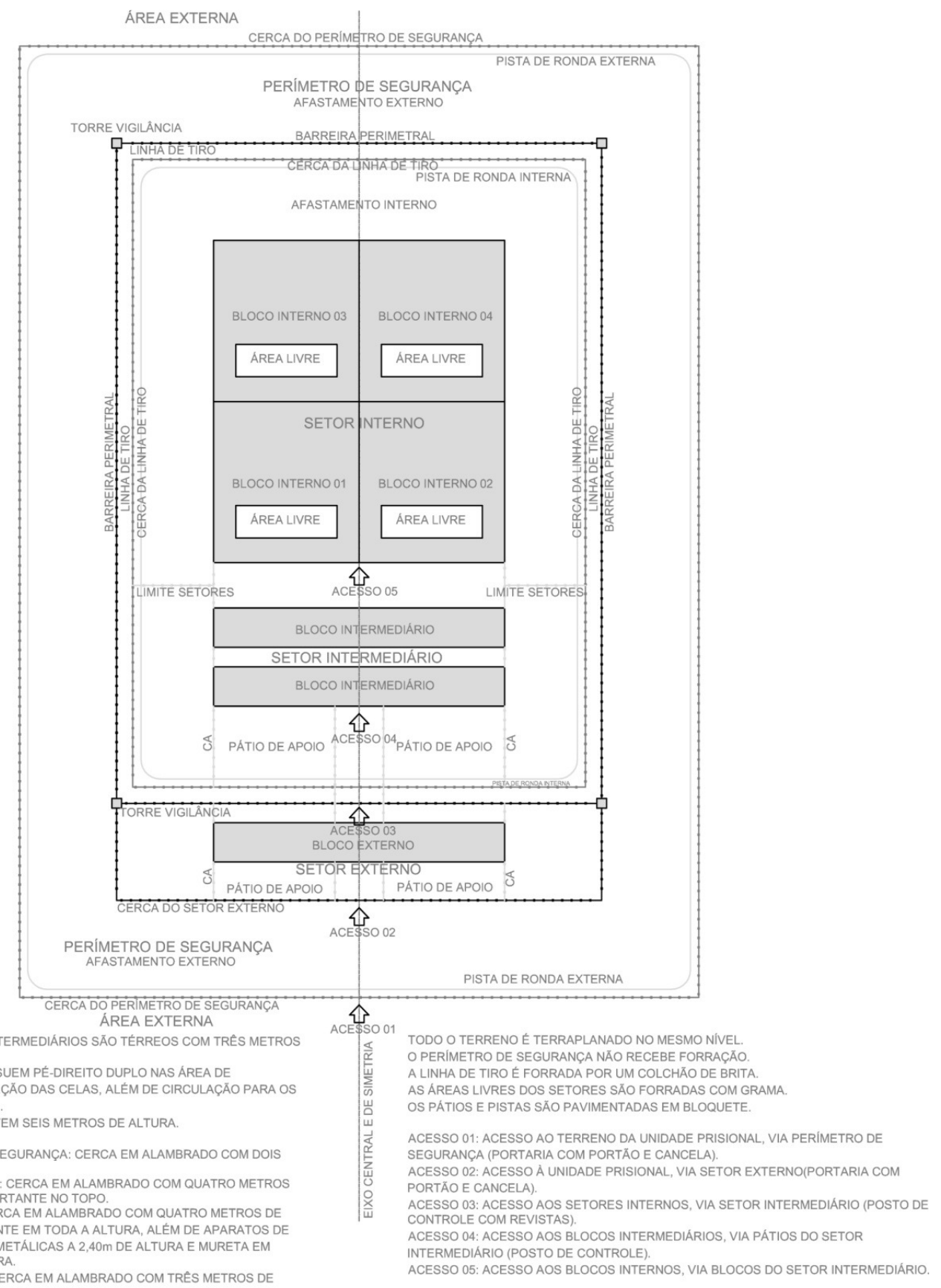

OS BLOCOS EXTERNOS EINTERMEDLARIOS SÄO TERREOS COM TRÉS METROS DEALTURA ATIVIDADES $(6 \mathrm{~m})$, COM EXCEÇĀO DAS CELAS, ALÉM DE CIRCULAÇÃO PARA OS FUNCIONARIOS NO NIVEL 3m.

AS TORRES DE VIGILÅNCIA TEM SEIS METROS DE ALTURA.

CERCA DO PERIMETRO DE SEGURANÇA: CERCA EM ALAMBRADO COM DOIS METROS DE ALTURA. DE ALTURA E ELEMENTO CORTANTE NO TOPO.

BARREIRA PERIMETRAL: CERCA EM ALAMBRADO COM QUATRO METROS DE ALTURA, ELEMENTO CORTANTE EM TODA AALTURA, ALEMDEAPARATOS DE BLOQUEIO VISUAL (TELHAS METÁLICAS A 2,40m DE ALTURA E MURETA EM CONCRETO A $60 \mathrm{~cm}$ DE ALTURA.

CERCA DA LINHA DE TIRO: CERCA EM ALAMBRADO COM TRESS METROS DE

CA (CERCA AUXILIAR): CERCA EM ALAMBRADO COM TRES METROS DE ALTURA PARA DELIMITAR AS AREAS LIVRES DE PESSOAS (PRESOS).

Figura 81 - Desenho de implantação de unidade prisional baseado na tecnologia de projeto. 


\section{Apêndice H - Avaliação da aplicação da tecnologia de projeto}

Neste apêndice, a análise do ajustamento aplicado aos projetos de referência realizado no capítulo 8, desta tese, é apresentada.

No ajustamento dos projetos de referência, cada um dos requisitos funcionais foi avaliado quanto o aprimoramento da arquitetura. $\mathrm{Na}$ análise de cada requisito, o ajustamento foi acompanhado da discrição do incremento obtido e de ressalvas ou observações quanto aos custos de construção e operação.

No quadro síntese apresentado, as legendas podem ser explicadas da forma seguinte:

- Os resultados plenos (P) significam um incremento arquitetônico, associado ao atendimento de todos os critérios do requisito disposto na tecnologia de projeto desenvolvida.

- Os resultados parciais (PA) apontam um incremento arquitetônico com o atendimento de parte destes critérios.

- Os resultados negativos $(\mathrm{N})$ correspondem a uma inadequação arquitetônica.

- A marcação 'sem aplicação' (S) diz respeito a uma inviabilidade do ajustamento, por dois motivos: primeiro, os itens exigem um grau de detalhamento não alcançado pela revisão dos projetos de referência, devido ao caráter amplo desta revisão (as particularidades se restringiram aos elementos centrais da edificação penal); segundo, os projetos de referência originais já atendiam ao requisito.

- A marcação 'aplicação parcial' (AP) indica o ajustamento quando estes projetos originais atendiam parte dos critérios, sendo complementados pela revisão aplicada.

- A marcação 'custo agregado' (C) destaca o acréscimo de custo de construção considerado inerente à configuração do nível de segurança máxima proposto, por isto não constituiu ponto negativo ao requisito. 


\begin{tabular}{|c|c|c|c|c|c|c|c|}
\hline \multicolumn{8}{|c|}{ 01. Tipo e categoria do estabelecimento penal } \\
\hline Item & Projeto & $\mathrm{S}$ & $\mathrm{F}$ & CA & $\mathrm{C}$ & $\mathbf{R}$ & Avaliação \\
\hline \multirow[t]{4}{*}{01.01} & PDF & $P$ & $P$ & $\mathrm{P}$ & PA & PC & \multirow{4}{*}{$\begin{array}{l}\text { O espaço arquitetônico foi ajustado ao perfil do preso, o que correspondeu } \\
\text { a uma modalidade arquitetônica, descrita pelo nível de segurança máximo } \\
\text { (simplicidade espacial e funcional). O ajustamento incrementou os projetos } \\
\text { (segurança: homogeneização do sistema de segurança; funcionalidade: } \\
\text { redução das tarefas e simplificação dos procedimentos; e conforto } \\
\text { ambiental: compatibilização das soluções), com aumento de custo de } \\
\text { construção (19\%), associado ao nível de segurança proposto. }\end{array}$} \\
\hline & PC & $\mathrm{P}$ & $P$ & $\mathrm{P}$ & $\mathrm{N}$ & PC & \\
\hline & MJ & $P$ & $P$ & $P$ & PA & PC & \\
\hline & EV & $P$ & $P$ & $P$ & PA & PC & \\
\hline \multirow[t]{4}{*}{01.02} & PDF & $P$ & $P$ & $P$ & PA & PC & \multirow{4}{*}{$\begin{array}{l}\text { O espaço arquitetônico teve a segurança priorizada e a humanizaçã } \\
\text { valorizada (programas de sociabilização e de benefícios aos presos, além } \\
\text { dos padrões de bem estar), o que descreve um modelo bem definido po } \\
\text { um estágio abaixo da disciplina-bloco (coletivização, racionalidad } \\
\text { geométrica, incremento das atividades socializantes e de reinserção social } \\
\text { e generalidade funcional). O ajustamento incrementou os projetos, com } \\
\text { exceção dos custos (aumento de áreas). }\end{array}$} \\
\hline & PC & $\mathrm{P}$ & $\mathrm{P}$ & $\mathrm{P}$ & PA & PC & \\
\hline & $\mathrm{MJ}$ & $P$ & $P$ & $P$ & $\mathrm{~N}$ & PC & \\
\hline & EV & $P$ & $P$ & $P$ & $N$ & PC & \\
\hline \multirow[t]{4}{*}{01.03} & PDF & $\mathrm{P}$ & $P$ & 1 & PA & PC & \multirow{4}{*}{$\begin{array}{l}\text { O espaço arquitetônico de segurança máxima apresenta características } \\
\text { próprias, relativas ao enquadramento no sistema penitenciário, ao } \\
\text { combinar os padrões modular e paralelo (compactados e horizontalizados). } \\
\text { O ajustamento incrementou os projetos (segurança: homogeneização do } \\
\text { sistema de segurança; e funcionalidade: redução das tarefas e simplificação } \\
\text { dos procedimentos), com aumento de custo de construção (19\%), associado } \\
\text { ao nível de segurança proposto. }\end{array}$} \\
\hline & PC & $\mathrm{P}$ & $\mathrm{P}$ & 1 & PA & PC & \\
\hline & MJ & $P$ & $P$ & 1 & PA & PC & \\
\hline & EV & $P$ & $P$ & I & $\mathrm{PA}$ & PC & \\
\hline
\end{tabular}

\begin{tabular}{|c|c|c|c|c|c|c|c|}
\hline \multicolumn{8}{|c|}{ 02. Porte do estabelecimento penal } \\
\hline Item & Projeto & $\mathrm{S}$ & $\mathrm{F}$ & $\mathrm{CA}$ & C & $\mathbf{R}$ & Avaliação \\
\hline \multirow[t]{4}{*}{02.01} & PDF & $\mathrm{P}$ & $\mathrm{P}$ & 1 & $\mathrm{P}$ & $\mathrm{P}$ & \multirow{4}{*}{$\begin{array}{l}\text { Os projetos tiveram as áreas proporcionalizadas com as capacidades: a } \\
\text { área construída média foi aumentada de } 16,20 \text { para } 19,41 \mathrm{~m}^{2} / \text { vaga. Os } \\
\text { projetos distrital e paulista receberam a circulação exclusiva para os } \\
\text { funcionários. O projeto distrital teve redução de área com redução de } \\
\text { custo de construção. A segurança (mobilidade e proteção dos } \\
\text { funcionários) e a funcionalidade (realização das atividades dos presos) } \\
\text { foram favorecidas. O ajustamento incrementou os projetos com um } \\
\text { aumento de custos associado ao nível de segurança proposto. }\end{array}$} \\
\hline & PC & $P$ & $P$ & 1 & PA & PC & \\
\hline & MJ & $S$ & $P$ & 1 & PA & PC & \\
\hline & EV & $\mathrm{S}$ & $P$ & 1 & PA & PC & \\
\hline \multirow[t]{4}{*}{02.02} & PDF & $\mathrm{PA}$ & $\mathrm{PA}$ & 1 & $P$ & $\mathrm{P}$ & \multirow{4}{*}{$\begin{array}{l}\text { Os projetos distrital e paulista tiveram as capacidades reduzidas de } 1.464 \\
\text { e } 768 \text { vagas para } 1.152 \text { e } 576 \text { vagas, respectivamente. O projeto federal } \\
\text { teve a capacidade aumentada de } 374 \text { para } 512 \text { vagas. O projeto privado } \\
\text { manteve a capacidade ( } 576 \text { vagas). A segurança (submissão dos presos) e } \\
\text { a funcionalidade (serviços penitenciários) foram favorecidas, enquanto o } \\
\text { custo da vaga médio aumentou de } \mathrm{R} \$ 59,5 \text { para } \mathrm{R} \$ 75 \text { mil/vaga. O } \\
\text { ajustamento incrementou os projetos com um aumento de custos } \\
\text { associado ao nível de segurança proposto. }\end{array}$} \\
\hline & PC & $\mathrm{P}$ & $\mathrm{P}$ & 1 & PA & PC & \\
\hline & MJ & $P$ & $\mathrm{P}$ & $\mathrm{I}$ & PA & PC & \\
\hline & EV & - & - & 1 & - & - & \\
\hline \multirow[t]{4}{*}{02.03} & PDF & $S$ & $S$ & $S$ & $S$ & $\mathrm{~S}$ & \multirow{4}{*}{$\begin{array}{l}\text { A revisão dos projetos de referência se restringiu ao projetado que não } \\
\text { prevê ampliações. }\end{array}$} \\
\hline & PC & $S$ & $S$ & $S$ & $S$ & $S$ & \\
\hline & MJ & $S$ & $S$ & $S$ & $S$ & $S$ & \\
\hline & EV & $\mathrm{S}$ & $S$ & $\mathrm{~S}$ & $S$ & $\mathrm{~S}$ & \\
\hline
\end{tabular}

\begin{tabular}{|c|c|c|c|c|c|c|c|}
\hline \multicolumn{8}{|c|}{ 03. Custo do estabelecimento penal } \\
\hline Item & Projeto & $\mathrm{S}$ & $\mathrm{F}$ & $C A$ & $\mathrm{C}$ & $\mathbf{R}$ & Avaliação \\
\hline \multirow[t]{4}{*}{03.01} & PDF & $P$ & $P$ & $\mathrm{I}$ & PA & $P C$ & \multirow{4}{*}{$\begin{array}{l}\text { Os projetos tiveram as modulações revistas e as áreas construídas } \\
\text { ampliadas, com exceção do projeto distrital. Este rearranjo arquitetônico } \\
\text { favoreceu a segurança e a funcionalidade com aumento dos custos de } \\
\text { construção, mas os custos unitários foram reduzidos em } 6 \% \text {, assim como, } \\
\text { os custos operacionais dos projetos distrital e paulista foram reduzidos. } \\
\text { ajustamento incrementou os projetos com um aumento de custos } \\
\text { associado ao nível de segurança proposto. No projeto privado, o } \\
\text { ajustamento teve um impacto menor. }\end{array}$} \\
\hline & $\mathrm{PC}$ & $\mathrm{P}$ & $P$ & 1 & $\mathrm{PA}$ & $P C$ & \\
\hline & MJ & $P$ & $P$ & 1 & $\mathrm{PA}$ & PC & \\
\hline & EV & PA & PA & 1 & PA & PA & \\
\hline \multirow[t]{3}{*}{03.02} & PDF & $\mathrm{P}$ & $P$ & 1 & $\mathrm{PA}$ & PC & \multirow{3}{*}{$\begin{array}{l}\text { Os projetos tiveram um acréscimo total em } 19 \% \text { e do custo da vaga em } \\
25 \% \text {, enquanto o custo unitário foi reduzido em } 6 \% \text {. Os mesmos tiveram } \\
\text { um aumento do contingente operacional em } 10 \% \text {. Estes incrementos }\end{array}$} \\
\hline & $\mathrm{PC}$ & $\mathrm{P}$ & $P$ & 1 & $\mathrm{PA}$ & PC & \\
\hline & MJ & $P$ & $P$ & 1 & PA & PC & \\
\hline
\end{tabular}




\begin{tabular}{|c|c|c|c|c|c|c|c|}
\hline & EV & $P$ & $P$ & 1 & PA & PC & $\begin{array}{l}\text { caracterizam a modalidade arquitetônica de segurança máxima proposta: } \\
\text { a melhoria dos sistemas de segurança e operação, aliada à humanização } \\
\text { do espaço prisional. O ajustamento incrementou os projetos com um } \\
\text { aumento de custos associado ao nível de segurança proposto. }\end{array}$ \\
\hline \multirow[t]{4}{*}{03.03} & PDF & $P$ & $P$ & $P$ & PA & PC & \multirow{4}{*}{$\begin{array}{l}\text { Os projetos tiveram os requisitos de bem estar contemplados, por meio } \\
\text { do dimensionamento, composição, ambientação e aparelhamento dos } \\
\text { espaços. O dimensionamento responde pela totalidade do aumento do } \\
\text { custo de construção ocorrido. As adequações pormenorizadas focaram os } \\
\text { elementos centrais da edificação penal (ver itens } 16,17,18 \text { e 19). O } \\
\text { ajustamento incrementou os projetos com um aumento de custos } \\
\text { associado ao nível de segurança proposto. }\end{array}$} \\
\hline & PC & $\mathrm{P}$ & $\mathrm{P}$ & $P$ & PA & PC & \\
\hline & $\mathrm{MJ}$ & $\mathrm{P}$ & $\mathrm{P}$ & PA & PA & $P C$ & \\
\hline & EV & PA & $\mathrm{PA}$ & PA & PA & $\mathrm{PA}$ & \\
\hline \multirow[t]{4}{*}{03.04} & PDF & $S$ & $S$ & $S$ & $S$ & $\mathrm{~S}$ & \multirow{4}{*}{$\begin{array}{l}\text { Os projetos paulista e federal foram remodelados com base nos conceitos } \\
\text { dos padrões arquitetônicos modular e paralelo. O projeto paulista } \\
\text { apresentou uma redução no custo operacional. O ajustamento } \\
\text { incrementou os projetos com um aumento de custos associado ao nível } \\
\text { de segurança proposto. }\end{array}$} \\
\hline & PC & $P$ & $\mathrm{P}$ & $\mathrm{S}$ & $\mathrm{PA}$ & PC & \\
\hline & MJ & $P$ & $\mathrm{P}$ & $S$ & PA & PC & \\
\hline & EV & $S$ & $S$ & $S$ & $S$ & $S$ & \\
\hline
\end{tabular}

04. Isolamento Social

\begin{tabular}{|c|c|c|c|c|c|c|c|}
\hline Item & Projeto & $\mathrm{S}$ & $\mathrm{F}$ & CA & C & $\mathbf{R}$ & Avaliação \\
\hline \multirow[t]{4}{*}{04.01} & PDF & PA & $S$ & $S$ & PA & PAC & \multirow{4}{*}{$\begin{array}{l}\text { Os projetos tiveram a impermeabilidade incrementada, através da } \\
\text { inserção de perímetro de segurança (projetos distrital e privado), com } \\
\text { adição ao custo de construção ( } \$ 1,22 \text { milhões), ou mantida, através da } \\
\text { substituição do muro por cerca (projetos paulista e federal), com dedução } \\
\text { no custo de construção ( } \$ \$ \$ 7,11 \text { milhões). A segurança e o conforto } \\
\text { ambiental foram favorecidos, enquanto a funcionalidade foi } \\
\text { desfavorecida. O ajustamento incrementou os projetos com uma } \\
\text { oscilação nos custos associada ao nível de segurança proposto. }\end{array}$} \\
\hline & PC & $S$ & PA & $P$ & $\mathrm{P}$ & $\mathrm{P}$ & \\
\hline & $\mathrm{MJ}$ & $S$ & PA & $P$ & $\mathrm{P}$ & $P$ & \\
\hline & EV & $P$ & $P$ & $S$ & PA & PC & \\
\hline \multirow[t]{4}{*}{04.02} & PDF & $S$ & $S$ & 1 & $\mathrm{~S}$ & $S$ & \multirow{4}{*}{$\begin{array}{l}\text { Os projetos já apresentavam uma convergência com a demanda e as } \\
\text { soluções formal e informal eram equivalentes. Não houve alteração nos } \\
\text { projetos. }\end{array}$} \\
\hline & PC & $S$ & $S$ & 1 & $S$ & $S$ & \\
\hline & MJ & $S$ & $S$ & 1 & $S$ & $S$ & \\
\hline & EV & $S$ & $S$ & 1 & $S$ & $S$ & \\
\hline \multirow[t]{4}{*}{04.03} & PDF & $\mathrm{P}$ & $P$ & $I$ & $\mathrm{P}$ & $\mathrm{P}$ & \multirow{4}{*}{$\begin{array}{l}\text { Os projetos tiveram a visita social e conjugal implantada (projetos distrital } \\
\text { e paulista) ou ampliada (projeto federal), com adição aos custos de } \\
\text { construção nos casos paulista e federal (R\$ } 4,28 \text { milhões e } R \$ 1,79 \text { milhão, } \\
\text { respectivamente) ou dedução de } R \$ 1,37 \text { milhão no projeto distrital. Isto } \\
\text { favoreceu a segurança (redução de vulnerabilidades) e a funcionalidade } \\
\text { (redução de tarefas). O ajustamento incrementou os projetos com um } \\
\text { aumento de custo associado ao nível de segurança proposto. }\end{array}$} \\
\hline & PC & $P$ & $P$ & 1 & $\mathrm{PA}$ & PC & \\
\hline & MJ & $P$ & $P$ & 1 & PA & PC & \\
\hline & EV & $S$ & $S$ & 1 & $S$ & $S$ & \\
\hline 04.04 & & - & - & - & - & - & $\begin{array}{l}\text { O item não se aplica, pois os projetos são padronizados ou modelos, sem } \\
\text { localização determinada. }\end{array}$ \\
\hline
\end{tabular}

\begin{tabular}{|c|c|c|c|c|c|c|c|}
\hline \multicolumn{8}{|c|}{ 05. Isolamento Individual } \\
\hline Item & Projeto & $\mathrm{S}$ & $\mathrm{F}$ & $\mathrm{CA}$ & $C$ & $\mathbf{R}$ & Avaliação \\
\hline \multirow[t]{4}{*}{05.01} & PDF & $\mathrm{S}$ & $\mathrm{S}$ & $\mathrm{S}$ & $\mathrm{S}$ & $\mathrm{S}$ & \multirow{4}{*}{$\begin{array}{l}\text { Os projetos já apresentavam celas coletivas, o que passou a ser favoráve } \\
\text { diante da modalidade arquitetônica proposta (a caracterização informa } \\
\text { passou a ser convergente com a demanda). Não houve alteração nos } \\
\text { projetos. }\end{array}$} \\
\hline & PC & $\mathrm{S}$ & $S$ & $\mathrm{~S}$ & $S$ & $S$ & \\
\hline & $\mathrm{MJ}$ & $S$ & $\mathrm{~S}$ & $S$ & $\mathrm{~S}$ & $\mathrm{~S}$ & \\
\hline & EV & $\mathrm{S}$ & $\mathrm{S}$ & $\mathrm{S}$ & $\mathrm{S}$ & $\mathrm{S}$ & \\
\hline \multirow[t]{4}{*}{05.02} & PDF & $\mathrm{P}$ & $\mathrm{P}$ & 1 & $\mathrm{P}$ & $\mathrm{P}$ & \multirow{4}{*}{$\begin{array}{l}\text { Os projetos foram compactados pelo fracionamento da população } \\
\text { prisional. O projeto distrital teve as quantidades de alas carcerárias e celas } \\
\text { reduzidas (redução de } \mathrm{R} \$ 5,61 \text { milhões). O projeto paulista reduziu a } \\
\text { quantidade de alas carcerárias, e aumentou o número de celas (adição de } \\
\mathrm{R} \$ 588 \text { mil). O projeto federal aumentou o número de celas (adição de } \mathrm{R} \$ \\
1,98 \text { milhão). O ajustamento incrementou os projetos (redução de } \\
\text { vulnerabilidades e redução de tarefas) com um aumento de custo } \\
\text { associado ao nível de segurança proposto. }\end{array}$} \\
\hline & PC & $\mathrm{P}$ & $\mathrm{P}$ & $\mathrm{I}$ & $\mathrm{PA}$ & $\mathrm{P}$ & \\
\hline & $\mathrm{MJ}$ & $\mathrm{PA}$ & $\mathrm{P}$ & $\mathrm{I}$ & $\mathrm{PA}$ & PAC & \\
\hline & EV & $S$ & $S$ & 1 & $\mathrm{~S}$ & $S$ & \\
\hline \multirow[t]{4}{*}{05.03} & PDF & $\mathrm{S}$ & $\mathrm{S}$ & $\mathrm{S}$ & $\mathrm{S}$ & $\mathrm{S}$ & \multirow{4}{*}{$\begin{array}{l}\text { Os projetos já apresentavam uma convergência com a demanda e as } \\
\text { soluções formal e informal eram equivalentes. Não houve alteração nos } \\
\text { projetos. }\end{array}$} \\
\hline & PC & $\mathrm{S}$ & $S$ & $S$ & $S$ & $S$ & \\
\hline & MJ & $\mathrm{S}$ & $S$ & $S$ & $S$ & $S$ & \\
\hline & EV & $\mathrm{S}$ & $\mathrm{S}$ & $\mathrm{S}$ & $S$ & $\mathrm{~S}$ & \\
\hline \multirow[t]{3}{*}{05.04} & PDF & $\mathrm{P}$ & $\mathrm{P}$ & $I$ & $\mathrm{P}$ & $\mathrm{P}$ & \multirow{3}{*}{$\begin{array}{l}\text { Os projetos tiveram as quantidades de celas individuais adequadas às } \\
\text { capacidades dos estabelecimentos. Os projetos distrital e paulista tiveram } \\
\text { redução de celas (dedução de } \mathrm{R} \$ 5,61 \text { milhões e } \mathrm{R} \$ 1,33 \text { milhão, }\end{array}$} \\
\hline & PC & $P$ & $P$ & 1 & $P$ & $P$ & \\
\hline & $\mathrm{MJ}$ & $P$ & $P$ & $\mathrm{I}$ & $P$ & $\mathrm{P}$ & \\
\hline
\end{tabular}




\begin{tabular}{|c|c|c|c|c|c|c|c|}
\hline & EV & S & S & I & S & S & $\begin{array}{l}\text { respectivamente). Os projetos federal e privado não tiveram alterações. } \\
\text { Os projetos distrital e federal receberam blocos de isolamento. O } \\
\text { ajustamento incrementou os projetos (a criação de blocos favoreceu a } \\
\text { redução de tarefas) com um aumento de custo associado ao nível de } \\
\text { segurança proposto. }\end{array}$ \\
\hline $\mathbf{0 5 . 0 5}$ & PDF & S & S & I & S & S & $\begin{array}{l}\text { Os projetos já apresentavam celas com oito vagas, o que passou a ser } \\
\text { favorável diante da modalidade arquitetônica proposta (a caracterização } \\
\end{array}$ \\
\cline { 2 - 8 } & PC & P & P & I & PA & PC & $\begin{array}{l}\text { informal passou a ser convergente com a demanda). Como exceção, o } \\
\text { projeto paulista teve uma redução de capacidade das celas. O ajustamento } \\
\text { incrementou este projeto na segurança (submissão dos presos) e na } \\
\text { funcionalidade (simplificação dos procedimentos) com um aumento de } \\
\text { custo associado ao nível de segurança proposto. }\end{array}$ \\
\hline
\end{tabular}

06. Organização do Espaço

\begin{tabular}{|c|c|c|c|c|c|c|c|}
\hline Item & Projeto & $\mathrm{S}$ & $\mathrm{F}$ & CA & C & $\mathbf{R}$ & Avaliação \\
\hline \multirow[t]{4}{*}{06.01} & PDF & $\mathrm{P}$ & $\mathrm{P}$ & $\mathrm{P}$ & $\mathrm{P}$ & $\mathrm{P}$ & \multirow{4}{*}{$\begin{array}{l}\text { Os projetos tiveram as propriedades utilitaristas enfatizadas, em } \\
\text { termos da segurança (vigilância e proteção dos funcionários), da } \\
\text { funcionalidade (redução de tarefas e simplificação de } \\
\text { procedimentos) e do conforto ambiental (padrões mínimos de } \\
\text { ventilação e iluminação). Estes aprimoramentos foram } \\
\text { contrabalanceados, ao se buscar uma proximidade dos valores } \\
\text { encontrados no sistema penitenciário. O ajustamento incrementou } \\
\text { os projetos com um aumento de custo, associado à modalidade } \\
\text { arquitetônica proposta. }\end{array}$} \\
\hline & PC & PA & $\mathrm{P}$ & $\mathrm{P}$ & PA & PC & \\
\hline & MJ & $\mathrm{P}$ & $P$ & $\mathrm{P}$ & $\mathrm{PA}$ & PC & \\
\hline & EV & $\mathrm{PA}$ & $P$ & $P$ & $\mathrm{PA}$ & PC & \\
\hline \multirow[t]{4}{*}{06.02} & PDF & $P$ & $P$ & $P$ & $P$ & $\mathrm{P}$ & \multirow{4}{*}{$\begin{array}{l}\text { Os projetos foram aprimorados quanto à disciplina espacial, ao } \\
\text { apresentarem a geometria, especialização e a hierarquização } \\
\text { racionalizada (localização e interligação das atividades socializantes, } \\
\text { benefícios aos presos e pátios de sol dos presos). As atividades } \\
\text { foram concentradas nas áreas internas e foi adotada a vigilância } \\
\text { direta (concentração funcional). O ajustamento incrementou os } \\
\text { projetos (homogeneização e otimização dos sistemas de segurança e } \\
\text { operação) com um aumento de custo, associado ao nível de } \\
\text { segurança proposto. }\end{array}$} \\
\hline & PC & $\mathrm{P}$ & $\mathrm{P}$ & $P$ & PA & PC & \\
\hline & MJ & $\mathrm{P}$ & $\mathrm{P}$ & $P$ & PA & PC & \\
\hline & EV & $\mathrm{PA}$ & $P$ & $P$ & PA & PC & \\
\hline \multirow[t]{4}{*}{06.03} & PDF & PA & $\mathrm{P}$ & $\mathrm{P}$ & $P$ & PC & \multirow{4}{*}{$\begin{array}{l}\text { Os projetos foram ajustados quanto ao nível de segurança (redução } \\
\text { de vulnerabilidades e maximização da segurança). A humanização foi } \\
\text { prestigiada com áreas adequadas para as atividades (em particular, } \\
\text { para os programas socializante e de benefícios aos presos), além da } \\
\text { manutenção dos padrões mínimos de bem-estar, em especial, dos } \\
\text { elementos centrais da edificação penal (principalmente, ventilação, } \\
\text { iluminação e mobiliário). O ajustamento incrementou os projetos } \\
\text { com um aumento de custo, associado ao nível de segurança } \\
\text { proposto. }\end{array}$} \\
\hline & PC & PA & $P$ & $P$ & $\mathrm{P}$ & PC & \\
\hline & MJ & PA & $\mathrm{P}$ & PA & $\mathrm{P}$ & PAC & \\
\hline & EV & $P$ & PA & PA & $P$ & PAC & \\
\hline \multicolumn{8}{|c|}{ 07. Geometria } \\
\hline Item & Projeto & $\mathrm{S}$ & $\mathrm{F}$ & CA & $\mathrm{C}$ & $\mathbf{R}$ & Avaliação \\
\hline \multirow[t]{4}{*}{07.01} & PDF & $\mathrm{P}$ & $P$ & $S$ & $S$ & $\mathrm{P}$ & \multirow{4}{*}{$\begin{array}{l}\text { Os projetos tiveram a geometria centralizada (projeto distrital), } \\
\text { horizontalizada (projeto paulista) e retificada (projeto federal), e a } \\
\text { configuração de blocos intermediários em paralelo (projetos paulista } \\
\text { e federal). Isto aumentou o perímetro médio (de } 1.398 \text { para } 1.800 \mathrm{~m} \text { ) } \\
\text { e os índices de } 2,13 \text { para } 2,80 \mathrm{~m} / \text { vaga, e de } 0,13 \text { para } 0,15 \mathrm{~m} / \mathrm{m}^{2} \text {. } \\
\text { Estes índices extrapolaram os limites médios definidos. Os projetos } \\
\text { paulista e privado tiveram redução da vigilância ( } 1 \% \text { da área reduzida } \\
\text { e } 2 \text { pontos cegos aumentados, respectivamente). O ajustamento } \\
\text { incrementou parcialmente os projetos (segurança: vigilância } \\
\text { externa) com aumento de custo. }\end{array}$} \\
\hline & PC & $\mathrm{N}$ & $P$ & $P$ & PA & PAC & \\
\hline & $\mathrm{MJ}$ & $\mathrm{P}$ & $\mathrm{P}$ & $P$ & $P$ & $P$ & \\
\hline & EV & $\mathrm{N}$ & $\mathrm{P}$ & $S$ & $\mathrm{~S}$ & $N$ & \\
\hline \multicolumn{8}{|c|}{ 08. Funcionalidade } \\
\hline Item & Projeto & $\mathrm{S}$ & $\mathrm{F}$ & $\mathrm{CA}$ & C & $\mathbf{R}$ & Avaliação \\
\hline \multirow[t]{4}{*}{08.01} & PDF & $P$ & & 1 & $\mathrm{~N}$ & PC & \multirow{4}{*}{$\begin{array}{l}\text { Os projetos tiveram ampliação funcional com acréscimo de } \\
\text { atividades e área construída }(48,75 \%) \text {, com exceção do projeto } \\
\left.\text { distrital (redução de } 0,05 \mathrm{~m}^{2}\right) \text {. O ajustamento incrementou os } \\
\text { projetos (compatibilização das atividades com a segurança: } \\
\text { submissão dos presos; e funcionalidade: em especial, a realização } \\
\text { das atividades dos presos), com ressalvas operacionais }\end{array}$} \\
\hline & PC & $P$ & & I & $\mathrm{N}$ & PC & \\
\hline & MJ & AP & AP & 1 & PA & $\mathrm{AP}$ & \\
\hline & EV & AP & $\mathrm{AP}$ & 1 & PA & $\mathrm{AP}$ & \\
\hline
\end{tabular}




\begin{tabular}{|c|c|c|c|c|c|c|c|}
\hline & & & & & & & $\begin{array}{l}\text { (funcionalidade: complexidade dos procedimentos) e aumento de } \\
\text { custo de construção, associados ao nível de segurança proposto. }\end{array}$ \\
\hline \multirow[t]{4}{*}{08.02} & PDF & $P$ & $\mathrm{P}$ & $\mathrm{PA}$ & $\mathrm{P}$ & $\mathrm{P}$ & \multirow{4}{*}{$\begin{array}{l}\text { Os projetos tiveram a simplicidade funcional aplicada aos recintos } \\
\text { para ajustar ao mínimo previsto (dimensionamento e } \\
\text { aparelhamento). O projetos distrital e paulista tiveram áreas } \\
\text { minimizadas. Os projetos federal e privado tiveram as áreas } \\
\text { aumentadas. O ajustamento incrementou os projetos } \\
\text { (compatibilização das atividades com a segurança: submissão dos } \\
\text { presos; e a funcionalidade: em especial, a realização das atividades } \\
\text { dos presos), com aumento de custo de construção, associado ao } \\
\text { nível de segurança proposto. }\end{array}$} \\
\hline & PC & $\mathrm{P}$ & $\mathrm{P}$ & PA & $P$ & $P$ & \\
\hline & $\mathrm{MJ}$ & $\mathrm{P}$ & $\mathrm{P}$ & $P$ & PA & PC & \\
\hline & EV & $P$ & $P$ & $P$ & $\mathrm{PA}$ & PC & \\
\hline \multicolumn{8}{|r|}{ (6) } \\
\hline Item & Projeto & $\mathrm{S}$ & $\mathrm{F}$ & $\mathrm{CA}$ & C & $\mathbf{R}$ & Avaliação \\
\hline \multirow[t]{4}{*}{09.01} & PDF & $\mathrm{P}$ & $\mathrm{P}$ & 1 & $P$ & $P$ & \multirow{4}{*}{$\begin{array}{l}\text { Os projetos tiveram os programas incrementados (de } 78 \% \text { para } \\
83 \% \text { ), em particular com a inclusão de local para a visita social e } \\
\text { circulação exclusiva para os funcionários. Os locais de socialização e } \\
\text { laboreducação foram ajustados (de } 2,51 \text { para } 2,37 \mathrm{~m}^{2} / \text { vaga e de } 2,16 \\
\text { para } 2,09 \mathrm{~m}^{2} / \text { vaga). O ajustamento incrementou os projetos } \\
\text { (segurança: submissão dos presos; e funcionalidade: otimização da } \\
\text { estrutura operacional) com aumento de custo de construção (com } \\
\text { exceção do projeto distrital), associado ao nível de segurança } \\
\text { proposto. }\end{array}$} \\
\hline & $\mathrm{PC}$ & $\mathrm{P}$ & $\mathrm{P}$ & 1 & $\mathrm{~N}$ & $\mathrm{C}$ & \\
\hline & $\mathrm{MJ}$ & AP & $\mathrm{AP}$ & $\mathrm{I}$ & $\mathrm{PA}$ & APC & \\
\hline & EV & AP & AP & 1 & PA & APC & \\
\hline \multirow[t]{4}{*}{09.02} & PDF & $\mathrm{S}$ & $S$ & $S$ & $S$ & $\mathrm{~S}$ & \multirow{4}{*}{$\begin{array}{l}\text { Os projetos já apresentavam uma convergência com a demanda, ao } \\
\text { adotarem a solução formal (atividades e serviços de apoio e } \\
\text { infraestrutura). Não houve alteração nos projetos. }\end{array}$} \\
\hline & $\mathrm{PC}$ & $\mathrm{S}$ & $\mathrm{S}$ & $S$ & $\mathrm{~S}$ & $S$ & \\
\hline & MJ & $\mathrm{S}$ & $\mathrm{S}$ & $\mathrm{S}$ & $\mathrm{S}$ & $\mathrm{S}$ & \\
\hline & EV & $\mathrm{S}$ & $\mathrm{S}$ & $\mathrm{S}$ & $\mathrm{S}$ & $\mathrm{S}$ & \\
\hline \multicolumn{8}{|c|}{ 10. Espacialização } \\
\hline Item & Projeto & $S$ & $\mathrm{~F}$ & CA & $\mathrm{C}$ & $\mathbf{R}$ & \multirow{5}{*}{$\begin{array}{l}\text { Avaliação } \\
\text { Os projetos tiveram a setorização caracteristicamente internalizada } \\
\text { (de } 10 / 11 / 79 \% \text { para } 7 / 14 / 77 \% \text { ), em especial o projeto federal. A } \\
\text { profundidade topológica média diminuiu (de } 18 \text { para } 17 \text { camadas), } \\
\text { enquanto a concentração topológica no setor interno aumentou } \\
\text { blocos de vivência compactos (de } 12 \text { para } 13 \text { camadas). O } \\
\text { ajustamento incrementou os projetos (segurança: submissão dos } \\
\text { presos; e funcionalidade: otimização da estrutura operacional) com } \\
\text { um aumento de custo de construção associado ao nível de segurança } \\
\text { proposto. }\end{array}$} \\
\hline \multirow[t]{4}{*}{10.01} & PDF & $\mathrm{P}$ & $\mathrm{P}$ & 1 & $\mathrm{PA}$ & PC & \\
\hline & PC & $\mathrm{P}$ & $\mathrm{P}$ & $\mathrm{I}$ & $\mathrm{N}$ & PAC & \\
\hline & $\mathrm{MJ}$ & $P$ & $P$ & $\mathrm{I}$ & PA & C & \\
\hline & EV & $S$ & $S$ & $I$ & $S$ & - & \\
\hline \multirow[t]{4}{*}{10.02} & PDF & $\mathrm{P}$ & $\mathrm{P}$ & 1 & $\mathrm{PA}$ & PC & \multirow{4}{*}{$\begin{array}{l}\text { Os projetos receberam circulações exclusivas para os funcionários } \\
\text { (projetos distrital e paulista) e os desenhos-síntese de cela } \\
\text { (possibilidade de visualização interna): os locais livres passaram de } \\
14 \% \text { para } 11 \% \text {, os locais vigiados de } 74 \% \text { para } 65 \% \text { e os locais } \\
\text { proibidos de } 12 \text { para } 24 \% \text {. Os custos de construção foram } \\
\text { adicionados em } \mathrm{R} \$ 15,19 \text { milhões. O ajustamento incrementou os } \\
\text { projetos (segurança: acessibilidade e mobilidade dos funcionários; e } \\
\text { funcionalidade: redução das tarefas) com um aumento de custo } \\
\text { associado ao nível de segurança proposto. }\end{array}$} \\
\hline & $P C$ & $\mathrm{P}$ & $\mathrm{P}$ & 1 & $\mathrm{PA}$ & $C$ & \\
\hline & $\mathrm{MJ}$ & $\mathrm{P}$ & $\mathrm{P}$ & 1 & $\mathrm{P}$ & $P$ & \\
\hline & EV & $P$ & $P$ & 1 & $P$ & $P$ & \\
\hline \multirow[t]{4}{*}{10.03} & PDF & $\mathrm{P}$ & $\mathrm{P}$ & 1 & $\mathrm{~N}$ & PC & \multirow{4}{*}{$\begin{array}{l}\text { Os projetos distrital e paulista tiveram a divisão social enfatizada } \\
\text { com a criação de locais de visita social dotados de acesso exclusivo. } \\
\text { Os projetos tiveram os locais de visita internalizados (redução do } \\
\text { deslocamento dos presos), com exceção do projeto privado. A } \\
\text { profundidade topológica aumentou (criação dos bastidores). O } \\
\text { ajustamento incrementou os projetos (segurança: redução de } \\
\text { vulnerabilidades; e funcionalidade: representação social e proteção } \\
\text { das visitas) com um aumento de custo de construção associado ao } \\
\text { nível de segurança proposto. }\end{array}$} \\
\hline & PC & $\mathrm{P}$ & $\mathrm{P}$ & 1 & $\mathrm{~N}$ & PC & \\
\hline & MJ & $P$ & $P$ & 1 & $\mathrm{PA}$ & PC & \\
\hline & EV & $S$ & $S$ & 1 & $S$ & - & \\
\hline \multirow[t]{4}{*}{10.04} & PDF & $P$ & $\mathrm{P}$ & 1 & $\mathrm{P}$ & $P$ & \multirow{4}{*}{$\begin{array}{l}\text { Os projetos tiveram o número de blocos de vivência e alas } \\
\text { carcerárias ajustado, em especial, o projeto distrital passou de } 16 \\
\text { alas para } 8 \text { e o projeto paulista passou de } 8 \text { para } 4 \text { blocos. Nos } \\
\text { projetos foram configurados quatro blocos de vivência dotados das } \\
\text { atividades rotineiras dos presos. Os projetos mantiveram o } \\
\text { percentual de área do setor interno em } 75 \% \text {. O ajustamento } \\
\text { incrementou os projetos (segurança: redução de áreas; e } \\
\text { funcionalidade: otimização da estrutura operacional) com redução }\end{array}$} \\
\hline & PC & $P$ & $P$ & $\mathrm{I}$ & $P$ & $P$ & \\
\hline & MJ & $S$ & $\mathrm{~S}$ & 1 & $S$ & $\mathrm{~S}$ & \\
\hline & EV & $S$ & $S$ & 1 & $S$ & - & \\
\hline
\end{tabular}




\begin{tabular}{|c|c|c|c|c|c|c|c|}
\hline & & & & & & & de custo (redução de área e capacidade). \\
\hline \multirow[t]{4}{*}{10.05} & PDF & $P$ & $P$ & I & $P$ & $P$ & \multirow{4}{*}{$\begin{array}{l}\text { Os projetos apresentam dimensões compatíveis com os índices } \\
\text { previstos na tecnologia de projeto. Para tanto, os mesmos tiveram a } \\
\text { geometria retificada e acréscimos de área e de benfeitorias, } \\
\text { principalmente, nos programas de socialização e benefícios aos } \\
\text { presos (exceção do projeto distrital), além dos elementos centrais da } \\
\text { edificação penal. O ajustamento incrementou os projetos com um } \\
\text { aumento de custo de construção associado ao nível de segurança } \\
\text { proposto (configuração do modelo de segurança máxima). }\end{array}$} \\
\hline & PC & $\mathrm{P}$ & $\mathrm{P}$ & $\mathrm{I}$ & $\mathrm{N}$ & PC & \\
\hline & MJ & $P$ & $P$ & I & PA & PC & \\
\hline & EV & $P$ & $P$ & I & PA & PC & \\
\hline \multirow[t]{4}{*}{10.06} & PDF & $\mathrm{P}$ & $\mathrm{P}$ & 1 & $\mathrm{PA}$ & PC & \multirow{4}{*}{$\begin{array}{l}\text { Os projetos tiveram os locais coletivos funcionalmente regularizados } \\
\text { pela policrestia. Os projetos receberam os desenhos-síntese de cela } \\
\text { e pátios de sol dos presos que agregaram algumas atividades. Os } \\
\text { projetos distrital e paulista receberam os locais de visita social e } \\
\text { conjugal que podem atuar como salas multiuso nos blocos de } \\
\text { vivência. O ajustamento incrementou os projetos (segurança: } \\
\text { disciplina interna; e funcionalidade: otimização das estruturas física } \\
\text { e operacional) com um aumento de custo de construção associado } \\
\text { ao nível de segurança proposto. }\end{array}$} \\
\hline & PC & $P$ & $P$ & 1 & PA & PC & \\
\hline & $\mathrm{MJ}$ & $\mathrm{P}$ & $\mathrm{P}$ & 1 & $\mathrm{P}$ & $\mathrm{P}$ & \\
\hline & EV & $P$ & $P$ & I & $P$ & $P$ & \\
\hline \multicolumn{8}{|c|}{ 11. Dimensionamento } \\
\hline Item & Projeto & $\mathrm{S}$ & $\mathrm{F}$ & CA & C & $\mathbf{R}$ & Avaliação \\
\hline \multirow[t]{4}{*}{11.01} & PDF & $\mathrm{P}$ & $\mathrm{P}$ & $\mathrm{S}$ & $\mathrm{P}$ & $\mathrm{P}$ & \multirow{4}{*}{$\begin{array}{l}\text { Os projetos tiveram as áreas construídas aumentadas de } \\
16,20 \mathrm{~m}^{2} / \text { vaga para } 19,41 \mathrm{~m}^{2} / \text { vaga, principalmente pela inclusão de } \\
\text { locais de sociabilização e pela internalização do programa nos blocos } \\
\text { de vivência. A circulação aumentou de } 15 \% \text { para } 16,5 \% \text { da área } \\
\text { construída. As circulações exclusivas para os funcionários ficaram em } \\
10,5 \% \text { da área construída. O ajustamento incrementou os projetos } \\
\text { (simplicidade funcional) com um aumento de custo de construção } \\
\text { associado ao nível de segurança proposto. }\end{array}$} \\
\hline & PC & $P$ & $P$ & $\mathrm{~S}$ & $\mathrm{~N}$ & PC & \\
\hline & MJ & $P$ & $P$ & $\mathrm{~S}$ & PA & PC & \\
\hline & EV & APPA & APPA & $\mathrm{S}$ & PA & $\begin{array}{c}\text { APPA } \\
\text { C }\end{array}$ & \\
\hline \multirow[t]{4}{*}{11.02} & PDF & $S$ & $S$ & 1 & $S$ & $\mathrm{~S}$ & \multirow{4}{*}{$\begin{array}{l}\text { Os projetos se restringiram a dimensionar as circulações gerais } \\
\text { (circulação central do setor interno e circulações dos blocos de } \\
\text { vivência) e os locais dos programas de sociabilização e benefícios aos } \\
\text { presos (salão de visita, salas de aula e oficinas), além dos elementos } \\
\text { centrais da edificação penal (ver itens } 09.01,16,17,18 \text { e } 19 \text { ). Não } \\
\text { houve redimensionamento individualizado das demais áreas } \\
\text { internas. O dimensionamento realizado favoreceu o ajustamento, ao } \\
\text { convergir com o nível de segurança proposto (simplicidade } \\
\text { funcional). }\end{array}$} \\
\hline & $\mathrm{PC}$ & $\mathrm{S}$ & $\mathrm{S}$ & 1 & $\mathrm{~S}$ & $\mathrm{~S}$ & \\
\hline & $\mathrm{MJ}$ & $\mathrm{S}$ & $\mathrm{S}$ & 1 & $S$ & $\mathrm{~S}$ & \\
\hline & EV & $\mathrm{S}$ & $S$ & I & $S$ & $\mathrm{~S}$ & \\
\hline \multirow[t]{4}{*}{11.03} & PDF & APPA & APPA & $\mathrm{S}$ & PA & $\begin{array}{c}\text { APPA } \\
\text { C }\end{array}$ & \multirow{4}{*}{$\begin{array}{l}\text { Os projetos tiveram as áreas de terreno aumentas de } 35,88 \mathrm{~m}^{2} / \mathrm{vaga} \\
\text { para } 97,18 \mathrm{~m}^{2} / \text { vaga com a inclusão de afastamentos maiores }(30 \mathrm{~m}) \text {. } \\
\text { O projeto distrital teve a menor adequação e o projeto federal a } \\
\text { maior. Com isto, a taxa de ocupação média caiu de } 31 \% \text { para } 18 \% \text {. O } \\
\text { ajustamento incrementou os projetos (segurança: fechamento } \\
\text { institucional; e conforto ambiental: áreas livres externas) com um } \\
\text { aumento de custo de construção associado ao nível de segurança } \\
\text { proposto. }\end{array}$} \\
\hline & PC & $\mathrm{P}$ & $\mathrm{P}$ & $\mathrm{P}$ & PA & PC & \\
\hline & MJ & $P$ & $P$ & $\mathrm{P}$ & $\mathrm{N}$ & PC & \\
\hline & EV & $P$ & $P$ & $P$ & $\mathrm{PA}$ & PC & \\
\hline \multicolumn{8}{|c|}{ 12. Circulação } \\
\hline Item & Projeto & $\mathrm{S}$ & $\mathrm{F}$ & $\mathrm{CA}$ & C & $\mathbf{R}$ & \multirow{5}{*}{$\begin{array}{l}\text { Avaliação } \\
\text { Os projetos tiveram os acessos e circulações de funcionários e } \\
\text { visitantes isolados dos locais de permanência dos presos, o que } \\
\text { reduziu os pontos de conflito de } 75 \text { para } 36 \text { (em especial, nos } \\
\text { projetos distrital e paulista). A área de circulação e a profundidade } \\
\text { topológica foram reduzidas (ver itens } 10.01 \text { e 11.01). Os anéis } \\
\text { topológicos foram reduzidos (projeto distrital de três para um). O } \\
\text { ajustamento incrementou parcialmente os projetos (segurança: } \\
\text { disciplina interna; e funcionalidade: otimização da estrutura). }\end{array}$} \\
\hline \multirow[t]{4}{*}{12.01} & PDF & $\mathrm{P}$ & $P$ & 1 & $\mathrm{~S}$ & $P$ & \\
\hline & PC & $P$ & $\mathrm{P}$ & 1 & $S$ & $\mathrm{P}$ & \\
\hline & $\mathrm{MJ}$ & APPA & APPA & 1 & $S$ & APPA & \\
\hline & EV & APPA & APPA & I & $S$ & APPA & \\
\hline \multirow[t]{4}{*}{12.02} & PDF & $P$ & $P$ & $S$ & $P$ & $P$ & \multirow{4}{*}{$\begin{array}{l}\text { Os projetos foram configurados segundo o padrão arquitetônico } \\
\text { paralelo. As circulações centrais foram padronizadas em } 5,0 \mathrm{~m} \text { de } \\
\text { largura (projetos paulista e federal). A quantidade de circulações foi } \\
\text { reduzida de } 1,80 \mathrm{~m} / \text { vaga para } 1,36 \mathrm{~m} / \text { vaga, sendo } 75 \% \text { no setor } \\
\text { interno (eram } 70 \% \text { ). O número médio de derivações foi reduzido de } \\
23 \text { para } 18 \text {. As distancias foram ajustadas: celas/locais de visita e } \\
\text { atividades de } 93 \text { e } 89 \mathrm{~m} \text { para } 34 \text { e } 46 \mathrm{~m} \text {, respectivamente; } \\
\text { celas/pátios de } 31 \text { para } 43 \mathrm{~m} \text {; acesso da unidade prisional/locais de }\end{array}$} \\
\hline & PC & $\mathrm{P}$ & $\mathrm{P}$ & $\mathrm{S}$ & $P$ & $P$ & \\
\hline & MJ & $\mathrm{P}$ & $P$ & $\mathrm{~S}$ & $P$ & $P$ & \\
\hline & EV & $P$ & $P$ & $S$ & $P$ & $P$ & \\
\hline
\end{tabular}




\begin{tabular}{|c|c|c|c|c|c|c|c|}
\hline & & & & & & & $\begin{array}{l}\text { visita de } 89 \text { ou } 160 \mathrm{~m} \text { para } 173 \mathrm{~m} \text {. O ajustamento incrementou os } \\
\text { projetos (segurança: disciplina interna; e funcionalidade: redução de } \\
\text { tarefas). }\end{array}$ \\
\hline \multirow[t]{4}{*}{12.03} & PDF & $\mathrm{S}$ & $S$ & 1 & $\mathrm{~S}$ & $\mathrm{~S}$ & \multirow{4}{*}{$\begin{array}{l}\text { Os projetos já apresentavam uma convergência com a demanda, ao } \\
\text { adotarem a solução formal (atividades e serviços de apoio e } \\
\text { infraestrutura). Não houve alteração nos projetos. }\end{array}$} \\
\hline & PC & $S$ & $S$ & 1 & $S$ & $S$ & \\
\hline & MJ & $\mathrm{S}$ & $\mathrm{S}$ & 1 & $S$ & $S$ & \\
\hline & EV & $\mathrm{S}$ & $\mathrm{S}$ & 1 & $\mathrm{~S}$ & $S$ & \\
\hline \multirow[t]{4}{*}{12.04} & PDF & $P$ & 1 & 1 & 1 & $\mathrm{P}$ & \multirow{4}{*}{$\begin{array}{l}\text { Os projetos receberam escapes nos postos de controle, em especial, } \\
\text { através do desenho-síntese desenvolvido. O ajustamento } \\
\text { incrementou os projetos (segurança: proteção dos funcionários). }\end{array}$} \\
\hline & $\mathrm{PC}$ & $\mathrm{P}$ & $\mathrm{I}$ & 1 & 1 & $\mathrm{P}$ & \\
\hline & $\mathrm{MJ}$ & $\mathrm{P}$ & 1 & 1 & 1 & $\mathrm{P}$ & \\
\hline & EV & $P$ & $\mathrm{I}$ & I & 1 & $P$ & \\
\hline \multicolumn{8}{|c|}{ 13. Conforto Ambiental } \\
\hline Item & Projeto & $\mathrm{S}$ & $\mathrm{F}$ & $\mathrm{CA}$ & $\mathrm{C}$ & $\mathbf{R}$ & Avaliação \\
\hline \multirow[t]{4}{*}{13.01} & PDF & $\mathrm{S}$ & $\mathrm{s}$ & $\mathrm{S}$ & $\mathrm{S}$ & $\mathrm{S}$ & \multirow{4}{*}{$\begin{array}{l}\text { Os projetos se restringiram a ambientar os elementos centrais da } \\
\text { edificação penal (ver itens } 16,17,18 \text { e 19). Não houve ambientação } \\
\text { individualizada das demais áreas internas. }\end{array}$} \\
\hline & $P C$ & $S$ & $S$ & $S$ & $S$ & $S$ & \\
\hline & MJ & $\mathrm{S}$ & $\mathrm{S}$ & $\mathrm{S}$ & $\mathrm{S}$ & $\mathrm{S}$ & \\
\hline & EV & $S$ & $S$ & $\mathrm{~S}$ & $S$ & $\mathrm{~S}$ & \\
\hline \multirow[t]{4}{*}{13.02} & PDF & $\mathrm{P}$ & 1 & APPA & $\mathrm{P}$ & $\mathrm{P}$ & \multirow{4}{*}{$\begin{array}{l}\text { Os projetos tiveram as áreas internas livres ampliadas, com uma } \\
\text { redução da taxa de ocupação de } 38 \% \text { para } 28 \% \text {. O perímetro médio } \\
\text { dos edifícios aumentou de } 1.398 \text { para } 1.800 \mathrm{~m} \text { e os índices de } 2,13 \\
\text { para } 2,80 \mathrm{~m} / \text { vaga, e de } 0,13 \text { para } 0,15 \mathrm{~m} / \mathrm{m}^{2} \text {. Estes índices } \\
\text { extrapolaram os limites médios definidos (em especial, o projeto } \\
\text { paulista). O ajustamento incrementou parcialmente os projetos, ao } \\
\text { desfavorecer a segurança (ver item } 07.01 \text { ) com um aumento de } \\
\text { custo eventualmente desnecessário (projeto paulista). }\end{array}$} \\
\hline & $\mathrm{PC}$ & PA & 1 & $P$ & PA & PAC & \\
\hline & MJ & $P$ & 1 & $P$ & $P$ & $P$ & \\
\hline & EV & $\mathrm{PA}$ & I & APPA & $P$ & PAC & \\
\hline \multicolumn{8}{|c|}{ 14. Aparatos de segurança } \\
\hline Item & Projeto & $\mathrm{S}$ & $\mathrm{F}$ & $\mathrm{CA}$ & C & $\mathbf{R}$ & Avaliação \\
\hline \multirow[t]{4}{*}{14.01} & PDF & $\mathrm{S}$ & $\mathrm{S}$ & $\mathrm{S}$ & $\mathrm{S}$ & $\mathrm{S}$ & \multirow{4}{*}{$\begin{array}{l}\text { A revisão dos projetos de referência se restringiu aos elementos } \\
\text { centrais da edificação penal (ver itens } 16,17,18 \text { e 19). Não houve } \\
\text { revisão dos itens de segurança nas demais áreas ou elementos. }\end{array}$} \\
\hline & PC & $\mathrm{S}$ & $\mathrm{S}$ & $\mathrm{S}$ & S & $\mathrm{S}$ & \\
\hline & MJ & $\mathrm{S}$ & $\mathrm{S}$ & $\mathrm{S}$ & $\mathrm{S}$ & $\mathrm{S}$ & \\
\hline & EV & $\mathrm{S}$ & $\mathrm{S}$ & $\mathrm{S}$ & $\mathrm{S}$ & $\mathrm{S}$ & \\
\hline \multirow[t]{4}{*}{14.02} & PDF & APPA & I & 1 & PA & PAC & \multirow{4}{*}{$\begin{array}{l}\text { Os projetos receberam cercamento interno para disciplinar os fluxos, } \\
\text { com exceção do projeto privado. O ajustamento incrementou os } \\
\text { projetos (segurança: disciplina interna) com um aumento de custo } \\
\text { associado ao nível de segurança proposto. }\end{array}$} \\
\hline & PC & APPA & 1 & 1 & PA & PAC & \\
\hline & $\mathrm{MJ}$ & APPA & 1 & 1 & PA & PAC & \\
\hline & EV & $\mathrm{S}$ & $\mathrm{S}$ & $\mathrm{S}$ & $S$ & $\mathrm{~S}$ & \\
\hline
\end{tabular}

\begin{tabular}{|c|c|c|c|c|c|c|c|}
\hline \multicolumn{8}{|c|}{ 15. Controle } \\
\hline Item & Projeto & $S$ & $\mathrm{~F}$ & $\mathrm{CA}$ & $C$ & $\mathbf{R}$ & Avaliação \\
\hline \multirow[t]{4}{*}{15.01} & PDF & $P$ & $\mathrm{P}$ & 1 & PA & PC & \multirow{4}{*}{$\begin{array}{l}\text { Os projetos tiveram o esquema de vigilância baseado no padrão } \\
\text { arquitetônico modular. A vigilância interna média aumentou de } 62 \% \\
\text { para } 80 \% \text {, sendo } 86 \% \text { no setor interno (era } 68 \% \text { ). Os projetos paulista e } \\
\text { federal foram mais beneficiados e o projeto privado, menos. Isto é } \\
\text { atribuído à espacialização e à implantação de circulações exclusivas } \\
\text { (projetos distrital e paulista). O ajustamento incrementou os projetos } \\
\text { (segurança: vigilância; e funcionalidade: otimização operacional) com } \\
\text { um aumento de custo de construção, associado ao nível de segurança } \\
\text { proposto. }\end{array}$} \\
\hline & PC & $\mathrm{P}$ & $\mathrm{P}$ & 1 & PA & PC & \\
\hline & $\mathrm{MJ}$ & APPA & AP & 1 & $\mathrm{P}$ & $\mathrm{P}$ & \\
\hline & EV & APPA & APPA & I & $S$ & $\mathrm{PA}$ & \\
\hline \multirow[t]{4}{*}{15.02} & PDF & AP & AP & 1 & $\mathrm{P}$ & $\mathrm{P}$ & \multirow{4}{*}{$\begin{array}{l}\text { Os projetos receberam o desenho-síntese de posto de controle que } \\
\text { implementou a inverificabilidade institucional (ver item 19). A revisão } \\
\text { se restringiu aos postos de controle - não houve revisão das torres de } \\
\text { vigilância ou das circulaçães exclusivas para os funcionários. O } \\
\text { ajustamento incrementou os projetos (segurança: proteção dos } \\
\text { funcionários; funcionalidade: simplificação das tarefas; e custo: } \\
\text { otimização e, eventualmente, redução das equipes). }\end{array}$} \\
\hline & PC & AP & AP & I & $P$ & $P$ & \\
\hline & MJ & AP & $\mathrm{AP}$ & 1 & $P$ & $P$ & \\
\hline & EV & AP & $\overline{A P}$ & I & $P$ & $P$ & \\
\hline \multirow[t]{4}{*}{15.03} & PDF & $\mathrm{P}$ & $\mathrm{P}$ & 1 & $S$ & $\mathrm{P}$ & \multirow{4}{*}{$\begin{array}{l}\text { Os projetos tiveram a área externa vigiada aumentada de } 93 \% \text { para } \\
96 \% \text { e quantidade de pontos cegos de } 7 \text { para } 6 \text {, em média. Os projetos } \\
\text { paulista e privado tiveram a quantidade de pontos cegos aumentados } \\
\text { devido à geometria (ver item 07.01). O projeto paulista teve a área de } \\
\text { visualização reduzida em } 1 \% \text {. A visualização das coberturas e a } \\
\text { comunicação entre as torres de vigilância permaneceram íntegras. O } \\
\text { ajustamento incrementou parcialmente os projetos (segurança: } \\
\text { vigilância; e funcionalidade: otimização da estrutura operacional). }\end{array}$} \\
\hline & PC & $N$ & PA & 1 & $S$ & $\mathrm{~N}$ & \\
\hline & $\mathrm{MJ}$ & $\mathrm{P}$ & $P$ & I & $S$ & $\mathrm{P}$ & \\
\hline & EV & $\mathrm{PA}$ & PA & 1 & $S$ & $\mathrm{PA}$ & \\
\hline
\end{tabular}




\begin{tabular}{|c|c|c|c|c|c|c|c|}
\hline \multirow[t]{4}{*}{15.04} & PDF & $P$ & $P$ & I & PA & PC & \multirow{4}{*}{$\begin{array}{l}\text { Os projetos tiveram o esquema de vigilância integrado, o que } \\
\text { contribuiu para o aumento das áreas externas e internas vigiadas } \\
\text { (média), em } 29 \% \text { e } 3 \% \text {, respectivamente. Os projetos distrital e paulista } \\
\text { receberam circulações exclusivas para os funcionários. A } \\
\text { inexpugnidade e a operacionalidade foram tratadas no posto de } \\
\text { controle (ver item 19). O ajustamento incrementou os projetos } \\
\text { (segurança: vigilância; e funcionalidade: coordenação dos } \\
\text { procedimentos) com um aumento de custo de construção, associado } \\
\text { ao nível de segurança proposto. }\end{array}$} \\
\hline & $P C$ & $P$ & $P$ & 1 & $P$ & $P$ & \\
\hline & MJ & $P$ & PA & I & PA & PC & \\
\hline & EV & APPA & $\overline{A P P A}$ & I & $P$ & PA & \\
\hline \multirow[t]{4}{*}{15.05} & PDF & $\mathrm{P}$ & $P$ & 1 & $\mathrm{P}$ & $\mathrm{P}$ & \multirow{4}{*}{$\begin{array}{l}\text { Os projetos tiveram o esquema de vigilância baseado no padrão } \\
\text { arquitetônico modular. Os mesmos tiveram a área vigiada de } \\
\text { circulação aumentada de } 51 \% \text { para } 66 \% \text {, principalmente, em função da } \\
\text { retificação geométrica e do posicionamento dos postos de controle } \\
\text { (simplicidade funcional). O projeto paulista foi o mais beneficiado. O } \\
\text { ajustamento incrementou os projetos (segurança: controle dos fluxos; } \\
\text { e funcionalidade: otimização da estrutura operacional) com um } \\
\text { aumento do custo de construção, associado ao nível de segurança } \\
\text { proposto. }\end{array}$} \\
\hline & PC & $P$ & $P$ & 1 & $P$ & $P$ & \\
\hline & $\mathrm{MJ}$ & $P$ & $P$ & I & $P$ & $P$ & \\
\hline & EV & $P$ & $P$ & I & $P$ & $P$ & \\
\hline \multirow[t]{4}{*}{15.06} & PDF & $\mathrm{P}$ & $\mathrm{P}$ & 1 & $\mathrm{P}$ & $\mathrm{P}$ & \multirow{4}{*}{$\begin{array}{l}\text { Os projetos tiveram o número médio de torres de vigilância mantido } \\
\text { (quatro torres) e de postos de controle reduzido de nove para sete } \\
\text { ( } 22 \% \text { de redução). Isto foi obtido pela internalização dos programas de } \\
\text { socialização e benefícios dos presos e pelo posicionamento estratégico } \\
\text { dos postos. O ajustamento incrementou os projetos (segurança: } \\
\text { redução de vulnerabilidades; e funcionalidade: otimização da } \\
\text { estrutura) com redução de custos de construção e operação } \\
\text { (otimização da estrutura física e operacional), associada ao nível de } \\
\text { segurança proposto. }\end{array}$} \\
\hline & PC & $P$ & $P$ & 1 & $P$ & $P$ & \\
\hline & $\mathrm{MJ}$ & $P$ & $P$ & I & $P$ & $P$ & \\
\hline & EV & $P$ & $P$ & I & $P$ & $P$ & \\
\hline \multirow[t]{4}{*}{15.07} & PDF & APPA & APPA & 1 & PA & PAC & \multirow{4}{*}{$\begin{array}{l}\text { Os projetos tiveram os postos de controle evidenciados nos locais } \\
\text { vigiados (avanços e elevações). Em parte, estas propriedades eram } \\
\text { previstas nos projetos originais. O projeto paulista recebeu a maior } \\
\text { intervenção. Estas propriedades foram mais bem tratadas no posto de } \\
\text { controle (ver item 19). O ajustamento incrementou parcialmente os } \\
\text { projetos (segurança: submissão dos presos; e funcionalidade: relações } \\
\text { sociais e de poder) com aumento do custo de construção (ver item } \\
19.04 \text { ), associado ao nível de segurança proposto. }\end{array}$} \\
\hline & PC & & & I & PA & PC & \\
\hline & MJ & APPA & APPA & I & PA & PAC & \\
\hline & EV & & $\overline{\text { APPA }}$ & 1 & $\overline{P A}$ & PC & \\
\hline
\end{tabular}

\begin{tabular}{|c|c|c|c|c|c|c|c|}
\hline \multicolumn{8}{|c|}{ 16. Barreira Perimetral } \\
\hline Item & Projeto & $S$ & $\mathrm{~F}$ & CA & C & $\mathbf{R}$ & Avaliação \\
\hline \multirow[t]{4}{*}{16.01} & PDF & $\mathrm{P}$ & $\mathrm{I}$ & $\mathrm{I}$ & PA & PAC & \multirow{4}{*}{$\begin{array}{l}\text { Os projetos tiveram a barreira em cerca preparada para garantir, ao } \\
\text { máximo, a estanqueidade da unidade prisional (afastamentos, pistas de } \\
\text { ronda, linha de tiro e aparatos de segurança). O projeto distrital teve a } \\
\text { cerca reforçada. Os projetos paulista e federal tiveram a barreira } \\
\text { mudada de muro para cerca. O ajustamento incrementou parcialmente } \\
\text { os projetos (a contenção de fugas era providenciada com o muro) com } \\
\text { redução de custo de construção, associada à modalidade de segurança } \\
\text { máxima proposta. }\end{array}$} \\
\hline & $\mathrm{PC}$ & $S$ & $\mathrm{I}$ & $\mathrm{I}$ & $\mathrm{P}$ & $\mathrm{AP}$ & \\
\hline & MJ & $\mathrm{S}$ & $\mathrm{I}$ & 1 & $\mathrm{P}$ & $\mathrm{AP}$ & \\
\hline & EV & $P$ & I & 1 & $P$ & $P$ & \\
\hline \multirow[t]{4}{*}{16.02} & PDF & $\mathrm{P}$ & $P$ & 1 & PA & PC & \multirow{4}{*}{$\begin{array}{l}\text { Os projetos tiveram a barreira em cerca preparada para garantir, ao } \\
\text { máximo, a impermeabilidade da unidade prisional (afastamentos e } \\
\text { bloqueio visual). O projeto distrital e privado tiveram a cerca fechada. Os } \\
\text { projetos paulista e federal tiveram a barreira mudada de muro para } \\
\text { cerca. O ajustamento incrementou parcialmente os projetos (o } \\
\text { rompimento da comunicação informal era parcialmente previsto) com } \\
\text { redução de custo de construção, associada ao nível de segurança } \\
\text { proposto. }\end{array}$} \\
\hline & PC & $S$ & $S$ & 1 & $P$ & AP & \\
\hline & MJ & $\mathrm{S}$ & $\mathrm{S}$ & 1 & $\mathrm{P}$ & AP & \\
\hline & EV & $P$ & $P$ & I & PA & PC & \\
\hline \multirow[t]{4}{*}{16.03} & PDF & $P$ & I & 1 & PA & PAC & \multirow{4}{*}{$\begin{array}{l}\text { Os projetos tiveram a barreira em cerca preparada para garantir, ao } \\
\text { máximo, a inexpugnidade da unidade prisional (afastamentos e aparatos } \\
\text { de segurança). Os projetos distrital e privado tiveram a cerca reforçada. } \\
\text { Os projetos paulista e federal tiveram a barreira mudada de muro para } \\
\text { cerca. O ajustamento incrementou parcialmente os projetos, ao } \\
\text { equiparar a segurança (contenção de invasões) (ver item 16.04) com } \\
\text { redução de custo de construção, associada ao nível de segurança } \\
\text { proposto. }\end{array}$} \\
\hline & PC & $\mathrm{S}$ & $\mathrm{I}$ & 1 & $\mathrm{P}$ & $\mathrm{AP}$ & \\
\hline & MJ & $S$ & I & I & $\mathrm{P}$ & AP & \\
\hline & EV & $P$ & 1 & I & PA & PC & \\
\hline 16.04 & PDF & AP & AP & $\mathrm{I}$ & PA & PC & Os projetos tiveram a barreira em cerca preparada para garantir, ao \\
\hline
\end{tabular}




\begin{tabular}{|c|c|c|c|c|c|c|c|}
\hline & PC & $\mathrm{S}$ & $S$ & 1 & $P$ & $P$ & \multirow{3}{*}{$\begin{array}{l}\text { máximo, o fechamento da unidade prisional (afastamentos, pistas, linha } \\
\text { de tiro e aparatos de segurança). Os projetos distrital e privado tiveram } \\
\text { a cerca reforçada. Os projetos paulista e federal tiveram a barreira } \\
\text { mudada de muro para cerca. O ajustamento incrementou os projetos, } \\
\text { ao equiparar o fechamento (segurança e funcionalidade), com redução } \\
\text { de custo de construção, associada ao nível de segurança proposto. }\end{array}$} \\
\hline & MJ & $\mathrm{S}$ & $S$ & 1 & $P$ & $P$ & \\
\hline & EV & $A P$ & AP & I & PA & PC & \\
\hline \multirow[t]{4}{*}{16.05} & PDF & $S$ & $S$ & $S$ & $S$ & $S$ & \multirow{4}{*}{$\begin{array}{l}\text { Os projetos já apresentavam uma convergência com a demanda, ao } \\
\text { adotarem formas regulares. Não houve alteração nos projetos. }\end{array}$} \\
\hline & $\mathrm{PC}$ & $S$ & $\mathrm{~S}$ & $S$ & $S$ & $\mathrm{~S}$ & \\
\hline & MJ & $S$ & $S$ & $\mathrm{~S}$ & $\mathrm{~S}$ & $\mathrm{~S}$ & \\
\hline & EV & $S$ & $\mathrm{~S}$ & $S$ & $S$ & $S$ & \\
\hline \multirow[t]{4}{*}{16.06} & PDF & $S$ & 1 & 1 & $\mathrm{P}$ & $\mathrm{P}$ & \multirow{4}{*}{$\begin{array}{l}\text { As barreiras tiveram a altura média reduzida de } 6,45 \mathrm{~m} \text { para } 4,0 \mathrm{~m} \text {, cujo } \\
\text { fechamento foi garantido, ao máximo, pela preparação da cerca } \\
\text { (afastamentos, pistas, linha de tiro e aparatos de segurança). O } \\
\text { ajustamento incrementou os projetos, ao equiparar a segurança } \\
\text { (estanqueidade e impermeabilidade), com redução de custo de } \\
\text { construção, associada ao nível de segurança proposto. }\end{array}$} \\
\hline & PC & $S$ & 1 & 1 & $P$ & $P$ & \\
\hline & $\mathrm{MJ}$ & $S$ & 1 & 1 & $\mathrm{P}$ & $\mathrm{P}$ & \\
\hline & EV & $S$ & I & I & $P$ & $P$ & \\
\hline \multirow[t]{4}{*}{16.07} & PDF & $\mathrm{P}$ & $P$ & 1 & $\mathrm{PA}$ & PC & \multirow{4}{*}{$\begin{array}{l}\text { Os projetos tiveram a cerca preparada para garantir, ao máximo, a } \\
\text { proteção aos funcionários (aparatos de segurança). Os projetos distrital } \\
\text { e privado tiveram a cerca reforçada. Os projetos paulista e federal } \\
\text { tiveram a barreira mudada de muro para cerca. O ajustamento } \\
\text { incrementou parcialmente os projetos, ao equiparar o fechamento } \\
\text { (segurança: vulnerabilidades; e funcionalidade: procedimentos), com } \\
\text { redução de custo de construção, associada ao nível de segurança } \\
\text { proposto. }\end{array}$} \\
\hline & PC & $P$ & $P$ & 1 & PA & PC & \\
\hline & MJ & $\mathrm{P}$ & $P$ & 1 & PA & PC & \\
\hline & EV & $P$ & $P$ & 1 & PA & PC & \\
\hline \multirow[t]{4}{*}{16.08} & PDF & $\mathrm{PA}$ & $P$ & 1 & PA & PC & \multirow{4}{*}{$\begin{array}{l}\text { Os projetos tiveram a cerca preparada para garantir, ao máximo, o } \\
\text { fechamento da unidade prisional. Os projetos distrital e privado } \\
\text { receberam parte dos aparatos. Os projetos paulista e federal receberam } \\
\text { a totalidade dos aparatos. O ajustamento incrementou os projetos, ao } \\
\text { equiparar o fechamento (segurança e funcionalidade), com aumento de } \\
\text { custo de construção, associado ao nível de segurança proposto. }\end{array}$} \\
\hline & PC & $\mathrm{P}$ & $P$ & 1 & PA & PC & \\
\hline & $\mathrm{MJ}$ & $P$ & $P$ & 1 & $\mathrm{PA}$ & PC & \\
\hline & EV & APPA & $P$ & I & $\mathrm{PA}$ & PC & \\
\hline \multirow[t]{4}{*}{16.09} & PDF & $S$ & $S$ & $S$ & $S$ & $S$ & \multirow{4}{*}{$\begin{array}{l}\text { Os projetos já apresentavam uma convergência com a demanda, ao } \\
\text { adotarem a linha de tiro. Não houve alteração nos projetos. }\end{array}$} \\
\hline & PC & $\mathrm{S}$ & $\mathrm{S}$ & $S$ & $\mathrm{~S}$ & $\mathrm{~S}$ & \\
\hline & MJ & $S$ & $S$ & $S$ & $\mathrm{~S}$ & $S$ & \\
\hline & EV & $\mathrm{S}$ & $S$ & $S$ & $S$ & $S$ & \\
\hline \multirow[t]{4}{*}{16.10} & PDF & APPA & $P$ & $S$ & $\mathrm{PA}$ & PAC & \multirow{4}{*}{$\begin{array}{l}\text { As barreiras tiveram as propriedades de fechamento reforçadas, ao } \\
\text { receberam afastamentos ampliados, o que aumentou a quantidade de } \\
\text { barreira. Os projetos federal e privado tiveram aumentos maiores. O } \\
\text { ajustamento incrementou os projetos (segurança: estanqueidade, } \\
\text { impermeabilidade e inexpugnidade; e funcionalidade: proteção dos } \\
\text { funcionários) com aumento de custo de construção, associado à } \\
\text { modalida de segurança máximo proposta. }\end{array}$} \\
\hline & PC & APPA & $\mathrm{P}$ & $S$ & $\mathrm{PA}$ & PAC & \\
\hline & MJ & $P$ & $P$ & $S$ & $\mathrm{PA}$ & PC & \\
\hline & EV & APPA & $P$ & $\mathrm{~S}$ & PA & PAC & \\
\hline \multirow[t]{4}{*}{16.11} & PDF & $\mathrm{S}$ & $S$ & 1 & $S$ & $\mathrm{~S}$ & \multirow{4}{*}{$\begin{array}{l}\text { Os projetos distrital e paulista apresentam as pistas de ronda. O projeto } \\
\text { federal recebeu pistas de ronda externa e interna. O projeto privado } \\
\text { recebeu pista externa. O ajustamento incrementou os projetos } \\
\text { (segurança: redução de vulnerabilidades; e funcionalidade: mobilidade } \\
\text { dos funcionários) com aumento de custo de construção, associado ao } \\
\text { modelo de segurança máximo proposto. }\end{array}$} \\
\hline & PC & $\mathrm{S}$ & $S$ & 1 & $\mathrm{~S}$ & $\mathrm{~S}$ & \\
\hline & MJ & $\mathrm{P}$ & $\mathrm{P}$ & 1 & $\mathrm{PA}$ & PC & \\
\hline & EV & APPA & PA & 1 & $\mathrm{PA}$ & PC & \\
\hline
\end{tabular}

\begin{tabular}{|c|c|c|c|c|c|c|c|}
\hline \multicolumn{8}{|c|}{ 17. Cela } \\
\hline Item & Projeto & $\mathrm{S}$ & $\mathrm{F}$ & CA & C & $\mathbf{R}$ & Avaliação \\
\hline \multirow[t]{4}{*}{17.01} & PDF & $\mathrm{S}$ & $S$ & $\mathrm{~S}$ & $\mathrm{~S}$ & $\mathrm{~S}$ & \multirow{4}{*}{$\begin{array}{l}\text { Os projetos já apresentavam uma convergência com a demanda, ao } \\
\text { adotarem uma geometria simples. Não houve alteração nos projetos. }\end{array}$} \\
\hline & PC & $S$ & $S$ & $S$ & $S$ & $S$ & \\
\hline & $\mathrm{MJ}$ & $S$ & $S$ & $S$ & $\mathrm{~S}$ & $\mathrm{~S}$ & \\
\hline & EV & $\mathrm{S}$ & $\mathrm{S}$ & $\mathrm{S}$ & $\mathrm{S}$ & $\mathrm{S}$ & \\
\hline \multirow[t]{4}{*}{17.02} & PDF & $P$ & $A P$ & $P$ & PA & PAC & \multirow{4}{*}{$\begin{array}{l}\text { As celas tiveram ampliação funcional com acréscimo de atividades e } \\
\text { área construída }(48,75 \%) \text {, com exceção da área do projeto paulista } \\
\left.\text { (redução de } 0,05 \mathrm{~m}^{2}\right) \text {. O ajustamento incrementou os projetos } \\
\text { (segurança: organização funcional; e funcionalidade: e realização das } \\
\text { atividades), com ressalvas operacionais (funcionalidade: } \\
\text { complexidade dos procedimentos) e aumento de custo de construção } \\
\text { ( } 36 \% \text { do acréscimo total), associados ao modelo de segurança } \\
\text { máxima proposto. }\end{array}$} \\
\hline & PC & $P$ & $A P$ & $P$ & $P$ & & \\
\hline & $\mathrm{MJ}$ & $\mathrm{P}$ & $A P$ & $\mathrm{P}$ & $\mathrm{PA}$ & PAC & \\
\hline & EV & $P$ & $A P$ & $P$ & PA & PAC & \\
\hline
\end{tabular}




\begin{tabular}{|c|c|c|c|c|c|c|c|}
\hline \multirow[t]{4}{*}{17.03} & PDF & $S$ & $S$ & $S$ & $S$ & $S$ & \multirow{4}{*}{$\begin{array}{l}\text { Os projetos já apresentavam uma convergência com a demanda, ao } \\
\text { disponibilizarem os serviços de higiene pessoal e sanitários. Não } \\
\text { houve alteração nos projetos. }\end{array}$} \\
\hline & $P C$ & $S$ & $S$ & $S$ & $S$ & $S$ & \\
\hline & MJ & $S$ & $S$ & $S$ & $S$ & $S$ & \\
\hline & EV & $S$ & $\mathrm{~S}$ & $S$ & $\mathrm{~S}$ & $\mathrm{~S}$ & \\
\hline \multirow[t]{4}{*}{17.04} & PDF & $P$ & AP & $P$ & PA & PAC & \multirow{4}{*}{$\begin{array}{l}\text { As celas tiveram ampliação do mobiliário para suportar as atividades } \\
\text { e valorizar a individualidade (mesa coletiva com bancos, mesa } \\
\text { individual, prateleiras de uso comum e guarda de pertences). O } \\
\text { ajustamento incrementou os projetos (segurança: organização } \\
\text { funcional; e funcionalidade: realização das atividades), com ressalvas } \\
\text { (funcionalidade: complexidade dos procedimentos, com exceção do } \\
\text { projeto paulista) e aumento de custo de construção ( } 5 \% \text { do acréscimo } \\
\text { total), associados ao nível de segurança proposto. }\end{array}$} \\
\hline & PC & $P$ & $P$ & $P$ & PA & $C$ & \\
\hline & $\mathrm{MJ}$ & $P$ & AP & $P$ & PA & PAC & \\
\hline & EV & $P$ & AP & $P$ & PA & PAC & \\
\hline \multirow[t]{4}{*}{17.05} & PDF & $P$ & $\mathrm{AP}$ & $P$ & $S$ & $P$ & \multirow{4}{*}{$\begin{array}{l}\text { As celas tiveram o particionamento do espaço aumentado para } \\
\text { organizar as atividades (dormitório, estar e banheiro). O banheiro foi } \\
\text { locado ao fundo da cela no projeto distrital. Este particionamento } \\
\text { utilizou divisórias sem portas e obedeceu à simplicidade geométrica. } \\
\text { O ajustamento incrementou os projetos (segurança: organização } \\
\text { funcional; e funcionalidade: compatibilização das atividades), com } \\
\text { ressalvas operacionais (funcionalidade: complexidade dos } \\
\text { procedimentos), associadas ao nível de segurança proposto. }\end{array}$} \\
\hline & PC & $P$ & AP & $P$ & $S$ & $P$ & \\
\hline & $\mathrm{MJ}$ & $\mathrm{P}$ & $\mathrm{AP}$ & $P$ & $S$ & $P$ & \\
\hline & EV & $P$ & AP & $P$ & $S$ & $P$ & \\
\hline \multirow[t]{4}{*}{17.06} & PDF & APPA & $P$ & $I$ & PA & PC & \multirow{4}{*}{$\begin{array}{l}\text { As celas tiveram as relações sociais e individuais valorizadas } \\
\text { (organização funcional, subdivisões físicas e mobiliário). Os locais } \\
\text { sociais e individuais foram formalizados (nos projetos distrital e } \\
\text { paulista, o local individual não existia). O local comum (banheiro) foi } \\
\text { subdividido. O ajustamento incrementou os projetos (funcionalidade: } \\
\text { manifestações dos presos), com ressalva (segurança: aumento das } \\
\text { vulnerabilidades) e aumento de custo de construção (41\%), } \\
\text { associados ao nível de segurança proposto. }\end{array}$} \\
\hline & PC & $P$ & $P$ & I & PA & PC & \\
\hline & $\mathrm{MJ}$ & APPA & $P$ & 1 & PA & PAC & \\
\hline & $\mathrm{EV}$ & APPA & $P$ & I & PA & $\overline{\text { PAC }}$ & \\
\hline \multirow[t]{4}{*}{17.07} & PDF & APPA & $A P$ & $P$ & PA & PAC & \multirow{4}{*}{$\begin{array}{l}\text { As celas tiveram a ampliação da área (de } 2,00 \text { para } 3,20 \mathrm{~m}^{2} / \text { vaga) e } \\
\text { cubagem (de } 5,09 \text { para } 9,78 \mathrm{~m}^{3} / \text { vaga), limitada por critérios mínimos } \\
\text { (dimensões das camas e mesas, circulação, ventilação e iluminação). } \\
\text { O projeto paulista teve a área diminuída em } 0,05 \mathrm{~m}^{2} \text { (redução da } \\
\text { capacidade). O ajustamento incrementou os projetos (segurança, } \\
\text { funcionalidade e conforto ambiental), com ressalva (funcionalidade: } \\
\text { complicação dos procedimentos) e aumento de custo de construção } \\
(36 \%) \text {, associados ao nível de segurança proposto. }\end{array}$} \\
\hline & $P C$ & AP & AP & $P$ & $P$ & AP & \\
\hline & $\mathrm{MJ}$ & $P$ & AP & $P$ & PA & PC & \\
\hline & EV & $P$ & AP & $P$ & PA & PC & \\
\hline \multirow[t]{4}{*}{17.08} & PDF & $\mathrm{P}$ & 1 & $P$ & PA & PC & \multirow{4}{*}{$\begin{array}{l}\text { As celas tiveram as aberturas de iluminação e ventilação centralizadas } \\
\text { e aumentadas de } 13,65 \% \text { para } 25 \% \text {, a ventilação cruzada e a } \\
\text { regulagem foram viabilizadas }{ }^{131} \text {. Os nichos das camas receberam } \\
\text { aberturas. Aliado a isto, o mobiliário e o particionamento foram } \\
\text { simplificados (geometria e dimensionamento). O ajustamento } \\
\text { incrementou os projetos (segurança: impermeabilidade), com } \\
\text { aumento de custo de construção (zenital) ( } 9 \% \text { ), associados ao nível de } \\
\text { segurança máximo proposto. }\end{array}$} \\
\hline & PC & $P$ & 1 & $P$ & PA & PC & \\
\hline & MJ & $P$ & I & $A P$ & PA & APC & \\
\hline & EV & APPA & I & $A P$ & PA & PAC & \\
\hline \multirow[t]{4}{*}{17.09} & PDF & PA & $P$ & $P$ & PA & PC & \multirow{4}{*}{$\begin{array}{l}\text { As celas tiveram o fechamento providenciado por grade dupla } \\
\text { (zenital), brise em concreto (fachada) e porta chapeada de correr com } \\
\text { visor. Os demais projetos apresentam grades simples. O projeto } \\
\text { distrital não possui visor na porta. Os projetos paulista e federal } \\
\text { apresentam portas em grade. O ajustamento incrementou os projetos } \\
\text { (segurança: estanqueidade e impermeabilidade; funcionalidade: } \\
\text { simplificação dos procedimentos; e o conforto ambiental), com } \\
\text { aumento de custo de construção (30\%), associados ao nível de } \\
\text { segurança }\end{array}$} \\
\hline & PC & AP & $P$ & $P$ & PA & PC & \\
\hline & MJ & $P$ & $P$ & APPA & PA & PC & \\
\hline & $\mathrm{EV}$ & $\mathrm{AP}$ & APPA & APPA & PA & PAC & \\
\hline \multirow[t]{4}{*}{17.10} & PDF & $P$ & I & $P$ & PA & PC & \multirow{4}{*}{$\begin{array}{l}\text { As celas tiveram o fechamento flexibilizado pela abertura zenital, } \\
\text { associada à ronda pela cobertura - a vigilância é viável. Nos projetos, } \\
\text { a visualização ocorre com a exposição dos funcionários ou com a } \\
\text { inversão da vigilância (projetos distrital e paulista). O ajustamento } \\
\text { incrementou os projetos (segurança: territorialidade e visualização; e }\end{array}$} \\
\hline & PC & $P$ & I & $P$ & PA & PC & \\
\hline & MJ & $P$ & I & AP & PA & PC & \\
\hline & EV & $P$ & I & AP & PA & PC & \\
\hline
\end{tabular}

${ }^{131}$ A ventilação e a iluminação da cela foram testadas em simulações computadorizadas (capítulo 8), com inconformidade na iluminação do dormitório da cela. 


\begin{tabular}{|c|c|c|c|c|c|c|c|}
\hline & & & & & & & $\begin{array}{l}\text { conforto ambiental: aberturas para ventilação e iluminação), com } \\
\text { aumento de custo de construção, associado ao nível de segurança } \\
\text { máximo proposto. }\end{array}$ \\
\hline \multirow[t]{4}{*}{17.11} & PDF & $P$ & 1 & I & PA & PC & \multirow{4}{*}{$\begin{array}{l}\text { As celas tiveram a visualização do interior aumentado de } 58 \% \text { para } \\
79 \% \text {, devido ao zenital associado ao visor da porta. Isto apesar do } \\
\text { acréscimo e complicação do espaço e do mobiliário. O ajustamento } \\
\text { incrementou os projetos (segurança: visualização), com aumento de } \\
\text { custo de construção (zenital e visor da porta), associado ao nível de } \\
\text { segurança máximo proposto. }\end{array}$} \\
\hline & $P C$ & $P$ & 1 & I & PA & $P C$ & \\
\hline & $\mathrm{MJ}$ & $P$ & I & 1 & PA & PC & \\
\hline & EV & $P$ & I & 1 & $\overline{P A}$ & $P C$ & \\
\hline
\end{tabular}

\begin{tabular}{|c|c|c|c|c|c|c|c|}
\hline \multicolumn{8}{|c|}{ 18. Pátio de sol dos presos } \\
\hline Item & Projeto & $\mathrm{S}$ & $\mathrm{F}$ & $\mathrm{CA}$ & C & $\mathbf{R}$ & Avaliação \\
\hline \multirow[t]{4}{*}{18.01} & PDF & $\mathrm{P}$ & $\mathrm{P}$ & $\mathrm{P}$ & $\mathrm{P}$ & $\mathrm{P}$ & \multirow{4}{*}{$\begin{array}{l}\text { Os pátios tiveram ampliação funcional com acréscimo de atividades e } \\
\text { área construída ( } 10 \% \text { ), com exceção dos projetos distrital e paulista que } \\
\text { tiveram a visita retirada do pátio (redução de } 786 \mathrm{~m}^{2} \text { e } 52 \mathrm{~m}^{2} \text { ). Algumas } \\
\text { atividades ainda devem ocupar locais específicos. O ajustamento } \\
\text { incrementou os projetos (segurança: organização funcional; e } \\
\text { funcionalidade: realização das atividades), com ressalvas operacionais } \\
\text { (funcionalidade: complexidade dos procedimentos) e redução de custo } \\
\text { de construção, associadas ao nível de segurança proposto. }\end{array}$} \\
\hline & PC & $P$ & $P$ & $P$ & $P$ & $P$ & \\
\hline & MJ & $\mathrm{P}$ & $\mathrm{AP}$ & $P$ & PA & PC & \\
\hline & EV & $P$ & AP & $P$ & PA & PC & \\
\hline \multirow[t]{4}{*}{18.02} & PDF & P & $P$ & 1 & $P$ & $P$ & \multirow{4}{*}{$\begin{array}{l}\text { Os projetos apresentavam uma convergência parcial com a demanda, } \\
\text { ao apresentarem um pátio de sol para cada grupo de presos (ala } \\
\text { carcerária), com exceção dos projetos distrital e federal. O projeto } \\
\text { distrital teve as alas carcerárias reduzidas (pátios de sol). O projeto } \\
\text { federal recebeu dois pátios de sol a mais. O ajustamento incrementou } \\
\text { os projetos (segurança: submissão dos presos), com ressalva } \\
\text { (funcionalidade: aumento das tarefas) e aumentou o custo de } \\
\text { construção (aumento de área), associados ao nível de segurança } \\
\text { proposto. }\end{array}$} \\
\hline & PC & $\mathrm{S}$ & $\mathrm{S}$ & 1 & $\mathrm{~S}$ & $\mathrm{~S}$ & \\
\hline & MJ & $\mathrm{P}$ & $\mathrm{N}$ & 1 & PA & $\mathrm{C}$ & \\
\hline & EV & $S$ & $S$ & 1 & $\mathrm{~S}$ & $\mathrm{~S}$ & \\
\hline \multirow[t]{4}{*}{18.03} & PDF & $\mathrm{P}$ & $\mathrm{P}$ & 1 & $\mathrm{P}$ & $\mathrm{P}$ & \multirow{4}{*}{$\begin{array}{l}\text { Os pátios tiveram as capacidades e as demandas ajustadas para } 36 \\
\text { usuários por turno e } 144 \text { usuários diários. O projeto distrital teve } \\
\text { redução da capacidade e da demanda. Os projetos paulista e federal } \\
\text { tiveram redução da capacidade e aumento da demanda. O projeto } \\
\text { privado teve aumento da capacidade. O ajustamento incrementou os } \\
\text { projetos (segurança dos presos; e funcionalidade: redução das tarefas), } \\
\text { com diminuição do custo de construção (dedução de área), associado } \\
\text { ao nível de segurança proposto. }\end{array}$} \\
\hline & PC & $\mathrm{P}$ & $\mathrm{PA}$ & $\mathrm{I}$ & $\mathrm{P}$ & $\mathrm{P}$ & \\
\hline & MJ & $\mathrm{P}$ & PA & 1 & $\mathrm{P}$ & $P$ & \\
\hline & EV & PA & $\overline{A P P A}$ & 1 & $\overline{P A}$ & C & \\
\hline \multirow[t]{4}{*}{18.04} & PDF & APPA & $S$ & 1 & $\mathrm{~S}$ & AP & \multirow{4}{*}{$\begin{array}{l}\text { Os projetos já apresentavam uma convergência com a demanda, ao } \\
\text { apresentarem uma geometria simples. Como exceção, o projeto } \\
\text { paulista teve a geometria aprimorada. Os projetos receberam chanfros } \\
\text { nos cantos opostos ao posto de controle. O ajustamento incrementou } \\
\text { os projetos (segurança: estanqueidade e vigilância). }\end{array}$} \\
\hline & PC & $\mathrm{P}$ & $S$ & $I$ & $S$ & $\mathrm{P}$ & \\
\hline & MJ & APPA & $S$ & 1 & $\mathrm{~S}$ & $\mathrm{AP}$ & \\
\hline & EV & $\overline{\text { APPA }}$ & $S$ & 1 & $\mathrm{~S}$ & $\mathrm{AP}$ & \\
\hline \multirow[t]{4}{*}{18.05} & PDF & $\mathrm{P}$ & PA & 1 & $\mathrm{P}$ & $\mathrm{P}$ & \multirow{4}{*}{$\begin{array}{l}\text { Os pátios tiveram a espacialidade adequada para organizar as } \\
\text { atividades previstas (diferentes áreas cobertas e pisos em nível), } \\
\text { enquanto a simplicidade geométrica do local foi mantida. O } \\
\text { ajustamento incrementou os projetos (segurança: organização } \\
\text { funcional; e funcionalidade: realização das atividades), com ressalva } \\
\text { (funcionalidade: complicação dos procedimentos) e aumento parcial do } \\
\text { custo de construção, associados ao nível de segurança proposto. }\end{array}$} \\
\hline & PC & $\mathrm{P}$ & PA & 1 & PA & $P C$ & \\
\hline & MJ & $P$ & PA & 1 & PA & $P C$ & \\
\hline & EV & $P$ & PA & I & PA & PC & \\
\hline \multirow[t]{4}{*}{18.06} & PDF & APPA & AP & 1 & $\mathrm{P}$ & $\mathrm{P}$ & \multirow{4}{*}{$\begin{array}{l}\text { Os pátios tiveram ampliação do mobiliário para suportar as atividades e } \\
\text { preservar a individualidade (mesas coletivas com bancos, arquibancada } \\
\text { e bancos). O projeto paulista não tinha mobiliário. O ajustamento } \\
\text { incrementou os projetos (segurança: organização funcional; e } \\
\text { funcionalidade: realização das atividades), com ressalva (segurança: } \\
\text { visibilidade; e funcionalidade: complexidade dos procedimentos) e } \\
\text { aumento de custo de construção, associados ao nível de segurança } \\
\text { proposto. }\end{array}$} \\
\hline & PC & $\mathrm{P}$ & $\mathrm{P}$ & $I$ & PA & $C$ & \\
\hline & MJ & $P$ & $P$ & 1 & PA & C & \\
\hline & EV & APPA & AP & 1 & $P$ & $P$ & \\
\hline \multirow[t]{4}{*}{18.07} & PDF & $P$ & $P$ & 1 & $P$ & $P$ & \multirow{4}{*}{$\begin{array}{l}\text { Os pátios tiveram a cantina/distribuição retiradas. O projeto paulista } \\
\text { não tinha cantina ou distribuição. O ajustamento incrementou os } \\
\text { projetos (segurança: redução de vulnerabilidades; e funcionalidade: } \\
\text { redução de tarefas), com redução de custo de construção. }\end{array}$} \\
\hline & PC & $S$ & $S$ & 1 & $\mathrm{~S}$ & $S$ & \\
\hline & $\mathrm{MJ}$ & $P$ & $P$ & 1 & $P$ & $P$ & \\
\hline & EV & $P$ & $P$ & 1 & $P$ & $P$ & \\
\hline 18.08 & PDF & $P$ & $\mathrm{PA}$ & $I$ & $\mathrm{PA}$ & PC & Os pátios tiveram as relações sociais valorizadas (diversidade espacial e \\
\hline
\end{tabular}




\begin{tabular}{|c|c|c|c|c|c|c|c|}
\hline & $P C$ & $P$ & PA & 1 & PA & PC & \multirow{3}{*}{$\begin{array}{l}\text { mobiliário). Os locais sociais foram formalizados. Em contrapartida, a } \\
\text { privacidade foi minimizada. Os sanitários foram devassados } \\
\text { (minimização das divisórias). O ajustamento incrementou os projetos } \\
\text { (segurança: organização funcional; e funcionalidade: manifestações dos } \\
\text { presos), com ressalva (funcionalidade: complexidade dos } \\
\text { procedimentos) e aumento de custo de construção, associado ao nível } \\
\text { de segurança proposto. }\end{array}$} \\
\hline & MJ & $P$ & PA & 1 & PA & $P C$ & \\
\hline & EV & $P$ & PA & 1 & $P$ & $P$ & \\
\hline \multirow[t]{4}{*}{18.09} & PDF & $\mathrm{P}$ & $\mathrm{P}$ & 1 & $\mathrm{P}$ & $P$ & \multirow{4}{*}{$\begin{array}{l}\text { Os pátios tiveram a ampliação da área (de } 3,46 \text { para } 8,41 \mathrm{~m}^{2} / \mathrm{vaga} \text { ), } \\
\text { associada ao ajuste dos grupos de presos e o uso alternado do local, } \\
\text { com exceção dos projetos distrital e paulista (redução de } 786 \mathrm{~m}^{2} \text { e } \\
52 \mathrm{~m}^{2} \text { ). O ajustamento incrementou os projetos (compatibilização da } \\
\text { dimensão com a segurança e a funcionalidade, em especial, com a } \\
\text { realização das atividades dos presos), com ressalva (funcionalidade: } \\
\text { complicação dos procedimentos) e aumento de custo de construção, } \\
\text { associado ao nível de segurança proposto. }\end{array}$} \\
\hline & PC & $\mathrm{P}$ & $\mathrm{P}$ & 1 & $\mathrm{P}$ & $\mathrm{P}$ & \\
\hline & $\mathrm{MJ}$ & $\mathrm{P}$ & PA & $I$ & $\mathrm{PA}$ & PC & \\
\hline & EV & $P$ & PA & I & PA & PC & \\
\hline \multirow[t]{4}{*}{18.10} & PDF & APPA & 1 & $\mathrm{P}$ & $\mathrm{P}$ & $\mathrm{P}$ & \multirow{4}{*}{$\begin{array}{l}\text { Os pátios tiveram a abertura superior rebaixada em relação ao piso e } \\
\text { duas áreas cobertas criadas (aeração e sombreamento), enquanto a } \\
\text { ventilação cruzada e a regulagem foram vetadas }{ }^{132} \text {. O ajustamento } \\
\text { incrementou os projetos (segurança: impermeabilidade; e conforto } \\
\text { ambiental: circulação de ar), com ressalva (segurança: aumento das } \\
\text { vulnerabilidades), associada ao nível de segurança proposto. }\end{array}$} \\
\hline & PC & $\mathrm{PA}$ & 1 & $P$ & PA & C & \\
\hline & MJ & $\mathrm{P}$ & 1 & PA & $P$ & $P$ & \\
\hline & EV & $\mathrm{PA}$ & I & $P$ & $P$ & $P$ & \\
\hline \multirow[t]{4}{*}{18.11} & PDF & $P$ & $P$ & 1 & PA & C & \multirow{4}{*}{$\begin{array}{l}\text { Os projetos já apresentavam uma convergência com a demanda } \\
\text { (fechamento da abertura superior com aparatos de segurança), ao } \\
\text { apresentarem grade na abertura superior. Como exceção, o projeto } \\
\text { paulista recebeu a grade. O ajustamento incrementou o projeto } \\
\text { (segurança: estanqueidade). }\end{array}$} \\
\hline & PC & $S$ & $S$ & 1 & $\mathrm{~S}$ & $\mathrm{~S}$ & \\
\hline & MJ & $S$ & $\mathrm{~S}$ & 1 & $S$ & $\mathrm{~S}$ & \\
\hline & EV & $\mathrm{S}$ & $S$ & 1 & $S$ & $S$ & \\
\hline \multirow[t]{4}{*}{18.12} & PDF & $S$ & $S$ & 1 & $S$ & $S$ & \multirow{4}{*}{$\begin{array}{l}\text { Os projetos já apresentavam uma convergência com a demanda } \\
\text { (maximização da vigilância interna), ao adotarem uma geometria } \\
\text { simples. Não houve alteração nos projetos. }\end{array}$} \\
\hline & PC & $S$ & $S$ & 1 & $S$ & $\mathrm{~S}$ & \\
\hline & $\overline{M J}$ & $S$ & $S$ & I & $S$ & $S$ & \\
\hline & EV & $S$ & $S$ & I & $S$ & $S$ & \\
\hline
\end{tabular}

\begin{tabular}{|c|c|c|c|c|c|c|c|}
\hline \multicolumn{8}{|c|}{ 19. Posto de controle } \\
\hline Item & Projeto & $\mathrm{S}$ & $\mathrm{F}$ & CA & $\mathrm{C}$ & $\mathbf{R}$ & Avaliação \\
\hline \multirow[t]{4}{*}{19.01} & PDF & $\mathrm{P}$ & $P$ & 1 & PA & PC & \multirow{4}{*}{$\begin{array}{l}\text { Os postos tiveram a vigilância otimizada com a concentração dos pontos } \\
\text { geradores isométricos (simplicidade geométrica) (em especial, o posto } \\
\text { do projeto paulista). O ajustamento incrementou os projetos } \\
\text { (segurança: concentração do campo de visão; e funcionalidade: } \\
\text { simplificação dos procedimentos), com aumento do custo de construção } \\
\text { (aumento de área), associado ao nível de segurança máxima proposto. }\end{array}$} \\
\hline & PC & $\mathrm{P}$ & $P$ & 1 & PA & PC & \\
\hline & MJ & $\mathrm{P}$ & $\mathrm{P}$ & 1 & PA & PC & \\
\hline & EV & $P$ & $P$ & 1 & PA & PC & \\
\hline \multirow[t]{4}{*}{19.02} & PDF & $S$ & APPA & 1 & PA & PAC & \multirow{4}{*}{$\begin{array}{l}\text { Os postos tiveram mobiliário incluído para melhorar as condições de } \\
\text { trabalho (bancada). Os projetos apresentam o sanitário para os } \\
\text { funcionários (fora e próximo aos postos) (com exceção do projeto } \\
\text { paulista). O ajustamento incrementou parcialmente os projetos } \\
\text { (funcionalidade: realização das atividades), com aumento de custo de } \\
\text { construção, associado ao nível de segurança proposto. }\end{array}$} \\
\hline & $\mathrm{PC}$ & $S$ & $\mathrm{P}$ & 1 & PA & PC & \\
\hline & $\mathrm{MJ}$ & $\mathrm{S}$ & $P$ & 1 & $\mathrm{PA}$ & PAC & \\
\hline & EV & $S$ & APPA & 1 & PA & PAC & \\
\hline \multirow[t]{4}{*}{19.03} & PDF & PA & PA & 1 & PA & PAC & \multirow{4}{*}{$\begin{array}{l}\text { Os postos tiveram os visores ampliados (totalidade do perímetro } \\
\text { disponível) e reconfigurados (inclinações e entrecortes) para favorecer a } \\
\text { visualização externa (contato visual constante) (em especial, o posto do } \\
\text { projeto paulista). O ajustamento incrementou os projetos (segurança: } \\
\text { visualização e garantia do contato visual; e funcionalidade: redução de } \\
\text { tarefas e simplificação de procedimentos), com aumento de custo de } \\
\text { construção, associado ao nível de segurança proposto. }\end{array}$} \\
\hline & PC & $\mathrm{P}$ & $\mathrm{P}$ & 1 & PA & PC & \\
\hline & MJ & PA & PA & 1 & PA & PAC & \\
\hline & EV & $P$ & $P$ & 1 & PA & PC & \\
\hline \multirow[t]{3}{*}{19.04} & PDF & $P$ & PA & $P$ & PA & PC & \multirow{3}{*}{$\begin{array}{l}\text { Os postos tiveram as dimensões aumentadas (de } 13,25 \mathrm{~m}^{2} \text { para } 16,0 \mathrm{~m}^{2} \text { ) } \\
\text { (com exceção do projeto privado), de modo associado à vigilância e à } \\
\text { operação. Este redimensionamento buscou efetivar os padrões mínimos }\end{array}$} \\
\hline & PC & $P$ & $\mathrm{P}$ & $P$ & $\mathrm{~N}$ & $P C$ & \\
\hline & MJ & $P$ & PA & $P$ & PA & $P C$ & \\
\hline
\end{tabular}

${ }^{132}$ A ventilação e a iluminação do pátio de sol foram testadas em simulações computadorizadas (capítulo 8). 


\begin{tabular}{|c|c|c|c|c|c|c|c|}
\hline & EV & $P$ & PA & PA & P & $P$ & $\begin{array}{l}\text { de bem-estar (sensação de enclausura e insegurança). O ajustamento } \\
\text { incrementou os projetos (segurança: integridade dos funcionários; } \\
\text { funcionalidade: simplificação da visualização; e conforto ambiental: } \\
\text { proporção das aberturas), com aumento de custo de construção, } \\
\text { associado ao nível de segurança proposto. }\end{array}$ \\
\hline \multirow[t]{4}{*}{19.05} & PDF & $\mathrm{P}$ & $P$ & $P$ & PA & PC & \multirow{4}{*}{$\begin{array}{l}\text { Os postos tiveram os aparatos de segurança complementados e } \\
\text { reforçados no bloqueio das aberturas, comunicação e intervenções, } \\
\text { manuseio remoto de portas e evasão dos funcionários (em especial, o } \\
\text { posto do projeto paulista). O ajustamento incrementou os projetos } \\
\text { (segurança: separação física e a integridade dos funcionários; } \\
\text { funcionalidade: simplificação dos procedimentos; e conforto ambiental: } \\
\text { viabilização das aberturas), com aumento de custo de construção, } \\
\text { associado ao nível de segurança proposto. }\end{array}$} \\
\hline & PC & $P$ & $P$ & $P$ & $\mathrm{~N}$ & PC & \\
\hline & MJ & $P$ & $P$ & $\mathrm{P}$ & PA & C & \\
\hline & EV & $P$ & $P$ & $P$ & PA & C & \\
\hline \multirow[t]{4}{*}{19.06} & PDF & $\mathrm{P}$ & 1 & PA & PA & C & \multirow{4}{*}{$\begin{array}{l}\text { Os postos tiveram as aberturas de iluminação e ventilação corretamente } \\
\text { dimensionadas (em especial, o posto do projeto paulista) ou } \\
\text { reconfiguradas, segundo o princípio de vigilância }{ }^{133} \text {. Os postos também } \\
\text { receberam ventilação cruzada e regulagem das aberturas. O } \\
\text { ajustamento incrementou os projetos (compatibilização do conforto } \\
\text { ambiental com a segurança: fechamento e padrões de bem-estar), com } \\
\text { aumento de custo de construção, associado ao nível de segurança } \\
\text { proposto. }\end{array}$} \\
\hline & PC & $P$ & 1 & $P$ & $\mathrm{~N}$ & C & \\
\hline & $\mathrm{MJ}$ & $P$ & 1 & PA & PA & C & \\
\hline & EV & $P$ & 1 & $\mathrm{PA}$ & $\mathrm{PA}$ & $\mathrm{C}$ & \\
\hline
\end{tabular}

${ }^{133}$ A ventilação e a iluminação do posto de controle foram testadas em simulações computadorizadas (capítulo 8), com inconformidade na ventilação, a depender do parâmetro adotado. 
